UNIVERSIDADE DE SÃO PAULO

FACULDADE DE FILOSOFIA, LETRAS E CIÊNCIAS HUMANAS DEPARTAMENTO DE GEOGRAFIA

PROGRAMA DE PÓS-GRADUAÇÃO EM GEOGRAFIA HUMANA

\title{
DAS TERRAS DOS ÍNDIOS A ÍNDIOS SEM TERRAS O ESTADO E OS GUARANI DO OCO'Y: VIOLÊNCIA, SILÊNCIO E LUTA
}

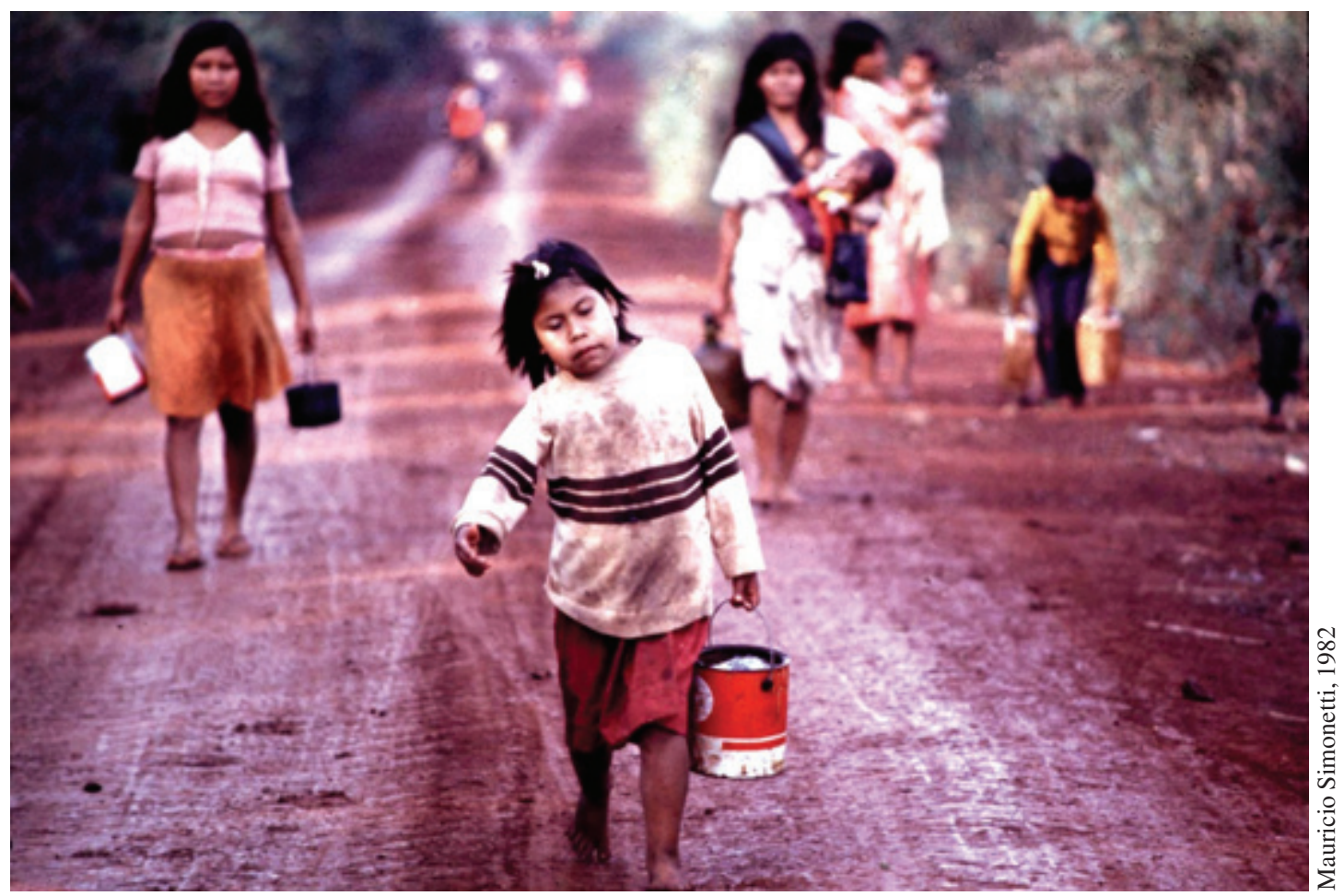

Maria Lucia Brant de Carvalho 


\title{
UNIVERSIDADE DE SÃO PAULO
}

FACULDADE DE FILOSOFIA, LETRAS E CIÊNCIAS HUMANAS

DEPARTAMENTO DE GEOGRAFIA

PROGRAMA DE PÓS-GRADUAÇÃO EM GEOGRAFIA HUMANA

\section{DAS TERRAS DOS ÍNDIOS A ÍNDIOS SEM TERRAS O ESTADO E OS GUARANI DO OCO'Y: VIOLÊNCIA, SILÊNCIO E LUTA}

\author{
Maria Lucia Brant de Carvalho
}

Tese apresentada ao Programa de Pós-Graduação em Geografia Humana do Departamento de Geografia da Faculdade de Filosofia, Letras e Ciências Humanas da Universidade de São Paulo, para obtenção do título de Doutora em Geografia.

Orientador: Professor Doutor Ariovaldo Umbelino de Oliveira 
AUTORIZO A REPRODUÇÃO E DIVULGAÇÃO TOTAL OU PARCIAL DESTE TRABALHO, POR QUALQUER MEIO CONVENCIONAL OU ELETRÔNICO, PARA FINS DE ESTUDO E PESQUISA, DESDE QUE CITADA A FONTE.

Catalogação na Publicação Serviço de Biblioteca e Documentação

Faculdade de Filosofia, Letras e Ciências Humanas da Universidade de São Paulo

Carvalho, Maria Lucia Brant de

C331t Das Terras dos Índios a Índios sem Terras. O Estado e os Guarani do Oco'y. Violência, Silencio e Luta. / Maria Lucia Brant de Carvalho; orientador Ariovaldo Umbelino de Oliveira. - São Paulo, 2013. 834 f.il.

Tese (Doutorado) - Faculdade de Filosofia, Letras e Ciências Humanas da Universidade de São Paulo. Departamento de Geografia. Área de concentração: Geografia Humana.

1. Geopolitica. America do Sul. Brasil. 2. Guarani. Indígenas . 3. Território . 4. Tríplice Fronteira. 5. Estado. I. Oliveira, Ariovaldo Umbelino de, orient. II. Título. 


\section{FOLHA DE APROVAÇÃO}

Maria Lucia Brant de Carvalho

Das Terras dos Índios a Índios Sem Terras.

O Estado e os Guarani do Oco'y:

Violência, Silêncio e Luta

Tese apresentada ao Programa de Pós-Graduação em

Geografia Humana do Departamento de Geografia da

Faculdade de Filosofia, Letras e Ciências Humanas da

Universidade de São Paulo, para obtenção do título

de Doutora em Geografia.

Orientador: Professor Doutor Ariovaldo Umbelino de Oliveira

Aprovado em:

Banca Examinadora

Prof. Dr.(a)

Instituição:

Assinatura

Prof. Dr.(a)

Instituição:

Assinatura

Prof. Dr.(a)

Instituição:

Assinatura

Prof. Dr.(a)

Instituição:

Assinatura

Prof. Dr.(a)

Instituição:

Assinatura 


\section{Terra Indígena Avá-Guarani do Oco’y}

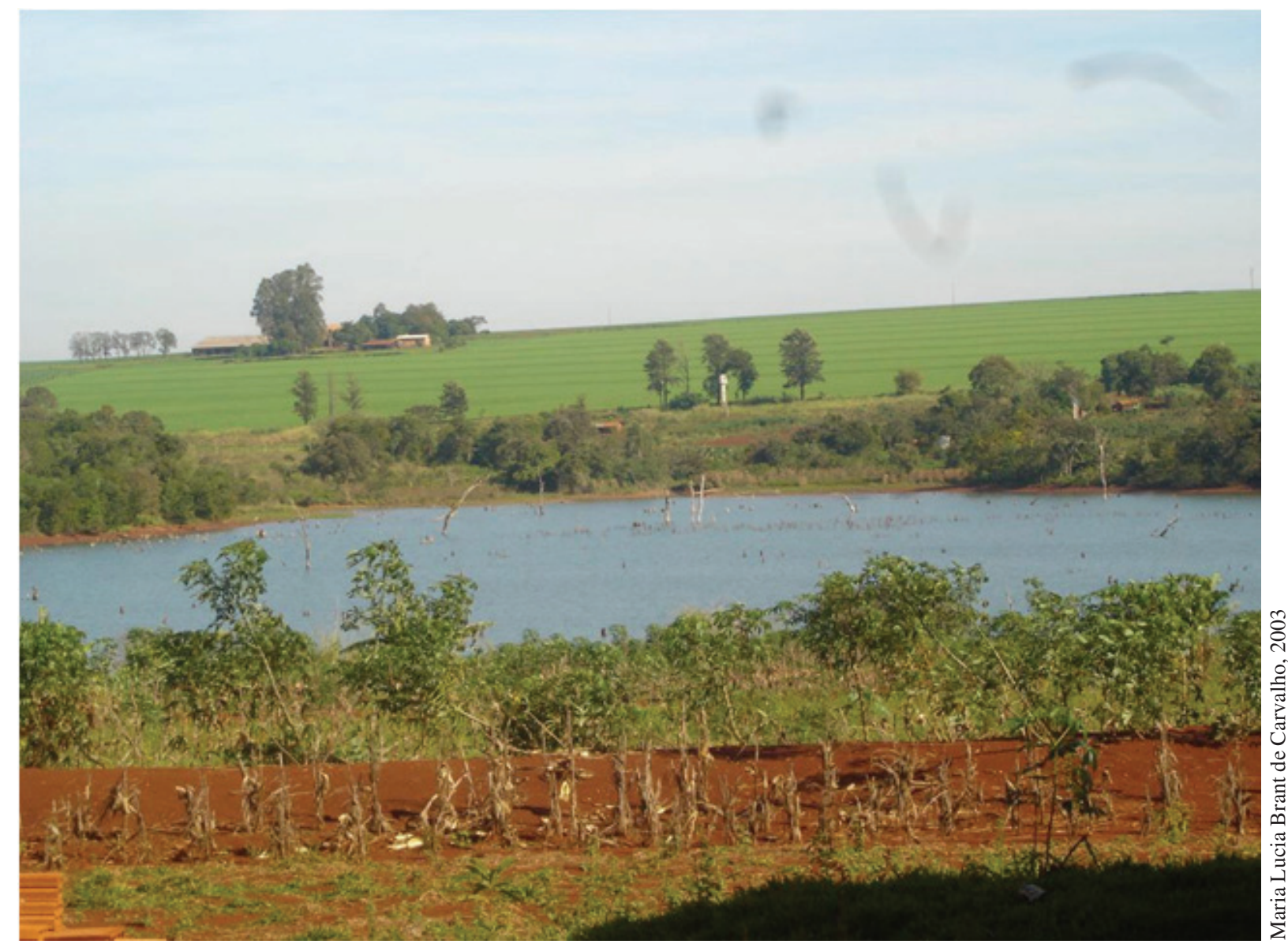

Três superposições: Glebas de Colonos, Área de Preservação Permanente/APP da Usina Hidrelétrica de Itaipu e Terra Indígena. As Terras Indígenas por lei são de uso exclusivo.

Aos Guarani do Oco’y:

Uma terra com Mata, com água boa e

longe dos brancos... 
A riqueza da história que será contada aqui não está contida somente nas ações praticadas, mas no conjunto de relações que elas desvelam e na presença implícita de um verdadeiro plano próprio de trabalho, orgânico e adaptado a um país empobrecido pelo poder de homens, que em nome da lógica do capital, ultrapassam toda e qualquer barreira legal, ética, humanista e ambiental.

Baseado nas Cartas do Cárcere do filósofo italiano Antonio Gramsci (1891-1937)

"As coisas e as conexões mais triviais devem ser examinadas e atentamente discutidas, pois em sua forma e nas relações que constroem existem aspectos importantes a serem conhecidos e dominados. Em tempo de desordem sangrenta, de confusão organizada, de arbitrariedade consciente, de humanidade desumanizada, nada deve parecer natural, nada deve parecer impossível de mudar".

Bertold Brecht, dramaturgo alemão (1898-1956) 


\section{AGRADECIMENTOS}

Aos Guarani do Oco’y pela oportunidade de convivência ao longo dos anos de 2001 a 2007, nos quais pude mergulhar - ainda que não tão profundamente como gostaria, nas ondas de seu pensamento milenar, no decorrer de sua história épica, vivenciando de forma compartilhada suas agruras frente ao poder dos "brancos", ou melhor, na verdade, frente ao poder do Estado brasileiro. Apesar da secular espoliação de suas terras, em nenhum momento os vi praguejar diante da situação vivida. Em todas as horas apresentam-se de forma a combinar características de personalidade comparáveis somente a grandes diplomatas, conhecedores da história, seres altivos e ao mesmo tempo doces, de correção de caráter ímpar e inigualável, infelizmente, negociadores em posição assimétrica de poder, por fim, merecedores do mais profundo respeito e atenção de minha parte. Sem dúvida um povo evoluído em termos humanísticos, que o Brasil ainda está, a esta altura da história, para conhecer, devendo se orgulhar de tê-los como cidadãos ao invés de espoliá-los. Dedico este trabalho a eles esperando que possa contribuir para que estejam futuramente instalados em território adequado as suas condições de vida, produção de seu sustento, saúde e religião.

Ao meu pai Jorge Alberto Brant de Carvalho (in memoriam) que ensinou aos filhos os princípios da honestidade, organização e meticulosidade.

A minha mãe Maria do Carmo Brant de Carvalho, que todas as vezes que precisei sempre estendeu a mão, sem titubear.

Aos indigenistas: Fernando Schiavinni de Castro, Julio César de Moraes e Marcio Alvim, grandes amigos que sempre lutaram pela liberdade, respeito, reconhecimento étnico e autodeterminação dos povos indígenas encarando toda sorte de adversidades.

Ao professor e orientador Doutor Ariovaldo Umbelino de Oliveira que me ensinou a olhar sob a perspectiva da geografia humana e especificamente da geopolítica do território latinoamericano.

Ao meu companheiro Julio Turra Filho, pelo auxílio e esclarecimento nas discussões pertinentes a geografia, história e política na América Latina.

A Antônio do Amaral Rocha pelo trabalho de editoração e pela solidariedade com que me atendeu. 


\section{Das Terras dos Índios a Índios Sem Terras. O Estado e os Guarani do Oco'y: Violência, Silêncio e Luta}

Palavras-Chave: Guarani; Geopolítica; Território; Tríplice Fronteira.

\section{Síntese}

A população indígena Guarani desde tempos imemoriais ocupa tradicionalmente as Bacias do Rio Paraguai, Paraná e Uruguai e seus afluentes, ou seja, a grande Bacia do Prata. A região da Bacia do Paraná na Tríplice Fronteira entre Brasil, Paraguai e Argentina é denominada pelos Guarani como sendo uma parcela do Tekoa Guassu (conjunto de várias aldeias Guarani ou Aldeia Grande). Ali possuem o direito de permanecer, reconhecido legalmente desde a época colonial portuguesa e pelas sucessivas constituições brasileiras. No decorrer do século XX com a instalação de empreendimentos estatais brasileiros na região do oeste paranaense, os Guarani foram esbulhados de suas terras desaparecendo assim, inúmeras aldeias. Instalou-se um processo de desconstrução do território indígena. Grande parte da população indígena foi expulsa para o Paraguai, concentrando-se junto às aldeias ali existentes, localizadas na fronteira com o Brasil. Apesar das pressões, uma única população Guarani conseguiu resistir no Brasil. Trata-se dos habitantes da antiga aldeia do Oco’y-Jacutinga. Em 1973, ela teve a maior parte de suas terras ocupadas pelo INCRA, visando reassentar colonos retirados do Parque Nacional do Iguaçu. Em 1982 a parte restante do território indígena, foi totalmente inundada com a construção da Usina Hidrelétrica de Itaipu. Somente parte dos indígenas foram compulsoriamente reterritorializados para a Terra Indígena Avá-Guarani do Oco’y. A transferência da população, legalmente deveria ser de todo o agrupamento indígena, para terras de igual extensão e ambientalmente semelhantes à anterior, e ainda seu uso deveria ser exclusivo. Oco'y apresenta dimensões diminutas, menores que a anterior e ambientalmente comprometida. É sobreposta à Área de Preservação Permanente do reservatório da Usina Hidrelétrica de Itaipu, terras em que, antes, constituía-se parte de Glebas de Colonos, os quais não foram indenizados pelo INCRA. Dada a insuficiência de terras e os problemas sociais decorrentes das superposições, os Guarani sofrem toda sorte de impactos sociais, ambientais, econômicos e sanitários. Tentativas de reterritorialização por parte dos indígenas foram reprimidas pelo Estado. Encontram-se acuados e necessitam de terras em ambiente adequado para sua reprodução física e cultural. Para esta solução, é preciso descartar falsas versões, que atribuem à emigração de indivíduos Guarani provenientes do Paraguai, a existência de excesso demográfico no Oco’y. Esta assertiva vem sendo utilizada, impedindo e mascarando a resolução do problema fundiário. O crescimento demográfico no Oco'y é semelhante ao de qualquer aldeia da etnia. Na verdade, não é a população indígena que é excessiva, mas o território onde foi reassentada que se apresenta insuficiente e inadequado desde a sua instalação no local. Tal situação é fruto de histórico descumprimento das leis pelos poderes Executivo e Judiciário federais, favorecendo grupos de poder locais. 


\title{
From the Indian Lands to the Indians with no Land. The Guarani do Oco'y's Route: Violence, Silence and Fight
}

Key-words: Guarani; Geopolitics; Territory; Triple Border.

\begin{abstract}
Traditionally, since memorable times, the Paraguay, Paraná and Uruguay Bays and their tributaries, known as the greater Prata Bay, have been occupied by the Guarani Indian population. The Paraná Bay in the triple border between Brazil, Paraguay and Argentina is identified by part of the Guarani as Tekoa Guassu (a cluster of many Guarani villages or Big Village). Their right to live there is legally recognized by the consecutive Brazilian Constitutions since Portuguese Colonial Times. During the $20^{\text {th }}$ century the Guarani were evicted from their lands due to the Brazilian government's enterprises in the west region of the Paraná State which caused the disappearance of countless villages. It initiated a process of dissipating the Indian Territory. Great part of the Indian population was pushed to Paraguayan lands in the border with Brazil where other villages already existed. In spite of that, one Guarani population, the inhabitants of the old village known as Oco'y-Jacutinga managed to resist in Brazilian territory. However, in 1973, the majority of its lands was occupied by INCRA, to resettle colonists that were withdrawn from Iguaçu National Park. In 1982 the remaining part of the Indian Territory was completely flooded with the construction of Itaipu Hydroelectric Power Plant. Only part of the Indians were compulsorily relocated to the Indian Land of Avá-Guarani do Oco'y. Legally the transference of that population should be for whole Indian group to lands of the same extension and environmentally similar to the previous ones with exclusive occupation. Oco'y, conversely, presents diminutive dimensions, smaller than the preceding one and environmentally impaired. It is overlaped by the Area of Permanent Preservation of Itaipu Hydroelectric Power Plant reservoir; lands that were previously part of the colonist areas, which were not reimbursed by INCRA. Due to the small quantity of land and the social problems developed by the overlapping, the Guarani Indians suffer all kinds of social, environmental, economic and sanitary impact. Indian resettlement attempts were restrained by the State. They are cornered and need the land in a proper environment for their physical and cultural reproduction. For a solution to that matter, it is necessary to throw away false versions that attribute emigration of Guarani Indians from Paraguay due to demographic excess in Oco'y. The use of such statement is an impediment to the resolution for the land property problem. The demographic growth in Oco'y is similar to any other of its ethnic villages. Actually, it is not the Indian population that is excessive but the place where they were resettled that is insufficient and inadequate from the start. Those circunstances are a consequence of the historical unbinding of the law from the Brazilian Judiciary and Executive Federal Institutions on behalf of local power groups.
\end{abstract}




\title{
De las Tierras de los Indios a los Indios Sin Tierras La Trayectoria de los Guarany de Oco'y: Violencia, Silencio y Lucha
}

\author{
Palabras-Clave: Guarany; Geopolítica; Território; Triple Frontera.
}

\section{Resumo}

La población indígena Guarany, desde tiempos inmemoriales, ocupa tradicionalmente las Cuencas del Río Paraguay, Paraná y Uruguay y sus afluyentes, ó sea, la grande Cuenca Platina. La región de la Cuenca del Paraná en la Triple Frontera de Brasil, Paraguay e Argentina es denominada por los Gurarany como siendo parte del Tekoa Guazú (conjunto de aldeas Guarany ó Aldea Grande). Allí tienen el derecho de permanecer, reconocido legalmente desde la época colonial portuguesa y por las constituciones brasileñas que se siguieron. En el curso del siglo XX, con la instalación de emprendimientos estatales brasileños en la región del oeste paranaense, los Guarany fueran expulsados de sus tierras desapareciendo entonces muchas aldeas. Así se ha instalado un proceso de desmantelamiento del territorio indígena, con gran parte de la población expulsada para territorio paraguayo, donde se concentró junto a aldeas allí existentes cerca de la frontera con Brasil. Mismo sufriendo presiones, una sola población Guarany resistió en territorio brasileño y son los habitantes de la antigua aldea Oco'y-Jacutinga. En 1973, esta aldea tuve la mayor parte de sus tierras ocupadas por el INCRA, con el objetivo de entregarlas a colonos retirados del Parque Nacional del Iguazú. En 1982 la parte que todavía existía de territorio indígena, fue totalmente inundada con la construcción de la Usina Hidroeléctrica de Itaipu. Una sola parte de los indígenas fue de forma compulsoria reterritorializada en la Tierra Indígena AváGuarani del Oco’y. La transferencia de esta población debería haber sido hecha, legalmente, de todo el grupo para tierras de igual extensión y que fuesen semejantes a la anterior del punto de vista ambiental y con utilización exclusiva. Pero, Oco'y presenta dimensiones reducidas, más chicas que la tierra anterior y comprometidas ambientalmente. Además, esta tierra esta sobrepuesta a una Área de Preservación Permanente de la Usina Hidroeléctrica de Itaipu, tierras que anteriormente eran parte de los lotes de colonos, los cuales no fueron indemnizados por el INCRA. Delante de la insuficiencia de tierras y los problemas sociales provocados por las superposiciones, los Guarany sufren toda suerte de impactos sociales, ambientales, económicos y sanitarios. Tentativas por parte de los indígenas de recuperar tierras tradicionales fueron reprimidas por el Estado. Resulta que hoy, los Guarany están aislados y necesitan tierras ambientalmente adecuadas para su reproducción física y cultural. Para esta solución es necesario descartar falsas versiones que atribuyen a la emigración oriunda del Paraguay de individuos Guarany el origen de un excedente demográfico en el Oco'y. Esta versión es utilizada para mascarar la resolución del problema de la tierra. El crecimiento demográfico en el es semejante al de otra cualquier aldea de la misma etnia. En verdad, no es la población indígena que es excesiva, sino el territorio donde fue localizada que se presenta insuficiente e inadecuado desde su instalación en el mismo. Situación que resulta de histórico no cumplimiento de las leyes por los poderes Ejecutivo y Judicial federales, favoreciendo así a grupos de poder locales. 


\section{SUMÁRIO}

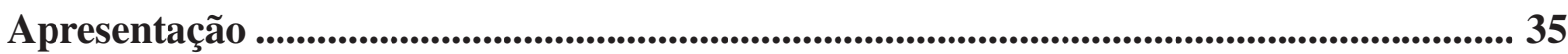

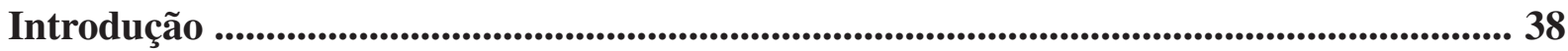

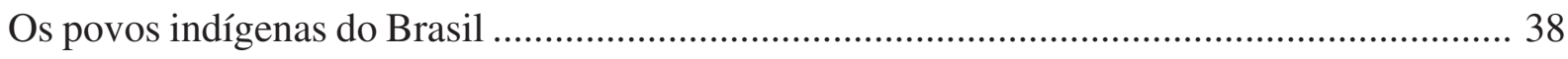

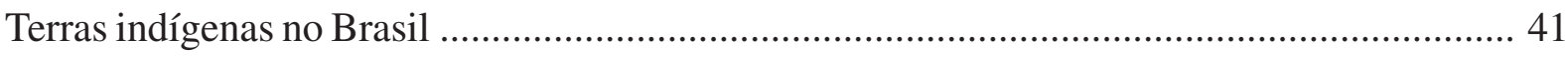

Distribuição da população indígena no Brasil .......................................................................... 45

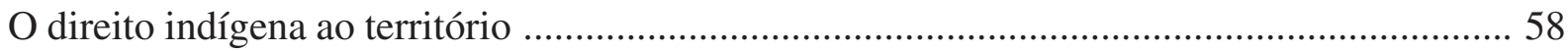

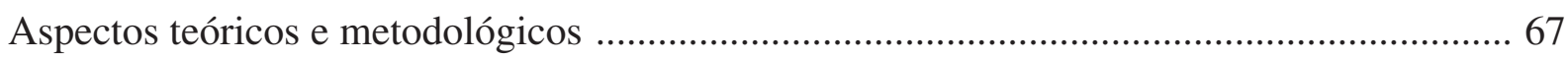

Capítulo 1 - A Ação Civil Pública no 87.101.8182-2 em que acusou os Avá-Guarani de

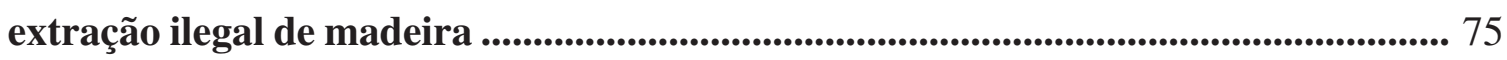

1.1. A suposta "extração" de madeira realizada pelos Guarani .............................................. 76

1.2. Sobre a questão formulada pela Justiça Federal de Foz do Iguaçu .................................. 87

Capítulo 2 - As populações indígenas Guarani ........................................................................... 91

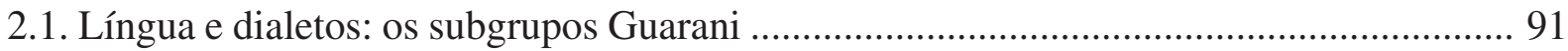

2.2. A imemorialidade da ocupação geográfica Guarani ....................................................... 92

2.3. A atual dispersão geográfica dos Guarani .............................................................. 93

2.4. Algumas características demográficas qualitativas ...................................................... 97

2.5. As formas de ocupação e mobilidade espacial Guarani no território .............................. 101

2.6. Crescimento demográfico e dispersão geográfica Guarani no Brasil, Paraguai e

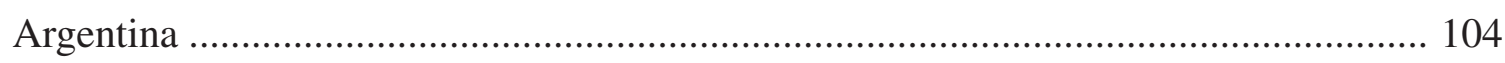

2.7. As terras Guarani oficializadas e as existentes de fato no Brasil .................................... 111

2.8. A ocupação Ñandeva no Tekoa Guassu ...................................................................... 113

2.9. Os conceitos de território e terra indígena ............................................................... 117

Capítulo 3 - Contexto de vida na Terra Indígena Avá-Guarani do Oco’y ........................ 119

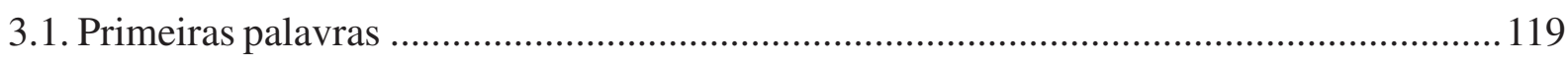


3.2. O depoimento dos idosos.....

3.3. Cântico Guarani entoado na Casa de Reza do Oco'y ................................................... 125

3.4. Morfologia geográfica da Terra Indígena Avá-Guarani do Oco’y

3.4.1. Cálculo aproximativo da área da Terra Indígena Avá-Guarani do Oco’y disponível às famílias indígenas

3.5. Características ambientais da Terra Indígena Avá-Guarani do Oco’y e seu entorno

3.5.1. A finalidade da APP do "lago": refúgio biológico de espécies da biodiversidade necessárias à subsistência dos Avá-Guarani ou mata ciliar de proteção das margens do reservatório da Usina Hidrelétrica de Itaipu?

3.5.2. A economia indígena tradicional Guarani

3.5.3. A economia Avá-Guarani de extrativismo e agricultura itinerante frente ao contexto fundiário/ambiental da Terra Indígena do Oco'y

3.5.3.1. As atividades de extrativismo

3.5.3.2. Agricultura

3.5.3.3. Artesanato 178

3.5.3.4. Relações monetárias com a sociedade externa 180

3.5.3.5. O direito à autossuficiência econômica versus assistencialismo imposto por falta de terras

3.6. Condições sanitário-ambientais: qualidade das águas; saneamento em terra; malária; contaminação por agrotóxicos

3.6.1. Qualidade das águas .... 187

3.6.2. O saneamento em terra 196

3.6.3. A malária 197

3.6.4. Os agrotóxicos 199

3.7. O contexto de saúde 222

3.8. O contexto de vida dos Avá-Guarani em Tekoa Ãnetete 229

\section{Capítulo 4 - A imemorialidade da ocupação Guarani no Oeste Paranaense e} seus direitos ao território 246

4.1. Esclarecimentos preliminares 246

4.2. A Imemorialidade da Ocupação Guarani no Tekoa Guassu. As Reduções Jesuíticas nos séculos XVI e XVII. Os Ataques Bandeirantes no século XVII. A resistência indígena: os Guarani no Tape e os Cainguá (Gente da Floresta) do Itatin e Guairá 
4.2.1. A imemorialidade da ocupação Guarani no Tekoa Guassu ........................................ 261

4.2.2. As Reduções Jesuíticas nos séculos XVI e XVII ......................................................... 266

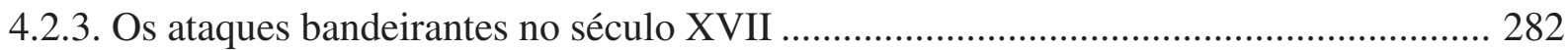

4.2.4. A resistência Guarani no Tape e os Cainguá (Gente da Floresta) do Itatin e do Guairá.. 288 4.3. A existência de 32 aldeias identificadas presentes no século XX no Oeste do Paraná.... 297

4.4. As formas pelas quais se deram os esbulhos das terras de onde os Guarani do Oco'y são provenientes, Aldeias: “Guarani” (década de 40), "São João Velho” (década de 60), “Colônia-Guarani”" (década de 70), e “Ocoy-Jacutinga (década de 70 e 80)”. 327

4.5. A persistência Guarani em se manter em seu território localizado no oeste paranaense .... 340

\section{Capítulo 5 - O processo oficialmente realizado de desterritorialização da população}

indígena Avá-Guarani da terra de ocupação tradicional Oco’y-Jacutinga e a reterritorialização na atual Terra Indígena Avá-Guarani do Oco’y. Aspectos antropológicos e jurídicos ........................................................................................................ 345

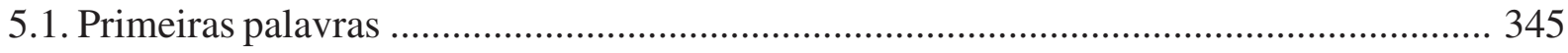

5.2. O processo histórico de esbulho ocorrido nas terras indígenas da região ........................ 347

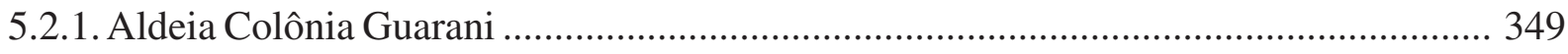

5.2.2. Aldeia Oco'y-Jacutinga: o processo de desterramento .............................................. 356

5.2.3. O INCRA promove a invasão do território indígena (1973) ...................................... 364

5.2.4. A Usina Hidrelétrica de Itaipu inunda o restante do território indígena (1982) ........... 368

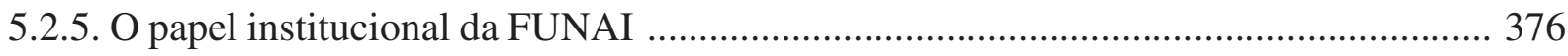

5.2.5.1. As ações dos Grupos de Trabalho/GTs ..................................................................... 377

5.2.5.1.1. As ações do primeiro Grupo de Trabalho/ GT FUNAI-INCRA (1977) ................ 377

5.2.5.1.2. Tratativas entre as Instituições FUNAI - ITAIPU. Período de 19.05 .77 a 22.06 .77 ... 381

5.2.5.1.3. As ações do segundo Grupo de Trabalho FUNAI-INCRA antes da inundação do

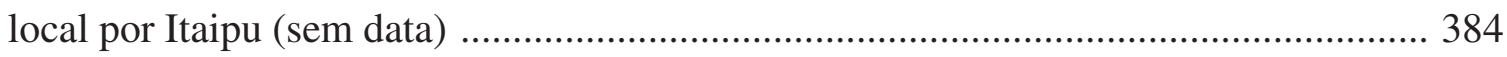

5.2.5.2. O Laudo Antropológico de Célio Horst: Os Critérios de Indianidade (1981) .......... 389

5.2.5.3. As tentativas de titulações individuais de terra aos indígenas pelos órgãos INCRA e

FUNAI. Tratativas entre as Instituições Governamentais: FUNAI - INCRA - ITAIPU.

E não governamentais: CJP e ANAI. Laudos Antropológicos e Cartas dos Guarani.

Período de 19/06/81 a 05/02/82

5.2.6. O espaço físico que foi oficializado ilegalmente da atual Terra Indígena Avá-Guarani do

Oco'y 408 
5.2.6.1. A ilegal passagem de "4 lotes individuais" de terras pelo INCRA, para somente 4 famílias indígenas $(177,5601 \mathrm{ha})$

5.2.6.2. A passagem de pequenas parcelas de terras pela Itaipu Binacional para os índios

Guarani: 88,5941 ha ou 73,5925 ha, ou na verdade 54,3199 hectares?

Única compensação em terras, realizada pela hidrelétrica 437

5.3. População versus território: muita gente para pouca terra 441

5.3.1. Análise demográfica da população sobre o território 442

5.3.2. Censo demográfico do Oco'y a partir de fontes históricas variadas 444

\section{Capítulo 6 - O Instituto Ambiental do Paraná/IAP pretendeu proibir os Guarani de} plantar na própria Terra Indígena Avá-Guarani do Oco'y ........................................ 447

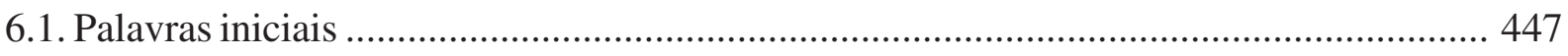

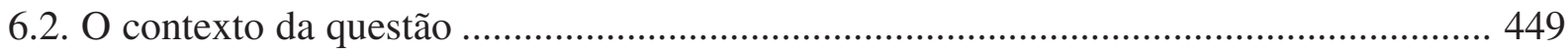

6.3. Os fatos que envolvem o contexto referente ao IAP proibir que os Guarani plantem na própria Terra Indígena Avá-Guarani do Oco’y

6.4. O problema colocado, origens e razões, segundo Rubem Thomaz de Almeida, antropólogo contratado pela Usina Hidrelétrica de Itaipu

6.5. A ação das instituições Usina Hidrelétrica de Itaipu, FUNAI e Prefeitura de São Miguel do Iguaçu que culminaram no problema

6.6. A beligerância entre índios Guarani e colonos: INCRA desapropria terra de colonos em função do reservatório e APP de Itaipu, coloca no local os Guarani e não indeniza os colonos 460

6.7. Razões colocadas pelo IAP para multar as três instituições 463

6.8. O que o IAP não observou, deixando de fiscalizar ..... 466

6.8.1. A determinação legal quanto à extensão da Área de Preservação Permante/APP do reservatório de Itaipu e a verdadeira extensão existente

6.8.2. A contaminação de todo ser vivente na Terra Indígena do Oco’y, em razão dos agrotóxicos utilizados pelos colonos lindeiros

6.8.3. A proximidade da população indígena ao reservatório da U. H. de Itaipu, razão pela qual os Guarani são contaminados pelo mosquito anófheles, transmissor da malária .... 477 


\section{Capítulo 7 - A Geopolítica da Tríplice Fronteira: O processo histórico de como a}

sociedade hegemônica construiu a região em função dos interesses do capital ...... 480

7.1. O processo de desconstrução do território indígena visando o domínio geopolítico estatal através da implantação da economia de mercado na região da Tríplice Fronteira 480

7.2. Conceitos fundamentais 482

7.3. A Geopolítica brasileira na região da Bacia Platina 504

7.3.1. Definição dos conceitos de Geografia Política e Geopolítica 504

7.3.2. O estado da arte da Geografia Política e da Geopolítica no Brasil 506

7.3.3. Preocupação geral da geopolítica brasileira desde os anos 20 do século XX:

o arranjo interno da unidade nacional e da integração territorial 508

7.3.4. Primeiras preocupações com as projeções externas do poder de Estado brasileiro - As ideias do General Mario Travassos 520

7.3.5. O Imperialismo norte-americano e a geopolítica de Golbery 529

7.3.5.1. O intervencionismo norte-americano sobre a América 529

7.3.5.2. Do ponto de vista do lado de cá: Golbery e as manobras geopolíticas destinadas: ao Brasil, ao continente sul-americano e na defesa do Atlântico Sul em 1952, 1959 e 1960 .... 574

7.3.6. As ditaduras militares e o modelo econômico desenvolvimentista implantado na América Latina

7.3.7. As manobras estratégicas da geopolítica brasileira no Prata ..................................... 666

7.4. Ser indígena numa sociedade regida pelo modo de produção capitalista. 795

Considerações finais 806

Referencias bibliográficas 819 


\section{LISTA DE ABREVIATURAS E SIGLAS}

ACP - Ação Civil Pública

AERBAU - Administração Executiva Regional de Bauru da FUNAI/SP

AERCW Administração Executiva Regional de Curitiba da FUNAI/PR

AERGU - Administração Executiva Regional de Guarapuava da FUNAI/PR

ALPRO - Aliança para o Progresso

AMOP - Associação dos Municípios do Oeste do Paraná

ARG - Argentina

APP - Área de Preservação Permanente

APS - Aborigenes Protection Society

BA - Bacia Amazônica

BIC - Business International Corporation

BIRD - Banco Interamericano de Desenvolvimento

BM - Banco Mundial

BR - Brasil

CENTO - Central Treaty Organization (Organização do Tratado Central)

CEPA - Centro de Estudos e Pesquisas Arqueológicas da UFPR

CIA - Central Intelligence Agency (Agencia Central de Inteligencia)

$\mathrm{CF}$ - Constituição Federal

CIMI - Conselho Indigenista Missionário

CJP - Comissão de Justiça e Paz

CGID - Coordenadoria Geral de Identificação e Demarcação de Terras Indígenas da FUNAI/DF

CGPIMA - Coordenadoria Geral de Patrimônio Indígena e Meio Ambiente da FUNAI/DF

CODESP - Companhia Docas do Estado de São Paulo

CSN - Companhia Siderúrgica Nacional

CTI - Centro de Trabalho Indigenista

CTL - Coordenação Técnica Local da FUNAI 
DAF - Diretoria de Assuntos Fundiários da FUNAI/DF substituído pela DPT

DEDOC - Departamento de Documentação da FUNAI/DF

DEID - Departamento de Identificação e Demarcação de Terras Indígenas da FUNAI/DF substituído pelo CGID

DEPIMA - Departamento de Patrimônio Indígena e Meio Ambiente da FUNAI/DF substituído pelo CGPIMA

DNPM - Departamento Nacional de Produção Mineral

DOU - Diário Oficial da União

DPT - Diretoria de Proteção Territorial da FUNAI/DF

DSEI - Distrito Sanitário Especial Indígena

DSN - Doutrina de Segurança Nacional

EI - Estatuto do Índio. Lei nº 6001. 19.12.1973.

EROS - Earth Resources Observation Sattelite Program

EUA - United States of America (Estados Unidos da America)

FAB - Força Aérea Brasileira

FBI - Federal Bureau of Investigation (Escritório Federal de Investigação)

FEB - Força Expedicionária Brasileira

FOIRN - Federação das Organizações Indígenas do Rio Negro

FFLCH - Faculdade de Filosofia, Letras e Ciências Humanas da Universidade de São Paulo/SP

FUNAI - Fundação Nacional do Índio

FUNASA - Fundação Nacional de Saúde

GC - Gleba de Colonos

GT - Grupo de Trabalho

$\mathrm{HA}$ - hectare

IAP - Instituto Ambiental do Paraná em Curitiba/Pr

IB - Itaipu Binacional

IBAMA - Instituto Brasileiro do Meio Ambiente e dos Recursos Naturais Renováveis

IBCCF - Instituto de Biofísica Carlos Chagas Filho da UFRJ

IBGE - Instituto Brasileiro de Geografia e Estatística

INCRA - Instituto Nacional de Colonização e Reforma Agrária

ISA - Instituto Socioambiental

JF - Justiça Federal 
JK - Juscelino Kubitschek

LA - Laudo Antropológico

LASO - Latin American Security Operation (Operação Latino Americana de Segurança)

MAB - Movimento dos Atingidos por Barragens

MINTER - Ministério do Interior

MJ - Ministério da Justiça

MMA - Ministério do Meio Ambiente

MPF - Ministério Público Federal

MST -Movimento dos Sem Terra

NESC - Núcleo de Estudos de Saúde Coletiva do Centro de Ciências da Saúde/CCS/UFRJ

NPRs - Notas Promissórias Rurais

OEA - Organização dos Estados Americanos

OG - Organização Governamental

OIT - Organização Internacional do Trabalho

ONG - Organização Não Governamental

OTAN - Organização do Atlântico Norte

OTASE- Organização do Tratado da Ásia do Sudeste

PGR - Procuradoria Geral da República

PI - Posto Indígena da FUNAI substituído por CTL

PIA - Parque Indígena Aripuanã

PIB - Produto Interno Bruto

PIN - Plano de Integração Nacional

PNB - Produto Nacional Bruto

PNI - Parque Nacional do Iguaçu/Pr

PNUMA - Programa das Nações Unidas para o Meio Ambiente

PPTAL - Projeto Integrado de Proteção às Populações e Terras Indígenas da Amazônia Legal

PR - Paraná

PUC - Pontifícia Universidade Católica de São Paulo/SP

PNX - Parque Nacional do Xingu

PY - Paraguai

RADAM - Radar Amazônia

VI ${ }^{\circ}$ CCR - Sexta Câmara de Coordenação e Revisão da Procuradoria Geral da República/ Ministério Publico Federal em Brasília/DF 
SMS - Secretaria Municipal de Saúde

SOA - School of the Americas - Escola das Américas

SOA Watch - School of Americas Watch - Observador da Escola das Américas

SPI - Serviço de Proteção ao Índio

SPU - Secretaria de Patrimônio da União

TAC - Termo de Ajuste de Conduta

TI - Terra Indígena

UC - Unidade de Conservação

UFRJ - Universidade Federal do Rio de Janeiro

UHE - Usina Hidrelétrica de Itaipu

UFPR - Universidade Federal do Paraná

UFRJ - Universidade Federal do Rio de Janeiro

URSS - União das Repúblicas Socialistas Soviéticas

US-AID - Agência Internacional de Desenvolvimento dos Estados Unidos

USARCARIB - Escola do Caribe do Exército dos EUA

USARSA - United States Army School of the Americas - Escola das Américas do Exercito dos EUA

USP - Universidade de São Paulo/SP

WHINSEC - Western Hemisphere Institute for Security Cooperation - Instituto do Hemisfério Ocidental para a Cooperação em Segurança 


\section{LISTA DE TABELAS}

Tabela A. Situação fundiária das Terras Indígenas no Brasil em 2006 45

Tabela B. Situação fundiária das Terras Indígenas no Brasil em 2013 46

Tabela C. Brasil - Estrutura Fundiária - Estabelecimentos Rurais e Área Ocupada em Hectares. 1940 a 1995/6 48

Tabela D. Estrutura Fundiária dos Estabelecimentos Rurais em 1940. Os extremos em termos de extratos de áreas (pequena e grande propriedade)

Tabela E. Estrutura Fundiária dos Estabelecimentos Rurais em 1995/6. Os extremos em termos de extratos de áreas (pequena e grande propriedade) 49

Tabela 2.1. População Guarani no Brasil, Paraguai e Argentina/2001 105

Tabela 2.2. População Guarani no Brasil, Paraguai e Argentina/2004 106

Tabela 2.3. População Guarani no Brasil, Paraguai e Argentina/2008 106

Tabela 2.4. Comportamento demográfico da população Guarani nos três países da Tríplice

Fronteira: Brasil, Paraguai e Argentina ao longo de 2001-2004-2008 107

Tabela 2.5. Porcentagens de variação do comportamento demográfico da população

Guarani nos três países da Tríplice Fronteira: Brasil, Paraguai e Argentina ao longo de 2001-2004-2008, tendo como ano-base 2001

Tabela 2.6. Comportamento demográfico da população Guarani no

Brasil /2001-2004-2008 108

Tabela 2.7. Comportamento demográfico da população Guarani no Paraguai /2001-2004-2008

Tabela 2.8. Comportamento demográfico da população Guarani no Argentina /2001-2004-2008 109

Tabela 2.9. Porcentagens de crescimento demográfico em cada um dos países, Br, Py e Arg. por subgrupo étnico, de 2001 a 2008

Tabela 3.1. As medidas contadas da beira do lago ao colono lindeiro, passando por cada residência indígena, de ambos os lados da TI. Inseridas todas as habitações existentes em número de 95 (outubro/2001) 138

Tabela 3.2. Terra Indígena Avá-Guarani do Oco’y. Comparativo entre a área repassada como 
compensação pela UHE Itaipu, demarcada pela FUNAI, as frações em sobreposição e a verdadeira área disponível aos Guarani

Tabela 3.3. Distribuição das partes do território através do tempo destinado a cada Unidade Familiar Extensa/UFE da Terra Indígena Avá-Guarani do Oco’y

Tabela 3.4. Terra Indígena Avá-Guarani do Oco’y. Disponibilidade de terra para cada família extensa

Tabela 3.5. Largura média da Faixa de Proteção da Usina Hidrelétrica de Itaipu na margem esquerda do Rio Paraná

Tabela 3.6. Condições de produção do artesanato vendido Terra Indígena Avá-Guarani do

Oco’y

Tabela 3.7. Histórico de aplicação em ciclo anual de borrifação dos agrotóxicos 202

Tabela 4.1. 32 (trinta e duas) Terras Indígenas Guarani recentemente invadidas e ocupadas no século XX no Oeste do Estado do Paraná / BRASIL 315 a 318

Tabela 4.2. 7 (sete) Terras Indígenas Guarani recentemente invadidas no século XX no Paraguai

Tabela 4.3. População Indígena vinculada a Coordenação Técnica Local/CTL Costa Oeste do Paraná subordinada a Coordenação Regional da FUNAI de Chapecó/SC 342

Tabela. 5.1. Pelo menos 10 aldeias Guarani existiam ainda em 1940 360

Tabela 5.2. REGISTRO GERAL MATRÍCULA Nº 8933 / 8934 / 8935 / 8936 LIVRO Nº 2. Cartório de ARLEI COSTA - Oficial de Registro de Imóveis. Município de SÃO MIGUEL do IGUAÇU - EST. PARANÁ. Assina o documento pelo cartório, o Escrivão Distrital, João Cornella Fagion. Partes contratantes: INCRA e Comunidade Indígena AvaGuarani assistida pela FUNAI. Data do documento 25/08/83 e 29/08/83. Data da assinatura em Cartório 26.07.85

Tabela 5.3. Incra titula terras para 4 famílias indígenas. Registro Geral de Matrícula no 8933 (tomado um registro como exemplo). (Anexo no $11 \mathrm{~F} 1$ ) 435

Tabela 5.4. Escritura Pública de Doação que fazem Pedro Alves e Outros, em favor de Comunidade Indígena Avá-Guarani. (Anexo nº $11 \mathrm{G}$ ) 436

Tabela 5.5. Censo demográfico do Oco’y a partir de fontes históricas variadas. .444 a 445

Tabela 7.1. Representantes dos governos civis, respectivos anos do Golpe de Estado e governos militares 569

Tabela 7.2. Crescimento populacional de Foz do Iguaçu: 1889 a 2003 732

Tabela 7.3. Repasse atual e acumulado de royalties de Itaipu aos 16 municípios lindeiros ... 747 Tabela 7.4. 16 municípios lindeiros e correspondente área alagada .747 a 748 


\section{LISTA DE FIGURAS}

CD - Figura A. Mapa das Terras Indígenas no Brasil 52

Figuras 1 e 2. Madeiras desvitalizadas no interior do reservatório de Itaipu em frente à TI

do Oco'y e APP de Itaipu 78

Figuras 3 e 4. Madeiras desvitalizadas ás margens do reservatorio de Itaipu, em frente à

TI do Oco’y e APP de Itaipu ..... 79

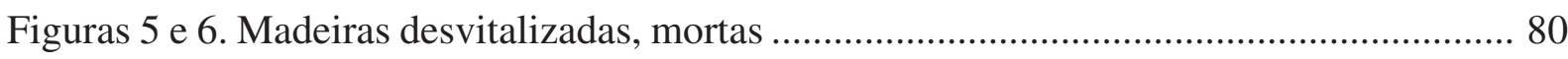

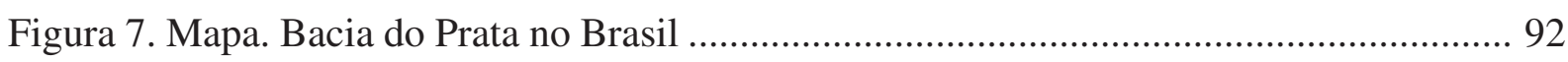

Figura 8. Mapa do Peabiru em ramificação percorrida por Cabeza de Vaca (1540) ................ 94

CD-Figura 9. Mapa. Dispersão geográfica atual Guarani no Brasil, Paraguai e

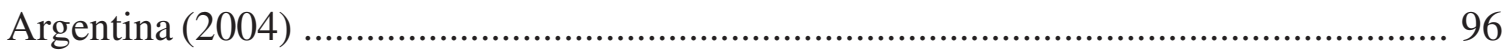

CD-Figura 10. Mapa. Os Guarani na fronteira Brasil, Paraguai e Argentina/2008 ................. 97

Figura 11. Região onde se realiza o Oguata Porã (a Bela Caminhada) ................................ 103

Figura 12. Mapa aproximado dos limites de circulação tradicional Ñandeva ......................... 114

Figura 13. Foto Aérea. TI Avá-Guarani do Oco’y/São Miguel do Iguaçu/ Paraná ................ 130

Figura 14. Foto aérea da situação do entorno da TI do Oco’y considerando as Glebas de

Colonos/ São Miguel do Iguaçu/ Paraná

Figura 15. Foto aérea da parte sul do reservatório da UHE Itaipu, TI Avá-Guarani do

Oco’y e parte do Parque Nacional do Iguaçu/ Paraná

Figura 16. Foto aérea da totalidade do reservatório da UHE Itaipu e parte do

Parque Nacional do Iguaçu/ Paraná

CD-Figura 17. Planta da demarcação da TI Avá-Guarani do Oco’y/São Miguel do Iguaçu/Pr

CD-Figura 18. Croqui. Cálculo da medição transversal, contada da beira do lago ao colono lindeiro, passando por cada residência indígena, referente à área territorial disponível aos Guarani, de ambos os lados da TI. Inseridas todas as habitações existentes em número de 95 (outubro/2001)

Figura 19. Croqui. Área da Terra Indígena Avá-Guarani do Oco’y demarcada 139

Figura 20. Croqui. Área da APP de Itaipu sobreposta à Terra Indígena Avá-Guarani do Oco’y demarcada 
Figura 21. Croqui. Área da APP de Itaipu e terra invadida pelos colonos sobrepostas

à Terra Indígena do Oco’y demarcada 140

Figura 22. Croqui. Reservatório de águas, Faixa de Segurança e área marginal de Área de

Preservação Permanente da Usina Hidrelétrica de Itaipu em frente a

Terra Indígena Avá-Guarani do Oco’y

Figura 23. Foto. Residência Avá-Guarani na Terra Indígena do Oco’y

Figura 24 A e B. Foto. Pátio de reuniões. Em círculo mulheres de um lado,

homens de outro

Figura 25. Foto. Caminho de residência indígena passando pela APP em direção ao

reservatório da Usina Hidrelétrica de Itaipu

Figura 26. Foto. Crianças brincam no quintal da residência

Figura 27. Foto. Pajé conhecedor das ervas, demonstrando os remédios existentes na mata ... 171

Figura 28. Foto. Exemplo da situação quanto à disponibilidade territorial de uma família ... 175

Figura 29. Foto. Limites territoriais da Terra Indígena: entre o reservatório e os colonos .... 175

Figura 30. Foto. Imagem de roça familiar. Residência de Seu Guilherme

Figura 31. Maio de 1982. O artesanato que havia sido produzido no Oco'y-Jacutinga e foi trazido para o Oco'y

Figura 32. Foto. Acesso a água (barrenta, turva) quando passaram a viver no Oco’y em maio de 1982, o próprio Córrego Santa Clara, antes da inundação do reservatório da Itaipu ... 188

Figura 33. Foto. Acesso a água quando passaram a viver no Oco’y em 1982

Figura 34. Foto. Crianças como de costume banhando-se no reservatório da

Itaipu Binacional

Figura 35. Foto. Funcionário da Secretaria Municipal de Saúde de São Miguel do Iguaçu

(04/2002) colhendo lâmina p/ diagnóstico e controle de malária no Oco’y

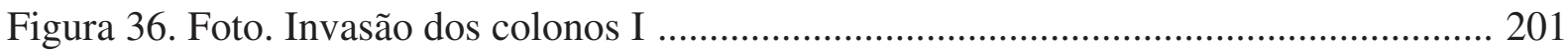

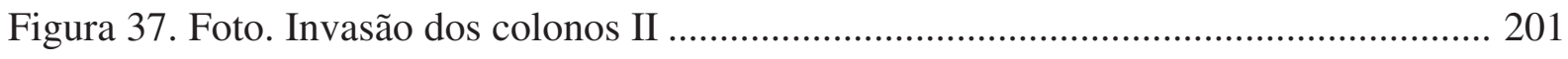

Figura 38. Croqui. Visão virtual e cinemática quanto ao uso de agrotóxicos pelos colonos

lindeiros e impactos sanitário-ambientais provocados na Terra Indígena

Figura 39. Foto. Veículo da FUNAI em estrada em frente à residência de Seu Guilherme e

gleba do colono lindeiro ao fundo. Área em aclive

Figura 40. Foto. No mesmo local, um pouco abaixo, foto realizada da "varanda" da casa de

Seu Guilherme, sobre o seu quintal/roça, o mesmo veículo parado na estrada da foto acima. Terreno em aclive 
Figura 41. Foto. Foto realizada da "varanda" da residência de Seu Guilherme em direção oposta, voltada à área do reservatório, local esse que se apresenta como também parte do roçado e área de coleta desta família, assim como também é APP de Itaipu. Terreno em declive

Figura 42. Foto. Colono pulverizando os agrotóxicos em terras já invadidas da Comunidade Indígena do Oco’y

Figura 43. Foto. Galinhas do Oco’y em área invadida pelos colonos, ciscando em local contaminado pelo agrotóxico 208

Figura 44. Foto. Crianças sendo pesadas na TI do Oco'y 223

Figura 45. Mapa. Estado do Paraná. Mesorregiões geográficas ....

Figura 46. Mapa. Tríplice Fronteira entre Brasil, Paraguai e Argentina. Parque Nacional do Iguaçu. Usina Hidrelétrica de Itaipu. Terra Indígena Avá-Guarani do Oco’y 254

Figura 47. Mapa. O Caminho do Peabiru 263

Figura 48. Mapa. Pesquisas Arqueológicas desenvolvidas pelo CEPA/UFPR no Estado do

Paraná e adjacências, que revelaram sítios e fases da Tradição Tupiguarani. (2002) ..... 264

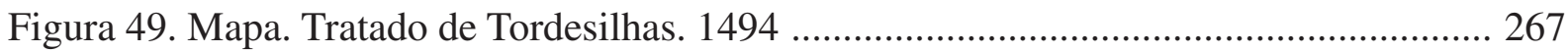

CD-Figura 50. Viagem de Ulrich Schmidel ao Sul. 1552/1553 .......................................... 271

CD-Figura 51. Mapa. Peabiru e ramais. Comunidades espanholas e Reduções Jesuíticas dos séculos XVI e XVII no Guaíra/PR e no Tape/Sete Povos das Missões/RGS, localizadas em terras de tradicional ocupação Tupi-Guarani 273

Figura 52. Mapa. Reduções Jesuíticas no Sul: Guairá, Tape e Itatin ................................... 274

Figuras 53. Província do Paraguai no início do século XVII ............................................... 276

Figuras 54. Província do Paraguai no início do século XVII ................................................. 277

Figura 55. Imagem. Construção de uma redução jesuítica no Guairá ................................... 278

Figura 56. Tradição arqueológica Tupiguarani no estado do Paraná (1976) ........................ 281

Figura 57. Mapa. Rumos da expansão bandeirante ............................................................... 283

Figura 58A. Mapa. Ataques bandeirantes ao Paraná, especialmente no Guairá.

Período de 1580-1600 285

Figura 58B. Mapa. Ataques bandeirantes ao Paraná, especialmente no Guairá.

Período de 1600-1620 286

Figura 58C. Mapa. Ataques bandeirantes ao Paraná, especialmente no Guairá.

Período de 1620-1640 
Figura 59. Imagem. Cunhambebe, líder da Confederação dos Tamoios; simboliza a resistência indígena ao domínio europeu

Figura 60. Mapa. Urnas assinalando os pontos de coleta arqueológica nas proximidades

da Colônia Militar de Foz do Iguaçu, entre 1892 e 1894. (mapa extraído de Ambrosetti, 1895

CD-Figura 61. Mapa. Mapa etno-histórico do Brasil apontando a presença tradicional Guarani inclusive na região de interesse desta pesquisa, Oeste do Paraná. 1944. (Região do Tekoa Guassu)

Figura 62. Mapa. Ocupação territorial Ñandeva (Txiripá), Mbya e Kaiowá (Paí-Tavyterã)

na região de confluência entre as três fronteiras, Brasil, Paraguai e Argentina 303

Figura 63. Mapa A. Chegada da colonização no oeste paranaense do período de 1860 a 1880, incidindo sobre as terras de ocupação tradicional Guarani 305

Figura 63. Mapa B. Chegada da colonização no oeste paranaense do período de

1880 a 1900, incidindo sobre as terras de ocupação tradicional Guarani 306

Figura 63. Mapa C. Chegada da colonização no oeste paranaense do período de 1900 a 1920, incidindo sobre as terras de ocupação tradicional Guarani 307

Figura 63. Mapa D. Chegada da colonização no oeste paranaense do período de 1920 a 1940, incidindo sobre as terras de ocupação tradicional Guarani 308

Figura 63. Mapa E. Chegada da colonização no oeste paranaense no período de 1940 a 1960, incidindo sobre terras de ocupação tradicional Guarani, porém, ficando livre Oco'y-Jacutinga e aldeias próximas 309

CD-Figura 64A. Mapa. Identificação de 32 aldeias Guarani desaparecidas no oeste paranaense a partir de 1940 até 1982, em fração do Tekoa Guassu, território na banda brasileira. Situação fundiária indígena geral, atualmente no estado do Paraná (2002); Indicativos da situação fundiária atual da sub-família Avá-Guarani no Paraná (2002) ....311 CD-Figura 64B. Mapa. Identificação de 32 aldeias Guarani desaparecidas no oeste paranaense a partir de 1940 até 1982, em fração do Tekoa Guassu, território na banda brasileira. Situação fundiária indígena geral, atualmente no estado do Paraná (2002); Indicativos da situação fundiária atual da sub-família Avá-Guarani no Paraná (2002). Mapa original somente em CD

Figura 65. Mapa de las parcialidades indígenas del Paraguay 319

Figura 66. Mapa. Mapa dos Departamentos (estados) do Paraguai 320

Figura 67. Foto. Homenagem a Dona Narcisa Tacua Catu de Almeida (in memoriam) 330 
Figura 69 A e B. Fotos. Recipiente cerâmico da tradição Tupiguarani removido da área do

Parque Nacional do Iguaçu 336 a 337

CD-Figura 70. Mapa A Imemorial Terra de Ocupação Tradicional Guarani do

Oco’y-Jacutinga uma das regiões de ocupação tradicional dos Avá-Guarani, anterior à década de 40/século XX 358

CD-Figura 70. Mapa B. Base Cartográfica que indica a presença limítrofe ao Ocoy-Jacutinga de outras nove aldeias Guarani, entre o Rio Ocoí e o Rio Paraná correspondente as Imemoriais Terras de Ocupação Tradicional Guarani

Figura 71. Croqui A. Território do Oco’y-Jacutinga, cortado pela estrada estadual

Foz-Guaíra. Década de 40. Reduzido à 1500ha 362

Figura 71. Mapa B. O território de ocupação do Oco’y-Jacutinga segundo a ABA (1981).. 363

Figura 72. Croqui A. Os Guarani são empurrados pelo PIC OCOI I-INCRA para beira do rio

Paraná, ainda parte do território indígena, local previsto para ser inundado pela Itaipu pelo PIC-OCOI II - INCRA (Decreto de 1971)

CD-Figura 72. Croqui B. O Oco'y-Jacutinga invadido pelo INCRA (1973) e tomado pelos colonos (1976), recém retirados do PNI. 1/3 (4168 ha) do “Terreno OCOI” (12500 ha), denominado de "área útil” pelo PIC-OCOI I-INCRA é ocupado pelos colonos à leste. A presença indígena próxima ao rio Paraná, ainda em território indígena (1976) à oeste. A Funai chega ao local em 1977 e não reconhece o "território de imemorial ocupação Guarani”. Segundo Itaipu os Guarani ocupavam 100 ha neste local 368

Figuras 73. Imagem A. A Oeste a região original do Oco'y-Jacutinga que foi inundado pela represa da Usina Hidrelétrica de Itaipu. 1982. Área superior aos 100 ha informados pela mesma. Na verdade 2/3 do território indígena original, conforme previsto pelo PIC-OCOI II-INCRA, 8.332 hectares aproximadamente. No centro a Terra Indígena do Oco’y (1982), com 231,88 hectares. Detalhe da ilha (100 ha) onde Itaipu pretendia reassentar os Guarani. No extremo leste, o rio Ocoí desaguando na represa da hidrelétrica 373

Figuras 73. Imagem B. Área original do Ocoy-Jacutinga prevista pelo PIC-OCOI II -INCRA para ser inundada por Itaipu, aproximadamente 8332 ha. Detalhe da ilha (100 ha) onde Itaipu pretendia reassentar os Guarani. Área original do Ocoy-Jacutinga que foi ocupada pelos Colonos através do PIC OCOI I-INCRA em 1973, aproximadamente 4168 ha ... 374 Figuras 73. Imagem C. Visão do conjunto das áreas lago de Itaipu, Terra Indígena do Oco’y e Parque Nacional do Iguaçu 
Figuras 73. Imagem D. Visão do conjunto das áreas lago de Itaipu, Terra Indígena do Oco’y e Parque Nacional do Iguaçu .....

Figura 74. Croqui. Simulação aproximada do que acontece atualmente na TI do Oco’y com referencia as três áreas superpostas: Terra de Colonos; Terra Indígena; e Área de Preservação Permanente de Itaipu 440

Figura 75A. Foto. Murundu criado pela Itaipu, FUNAI e Prefeitura de São Miguel do

Iguaçu na "divisa" entre os colonos e os Guarani 448

Figura 75B. Foto. Murundu na "divisa” entre o reservatório e os Guarani e terra desmatada na TI

Figura 75C. Mapa. Larguras do reservatório da Usina Hidrelétrica de Itaipu em frente a

Terra Indígena do Oco’y 469

Figura 76. Presidente da Republica do Brasil: Getulio Vargas 508

Figura 77. Mapa Territórios Federais. Iguaçu, Ponta Porã, Guaporé, Rio Branco, Amapá e

Fernando de Noronha.

Figura 78. O quadro denominado Progresso Americano de John Gast de 1872

Figura 79. Foto do Presidente estadounidense Theodore D. Roosevelt

Figura 80. Ilustração demonstrando Roosevelt conduzindo a Marinha Norte-Americana ao

Mar do Caribe, para atacar os países da America Central .

Figura 81. Instalações onde funcionou a Escola de das Américas no Panamá

Figura 82. Emblema atual do Western Hemisphere Institute for Security Cooperation

(WHINSEC) - Instituto do Hemisfério Ocidental para a Cooperação em Segurança .... 555

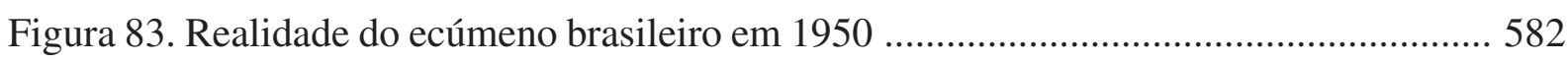

Figura 84. A ideia de manobra geopolítica para a integração e valorização do território nacional 584

Figura 85: Manobra geopolítica para integração do território nacional de Golbery .............. 586

Figura 86. JK eleito Presidente do Brasil em 1956. ............................................................... 596

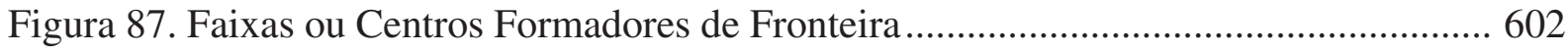

Figura 88. Mapa. Compartimentação Geopolítica da America do Sul ................................. 610

Figura 89. O “Império Brasileiro”. Áreas Ecumênicas e Geopolíticas ................................. 612

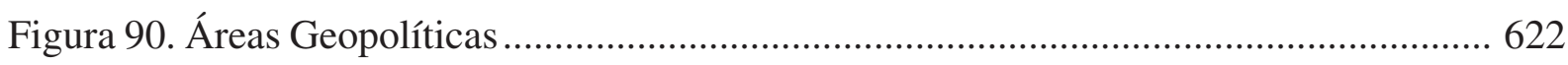

Figura 91. Inauguração da Estrada de Ferro Brasil-Bolívia em 05.01.1955 ........................ 667

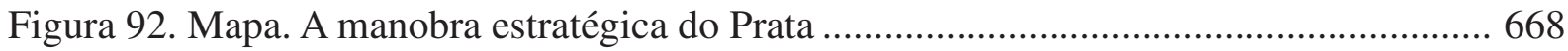

Figura 93. Terminal de contêineres do Porto de Santos, o maior da América do Sul ............ 669 
Figura 94. Ruta Nacional N² 2. "Mariscal José Félix Estigarribia”. Assunção - Cel Oviedo .... 672 Figura 95. Ruta Nacional N 7. "Dr. José Gaspar Rodríguez de Francia".

Cel Oviedo - Ciudad Del Este 672

Figura 96. A ponte da Amizade Brasil-Paraguai 675

Figura 97. BR-277. Porto de Paranaguá a Foz do Iguaçu. Brasil. 678

Figura 98. Porto de Paranaguá na Baía de Paranaguá . 679

Figura 99. Rio Paraná, a Usina Hidreletrica de Itaipu e o vertedouro 689

Figura 100. Informações sobre Foz do Iguaçu 734

Figura 101. Turismo em Foz. "O Marco das Três Fronteiras recebeu a visita da

Coluna Prestes" 736

Figura 102. Turismo em Foz. Vista aérea da Usina Hidreletrica de Itaipu, "a maior do mundo em geração de energia"

Figura 103. Turismo em Foz. Cataratas JL Shopping, "o maior shopping center do oeste paranaense" 738

Figura 104. Turismo em Foz. "Panorama do lado brasileiro das Cataratas do Iguaçu.

Ao fundo é possível ver a passarela do lado argentino"

Figura 105. Turismo em Foz. Mesquita Omar Ibn Al-Khattab; "a cidade abriga a segunda

maior comunidade muçulmana do Brasil"

Figura 106. Turismo em Foz. "Ponte Internacional da Amizade"

Figura 107. Turismo em Foz. "O Espaço das Américas, localizado junto ao Marco das

Três Fronteiras: do lado esquerdo, a fronteira com a Argentina (delimitada pelo Rio

Iguaçu) e do direito, com o Paraguai (delimitada pelo Rio Paraná)"

Figura 108. Turismo em Ciudad del Este. Turismo de compras no Centro de

Ciudad del Este 742

Figura 109. Faixa de influencia dos brasileiros no Paraguai ................................................. 762

Figura 110. Evolução do desmatamento no estado do Paraná. 1900-2000 807

Figura 111. Ocupantes Guarani do PNI. O Sr. da direita com 100 e poucos anos,

liderança espiritual, é irmão de Dona Narcisa, ambos quando crianças viveram na Aldeia Guarani, no que hoje é considerado o PNI 808

Figura 112. Foto de reunião na Justiça Federal ...................................................................... 809

Figura 113. Cacique Simão Villalva baleado nas costas ........................................................ 811

Figuras 114. (Fotos A, B, C, D e E) Outras lideranças indígenas baleadas .812 a 814

Figura 115. As armas utilizadas. De um lado armas de fogo e balas de borracha.

De outro estilingue com balas de barro 


\section{LISTA DE ANEXOS}

\section{Capítulo 3}

Anexo 10. Memorial Descritivo da Terra Indígena Avá-Guarani do Oco’y.

Anexo 1. RIBEIRO, Mucio Nobre Costa. Terra Indígena Avá-Guarani do Oco’y. Diagnóstico Preliminar sobre a qualidade das águas. DEPIMA/FUNAI/Brasília. Julho/2002. 70 p.

Anexo 2. Documento $\mathrm{n}^{\circ}$ GB-FI/2002/00120-0, com pedido formal de informações específicas, dirigidas ao Dr Antonio Correa Ribas, na época Diretor Geral da Itaipu Binacional.

Anexo 3. Matéria do jornal Gazeta do Povo de 17.05.2002 sob o título "Surto de malária atinge 37 índios. A maioria são crianças avá-guarani da reserva de Ocoí”.

Anexo 4. Prontuários de saúde de alguns habitantes indígenas de Oco’y.

Anexo 5. Enviado em 06.11.2001 o ofício nº 01/AERBAU/FUNAI/SP para a Fundação Nacional da Saúde em Curitiba/ FUNASA /Ministério da Saúde .

Anexo 6. Parecer DIESP n ${ }^{\circ}$ 02, sem data, assinado por Sonia de Paula Borba/ Chefe DIESP.

Anexo 7. Parecer Médico assinado pela Dra Maria das Graças Serafim de data equivocada, 21.01.2001.

Anexo 8. Lista dos produtos agrotóxicos que são utilizados na região por alguns colonos lindeiros à Terra Indígena, fornecida pela Secretaria de Agricultura de São Miguel do Iguaçu/Pr.

Anexo 9. Moraes, Julio Cesar de. Agrotóxicos no entorno da Terra Indígena Avá-Guarani (Oko’y), em São Miguel do Iguaçu-PR: Sobrevivência física e cultural em risco da população indígena Avá-Guarani. Administração Executiva Regional da FUNAI em Bauru/AERBAU-SP: julho de 2004; MALM, O. \& outros. Relatório de visita da equipe do Núcleo de Estudos de Saúde Coletiva/NESC e do Instituto de Biofísica Carlos Chagas Filho/IBCCF da Universidade Federal do Rio de Janeiro/UFRJ à aldeia Avá-Guarani situada na região do Oco’y Jacutinga, município de São Miguel do Iguaçu/Pr, à convite da FUNAI/Ministério da Justiça/MJ. Rio de Janeiro: NESC-IBCCF/UFRJ. 11p; e, MALM, O. \& outros. Avaliação do contexto de saúde humana e ambiental, com ênfase na contaminação por metais pesados e 
pesticidas, junto à população Guarani da Terra Indígena Avá-Guarani (Oco’y), desterrados de seu imemorial território de ocupação tradicional por Grandes Projetos (Parque Nacional do Iguaçu e UHE Itaipu) e circundados por áreas agrícolas de monoculturas. Rio de Janeiro: NESC-IBCCF/UFRJ; AERBAU-CGPIMA/FUNAI; Projeto apresentado ao Edital 038/2005 - CNPQ. 2006. 25 p.

\section{Capítulo 5}

Anexo n. 1: Documentos pertinentes às decisões fundiárias referentes a aldeia Colônia-Guarani/ Três Lagoas/ Foz do Iguaçu. 5 documentos do ano de 1976. 9 páginas.

Anexo n. 1A: Ofício 045/76 - GAB/4 DR/ FUNAI/Curitiba 20.02.76. 3 páginas.

Anexo n. 1B: Ofício INCRA - 4(09) n 1733/76, Curitiba 24.05.76. 1 página.

Anexo n. 1C: Memo $n^{\circ}$ ?/GAB/4 DR/FUNAI, Curitiba 28.05.76. 1 página.

Anexo n. 1D:Ofício FUNAI. $n^{\circ}$ ?, junho/76 (dirigido ao Presidente do INCRA). 2 páginas.

Anexo n. 1E: Processo CR (09) 1142/76, INCRA, Curitiba (09) T- 29.06.76. 2 páginas.

Anexo n. 2: Fotografias da Aldeia Colônia-Guarani/Três Lagoas/ Foz do Iguaçu de 1958, comprovando a existência da aldeia na região. 11 fotografias.

Foto A; Foto B; Foto C; Foto: D; Foto: E; Foto F; Foto G; Foto H; Foto I; Foto J; Foto K.

Anexo n. 3: Portaria n. 162/P de 23.03.1977 instituindo Grupo de Trabalho/GT sem a presença de Antropólogo. 1 página.

Anexo n. 4: Oficio do INCRA PIC OCOI $n^{\circ} 140 / 77$ de 20.04.77, recenseando a população Guarani do Oco'y-Jacutinga e informando a posteriori a FUNAI. 1 página.

Anexo n. 5: Primeiro GT FUNAI/INCRA em 19.04.1977 e Tratativas entre as Instituições FUNAI - ITAIPU. Período de 19.05.77 a 22.06.77. 5 documentos /1977. 23 páginas.

Anexo n. 5A: Relatório Final FUNAI/INCRA do Subgrupo de Trabalho XV, GT em campo sem prévio Laudo Antropológico, 19.04.1977. 17 páginas.

Anexo n. 5B: Documento Interno do Diretor do Departamento Geral de Operações para o Presidente da FUNAI Gerson da Silva Alves, of.n(apagado)/DGO/77.19.05.77. 2 páginas.

Anexo n. 5C: Documento do Servidor Saul Carvalho Lopes de junho de 1977 ao Chefe da DR de Curitiba/FUNAI. 1 página.

Anexo n. 5D. Ofício do Presidente da FUNAI, General Ismarth de Araujo Oliveira para o Presidente de Itaipu General José Costa Cavalcanti, oficio n²85/PRES/BSB de 01/06.1977. 2 páginas. 
Anexo n. 05E. Ofício complementar n 04(?)6/GAB/P de 22.06.1977 do Presidente da FUNAI para o Presidente da Itaipu. 1 página.

Anexo n. 6. Segundo GT da FUNAI em campo, sem prévio Laudo Antropológico. Relatório de Viagem Edivio Battistelli, FUNAI, sem data, processo n. 1053/1976, fls. 143/44/45. 3 páginas.

Anexo n. 7: Laudo Antropológico. Célio Horst (ITE n 023/81-AGESP), 03.06.1981. 7 páginas.

Anexo n. 8: Critérios de Indianidade. Célio Horst: "Gráfico Demonstrativo da Identificação Étnica dos Habitantes do PIC-OCOI/Mun. de Foz do Iguaçu/PR. 05.81”. 3 páginas.

Anexo n. 9: Documentos a respeito de Títulos definitivos de Propriedade da Terra para Indígenas. 15 documentos. 54 páginas.

Anexo n. 9A. DOC FUNAI of. n. 260/81/4 DR Curitiba, 19/06/1981 do Delegado Regional da $4^{\circ}$ DR Harry L. Ávila Teles para o Coord. Geral da Coordenadoria Regional do INCRA Curitiba. Dr. José Guilherme Lobo Cavagnari. 2 páginas.

Anexo n. 9B. Ofício INCRA - 4 (09) nº 445 de 10/07/81 do Coordenador Regional do INCRA/PR. José Guilherme D. Cavagnari, para o Presidente da FUNAI. 2 páginas.

Anexo n. 9C. 4 (quatro) documentos referentes a TÍTULO DEFINITIVO DE PROPRIEDADE $n^{\text {os }}$ 1) 4(09)92(02) 831; 2) 4(09)92(02)832; 3) 4(09)92(02)835; 4) 4(09)92(02) 837 emitidos pelo Ministério da Agricultura - INCRA. Curitiba 06/07/1981. 20 páginas.

Anexo n. 9D. Ministério do Interior. FUNAI. Ofício n. 122/DGPI BSB, 12/08/1981. De Claudio H. Pagano de Mello / Diretor do Departamento Geral do Patrimônio Indígena - DGPI para Dr. Odair Zanatta / Diretor do INCRA - DF Departamento de Recursos Fundiários. 2 páginas.

Anexo n. 9E. Modelo de Título definitivo que o DGPI/FUNAI faz para o INCRA. Sem data. 1 página.

Anexo n. 9F. Ofício E/DG/ 0337/81 Itaipu Binacional. RJ, 20/08/1981. Do Diretor Geral José Costa Cavalcanti para Presidente da FUNAI João Carlos Nobre da Veiga. 3 páginas.

Anexo n. 9G. Ofício n. 357/PRES BSB 10/09/1981 do Presidente da FUNAI/MI Octavio Ferreira Lima para Diretor Geral de Itaipu Binacional Gen. José Costa Cavalcanti. 2 páginas.

Anexo n. 9H. Ofício INCRA/32/n 547/81 BSB. 05/10/1981 Do Diretor Substituto do DF Milton Santos de Amorim para o Diretor do Departamento Geral do Patrimônio Indígena DGPI-FUNAI Dr. Cláudio H. Pagano de Mello. 2 páginas.

Anexo n. 9I. Ref. Ofício INCRA/32/n. 547/81 - Modelo de Título de Reconhecimento de Domínio que o INCRA outorga a... 2 páginas. 
Anexo n. 9J. Doc Interno /FUNAI. REF: Processo INCRA/BR/N 5759/81. Interessado: FUNAI. Informação PJR n. 337/81. Do Procurador Autárquico Sérvulo TB Costa para a Chefe da PJR Maria Jovita Wolney Valente. 4 páginas.

Anexo n. 9K. Carta dos Guarani do Oco’y para o Presidente da FUNAI Paulo Moreira Leal em 02/12/81. 3 páginas.

Anexo n. 9L. Os mesmos indígenas fazem Escritura Pública em Cartório do Registro Civil Tabelionato - Distrito de Itacorá - Município e Comarca de São Miguel do Iguaçu Livro 2I fls 150, 04/12/1981. 2 páginas.

Anexo n. 9M. FUNAI - Informação n. 16/81/4O DR. O Delegado Regional da 4a DR Curitiba/ FUNAI Harry Luiz Ávila Teles informa ao Superintendente Administrativo da FUNAI sobre reunião havida entre ele/FUNAI, Comissão de Justiça e Paz, ANAÍ, e os repórteres dos jornais O Estado de São Paulo, O Estado do Paraná, Gazeta do Povo, O Globo, Canal 4 TV Iguaçu de Curitiba. Curitiba 23/12/1981. 5 páginas.

Anexo n. 9N. Memo n. 22/82/GAB/4 DR de 07/01/82 do Delegado Regional Harry L. A. Teles para o Diretor do Depto. Geral de Patrimônio Indígena. 2 páginas.

Anexo n. 90. Carta dos Guarani de Barra do Ocoí - Jacutinga, Foz do Iguaçu/PR de 05/02/82 dirigida ao Presidente da FUNAI Coronel Paulo Moreira Leal e ao Presidente de Itaipu Binacional General Costa Cavalcanti. 2 páginas.

Anexo n. 10: Parecer da Antropóloga Rosane Cossich Furtado/ FUNAI: Área Indígena Ocoí . 20.11.86. 3 páginas.

Anexo n. 11: Procedimentos fundiários realizados por ITAIPU Binacional, INCRA e FUNAI referentes ao desterramento dos Guarani do Oco'y-Jacutinga e reassentamento na Terra Indígena do Oco’y. 13 (treze) documentos. 30 (trinta) páginas.

Anexo n.11A. Carta Aberta dos Guarani. 06/05/82. 1 página.

Anexo n. 11B. "Reunião para tratar de reassentamento do grupo indígena Ava-Guarani”. Escritório Regional da Itaipu em Curitiba. 07/05/82. 2 páginas.

Anexo n.11C. Parecer Jurídico de especialista em Direito Indígena, ex-presidente da FUNAI e Procurador do Estado do Paraná do Dr. Carlos Frederico Mares de Souza Filho. "Sobre a forma de transmissão da propriedade e posse aos Índios Avá-Guarani do Rio Ocoí da nova área a lhes ser destinada". 10.05.82. 3 páginas.

Anexo n. 11D. ATA DE REUNIÃO realizada em 12/05/82 - FUNAI, CJP, CIMI/SUL, CIMI, ANAI na aldeia “LOCAL: Jacutinga-Ocoí. Acampamento dos índios Ava-Guarani”.12.05.82. 1 página. 
Anexo n. 11E. "CROQUI DA ÀREA DA RESERVA AVA-GUARANI'. INCRA e ITAIPU. 1 página.

Anexo n. 11F. Composto de 5 (cinco) documentos, descritos abaixo. 9 páginas.

Anexo n. 11 Fo. Portaria n. 444/P de 29 de junho de 1983. Ministério do Interior/Minter FUNAI - Gabinete do presidente, o presidente da FUNAI Paulo Moreira Leal. 1 página.

Anexo n. 11 F1. “Arlei Costa (Tabelião Responsável) - Oficial do Registro de Imóveis São Miguel do Iguaçu - Paraná Registro Geral Matrícula n 8933 livro nº 2. 25/08/1983; 29.08.83; 26.07.85. 2 páginas.

Anexo n. 11 F2. "Arlei Costa (Tabelião Responsável) - Oficial do Registro de Imóveis São

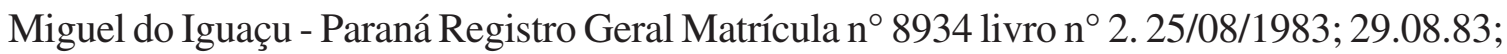
26.07.85. 2 páginas.

Anexo n. 11 F3. "Arlei Costa (Tabelião Responsável) - Oficial do Registro de Imóveis São Miguel do Iguaçu - Paraná Registro Geral Matrícula nº 8935 livro nº 2. 25/08/1983; 29.08.83; 26.07.85. 2 páginas.

Anexo n. 11 F4. “Arlei Costa (Tabelião Responsável) - Oficial do Registro de Imóveis São Miguel do Iguaçu - Paraná Registro Geral Matrícula nº 8936 livro nº 2. 25/08/1983; 29.08.83; 26.07.85. 2 páginas.

Anexo n. 11G. República Federativa do Brasil. Distrito Aurora do Iguaçu - Município São Miguel do Iguaçu - Estado do Paraná, Comarca de São Miguel do Iguaçu. Arlei Costa e Altair Costa (Tabeliões Responsáveis). Assina o documento o Tabelião João Cornella Fagion. Escritura Pública de Doação que fazem Pedro Alves e outros, em favor de Comunidade Indígena Avá-Guarani. 25/08/1983. 3 páginas.

Anexo n. 11H. República Federativa do Brasil. Distrito Aurora do Iguaçu - Município São Miguel do Iguaçu - Estado do Paraná, Comarca de São Miguel do Iguaçu. Arlei Costa e Altair Costa (Tabeliões Responsáveis). Assina o documento o Tabelião João Cornella Fagion. Escritura Pública de Compra e Venda que fazem Itaipu-Binacional e Comunidade Indígena Avá-Guarani, como abaixo se declara: - Valor C $\$ 1,00.25 / 08 / 1983.6$ páginas.

Anexo n. 11I. República Federativa do Brasil. Distrito Aurora do Iguaçu - Município São Miguel do Iguaçu - Estado do Paraná, Comarca de São Miguel do Iguaçu. Arlei Costa e Altair Costa (Tabeliões Responsáveis). Assina o documento o Tabelião João Cornella Fagion. "Escritura Pública de Servidão de Passagem que fazem Marcelino Leitchweis e sua mulher em favor da Comunidade Indígena Avá-Guarani. 17/11/1983. 3 páginas. 
Anexo n. 11J. Mapa da Demarcação da Terra Indígena Avá-Guarani do Oco’y. 31/07/82. 231,88 ha. 1 página.

Anexo n. 12. Artigos de jornais e documentos que apontam as dificuldades fundiárias vividas pelos Ava-Guarani do Oco’y, e que anunciam a pretensão Guarani de retomar suas terras de ocupação tradicional em área de Unidade de Conservação administrada pelo IBAMA, o Parque Nacional do Iguaçu: Anos: a) 27.06.91; b) 02.07.91; c) 24.10.91; d) 29.10.91; e)24.07.92; f) ?/?/93; g) 19.09.05. 11 páginas.

Anexo n.13. Carta Circular nº 01/2005 de 18.09.2005 da Antropóloga Maria Lucia Brant de Carvalho referente à retomada Guarani de terras tradicionais no Kaaguy Guassu: Tupã Vera, atualmente em sua totalidade de usufruto da Unidade de Conservação administrada pelo IBAMA, o Parque Nacional do Iguaçu. 4 páginas.

Anexo n.14. Itaipu paga mais (US\$12,9 milhões em royalties. 10.08.2002. 1 página.

\section{Capítulo 6}

Anexo 1. Carta enviada em 13.04.2004 pelo antropólogo Rubem Thomaz de Almeida/ consultor da Usina Hidrelétrica de Itaipu e carta dos Guarani à Procuradora da República Dra Deborah Duprat da $\mathrm{VI}^{\circ}$ Câmara de Coordenação e Revisão/VI ${ }^{\circ} \mathrm{CCR}$ Populações Indígenas e Minorias da Sub-Procuradoria Geral da República, o Instituto Ambiental do Paraná/IAP estaria proibindo os Guarani de plantarem na própria Terra Indígena do Oco’y.

\section{Considerações finais}

Anexo 1. Artigos de jornais e documentos que apontam a pretensão dos Avá-Guarani do Oco’y em retomar suas terras de ocupação tradicional em área de Unidade de Conservação administrada pelo IBAMA, o Parque Nacional do Iguaçu. Anos: a) 27.06.91; b) 02.07.91; c) 24.10.91; d) 29.10.91; e) 24.07.92; f) ?/?/93; g) 19.09.05.

Anexo 2. Carta Circular No 01/2005, de 18.09.2005 de Maria Lucia Brant de Carvalho.

Anexo 3 e 4 . Anúncio sobre o pedido de Reintegração de Posse pelo IBAMA do Parque Nacional do Iguaçu.

Anexo 5. Carta ao Juiz Federal Ronny Ferreira/Foz do Iguaçu e a Procuradora da Republica Dra Deborah Duprat/VI Câmara de Coordenação e Revisão do Ministério Público Federal/Bsb. Anexo 6. Intimação entregue pelo Juiz Federal Ronny Ferreira ao cacique Simão Villalva. 
Anexo 7. Documento. Reconhecimento pelos Guarani do Laudo Antropológico da antropóloga Maria Lucia Brant de Carvalho. 01.09.06.

Anexo 8. O que a mídia anunciava como razão pelo fato de os Guarani estarem ocupando a Unidade de Conservação.

Anexo 9. O Juiz Rony Ferreira aprova em 03.10.05 a reintegração de posse solicitada pelo IBAMA.

Anexo 10. O IBAMA anuncia negociações com a FUNAI, para a aquisição de terra para os Guarani.

Anexo 11. Os Guarani recebem o apoio dos professores da UFRJ.

Anexo 12. Carta a Dra Deborah Macedo Duprat de Britto Pereira/Sub-Procuradora Geral da República/VI ${ }^{\circ}$ Câmara de Coordenação e Revisão - Comunidades Indígenas e Minorias Procuradoria Geral da República, de Maria Lucia Brant de Carvalho.

Anexo 13. Carta a Dra Deborah Macedo Duprat de Britto Pereira/Sub-Procuradora Geral da República/VI ${ }^{\circ}$ Câmara de Coordenação e Revisão - Comunidades Indígenas e Minorias Procuradoria Geral da República, de Maria Lucia Brant de Carvalho. 04.11.2005.

Anexo 14. Documento escrito por Maria Lucia Brant de Carvalho sobre a forma como os Guarani foram retirados do Parque nacional do Iguaçu em 22.11.05.

Anexo 15. Parecer da AGU de 24.02.2006 indicando a "compra de terras" para os Guarani Anexo 16. Laudo Antropológico: Terra Indígena Avá-Guarani do Ocoí. Município de São Miguel do Iguaçu, Estado do Paraná - Pedido de Aquisição do Imóvel Rural. "FAZENDA JAMAICA" - Processo FUNAI/BSB n².960/08. 


\section{APRESENTAÇÃO}

O estudo ora apresentado tem como problema central investigar um contexto de cunho geopolítico, a saber, o processo de desterritorialização indígena, imposto pelos interesses da sociedade hegemônica na instalação do capital no oeste paranaense, no decorrer do século XX, em contrapartida à luta pelo reconhecimento legal do direito dos Guarani do Oco'y, a parte de seu território imemorial e tradicionalmente ocupado, nesta mesma região brasileira.

A autora, antropóloga da Fundação Nacional do Índio/FUNAI passou a estudar a partir de 2001 o contexto vivido pela população indígena Avá-Guarani, habitante da Terra Indígena AváGuarani do Oco’y/São Miguel do Iguaçu/Paraná/Brasil, objetivando inicialmente a produção de Laudo Antropológico para a Justiça Federal de Foz do Iguaçu, que solicitava um parecer, indagando a extensão de terras necessárias ao referido agrupamento indígena. Diante dos desdobramentos sociopolíticos que o caso vinha trazendo à cena indigenista nacional, considerou-se que a questão poderia ser uma reflexão paradigmática, de âmbito acadêmico, sobre as possibilidades de estudos geopolíticos voltados à inserção de sociedades indígenas habitantes de fronteira, em meio ao território e a sucessão de ocupação pelo capital, bem como focar a legitimidade dos processos ocorridos junto ao Estado, pontuando os fatos e as leis. A partir da pesquisa realizada, foi trabalhado um segundo material, a tese ora apresentada.

Na Introdução, são apresentados aspectos gerais sobre os povos indígenas e as Terras Indígenas no Brasil. A partir da informação sobre a distribuição das populações indígenas sobre as respectivas quantidades de terras a elas reservadas no país, são discutidos alguns dos principais conceitos em que se pauta a pesquisa, sendo fundamentais as referências sobre os Direitos Indígenas previstos constitucionalmente, perante ás terras que ocupam. Em seguida são apresentados os aspectos teórico-metodológicos que envolvem a pesquisa.

O Capítulo 1 refere-se ao fato que a criação da Terra Indígena Avá-Guarani do Oco’y pela Itaipu Binacional e FUNAI resultou num problema ambiental, gerado pelo próprio Estado. O Ministério Público Federal e a Justiça Federal promoveram em 1989 uma Ação Civil Pública contra a princípio, os Guarani e posteriormente contra a FUNAI e o IBAMA, por suposta "extração" de 
madeira realizada pelos Guarani do Oco’y e venda da mesma em área ilegal. O local em que se deu a ação foi na Área de Preservação Permanente do reservatório da Usina Hidrelétrica de Itaipu, mesmo local onde anos antes, a Itaipu Binacional e a FUNAI, haviam reassentado os Guarani, na área que veio a ser a Terra Indígena Avá-Guarani do Oco’y. A partir dessa superposição ilegal, se estabeleceu em 2001 um impasse sobre a ocupação do território: ou os Guarani na Terra Indígena ou a Área de Preservação Permanente do reservatório da Itaipu Binacional: espaço para os dois não havia. Também se descortinou a ilegalidade da situação em que foram colocados os indígenas.

O Capítulo 2 apresenta o conjunto do agrupamento étnico Guarani, no que tange a vários aspectos da atualidade: classificação linguística; localização geográfica; distribuição populacional; menciona a antiguidade da ocupação em seu território no Brasil, tema que será à frente tratado; se refere às formas atuais de ocupação da região, pós-colonização; levanta aspectos socioculturais em relação a mobilidade Guarani sobre o território; e por fim define o território específico onde o conjunto das famílias Guarani, que vieram a formar a Terra Indígena do Oco’y, são provenientes, o denominado Tekoa Guassu (Aldeia Grande, ou melhor, grupo de aldeias Guarani em um grande território), território esse, localizado inclusive na área de fronteira, na Tríplice Fronteira entre Brasil, Paraguai e Argentina.

O Capítulo 3 discute as condições de vida a que os índios Guarani foram submetidos ao serem instalados na Terra Indígena Avá-Guarani do Oco’y, diante da superposição de áreas de terras e pequena área territorial. Descreve a insustentabilidade do território em função da população indígena que o habita, perante a absoluta falta de terras e de condições ambientais, as precárias condições sanitárias, fatores que no seu conjunto comprometem a saúde, a reprodução física e cultural da população Guarani. Em seguida, discute o contexto vivido em outra aldeia, Tekoa Ãnetete, na qual a população é tributária de Oco’y. As populações Guarani dessas duas aldeias até então (2000) eram as únicas que resistiam no meio do extremo oeste paranaense, se comparadas ás inúmeras aldeias que em passado recente, existiam na mesma região.

Diante do inexplicável desaparecimento de inúmeras aldeias Guarani da região do Oeste paranaense, o Capítulo 4 levantou e comprovou a imemorialidade da ocupação Guarani na região do oeste do Paraná, que se dá, de acordo com fontes arqueológicas desde 80 DC (Depois de Cristo). Discute o desaparecimento delas e seus correspondentes aspectos legais. Objetiva verificar também como a sociedade envolvente acabou por se estabelecer, redundando em esbulho de grande parte do território indígena.

Várias terras Guarani foram desaparecendo ao longo do século XX. São tratadas o caso de quatro delas. Entre elas a aldeia Avá-Guarani do Oco’y-Jacutinga, na década de 70, foi invadida 
por funcionários do INCRA, em função de reassentar no seu lugar famílias de colonos, os quais haviam sido antes evacuados da área que havia se tornado o Parque Nacional do Iguaçu. Reduzida a Terra Indígena à parte que restou, junto ás margens do rio Paraná, em 1982 acabou por ser inundada pela Itaipu Binacional, como parte das terras destinadas à instalação do reservatório daquela Hidrelétrica. Os Guarani nesta época foram compulsoriamente reassentados, na que veio a ser a Terra Indígena Avá-Guarani do Oco’y. O Capítulo 5 discute como se deu esse processo oficialmente, a desterritorialização dos Guarani do Oco'y-Jacutinga e reterritorializaçao na Terra Indígena Avá-Guarani do Oco’y. Ao todo o processo abarca cerca de 30 anos, sendo apresentado como os fatos foram tratados a nível institucional e concomitantemente o que previa a legislação indigenista correspondente.

O Capítulo 6 discute a questão sobre as contradições criadas pelo próprio Estado, no sentido de ter estabelecido os Guarani no Oco’y. Após os reclamos desses indígenas sobre a falta de terras para subsistência, inadvertidamente a FUNAI e a Itaipu Binacional promoveram o corte e derrubada das poucas áreas florestadas da APP de Itaipu localizada na própria Terra Indígena do Oco’y, visando liberar mais espaços para a agricultura indígena. O Instituto Ambiental do Paraná/IAP em 08.10.2003 multou os órgãos e pretendeu proibir os Guarani, de estabelecer seus cultivos na própria Terra Indígena Avá-Guarani do Oco’y, considerando ser ela somente APP de Itaipu.

O Capítulo 7 discute o processo histórico decorrido no século XX, de como a sociedade hegemônica construiu a região da Tríplice Fronteira em função dos interesses do capital, por meio da Geopolítica equacionada pelos militares brasileiros e seus projetos, e, ainda, pela influencia do intervencionismo norte-americano no país. Assim se verifica as razões em termos de deslocamento populacional de indígenas e de camponeses da região.

Nas Considerações finais introduz informações sobre a situação ambiental no estado do Paraná em termos de áreas florestadas, discutindo um contexto específico: o fato de que parte das famílias Guarani de Oco’y, em 03 de setembro de 2005, reocuparam fração de seu território tradicional, única área florestada na região, onde é possível viver conforme seus usos, costumes e tradições. O local: Parque Nacional do Iguaçu/PNI. Dessa forma, dado à imemorialidade da ocupação e a tradicionalidade na forma de ocupação dos Guarani, no que tange à esse local, veremos por fim, a realidade Guarani na região e o tratamento que foi dado ao fato, pelos poderes de Estado e grupos de poder locais. 


\section{INTRODUÇÃO}

\section{Os povos indígenas do Brasil}

Os indígenas sobrevivem, não só fisicamente como alguns podem supor, mas também sob o ponto de vista de suas tradições socioculturais. Darcy Ribeiro calculava a população de indígenas em 6 milhões de indivíduos aproximadamente, em 1500. Após os genocídios cometidos durante séculos de extermínio, o mesmo autor calculava que na década de 50 do século XX, eles somavam em torno de 98 mil indivíduos, embora essa cifra também sofresse de certa imprecisão, dada as dificuldades de acesso ás terras indígenas na época e ao desconhecimento de grupos, que mais tarde foram identificados. Em proporção à população total anteriormente apresentada, a população indígena vem aumentando rapidamente nas últimas décadas. Hoje, no Brasil, vivem em torno de 817 mil índios, distribuídos entre 688 Terras Indígenas e em algumas áreas urbanas, os quais perfazem cerca de $0,4 \%$ da população brasileira, segundo dados do Censo de 2010 e informação da FUNAI de 2013. Atualmente há cerca de 220 diferentes povos, 220 sociedades indígenas diferentes entre si, as quais falam 180 línguas distintas, portanto 180 culturas indígenas diferentes entre si. Há também 82 referências de grupos indígenas ainda não contatados, "os isolados”, dos quais 32 foram confirmados. Existem também grupos que estão requerendo o reconhecimento de sua condição de "indígena", junto ao órgão indigenista federal, esses grupos, em geral, foram obrigados durante períodos repressivos, a mascarar sua identidade étnica, afim de preservar a própria vida.

O critério da "auto identificação" étnica nas últimas décadas vem sendo o mais amplamente aceito pelos estudiosos da temática indígena. Atualmente o termo "indígena" é definido como todo o indivíduo que é reconhecido como membro descendente de comunidade pré-colombiana, que se auto identifica etnicamente com determinada etnia e é identificado ao mesmo tempo pelo seu grupo, como fazendo parte desse grupo étnico específico.

As populações indígenas são vistas pela sociedade brasileira ora de forma preconceituosa geralmente elites municipais rurais com fortes interesses nas terras e recursos ambientais indíge- 
nas, onde se utilizam de um rol de termos para desqualificá-los, justificando assim, ações contra os índios e invasão de seus territórios; ora são vistos de forma idealizada - geralmente por populações urbanas, distanciadas das Terras Indígenas, as quais tendem a ter deles uma imagem positiva, como os "donos da terra" e seus "primeiros habitantes", aqueles que "sabem conviver com a natureza sem depredá-la" etc. São vistos ainda como parte do "passado", em suposto processo de desaparecimento, embora, como provam os últimos Censos constata-se o alto crescimento da população indígena. Há ainda alguns grupos da sociedade brasileira que percebem os índios como culturalmente distintos e seus contemporâneos, que vivem no mesmo país, compartilham problemas comuns, como as consequências da degradação ambiental, o conflito por terras, a violência etc.

Qualquer grupo social humano elabora e constitui um universo de conhecimentos integrados, com fortes ligações com o meio em que vive e se desenvolve. Como a cultura de qualquer outra sociedade humana, as sociedades indígenas modificam-se constantemente e reelaboram-se com o passar do tempo. Entendendo cultura como o conjunto de respostas que uma determinada sociedade humana dá às experiências por ela vividas e aos desafios que encontra ao longo do tempo, percebe-se o quanto as diferentes culturas são dinâmicas e estão em contínuo processo de transformação.

As mudanças ocorridas nas sociedades indígenas com o contato, - falarem português, usarem vestimentas, utilizarem-se de modernas tecnologias - não fazem com que percam sua própria identidade étnica e deixem de ser o que sempre foram - sociedades indígenas - que vivendo em suas terras recebem novas informações, a partir de um pensamento estruturado de acordo com suas ancestrais matrizes socioculturais. Assim estas sociedades mantêm o seu próprio "ethos", termo antropológico que designa particular costume, uso, característica, disposição, caráter, através de uma atitude peculiar de determinado povo, grupo ou cultura, que os distingue de outros povos, grupos ou culturas.

O Brasil possui uma imensa diversidade étnica e linguística, estando entre as maiores do mundo. São 180 línguas faladas pelos membros destas sociedades, as quais pertencem a mais de 30 famílias linguísticas diferentes.

A língua é o esteio onde se dá a organização da experiência e do conhecimento humano. Através da língua se conhece a especificidade da cultura e da história de um povo. Por meio dela pode-se conhecer todo o particular universo cultural, no que se refere ao conjunto de respostas que um povo emite sobre as experiências por ele vividas. 
Estima-se que cerca de 1.300 línguas indígenas diferentes eram faladas no Brasil há 500 anos. Hoje são 180, número que exclui aquelas faladas pelos índios isolados, uma vez que não estando em contato com a sociedade nacional, ainda não puderam ser conhecidas. O desaparecimento de tantas línguas representa grande perda para a humanidade, pois cada uma delas expressa uma cosmologia, uma vasta gama de conhecimentos, uma forma única de se posicionar diante da vida e do mundo.

O método utilizado de reconhecimento das línguas indígenas no Brasil é a classificação pelo tipo genético. Reúnem-se numa mesma classe as línguas que tenham tido origem comum numa outra língua mais antiga, já extinta. As línguas faladas pelos diversos povos são agrupadas em famílias linguísticas, e estas famílias são reunidas em troncos linguísticos buscando sempre a origem comum numa língua anterior. Para exemplificar citemos o caso de um agrupamento indígena, os Krahô. Eles fazem parte do Tronco Linguístico Macro-Jê, da família linguística Jê, da língua Timbira, do dialeto Krahô.

As línguas indígenas no Brasil são agrupadas em famílias, classificadas como pertencentes aos troncos linguísticos Tupi, Macro-Jê e Aruak. Há Famílias, entretanto, que não puderam ser identificadas como relacionadas a nenhum destes troncos. São elas: Karib, Pano, Maku, Yanoama, Mura, Tukano, Katukina, Txapakura, Nambikwara e Guaikuru. Além disso, outras Línguas não puderam ser classificadas pelos linguistas no interior de nenhuma Família, permanecendo nãoclassificadas ou isoladas, como a língua falada pelos Tükúna, a língua dos Trumái, a dos Irântxe etc. Ainda existem as línguas que se subdividem em diferentes dialetos, como, por exemplo, os falados pelos Krikatí, Ramkokamekrá (Canela), Apinayé, Krahô, Gavião (do Pará), Pükobyê e Apaniekrá (Canela), que são, todos, dialetos diferentes da língua Timbira.

Hoje ainda alguns grupos indígenas falam somente sua própria língua materna. Outros vários grupos falam além da própria língua, o português como segunda língua. Há também sociedades indígenas que em contato já antigo com a sociedade brasileira, perderam sua língua original e falam somente o português. Porém, o tempo de contato, embora possa contribuir, não é critério definitivo para manutenção ou perda da língua.

Podemos citar como exemplo os Guarani de que trataremos neste trabalho. Eles possuem cerca de 500 anos de contato com os colonizadores. Em inúmeras aldeias desse agrupamento étnico, as mulheres e crianças intencionalmente não falam o português, ou falam muito superficialmente. Em geral, entre eles é somente os homens que dialogam com o "outro", o não índio. Nesse caso a sociedade Guarani, reagindo ao outro, ao elemento de fora, vem se utilizando dessa 
estratégia através de gerações, objetivando manter entre seus pares de forma mais ampla possível os próprios moldes socioculturais, visando minimizar as interferências, o que de certa forma conseguem, já que o "ethos" Guarani é bastante claro e presente. Assim a manutenção da língua diariamente por parte dos Guarani é também uma ação política, na medida em que preservam os próprios códigos, em detrimento das lógicas da sociedade envolvente e dominante. Outro exemplo o agrupamento indígena Krahô, com cerca de 80 anos de contato, em algumas aldeias notase que além da própria língua, falam razoavelmente o português, em outras aldeias falam quase que exclusivamente a língua materna.

A mesma sociedade indígena pode ser conhecida por várias denominações e elas nem sempre são escritas da mesma forma. Isto depende da convenção feita pelos não índios que lhes deram uma ou outra denominação, já que os próprios falantes originais das línguas indígenas eram ágrafos. Neste sentido em 1953, a Associação Brasileira de Antropologia (ABA) estabeleceu uma "Convenção para a grafia dos nomes tribais". Embora esta convenção seja em geral respeitada pelos antropólogos, há alguns aspectos que nunca foram seguidos.

\section{Terras indígenas no Brasil}

Para os povos indígenas, a terra é muito mais do que simples meio de subsistência. Ela representa o suporte da vida social e está diretamente ligada ao sistema de crenças e conhecimento. Não é apenas um recurso natural - e tão importante quanto este - é um recurso sociocultural.

Alcida Rita Ramos (1986)

\section{O território}

A territorialidade indígena está vinculada a uma relação sociocultural que os povos indígenas mantêm com o ambiente que ocupam, relação esta, que foi construída ao longo de sua história. Suas técnicas de trabalho e sua sobrevivência física estão culturalmente adaptadas à exploração de um determinado habitat. Aspectos de ordem social, ritual ou religiosa pesam igualmente na importância que o território tem para as populações indígenas. Como diria Carmem Junqueira (1991), a terra é o cenário de sua cultura. Souza Filho acrescenta a essa ideia, afirmando:

A existência física de um território, com um ecossistema determinado e o domínio, controle ou saber que tenha o povo sobre ele, é determinante para a própria existência do povo. É no território e em 
seus fenômenos naturais que se assentam as crenças, a religiosidade, a alimentação, a farmacopeia e a arte de cada povo (SOUZA FILHO: 1998:120).

A relação entre o indígena e seu território não se rege exatamente pelas normas do Direito Civil. Segundo a visão do Professor de Direito, Dr Jose Afonso da Silva, assim ele afirma:

A posse indígena extrapola da órbita puramente privada, porque não é e nunca foi uma simples ocupação da terra para explorá-la, mas base de seu habitat, no sentido ecológico de interação do conjunto de elementos naturais e culturais que propiciam o desenvolvimento equilibrado da vida humana. Esse tipo de relação não pode encontrar agasalho nas limitações individualistas do direito privado (SILVA:1992:49).

O território indígena a partir do contato com a sociedade nacional

O domínio das populações indígenas sobre seus territórios, a partir do contato com a sociedade nacional passa a ter outra dimensão. Se antes se configurava numa luta por território entre as próprias e diferentes sociedades indígenas, a partir da conquista a luta passa a se apresentar assimétrica, os atores são os empreendimentos públicos ou privados e o Estado Nacional versus grupos étnicos minoritários, em cada contexto regional. Ladeira analisa o conceito "território indígena" frente a esta realidade:

A relação das sociedades indígenas com o espaço físico e os chamados recursos naturais vêm, desde o período colonial, passando por transformações que se operam no âmbito das sucessivas e múltiplas formas de convivência com a sociedade nacional, desde o início de seu processo de formação. E, a partir do período colonial, o jogo e o contexto político-econômico da sociedade nacional vão determinar, geograficamente, as formas de ocupação, impondo limites e condições, enfim, administrando o território do Estado como um todo. Assim, relações entre as sociedades indígenas e a sociedade nacional (a partir do séc. XVII) passam a se operar a partir do pressuposto da existência de uma base territorial fixa, para os índios, seja ela qual for. E será esse o mecanismo adotado pelo Estado para conferir ou reconhecer a identidade étnica de um grupo indígena.

Considerando que o conceito de território não é próprio das sociedades indígenas, e que as delimitações territoriais são historicamente fixadas por meio de estratégias de poder e controle político do Estado, conclui-se que os territórios e as Terras indígenas são espaços dominados que, inevitavel- 
mente, forçam os índios à firmar um pacto eterno de dependência com o Estado. A dinâmica expropriação<=>concessão de terras e limites, através da qual se supõe, ou se induz a crer, estar propiciando aos índios a liberdade e o exercício de gestão (dentro dos limites impostos e fixos) é a contradição inerente e latente do conceito de território indígena e de políticas e legislações indigenistas. (LADEIRA: 2001:89) (grifos nossos).

O indígena amazonense Gersem Santos, então vice-presidente da FOIRN em declaração (08.05.1996), resumiu na visão indígena a singularidade semântica da palavra "território":

Na concepção tradicional, original não existia o termo território. Não teria sentido discutir isso. O sentido do território só existe após o contato. Antes do contato o índio podia ir e vir, ele definia sua própria vida, seu destino, sem tutela, sem nada e sem pré-condições. Depois do contato há pré-condições. Estas são impostas pela dominação, pela exploração e pela violência. E você precisa afirmar-se. Antes não, a natureza te garante isto. A terra te garante isso. Por isto a terra é tudo. Depois a terra já não é tudo. Você precisa de elementos políticos. Aí você tem um conceito de território que tem sentido de poder, sentido de domínio e de limite. Território é limite. É você limitar o espaço. A terra é uma coisa ilimitada, ilimitável. Ela é tudo. Como você vai considerar limite numa concepção ilimitada de terra que seria o território! Não tem como fazer a relação. Só é possível pensar o território depois do contato porque você limita as coisas. (FARIA: 1997:268)

Após o contato os povos indígenas percebem que agora a preocupação fundamental é assegurar o domínio sobre o território, visando manter as condições de sobrevivência física e cultural. Tornam-se um referencial, antes praticamente inexistente, as relações com o espaço, com os vizinhos não índios, com o Estado, formando um sistema geopolítico próprio sobre o território. Contribui para essa ideia a afirmação de Ladeira:

A consciência e o controle interno se justificam, pois os índios sabem que suas áreas já estão demarcadas ou definidas, dificilmente serão ampliadas, estão circundadas por fazendas e áreas degradadas, sendo que somente a população é fator de crescimento. Portanto, é necessário um planejamento interno constante dos usos dos "recursos naturais". Soma-se a essas considerações, a observação de que as alternativas de subsistência para as comunidades indígenas também devem ser construídas internamente, a partir do zoneamento e das práticas tradicionais de manejo existentes, para que efetivamente sejam assimiladas pela coletividade indígena (LADEIRA: 2001:48) (grifos nossos). 
O termo utilizado pela legislação é terra e não território, o que a princípio transforma, alterando o ideal de espaço geográfico utilizado pelos povos indígenas. O Doutor Carlos Frederico Marés de Souza Filho ${ }^{1}$ discute a seguir, o conceito jurídico de território, na perspectiva do Estado em relação aos povos indígenas:

Para a cultura constitucional, o território é um dos elementos formadores do Estado e, fisicamente, o limite de seu poder. (...) Ultrapassado o conceito ou não, os Estados continuam muito ciosos do território, tentando ainda manter sua estreita vinculação com o exercício da soberania (...).

Exatamente por isso, e especialmente nos séculos XIX e XX, as leis não admitem o nome território para indicar o espaço vital dos povos indígenas, chamando-se simplesmente de terras, como se se tratasse de terras particulares dentro do território nacional. É claro que o fenômeno não se enquadra muito bem em todo o sistema, como já vimos no exemplo do balão que se quer encaixotar. Houve necessidade de se fazer verdadeiro malabarismo jurídico, por a funcionar o gênio criador brasileiro para amoldar o direito ao território dos povos indígenas limites das terras particulares, sem sê-las.

Repugna ao poder público, aos juristas de uma forma geral e aos Tribunais chamar as terras indígenas de território, tanto quanto chamá-los de povos. Estas duas palavras, povo e território, somadas à soberania, tem o som de tambores belicosos, de guerra de libertação, de insurreição e de independência, e, por isso, sofrem imediata e irracional repulsa de todos os setores que se dizem nacionalistas, especialmente militares. E ntretanto, em análise mais acurada, podemos observar que o conceito de território, está escondido atrás das normas constitucionais que regem a matéria e, especialmente, atrás da coerência sistêmica da Constituição e de todo o ordenamento jurídico (SOUZA FILHO: 1998:120-1).

Quanto ás considerações do último parágrafo mencionado consideramos que a ideia se aplica de forma relativa, pois para a maioria dos povos indígenas da Amazônia Legal ela tem validade, por mais camuflado que esteja o termo, seus "territórios" foram reconhecidos como tal; ao contrario, para as populações indígenas do centro-oeste, nordeste, sul e sudeste essa ideia de território não se aplica, especialmente, de forma mais contundente com relação aos Guarani, por conta da grande extensão de seu verdadeiro território, como iremos discutir de forma mais acurada nos capítulos 2 e 4, e das pressões da sociedade majoritária no decorrer da colonização sobre ele. Para esses o termo correto e real a ser aplicado, dada a perspectiva estatal imposta, seria mesmo o termo "terras", que estão localizadas, assim como somadas as terras de não índios, no interior de seu verdadeiro "território".

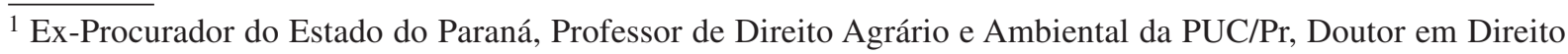
Público pela UFPR e Ex-Presidente da FUNAI.
} 


\section{Distribuição da população indígena no Brasil}

Os povos indígenas vivem nos mais diversos pontos do país e representam, em termos demográficos, um pequeno percentual da população brasileira. Todavia, as 220 diferentes sociedades indígenas são um exemplo concreto e significativo da grande diversidade cultural existente no país.

No que se refere à distribuição dessa diversidade populacional indígena sobre o solo brasileiro, essas sociedades vivem em todas as regiões, com exceção do estado do Rio Grande do Norte. No Piauí, existem grupos que vivem no interior do estado, os quais em determinada conjuntura histórica de características repressivas, foram obrigados a velar sua própria identidade e hoje voltaram a se auto identificar como indígenas, reivindicando esse reconhecimento junto à FUNAI. Em 2006 havíamos feito as seguintes considerações:

Informa a FUNAI (2006) que a superfície do total das 488 terras indígenas, cujos processos de demarcação estão pelo menos na fase delimitada em diante, é de 105.673.003 hectares, perfazendo $12,41 \%$ do total do território brasileiro. Outras 123 terras ainda estão por serem identificadas, não sendo suas possíveis superfícies somadas ao total indicado. Registra-se, ainda, que há várias referências a terras presumivelmente ocupadas por índios e que estão por serem pesquisadas, no sentido de se definir se são ou não indígenas. A tabela abaixo aponta a situação das 611 terras indígenas do

Tabela A. Situação fundiária das Terras Indígenas no Brasil em 2006

\begin{tabular}{|l|l|l|l|}
\hline \multicolumn{4}{|c|}{ SITUAÇÃO DAS TERRAS INDÍGENAS } \\
\multicolumn{4}{|c|}{ (Resumo Geral) } \\
\hline & $\mathbf{N}^{\mathbf{0}}$ de T.I's & $\%$ & Hectares \\
\hline EM ESTUDO & 123 & - & 0 \\
\hline DELIMITADA & 33 & 1,66 & 1.751 .576 \\
\hline DECLARADA & 30 & 7,67 & 8.101 .306 \\
\hline HOMOLOGADA & 27 & 3,40 & 3.599 .921 \\
\hline REGULARIZADA & 398 & 87,2 & 92.219 .200 \\
\hline TOTAL & 611 & 100 & 105.672 .003 \\
\hline
\end{tabular}

Fonte: www.funai.gov.br - 2006. 
Atualizando os dados para 2013, temos:

\section{Tabela B. Situação fundiária das Terras Indígenas no Brasil em 2013}

\begin{tabular}{|l|l|l|l|}
\hline \multicolumn{4}{|c|}{ SITUAÇÃO DAS TERRAS INDÍGENAS } \\
& (Resumo Geral) \\
\hline & $\mathbf{N}^{\mathbf{0}}$ de T.I's & $\%$ & Hectares \\
\hline EM ESTUDO & 115 & - & - \\
\hline DELIMITADA & 30 & 1,84 & $2.024 .366,0000$ \\
\hline DECLARADA & 51 & 2,43 & $2.679 .132,0452$ \\
\hline HOMOLOGADA & 12 & 0,46 & $513.762,0717$ \\
\hline REGULARIZADA & 428 & 95,21 & $104.616 .529,3229$ \\
\hline RESERVA INDIGENA & 36 & 0,04 & $44.358,5230$ \\
\hline TOTAL & 672 & 100 & $109.878 .147,9628$ \\
\hline
\end{tabular}

Fonte: www.funai.gov.br - 2013.

Esse total de 12,41\% (2006) ou 12,90 \% (2013) do país, que compreende o conjunto das Terras Indígenas, vem dando margem a muita discussão. Alguns segmentos da população brasileira contrários aos direitos indígenas passaram a afirmar que os índios teriam "terras demais". A ideia que se procura propagar com esse tipo de argumentação é a de que, com a regularização das terras indígenas, se estaria reduzindo a quantidade de terras disponíveis para a agricultura e outras atividades econômicas, resultando em escassez de terras, fundamentalmente em relação aos trabalhadores rurais. Assim a matéria carece de maiores esclarecimentos.

O Professor Ariovaldo Umbelino de Oliveira demonstrou em suas palestras, o processo de apropriação fundiária no Brasil. Sua base foi desde sempre a grande propriedade (capitanias hereditárias, sesmarias) associada ao trabalho escravo, visando exploração extrativista ou monoculturas para exportação (pau-brasil, cana-de-açúcar, mineração etc.), tendo esse processo tido continuidade até os dias de hoje, com o café na primeira metade do século XX, posteriormente a laranja, o gado e a soja.

O Brasil foi o último país a abolir a escravatura (1888), e apesar disso não foram assegurados terras, aos ex-escravos.

Terras devolutas e indígenas foram ilegalmente tomadas através da grilagem, processo pelo qual indivíduos se apossavam de terras alheias mediante falsas escrituras de propriedade. 
Apesar da Lei de Terras que limitava os latifúndios, estes foram criados ilegalmente excedendo as dimensões máximas fixadas por lei. Todo esse quadro desde sempre careceu de fiscalização governamental.

A massa populacional sem terra no campo, também não foi absorvida amplamente pela indústria como se esperava. Assim uma grande massa sem terra e sem emprego, é um problema social que se tem de encaminhar no país, revendo a estrutura fundiária no campo.

O Brasil possui superfície aproximada de 850 milhões de hectares. A Amazônia é considerada ainda um vazio demográfico. Três quartos da população brasileira vivem em áreas urbanas e industrializadas do centro-sul.

Segundo estudo realizado pelo Professor Ariovaldo Umbelino de Oliveira, a partir de dados do IBGE, sobre a estrutura fundiária brasileira no que se refere a "estabelecimentos rurais" e “área ocupada em hectares", sua distribuição em pleno século XX continua se apresentando extremamente desigual, como mostra a tabela a seguir: 


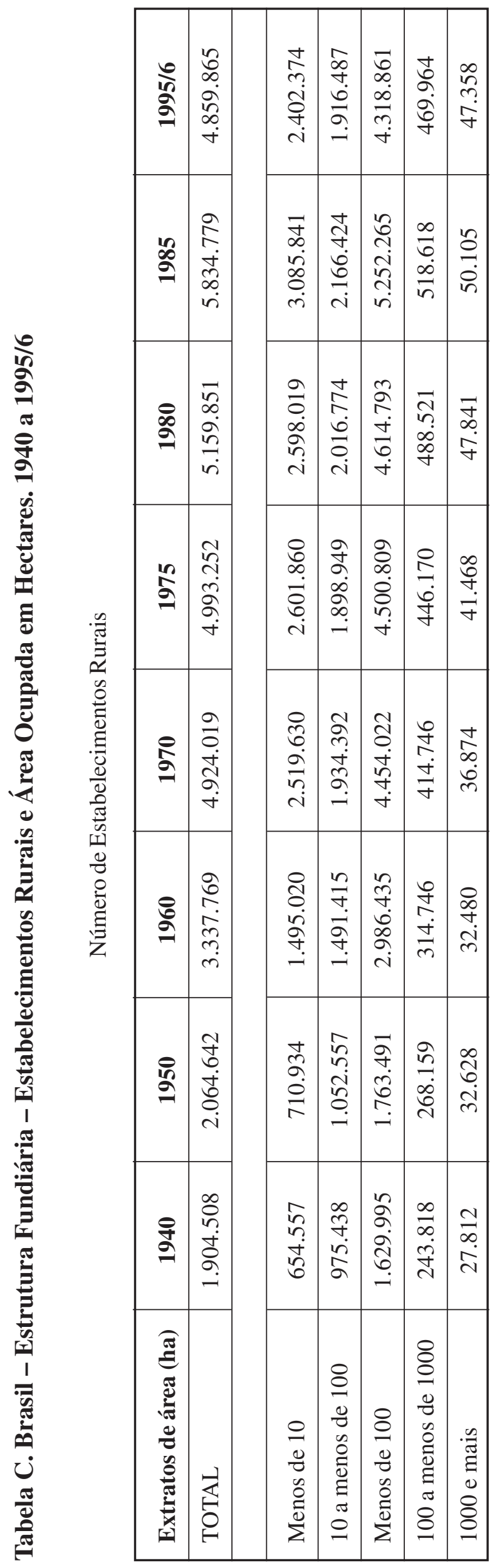

\begin{tabular}{|c|c|c|c|c|c|c|}
\hline $\begin{array}{l}\frac{0}{2} \\
\frac{\sigma}{2}\end{array}$ & 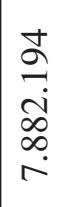 & $\begin{array}{l}n \\
\infty \\
n \\
\tilde{a} \\
\hat{\delta} \\
i \\
\sigma\end{array}$ & 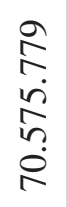 & 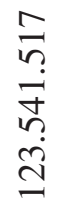 & 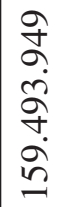 & 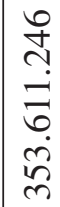 \\
\hline $\begin{array}{l}n \\
\infty \\
0\end{array}$ & 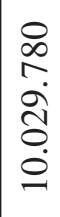 & $\begin{array}{l}\infty \\
\sigma \\
\infty \\
\infty \\
\sigma \\
0 \\
0\end{array}$ & $\begin{array}{l}\frac{\infty}{\pi} \\
\infty \\
\infty \\
\stackrel{2}{2} \\
\stackrel{1}{2}\end{array}$ & $\begin{array}{l}\hat{n} \\
\hat{n} \\
\hat{\alpha} \\
\infty \\
\dot{m} \\
\end{array}$ & 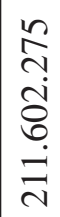 & 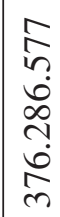 \\
\hline $\begin{array}{l}\stackrel{\circ}{\circ} \\
\stackrel{0}{0}\end{array}$ & $\begin{array}{l}\hat{n} \\
\text { r. } \\
\dot{0} \\
8 \\
0\end{array}$ & $\begin{array}{l}\stackrel{9}{+} \\
\stackrel{+}{+} \\
\stackrel{g}{+} \\
\dot{0}\end{array}$ & 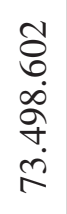 & 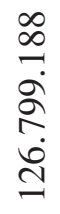 & 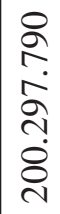 & $\begin{array}{l}\vec{Y} \\
\dot{y} \\
\dot{v} \\
\delta \\
\tilde{D} \\
\tilde{ల}\end{array}$ \\
\hline$\frac{n}{2}$ & $\begin{array}{l}0 \\
0 \\
0 \\
i \\
\infty \\
0 \\
\infty\end{array}$ & 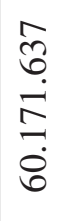 & 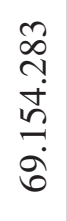 & 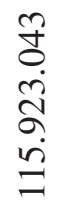 & 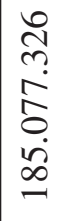 & 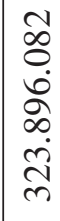 \\
\hline 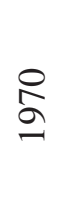 & $\begin{array}{l}n \\
\alpha \\
\dot{\gamma} \\
\infty \\
0 \\
0\end{array}$ & 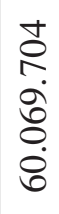 & $\begin{array}{l}\frac{\partial}{a} \\
\hat{n} \\
\frac{0}{0}\end{array}$ & 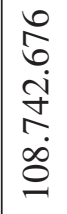 & 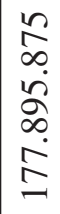 & 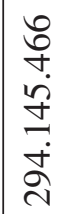 \\
\hline 융 & $\begin{array}{l}\infty \\
\infty \\
\tilde{n} \\
\tilde{\sigma} \\
\tilde{n}\end{array}$ & 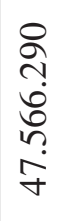 & $\begin{array}{l}\pi \\
\sigma \\
\infty \\
n \\
\tilde{n} \\
\tilde{n}\end{array}$ & 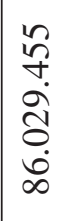 & 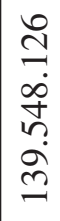 & 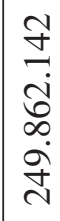 \\
\hline$\stackrel{\circ}{2}$ & 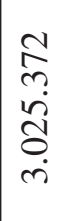 & 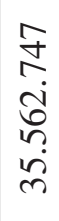 & 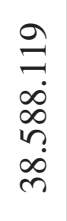 & 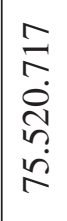 & 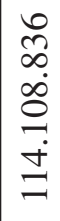 & 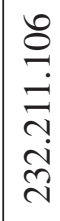 \\
\hline$\stackrel{8}{9}$ & $\begin{array}{l}\hat{\sigma} \\
\dot{\sigma} \\
\dot{\sigma} \\
\infty \\
\dot{\gamma}\end{array}$ & 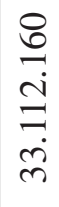 & 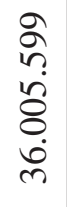 & $\begin{array}{l}2 \\
\partial \\
\dot{\infty} \\
\dot{0} \\
\dot{8}\end{array}$ & 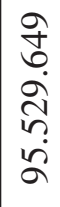 & 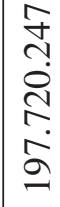 \\
\hline 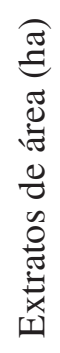 & $\begin{array}{l}0 \\
0 \\
0 \\
n \\
0 \\
0 \\
\sum_{2}^{0}\end{array}$ & $\begin{array}{l}8 \\
0 \\
0 \\
0 \\
0 \\
0 \\
\mathbb{E} \\
\Xi \\
0 \\
0\end{array}$ & $\begin{array}{l}8 \\
0 \\
0 \\
0 \\
0 \\
0 \\
\sum^{0}\end{array}$ & $\begin{array}{l}8 \\
0 \\
0 \\
0 \\
0 \\
0 \\
0 \\
0 \\
\Xi \\
\tilde{0} \\
\delta\end{array}$ & $\begin{array}{l}\text {.0 } \\
\text { పే } \\
0 \\
\delta \\
\delta \\
0\end{array}$ & $\begin{array}{l}\text { 崖 } \\
0 \\
0\end{array}$ \\
\hline
\end{tabular}


Se analisarmos os extremos dessa Tabela, veremos que o total da área ocupada por imóveis rurais em relação ao espaço territorial brasileiro em 1940 eram 23,26\% e em 1995/6, subiram para $41,60 \%$.

A partir dessa estrutura fundiária veremos que nestas mesmas datas, seus extremos em termos de extratos de áreas rurais (as menores e as maiores propriedades), apresentam o seguinte comportamento:

Tabela D. Estrutura Fundiária dos Estabelecimentos Rurais em 1940. Os extremos em termos de extratos de áreas (pequena e grande propriedade)

\begin{tabular}{|c|c|c|c|}
\hline Extratos de áreas & Total & Com menos de 10 há & Com 1000 ha ou mais \\
\hline $\begin{array}{l}\mathrm{N}^{\circ} \text { de estabelecimentos } \\
\text { rurais }\end{array}$ & $1.904 .508(100 \%)$ & $654.557(34,36 \%)$ & $27.812(1,46 \%)$ \\
\hline $\begin{array}{l}\text { Área ocupada em } \\
\text { hectares }\end{array}$ & $197.720 .247(100 \%)$ & $2.893 .439(1,46 \%)$ & $95.529 .649(48,31 \%)$ \\
\hline
\end{tabular}

Organizado: Maria Lucia Brant de Carvalho. Fontes: Ariovaldo Umbelino de Oliveira e IBGE

Tabela E. Estrutura Fundiária dos Estabelecimentos Rurais em 1995/6. Os extremos em termos de extratos de áreas (pequena e grande propriedade)

\begin{tabular}{|c|c|c|c|}
\hline Extratos de áreas & Total & Com menos de 10 há & Com 1000 ha ou mais \\
\hline $\begin{array}{l}\mathrm{N}^{\circ} \text { de estabelecimentos } \\
\text { rurais }\end{array}$ & $4.859 .865(100 \%)$ & $2.402 .374(49,43 \%)$ & $47.358(0,97 \%)$ \\
\hline $\begin{array}{l}\text { Área ocupada em } \\
\text { hectares }\end{array}$ & $353.611 .246(100 \%)$ & $7.882 .194(2,22 \%)$ & $159.493 .949(45,10 \%)$ \\
\hline
\end{tabular}

Organizado: Maria Lucia Brant de Carvalho. Fontes: Ariovaldo Umbelino de Oliveira e IBGE

Dessa forma pode-se extrair que em 1940, os pequenos proprietários com menos de 10 hectares somavam 34,36\% dos estabelecimentos rurais no Brasil e possuíam 1,46\% de hectares dessas terras. Ao passo que os grandes proprietários com 1000 hectares ou mais, somavam 1,46\% dos estabelecimentos rurais no Brasil e possuíam 48,31\% de hectares dessas terras, um contingente mínimo de estabelecimentos rurais, possuíam quase a metade das terras rurais.

Em 1995/6, o quadro permanece semelhante. Os pequenos proprietários com menos de 10 hectares somavam 49,43\% dos estabelecimentos rurais no Brasil e possuíam 2,22\% de hectares dessas terras. Ao passo que os grandes proprietários com 1000 hectares ou mais, 
somavam $0,97 \%$ dos estabelecimentos rurais no Brasil e possuíam 45,10\% de hectares dessas terras rurais, novamente um contingente mínimo de estabelecimentos rurais, possuíam quase a metade das terras rurais.

Ou seja, quase a metade dos estabelecimentos rurais possuía/possui uma porcentagem mínima de terras de 1,5 a 2,5 \%, ao passo que uma minoria de 1,5 a $1 \%$ dos estabelecimentos rurais, possui quase a metade da quantidade de terras rurais no Brasil. Em um país de dimensões gigantescas, está claro a desproporcional quantidade de terras, concentradas nas mãos de uma diminuta elite rural.

Aqui estamos nos referindo de 1,5\% (1940) a 1\% (1995/6) das empresas rurais e/ou proprietários privados, que detinham de 48\% (1940) a 45\% (1995/6) da área rural do Brasil, ao passo que com relação aos indígenas que eram 0,25\% (450.000 indivíduos/2006) ou 0,4\% (817.000 indivíduos/2013) da população brasileira e estamos nos referindo a 225 povos (2006) e 220 povos (2013), os quais detinham 12,41\% (2006) e 12,90\% (2013) da superfície nacional. Estes últimos possuem modelo de exploração sustentável, o qual conserva a biodiversidade de nossas florestas e os muitos conhecimentos associados a elas, estando entre as terras de florestas tropicais, as últimas e mais preservadas da Terra. Informava em 2006 a própria FUNAI, à respeito da concentração de terras no Brasil:

(...) Além disso, estatísticas elaboradas pelo Incra mostraram claramente que, somando-se as terras

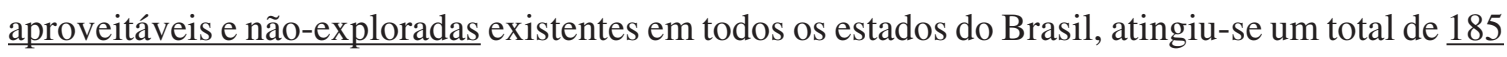
milhões de hectares, o que corresponde, aproximadamente, ao dobro de todas as terras indígenas. Logo, é a extrema concentração da propriedade fundiária em mãos de poucos membros da sociedade brasileira e sua má ou falta de utilização que levam a larga margem da população rural a não dispor de terras para trabalhar, e não a grande extensão dos territórios indígenas. (...) Há ainda, 255 milhões de hectares de terras não discriminadas ou cadastradas pelo órgão fundiário (INCRA). Isto significa que, mesmo ressalvando-se as áreas urbanas e aquelas destinadas à proteção ambiental, ao uso das forças armadas etc., resta muita terra para a expansão das atividades econômicas, sem que seja necessário proceder à invasão do habitat das populações indígenas. (FUNAI: 2006)

Portanto, está claro, o reconhecimento dos limites das terras indígenas não inviabiliza o desenvolvimento do meio rural. Sobre isto existem dados, segundo os quais, afirma Oliveira: As terras indígenas não obstaculizam a expansão das atividades agrícolas ou pecuárias, uma vez que as terras indígenas constituem parte menor do estoque de terras que poderia ser destinado a 
programas governamentais de colonização e/ou reforma agrária. (OLIVEIRA, João Pacheco: Terras Indígenas no Brasil, CEDI/Museu Nacional, 1987).

Isto posto, observemos agora, perante o total nacional que compreende o conjunto das Terras Indígenas, em detalhe a distribuição dessa população indígena sobre a citada dimensão.

Na Amazônia Legal, habitam cerca de $60 \%$ das populações indígenas, região que apresenta menor densidade populacional não indígena e terras ambientalmente mais preservadas. Esses povos detêm $98 \%$ das terras consideradas indígenas no Brasil.

Por outro lado, nas regiões centro-oeste, nordeste, sudeste e sul do país, estão localizados $40 \%$ das populações indígenas, regiões essas ambientalmente menos preservadas e densamente ocupadas pela sociedade envolvente, portanto, as terras mais disputadas. Os povos indígenas que habitam essas regiões detêm apenas $2 \%$ das terras consideradas indígenas. Essa disparidade de terras pode ser inicialmente compreendida, quando se observa o Mapa das Terras Indígenas no Brasil. (CD-Figura A).

O fato é que as necessidades de terras e ambientes preservados dos $40 \%$ da população indígena, que detêm os $2 \%$ das terras, em nada diferem das dos outros $60 \%$ da população indígena, que detêm os $98 \%$ das terras. Como entender a questão?

Esse desequilíbrio entre disponibilidade regional de terras e quantidade de população indígena, tendo em mente a observação da geografia do Brasil quanto as suas características de adensamento populacional e aporte de recursos naturais, pode-se supor inicialmente que a diferença entre os tempos de colonização, mais antiga (centro-oeste, nordeste, sudeste e sul) e mais recente (Amazônia Legal), seja o diferencial.

Pode-se imaginar que o contexto histórico de garantia dos direitos indígenas às suas terras era outro no passado, o que na verdade, em termos legais não diferia tanto assim, como veremos ao longo desse trabalho, as sucessivas legislações sempre garantiram os direitos à terra aos povos indígenas desde o Brasil Colônia.

A atual Constituição de forma semelhante a outras legislações do passado considera que as sociedades indígenas não podem estar dissociadas da questão territorial, dado o papel relevante que a terra apresenta para a reprodução física e cultural, delas.

Apesar de a legislação ser a princípio voltada a toda e qualquer sociedade indígena, na verdade a defesa estatal da integridade territorial indígena é marcada em cada época e local, por diferentes contextos.

Dado o contexto histórico da colonização, de início pode parecer "natural" a distribuição da população indígena sobre as terras apresentadas. Porém, se olharmos atentamente esse contexto, 


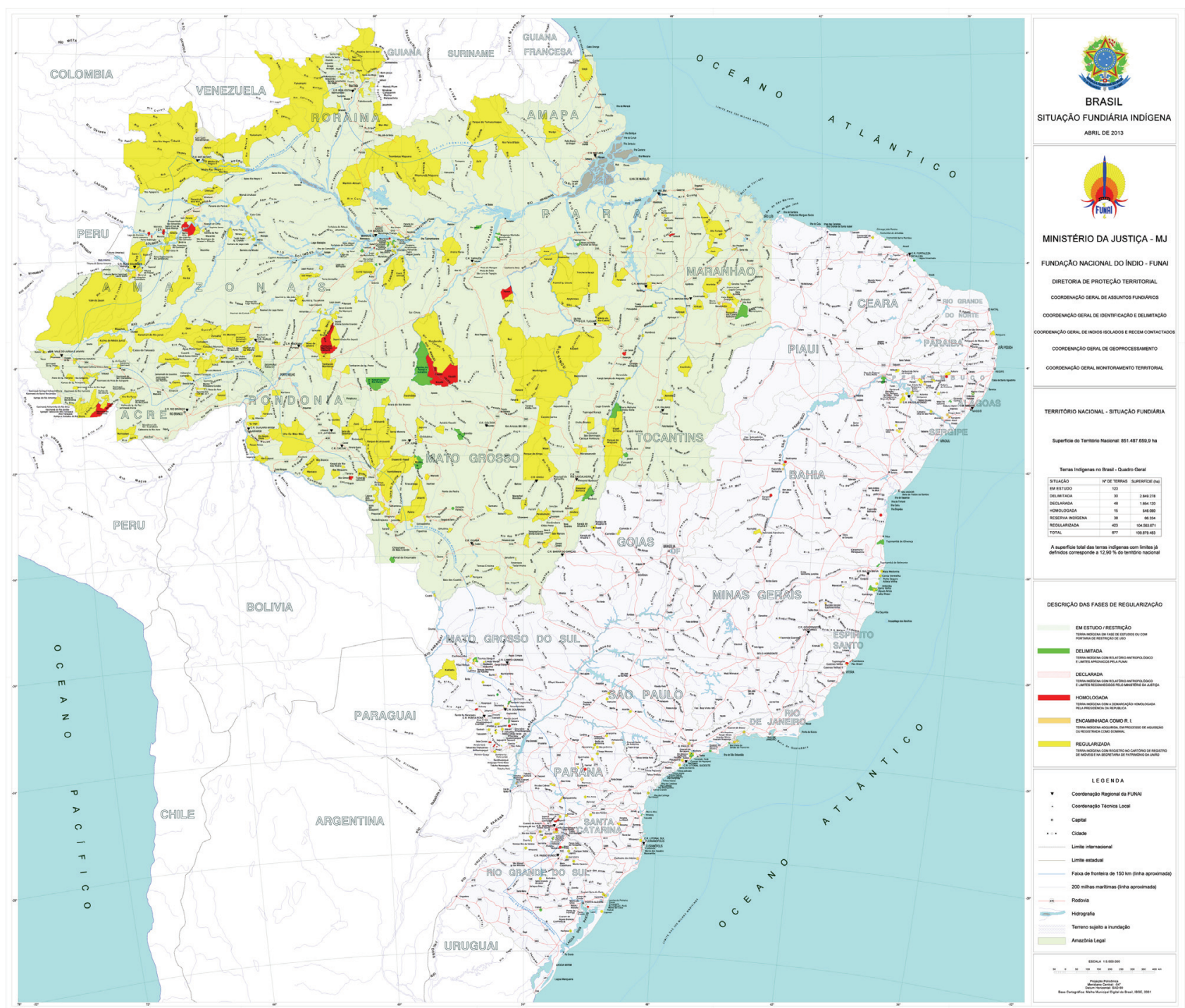

CD-Figura A. Mapa das Terras Indígenas no Brasil.

Fonte: www.funai.gov.br, 2013. 
sob o ponto de vista histórico e geopolítico atual, podemos perceber que esta realidade pode tomar outros contornos. A questão é: A partir desta conjuntura geográfica indígena estabelecida através do tempo neste espaço territorial brasileiro (não sem influência do próprio Estado), como o Estado Nacional atualmente conduz a política de terras voltada para os indígenas? Esta questão pode ser respondida através das reflexões a seguir.

A ocupação não indígena mais intensa da Amazônia Legal é relativamente recente, dos anos 70 para cá. São áreas que possuem mais baixo adensamento populacional - o que é uma condicionante histórica transitória, e ainda, riquezas naturais úteis em grande quantidade (minerais, vegetais, microrganismos, animais, aquíferas, madeireiras etc.), ou seja, biodiversidade, por conta da qual o Brasil é o país mais rico do mundo. As políticas em torno da conservação ambiental e da preservação da biodiversidade, surgiram com maior fôlego também nas últimas décadas. No bojo desse processo existe uma valorização por certos setores também das Comunidades Indígenas e de seus conhecimentos, assim como de suas terras e de seu patrimônio físico ambiental.

Defender hoje a garantia da posse das Terras Indígenas na Amazônia Legal representa para certos setores do Estado Nacional e internacionais, uma espécie de reserva de mercado, uma reserva de fundos a médio e longo prazo, guardada para futuras explorações, enquanto não se conhece profundamente a potencialidade e os mecanismos de exploração deste território. O Estado preserva, enquanto ao mesmo tempo atrai investimentos, para a proteção da Amazônia Legal e na esteira para a proteção dos povos indígenas.

As demarcações de terras na Amazônia Legal são especialmente financiadas por organismos internacionais e nacionais que aglutinam recursos no projeto denominado Projeto Integrado de Proteção às Populações e Terras Indígenas da Amazônia Legal / PPTAL gerenciado pela FUNAI. Nele participam o Grupo dos Sete / G-7, integrado pelos países: Alemanha, Canadá, Estados Unidos, França, Itália, Japão e Reino Unido. O Projeto teve início em Genebra em 1991, com um aporte de U\$ 250 milhões de dólares.

O que baliza o processo demarcatório das Terras Indígenas financiado pelo PPTAL? Segundo texto da própria FUNAI, o objetivo do PPTAL é: proteger as florestas tropicais e conservar a biodiversidade, reduzindo as emissões de carbono e promovendo um maior conhecimento das atividades sustentáveis da Floresta Tropical (FUNAI: 2006). Assim, onde se encontra o elemento indígena nesses objetivos?

Participam também desse empreendimento o Banco Mundial, o Banco Interamericano de Desenvolvimento / BIRD, o $\underline{\mathrm{KfW}}$ - Banco de Desenvolvimento do Governo Alemão e o Gover- 
no Brasileiro. Em 2006 havia segundo o site da FUNAI, um total de aproximadamente US\$ 21 milhões disponíveis, sob a rubrica de Recursos e Fontes, assim compartilhados:

$$
\begin{aligned}
& \text { - US\$ 2,1 milhões - RFT ( } \underline{\text { Banco Mundial }} \text { ) } \\
& \text { - DM } 30 \text { milhões (US\$ 16,6 Milhões) - } \underline{\text { KfW }} \text { (Governo da Alemanha) } \\
& \text { - US\$ 2,2 milhões - Contrapartida do Governo do Brasil. }
\end{aligned}
$$

Nesta conjuntura ambiental de Amazônia Legal, os povos indígenas instalados sobre recursos naturais de altíssimo potencial econômico, vêem por enquanto suas terras serem relativamente protegidas ${ }^{2}$ através da demarcação, sendo eles ao mesmo tempo, fonte inesgotável de conhecimentos sobre a biodiversidade de seus próprios territórios.

Por outro lado, vem ocorrendo à 500 anos ocupação da área territorial correspondente ao centro-oeste, nordeste, sudeste e sul. Essas áreas compreendem os maiores centros urbanos do país, a maior concentração populacional, assim como são as regiões onde estão estabelecidas há mais tempo os maiores interesses do capital. A disputa pelas terras é maior, portanto, elas vêm sendo historicamente mais valorizadas pela sociedade envolvente.

As populações indígenas dessas regiões vêm sendo fortemente espoliadas de suas terras pela sociedade nacional envolvente. Passaram a habitar terras, além de fixas, via de regra, muito menores em extensão, cercadas e ameaçadas em sua qualidade ambiental, vivendo dessa forma certo confinamento territorial. Em áreas de Mata Atlântica, essas populações habitam regiões ambientalmente conservadas, as quais se caracterizam por serem os últimos e poucos redutos de biodiversidade, sendo essas terras disputadas também por Unidades de Conservação, posseiros, turismo, empreendimentos etc. Observa-se, portanto, histórica perda de terras por parte dos índios dessas regiões, apresentando situação fundiária mais frágil e injusta. Ladeira (2001:40) refere-se à mesma situação:

(...) é, no reduto Mata Atlântica / povos indígenas das regiões sul e sudeste, que surgem os impasses mais críticos, os debates teóricos mais antagônicos e os projetos de desenvolvimento econômico, equacionados de forma mais injusta e lesiva aos povos indígenas. Pois, se a população indígena do país corresponde à $0,2 \%$ da população total e as terras indígenas destinadas a cerca de 200

\footnotetext{
${ }^{2}$ Apesar desse suporte voltado às demarcações de terra indígena na Amazônia Legal, o panorama demonstra que na realidade ocorrem invasões também nessas terras, através do avanço da fronteira agrícola, de extração de madeira e outros recursos naturais, de mineração, pelo agronegócio etc, o que demandaria também projetos voltados à maior vigilância das mesmas.
} 
grupos indígenas compõem perto de $11 \%$ do território nacional, $40 \%$ da população indígena do país, presente nas regiões sul, sudeste, centroeste e nordeste possui somente $\underline{1,3 \% \text { de áreas }}$ identificadas pela FUNAI (Pacheco de Oliveira, 1996). O “Mapa da Fome entre os Povos Indígenas no Brasil" (INESC, 1994) demonstra que os povos indígenas dessas regiões vivem as situações mais críticas. Contribui para essa situação o fato de restar somente cerca de $8 \%$ da Mata Atlântica original (LADEIRA: 2000:98).

Faria faz a seguinte assertiva sobre o papel do Estado: (...) de acordo com a conjuntura política, o Estado Brasileiro, através de ações governamentais, estabelece prioridades diferenciadas em relação à questão indígena, e, especificamente, à demarcação de terra. Ora o Estado impulsiona o processo de regularização, ora o retrai e cai na inércia (FARIA: 1997:38).

Apesar de haver concordância com Faria, deve-se acrescentar que não é apenas uma diferença temporal desta ou daquela determinada conjuntura política, mas, além disso, e, aliado a isso, há uma diferença espacial que determina este ou aquele foco geopolítico de Estado, sobre as áreas que compreendem as terras indígenas.

Na realidade atual a impressão que é fornecida é que são duas forças externas aos interesses dos próprios indígenas, que impulsionam ou não a demarcação de suas terras. Quando o Estado impulsiona a demarcação, fundamentalmente na Amazônia Legal, está garantindo naquele momento o território para um uso futuro, uso esse indígena, como provavelmente também, para uso não indígena, por ex: a pesquisa e futura exploração da biodiversidade. Quando retrai e cai na inércia, é quando as áreas ocupadas por indígenas, também são, desde a colonização, áreas concorridas, de interesse também de outros grupos de poder, terras nas quais acabam apresentando processos de negociação mais longos e difíceis, no sentido de garantir a posse indígena dos territórios por meio da demarcação, é muitas vezes o caso das outras áreas, extra-Amazônia Legal.

A demarcação por si só não representa garantias aos indígenas, na medida em que não se controlam adequadamente as invasões, questão que a FUNAI em todo país tem dificuldades de gerir, na medida em que existe escassez de agentes públicos para realizar razoável fiscalização, estando assim, grande parte das terras indígenas de alguma forma invadidas.

Nas terras indígenas do centro-oeste, nordeste, sudeste e sul a "garantia da terra" é a primeira e maior reivindicação dessas populações, o que é confirmado por Antunha Barbosa referindose a esse contexto num estudo sobre a população Guarani: $\mathrm{O}$ seu espaço preservado tem sido ainda a grande bandeira dos povos indígenas no Brasil. Antes de qualquer outra reivindicação 
(saúde, educação, comida) é a terra que lhes importa. É a sua soberania nela, (...) é no espaço, soberano que se exerce a própria identidade (ANTUNHA BARBOSA: 1994:15).

A partir dessas considerações, é possível supor como se dá a atual geopolítica do Estado brasileiro com relação às terras ocupadas pelos povos indígenas. Pode-se concluir que o critério atual de "proteção" governamental pode estar passando pelo viez das que possuem biodiversidade significativa a ser explorada em local de baixa concorrência territorial, das que possuem a posse de territórios não tão significativos em termos ambientais, menores em extensão, aliados a alta concorrência territorial, formada por grupos de interesse diversos, externos aos índios.

As Terras Indígenas da região sul, juntamente com as situadas no centro-oeste, sudeste e nordeste brasileiro se encontram em precária situação no que tange à resolução fundiária de suas terras, conforme as demandas de suas populações. Diante da situação verificada a partir dos trabalhos desenvolvidos no sul, a saber - $\underline{\text { a dificuldade de reconhecimento por parte do Estado }}$ Nacional dos direitos constitucionais previstos dessas populações indígenas e acompanhando o que ocorre nas outras regiões citadas, é de se supor que elas compartilhem o mesmo problema.

Assim tudo leva a crer que não é a defesa dos direitos e das terras indígenas "a priori”, que vem garantindo a atenção do Estado no processo demarcatório, mas na verdade, o que essas terras contem no seu interior, ou seja, maior ou menor disponibilidade de biodiversidade aliada ao conhecimento da população que nela habita, dependendo ainda, da concorrência territorial. A situação vivida pela população Guarani no Oeste paranaense, como veremos ao longo desse trabalho, é exemplo do que se afirma aqui.

A partir deste dado específico, a distribuição das populações indígenas sobre a respectiva quantidade de terras a elas reservadas em terras brasileiras, se discute os principais conceitos em que se pautam a pesquisa, os autores e os aspectos teóricos e metodológicos que a envolvem. Assim espera-se poder contribuir para a reflexão, sobre as atuais possibilidades de estudos de Geografia Humana, voltadas as populações indígenas sobre o território brasileiro e legitimidade dos processos políticos junto ao Estado Nacional.

Embora haja concordância a respeito da discussão inicial sobre a questão “Território Indígena" versus "Terra Indígena", sendo o primeiro termo, considerado estar assentado nas bases e condições materiais e extramateriais (socioculturais) da própria realidade indígena; e o segundo termo, estar assentado numa política do Estado, que administrando a questão, projeta toda uma carga de significados de interesses geopolíticos do próprio Estado, em que ao final este, limita o Território Indígena, tornando-o uma ou algumas Terra(s) Indígena(s), fixa(s) e limitada(s); toda- 
via, diante da questão Guarani a ser analisada neste trabalho, por ela estar muito aquém dos próprios parâmetros legais que o Estado impôs, fez-se necessário que a análise se desse dentro desses próprios parâmetros/limites, ou seja, pela lei, como único meio indicativo às autoridades estatais de fazer valer o direito indígena sobre seu território de ocupação imemorial.

Assim este trabalho não é uma reflexão livre sobre o direito indígena ao território. Esta pesquisa foi realizada em um contexto de uma antropóloga da instituição FUNAI, analisando a situação de uma determinada população indígena, que apresentava complexo problema fundiário, em que era necessário apresentar os fatos e uma solução legal, ao próprio Estado. Neste sentido não cabia exatamente discutir a lei em si, mas tentar demonstrar ao Estado que acompanhava esse processo através de suas instituições ${ }^{3}$, fazê-los ver o contexto em que a Comunidade Indígena se encontrava, demonstrando os fatos acontecidos, os quais se apresentavam contrários aos direitos que o Estado, através de seu poder legislativo, admitia como válidos. Ou seja, esperavase que fosse retomado o caminho do bom senso, da lei como instrumento de normatizar o que está em desacordo, portanto, que pelo menos a lei fosse cumprida no sentido de os Guarani reaverem seus direitos territoriais.

Portanto, essa pesquisa possui uma moldura pré-definida, dentro desses limites. Com esta ferramenta era possível nos movimentar. Numa mão os fatos, na outra o apoio jurídico. Quanto a esse, o suporte jurídico, não existiu no âmbito institucional, de forma que o arcabouço jurídico existente nesta tese é aqui exposto através da visão de uma antropóloga-geógrafa, que vem acompanhando o processo vivido pela Comunidade Indígena do Oco’y.

É bom que se deixe claro que esta foi a nossa estreia (batismo de fogo) na questão "fundiária" indígena. Anteriormente nosso trabalho estava envolvido com outras questões relativas à saúde e meio-ambiente. Considerando que a parte que nos coube neste trabalho de pesquisa, acabou por se tratar de uma verdadeira "revisão" do caso, dado os inúmeros procedimentos oficiais já realizados e "solucionados em termos" pela FUNAI, dessa forma, a fim de revê-lo, foi necessário perscrutar passo a passo os fatos acontecidos e as leis, para que com segurança, emitíssemos um parecer antropológico condizente, a altura do problema colocado.

Desta forma, esta investigação antropológica e geográfica e para além dela, pois também se constituiu numa revisão jurídica, resultou ao final descortinar um resumo de erros cometidos no passado, em que se questiona ao fim, a validade da lei, se ela não é cumprida. O poder de Estado,

\footnotetext{
${ }_{3}^{3}$ FUNAI, Ministério Público e Justiça Federal de Foz do Iguaçu, VI ${ }^{\circ}$ Câmara de Coordenação e Revisão da Procuradoria Geral da República em Brasília.
} 
neste estudo de caso se movimenta acima e abaixo desses parâmetros legais, está desencarnado deles, embora aparentemente esteja ao seu lado.

Neste contexto seria incorreto afirmar que não há legislação suficiente para garantir a posse de pelo menos as terras ocupadas pelos indígenas, elas existem, todavia, elas não são suficientes para garantir na verdade o próprio "estado de direito".

A história que será contada neste trabalho mantém os envolvidos numa rede de pensamento circular. Embora tenha sido dada publicidade aos fatos, exposto as leis concernentes e sua discrepância frente a esta realidade, tendo sido revisto detalhadamente todos os mecanismos utilizados no passado para burlá-las, como ainda por fim foi apresentado o conteúdo desse material às autoridades estatais responsáveis pela questão, no entanto, as graves injustiças permaneceram. Os Guarani continuam confinados em terras muito inapropriadas, na própria Terra Indígena AváGuarani do Oco'y. Num contexto em que se resume a um misto de genocídio, opressão, repressão, injustiça, inconformidade, luta desigual, abuso de poder e dissimulação por parte do poder constituído, indaga-se, e agora, o que fazer? É no interior da Universidade que procuramos discutir, visando reabrir os caminhos para esses indígenas e para outros que poderão estar sujeitos à situação semelhante, para que assim também outros estudiosos da questão possam dar um passo a frente, para compreender nessa intrincada rede, como o poder funciona e tentar ultrapassálo, por meio da própria legalidade e publicidade sobre os fatos.

\section{O direito indígena ao território}

Assim a questão fundamental neste trabalho é discutir o Direito Indígena ao seu Território ou às suas Terras. Neste sentido, a análise deve contar fundamentalmente com os parâmetros legais criados pela nossa sociedade, para imputar a outra sociedade, a indígena, os limites em que elas podem existir e exercer seu direito à vida e a terra.

No Brasil há o reconhecimento legal, de forma diferenciada, dos direitos específicos às terras dos povos indígenas, diferentemente de outros países latino-americanos onde também possuem populações indígenas.

Esses últimos foram mais fortemente submetidos à ordem estatal dirigida por uma minoria "branca", tratando seus direitos comunitários à terra de forma indistinta de outras populações, ou seja, imperou a propriedade individual da terra, sendo seus modos de organização comunitária e 
por decorrência seus direitos comunais, ceifados pelo poder estatal. Isso ocorreu talvez pelo fato de estarem mais expostos, já que são demograficamente a maioria da população - mão de obra para todas as finalidades em seus territórios - em que diante de sua magnitude populacional, ocupam praticamente toda a extensão dos países em que vivem.

No caso brasileiro os indígenas por serem minoria em um país de grandes proporções, conseguiram manter-se de certa forma, por longos períodos, isolados nos grotões territoriais, considerando que ainda hoje há vários grupos ainda não contatados; ou tiveram também, até certa altura para onde se refugiar da influência do não índio, se dirigindo à regiões menos ocupadas, como foi verificado no decorrer do processo da colonização em direção ao oeste brasileiro; como ainda, outros grupos puderam conviver com suas diferenças em meio a outros povos não indígenas, não sem grandes perdas, sacrifícios e esbulhos, como é o caso dos Guarani no sul e sudeste brasileiro. O caso é que os índios do Brasil, conseguiram se manter em territórios legalmente reservados a eles de forma comunitária, e hoje se apresentam ao mundo como populações ainda bastante originais, na medida em que conservam sua identidade e tradições socioculturais. Diante dessa condição, pode também prosperar movimentos sociais dos próprios povos indígenas e de apoio por setores da sociedade nacional (Ongs), que redundaram na situação que encontramos hoje.

O contexto jurídico sobre o tema "Direito Indígena à Terra", é descrito pela legislação brasileira e comentado em inúmeras publicações, entre elas destacam-se: - a obra Os Direitos do Índio: Ensaios e Documentos (1987) de autoria da antropóloga, Professora Manuela Carneiro da Cunha; em seu capítulo 2, denominado Terra Indígena: história da doutrina e legislação foi reunida toda legislação acerca do assunto, onde traz as resoluções que ao longo da história do país foram proferidas pelas leis então vigentes; - outro trabalho que deve ser consultado é Os direitos originários dos índios sobre as terras que tradicionalmente ocupam e suas consequências jurídicas, de autoria do Juiz do Tribunal Regional Federal da $1^{\circ}$ Região, Dr. Fernando da Costa Tourinho Neto, trabalho contido no livro Os Direitos Indígenas e a Constituição (1993); - outra publicação que deve ser necessariamente visitada, denominada, O Renascer dos povos indígenas para o direito (1998), é de autoria do Professor Dr. Carlos Frederico Marés de Souza Filho; - o artigo Terras tradicionalmente ocupadas pelos índios do Professor Titular da Faculdade de Direito da Universidade de São Paulo, Jose Afonso da Silva, contido no livro Curso de Direito Constitucioonal Positivo, também é publicação esclarecedora sobre o tema.

O direito comunitário à terra pelos povos indígenas é garantido pelas normas legais no país desde o Brasil-Colônia, o que pode ser considerado um avanço diante da situação existente em 
outros países sul-americanos. Carneiro da Cunha (1987) demonstra as primeiras leis que garantiram esse direito.

As Cartas Régias de 30.07.1609 e a de 10.09. 1611, promulgadas por Filipe III, afirmam o pleno domínio dos índios sobre seus territórios e sobre as terras que lhes são alocadas nos aldeamentos: (...) os gentios são senhores de suas fazendas nas povoações, como o são na Serra, sem lhes poderem ser tomadas, nem sobre ellas se lhes fazer moléstia ou injustiça alguma; nem poderão ser mudados contra suas vontades das capitanias e lugares que lhes forem ordenados, salvo quando elles livremente o quizerem fazer... (Carta Régia, 10.09.1611. In: CARNEIRO DA CUNHA: 1987:58).

A segunda lei de âmbito nacional, publicada em defesa dos direitos indígenas ás terras que ocupam, talvez a mais importante delas, deu-se em 1680, quando foi promulgado o $\underline{\text { Alvará de } 1^{\circ}}$ de abril, que declarou que: as sesmarias concedidas pela Coroa Portuguesa não podiam afetar os direitos originais dos índios sobre suas terras. "Primários e naturais senhores" de suas terras eram enquanto tais isentos de qualquer foro ou tributo sobre elas.

E para os ditos Gentios, que assim decerem, e os mais, que ha de presente, melhor se conservem nas Aldeas: hey por bem que senhores de suas fazendas, como o são no Sertão, sem lhe poderem ser tomadas, nem sobre ellas se lhe fazer moléstia. E o Governador com parecer dos ditos Religiosos assinará aos que descerem do Sertão, lugares convenientes para neles lavrarem, e cultivarem, e não poderão ser mudados dos ditos lugares contra sua vontade, nem serão obrigados a pagar foro, ou tributo algum das ditas terras, que ainda estejão dadas em Sesmarias e pessoas particulares, porque na concessão destas se reserva sempre o prejuízo de terceiro, e muito mais se entende, e quero se entenda ser reservado o prejuízo, e direito os Índios, primários e naturaes senhores dellas (CARNEIRO DA CUNHA: 1987:59).

Segundo Carneiro da Cunha, a origem dos direitos indígenas sobre suas terras, estão assentados fundamentalmente na seguinte premissa:

Os direitos territoriais indígenas derivam do reconhecimento de sua posse imemorial (Cavalcanti, 1951, p. 53) e de o fato do indigenato ser a fonte primária e congênita da posse territorial (Mendes Jr, 1912, p. 57, e Affonso da Silva, 1984, p. 4), reconhecido expressamente em várias leis coloniais e em particular no Alvará de $1^{\circ}$ de abril de 1680, que declara os índios "primários e naturais senhores (das terras), devendo seus direitos serem preservados diante de concessões de terras a par- 
ticulares. É um direito decorrente da ocupação primitiva (Dallari, 1980, p.9), um direito histórico (Carneiro da Cunha, 1981b). (CARNEIRO DA CUNHA:1987:33).

Deve-se esclarecer essa serie de conceitos correlatos, que são citados de forma recorrente no âmbito indigenista, e que são fundamentais para compreender o direito indígena ao território, são eles: "Posse Imemorial", "Ocupação Primitiva”, "Direito Histórico", "Direitos como povos originários" que aparecem em nossa última Constituição (1988), "Direito Consuetudinário" e "Indigenato".

Todos eles expressam a antiguidade dos índios em termos históricos no território, mais especificamente sua anterioridade perante a presença do não índio. Daí o seu direito sobre as terras ser, originário, primitivo, imemorial, histórico e ainda, legítimo por si.

Assim os conceitos de Direito Consuetudinário e Indigenato, resumem de forma clara, essa espécie de direito.

O primeiro quer dizer que os indígenas por serem os povos originários ou autóctones eles obtêm o direito consuetudinário, isto é, o direito fundado nos costumes, através de um complexo de normas não escritas, originárias dos usos e costumes tradicionais desse povo, a qual sua existência é anterior a qualquer legislação do país, de obter, a posse dos territórios que ocupam.

Quanto ao segundo termo, Indigenato, é definido pelo Professor Jose Afonso da Silva, o qual reitera novamente antes de mais nada que o direito indígena sobre suas terras, extrapola o direito civil comum. Ele indica que o Alvará de $1^{\circ}$ de abril de 1680 , que não foi revogado, referese que nas terras outorgadas a particulares, sempre será reservado o direito dos índios, primários e naturais senhores delas. Criou-se a partir dessa premissa a figura jurídica do Indigenato, ou seja, é reconhecido "o direito originário e preliminarmente reservado aos povos indígenas". O Indigenato é legitimo por si, não é um fato que depende de legitimação. O Indigenato é um direito que jamais pode ser confundido com uma posse, sujeita a legitimação e registro. Antes dos povos indígenas não havia ninguém neste território, não havia títulos anteriores a seus direitos originários. O Indigenato é, dessa forma, a fonte primária e ainda congênita da posse territorial. (SILVA:1992:46) Ele ainda é insuscetível de gerar direito à particulares (ANTUNHA BARBOSA: 1994:135), é um direito do agrupamento, da Comunidade.

Carneiro da Cunha aponta: 
Os direitos territoriais dos índios estão garantidos na Constituição vigente ${ }^{4}$, que data de 1969 , seguindo uma tradição constitucional que remonta a 1934 (Const. 1934, art. 129; Const. 1937, art. 154; Const. 1946, art. 216; Const. 1967, art. 186). Esses direitos são reiterados no Estatuto do Índio e no Estatuto da Terra (art $2^{\circ}$, parágrafo $\left.4^{\circ}\right)^{5}$. Na sua formulação atual a Constituição atribui à União a propriedade das terras indígenas (art. $\left.4^{\circ}, I V\right)$ e aos índios a sua posse permanente e o usufruto exclusivo de suas riquezas. (CARNEIRO DA CUNHA: 1987:32-3)

Com base nessas legislações citadas veremos ao longo desse trabalho, em cada período em que se deram os fatos, o contexto de esbulho vivido em quatro aldeamentos dos quais os Guarani do Oco'y são provenientes, e, paradoxalmente as correspondentes legislações que garantiriam os seus direitos à terra e como elas foram desconsideradas e/ou burladas.

A Constituição Federal vigente (1988) é texto denso, que necessita de maior esclarecimento conceitual. Visando acompanhar as ideias que serão aqui expostas à seu respeito, disponibilizamos primeiramente o próprio texto constitucional.

Capítulo VIII - Dos Índios. Art. 231. São reconhecidos aos índios sua organização social, costumes, línguas, crenças e tradições, e os direitos originários sobre as terras que tradicionalmente ocupam, competindo à União demarcá-las, proteger e fazer respeitar todos os seus bens.

Paragráfo $1^{\circ}$ : São terras tradicionalmente ocupadas pelos índios as por eles habitadas em caráter permanente, as utilizadas para suas atividades produtivas, as imprescindíveis à preservação dos recursos ambientais necessários ao seu bem-estar e as necessárias a sua reprodução física e cultural, segundo seus usos, costumes e tradições.

Paragráfo $2^{\circ}$ : As terras tradicionalmente ocupadas pelos índios destinam-se à sua posse permanente, cabendo-lhes o usufruto exclusivo das riquezas do solo, dos rios e dos lagos nelas existentes.

Parágrafo $3^{\circ}$ : $\mathrm{O}$ aproveitamento dos recursos hídricos, incluídos os potenciais energéticos, a pesquisa e a lavra das riquezas minerais em terras indígenas só podem ser efetivados com autorização do Congresso Nacional, ouvidas as comunidades afetadas, ficando-lhes assegurada participação nos resultados da lavra, na forma da lei.

\footnotetext{
${ }^{4}$ Vigente na época em que publicou esse livro (1987) era válida a Constituição de 1967 e a Emenda Constitucional de 1969; o livro foi publicado nesta data como material auxiliar nas discussões da Constituinte, que daria origem a Constituição de 1988.

${ }^{5}$ Lei ${ }^{\circ} 4504$ de 30/11/1964. Estatuto da Terra. Título I. Capítulo I. Artigo $2^{\circ}$. É assegurado a todos a oportunidade de acesso à propriedade da terra, condicionada pela sua função social, na forma prevista nesta lei. Parágrafo $4^{\circ}$. É assegurado às populações indígenas o direito à posse das terras que ocupam ou que lhes sejam atribuídas de acordo com a legislação especial que disciplina o regime tutelar a que estão sujeitas.
} 
Parágrafo $4^{\circ}$ : As terras de que trata este artigo são inalienáveis e indisponíveis, e os direitos sobre elas, imprescritíveis.

Parágrafo $5^{\circ}$ : É vedada a remoção dos grupos indígenas de suas terras, salvo, ad referendum do Congresso Nacional, em caso de catástrofe ou epidemia que ponha em risco sua população, ou no interesse da soberania do país, após deliberação do Congresso Nacional, garantido em qualquer hipótese, o retorno imediato logo que cesse o risco.

Parágrafo $6^{\circ}$ : São nulos e extintos, não produzindo efeitos jurídicos, os atos que tenham por objeto a ocupação, o domínio e a posse das terras a que se refere este artigo, ou a exploração das riquezas naturais do solo, dos rios e dos lagos nelas existentes, ressalvado relevante interesse público da União, segundo o que dispuser lei complementar, não gerando a nulidade e a extinção direito à indenização ou a ações contra a União, salvo, na forma da lei, quanto às benfeitorias derivadas da ocupação de boa-fé.

Art. 232. Os índios, suas comunidades e organizações são partes legítimas para ingressar em juízo em defesa e de seus direitos e interesses, intervindo o Ministério Público em todos os atos do processo (CONSTITUIÇAO FEDERAL DO BRASIL: 1988) (grifos nossos).

Assim, no texto constitucional atual (1988) são destacados conceitos fundamentais, associando as especificidades dessas populações às terras que tradicionalmente ocupam. São eles: o direito às próprias formas de organização sociocultural nas terras que ocupam; - "os direitos originários sobre as terras"; - "terras tradicionalmente ocupadas"; - o ambiente necessário à sua reprodução física e cultural; - "a posse permanente da terra"; - "o usufruto exclusivo da terra"; - "a inalienabilidade e a indisponibilidade da terra"; - e, "a imprescritibilidade dos direitos sobre as terras", termos esses que devem ser claramente definidos e discutidos.

O Artigo 231, assim se refere: São reconhecidos aos índios sua organização social, costumes, línguas, crenças e tradições... .

Quanto a essa forma textual, deve-se associar ressaltando o marco histórico acontecido. Após a sociedade civil realizar reflexão crítica sobre a política de integração dos indígenas à sociedade nacional realizada pelo Estado, a Constituição Federal de 1988 reconheceu finalmente essas populações enquanto realidades socioculturais diferenciadas, levando em conta seus direitos às formas próprias de organização sociocultural.

O mesmo artigo ainda afirma: São reconhecidos aos índios... os direitos originários sobre as terras que tradicionalmente ocupam, competindo à União demarcá-las, proteger e fazer respeitar todos os seus bens. 
Por esse enunciado legal, nos parece que a atual Constituição passou a vincular os direitos originários dos povos indígenas, ou seja, o Indigenato, passando este conceito a estar associado não há qualquer terra e não de qualquer modo, mas somente sobre as terras que "tradicionalmente" ocupam. O parágrafo $1^{\circ}$, considera o termo "terras tradicionalmente ocupadas":

- as por eles habitadas em caráter permanente;

- as utilizadas para suas atividades produtivas;

- as imprescindíveis à preservação dos recursos ambientais necessários ao seu bem-estar; e,

- as necessárias a sua reprodução física e cultural, segundo seus usos, costumes e tradições.

Estas quatro condições, todas necessárias e nenhuma suficiente sozinha, são os requisitos para que se possam realizar os procedimentos de demarcação das terras indígenas hoje no Brasil, ou seja, para se dar o reconhecimento administrativo das terras por parte do Estado.

Assim a atual Constituição prioriza no processo demarcatório a questão da "forma de ocupação", se ela se dá através de posse permanente dos índios nas terras e se ela se dá de acordo com os usos, costumes e tradições das sociedades indígenas.

Contribui para definir essa ideia, o pensamento de Jose Afonso da Silva, sobre ao que se refere o termo tradicionalmente: não a uma circunstância temporal, mas ao modo tradicional dos índios ocuparem e utilizarem as terras e ao modo tradicional de produção, enfim ao modo tradicional de como eles se relacionam com a terra (SILVA: 1992:47).

Dessa forma, entende-se que esta Constituição sub-repticiamente limitou o direito a terra à somente aqueles indígenas que continuam mantendo seus usos e costumes tradicionais. A título de elucidação, não teriam um espaço geográfico próprio no Brasil, por exemplo, os indígenas que se encontram em situação semelhante aos indígenas estadunidenses, pois apesar de serem os povos originários daquele país, muitos grupos perderam vários dos seus costumes tradicionais, e hoje alguns deles são profissionais liberais em seu próprio território.

Sim, a demarcação é apenas a confirmação, o reconhecimento administrativo do Estado. Isto porque as terras indígenas pela própria ocupação já são reconhecidas por si. Assim outro parâmetro legal que deve ser ressaltado, é o Artigo 25 do Estatuto do Índio (Lei n. 6001 de 1973), que garante os direitos indígenas as terras que ocupam, independentemente de sua demarcação.

Artigo 25: $\mathrm{O}$ reconhecimento do direito dos índios e grupos tribais à posse permanente das terras por ele habitadas, nos termos do artigo 198, da Constituição Federal, independerá de sua demarcação, e será assegurado pelo órgão federal de assistência aos silvícolas, atendendo à situação atual e ao consenso histórico sobre a antiguidade da ocupação, sem prejuízo das medidas cabíveis que, na omissão ou erro do referido órgão, tomar qualquer dos Poderes da República. 
O advogado Júlio Gaiger, ex-presidente da FUNAI, afirma à esse respeito:

Segundo o artigo 231 (CF), cabe a União Federal demarcar e proteger as Terras Indígenas. Os direitos indígenas sobre suas terras, porém, não dependem da demarcação. A demarcação é providência administrativa que visa identificar com maior precisão as terras indígenas, mas não tem o condão de constituir ou desconstituir direitos. O preceito constitucional de maior importância sobre as terras tradicionalmente ocupadas pelos índios, todavia, é o que reconhece que o direito dos índios sobre eles é originário (artigo 231 caput). Isso significa que a Constituição reconhece que os direitos territoriais indígenas precedem o Estado enquanto fonte de direito, exatamente por serem direitos anteriores ao próprio Estado. Coerentemente com esta compreensão, a expressão utilizada no texto constitucional, ao se referir aos direitos indígenas, é reconhecer. Em outras palavras, se os direitos indígenas são anteriores ao Estado, não cabe à Constituição senão reconhecê-los, sabendo-os preexistentes (GAIGER: 1989:5) (grifos nossos).

Deve-se considerar que historicamente o Brasil ainda não demarcou todas as terras indígenas, e mesmo que o tivesse feito, estamos lidando com grupos sociais, que ao longo do tempo, nascem, se reproduzem, crescem ou não demograficamente, morrem, partes se transferem de lugar, assim o processo é dinâmico, não tem um final exato para findar o processo demarcatório.

Como veremos adiante, as aldeias nas quais os Guarani do Oco’y são provenientes, não estavam ainda demarcadas e nem por isso deixavam de existir os direitos sobre elas. Portanto, a fonte de direito maior que os indígenas possuem sobre suas terras é o direito originário e congênito, ou seja, o conceito de Indigenato.

Embora os índios do Brasil detenham "a posse permanente" e o "usufruto exclusivo das riquezas do solo, dos rios e dos lagos" existentes em suas terras, conforme o parágrafo $2^{\circ}$ do Art. 231 da Constituição, elas constituem patrimônio da União. Questão que de certa forma se constitui numa ambiguidade, pois, se por um lado, estão protegidas a princípio por qualquer tipo de negociação proveniente da parte de terceiros ou mesmo até da parte dos próprios indígenas (individual ou coletivamente), por outro, estão à mercê do plano geopolítico do Estado.

A Constituição Federal de 1988 garante aos índios: - a posse permanente da terra e o usufruto exclusivo da terra (parágrafo $2^{\circ}$ do Art. 231); - a inalienabilidade e a indisponibilidade da terra, e, a imprescritibilidade dos direitos sobre as terras (parágrafo $2^{\circ}$ do Art. 231); - é vedada a remoção dos grupos indígenas de suas terras (parágrafo $5^{\circ}$ do Art. 231); - são nulos e extintos, não produzindo efeitos jurídicos, os atos que tenham por objeto a ocupação, o domínio e a posse 
das terras ou a exploração das riquezas naturais do solo, dos rios e dos lagos nelas existentes (parágrafo $6^{\circ}$ do Art. 231).

Porém, há exceções a garantia dessa posse permanente. Quando está em jogo a soberania do país, o relevante interesse público da União; e somente pode se dar o aproveitamento, a remoção, a ocupação, o domínio, a posse e a exploração dessas terras, após deliberação do Congresso $\mathrm{Nacional}^{6}$, e ainda, segundo o que dispuser lei complementar (CF:Artigo 231:parágrafos $3^{\circ}, 5^{\circ}$ e 6º); no caso o Estatuto do Índio (Lei 6001/1973), há previsão para todas essas situações.

Desta forma, este é o caso do presente trabalho. Fundamentalmente em relação ao parágrafo $3^{\circ}$ : O aproveitamento dos recursos hídricos, incluídos os potenciais energéticos.... ouvidas as comunidades afetadas, ficando-lhes assegurada participação nos resultados da lavra, na forma da lei.

Apesar de fortes oposições, o poder legislativo vem historicamente garantindo aos índios a posse das terras que ocupam. Ao contrário, como é o caso deste trabalho, nem sempre o poder executivo vem cumprindo a legislação, assim como também, o poder judiciário nem sempre a referenda como prevê a lei. Carneiro da Cunha comenta a esse respeito:

Apesar da força do texto constitucional e talvez precisamente por causa dela, tenta-se descaracterizar os sujeitos desses direitos territoriais, reduzir a extensão dos territórios assegurados e desfigurar em leis ordinárias e decretos o que dispõe a Constituição (CARNEIRO DA CUNHA: 1987:33).

Como veremos ao longo deste trabalho, exatamente as três premissas citadas pela professora Carneiro da Cunha, foi o caso ocorrido com os índios Guarani do Oco’y: O INCRA e a própria FUNAI tentaram descaracterizar os sujeitos desses direitos territoriais como "não índios"; IBDF/ IBAMA, INCRA e ITAIPU, reduziram enormemente a extensão do território desses indígenas, assegurados por leis vigentes; e por fim todas estas instituições governamentais, desfiguraram os fatos, através da má utilização das leis, sobre o que na verdade dispunha a Constituição, com a finalidade de não indenizar em terras o que era assegurado por lei. Esse é o tema fundamental deste trabalho, como o próprio Estado, a quem incumbiria proteger os direitos de seus tutelados, pois, são seus representantes legais, se utiliza desses próprios artifícios em prejuízo aos interesses e direitos dos indígenas.

Por fim, a questão fundamental que a Constituição não prevê é quando ocorre o esbulho, ou seja, quando os índios são privados da posse por violência ou fraude. A Constituição Federal só

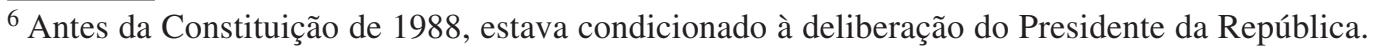


reconhece as terras que são ocupadas de forma permanente. Mas e se esses índios foram esbulhados de suas terras de ocupação imemorial, as quais eram tradicionalmente ocupadas? Como complicador, e se esse esbulho foi proveniente de ação do próprio Estado Nacional? É o que veremos neste trabalho.

\section{Aspectos teóricos e metodológicos}

O eixo teórico-metodológico dessa pesquisa se baseia em uma visão voltada às contradições existentes nas relações estabelecidas em determinada região (Tríplice Fronteira), entre os interesses geopolíticos e econômicos do Estado brasileiro e os interesses e direitos dos indígenas Guarani. O interesse dessa pesquisa está voltado para esta "fricção interétnica" produzida nas relações de contato entre as sociedades indígenas e as instituições representantes do Estado nacional, e a resultante assimetria dessas relações. Assim o eixo teórico parte de uma visão voltada às contradições existentes nessa relação, o que pressupõe um certo método de análise que vem a ser o método da dialética materialista.

Segundo Hegel, a natureza verdadeira e única da razão e do ser, que são identificados um ao outro, se definem segundo processo racional que precede pela união incessante de contrários tese e antítese - que resulta numa categoria superior, a síntese.

Marx incorporou em sua teoria este raciocínio tese x antítese: síntese, porém, contestou Hegel na medida em que considerou que a dialética para este, "estaria de cabeça para baixo", sendo necessário pô-la de "cabeça para cima", ou seja, não é a razão dos homens que determina o real, mas o lugar que cada homem ocupa, a partir de uma base material dada, que se reflete no seu pensamento. Assim Marx escreveu:

\footnotetext{
Meu método dialético, por seu fundamento, difere do método hegeliano, sendo a ele inteiramente oposto. Para Hegel o processo do pensamento - que ele transforma em sujeito autônomo sob o nome de ideia - é o criador do real, e o real é apenas sua manifestação externa. Para mim, ao contrário, o ideal não é mais que o material transposto para a cabeça do ser humano e por ela interpretado. (MARX: 1890:16).
}

A dialética materialista possui como ideia central que o mundo não pode ser considerado como um complexo de coisas acabadas, mas de processos fundados em uma base material 
dada, onde as coisas e os reflexos delas na consciência, isto é, os conceitos, estão em incessante movimento, gerados pelas mudanças qualitativas que decorrem necessariamente do aumento de complicação quantitativa. Trotsky afirmou a esse respeito, o que consideramos ser a base de nosso trabalho:

Quando as mudanças quantitativas sobrepassam certos limites se convertem em mudanças qualitativas. Determinar o momento preciso o ponto crítico em que a quantidade se transforma em qualidade é uma das tarefas mais difíceis ou importantes em todas as esferas do conhecimento inclusive da sociologia (TROTSKY: 1972:28).

Segundo Marx, a dialética é o processo de descrição exata do real. A dialética se resume ao desenvolvimento de processos, fatos concretos, gerados por oposições, que provisoriamente se resolvem em unidades. Cada acontecimento histórico é determinado por uma multiplicidade de fatores fundamentais e secundários. A dialética demonstra que fatores de $2^{\circ}, 3^{\circ}$ ou $10^{\circ}$ ordem em um momento dado, pode vir a assumir uma importância decisiva.

Marx descobriu uma base para a classificação científica das sociedades humanas, o desenvolvimento de suas forças produtivas e a estrutura de suas formas de propriedade, que constituem a anatomia social da sociedade de classes. $\mathrm{O}$ marxismo substitui por uma classificação dialética materialista a classificação vulgarmente descritiva. Trotsky afirmou a respeito:

O pensamento dialético está para uma película cinematográfica, assim como o pensamento vulgar está para uma fotografia. O filme não invalida a fotografia imóvel, senão combina uma série delas de acordo com as leis do movimento. O vício fundamental do pensamento vulgar está enraizado no eixo de que quer se contentar com fotografias inertes de uma realidade que consiste em eterno movimento (TROTSKY: 1972:29).

O pensamento dialético dá aos conceitos por meio de aproximações sucessivas, correções, riqueza de conteúdo e flexibilidade, que o aproxima do fenômeno vivido. Trotsky afirmou como exemplo: Não há um capitalismo em geral senão um capitalismo dado, em uma etapa dada do desenvolvimento. Não há um estado operário em geral, senão um estado operário dado, em uma país atrasado, dentro de um certo capitalismo (TROTSKY: 1972:29). Por fim Trostky concluiu: A dialética não nega o silogismo ${ }^{7}$, senão que nos ensina a combinar os silogismos de forma tal que nos leve a uma compreensão mais certa da realidade eternamente em mudança (TROTSKY: 1972:30).

\footnotetext{
${ }^{7}$ Silogismo: argumento formado por três proposições (a maior, a menor e a conclusão), de tal modo que a conclusão é deduzida da maior por intermédio da menor.
} 
O método utilizado nesta pesquisa é a dialética materialista, porque nossa base de reflexão é o conflito de interesses e as contradições existentes na tomada de decisões, gerado a partir do encontro entre as sociedades indígenas e as instituições representantes do Estado Nacional. Esse contexto expõe pela realidade dos fatos observados, os diferentes interesses que estão em interação, explicando as contradições existentes nas relações políticas, econômicas e socioculturais que estabelecem, através de certas leis e categorias que se repetem. Na realidade é o conflito de interesses existente entre os representantes da classe dominante, que detém o poder econômico, que por sua vez também controlam o poder político de Estado no âmbito da sociedade nacional, que explica como se dão essas relações, a qual revela através das bases materiais dadas, as "praxis" adotadas, frente aos interesses e direitos das Comunidades Indígenas.

O método de pesquisa aqui utilizado se baseia em prescrutar através de alguns eixos de observação: - a história oral contada pelos Guarani através de entrevistas gravadas; - a percepção das condições territoriais vividas por eles na prática ao longo do tempo e atualmente; - as determinações existentes na legislação federal brasileira que amparam o direito indígena aos territórios que ocupavam/ocupam; - as práticas institucionais adotadas pelo poder de Estado para com essa população, que são em sua essência, contraditórias aos direitos indígenas. Assim a partir de uma base material concreta, trabalharemos com a tese $\mathrm{x}$ a antítese, cuja dinâmica produzirá uma síntese desta realidade. Desta forma serão analisados:

Espaço necessário e o vivido na Terra Indígena do Oco’y. Pontuar as condições materiais de existência da população indígena na Terra Indígena do Oco’y, terra esta em que foram reassentados após parte de seu território original ser alagado pela Itaipu Binacional. A área em si apresenta-se inviável, dado que as condições fundiárias e ambientais não permitem o desenvolvimento do modo específico de sobrevivência física e cultural da população indígena, sendo a antítese do que a legislação federal determina, a qual prevê o amparo ao direito indígena sobre as terras que ocupam. O local produz efeitos seriamente comprometedores da saúde da população indígena, estando sua sobrevivência submetida à riscos graves. Nessa medida se discutirá sobre a contradição existente entre o espaço necessário de fato e de direito garantido constitucionalmente, frente ao espaço vivido.

O território Guarani ontem e hoje no tempo e no espaço. A partir de um grande território Guarani (Tekoa Guassu) existente em sua plenitude até 1940 que englobava inclusive o Oeste paranaense, composto ali de pelo menos 32 aldeias, observa-se na década de 80 o seu quase que total desaparecimento. Para ilustrar esse fato, é detalhada a ocupação indígena seguida de esbulho, 
ocorridas em quatro aldeias existentes no Tekoa Guassu, a saber, as aldeias “Guarani”, "São João Velho", "Colônia-Guarani” e “Oco’y-Jacutinga”. No processo verificado nota-se que as áreas de terras imemorialmente ocupadas pelos Guarani, as quais possuíam direitos constitucionalmente garantidos há tempos sobre elas, acabaram por sofrer completa redução em número e em extensão de terras. Os próprios órgãos governamentais encarregados (SPI e FUNAI) da proteção dos direitos das populações indígenas sobre as terras que ocupavam, obrigou-os, no processo histórico verificado, a "liberar" as áreas de terras, seja para os Grandes Projetos que se instalaram na região (PNI e UHE), seja para reassentamento de população não indígena, as quais foram antes obrigadas a se retirar das áreas que vieram a ser ocupadas por esses grande projetos. Na verdade os órgãos indigenistas teriam como missão institucional defender a posse indígena sobre o território ocupado. Decorrente da instalação desses dois grandes projetos estatais, a população indígena Guarani passou a viver um processo de encurralamento sobre o território, sendo transferida das aldeias em que viviam para outras aldeias, que cada vez em menor número, já se encontravam habitadas por outras populações indígenas. Provocava-se assim superpovoamento em terras proporcionalmente cada vez menores e em menor número, o que consequentemente sufocava/sufoca as expectativas de sobrevivência da população indígena, diante da crescente constrição territorial. No processo de transferência dessas populações, nota-se por um lado, o superpovoamento em algumas poucas aldeias no interior do país e, por outro, grande parte dessa população Guarani foi expulsa para fora do Brasil, tornando-se assim o Leste paraguaio densamente ocupado. O Estado se desincumbe e transfere para aquele país, a responsabilidade sobre as populações indígenas. Impedimentos quanto à permanência dos mesmos que transitam desde tempos imemoriais entre as fronteiras e pretendem viver no território brasileiro, também se faz sentir. Assim, de detentores outrora de um grande território no Brasil, tornaram-se praticamente indígenas sem-terra, desterritorializados.

O processo de desterramento do Oco’y-Jacutinga e o reassentamento no Oco’y. Será trabalhado tematicamente, para demonstrar as contradições existentes entre as práticas adotadas pelo Estado e o que a legislação federal determinava com relação a questão de desterramento indígena, no contexto de remoção dos mesmos, em função de obra pública. O território de ocupação imemorial do Oco’y-Jacutinga, suas características, e como foram sendo esbulhados em todo o processo histórico pelos representantes do Estado pelas Instituições IBAMA, INCRA e UHE, tendo a própria FUNAI as apoiado, em detrimento dos interesses indígenas. A FUNAI relega-os a uma nova parcela do território, o Oco'y, menor e de baixa qualidade ambiental, que em nada 
corresponde ao anterior, em oposição à todos os preceitos constitucionais vigentes, fundamentalmente o direito à terras em extensão igual e ambientalmente semelhantes a anterior.

Discurso dos índios Guarani x discurso do poder de Estado. Veremos no processo histórico descrito, as contradições existentes entre o discurso dos índios Guarani e o discurso do poder de Estado através da FUNAI, INCRA, UHE e IBAMA, sobre os fatos ocorridos.

As práticas Institucionais ilegais adotadas do poder executivo e as determinações legais das sucessivas Constituições Federais. Observar-se-à as contradições existentes entre o status legalmente estabelecido ao longo do tempo pela Constituição Federal e outras leis específicas que tratam da questão indígena, e, as práticas institucionais do poder executivo, os órgãos estatais UHE, IBDF/IBAMA e INCRA, inclusive as práticas da Instituição que detém o poder de Estado para executar a política indigenista, que justamente tem a missão Constitucional de defender os interesses, os direitos, o patrimônio físico e cultural, indígenas, a FUNAI. Veremos como o Estado através da tutela da FUNAI, desistiu da lealdade devida aos povos indígenas, para assumir os interesses da parte contrária. Nessa medida de como a FUNAI apesar da ampla legislação existente, pode atuar como um braço de contenção/repressão aos povos indígenas, perante os interesses de Estado e da classe dominante.

A legislação e as práticas adotadas pelos representantes da lei (poder jurídico). De como a Justiça Federal de Foz do Iguaçu ignora e se cala, criando um cordão de isolamento em torno dos índios Guarani, frente a possível resolução fundiária, os quais atuando em clara ilegalidade, acabam por demonstrar que mais forte que a superestrutura jurídica, é a base material organizada em torno da valorização do capital, que explica a contradição entre a forma jurídica e a ação prática dos homens que detém o poder jurídico.

A fronteira: Emigração para o Brasil x Imigração do Brasil. A realidade demográfica e territorial no Oco'y e a manipulação desta realidade pelo poder. O discurso do poder político e econômico, o qual se recusa a discutir a readequação das terras destinadas à população indígena no Oco’y, culpabilizando a própria população Guarani pelo excesso populacional. De forma inverídica é justificado publicamente por este discurso, que o excesso populacional no Oco’y, se dá em razão de suposta emigração do Paraguai para o Brasil, quando na verdade há um grande contingente populacional vivendo no Brasil em poucas e parcas terras, as quais, vem sendo paulatinamente subtraídas de forma ilegal por esses mesmos órgãos de Estado, obrigando, ao contrário do que é veiculado, a imigração dos Guarani do Brasil para o Paraguai. Quando os Guarani, os próprios, filhos e netos, descendentes daqueles que viviam antes no Brasil e foram obrigados 
a se dirigirem ao Paraguai, quando tentam se reestabelecer no Brasil são acusados de vir do Paraguai, de "paraguaios", portanto, implicitamente sem direitos ao território no Brasil.

Por fim é trabalhado como a sociedade dominante construiu a região da Tríplice Fronteira em função dos interesses do capital e dos interesses Geopolíticos de Estado na região, que resulta na substituição na região de populações indígenas e camponesas por proprietários de terras e Grandes Projetos de Estado.

Quanto às técnicas de pesquisa utilizadas em campo e gabinete. A pesquisa de campo iniciou-se em agosto de 2001, na Terra Indígena Avá-Guarani do Oco’y, localizada no município de São Miguel do Iguaçu, esse localizado a cerca de $40 \mathrm{Km}$ de Foz do Iguaçu, estado do Paraná/ Brasil. Foram realizadas 8 (oito) viagens a campo, em média de permanência de 15 dias cada viagem, que findaram em 2007.

A pesquisa de dados primários, colhidas através de pesquisa-ação e pesquisa participante, contou com os seguintes colaboradores fixos e eventuais:

a) História Oral contada fundamentalmente pelos Avá-Guarani da Terra Indígena Avá-Guarani do Oco'y, especificamente Conselho de Anciões, Pajés, Caciques, Lideranças da Comunidade, Professores Indígenas, Agentes de Saúde Indígenas, Agentes de Saneamento Indígenas e, em menor intensidade pelos Guarani da Terra Indígena Tekoa Ãnetete, localizada no município de Diamante D’Oeste, também no estado do Paraná, todos entrevistados através de gravação e transcrição de entrevistas.

b) Depoimento de funcionários locais da aldeia, a saber: Chefe de Posto da FUNAI, médicos, enfermeiras e atendentes de enfermagem do Posto de Saúde da aldeia subordinados à FUNASA; professores e diretor da escola indígena da aldeia, subordinados à prefeitura de São Miguel do Iguaçu; técnico agrícola da Usina Hidrelétrica de Itaipu.

c) Entrevistas com o Professor de História Paulo Porto, que realizou trabalho indigenista na área de educação na TI Avá-Guarani do Oco’y; com o antropólogo Evaldo Mendes que realizou pesquisa de doutoramento na mesma aldeia; com o arqueólogo Professor Dr Igor Chymz da Universidade Federal do Paraná em Curitiba, que realizou inúmeros levantamentos arqueológicos no oeste paranaense; com a Dra Maria das Graças Serafim, assim como com o Coordenador Estadual e seus técnicos da FUNASA de Curitiba; com o engenheiro agrimensor Sérgio Campos da Administração Executiva Regional da FUNAI em Curitiba.

d) Trabalho conjunto com o biólogo Julio Cesar de Moraes/ex-indigenista da FUNAI e toda a equipe de pesquisa em agrotóxicos da Universidade Federal do Rio de Janeiro/UFRJ. 
d) Reuniões várias com os sucessivos Procuradores da República do Ministério Público Federal de Foz do Iguaçu e seus assessores diretos responsáveis pelo caso; com o Juiz Federal Rony Ferreira também responsável pelo caso em Foz do Iguaçu; com diretores e antropólogo da Usina Hidrelétrica de Itaipu; com o Administrador da Administração Regional da FUNAI em Guarapuava/AERGU/FUNAI; com os Diretores da FUNAI em Brasília a saber: Artur Nobre Mendes, Diretor de Assuntos Fundiários/DAF e seus técnicos; Guilherme Carrano, Diretor da Coordenadoria Geral de Patrimônio Indígena e Meio Ambiente/CGPIMA e seus técnicos; com o Presidente da FUNAI, Mercio Pereira Gomes; com a Procuradora da República Dra Deborah Duprat responsável pela VI ${ }^{\mathrm{a}}$ Câmara de Coordenação e Revisão - Populações Indígenas e Minorias da Sub-Procuradoria Geral da República em Brasília; com o Diretor-Chefe da Advocacia Geral da União em Brasília, Dr Manoel Lauro Volkmer de Castilho.

A busca de dados secundários se deu nas seguintes Instituições:

a) Posto de Saúde da FUNASA na Terra Indígena Avá-Guarani do Oco’y/ São Miguel do Iguaçu/Pr;

b) Posto Indígena da FUNAI na Terra Indígena Avá-Guarani do Oco’y/ São Miguel do Iguaçu/Pr;

c) Coleta de dados com técnicos agrícolas da Secretaria de Agricultura da Prefeitura de São Miguel do Iguaçu; com técnicos da Secretaria de Saúde de São Miguel do Iguaçu; com a Prefeitura de São Miguel do Iguaçu; com a Pastoral da Terra de São Miguel do Iguaçu/Pr;

d) Administração Executiva Regional de Guarapuava/ AERGU/FUNAI/Pr;

e) Ministério Público Federal de Foz do Iguaçu/Pr;

f) Parque Nacional do Iguaçu/Foz do Iguaçu/Pr;

g) Usina Hidrelétrica de Itaipu; Foz do Iguaçu/Pr

h) Administração Executiva Regional de Curitiba/AERCW/FUNAI/Pr;

i) Coordenadoria Estadual de Saúde do Índio da FUNASA em Curitiba/Pr;

j) Instituto Ambiental do Paraná/IAP em Curitiba/Pr;

k) Universidade Federal do Paraná/UFPR em Curitiba/Pr;

1) Departamento de Documentação/DEDOC/FUNAI em Brasília/DF;

m) Universidade de São Paulo/SP;

n) Pontifícia Universidade Católica de São Paulo/PUC-SP

o) Centro de Trabalho Indigenista/CTI em São Paulo/SP.

p) Artigos, mapas e outras publicações pesquisados na internet. 
Por razões técnicas todos os Anexos apresentados nesta tese terão numeração individualizada em cada um dos capítulos e serão dispostos em CD à parte, sendo indicado nas pastas "capitulo X" cada um dos anexos correspondentes. Estão também no mesmo CD todas as Figuras que não couberam em folha A4. Estas Figuras aparecem no decorrer do texto da seguinte forma: "CD-Figura x". 


\section{CAPÍTULO 1 \\ A AÇÃO CIVIL PÚBLICA Nº 87.101.8182-2 EM QUE ACUSOU OS AVÁ-GUARANI DE EXTRAÇÃO ILEGAL DE MADEIRA}

Nosso primeiro contato com a questão dos Avá-Guarani da Terra Indígena Avá-Guarani do Oco’y, localizados no município de São Miguel do Iguaçu no estado do Paraná/PR, se deu em 31.08.2001, data em que fomos indicados pelo Departamento de Patrimônio Indígena e Meio Ambiente/DEPIMA ligado à Fundação Nacional do Índio/FUNAI, para realizar Laudo Antropológico ${ }^{1}$ sobre essa Comunidade Indígena.

Havia uma determinação anterior da Justiça Federal/JF de Foz do Iguaçu/PR, incluída como parte dos autos da Ação Civil Pública/ACP no 87.101.8182-2, movida pelo Ministério Público Federal/MPF de Foz do Iguaçu contra a FUNAI e o Instituto Brasileiro do Meio Ambiente e dos Recursos Naturais Renováveis/IBAMA, que determinava tal trabalho, o Laudo Antropológico.

O Juiz Federal Dr. Rony Ferreira, em Ata de Audiência ocorrida no dia 21.08.2001, exigia tal Laudo para responder a seguinte questão: "qual tamanho de área territorial a comunidade indígena Avá-Guarani do Oco’y necessita para a sua sobrevivência?”. Quanto a ACP citada, ela acusava os Avá-Guarani de extração ilegal de madeira e movia tal ACP contra FUNAI e IBAMA por não ter fiscalizado a área.

Revendo os fatos, em maio de 1982 os Avá-Guarani haviam sido reterritorializados em área que veio a ser a futura Terra Indígena Avá-Guarani do Oco'y, por acordo firmado entre a Usina Hidrelétrica de Itaipu conhecida como Itaipu Binacional e FUNAI, em área de terras de 231,88 hectares de extensão. Essa área de terras destinada aos Avá-Guarani e no mesmo ano demarcada pela FUNAI, nada mais era do que uma fração da Área de Preservação Permanente/APP do reservatório da Usina Hidrelétrica de Itaipu.

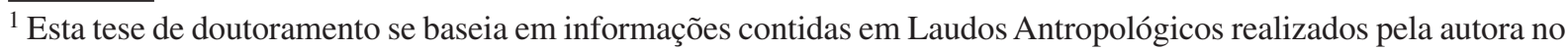
período de 2001 a 2005. Este capítulo toma em parte informações do seguinte trabalho. BRANT DE CARVALHO, Maria Lucia. LAUDO ANTROPOLÓGICO. Introdução: Proposta de Trabalho referente à Laudo Antropológico sobre a Terra Indígena do Oco’y. Ref: Comunidade Indígena da Terra Indígena Avá-Guarani do Oco’y. Município de São Miguel do Iguaçu. Estado do Paraná. Brasil. São Paulo: AERBAURU/SP/FUNAI/MJ. 2002. 27 p.
} 


\subsection{A suposta "extração" de madeira realizada pelos Guarani}

A criação desta Terra Indígena/TI por estas instituições resultou em um primeiro problema ambiental, que foi gerado assim pelo próprio Estado, na medida em que instalou indevidamente a Comunidade Indígena em uma APP, destinada à outra finalidade, a ser APP da Usina Hidrelétrica de Itaipu.

A ACP nº 87.101.8182-2, movida pelo MPF de Foz do Iguaçu contra FUNAI e IBAMA data de 10.10.90, referia-se a suposta "extração ilegal de madeira” realizada em 1989 pelos AváGuarani do Oco’y e posterior venda dessa madeira.

Nessa ação era descrito que o fato se dava em terras caracterizadas como APP; porém, não especificava tal área, ou seja, que ela se constituía em APP de propriedade da Itaipu Binacional, havendo sobreposição com Terra Indígena/TI, questão fundamental a ser averiguada, o que de antemão já mostrava sua condição de ilegalidade.

Essa Ação em um primeiro momento voltada contra os próprios Guarani, concluiu por fim, na determinação da JF de Foz do Iguaçu de que a FUNAI e o IBAMA sofressem multa e obrigações ativas, em razão da não fiscalização da área - desdobramento da questão da suposta madeira extraída anteriormente, retirada da APP; a FUNAI deveria oferecer cestas básicas aos índios, o que foi feito somente até 1992, apenas dois anos, quando se interrompeu sob alegação de não haver verbas no órgão; quanto ao IBAMA, deveria fiscalizar a área e proceder o reflorestamento nas áreas supostamente desmatadas pelos índios.

Em 2001 o MPF e a JF de Foz do Iguaçu receberam relatório do IBAMA, que demonstrava a impossibilidade de proceder ao reflorestamento, justificavam, argumentando sobre a exiguidade da área para esse fim e para ao mesmo tempo manter na área a Comunidade Indígena.

Além de não ser possível às Instituições atender as determinações judiciais (alimentar os índios e reflorestar a área), a questão da suposta "extração" de madeira da APP, culminou em um impasse: ou os índios na TI do Oco’y ou a APP de Itaipu, espaço para os dois não havia, segundo afirmavam os técnicos do IBAMA.

Diante da resposta do IBAMA, a JF suspendeu temporariamente a multa e conforme solicitação do Juiz Federal Dr. Rony Ferreira, em Ata de Audiência (21.08.2001) sobre autos da Ação Civil Pública, foi solicitado o "Laudo Antropológico" à FUNAI, indagando a dimensão de terras necessárias à sobrevivência dos Avá-Guarani.

Como antropóloga da FUNAI fui escalada para confeccionar tal Laudo Antropológico. A questão colocada pela ACP, afirmava que os Avá-Guarani do Oco’y teriam supostamente “extraí- 
do através de desmatamento parte da área de sua reserva e posteriormente vendido a madeira". Portanto, impunha-se antes de qualquer outra coisa, proceder junto aos índios Guarani a verificação dos fatos realmente ocorridos.

Como vimos essas autoridades não questionavam a "instalação" dos índios em área inapropriada, na APP de Itaipu. Portanto, impunha-se também a verificação da legalidade da área, que apesar do próprio processo não apontar, acabava por suscitar, na medida em que esta sobreposição é ilegal. Ao esclarecer toda a questão, surgiram outros elementos diretamente relacionados, ligados às condições de vida da população indígena no local, que serão citados neste capítulo e explorados no Capítulo 3.

Deve-se destacar que os acontecimentos não haviam sido anteriormente esclarecidos junto aos principais protagonistas da situação, os indígenas Avá-Guarani. Face às práticas de subsistência desses indígenas que implicam na necessidade fundamental de espaços florestados - pois é deles que provém a maioria dos produtos para sua subsistência, indagou-se antes, o que teria acontecido, já que o fato em si, “extração de madeira” realizada por eles, parecia contraditório e improvável, diante de seu modo de vida.

Dessa forma foi verificado através do relato dos próprios Avá-Guarani que após eles passarem a habitar a Terra Indígena do Oco’y em maio de 1982 - surpreendentemente em fração da APP do reservatório de Itaipu - mais tarde o Chefe de Posto da FUNAI no Oco'y solicitou à Itaipu a retirada de madeira caída às margens do referido reservatório.

Isso se deu porque com o advento criado por meio de inundação artificial do reservatório de Itaipu, que ocorreu em fins de outubro de $1982^{2}$, as árvores existentes nessa área, ás margens do Córrego Santa Clara, afluente do rio Ocoí, que por sua vez era afluente do rio Paraná, áreas estas de terras, todas, que em suas margens eram antes, florestadas, essas árvores tornaram-se desvitalizadas, mortas. O fato é comprovável através das imagens produzidas na TI do Oco’y e APP de Itaipu, nas quais nota-se até hoje (2012), a existência de árvores desvitalizadas tanto no interior quanto às margens dos locais que vieram a ser o reservatório da Itaipu Binacional. (Fotos 1 a 6)

\footnotetext{
${ }^{2}$ A Itaipu Binacional criou o reservatório em 14 dias, por meio da inundação do rio Paraná e de seus afluentes, no período de 23 de outubro a 05 de novembro de 1982. Disponível em: http://www.itaipu.gov.br/nossa-historia/ desafiohumano. Acesso em 26.ago.2012.
} 

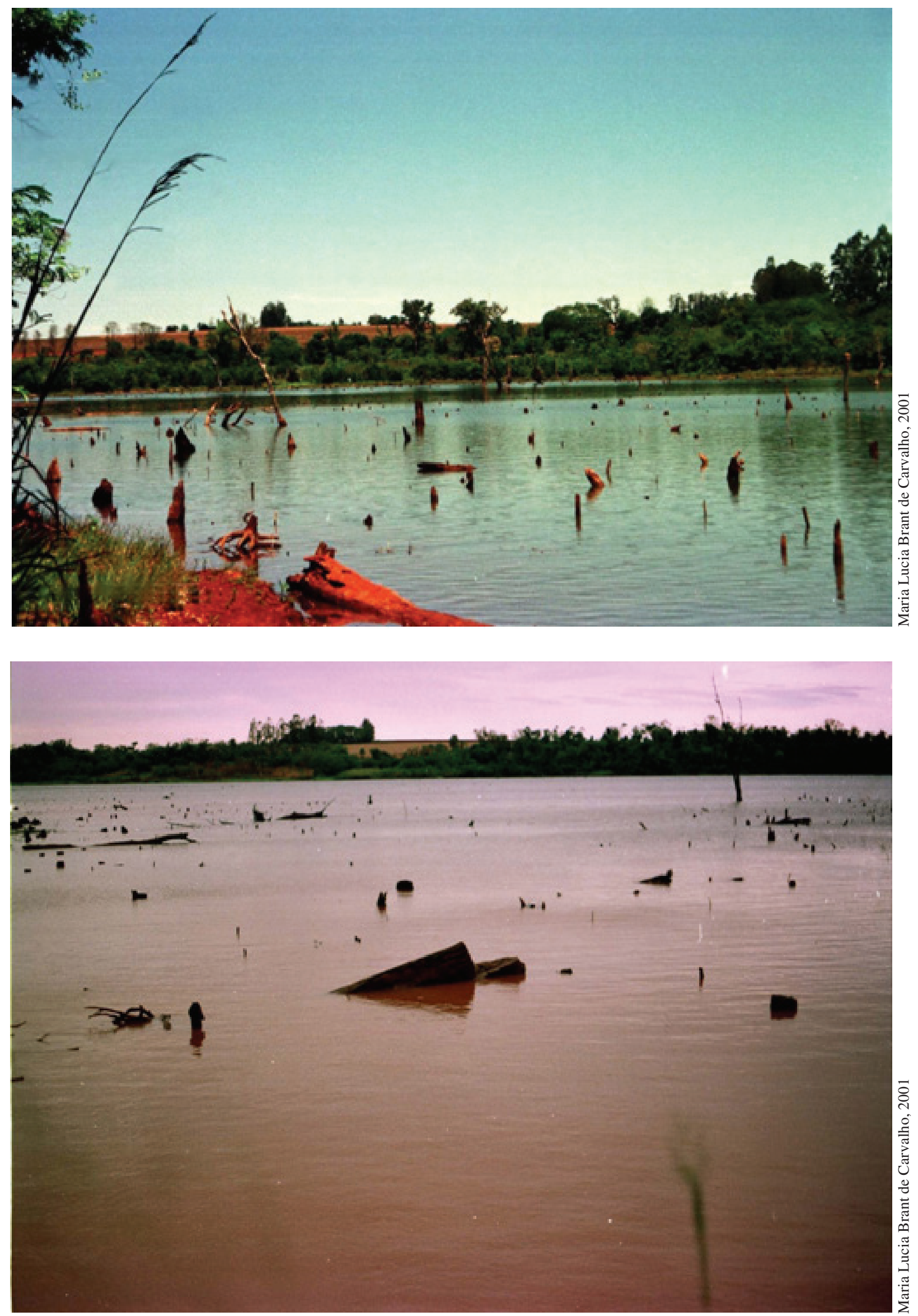

Figuras 1 e 2. Árvores desvitalizadas no interior do reservatório de Itaipu em frente à TI do Oco’y e APP de Itaipu. 

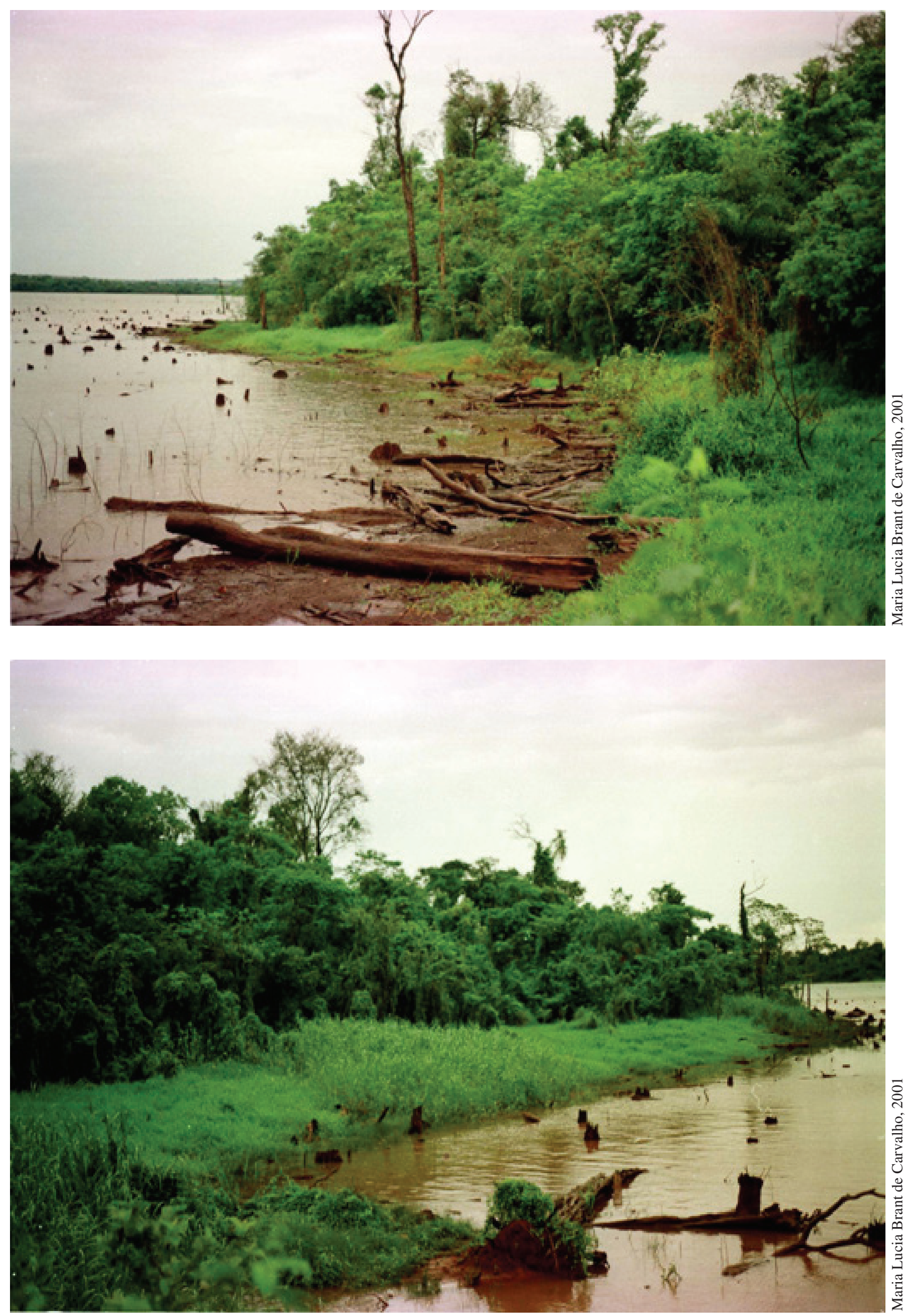

Figuras 3 e 4. Árvores desvitalizadas ás margens do reservatorio de Itaipu, em frente à TI do Oco’y e APP de Itaipu. 

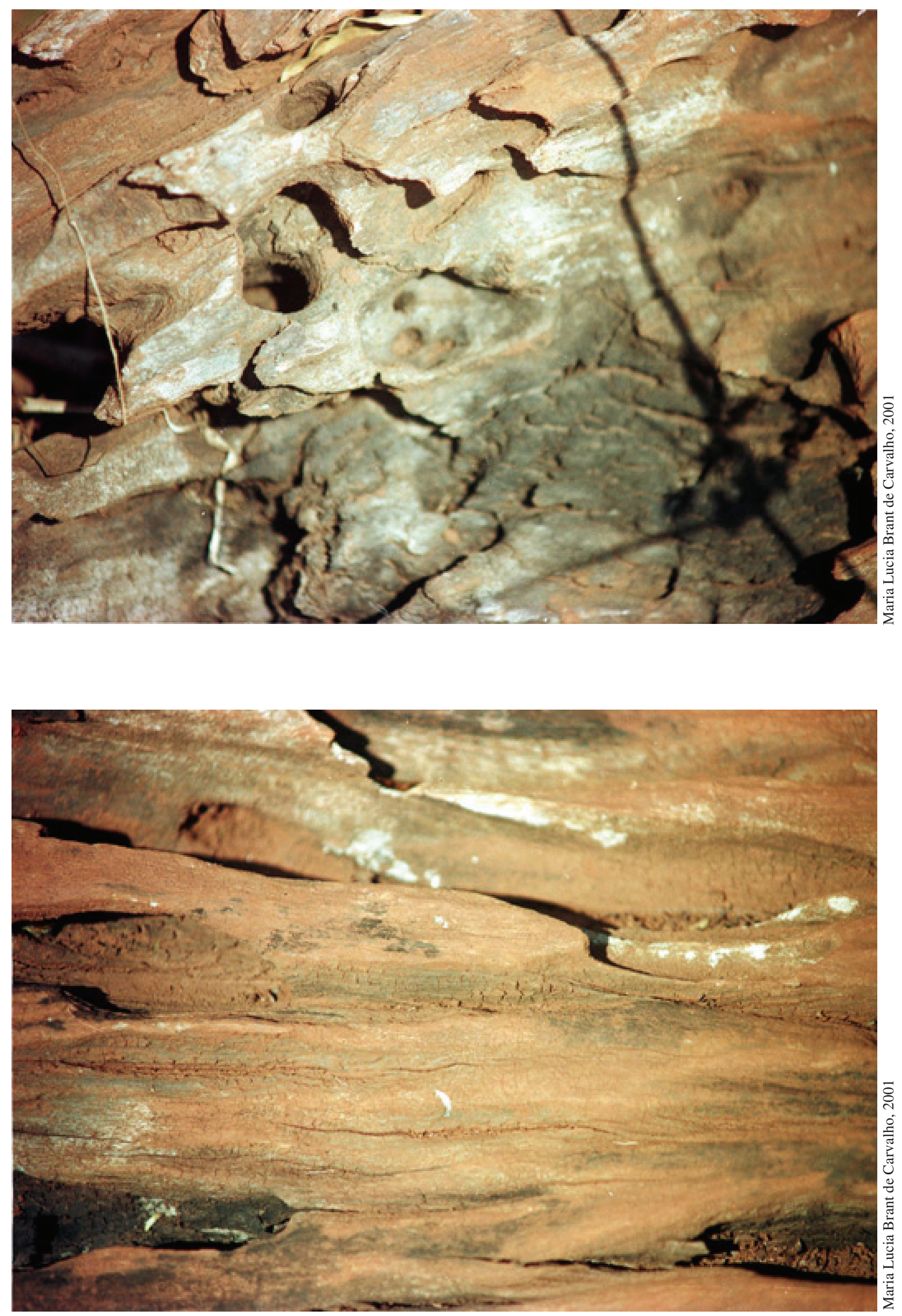

Figuras 5 e 6. Madeiras desvitalizadas, mortas. 
A princípio, segundo depoimento dos Avá-Guarani, seu interesse em utilizar esta madeira era dela fazer lenha para cozinhar seus alimentos e, assim, suprir necessidades básicas de subsistência. Deve-se ressaltar que a tecnologia indígena normalmente empregada nas atividades de subsistência é de baixo impacto - corte de madeira a machado, levando considerável tempo para transformar um tronco de árvore desvitalizado em lenha para uso, sendo o mesmo utilizado pelas famílias ao longo do tempo, contexto o qual, ecologicamente não agridem os ambientes preservados.

Ao constatar que esses índios passavam por sérias dificuldades para manter a própria subsistência - o que também se mostrava como fato surpreendente, pois legalmente Terra Indígena deveria apresentar espaço e ambiente, suficientes para sua sustentabilidade - o Chefe de Posto da FUNAI resolveu ser interessante vender parte dessa madeira, para assim obter recursos financeiros, os quais seriam destinados à compra de produtos alimentares básicos. O Chefe de Posto da FUNAI, Reinaldo, segundo o testemunho dos indígenas, com o intento de ajudá-los, assistindo ao problema imediato das famílias que passavam fome, aconselhou-os assim, a cortar a madeira para uso (lenha) e para venda.

Constatou-se que o referido funcionário da FUNAI, agiu de forma assistencial e não técnica, talvez não se apercebendo do contexto que o rodeava. Optou por medida de curto prazo, sem procurar resolver o problema maior: a falta de condições desses indígenas de proverem sua alimentação, no seu próprio espaço, nesta fração territorial e nas formas costumeiras como concebem fazê-lo, como é de direito Constitucional das populações indígenas.

Autorizada a retirada de madeira pela Hidrelétrica, a ação foi feita com uma "moto-serra" fornecida pela própria Itaipu Binacional. Ela se prestou aos dois usos: à subsistência dos índios (lenha) e venda através da FUNAI, o que serviu para suprir necessidades alimentares básicas dos Guarani. O procedimento foi realizado por duas vezes.

De acordo com o Cacique, antes da venda das duas levas de madeira, essa intenção não passava pela cabeça dos Avá-Guarani: "A gente nem sabia que era possível vender as árvore..., a FUNAI e a Itaipu que ensino pra gente..."; em seguida afirma: "vendeu como lenha cortada, desta largura..." (mostra a extensão entre as mãos, cerca de $70 \mathrm{~cm}$ de largura). O pajé completou afirmando que as madeiras boas, de lei, já não existiam na área quando os Avá-Guarani chegaram, pois "os colonos já tinham tirado toda a madeira boa antes de nós".

Segundo relataram os Avá-Guarani, o Chefe do Posto Indígena/PI Reinaldo negociou com a serraria próxima à Vila de Santa Rosa do Ocoí, solicitando que viesse buscar a madeira. A serraria comprou e pagou aos Avá-Guarani. Nesse ínterim foi substituído o Chefe de Posto. O novo Chefe Walderico, pouco familiarizado com o contexto vivido no Oco'y, ao assumir o Posto 
deparou-se com a saída de caminhão de madeira da área, e, no seu raciocínio - a princípio correto, tentou impedi-lo, denunciando às autoridades a situação. Os Avá-Guarani ficaram descontentes com o procedimento do novo Chefe, pois o antigo já havia firmado anteriormente o acordo com a serraria.

Neste contexto, foi iniciada a Ação Civil Pública nº 871018182-2. O objeto dessa Ação foi a segunda vez em que foi retirada e vendida a madeira. Nela consta que os Avá-Guarani teriam "extraído" madeira de parte de sua reserva e posteriormente vendido.

O comentário do Cacique à respeito de todo incidente: Tinha lei e a gente nem sabia..., nem de indio... nem de ambiente.... .

O que foi constatado se resume aos seguintes fatos:

a) No momento em que o IBAMA visitou o local, para verificar as possibilidades de reflorestamento, atestou de maneira genérica que não seria possível fazê-lo devido ao pequeno espaço disponível na APP. Dessa forma, afirmaram os técnicos do IBAMA que "o local comportava ou a população indígena ou o reflorestamento, pois espaço para os dois não havia". Acrescentamos ainda em 2001, em informação preliminar à Justiça Federal e ao Ministério Público Federal, ambos de Foz do Iguaçu, que realmente não haveria espaço para o reflorestamento por duas razões: As árvores caídas, mortas, cortadas e vendidas eram provenientes do interior e das margens do reservatório, onde não se poderia mais reflorestar face à óbvia umidade existente nesses locais. Afirmava que apesar de toda a área se tratar na verdade de uma pequena Mata Ciliar do reservatório da Itaipu Binacional, tudo o que não consistia em área de roças ou de residências indígenas, eram Matas. Observou-se naquela época que por insuficiência de terras os Avá-Guarani estavam também se utilizando da área que consideravam ser APP de Itaipu, para a coleta de produtos florestais.

b) A madeira foi "vendida" por ideia e indicação de funcionário da FUNAI, contando com a contribuição de Itaipu, na medida em que forneceu a moto-serra e deu autorização para a retirada da madeira. Fato que realmente não poderia acontecer dado que tanto TI quanto APP são Áreas de Preservação Permanente. Especialmente em Terra Indígena os índios tem livre acesso aos $\underline{\text { recursos ambientais para a finalidade de subsistência. Por seu turno na APP de Itaipu não pode }}$ haver extração de madeira saudável, pois do contrário a área corre o risco de assorear, fato que é proibido pelo Código Florestal, Lei no 4777 (15.09.1965), Artigo 2, letra “a”, item $3^{3}$. Muito menos pode ocorrer a venda delas.

\footnotetext{
$\overline{3}$ BRASIL. Lei no 4777 (15.09.1965). Código Florestal. Disponível em: http://licenciamento.cetesb.sp.gov.br/ legislacao/federal/leis/1965_Lei_Fed_4771.pdf. Acesso em 26.ago.2012.
} 
Art. $2^{\circ}$ Consideram-se de preservação permanente, pelo só efeito desta Lei, as florestas e demais formas de vegetação natural situadas: a) ao longo dos rios ou de qualquer curso d'água desde o seu nível mais alto em faixa marginal cuja largura mínima será: (Redação dada pela Lei no 7.803 de 18.7.1989). 3 - de 100 (cem) metros para os cursos d'água que tenham de 50 (cinquenta) a 200 (duzentos) metros de largura; (Redação dada pela Lei no 7.803 de 18.7.1989).

c) Até que se esclarecesse "a forma" da retirada e venda das madeiras, suspeitava-se que os indígenas teriam “extraído a madeira" através de desmatamento do local. O que foi comprovado é que a madeira não havia sido extraída, e, sim que foi aproveitada de árvores já caídas, desvitalizadas, mortas, existentes em grande quantidade nas margens e no interior do reservató-

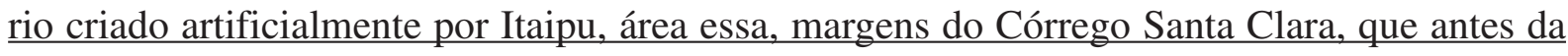
formação daquele reservatório, era florestada.

A questão de possível “desmatamento”, por parte dos índios foi esclarecida e descartada já de início, através dos depoimentos dos indígenas. Comprovou-se o que desde o início julgávamos improvável, a possibilidade de "desmatamento", na medida em que ele seria uma profunda contradição com o modo de reprodução sociocultural em que a população indígena realiza suas atividades de subsistência, pois é da Mata que advém a maioria dos produtos necessários à sua sobrevivência, não sendo, portanto, a ação, de interesse dos Guarani. O que era fato, é que o interesse dos indígenas pela madeira morta resumia-se a princípio obter lenha para a satisfação das necessidades de subsistência na área em que viviam o que é seu direito Constitucional, conforme Artigo 231 \#1 da Constituição Federal/CF${ }^{4}$.

Art. 231 - São reconhecidos aos índios sua organização social, costumes, línguas, crenças e tradições, e os direitos originários sobre as terras que tradicionalmente ocupam, competindo à União demarcá-las, proteger e fazer respeitar todos os seus bens. $\$ \mathbf{1}^{\mathbf{0}}$ - São terras tradicionalmente ocupadas pelos índios, as por eles habitadas em caráter permanente, as utilizadas para suas atividades produtivas, as imprescindíveis à preservação dos recursos ambientais necessários a seu bem-estar e as necessárias a sua reprodução física e cultural, segundo seus usos, costumes e tradições.

d) O Chefe de Posto Reinaldo orientou equivocadamente os índios pela decisão da "venda de madeira", auxiliado pela Itaipu, na medida em que autorizou a ação, emprestando ainda a moto-

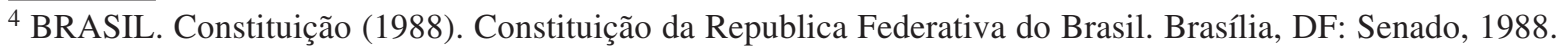


serra; tanto a ideia da venda de madeira, a contratação da mesma junto a serraria, quanto o material utilizado para cortar a lenha com o qual é possível produzir madeira em grande quantidade e por fim a autorização da hidrelétrica, fazem parte de realidades exteriores e inusuais aos usos e costumes indígenas. Assim notou-se que os índios foram levados por terceiros a praticar a ação.

e) O Chefe de Posto mediou a contratação da venda de madeira, com intenção de suprir "necessidades básicas de subsistência" no sentido de auxiliar assistencialmente a população indígena de forma imediata e urgente, pois esta passava fome na área de terras que havia sido destinada a ela. O problema é que a Terra Indígena do Oco’y deveria ser sustentável, suprindo as diversas necessidades de subsistência da população indígena que abrigava, o que não acontecia no local, pois as terras para a população indígena apresentavam-se insuficientes, qualitativamente em termos ambientais e quantitativamente em termos de extensão territorial, o que era contraditório com a Constituição Federal da época, assim como com o Artigo 231 \#1 da Constituição Federal atual $(1988)^{5}$.

f) A existência de clara ilegalidade quanto à sobreposição de APP de Itaipu e Terra Indígena do Oco’y; Somadas, a largura da APP em frente ao Oco’y e a largura da própria Terra Indígena, perfazem um total de 238 metros em média, o que corresponde quase a mesma medida somente da APP de Itaipu no Brasil, oficialmente declarada pela empresa como perfazendo 210 metros.

Como vimos os indígenas não praticaram "extração de madeira", mas aproveitaram madeira

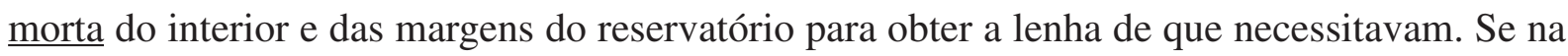
Terra Indígena a população necessita utilizar dos recursos ambientais para sua subsistência, na APP do lago de Itaipu não se pode utilizar nenhum recurso. Diante do fato que as terras disponíveis a população indígena se apresentavam muito pequena em extensão, estaria evidente que os Avá-Guarani iriam acabar por utilizar também a área considerada como APP.

Afirmamos que neste local, as duas formas APP e TI não convergiam para os mesmos interesses, ou seja, a preservação ambiental para o meio ambiente e para os índios, pois não havia espaço suficiente para a sobrevivência da população indígena. AAPP de Itaipu no local justificase por se tratar de pequena Mata Ciliar para proteger o reservatório de assoreamento, e, não exatamente de Preservação Permanente de recursos ambientais, os quais ela quase não possui (por ex.: quase nenhuma fauna).

g) As Terras Indígenas são de uso exclusivo dos mesmos, o que não acontece no local já que é utilizada também como APP do reservatório de Itaipu, fato que contradiz o Artigo 231 \# $6^{\circ}$ da

\footnotetext{
${ }^{5}$ Ibidem.
} 
Constituição Federal/CF ${ }^{6}$ e os Artigos 18 e 39 \# 2 $2^{\circ}$ do Estatuto do Índio/EI, Lei n 6001 de 19.12.1973. Ainda de acordo com a legislação, até as águas do lago/reservatório deveriam ser de uso exclusivo dos indígenas, conforme o Artigo 231 \# 2\% CF e Artigos 22 e 24 \#1\%/EI. Citamos aqui somente a $\mathrm{CF}$ :

Art. 231 - São reconhecidos aos índios sua organização social, costumes, línguas, crenças e tradições, e os direitos originários sobre as terras que tradicionalmente ocupam, competindo à União demarcá-las, proteger e fazer respeitar todos os seus bens.

$\S \mathbf{2}^{\mathbf{o}}$ - As terras tradicionalmente ocupadas pelos índios destinam-se a sua posse permanente, cabendo-lhes o usufruto exclusivo das riquezas do solo, dos rios e dos lagos nelas existentes.

$\S 6^{0}$ - São nulos e extintos, não produzindo efeitos jurídicos, os atos que tenham por objeto a ocupação, o domínio e a posse das terras a que se refere este artigo, ou a exploração das riquezas naturais do solo, dos rios e dos lagos nelas existentes, ressalvado relevante interesse público da União, segundo o que dispuser lei complementar, não gerando a nulidade e a extinção direito a indenização ou ações contra a União, salvo, na forma da lei, quanto às benfeitorias derivadas da ocupação de boa fé.

Ou seja, a lei estava em conflito por conta do estabelecimento indevido dos indígenas pela própria FUNAI e Itaipu, em APP do reservatório da hidrelétrica de Itaipu. Afirmávamos que neste caso, a consideração da legislação pelas autoridades (JF e MPF) estavam atendendo às necessidades da Usina Hidrelétrica de Itaipu, na forma de uma APP, e não estavam atendendo aos direitos indígenas, que garantiriam terras sustentáveis e de uso exclusivo das Terras e dos Recursos Naturais existentes nela. Acrescentávamos que pela avaliação em campo, mesmo que se tornasse a área toda (APP de Itaipu somada a TI) de uso exclusivo dos indígenas, estas terras, estariam ainda assim, longe de ser suficientes para aquela Comunidade Indígena. Pretender equilibrar, em um mesmo diminuto local, pequena APP, com pequena TI, que apresentava grande número de população, demonstrava ser impossível.

Denunciado o caso da venda de madeira, sem que os órgãos federais tivessem ciência plena dos fatos ocorridos na aldeia, foram imputadas as responsabilidades, a princípio contra os AváGuarani, posteriormente contra a FUNAI e IBAMA.

\footnotetext{
${ }^{6}$ Op. cit.
} 
Enfim, o problema na verdade surgiu porque os índios foram inadequadamente instalados na APP de Itaipu, área que não poderia de forma alguma ser utilizada. Fatos que indicariam a necessidade de uma retratação pública por parte das autoridades quanto a acusação feita sobre os AváGuarani, e, revisão jurídica do processo, questionando antes de qualquer coisa a instalação ilegal dos indígenas na APP, fato de responsabilidade da FUNAI e da Itaipu Binacional.

A partir destas considerações, este estudo indagava (0ut/2001):

a) Porque a população indígena Avá-Guarani foi assentada em um local totalmente impróprio para sua habitação, em uma área com ínfimas dimensões e que se caracterizava ambientalmente por ser apenas uma pequena Mata Ciliar, APP do reservatório da Usina Hidrelétrica de Itaipu? Dessa forma não foi reconhecida a sua organização social, pois esta não pode se dar neste espaço mínimo. Assim sequer a área poderia ser demarcada como Terra Indígena.

b) Os Guarani teriam direito a território de igual extensão e ambientalmente semelhante ao anterior, aonde habitavam, conforme reza a lei. Segundo depoimentos dos indígenas seu território tradicional se constituíam de terras de maior amplitude e mais ricas em termos ambientais ${ }^{7}$. Portanto, não foram reconhecidos seus direitos originários sobre as terras que ocupavam.

c) Esta APP não é um local de dimensões tanto qualitativas quanto quantitativas que se possa considerar, por exemplo, um "refúgio biológico" de espécies animais ou vegetais. Ela não tem esta característica. Dado o diminuto território, ele é considerado APP tão somente por apresentar uma pequena Mata Ciliar que visa proteger as margens do reservatório da Itaipu contra possível assoreamento, sendo esta sua finalidade principal, e, não possui características suficientes para ser Terra Indígena.

d) Quanto ao uso exclusivo dos índios, este não se dá, dada a superposição com a APP; a área não se presta às necessidades de reprodução física e cultural, segundo os usos, costumes e tradições dos Avá-Guarani. Porque, então, em flagrante contradição com a legislação existente, Estatuto do Índio e Constituição Federal, essa área foi demarcada como “Terra Indígena”?

e) Porque funcionário da FUNAI, ao invés de encaminhar providências para se obter terras suficientes às necessidades indígenas, como reza a lei, incentivou a venda de madeira para custear a alimentação dos índios? Essa alimentação, por direito e de fato, deveria ser provida com recursos extraídos da própria terra indígena que deveria ser sustentável. Indagava-se como a FUNAI estaria lidando com a questão fundiária daqueles a quem lhe incumbiria proteger legalmente?

\footnotetext{
${ }^{7}$ A Itaipu afirmou na Ação Civil Pública que destinou área de terras maior, o próprio Oco’y, do que a que viviam antes, no Oco'y-Jacutinga.
} 
f) Se indagava quais foram as medidas compensatórias providenciadas pela Itaipu Binacional, visando mitigar e/ou compensar os prejuízos sofridos pelos indígenas, quando da remoção de seu território de ocupação tradicional, o Oco'y-Jacutinga, pelo fato de que a Itaipu Binacional havia inundado este território anterior, onde os Guarani satisfaziam suas necessidades de subsistência?

g) Teria havido um Laudo Antropológico (LA) e um Grupo de Trabalho (GT) da FUNAI destinado a tratar da Identificação e Delimitação das terras de ocupação tradicional do grupo, dado que envolvia a desterritorialização da população indígena de seu território tradicional, por conta da inundação pela Usina Hidrelétrica de Itaipu, e, reterritorialização para outra localidade, no caso, na Terra Indígena Avá-Guarani do Oco’y?

Nenhuma das características observadas em Terras Indígenas, considerando-se o que a legislação federal assegura, foram levadas em conta na questão do reassentamento dos índios AváGuarani na Terra Indígena do Oco’y, pois tanto o território quanto o ambiente não preenchem nenhum dos quesitos suficientes para se considerar esse local como Terra Indígena.

Assim com estas questões a esclarecer, dificuldade grave por parte da população indígena de suprir as necessidades básicas de subsistência na Terra que lhes foi destinada; parcas terras; e, sobreposição de áreas de forma indevida, se iniciava nosso estudo. Assim, buscaram-se os fatos e as leis correspondentes de cada época.

Nem antes, nem depois de discutido por meio do Laudo Antropológico, a JF e o MPF de Foz do Iguaçu chegaram a questionar a razão pela qual os Avá-Guarani do Oco’y haviam sido instalados por acordo entre a FUNAI e Itaipu, em área de APP de Itaipu, local tecnicamente inapropriado e ilegal, tendo sido essa área inclusive demarcada pela FUNAI. Até o presente momento a questão fundiária, apesar de debatida, permanece sem resolução (outubro/2012).

\subsection{Sobre a questão formulada pela Justiça Federal de Foz do Iguaçu}

Quanto à questão formulada pelo Juiz Federal Dr. Rony Ferreira e pelo Procurador da República Dr. Jessé Ambrósio dos Santos Junior, ambos de Foz do Iguaçu, que concluiu pela necessidade de realização de Laudo Antropológico pela FUNAI, esya consistia em determinar: “qual $\underline{\text { tamanho de área territorial a comunidade indígena Avá-Guarani do Oco’y necessita para a sua }}$ sobrevivência?"

O MPF-Foz do Iguaçu de acordo com os Autos da Ação Civil Pública nº 87.1018182-2 (10.10.90), - que não tratava da questão fundiária da Terra Indígena do Oco’y, movida contra 
FUNAI, IBAMA e Usina Hidrelétrica de Itaipu, na época manifestava preocupação com a reivindicação indígena por mais terras e ainda afirmava que o território anterior, o Oco’y-Jacutinga, era de dimensão maior que o atual, o Oco'y.

Relatam os Avá-Guarani que suas formas de vida tradicional foram subitamente interrompidas em dois momentos: em 1973 por invasão e tomada de parte do território do Oco’y-Jacutinga por terceiros, através da ação de funcionários do Instituto Nacional de Colonização e Reforma Agrária/INCRA, e, em seguida, em 1982, quando o restante de seu território original deixou de existir, pela inundação causada pelo reservatório da Usina Hidrelétrica de Itaipu. Questões estas que retomaremos ao longo do trabalho.

Ficou constatada inicialmente a situação de extrema precariedade fundiária e ambiental em que a população Avá-Guarani vem vivendo, sendo impossível manter-se economicamente nas terras do Oco'y - o que contradiz o Artigo 231 \# $1^{\circ}$ da Constituição Federal Brasileira - e consequentemente vem afetar seriamente as condições de subsistência e saúde da comunidade indígena.

Assim já era fato dado que o território no qual os Avá-Guarani se encontravam era fundiária e ambientalmente inapropriado para a moradia da população, colocando em risco a vida da comunidade através de inúmeros fatores: - é território insuficiente para desenvolvimento da economia indígena; - há invasão de terras pelos colonos lindeiros à Terra Indígena do Oco’y; - há indícios prováveis de contaminação por agrotóxicos de tudo o que há vida na Terra Indígena, proveniente da borrifação nos plantios dos colonos lindeiros, muito próximos que estão dos indígenas, e, escoamento pela microbacia, perpassando a Terra Indígena e desaguando no reservatório de Itaipu; - a área se caracteriza por ser o único local do estado do Paraná onde se observa casos de malária, pois os indígenas residem, inadvertidamente, às margens do reservatório da Itaipu Binacional, águas que permanecem em grande parte do tempo paradas; - a qualidade da água que consomem, de acordo com os relatos indígenas, está seriamente prejudicada. Todos estes fatos serão tratados no Capítulo 3.

Verificamos que todo o histórico dessa área foi marcado por erros, com a ausência, do que era essencial: informações e estudos verdadeiramente técnicos de caráter antropológico e legal. Afirmávamos que o Laudo Antropológico/LA deveria ser pormenorizado, tanto em relação aos fatos ocorridos quanto à legislação que sustenta a questão indígena, para que assim pudéssemos responder a todo e qualquer questionamento por parte de quaisquer instituições envolvidas.

A partir dessas constatações e dado que o LA não poderia se limitar à apenas a questão colocada pela JF, indicamos inicialmente, que para responder à formulação solicitada, dever-seia considerar as seguintes questões: 
- que não existia até o momento uma área específica a ser destinada aos Avá-Guarani, para que se pudesse examiná-la, com o objetivo de determinar sua adequação fundiária e ambiental;

- que o cálculo solicitado pela JF e MPF não poderia ser considerado “abstratamente", pois o território indígena não poderia ser definido, limitado à apenas um condicionante "certa quantidade de terras em hectares"; a resposta deveria necessariamente considerar, além do aspecto referente à dimensão fundiária, os aspectos ambientais, socioeconômicos, socioculturais, populacionais, históricos, geográficos e legais. Isso evidentemente tornava a questão mais complexa;

- que isto caberia ao Laudo Antropológico avaliar, o que pressupunha pesquisa de campo e de gabinete.

Informava ainda que os estudos objetivando dimensionar terras para população indígena se dividem em dois momentos: o primeiro e mais extenso, Laudo Antropológico; o segundo de caráter mais operacional, a formação de Grupo de Trabalho/GT de responsabilidade legal do Departamento de Identificação e Delimitação/DEID, que por sua vez é subordinado ao Departamento de Assuntos Fundiários/DAF/Bsb/FUNAI, ambos os trabalhos estabelecidos conforme o Decreto $\mathrm{n}^{\mathrm{o}} 1775$ de $08.01 .96^{8}$ e a Portaria $\mathrm{n}^{\mathrm{o}} 14$ de $09.01 .96^{9}$.

Justificamos perante à JF que a contemplação de vários aspectos eram necessários para proceder-se à adequação ambiental/fundiária do território a ser escolhido. Após a pesquisa realizada pelo LA este teceria as devidas recomendações. A segunda etapa consistiria na procura e escolha de novo local, que faria parte legalmente das atribuições do Grupo de Trabalho/GT, que uma vez coordenado pelo antropólogo que redigiu o Laudo Antropológico, iria viabilizar suas recomendações.

Por sua vez o Grupo de Trabalho/GT sairia em busca de outras terras e/ou ampliação do território atual, quando então analisaria as condições e os procedimentos legais com relação às terras encontradas e, por fim, ofereceria elementos para efetivar a reterritorialização da população indígena em terras adequadas às necessidades do agrupamento.

Assim a resolução, objetivando subsidiar futuramente o cálculo solicitado, seria de competência também do Grupo de Trabalho/GT/DEID/DAF/FUNAI, pois esses dois trabalhos visari-

\footnotetext{
${ }^{8}$ BRASIL. Decreto, $n^{\circ} 1775$ (08.01.96). Dispõe sobre o procedimento administrativo de demarcação das terras indígenas e dá outras providencias. Diário Oficial da União. Brasília, DF, 09.jan.1996, p. 265.

${ }^{9}$ BRASIL. Portaria/FUNAI, $n^{\circ} 14$ (09.01.96). Estabelece regras sobre a elaboração do Relatório circunstanciado de identificação e delimitação de Terras Indígenas a que se refere o parágrafo $6^{\circ}$ do artigo $2^{\circ}$, do Decreto $\mathrm{n}^{\circ}$ 1.775, de 08 de janeiro de 1996. Disponível em: 6ccr.pgr.mpf.gov.br/legislacao/legislacao-docs/demarcacao/ portaria_funai_14.pdf. Acesso em 26.ago.2012.
} 
am a identificação e delimitação de possível território para a população indígena; assim as dimensões territoriais e às características ambientais de novo território necessárias ao agrupamento indígena, só poderia ser tecnicamente efetivada, através do desenrolar dos procedimentos legais do próprio GT.

Neste momento então, avaliar-se-ia a questão colocada, de acordo com os procedimentos administrativos regulares da FUNAI, respondendo juntos LA e GT, à questão colocada pelo Ministério Público Federal e a Justiça Federal de Foz do Iguaçu, “qual a dimensão de terras necessárias à sobrevivência dos índios Guarani."

Poder-se-ia supor, assim, que não se obtinha elementos para responder de imediato à questão, com a objetividade que se esperava. 


\section{CAPÍTULO 2 AS POPULAÇÕES INDÍGENAS GUARANI}

A população indígena específica de que tratamos, os Avá-Guarani do Oco’y, antes de qualquer coisa deve ser situada no contexto da historiografia geral Guarani, como fazendo parte do conjunto de um agrupamento étnico maior, com o qual se relaciona.

Dessa forma serão descritos neste capítulo dados fundamentais sobre a etnia, tais como: - a localização da imemorial ocupação geográfica da etnia como um todo; - os subgrupos étnicos Guarani existentes e suas divisões linguísticas e territoriais; - a dispersão geográfica atual da população Guarani; - o contexto de reconhecimento fundiário Guarani no Brasil.

Em seguida se demonstrará dados demográficos qualitativos, apontando alguns aspectos socioculturais notadamente marcantes da etnia, como as formas pós-colonização de ocupação e mobilidade sobre o território tradicional. Trata também de aspectos demográficos quantitativos, por meio de análise de uma serie de censos sobre os Guarani, ainda que em um curto espaço de tempo.

Após definir a ocupação territorial dos Guarani em geral e em cada uma de suas subdivisões, nos interessa focar especialmente os Avá-Guarani, habitantes da Tríplice Fronteira entre Brasil, Paraguai e Argentina, dada sua circulação amiúde por entre essas fronteiras, população indígena essa, objeto de estudo deste trabalho.

Dada a importância para o trabalho da história e da arqueologia Guarani na região, estes temas serão tratados em capítulo a parte.

\subsection{Língua e dialetos: os subgrupos Guarani}

Em termos linguísticos os Guarani, fazem parte do Tronco Linguístico Tupi, da Família Linguística Tupi-Guarani, da Língua Guarani, apresentando no Brasil os três dialetos: Kaiowá1, $\tilde{N}$ andeva $a^{2}$ e $M b y a^{3}$.

\footnotetext{
${ }^{1}$ Os Kaiowá são grafados também como Kayová ou Kaiová e designados também por Paï-Tavyterã.

${ }^{2}$ Os Ñandeva são designados também por Txiripá, Xiripá, Chiripá, Avá-Chiripá, Avá, Ava Katu Ete, AváGuarani ou como são chamados no MS apenas de Guarani.

${ }^{3}$ Os Mbyá são grafados também como Mbyá-Guarani ou Guarani-Mbyá.
} 
A população indígena Guarani existente no Brasil é classificada pela literatura etnográfica de acordo com algumas diferenças dialetais, de costumes e de práticas rituais, subdividindo-se nos três principais subgrupos: Kaiowá, Ñandeva e Mbyá.

No Paraguai esses mesmos subgrupos recebem outras denominações: os Kaiowá são denominados Paï-Tavyterã; os Ñandeva por Txiripá ou ainda por Avá-Txiripá; e os Mbyá, da mesma forma como se refere no Brasil, Mbyá.

Na Argentina os Mbyá são identificados também como Mbyá. Ainda há entre os Guarani os Ache que vivem no Paraguai, chamados impropriamente de Guajaki.

\subsection{A imemorialidade da ocupação geográfica Guarani}

Subdivididos em seus subgrupos a população indígena Guarani ocupa desde tempos imemoriais as Bacias do Rio Paraguai, Paraná e Uruguai e seus afluentes, ou seja, a grande Bacia do Prata, como é denominada no Brasil, em espaço territorial brasileiro (Figura 7).

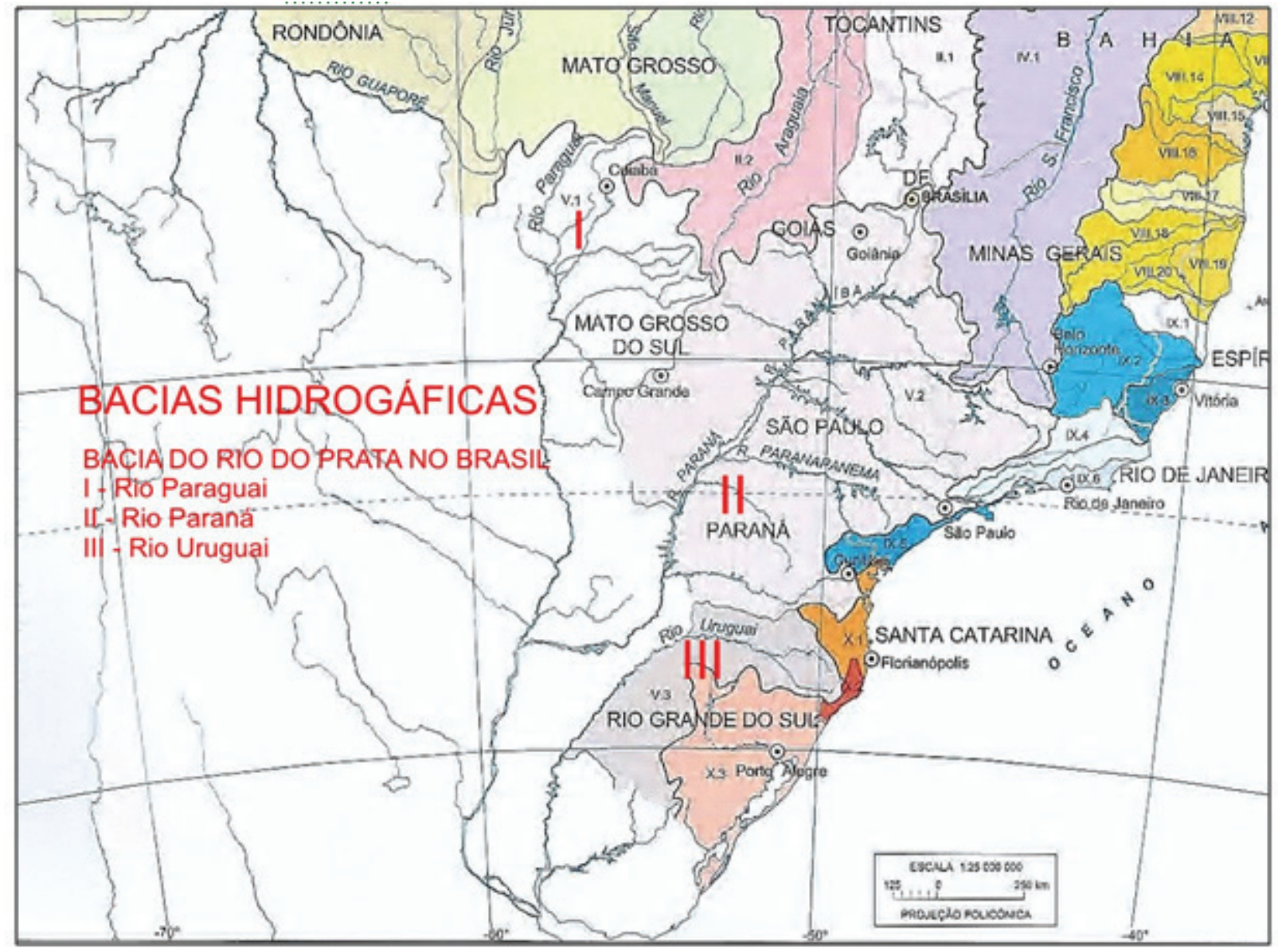

Figura 7. Mapa. Bacia do Prata no Brasil.

Fonte: Atlas Geográfico Escolar/IBGE. Rio de Janeiro: IBGE, 2002, p. 108. 
O território Guarani está para além da fronteira brasileira. Habitam tradicionalmente grande parte do sul e sudeste da região sul-americana, ocupando vasto território, o qual foi identificado desde a chegada dos primeiros colonizadores europeus no século XVI; este território compreende parte de vários países da América do Sul da atualidade: Brasil, Uruguai, Argentina, Paraguai, Bolívia e Peru. Descritos ao longo dos séculos subsequentes por inúmeros relatos de viajantes, missionários, exploradores, bandeirantes, arqueólogos e etnógrafos, os documentos demonstram a ampla dispersão geográfica das aldeias Guarani em toda a região territorial citada, desde tempos imemoriais, atravessando os séculos, até a atualidade. Receberam no passado várias denominações além do Guarani, Mbiazes, Carijó, Kainguá, entre outras.

Para se ter a medida da vastidão territorial da ocupação da etnia no passado é importante observar o caminho transcontinental de comunicação entre as aldeias Guarani, denominado Peabiru, na língua guarani $P e=$ caminho, abiru = batido. Configurava-se em uma estrada aberta em meio à mata, de um metro e meio de largura, semeada com gramíneas que tinham facilidade de se alastrar, conforme as passadas dos caminhantes. Tais gramíneas mantinham a estrada trafegável, sem que a mata a reencobrisse.

O Peabiru iniciava-se às margens do oceano Atlântico através de dois ramais, um na altura de São Vicente/SP e outro em Florianópolis/SC, unia-se no estado do Paraná e atravessando Argentina, Paraguai e Bolívia, terminava no oceano Pacífico, já no Peru. Ao longo do caminho principal e de suas várias ramificações secundárias, encontravam-se inúmeras aldeias Guarani. O território descrito que envolve vários estados brasileiros e países vizinhos é reconhecido arqueológica e antropologicamente como território de imemorial ocupação da etnia.

O caminho foi identificado primeiramente em 1540 pelo explorador espanhol Cabeza de Vaca, que o percorreu a partir da Ilha de Santa Catarina, onde é hoje Florianópolis, chegando apenas até a Assunção no Paraguai (Figura 8).

\subsection{A atual dispersão geográfica dos Guarani}

A partir da colonização o território Guarani passou a ser ocupado, tornando-se o sul e sudeste, densamente habitado por não índios. Subtraíram-se dessa forma grandes espaços territoriais outrora ocupados pela etnia, passando o agrupamento a manter contato relativamente sistemático com a sociedade nacional. 


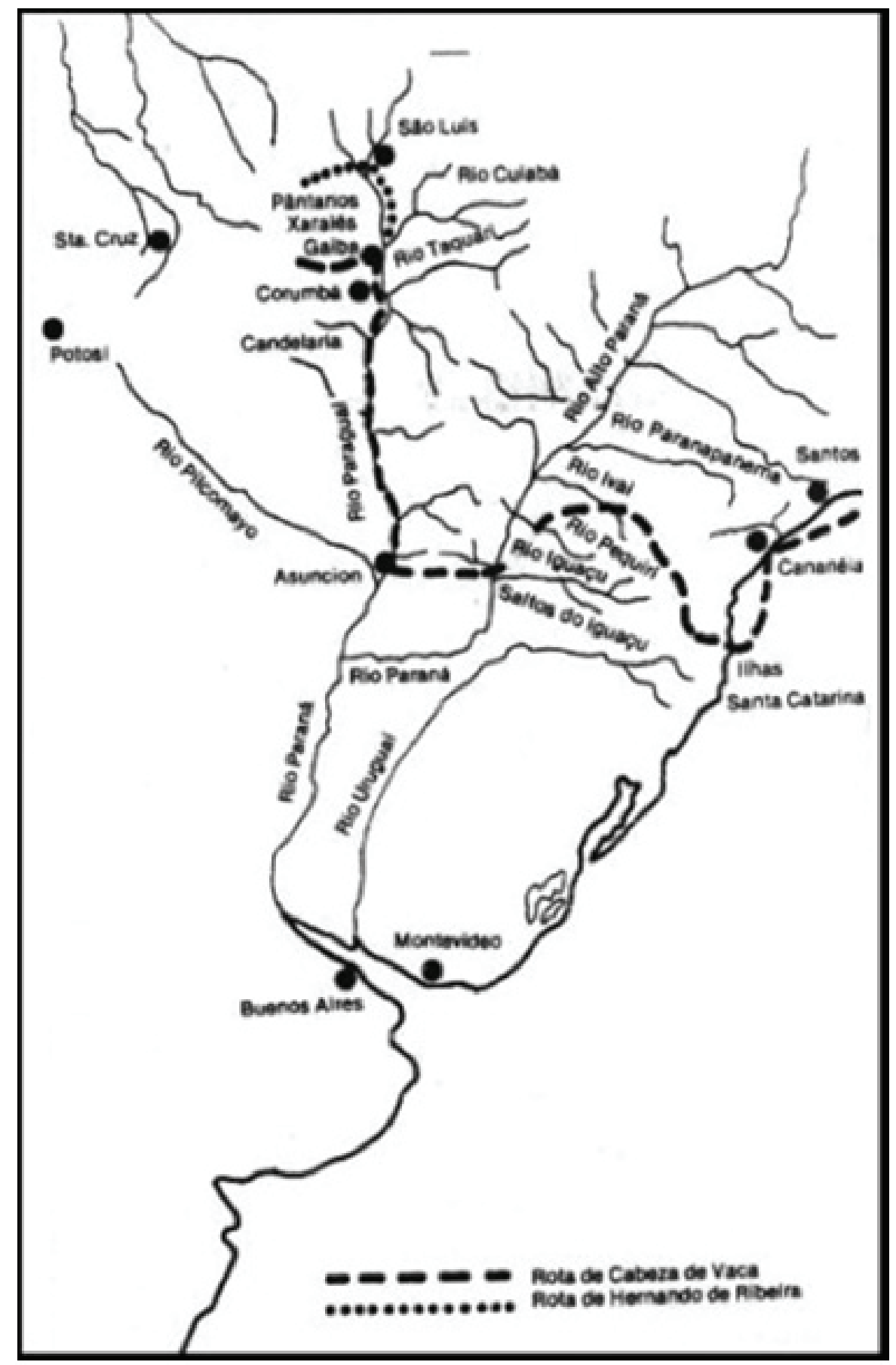

Figura 8. Mapa do Peabiru em ramificação percorrida por Cabeza de Vaca (1540).

Fonte: Cabeza de Vaca, A.N. Naufrágios e Comentários. Porto Alegre: L\&PM, 1999, p 120.

Os Guarani até os anos 70 do século XX, em sua concepção religiosa, não concebiam "lutar" pela terra. Preferiam retirar-se - quando ainda tinham terras para ir, a enfrentar a luta direta, já que Ñanderu (O “Deus” Guarani), segundo eles, “deu a terra para todos morar, não havendo assim sentido em brigar por ela"; esta é uma das razões pelas quais seus direitos territoriais eram pouco legitimados, eles se retiravam antes de qualquer procedimento oficial. Ladeira, afirmou a esse respeito: 
Avessos a qualquer tipo de disputa pela terra, os Guarani aceitam a defesa de suas áreas através das disputas judiciais em razão de que estas se constituem num confronto "teórico", intermediado por aliados, do qual participam diversos atores. A partir da década de 80, quando se tornou inevitável o reconhecimento oficial das áreas ocupadas pelos Guarani no litoral, as consequentes articulações entre as diversas instituições para se efetivarem os procedimentos administrativos de regularização das mesmas obrigaram os Guarani a remodelar suas formas de relacionamento, agora muito mais complexas, com os diversos setores da sociedade nacional. Se antes se encontravam "livres" para determinar as relações de contato circunstanciais, mantendo suas aldeias preservadas de ingerências externas, passaram então a ser alvos de interesses políticos, de sobreposição de programas assistenciais descontínuos, de maiores expressões de solidariedade e também de discriminação. Enfim, demarcação e reconhecimento de suas áreas põem termo à invisibilidade antes pretendida e afetam o modo de vida anterior (LADEIRA:2000: 782-4).

A configuração atual da dispersão geográfica das aldeias pertencentes aos subgrupos Guarani existentes na América do Sul, excluídos desse levantamento os pertencentes aos países Bolívia e Peru, aparece nos mapas abaixo. (Figuras 9 e 10). Sobre estes habitantes em solo boliviano e peruano, assim como os do Chaco paraguaio e do Uruguai, não possuímos maiores informações.

Centraremos neste capítulo uma abordagem geral sobre os Guarani habitantes do Brasil, Paraguai e Argentina e mais especificamente, ao longo de todo o trabalho, naqueles Guarani que se encontram nas imediações da Tríplice Fronteira desses países.

Para tanto é importante conhecer de forma conjugada, as divisões linguísticas entre os Guarani e suas ocupações em cada um desses países. As informações nos mapas a seguir que se referem a ocupação no Paraguai e Argentina foram compiladas de "Guarani Retã 2008. Povos Guarani na Fronteira Argentina, Brasil e Paraguai"“4 e sobre a ocupação no Brasil, foram compiladas de "Terras Guarani no Litoral. As matas que foram reveladas aos nossos antigos avós"5.

As populações Kaiowá/Paï Tavyterã, localizam-se respectivamente no sul de Mato Grosso do Sul e na região nordeste do Paraguai, nos Departamentos de Concepcion e Amambay, apresentando-se interligadas através de um mesmo território geográfico, composto pós-colonização de Estados Nacionais distintos, Brasil e Paraguai.

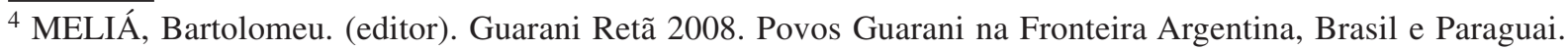
Vários autores. Colaboração Internacional: UNaM, ENDEPA;CTI, CIMI, ISA, UFGD; CEPAG, CONAPI,SAI,GAT,SPSAJ,CAPI.2008.

${ }^{5}$ LADEIRA, M. I. Terras Guarani no Litoral. As matas que foram reveladas aos nossos antigos avós. São Paulo: CTI. 2004.
} 


\section{Território Guarani}
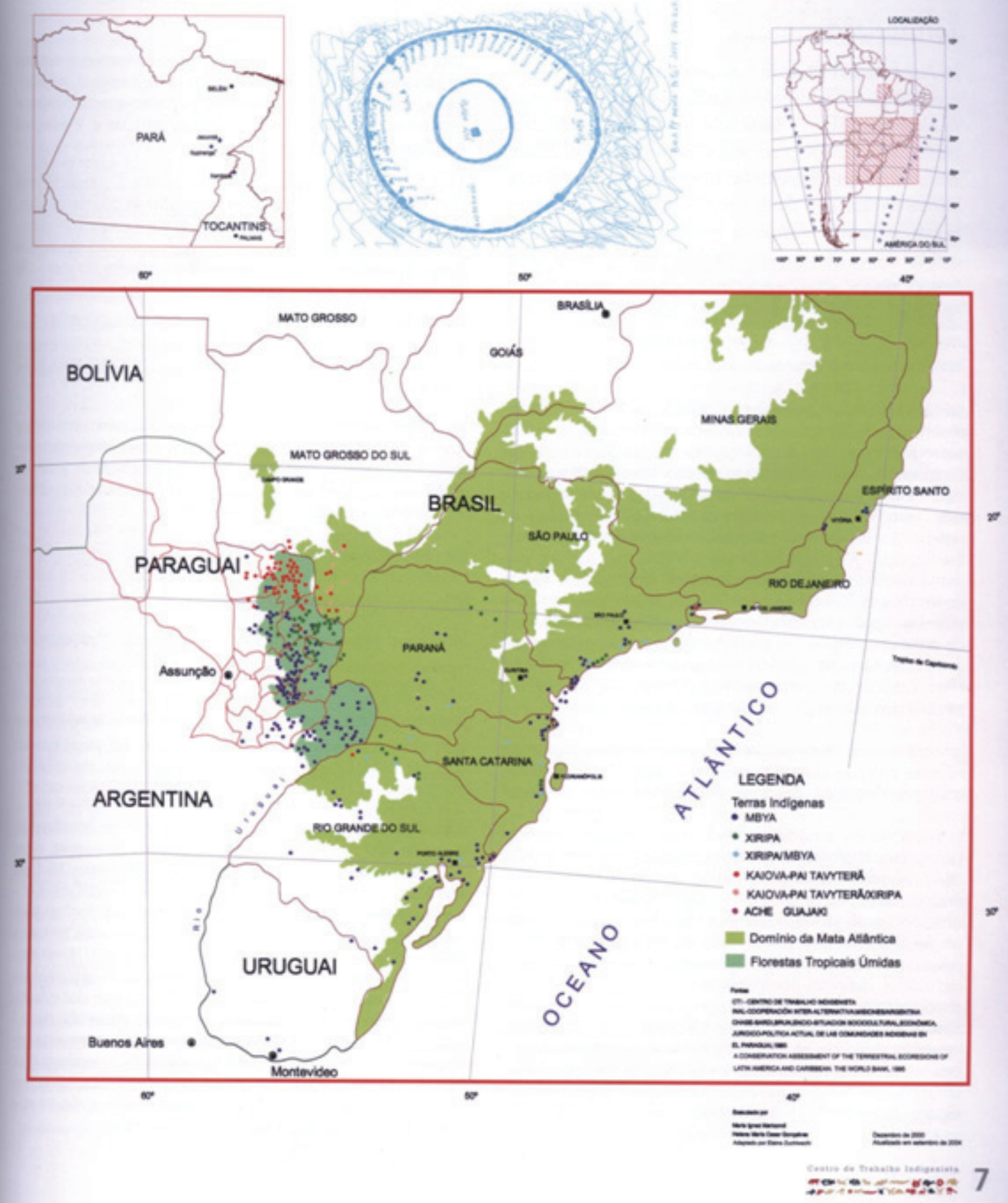

CD-Figura 9. Mapa. Dispersão geográfica atual Guarani no Brasil, Paraguai e Argentina (2004).

Fonte: LADEIRA, M. I. Terras Guarani no Litoral. As matas que foram reveladas aos nossos antigos avós. São Paulo:CTI. 2004, p 7 


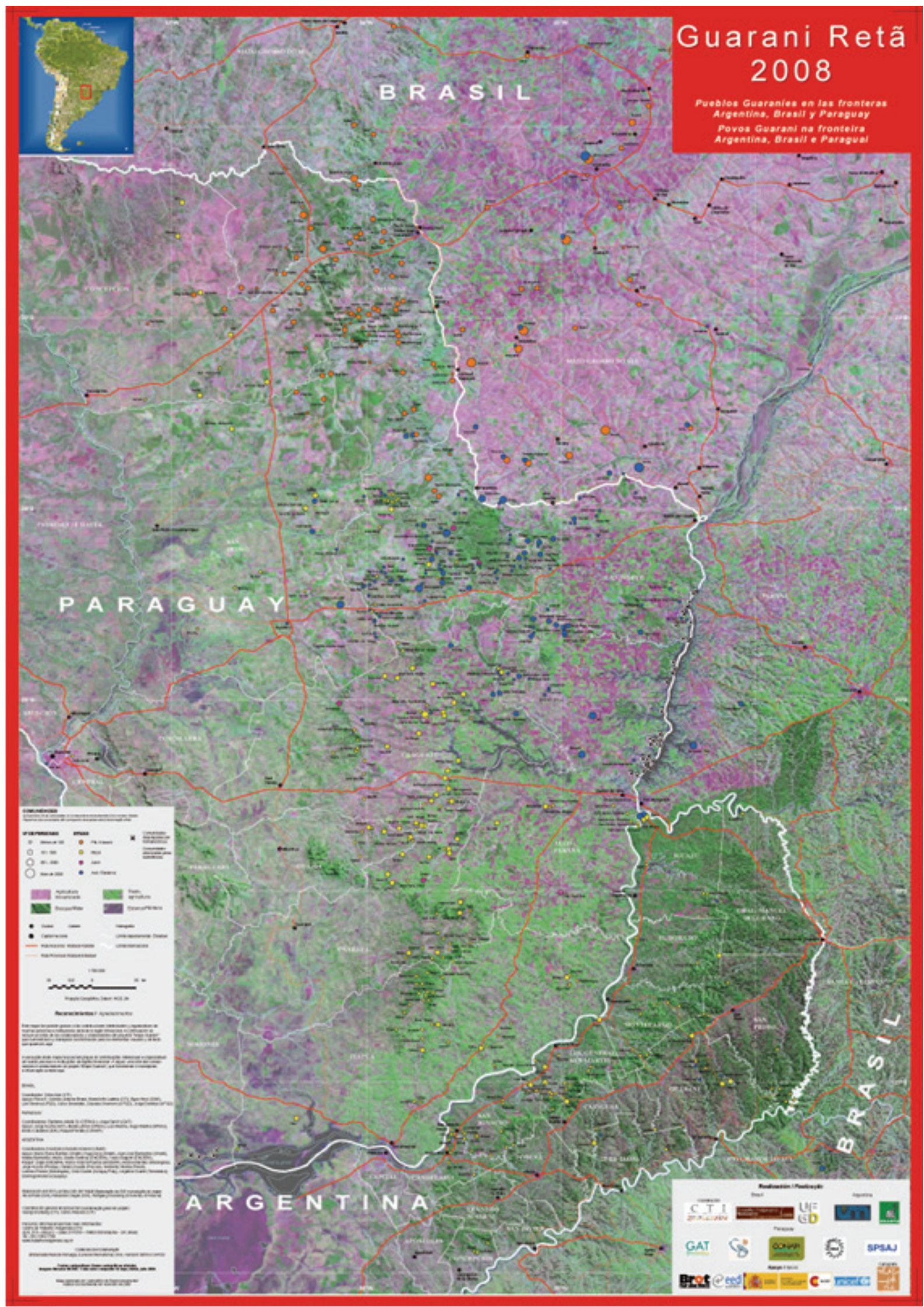

CD-Figura 10. Mapa. Os Guarani na fronteira Brasil, Paraguai e Argentina/2008.

Fonte: MELIÁ, Bartolomeu. (editor). Guarani Retã 2008. Povos Guarani na Fronteira Argentina, Brasil e Paraguai. Vários autores. Colaboração Internacional: UNaM, ENDEPA;CTI, CIMI, ISA, UFGD; CEPAG, CONAPI,SAI,GA,SPSAJ,CAPI. 2008. 
As populações Ñandeva também denominadas no Brasil de $\underline{\text { Avá-Guarani }}$ entre outras denominações, e, Txiripá ou ainda Avá-Txiripá no Paraguai, vivem respectivamente nos dois países, apresentando-se também interligadas através de um mesmo território, composto pós-colonização de Estados Nacionais distintos. No Brasil ocupam o Mato Grosso do Sul, o interior dos estados de São Paulo e Paraná, estando conectados pelo mesmo território no Paraguai, com grande parte da banda oriental deste país, nos Departamentos de Amambay, Canindeyú, Caaguazú e Alto Paraná. Ainda no Brasil ocupam o litoral de São Paulo e Santa Catarina. Na Argentina embora seja ocupada predominantemente pelos Mbyá, os Ñandeva também ocupam em menor número e no mesmo espaço, o seu nordeste, a Província de Misiones, também interligados por um mesmo território, composto pós-colonização de Estados Nacionais distintos, Argentina e Brasil. Estão dessa forma na Tríplice Fronteira, entre Brasil, Paraguai e Argentina.

Quanto aos Mbyá, vivem no Brasil em aldeias no interior e litoral dos estados do sul - Paraná, Santa Catarina e Rio Grande do Sul, e no sudeste - São Paulo, Rio de Janeiro e Espírito Santo vivem em aldeias espalhadas pelo litoral, na Mata Atlântica. Encontram-se ainda alguns núcleos de aldeias Mbyá, nos estados do Pará, Maranhão e Tocantins. Separados pós-colonização da mesma forma, por Estados Nacionais distintos, os Mbyá estão presentes também em aldeias na região oriental do Paraguai, nos Departamentos de Concepcion, San Pedro, Canindeyú, Alto Paraná, Caaguazu, Itapúa, Caazapá e Guaira, e, no nordeste da Argentina em toda a Província de Misiones, e ainda, existem algumas aldeias no Uruguai, que pouco conhecemos a respeito delas.

Ainda há entre os Guarani os Ache, que ocupavam as matas do centro do Paraguai oriental. Vítimas de genocídio desde os anos 50 do século XX restam apenas seis aldeias que se localizam nos Departamentos de Caazapá e Caaguazú em solo paraguaio.

Tanto um quanto outro mapa, citados respectivamente, seus autores estão em contato amiúde com o contexto Guarani assim demonstrado: Ladeira no litoral de todo o Brasil e Meliá no Paraguai e Argentina. A área que interessa a essa pesquisa localiza-se no oeste do Paraná/Brasil na fronteira com Paraguai e Argentina, área mais de difícil acesso, à ambos os autores; somente em área próxima a estas fronteiras, em visita realizada recentemente por nós em 2012, no extremo oeste do Paraná, percorrendo em direção ao sul, do município de Guaíra ao município de São Miguel do Iguaçu, encontramos 14 aldeias Guarani, que ali já habitavam a não pouco tempo. São elas: Teoha Porã, Tekoha Karumbey, Tekoha Marangatu, Tekoha Y’y Hovy, Tekoha Jevy, Tekoha Mirim e Tekoha Guarani, as sete no município de Guaíra; Tekoha Araguaju, Tekoha Nhemboete e Tekoha Poha Renda, as três no município de Terra Roxa; Tekoha Vy’a Renda no município de 
Santa Helena; Tekoha Avá Guarani do Oco’y no município de São Miguel do Iguaçu; Tekoha Anetete e Tekoha Itamarã, as duas no município de Diamante D’Oeste.

Somente duas haviam sido pontuadas por ambos autores, Oco'y e Anetete, as duas já consideradas "regularizadas".

Ainda sobre a mesma questão, nestes mapas chama à atenção, a tendência a um certo vazio demográfico de populações Guarani, existentes em regiões de terras tradicionalmente ocupadas, como o sul do Mato Grosso do Sul e todo o oeste do Paraná, regiões estas, extensivamente ocupadas por estas populações indígenas até as décadas finais do século XX; por outro lado nota-se cada vez maior concentração demográfica dessas populações Guarani no Paraguai, na fronteira com o Brasil. Assim se estes mapas saíssem da condição estática e passassem a uma condição cinemática, de movimento ao longo do tempo, veríamos que os Guarani estão sendo compulsoriamente forçados a imigrar do Brasil. Sobre estas questões de fronteira, elas serão tratadas ao longo deste trabalho, sendo dedicado à frente, capítulo especial sobre o tema.

\subsection{Algumas características demográficas qualitativas}

Por tratar-se de população indígena numerosa, hoje os Guarani ocupam pequenas áreas de terras ao longo de extenso território descontínuo. Assim tendo em mente a grande área de terras ocupadas, os Guarani não possuem um território único e homogêneo, como sucede de forma diferente, com outros grupos étnicos do Brasil.

As populações indígenas em geral no Brasil, independentemente da etnia, possuem uma dinâmica própria de crescimento demográfico e ocupação de territórios, onde os casamentos entre jovens se dão em tenra idade, são em geral exogâmicos, ou seja, se casam com membros de fora de sua família extensa e/ou de fora de sua aldeia, apresentam curtos periodo de tempo entre gerações, alto número de filhos por mulher, e, nos últimos anos, vem apresentando diminuição do número de óbitos, fundamentalmente o infantil; ainda, apresentam dinâmica mobilidade espacial de indivíduos entre as diversas aldeias da etnia. As características demográficas citadas são elementos constituintes dessas sociedades, sendo estas práticas inerentes à cultura indígena, sendo erro crasso, desdenhar esta dinâmica cultural em relação ao território ocupado.

Ainda com relação à dinâmica cultural em torno da parcela do território ocupado, estudos etno-botânicos nos ensinam outra característica demográfica importante sobre estas sociedades; 
é que toda população indígena, tradicionalmente, habita determinado local de seu próprio território, por certo período e posteriormente migra, revezando de áreas no interior de seu próprio território, a fim de buscar local que apresente melhores níveis, sob o ponto de vista ambiental, para suprir suas necessidades socioeconômicas de subsistência.

São sociedades de andarilhos, que ocupam seu território de forma semicircular sobre os ambientes. Na medida em que os solos das roças começam apresentar improdutividade, em geral de 3 em 3 anos, mudam as roças de local e continuam se servindo dos produtos ali plantados nas roças anteriores, é a chamada agricultura itinerante; ou que os ambientes do entorno das aldeias comecem a demonstrar pouco oferecimento de matérias-primas de coleta (de 10 em 10 ou 15 em 15 anos), o que faz com que torne o ambiente pouco atrativo, tanto para eles, quanto para os animais que ali se alimentam, os quais os indígenas os caçam; ou ainda, que sanitariamente os ambientes das aldeias se tornem insalubres pelo uso humano; por todas estas razões, os indígenas transferem as próprias aldeias de lugar, para outros mais intocados, e, portanto, preservados em

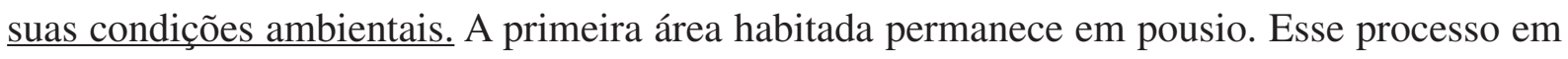
geral se dá em varias áreas de terras, que são utilizadas no sistema de uso e pousio, de modo semicircular sobre o território.

Depois que o ambiente da área que habitavam inicialmente se recompõe em certos níveis de excelência, o que leva em média de 20 a 30 anos, voltam a habitar a terra que outrora habitaram inicialmente. As outras áreas permanecem em pousio, neste sistema de revezamento sobre o território. Os locais habitados anteriormente, se recuperaram ambientalmente, agora com terras mais férteis para as roças, com maior disponibilidade de recursos, mais frutos e árvores crescidas a partir dos frutos caídos e não utilizados, com maior disponibilidade de animais para caça que puderam se reproduzir sem interferência humana, e por fim, sanitariamente mais limpo, pelo uso não humano e pela ação do sol, das chuvas e dos ventos.

Com este sistema de uso e pousio, a resiliência ambiental das terras indígenas é mantida, ou seja, o ambiente em que já habitaram, invariavelmente tem plenas condições de voltar ao estado em que se encontrava anteriormente, isto é, rico e preservado na sua diversidade de espécies vegetais e animais, a biodiversidade, acrescidas ainda de espécies vegetais que foram anteriormente cultivadas pelos indígenas. Daí o manejo ambiental indígena ser considerado a forma que mais preservou até hoje, os ambientes das florestas tropicais, mantendo dessa forma sua rica biodiversidade.

Isto está cada dia mais difícil para os Guarani, muitas vezes tem se encontrado "ilhados" nas pequenas matas que ocupam, sem poder por em prática o hábito de preservação, através do 
sistema de uso e pousio. Essa é uma das tantas razões que provocam a saída de grupos familiares Guarani em busca de novas terras.

\subsection{As formas de ocupação e mobilidade espacial Guarani no território}

Os Guarani como outros grupos indígenas, caracterizam-se por manter constante mobilidade espacial, em especial, dada a sua magnitude populacional, isto fica mais evidente entre eles. $\mathrm{E}$ isso se dá, além da razão do sistema de uso e pousio, também por outros aspectos socioculturais.

As aldeias Guarani mantêm entre si estreitas relações políticas, econômicas, matrimoniais e religiosas. São constantes as visitas entre seus moradores. Elas podem durar alguns poucos dias, semanas, meses ou até anos; a partir de uma visita à parentela mais próxima, determinada família pode resolver instalar residência naquela aldeia visitada. Quando se visita qualquer aldeia Guarani, não há uma delas onde não se encontre parentes de indivíduos de outras aldeias, próximas ou distantes.

Segundo Ladeira (2001), "a relação de parentesco é fundamental na definição do território enquanto espaço Guarani, gerando a base da organização social que é a família extensa, a qual possui autonomia política e econômica." Ela acrescenta: “A emigração ou a fixação é assim orientada pelos laços de parentesco e/ou pela identidade de seu sub-grupo." (grifos nossos).

Essa constante mobilidade espacial ocorre por conta das relações sociais de "reciprocida$d e "$ mantidas entre membros de aldeias localizadas tanto próximas, quanto distantes umas das outras. Acontecem basicamente por dois determinantes socioculturais: - um, pelas próprias relações de parentesco, que envolvem vários fatores: - a busca de casamentos com indivíduos pertencentes a outras aldeias; - a formação de famílias numa ou outra aldeia; as visitas aos parentes em outras aldeias que podem durar meses ou anos; e ainda, a mudança pelas famílias de uma para outra aldeia; nesse contexto trocam-se também informações, pajelanças, medicamentos, sementes, também se dá os encontros de lideranças, entre outras formas de reciprocidade; - o outro aspecto, de arcabouço sócio-religioso, se dá pela procura mitológica (espiritual) e terrena (ecológica) da “Terra sem Males", como é denominada por eles Yvy-marã ei, e, fartamente descrita por levantamentos etnográficos desde o século XVI. Resumidamente consiste no caminhar = oguata para o leste, em busca das matas que sobraram, a Mata Atlântica, procurando, portanto, terras mais intocadas ou preservadas da destruição pelo não índio. $\mathrm{O}$ 
mito varia em caminhar para o leste (Mbyá e Nandeva) ou para zênite (Kaiowá) ${ }^{6}$. A seguir um trecho do mito contado por um pajé Guarani:

Quando Nhanderuvuçu (nosso grande Pai) resolveu acabar com a terra, devido à maldade dos homens, avisou antecipadamente Guiraypoty, o grande pajé, e mandou que dançasse. Este lhe obedeceu, passando toda a noite em danças rituais. E quando Guiraypoty terminou de dançar, Nhanderuvuçu retirou um dos esteios que sustentam a terra, provocando um incêndio devastador. Guiraypoty, para fugir do perigo, partiu com sua família, para o Leste, em direção ao mar. Tão rápida foi a fuga, que não teve tempo de plantar e nem de colher a mandioca. Todos teriam morrido de fome se não fosse seu grande poder que fez com que o alimento surgisse durante a viagem. Quando alcançaram o litoral, seu primeiro cuidado foi construir uma casa de tábuas, para que, quando viessem as águas, ela pudesse resistir. Terminada a construção, retomaram a dança e o canto. O perigo tornava-se cada vez mais iminente, pois o mar, como que para apagar o grande incêndio, ia engolindo toda a terra. Quanto mais subiam as águas, mas Guiraypoty e sua família dançavam. E para não serem tragados pela água, subiram no telhado da casa. Guiraypoty chorou, pois teve medo. Mas sua mulher lhe falou: - Se tens medo, meu pai, abre teus braços para que os pássaros que estão passando possam pousar. Se eles sentarem no teu corpo, pede para nos levar para o alto. E, mesmo em cima da casa, a mulher continuou batendo a taquara ritmadamente contra o esteio da casa, enquanto as águas subiam. Guiraypoty entoou então o nheengaraí, o canto solene guarani. Quando iam ser tragados pela água, a casa se moveu, girou, flutuou, subiu... subiu até chegar à porta do céu, onde ficaram morando. Esse lugar para onde foram chamase Yvy marã ei (a "terra sem males"). Aí as plantas nascem por si próprias, a mandioca já vem transformada em farinha e a caça chega morta aos pés dos caçadores. As pessoas nesse lugar não envelhecem e nem morrem: aí não há sofrimento!

Assim do ponto de vista Guarani, "por conta da maldade dos homens", eles estão a espera de uma catástrofe, o grande incêndio seguido pelo grande dilúvio, para chegar até a Terra Sem Males.

Ladeira discorre sobre a reprodução da sociedade Guarani ser condicionada pelas relações de dependência entre as várias aldeias, e ainda de como a mobilidade espacial é condição para a formação da própria sociedade Guarani:

\footnotetext{
${ }^{6} \mathrm{O}$ fato de buscar a Terra Sem Males caminhando para o céu pelos Kaiowá, ou seja, de fato se dará este encontro somente "após a morte", demonstra a falta de esperança do subgrupo em ver resolvida a séria situação fundiária por que passam, o que indica a existência e razão dos altos índices de suicídio cometidos por eles. É um clamor que pouco tem sido considerado pelo governo brasileiro.
} 
Na concepção de território dos Guarani está implícita uma dinâmica (política, social, religiosa e econômica) entre seus vários núcleos, essencial à reprodução de seu mundo. Como consequência, a mobilidade entre aldeias de diversas regiões permite aos Guarani a apreensão de seu território, garantindo sua reprodução enquanto povo e etnia. A forma como os grupos familiares se organizam no seu território e o desenho de sua mobilidade entre aldeias, em função da procura de casamentos e relações de parentesco, trazem, implícita, uma busca de equilíbrio fundada numa ideia de harmonia e prosperidade social. No entanto, a conquista e a retenção dessa prosperidade podem ocorrer em momentos e circunstâncias distintas em cada aldeia. Desta forma, a reprodução da sociedade Guarani como um todo é condicionada pela relação de dependência entre as várias aldeias. (Ladeira: 2000 b: 250).

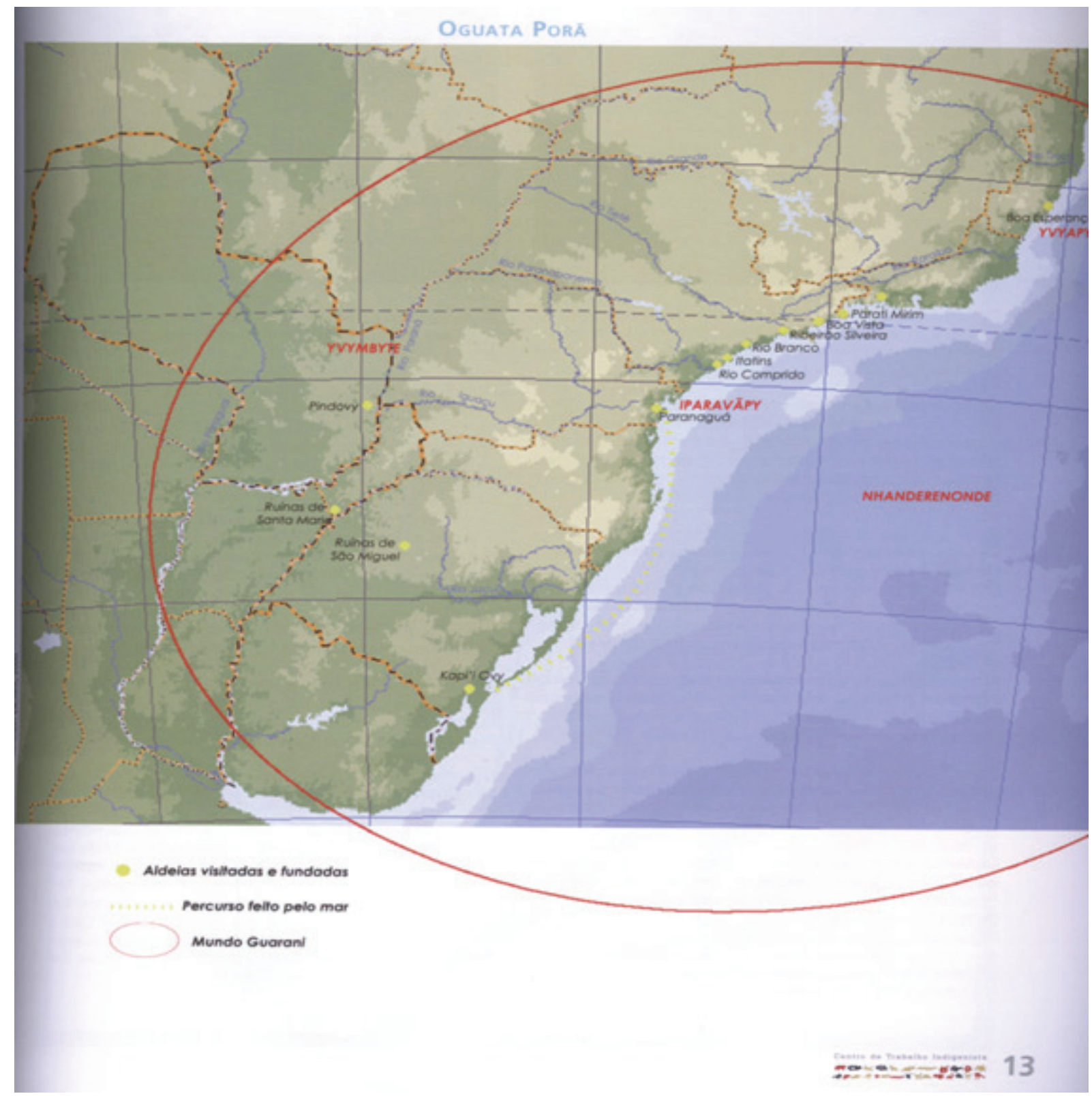

Figura 11. Região onde se realiza o Oguata Porã (a Bela Caminhada).

Fonte: LADEIRA, M. I. Terras Guarani no Litoral. As matas que foram reveladas aos nossos antigos avós. São Paulo:CTI. 2004, p 17. 
Os Guarani mantêm como fator culturalmente inerente à sua sociedade, a circulação de famílias entre as diversas aldeias, assim como a circulação de grupos de famílias dispostas a formarem novas aldeias sobre o amplo território, o qual é considerado por eles, com razão, historicamente retalhado por não índios. Decorre daí que os Guarani, como povos originários dessa região, tem o direito a posse em vários pontos deste território, por ser ele, justamente, "território tradicional de ocupação da etnia".

Dessa maneira, a dinâmica social extrapola os limites territoriais de cada uma das aldeias, ela se dá entre todas as várias aldeias. Nesta medida é que se realiza a visão de pertencimento do grupo étnico ao macroterritório Guarani, frente à ampla dispersão geográfica de suas aldeias em todo o sul e sudeste latino-americano.

Portanto, o território Guarani, para eles próprios é um complexo territorial, em que hoje segmentos populacionais majoritários não Guarani, ocupam as áreas entremeadas deste grande território da etnia.

Diante das características específicas desta população indígena - grande população, espalhada por extenso território descontínuo, havendo constantes idas e vindas de indivíduos por entre as aldeias, verifica-se que o entendimento sobre esta população no decorrer do tempo e na ocupação do espaço, não pode se dar através de uma visão simplista, estática, de grupos familiares residentes de forma fixa, mas sim através de uma visão cinemática, ou seja, de grupos familiares Guarani em constante movimento por entre suas várias aldeias, e, ainda, de grupos familiares que se retiram para vir a compor novas aldeias.

\subsection{Crescimento demográfico e dispersão geográfica Guarani no Brasil, Paraguai e Argentina}

Os Guarani são hoje numericamente, a primeira ou segunda (impossível obter esses números exatos), maior população indígena existente no país e também uma das maiores da América Latina.

Há grandes dificuldades em recensear os Guarani, eles veem como uma forma de controle externo e por isso não gostam de serem contados, afirmam, que animais é que são contados!; ainda, dada a magnitude populacional espalhada por extenso território, a mobilidade espacial de seus indivíduos dificulta essa contagem, pois se deveria assim, recensear todos ao mesmo tempo 
no mesmo dia, para se chegar a um número realmente consistente; outro fator é a acessibilidade às aldeias que varia de lugar para lugar; e por fim, é o conhecimento atualizado do surgimento e/ ou desaparecimento de aldeias; no entanto, nos últimos anos os serviços de saúde tem auxiliado nesse sentido, fazendo levantamentos de população por aldeia, porém, não são todas as aldeias que contam com esses serviços.

O crescimento demográfico com relação aos Guarani deve conter duas variáveis bem delimitadas: crescimento vegetativo e emigração/imigração, dado que para os Guarani, a mobilidade espacial é uma constante, inclusive entre países.

Os dados a seguir apresentados não possuem este nível de detalhe, porém a partir de levantamentos de numero de população por subgrupo, em três períodos distintos, podemos exercitar uma aproximação e buscar verificar qual é essa realidade.

Segundo informações de Ladeira (2001) a população Guarani existente no Brasil, Paraguai e Argentina somavam aproximadamente em 2001, época do início de nossa pesquisa de campo (2001-2007), em torno de 58 mil indígenas, assim distribuídos:

\section{Tabela 2.1. População Guarani no Brasil, Paraguai e Argentina/2001}

\begin{tabular}{|l|c|c|c|c|}
\hline Subgrupo & Brasil & Paraguai & Argentina & Totais \\
\hline Mbyá & 6.000 & 5.000 & 4.000 & 15.000 \\
\hline Nandeva & 7.000 & 7.000 & 0 & 14.000 \\
\hline Kaiowá & 20.000 & 9.000 & 0 & 29.000 \\
\hline Total & 33.000 & 21.000 & 4.000 & 58.000 \\
\hline
\end{tabular}

Fonte: LADEIRA, Maria Inês. Espaço geográfico Guarani-Mbya: Significado, Constituição e Uso. Tese de doutorado. São Paulo, FFLCH/USP, 2001, p. 35-6

O levantamento aproximativo de Assis \& Garlet, publicado em 2004, apontou para as seguintes cifras, resumida na tabela a seguir: 
Tabela 2.2. População Guarani no Brasil, Paraguai e Argentina/2004

\begin{tabular}{|l|c|c|c|c|}
\hline Subgrupo & Brasil & Paraguai & Argentina & Totais**** \\
\hline Mbyá & $4.377^{*}$ & 11.500 & 3.646 & 19.200 \\
\hline Nandeva & 6.300 & 9.000 & 350 & 15.650 \\
\hline Kaiowá & $21.857^{* *}$ & $8.026 * * *$ & 0 & 29.900 \\
\hline Total & 32.534 & 28.526 & 3.996 & 65.000 \\
\hline
\end{tabular}

* Descontadas ás populações Mbyá do Pará e Tocantins.

** Dados sobre os Kaiowá de 1997.

*** Dados sobre os Kaiowá de 1997.

***** Totais aproximados.

Fonte: ASSIS, V. de \& GARLET, I.J. Analise sobre as populações Guarani Contemporâneas: Demografia, Espacialidade e Questões Fundiárias. Revista das Índias, 2004, vol. LXIV, nº 230 P. 35-54. ISSN: 0034-8341

Por fim o censo demográfico mais recente, de Meliá, publicação de 2008, apontou para os seguintes dados, acrescidos das comunidades Ache-Guarani:

Tabela 2.3. População Guarani no Brasil, Paraguai e Argentina/2008

\begin{tabular}{|l|c|c|c|c|}
\hline Subgrupo & Brasil & Paraguai & Argentina & Totais \\
\hline Mbyá & 7.000 & 15.000 & 5.500 & 27.500 \\
\hline Nandeva & 13.000 & 13.200 & 1.000 & 27.200 \\
\hline Kaiowá & 31.000 & 13.000 & 0 & 44.000 \\
\hline Ache & 0 & 1.200 & 0 & 1.200 \\
\hline Total & 51.000 & 42.400 & 6.500 & 99.900 \\
\hline
\end{tabular}

Fonte: MELIÁ, Bartolomeu. (editor). Guarani Retã 2008. Povos Guarani na Fronteira Argentina, Brasil e Paraguai. Vários autores. Colaboração Internacional: UNaM, ENDEPA; CTI, CIMI, ISA, UFGD; CEPAG, CONAPI, SAI, GAT, SPSAJ, CAPI. 2008. p 18.

Contando com possíveis inconsistências de alguns dos dados, pelos motivos expostos anteriormente, vejamos o comportamento demográfico do total dos Guarani, em cada país ao longo desses anos, através de algumas projeções ${ }^{7}$ :

\footnotetext{
${ }^{7}$ Descontados os Ache, dado não possuirmos informações para comparação com outros anos desse sub-grupo.
} 
Tabela 2.4. Comportamento demográfico da população Guarani nos três países da Tríplice Fronteira: Brasil, Paraguai e Argentina ao longo de 2001-2004-2008

\begin{tabular}{|l|c|c|c|}
\hline Países & $\mathbf{2 0 0 1}$ & $\mathbf{2 0 0 4}$ & $\mathbf{2 0 0 8}$ \\
\hline Brasil & 33.000 & 32.534 & 51.000 \\
\hline Paraguai & 21.000 & 28.526 & 41.200 \\
\hline Argentina & 4.000 & 3.996 & 6.500 \\
\hline Total & 58.000 & 65.056 & 98.700 \\
\hline
\end{tabular}

Fonte: Organização Maria Lucia Brant de Carvalho

Levando em consideração todos Guarani ao longo de apenas 4 (quatro) anos, verifica-se um crescimento demográfico significante de 58.000 indígenas em 2001 para 65.056 indígenas em 2004, ou seja, crescimento de $12,06 \%$ neste período;

Levando novamente em consideração todos Guarani ao longo de 7 (sete) anos, verifica-se um crescimento demográfico significante, de 58.000 indígenas em 2001 para 98.700 em 2008, o que significa $70,17 \%$ de crescimento, portanto, quase dobraram de número de indivíduos em apenas sete anos no Brasil, Paraguai e Argentina.

Se considerarmos novamente o comportamento demográfico ao longo dos três períodos, nos três países chegamos ao seguinte resultado. Tomando por base o total da população existente em 2001 (100\%), o comportamento demográfico variou da seguinte forma, exposta na tabela a seguir.

Tabela 2.5. Porcentagens de variação do comportamento demográfico da população Guarani nos três países da Tríplice Fronteira: Brasil, Paraguai e Argentina ao longo de 2001-2004-2008, tendo como ano-base 2001

\begin{tabular}{|l|c|c|c|}
\hline Países & 2001 (Ano-base) & $\mathbf{2 0 0 4}$ & $\mathbf{2 0 0 8}$ \\
\hline Brasil & $33.000 /(100 \%)$ & $32.534(-0,42 \%)$ & $51.000(+54,54 \%)$ \\
\hline Paraguai & $21.000 /(100 \%)$ & $28.526(+35 \%)$ & $41.200(+96,19 \%)$ \\
\hline Argentina & $4.000 /(100 \%)$ & $3.996(-0,1 \%)$ & $6.500(+62,5 \%)$ \\
\hline
\end{tabular}

Fonte: Organização Maria Lucia Brant de Carvalho

No Brasil e na Argentina em 2001 e 2004 os números demonstram que a população Guarani não cresceu, e, até chegou a diminuir de forma sensível, no Brasil - 0,42\% e na Argentina - 0,1\%, dado que o normal seria haver crescimento demográfico, aumentar o numero de filhos por mu- 
lher, como vem ocorrendo em outros países e épocas, aumentando assim o total da população; Assim pode ter havido crescimento vegetativo combinado com alta emigração desses países; No mesmo período de 2001 a 2004 no Paraguai houve um crescimento demográfico expressivo de $35 \%$ da população Guarani e isso pode ser atribuído aos mesmos dois fatores: crescimento vegetativo somado, portanto, a alta imigração para esse país.

Considerando o período de 2001 a 2008, no Brasil o crescimento demográfico foi de 54,54\%. $\mathrm{Na}$ Argentina foi de 62,5\%, apesar de que em números absolutos o crescimento ter sido baixo neste país, porém, deve-se levar em conta que em 2001 não havia nenhum Ñandeva e em 2008 passou a apresentar 1000 indivíduos deste sub-grupo, o que demonstra inédita emigração Nandeva para a Argentina, por isso a taxa percentual tão alta (ver abaixo Tabela 2.8). Porém, o que mais chama a atenção é o crescimento demográfico tão alto no Paraguai, de 96,19\%, desproporcional ao comportamento verificado nos outros países. Conclui-se novamente, que está havendo além de crescimento vegetativo, maior imigração para o Paraguai, questão que trataremos neste trabalho mais a frente, por meio de análise qualitativa dos fatos.

Contando novamente com possíveis inconsistências de alguns dos dados, vejamos agora o comportamento demográfico de cada subgrupo Guarani, Mbyá, Nandeva e Kaiowá, em cada um dos países ao longo desses anos, através de algumas projeções:

Tabela 2.6. Comportamento demográfico da população Guarani no Brasil 2001-2004-2008

\begin{tabular}{|l|c|c|c|}
\hline Brasil & $\mathbf{2 0 0 1}$ & $\mathbf{2 0 0 4}$ & $\mathbf{2 0 0 8}$ \\
\hline Mbyá & 6.000 & 4.377 & 7.000 \\
\hline Nandeva & 7.000 & 6.300 & 13.000 \\
\hline Kaiowá & 20.000 & 21.857 & 31.000 \\
\hline Total & 33.000 & 32.534 & 51.000 \\
\hline
\end{tabular}

Fonte: Organização Maria Lucia Brant de Carvalho 
Tabela 2.7. Comportamento demográfico da população Guarani no Paraguai 2001-2004-2008

\begin{tabular}{|l|c|c|c|}
\hline Paraguai & $\mathbf{2 0 0 1}$ & $\mathbf{2 0 0 4}$ & $\mathbf{2 0 0 8}$ \\
\hline Mbyá & 5.000 & 11.500 & 15.000 \\
\hline Nandeva & 7.000 & 9.000 & 13.200 \\
\hline Kaiowá & 9.000 & 8.026 & 13.000 \\
\hline Total & 21.000 & 28.526 & 41.200 \\
\hline
\end{tabular}

Fonte: Organização Maria Lucia Brant de Carvalho

Tabela 2.8. Comportamento demográfico da população Guarani no Argentina 2001-2004-2008

\begin{tabular}{|l|c|c|c|}
\hline Argentina & $\mathbf{2 0 0 1}$ & $\mathbf{2 0 0 4}$ & $\mathbf{2 0 0 8}$ \\
\hline Mbyá & 4.000 & 3.646 & 5.500 \\
\hline Nandeva & 0 & 350 & 1.000 \\
\hline Kaiowá & 0 & 0 & 0 \\
\hline Total & 4.000 & 3.996 & 6.500 \\
\hline
\end{tabular}

Fonte: Organização Maria Lucia Brant de Carvalho

Levando em consideração os três subgrupos Guarani, Kaiowá, Ñandeva e Mbyá ao longo de apenas 4 (quatro) anos, verifica-se crescimento demográfico significante de 58.000 indígenas em 2001, para 65.056 indígenas em 2004, ou seja, crescimento de 12,06\% neste período, havendo pouca variação em todos os subgrupos, exceto quanto aos Mbyá, que no Brasil houve um decréscimo nesse período de - 27,05\% (Tabela 2.6.), ao mesmo tempo em que no Paraguai, os mesmos Mbyá apresentam um acréscimo populacional de 130\% (Tabela 2.7.). Este comportamento demográfico representa não só crescimento demográfico vegetativo, mas também, mobilidade espacial de um país para outro, no caso é possível que muitos indivíduos Mbyá emigraram do Brasil para o Paraguai.

Levando em consideração os três subgrupos Guarani, Kaiowá, Ñandeva e Mbyá ao longo de 7 anos, de 2001 a 2008, vejamos por subgrupo e país, as porcentagens de crescimento demográfico. 
Tabela 2.9. Porcentagens de crescimento demográfico em cada um dos países, Br, Py e Arg, por subgrupo étnico, de 2001 a 2008

\begin{tabular}{|l|c|c|}
\hline $\begin{array}{l}\text { Brasil } \\
\text { 2001 a 2008 }\end{array}$ & $\begin{array}{c}\text { Paraguai } \\
\text { 2001 a 2008 }\end{array}$ & $\begin{array}{c}\text { Argentina } \\
\mathbf{2 0 0 1} \text { a 2008 }\end{array}$ \\
\hline Mbyá1 6,66\% & Mbyá $200 \%$ & Mbyá $37,5 \%$ \\
\hline Nandeva $85,71 \%$ & Nandeva $88,6 \%$ & Nandeva $0 \mathrm{p} /$ \\
& & 1000 indivíduos \\
\hline Kaiowá 55\% & Kaiowá $44,4 \%$ & Kaiowá 0 \\
\hline Total $54,54 \%$ & Total $96,19 \%$ & Total $62,5 \%$ \\
\hline
\end{tabular}

Fonte: Maria Lucia Brant de Carvalho

Verifica-se que houve um crescimento demográfico bastante acentuado em quase todos os países e isso se deu talvez, pelo menor número de óbitos infantil nos últimos anos, acrescido de uma política consciente ou inconsciente de recuperação de população por parte dos Guarani, ou seja, os Guarani estão realmente tendo mais filhos.

Verifica-se novamente que houve uma exceção quanto aos Mbyá, no Brasil houve um crescimento desacelerado nesse período de apenas 16,66\%, enquanto no Paraguai, os mesmos Mbyá apresentam um acréscimo populacional de $200 \%$. Este comportamento demográfico representa novamente não só crescimento demográfico vegetativo, mas também, mobilidade espacial de um país para outro, no caso é possível, que muitos indivíduos Mbyá emigraram do Brasil para o Paraguai. Porém, essas proporções apresentam disparidade entre porcentagem de Mbyá saídos do Brasil e porcentagem de Mbyá que entraram no Paraguai. Portanto, é possível que outros Guarani que emigraram do Brasil para o Paraguai, estejam sendo contados como sendo somente população do sub-grupo "Mbyá", quando na verdade é possível que sejam também emigrantes do subgrupo Ñandeva, o que é bastante factível como veremos ao longo deste trabalho.

Assim nota-se que o comportamento demográfico nos três países é de alto crescimento, que pode ser atribuído tanto ao crescimento vegetativo que é real em todas as aldeias, quanto à migração de um país para outro. Se as taxas são similares no Brasil e na Argentina, novamente no Paraguai ela é exponencialmente maior, 96,19\% de crescimento de 2001 a 2008, quase dobrando a população Guarani, diferentemente dos outros dois países, o que indica que ali ocorre não só o alto crescimento vegetativo, mas, também a emigração de população Guarani saindo dos outros países, em direção ao Paraguai. 
Verificamos, portanto, preliminarmente a movimentação Guarani intrapaíses da Tríplice Fronteira (BR, PY e ARG) ao longo desses anos apontados 2001-2004-2008. Mobilidade espacial que pode ser provocada por fatores internos ou externos à cultura Guarani; ou seja, por decisão interna dos Guarani ou por imposição externa, dada a conjuntura política em cada país, que faz mais ou menos pressão para a tomada de suas terras e a consequente retirada dos Guarani. Isso é fato, basta rever o mapa de Ladeira (Figura 8), que demonstra as aldeias Guarani extremamente concentradas no Paraguai, de forma descrescente na Argentina e mais rarefeita no Brasil; mais especificamente em nosso país, verificamos a quase inexistência dessa população em todo o oeste paranaense, local foco de nossa pesquisa, justamente em região que era até recentemente, fins do século XX, extensivamente ocupadas pelos Guarani-Ñandeva.

O período de 2001-2008 apesar de acompanhar a mesma tendência, não é o período que mais nos interessa conhecer; e sim o período de 1940 a 1990, período histórico o qual, apesar de não possuirmos o censo Guarani da época, esta tese irá discorrer por meio da exposição de fatos, que demonstrará a mesma situação, a expulsão dos Guarani da fronteira brasileira para a paraguaia.

\subsection{As terras Guarani oficializadas e as existentes de fato no Brasil}

As terras Guarani já oficializadas no Brasil apresentam-se em espaços pontuais, relativamente diminutos para as necessidades de subsistência de sua população. Vivem o ônus de ser um grupo minoritário em cada região, mais fragilizado por conta da diferença cultural, frente à sociedade envolvente brasileira, sofrendo assim, constante pressão e tentativa de controle sobre suas terras nas várias regiões onde habitam.

Assim descreveu Ladeira (2001) sobre o contexto populacional e fundiário Guarani no Brasil:

No Mato Grosso do Sul, concentram-se cerca de 22 áreas Kaiova e Nhandéva reconhecidas pelo governo federal (reservadas pelo SPI - Serviço de Proteção aos Índios, ou demarcadas pela FUNAI e homologadas por decreto presidencial), além de quase uma centena de áreas tradicionais reivindicadas pelas comunidades que delas foram expulsas, evidenciando uma crítica situação fundiária.

Nas regiões Sul e Sudeste do Brasil (do estado do Rio Grande do Sul ao Espírito Santo) encontram-se, atualmente, cerca de 100 áreas ocupadas pelos Mbya e Nhandéva, além de outros locais de parada provisória e/ou sistemática. Na faixa litorânea desses estados estão cerca de 60

aldeias das quais somente 16 áreas guarani (a maioria no estado de São Paulo), somando um 
montante de 19.075 hectares, foram homologadas pela presidência da república. No interior dos estados do sul, dentre as 40 áreas onde vivem índios Guarani, as 10 áreas que foram homologadas são ocupadas predominantemente pelos índios Kaingang (RS, SC, PR) e Xokleng (SC), sendo que os Guarani ocupam uma pequena porção dessas áreas. Apesar de diminutas, nem todas as Terras homologadas estão livres e desimpedidas para o uso exclusivo dos Guarani (LADEIRA:2001:35).

Portanto, a realidade dos procedimentos de reconhecimento fundiário da etnia Guarani pelo Estado é preocupante, na medida em que sendo um dos maiores agrupamentos étnicos do Brasil, apresenta diminuta extensão de terras oficializadas. Na verdade, das 200 áreas citadas, somente 38, ou seja, menos de 1/5, obtêm o reconhecimento oficial como terras de posse da etnia Guarani.

Ladeira, em artigo no livro "Povos Indígenas no Brasil 1996-2000", comenta a respeito da conjuntura territorial vivida pelos Guarani em meio a sociedade nacional:

(...) Mesmo estas áreas não estão totalmente livres de outras ocupações e das mais variadas formas de pressão, uma vez que os limites das terras Guarani são impostos pela ocupação envolvente. A região ainda é disputada entre latifundiários, pequenos proprietários, posseiros e Unidades de Conservação (LADEIRA: 2000: p782). (...) Estão cada vez mais confinados, a pressão aumenta. Sofrem os efeitos do crescimento e do modelo de ocupação no entorno das aldeias. Muitas áreas estão cercadas por cidades, loteamentos, estradas, barragens, entre outros fatores que as afetam de modo direto ou indireto. Ainda assim, é importante manter as pequenas aldeias, que funcionam como suporte para a articulação, das dinâmicas sociais. Significa privilegiar a manutenção do território como um todo (LADEIRA:2000:785).

Partindo da concepção que o território Guarani concebido e utilizado na prática por eles é mais extenso do que as terras que lhes são demarcadas; e, que mesmo estas, apresentam dificuldades historicamente observáveis, no que se refere à efetivação dos procedimentos demarcatórios oficiais junto ao Estado pelo órgão responsável pela condução da política indigenista, FUNAI, e sua proteção contra invasões, verifica-se que conforme a época, esses indígenas são considerados pelo órgão, injustificadamente, como:

- "nômades", utilizando-se do argumento de ser desnecessário "fixar bases territoriais" para o grupo, já que sempre migram... (?) ${ }^{8}$; o que ocorre em geral é que apenas as famílias de algumas

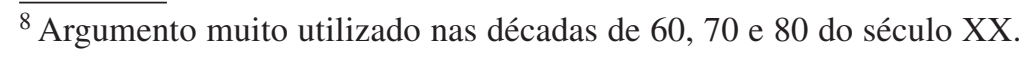


aldeias migram, ou seja, raramente migram em bloco, todo o agrupamento, abandonando assim permanentemente a parcela do território ocupada por uma aldeia; quando isso realmente ocorre, é porque os Guarani consideram não ser mais viável viver no local;

- ora são tratados como "estrangeiros, paraguaios ou argentinos", ou seja, que não possuiriam "cidadania" brasileira; a identidade sociocultural Guarani é supranacional, existe anteriormente à própria constituição dos vários Estados Nacionais onde habitam; este critério é refutável, pois os limites entre Estados Nacionais foram definidos em termos históricos há poucos séculos (4 a 5 séculos), a Província do Paraguai por exemplo no início do século XVII, fase inicial da colonização, abarcava os estados do Mato Grosso, Paraná, Santa Catarina e Rio Grande do Sul, nos quais os Guarani já os habitavam há vários séculos, assim, são povos que habitam imemorialmente todas estas fronteiras.

- ora ainda, através de critérios amplamente questionáveis não lhes reconhecem a própria "identidade indígena" através dos conhecidos e não reconhecidos antropologicamente, "critérios de identidade", utilizados durante os governos militares para destituir a identidade daqueles que se opunham às decisões do regime ditatorial e autoritário;

- mais recentemente, tentam descaracterizar seus territórios, utilizando o argumento de não serem eles "tradicionais".

Todo o tipo de artifício foi e tem sido utilizado, para lhes retirar o direito a terra onde viviam/vivem.

\subsection{A ocupação Ñandeva no interior do Tekoa Guassu}

A porção territorial em que os Avá-Guarani do Oco’y juntamente com outras populações da etnia Guarani do sub-grupo Ñandeva, consideram seu território tradicional, imemorialmente ocupado, compreende a Bacia do Paraná na região da Tríplice Fronteira localizada entre o Brasil, Paraguai e Argentina. Esta área de ocupação tradicional Guarani-Ñandeva, é formada por floresta tropical úmida e compreende o sudeste do Paraguai, até o rio Aguaray-Guazu, sobre a Serra do Maracaju, que delimita a fronteira territorial entre os Mbyá e os Nandeva; continua para o sul, cruzando o rio Jejuí, seguindo até o Rio Acaray, no Paraguai; contorna pelo nordeste da Argentina, em toda a província de Misiones (predominantemente Mbyá, com alguma presença Ñandeva); e no Brasil, já em domínio de Mata Atlântica, ocupam grande parte do sudoeste, centroeste e noroeste paranaense, ou seja, do Rio Iguaçu, prolongando-se por ele, em direção leste, até as 
cabeceiras do rio Piquiri, do Ivaí, do Tibagi e do Paranapanema, na fronteira com São Paulo; por fim, ocupam ainda, o sul do Mato Grosso do Sul, que compreende a fronteira até o Rio Iguatemi, sobre a Serra do Maracaju (Figura 12).

O conjunto da população Guarani-Ñandeva no Brasil, também denominados de GuaraniTxiripá no Paraguai, tem como território de imemorial ocupação, esta região. Ela é denominada tradicionalmente pelos Guarani como sendo parte do Tekoa Guassu, que traduzido expressa "conjunto grande de aldeias ou de terras Guarani, ou ainda território grande Guarani".

As populações das aldeias pertencentes ao Tekoa Guassu, localizadas nesses três países, estabelecem amiúde relações de reciprocidade desde tempos imemoriais. Segundo dados arqueológicos mais antigos ${ }^{9}$ encontrados nesta região em que estudamos, os Guarani habitam este

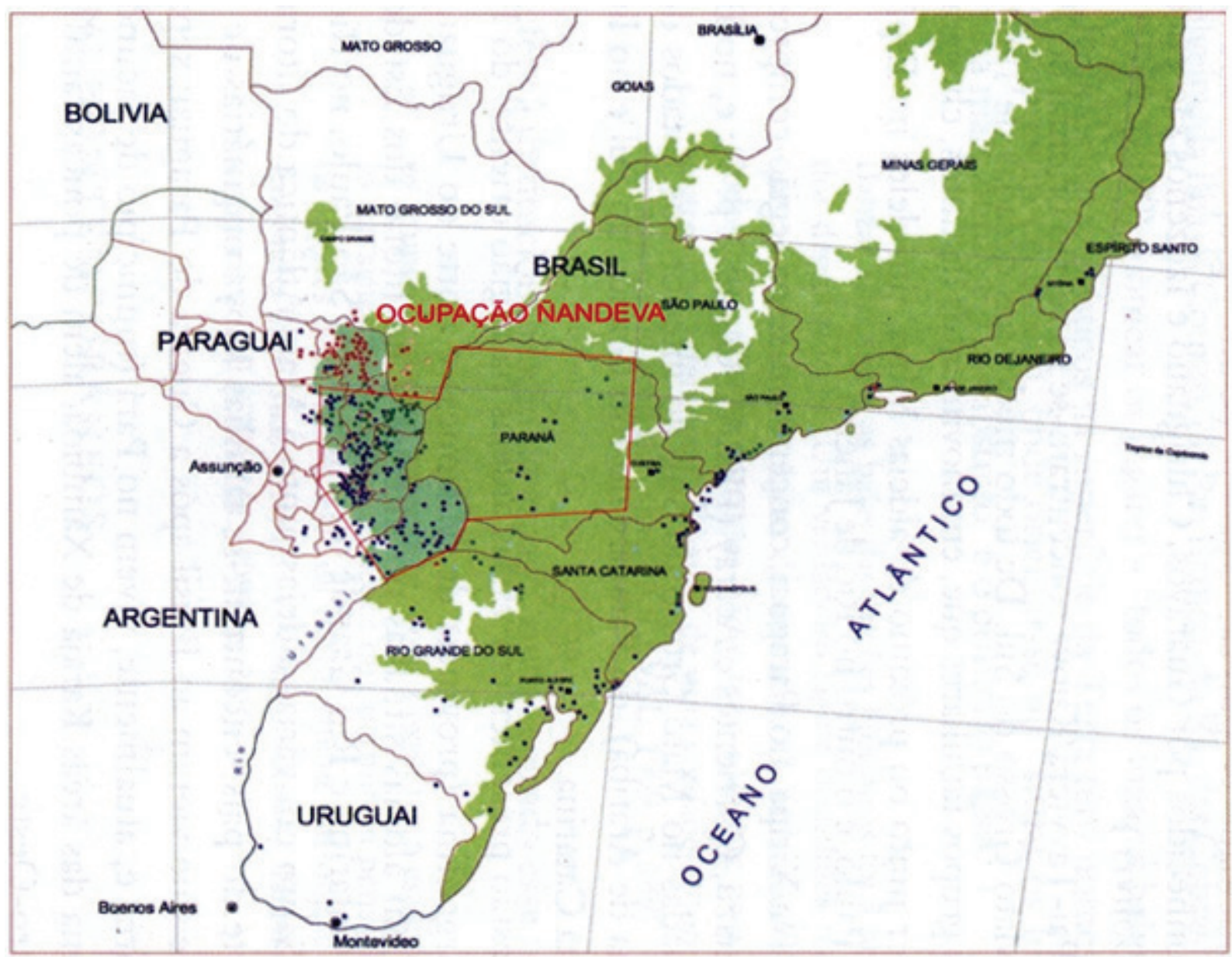

Figura 12. Mapa aproximado dos limites da ocupação Nandeva, sua área de maior circulação. Fonte: Elaboração. Maria Lucia Brant de Carvalho. 2012.

\footnotetext{
${ }^{9}$ Quanto à questão da tradicionalidade histórica e arqueológica da ocupação Guarani no território, dada sua importância, será desenvolvida em outro capítulo, específico para esse fim.
} 
território, desde pelo menos o século I Depois de Cristo (D.C.) (Chmyz:2002). Esta região podese afirmar que constitui o "berço" da cultura Guarani, a partir das subdivisões que conhecemos hoje, Kaiowá, Ñandeva e Mbyá, questão que veremos a frente.

Como povos habitantes de fronteira possuem o direito de ir e vir entre os países, já que a existência de seu território de ocupação tradicional, o Tekoa Guassu, é anterior ao estabelecimento dos próprios Estados Nacionais. Este direito é amparado pela Convenção Internacional de Genebra n. ${ }^{\circ}$ 169, da Organização Internacional do Trabalho/OIT de 27.06.1989, o qual o Brasil ratificou pelo Decreto Legislativo n. ${ }^{\circ} 143$ do Senado Federal em 20.06.2002 ${ }^{10}$ e pelo Decreto Presidencial $\mathrm{n}^{\mathrm{o}} 5051$ de 19.04.2004 ${ }^{11}$. Assim esta Convenção determina a respeito:

\section{PARTE I - POLÍTICA GERAL ARTIGO 1}

A presente Convenção aplica-se a;

a) povos tribais em países independentes cujas condições sociais, culturais e econômicas os distingam de outros segmentos da comunidade nacional e cuja situação seja regida, total ou parcialmente, por seus próprios costumes ou tradições ou por uma legislação ou regulações especiais;

b) povos em países independentes considerados indígenas pelo fato de descenderem de populações que viviam no país ou região geográfica na qual o país estava inserido no momento da sua conquista ou colonização ou do estabelecimento de suas fronteiras atuais e que, independente de sua condição jurídica, mantêm algumas de suas próprias instituições sociais, econômicas, culturais e políticas ou todas elas.

\section{PARTE II - TERRA}

\section{ARTIGO 13}

1. Na aplicação das disposições desta Parte da Convenção, os governos respeitarão a importância especial para as culturas e valores espirituais dos povos interessados, sua relação com as terras ou territórios, ou ambos, conforme o caso, que ocupam ou usam para outros fins e, particularmente, os aspectos coletivos dessa relação.

2. O uso do termo terras nos artigos 15 e 16 incluirá o conceito de territórios, que abrange todo o ambiente das áreas que esses povos ocupam ou usam para outros fins.

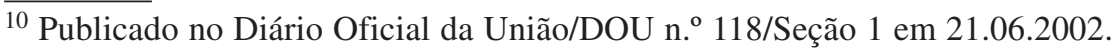

${ }^{11}$ Publicado no DOU de 20.04.2004.
} 


\begin{abstract}
ARTIGO 14
1. Os direitos de propriedade e posse de terras tradicionalmente ocupadas pelos povos interessados deverão ser reconhecidos. Além disso, quando justificado, medidas deverão ser tomadas para salvaguardar o direito dos povos interessados de usar terras não exclusivamente ocupadas por eles às quais tenham tido acesso tradicionalmente para desenvolver atividades tradicionais e de subsistência. Nesse contexto, a situação de povos nômades e agricultores itinerantes deverá ser objeto de uma atenção particular.

2. Os governos tomarão as medidas necessárias para identificar terras tradicionalmente ocupadas pelos povos interessados e garantir a efetiva proteção de seus direitos de propriedade e posse.

3. Procedimentos adequados deverão ser estabelecidos no âmbito do sistema jurídico nacional para solucionar controvérsias decorrentes de reivindicações por terras apresentadas pelos povos interessados.
\end{abstract}

\title{
PARTE VII - CONTATOS E COOPERAÇÃO ALÉM-FRONTEIRAS ARTIGO 32
}

Os governos tomarão medidas adequadas, inclusive por meio de acordos internacionais, para facilitar contatos e cooperação além-fronteiras entre povos indígenas e tribais, inclusive atividades nas áreas econômica, social, cultural, espiritual e ambiental.

Este trabalho é focado no histórico dos Guarani do subgrupo Nandeva pertencentes à extinta aldeia do Oco'y-Jacutinga, localidade que tradicionalmente ocupavam no extremo oeste paranaense/Brasil, entre os rios Paraná, Ocoí e córrego Jacutinga. Portanto, essa é uma, das várias aldeias integrantes do Tekoa Guassu, aldeias as quais se localizavam em passado recente até os anos 80 do século XX, em suas cercanias.

Após as terras dessa aldeia terem sido inundadas pelo reservatório da Usina Hidrelétrica de Itaipu em 1982, alguns grupos familiares foram compulsoriamente reterritorializados para a denominada Terra Indígena Avá-Guarani do Oco'y, ás margens do extinto Córrego Santa Clara, também inundado pela Itaipu. O Oco'y esta estabelecido em zona rural, na chamada Vila Santa Rosa do Ocoí, município de São Miguel do Iguaçu, localizado a cerca de $40 \mathrm{~km}$ de Foz do Iguaçu/Paraná. Nesta aldeia nota-se a presença também de Guarani do sub-grupo Mbyá. Os Ñandeva do Oco'y autodenominam-se Avá-Guarani, traduzido expressa Homens-Guarani. 


\subsection{Os conceitos de território e terra indígena}

Para concluir este capítulo é interessante refletir sobre como o conceito de "território", vem sendo, de forma insuficiente e incorreta, substituído pelo conceito de "terra indígena", especialmente com relação aos Guarani.

A preocupação com a definição de limites e cartografias para os territórios indígenas não partiu dessas sociedades. As situações de contato a partir da conquista rompem antigas alianças e hostilidades e, em razão da necessidade de confinar as comunidades indígenas para promover sua própria ocupação expansionista, a sociedade nacional produz a categoria de "terra indígena", associando-a ao significado mais amplo de "território", enquanto um espaço suficiente para o desenvolvimento de todas as relações e vivências definidas pelas tradições e cosmologias. Com relação aos Guarani, a redução do conceito de seu território ao de suas terras é completamente imprópria (LADEIRA: 2000:784).

Os advogados indigenistas Antunha Barbosa e Barbosa (1987), afirmaram a respeito do dimensionamento do "território" Guarani, também em contraposição às "terras" Guarani:

Hoje, a compreensão do que se denomina território Guarani - que são as várias aldeias e os caminhos que eles utilizam para ir de uma a outra, compreendendo os vários espaços utilizados que interferem no seu modo de vida, como as matas - não só as pertencentes aos limites das áreas oficialmente demarcadas, mas as áreas verdes vizinhas circundantes - os rios, as águas que também passam pelas aldeias e que não têm nascentes nos limites das áreas, extrapola, ainda hoje, o que se pode esperar como território garantido pelos poderes constituídos. (ANTUNHA BARBOSA e BARBOSA:1987:13).

Considerando que no passado pré-colonial o conjunto territorial no Brasil que vai de São Paulo ao Rio Grande do Sul até o leste paraguaio, nordeste argentino e norte uruguaio, era praticamente todo de posse Guarani e de outras etnias, e, a migração entre áreas era - como continua sendo - usual, a partir da colonização e do contato mais amiúde com a sociedade envolvente, a grande mudança histórica foi que seus territórios passaram a se constituir de áreas menores, - e quando reconhecidas oficialmente, o são como "terras indígenas" - encravadas em meio a uma região do Brasil, a qual se caracteriza pela maior densidade demográfica não indígena do país e ainda, a economicamente mais valorizada, decorre daí a maior dificuldade de reconhecimento das terras Guarani. 
Assim a situação fundiária apresentada, justifica-se na verdade, por ser o grupo composto por grande número de indivíduos, que necessitam de parcelas pontuais sobre vasto território, o que na visão geopolítica de Estado representaria risco de se estar "promovendo a permanência destes indígenas em espaços caros ao capital"; na medida em que se legitima a criação de mais bases territoriais, se vai, portanto, na contramão da política dominante, de Estado e das classes dominantes, apesar de ser protegido este "direito de permanência" indígena no território, por lei. É a situação que veremos neste trabalho.

A busca pela abertura de novas aldeias pelos Guarani têm-se verificado mais intensa em função de duas taxas invertidas: as históricas perdas de terras e o alto crescimento demográfico do agrupamento. Assim a luta pela sobrevivência faz com que procurem outras terras, ressurgindo assim, dialeticamente, novas aldeias Guarani. A busca dessa população por terras livres da ingerência da sociedade envolvente, muito embora não seja seu primordial determinante de origem, está contida no cerne do milenar mito Guarani, denominado "Terra Sem Males".

Apesar da restrição territorial em cada local considerado "Terra Indígena", os Guarani mantêm forte relação simbólica e prática com todas as parcelas do território ocupado ao longo de séculos, sem perder de vista o macroterritório Guarani original, mantendo tradicional circulação de famílias, entre as diversas aldeias e trilhas existentes em seu interior. Os Guarani mantém assim a presença - mesmo que em espaços diminutos - em praticamente toda extensão do seu território tradicional. Como Ladeira (2001) se refere: "manter a dinâmica territorial tem sido a forma mais efetiva de exercer sua autonomia". 


\title{
CAPÍTULO 3 \\ CONTEXTO DE VIDA NA TERRA INDÍGENA AVÁ-GUARANI DO OCO'Y
}

\author{
Quem me dera ao menos uma vez \\ Explicar o que ninguém consegue entender \\ Que o que aconteceu ainda está por vir \\ E o futuro não é mais como era antigamente.
}

Quem me dera ao menos uma vez

Que o mais simples fosse visto

Como o mais importante

Mas nos deram espelhos e vimos um mundo doente.

Quem me dera ao menos uma vez

Como a mais bela tribo

Dos mais belos índios

Não ser atacado por ser inocente.

Nos deram espelhos e vimos um mundo doente

Tentei chorar e não consegui.

Trechos de "Índios"

Renato Russo

\subsection{Primeiras palavras}

Os Ñandeva ou os Avá-Guarani ${ }^{1}$ como se autodenominam os Guarani do Oco’y possuem como território de imemorial ocupação, um conjunto de terras na região da Tríplice Fronteira, entre as quais as terras do Oco’y-Jacutinga. Esta terra a partir dos anos 40 do século XX passou a sofrer várias reduções de seu território original e em 1982 apresentava seus limites da seguinte forma: a oeste o rio Paraná, ao norte o rio Ocoí e ao sul o córrego Jacutinga.

Em fins de outubro de 1982 ocorreu a grande inundação em função da instalação do reservatório da Usina Hidrelétrica de Itaipu/UHE Itaipu ${ }^{2}$, a qual inundou entre outras regiões, tam-

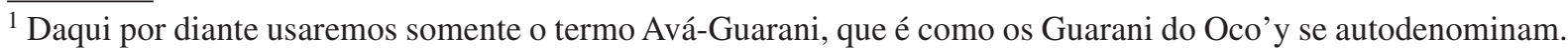

${ }^{2}$ Usina Hidrelétrica de Itaipu/UHE Itaipu ou também denominada Itaipu Binacional/IB.
} 
bém a bacia do rio Ocoî ${ }^{3}$ e de seus afluentes, cobrindo pelas águas inclusive as terras do Oco’yJacutinga.

Meses antes, em maio do mesmo ano, somente parte das famílias indígenas dessa aldeia, 19 (dezenove) famílias, foram compulsoriamente reterritorializadas para local que veio a se tornar a Terra Indígena Avá-Guarani do Oco’y, onde estão até hoje, portanto, há 30 anos, terra esta destinada oficialmente, apesar de forma ilegal, a apenas 4 (quatro) famílias indígenas.

Outra parte dessa população do Oco’y-Jacutinga em período anterior, foi obrigada a se dirigir para outras aldeias tanto no Brasil como no Paraguai, ocupando terras já ocupadas por outras populações indígenas Guarani. No Brasil os Guarani foram encaminhados contra sua vontade para ocupar aldeias Guarani e também aldeias da etnia Kaingang, todas já habitadas, em terras reconhecidas para as suas respectivas populações mais antigas. Algumas famílias extensas, antigos moradores do Oco'y-Jacutinga, posteriormente, vieram a se juntar novamente à população que primeiro se estabeleceu no Oco'y. O retorno de famílias que vieram a se juntar às primeiras famílias que se estabeleceram no Oco’y (19 (dezenove) famílias), contribuiu para haver excesso populacional no Oco’y diante das parcas terras oferecidas pelas instituições responsáveis do governo brasileiro, oficialmente para apenas 4 (quatro) famílias.

A transferência da população indígena, realizada em nome de compensação pelas terras perdidas, por meio de acordo entre Itaipu Binacional, FUNAI e INCRA, legalmente deveria se dar conforme os ditames legais do Estatuto do Índio, Lei no 6001 de 19.12.1973, que em seu Artigo 20, parágrafo $1^{\circ}$, letra d, parágrafo $2^{\circ}$, letra c e parágrafo $3^{\circ}$ e $4^{\circ 4}$, fundamentalmente determinam a transferência do conjunto do agrupamento indígena para terras em "área equiva-

\footnotetext{
${ }^{3} \mathrm{O}$ rio OCOÍ recebeu esta denominação dada pelos Guarani, originalmente, eles explicam, chamava-se HOKO'Y, isto é, lugar onde viviam à beira-rio muitos pássaros HOKO (Socó), Y na língua Guarani significa água, os pássaros Socó viviam em bando sobre as águas desse rio, daí o nome dado pelos Guarani de HOKO'Y, sendo posteriormente abrasileirado para OCOÍ.

${ }^{4}$ Art. $20^{\circ}$. Em caráter excepcional e por qualquer dos motivos adiante enumerados, poderá a União intervir, se não houver solução alternativa, em áreas indígenas, determinada a providência por decreto do Presidente da República.

Parágrafo $1^{\circ}$. A intervenção poderá ser decretada: (...) d) para a realização de obras públicas que interessem ao desenvolvimento nacional.

Parágrafo $2^{\circ}$ : A intervenção executar-se-à nas condições estipuladas no decreto e sempre por meio suasórios, dela podendo resultar, segundo a gravidade do fato, uma ou algumas das medidas seguintes: (...) c) remoção de grupos tribais de uma para outra área.

Parágrafo $3^{\circ}$ : Somente caberá a remoção de grupo tribal quando de todo impossível ou desaconselhável a sua permanência na área sob intervenção, destinando-se à comunidade indígena removida área equivalente a anterior, inclusive quanto às condições ecológicas.

Parágrafo $4^{\circ}$ : A comunidade indígena removida será integralmente ressarcida dos prejuízos decorrentes da remoção.
} 
lente à anterior, inclusive quanto às condições ecológicas" e ainda, conforme o Artigo 198, parágrafos $1^{\circ}$ e $2^{\circ}$ da Emenda Constitucional de $1969^{5}$, basicamente deveria ser "reconhecido o seu direito ao usufruto exclusivo das riquezas naturais e de todas as utilidades nelas existentes" ${ }^{\prime}$.

Como veremos ao longo deste capítulo, que trata das condições de vida da população AváGuarani apresentadas na atualidade (2001-2005), a Terra Indígena Avá-Guarani do Oco’y apresenta dimensões diminutas para as necessidades de sobrevivência da população indígena, muito menor que a anterior e ambientalmente comprometida. É sobreposta à Área de Preservação Permanente/APP do reservatório da Itaipu Binacional, terras que, antes, se constituíam em parte, de Glebas de Colonos, os quais foram desapropriados em função da constituição da APP de Itaipu, sem que fossem indenizados pelo Instituto Nacional de Colonização e Reforma Agrária/ INCRA ${ }^{7}$. Assim ocorre no Oco'y, tripla sobreposição de domínios, Glebas de Colonos, APP de Itaipu e Terra Indígena dos Avá-Guarani do Oco’y, cada qual disputando uma fatia dessas terras.

Dada a insuficiência de terras compensadas destinadas a um numero restrito de famílias, somente para 4 (quatro) famílias extensas, e, os problemas sociais causados em decorrência das superposições, os Guarani sofrem toda sorte de impactos sociais, ambientais, econômicos e sanitários. Fatos estes que veremos neste capítulo e que contrariam toda a legislação indigenista, ambiental e sanitária brasileira.

Em outubro e dezembro de 2001 e abril de 2002 realizamos as primeiras pesquisas de campo na Terra Indígena Avá-Guarani do Oco’y, quando foi constatado o contexto de vida apresentado atualmente por essa população indígena, tema deste capítulo ${ }^{8}$.

\footnotetext{
${ }_{5}^{5}$ Artigo $198^{\circ}$. As terras habitadas pelos silvícolas são inalienáveis nos termos que a lei federal determinar, a eles cabendo sua posse permanente e ficando reconhecido seu direito ao usufruto exclusivo das riquezas naturais e de todas as utilidades nelas existentes.

Parágrafo $1^{\circ}$ : Ficam declaradas a nulidade e a extinção dos efeitos jurídicos de qualquer natureza que tenham por objetivo o domínio, a posse ou a ocupação de terras habitadas pelos silvícolas.

Parágrafo $2^{\circ}$ : A nulidade e a extinção de que trata o Parágrafo anterior não dão aos ocupantes direito a qualquer ação ou indenização contra a União e a Fundação Nacional do Ííndio.

${ }^{6}$ Todo o processo de fato e legal, institucionalmente realizado de transferência dos Guarani do Ocoy-Jacutinga para a Terra Indígena Avá-Guarani do Oco’y será discutido no capítulo 5 deste trabalho.

${ }^{7}$ Idem.

${ }^{8}$ Esta tese de doutoramento se baseia em varias informações contidas em Laudos Antropológicos realizados pela autora no período de 2001 a 2005. Este capítulo toma informações em parte dos seguintes trabalhos: - BRANT DE CARVALHO, Maria Lucia. LAUDO ANTROPOLÓGICO (1). Contaminação por agrotóxicos pela comunidade indígena AVÁ-GUARANI. Terra Indígena do Oco’y/ São Miguel do Iguaçu/ Paraná. São Paulo: AER BAURU/SP/FUNAI/ MJ. 11.03.2002, 64 páginas; e, - BRANT DE CARVALHO, Maria Lucia. LAUDO ANTROPOLÓGICO. $3^{\circ}$. Parte: O Contexto Atual Vivido Pela População Indígena Avá-Guarani na Terra Indígena do Oco'y/São Miguel do Iguaçu/ Pr. Ref: Comunidade Indígena AVÁ-GUARANI. TERRA INDÍGENA OCO'Y. Município de São Miguel do Iguaçu. Estado do Paraná. Brasil. AERBAURU/SP/FUNAI/MJ. São Paulo. 147 páginas. 2002.
} 
Outros colaboradores foram sendo incorporados aos trabalhos na medida em que verificávamos a necessidade de se juntar ao estudo, profissionais das áreas: ambiental, agronômica, médica e sanitária.

Pudemos contar com a presença em campo do geólogo Mucio Nobre C. Ribeiro, ex-servidor do antigo Departamento de Patrimônio Indígena e Meio Ambiente/DEPIMA/FUNAI/SedeBrasília, o qual desenvolveu o trabalho “Terra Indígena Avá-Guarani do Oco’y: Diagnostico Preliminar da Qualidade das Águas" em julho de 2002 .

Outro profissional o qual pudemos contar em campo, foi o biólogo Julio Cesar de Moraes, ex-servidor, indigenista, da antiga Administração Executiva Regional da FUNAI em Bauru/ AERBAU-SP, o qual desenvolveu o trabalho "Agrotoxicos no entorno da Terra Indígena AváGuarani (Oko’y), em São Miguel do Iguaçu-PR: Sobrevivência física e cultural em risco da população indígena Avá-Guarani”, trabalho de julho de $2004^{10}$.

Na esteira de seu trabalho, tentamos contar com os profissionais de saúde, fundamentalmente médicos responsáveis pela saúde indígena na época, apoio este sem sucesso, do Distrito Sanitário Especial Indígena/DSEI, sede em Curitiba/FUNASA, organização governamental esta, substituída hoje pela Secretaria Especial de Saúde Indígena/SESAI.

Diante desta negativa e através daquele biólogo, pudemos contar com o apoio em campo de duas médicas e uma psicóloga, respectivamente, as Professoras Doutoras Letícia Legay e Heloisa Pacheco Ferreira, e a Professora Doutora Regina Helena Simões, as três do Núcleo de Estudos de Saúde Coletiva/NESC do Centro de Ciências da Saúde da Universidade Federal do Rio de Janeiro/UFRJ; com esta equipe também se juntou o Professor Doutor Olaf Malm, Coordenador Chefe do Laboratório de Radioisópotos EPF do Programa de Biofísica Ambiental e Biotecnologia do Instituto de Biofísica Carlos Chagas Filho/IBCCF da Universidade Federal do Rio de Janeiro/ UFRJ. Esta equipe em vistoria de quatro dias, em junho de 2005, produziu o "Relatório de visita da equipe do Núcleo de Estudos de Saúde Coletiva/NESC e do Instituto de Biofísica Carlos Chagas Filho/IBCCF da Universidade Federal do Rio de Janeiro/UFRJ à aldeia Avá-Guarani

\footnotetext{
${ }_{9}^{9}$ RIBEIRO, Mucio Nobre Costa. Terra Indígena Avá-Guarani do Oco’y. Diagnóstico Preliminar sobre a qualidade das águas. DEPIMA/FUNAI/Brasília. Julho/2002. 70p.

${ }^{10}$ MORAES, Julio Cesar de. Agrotóxicos no entorno da Terra Indígena Avá-Guarani (Oko’y), em São Miguel do Iguaçu-Pr: Sobrevivência física e cultural em risco da população indígena Avá-Guarani. São Paulo: AER BAURU/ FUNAI, Julho de 2004.
} 
situada na região do Oco’y Jacutinga, município de São Miguel do Iguaçu/Pr, à convite da FUNAI/ Ministério da Justiça/MJ"11.

Após este estudo preliminar os integrantes do NESC e IBCCF/ambos da UFRJ e nós servidores da FUNAI envolvidos, produzimos um Projeto denominado "Avaliação do contexto de saúde humana e ambiental, com ênfase na contaminação por metais pesados e pesticidas, junto à população Guarani da Terra Indígena Avá-Guarani (Oco’y), desterrados de seu imemorial território de ocupação tradicional por Grandes Projetos (Parque Nacional do Iguaçu e UHE Itaipu) e circundados por áreas agrícolas de monoculturas" ${ }^{12}$, projeto desenvolvido em 2006, o qual foi negado financiamento pelo Edital 038/2005 - CNPQ, por não ser considerado prioritário.

Todos esses estudos desenvolvidos preliminarmente buscando levantar a situação vivida no Oco’y, desdobrando-se em projetos e recomendações de controle e mitigação dos problemas apresentados, apesar de entregue a todas as autoridades competentes, em parte para a FUNASA, no todo para a FUNAI, MPF e JF de Foz do Iguaçu, VI ${ }^{a}$ Câmara de Coordenação e Revisão da Procuradoria Geral da República/ Ministério Publico Federal em Brasília, não foram devidamente considerados, permanecendo a situação vivida no Oco'y praticamente tal como se apresentou, com exceção de algumas poucas medidas mitigadoras, não estruturais, por parte da Itaipu Binacional e FUNAI.

\subsection{O depoimento dos idosos}

A primeira medida tomada por nós, ao chegar no Oco’y, em 2001, foi solicitar às lideranças uma reunião com os indivíduos mais velhos daquela aldeia. Buscávamos compreender quais as características da aldeia anterior, que haviam sido forçados a abandonar, o Oco’y-Jacutinga, em comparação com a aldeia atual, o Oco'y. O encontro começou em uma segunda de manhã e terminou às $18 \mathrm{hs}$, com um breve convite por parte de um dos senhores presentes, com um

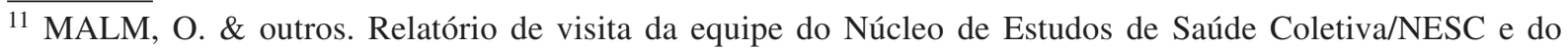
Instituto de Biofísica Carlos Chagas Filho/IBCCF da Universidade Federal do Rio de Janeiro/UFRJ à aldeia AváGuarani situada na região do Oco'y Jacutinga, município de São Miguel do Iguaçu/Pr, à convite da FUNAI/ Ministério da Justiça/MJ. Rio de Janeiro: NESC-IBCCF/UFRJ. 11p.

${ }^{12}$ MALM, O. \& outros. Avaliação do contexto de saúde humana e ambiental, com ênfase na contaminação por metais pesados e pesticidas, junto à população Guarani da Terra Indígena Avá-Guarani (Oco'y), desterrados de seu imemorial território de ocupação tradicional por Grandes Projetos (Parque Nacional do Iguaçu e UHE Itaipu) e circundados por áreas agrícolas de monoculturas. Rio de Janeiro: NESC-IBCCF/UFRJ; AERBAU-CGPIMA/ FUNAI; Projeto apresentado ao Edital 038/2005 - CNPQ. 2006. 25p.
} 
tapinha nas costas, dizendo: Então, amanhã aqui de novo?! Assim foi durante toda a semana, até inclusive o próximo sábado. Muitas recordações vieram à tona e foi gratificante para eles se lembrarem da vida que viviam antigamente. Não tão gratificante assim foi perceber a diferença de estilo de vida a que passaram a estar submetidos na atualidade. Esses "discursos" estão espalhados por todo o trabalho, aqui em evolução. Uma conversa com o pajé mais velho da aldeia, Seu "Guilherme", hoje com cento e poucos anos, nesse mesmo sentido temático, foi gravada, e, traduzida posteriormente, assim ele afirma:

As roças tão juntinho de casa, não tem lugar onde fazer.

Antigamente não sofria, caça tinha de diferente tipo: anta, quati, porco-do-mato, tatu. Muita fruta: jaborati, guavirova, coqueiro, jaracatia, yvapuru, jaboticaba, palmito, não precisava compra nada. Muito pássaro: nhambu, perdigão, macuco... não dependia de coisa do branco, hoje nós depende tudo. Não tem condição de compra, toda dificuldade nós temo hoje.

Remédio? agora é diferente... . Antes a gente tinha cedro, cedrinho, cangarossa, ipy, guiné, pariparoba, coroba, cabriúva, arapacho, peroba, pacová. Não encontra mais mel.

Hoje nós cobre a casa com capim colonião, não dura nada... antigamente cobria com bambu, coqueiro e capim sapé, hoje não tem mais, muito pouco, não dá mais nada.

De peixe que tinha lá no Oco'y-Jacutinga? Corvina, pacu, dourado, jurutá, bocudo, pirá, tinha quase tudo..., mas não pega a quantidade que tinha lá no Oco'y-Jacutinga, agora quando tem, tem tudo pouquinho. Na verdade aqui só tem corvina, traíra e só em alguma época. Hoje aqui só o peixe, ave e caça nada.

Antigamente a gente via as árvores florescendo, a canela, era sinal que era época de planta..., na época de frio não pode planta nada. Falta muita coisa da natureza pra nós, por causa disso a gente não tá podendo preservar a cultura como a gente quer. Por causa disso vem muita doença, o vento traz muita doença, o mato, a natureza, segura tudo... . Não tem mais mato, vem as doenças do Paraguai, de tudo quanto é lugar.

O colono mata a vegetação com produto químico, para planta soja e milho. Põe veneno na soja para matar lagarta, percevejo; no milho, para matar a lagarta da espiga. O veneno tem cheiro forte, dá dor de cabeça, dor de garganta, se os animais vão lá come, morre tudo. As crianças brincam no meio da soja, é perigoso... .

Contamina a água que a gente usa, na época da chuva a enxurrada é muito forte e traz todo esse produto para dentro da aldeia. Os peixes no mês de janeiro e fevereiro fica tudo boiando morto.

Depoimento de Seu Guilherme, Pajé mais idoso do Oco’y, em outubro de 2001, traduzido por Pedro Alves, hoje ex-Cacique da TI do Oco’y. 
Nota-se clara diferença ambiental de uma terra para outra, e, de como a existência e depois a falta de certos recursos naturais passaram a influenciar negativamente os modos de vida dos Avá-Guarani, impedindo sua reprodução física e cultural conforme suas próprias determinações socioculturais, direito este que é garantido constitucionalmente.

Seu Guilherme estava com câncer de esôfago, um tipo de câncer, segundo a médica da aldeia, "diferente", que deveria ser pesquisado a causa que lhe deu origem, pois se constituí em uma mancha branca, de aparência singular, diversa de outros casos de câncer...

\subsection{Cântico Guarani entoado na Casa de Reza do Oco’y}

A Casa de Reza é um espaço de congregação entre as gerações, em cada aldeia Guarani. Ali se reza e se cura, se toca, se dança e se canta, se reúne e se discute, se ouve e se aprende. Abaixo um cântico entoado no Oco'y, para que as sucessivas gerações aprendam quem é quem na historia vivida. Em seguida ela está traduzida.

Jurua kuéry iopota ri teima ojekuéry ñembo'épy

año año ña ñembo'e.

Oguerojeapo ey aguãre romoangeko,

Ñamandu Ru Ete Tenondegua!

Ogueropochy pa katuí jeguakáva jeayu porãngue i reko,

ogueropochy pa katuí jachukáva jeayu porãngue i reko:

guírami ojekuéri rami ey,

ndoreropy yvatéi ramo,

ndoreywyra kuatiái,

kuatia arandu ndoroikuaái ramo,

ore kuruchu i ey ramo, je.

Nde ree meme rojerovia roãmy,

Ñamandu Ru Ete Tenondegua!

Ojekuéry rami tamora'eñande rerekóramo,

kova'e nde ere va'ekue y,

Ore Ru Ñamandu Ete Tenondegua! 
A'e rami ramo jepe,

jeguakáva oñembo'e porã $i$ va'e,

jachuakáva oñembo'e porã i va'e,

oecha ramo jepe,

oendu ramo jepe oguere katu ey va'erã,

ndo guero katu pyry eyi jewy,

ojapychaka mbaraete porã ty va'e opy roka rupi,

oguerojere tatachina reko achy,

oupi ndéwy ijyvára jerojy rupa

opa marangua mbytépy,

Ywypo amboae i kuéry oguerovaé i jepi

u'ichi reko achy,

avachi vai kue i roupi i a gua,

A'e raminguáre jepe,

u'ichi reko achy,

avachi vai kue $i$,

mba'eve ko nde ywy reko achy áry roechávare,

mba'eve ko nde ywy reko achy áry roechávare,

kova'e re raga ri ty ra'e

nde egui ore resarái kyry i va'e era y ko.

Kova'e ñemoingo ey aguáre jewy jewy romoangeko,

Namandu Ru Ete tenondegua!

A'e kuéry, oipuru ore ayvu ete i va'e

ore mbotawy che wy,

a'e wy aipo e'i Ñe egy Mbyte i, je,

a'e N $e^{\prime}$ e Rarõ a.

A’e rami ramo, jurua kuéry ojeawy i ramó jepe,

aendu vei pa i va'e.

A'e rami ramo ae, mbaraete ve reko rã

mba'e e'iuka ño eterei va'erã

Ñande Ru Tenonde kuéry. 
A'e rami ramo ma, ne amba poata rei katu ey re

rojaeo ñendu jewy va'erã.

Nde ree meme rojerovia ro'ãmy,

nde guero chapukái,

Ñamandu Ru Ete Tenondegua!

\section{Cântico Guarani entoado na Casa de Reza do Oco’y - Tradução}

Os estrangeiros, enganosamente, desejam

que nossas rezas sejam como suas rezas.

Para que não façam isso é que lhe rogo,

Pai Ñamandu Verdadeiro, o Primeiro!

Eles não gostam nada da vida que levam os bem-amados e bons jeguakávas, elas não gostam nada da vida que levam as bem-amadas e boas jachukávas:

essa vida é outra vida,

nós não temos altas casas,

não temos livros, nem sabemos ler seus papéis sábios,

não rezamos para os santos filhos de seus deuses

e não temos também suas cruzinhas,

Só confiamos em ti em nossas consciências,

Pai Namandu Verdadeiro, o Primeiro!

E mesmo que desejem que sejamos como eles,

tu nunca dispuseste nada a esse respeito,

Pai Ñamandu Verdadeiro, o Primeiro!

E se as coisas estão desse jeito,

os jeguakávas que rezam muito bem,

as jachuakávas que rezam muito bem,

se eles vêem

e ouvem coisas que só os entristecem,

nem assim ficam tristes, 
e envolvem as casas dos que ouvem palavras sagradas

com a neblina imperfeita que levam,

e elevam até ti o leito em que desce a divindade

em meio a todo o mal que existe.

Os estrangeiros trazem sempre

farinha ruim

e milho estragado para comermos,

Mas nada, nada disso,

nem a farinha ruim,

nem o milho estragado,

nem nada do que vemos em tua morada terrestre,

nem nada do que ouvimos em tua morada terrestre,

nos farão esquecer um instante de ti.

Para que isso não aconteça é que sempre te imploro,

Ñamandu Pai Verdadeiro, o Primeiro!

Eles usam nossas palavras sagradas

porque querem nos enganar,

e falam que a medula da palavra-alma

é o anjo da guarda

Então, embora os cristãos se enganem, escuto-os sem lhes dar importância,

Assim, para meu fortalecimento espiritual,

nossos Primeiros Pais

me farão dizer muitas e muitas palavras.

Por tudo isso é que te faremos ouvir

de novo nossas súplicas

em tua morada inacessível.

Em ti confiamos em nossas consciências,

em loas te louvamos,

Ñamandu Pai Verdadeiro, o Primeiro!

Tradução: L. Miranda e J. V. Baptista 
Os Guarani no tocante a sua vida espiritual almejam ser "homens-deuses". Assim, a correção do caráter é um aspecto marcadamente desenvolvido pela cultura Guarani, por meio da educação das sucessivas gerações.

\subsection{Morfologia geográfica da Terra Indígena Avá-Guarani do Oco’y}

Para que possamos ter claras as dimensões dos problemas vividos nesta Terra Indígena/TI, superposta ao mesmo tempo à Área de Preservação Permanente/APP e à Glebas de Colonos/GC, se faz necessário compreender primeiramente a morfologia geográfica deste território, referente à sua localização, extensão, situação do entorno e do relevo, população que o habita, como também suas características ambientais em terras e águas (Figura 13).

A Comunidade Indígena Avá-Guarani do Oco’y, vive atualmente em duas estreitas faixas de terras, remanescentes de floresta subtropical úmida, localizadas às margens do extinto Córrego Santa Clara, que foi inundado em 1982 pela UHE Itaipu; Ele foi substituído por um braço de lago que passou a pertencer ao reservatório desta Usina Hidrelétrica.

Ao observar a Figura 13 o terreno apresenta o formato de um "V". No seu interior encontrase o braço de lago pertencente ao reservatório maior, gerador de energia da Usina Hidrelétrica de Itaipu. As bordas de terras internas a esse "V", os primeiros 100 metros transversais ao lago, há remanescentes florestais que compreendem, segundo os técnicos da empresa, a Área de Preservação Permanente/APP da Itaipu Binacional. Em todo o entorno do reservatório da Itaipu a APP possui oficialmente e de fato em media 210 metros de largura. Somente no Oco'y isto é uma exceção. Neste local não existe linha de fronteira que separe a APP da Terra Indígena, pois na verdade encontram-se sobrepostas.

O próprio "V" de terras corresponde a Terra Indígena Avá-Guarani do Oco’y, que apresenta 238 metros de largura em média (na verdade, 138 metros, se descontada a APP) por 7 Km de comprimento cada braço deste "V" e um perímetro de 24,347 km.

Assim esse terreno possuí apenas 238 metros de largura em média, tanto de um lado como de outro, das faixas de terras envolta do reservatório, ou seja, contados da margem do lago, passando pela APP, pela Terra Indígena, até o início das glebas dos colonos lindeiros.

Os lados externos do "V" são ocupados tanto de um lado como de outro da área por colonos. A princípio não existe linha divisoria que separe a Terra Indígena das Glebas dos Colonos. Contam os Guarani que os marcos divisórios por várias vezes foram postos pelo poder público e 


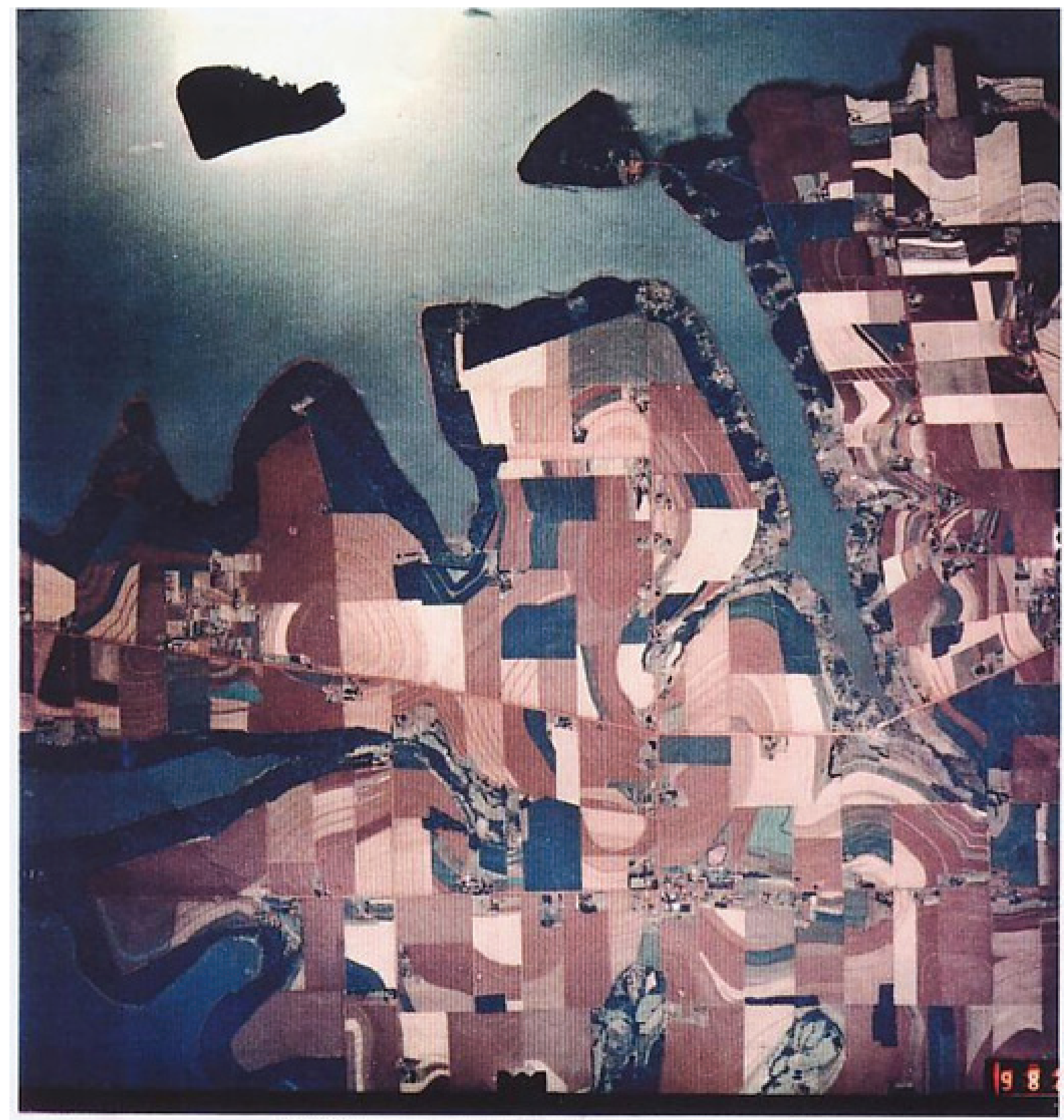

\begin{tabular}{|c|c|}
\hline \multicolumn{2}{|c|}{ ITAFE Rav ACTONA. } \\
\hline \multicolumn{2}{|c|}{ 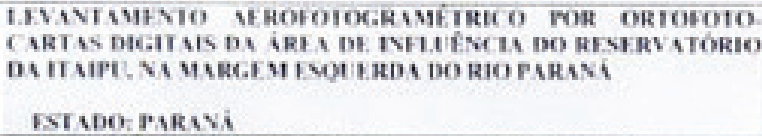 } \\
\hline 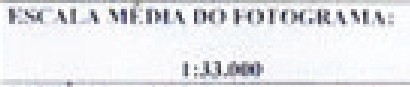 & 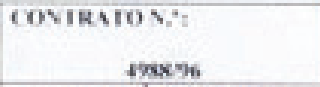 \\
\hline $\begin{array}{l}\text { DISTINA FOKALCA.IHHAD: } \\
\qquad 152.790 \mathrm{~mm}\end{array}$ & 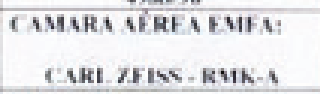 \\
\hline 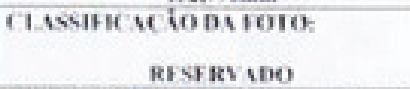 & $\begin{array}{r}\text { T.ICIVCI B.MA: } \\
\text { e1996 }\end{array}$ \\
\hline 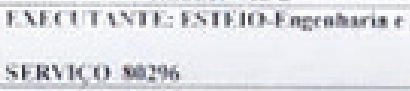 & $\operatorname{ates} \times, \mathrm{A}$ \\
\hline
\end{tabular}

Figura 13. Foto Aérea. TI Avá-Guarani do Oco’y/São Miguel do Iguaçu/ Paraná Fonte: Itaipu Binacional. 1996. 
em seguida derrubados pelos colonos, os quais avançam com seus tratores plantando cultivos sobre a área de terras com matas que foi destinada aos indígenas.

A estrada existente ao longo de todo o comprimento da área, ao invés de passar entre as duas terras, indígena e de colonos, o que seria o esperado e lógico, pois demarcaria com melhor precisão os limites entre áreas, passa apenas por dentro da Terra Indígena. A estrada subtrai ainda mais o parco espaço territorial indígena de remanescente florestal.

Já em 2007, em quase sua totalidade a Terra Indígena havia sido invadida pelos colonos até o limite da estrada, criando forçosamente outro limite, agora realmente até a estrada.

Quanto ao relevo, as duas faixas de terras do Oco'y apresentam-se em uma microbacia, logicamente em declive, onde os colonos habitam as glebas existentes nas bordas externas e acima desta bacia, em seguida a população indígena encontra-se no meio, entre os colonos e as águas do reservatório, que é a parte mais baixa da bacia. Como veremos, a conjuntura geográfica de ocupação do território pelas populações que ali residem, somada a APP de Itaipu, além dos problemas internos relativos à insuficiência de terras que acontecem na própria Terra Indígena, o entorno traz na forma de impactos ambientais, consequências extremamente prejudiciais à vida econômica, sanitária e de saúde da população Guarani (Figuras 14, 15 e 16).

Pelo seu interior as águas do lago, pela parte externa os colonos lindeiros, estão geopoliticamente, portanto, cercados em um pequeno território.

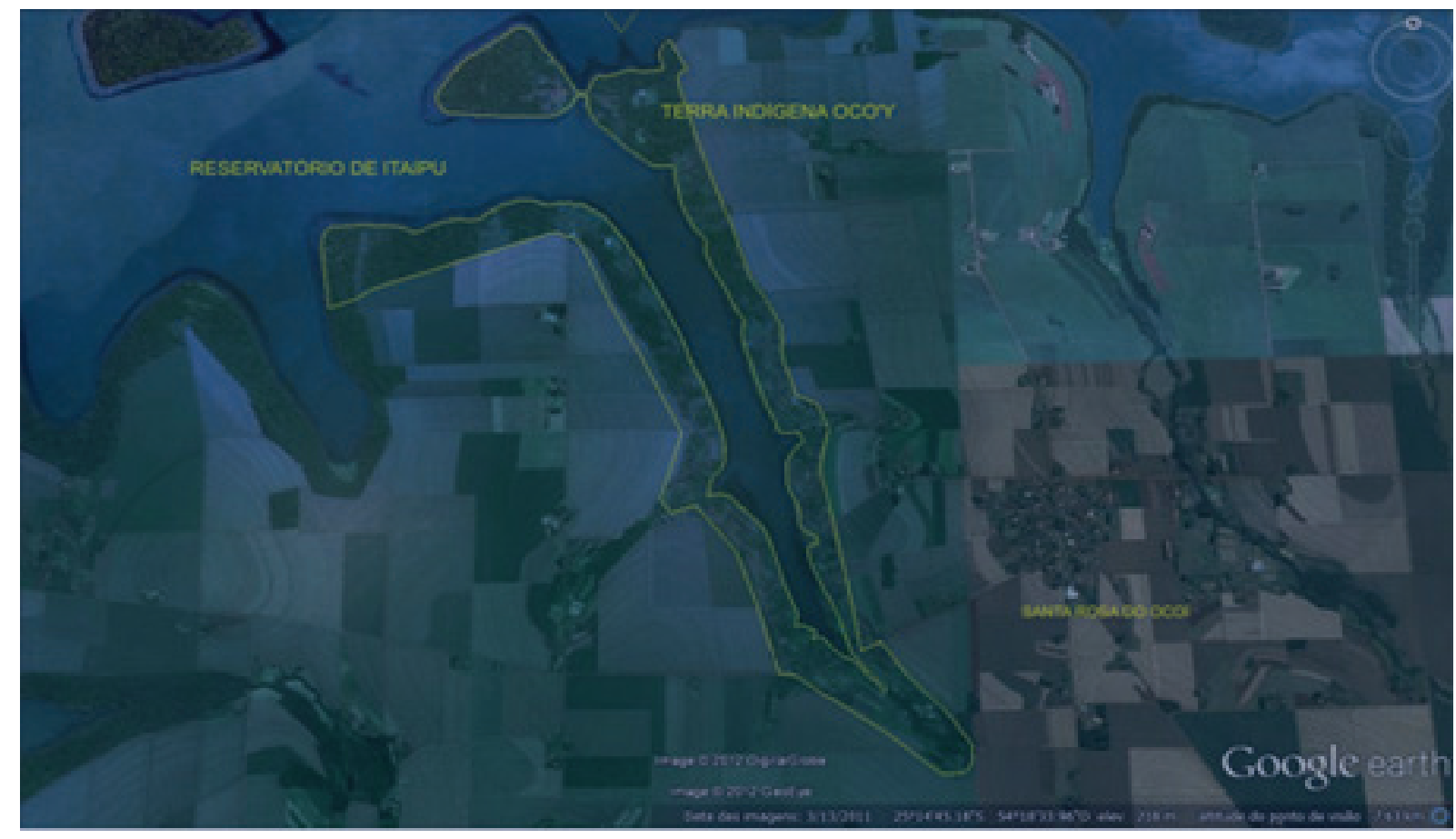

Figura 14. Foto aérea da situação do entorno da TI do Oco’y considerando as Glebas de Colonos/ São Miguel do Iguaçu/ Paraná.

Fonte: Digital Globe. Google. 2005. 


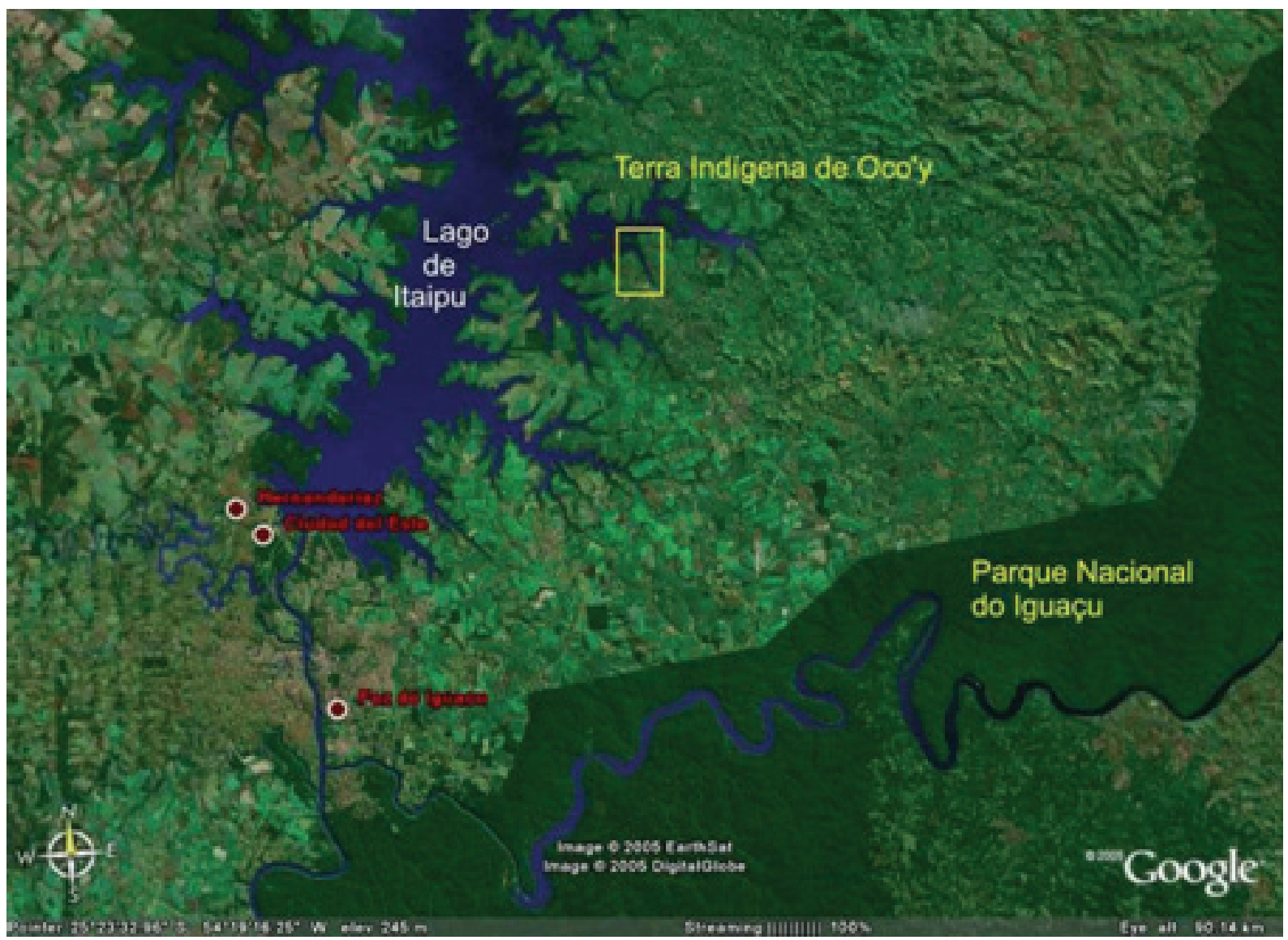

Figura 15. Foto aérea da parte sul do reservatório da UHE Itaipu, TI Avá-Guarani do Oco’y e parte do Parque Nacional do Iguaçu/ Paraná.

Fonte: Digital Globe. Google. 2005.

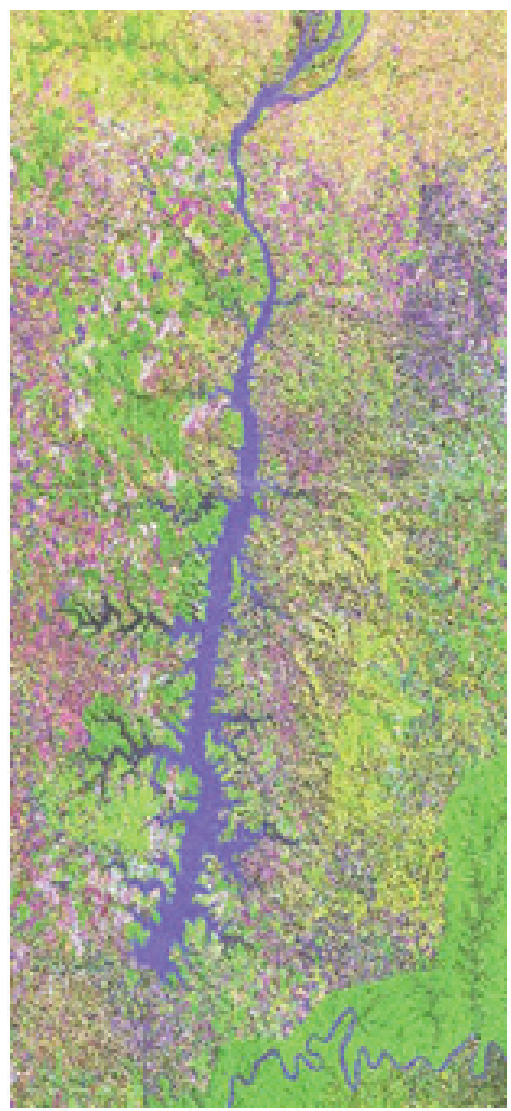

Figura 16. Foto aérea da totalidade do reservatório da UHE Itaipu e parte do Parque Nacional do Iguaçu/ Paraná.

Fonte: Usina Hidrelétrica de Itaipu. FAIXA DE PROTEÇÃO. Decreto Lei $\mathrm{n}^{\mathrm{o}}$ 83.225 de 01.03.79. 
Apresentam-se literalmente confinados em duas estreitíssimas faixas de terras que somavam ao todo, ao ser demarcado pela FUNAI, 231,8870 ha. Somados 177,56 ha “cedidos" pelo INCRA mais os 73,59 ha adquiridos por Itaipu, resulta em 251,15 ha, extensão oficialmente destinada à Comunidade Indígena Avá-Guarani.

Esta última quantidade de terras (251,15 ha) aparece em inúmeros relatórios da FUNAI sobre o agrupamento indígena, porém, na realidade, segundo medição da própria FUNAI e sua posterior demarcação em 31.07.1982, passou a apresentar 231,8870 hectares (Figura 17), o que significa uma redução significativa de 19,27 hectares, considerando-se o tamanho diminuto da área. Em anexo o Memorial Descritivo (Anexo 10).

A razão da supressão de terras é que quando a Hidrelétrica fechou as comportas e inundou o território formando o reservatório em outubro de 1982, o Córrego Santa Clara foi coberto, inundando além dele as terras que o margeavam. Os 19,27 hectares de terras perdidos estavam incluídos como parte da área destinada aos índios, pelo acordo de transferência entre FUNAI e Itaipu Binacional. Portanto, como relatado pelos próprios Guarani, após terem sido reassentados no Oco’y assistiram a inundação de seu novo “território", perdendo mais uma vez terras.

No mesmo momento foi inundado também o Oco’y-Jacutinga, território tradicionalmente ocupado pelos Guarani, o qual foram obrigados a se retirar pouco tempo antes em benefício da Hidrelétrica. Segundo depoimentos indígenas, o Oco’y-Jacutinga apresentava muito maior extensão e melhor diversidade ambiental que o Oco'y. 


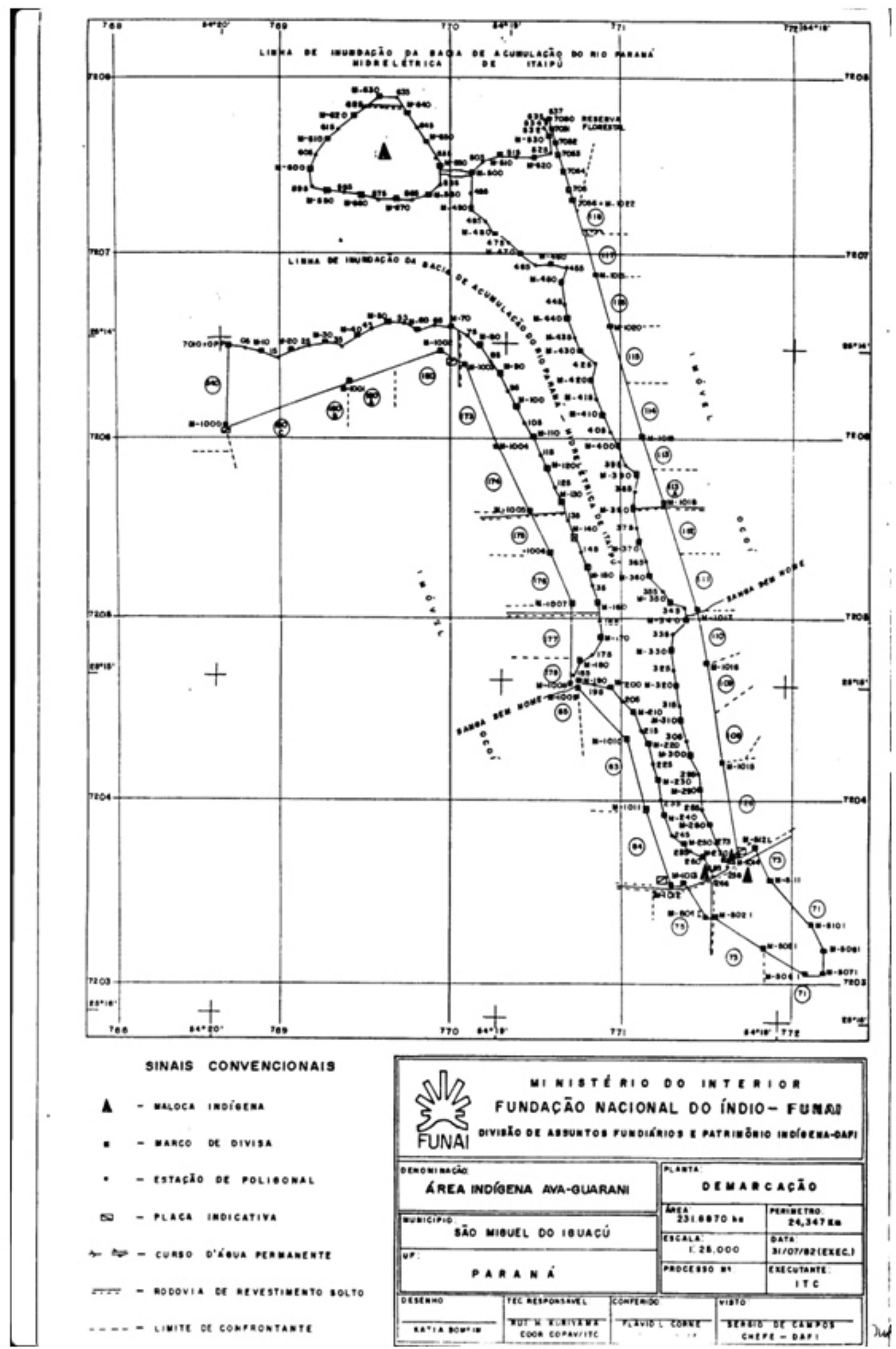

CD - Figura 17. Planta demarcação. TI Avá-Guarani do Oco’y/São Miguel do Iguaçu/Pr. Fonte: DAFI/FUNAI/MI. 31.07.1982. 
O Memorial Descritivo da Terra Indígena Avá-Guarani do Oco’y se encontra no Anexo 10.

Atualmente se forem medidas as terras de posse indígena, se verificará que de um lado, externamente, ela é constantemente invadida pelos colonos, os quais derrubam a área de remanescentes florestais destinada aos indígenas, plantando no seu lugar, cultivos monocultores, soja, trigo, aveia... nos quais utilizam todo o tipo de agrotóxicos, adquiridos legalmente no Brasil e ilegalmente no Paraguai; e, por outro lado, pelas bordas internas, pelo reservatório e APP de Itaipu, às margens da represa estão sendo assoreadas pelo uso que os indígenas fazem, que sem outra alternativa territorial, utilizam o local para residir e plantar. Nos dois casos, sendo pressionados os limites de ambos os lados da TI demarcada ${ }^{13}$, resulta na progressiva diminuição da área reservada aos indígenas, os quais, ainda, como agravante, possuem população grande e em constante crescimento vegetativo.

Portanto, a população indígena encontra-se "engessada" em uma área de terras muito pequena, estando cercada e invadida em todo o perímetro da área. Apresenta-se na prática sem limites definidos e diante dos usos indevidos por terceiros, a área real de uso indígena, atualmente é menor do que foi demarcada.

Antes de iniciar a exposição sobre as condições existentes no Oco’y para os Guarani realizarem suas atividades de subsistência, é necessário que se compreenda algumas questões relativas ainda ao dimensionamento da área, tema que será exposto a seguir.

\subsubsection{Cálculo aproximativo da área da Terra Indígena Avá-Guarani do Oco’y disponível às famílias indígenas}

Para entendermos a dimensão do grave problema fundiário vivenciado por esta Comunidade Indígena, basta fazermos o cálculo da metragem da área com relação aos espaços ocupados na prática pelas famílias indígenas.

As áreas utilizadas pelos indígenas no Oco’y podem ser classificadas em três grupos: - o primeiro o espaço correspondente em "tese" a área de coleta; - o segundo compreende os espaços utilizados para outras finalidades, como estradas, Posto de Saúde/FUNASA, Posto Indígena/FUNAI,

\footnotetext{
13 TI demarcada, que já se apresentava como área diminuta para a real população existente no inicio do reassentamento em 1982; foi reconhecida pela FUNAI e, portanto, a princípio, deveria ser de uso exclusivo dos indígenas.
} 
poços artesianos, local para reuniões, campinho, escola, Casas de Rezas etc; e, - o terceiro ocupado em função das habitações, roças e criação de animais, irremediavelmente todos juntos.

A área de terras a princípio demarcada para os Ava-Guarani do Oco’y corresponde a 231,88 hectares, nas quais pela legislação seu uso é livre e exclusivo, mantidas as condições tradicionais de uso, ou seja, as formas tradicionais de ocupação, extrativismo e agricultura itinerante.

Apesar de ter sido demarcada oficialmente a área nestas dimensões, incongruente com os ditames legais (tema que veremos em detalhe no capítulo 5), em parte da mesma área foi estabelecida ao mesmo tempo a APP de Itaipu; como vimos os primeiros 100 (cem) metros às margens da represa, nas duas faixas de terras, APP e TI encontram-se superpostas. Na APP é permitida a utilização pela população indígena pelas autoridades locais (Itaipu Binacional e FUNAI), porém, com restrições.

Os Guarani foram alertados por estas autoridades, para que não utilizassem o espaço da APP para outra finalidade que não a coleta de produtos florestais, em razão de haver proibição legal pelos órgãos ambientais de desmatamento de APP. Como os indígenas consideram mesmo que margem de "rio" (o lago, a represa) não deve ser retirada vegetação para o estabelecimento de cultivos, enquanto puderam, seguiram a determinação, reservando-a preferencialmente para essa finalidade, coleta. Contexto que presenciamos até 2003. Desta forma, embora o Código Florestal ${ }^{14}$, determinasse que nas APPs em margem de rio, lago ou represa sejam proibitivos qualquer tipo de uso, assim como por outro lado em Terra Indígena não pode haver restrições de uso tradicional da terra de qualquer natureza, sendo seu uso ainda exclusivo, inclusive o acesso ás águas existentes, todavia, pela determinação das autoridades locais não se poderia ali construir casas, estabelecer roças, Casas de Rezas, ou qualquer outro equipamento, fato que passou a ocorrer a partir de 2003.

Se considerarmos a medição transversal da área (visualizar o "V"), ou seja, os espaços que vão das margens da represa, atravessando a Terra Indígena (incluindo nela a Área de Preservação Permanente de Itaipu), até o limite das glebas dos colonos, passando por cada uma das 95 (noventa e cinco) residências indígenas (2001), de ambos os lados da TI, em média estes espaços possuem como vimos, 238,22 metros de largura, medidos em nossa primeira visita a campo (outubro/2001), em conjunto com os Guarani, por meio da feitura de um croqui, em que utilizávamos duas trenas, compridas cordas que eram posteriormente comparadas as trenas, barco e vários homens, para puxar as cordas das margens do lago, passando ao lado das residências indígenas, até a beira das terras dos colonos, endireitá-las retas, medir, comparar à trena e anotar, feito isso em cada uma das 95 residências indígenas. (Figura 18).

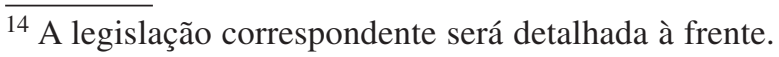




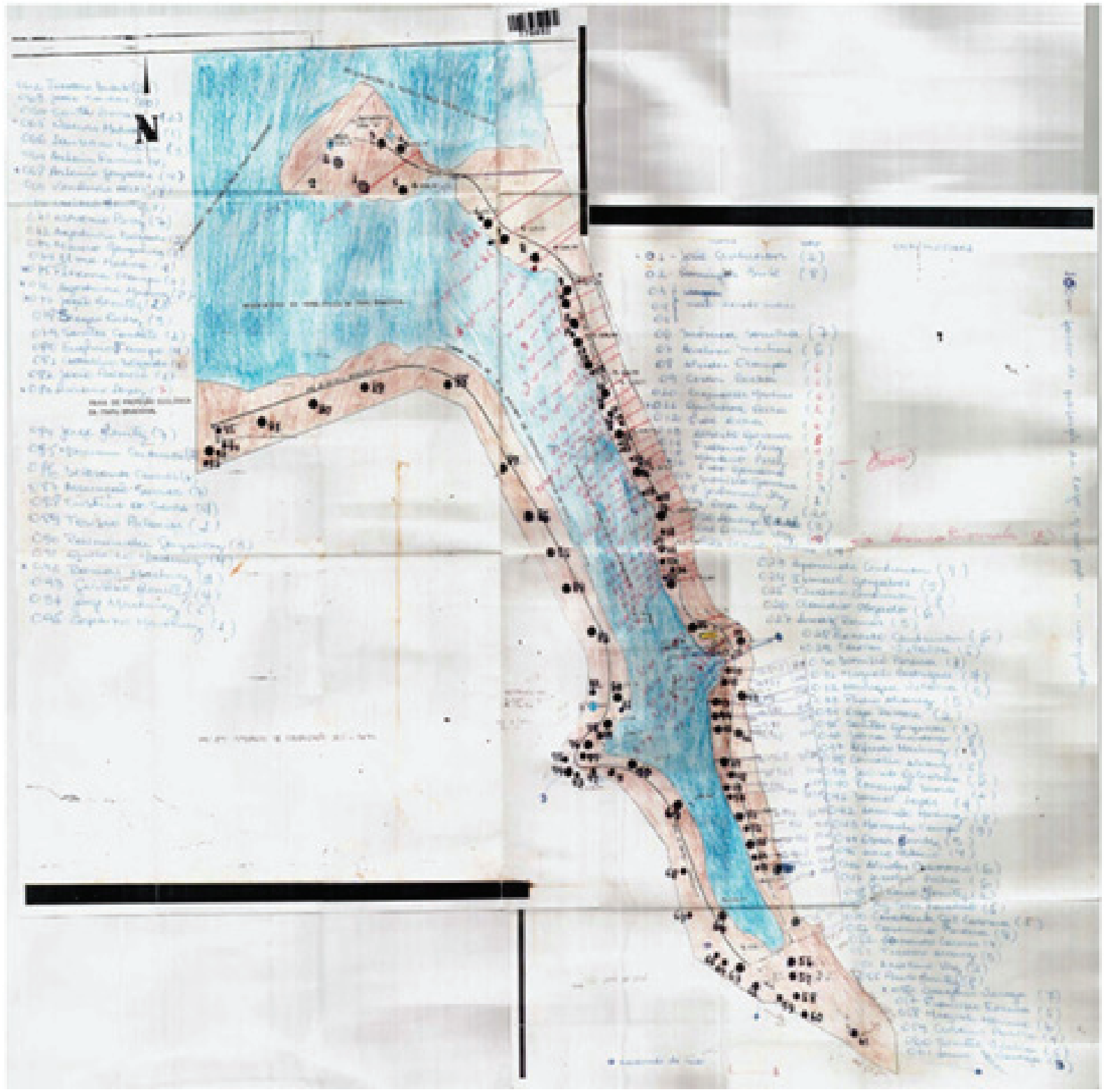

CD-Figura 18. Croqui. Cálculo da medição transversal, contada da beira do lago ao colono lindeiro, passando por cada residência indígena, referente à área territorial disponível aos Guarani, de ambos os lados da TI. Inseridas todas as habitações existentes em número de 95 (outubro/2001).

Autores: Os Avá-Guarani do Oco’y e Maria Lucia Brant de Carvalho. Outubro/2001. 
Tabela 3.1. As medidas contadas da beira do lago ao colono lindeiro, passando por cada residência indígena, de ambos os lados da TI. Inseridas todas as habitações existentes em número de 95 (outubro/2001)

\begin{tabular}{|c|c|c|c|c|c|c|c|}
\hline $\operatorname{casa}^{0}$ & Metros & $\operatorname{casa} n^{\circ}$ & metros & $\operatorname{casa} n^{0}$ & metros & $\operatorname{casa}^{0}$ & metros \\
\hline 1 & 314 & 25 & 210 & 49 & 179 & 73 & 176,2 \\
\hline 2 & 442 & 26 & 217 & 50 & 175 & 74 & 286,2 \\
\hline 3 & 387 & 27 & 210 & 51 & 175 & 75 & 289 \\
\hline 4 & 307 & 28 & 222 & 52 & 370,2 & 76 & 161,2 \\
\hline 5 & 307 & 29 & 250 & 53 & 370,2 & 77 & 197 \\
\hline 6 & 244 & 30 & 240 & 54 & 370,2 & 78 & 177,8 \\
\hline 7 & 248 & 31 & 240 & 55 & 370,2 & 79 & 177,8 \\
\hline 8 & 250 & 32 & 270 & 56 & 370,2 & 80 & 206 \\
\hline 9 & 220 & 33 & 280 & 57 & 370,2 & 81 & 206 \\
\hline 10 & 236 & 34 & 286 & 58 & 283 & 82 & 206 \\
\hline 11 & 239 & 35 & 203,6 & 59 & 300 & 83 & 206 \\
\hline 12 & 207 & 36 & 213 & 60 & 300 & 84 & 208 \\
\hline 13 & 207 & 37 & 203 & 61 & 300 & 85 & 178 \\
\hline 14 & 231 & 38 & 206 & 62 & 175 & 86 & 240 \\
\hline 15 & 291 & 39 & 180 & 63 & 175 & 87 & 240 \\
\hline 16 & 231 & 40 & 183 & 64 & 175 & 88 & 253 \\
\hline 17 & 246 & 41 & 185 & 65 & 190 & 89 & 253 \\
\hline 18 & 248 & 42 & 270 & 66 & 178 & 90 & 253 \\
\hline 19 & 300,2 & 43 & 270 & 67 & 178 & 91 & 253 \\
\hline 20 & 250 & 44 & 275 & 68 & 178 & 92 & 253 \\
\hline 21 & 244,5 & 45 & 171 & 69 & 178 & 93 & 253 \\
\hline 22 & 235 & 46 & 198 & 70 & 178 & 94 & 253 \\
\hline 23 & 245 & 47 & 198 & 71 & 356,2 & 95 & 253 \\
\hline 24 & 240 & 48 & 198 & 72 & 176,2 & & \\
\hline
\end{tabular}

Media total: 238,22 metros -100 metros $($ APP $)=138,22$ metros

Fonte: Os Avá-Guarani e Maria Lucia Brant de Carvalho. Outubro/2001.

Descontados 100 metros de cada lado da TI de APP, sobram 138,22 metros em média de largura, de terras passíveis de utilização pelas famílias indígenas, de forma "livre" de qualquer ingerência. Subtraindo-se 100 metros de cada lado do lago, ou seja, 200 metros multiplicado por 
7 km de comprimento, resulta em uma restrição de uso de 1.400 .000 metros quadrados aproximadamente ou 140 hectares, em favor da APP de Itaipu (Figuras 19 e 20).

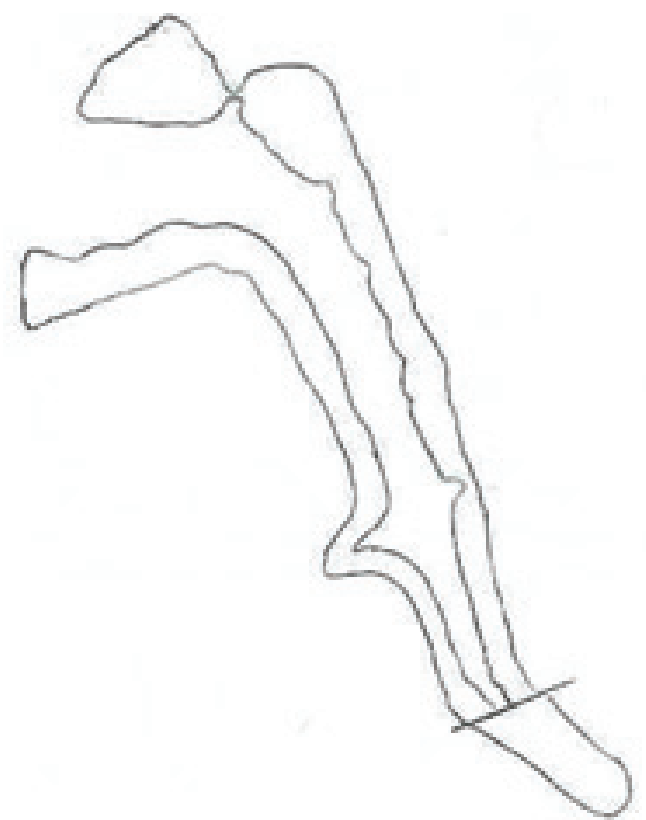

Figura 19. Croqui. Área da Terra Indígena AváGuarani do Oco’y demarcada.

Organização: Maria Lucia Brant de Carvalho, 2007.

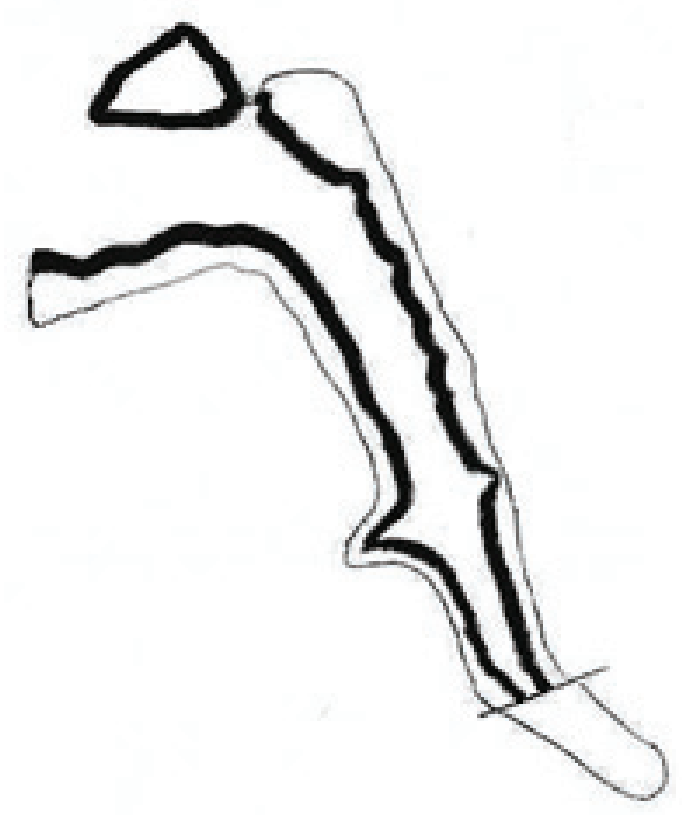

Figura 20. Croqui. Área da APP de Itaipu sobreposta à Terra Indígena Avá-Guarani do Oco'y demarcada.

Organização: Maria Lucia Brant de Carvalho, 2007

No limite entre áreas dos indígenas e dos colonos, os Guarani mantinham nas bordas externas de sua área, um pequeno remanescente florestal, que servia como "barreira natural” à aspersão de agrotóxicos praticada pelos colonos, muito próximos que estão da Terra Indígena. Era como um "muro de vegetação" para a proteção natural, estabelecido ao longo de todo comprimento da área.

Os colonos ao longo dos anos vêm invadindo por estas bordas externas, toda a área paralela à Terra Indígena, em cerca de 3 a 4 metros por $7 \mathrm{~km}$ de comprimento (situação em 2006), chegando na atualidade com seus cultivos até às margens da estrada. Assim, esse muro natural de proteção criado pelos Guarani não existe mais. As monoculturas dos colonos que se alternam entre soja, milho, trigo e aveia, encontram-se frente a frente com as residências indígenas. Juntas, praticamente no mesmo espaço, o manejo praticado pelos colonos interfere no manejo da terra praticado pelos índios, como também na sua saúde, como veremos à frente.

Conforme já descrito esta estrada passava somente por dentro das terras indígenas. No atual momento ela passou a ser o limite entre áreas. Observa-se que até a estrada vêm diminuindo de largura; os índios afirmam que os colonos passam a patrola na terra, jogando mais terra na borda 
da estrada, diminuindo assim a largura até mesmo dela, ampliando cada dia mais e o que conseguem, seus limites. Considerando mais esse fato, acabou por reduzir a área útil indígena de 138,22 metros para 134,72 metros de largura em média, em cada uma das faixas de terras. Subtraindo-se os 3,5 metros de cada lado das faixas, multiplicado por $7 \mathrm{Km}$ de comprimento, ou seja, 7 metros multiplicado por $7 \mathrm{~km}$, resulta em uma perda de 49.000 metros quadrados ou $\underline{4,9}$ hectares de terras aproximadamente, invadidos e tomados pelos colonos (Figura 21).

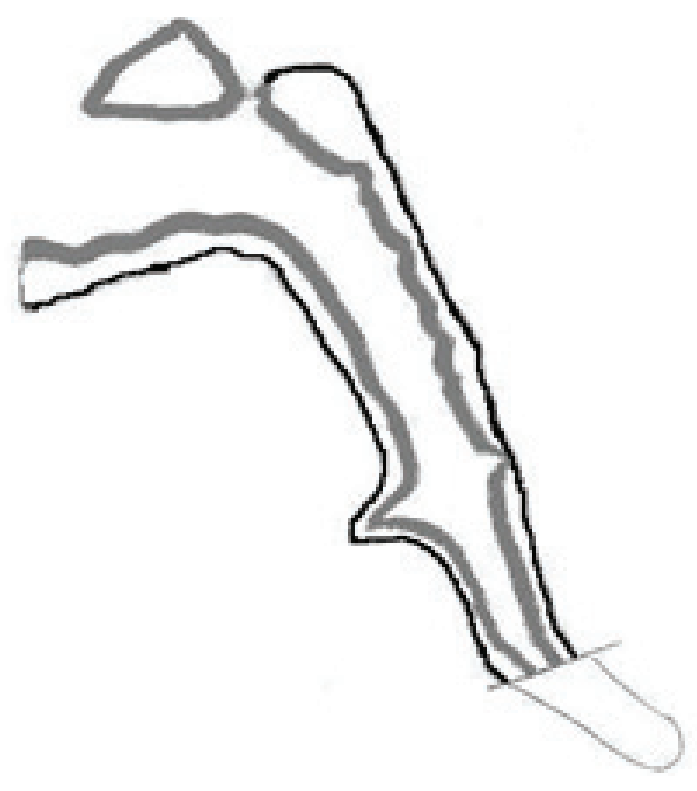

Figura 21. Croqui. Área da APP de Itaipu e terra invadida pelos colonos sobrepostas à Terra Indígena do Oco’y demarcada.

Organização: Maria Lucia Brant de Carvalho, 2007.

Somadas, a APP (1.400.000 metros quadrados) e a invasão dos colonos (49.000 metros quadrados) resulta em 1.449.000 metros quadrados ou 144,9 hectares de terras que foram reservadas oficial e teoricamente aos índios através de demarcação pela FUNAI, mas que na prática encontram-se respectivamente, com restrição de uso e indisponibilizadas aos mesmos. Se subtraírmos dos 231,88 ha esses 144,9 ha terras, restam na realidade aos índios, para todos os usos, livres de qualquer ingerência, apenas 86,88 ha.

Se calcularmos aproximadamente as áreas que compreendem o espaço utilizado para outras finalidades ${ }^{15}$, equipamentos como estradas, Posto de Saúde/FUNASA, Posto Indígena/FUNAI, poços artesianos, local para reuniões, campinho, escola, Casas de Rezas etc, resultará em um total de aproximadamente 9,3 ha. Dos 86,88 ha se descontarmos os 9,3 ha referentes aos equipamentos, resta disponível 77,58 ha, ao uso "livre" dos Guarani. A situação fundiária da Terra Indígena Avá-Guarani do Oco’y resume-se a seguinte tabela a seguir:

\footnotetext{
15 A) Estradas: 5 metros de cada lado das faixas $\mathrm{x} 7 \mathrm{~km}=10$ metros $\mathrm{x} 7000$ metros $=70.000$ metros quadrados $=7$ ha. B) Escola em torno de 0,3 ha; C) Campinho em torno de 1 ha; D) Outros 1 ha. Total: 9,3 ha.
} 
Tabela 3.2. Terra Indígena Avá-Guarani do Oco’y. Comparativo entre a área repassada como compensação pela UHE Itaipu, demarcada pela FUNAI, as frações em sobreposição e a verdadeira área disponível aos Guarani

\begin{tabular}{|l|c|}
\hline Área de compensação doada aos indígenas & 251,15 ha \\
\hline Área subtraída pela inundação do Córrego Santa Clara pela UHE Itaipu & $-19,27$ ha \\
\hline Área demarcada pela FUNAI & 231,88 ha \\
\hline APP de Itaipu ocupa Terra Indígena demarcada & $-140,00$ ha \\
\hline Invasão de colonos ocupa Terra Indígena demarcada & $-4,90$ ha \\
\hline Área disponível aos Guarani & 86,88 ha \\
\hline Equipamentos & $-9,30$ ha \\
\hline Área disponível na prática aos Guarani & 77,58 ha \\
\hline
\end{tabular}

Elaboração: Maria Lucia Brant de Carvalho. 2007

Em nossa primeira visita a campo ao Oco’y (out/2001), verificamos a existência ao longo da estrada que corta a área em seu comprimento, todas as casas “coladas” às suas respectivas roças e criação de animais, praticamente enfileiradas, seguidas umas as outras, em alguns casos, com alguns remanescentes florestais na intersecção entre elas. Essa área corresponde aos 77,58 ha de uso "livre" destinado aos Guarani.

Com o passar dos anos, as famílias cresceram, esses remanescentes florestais entre "quintais" de cada família/casa, existentes na área de 77,58 ha, foram sendo suprimidos e instalados no seu lugar, mais roçados.

Porém, dada a insuficiência de terras, essa supressão de remanescentes florestais não acontece mais somente nestes locais. Nos últimos anos, principalmente a partir de 2004, quando a Itaipu Binacional, a FUNAI e a Prefeitura de São Miguel do Iguaçu, diante dos reclamos indígenas por mais terras, em que alegavam sua falta inclusive para a finalidade de instalação de mais roças, neste contexto, estas instituições promoveram inadvertidamente o desmatamento de boa parte da APP de Itaipu, quando então os Guarani passaram também a utilizá-la com esse objetivo, instalação de mais roças.

A partir deste fato, a existência de roças na área de APP, verificou-se que segundo a visão de outra autoridade local, o Instituto Ambiental do Paraná/IAP, os índios estariam "invadindo" a área de APP, quando na verdade ela é parte da Terra Indígena que foi demarcada, destinada aos indígenas pela própria Itaipu e FUNAI. A partir desse momento os índios passaram a ser proibidos de plantar em sua própria Terra Indígena. Esse fato será objeto de discussão no capítulo 4. 
Para que possamos vislumbrar a quantidade de terras verdadeiramente disponível às famílias indígenas do Oco’y, realizamos algumas projeções no sentido de poder demonstrar mais claramente os problemas fundiários ali vividos. Porém, esses cálculos não podem ser considerados exatos, na medida em que, por exemplo: - dado que os espaços reservados às áreas de coleta são subdivididos para uso comum, cada parcela variável de terras é utilizada em função de alguns grupos variáveis de famílias; - a organização da produção, por exemplo, de roças, está dividida por um lado, entre "famílias extensas" ${ }^{16}$, que organizam a produção de forma que algumas famílias próximas plantam juntas a mesma roça, outras não o fazem em conjunto; como ainda ocorre que "famílias nucleares", organizam a produção, individualmente, de sua própria roça. Assim, os cálculos a seguir são apenas aproximativos, objetivando verificar como esse processo se dá ao longo do tempo, em termos de dimensão territorial disponível às atividades econômicas das famílias indígenas versus seu crescimento demográfico.

A população indígena existente no Oco’y somava na época do início desta pesquisa 80 famílias extensas residentes em 95 casas $^{17}$ e 449 habitantes (12/outubro/2001), com o passar dos anos a população cresceu demograficamente, apresentando 113 famílias/casas e 482 indivíduos em 2002, dois anos depois 125 famílias/casas e 600 indivíduos (2004), sendo que neste último ano 25 famílias (64 indivíduos) se retiraram em busca de outro local para viver, e, posteriormente algumas delas retornaram, sendo por fim o último dado pesquisado, essa comunidade apresentava 135 famílias/casas e 618 indivíduos (março/2007).

Se calcularmos 77,58 ha divididos por 80 famílias/casas, grosso modo resultou em 0,96975 ha disponíveis para cada família extensa em 2001, data em que utilizavam essas terras consideradas "livres" para todas as atividades, que incluíam habitações, roças e criação de animais (todas irremediavelmente juntas de forma indevida), assim como incluía neste período, ainda parte da própria área de coleta entre casas, área essa que aqui não se confunde com a área de coleta sobreposta à APP.

Em 2004, os mesmos 77,58 ha divididos agora por 125 famílias/casas, resultou em 0,62064 ha disponíveis para cada família extensa. As áreas de coleta, remanescentes florestais existentes

\footnotetext{
$\overline{16}$ A Família Nuclear é composta por pai, mãe e filhos; A Família Extensa é composta por avós, filhos e filhas, genros e noras, netos, bisnetos, que em geral vivem na mesma casa e/ou mesmo terreno, em algumas casas próximas umas a outras, organizando em conjunto, suas atividades de subsistência.

${ }^{17}$ Neste primeiro ano fizemos o calculo do numero de famílias extensas ( 80 famílias extensas residentes em 95 casas); os cálculos seguintes, referentes aos outros anos, foram feitos com a informação somente de numero de casas.
} 
entre os "quintais" familiares nesta área (e não na APP), já haviam sido suprimidos para instalação de mais roças, e, no entanto, cada família passou a obter menos terras disponíveis, pois a população naturalmente ao longo do tempo cresceu demograficamente. Ao mesmo tempo os plantios, passaram a se dar também na APP.

Em 2007, os mesmos 77,58 ha divididos agora por 135 famílias/casas, resultou em 0,57466 ha disponíveis para cada família. Os plantios embora proibidos pelo IAP na APP, gerando conflitos, impedindo a satisfação das necessidades mínimas de subsistência indígena por longo período, passaram mais tarde, a se estender mais ainda pela outra área, a de APP.

Resguardadas as margens de erro possível desses cálculos, pois são aproximativos, essa análise baseia-se no fato de que se pode observar na prática, que os indígenas do Oco’y passaram a ocupar também para a finalidade de instalação de roças, a área destinada pelas autoridades estatais Itaipu, INCRA e FUNAI, à APP. Apesar de toda área ser demarcada para os indígenas, no momento em que os cultivos indígenas passaram a adentrar a APP, extrapolaram nas duas últimas projeções (2004-2007), os 77,58 ha, que, em realidade, haviam sido disponibilizados a eles, fato que passou a gerar o conflito com outra autoridade ambiental estatal, o IAP.

Quanto a área destinada a finalidade de coleta, área esta sobreposta a APP, são utilizados pelos Guarani todos os espaços disponíveis na Terra Indígena que foi demarcada, sendo eles ainda insuficientes.

Se fizermos a projeção de 140 ha, a área considerada pelas autoridades estatais como APP de Itaipu e reservada de forma questionável pelas mesmas autoridades, "a somente a finalidade de coleta ao agrupamento indígena" (sem contar as áreas de roças que vem sendo estabelecidas na mesma área de APP), para efeito de cálculo, divididos os 140 ha por 80 famílias/casas (2001), resultará em 1,75 ha de área de coleta para cada família; na projeção de 2004, 125 famílias/casas resultará em 1,12 ha para cada família; e na projeção de 2007, 135 famílias/casas, resultará em 1,03 ha para cada família. 
Tabela 3.3. Distribuição das partes do território através do tempo destinado a cada Unidade Familiar Extensa/UFE da Terra Indígena Avá-Guarani do Oco’y

\begin{tabular}{|c|c|c|c|c|c|c|c|}
\hline \multirow{2}{*}{$\begin{array}{l}\text { Espaço } \\
\mathbf{x} \\
\text { Período }\end{array}$} & \multicolumn{2}{|c|}{ População } & \multirow{2}{*}{$\begin{array}{c}\text { Área com } \\
\text { restrição } \\
\text { de uso a APP: } \\
\text { Uso } \\
\text { Coleta/UFE }\end{array}$} & \multirow{2}{*}{$\begin{array}{l}\text { Terras livres/UFE } \\
\text { (A) Habitações } \\
\text { (B) Roças } \\
\text { (C) Coleta parcial }\end{array}$} & \multirow{2}{*}{$\begin{array}{l}\text { Equipa- } \\
\text { mentos }\end{array}$} & \multirow{2}{*}{$\begin{array}{c}\text { Área } \\
\text { invadida } \\
\text { por colonos }\end{array}$} & \multirow{2}{*}{$\begin{array}{c}\text { Terra } \\
\text { indígena } \\
\text { demarcada }\end{array}$} \\
\hline & $\begin{array}{c}\text { Famílias/ } \\
\text { casas }\end{array}$ & $\begin{array}{l}\text { Indiví- } \\
\text { duos }\end{array}$ & & & & & \\
\hline 2001 & 80 & 449 & 1,75 ha & $\begin{array}{c}0,96975 \text { ha } \\
(\mathrm{A}-\mathrm{B}-\mathrm{C})\end{array}$ & 9,3 ha & $\begin{array}{c}\text { Menor } \\
\text { que } 4,9 \text { ha }\end{array}$ & 231,88 ha \\
\hline 2004 & 125 & 600 & 1,12 ha & $\begin{array}{c}0,62064 \text { ha } \\
\text { (A-B) }\end{array}$ & 9,3 ha & $\begin{array}{c}\text { Menor } \\
\text { que } 4,9 \text { ha }\end{array}$ & 231,88 ha \\
\hline 2007 & 135 & 618 & 1,03 ha & $\begin{array}{l}0,57466 \text { ha } \\
\text { (A-B) }\end{array}$ & 9,3 ha & 4,9 ha & 231,88 ha \\
\hline $\begin{array}{l}\text { Áreas } \\
\text { totais }\end{array}$ & & & 140 ha & 77,58 ha & 9,3 ha & 4,9 ha & 231,88 ha \\
\hline
\end{tabular}

Elaboração: Maria Lucia Brant de Carvalho, 2007.

Através da projeção da Tabela 3.3, nota-se que conforme a população indígena cresce demograficamente, na medida em que o espaço total é fixo e mínimo, diminuem todos os espaços possíveis à satisfação das necessidades de subsistência de cada uma das famílias extensas indígenas. Esse espaço não oferece nenhuma margem de alargamento para o "desafogamento", pelo contrario, só vem diminuindo com o tempo, com as invasões, com os usos compartilhados inadequados, com a falta de compreensão que a população indígena cresce demograficamente, com a falta de consideração de que deveriam ter recebido terras semelhantes em dimensão e qualidade ambiental a que possuíam anteriormente, e ainda, destinadas a todo o agrupamento existente no Oco’y-Jacutinga e não somente a 4 (quatro) famílias.

Em 2001 os Guarani utilizavam a área que também é considerada APP, somente como espaço de coleta; de 2003-4 em diante, de forma crescente, a área referida, passou a ser também utilizada como espaço para o estabelecimento de roças. Na medida em que há crescimento demográfico e o espaço apresenta-se pequeno e fixo, crescem o número de espaços de roças e diminuem os espaços de coleta.

O que resta como "área de coleta" e roças ali iniciadas, encontram-se na área demarcada para os indígenas, porém, ela vem sendo considerada prioritariamente como APP de Itaipu pelo poder público estadual IAP, considerando a existência já de assoreamento das margens do lago, gerando dessa forma conflitos com os índios, na medida em que passaram a ser proibidos de plantar no local. 
Pode-se observar agora, que as áreas de uso indígena apresentam mais um complicador, nota-se que as taxas são invertidas, se as roças crescem em termos de dimensões, decrescem as áreas de coleta, ou seja, elas também competem entre si por espaço, sendo tanto um como outro espaço, imprescindíveis aos indígenas; acrescente-se ainda, que são cada um desses usos nos referidos espaços, insuficientes para a demanda de subsistência apresentada pelos indígenas. Assim, as próprias áreas, reservadas teoricamente aos indígenas, de coleta e roça, competem por espaço entre si.

Configura-se, portanto, a totalidade do espaço, excessivamente pequeno para as necessidades de subsistência da população indígena, sendo que nesse espaço fixado, a área útil para cada família extensa, descresse na mesma proporção em que se verifica o crescimento demográfico desta população indígena.

Tabela 3.4. Terra Indígena Avá-Guarani do Oco’y. Disponibilidade de terra para cada família extensa

\begin{tabular}{|l|c|c|c|}
\hline Ano/finalidade & $\begin{array}{c}\text { Terras livres: } \\
\text { (A) Habitações } \\
\text { (B) Roças } \\
\text { (C) Coleta parcial }\end{array}$ & $\begin{array}{c}\text { Área c/ restrição de } \\
\text { uso (APP) Coleta }\end{array}$ & Total \\
\hline 2001 & 0,96975 ha (A-B-C) & 1,75 ha & 2,71975 ha \\
\hline 2004 & 0,62064 ha(A-B) & 1,12 ha & 1,74064 ha \\
\hline 2007 & 0,57466 ha(A-B) & 1,03 ha & 1,60466 ha \\
\hline
\end{tabular}

Elaboração: Maria Lucia Brant de Carvalho, 2007.

Disponibilizar seja 2,71975ha, 1,74064 ha ou 1,60466 ha para cada família extensa indígena, nestes cálculos, considerada toda área como Terra Indígena (TI + APP), mesmo assim, mostra-se insuficiente para as necessidades de subsistência dessa população, sendo essas quantidades de terras inconcebíveis, em se tratando para a finalidade de reprodução física e cultural "indígena".

A título de exemplo, no estado do Paraná, junto à sociedade envolvente, segundo o IAP (Site: 2007) o módulo rural destinado a cada família não indígena em 1991 perfazia 20 hectares, sendo considerado esse número razoável, a depender logicamente da qualidade da terra.

Esta área destinada aos não indígenas está vinculada a uma lógica de uso diversa da lógica indígena. Ela é circunscrita a finalidade de assentamento rural, em área desmatada, com o objetivo de estabelecer área agricultável, o que difere diametralmente do conceito de "Terra Indígena". 
Em geral o agricultor não indígena utiliza a terra para o estabelecimento de uma ou mais monoculturas, onde extrai dela tudo o que é possível oferecer, em menor periodo de tempo e na maior quantidade, possíveis, é a lógica capitalista de produção; produz na maioria das vezes não para si próprio, mas para troca do produto no mercado. Neste sistema, vendido um ou dois produtos produzidos em grandes quantidades, se compra em seguida o restante das mercadorias necessárias a sobrevivência dessa família não indígena, ou seja, o agricultor está inserido na economia de mercado.

A família indígena produz em termos agrícolas e coleta em termos florestais, grande diversidade de produtos que estão espalhados pelo seu território; ao longo do tempo utilizam estes recursos, restritos à satisfação das várias necessidades do dia a dia, ou seja, o consumo é voltado apenas às necessidades de subsistência, portanto, são retirados recursos da terra em quantidades pequenas para o abastecimento diário de cada uma das famílias. Não há a intenção, nem a tecnologia para satisfazer as necessidades através do acúmulo de bens. $\mathrm{O}$ espaço indígena ainda apresenta outra característica que extrapola a questão puramente material, ele também é considerado um espaço ao mesmo tempo de reprodução cultural e histórica das famílias que ali vivem. A vida se realiza no interior do próprio espaço indígena, seja ele uma aldeia ou várias aldeias da mesma etnia que se relacionam.

Assim são relações diferentes com o espaço. As qualidades em termos ambientais desses territórios também diferem, um necessita de terras desmatadas, interessando a ele produzir um ou dois produtos em grandes quantidades; outro necessita de terras em sua maioria florestadas, interessando a ele a diversidade, extraída em pouca quantidade.

Tanto uma como outra família apresentam várias necessidades a serem satisfeitas. Enquanto o primeiro necessita da terra para uso agrícola do tipo monocultor, ele conclui a satisfação de suas necessidades no momento da troca desse produto produzido pela troca dos produtos comprados necessários a família, em espaço fora do seu, no próprio mercado. O segundo necessita da diversidade de recursos existentes no interior de seu próprio território, para satisfazer grande parte de suas necessidades de subsistência física e cultural.

Desse modo as várias necessidades dessas populações são satisfeitas de formas diferentes, uma se dá na relação com o mercado, outra se dá na relação com o próprio território. As tecnologias utilizadas também são diferentes, no primeiro caso intensiva, no segundo extensiva. O que se pode concluir é que uma família de agricultor necessita geralmente de menos terras para satisfazer todo o conjunto de suas necessidades de sobrevivência do que uma família indígena. 
Para isso há modalidades legais diferentes, previstas para cada grupo social, no caso o Estatuto da Terra para os agricultores e o Estatuto do Índio para os povos indígenas.

No caso em que analisamos cada família indígena possui cerca de 12,5 vezes menos terra, que uma família de um agricultor.

Esta situação vivenciada pelos indígenas é inconstitucional, na medida em que a disponibilidade de terras para os indígenas é muito pequena, tornando-se insustentável, sendo contraditório com os direitos historicamente consagrados pela legislação indigenista brasileira, fundamentalmente com o Capítulo VIII - Dos Índios, o Artigo 231 da Constituição Federal, o qual afirma:

Art. 231. São reconhecidos aos índios sua organização social, costumes, línguas, crenças e tradições, e os direitos originários sobre as terras que tradicionalmente ocupam, competindo à União demarcá-las, proteger e fazer respeitar todos os seus bens.

Paragráfo $1^{\circ}$ : São terras tradicionalmente ocupadas pelos índios as por eles habitadas em caráter permanente, as utilizadas para suas atividades produtivas, as imprescindíveis à preservação dos recursos ambientais necessários ao seu bem-estar e as necessárias a sua reprodução física e cultural, segundo seus usos, costumes e tradições.

Paragráfo $2^{\circ}$ : As terras tradicionalmente ocupadas pelos índios destinam-se à sua posse permanente, cabendo-lhes o usufruto exclusivo das riquezas do solo, dos rios e dos lagos nelas existentes.

Parágrafo $4^{\circ}$ : As terras de que trata este artigo são inalienáveis e indisponíveis, e os direitos sobre elas, imprescritíveis.

Parágrafo $6^{\circ}$ : São nulos e extintos, não produzindo efeitos jurídicos, os atos que tenham por objeto a ocupação, o domínio e a posse das terras a que se refere este artigo, ou a exploração das riquezas naturais do solo, dos rios e dos lagos nelas existentes, ressalvado relevante interesse público da União, segundo o que dispuser lei complementar, não gerando a nulidade e a extinção direito à indenização ou a ações contra a União, salvo, na forma da lei, quanto às benfeitorias derivadas da ocupação de boa-fé (Constituição Brasileira: 1988).

Dessa forma as autoridades estatais (Itaipu Binacional, INCRA e FUNAI) responsáveis pelo inadequado estabelecimento da população indígena no Oco'y, não contavam talvez com o trinômio população versus tempo versus espaço. Como veremos, o crescimento demográfico (vegetativo e migração) no Oco'y é semelhante a qualquer aldeia da etnia, ele deveria ser previsto por estas autoridades ao destinar a terra para os índios ${ }^{18}$.

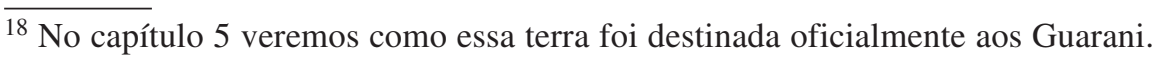


Pode-se concluir que conforme a população cresce demograficamente no decorrer do tempo, encurtam-se a cada dia mais os limitados espaços destinados a qualquer dos usos, gerando toda a sorte de conflitos: os reclamos dos indígenas diante da insustentabilidade do local; o aparente conflito entre as instituições; o conflito de limites entre indígenas, colonos e APP. O fato remete ao problema população versus território.

Ao invés de se focar a questão no irrisório espaço fundiário destinado aos índios Avá-Guarani, questão que será tema do capítulo 5, ao contrário, a questão populacional passou a se tornar o "problema", a ser equacionado pelas mesmas instituições que destinaram essa área de terras aos indígenas. Dessa forma, os Avá-Guarani passaram a ser culpabilizados pelo seu natural crescimento demográfico. Como veremos as instituições referidas, veem ao longo do tempo, imprimindo através da mídia local e nacional, a ideia que a causa de todos os problemas no Oco’y é “a suposta imigração Guarani proveniente do Paraguai para o Brasil”.

\subsection{Características ambientais da Terra Indígena Avá-Guarani do Oco’y e seu entorno}

A sobrevivência das populações indígenas depende fundamentalmente de ambientes florestados, onde buscam a diversidade dos recursos necessários à sua subsistência, caracterizada pelo extrativismo e pela agricultura consorciada e itinerante.

No que se refere às características ambientais das terras do Oco’y, se deve estar atento à compreensão das inter-relações que os agrupamentos indígenas, como os Avá-Guarani, desenvolvem com os recursos naturais de sua região, sua distribuição espaço-temporal, e ainda, como fatores de ordem externa podem alterar as tradicionais formas de ocupação.

\subsubsection{A finalidade da APP do "lago"19": refúgio biológico de espécies da biodiversidade necessárias à subsistência dos Avá-Guarani ou mata ciliar de proteção das margens do reservatório da Usina Hidrelétrica de Itaipu?}

Os primeiros 100 metros de terras transversais a partir das margens do reservatório da Itaipu, em toda a extensão interna lindeira à TI do Oco’y, em termos ambientais, a princípio,

\footnotetext{
19 "Lago" é o significado semântico dado pelos Guarani ao reservatório de Itaipu, demonstrando assim que para eles, o que mais se aproxima de suas necessidades é o "lago", na verdade, o rio.
} 
técnico e legal, não poderiam ser utilizados pela Comunidade Indígena como o é, hoje em praticamente todas as parcelas da terra.

Estes primeiros 100 metros destinam-se a duas finalidades que se complementam: - proteger através do enraizamento das árvores existentes, a manutenção da "faixa de segurança", com relação à cota mínima e máxima de volume d'água do reservatório da Hidrelétrica de Itaipu (volume mínimo 220 metros e máximo 225 metros a nível do mar), garantindo dessa forma a estabilidade do nível das águas, o qual é controlado pelas comportas da Binacional; - em seguida à faixa de segurança, em terra firme, proteger a "área marginal” florestada, a APP, que aqui denominar-se-à de "mata ciliar", a qual visa proteger o reservatório da Hidrelétrica contra possível assoreamento, ou seja, em caso de haver desmatamento, aconteceria desbarrancamento de terra, essa terra cobriria o fundo da represa tornando-a portanto, mais rasa, e, por fim, a água não tendo para onde correr invadiria a terra firme, no caso, em direção aos próprios Guarani (Figura 22).

Portanto, a existência do reservatório de água se deve à finalidade de produzir energia elétrica. Assim ele é utilizado conforme as atividades próprias da hidrelétrica, quando ela necessita disponibilizar das águas, dando vazão ou não a este recurso, quando dele necessita. Assim da mesma forma a APP ali criada visa proteger o reservatório, atendendo às necessidades ambientais para a finalidade de aproveitamento hidrelétrico de tal reservatório da Usina Hidrelétrica de Itaipu.

Desta forma, estas terras deveriam ter sido mantidas desde o início conforme havia sido planejado oficialmente pela própria Itaipu Binacional e pelo INCRA, através do denominado "Projeto Integrado de Colonização - PIC OCOI-II / INCRA"20 (1971), como "área reservada ao alagamento da represa da Usina Hidrelétrica de Itaipu”, com esta única e exclusiva finalidade, área alagada somada a "mata ciliar", que visa proteger a faixa de segurança contra o assoreamento, através do remanescente florestal.

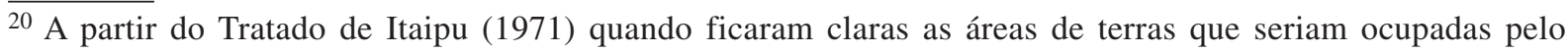
reservatório da hidrelétrica, foi necessário um estudo de remanejamento fundiário. Dessa forma o INCRA em 1971 subdividiu as áreas de terras que seriam afetadas na região do rio Ocoí, através de dois projetos, os denominados Projetos Integrados de Colonização do rio Ocoí: São eles - PIC OCOI-II corresponde à área reservada pelo INCRA para alagamento e área marginal de APP da Itaipu, que faz um contraponto ao PIC OCOI-I que corresponde à área reservada pelo INCRA para reassentamento dos colonos que foram obrigados a sair de suas terras em função da criação do reservatório da Itaipu em suas terras.
} 


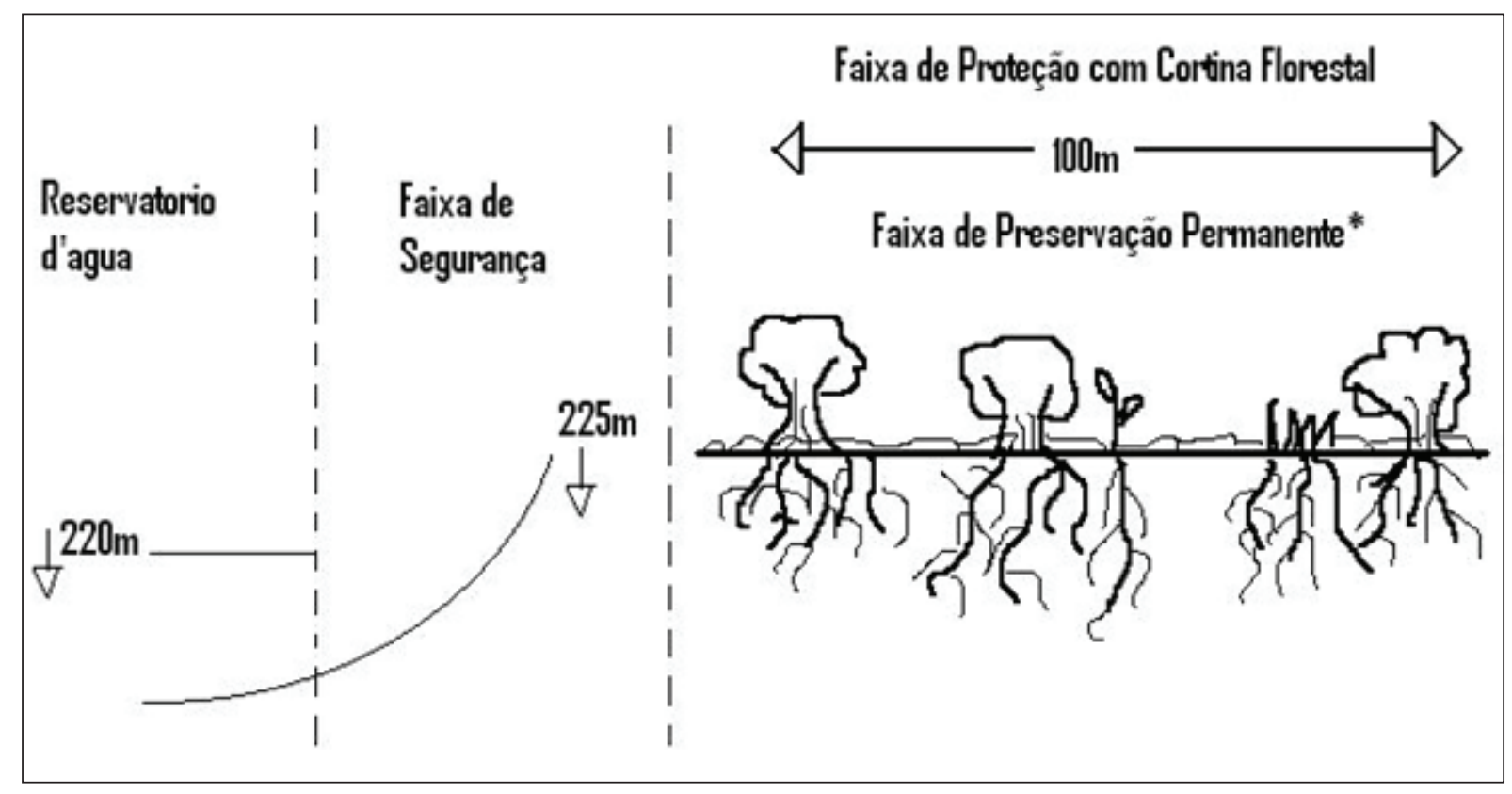

Figura 22. Croqui. Reservatório de águas, Faixa de Segurança e área marginal de Área de Preservação Permanente da Usina Hidrelétrica de Itaipu em frente a Terra Indígena Avá-Guarani do Oco’y.

* Faixa de Preservação Permanente. Em todo o reservatório 210 metros. No reservatório em frente à Terra Indígena Avá-Guarani do Oco’y é de 100 metros.

Organização: Maria Lucia Brant de Carvalho. 2004.

Por estas razões ambientais, a área em questão é considerada oficialmente como “Área de Preservação Permanente" de responsabilidade conjunta do Instituto Ambiental do Paraná/IAP e do Instituto Brasileiro do Meio Ambiente e dos Recursos Naturais Renováveis/IBAMA, dada a interestadualidade e internacionalidade da obra.

No que se refere à questão ambiental, esta área de APP é imprópria para ocupação humana por qualquer população. Tanto é que à volta toda do grande reservatório de $1350 \mathrm{~km} 2^{21}$ da UHE Itaipu com 170 km de perímetro, não é permitido viver nenhuma população, no entanto, curiosamente, isso não se aplica aos Guarani do Oco’y.

Em toda a margem de APP da Itaipu Binacional, com área total de 60.701 ha, em uma extensão total de $2919 \mathrm{~km}$, ela possui oficialmente a largura de 210 metros $^{22}$ no Brasil e 205

\footnotetext{
${ }^{21} \mathrm{O}$ reservatório da Itaipu possui área total de $1350 \mathrm{~km} 2$, sendo $780 \mathrm{~km} 2$ do lado brasileiro e $570 \mathrm{~km} 2$ do lado paraguaio.

${ }^{22}$ Como veremos no Capitulo VI, se considerada a largura entre as margens do reservatório da Itaipu em toda a extensão do mesmo inclusive em frente ao Oco'y, pela legislação ambiental (Código Florestal (15.09.1965) Lei $\mathrm{n}^{\circ} 4771$, Artigo $2^{\circ}$ ) a APP deveria ser bem maior que os próprios 210 metros fixados pela hidrelétrica, no caso do reservatório em frente esta Terra Indígena, um pequeno afluente, de outro afluente do rio Paraná, a APP neste lugar deveria atingir inclusive as glebas dos colonos. O que demonstra que a inexistência de licenciamento ambiental até hoje pelo IBAMA, da monumental obra de engenharia da hidrelétrica de Itaipu, continua produzindo efeitos, os quais não vêm sendo cumpridos e observados durante os últimos 41 anos pelas próprias instituições responsáveis, respectivamente Itaipu e IBAMA.
} 
metros no Paraguay, como atesta os dados da Itaipu Binacional demonstrados na Tabela 3.5, porém, somente em frente à Terra Indígena do Oco’y, ela possui 100 metros.

\section{Tabela 3.5. Largura média da Faixa de Proteção da Usina Hidrelétrica de Itaipu na margem esquerda do Rio Paraná}

\section{Áreas Protegidas}

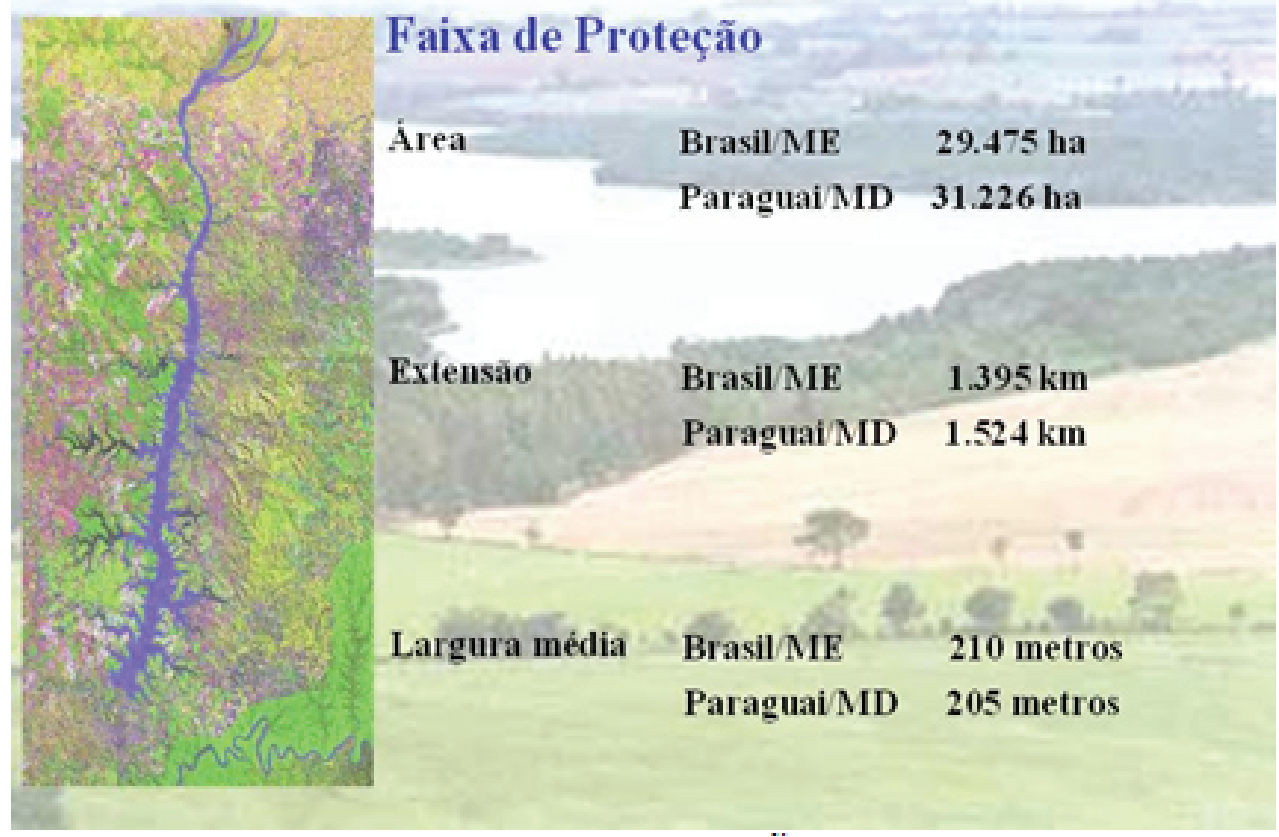

Fonte: Usina Hidrelétrica de Itaipu. FAIXA DE PROTEÇÃO. Decreto Lei nº 83.225 de 01.03.79.

Somados os 100 metros oficiais de largura da APP da UHE Itaipu somente na região da TI Oco’y aos 138 metros de largura em média da própria TI Avá-Guarani do Oco’y, resulta em um total de 238 metros, que é aproximadamente a extensão da largura que apresenta somente a APP de Itaipu, em todo o grande território que foi inundado.

Observando-se a Foto Área do Oco’y (Figura 13) e o Mapa da demarcação da Terra Indígena Avá-Guarani do Oco’y (Figura 17), no início deste capítulo, pode-se notar que a Terra Indígena foi superposta totalmente a APP, seja ela de 100 ou 210 metros.

Assim, tudo leva a crer que os Guarani, na verdade, não foram recompensados pela inundação de suas terras originais do Oco'y-Jacutinga, alagadas pela Hidrelétrica, substituindo-as por novas terras, mas apenas foram reinstalados indevidamente na própria APP de Itaipu. Apenas foi utilizado um artifício, desdobrando-a em duas áreas, aparentemente independentes, mas, que na realidade, configura-se uma só, a própria APP de Itaipu. 
Quando os Guarani foram reassentados no Oco’y em 1982 passaram a usar a APP como espaço reservado à coleta de produtos florestais. Por falta de terras estão também nos últimos anos (2004-5-6-7...2012) se utilizando de parte da área de APP de 100 metros para seus plantios, o que faz com que suprimam alguns espaços vegetados dela. Assoreando como já acontece em algumas partes, gera-se eventuais riscos e prejuízos aos plantios indígenas, gera-se problemas técnicos junto à hidrelétrica, gera-se problemas legais junto aos órgãos ambientais (IAP), na medida em que esses órgãos tentam impedir que os Guarani plantem no local, apesar de ser a área demarcada como Terra Indígena. Disso resulta ao final, que ocorre a redução maior ainda da margem de manobra em termos de manejo ambiental do espaço dos próprios Guarani, como ainda, gera intranquilidade na Comunidade Indígena, já que seus direitos sobre suas terras, há tempos, não tem sido levado em conta.

Tanto APP quanto TI, são Áreas de Preservação Permanente. Em termos técnicos elas poderiam relativamente conviver como no caso de algumas Unidades de Conservação sobrepostas às Terras Indígenas, porém, poderia ocorrer, somente quando nos casos onde convergem para os mesmos interesses, a saber: - preservação ambiental: visando a conservação da biodiversidade das espécies animais e vegetais para o meio ambiente e para subsistência dos povos indígenas; e, quando há espaço suficiente e qualidade ambiental para os povos indígenas sobreviverem conforme seus usos e costumes tradicionais, e, ainda, desde que não interfira no "modus vivendi” indígena.

Deve-se ter claro que esta APP não é um local de dimensões tanto qualitativas, quanto quantitativas, que se possa considerar um "refúgio biológico" de espécies animais e vegetais, não, ela não apresenta esta característica, apesar de ser uma APP; ela é considerada APP - dada a pequenez de seu território - por ser uma pequena mata, que visa somente proteger as margens da represa da Usina Hidrelétrica de Itaipu contra o assoreamento.

Portanto, no caso aqui relatado, os interesses são divergentes, pois a APP cumpre a limitada função de "proteção do reservatório contra assoreamento", e, não exatamente de "preservação ambiental de recursos", os quais ela quase não possui (por ex: fauna terrestre nenhuma). A APP serve assim tão somente à Usina Hidrelétrica de Itaipu e não à Comunidade Indígena, pois não possui, como veremos, nem em quantidade nem em qualidade, a diversidade de recursos ambientais necessários à subsistência indígena.

Assim, superpostas TI e APP, em um espaço tão diminuto fundiária e ambientalmente para a população indígena viver, considerando que nesta pequena mata há, ainda, restrições de uso, possuem, portanto, a mesma área, finalidades distintas, finalidades divergentes e não convergentes, como a princípio poderia parecer. 
Na verdade, a superposição desta APP sobre a TI, passa a ser um impedimento a mais à plena utilização da área pela população indígena, limitando e interferindo negativamente no espaço indígena ${ }^{23}$, o que traz prejuízos à sobrevivência desta população no local.

Portanto, a área por princípio técnico não poderia ser ocupada pelos Avá-Guarani, muito menos sobrepostamente demarcada para os mesmos, pois ela é uma APP, uma área de preservação permanente, que visa apenas assegurar às margens firmes do reservatório evitando o assoreamento, nada mais, além disso.

As duas pretensões (TI e APP), no caso específico como estão configuradas, em terras de pequenas dimensões para as duas finalidades, acabam por ser concorrentes e não complementares neste espaço geográfico, demonstrando, portanto, sua inviabilidade como Terra Indígena.

O fato por princípio legal gera conflito de interesses, na medida em que, se as APPs não podem ser utilizadas de forma alguma, por outro lado as Terras Indígenas são de uso exclusivo dos mesmos. A questão é prevista pela legislação ambiental e indigenista da seguinte forma.

Segundo a legislação ambiental este território é a princípio duplamente de responsabilidade federal do IBAMA, caracterizando-se concomitantemente como Área de Preservação Perma-

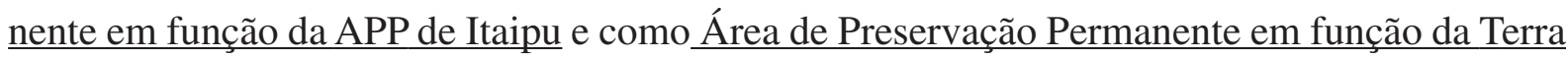
Indígena/TI, todas as duas situações descritas conforme o Código Florestal Lei nº 4771 de 15.09.1965, na época da analise ainda em vigor.

No que se refere à primeira, APP de Itaipu, o Código Florestal, Artigo $2^{\circ}$ letra "a" item " 3 " e letra "b", determinava:

Artigo $2^{\circ}$. Consideram-se de preservação permanente, pelo só efeito dessa Lei, as florestas e demais formas de vegetação natural situadas:

a) ao longo dos rios ou de qualquer outro curso d'água desde o seu nível mais alto em faixa marginal cuja a largura mínima seja: (...) 3) de 100 (cem) metros para o curso d'água que tenham 50 (cinquenta) metros a 200 (duzentos) metros de largura; ${ }^{24}$

b) ao redor das lagoas, lagos ou reservatórios d'água, naturais ou artificiais.

\footnotetext{
${ }^{23}$ Por exemplo na medida em que a UH de Itaipu dá vazão as águas, os peixes existentes no reservatório boiam mortos, o que mais uma vez prejudica a satisfação das necessidades de subsistência indígena.

${ }^{24} \mathrm{O}$ curso d'água do reservatório em frente ao Oco'y em várias partes possui mais que 200 metros de largura, assim como a maioria do reservatório todo de Itaipu. No entanto foi fixado 100 metros de APP em frente ao Oco'y e 210 metros em todo o restante do reservatório. Como veremos até essa margem de APP de 210 metros, deveria ser maior do que realmente ela é. Fato que demostra que Itaipu sequer se submeteu até hoje ao licenciamento ambiental obrigatório pelo IBAMA. Complementarmente ver nota $\mathrm{n}^{\circ} 13$.
} 
Ainda seu Artigo $3^{\circ}$, Parágrafo $1^{\circ}$, Artigo $4^{\circ}$, Parágrafo $1^{\circ}, 6^{\circ}$ e $7^{\circ}$, determinam:

Artigo $3^{\circ}$ : Consideram-se, ainda, de preservação permanente, quando assim declaradas por ato do poder Público, as florestas e demais formas de vegetação natural destinadas;

Parágrafo $1^{\circ}$ : A supressão total ou parcial de florestas de preservação permanente só será admitida com prévia autorização do Poder Executivo Federal, quando for necessária a execução de obras, planos, atividades ou projetos de utilidade pública ou interesse social.

Artigo $4^{\circ}$. A supressão de vegetação em área de preservação permanente somente poderá ser autorizada em caso de utilidade pública ou de interesse social, devidamente caracterizados e motivados em procedimento administrativo próprio, quando inexistir alternativa técnica e locacional ao empreendimento proposto.

Parágrafo $1^{\circ}$. A supressão de que trata o caput deste artigo dependerá de autorização do órgão ambiental estadual competente, com anuência prévia, quando couber, do órgão federal ou municipal de meio ambiente, ressalvado o disposto no parágrafo $2^{\circ}$ deste artigo.

Parágrafo $6^{\circ}$. Na implantação de reservatório artificial é obrigatória a desapropriação ou aquisição, pelo empreendedor, das áreas de preservação permanente criadas no seu entorno, cujos parâmetros e regimes de uso serão definidos por resolução do CONAMA.

Parágrafo $7^{\circ}$. É permitido o acesso de pessoas e animais às áreas de preservação permanente, para obtenção de água, desde que não exija a supressão e não comprometa a regeneração e a manutenção a longo prazo da vegetação nativa.

Assim pelo exposto deve-se ponderar entre outras coisas, de que não era o caso "de inexistir alternativa técnica e locacional ao empreendimento proposto", conforme o Artigo $4^{\circ}$, no caso a instalação da Terra Indígena do Oco’y ali não era de necessidade fundamental, logicamente os Guarani poderiam ter sido reassentados em outros vários lugares, que não na APP de Itaipu, ressalte-se, por decisão dela própria. Assim como, ao contrário do que o parágrafo $6^{\circ}$ acima determina os colonos lindeiros ao Oco’y, reclamam que suas terras existentes às margens do Córrego Santa Clara não foram indenizadas pelo INCRA, quando da instalação no mesmo local da população indígena do Oco’y. Questão que será tratada no capitulo V.

No que se refere a TI o mesmo Código Florestal, Lei n 4771, em seu Artigo $3^{\circ}$, letra g, Parágrafo $2^{\circ}$, determinava:

Artigo $3^{\circ}$ : Consideram-se, ainda, de preservação permanente, quando assim declaradas por ato do poder Público, as florestas e demais formas de vegetação natural destinadas;

g) a manter o ambiente necessário à vida das populações silvícolas. 
Parágrafo $2^{\circ}$ : As florestas que integram o Patrimônio Indígena ficam sujeitas ao regime de Preservação Permanente (letra "g”) pelo só efeito dessa lei".

Artigo $3^{\circ}$ : A exploração dos recursos florestais em terras indígenas somente poderá ser realizada pelas comunidades indígenas em regime de manejo florestal sustentável, para atender a sua subsistência, respeitados os Artigos $2^{\circ}$ e $3^{\circ}$ deste Código.

Porém, e isso não foi observado, é que as populações indígenas têm por direito constituído, sobreviver em um território que seja fundiária e ambientalmente, suficientes à sua reprodução física e cultural, desta forma de acordo com seu modo específico de conceber esta sobrevivência, através de suas próprias práticas de subsistência, como preconiza a Constituição Federal, Artigo 231, parágrafos $1^{\circ}, 2^{\circ}, 4^{\circ}$ e $6^{\circ}$, anteriormente já descritos, sendo que conforme parágrafo $2^{\circ} \mathrm{em}$ especial, seu uso deve ser exclusivo. Da mesma forma o Estatuto do Índio/ Lei 6001 de 19.12.1973, legislação concernente à época em que se deu a instalação dos Guarani no Oco’y, na verdade, na área de APP de Itaipu, ele assim determinava: Artigo 18. As terras indígenas não poderão ser objeto de arrendamento ou de qualquer ato ou negócio jurídico que restrinja o pleno exercício da posse direta pela comunidade indígena ou pelos silvícolas.

Ainda, no Estatuto do Índio, através do Título IV. Dos Bens e Renda do Patrimônio Indígena em seu Artigo 39, parágrafo $2^{\circ}$, refere-se sobre a questão do usufruto dos bens em terras indígenas: Artigo 39. Constituem bens do Patrimônio Indígena: (...) II- o usufruto exclusivo das riquezas naturais e de todas as utilidades existentes nas terras ocupadas por grupos tribais ou comunidades indígenas e nas áreas a eles reservadas.

Ainda, no Capítulo II, Das Terras Ocupadas o Artigo 22, determina: Cabe aos índios ou silvícolas a posse permanente das terras que habitam e o direito ao usufruto exclusivo das riquezas naturais e de todas as utilidades naquelas terras existentes.

Ainda, no Artigo 24. Parágrafo $1^{\circ}$. Incluem-se no usufruto, que se estende aos acessórios e $\underline{\text { seus acrescidos, o uso dos mananciais e das águas dos trechos das vias fluviais compreendidos }}$ nas terras ocupadas.

Dessa forma, até as águas do reservatório seriam de uso exclusivo dos Avá-Guarani. Se a Terra Indígena é de uso exclusivo, os Avá-Guarani, se lhes aprouvessem não necessitariam cumprir esta recomendação de restringir suas atividades até o limite da APP, e, assim, poderiam avançar com suas roças sobre ela, questão essa que eles procuraram respeitar na medida do possível, como já nos referimos anteriormente. 
A legislação está em claro conflito. Esta área de APP cumpre a 30 anos duas funções superpostas, nas quais de fato e legalmente ambas estão incorretas, pois, na área marginal do reservatório ninguém poderia residir; e por ser justamente, apenas uma estreita área marginal, ela não é suficiente como área florestada para suprir as inúmeras necessidades de sobrevivência indígena impedindo os Guarani de possuírem acesso suficiente as matérias-primas necessárias à sua subsistência, além de ser ainda a Terra Indígena, de uso exclusivo dos mesmos.

Desta forma o órgão ambiental na medida em que proíbe o plantio indígena no local, está atendendo as necessidades da Usina Hidrelétrica de Itaipu, na forma de uma APP, e o mesmo órgão juntamente à FUNAI e à Itaipu, não estão atendendo às necessidades dos índios, de uso exclusivo, assim como de suficiência do espaço para se manter o bem-estar físico e cultural dos mesmos. Questão esta que será vista no capítulo 6.

Pela avaliação realizada em campo, mesmo que tornasse a área toda, as duas somadas juntas (APP e TI), de uso exclusivo dos índios, estas terras estariam ainda assim longe de ser suficientes para as necessidades de subsistência da Comunidade Indígena. Essas terras não possuem espaço fundiário para ser considerada legalmente uma Terra Indígena. Assim vejamos como se dá as formas de subsistência indígena no local.

\subsubsection{A economia indígena tradicional Guarani}

Oisapeva (o solo) é Ñanderu que ilumina nossa terra para nós andar...

Pajé Honório

Abril/2002

As populações indígenas na sua grande maioria tradicionalmente quase não participam das relações de mercado, ou melhor, se o fazem, ainda é de forma bastante incipiente, rarefeita, não regular. Acessar o mercado exige poupança, acúmulo de bens monetários, o que na grande maioria das vezes não é o costume dessas populações, há barreiras historicamente determináveis pelos âmbitos culturais, linguísticos e socioeconômicos, para que isso se dê satisfatoriamente.

Tradicionalmente a economia da população indígena é de subsistência; produzem para o aprovisionamento de todas as esferas de suas vidas, criando os bens necessários à própria sobrevivência: alimentos, habitações, utensílios, adornos, medicamentos, transporte, instrumentos de trabalho para caça e pesca, assim, uma infinidade de bens para satisfazer seu cotidiano. Desta 
forma caracteriza-se essencialmente por reproduzirem a própria subsistência, em espaços amplos, utilizando-se de recursos ambientais, que conservados, encontram-se acessíveis nestes territórios. Como já nos referimos, há pouca (limitada em geral ao artesanato no caso dos Guarani) ou nenhuma inserção nas relações de mercado.

Em outro trabalho, de dissertação de mestrado ${ }^{25}$, definimos a conformação geral dos ambientes que compõem as Terras Indígenas.

Uma Terra Indígena é composta de uma aldeia ou de um grupo de aldeias de uma mesma filiação étnica; possuem coletivamente determinado território, onde estão incluídos os espaços da própria aldeia com as habitações, os espaços de banho, de lazer, áreas de utilização comum dos indivíduos, como a Casa dos Homens, o Pátio ou a Casa de Reza. A área indígena não se reduz ao espaço da aldeia. Há também espaços de roças, na maioria das vezes pequenas, familiares, que se espalham pelo território conforme a adequação do local para o cultivo e as necessidades de cada grupo familiar. Existem ainda espaços míticos - os cemitérios, locais sagrados e mitológicos, ancestralmente construídos - que oferecem um significado particular à ocupação. Por fim, há os espaços de perambulação comuns, que o grupo indígena utiliza para pesca, caça e coleta de produtos alimentares, medicinais, de vestuário, para habitação, para o transporte, fonte de matéria-prima para a produção de inúmeros utensílios e adornos, todos adaptados às determinações e necessidades de cada cultura indígena específica.

Esta economia é baseada no extrativismo (caça, pesca e coleta) em áreas de circulação e na agricultura consorciada, que se dá de forma itinerante. Assim a forma de ocupação socioeconômica dos territórios indígenas se dá através da alternância de ambientes, isto porque o grupo indígena necessita mudar de espaços em intervalos relativamente regulares, a fim de evitar a escassez, deixando assim de degradar os ambientes, impedindo o esgotamento dos recursos ambientais disponíveis em cada região de determinado ambiente.

Vejamos as razões pelas quais os povos Guarani necessitam alternar de ambientes.

Quanto às atividades agrícolas que se dão nos espaços de roças, estas são abertas nas capoeiras já existentes, na forma de clareiras na mata, o que facilita o trabalho e não compromete as áreas de floresta clímax.

\footnotetext{
25 BRANT DE CARVALHO, Maria Lucia. Saúde de populações indígenas: Tendências após os impactos do contato. Dissertação de Mestrado em Ciências Sociais (Antropologia). São Paulo: Pontifícia Universidade Católica de São Paulo. /PUC-SP. 1997. p. 16.
} 
Segundo os Guarani do Oco’y relatam, tradicionalmente as práticas utilizadas por eles no Oco’y-Jacutinga, se resumiam a cada família extensa utilizar uma porção de terras de cerca de 8 a 10 hectares de extensão por certo período de tempo.

Nelas eram plantadas uma diversidade de produtos consorciados. Cada família extensa subdividia este espaço de uso em cinco blocos de aproximadamente 2 hectares cada um, para serem usados ao longo de alguns anos; cerca de 4 hectares eram reservados para o plantio de árvores altas, que necessitam de mais tempo para crescer; outros 6 hectares eram manejados em rodízio de cerca de 2 hectares cada um, onde cultivavam plantas úteis. A abertura do terreno de cada 2 hectares dava-se através do sistema de corte e queima e o plantio dava-se somente nos primeiros dois a três anos, posteriormente àquela família mudava suas roças de lugar, abrindo novas, em outros 2 hectares, deixando àquelas primeiras áreas em pousio e assim sucessivamente. O pousio é referente à terra e não a utilização dos plantios. Os diversificados recursos plantados nelas continuavam a ser consumidos. Assim ia-se trabalhando ao longo do tempo em rodízio, cerca de três roças.

Havia também outros locais (nichos) onde eram cultivados outros recursos, próximo as casas, em locais de passagem, no meio da mata, entre outros. Ao fim de quinze a vinte anos, deixava-se em pousio aquele espaço, trabalhando em outros 10 hectares. $\mathrm{O}$ espaço anterior continuava a ser utilizado, na medida em que possuíam uma diversidade de plantas úteis tanto ao consumo dos homens como à sobrevivência animal. Ali se tornava assim também um espaço interessante à caça, na medida em que os animais procuravam os alimentos. É o que Moran (1994) denomina de "caça programada", ou seja, na medida em que conheciam o florescimento de determinada espécie vegetal, assim como conheciam os hábitos alimentares dos animais, os indígenas os procuravam na época certa, a fim de abatê-los. Assim plantava-se não só para os homens, mas também para os animais. Ao fim de cada período de dois a três rodízios em 10 hectares, voltava-se novamente a trabalhar o primeiro local já ocupado.

Cabe esclarecer que este modelo Guarani, muito similar ao modelo original da maioria dos grupos indígenas do Brasil, foi desenvolvido na medida em que suas terras tornaram-se no sul do país mais reduzidas, diante das pressões territoriais pelos integrantes da sociedade nacional. No caso de outros grupos indígenas que possuem mais terras, o modelo é semelhante, escolhidos conforme as necessidades de cada grupo familiar porém, as roças são feitas em espaços mais diversificados e nos melhores solos possíveis de serem encontrados.

Lidando desta maneira com os recursos ambientais assegurar-se-á: - a fertilidade dos espa- 
ços na medida em que não se esgota a terra com sucessivos plantios no mesmo local ${ }^{26}$; - os diversificados recursos para subsistência humana e animal, plantados em vários pontos à disposição no território; por fim, a recomposição da floresta, tornada ainda mais rica em termos de diversidade de produtos, como de recomposição continua de serapilheira, apresentando dessa forma maior fertilidade.

Quanto à ordenação territorial indígena deve-se compreender que suas estratégias de ocupação, são realizadas através de uma visão de mundo na qual identificam, escolhem e significam vários recursos naturais, disponíveis na matriz ambiental da região, de acordo com a sazonalidade natural do ambiente.

Dessa forma, o mesmo acontece com o extrativismo no que se refere à alternância de ambientes: a sazonalidade dos diversos recursos ambientais de caça, pesca e coleta, exigem sua procura em épocas e locais distintos do território, ou seja, os recursos não estão todos à disposição no mesmo local e nem na mesma época; isso faz com que a população indígena assim como a população animal, na busca de recursos, sejam também "transportadores ou dispersores" de sementes e mudas de uma região para outra, mantendo assim a rica diversidade dos biomas florestados.

Tradicionalmente as populações indígenas quando percebem que os recursos de fauna de determinada região poderão entrar em escassez, antes que isso aconteça, a comunidade muda a aldeia de lugar, visando que o abastecimento do grupo não cesse, como também que fauna e flora livres, possam se recompor naturalmente, ainda deixando para trás plantios interessantes à população animal e humana. Passados cerca de 20 a 30 anos o grupo poderá novamente voltar a habitar aquele mesmo local, que estará assim recomposto em sua diversidade de recursos vegetais e animais.

São por estas razões, que as comunidades indígenas necessitam fundamentalmente de territórios amplos e ambientes florestados, para que alternando de ambientes, possa manter a sustentabilidade econômica do mesmo e consequentemente a sua própria.

Dessa forma tradicionalmente a sobrevivência do grupo indígena depende fundamentalmente dos recursos ambientais existentes em seu território, para satisfazer a maioria de suas necessidades de sobrevivência.

\footnotetext{
$\overline{26}$ Os povos indígenas contam na prática somente com os recursos ambientais bióticos e abióticos para realizar suas necessidades de subsistência; sua cultura com relação às atividades agrícolas, não está voltada para o consumo de bens de mercado, como adubos ou implementos agrícolas sofisticados, além do que não possuem renda para isto. Assim, não faz parte dos hábitos indígenas, este tipo de relação com o mercado, vivem uma realidade própria, diversa do homem ocidental comum, profundamente dependente do manejo do ambiente que os cercam.
} 
Uma das formas de preservar nossas florestas, ainda com intercâmbio efetivo de populações humanas com a biodiversidade existente, e assim, mantendo a sustentabilidade ambiental delas, é fiscalizar a preservação e a proteção das Terras Indígenas, terras estas é claro, suficientes ao modo de produção da economia indígena.

Com o contato com a sociedade nacional, as populações indígenas vão cada vez mais necessitando de bens que não podem produzir: instrumentos de trabalho, roupas, medicamentos para as doenças que não conhecem, alimentos, entre outros bens. Contribui para isso não só a curiosidade cultural pelo outro (da sociedade nacional), mas também a falta dos recursos tradicionais necessários, em razão de apresentarem territórios insuficientes e impactados ambientalmente, como é o caso que analisamos.

A partir da ocupação do território no entorno pela sociedade envolvente a questão fundiária/ ambiental toma proporções extremamente relevantes para as populações indígenas, na medida em que em territórios demarcados, portanto fixados para sempre, deve-se assegurar tanto territórios de dimensões suficientes, para que se deem estas alternâncias de ambientes, quanto ambientes preservados, para que este modelo econômico possa continuar sendo colocado em prática.

Vivendo sob a limitação de território demarcado, ou seja, limitado, em alguns casos extremos, onde não podem mais alternar de ambientes, o que seria a base de sua economia tradicional, e, com a depredação ambiental deste único território limitado que restou, tem-lhes sido retirada as condições de sobrevivência costumeiras e de direito. Nesta situação, a população indígena sofrerá um engessamento econômico progressivo e cada vez menos poderá satisfazer suas necessidades de sobrevivência, o que vem a repercutir na comunidade, passando a apresentar em geral um estado socioeconômico e de saúde precário.

A sobrevivência de populações indígenas em espaços próximos onde foram instaladas populações provenientes da sociedade nacional acarreta uma serie de impedimentos as primeiras, pois, as formas e escalas de extração de recursos - de subsistência e de mercado - contêm em si enorme diferenciação.

A primeira praticada pelas populações indígenas em áreas florestadas, via de regra não provoca danos ambientais, porque são retirados os vários recursos de forma diversificada e em pouca quantidade, limitados à subsistência. Já a segunda, onde já é imprescindível o desmatamento das áreas florestadas, dá-se em escala de mercado, extraindo em geral do solo apenas um único produto, este quase sempre exótico, como a soja, e, ainda, através de monoculturas, portanto, em grandes quantidades. Assim se desfigura a paisagem anterior, naturalmente diversificada, 
trazendo também o desequilíbrio ambiental, já que altera direta e indiretamente toda a vida ao seu redor: fauna, flora, fluxo das águas, desgaste do solo, poluição (em especial os agrotóxicos) e consequentemente as formas de vida das próprias populações indígenas.

Historicamente esta tem sido a principal razão pela qual os grupos indígenas têm apresentado cada vez maior estado de pobreza: invasão e tomada de seus maiores patrimônios, o territorial e o ambiental. Subtraindo-se o patrimônio físico, subtrai-se logicamente parte do patrimônio cultural.

Grupos indígenas que vivem esta situação extrema passam cada vez mais a depender dos órgãos de assistência social, fato que se apresenta contraproducente, pois gerações sucessivas vão perdendo o referencial de como construir o cotidiano, ao mesmo tempo em que inexistem muitas vezes, as condições satisfatórias para terem acesso aos mecanismos socioeconômicos da sociedade envolvente. Inúmeras dificuldades interétnicas se apresentam neste caso, por um lado há barreiras culturais, fundamentalmente o preconceito racial por parte da sociedade envolvente, por outro lado há barreiras socioculturais, linguísticas e econômicas, havendo pouca prontidão (desconhecimento cultural das normas e regras da sociedade majoritária) por parte da população indígena, para que participe plenamente em pé de igualdade junto à sociedade brasileira.

Por isso a importância de se levar em conta que o Brasil é um país pluricultural, em que segmentos como as populações indígenas, possuem suas especificidades socioculturais e econômicas que devem ser levadas democraticamente em consideração.

\subsubsection{A economia Avá-Guarani de extrativismo e agricultura itinerante frente ao contexto fundiário/ambiental da Terra Indígena do Oco’y}

Com referência à extensão territorial e a qualidade ambiental da Terra Indígena Avá-Guarani do Oco’y, a Comunidade Indígena vem sofrendo prejuízos materiais e imateriais devido a não contemplação de suas necessidades de subsistência, impedindo uma apropriação ideal territorial/ ambiental, conforme a tradição Guarani.

É importante destacar a relação dos Guarani com cada uma das terras que ocupam, denominada na língua de "Tekoha”, que significa, segundo os próprios Guarani: “o lugar onde podem se realizar as leis, os costumes, o modo de ser Guarani”. Segundo afirma um dos maiores especialistas vivos na cultura Guarani, Padre Bartolomeu Meliá, o Tekohá “significa e produz ao mesmo tempo relações econômicas, relações sociais e organização político-religiosa essenciais para a vida Guarani” (MELIÁ: 1987). 
Nesta área territorial o extrativismo (caça, pesca e coleta) e a agricultura itinerante não podem se realizar de forma satisfatória, estando a base econômica indígena seriamente comprometida. Concorrem para isso vários fatores, descritos a seguir.

Como já descrito a área territorial ocupada por esta Comunidade Indígena do Oco’y, compreende apenas 238 metros de largura por $7 \mathrm{~km}$ de comprimento, em cada uma das faixas de terras. Em outubro de 2001 ali viviam 449 indivíduos indígenas, em março de 2007 haviam 618 indivíduos. Neste espaço as habitações indígenas encontram-se lado a lado por toda extensão da área territorial, quando o usual é cada família extensa ter um nicho separado de outras famílias extensas. Verifica-se que os Guarani na prática, tem como possibilidade de utilização para todas as suas atividades, somente os espaços ao redor de suas habitações, sendo estes insuficientes com relação ao manejo econômico tradicional indígena, praticado insatisfatoriamente, por falta de espaço físico, dado que o que lhes foi repassado a título de compensação pelas terras anteriores, não corresponde a realidade fundiária que antes obtinham.

A funcionalidade necessária ao manejo econômico indígena do território, não pode se dar aqui pois o que deveria acontecer em espaços horizontalmente extensivos (caça, pesca, coleta e agricultura itinerante) e ainda de forma intermitente (uso e pousio de vários ambientes), sistemática indígena já descrita, que mantém a sustentabilidade ambiental do território, ao contrário no Oco’y, se dá de forma intensiva, atividades verticalizadas, ou seja, todas as atividades econômicas estão superpostas umas às outras e encontram-se impedidos de poder praticar a necessária intermitência.

\subsubsection{As atividades de extrativismo}

Vejamos como se dão as atividades de Extrativismo (caça, pesca e coleta). O pequeno remanescente florestal existente no Oco'y corresponde ao espaço em sobreposição, a APP da UHE Itaipu, que "em tese", se configuraria como eminentemente destinada à "coleta, caça e pesca". Este espaço deveria prover a maior parte das necessidades de matérias-primas para esses indígenas. 
Caça

O múndeu (armadilha de caça) faz de madeira, amarra com cipó, o laço é de casca de cipó de imbé, não faz mais, não tem o que caça... . O cipó imbé serve para laça e também para come. Para ter festa tem que ter caça, mel, como não tem, quase não tem mais festa... .

Pajé Honório

Outubro/2001

Neste território estudado não há disponibilidade no que se refere à possibilidade de obter caça (proteína animal), pois ali não pode ser refúgio de espécies de fauna, pelas seguintes razões.

Não é possível haver zonas de "refúgio animal" se toda a área está praticamente ocupada pelas habitações e roças indígenas. Apesar de existir área florestada, progressivamente cada vez menos, os seres humanos se encontram muito próximos da pequena APP, portanto, dada a intensiva ocupação de seu interior, os animais não encontrariam refúgio. Se os recursos ambientais já são poucos para os próprios Guarani, para os animais é praticamente inexistente. Deveria haver espaços livres, florestados e afastados dos humanos, para os animais poderem sobreviver e se reproduzir. Proporcionalmente, as áreas florestadas deveriam ser muito maiores que as áreas de roças, porém, eram pouco maiores até 2003-4 e a partir deste ano tornaram-se menores do que as áreas de roças. Portanto, falta espaço físico, territorial, ambiental, na TI.

Outro fato que concorre para a inexistência de fauna refere-se ao modo de produção da economia dos colonos lindeiros ao Oco’y. Indevidamente muito próximos que estão, limítrofes à Terra Indígena - quando não a invadem (estando com seus cultivos a menos de 5 metros das residências indígenas), estes praticam total desmatamento de toda área do entorno da TI, em extensões relativamente grandes, contínuas e maiores que a própria Terra Indígena, plantando monoculturas (soja, milho, trigo e aveia) para destino comercial. Estas áreas circundam toda a TI. Portanto, a região deixa de constituir-se em atrativo, na medida em que a maioria dos ambientes não oferece os diversificados alimentos necessários à sobrevivência das espécies de animais silvestres. Os poucos animais que existem no local, silvestres ou não, criados pelos Guarani, segundo depoimentos, muitas vezes após ciscar nas roças dos colonos, falecem em seguida, contaminados pelos agrotóxicos utilizados pelos colonos.

Portanto, este território não indígena, excessivamente próximo a TI e muito maior em extensão que ela, não contribui para ser refúgio de espécies animais, e, por conseguinte, também de diversidade de vegetais, pois não há o transporte animal de sementes de um lugar para outro, cadeia alimentar esta, necessária e componente do extrativismo indígena. 


\section{Pesca}

Peixe tinha (no Oco'y-Jacutinga) lambari, traíra, jundiá, jacarepetenguá, ipiaú, xango, tucunaré, almado, o peixe sapo, paraí, piaba, dourado, picãpé, lambari-xato, surubi, pirapará, piracanjú, pacú, salmão, mancuruju (jaú), patí, mandí (pintado), tartaruga... usava várias graxa do peixe de remédio, para fazer massagem... . O timbó a gente punha na água, batendo na água e fazia o peixe dormi, aí a gente pegava bastante... . O peixe que a gente pesca aqui não é puro, com vida, o peixe quando a gente pesca parece que já tá morto. Quando chove o peixe morre na água com o veneno...

Cacique Pedro Alves

Outubro/2001

Quanto à pesca apesar de haver certa disponibilidade no reservatório da Usina Hidrelétrica de Itaipu, segundo depoimentos dos Avá-Guarani, em muito menor número e diversidade do que havia no Oco'y-Jacutinga, ali os cardumes sofrem dois tipos de impactos ambientais, na medida em que há periodicamente baixas nessa população, por causas não naturais.

A Hidrelétrica altera o regime do volume d'água através da abertura e fechamento das comportas, o que provoca muitas vezes o esvaziamento rápido, não total, do pequeno braço de lago, daquela represa. Nas ocasiões que o volume de água encontra-se baixo, ocasiona grande mortalidade dos peixes. Esta fauna pesqueira compõe a única fonte de proteína animal, consumida por estes índios.

Outra questão refere-se à interferência química nas águas do lago e por conseguinte na vida dos peixes. Estando em uma microbacia, com as chuvas, principalmente de verão que são mais fortes, o local que é em declive, sofre a ação do carreamento de produtos agrotóxicos proveniente das terras dos colonos lindeiros ao Oco'y. Os produtos perpassam a Terra Indígena, desaguando no lago, provocando o mesmo efeito, a mortalidade dos peixes. Logicamente pela cadeia alimentar deve ocorrer a contaminação da população indígena, consumidora desses peixes e águas. Por conta desta afirmação, veremos no capítulo 6 a reação da Hidrelétrica, que determinou que passassem a patrola no restante da APP, segundo seu interlocutor "para abrir mais espaços para as roças". Na verdade ao deslocar grande quantidade de terras levantaram grandes murundus (montes de terras) entre as terras dos colonos e dos indígenas e também entre as terras dos indígenas e do reservatório, buscando dessa forma evitar, e, por conseguinte, não ser responsabilizada pela contaminação. Com essa ação a hidrelétrica entrou em conflito com o IAP, na medida em que eliminou considerável parte do restante da APP. 


\section{Coleta}

Hoje não tem mais madeira para o arco, fazia cesto de cipó e taquara para guardar feijão, hoje não tem mais material na mata, não tem mais material para nada... .

Pajé Honório

Outubro/2001

O pequeno remanescente florestal de APP existente no Oco'y se caracteriza por ser apenas - como o próprio nome indica - "mata ciliar", pertencente ao reservatório da Itaipu Binacional.

Os Avá-Guarani o utilizam sem outra alternativa, como único espaço possível de coleta, procurando preservar e recompor esses poucos fragmentos florestais, conscientes que são de sua necessidade como fonte minimamente diversificada de matérias-primas para sua subsistência. Pode-se atestar o fato, observando-se qualquer foto da área em 2001 (Figuras 23, 24 A e B, 25 e 26), há sempre de alguma forma vegetação, natural ou plantada, dessa forma, todos os espaços no Oco’y que não são ocupados por roças ou residências, eram até 2003-4, matas.

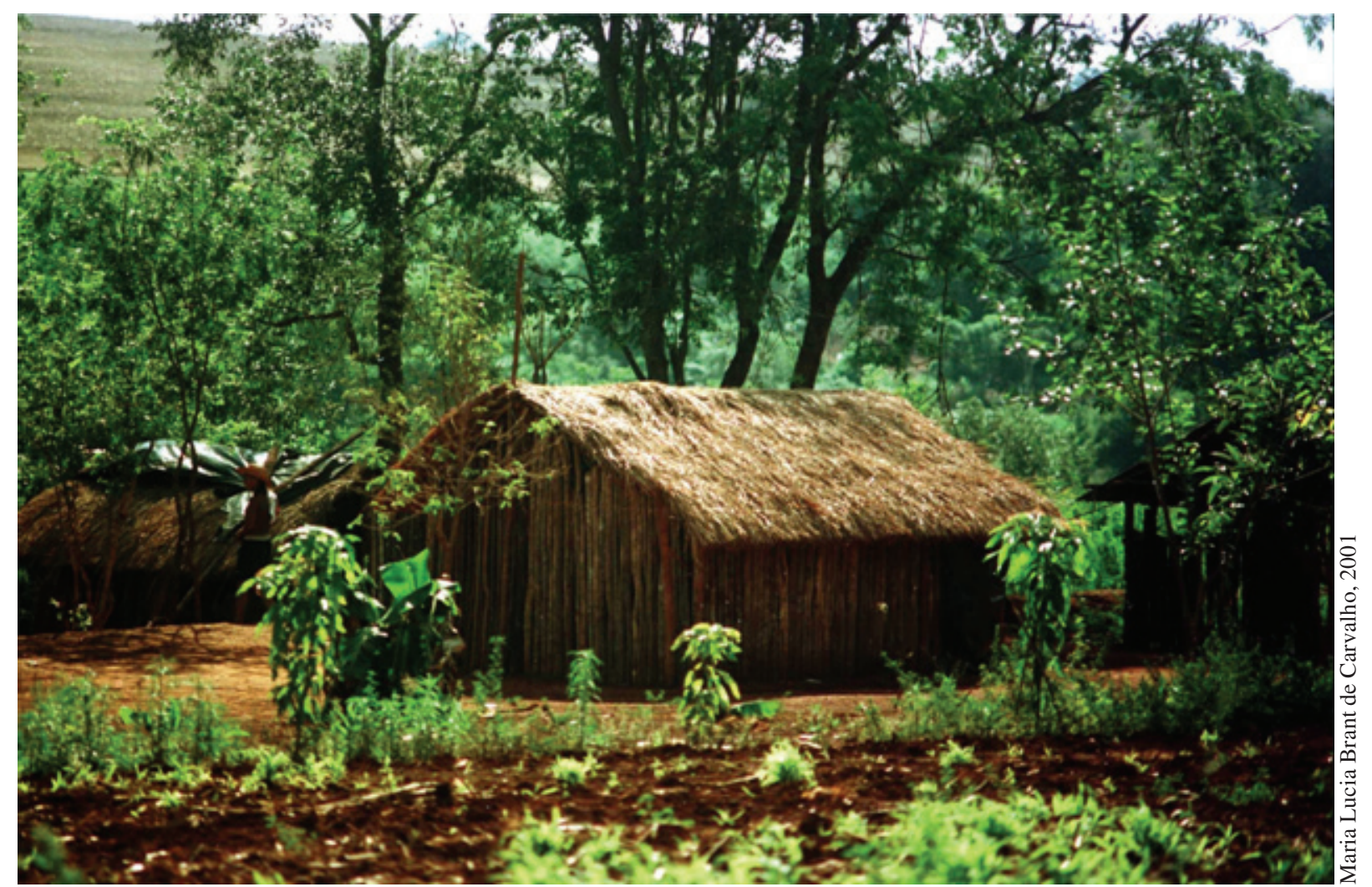

Figura 23. Foto. Residência Avá-Guarani na Terra Indígena do Oco’y.

Acima da residência na figura $\mathrm{N}^{\circ} 23$, nota-se o declive e a proximidade do desmatamento e plantio nas terras dos colonos lindeiros. 

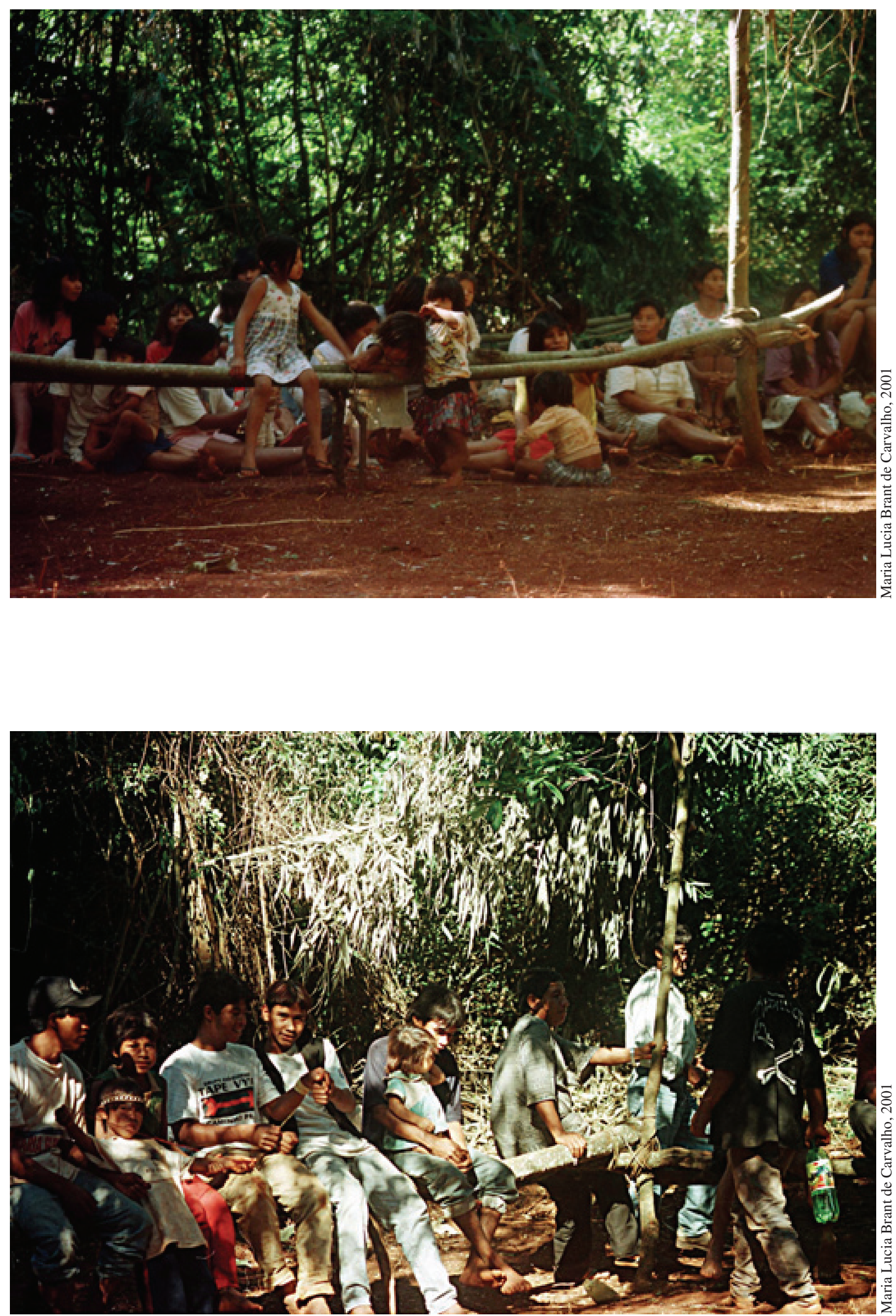

Figura 24 A e B. Foto. Pátio de reuniões. Em círculo mulheres de um lado, homens de outro. 


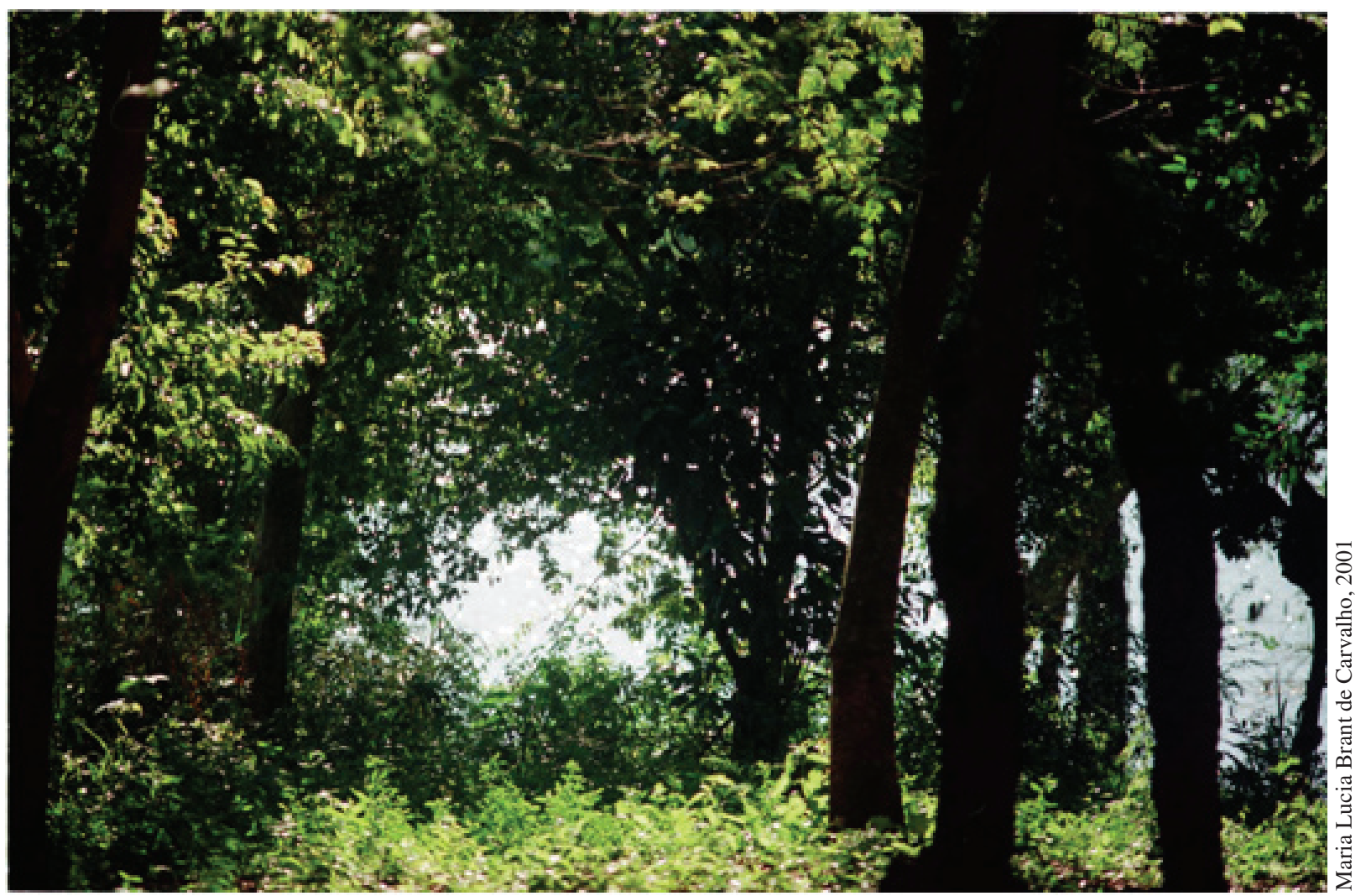

Figura 25. Foto. Caminho de residência indígena passando pela APP em direção ao reservatório da Usina Hidrelétrica de Itaipu.

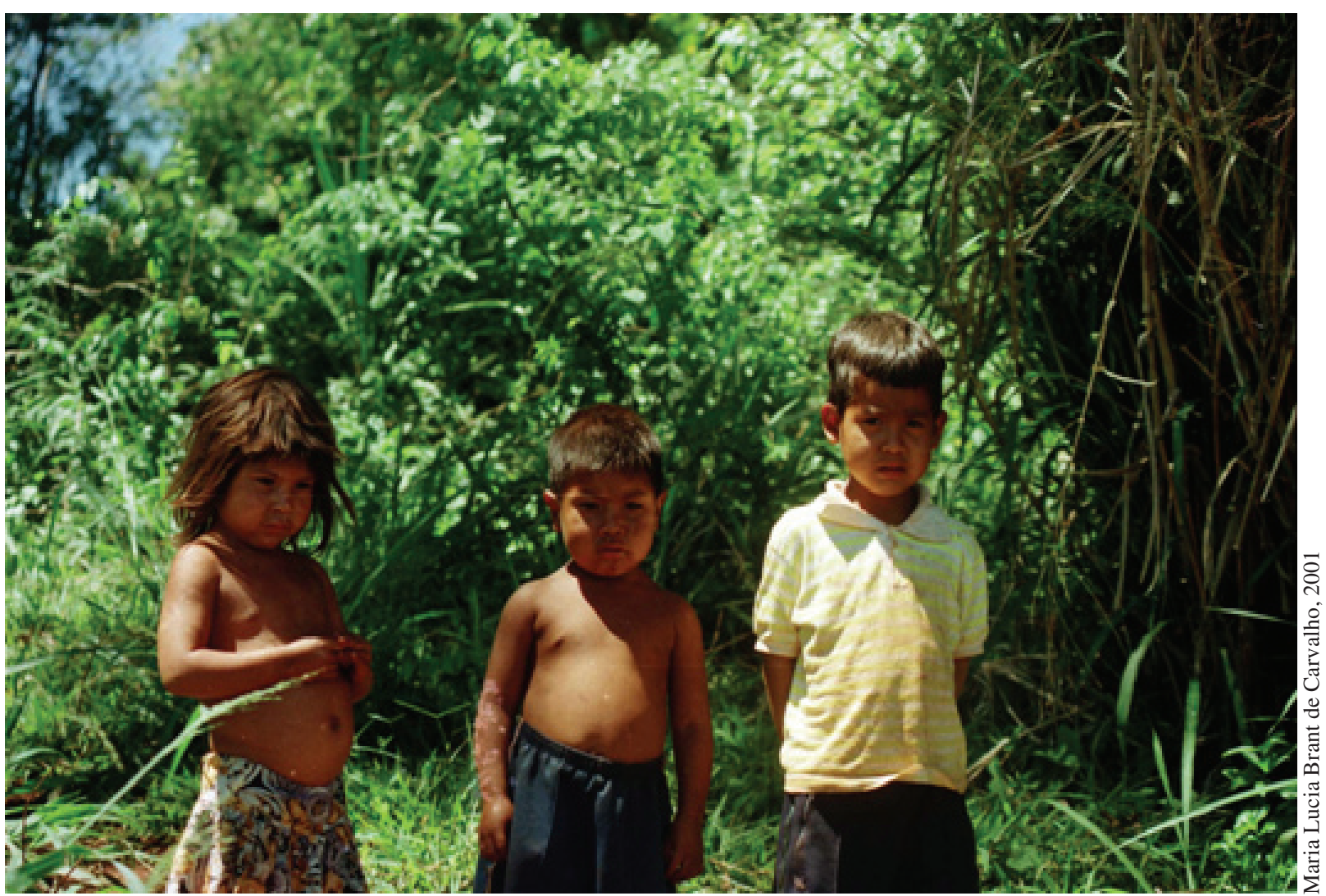

Figura 26. Foto. Crianças brincam no quintal da residência. 
Em todas fotos do interior da TI a mata está ao fundo em 2001. Na Figura ${ }^{\circ} 25$ nota-se mais uma vez o declive da APP em direção ao reservatório.

A Mata para a maioria de nós é uma paisagem verde, fresca, agradável para passear, indistinta em seus recursos, ao contrário, para as populações indígenas ela significa no plano material reserva de produtos úteis para todas as necessidades.

Conversando com Cacique Reroy'vyju (apelidado pelo nome cristão de "Pedro Alves") referente ao que deixou de haver de recursos ambientais disponíveis à comunidade, quando foram reassentados na Terra Indígena do Oco’y, obtivemos a seguinte resposta (outubro/2001):

(...) Tatu, lagarto, cotia, paca, nhambu, porco-do-mato, cachorro-do-mato, gato-do-mato, irara, onça. Mel de abelha: jataí, europa, a gente tirava 20 litros de mel, um latão, nossa mãe fazia bolo de milho e nós molhava no mel.

Bastante peixe. Carne de veado. Erva-mate a gente sapecava no fogo e moía, não sobrou nenhum pé nativo. Bambu para artesanato, para fazer peneira de feijão.

Sumiu um monte de mina d'água. (Ervas medicinais): pariparoba, açoita-cavalo, pé de guavirovera, jaboticaba, a casca é bom para quando tiver diarreia com sangue. Aguaí, da semente dá para faze colar, o fruto a gente comia, e a "folha" da casca a gente usava para faze remédio.

Quando criança eu só comia raízes e frutas, não ficava doente, a água era limpa, saudável, comia peixe,... vivo, bem sadio, agora quando a gente tira o peixe aqui parece que ele já tá morto. A raiz era tudo natural, banana nativa, mamão, laranja nativos... a água agora não passa a sede, a água antes era bem natural, bem limpa, cheiro de flor, agora cheira a poluição. Algumas raízes comia crua, essa não tem mais.

A criança agora começa a cresce um pouquinho e já morre, antes não era assim. A comida agora empacotada é tudo poluída, a bebida, refrigerante de agora..., a gente procurava mel de abelha e fazia suco. Bebida de batata-doce e milho branco, as mães não fazem mais, elas querem comida empacotada, quando o marido traz tudo empacotado "aquilo é homem" e o homem quer bebida natural.

Quando mudar para outra terra nos vamo mudar esquema de vivência. Não é voltar ao tempo dos antigo, porque não dá, mas é comer tudo natural... .

A gente faz pão caseiro o bodiapé..., a mulher não tem mais coragem de socar o milho no pilão. Os homens faziam mundéu (armadilha) para trazer carne para casa. Agora não faz mais, não tem nada de caça aqui. Antigamente nós vivia dentro da mata, de mel, de cáça, plantava mandioca, batata-doce, milho pupuruca, amendoim, a roça era longe da casa, para vir bichinho, e nós caça; aí a gente fazia mundéu na beira da roça e pegava paca, cotia...agora vivemo nesse cantinho, nem gambá pega mais aqui! 
De caça tinha anta, capivara, porco do mato, cateto, veado, cotia, paca, tatu, quati, macaco, bugio, raposa, rato do mato, lebre, ouriço, preá, tamanduá-bandeira, tamanduá-mirim, onça, jaguatirica, gato-do-mato, surum, cangussu, ichó (coró). Usava banha para comer..., para fazer remédio, o couro; a casca do tatu para fazer remédio para umbigo de criança; usava graxa de quati para deixar o cabelo bonito; banha de capivara para bronquite; unha de veado para colar; o couro de veado e de anta para forrar o jirau.

(Frutas): guavirova, jaburiti, jaracatiá, pitanga, jaboticaba, ivavidju, aguaí, pacuri, caraguatá, concum (a folha usa para tererê), uvaia, araticum, guambé, apipu (laranja do mato), coquinho, canela, timbó...

Peixe tinha lambari, traíra, jundiá, jacarepetenguá, ipiaú, xango, tucunaré, almado, o peixe sapo, paraí, piaba, dourado, picãpé, lambari-xato, surubi, pirapará, piracanjú, pacú, salmão, mancuruju (jaú), patí, mandí (pintado), tartaruga.... usava várias graxa do peixe de remédio, para fazer massagem... . O timbó a gente punha na água, batendo na água e fazia os peixe dormi, aí a gente pegava bastante... . O peixe que a gente pesca aqui não é puro, com vida, o peixe quando a gente pesca parece que já tá morto. Quando chove o peixe morre na água com o veneno... .

A palmeira a gente usava a folha para cobrir a casa; a fruta para comer e fazer bebida, a tchicha; o talo para fechar a casa; o miolo para fazer guisado pra comer angu com milho; nela a gente pega coró...

A roça de lá tinha feijão de vara, arroz, batata-doce, mandioca, milho pururuca, amendoim... não plantava muito porque na mata tinha muita coisa... a gente não precisava comprar nada. Aqui nem adianta refloresta porque não vai vir bicho nenhum é muito pequeno. A gente procura não tem mato, a gente procura, procura não tem mais remédio..."

Através deste depoimento, pode-se observar que: - os Guarani do Oco’y adultos possuem os conhecimentos necessários a sua reprodução socioeconômica, porém, o ambiente em que foram instalados não proporciona a realização a contento das formas tradicionais de reprodução física e cultural da população indígena; - compromete o conhecimento das novas gerações, as quais não estão tendo a oportunidade de vivenciar esta possibilidade de associação entre os conhecimentos acumulados pela sua cultura e o atual ambiente, estando dessa forma, os conhecimentos e as práticas dos mais velhos, limitadas, reduzidas e interrompidas neste território. $\mathrm{O}$ fato remete a perda de direitos constitucionais indiscutíveis, o direito à terra como povos originários que são, conforme seus usos e costumes tradicionais, e ainda o direito, quando da transferência do conjunto do agrupamento indígena para o Oco'y, para terras em “área equivalente à anterior, inclusive quanto às condições ecológicas", conforme já descrito. 
Observa-se como a cultura material é importante sendo uma das bases fundamentais de sustentação da cultura, que por sua vez, é a maneira específica de como se dá a organização da vida destas populações, a única forma como elas concebem sobreviver, direito este duramente conquistado e garantido constitucionalmente, porém, na prática, no caso, não efetivado.

Os Guarani se referem ao espaço do Oco’y, que apesar de pequeno, possui certa diversidade de recursos, porém, em quantidades pequenas, muitas vezes somente uma espécie de cada árvore. Na prática esta única árvore, como é de conhecimento das ciências ambientais, estará provavelmente fadada ao desaparecimento.

Levantamos com o pajé da aldeia as utilidades de alguns produtos medicinais que este pequeno remanescente florestal existente no Oco’y oferece, o que para nós podem parecer que são recursos significativos, para os Avá-Guarani são considerados escassos:

Pariparoba: p/tosse, bronquite; Mamona - p/ picada de cobra; Casca de capota: p/ sinusite; Alfavaca do mato - p/ inchadura do nervo e dores; Cipó-timbó - p/ dor de estomâgo, fruto comestível lembra abacaxi, batendo na água no remanso do rio faz os peixes "dormir" (ficam sem oxigênio e boiam), coloca o pari (cesto de cerca de 2 metros de comprimento) na corredeira; Casca do "rabo do bugio" - serve como vermífugo e também para abrir o apetite; Sapuá (yy sapuú) - p/ferida de boca; Yasitarebiú (matinho redondo) - dor de vista; Jateí caá (erva do alemãozinho) - dor de estomâgo...

E assim foi relatado um grupo de 45 espécies e suas utilidades. O pajé colocava que: existem, mas pouquinhos pés de cada um, quase não pode ser usado como os Guarani precisam.

Para alguns medicamentos produzidos pelo pajé (Figura 27), o mesmo relata que existem alguns elementos e faltam outros, prejudicando a combinação deles, necessária à confecção do mesmo. Eles frisam que a área apesar de possuir produtos, não oferece todas as qualidades que tradicionalmente os Guarani utilizam; e mesmo as existentes são em número pequeno de exemplares, não havendo disponibilidade suficiente para a satisfação de todo o grupo, o que se conclui que a área apresenta baixa possibilidade de consumo satisfatório no que se refere aos produtos de coleta.

Dada sua extensão diminuta de remanescentes florestais versus a população indígena que proporcionalmente a ocupa (449 indivíduos/2001), neste local não há possibilidade de realizar alternância de espaço para outras áreas mais preservadas, como é o costume indígena, pois não há outro espaço para se fazer o revezamento. 


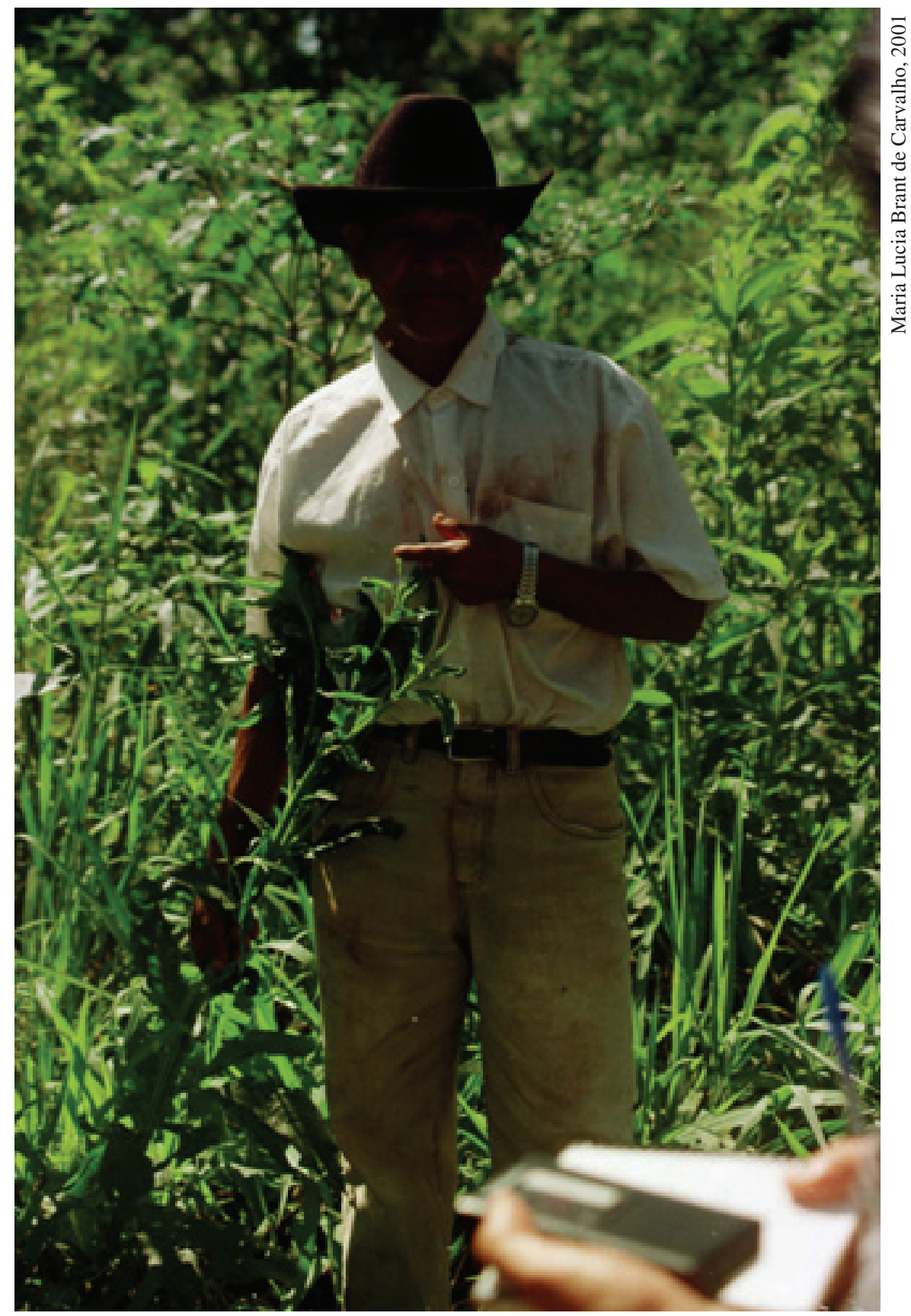

Figura 27. Foto. Pajé conhecedor das ervas, demonstrando os remédios existentes na mata.

Obrigados a realizar o uso continuado dos mesmos espaços, este remanescente florestal sem ter o tempo necessário para se refazer através do revezamento da população para outros espaços, seus recursos ambientais vão progressivamente degradando como um todo. Os poucos produtos existentes são consumidos seguidamente pelos Guarani, faltando a necessária possibilidade de intermitência, uso e pousio, para que possam soltar as sementes, rebrotar, haver a dispersão de sementes por meio do transporte animal para outros locais, etc. Isso se dá contra a vontade e sem que a população indígena consiga evitar. 
Através do manejo indígena tenta-se preservar a área, mas a unidade territorial/ambiental existente é mínima e nesse local completamente cercado, não há possibilidade de se buscar os recursos fora da área demarcada, pois não há os elementos necessários externamente, toda a região encontra-se desmatada.

Os Guarani afirmam que esperam há cerca de 20 anos, esta mata retomar suas características de Kaa Anetete (Mata verdadeira, i.e., de Mata Alta; quando chegaram em 1982, ela já havia sido explorada pelos colonos, as madeiras nobres por exemplo, haviam sido retiradas em sua maioria. Apontaram pequenas zonas de preservação total, "construídas" ao longo do tempo por eles, em que proíbem qualquer família morar, pois se constitui área de reserva de recursos. Elas são poucas e pequenas. Os remanescentes florestais existentes, como se apresentavam de 2001 a 2003, representavam um esforço continuado por parte destes indígenas em consegui-los manter.

Conclui-se que o espaço é reduzido em extensão e diversidade ambiental, considerando-se as necessidades específicas de extrativismo da população indígena que proporcionalmente ocupa a área. Ela é considerada uma APP, visando única e exclusivamente proteger às margens do lago de Itaipu da possibilidade de assoreamento, e não exatamente caracteriza-se como um refúgio biológico de espécies de fauna e flora, o que se assim fosse, protegeria tanto o meio ambiente como o patrimônio físico e cultural indígena.

A população Guarani fundamentalmente dependente dos recursos ambientais para sobrevi-

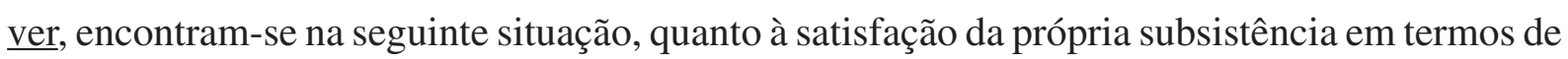
extrativismo.

Nesta área não há unidade territorial/ambiental para a existência de caça, por não existir área territorial possível à perambulação de fauna, animais silvestres que vivem na terra e ar; Os peixes em certos períodos morrem por interferência de terceiros: ou por falta de oxigênio ou por contaminação de agrotóxicos, que são repassados aos Avá-Guarani, na medida em que são os peixes consumidos por eles. Inexiste suficiente produtos para a coleta, pois não há diversidade de recursos ambientais em qualidades e quantidades desejáveis para o extrativismo indígena, diante do mínimo espaço físico. Assim as atividades de extrativismo encontram-se comprometidas. Isso faz com que as roças tenham importância fundamental na dieta dessa população, já que são na prática, juntamente com os peixes do lago, quase as únicas fontes alimentares dos Guarani do Oco’y. 


\subsubsection{Agricultura}

A gente fazia duas roças ao mesmo tempo, uma enquanto crescia a outra ia começando. Plantava também para os bichos, fazia ceva de milho para os animais.

Cacique Pedro Alves- outubro/2001

As roças em qualquer aldeia da etnia nunca são ao lado das habitações, mas como a área do Oco’y é pequena e estreita, não há espaço para as moradias e roças de cada família extensa se espalhar pelos vários pontos do território, como o fazem os Guarani normalmente em outras terras. Esse conjunto territorial apresenta-se em toda sua extensão ocupado pelas habitações, seguidas umas das outras, como se estivessem em uma rua urbana ${ }^{27}$, as casas estão muito próximas, entremeadas pelas roças de cada família, cercadas por alguns remanescentes florestais nas laterais do território. As habitações e roças de cada família apresentam-se em espaços equidistantes de 10,20, 30 metros os familiares próximos (membros pertencentes a cada família extensa), e de 70 a no máximo 90 metros umas das outras, as parentelas entre si. Ver Figura 18. Croqui, contendo as habitações.

Dessa forma, cada uma das roças se localizam indevidamente próximas às habitações de cada família, único lugar possível de realizá-las. Esses locais deveriam conter apenas os quintais das habitações, onde em geral são ocupados também pelas criações de animais domésticos. Assim os animais ciscam indevidamente sobre os brotos dos cultivos indígenas, já limitados para eles próprios, competindo pela alimentação com a população indígena. Daí que os Avá possuem poucos animais de criação.

Nestes espaços de agricultura, os Guarani costumam plantar milho (avatí-etei), mandioca (mandi'o), batata-doce (jety), amendoim (manduvi), feijão (kumandá), cabaça (yakuá), cana (takuare'e), fumo (pety), melancia (xanjau), abóbora e algumas frutas.

A seguir os depoimentos Guarani a respeito das condições para fazer suas roças:

Pedro Alves: Faz 20 ano que planto no mesmo lugar a roça: de milho, mandioca branca e amendoim. A roça tem que deixa cresce o mato mais ou menos 1 metro, para daí roçar, assim dá bem, tem que planta só uma vez e depois muda de lugar.

\footnotetext{
${ }^{27}$ Sistemática essa que no Paraná os projetos colonizadores dos tempos dos governos autoritários obrigaram em varias terras indígenas, a manter essa disposição das casas.
} 
Seu Honório: Faz 7 ano que estou aqui no Oco'y, planto há 7 ano no mesmo lugar, antes era só minha família (4 pessoas) agora é meu genro com minha filha e dois netinho, então eu divido esse mesmo espaço com eles (de 4 para 8 pessoas); não dá para mudar de lugar e cada vez tem que dividir mais o espaço. A terra aqui foi usada muitas vezes, vai ficando fraca; a nossa cultura não rende muito porque não usamo adubo... . O milho tem lugar aqui que não dá nada, tem que por calcário.

Mãe de família: (...) Tenho já cinco neto, três de um filho e dois de outra. Muita família, terra pequena, terra não dá para planta tudo que precisa, não tem espaço, logo os filho mais crescido vão se casa e como é que faz?

Outra mãe Guarani: O espaço é muito pequeno, logo minha filha vai casa e como faz?? Aqui não tem espaço, para faze roça pra família dela....

Teodoro: Planto há 7 ou 8 anos no mesmo lugar. Plantei milho, não tem terra, tem que esperar colher para plantar outra coisa, por ex.: milho com rama de mandioca não dá.

Os Guarani querem uma terra boa para mandioca: Cacique: (...) a terra é muito dura, tem que ser arenosa, tem que ser fofa, para plantar mais fácil, tem lugares que vai bem aqui, tem lugares que ela amarga.

Portanto, a agricultura indígena no Oco’y não pode se dar de forma itinerante, pois não há espaço físico para o revezamento, a necessária alternância de ambientes. Cultivando as roças continuamente nos mesmos locais, contribui para o desgaste do solo e consequentemente gera baixa produtividade das culturas agrícolas. Quando estes solos esgotarem-se, por enquanto, não haverá outros que os substituam. A sorte dos Avá é que no Paraná, a terra roxa é uma, senão a mais, fértil do mundo.

Em cada uma das roças existem limitados espaços agricultáveis, o que não é possível plantar, conforme declaram os Avá, mais que três cultivos por temporada, chegando-se a situação, por exemplo, como foi demonstrado, de ter que dobrar ao meio o pé de milho, para que o feijão possa receber sol! Assim elas são insuficientes para a demanda de subsistência das famílias indígenas existentes. As áreas de roça deveriam ser suficientes para abastecer as famílias durante pelo menos um ciclo de produção inteiro. Para exemplificar a situação das terras, analisemos as fotos a seguir (Figuras 28, 29 e 30): 


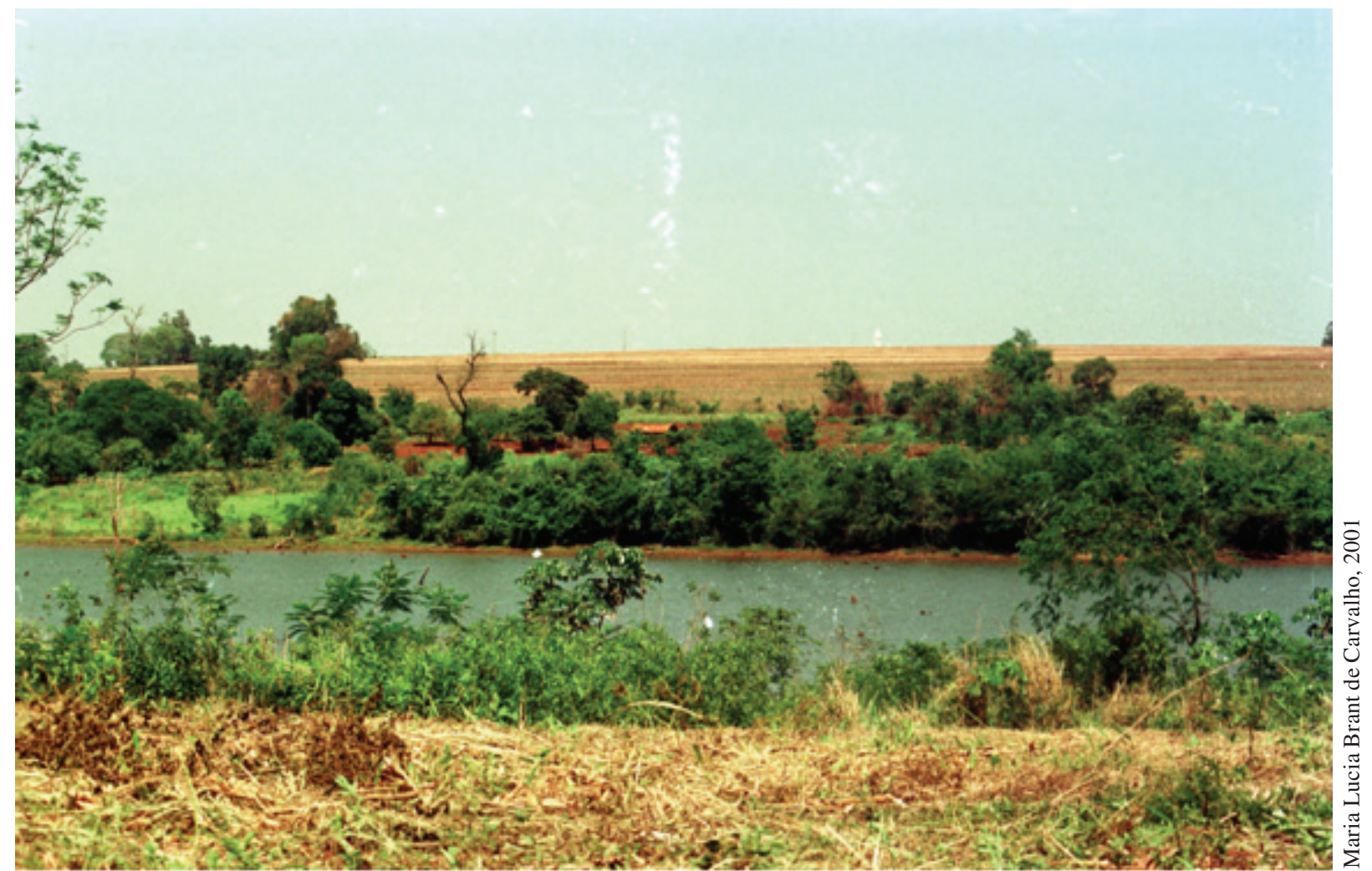

Figura 28. Foto. Exemplo da situação quanto à disponibilidade territorial de uma família.

Ao analisar a foto anterior verificamos: a) Em primeiro plano, margem direita da TI, área roçada que deveria ser na lógica das autoridades estatais unicamente APP; b) em seguida a estreita APP sobrante neste ponto da TI às margens do reservatório; c) o próprio reservatório da Itaipu; d) margem esquerda da TI, contendo: $1^{\circ}$ ) A APP superposta a área de coleta desta família; $2^{\circ}$ ) círculo marrom, área de roçado de uma família, juntamente com sua habitação no meio e criação de animais; $3^{\circ}$ ) em marrom claro ao fundo e mais elevada em termos de relevo, gleba de colono lindeiro ao Oco’y, área muitas vezes maior que a Terra Indígena, totalmente desmatada e roçada com monocultura e utilização de agrotóxicos. 


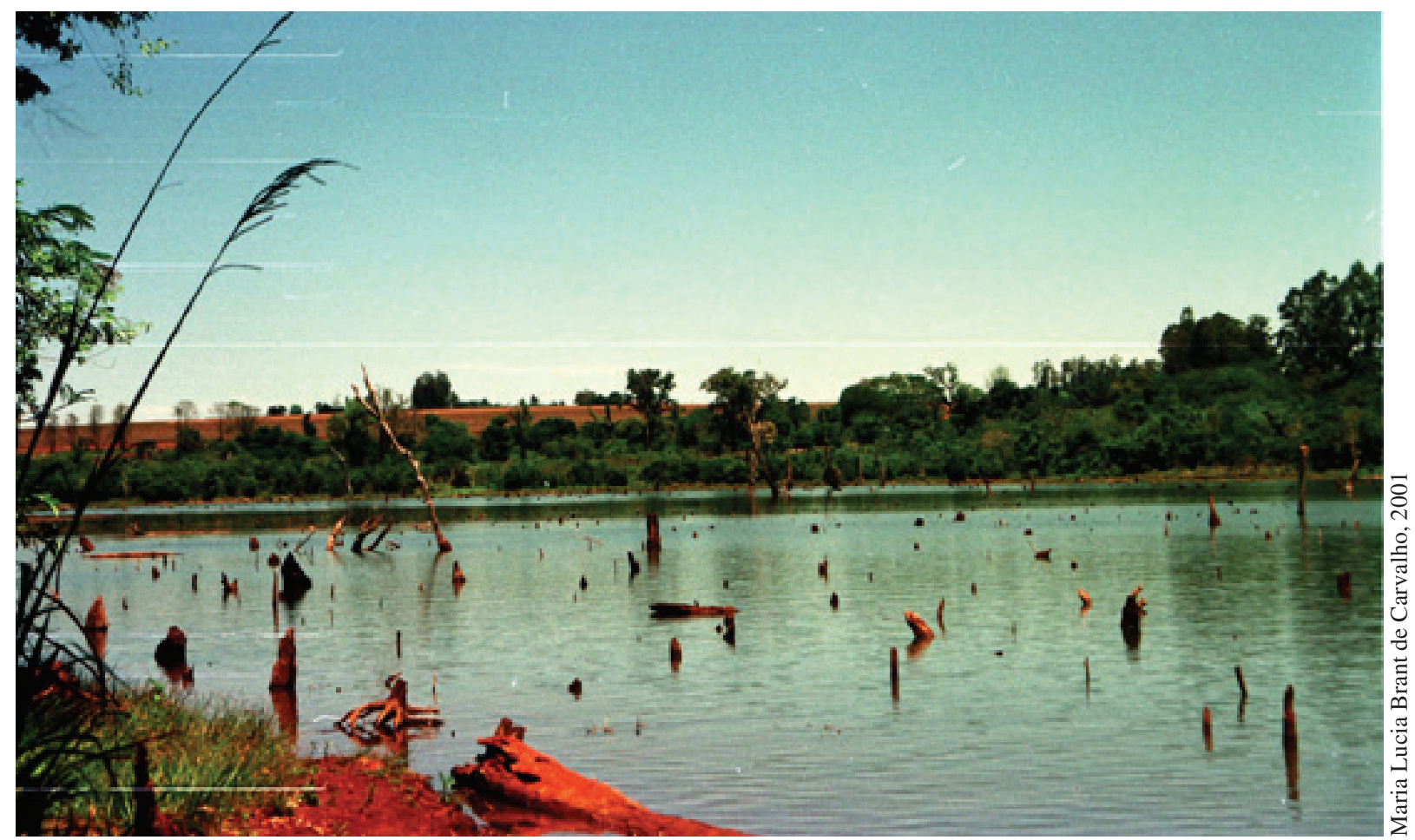

Figura 29. Foto. Limites territoriais da Terra Indígena: entre o reservatório e os colonos.

Em primeiro plano aparece o reservatório contendo madeira morta do remanescente florestal que existia junto ao Córrego Santa Clara; em segundo plano, uma estreita faixa de terras notase a APP simultaneamente à TI (área de coleta de matérias-primas dos Guarani); por fim ao fundo, colada a TI, em marrom claro, glebas dos colonos totalmente desmatadas.

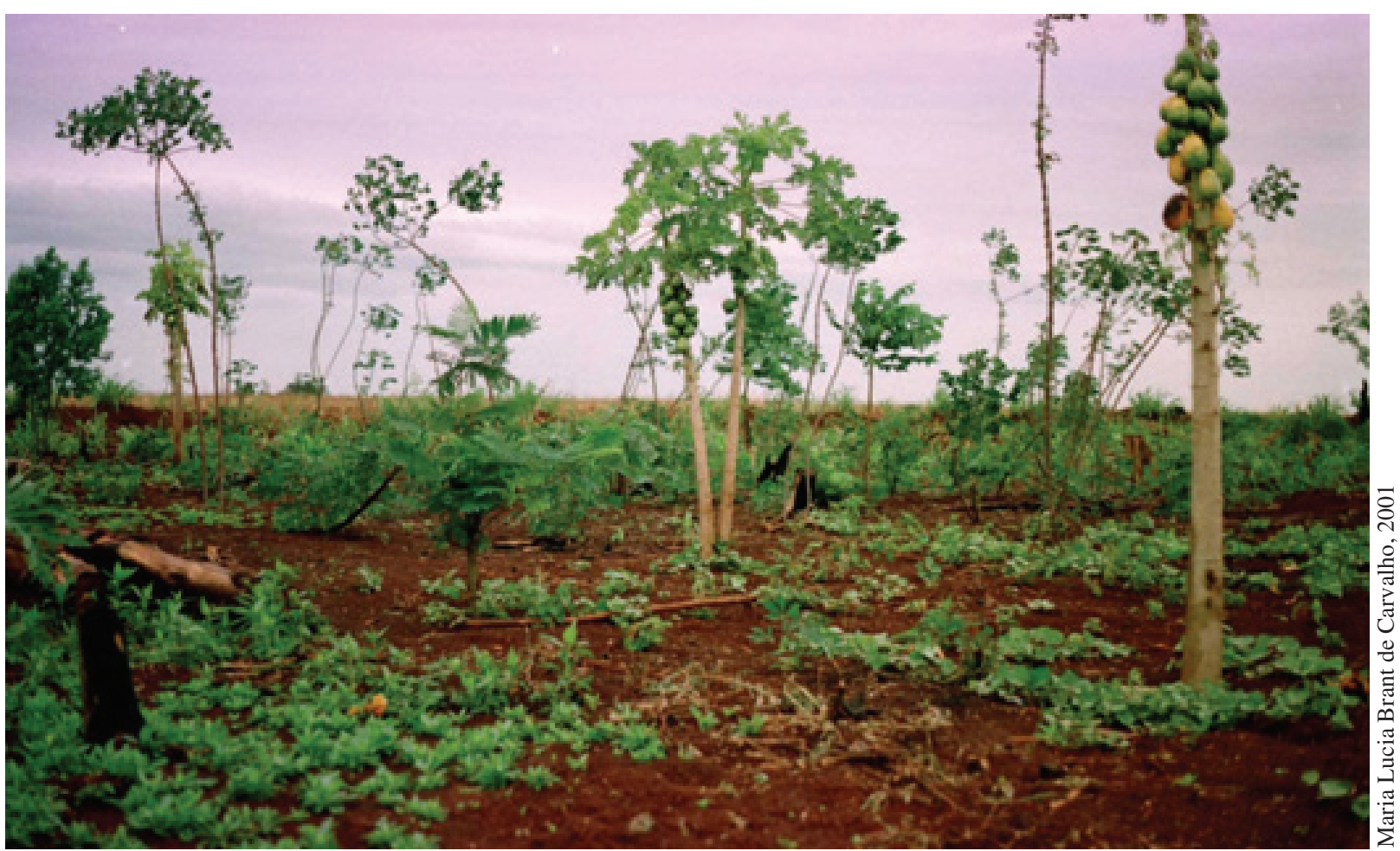

Figura 30. Foto. Imagem de roça familiar. Residência de Seu Guilherme. 
Como vimos anteriormente as roças em qualquer aldeia, devem ser afastadas do espaço de moradia, devem possuir espaços suficientemente amplos para satisfazer as necessidades de subsistência de cada grupo familiar, devem poder alternar de ambientes, devem ser em local onde os solos sejam bons, assim como ainda deve ser afastado o suficiente para que os animais venham buscar os alimentos, que são cevados para eles.

No Oco’y os indígenas lutam de todas as formas procurando manter a sustentabilidade ambiental do espaço. Estas roças estão cercadas pela APP que corresponderia a área de extrativismo destinada a esses índios. Apesar da população indígena procurar respeitar os primeiros 100 metros proibitivos de ocupação às margens do reservatório, porém, não puderam evitar a abertura de certos espaços, afim de plantar suas roças e construir suas casas, fato que foi contra o princípio da intocabilidade da APP. Como se observou anteriormente, dada todas as dificuldades e limitações descritas para exercer suas atividades de subsistência em tão pouco espaço, os Guarani ocupam somente com estas atividades agrícolas, atualmente cerca de 105,7552 ha, extrapolando na prática, o disponibilizado a eles de forma dúbia, pelas autoridades estatais.

Os Guarani enxergam como impossível ocupar mais espaços para roças no Oco’y. Por outro lado colocam a necessidade de ter acesso tanto a mais áreas florestadas, como a mais áreas de roças.

Considerando que todas as atividades econômicas se dão em local onde as habitações da população indígena apresentam-se seguidas umas das outras, circundadas de todas as atividades produtivas, que no caso se reduz às: - roças, insuficientes em extensão, gerando dificuldades para abastecer as famílias, assim como ocorre dificuldades de manejo, não há possibilidade de se alternar de ambientes, o que gera o desgaste da terra e cultivos cada vez mais fracos; - as criações de animais domésticos; - a pesca no lago; e, - a coleta de algumas espécies florestais; e que elas conjuntamente ocupam praticamente todo a área, pode-se verificar que apesar do manejo ambiental indígena procurar ser adequado, diante das condições territoriais o modelo econômico tradicional Guarani ali não pode se dar satisfatoriamente.

Pode-se concluir que a base econômica da população indígena está comprometida e a razão fundamental do problema é a exiguidade da terra, aliada a sofrível qualidade ambiental dessa APP, como ainda a inexistência da devida proteção ambiental do entorno da TI.

A premissa básica e fundamental da gestão das terras indígenas é a questão da sustentabilidade ambiental, o que aqui não foi contemplado. Uma Terra Indígena deve necessariamente atender aos mecanismos e critérios de ocupação e controle territorial da população indígena, do contrário ela não poderia ser caracterizada "legalmente" como tal. 
Dessa forma a APP deveria ter sido preservada em função dos interesses da Itaipu e a população indígena nem deveria ter sido reassentada neste local, dado que é inapropriada para suas necessidades de subsistência.

Dada a insustentabilidade da terra verificada no Oco’y, vejamos então como se dá a produção de excedentes pelos Guarani, o qual geraria alguma fonte de renda, substituindo pela compra de produtos, as matérias-primas que não podem acessar no local.

\subsubsection{Artesanato}

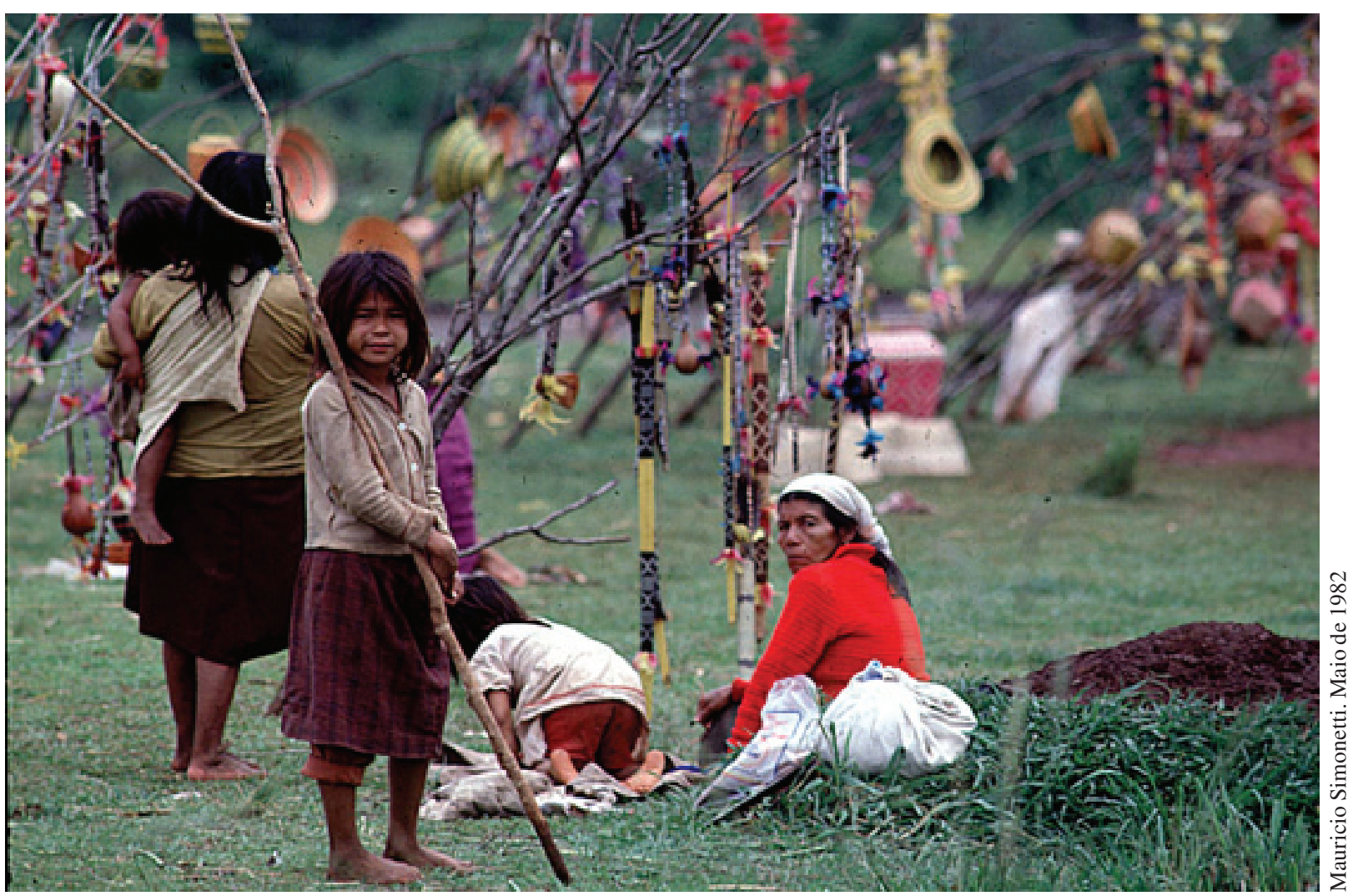

Figura 31. Foto. Maio de 1982. O artesanato que havia sido produzido no Oco'y-Jacutinga e na mudança foi trazido para o Oco'y.

A foto anterior foi clicada no momento em que os Avá-Guarani haviam recentemente chegado pela primeira vez no Oco’y, em maio de 1982. Este artesanato, rico em cores e texturas foi produzido com matéria-prima do Oco'y-Jacutinga e trazido na mudança para o Oco'y. Ao ser mostrada a foto aos Avá-Guarani eles reconheceram as parentes e afirmaram o que foi dito acima. Em seguida afirmaram: Aqui não dá mais para fazer assim, não tem os recursos que lá tinha! 
No Oco’y os Guarani produzem alguns artesanatos os quais se caracterizam como praticamente os únicos excedentes que obtêm alguma saída para venda no mercado. Com o recurso obtido trocam por alguns produtos industrializados que hoje se fazem necessários. São artesanatos como cestaria, miniatura de animais, instrumentos de caça, maracás, colares, pulseiras, anéis... etc.

A comunidade indígena tem apresentado precárias condições para produzir estes produtos, isto porque não existem mais quase matérias-primas disponíveis no Oco’y, o que acaba por afetar o poder de compra dessa população, considerando as necessidades em relação a carência por que passam.

A maioria do artesanato produzido geralmente é vendido pela Associação Indígena, vejamos a seguir na Tabela 3.6., as condições em que estão sendo produzidos.

Tabela 3.6. Condições de produção do artesanato vendido Terra Indígena Avá-Guarani do Oco'y

\begin{tabular}{|l|c|c|c|}
\hline Produto & Preço(2001) & Faz/Não faz & $\begin{array}{c}\text { Disponibilidade de } \\
\text { Matéria-prima }\end{array}$ \\
\hline Bichinho & $\mathrm{R} \$ 1(\mathrm{p}) ; 3(\mathrm{~m}) ; 5(\mathrm{~g})$ & Faz & Logo faltará caixeta \\
\hline Chocalho & $\mathrm{R} \$ 3$ & Não faz mais & Guambé grosso \\
\hline Arco e flecha & $\mathrm{R} \$ 5$ & Não faz mais & Embira e taquara \\
\hline Colar & $\mathrm{R} \$ 2$ e 3 & Faz & \\
\hline Pulseira & $\mathrm{R} \$ 2$ e 3 & Faz & \\
\hline Balaio & $\mathrm{R} \$ 5$ e 10 & Não faz mais & Taquara \\
\hline Crucifixo & $\mathrm{R} \$ 3$ & Faz & Taquara \\
\hline Peneira & $\mathrm{R} \$ 7$ & Não faz mais & \\
\hline
\end{tabular}

Fonte: Maria Lucia Brant de Carvalho. Pesquisa de campo, 2001.

Sua tradição artesanal em cestaria, principal atividade artesanal que poderiam obter algum recurso monetário, não pode ser desenvolvida pela carência de matéria-prima. Ela possibilitaria um reforço em sua economia.

Estes aspectos têm implicações socioculturais importantes. A falta de matéria-prima para inúmeras atividades, não só referente ao artesanato, mas a tudo que foi descrito até o momento, resulta além da carência econômica, no fato de que as crianças não estão podendo aprender uma série de atividades que são fundamentais à sobrevivência dos Avá-Guarani, sendo este o modo como os adultos concebem a sobrevivência. Crianças nascidas neste contexto, em que não possu- 
em quase acesso ao mundo externo e o acesso ao seu próprio espaço lhes são negados, o que pode resultar dessa situação?

Esta conjuntura se arrasta há 30 anos, desde que foram reassentados inapropriadamente no Oco'y. Como contraponto o fato é que os Avá-Guarani buscam nas profundezas de sua cosmologia religiosa, a força necessária para continuar, demonstrando aos "juruá" (os brancos, os não índios) uma incrível lisura no trato com os mesmos e com a própria vida, digna do mais profundo respeito.

\subsubsection{Relações monetárias com a sociedade externa}

Vejamos como se dá as relações econômicas dos Guarani do Oco’y com a sociedade externa, a partir dos indivíduos que recebem algum valor monetário, baseado no salário mínimo de $\mathrm{R} \$$ 180,00 (cento e oitenta reais) em 2001.

Havia à época 32 aposentados recebendo salário-mínimo. Em geral os aposentados contribuem com esse dinheiro em prol de sua própria família extensa. Supondo uma família extensa de em média 12 pessoas, resulta em média $\mathrm{R}$ \$15,00 indivíduo/mês. Não são todas as famílias que possuem um aposentado.

As gestantes recebem auxílio-maternidade durante quatro meses, no valor de $\mathrm{R} \$ 180,00$. Na aldeia há um professor; dois agentes de saúde; um agente de saneamento; e um motorista; recebem cada um mensalmente, o mesmo valor $\mathrm{R} \$ 180,00$.

Quanto ao Bolsa-Escola é recebido R \$ 15,00 por criança; no máximo três crianças de cada família podem receber o auxílio, o que resulta em $\mathrm{R} \$ 45,00$ por família independentemente do número de filhos.

Quando trabalham como boias frias, conseguem trabalhar apenas de 15 a 20 dias por ano, recebendo em torno de $\mathrm{R} \$ 12,50$ por cada oito horas de trabalho (2001). Ou ainda, na colheita de feijão, recebem $R \$ 1,50$ a carreira de feijão retirada. O trabalho fora como boia fria coincide com a sazonalidade dos tempos de plantar e colher dos seus próprios roçados, prejudicando assim o andamento de suas atividades de subsistência. O trabalho externo é informal, portanto, desregulamentado. Empregos formais dificilmente conseguem, quase sempre em função do preconceito racial, quando são dessa forma explorados.

Conclui-se então, o quão difícil é a situação vivenciada, não conseguem internamente extrair 
da terra os recursos necessários pela falta de terras e ambientes florestados; o acesso que possuem ao mundo externo é custoso e de retorno pífio; este processo está levando a exaustão do modo de vida destes indígenas, pondo em risco à manutenção da própria vida dos mesmos. Isso se dá por uma única razão, falta de terras, o que leva necessariamente a um problema legal e político, os quais serão analisados à frente.

\subsubsection{O direito à auto-suficiência econômica versus assistencialismo imposto por falta de terras}

A população Guarani, possuidora de conhecimentos sobre conservação ambiental que acumulou durante séculos neste território, a partir do quadro verificado - falta de terras, questão gerada pela ação do próprio Estado como veremos a frente, seu destino tem sido cair dependente do mesmo Estado, o qual presta "em tese", assistência social à especificidade dessa população culturalmente diversa, fato que ocorre inadvertidamente no Oco’y. A situação exposta a seguir contradiz toda a legislação que garante terras/ambientes necessários ao bem-estar físico e cultural desta população.

A partir de cada instituição que presta alguma assistência observa-se como funciona o sistema de doações na TI do Oco’y, pesquisa realizada no $2^{\circ}$ semestre de 2001:

- CONAB: O fornecimento ocorria anteriormente todo mês, atualmente segundo o Chefe de Posto da FUNAI, esta instituição somente enviará duas vezes por ano os seguintes alimentos: feijão e arroz e macarrão.

- FUNASA: Fornece leite de soja para as crianças subnutridas.

- FUNAI: Em 1990 o Ministério Público Federal de Foz do Iguaçu, obrigava a FUNAI através do processo $\mathrm{n}^{\circ} 871018182-2$ a fornecer cestas básicas, diante da carência de recursos de subsistência verificado nestas terras. A FUNAI forneceu com certa regularidade até 1992. Alegando falta de recursos financeiros, o órgão parou de enviar com a regularidade anterior, e, hoje, uma vez por ano envia feijão, arroz, macarrão, beiju e bolacha.

- Campanha da Fraternidade/ Igreja: foram destinados roupas usadas e alimentos somente neste momento da pesquisa (2001), ou seja, fornecimento irregular, pontual.

- Prefeitura de São Miguel do Iguaçu: O fornecimento é destinado a título de merenda escolar, portanto recebem somente as crianças em idade de frequentar a escola. É realizado o 
fornecimento mensal a dois grupos diferentes de crianças, quando recebem duas refeições ao dia (manhã e tarde). A seguir os produtos e seus respectivos períodos de fornecimento:

Semanal: 160 pães; 45 litros de leite; $18 \mathrm{~kg}$ de polpa de fruta. Quinzenal: Frango, carne, ovos e salsicha*; Cenoura 9kg; Batata 15 kg; Cebola 5 kg; Alho 1 kg; Alface 8 pés; Repolho 8 pés; Tomate 8 pés; mandioca 8 kg; Laranja 30 kg; Banana 30 kg; De 45 em 45 dias: sal 7 kg; achocolatado $12 \mathrm{~kg} *$; arroz $75 \mathrm{~kg}$; açucar $25 \mathrm{~kg} *$; biscoito doce $13 \mathrm{~kg}$ *; biscoito salgado $26 \mathrm{~kg} *$; café $3 \mathrm{~kg}$; caldo de carne 3 pacotes; chá mate 2 caixas; doce de leite 4 potes*; extrato de tomate 10 latas*28; farinha de mandioca 3 caixas; feijão $35 \mathrm{~kg}$; fubá $35 \mathrm{~kg}$; groselha 3 litros; macarrão 60 kg; óleo de soja 20 latas.

Ou seja, nada comparável a saudável alimentação que os Guarani tinham por hábito antigamente. A especificidade dos costumes indígenas não tem sido em nada considerada. Cria-se dessa forma, ao incutir nas crianças, outros hábitos, que seus pais não lhes poderão oferecer da mesma forma. As crianças estudantes, segundo as mães, algumas vezes acabam por rejeitar os alimentos oferecidos em casa. Elas pouco compreendem os problemas estruturais que as famílias passam e acabam valorizando outras formas de hábitos alimentares, em detrimento de seus próprios, criando situações contraditórias, na medida em que suas necessidades básicas são satisfeitas noutro local, diferente do seu espaço sociocultural real, que é junto à própria família indígena.

Esse processo vivido contribui ainda para não estimular as crianças a procurar por si mesmas juntamente com suas famílias, as fontes costumeiras de subsistência na própria terra. Assim hábitos como plantar e colher através das gerações vão, a princípio, sendo relegados como de pouca importância.

Pontuando não é a escola que deve prover a alimentação básica das crianças e sim a própria Terra Indígena, através do trabalho da população indígena, em terras, fundiária e ambientalmente, adequadas.

Como se observa diante da falta evidente de condições fundiárias e ambientais para o espaço prover em qualidade e quantidade necessárias aos requerimentos básicos de subsistência da Comunidade Indígena, apenas alguns setores da população, crianças em idade escolar, recebem cotidianamente alimentação proveniente da escola, a qual não se caracteriza por merenda escolar, e sim, por "alimentos", diante da falta dos mesmos.

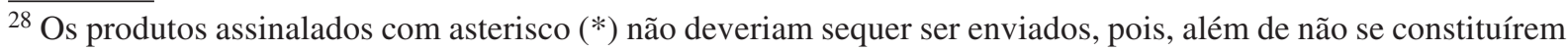
em produtos verdadeiramente nutritivos, estragam os dentes, já que não é habito diário a escovação com pasta e escova de dentes.
} 
Todos os outros indivíduos, crianças recém-nascidas até a idade escolar, jovens, mulheres e homens adultos, idosos, recebem auxílio, porém, via de regra, de forma irregular. Na medida em que essa assistência regular atinge somente as crianças que frequentam a escola, todos os outros estão, portanto, em linhas gerais, excluídos destes “benefícios”.

Desta forma, em termos práticos, mantêm-se todos os outros em patamar de miserabilidade, a qual é imposta, mantendo-se somente as crianças mais fortes, sendo nestas, inculcados valores diferentes dos seus através de mensagens “colonizantes” geradas pela escola, na qual é ministrada por professores em sua maioria não índios, no caso, descendentes de alemães e italianos, havendo limitado espaço para o próprio professor indígena, em decorrência, para a própria cultura indígena.

Deve-se considerar que o ensino em Terra Indígena, tem o direito previsto constitucionalmente de ser uma escola eminentemente de padrões indígenas. Apesar da boa vontade do diretor e das professoras não indígenas, que compreendem relativamente às complexas questões voltadas à diferença cultural, o sistema de ensino estruturado pela direção da Secretaria Municipal de Educação do município de São Miguel do Iguaçu, nesta aldeia, através de diretora descendente de alemães, traz uma carga de conteúdos bastante etnocêntricos, não tendo se dado conta ainda da necessidade de formatar a escola direcionando-a de acordo com os padrões socioculturais indígenas, dando maior liberdade assim aos indígenas para contribuírem na formatação da escola, sistema este em andamento, reconhecido pelo Ministério de Educação e Cultura/MEC e obrigatório nos municípios onde existem populações indígenas. Os professores da escola devem ter maior acesso à coordenação do MEC, no sentido de haver melhor comunicação e acesso às informações/discussões sobre a formação da escola indígena.

As medidas assistenciais prestadas deveriam se dar em apenas alguns momentos pontuais, de emergência, curtos espaços de tempo, porém, nesta aldeia, tornaram-se fato corriqueiro, diante da falta de terras e ambientes necessários à satisfação econômica da população indígena.

Esta assistência social embora necessária, mas não nesses moldes, não cobre as necessidades como um todo da população indígena. Sendo os recursos insuficientes para manutenção da Comunidade Indígena, a qualidade de vida e saúde desta população por todos os motivos expostos não apresenta nível razoável. Como veremos os indígenas do Oco’y apresentam níveis altos de anemia, desnutrição, subnutrição, verminoses, escabioses, diarreias, sendo ainda afetados, por águas contaminadas, por epidemia de malária e por contaminação por agrotóxicos, questões essas que poderiam ser preventivamente evitadas. E isto se dá em um contexto, em que a popu- 
lação indígena apresenta deficiências nutricionais pela falta de terras para o provimento alimentar básico. É de se imaginar a repercussão destas doenças sobre um estado geral de saúde deficiente.

As ações "assistenciais" como hoje estão configuradas, assistencialismo por si, sem visão de futuro, é também antieducativa, não resolvem os problemas estruturais de fundo, é imediatista, estabelece uma realidade inadequada e irreal, e ainda atinge o problema de forma superficial e relativa, pois não são alimentados adequadamente o conjunto populacional, a Comunidade Indígena. São 30 anos que os Guarani vem vivendo esta situação de "exceção", pela falta de terras.

Uma criança indígena que nasceu há 30 anos atrás neste contexto, período em que foram reassentados no Oco’y, cresceram e hoje são adultos. Diante da falta de território e ambiente adequado - direito fundamental às especificidades desta população - o que esta criança, hoje um adulto, aprendeu com seus pais sobre as espécies ambientais, sobre os recursos naturais de fauna e flora, sobre a infinidade de usos que seus pais conheceram para elas, se neste local, onde foram reassentados não existe quase o patrimônio físico necessário para viabilizar e realizar este patrimônio cultural? Gerações inteiras que nascem neste contexto, terão sérias dificuldades em produzir a própria subsistência.

Na verdade é antieconômico para o governo não dispor as terras necessárias aos indígenas, talvez em longo prazo gaste-se mais recursos monetários tentando "remendar, remediar o irremediável", do que, se ao contrário, se colocasse à disposição as terras e ambientes necessários a esta população viver, como lhe é de direito constitucional.

A unidade territorial/ambiental que deveria ser possível prover as necessidades de subsistência suficiente à população, não o faz, por falta de espaço físico. A renda monetária possível de ser adquirida é irrisória, não permitindo obter razoável poder de compra. Se o espaço não provê e nem é possível adquirir externamente, são obrigados a cair dependentes do assistencialismo, o qual a própria população indígena não possui qualquer controle, ficando a mercê de donativos para sobreviver, via de regra através de fornecimento irregular, comum entre as instâncias governamentais, haja visto, o próprio caso da FUNAI, que é o órgão indigenista responsável pela questão. Nos últimos anos (2004 em diante) a UHE Itaipu passou a oferecer cestas básicas à comunidade do Oco'y, e isto se tornou uma espécie de moeda de troca, em que ou se cumpre as determinações da hidrelétrica, que inclui inclusive que será o cacique de Oco’y, ou as cestas básicas não serão disponibilizadas, assim foi o relato de integrantes da comunidade neste ano de 2012, quando passamos por lá. Este estado de coisas gera o comprometimento econômico, sociocultural e de saúde de gerações inteiras. Ainda também apresenta o efeito de controle polí- 
tico sobre a comunidade indígena, na medida em que dependem de estranhos, para a viabilização de necessidades básicas como é o caso da subsistência alimentar.

É importante ressaltar que estes indivíduos quase não têm acesso ao mundo externo, é comum serem discriminados pelos não índios, possuem por seu lado claras dificuldades de inserção em um mundo culturalmente diferente do seu. Seu mundo interno, a aldeia, a Terra Indígena, na prática, lhes tem sido negado simplesmente o acesso, embora haja legislação clara que lhes assegurem este direito. Nesta situação qual será o destino destas populações se mantido este estado de coisas, senão a pobreza, o alcoolismo e a marginalidade social. O próprio Estado a quem incumbiria a proteção desses povos, vem coibindo esta população indígena, levando-a ao desespero. Exemplos não faltam, haja vista, a experiência acontecida com os Guarani do Mato Grosso do Sul com a fronteira com o Paraguai, índices alarmantes de suicídio. É o caso hoje de Naviraí/MT, os Guarani diante da falta de reconhecimento de suas terras, estão sendo ameaçados de reintegração de posse por parte da Justiça, que é aliada à fazendeiros na região. Os Guarani informam que se isso acontecer, se forem retirados de suas terras (hoje pequeno local na margem do rio) irão cometer suicídio coletivo. Essa é a opção mais curta e única, na visão destes Guarani, para atingir a Terra Sem Mal.

Os povos indígenas possuem o direito legalmente constituído de possuir territórios que satisfaçam as necessidades de sobrevivência física e cultural, e ainda, nos moldes socioculturais próprios e específicos como concebem praticar esta sobrevivência.

Todos estes fatos contradizem a legislação existente a qual determina a garantia dos direitos desse segmento populacional diferenciado por sua especificidade sociocultural. Caracteriza-se desta forma a questão do Oco’y no Paraná, como um desrespeito total a lei em vigor, ao Artigo 231 da Constituição Federal e Lei no 6001/ Estatuto do Índio.

\subsection{Condições sanitário-ambientais: qualidade das águas; saneamento em terra; malária; contaminação por agrotóxicos}

A partir da realidade ambiental verificada no Oco’y, a saber: - as precárias condições de captação e distribuição de água aos seus moradores; - as precárias condições de saneamento ambiental em terras; - a contaminação dos Avá por malária por estarem muito próximos, ao lado do reservatório de água; - e, a contaminação por agrotóxicos desses indígenas por aspersão 
proveniente das terras dos colonos lindeiros; por estas razões solicitamos a FUNAI o acompanhamento de ambientalistas do quadro, para analisarmos conjuntamente a situação.

Dois desses temas, "águas e agrotóxicos”, conseguimos obter alguma atenção do órgão indigenista, ainda que apenas de forma preliminar, diagnosticando a situação encontrada, porém, não conseguimos finalizar os trabalhos que propúnhamos a fim de oferecer algum suporte à comunidade indígena, através da continuidade das pesquisas, do apontar soluções, modificando dessa forma a qualidade da situação encontrada, objetivo primordial dos técnicos envolvidos.

As situações restantes acima apontadas foram apenas constatadas por mim; todas as situações citadas foram encaminhadas às autoridades responsáveis FUNAI, MPF e JF de Foz do Iguaçu, e por fim, a VI ${ }^{\mathrm{a}}$ Câmara de Coordenação e Revisão do MPF em Brasília, solicitando a todos providencias, com indicações do que poderia ser feito, em resumo, continuidade das pesquisas iniciadas, algumas medidas de mitigação e necessidade de compensação em outras terras.

Considerando que diversas aldeias Avá-Guarani sofreram com os impactos socioambientais e territoriais decorrentes da construção da UHE de Itaipu, antes de qualquer coisa é necessário apontar que a obra de construção da Usina Hidrelétrica de Itaipu foi realizada sem que houvesse Licenciamento Ambiental, a resolução CONAMA que exigia tal Licenciamento foi decretada em data posterior. Ainda assim, após a Resolução CONAMA estar em vigor, era previsto que a obra deveria apresentar ao IBAMA um Termo de Ajuste de Controle/TAC, revendo os impactos socioambientais e territoriais provocados; porém, apesar da exigência por varias vezes solicitada pelo IBAMA e até onde pudemos acompanhar esta situação no Oco’y (2007), jamais a Itaipu Binacional se submeteu as leis brasileiras ou paraguaias, alegando que por ser a obra produto de um “Alto Tratado Internacional” entre o Brasil e o Paraguai, que a empresa não seria obrigada a cumprir as leis de um ou outro país...???!!!

Dessa forma a Itaipu Binacional vem ao longo dos anos divulgando publicamente, que está de "forma espontânea" cumprindo seu papel diante dos problemas ambientais causados pelo empreendimento; portanto, a empresa vem fazendo "o que ela própria, de forma arbitrária, considera que deva ser feito" em termos de ações ambientais mitigadoras de impactos, e, assim não se submete ao que o IBAMA preconizaria nestes termos, muito menos segue diretrizes indigenistas que a FUNAI seria obrigada a seguir. 


\subsubsection{Qualidade das águas}

Inicialmente foi disponibilizada a presença do geólogo Mucio Nobre C. Ribeiro, ex-servidor do antigo Departamento de Patrimônio Indígena e Meio Ambiente/DEPIMA/FUNAI/SedeBrasília, o qual a partir de duas visitas a campo em dezembro de 2001 e abril de 2002 desenvolveu o trabalho “Terra Indígena Avá-Guarani do Oco’y: Diagnostico Preliminar da Qualidade das Águas" entregue em julho de $2002^{29}$. Em anexo encontra-se este trabalho na íntegra (Anexo 1).

O diagnostico preliminar de Ribeiro foi entregue como anexo ao Laudo Antropológico que desenvolvíamos sobre o contexto de vida na TI Avá-Guarani do Oco’y. Juntos passamos a analisar a situação no Oco’y.

Em maio de 1982 os Guarani foram reassentados no Oco’y. Somente dois anos depois, em 1984 a Itaipu Binacional fez o poço artesiano em um local que é denominado por eles de "ilha"30, localizado, a partir de quem chega no Oco'y, caminhando pela estrada existente na Terra Indígena pela vertente à direita, em direção ao seu extremo oposto, ao final desta estrada.

Somente treze anos depois, em 1997 a FUNASA puxou a rede de água "encanada"; na verdade, não está encanada, pois se constituem de mangueiras plásticas pretas que dispostas à flor da terra, se encontram desta forma expostas ao sol; por essa razão as águas chegam muito quentes, quase fervendo nas casas, não sendo possível quase sempre, segundo os Avá-Guarani, utilizá-las para beber ou se banhar devido a alta temperatura. Na oportunidade em que fazíamos a vistoria, os Avá apontaram que essa "água encanada" vem com ferrugem, em certos períodos do ano.

Desta forma enquanto não se construiu o poço artesiano e esta rede "encanada", os AváGuarani permaneceram durante 15 (quinze) anos utilizando para todos os diversos usos - beber, tomar banho, cozinhar, lavar roupas, dar de beber aos animais... - inicialmente, de maio a outubro de 1982, das águas do Córrego Santa Clara e em seguida, após sua inundação, das águas do reservatório da Itaipu; assim como, utilizaram também em todo o período e até hoje de algumas fontes de água menores (olhos d'água e nascentes) e alguns poços artesianos individuais abertos nas imediações das casas, os quais são próximos, a poucos metros, do reservatório da Itaipu.

\footnotetext{
${ }^{29}$ RIBEIRO, Mucio Nobre Costa. Terra Indígena Avá-Guarani do Oco’y. Diagnóstico Preliminar sobre a qualidade das águas. DEPIMA/FUNAI/Brasília. Julho/2002. 70p.

${ }^{30}$ Quando ocorreu a inundação do território para a criação do reservatório da Itaipu, esse fragmento de terras ficou ilhado do restante pelas águas, assim Itaipu aterrou o espaço entre terras no local, fazendo novamente a ligação com o restante das terras continentais. Ver Figura 13, canto superior direito da foto área da TI do Oco’y.
} 


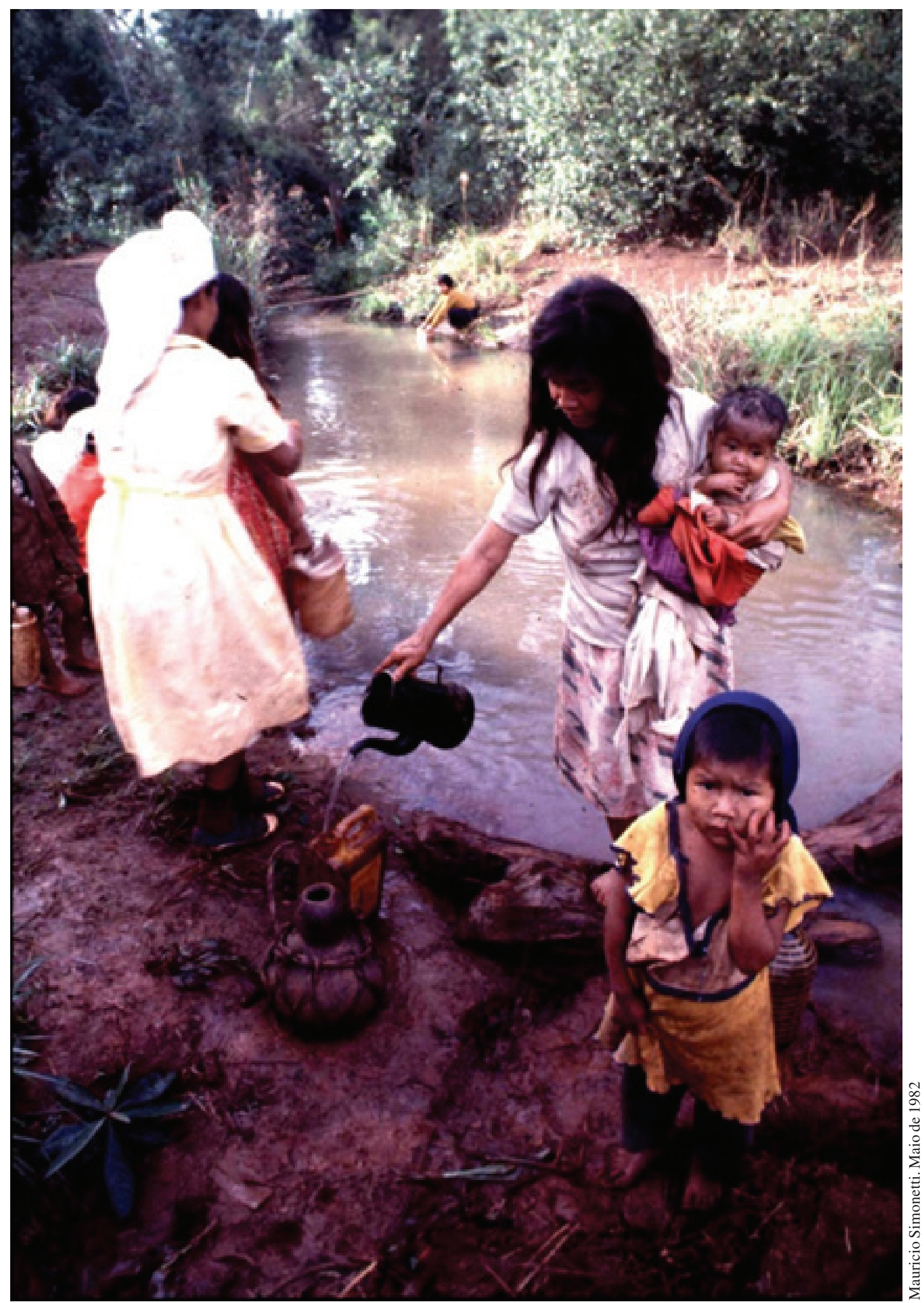

Figura 32. Foto. Acesso a água (barrenta, turva) quando passaram a viver no Oco’y em maio de 1982, o próprio Córrego Santa Clara, antes da inundação do reservatório da Itaipu. 


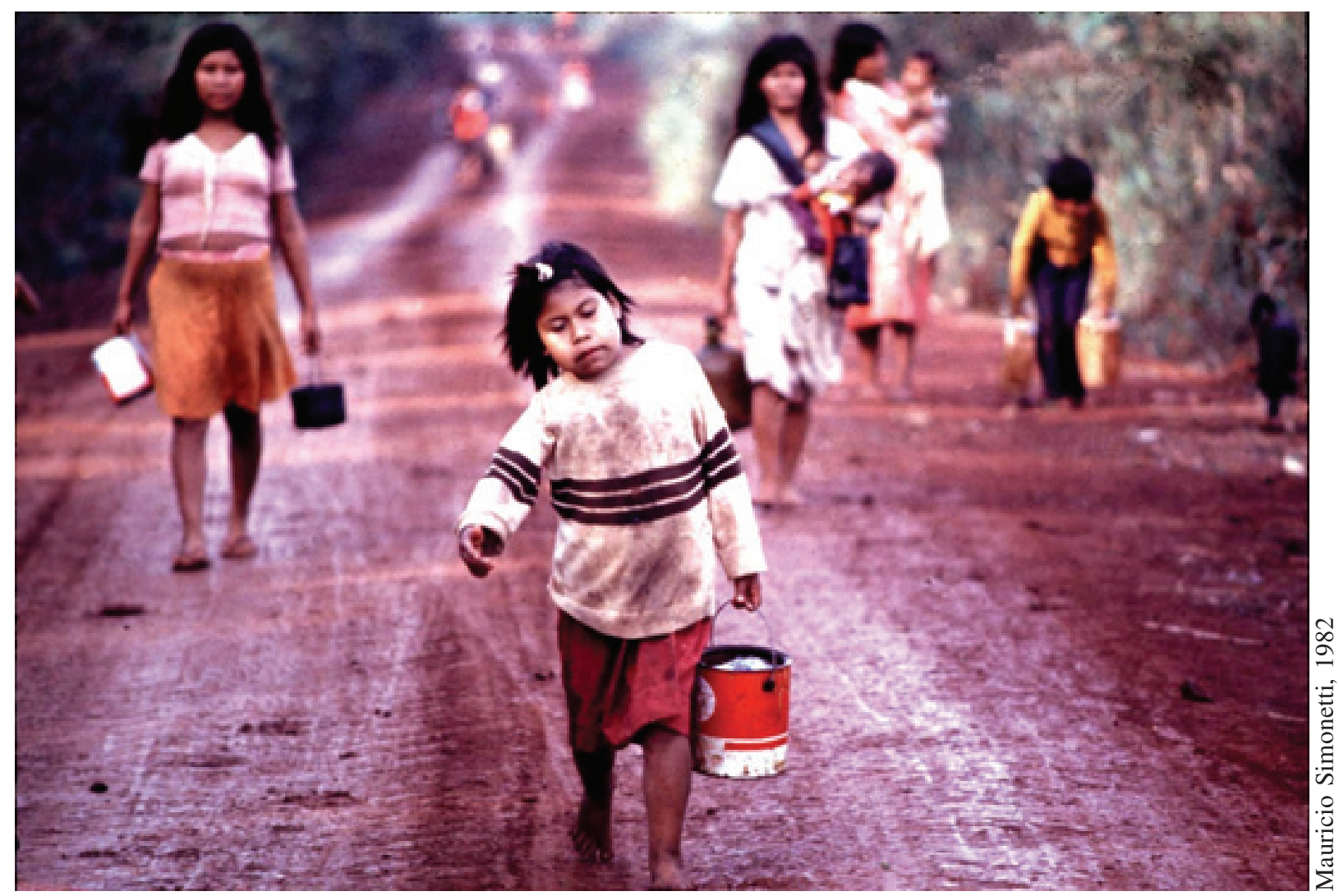

Figura 33. Foto. Acesso a água quando passaram a viver no Oco’y em 1982.

Nota-se através das fotos anteriores, a forma absolutamente imediatista e sem planejamento com que foram reassentados no Oco’y.

Segundo os Avá-Guarani, quando Itaipu se utiliza das águas do reservatório, reduzindo assim seu volume, os poços individuais das casas que se localizam próximos, quase que "secam", portanto, as águas dos poços são provavelmente as mesmas águas do lençol freático que abastece o reservatório.

Em 1997 quando a FUNASA puxou a rede de água "encanada", esta, porém, não teve a capacidade de abastecer todas as casas do Oco'y. Os Avá-Guarani relatam que a bomba d'água existente é insuficiente para puxar água de forma a abastecer todas elas. Em abril de 2002, verificamos que esta rede abastecia somente 43 , das 123 casas que haviam no local. As outras 80 casas, principalmente as que se encontram do lado oposto onde se encontra a bomba (na ilha), apesar de quase todas possuírem a "rede instalada", praticamente não possuem acesso, por falta d'água nas mangueiras, já que foram consumidas antes pelas casas que se encontram mais próximas do poço. Os Avá-Guarani afirmam que para todos que moram adiante das 43 primeiras casas ligadas a rede, falta água cotidianamente. Fato que faz com que eles continuem utilizando daquelas mesmas águas já descritas, quando não havia o poço e o "encanamento". 


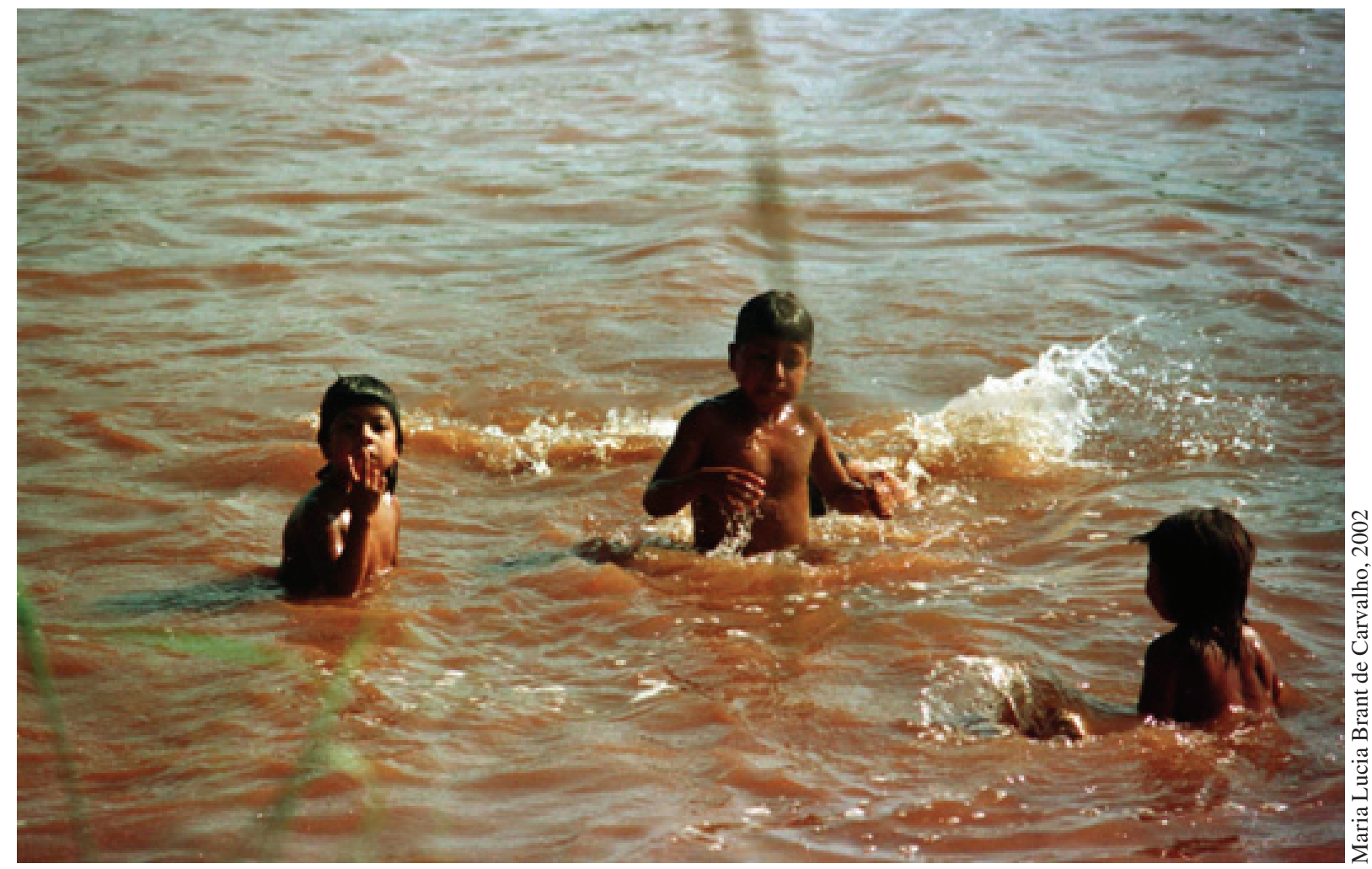

Figura 34. Foto. Crianças como de costume banhando-se no reservatório da Itaipu Binacional.

Mesmo as águas da rede que abastecem apenas as primeiras 43 casas, segundo os AváGuarani afirmam, - lembremos, não é possível beber a água proveniente dela, pois vem quase “fervendo de quente", devido à exposição da caixa d'água e das mangueiras ao sol.

Assim, a maioria dos Avá-Guarani utilizam, na verdade, cotidianamente, três qualidades de fontes de águas: alguns raros poços individuais ao lado de suas casas, quando os têm, as fontes de água menores (olhos d'água e nascentes) espalhados pela terra e as águas do reservatório da Itaipu. Todas essas águas são de qualidade questionável, estão em sua maioria, como veremos, contaminadas biológica e/ou quimicamente.

Em reunião com a FUNASA em Curitiba em 2001, foi declarado pelo engenheiro sanitário responsável, que a Instituição faz somente o controle de potabilidade das águas da rede geral; ou seja, daquelas águas que se apresentam na rede "encanada", nas 43 casas primeiras, as quais quase não é possível ser utilizada pelos Avá-Guarani, devido a água ser quente demais. E vimos que a maioria da população, na verdade utiliza todas as outras fontes, que não a da rede. Portanto, o controle de potabilidade das águas que os Guarani consomem de fato, não é realizado.

Esse controle mostrou-se ainda mais parcial, na medida em que indagando à médica da aldeia contratada pela FUNASA, sobre possíveis exames a serem feitos nos indivíduos, quanto à contaminação de agrotóxicos (na época, outubro/2001, ainda não tínhamos verificado todos os 
fatos aqui descritos relativos ás condições das águas) ela afirmou que: não é possível pela FUNASA detectar, pois os exames para agrotóxicos são específicos e a FUNASA, não faz..., só faz os de potabilidade.

Ao que foi respondido, ora sendo a FUNASA institucionalmente responsável pela saúde indígena, se ela não possui capacidade técnica para realizar os exames a respeito da contaminação por agrotóxicos, que encaminhe então a situação, para quem os faça. Como veremos à frente, ao analisarmos as questões relativas aos agrotóxicos, foi solicitado oficialmente providências junto FUNASA.

O tema referente à "qualidade das águas", devido sua especificidade técnica, a nosso pedido foi desenvolvido pelo geólogo Mucio Nobre da Costa Ribeiro do DEPIMA/FUNAI/Bsb. Relato abaixo o que foi realizado por nós, mais especificamente analisado pelo geólogo.

Ao buscarmos subsídios técnicos com relação ao componente ambiental, avaliamos que a melhor fonte para isso seria os arquivos da própria Itaipu. Assim no dia 09.04.2002 as 16 hs, fomos ao encontro do responsável técnico na Itaipu pela questão indígena, João Carlos Zehnpfennig, o qual nos recebeu e além do pedido de dados, protocolamos o documento $\mathrm{n}^{\circ} \mathrm{GB}$ FI/2002/00120-0, com pedido formal de informações específicas, dirigidas ao Dr Antonio Correa Ribas, na época Diretor Geral da Itaipu Binacional (Anexo 2). Nunca foi respondido.

Dessa forma, outro trabalho veio a contribuir para analise ambiental pretendida. Dado que segundo Ribeiro um dos mais importantes parâmetros para o estudo de qualidade ambiental é a qualidade da água, foi acessado o relatório denominado "Avaliação sanitária das águas destinadas para consumo na Reserva Avá-Guarani, Aldeia Oco’y em São Miguel do Iguaçu” de autoria de duas biólogas, Jussara Nascimento Hickson e Maria Lucia S. R. Dalla Costa, ambas do Instituto Ambiental do Paraná-IAP, realizado no período de 19 a 29 de março de 2001. Trabalho que se encontra anexado ao trabalho de Ribeiro no Anexo 1.

Em resumo abaixo algumas das constatações de Ribeiro:

- A TI Oco’y possui um sistema de distribuição de água bastante precário, onde o processo de cloração é feito de forma manual. O cloro é colocado em uma caixa d'água com capacidade de 250 1, pelo agente de saúde no período da manhã. O agente precisa caminhar $3 \mathrm{~km}$ para esta tarefa. A rede de água possui uma extensão de $10.050 \mathrm{~m}$, com um único reservatório com capacidade para 10.000 1, que se encontra distante a aproximadamente $8.000 \mathrm{~m}$ do poço artesiano (RIBEIRO:2002:4); - O sistema de abastecimento de água está deficiente no seu dimensionamento para o abastecimento de todas as casas na aldeia... (p. 4); 
- Não existem reservatórios de água adequados nas moradias indígenas para guardar as águas da rede, o que provoca o armazenamento da água de consumo direto e uso nas tarefas do lar em locais impróprios... facilitando a contaminação (p. 4);

- Há "indícios de contaminação por coliformes, que confirmam a precariedade e falhas das instalações na rede de distribuição, tanto quanto na ausência de estrutura adequada nas instalações de abastecimento de água que servem as residências indígenas” (p. 5);

- Constatamos o estado de abandono das instalações sanitárias na maioria das casas e verificamos a existência de condições sub-humanas a que está submetida a população Guarani (p. 5);

- Constatamos que o atual sistema de abastecimento de água encanada que já é precário nas instalações, necessita de ampliação para atender as inúmeras famílias e devido a essa carência de instalações adequadas, boa parcela dos índios utiliza água in natura proveniente de pequenos olhos d'água concentrados em maior quantidade nos níveis topográficos mais elevados em relação ao nível d'água do reservatório da Itaipu... . Esses pequenos olhos d'água não possuem qualquer tipo de proteção ou estrutura adequada de captação... que promovem ambiente propício para a proliferação de bactérias nocivas a saúde (p. 6);

- Notamos que existem muitos pontos de uso d'água nas margens da área alagada pela Itaipu, o que deixa a desejar a qualidade dessa água. Não é recomendável que os índios continuem a consumir essa água “in natura”. Enquanto não tivermos maior controle sobre essa água, recomendo que todos sejam interditados. Qual vai ser a alternativa de água para consumo para suprir as necessidades diárias dos índios? (p. 6);

- Constatamos que existem na TI muitos pontos de pequenas surgências naturais de água (olhos d'água) que ainda precisam ser mapeados... e que merecem ser melhor protegidos e monitorados na sua qualidade, pois os mesmos possuem um papel importante no "abastecimento alternativo" de água da população indígena (p. 7);

- os índios estão completamente desassistidos de uma política direcionada a educação ambiental associada a parâmetros práticos de controle e monitoramento da qualidade da água (p. 8);

- os índios não recebem orientação educacional sobre a proteção de poços e uso das instalações sanitárias, o que acentua os riscos à saúde das famílias, notadamente das crianças que ficam mais sujeitas ás doenças ligadas ao baixo padrão sanitário (p. 10);

- FUNAI e FUNASA deveriam promover uma campanha ampla com elaboração de cartilha com essas informações básicas...(p. 10);

- do total de 123 construções de uso indígena (incluindo Casa de Reza e Posto Indígena), 91 das casas possuem instalação de rede de água com saída no terreno, porem nem todas chegam água, segundo os Guarani somente chegam água em 43 casas; 26 casas não possuem nem água encanada, nem pontos de água naturais, utilizam água de poço ou água encanada de terceiros (p. 10); 
Outra questão verificada foi a do cemitério indígena. A Itaipu Binacional em 1984 construiu o poço artesiano na "ilha", local onde já estava instalado o cemitério indígena em suas proximidades, a menos de 30 metros, em local topograficamente acima do poço. Desta forma as águas desse poço, estão provavelmente passíveis de contaminação pelos restos mortais enterrados no cemitério Guarani, segundo se referiu Ribeiro (2002:15):

É preciso realização de analise especifica da água, para verificar eventuais conteúdos de Nitrato, Nitrito e Fosfato, decorrentes de líquidos originados da putrefação de corpos humanos que poderiam penetrar no solo e contaminar as águas do aquífero referente aquele poço artesiano.

Assim os Avá-Guarani ao se utilizarem dessas águas do poço da Itaipu é provável que passaram a consumir também partículas de cadáveres de seus parentes. Essa analise também, apesar dos encaminhamentos feitos, não foi a frente.

Ribeiro como eu, viu com preocupação também a questão dos agrotóxicos, questão que será detalhada a frente. Como vimos anteriormente, segundo relato dos Guarani, por meio das chuvas que carreiam para dentro do reservatório os agrotóxicos aplicados pelos colonos lindeiros ao Oco’y, os peixes morrem principalmente no verão, contaminados.

Os Guarani associam também à época das chuvas de verão, haver entre eles sempre muita diarreia, diarreia com sangue, muito provavelmente e novamente pela mesma razão, é nas chuvas de verão que os agrotóxicos utilizados pelos colonos, são mais intensamente carreados para o reservatório e para a própria Terra Indígena, na medida em que primeiro passam por ela, para depois chegar ao reservatório.

Ribeiro afirmou: "Vários índios Guarani nos relataram que logo após os períodos de "bater o veneno" no terreno por parte dos colonos vizinhos, poucas horas depois aparecem animais mortos como galinhas a até cachorros dentro da área indígena”. (RIBEIRO: 2002:17)

Toda a área de captação da microbacia do Córrego de Santa Clara está sujeita a contaminação por agrotóxicos, segundo afirmou o geólogo Ribeiro, técnico da FUNAI requisitado pelo Laudo Antropológico (2002) para analisar a questão. A maioria dos olhos d'água utilizados pelos índios, examinados pelo geólogo, estão sob a influência vizinha das áreas plantadas com os agrotóxicos, provenientes da aplicação realizada pelos colonos lindeiros ao Oco'y.

Após observar a invasão territorial por parte dos colonos vizinhos na terra indígena, que plantam com agrotóxicos em todo o seu entorno, produtos estes letais a saúde, Ribeiro afirmou: 
Além da possível penetração dos agrotóxicos no solo, temos que ter em mente que esses produtos de alto poder letal tendem a se acumular nos organismos de homens e animais, peixes e vegetais. Portanto, para termos uma resposta exata das possíveis contaminações desses produtos na população indígena Guarani é prudente que façamos em caráter emergencial uma coleta sistemática de sangue, cabelo e urina prioritariamente daqueles índios que estejam situados nas residências mais próximas dos limites das plantações dos colonos, ou seja, quase a sua total maioria. Para um controle maior sugere-se a coleta de solos, peixes e plantas em locais mais expostos ao acumulo dessa contaminação. Isso seria feito através de uma previa analise de parâmetros de declividade de terreno, amostragem de tipos de solos e plantas que possuem características próprias para maior acumulo dessas substancias nocivas (RIBEIRO: 2002:17-8).

Em resumo, conforme análise do IAP, relatada por Ribeiro, essas águas apresentam-se contaminadas por coliformes fecais e totais; Foi verificado que os poços individuais são em sua maioria descobertos ou precariamente cobertos, contendo não raras vezes insetos. Ainda essas águas estão sujeitas a contaminação pelo uso de agrotóxicos, já que a maioria dos acessos às nascentes e olhos d'águas, se encontram próximos ou dentro das plantações dos colonos lindeiros, na mesma microbacia.

Então até esta análise (2002) a opção disponível de águas das 80 casas que não recebem água da rede, de um total de 123 casas, eram essas, utilizavam as águas do lago e de poços menores, assim como de olhos d'água na mata, contendo muito provavelmente coliformes fecais, totais e agrotóxicos. Descrevem os índios que ao consumir estas águas "dá diarreia e coceira". A partir de 1997, as 43 casas que passaram a sub-utilizar ás águas da rede (pois vem muito quente), é provável que estejam utilizando-as também, com restos mortais de seus parentes.

Por fim Ribeiro faz no item VI - Recomendações Técnicas Emergenciais (Ribeiro:2002:212); no item VII - Conclusões Finais (p22 a 25); e por fim, no item VIII - Sugestões Emergenciais ao Ministério Publico Federal (p25). É importante acessá-las.

O que se observa quanto as águas é que diretrizes mínimas sobre o direito ao acesso a água em qualidade e quantidade não foram observadas na Terra Indígena do Oco’y. A Lei 9.433 de 08.01.1997 que instituiu a Política Nacional de Recursos Hídricos e criou o Sistema Nacional de Gerenciamento de Recursos Hídricos, assim determina:

Capítulo II - Dos objetivos:

Artigo $2^{\circ}$. São objetivos da Política Nacional de Recursos Hídricos: 
I - assegurar à atual e às futuras gerações a necessária disponibilidade de água, em padrões de qualidade adequados aos respectivos usos;

Capítulo III- Das Diretrizes Gerais de Ação:

Artigo $3^{\circ}$. Constituem diretrizes gerais de ação para implementação da Política Nacional de Recursos Hídricos:

I - a gestão sistemática dos recursos hídricos, sem dissociação dos aspectos de quantidade e qualidade;

II - a adequação de gestão de recursos hídricos às diversidades físicas, bióticas, demográficas, econômicas, sociais e culturais das diversas regiões do país;

III - a integração da gestão de recursos hídricos com a gestão ambiental;

A questão dos recursos hídricos no Oco’y, mais uma vez, também não foi pautada pelo que a legislação determina. Ribeiro em seu trabalho indica em pormenor toda a legislação a respeito adequada aos casos citados.

Assim, dever-se-ia rever muita coisa nesta Terra Indígena, o conceito de proteção de microbacias hidrográficas, visando proteger as nascentes, minimizando os impactos de ordem externa; assim como ser cumprida a própria legislação, no que se refere ao uso exclusivo do território pela população indígena; rever a questão da distancia legal entre pulverização de agrotóxicos e população humana; o acesso a água potável em qualidade e quantidade necessária a população indígena, e ainda muitas outras coisas aqui citadas.

O trabalho denominado “Terra Indígena Avá-Guarani do Oco’y: Diagnóstico Preliminar sobre a Qualidade das Águas”, de julho de 2002, foi entregue junto ao Laudo Antropológico, "O Contexto atual vivido pela população indígena Avá-Guarani na Terra Indígena do Oco’y/São Miguel do Iguaçu/Pr” (Brant de Carvalho:2002), à todas as autoridades responsáveis pelo caso, a saber FUNAI, MPF e JF de Foz do Iguaçu. Mais tarde também foi entregue para a VI ${ }^{\mathrm{a}}$ Camara de Coordenação e Revisão do MPF -Brasília. Foi pedido em ambos os trabalhos, o desenvolvimento de averiguação técnica (Laudo Técnico Pericial) quanto a qualidade das águas consumidas, através de solicitação direta ao MPF de Foz do Iguaçu, porém, não houve nenhum retorno das instituições, neste sentido.

Após a entrega dos dois trabalhos, foi construído pela FUNASA mais uma caixa d'água, tornando o sistema de abastecimento de água na aldeia relativamente mais adequado. 


\subsubsection{O saneamento em terra}

Quanto à manutenção das condições sanitárias nas próprias terras do Oco’y, as práticas tradicionalmente exercidas pelos Avá-Guarani não podem ser aplicadas a contendo, isto porque esses indígenas não podem sair do lugar, revezando de ambientes, falta espaço físico também para a realização dessas práticas as quais requerem uso e pousio, novamente alternância da população de ambientes.

Em terras indígenas suficientes, tradicionalmente as práticas de saneamento do ambiente se dão da seguinte forma: um ambiente que foi habitado pela comunidade indígena, agora já abandonado, com a falta de uso humano e de incremento de novos detritos (lixos orgânicos), combinado com as forças naturais dos ventos, do sol e das chuvas, as próprias forças da natureza se encarregam de sanear o ambiente; deve-se considerar que o "lixo", antes do contato, era todo orgânico e desfazia-se naturalmente, através dessas forças. Dessa forma, enquanto a comunidade habitava outro ambiente, o anterior era submetido a este saneamento natural, podendo retornar a população após um período de tempo considerável (20 a 30 anos) novamente para o ambiente inicial, tornado de novo saudável.

No caso de Oco’y fixados permanentemente nos mesmos locais pela exiguidade territorial a que foram obrigados, este processo de sedentarização levado às últimas consequências, gera o uso continuado dos mesmos espaços, somado ao incremento de novos detritos que diuturnamente chegam nas aldeias, agora, não só orgânicos. Na medida em que o ambiente naturalmente nunca pode se reciclar, pelo uso e pousio, consequentemente as condições sanitárias em que a população indígena esta submetida, progressivamente vai ficando cada vez mais comprometida.

Como agravante, as populações indígenas passaram após o contato com a sociedade nacional, a não só possuir lixos que não se deterioram nas aldeias, como também passaram a criar animais domésticos. A criação de animais para a finalidade de alimentação, não era costume indígena, a proteína animal que necessitavam, caçavam longe das residências. Esse costume foi "importado" de nossa sociedade, devido talvez a falta de proteína proveniente da caça ou mesmo a adoção de um costume cultural do não índio. Estas criações em todas as aldeias não se dão em cativeiro, e, no caso de Oco’y, diante da absoluta falta de espaço físico, se dão sobre as roças, soltos por entre os indivíduos, ao lado das casas, sendo que a maioria dos cães, galinhas e porcos, encontram-se todos juntos com os seres humanos, convivendo nos mesmos espaços. Em um lugar que falta comida até para os humanos, como esperar que manejem os animais em cativeiro? 
Adquiridos estes costumes, aliados à profunda sedentarização imposta no Oco'y por falta de espaço físico, é provocado assim, mais contaminação e mais doenças, resultando em inúmeras moléstias como verminoses, escabioses, doenças de pele, entre outras doenças; os casos são muito recorrentes, principalmente entre crianças. Os remédios que são utilizados, por exemplo, os vermífugos, se utilizados de forma muito recorrente, como na verdade são de fato, destroem a flora intestinal dos indivíduos, deixando de possuir assim os necessários “cílios" nos intestinos, os quais ajudam na evacuação. É comum nas aldeias fezes com sangue, indivíduos com intestinos ressecados, um dos resultados da ação de tanta medicação intensiva e falta de atenção preventiva. Assim o que se vê nas terras indígenas é que ataca-se as consequências e não as causas das doenças, entre outras razões, por falta de informação indigenista e de atenção à saúde de forma preventiva.

\subsubsection{A malária}

Como vimos antes, a população indígena habitar a APP, ao lado do reservatório de Itaipu é inapropriado. Isso se aplica também ao que se refere ao ambiente sanitário. A população indígena convive excessivamente próximo ás margens do reservatório, o qual permanece por longo período com volume constante, ou seja, com "água parada principalmente nas bordas" 31 , assim ali se tornou local ideal para o desenvolvimento do mosquito "Anófheles", transmissor da malária. Na água parada ele se reproduz. Basta haver uma pessoa contaminada com a doença, para que o mosquito ao picá-lo, retransmita a malária para todas as outras pessoas que picar. Como várias pessoas passaram a estar contaminadas e os mosquitos se reproduzem à todo instante, o caso se tornou uma epidemia de significativas proporções entre os Guarani do Oco’y. Até o ano de 2002 houveram 83 indivíduos que foram contaminados, sendo que 17 deles eram gestantes, o que agrava o caso, na medida em que elas não deveriam tomar neste estado, o medicamento. O Posto de Saúde da TI do Oco'y informou que somente nos meses de março e abril de 2002, houveram 37 casos. A malária que contraem é do tipo Vivax.

Segundo matéria do jornal Gazeta do Povo de 17.05.2002 sob o título "Surto de malária atinge 37 índios. A maioria são crianças Avá-guarani da reserva de Ocoí” (Anexo 3), assim relata a respeito da epidemia de malária na aldeia do Oco’y: a grande incidência da doença colocou as

\footnotetext{
$\overline{31}$ Em frente ao Oco’y o reservatório significa apenas um, dos tantos pequenos braços de lago que formou o reservatório de Itaipu.
} 
autoridades sanitárias em alerta porque a média histórica anual no local é de no máximo sete ou oito casos.

A Terra Indígena Avá-Guarani do Oco’y é o único local do estado do Paraná onde existe o problema, a manifestação de forma epidêmica de malária. Não por acaso também é o único local da APP do reservatório da UHE de Itaipu, onde ocorre habitação de população humana, os AváGuarani.

Ao indagar ao funcionário da Secretaria Municipal de Saúde (abril/2002) que realizava o controle da malária na TI (Figura 35), quantos casos mais, excluídos os da aldeia, haviam sido registrados na região, foi respondido: somente três casos, três pescadores que foram pescar no lago de Itaipu. Se três pescadores em pescaria esporádica estão sujeitos a contrair malária, os Guarani que habitam sem outra alternativa às margens do reservatório, estarão constantemente sujeitos a sofrer da doença, já que o mosquito normalmente reproduz-se ali. Se ninguém mais contraiu a doença, com exceção dos três pescadores, provavelmente ninguém mais reside como os Guarani, tão próximos do reservatório. Mostra-se assim mais uma vez, a inviabilidade do reassentamento dos indígenas ter se dado nestas terras, às margens do reservatório da Itaipu.

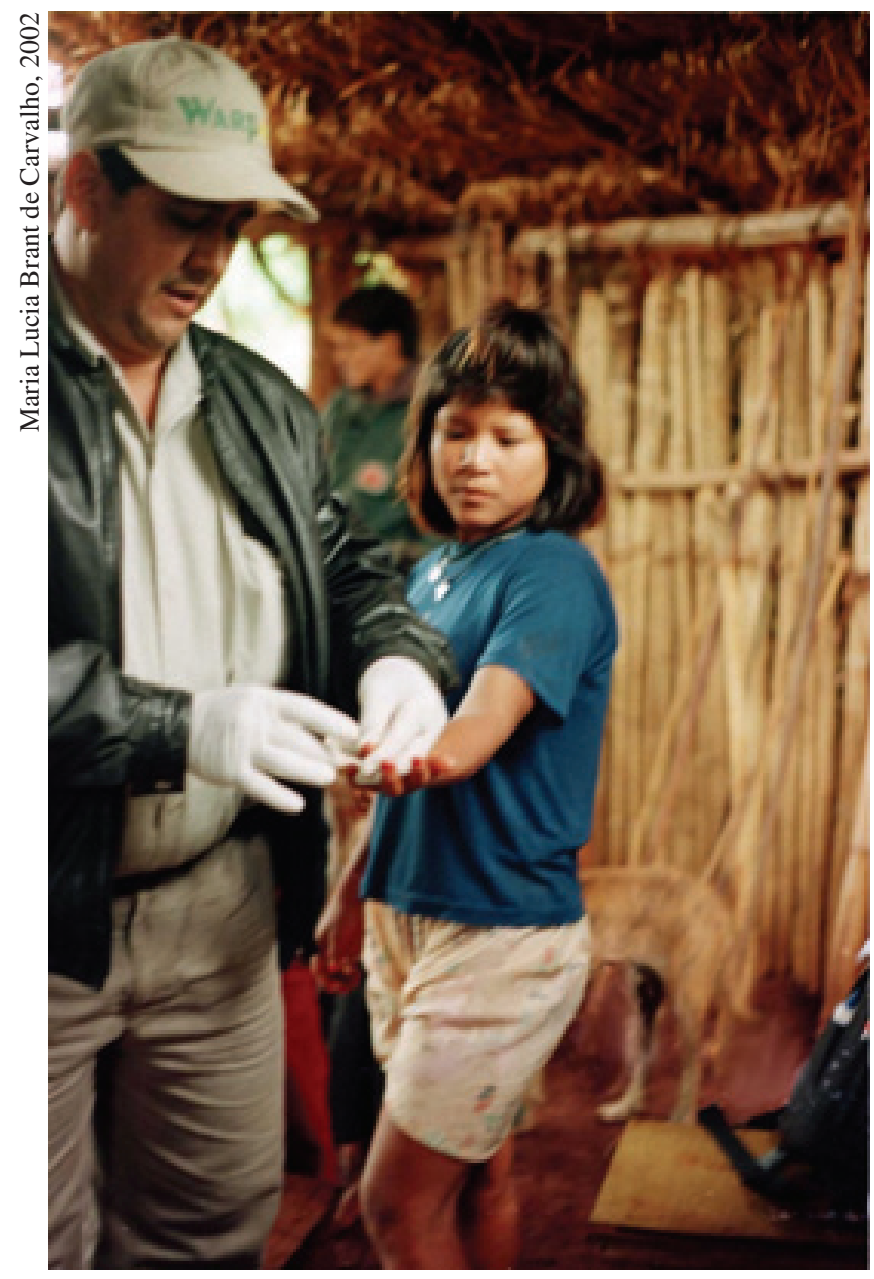

Figura 35. Foto. Funcionário da Secretaria Municipal de Saúde de São Miguel do Iguaçu (04/2002) colhendo lâmina p/ diagnóstico e controle de malária no Oco’y 
Ao entregarmos o Laudo Antropológico (2002) questionávamos ao MPF e JF de Foz do Iguaçu sobre a legalidade de qualquer núcleo populacional viver às margens do reservatório da Usina Hidrelétrica de Itaipu, ao que não houve qualquer retorno efetivo, nem a nós nem aos habitantes da aldeia.

Assim a FUNASA passou a tratar dos casos de malária, tanto os infectados, como no sentido preventivo, de tentar conter a instalação do próprio mosquito. Em áreas endêmicas de malária normalmente é feito borrifação para debelar o mosquito, assim é solicitado que a população indígena se afaste do local por pelos menos alguns dias, dada a toxidade do produto. Porém, no Oco’y, segundo depoimentos indígenas, a borrifação é feita na presença dos mesmos, na medida em que não há espaço físico para o afastamento da população durante a aplicação. Resulta daí que o produto borrifado também provavelmente contamina a população indígena de forma irremediável, já que ela permanece diariamente na mesma área de terras exposta à aplicação, assim objetivando o próprio controle da doença, o feito produz nova contaminação dos indígenas, agora com o produto químico.

\subsubsection{Os agrotóxicos}

Criação de abelha não deu certo porque o veneno dos colonos matava os bichinhos, ele posava lá e morria, vai na soja e no trigo do colono e traz o veneno para a caixinha...

Seu Honório Guarani

Outubro/2001

Limítrofes às bordas externas da Terra Indígena do Oco’y, inicia-se as glebas de terras dos colonos, os quais possuem outro modo de gestão territorial, o que se caracteriza em outro problema. Como vimos, as áreas agrícolas desses colonos, somadas em seu conjunto apresentam dimensões maiores que a Terra Indígena, se encontram em ambientes totalmente desmatados, com monoculturas instaladas, o que de antemão não contribui para a existência de fauna - a necessária caça - fonte de proteína animal, muito escassa na região e que compõe a subsistência dos Avá-Guarani.

Os colonos ao pilotar seus tratores, quando fazem a curva nos limites da Terra Indígena, invade-a, tomando na extensão da área reservada aos indígenas cerca de 14 linhas de milho, variando a depender do local em torno de 2, 4 a 7 metros de terras paralelas à Terra Indígena, por 
praticamente toda a sua extensão (7 Km) (Figura 36 e 37). Pelo cálculo apresentado inicialmente, somam aproximadamente 4,9 hectares perdidos, chegando o avanço da invasão na atualidade ao limite extremo, agora até a estrada, a qual passava antes, por dentro somente da Terra Indígena.

Estas terras perdidas entre a estrada indígena e o limite entre áreas pelo acordo entre FUNAI e Itaipu Binacional são de posse indígena e propriedade da União. Embora seja pouca a quantidade perdida, se levarmos em consideração a exiguidade da área total para os Guarani, ela se torna significativa. Todavia, não é este espaço devolvido que vai solucionar o problema fundiário do agrupamento indígena. A pergunta seguinte seria porque os colonos invadem essa área? Porque não é tomada nenhuma providência judicial, apesar de solicitado pelo Laudo Antropológico ao MPF e JF de Foz do Iguaçu? Estas indagações serão esclarecidas no capítulo 5, quando for verificado como as terras do Oco’y passaram a se constituir Terra Indígena.

Excessiva limitação das atividades de subsistência na própria Terra Indígena, o entorno totalmente desmatado, invasão pelas monoculturas dos colonos da já diminuta área de terras do Oco'y, neste contexto foi detectado como mais um agravante da situação, a proximidade dessas roças de soja, milho, trigo e aveia, que se alternam conforme a época, dos colonos lindeiros à Terra Indígena, e, com elas seu respectivo manejo.

Nos vários estágios de cultivo desses produtos são utilizados agrotóxicos como "herbicidas" para o desmate do campo, visando eliminar a vegetação a fim de instaurar os plantios, "fungicidas e bactericidas" para eliminar fungos e bactérias que aparecem em tais plantios em certo estágio inicial de seu crescimento, e, por fim, "inseticidas" para eliminar os insetos que atacam as plantações já crescidas. Algumas vezes no Oco’y foi presenciado a aplicação desses produtos, o odor fétido que permanece no ar é insuportável, as reações causadas nas pessoas, essas serão descritas à frente.

O remanescente florestal que aparece ao fundo na foto abaixo, corresponde a largura de terras que era de posse indígena, ainda na margem esquerda da estrada. Em primeiro plano notase a invasão dos colonos com o plantio de milho. 


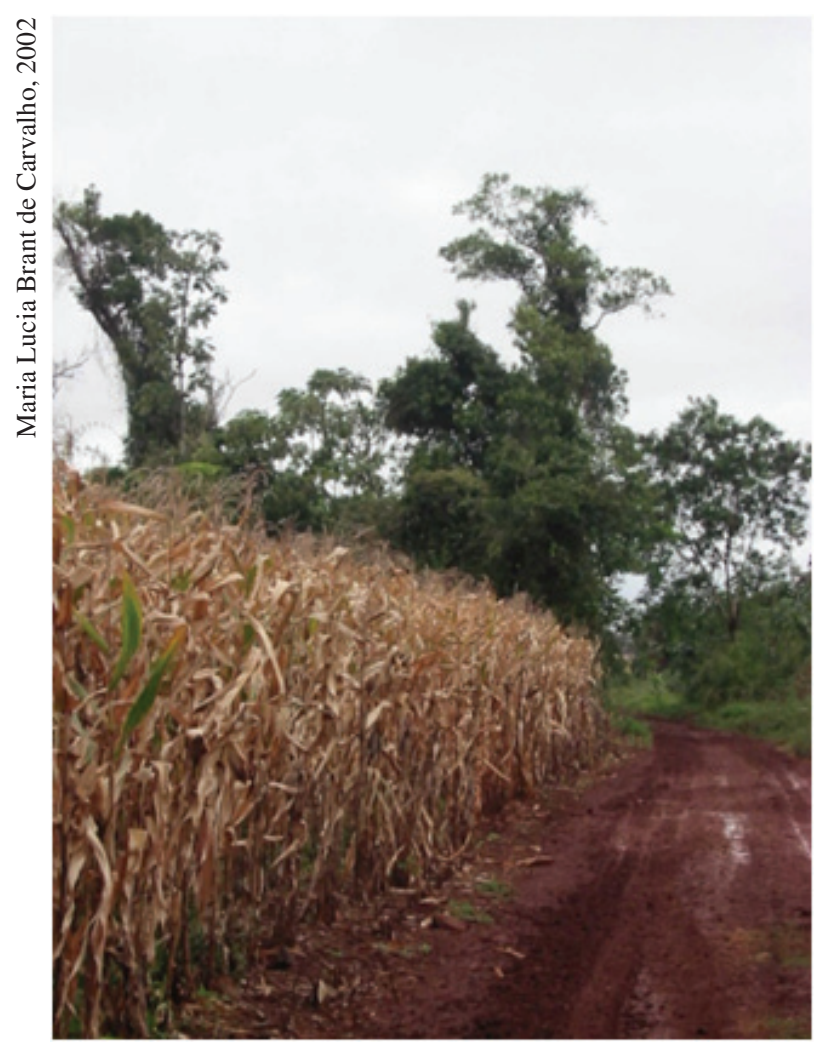

Figura 36. Foto. Invasão dos colonos I.

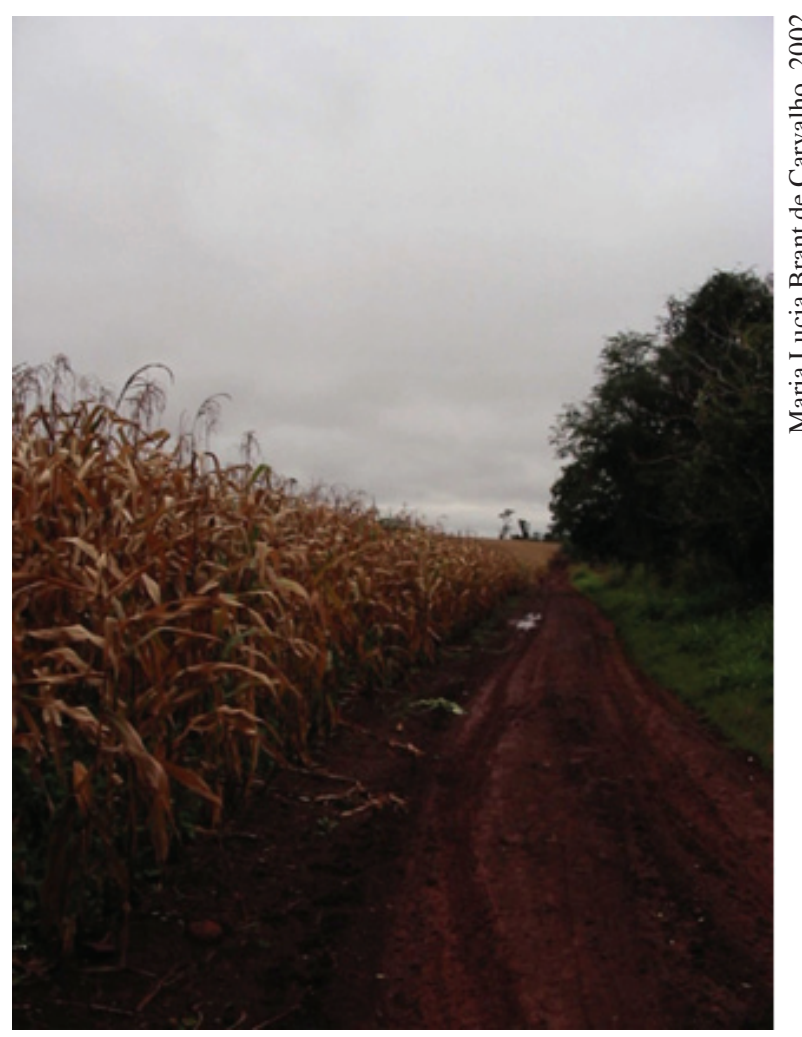

Figura 37. Foto. Invasão dos colonos II.

O mesmo plantio de milho, foto acima, ao longo de grande extensão da margem esquerda da estrada, no interior dos limites da Terra Indígena do Oco'y, que se encontra tomado pelos colonos. $\mathrm{O}$ mesmo remanescente florestal da foto anterior, avista-se ao fundo na foto e à esquerda.

A Tabela 3.7., refere-se ao histórico de aplicação, relatado por não índios, parentes de agricultores da região, durante um ciclo anual de borrifação de agrotóxicos nas áreas circunvizinhas ao Oco'y; apresenta os tipos de produtos utilizados para o milho e a soja, sua finalidade, época de ocorrência, demonstrando que durante o ano todo esses produtos tóxicos são utilizados no local, ou seja, no entorno e no interior da área invadida da Terra Indígena. 
Tabela 3.7. Histórico de aplicação em ciclo anual de borrifação dos agrotóxicos

\begin{tabular}{|c|c|c|}
\hline Produto/atividade & Finalidade & Época de ocorrência \\
\hline $\begin{array}{l}1^{\circ} \text { aplicação de secante } \\
\text { (herbicida) }\end{array}$ & Seca a soja antecipando a colheita & Fim de janeiro/início de fevereiro \\
\hline $\begin{array}{l}2^{\circ} \text { aplicação de 2-4-D } \\
\text { (herbicida) }\end{array}$ & $\begin{array}{l}\text { Elimina as ervas daninhas, início } \\
\text { do ciclo do milho }\end{array}$ & Fim de fevereiro/início de março \\
\hline $3^{\circ}$ plantio de milho & & Início de março \\
\hline $4^{\circ}$ aplicação de herbicidas & $\begin{array}{l}\text { Elimina as folhas largas das } \\
\text { ervas daninhas que } \\
\text { prejudica o desenvolvimento } \\
\text { do milho }\end{array}$ & Março/abril \\
\hline $\begin{array}{l}5^{\circ} \text { aplicação de fungicidas e } \\
\text { bactericidas }\end{array}$ & $\begin{array}{l}\text { Quando o milho está com } 8 \text { dias } \\
\text { é aplicado para eliminar } \\
\text { fungos e bactérias }\end{array}$ & Março/abril \\
\hline $6^{\circ}$ colheita do milho & & Final de junho/ julho \\
\hline $1^{\circ}$ aplicação de herbicidas & $\begin{array}{l}\text { Para eliminar as folhas } \\
\text { estreitas de ervas daninhas }\end{array}$ & Agosto \\
\hline $2^{\circ}$ plantio de soja & & Setembro/outubro \\
\hline $\begin{array}{l}3^{\circ} \text { aplicação de fungicidas } \\
\text { e bactericidas }\end{array}$ & Eliminar fungos e bactérias & Outubro/novembro/dezembro \\
\hline $\begin{array}{l}4^{\circ} \text { aplicação de secante } \\
\text { (herbicida) }\end{array}$ & $\begin{array}{l}\text { Seca a soja antecipando a } \\
\text { colheita (aplicar de } 5 \text { a } 7 \\
\text { dias antes da colheita }\end{array}$ & Fim de janeiro/início de fevereiro \\
\hline
\end{tabular}

Organização: Maria Lucia Brant de Carvalho, 2002.

Em relato de entrevistados, filhos e sobrinhos de colonos que enxergam como inadequada a aplicação do produto em suas próprias glebas, foi dito que seus parentes adquirem vários produtos agrícolas (agrotóxicos) no Paraguai, onde são mais baratos e não sofrem a fiscalização brasileira. Dessa forma estas embalagens não são devolvidas, como fazem obrigatoriamente com os produtos brasileiros depois de utilizados, em função do controle municipal/estadual. Os produtos “importados” são proibidos no Brasil, sendo seus níveis de intoxicação ignorados na região. Vários colonos do entorno do Oco’y os utilizam. Nos foi fornecida algumas dessas embalagens.

A questão da contaminação por agrotóxicos já seria considerada ambiental e sanitariamente grave por estar sendo aplicado em áreas de terras limítrofes à Terra Indígena, muito próximo ao 
núcleo populacional. Essa aplicação realiza-se não só limitada a área vizinha, mas como no próprio interior da Terra Indígena, por invasão, sendo aplicados os produtos tóxicos, frente à frente às habitações indígenas.

O fato que daí resulta digno de se fazer aplicar a legislação vigente é a intoxicação que a população Guarani vem sofrendo com relação à contaminação da própria área da Terra Indígena, em todo seu entorno, por meio das monoculturas vizinhas. Vejamos como se dá esse processo.

Esta TI por ser de ínfima dimensão e muito estreita, como já descrito, apenas 134,72 metros de largura em média atualmente, nesta diminuta área encontram-se as casas indígenas seguidas umas às outras, e por conseguinte toda a vida da aldeia: os quintais das habitações, as pessoas, os animais de criação, as roças e seus produtos, as áreas de coleta e seus produtos, o reservatório e os peixes que ali habitam, e por fim, fontes de águas menores de uso individual e coletivas. As monoculturas localizam-se muito próximas, emparelhadas, espacialmente seguidas pela estrada da Terra Indígena. Estes locais e, por conseguinte, toda a vida contida neles, estão sujeitos ao manejo praticado através do uso de agrotóxicos pelos colonos lindeiros.

Sendo as roças dos colonos quase que totalmente mecanizadas, estes não contam com contingente expressivo de mão-de-obra convivendo diariamente no ambiente, somente as próprias famílias trabalham nelas e depois do trabalho realizado, muitos se retiram da área, vivendo em núcleo "urbanizado", na Vila de Santa Rosa do Ocoí. Os Avá-Guarani, ao contrário, com uma população à época de 523 pessoas (abril/2002), são obrigados a conviver no mesmo ambiente, já que suas casas estão muito próximas, a menos de 5 metros de distância, onde a estrada faz o limite. Existem algumas casas indígenas do lado externo à estrada, em Terra Indígena, onde não existe qualquer fronteira com as glebas dos colonos, estas estão na prática cercadas pelas monoculturas.

Recordando a localização e o relevo das glebas dos colonos e da Terra Indígena, estas áreas encontram-se em uma microbacia, portanto em declive, onde os colonos encontram-se por todo o entorno, nas bordas dessa bacia (lados externos do "V"), sendo que em suas áreas não foram realizadas sequer as necessárias curvas de nível, as quais poderiam conter o carreamento de partículas; a comunidade indígena encontra-se no espaço intermediário (o próprio "V") e por fim as águas do reservatório da Itaipu embaixo (por dentro deste "V"). Portanto, nesta bacia, os ventos para qualquer lado que soprar, irão carrear resíduos de elementos tóxicos para a Terra Indígena e para as águas do reservatório. Com as fortes chuvas de "verão", segundo os Avá de outubro à janeiro, elas coincidem com a aplicação mais intensa dos vários produtos agrotóxicos, nessa época eles são carreados mais fortemente para este declive, sendo despejados no interior da Terra Indígena, atingindo todas as áreas de utilização diária da comunidade, acima descritas. 
Portanto, o fato tem como consequência bastante provável a contaminação de solos (roças e vegetação), águas do reservatório e os peixes que nelas vivem, fontes de águas menores (poços por infiltração e olhos d'água, alguns existentes nas próprias glebas dos colonos) e ar, os quais incidem direta e indiretamente nas populações humanas e animais que ali habitam (Figura 38).

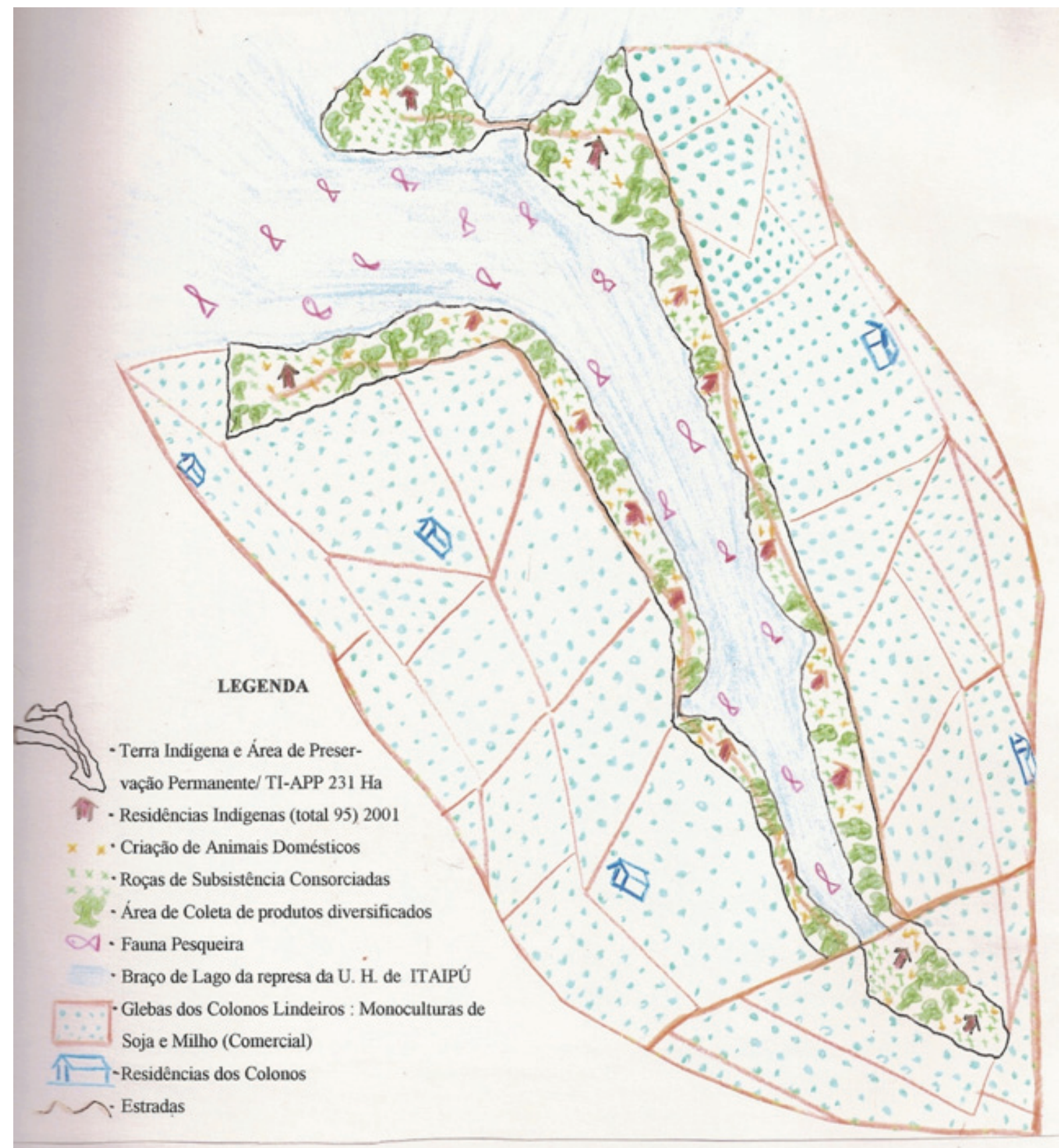

Figura 38. Croqui. Visão virtual e cinemática quanto ao uso de agrotóxicos pelos colonos lindeiros e impactos sanitário-ambientais provocados na Terra Indígena.

Elaboração: Maria Lucia Brant de Carvalho. 2002.

Para se ter uma ideia das curtas distâncias desta área em declive, observe-se a situação vivida na casa do pajé mais velho da aldeia, Seu Guilherme, através das fotos a seguir, elas estão em uma 
sequência espacial (Figura 39, 40 e 41). Elas procuram demonstrar as três seguintes distâncias: da gleba do colono lindeiro, com o plantio ainda baixo até à estrada (que é o limite atual entre as áreas); da estrada à roça e residência indígena; da residência indígena ao reservatório de Itaipu.

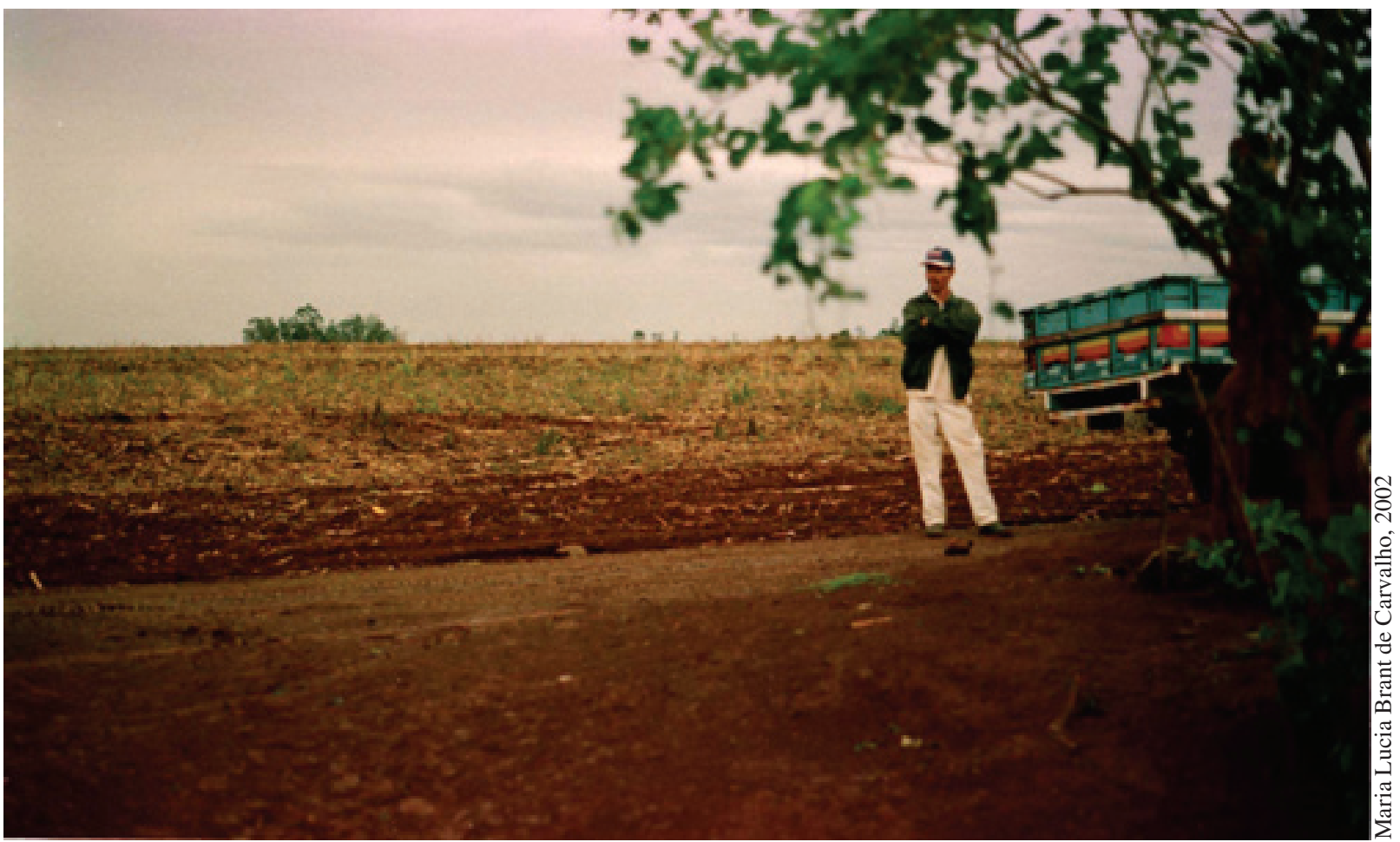

Figura 39. Foto. Veículo da FUNAI em estrada em frente à residência de Seu Guilherme e gleba do colono lindeiro ao fundo. Área em aclive.

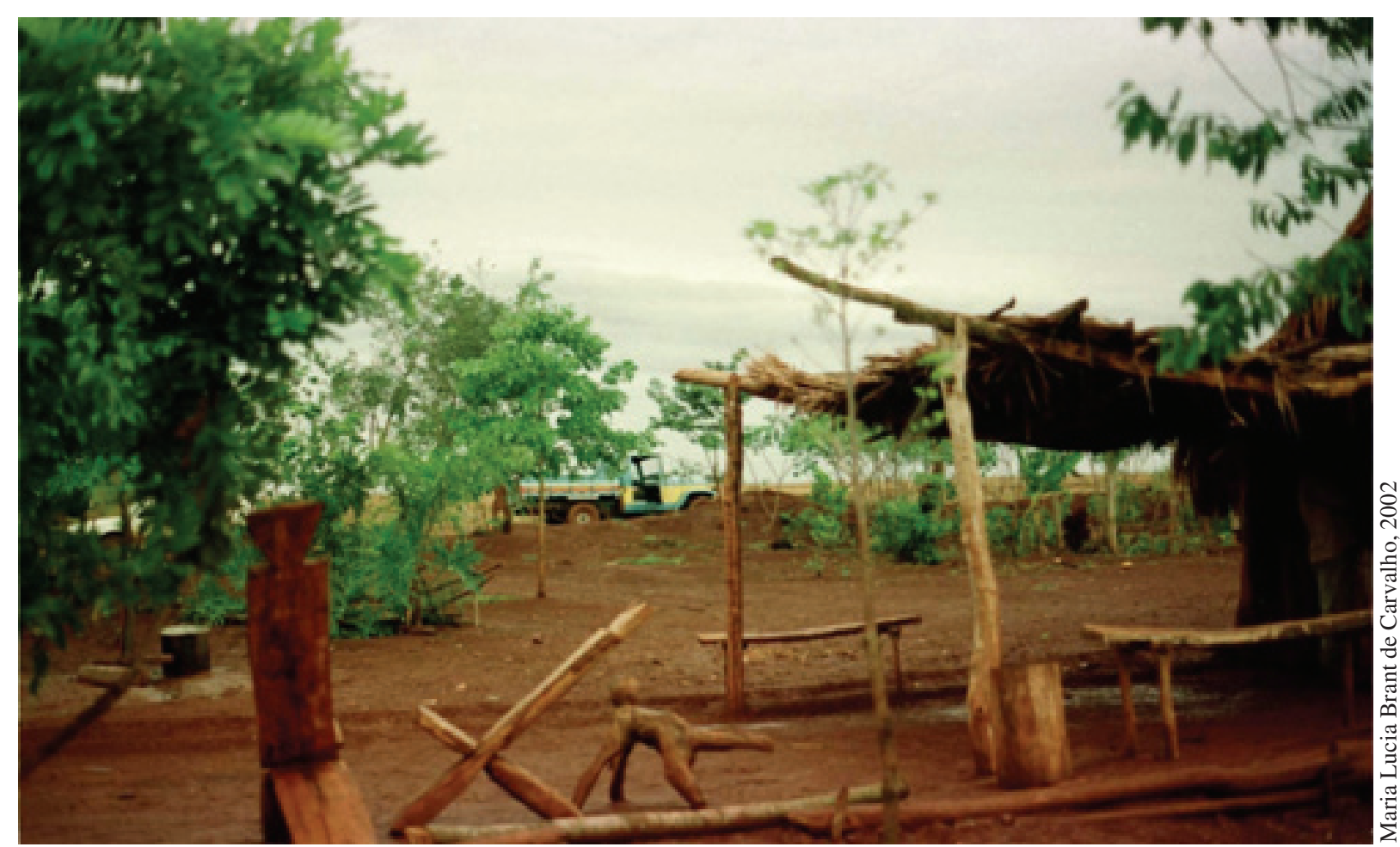

Figura 40. Foto. No mesmo local, um pouco abaixo, foto realizada da "varanda" da casa de Seu Guilherme, sobre o seu quintal/roça, o mesmo veículo parado na estrada da foto acima. Terreno em aclive. 


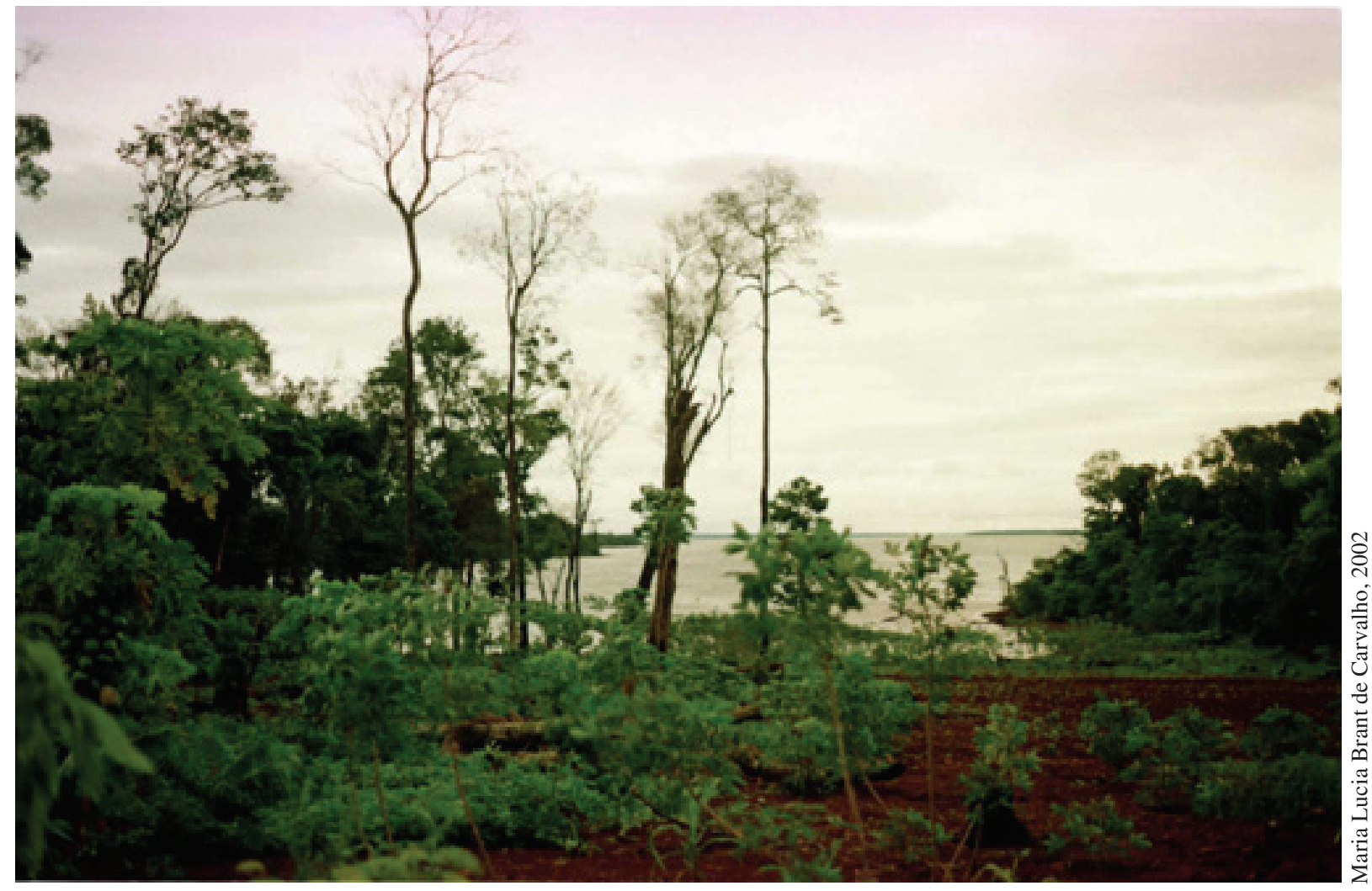

Figura 41. Foto. Foto realizada da "varanda" da residência de Seu Guilherme em direção oposta, voltada à área do reservatório, local esse que se apresenta como também parte do roçado e área de coleta desta família, assim como também é APP de Itaipu. Terreno em declive.

Os agrotóxicos são utilizados através de atomizadores manuais e pulverizadores tratorizados de barra (Figura 42), os quais provocam o carreamento de partículas por meio do ar (ventos) e das chuvas, afetando dessa forma a população indígena e os ambientes que ela utiliza, tendo provavelmente como decorrência, efeitos colaterais indesejáveis na saúde dos Guarani.

Considerando que nesta Terra Indígena, as únicas fontes de subsistência mais significativas disponíveis à Comunidade Guarani são suas pequenas roças e a pesca no lago, estas já insuficientes como fontes alimentares, nota-se como agravante o quanto estão sujeitas à contaminação por agrotóxicos.

Os Guarani descrevem vários sintomas com relação à presença destes agrotóxicos: fortes dores de cabeça, tonturas, náuseas, vômitos, diarreias, perda de apetite, tremores, desânimo, fraqueza nos membros, problemas de pele, entre outros. Autorizados pelos pacientes foram levantados vários prontuários de saúde de alguns habitantes indígenas de Oco’y (Anexo 4). Eles demonstram a existência de casos de crianças com síndrome de down, outras nascidas anencéfalas as quais foram a óbito em seguida, muitos abortos prematuros considerados "naturais" com fetos apresentando má formação, surdez, vários problemas respiratórios, e, ainda o caso de câncer de 


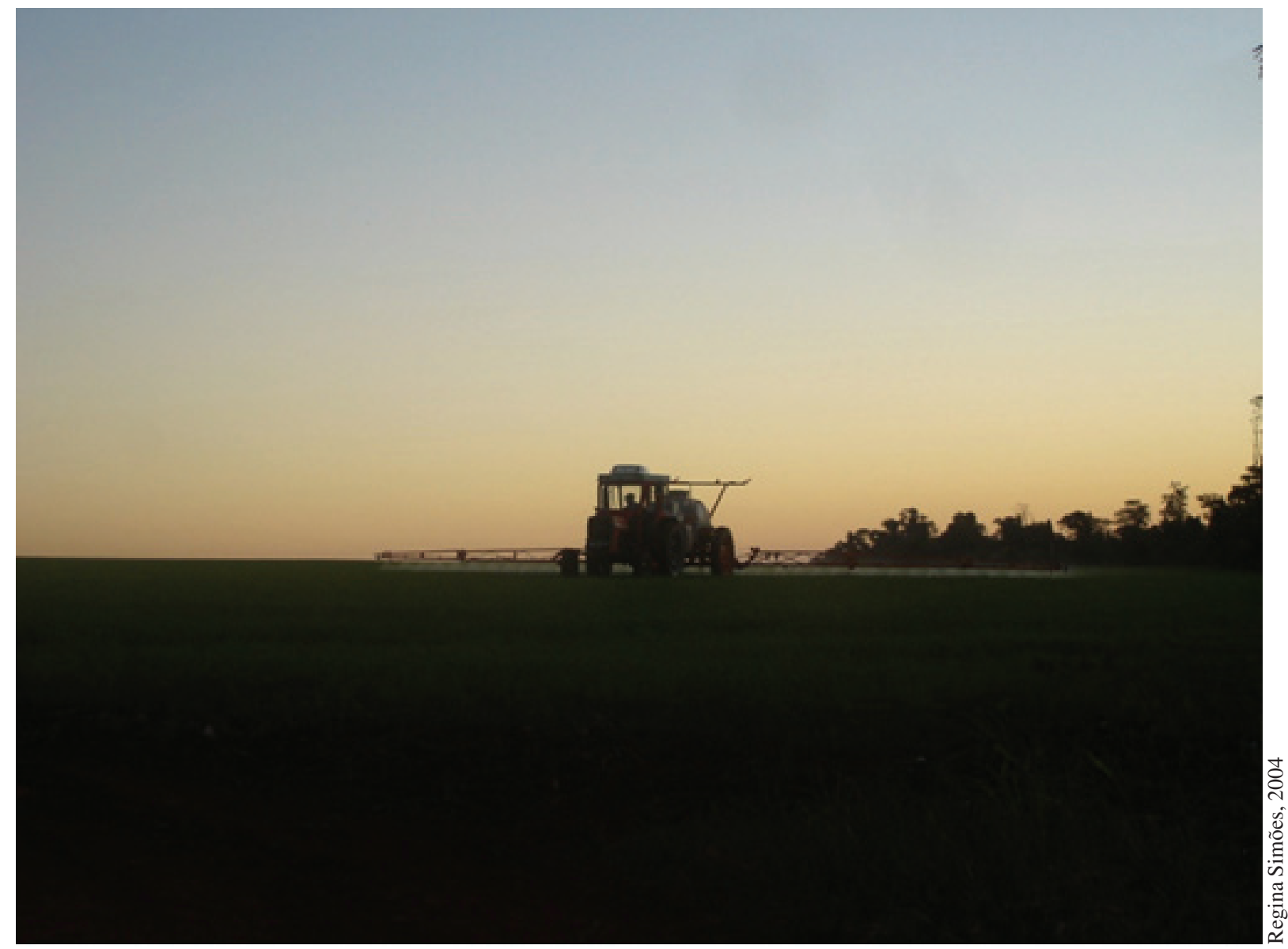

Figura 42. Foto. Colono pulverizando os agrotóxicos em terras já invadidas da Comunidade Indígena do Oco’y.

esofâgo de Seu Guilherme, a tal mancha branca, de aspecto diferente de outros casos de câncer, descrita no início deste capítulo, casos esses indicativos de possível contaminação por agrotóxicos, os quais apenas um deles foi levado a frente (por nós como veremos a seguir), apesar de solicitado, a necessária pesquisa específica, referente a essa contaminação a todos os casos à FUNASA.

Afirmam os Guarani que se os animais de criação da aldeia vão procurar alimentos na divisa entre áreas, na margem oposta da estrada, em contato com os produtos tóxicos, eles após ingerilos não sobrevivem, como é relatado por três diferentes depoimentos dos indígenas:

(...) A gente vê, senta de vez em quando umas pombinha no milho, daqui a pouquinho ela cai morta. (...) O peixe que a gente pesca aqui não é puro, com vida, o peixe quando a gente pesca parece que já tá morto. Quando chove o peixe morre na água com o veneno... . (...) Os colono mata a vegetação com produto químico, para planta soja e milho. Põe veneno na soja para matar lagarta, percevejo; no milho, para matar a lagarta da espiga. O veneno tem cheiro forte, dá dor de cabeça, dor de garganta, se os animais vão lá come, morre tudo. A criançada brinca no meio da soja, é perigoso... . (2002) (Figura 43). 
Descrevem os Guarani que o mesmo se dá com a fauna pesqueira do reservatório da Itaipu, com as chuvas, são carreados para dentro dele os produtos tóxicos, tendo como consequência peixes boiando mortos. O inseticida utilizado na soja denominado "Endosulfan", um organoclorado, segundo consulta que fizemos ao agrônomo Ari Gitzs, pode ser o causador da mortalidade dos peixes. Através da pesquisa feita mais tarde por Moraes (2004) foi confirmado que o produto realmente é utilizado pelos colonos lindeiros ao Oco'y.

Esta pesquisadora ao presenciar crianças indígenas brincando (mergulhando) em valas a beira da estrada, que formam poças d'água profundas, cobertas de espuma branca, muito provavelmente de origem tóxica, chamou-lhes a atenção sobre o fato, tentando lhes explicar o perigo. Ao comunicar esta situação às professoras não indígenas da aldeia, solicitando que as orientasse na escola a respeito da questão, as professoras relataram que é comum as crianças brincarem nestas poças cobertas de espuma branca e que apesar de alertá-las a não fazerem isto, não entendem bem o porquê, e continuam a brincar nelas...

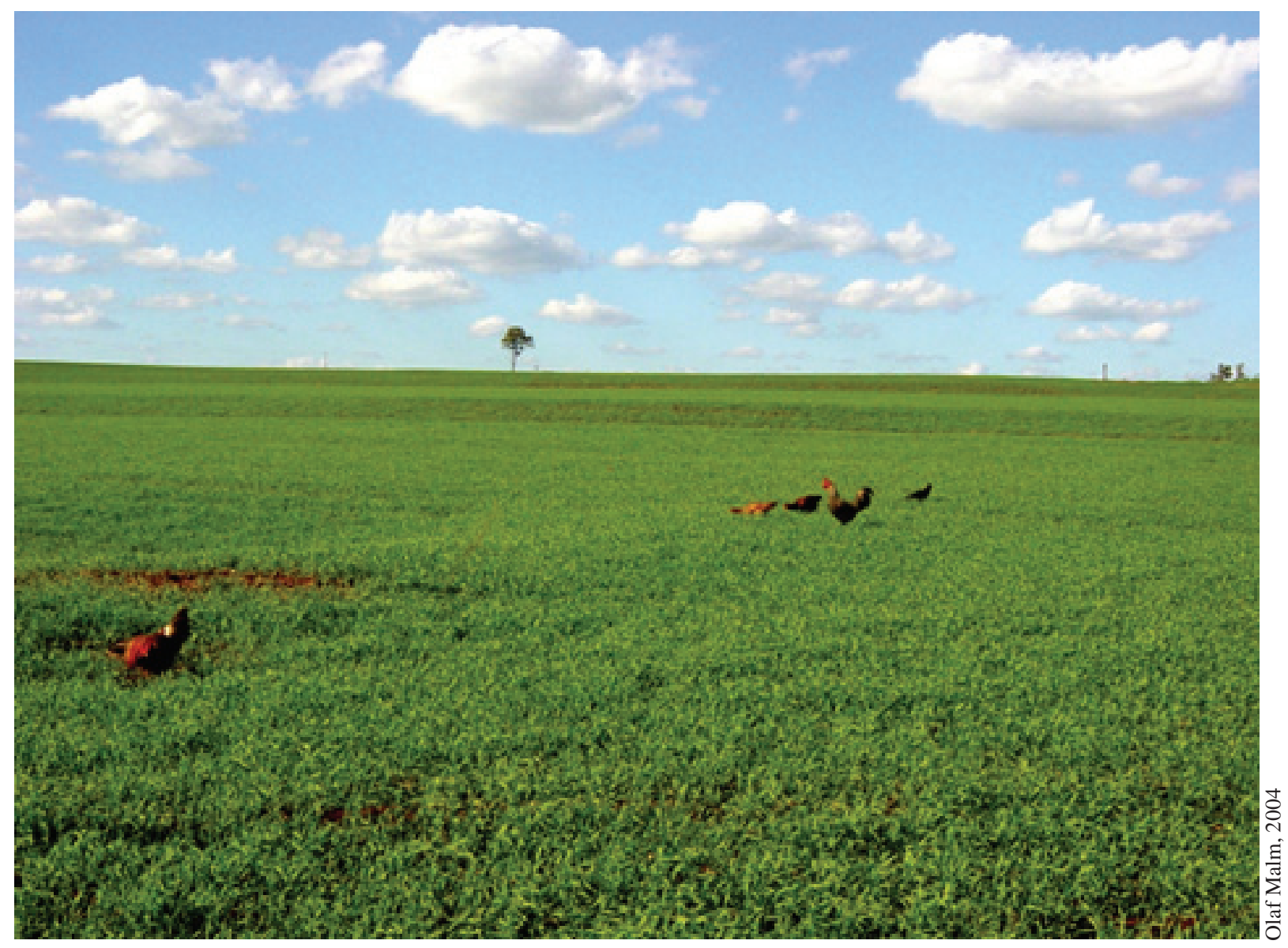

Figura 43. Foto. Galinhas do Oco’y em área invadida pelos colonos, ciscando em local contaminado pelo agrotóxico. 
Identificada a situação de risco grave a saúde foi enviado em 06.11.2001 o ofício $\mathrm{n}^{\circ}$ 01/ AERBAU/FUNAI/SP (Anexo 5) para a Fundação Nacional da Saúde em Curitiba/ FUNASA / Ministério da Saúde, indagando sobre a situação verificada à respeito de provável contaminação pelo uso de agrotóxicos próximos à Comunidade Indígena do Oco’y e como o órgão estaria lidando com o fato. Obteve-se como retorno dois pareceres: Parecer DIESP $n^{\circ}$ 02, sem data, assinado por Sonia de Paula Borba/ Chefe DIESP (Anexo 6) e Parecer Médico assinado pela Dra Maria das Graças Serafim de data equivocada, 21.01.2001 (Anexo 7), os quais os dois não respondem ao que foi indagado.

Procurada mais tarde pessoalmente por esta pesquisadora e pelo biólogo da FUNAI a médica citada, e, exposto novamente todo o problema, foi declarado por ela que: não havia no Oco'y nenhum caso clínico comprovado de contaminação por agrotóxico, para que houvesse a mobilização da FUNASA. Os exames a serem feitos para o caso são muito específicos e caros, realizados somente em grandes centros urbanos e por especialistas na matéria. Desta forma devem-se realizar procedimentos muito específicos para colheita de material humano e ambiental, assim como para encaminhamento e análise do material. Assim a questão deveria ser provocada através de uma logística própria e específica. Dessa forma foi contra-argumentado que: não havia nenhum caso clinico comprovado, porque nenhum caso foi devidamente encaminhado para exames específicos e que seria responsabilidade do órgão FUNASA realizar esse encaminhamento. Não houve concordância e a FUNASA permaneceu omissa.

Legalmente os Distritos Sanitários Especiais Indígenas/DSEI/ FUNASA/Ministério da Saúde assim como o Sistema Único de Saúde são corresponsáveis por zelar pela saúde das comunidades indígenas.

O Decreto Presidencial n 3156 de 27.08.99, dispõe sobre as condições para a prestação de assistência à saúde dos povos indígenas, no âmbito do Sistema Único de Saúde, pelo Ministério da Saúde. Este Decreto em seu Artigo 2o ${ }^{\circ}$, item I e V, afirma:

Artigo $2^{\circ}$ : Para o cumprimento no disposto do artigo anterior, deverão ser observadas as seguintes diretrizes destinadas à promoção, proteção e recuperação da saúde do índio, objetivando o alcance do equilíbrio bio-psico-social, com o reconhecimento do valor e da complementariedade das práticas da medicina indígena, segundo as peculiaridades de cada comunidade, o perfil epidemiológico e a condição sanitária:

I - o desenvolvimento de esforços que contribuam para o equilíbrio da vida econômica, política e social das comunidades indígenas. 


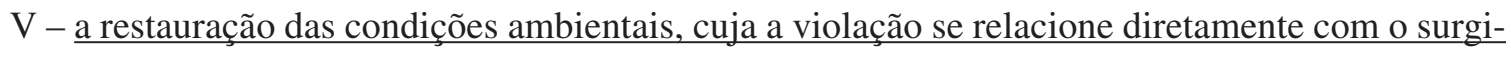
mento de doenças e de outros agravos à saúde.

Enquanto ainda esperava-se o retorno da FUNASA, se buscou também outros órgãos, estes especializados na questão contaminação por agrotóxicos. Portando uma lista dos produtos agrotóxicos que são utilizados na região por alguns colonos lindeiros à Terra Indígena, fornecida pela Secretaria de Agricultura de São Miguel do Iguaçu/Pr (Anexo 8) e as embalagens “importadas" do Paraguai, que foram colhidas por nós e antes, não devolvidas pelos colonos a este órgão, obteve-se duas entrevistas em dezembro de 2001 com especialistas do Departamento de Fiscalização/DEFIS da Secretaria de Estado da Agricultura e do Abastecimento - SEAB/PR e com especialistas da Secretaria Estadual da Saúde/ Departamento Estadual de Saúde no Trabalho/ PR; ao analisarem as listas, apenas dois exemplares, as embalagens e ainda ao ser descrita a situação vivida pelos Guarani, estes mostraram-se apreensivos, levantando uma série de problemas:

- verificaram a utilização de vários produtos proibidos no Brasil;

- verificaram a falta de distância mínima entre as áreas dos colonos e da comunidade indígena, em função do uso destes produtos; a distância mínima legal deveria ser de pelo menos 250 metros quando usados atomizadores e 50 metros quando utilizados pulverizadores tratorizados de barra, acrescidos de alguns cuidados como o estabelecimento de curvas de nível, e ainda, desde que os ventos não interferissem no momento da aplicação, carreando os produtos para local próximo ao núcleo populacional indígena;

- diante da indevida proximidade da aplicação, levantaram a questão da aspersão dos agrotóxicos sobre as roças de subsistência dos índios, inapropriada para este tipo de lavoura, comprometendo a produção da mesma, assim como provocando intoxicação na população indígena. O professor indígena da aldeia, havia comunicado recentemente quanto à sua preocupação sobre a improdutividade das roças, especialmente este ano, dizendo que iria faltar ainda mais alimentos;

- a contaminação de águas, solos e dos recursos neles existentes;

- o comprometimento da saúde das populações humanas e animais que habitam a área; descrevem que em populações com deficiências nutricionais pré-existentes, como é o caso desta população indígena, a questão se torna mais grave, tendo efeitos seriamente comprometedores da saúde.

Os técnicos do DEFIS/SEAB/PR e o Departamento Estadual de Saúde no Trabalho /Secretaria Estadual da Saúde /PR, colocaram-se à disposição, argumentando quanto à necessidade de 
realização de visitas à campo, onde confeccionariam em conjunto uma perícia, demonstrando a situação. Para isso eram necessários, a confecção de um projeto e obter o respectivo financiamento.

Afixado na Secretaria Estadual da Saúde/ Departamento Estadual de Saúde no Trabalho/ PR havia um cartaz da Organização Mundial da Saúde/OMS referindo-se à contaminação por agrotóxicos, onde era citada a seguinte estatística; há três milhões de indivíduos com intoxicação aguda por ano no mundo, sendo que deles $220 \mathrm{mil} /$ por ano, vem a falecer. Somente no estado do Paraná/Brasil de 1986 a 1998 houve 9.811 casos de intoxicação aguda notificados, destes 970 foram a óbito.

Diante dos fatos apresentados foi encaminhado por mim em 11.03.2002 através de documento de caráter urgente e específico denominado "Contaminação por agrotóxicos pela comunidade indígena AVÁ-GUARANI Terra Indígena do Oco’y/ São Miguel do Iguaçu/ Paraná” e posteriormente com maior detalhamento contido no próprio Laudo Antropológico (2002), documentos oficiais esses que foram remetidos para a FUNAI/Bsb, MPF e JF de Foz do Iguaçu, solicitando a verificação urgente e prioritária por meio de Laudo Pericial, quanto à contaminação das populações humanas e animais, dos produtos de roça e coleta, das águas utilizadas, assim como dos peixes consumidos por esta população indígena, pelos agrotóxicos utilizados pelos vizinhos. Foi informada a lista dos proprietários ${ }^{32}$, colonos lindeiros à Terra Indígena do Oco’y, assim como contatos com os responsáveis municipais ${ }^{33}$. Colocava-se a necessidade de acompanhar a perícia a ser feita, como ainda discutir os critérios metodológicos visando a pesquisa para a colheita de amostras.

Neste documento considerava-se também ser necessário o acompanhamento da FUNASA, como órgão responsável pela saúde indígena. Indagava-se ainda se havia a existência de licenciamento ambiental para o uso de agrotóxicos por parte dos colonos lindeiros, junto à Prefeitura de São Miguel do Iguaçu, pois a legislação obriga a certas normas, essas mais rígidas, quando há "núcleos populacionais" vizinhos ao local de aspersão. Colocava-se por fim a necessidade de ter acesso aos critérios utilizados no Receituário Agronômico desta Prefeitura. Solicitações essas as quais não se obteve qualquer retorno concreto na aldeia, por parte das autoridades mencionadas.

\footnotetext{
${ }^{32}$ Aloisio Welter; Plínio Lutkmeyr; Laurindo Shwingil; Pedro Guido Ledur; Seferino Beres; João Benck; Ervino Saltier; Selvino Welter; Bonifácio Jacomeli; Osmar Bergman; Maurício Schossler; Marcelino Leichtweis.

${ }^{33}$ Telefone da Prefeitura de São Miguel do Iguaçu 045-5658100 e do Secretário de Meio Ambiente Sr. Silas Murback 045-99634948.
} 
O Laudo Antropológico (2002) recomendava também ás autoridades estatais FUNAI/Bsb, MPF e JF de Foz do Iguaçu, que medidas disciplinares de cunho ambiental deveriam ser verificadas conjuntamente entre a FUNAI e o IBAMA, pois as áreas atingidas pela contaminação por agrotóxicos por parte dos colonos, entorno e o próprio interior da Terra Indígena do Oco’y e do reservatório da Itaipu, além de serem as duas APPs, são também áreas federais de responsabilidade ambiental desse último órgão, o IBAMA.

Vejamos os aspectos legais de toda a questão. A Lei Federal referente à questão dos agrotóxicos, Lei n 7.802 de 12.07.1989, afirma que:

Art. $1^{\circ}$ - A pesquisa, a experimentação, a produção, a embalagem e rotulagem, o transporte, o armazenamento, a comercialização, a propaganda comercial, a utilização, a importação, a exportação, $\underline{\text { }}$ destino final dos resíduos e embalagens, o registro, a classificação, o controle, a inspeção e a fiscalização de agrotóxicos, seus componentes e afins, serão regidos por esta lei.

Art. $3^{\circ}$ - Os agrotóxicos, seus componentes e afins, de acordo com definição do Art. $2^{\circ}$ desta Lei, $\underline{\text { só }}$ poderão ser produzidos, exportados, importados, comercializados e utilizados, se previamente registrados em Órgão Federal, de acordo com as diretrizes e exigências dos órgãos federais responsáveis pelos setores de saúde, do meio ambiente e da agricultura.

Questão colocada pelo Artigo $3^{\circ}$, que como vimos não é observada, alguns agrotóxicos são contrabandeados, logicamente não são registrados, portanto, não há qualquer controle sobre seu uso.

Ainda a mesma Lei Federal afirma que:

Art. $9^{\circ}$ - No exercício da sua competência, a União adotará as seguintes providências:

I - legislar sobre a produção, registro, comércio interestadual, exportação, importação, transporte, classificação e controle tecnológico e toxicológico;

Art. 10 - Compete aos Estados e ao Distrito Federal, nos termos dos Artigos 23 e 24 da Constituição Federal, legislar sobre o uso, a produção, o consumo, o comércio e o armazenamento dos agrotóxicos. $\underline{\text { seus componentes e afins, bem como fiscalizar o uso, o consumo, o comércio, o armazenamento e o }}$ transporte interno.

A União legisla sobre a produção, registro, $\underline{\text { importação, classificação e controle tecnológico }}$ e toxicológico, porém é de competência estadual legislar e fiscalizar o uso, consumo, o comércio, o armazenamento e o transporte interno. 
Quanto a competência a nível estatal do caso aqui tratado, difere conforme se dá a incidência do produto tóxico: o caso é um se restrito à própria gleba dos colonos; e é outro quando atinge indiretamente e diretamente as áreas da Terra Indígena e da APP de Itaipu.

No primeiro caso, quando se refere a utilização desses produtos contrabandeados pelos colonos e utilizados em suas próprias glebas, a União é responsável pela não fiscalização na fronteira entre países, e ainda, o órgão estadual competente (IAP) é responsável por não fiscalizar o uso e o consumo indevido no local, nas próprias glebas dos colonos.

Todavia, os colonos não se restringem a aplicação em suas próprias glebas; na medida em que se dá o contrabando do produto na fronteira com outro país e os produtos ilegais e legais, são aplicados inadvertidamente no entorno e no próprio interior de áreas federais, que se constituem em APPs, a Terra Indígena e o reservatório, o caso passa a ser de competência federal, quanto a investigação do registro, a "importação", a classificação e controle tecnológico e toxicológico, a fiscalização do uso, do consumo, do comércio, daí a responsabilidade do órgão federal IBAMA.

Como o Artigo $10^{\circ}$ da lei ${ }^{\circ} 7802$ supracitada, determina que compete aos Estados legislar e fiscalizar a questão dos agrotóxicos, deve-se nortear a conduta pelo que é determinado no estado do Paraná, quanto ao uso desses produtos tóxicos, assim é a Resolução nº 22/85 -SEIN atual IAP/ Secretaria do Meio Ambiente do Estado do Paraná, que normatiza a questão. Em seu Artigo $5^{\circ}$, refere-se:

Artigo $5^{\circ}$. Nas áreas agricultáveis, deverão ser adotadas medidas específicas de controle de erosão, de modo a diminuir a carreação de partículas do solo, onde se encontram absorvidos agrotóxicos, principalmente os organoclorados, para as coleções de água e áreas circunvizinhas.

O Artigo $7^{\circ}$ (7.1 e 7.2) da mesma lei refere-se quanto à distância a ser observada de núcleos populacionais, mananciais de captação de água, entre outros:

Artigo $7^{\circ}$. Não é permitida a aplicação aérea de agrotóxicos e outros biocidas em áreas situadas a uma distância mínima de 500 metros adjacente à mananciais de captação de água para abastecimento de populações, núcleos populacionais, escolas, habitações e locais de recreação, e, de 250 metros adjacentes a mananciais de água, moradias isoladas e agrupamento de animais e culturas susceptíveis a danos.

7.1. Será permitida, porém, a aplicação de agrotóxicos e biocidas nas lavouras, se efetuada por atomizadores ou canhões, numa distância mínima de 250 metros, e, por aparelhos costais ou tratorizados de barra, numa distância mínima de 50 metros, dos locais mencionados no item $7^{\circ}$. 
7.2. Em todos os casos as aplicações somente poderão ser feitas quando a direção do vento for tal que não leve resíduos de agrotóxicos e biocidas para os locais referidos no item $7^{\circ}$.

Os agrotóxicos são utilizados por atomizadores manuais e pulverizadores tratorizados de barra. A distância existente entre às roças de soja e milho onde são utilizados esses produtos e as habitações e roças indígenas, na melhor das hipóteses não há sequer 5 metros, quando deveria haver, respectivamente para as técnicas utilizadas 250 e 50 metros. Como vimos a aplicação indevida se dá adjacente à mananciais de captação de água para abastecimento da população, do núcleo populacional indígena, da escola indígena, das habitações e locais de recreação indígena e de agrupamento de animais e culturas agrícolas indígenas susceptíveis a danos.

Quanto ao declive e a localização do território. Como vimos não há sequer curvas de nível, muito menos controle de erosão no local. Inexistindo esses cuidados nas monoculturas e considerando que o Oco’y são duas línguas de terras em uma bacia, seja qual for a direção dos ventos e das chuvas, com a gravidade, os agrotóxicos são carreados logicamente para baixo, para o interior da Terra Indígena e reservatório de Itaipu. Dessa forma, não poderia haver a aplicação do produto tão próximo ao núcleo populacional indígena. Portanto, sem fiscalização a legislação não é aplicada.

Se formos verificar ao pé da letra da lei, para o tipo de atividade agrícola realizada pelos colonos em suas próprias terras é exigido licenciamento ambiental, conforme Artigo $2^{\circ}$, Parágrafo $1^{\circ}$ e $2^{\circ}$ e Anexo I da Resolução CONAMA n 237.

Artigo $2^{\circ}$. A localização, a construção, instalação, ampliação, modificação e operação de empreendimentos e atividades utilizadoras de recursos ambientais consideradas efetiva ou potencialmente poluidoras, bem como os empreendimentos capazes, sob qualquer forma, de causar degradação ambiental, dependerão de prévio licenciamento do orgão ambiental competente, sem prejuízo de outras licenças legalmente exigíveis.

Parágrafo $1^{\circ}$. Estão sujeitos ao licenciamento ambiental os empreendimentos e as atividades relacionadas no Anexo 1, parte integrante desta Resolução.

Anexo 1. Atividades ou empreendimentos sujeitos ao licenciamento ambiental:

Atividades agropecuárias:

-projeto agrícola

-projetos de assentamentos e de colonização 
Uso de recursos naturais:

- utilização do patrimônio genético natural;

- manejo de recursos aquáticos vivos;

- introdução de espécies exóticas e/ou geneticamente modificadas.

Parágrafo $2^{\circ}$. Caberá ao órgão ambiental competente definir os critérios de exigibilidade, o detalhamento e a complementação do Anexo 1, levando em consideração as especificidades, os riscos ambientais, o porte e outras características do empreendimento ou atividade.

Dessa forma o órgão ambiental competente, o IAP, deveria submeter a licenciamento ambiental as atividades dos colonos em suas próprias terras, pois esse assentamento realizado pelo INCRA no passado vem realizando projeto agrícola que traz riscos ambientais, na medida em que utiliza e modifica o patrimônio genético natural, introduz espécies exóticas e/ou geneticamente modificadas como a soja, por exemplo, está demasiadamente próximo do núcleo populacional indígena (Resolução n ${ }^{\circ} 22 / 85$ SEIN), como ainda danifica indiretamente o manejo de recursos aquáticos vivos do reservatório de Itaipu.

Porém, os colonos não se limitam a realizar essas atividades em suas próprias terras, mas invadem e realizam a mesma atividade de risco ambiental no "interior" da Terra Indígena, o que muda de figura a questão, tornando-a exponencialmente mais complexa.

Como vimos anteriormente a Terra Indígena assim como a área marginal do reservatório de Itaipu, segundo o Código Florestal Lei no 4771 de 15.09.1965, são consideradas Áreas de Preservação Permanente/APPs (respectivamente Artigo 3, letra "g"; Artigo 2o letra "b"), que por serem federais são de responsabilidade ambiental do IBAMA. Nelas, a princípio são proibidas a supressão total ou parcial de florestas (Artigo $3^{\circ}$, Parágrafo $1^{\circ}$ ) e quando ela pode se dar, em casos muito específicos, deve haver autorização do poder executivo federal competente (Artigo $3^{\circ}$, Parágrafo $1^{\circ}$ ) no caso o próprio IBAMA, para utilidade tal, que justifique interesse relevante, quando for necessária a execução de obras, planos, atividades ou projetos de utilidade pública ou interesse social (Artigo $3^{\circ}$, Parágrafo $1^{\circ}$ ), devidamente caracterizados e motivados em procedimento administrativo próprio, quando inexistir alternativa técnica e locacional ao empreendimento proposto (Artigo $4^{\circ}$ ). Ainda só é permitido o acesso de pessoas e animais às áreas de preservação permanente, para obtenção de água, desde que não exija a supressão e não comprometa a regeneração e a manutenção à longo prazo da vegetação nativa $\left(\right.$ Artigo $4^{\circ}$, Parágrafo $7^{\circ}$ ). No caso de Terra indígena é explicito que: Artigo $3^{\circ}$ : A exploração dos recursos florestais em 
terras indígenas somente poderá ser realizada pelas comunidades indígenas em regime de manejo florestal sustentável, para atender a sua subsistência, respeitados os Artigos $2^{\circ}$ e $3^{\circ}$ deste Código.

Nota-se que pelo Código Florestal as Terras Indígenas são consideradas por força de lei áreas de Preservação Permanente como qualquer Unidade de Conservação, como ainda elas são consideradas de forma correlata, Unidades de Conservação de uso direto e sustentável.

Conclui-se que não caberia a invasão, a supressão e muito menos a contaminação com agrotóxicos da população e da Terra Indígena, assim como indiretamente a contaminação com agrotóxicos da APP de Itaipu pelas atividades agrícolas dos colonos, nem no interior, nem no entorno próximo da Terra Indígena.

O Decreto Presidencial n ${ }^{\circ} 1141$ de 19.05. 94 dispõe sobre as ações de proteção ambiental,

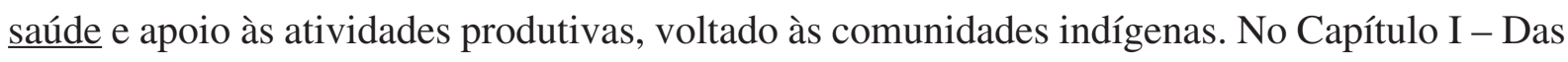
Disposições Gerais, em seu artigo $3^{\circ}$, apoia-se em lei correlata (Estatuto do Índio) o qual reconhece as especificidades culturais da vida indígena, quando afirma: Artigo $3^{\circ}$. As ações decorrentes deste Decreto fundamentar-se-ão no reconhecimento da organização social e política, dos costumes, das línguas, das crenças e tradições das comunidades indígenas.

Este mesmo decreto reconhece também que é dever do Estado, proteger ambientalmente o interior e o entorno das Terras Indígenas quando sujeitas a impactos, através de algumas medidas práticas, quando afirma em seu Capítulo II - Da Proteção Ambiental, Artigo 9º que:

Artigo $9^{\circ}$. As ações voltadas à proteção ambiental das terras indígenas e seu entorno destinam-se a garantir a manutenção do equilíbrio necessário à sobrevivência física e cultural das comunidades indígenas, contemplando:

I - diagnóstico ambiental, para conhecimento da situação, como base para as intervenções necessárias;

II - acompanhamento e controle da recuperação das áreas que tenham sofrido processo de degradação de seus recursos naturais;

III - controle ambiental das atividades potencial ou efetivamente modificadoras do meio ambiente, mesmo aquelas desenvolvidas fora dos limites das terras indígenas que as afetam;

IV - educação ambiental, dirigidas às comunidades indígenas e à sociedade envolvente, visando a participação na proteção do meio ambiente nas terras indígenas e seu entorno;

V - identificação e difusão de tecnologias indígenas e não-indígenas, consideradas apropriadas do ponto de vista ambiental e antropológico. 
Portanto, as atividades agrícolas dos colonos lindeiros, continua praticando ato passível de controle ambiental e penalização dos responsáveis, pois se dá tanto no entorno, como no próprio interior da Terra Indígena, trazendo impactos socioambientais, econômicos, sanitários e de saúde, substanciais à subsistência e a qualidade de vida indígena.

Também como vimos anteriormente, o Decreto Presidencial no 3156 de 27.08.99, dispõe

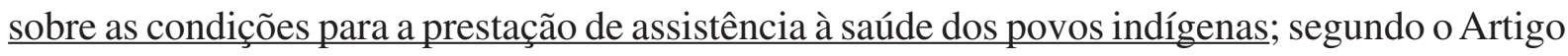
$2^{\circ}$, item $\mathrm{V}$, deverão ser observadas as seguintes diretrizes destinadas à promoção, proteção e recuperação da saúde do índio, objetivando o alcance do equilíbrio bio-psico-social, (...) segun-

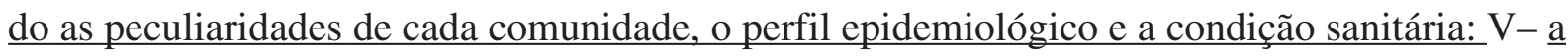
restauração das condições ambientais, cuja a violação se relacione diretamente com o surgimento de doenças e de outros agravos à saúde.

Assim através das leis citadas, há o reconhecimento legal da necessidade de proteção ambiental do interior das Terras Indígenas e de seu entorno, com medidas práticas, com os devidos diagnósticos, acompanhamentos, medidas de recuperação, de controle de atividades, de educação e difusão de tecnologias ambientais, visando proteger e recuperar a saúde do indígenas, através da restauração das condições ambientais, cuja violação tenha relação direta com o surgimento de doenças e de outros agravos à saúde.

Por seu turno o Sistema Nacional de Unidades de Conservação da Natureza/SNUC, Lei n ${ }^{\circ}$ 9985 de 18.07.2000, afirma em seu Capítulo II - Do Sistema Nacional de Unidades de Conservação da Natureza -SNUC, Artigo $4^{\circ}$, que:

Artigo $4^{\circ}$. O SNUC tem os seguintes objetivos: XIII - proteger os recursos naturais necessários à $\underline{\text { subsistência de populações tradicionais, }}$ respeitando e valorizando seu conhecimento e sua cultura e promovendo-as social e economicamente.

Ainda o SNUC afirma em seu Capítulo I - Das Disposições Preliminares, Artigo 2ª que:

Artigo $2^{\circ}$. Para os fins previstos nesta Lei, entende-se por: XVIII - zona de amortecimento: o entorno de uma unidade de conservação, onde as atividades humanas estão sujeitas a normas e restrições específicas, com o propósito de minimizar os impactos negativos sobre a unidade.

A atividade dos colonos na medida em que se dá no entorno e dentro da própria Terra Indígena e entorno da área marginal do reservatório, é passível de penalização e imputação de 
responsabilidades, pelo órgão ambiental, o IBAMA, que segundo a Resolução CONAMA nº 237 de 19.12.1997, que em seu Artigo 4º, item I, assim afirma:

Artigo $4^{\circ}$. Compete ao Instituto Brasileiro do Meio Ambiente e dos Recursos Naturais Renováveis $\underline{\text { IBAMA, }}$ orgão executor do SISNAMA, o licenciamento ambiental, a que se refere o artigo 10 da Lei $\mathrm{n}^{\circ} 6938$, de 31 de agosto de 1981, de empreendimentos e atividades com significativo impacto ambiental de âmbito nacional e regional, a saber:

I- localizadas ou desenvolvidas conjuntamente no Brasil em país limítrofe; (...) ; na plataforma continental; (...); em terras indígenas ou em unidades de conservação de domínio da União.

Complementarmente a Resolução CONAMA nº 013 de 06.12.1990, assim afirma:

Considerando a necessidade de estabelecer-se, com urgência normas referentes ao entorno das Unidades de Conservação visando a proteção dos ecossistemas ali existentes, RESOLVE:

Artigo $1^{\circ}$. O orgão responsável por cada Unidade de Conservação, juntamente com os orgãos licenciadores e de meio ambiente, definirá as atividades que possam afetar a biota da Unidade de Conservação.

Artigo $2^{\circ}$. Nas áreas circundantes das Unidades de Conservação, num raio de $10 \mathrm{Km}$, qualquer atividade que possa afetar a biota, deverá ser obrigatoriamente licenciada pelo orgão ambiental competente.

Parágrafo Único: o licenciamento a que se refere o caput deste artigo só será concedido mediante autorização do responsável pela Administração da Unidade de Conservação.

Portanto, legalmente deveria haver também “zonas de amortecimento" no entorno das Terras Indígenas, a fim de evitar ou mitigar os impactos socioambientais provenientes do exterior, conforme determina a Resolução CONAMA nº 013 e o SNUC para qualquer Unidade de Conservação.

Por todo o exposto, a licença ambiental para atuação dos colonos lindeiros atuarem nas suas próprias glebas de terras, por estar ao lado de APPs dessa natureza, Terra Indígena e APP de Itaipu, áreas federais, seria passível de anterior licenciamento e controle, podendo ser autorizada somente pelo Poder Executivo Federal (IBAMA), que salvo desconhecimento, não houve. Dessa forma, foi indicado pelo Laudo Antropológico que por um lado, deveria a FUNAI através do IBAMA, exigir o licenciamento ambiental para os colonos atuarem em suas próprias terras.

Os colonos praticam atividades agrícolas degradantes também dos recursos ambientais, da subsistência e da saúde da população indígena, no interior das APPs do local. Atingindo direta e indiretamente o próprio interior de áreas de outrem, agrava-se o contexto, considerando ainda que elas são Áreas de Preservação Permanente de cunho federal. 
Considerando as exigências legais e os riscos ambientais que acarretam as atividades agrícolas dos colonos lindeiros sobre as Terras Indígenas, e na medida em que já vem se realizando a degradação, o Laudo Antropológico considerou que haveria necessidade de realização de um Estudo de Impacto Ambiental e Relatório de Impacto sobre o Meio Ambiente/EIA-RIMA, conforme dita a Resolução CONAMA n 237 , que em seu Artigo $3^{\circ}$, afirma:

Artigo $3^{\circ}$. A licença ambiental para empreendimentos e atividades consideradas efetiva ou potencialmente causadoras de significativa degradação do meio dependerá de prévio estudo de impacto ambiental e respectivo relatório de impacto sobre o meio ambiente (EIA/RIMA), ao qual dar-se-à publicidade, garantida a realização de audiências públicas, quando couber, de acordo com a regulamentação.

Neste caso não estaria em discussão um licenciamento ou não, porque a atividade por si já é proibitiva, mas sim de compensar ou mitigar ambientalmente a Terra Indígena, pelos impactos sofridos e para logicamente proibir a atuação dos colonos no interior da mesma.

Porém, apesar de configurar todos esses vários delitos, esses não foram passíveis de penalização dos responsáveis e nenhuma medida para minorar os prejuízos da Terra Indígena foram tomadas, pelo contrário, a mesma situação continua exatamente igual até o momento. Por quê? Esta indagação será respondida ao longo deste trabalho.

Após a entrega do referido Laudo Antropológico (Brant de Carvalho: 2002), por seu turno a Itaipu Binacional e a FUNAI contrataram um trator da Prefeitura de São Miguel do Iguaçu, e, com a justificativa de estarem abrindo mais espaços de roças para os Avá-Guarani - ou seja, não se mencionou a necessidade de resolução do problema do exíguo espaço fundiário - suprimiram erroneamente de vez, os poucos remanescentes florestais, passando o trator em grande extensão da Terra Indígena, em grande parte da APP, o que resultou no desnudamento da pouca diversidade florestal que ainda existia, como ainda compactou a terra desnudada. O fato trouxe consequências legais, multa ás Instituições e a paradoxal proibição pelo IAP do plantio pelos AváGuarani na própria Terra Indígena, por provavelmente considerá-la somente APP de Itaipu, questões essas que serão discutidas no capítulo 6.

Por iniciativa nossa através da Administração Executiva Regional de Bauru da FUNAI, em contato com a Coordenadoria Geral de Patrimônio Indígena e Meio Ambiente/CGPIMA da FUNAI em Brasília, foi indicado o biólogo e indigenista Julio César de Moraes para identificar tecnicamente o problema da contaminação por agrotóxicos nas terras dos Avá-Guarani. 
O profissional buscou apoio técnico em universidade paulista (UNESP), para a confecção do trabalho. Após visita a campo e analisadas as listas de produtos fornecidas pelo Laudo Antropológico, este biólogo através de pesquisa bibliográfica preliminar, produziu um material em que analisa os efeitos de cada uma das substâncias químicas utilizadas pelos colonos lindeiros ao Oco’y, sobre seres humanos e animais em geral.

O material entregue em julho de 2004 no âmbito da AERBAURU/FUNAI/SP, denominado “Agrotóxicos no entorno da Terra Indígena Avá-Guarani (Okoy), em São Miguel do Iguaçu/Pr: Sobrevivência física e cultural em risco da população indígena Avá-Guarani”, foi encaminhado para a AERGU/FUNAI/Guarapuava, CGPIMA/FUNAI/Bsb, MPF e JF de Foz do Iguaçu. Diante da importância do conteúdo anexamos este trabalho na íntegra (Anexo 9).

Todos os trabalhos da antropóloga Brant de Carvalho (2002), do geólogo Ribeiro (2002) e do biólogo Moraes (2004), entregues a FUNAI/Bsb, MPF e JF de Foz do Iguaçu recomendavam a paralisação imediata do uso dos produtos tóxicos, em toda área de influência da microbacia do Córrego Santa Clara, o que não foi realizado. O trabalho de Moraes apontava a necessidade de monitorização biológica e ambiental da microbacia do Córrego Santa Clara, para em campo realizar então as devidas análises.

A partir do estudo de Moraes (2004) através das instâncias da FUNAI, AERBAURU/SP e CGPIMA/Bsb, foram contatados quatro pesquisadores, especialistas no tema contaminação por agrotóxicos do Núcleo de Estudos de Saúde Coletiva e do Instituto de Biofísica da Universidade Federal do Rio de Janeiro/UFRJ. Em uma primeira visita de reconhecimento de campo ao Oco'y (maio e junho/2005) os pesquisadores identificaram a situação, refletindo sobre o planejamento da pesquisa a ser feita, a coleta do material para análise.

Naquele momento foi conduzido até eles um rapaz guarani de nome Jorge Martinez, que não conseguia mais andar, segundo depoimento do indígena, por "fraqueza nas pernas e braços e desânimo”. Foram realizados exames clínicos pela médica/pesquisadora no que resultou na conclusão de que Jorge estava sendo tratado erroneamente com anti-depressivo (Protanol Cloridrato de Amitriptilina), o que segundo a médica, contribuía para piorar ainda mais o quadro clínico de debilidade por ele apresentado. Foram solicitados complementarmente alguns exames laboratoriais iniciais.

No mesmo ano esta antropóloga e o biólogo, ambos da FUNAI, reuniram-se com o Coordenador de Saúde Vinicius Reale Paraná, com o Chefe de Gabinete Jéferson Reale Paraná e alguns técnicos como o engenheiro sanitarista Alcione Altair Pimentel de Lara, todos da Coordenadoria 
Regional da FUNASA em Curitiba, reforçando o pedido de exame específico de Jorge Martinez quanto a provável contaminação por agrotóxicos, explanando toda a grave questão que envolvia os agrotóxicos na Terra Indígena, como também discutindo a questão do saneamento referente a água potável disponível. Desta reunião resultou somente que os exames iniciais pedidos para Jorge, foram encaminhados.

Segundo as análises realizadas pela médica Professora Doutora Heloisa Pacheco Ferreira (UFRJ), que se resume ao exame clínico do paciente, a vistoria ambiental in loco, somado aos exames laboratoriais, resultaram na conclusão de que este indivíduo sofria de contaminação por agrotóxicos, proveniente do composto químico 2-4-D ou o Agente Laranja, um organofosforado já proibido no Brasil.

Verificou-se que o produto tóxico, segundo explicação da medica citada, atuava da seguinte forma:

Atuava de forma a inibir a ação da Acetil Colinesterase (presente nas células vermelhas do sangue, nas sinapses nervosas e nos músculos estriados), que tem a função normalmente de destruir o neurotransmissor Acetil Colina, sendo esta uma ação necessária por permitir que o neurônio colinérigico retome seu estado de repouso após a ativação, evitando assim uma transmissão excessiva de Acetil Colina, que produziria uma super-estimulação do músculo e como consequência, debilidade e cansaço entre outros sintomas.

Em organismo humano sadio essa dinâmica esperada entre produção de Acetil Colina e destruição da Acetil Colinesterase normalmente faz com que a pessoa consiga executar através de comandos cerebrais, as tarefas motoras e intelectuais de forma adequada.

Em resumo, a partir dessa interação química do organismo com o herbicida (organofosforado), faz com que diminua a quantidade da enzima Acetil Colinesterase, portanto, sobra mais substância do que deveria de Acetil Colina, o que em excesso, altera as sinapses neuronais, levando a hiperestimulação da musculatura, causando as dificuldades apresentadas de locomoção e a consequente exaustão, como também o "desânimo", descritos pelo paciente. Além do desânimo e exaustão, outras funções do organismo podem ser afetadas, como o comprometimento da série vermelha do sangue, dependendo da quantidade e cronicidade da contaminação pelo agrotóxico.

Esses pesquisadores apesar de submeter o projeto de pesquisa a instância governamental (Edital 038/2005 - CNPQ), não conseguiram o necessário financiamento para o desenvolvimento do trabalho, o projeto não foi considerado "prioritário". Uma vez não obtido o financiamento o projeto foi reencaminhado em fins de 2005, para a Administração Executiva Regional de 
Guarapuava / AERGU / FUNAI responsável pela Terra Indígena, para a Coordenação Geral de Estudos e Pesquisas/FUNAI/Bsb, para o CGPIMA/FUNAI/Bsb, assim como para o MPF e a JF de Foz do Iguaçu, assim como ainda para a VI ${ }^{\mathrm{a}}$ Câmara de Coordenação e Revisão da Procuradoria Geral da República / VI ${ }^{\mathrm{a}}$ CCR/ PGR, para que assim dessem o devido encaminhamento; até o presente momento, também não houve nenhum retorno concreto de encaminhamento sobre o caso na própria aldeia. Assim a devida e urgente monitorização biológica e ambiental na microbacia do Córrego Santa Clara, uma das primeiras providencias a ser adotada, não foi realizada. Ambos os trabalhos dos pesquisadores, a saber, "MALM, O. \& outros. Relatório de visita da equipe do Núcleo de Estudos de Saúde Coletiva/NESC e do Instituto de Biofísica Carlos Chagas Filho/ IBCCF da Universidade Federal do Rio de Janeiro/UFRJ à aldeia Avá-Guarani situada na região do Oco’y Jacutinga, município de São Miguel do Iguaçu/Pr, à convite da FUNAI/Ministério da Justiça/MJ. Rio de Janeiro: NESC-IBCCF/UFRJ. 11p." e "MALM, O. \& outros. Avaliação do contexto de saúde humana e ambiental, com ênfase na contaminação por metais pesados e pesticidas, junto à população Guarani da Terra Indígena Avá-Guarani (Oco’y), desterrados de seu imemorial território de ocupação tradicional por Grandes Projetos (Parque Nacional do Iguaçu e UHE Itaipu) e circundados por áreas agrícolas de monoculturas. Rio de Janeiro: NESC-IBCCF/ UFRJ; AERBAU-CGPIMA/FUNAI; Projeto apresentado ao Edital 038/2005 - CNPQ. 2006. 25 p.”, encontram-se aqui anexados junto ao trabalho de Moraes (Anexo no 9).

\subsection{O contexto de saúde}

Pelos relatos dos profissionais de saúde existentes na aldeia, fica claro que os Guarani não estão conseguindo manter a sustentabilidade alimentar, descrevem não haver roças suficientes (na verdade, falta de espaço físico para o provimento alimentar básico), alimentação comprada de qualidade inadequada, barata diante do poder aquisitivo, composta em geral de farinha branca, macarrão, sal, açúcar, bolachas, doces e ás vezes quando é possível, “carnes de $3^{\circ}$ ”, ou seja, com muita gordura.

O retrato epidemiológico da Comunidade Indígena como um todo, apresenta estado de saúde precário, na qual a base fundamental está comprometida pela carência alimentar e condições sanitárias inadequadas; é comum os indivíduos apresentarem no Oco’y, desidratação, desnutrição, subnutrição, anemia, diarreia, verminoses, escabiose, gripes, pneumonia, além da malária e dos sintomas referentes à intoxicação por agrotóxicos, já descritos. 
Foi relatado pelos profissionais de saúde que nascem crianças fracas e quando as crianças de colo desmamam, caem logo em seguida em estado de subnutrição, período este que pode variar de 1 à 6 anos; é realizado o controle de crianças abaixo de 5 anos pelo Posto de Saúde da aldeia e das 98 crianças dessa faixa etária, 81 delas foram pesadas (2001), sendo que 14 estão desnutridas, 3 em estado grave, as 17 estando em acompanhamento; elas representam 34,6 \% do grupo populacional desta faixa etária. As que chegam à idade escolar passam a se alimentar na escola, através de merenda escolar, estas somam 111 crianças (2001). Nos adultos é visível o estado precário da saúde, muitos deles magros e pálidos.

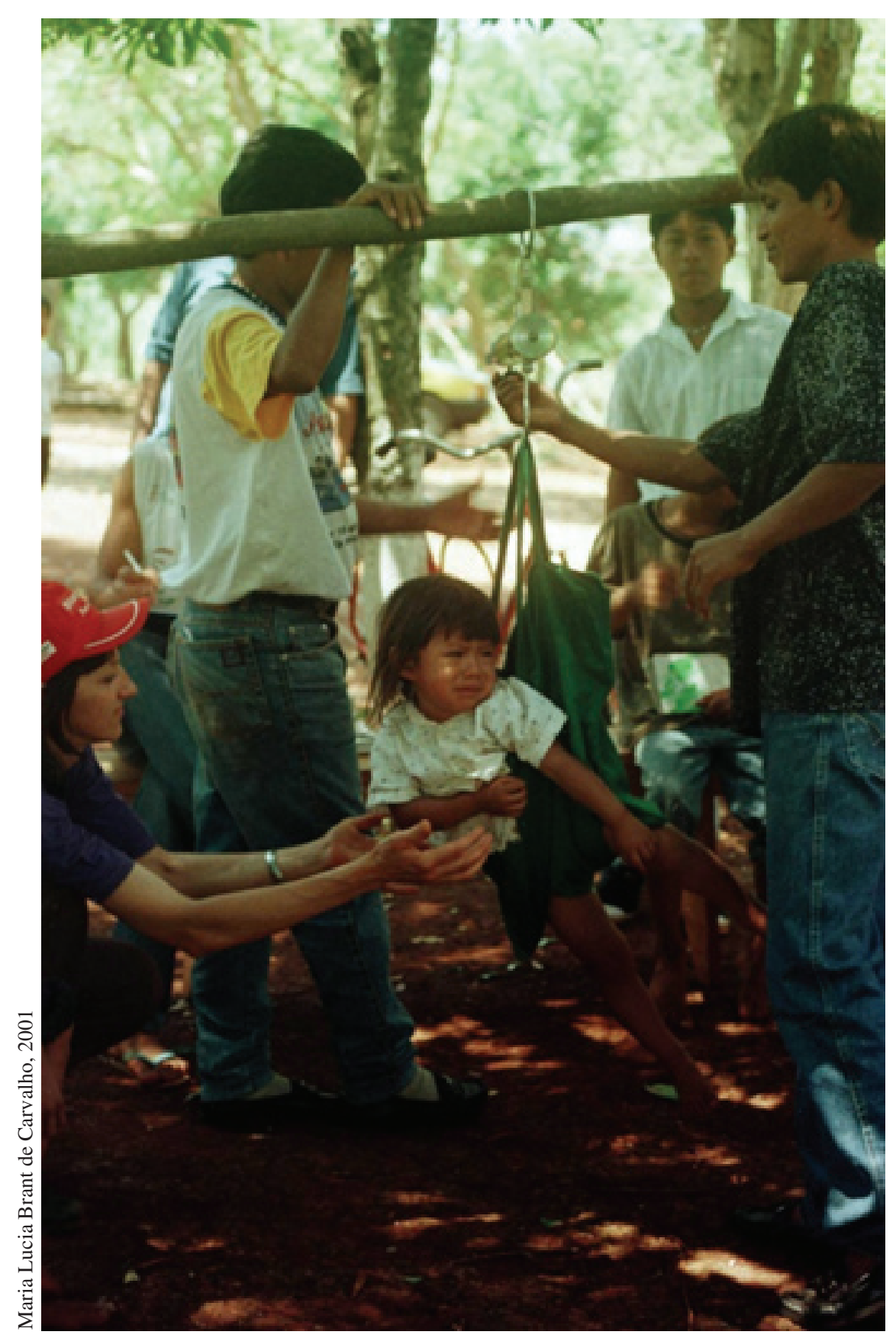

Figura 44. Foto. Crianças sendo pesadas na TI do Oco'y. 
Nos últimos quatro anos a auxiliar de enfermagem da TI percebeu que aumentou a taxa de desnutrição, ela associa a isso, a seguinte afirmação: muita coisa comprada barata que não tem valor nutritivo.

O pajé relatou que no dia-a-dia falta comida para a maioria das casas: as cestas básicas da CONAB, não alcança todas as pessoas o mês todo, vem todo o mês, mas não dá para o mês inteiro. As cestas são compostas de $5 \mathrm{Kg}$ de feijão, $10 \mathrm{Kg}$ de arroz e $1 \mathrm{Kg}$ de macarrão por família. Este fornecimento como vimos anteriormente, iria logo mais cessar; segundo o Chefe de Posto da FUNAI, a CONAB passou a fornecer cestas como essas somente duas vezes por ano.

Segundo relato da auxiliar de enfermagem Ivete em 11.10.2001, nesta TI, 15 gestantes apresentavam anemia, a maioria, segundo a visão da atendente: engravidam em seguida, estão sem controle de natalidade próprio, começam a engravidar com 12 anos. Em 2000 nasceram 16 crianças; de janeiro a outubro de 2001 nasceram 13 crianças. É claro que o componente alimentar, influencia essa situação.

Quanto ao papel do pajé, ele afirmou que a maioria das mães o procuram, que ele sabe fazer o medicamento que controla o nascimento das crianças, mas coloca, indagando: como dá pra fazer se não tem mais aqui todas as plantas, existe ainda uma ou outra planta, mas em pouca quantidade, outras nem existe mais para fazer a garrafada. Ele coloca ainda outro problema: nós temo dificuldade de passar o ensinamento para o pajé mais novo, se não tem a planta que precisa aqui.

Assim como foi já colocado, na medida em que se compromete o patrimônio físico, fica comprometido também o patrimônio cultural e por decorrência a saúde da população indígena.

Quanto à situação odontológica o dentista Dr Fabiano, afirmou que: a maioria das cáries são provocadas pelos hábitos alimentares adquiridos do meio externo, a alimentação que vem de fora (doces, balas, açucar etc), aliada ainda, a falta de escovação. Como já nos referimos a própria escola através da merenda escolar, também fornece alguns alimentos inadequados (entre eles os doces) contribuindo para difundir e criar hábitos de origem exógena, que além de pouco nutritivos, desdobra-se em mais problemas de saúde.

O hábito tradicional Guarani de fazer a higiene dos dentes era, segundo depoimentos dos indígenas, com os ossinhos do tórax de morcego, muito finos, semelhantes à palitos, sapecavam no fogo a fim de esterilizar e assim higienizavam os dentes. Hoje esse animal não é encontrado mais nessa área.

O dentista ainda afirma: os dentes de uns poucos são muito bons, quase de todos muito 
estragados; prótese todos querem; as gengivites, a inflamação dá-se devido ao acúmulo de placa bacteriana. Dessa forma pouca atenção e respeito são dados aos hábitos tradicionais, sendo que formas de adequação simples e criativas poderiam resolver problemas como esse apontado; quanto a interferência externa em termos alimentares, é considerada paradoxal e de auxílio duvidoso.

Dessa forma nega-se o direito de produzir satisfatoriamente a própria alimentação, na medida em que não há suficientes terras disponíveis; e com os parcos recursos financeiros que possuem acesso, os Avá-Guarani compram alimentos secos, os quais são possíveis de armazenar, pois nas casas indígenas não há refrigeração; esses alimentos "baratos" possuem baixo valor nutritivo, como descrito. A assistência social prestada em termos alimentares é em geral inadequada, sob o ponto de vista sociocultural dos costumes indígenas e incerta em seu fornecimento, não garantindo adequada cobertura. Assim troca-se uma alimentação sadia que poderiam produzir na própria terra se ela fosse adequada fundiária e ambientalmente, por uma alimentação comprada, barata, sendo ela fraca em termos nutritivos.

Os problemas respiratórios têm sido muito recorrentes entre todos os indivíduos, havendo naquele momento da pesquisa (11.10.2001) seis casos de pneumonia, complicações, segundo a médica, decorrentes de gripes não tratadas adequadamente.

Câncer, segundo a médica Dra Luz (2002), é comum de útero e próstata, dois casos foram a óbito recentemente..., fizemos três cirurgias de útero; ... agora o caso seu Guilherme no esôfago, é um câncer singular que deveria ser pesquisado, pois se constitui em uma mancha branca, diferente de outros casos de câncer. Há ainda, casos de crianças que nascem com síndrome de down, crianças nascidas anencéfalas que foram a óbito em seguida e o câncer de esofâgo de Seu Guilherme, casos que deveriam ser melhor pesquisados, diante da exposição ao agrotóxico.

Há um caso de AIDS na aldeia, o que se não bem assessorado pela equipe de saúde pode se tornar uma epidemia de graves consequências.

Quanto ao alcoolismo, na maioria das aldeias do Brasil quando a situação é socialmente muito estressante, como é o caso no Oco’y, os níveis de alcoolismo aumentam. Segundo a médica responsável, o alcoolismo se dá aqui em níveis preocupantes, em jovens e velhos; nos finais de semana os homens bebem, tomam escondido; hoje está mais controlado que antes.

O quadro de saúde da comunidade indígena Guarani do Oco’y é preocupante, consequência direta das condições fundiárias e socioambientais a que foram submetidos pelo próprio Estado (FUNAI e Itaipu Binacional), na medida em que conforme relato dos indígenas, foram 
reterritorializados em terras menores das que possuíam no Oco’y-Jacutinga, como também nelas inexiste a qualidade ambiental semelhante ao espaço anterior, questões essas que por determinação constitucional deveriam possuir os direitos garantidos.

Em termos fundiários a Terra Indígena Avá-Guarani do Oco’y, de fato e em termos legais não reúne características suficientes para assim ter sido oficialmente escolhida como terra substituta da anterior, em que essa comunidade habitava. Não é possível atender de forma minimamente satisfatória as necessidades de subsistência, tanto em termos de espaço físico, como em termos temporais, ao longo dos anos (uso e pousio). Como vimos o uso da terra se dá de forma continuada, em espaços mínimos para cada família, sem qualquer intermitência tanto com relação às necessidades de extrativismo (caça, pesca e coleta), quanto com relação a agricultura, atividades as quais deveriam ser itinerantes.

Em termos de qualidade ambiental, esse local não possui área florestada o suficiente para conter a necessária diversidade de recursos ambientais (fauna, flora e microrganismos), nem em qualidade e nem em quantidade, suficientes para atender à satisfação das necessidades de subsistência indígena. Pelas mesmas razões, falta de espaço e de intermitência; as condições sanitárias também se encontram comprometidas.

Como veremos adiante não foi considerado pelas autoridades estatais o volume populacional real do agrupamento nem o seu crescimento demográfico, quando ali foram reterritorializados. Nesse sentido ocorre previsível pressão demográfica sobre o ínfimo território do Oco’y.

Portanto, esse espaço não comporta a satisfação das necessidades de subsistência indígena, gerando quadro de insustentabilidade perante as necessidades de reprodução física e cultural da população Guarani do Oco’y.

Soma-se ainda à exposição dos indígenas a fatores de ordem externa, que poderiam ser claramente evitáveis. A área não possui qualquer proteção no entorno, estando a população indígena excessivamente próxima tanto da área interna limítrofe ao reservatório da Usina Hidrelétrica de Itaipu, quanto cercada externamente por todo o entorno pelas glebas dos colonos. A partir deste contexto a Comunidade Indígena sofre impactos sociais, ambientais e sanitários de toda ordem:

- a sobreposição da APP de Itaipu sobre a Terra Indígena, inicialmente já limita de forma prejudicial o uso indígena das terras e das águas. A população indígena foi reinstalada técnica e ilegalmente na mesma área de APP do reservatório, onde o mosquito transmissor da malária é presente no seu entorno, não só no Oco’y, mas em todo o entorno do reservatório, sendo 
inapropriado por lei qualquer população se estabelecer em APP; diante da indevida proximidade entre eles, provoca o quadro de malária verificado na população indígena. Na medida em que a hidrelétrica reduz o nível das águas do reservatório, os índios vêm uma de suas poucas fontes alimentares serem eliminadas, o pescado.

- a invasão da Terra Indígena por colonos, inicialmente já restringe o uso Guarani da mesma em menor porção de terras; as monoculturas instaladas no local provoca por meio de impactos socioambientais a contaminação por agrotóxicos, o que vem afetar a saúde da população indígena. É necessário Laudo Pericial para verificar a provável contaminação, ela se dá inclusive por produtos que são proibidos no Brasil. A contaminação provavelmente se dá nos seguintes locais:

- Roças, solos e seus produtos;

- Áreas de coleta, solos e seus produtos;

- Fontes de águas: reservatório de Itaipu, poços comuns e individuais, fontes naturais (olhos d'água);

- Animais de criação e o pescado existente no reservatório;

- A própria população indígena, diretamente pela aspersão e indiretamente através dos recursos ambientais citados, os quais consomem;

- Outro impacto sanitário-ambiental é caracterizado pela falta de disponibilidade de acesso a águas potáveis em quantidade e qualidade. É necessário Laudo Pericial visando verificar a contaminação provável de todas as fontes de água: reservatório da Itaipu, poços coletivos e individuais, fontes naturais, pelos seguintes elementos:

- restos mortais humanos (poço coletivo construído pela UHI ao lado de cemitério indígena);

- coliformes fecais e totais;

- contaminação por agrotóxicos.

A questão territorial é de vital importância para os Avá-Guarani do Oco’y, constituindo em reivindicação primordial da comunidade indígena. Colocam os Guarani, que qualquer outro benefício é questão secundária, primordialmente deve ser resolvida a questão fundiária. Em outros relatos anteriores o fato se repete, desde 1982, assim ao longo de 30 anos de demanda reprimida, foi verificado que foram realizados seis documentos antropológicos, inúmeros relatos da igreja (CIMI e CJP) e de organizações não-governamentais/ONGS, artigos em jornais locais, várias cartas escritas e enviadas pelos próprios Avá-Guarani, como ainda documentos da própria FUNAI, todos dirigidos a Presidência do órgão, documentos em que apontam para esta esperada resolução, a questão fundiária. 
Em antigo documento de 1994 da própria $\mathrm{FUNAI}^{34}$, é afirmado:

Ao longo dos anos os Guarani tem manifestado em todos os documentos à respeito dessa área, seu descontentamento em relação a escassez de terra recebida e sua inadequação às necessidades econômicas da comunidade, comprimidos que estão pelas águas do lago e pelas propriedades dos colonos da Gleba Ocoí. Desta forma é primordial e urgente a resolução da questão fundiária.

Sobre a insuficiência do território para as necessidades desta população indígena, o Estatuto do Índio assim como a Constituição Brasileira, são claros, ao determinar as condições necessárias para ser reconhecida certa porção de terras como Terra Indígena. Observemos Carta Magna:

Art. 231. São reconhecidos aos índios sua organização social, costumes, línguas, crenças e tradições, e os direitos originários sobre as terras que tradicionalmente ocupam, competindo à União demarcá-las, proteger e fazer respeitar todos os seus bens.

Paragráfo $1^{\circ}$ : $\underline{\text { São terras tradicionalmente ocupadas pelos índios as por eles habitadas em caráter }}$ permanente, as utilizadas para suas atividades produtivas, as imprescindíveis à preservação dos recursos ambientais necessários ao seu bem-estar e as necessárias a sua reprodução física e cultural, segundo seus usos, costumes e tradições.

Paragráfo $2^{\circ}$ : As terras tradicionalmente ocupadas pelos índios destinam-se à sua posse permanente, cabendo-lhes o usufruto exclusivo das riquezas do solo, dos rios e dos lagos nelas existentes.

Desta forma a área denominada “Terra Indígena Avá-Guarani do Oco’y”, não possui características suficientes para ser reconhecida legalmente como Terra Indígena, pois:

- não foram reconhecidos sua organização social, costumes, crenças e tradições, já que elas, por todo o exposto, se dão muito limitadamente no espaço atualmente ocupado;

- não foram reconhecidos os direitos originários sobre as terras que tradicionalmente ocupavam, já que, segundo depoimentos dos indígenas, ocupavam terras de maior extensão e de melhor qualidade ambiental. Segundo informações dos Guarani, foi prometido pela FUNAI e Itaipu Binacional que a situação seria provisória, no entanto, estão vivendo esta situação há 30 anos, desde 1982, quando ali foram reassentados;

- não foram reconhecidos os direitos que competem à União de proteger e fazer respeitar todos os seus bens;

\footnotetext{
${ }^{34}$ Relatório do Grupo de Trabalho FUNAI e Itaipu Binacional. Protocolo de Intenções de 20.05.1994. Processo FUNAI/Bsb n0178/94. Foz do Iguaçu em 20.07.1994: p. ilegível
} 
- não foram reconhecidos os direitos as terras tradicionalmente ocupadas pelos Avá-Guarani, na medida em que no local, as terras utilizadas para suas atividades produtivas, as imprescindíveis à preservação dos recursos ambientais necessários ao seu bem-estar, as terras necessárias a sua reprodução física e cultural, segundo seus usos, costumes e tradições, não podem se dar, pelo contrário, está configurado claramente a situação de grave confinamento dessa população, acarretando por isso mesmo inúmeros prejuízos sociais, culturais, econômicos, ambientais, sanitários e de saúde à Comunidade Indígena.

- não foram reconhecidos os direitos as terras tradicionalmente ocupadas pelos Guarani na medida em que neste local, não lhes cabe o usufruto exclusivo das riquezas do solo, dos rios e $\underline{\text { dos }}$ lagos nelas existentes. Os Avá-Guarani foram submetidos indevidamente pelo próprio Estado, ao contexto verificado, na medida em que o uso da Terra Indígena deve ser necessariamente "exclu-

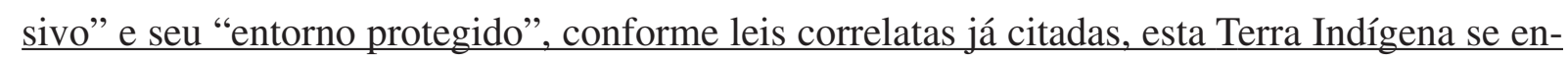
contra sobreposta a APP de Itaipu e invadida (também sobreposta como veremos mais tarde) pelas Glebas de Colonos.

$\mathrm{Na}$ análise feita fica claro a inviabilidade da população indígena Avá-Guarani viver de forma satisfatória nesta área territorial. Como pode-se observar a situação é estressante, sob todos os pontos de vista. Estas condições foram impostas por um conjunto de ações inadequadas, tanto do ponto de vista dos fatos, quanto do ponto de vista jurídico, quando de seu reassentamento em 1982 na Terra Indígena Avá-Guarani do Oco’y. Sobre essa questão, veremos as formas com que foram repassadas as terras para os Avá-Guarani no capítulo 5.

A questão dos Guarani do Oco’y, com base na legislação brasileira vigente, não foi observada e respeitada pelo próprio poder Executivo de Estado, a quem compete, a princípio, fazer justamente com que a lei seja cumprida por todos.

\subsection{O contexto de vida dos Avá-Guarani em Tekoa Ãnetete}

De 1982 a junho de 1995 os Guarani enviaram sistematicamente documentos a FUNAI e a Itaipu Binacional assim como realizaram diversos encontros com membros dessas instituições, colocando seu descontentamento com as terras recebidas do Oco'y, bem como solicitando outras terras.

Weber (1995) informou em documento desse mesmo ano, o andamento das discussões dos Avá-Guarani com a Itaipu no que se referia a resolução da questão da terra: 
De 1982 até hoje (1995) a Itaipu vem apenas implementando projetos emergenciais, sem, no entanto, atender ao problema central que envolve os Avá-Guarani - a questão da terra. Novamente em junho de 1995, os Avá-Guarani estabeleceram contato com o então Presidente da Itaipu Binacional, afim de obterem informações sobre o convênio que deveria ser assinado entre Itaipu, FUNAI, Prefeitura de São Miguel do Iguaçu e o Governo do estado do Paraná. Este convênio deveria proporcionar benefícios e soluções para os problemas da aldeia do Ocoí, mas fundamentalmente definir a questão da terra. O que os índios obtiveram, foram evasivas e novos prazos para a assinatura do convênio. Assim decidiram ocupar, uma área situada na faixa de proteção do lago, chamada Refúgio Bela Vista, com uma extensão de 622 hectares (Weber: 1995:68).

Weber colocou ainda que:

O departamento jurídico da Binacional tem questionado sistematicamente a reivindicação dos Guarani, quanto a receberem uma nova terra. Até o momento seu parecer é o de que a Empresa, ao demarcar a área do Ocoí e promover o reassentamento dos índios, cumpriu com sua responsabilidade, na medida em que atendeu as orientações do órgão tutor, bem como a legislação vigente sobre o assunto. Posição que tem sido sistematicamente criticada nos Laudos Antropológicos, realizados até o momento (Weber: 1995:69) (grifos nossos).

Quanto ao fato de como foi (des)cumprida a legislação vigente sobre o realocamento dos Guarani para o Oco’y, veremos em detalhe ao longo do capítulo 5.

Dessa forma no segundo semestre de 1995 ocorreu a ocupação de parte dos Guarani de Oco’y, no local denominado por eles de Paraná Porã, segundo a Itaipu, ocorreu a "invasão" do Refúgio Bela Vista, já que o local localiza-se em área de APP de Itaipu - novamente; como se observou, dada a escolha do local pelos Avá-Guarani, são poucos os locais florestados que restaram no oeste paranaense; todavia, pelos estudos históricos e antropológicos realizados sobre a região, essa área de terras também eram de posse dos Avá-Guarani, portanto, na verdade o que estava ocorrendo na visão deles, era "a reocupação" de uma área que também fora deles próprios.

Após essa reocupação do Paraná Porá, em 04 de março de 1997 é adquirida por Itaipu uma fazenda de 1774 hectares localizada em sua maior parte no município de Diamante D’Oeste e menor parte no município de Ramilândia no Paraná. Foram transferidas para o local todas as 21 famílias que estavam na área do Paraná Porã e 11 famílias que estavam no Oco’y.

Quando Itaipu adquiriu essas terras, o diretor-geral brasileiro da Itaipu, Euclides Scalco assim escreveu em 13.03.1997, ao presidente da FUNAI, Julio Gaiger: 
Com satisfação, informamos ter sido efetivada a aquisição, por esta Entidade binacional, da área rural de terras para o assentamento da comunidade indígena afetada pela formação do reservatório da Itaipu, conforme já fora adiantado em nossa correspondência (...). A próxima etapa dessa iniciativa da Itaipu, visando colaborar na solução da questão em tela, deverá ser o início das providências internas, exigidas no Anexo "A" do Tratado Brasil-Paraguai (Estatuto da Itaipu Binacional) para a doação da mencionada área à União Federal, mediante a assunção do encargo de transformá-la em reserva indígena. (E/GB/CT/0100/97, Curitiba, 13.03.1997)

Sete anos depois de ocupada (2004), os Avá-Guarani habitantes dessas terras, que veio a ser denominada Tekoa Ãnetete, explicaram para os trabalhos do Laudo Antropológico (Brant de Carvalho/2004), como esta terra foi adquirida por Itaipu. Segundo os Avá-Guarani, esta terra foi adquirida na "pressão" de Itaipu, sobre eles:

Tinha três áreas para ver: em Diamante D'Oeste, na Reserva de Itaipu (mun. Santa Helena) e na fazenda Guaçu (mun. Terra Roxa) ${ }^{35}$.

Era para visitar os três, mas Itaipu só levou no primeiro (Diamante D’Oeste). Falou pro Guarani que Terra Roxa seria muito caro, Itaipu não ia ter dinheiro pra paga. Aqui é mais perto. Aí os Guarani foram pra Paraná Porã. Aí Itaipu escolheu logo a mais barata (Diamante D’Oeste).

Tekoa Ãnetete na língua Guarani significa, Tekoa, lugar onde se pode viver conforme o

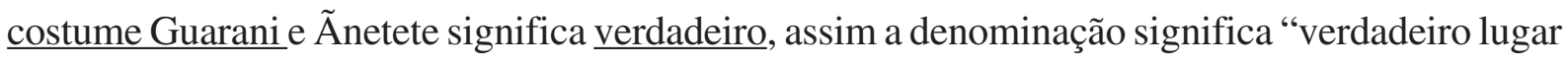
onde se pode viver conforme o costume Guarani”; todavia, os Guarani ao explicarem a qualidade ambiental destas terras, demonstram ser, esta denominação, na verdade, um profundo paradoxo perante a realidade apresentada:

Tem muita pedra aqui, maior parte é morro, é pouco o local que dá pra plantio. Não tem água no morro, na chuva o morro joga a água para baixo, alaga tudo, o cemitério com a chuva estoura tudo. Leva muito tempo pra seca, às vezes três semana, aí compromete tudo que planto. Aqui nós sofre muita inundação. Aqui era só vaca quando os Guarani vieram, plantação mesmo não tinha. A produção aqui se perde muito, se chove perde muita coisa e mato com água volta rápido. Muita água não dá pra faze a limpeza da roça tá tudo alagado, demora pra seca, acaba perdendo os plantio, apodrece. Todas as famílias que tão na parte baixa do território sofre com a inundação. Maior parte de Diamante é morro, ali ninguém pode mora, não tem água. No futuro não vai ter terra, família cresce a terra não.

\footnotetext{
$\overline{35}$ Esta última situa-se na antiga Ciudad Real de Guairá, local histórico, conhecido como tradicionalmente ocupado pelos Guarani, local em que na verdade desejavam se estabelecer.
} 
A partir da contradição entre a denominação do local de Tekoa Ãnetete e suas condições ambientais, nota-se que não foram os próprios Avá-Guarani que escolheram a terra e deram o nome ao local, ao contrário do que é difundido pela mídia por Itaipu. Ao visitá-la impressiona a grande quantidade de pedras existentes, em geral de difícil remoção, pois são pedras grandes. Verificou-se mais tarde, que essas terras realmente são as menos valorizadas da região do oeste paranaense, portanto, as mais baratas, por conter a natural dificuldade de haver muita pedra, dificultando o trabalho agrícola. Os Guarani que foram ali instalados passaram a ficar dependentes de máquinas contratadas pela Itaipu, para a retirada das pedras, para poder utilizar as terras.

Em Tekoa Ãnetete a própria condução interna das formas de manejo da terra, assim como o acesso dos indígenas para habitação no local (entrada - permanência - saída de famílias) são controlados por representantes da Usina Hidrelétrica de Itaipu.

A partir da instalação dos Avá-Guarani no Tekoa Ãnetete, junto a eles foi concebido um projeto socioeconômico de moldes desenvolvimentistas, conduzido por técnicos da Itaipu, em que inexistindo experiência indigenista, não tem levado em consideração as especificidades e necessidades da cultura Guarani, sobrepondo-se aos mesmos, tornando-os reféns de uma situação muito inusitada.

Segundo depoimento dos indígenas, as melhores terras são escolhidas para as "roças comunitárias" da Itaipu, restando aos próprios Avá-Guarani, para suas roças familiares, as terras menos favoráveis à agricultura, as quais inclusive não raras vezes sofrem enchentes, tendo as famílias já perdido várias vezes seus plantios, conforme descrito pelos Avá-Guarani. Nas "roças comunitárias" de Itaipu, são envolvidos comunitariamente os índios apenas no momento de realização do trabalho nelas; porém, os resultados obtidos dela, não são destinados aos índios, mas sim, são comercializados os produtos produzidos junto ao mercado externo, tal qual se faria em uma fazenda, onde são revelados publicamente e com muita satisfação, números altíssimos de produção de mandioca e outros artigos agrícolas, números esses que o próprio técnico agrícola de Itaipu admite como "um pouco exagerados".

Em relato, afirmaram ainda os Avá-Guarani, que em troca de sua "força de trabalho" em todas as atividades realizadas nas "roças comunitárias", recebem apenas cestas básicas e não raro ficam devedores nas contas do técnico de Itaipu. Eles se sentem "explorados" no trabalho com a terra e intimidados com a situação. Como agravante a Comunidade Indígena reunida reclama também da falta de acesso ao controle das entradas e saídas monetárias que ocorrem sob gerência técnica da Itaipu, o que faz com que os Avá-Guarani suponham que terceiros estejam se beneficiando dos recursos financeiros provenientes das "roças comunitárias", sendo eles próprios ex- 
cluídos dos benefícios. Esse sistema econômico desenvolvido pelo técnico de Itaipu é muito semelhante ao "sistema de barracão", desenvolvido em geral às escondidas, nos confins da Amazônia Legal, e, quando são identificados os fazendeiros que o praticam eles são presos e os funcionários considerados “escravos” são libertados. É o caso.

Ou seja, os Avá-Guarani do "verdadeiro lugar onde se pode viver conforme o costume Guarani", em realidade estão sendo explorados por um "sistema de barracão", onde sequer os produtos produzidos por eles, são destinados a eles próprios, mas para o mercado, sendo que a concepção constitucional que permeia a formação das Terras Indígenas, prevê o uso da terra fundamentalmente destinada à subsistência dos próprios indígenas.

Tentar transpor um modelo de economia de mercado para a população indígena é um dos maiores erros que se pode cometer em uma Terra Indígena. Ainda mais que os Guarani são no caso explorados como mão de obra barata em beneficio da Itaipu ou de seus técnicos. A própria FUNAI, marcada no passado por uma filosofia equivocadamente positivista, havia tentado também modelo de produção semelhante, destinado ao mercado, em terras indígenas, até os anos 80 . Após os anos 80 a FUNAI passou a enxergar o equívoco, desistindo pelo menos em tese, por ver o quão era inadequado, não era compreendido como necessário pelos indígenas, não respeitava as formas diversificadas de produção da subsistência indígena, não correspondia ao modelo de conservação e preservação indígena, provocava desmatamento de grandes áreas em função da instalação de monoculturas, comprometia assim a biodiversidade das terras indígenas, necessitava de implementos agrícolas sofisticados que os próprios índios não possuíam, não proporcionava a autogestão indígena, entre outras questões. Enfim, não respeitava a cultura indígena, conforme seus usos, costumes e tradições, que por direito constitucional eles teriam a determinação de conduzir suas próprias vidas, conforme ELES concebem viver.

As monoculturas extensas a partir do modelo acima descrito em Tekoa Ânetete, assim como a criação de gado ali também desenvolvida, que compacta o solo, comprometendo a curto e médio prazo as terras, não se caracteriza como modo de produção típico da economia Guarani. Pela falta de verdadeiro diálogo indigenista com os Avá-Guarani, são criadas situações socioambientais que se persistirem, degradarão solos e diversidade ambiental do local. Situação que os Guarani não terão condições técnicas e financeiras para reverter, tornando-se dependentes de um modo de produção, que na realidade não era, não é e nunca será o seu. A Constituição de 1988 reconheceu o direito a autodeterminação dos povos indígenas, que, como se vê no caso analisado, está sendo desrespeitado. 
A Terra Indígena deve ser gerida pelos indígenas e em função exclusivamente das necessidades indígenas, nas formas de produção tradicionais, que evitam o desgaste do solo e mantém a natural biodiversidade, fonte primeira da subsistência indígena, garantindo ainda, a sustentabilidade da terra à longo prazo. A sobrevivência física e cultural dos Guarani, depende de uma economia bastante diversificada em termos de produtos, caracterizada como "economia de subsistência indígena", como vimos anteriormente, modelo em que os membros da comunidade são responsáveis por todos os diversificados processos de produção, que envolvem a extração, o plantio e a colheita de inúmeras matérias-primas, necessárias à confecção de atividades imprescindíveis à manutenção da vida diária. Caracterizam-se como economias autossustentáveis, e para tanto, essencialmente dependentes de territórios florestados e amplos, ou seja, exatamente o avesso do modelo colocado em prática por Itaipu.

Como vimos os Guarani sentem-se intimidados diante desta situação, estando na verdade reféns desse contexto, pois, apesar de Tekoa Ãnetete ter sido destinada aos Avá-Guarani como compensação, a Terra Indígena esteve até a confecção do Laudo Antropológico em questão, não em nome da União, e sim em nome da Usina Hidrelétrica de Itaipu. Os Avá-Guarani de Tekoa Ãnetete, não conheciam, até novamente a confecção do LA a documentação da terra. Segundo eles, Itaipu não fornecia cópia dos documentos. Pelos documentos disponíveis em bibliografia, até a confecção do LA, a terra continuava em nome da Itaipu, e apontávamos que seria necessário, portanto, providenciar de forma urgente e rápida sua transferência, através da FUNAI, para o patrimônio da União.

Em 2006, portanto, somente nove anos depois de instalados no Tekoa Ãnetete, após a entrega de todos os Laudos Antropológicos (2002; 2003; 2004; e 2005) realizados por nós, apontando esses graves problemas e indicando a urgente resolução da documentação fundiária, nos foi comunicado verbalmente por funcionários da FUNAI, que Tekoa Ãnetete teria passado finalmente para o patrimônio da União, como Terra Indígena.

Segundo depoimentos indígenas, outro fato grave identificado é que a Itaipu Binacional quando adquiriu as terras de Tekoa Ãnetete, limitou a entrada à apenas as 32 (trinta e duas) famílias iniciais no local, como também determinou em um número máximo de 5 (cinco) famílias por ano, os que teriam a permissão da empresa para poder se instalar no Ãnetete!

Os Guarani de Tekoa Ãnetete, reclamam que “a FUNAI não dá documento pro Guarani que vieram do Paraguai, ele são tudo filho daquele que era do Brasil e foi para lá. Itaipu não deixa entra aqui”. Eles acrescentam que "Itaipu só deixa entra 5 famílias Guarani por ano aqui (Ãnetete)”. Perguntado “se sua filha quiser casar com Guarani nascido no Oco’y?” a resposta foi: 
“A Itaipu deixa, mas só dentro das 5 família por ano”. Perguntado "se sua filha quiser casar com Guarani lá do Paraguai?”a resposta foi: “Ah, aí a Itaipu não deixa”.

Como veremos adiante, os Guarani que a Itaipu aponta como paraguaios e não os aceita em Diamante D'Oeste, eles são os próprios, os filhos e os netos daqueles Guarani, que anos antes, foram obrigados a sair do Brasil em direção ao Paraguai, quando da inundação do Oco’y-Jacutinga pela Itaipu.

Estes fatos não ocorrem em qualquer outra terra indígena no Brasil, tratando-se de intervenção incorreta, arbitrária, que põe em risco a própria reprodução física da sociedade Guarani, interferindo profundamente nos seus mecanismos de organização interna, na dinâmica sociocultural das suas relações de reciprocidade. Itaipu realiza um controle de fronteira sobre os Guarani, decidindo arbitrariamente quem pode ou não viver em Ãnetete!

Assim na região, apesar de ter um representante da FUNAI, este não tem voz ativa, sujeitando-se às arbitrariedades da empresa, enquanto ela vem decidindo a seu modo, equivocado e autoritário, o destino da vida dos Avá-Guarani de Ãnetete.

Os Guarani do Oco'y afirmam que seus membros só podem se casar, quase que exclusivamente com membros de aldeias Guarani paraguaias, dada a falta de indivíduos Guarani na margem brasileira, com exceção feita a aldeia de Tekoa Ãnetete em Diamante D’Oeste ${ }^{36}$. Entretanto, nesta última aldeia, a Itaipu abusivamente limita a entrada ao número de 5 (cinco) famílias indígenas por ano!

A Itaipu, apesar de ter assessoria de antropólogo, não é um órgão indigenista. A Empresa, não levando em conta que os casamentos Guarani são exogâmicos, e só podem ser assim, do contrário a população correria o risco de fenecer por consanguinidade, impede, segundo depoimentos dos indígenas de Ãnetete, que famílias que tem membros Guarani nascidos no Paraguai tragam seus cônjuges, irmãos, filhos e netos, para viver no Ãnetete.

A intervenção é antiga. Em documento da própria Itaipu de 23 de agosto de 1988, denominado "Reserva Indígena Ava-Guarani: Subsídios Preliminares para Estudos do problemas da Reserva Ava-Guarani e da Participação da Itaipu Binacional nas Soluções 37 ”, em seu item "nº 2.

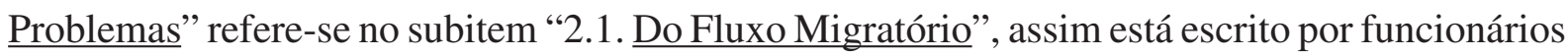
da hidrelétrica:

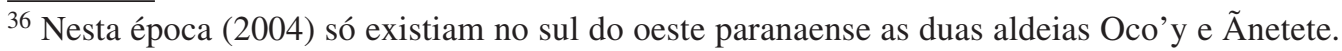

${ }^{37} \mathrm{Na}$ capa deste documento ainda está escrito a mão: "Trabalho obtido pelas misssionárias, por vias desconhecidas e divulgado entre os indios sem conhecimento e aprovação da Itaipu e FUNAI, com enfoque de que o mesmo seria imposto aos índios. Os índios tinham em mãos folhas xerox do trabalho".
} 
Por motivo de divergência de culto religioso, entre os crentes e os seguidores do culto ava-guaraní, os crentes chefiados por Fernando Martines ${ }^{38}$ saíram da reserva e tem seu retorno vetado (grifos nossos).

Mais a frente no ítem " $\mathrm{n}^{\circ}$ 3. Objetivos dos Projetos com Participação da Itaipu Binacional”, em seguida ao sub-item “3.2. Fixação do Índio na Reserva”, lê-se:

3.3. Controle de Fluxo Migratório. Conter aumento de famílias controlando, de alguma forma, a imigração de índios de outras localidades.

Seguindo esse raciocínio, nada antropológico e extremamente arbitrário, os Guarani dos dois países não poderão casar-se entre si e reproduzir sua sociedade como costumeiramente fazem há milênios. Isso, numa situação concreta em que os Guarani do Oco’y no Brasil só podem se casar com membros de Ãnetete (da qual estão limitados de entrar) ou de aldeias do Paraguai. Ainda, por esse pressuposto os de Oco’y irão ficar isolados do restante da sociedade Guarani?!

A aldeia do Oco'y no Brasil, nesta época (2004) era a única que havia restado na região do sul do oeste do Paraná, além de Ãnetete. A aldeia Acaray-mi ao lado de outras localizadas no Paraguai são as aldeias mais próximas, onde os Guarani podem selar seus laços de casamento. Praticamente todas as outras aldeias existentes no sul do oeste do Paraná/Brasil, próximas de Oco’y desapareceram, restando somente as aldeias Guarani em solo paraguaio.

Tentar separá-los por barreiras de Estados nacionais, como parece ser o procedimento de ambas Instituições, FUNAI e Itaipu, incorre em nova ilegalidade, pois os Guarani são povos autóctones da região, ocupam de forma imemorial a região das Três Fronteiras (Brasil, Paraguai e Argentina) anteriormente a qualquer tratado, legislação ou documentação. Trata-se de um direito consuetudinário assegurado por lei, fundado num complexo de normas não escritas, originárias dos usos e costumes tradicionais do povo Guarani. Apesar de não dominarem de forma exclusiva a extensa área que ocupavam no passado, continuam a fazer uso de forma tradicional de várias localidades desse território. Os Guarani não pertencem a uma ou outra nacionalidade, eles são supranacionais, estavam aqui antes de ser território espanhol e português, ou mais tarde, estavam antes que os próprios estados nacionais, brasileiro, paraguaio ou argentino se constituíssem como tais. Antes disso a região em questão constituía-se imemorialmente em terri-

\footnotetext{
${ }^{38}$ Fernando Martines, era um dos 4 chefes de famílias indígenas que haviam recebido um dos 4 títulos de propriedade da terra através do INCRA, na forma de modulo rural, portanto ilegal, como compensação de terras por Itaipu, questão essa, a forma de transmissão da terra para os índios, que veremos no capitulo 5.
} 
tório Guarani e de outras etnias indígenas. Portanto, estar aquém ou além daquelas fronteiras, não vem ao caso, pois a definição das fronteiras, arbitrária sob o ponto de vista Guarani, ocorreu posteriormente a sua ocupação.

A solução mais recente (2003-4) proposta por Itaipu para o problema, que ela considera "demográfico" e nunca "fundiário", é repetir procedimento semelhante realizado anteriormente nos anos 80 com o próprio Oco’y ${ }^{39}$. Assim, a empresa pretende levar famílias do Oco’y para o Tekoa Ãnetete, como atestam documentos da própria Itaipu, citados desde o relatório de 1988. Lideranças Guarani, em documentos recentes, afirmam que em Ãnetete “não cabe mais população". Realmente, não havia e não há no Ãnetete capacidade de suporte ambiental para abrigar mais população: poucas áreas planas passíveis de cultivo num território montanhoso e com muitas pedras grandes. Assim, se Itaipu insistir nesta medida, logo se iniciará outro conflito por mais terras.

A Itaipu não sabendo como lidar com o problema demográfico/fundiário criado por ela própria no Oco’y, como veremos adiante, ora impede a entrada de Guarani no Ãnetete limitando o número de famílias, ora quer levar os Guarani do Oco’y para o Ãnetete.

A diretoria de meio ambiente da Itaipu Binacional desde a gestão do governo FHC, já afirmava que não iria discutir a questão terras enquanto, nas suas palavras "vierem índios do Paraguai para o Brasil". Hoje continua afirmando o mesmo argumento, evitando destinar as terras à que tem direito os índios Guarani do Oco’y. Itaipu tenta justificar o inchaço populacional no Oco’y sob a pretensa ótica da migração, para justificar assim a relação grande população e pouca terra.

Apesar de haver inchaço populacional no Oco’y, assim há grande população em poucas terras, este dado de Itaipu trata-se de um artifício. No que se refere à migração os Guarani praticam como sempre praticaram, as trocas recíprocas entre aldeias, ou seja, a visita a parentes, os casamentos inter-aldeias, etc. Através dos casamentos realizados, que só podem ser exôgamicos, assim como atraem, também cedem membros do Oco’y. Esta taxa mantém certo equilíbrio, conforme estudos anteriores feitos por nós.

O problema na verdade é fundiário e não populacional como quer fazer crer a empresa. Assenta-se no fato de a Itaipu ter destinado à somente 4 famílias indígenas as terras do Oco’y, quando na verdade eram 70 famílias indígenas o número delas no Oco’y-Jacutinga. Assim como

\footnotetext{
${ }^{39}$ No Oco’y, a área territorial destinada por Itaipu ao assentamento da população indígena foi de forma ilegal, como veremos adiante, para apenas 4 famílias indígenas do Oco’y-Jacutinga. A empresa não se importou se em seguida foram assentadas mais 15 famílias, e depois mais e mais famílias que retornavam às terras do Oco’y, o qual na verdade era-lhes de direito ocupar, pois eram famílias desterradas também do Oco'y-Jacutinga. A questão terras para Itaipu resolveu-se naquele momento, "4 modulos rurais" para "indígenas"! e estava resolvido, não importava à empresa mais o número de indivíduos que viriam a ocupá-la.
} 
se assenta no fato de ter destinado a terra na forma de módulos rurais, apropriada - a forma - para colonos, Estatuto da Terra, quando na verdade tratava-se de população indígena, um Grupo Tribal, regida por outra legislação, Estatuto do Índio, legislação esta, específica para o modo de sobrevivência indígena. Assim a Terra Indígena do Oco’y, não se encontra exatamente inflada de população, as terras é que foram repassadas aos Guarani de forma ilegal, muito menores das que possuíam anteriormente, não compatíveis com as existentes no Oco’y-Jacutinga, região tradicional ocupação da população, a qual foi inundada pelo reservatório de Itaipu.

Quem visita a área do Oco’y e conhece minimamente a questão indígena, logo enxerga que a área é completamente inapropriada, que deveria ser destinada somente a outra finalidade (APP da Itaipu), mas que os Guarani ali foram encaixados de qualquer forma, espremidos entre o reservatório e os colonos. As terras em que configurava obrigação legal de Itaipu destinar aos Guarani, deveriam ser conforme o Artigo 20, parágrafo $3^{\circ}$ do Estatuto do Índio, ou seja, ser de extensão equivalente a anterior e ainda ecologicamente semelhante. Isto não ocorreu como provaremos no capítulo 5.

Contam os Guarani do Oco’y que a população indígena existente no antigo Oco’y-Jacutinga, muitos deles foram obrigados a força a dispersarem-se, inclusive para o Paraguai, na época do desterramento pelo INCRA (1973) e pela Itaipu (1982). Posteriormente estes dispersos voltaram ao local onde fora destinado as terras a eles, ou seja, ao Oco'y. Porém o Oco’y era muito pequeno já para as 4 famílias que ali passaram a habitar. Com o passar do tempo, diante da vinda de mais população que também obtinha direito às terras, o Oco'y tornou-se ainda mais impraticável.

É o que os índios Guarani do Oco’y, afirmam em sua simplicidade: “aqueles que vieram do Paraguai é os mesmos que foram antes daqui (Brasil) para lá (Paraguai), é as mesma família, tudo parente nosso".

A população indígena da TI do Oco’y transita fundamentalmente entre o Brasil e o Paraguai, pelas respectivas aldeias Oco’y e Acaray-mi. Assim como cede população indígena do Brasil para o Paraguai, atrai população indígena do Paraguai para o Brasil. Este dado não é o responsável pelo crescimento demográfico apresentado, pois apresenta-se equilibrado, como vimos em estudos anteriores, não há existência de mais indivíduos vindo de lá (Paraguai) para cá (Brasil). Porém, deve-se considerar que o crescimento demográfico no Oco'y é alto, e se dá de forma semelhante a qualquer aldeia Guarani, nas quais apresentam altas taxas de fecundidade (em media de 6 a 8 filhos/ mulher), assim como sucessão de gerações em curto período de tempo, casam-se cedo em torno de 14 a 16 anos. É aí que reside o crescimento demográfico alto da população indígena. 
Como a população indígena cresce rapidamente e as áreas territoriais são historicamente cada vez mais em menor número e diminutas em extensão, consequentemente a maioria das aldeias se encontram com superpopulação. Se não há disponibilidade de terras, inviabiliza-se a sobrevivência física e cultural, indígena.

Acresce ao fato a questão de que como houve uma verdadeira limpeza étnica na região expulsando índios Guarani de todo oeste paranaense, fundamentalmente para o Paraguai, as poucas aldeias que restaram no lado brasileiro - diante do diminuto percentual de terras disponíveis, estão superpovoadas.

Deve-se recordar ainda, que da mesma forma, os índios Guarani habitantes das aldeias do Paraguai, são povos que também perderam suas terras em função da inundação de Itaipu no lado paraguaio. E ali a situação de descaso oficial perante os povos indígenas ainda é maior. São Ñandeva /Chiripá da mesma forma que os de Oco'y.

O procedimento praticado por Itaipu é o mesmo que historicamente a FUNAI, durante a ditadura militar e até mesmo antes disso, vinha praticando nesta região do Paraná. Agiram de forma a ir contra os direitos territoriais indígenas na região, ocasionando o desaparecimento de inúmeras terras indígenas, inflando populacionalmente as poucas aldeias restantes. O resultado deste processo, pudemos verificar que das 32 (trinta e duas) aldeias levantadas ${ }^{40}$ por nós junto a informantes indígenas, que existiam entre os anos 40 e 80 do século XX no oeste paranaense, todas elas desapareceram, foram extintas. Apareceram somente após o conflito com Itaipu (1982) apenas 2 (duas) aldeias, o próprio Oco’y e Ãnetete, na região sul do oeste paranaense. A tendência da população tem sido crescer e não diminuir. Ao contrario a tendência das terras indígenas tem sido diminuir em numero e dimensões. Este é claramente um processo genocida.

Conter os índios Guarani provenientes do Paraguai para Oco’y e Ãnetete - como ainda dá margem de entendimento diante das pretensões de Itaipu, não é possível, não há como separálos, pois ali, antes de ser área de fronteira entre os três países, Brasil, Paraguai e Argentina, já era antes, originalmente, território Guarani. Como irão separar famílias inteiras de supostas "nacionalidades" distintas. Exige a Itaipu para discutir a destinação de terras aos Guarani um premissa falsa, uma nacionalidade "puramente" brasileira, que não existe, já que o povo Guarani foi, é e será sempre, supranacional.

Tentar separá-los por barreiras nacionais, como parece ser o raciocínio de Itaipu, significa incorrer em outra ilegalidade. Como população supranacional ela tem o direito de ir e vir por

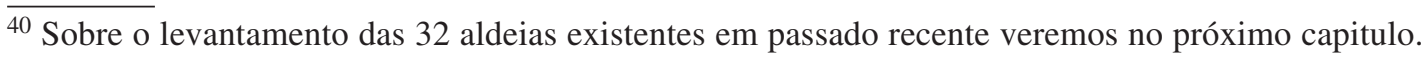


entre essas fronteiras, conforme assinalam as Convenções da Organização Internacional do Trabalho (OIT) de Genebra no $107(1957)^{41}$ e no $169(1989)^{42}$, das quais o Brasil é signatário sucessivamente de ambas.

É útil ainda tomarmos contato com a Convenção Internacional de Genebra $n^{\circ}$ 169/OIT, sobre os seguintes aspectos, já que a grande maioria deles não foram levados em conta no processo descrito nesta tese.

Parte I. Política General

\begin{abstract}
Artículo 1
El presente Convenio se aplica: a los pueblos en países independientes, considerados indígenas por el hecho de descender de poblaciones que habitaban en el país o en una región geográfica a la que pertenece el país en la época de la conquista o la colonización o del establecimiento de las actuales fronteras estatales y que, cualquiera que sea su situación jurídica, conservan todas sus propias instituciones sociales, económicas, culturales y políticas, o parte de ellas.

a) a los pueblos tribales en países independientes, cuyas condiciones sociales, culturales y económicas les distingan de otros sectores de la colectividad nacional, y que estén regidos total o parcialmente por sus propias costumbres o tradiciones o por una legislación especial;
\end{abstract}

Artículo 2

Los gobiernos deberán asumir la responsabilidad de desarrollar, con la participación de los pueblos interesados, una acción coordinada y sistemática con miras a proteger los derechos de esos pueblos y a garantizar el respeto de su integridad.

2. Esta acción deberá incluir medidas:

b) que promuevan la plena efectividad de los derechos sociales, económicos y culturales de esos pueblos, respetando su identidad social y cultural, sus costumbres y tradiciones, y sus instituciones;

\title{
Artículo 3
}

1. Los pueblos indígenas y tribales deberán gozar plenamente de los derechos humanos y libertades fundamentales, sin obstáculos ni discriminación. Las disposiciones de este Convenio se aplicarán sin discriminación a los hombres y mujeres de esos pueblos.

\footnotetext{
$\overline{{ }^{41}}$ A Convenção Internacional de Genebra $n^{\circ}$ 107/OIT criada em 1957 e ratificada pelo Congresso Nacional brasileiro em 1966, em seguida pelo Estatuto do Índio de 1973, Lei 6001, assim afirma em seu Título VII, Disposições Gerais, Artigo 66: Artigo 66. O órgão de proteção ao silvícola fará divulgar e respeitar as normas da Convenção de Genebra 107, promulgada pelo decreto n ${ }^{\circ} 58.824$ de 14/07/1966.

${ }^{42} \mathrm{Em} 1989$, é criada a Convenção ${ }^{\circ} 169$ da Organização Internacional do Trabalho/OIT (Genebra), ratificada pelo governo brasileiro em 2003, a qual substitui a primeira, fundamentalmente afim de eliminar a orientação assimilacionista dos governos com relação a estes povos, reconhecendo desta forma, o direito dos mesmos à autodeterminação cultural e econômica.
} 
2. No deberá emplearse ninguna forma de fuerza o de coerción que viole los derechos humanos y las libertades fundamentales de los pueblos interesados, incluidos los derechos contenidos en el presente Convenio.

\section{Artículo 4}

1. Deberán adoptarse las medidas especiales que se precisen para salvaguardar las personas, las instituciones, los bienes, el trabajo, las culturas y el medio ambiente de los pueblos interesados.

2. Tales medidas especiales no deberán ser contrarias a los deseos expresados libremente por los pueblos interesados.

3. El goce sin discriminación de los derechos generales de ciudadanía no deberá sufrir menoscabo alguno como consecuencia de tales medidas especiales.

\section{Artículo 5}

$\mathrm{Al}$ aplicar las disposiciones del presente Convenio:

a) deberán reconocerse y protegerse los valores y prácticas sociales, culturales, religiosos y espirituales propios de dichos pueblos y deberá tomarse debidamente en consideración la índole de los problemas que se les plantean tanto colectiva como individualmente;

b) deberá respetarse la integridad de los valores, prácticas e instituciones de esos pueblos;

\section{Artículo 7}

1. Los pueblos interesados deberán tener el derecho de decidir sus propias prioridades en lo que atañe al proceso de desarrollo, en la medida en que éste afecte a sus vidas, creencias, instituciones y bienestar espiritual y a las tierras que ocupan o utilizan de alguna manera, y de controlar, en la medida de lo posible, su propio desarrollo económico, social y cultural. Además, dichos pueblos deberán participar en la formulación, aplicación y evaluación de los planes y programas de desarrollo nacional y regional susceptibles de afectarles directamente.

3. Los gobiernos deberán velar por que, siempre que haya lugar, se efectúen estudios, en cooperación con los pueblos interesados, a fin de evaluar la incidencia social, espiritual y cultural y sobre el medio ambiente que las actividades de desarrollo previstas puedan tener sobre esos pueblos. Los resultados de estos estudios deberán ser considerados como criterios fundamentales para la ejecución de las actividades mencionadas.

4. Los gobiernos deberán tomar medidas, en cooperación con los pueblos interesados, para proteger y preservar el medio ambiente de los territorios que habitan.

\section{Artículo 8}

1. Al aplicar la legislación nacional a los pueblos interesados deberán tomarse debidamente en consideración sus costumbres o su derecho consuetudinario. 
2. Dichos pueblos deberán tener el derecho de conservar sus costumbres e instituciones propias, siempre que éstas no sean incompatibles con los derechos fundamentales definidos por el sistema jurídico nacional ni con los derechos humanos internacionalmente reconocidos. Siempre que sea necesario, deberán establecerse procedimientos para solucionar los conflictos que puedan surgir en la aplicación de este principio.

Parte II. Tierras

Artículo 12

Los pueblos interesados deberán tener protección contra la violación de sus derechos, y poder iniciar procedimientos legales, sea personalmente o bien por conducto de sus organismos representativos, para asegurar el respeto efectivo de tales derechos. Deberán tomarse medidas para garantizar que los miembros de dichos pueblos puedan comprender y hacerse comprender en procedimientos legales, facilitándoles, si fuere necesario, intérpretes u otros medios eficaces.

Artículo 13

1. Al aplicar las disposiciones de esta parte del Convenio, los gobiernos deberán respetar la importancia especial que para las culturas y valores espirituales de los pueblos interesados reviste su relación con las tierras o territorios, o con ambos, según los casos, que ocupan o utilizan de alguna otra manera, y en particular los aspectos colectivos de esa relación.

2. La utilización del término tierras en los artículos 15 y 16 deberá incluir el concepto de territorios, lo que cubre la totalidad del hábitat de las regiones que los pueblos interesados ocupan o utilizan de alguna otra manera.

\section{Artículo 14}

Deberá reconocerse a los pueblos interesados el derecho de propiedad y de posesión sobre las tierras que tradicionalmente ocupan. Además, en los casos apropiados, deberán tomarse medidas para salvaguardar el derecho de los pueblos interesados a utilizar tierras que no estén exclusivamente ocupadas por ellos, pero a las que hayan tenido tradicionalmente acceso para sus actividades tradicionales y de subsistencia. A este respecto, deberá prestarse particular atención a la situación de los pueblos nómadas y de los agricultores itinerantes.

2. Los gobiernos deberán tomar las medidas que sean necesarias para determinar las tierras que los pueblos interesados ocupan tradicionalmente y garantizar la protección efectiva de sus derechos de propiedad y posesión.

3. Deberán instituirse procedimientos adecuados en el marco del sistema jurídico nacional para solucionar las reivindicaciones de tierras formuladas por los pueblos interesados. 


\section{Artículo 15}

1. Los derechos de los pueblos interesados a los recursos naturales existentes en sus tierras deberán protegerse especialmente. Estos derechos comprenden el derecho de esos pueblos a participar en la utilización, administración y conservación de dichos recursos.

2. En caso de que pertenezca al Estado la propiedad de los minerales o de los recursos del subsuelo, o tenga derechos sobre otros recursos existentes en las tierras, los gobiernos deberán establecer o mantener procedimientos con miras a consultar a los pueblos interesados, a fin de determinar si los intereses de esos pueblos serían perjudicados, y en qué medida, antes de emprender o autorizar cualquier programa de prospección o explotación de los recursos existentes en sus tierras. Los pueblos interesados deberán participar siempre que sea posible en los beneficios que reporten tales actividades, y percibir una indemnización equitativa por cualquier daño que puedan sufrir como resultado de esas actividades.

Artículo 16

1. A reserva de lo dispuesto en los párrafos siguientes de este artículo, los pueblos interesados no deberán ser trasladados de las tierras que ocupan.

2. Cuando excepcionalmente el traslado y la reubicación de esos pueblos se consideren necesarios, sólo deberán efectuarse con su consentimiento, dado libremente y con pleno conocimiento de causa. Cuando no pueda obtenerse su consentimiento, el traslado y la reubicación sólo deberá tener lugar al término de procedimientos adecuados establecidos por la legislación nacional, incluidas encuestas públicas, cuando haya lugar, en que los pueblos interesados tengan la posibilidad de estar efectivamente representados. 3. Siempre que sea posible, estos pueblos deberán tener el derecho de regresar a sus tierras tradicionales en cuanto dejen de existir la causas que motivaron su traslado y reubicación.

4. Cuando el retorno no sea posible, tal como se determine por acuerdo o, en ausencia de tales acuerdos, por medio de procedimientos adecuados, dichos pueblos deberán recibir, en todos los casos posibles, tierras cuya calidad y cuyo estatuto jurídico sean por lo menos iguales a los de las tierras que ocupaban anteriormente, y que les permitan subvenir a sus necesidades y garantizar su desarrollo futuro. Cuando los pueblos interesados prefieran recibir una indemnización en dinero o en especie, deberá concedérseles dicha indemnización, con las garantías apropiadas.

5. Deberá indemnizarse plenamente a las personas trasladadas y reubicadas por cualquier pérdida o daño que hayan sufrido como consecuencia de su desplazamiento.

\section{Artículo 17}

Deberán respetarse las modalidades de transmisión de los derechos sobre la tierra entre los miembros de los pueblos interesados establecidas por dichos pueblos.

Deberá impedirse que personas extrañas a esos pueblos puedan aprovecharse de las costumbres de 
esos pueblos o de su desconocimiento de las leyes por parte de sus miembros para arrogarse la propiedad, la posesión o el uso de las tierras pertenecientes a ellos.

Artículo 18

La ley deberá prever sanciones apropiadas contra toda intrusión no autorizada en las tierras de los pueblos interesados o todo uso no autorizado de las mismas por personas ajenas a ellos, y los gobiernos deberán tomar medidas para impedir tales infracciones.

Artículo 19

Los programas agrarios nacionales deberán garantizar a los pueblos interesados condiciones equivalentes a las que disfruten otros sectores de la población, a los efectos de:

a) la asignación de tierras adicionales a dichos pueblos cuando las tierras de que dispongan sean insuficientes para garantizarles los elementos de una existencia normal o para hacer frente a su posible crecimiento numérico;

b) el otorgamiento de los medios necesarios para el desarrollo de las tierras que dichos pueblos ya poseen.

Parte VII. Contactos y Cooperación a Través de las Fronteras

Artículo 32

Los gobiernos deberán tomar medidas apropiadas, incluso por medio de acuerdos internacionales, para facilitar los contactos y la cooperación entre pueblos indígenas y tribales a través de las fronteras, incluidas las actividades en las esferas económica, social, cultural, espiritual y del medio ambiente.

Parte VIII. Administración

Artículo 33

1. La autoridad gubernamental responsable de las cuestiones que abarca el presente Convenio deberá asegurarse de que existen instituciones u otros mecanismos apropiados para administrar los programas que afecten a los pueblos interesados, y de que tales instituciones o mecanismos disponen de los medios necesarios para el cabal desempeño de sus funciones.

2. Tales programas deberán incluir:

b) la proposición de medidas legislativas y de otra índole a las autoridades competentes y el control de la aplicación de las medidas adoptadas en cooperación con los pueblos interesados.

Parte IX. Disposiciones Generales

Artículo 35

La aplicación de las disposiciones del presente Convenio no deberá menoscabar los derechos y las ventajas garantizados a los pueblos interesados en virtud de otros convenios y recomendaciones, instrumentos internacionales, tratados, o leyes, laudos, costumbres o acuerdos nacionales. 
Parte X. Disposiciones Finales

Artículo 36

Este Convenio revisa el Convenio sobre poblaciones indígenas y tribales, 1957.

Como veremos ao longo desta tese a lei de nada tem valido neste caso. A história que estamos vendo é uma representação midiatizada de um discurso marcado por feitos de poder. Um discurso proveniente da sociedade dominante para entreter a ela mesma. Para eles a presença milenar dos indígenas nas terras do oeste paranaense supostamente se desfez no ar e ainda, num passado antiquíssimo. A questão da presença indígena nas terras do oeste paranaense está atravessada por uma política dominante de produção do não saber. Ela materializa um discurso marcadamente ideológico e o faz funcionar como evidência. É a ordem do discurso da qual Foucault tanto falava. Os discursos são governados por formações discursivas, que regram o aparecimento de certos enunciados e determinam o que pode e deve ser dito num dado momento e num dado lugar.

A ordem do discurso dominante limita a visibilidade, fixa um sentido desejado e, neste caso, dirige o olhar do espectador. $\mathrm{O}$ objetivo da sociedade dominante não é problematizar a história dos Guarani na região; pelo contrário, é regrar o olhar de quem a enxerga. Ela põe em funcionamento mecanismos de organização do real, que são irreais.

Mas, a história é descontínua. É pulverizada por rupturas. A regularidade histórica é um efeito de sentido criado pela ideologia, que esconde a emergência da singularidade dos acontecimentos. A unidade histórica está ligada a sistemas de poder - a uma "ordem do discurso" que fixa um sentido desejado. Como veremos há um mosaico de sentidos, e não um sentido apenas. Todo discurso possui brechas. Nesse trabalho, nos colocamos em várias fissuras desse discurso midiático sobre a história do oeste paranaense, reproduzimos a interdição do indígena. É nessas fỉssuras que o sentido se mostra tenso e verdadeiro. É no entre-lugar que se ouve as vozes que estão sendo silenciadas, que se enxerga as múltiplas resistências.

Em CD anexo, na Pasta do Capitulo III encontram-se as fotos clicadas pelo fotógrafo Mauricio Simonetti quando da chegada dos Guarani ao Oco’y pela primeira vez. As denominamos “Chegada ao Oco’y em 1982". 


\title{
CAPÍTULO 4 \\ A IMEMORIALIDADE DA OCUPAÇÃO GUARANI NO OESTE PARANAENSE E SEUS DIREITOS AO TERRITÓRIO
}

\author{
Sobre a historia e a cultura, indígenas: \\ "Não se pode respeitar o que não se conhece". \\ Darcy Ribeiro
}

Os que num dado momento dominam são os herdeiros de todos os que venceram antes.

Walter Benjamin

\subsection{Esclarecimentos preliminares}

Quando em 1982 os Avá-Guarani foram retirados de suas terras de ocupação tradicional, o Oco’y-Jacutinga, em função da inundação para a criação do reservatório de Itaipu, deveria ter ocorrido alguns procedimentos legais, dentre os quais o reconhecimento fundiário das terras que ocupavam visando à compensação em novas terras, de igual tamanho e qualidade ambiental das terras anteriores, Lei 6001 de 19.12.1973 - Estatuto do Índio, Artigo 20, \# $1^{\circ}$ letra d, \# $2^{\circ}$ letra c, $\# 3^{\circ}$ e $\# 4^{\circ}$, procedimento que não existiu.

Assim deveria ter havido o reconhecimento da imemorialidade da ocupação indígena no local, legislação vigente à época, que tratava dos procedimentos de reconhecimento e posterior demarcação das terras indígenas. Na época as terras eram reconhecidas como indígenas, a partir de do vinculo histórico que os indígenas mantinham com elas. Tratava-se do reconhecimento do direito consuetudinário, isto é fundado nos costumes, que reconhecia o direito originário dos índios, como primeiros habitantes das terras, antes mesmo da formação do próprio Estado Nacional, e, portanto, o direito deles sobre elas, legislação existente desde o período colonial, já citada; legislação essa que se consubstanciou no denominado indigenato.

Essa legislação foi alterada com a Constituição Federal de 1988, pelo reconhecimento do modo de ocupação, se a forma de ocupação dos indígenas é tradicional ou não.

Nesse período um dos relatórios que constou à época dos procedimentos oficiais de transferência dos indígenas do Oco’y-Jacutinga para o Oco’y, foi o relatório denominado Relatório de Viagem $^{1}$, de autoria do Engenheiro Agrônomo da FUNAI, Edívio Battistelli, que fez no contexto

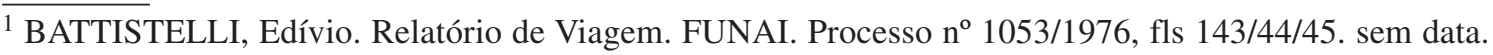


dos fatos a seguinte afirmação: O tempo de habitação destas terras por estas famílias variam muito, chegando até 49 anos, como existe um caso. Dado que o engenheiro agrônomo não era antropólogo ou historiador, para realizar tal assertiva, sua afirmação era, portanto, tanto técnica quanto historicamente, como vamos ver neste capítulo, inadequada.

Assim visando cobrir esta lacuna perante a Justiça Federal e Ministério Público Federal, ambos de Foz do Iguaçu, procuramos esclarecer a questão ${ }^{2}$.

Diante do desaparecimento de inúmeras aldeias da região do Oeste paranaense, o presente capítulo, pretende em linhas gerais, recuperar parte da historiografia dessa região, no que se refere à comprovação da ocupação tradicional do território pela população Guarani, em termos da imemorialidade dessa ocupação, discutindo o desaparecimento delas e seus correspondentes aspectos legais. Objetiva verificar também como a sociedade envolvente acabou por se estabelecer, redundando em esbulho de grande parte do território indígena. Deve-se considerar, e isso a historiografia "oficial" não leva em conta, a retomada em períodos diversos de grande parte (século XVII em diante) ou fração (século XX-XXI) de partes do território indígena tradicionalmente habitado, nessa mesma região.

A razão pela qual foi realizada esta pesquisa histórica e geográfica se insere em três indagações que necessariamente deveriam ser realizadas pelo Laudo Antropológico que realizamos anteriormente, pois, considerando as condições de vida existentes junto aos Guarani do Oco’y, estava claro que de alguma forma haviam sido esbulhados ${ }^{3}$ de suas terras.

a) A primeira indagação se resume a, de quais aldeias anteriores eram provenientes os Guarani do Oco’y, já que a ocupação Guarani é imemorialmente verificada de forma extensiva na região do Oeste paranaense. Assim para efeito dos trabalhos, se deveria provar a imemorialidade e a tradicionalidade da presença Guarani na região.

b) Na medida em que foi sendo respondida a primeira indagação, a seguinte questão se resumia a entender quais as legislações estavam em vigor quando se deram os referidos esbulhos, para então se poder encaminhar a nível legal a situação.

c) Diante do tratamento histórico dado ao espaço geográfico pelos que dominam a mídia regional no Oeste paranaense, a intenção deste capítulo foi também reatar as conexões históricas

\footnotetext{
${ }^{2}$ Este capítulo toma em parte informações do seguinte trabalho. BRANT DE CARVALHO, Maria Lucia. LAUDO ANTROPOLÓGICO. $1^{\circ}$ Parte: Plano Macro-Histórico das Populações Indígenas Avá-Guarani na Região Tradicional de Ocupação: Brasil/Paraguai/Argentina. Ref: Comunidade Indígena da Terra Indígena Avá-Guarani do Oco’y. Município de São Miguel do Iguaçu. Estado do Paraná. Brasil. São Paulo: AERBAURU/SP/FUNAI/ MJ. 2003, 138 p.

${ }^{3}$ Esbulho, i.e. privado da posse por fraude ou violência.
} 
sobre a recente presença dos Guarani no século XX, que haviam sido "desconectadas" sobre o território, por publicações provenientes desse próprio poder regional, visando assim mais uma vez comprovar a imemorialidade e a tradicionalidade da ocupação Guarani sobre o mesmo, assim como seus correspondentes direitos sobre ele. Objetivou assim desnudar determinado processo político existente, dado que esse poder regional, vem interpretando a questão demográfica e territorial dos Guarani do Oco’y, por meio de argumentos insustentáveis, os quais vêm comprometendo a solução da questão fundiária do grupo, trazendo de longa data intranquilidade à Comunidade Indígena, o que era necessário então, esclarecer.

Para efeito didático devemos começar do fim para o começo, assim serão esclarecidas preliminarmente a questão "c", "b" e "a" acima descritas.

Quanto a questão “c”", visa introduzir o tema do contexto sociopolítico existente regionalmente na época quando foi realizada a pesquisa, procurando reatar as conexões históricas que haviam sido "desconectadas" da região geográfica, pelo poder regional.

Quando nois chego aqui, não tinha nada, era tudo mato!! Nois que fizemo esta terra! Frase dita por imigrante polonês, quando da ocupação do oeste paranaense por imigrantes a partir dos anos 40 do século XX, sobre terras de ocupação tradicional Guarani. Extraído do filme "Vida de Polaco" de Silvio Back.

Entre os anos de 2001 à 2006 foram realizados alguns levantamentos sobre o contexto vivido pelos Guarani do Oco’y nas localidades das Mesorregiões, fundamentalmente Oeste e também na Noroeste e na Sudoeste paranaense (Figura 45). Por onde passávamos as populações indígenas e não indígenas ao tomarem conhecimento da pesquisa, informavam a respeito da existência de cemitérios indígenas, assim como de inúmeros objetos arqueológicos achados por curiosos, funcionários municipais, arqueólogos, professores universitários, agricultores, existindo até em alguns desses locais acervos municipais ou estadual, onde eram mantidos esses objetos.

Ao percorrer essa região do oeste paranaense, verificou-se que a presença atestando a ocupação Guarani é notória e recente. Territórios Guarani que já foram ocupados por não indígenas

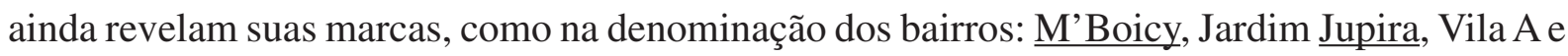
B de Itaipu, Vila Paraguaia, Vila Maracanã, Vila Carimã, Cataratas do Iguaçu, todos em Foz do Iguaçu; na denominação das localidades como Colônia Guarani, Ilha Acaray, (Foz do Iguaçu); nos nomes dos municípios por todo o estado do Paraná: Foz do Iguaçu, São Miguel do Iguaçu,

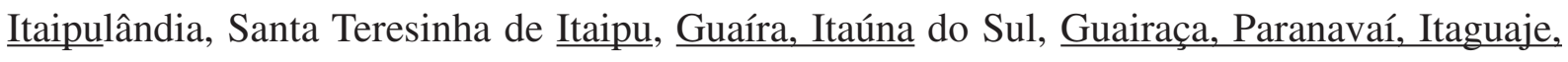
Iguaraçu, Santa Isabel do Ivaí, Amaporã, Tamboara, Tapira, Ivate, Icaraíma, Umuarama, Perobal, 
Iporã, Iracema, Maripa, Arapuã, Tupãssi, Iguatu, Anahí, Guaraniaçu, Ibema, Catanduvas, Cascavel, Capanema; como também nos nomes de rios: Paraná, Piquiri, Ivaí, Ocoí, Iguaçu, Paranapanema, Tibagi, Itararé; Poderíamos solicitar aos Guarani que traduzissem esses nomes, os quais nos seria apresentado certamente características geográficas e/ou ambientais destas regiões. Havia também indícios da presença Guarani nas ruínas das Missões Jesuíticas do Guairá e por fim nos inúmeros dados arqueológicos, históricos, geográficos e etnográficos já levantados anteriormente e os então, levantados por nós junto aos Guarani do Oco’y, atestando dessa forma sua recente presença na região.

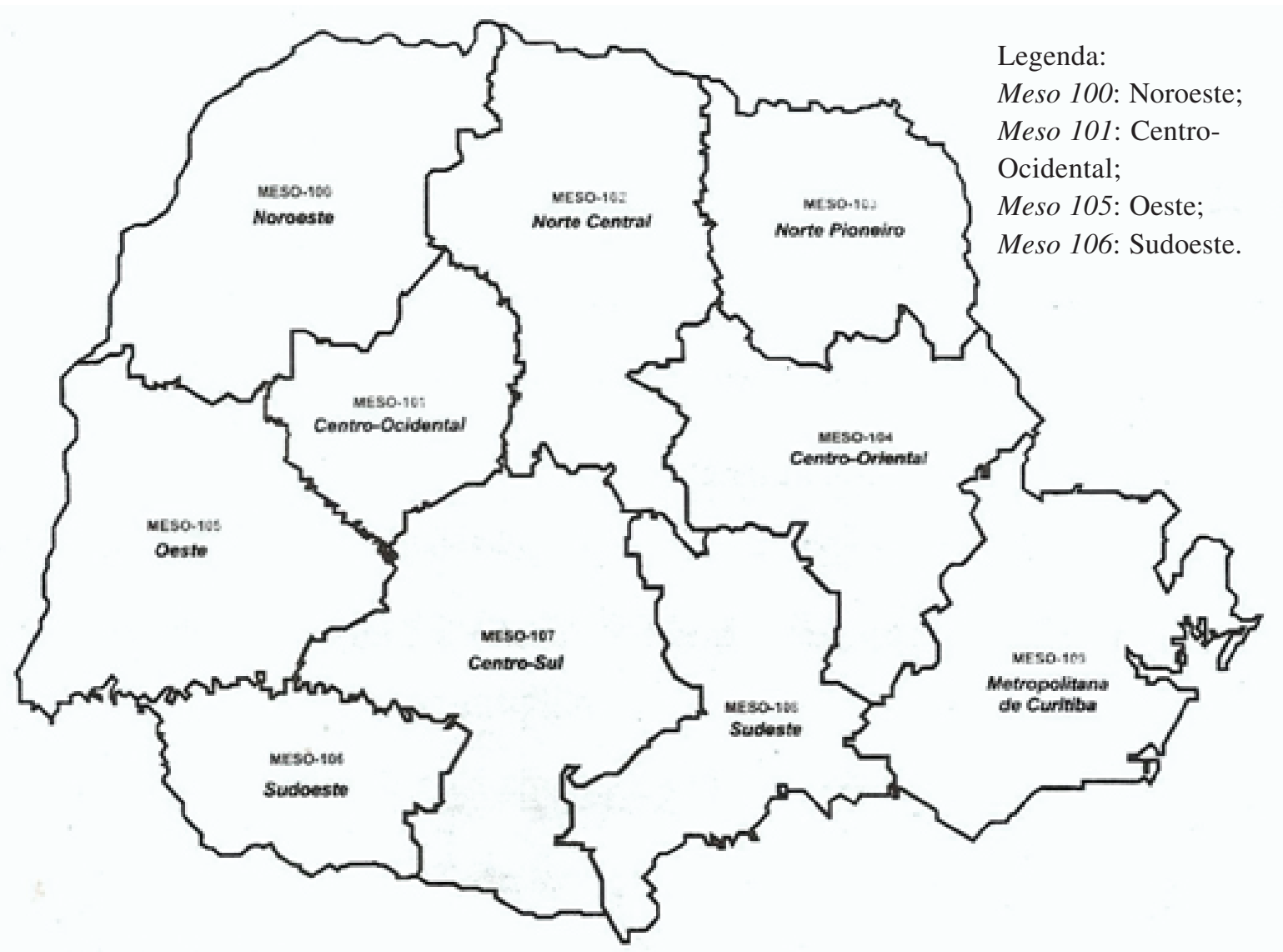

Fonte: Ipardes, 2005.

Figura 45. Mapa. Estado do Paraná. Mesorregiões geográficas.

Fonte: Caderno Estatístico Municipal de Foz do Iguaçu. Curitiba: IPARDES. 2005. 30 p. 
Esta área em que o imigrante, o senhor polonês se refere, que não tinha nada, que era tudo mato, era, na verdade, parte do território de ocupação imemorial de várias aldeias indígenas Guarani localizadas nas Mesorregiões citadas do oeste paranaense, mais especificamente dos Guarani do subgrupo Ñandeva, também autodenominados Avá-Guarani.

Certamente por estar o território indígena ambientalmente preservado em sua biodiversidade, na visão do senhor polonês, ele supunha, que ali não habitasse "ninguém". A partir da tensão existente, observável historicamente entre índios versus imigrantes, esta área foi possivelmente considerada pelos imigrantes como "território de ninguém", a ser desbravado e ocupado por meio de inúmeras formas, em geral caracterizadas pela violência, culminando na expulsão de seus primeiros habitantes, sendo este fato considerado "natural" pelos novos colonizadores.

Os Avá-Guarani do Oco’y possuem em seu repertório oral, guardado na memória, a ação dos "bugreiros", caçadores de índios, que como prova da "caçada" levavam para seus patrões as orelhas cortadas dos parentes ancestrais dos Guarani, os quais haviam sido mortos visando a "liberação" do território indígena.

Esse imaginário coletivo desenvolvido pela sociedade envolvente a respeito dos povos e das terras indígenas, como veremos se reproduz ainda hoje, por meio de mídias mais modernas e complexas.

Ao se realizar as pesquisas bibliográficas e de campo quanto a imemorialidade da ocupação da etnia, notou-se que havia duas tendências em tratar o tema, referente à presença indígena Guarani na região do Oeste paranaense.

Uma primeira tendência referia-se a literatura etnográfica existente, colhida por pesquisas de exploradores, viajantes, jesuítas, etnógrafos, arqueólogos, historiadores e antropólogos, os quais tiveram envolvimento ao longo do tempo com os próprios Guarani, acompanhando sua história, quando então produziram cada qual ao seu tempo, vasto material, em que dão conta da extensiva presença indígena Guarani desde épocas imemoriais na região Oeste do Paraná, ao longo desde pelo menos o século I (Depois de Cristo).

Podemos citar as pesquisas arqueológicas de Ambrosetti (realizadas no século XIX) e Chmyz (realizadas no século XX); as referências históricas dos diários de campo dos primeiros exploradores da região como Cabeza de Vaca e Schmidel (século XVI); os trabalhos dos missionários como Montoya e Maceta, onde se referem ás Reduções Jesuíticas do Guairá (séculos XVI e XVII) criadas em sua maioria sobre terras Guarani; as ações de destruição do Guairá pelos bandeirantes paulistas, como Raposo Tavares (século XVII); os levantamentos etnográficos mapeados por 
Nimuendajú (primeira metade do século XX); os levantamentos antropológicos de Edgard Assis Carvalho (segunda metade do século XX); e por fim os nossos próprios trabalhos antropológicos, nos quais também realizamos levantamentos etnográficos (realizados no século XXI).

Por outro lado a literatura histórica e geográfica não especializada na temática indígena, produzida no próprio estado do Paraná, analisa a questão da presença indígena Guarani sob ângulo de pensamento que difere do primeiro grupo. Por ser este segundo grupo, a literatura que domina a mídia informacional na região do Oeste paranaense, optamos por estudá-los com mais rigor.

Assim escrevíamos em nosso Laudo Antropológico (2003) sobre o assunto: Apesar da tímida - e não neutra - divulgação da existência hoje de povos indígenas na região do Oeste paranaense, eles estão ali. Com relação a este fato, o "establishment" local tenta por todo modo negar a presença dos mesmos, fundamentalmente através de duas vertentes de pensamento:

- a primeira, como realidade pertencente à apenas a um passado longínquo, na maioria das vezes não caracterizando a delimitação de seus territórios, apresentando os Guarani como simples coadjuvantes da história "branca”, oficial, negando enfim, a presença Guarani aqui e agora em pleno século XXI;

- a segunda, quando esses mesmos produtores de informação são obrigados a se deparar com a presença indígena real, atualmente e aqui nesta região do Oeste paranaense, reagem de modo a desenvolver um discurso caracterizado pelo preconceito, que pouco baseado na realidade dos fatos, afirmam que são os Guarani "índios aculturados".

Ao contrário do que afirmam, verificou-se que a maciça presença Guarani nessa região é mais recente do que querem imprimir ao leitor em várias publicações produzidas, pois até a década de 40 do século XX havia inúmeras aldeias da etnia no Oeste do Paraná, levantadas por esta pesquisa, principalmente no entorno de Foz do Iguaçu. Essas aldeias foram desaparecendo recentemente, ao longo das décadas de 40,50,60, 70 e 80, como veremos adiante.

É evidente para quem conhece os Guarani, que os mesmos possuem claramente sua identidade cultural definida, demonstrando forte resistência cultural, na medida em que se passaram 500 anos de colonização, suprimiram grande parte de suas terras e dos seus meios de sobrevivência tradicionais, e no entanto, continuam a ser indivíduos aldeados, em termos socioculturais essencialmente Guarani - seu ethos é muito claro, não foram, enfim, "integrados" à sociedade nacional, como esperava a política dominante.

Esses estudos científicos e materiais de divulgação turística provenientes do estado do Paraná trabalham de maneira seletiva, de forma que há informações que podem ser veiculadas e outras 
que não podem ser. Possuem uma visão "histórica" simples e linear, de que quando se instala a ocupação no território de grupo social pertencente à sociedade nacional, dão à entender que inevitavelmente os grupos indígenas "desapareceram”, como se um substituísse o outro naturalmente, desaparecendo no "ar" as primeiras populações, como se elas simplesmente deixassem de existir e não estivessem ocupando qualquer território, ou seja, como se supostamente estivessem "extintas".

Assim através destes trabalhos os povos indígenas são colocados compulsoriamente numa linha "evolutiva" da história, como se fossem apenas os seus "primeiros" protagonistas, sempre no tempo "passado", velando assim sua real contemporaneidade. Visam veicular na verdade, um resultado político, em que o "branco" em resumo é o "senhor" dessas terras. Assim denominamos estes trabalhos como sendo os representantes da "historiografia da dominação".

Como exemplo de situação que nega a presença Guarani na atualidade nessa região, podemos citar os trabalhos dos geógrafos Cardoso e Westphalen (1986) em que produziram o estudo denominado "Atlas Histórico do Paraná"4 . Ali se referem sobre a presença Guarani arqueologicamente identificada em mapa entre o período de 500 Antes de Cristo até 1500 Depois de Cristo. Assim são territorialmente identificados apenas e limitados a "pré-história" do Paraná colonizado, numa visão de história linear, em que depois de um grupo social necessariamente vem o outro a "substituir" o primeiro habitante no estado.

Em seguida na mesma publicação os mapas subsequentes que compreendem o período de 1500 até 1960 não apresentam a efetiva presença dos Guarani nessa região, embora textualmente se refira a presença deles no decorrer do período de 1500 a 1829, porém, como meros "coadjuvantes" da formação histórica "branca" do estado do Paraná. Nesse período segundo os autores, via de regra, as terras que foram sendo ocupadas pela sociedade envolvente, eram consideradas “despovoadas". Assim aonde, em que base territorial viviam nesse período os Guarani? Textualmente, a última vez que os autores se referem a “índios em geral”, é com a seguinte assertiva:

Em 20 de janeiro de 1829, foi transferido o Registro de tropas de Curitiba para o Rio Negro. Era preciso criar nessa localidade um núcleo de povoação que desse apoio aos tropeiros que entravam ou saíam do sertão, bem assim para conter ataques e correrias de índios da região.(CARDOSO e WESTPHALEN: 1986:54)

\footnotetext{
${ }^{4}$ CARDOSO, Jayme Antonio \& WESTPHALEN, Cecília Maria. Atlas Histórico do Paraná. $2^{\circ}$ edição. Curitiba: Chain Editora, 1986, 70p.
} 
Da mesma forma se dá o trabalho do geógrafo paranaense Roseira (2006). Em tese de mestrado denominada "Foz do Iguaçu - Cidade Rede Sul Americana", apesar de buscar as origens desta cidade de fronteira, limita-se no máximo a citar a região de estudo como sendo denominada originalmente de "Fronteira Guarani". Ao longo de todo o trabalho a denominação é citada inúmeras vezes, porém o autor ignora e deixa de explicitar o seu significado, ao menos a razão de sua origem. A "história” regional para o autor começa apenas quando se inicia a colonização pela sociedade nacional. Nega, portanto, a presença indígena tanto no passado como hoje. Na verdade, nota-se que não é intenção deliberada deste autor em suprimir a presença indígena, mas fruto de uma educação escolar que deixou de citá-los para as várias gerações de estudantes - apontando-os na realidade, como povos presentes originalmente e ainda contemporâneos - não fazendo parte dessa forma, do repertório do autor.

Por trás deste contexto de coisas, apresenta-se o grave problema fundiário existente no estado do Paraná com relação aos povos indígenas, especialmente de modo mais marcante com relação aos Guarani, por conta fundamentalmente da política oficial que foi implementada no século XX, como veremos ao longo deste e do próximo capítulo.

Os Guarani, são dentre as populações indígenas as que vêm tendo maior interface com a sociedade envolvente, tanto ao longo do tempo, há 500 anos, como no território, vivem como vimos anteriormente, nos espaços geográficos brasileiros mais valorizados do país, o sul e sudeste, áreas essas de grande ocupação e alta densidade demográfica não indígena, portanto, em locais onde se travam os maiores embates diante dos interesses fundiários do capital. Considerando que os Guarani são talvez a maior população indígena existente no Brasil, deve então residir aí, a razão pela qual ao longo do tempo, pouco se trabalhou institucionalmente pela demarcação de suas terras.

O caso que tratamos é bastante emblemático, pois se trata de população indígena tradicionalmente habitante da região noroeste, oeste e sudoeste do estado do Paraná, a qual vem resistindo a inúmeras pressões ao longo da história de contato com a sociedade envolvente, possuindo hoje, dentre os indígenas dessa região, a maior expressão de resistência no Brasil, são eles os próprios Guarani do Oco'y.

O estado do Paraná possui os solos mais férteis do mundo, a denominada Terra Roxa. Somente a partir da década de 40 do século XX essas terras passaram a ser realmente colonizadas

\footnotetext{
${ }^{5}$ ROSEIRA, Antonio Marcos. Foz do Iguaçu. Cidade rede Sul-Americana. Dissertação de Mestrado. Departamento de Geografia Humana. FFLCH/USP. São Paulo, 2006. 170 p.
} 
pelos imigrantes e brasileiros, pelo noroeste por grandes latifundiários, os denominados "barões do café" em geral paulistas e pela região sudoeste por pequenos proprietários, gaúchos, catarinenses e imigrantes europeus de várias nacionalidades.

Ao estudar a região ao longo dos séculos, especialmente ao longo do século XX, pode-se observar uma grande movimentação populacional nessa região. Índios Guarani, posseiros e pequenos proprietários, foram sendo todos, espacialmente substituídos nessa região, por duas principais razões: - pela agroindústria ou pelo agronegócio, primeiramente de café e em seguida a partir dos anos 60 pela soja; - pelos dois Grandes Projetos do Estado que ali se instalaram.

Os dois Grandes Projetos do Estado, o Parque Nacional do Iguaçu e a Usina Hidrelétrica de Itaipu, fontes de divisas importantes para o Brasil, respectivamente turismo e energia, e a Terra Indígena Avá-Guarani do Oco’y, localizam-se respectivamente próximo e na própria divisa na região da Tríplice Fronteira entre Brasil, Paraguai e Argentina.

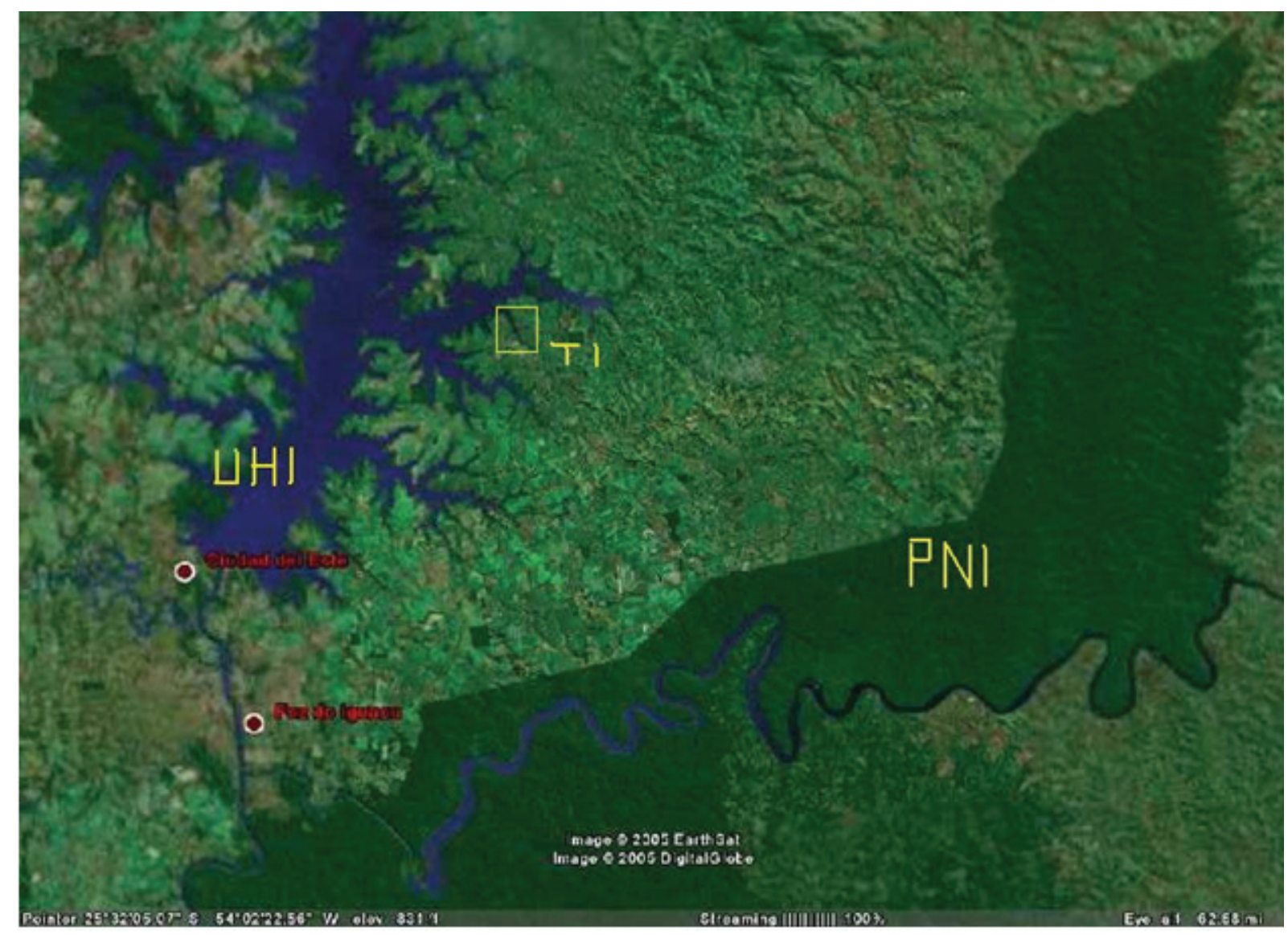

Figura 46. Mapa. Tríplice Fronteira entre Brasil, Paraguai e Argentina. Parque Nacional do Iguaçu. Usina Hidrelétrica de Itaipu. Terra Indígena Avá-Guarani do Oco’y.

Fonte: Google.Image.2005.Digital Globe. 
O Parque Nacional do Iguaçu fundado em 1939 com atualmente 185.262,50 hectares de terras no Brasil, é o maior parque nacional brasileiro extra-amazônico. Possui no seu interior o pólo turístico das Cataratas do Iguaçu, o qual atrai cerca de um milhão de visitantes anualmente, estando em segundo lugar no ranking turístico brasileiro, como local mais visitado do país (Parque Nacional do Iguaçu:Plano de Manejo/2000). É o único parque nacional do país que geram lucros para o Estado, enquanto que os outros são majoritariamente deficitários, segundo informações do próprio governo brasileiro. Ocupa frações de áreas de terras de 14 municípios paranaenses. Na fronteira argentina encontra-se o Parque Nacional do Iguassu, em área limítrofe ao parque brasileiro.

A Usina Hidrelétrica de Itaipu ocupa terras brasileiras e paraguaias, sendo por enquanto a maior Hidrelétrica do mundo em termos de potência instalada, 14.000 MW. O reservatório possui $1350 \mathrm{~km}^{2}$ (135.000 ha), sétimo em dimensão no país, sendo que $780 \mathrm{~km}^{2}$ (78.000 ha) estão localizados em terras brasileiras e $570 \mathrm{~km}^{2}$ (57.000 ha) estão no Paraguai. Nele há 29 bilhões de m3 de água represada, a qual gera 34\% de toda a energia consumida nas regiões Sul, Sudeste e Centro-Oeste do Brasil. De outra forma Itaipu atende $25 \%$ de toda a energia consumida no Brasil e 95\% de toda energia consumida no Paraguai. (Itaipu Binacional: Programa Cultivando Água Boa/s/data).

A rede hidrográfica paraguaia que drena suas águas diretamente ao reservatório de Itaipu (margem direita do rio Paraná) possui $10.500 \mathrm{~km} 2$, envolvendo total ou parcialmente 13 municípios deste país. A rede hidrográfica brasileira que drena suas águas diretamente ao reservatório de Itaipu (margem esquerda) possui mais de $8000 \mathrm{~km}^{2}$, envolvendo 29 municípios, 28 no Paraná e um no Mato Grosso do Sul, referências essas da própria Itaipu Binacional, acima citada. A hidrelétrica paga royaltes para os municípios lindeiros que foram atingidos pelo reservatório, são somas altas, por isso mesmo verifica-se que a Itaipu Binacional controla politicamente esses municípios, já que como dizia o velho ditado “quem paga a banda escolhe a música”.

Em função da construção da hidrelétrica, Itaipu trouxe para a região mais 40.000 trabalhadores nos anos 70 do século XX, transformando o espaço de pequenos e iniciais núcleos urbanos para um centro bastante populoso, como veremos a frente.

Os dois projetos citados previam logicamente a evacuação total das populações das suas regiões de abrangência, ou seja, de área de em torno de 320.000 hectares. Assim para instalaremse, exigiram à época grandes e sucessivos deslocamentos populacionais sobre essas terras.

\footnotetext{
${ }^{6}$ Ambas porcentagens citadas variam de publicação para publicação.
} 
Dessa forma a grande propriedade, seja ela, estatal ou particular, concentradora de renda e terras, obrigou a forçosa migração de populações em direção principalmente ao Paraguai. É o caso da maioria dos Guarani que viviam no Oeste paranaense e de grande parte dos camponeses denominados Brasiguaios, questão que trataremos a frente no capitulo 7.

A maioria da população Guarani do Oco'y de que tratamos, são descendentes diretos (os menores de 25 anos/2007) como também são parte da população (os indivíduos acima de 25 anos/2007), que são provenientes de quatro aldeias que justamente se encontravam no caminho desses dois Grandes Projetos governamentais, as quais foram atingidas direta ou indiretamente por eles, culminando na perda de suas terras, deixando de obter a devida compensação a qual era prevista por lei. Em levantamento realizado por essa pesquisa foi levantada a situação de mais 28 (vinte e oito) aldeias Guarani no entorno de Foz do Iguaçu, que foram sujeitos à situação semelhante. Talvez por isso mesmo, até o ano de 2006, o único estado da federação brasileira em que organizações de defesa dos direitos indígenas, ligadas a Igreja Católica, não tinham permissão de atuar, era o estado do Paraná.

Até hoje a Itaipu Binacional não possui o devido licenciamento ambiental exigido pelo órgão ambiental IBAMA, apesar dos inúmeros impactos socioambientais provocados pela formação do lago da hidrelétrica, como a expulsão dos Guarani e de outras populações de pequenos agricultores de suas terras, gerando a concentração urbana da população, a extinção e/ou redução de municípios, o desaparecimento de riquezas naturais como por exemplo às Sete Quedas, são estes apenas alguns dos vários impactos sofridos.

A Tríplice Fronteira atualmente é a porta de entrada e saída por Foz do Iguaçu, da zona de livre comércio entre o Brasil, Bolívia, Paraguai, Argentina e Uruguai, o Mercosul, corredor econômico que se liga por via rodoviária aos portos de Paranaguá no estado do Paraná e Santos no estado de São Paulo.

Hoje nessa região há também interesses dos Estados Unidos da América, por conta da existência de grande manancial de água, o “Aquífero Guarani”. Assim a política estadunidense justifica seu estabelecimento na fronteira paraguaia, visando dois supostos objetivos: - combater o "narcotráfico" e possíveis focos "terroristas árabes da Al Qaeda" na fronteira com o Brasil. Nos últimos anos que estávamos presentes (2005/2006), ali se instalaram em terras paraguaias, agentes técnicos e militares da inteligência dos EUA, o Exército daquele país e milícias armadas de fazendeiros, atuando de forma estratégica com o objetivo de expulsar indígenas (os Guarani), posseiros e pequenos agricultores da região de fronteira, sendo apoiados para isso, pelos grandes proprietários, os latifundiários 
brasiguaios e paraguaios. O novo processo, contribui para a política implementada há muitos anos, caracterizada historicamente em todo o Paraguai por extremo autoritarismo, tanto no meio rural como urbano, decorrente da política ditatorial do partido Colorado paraguaio, no qual apenas a elite dominante, um (1) \% da população paraguaia (a qual só se articula na língua espanhola) possui $77 \%$ das terras deste país; nesse contexto, contribuindo para essa política, está o governo estadunidense, que pouco a pouco fincam bases na região da fronteira ${ }^{7}$.

Desta forma a região como um todo possui uma tensão latente na qual os primeiros habitantes foram e continuam sendo, inevitavelmente envolvidos e espoliados.

Quanto a questão “b” no que se refere à questão legal, quando dos esbulhos sofridos pelos Guarani.

A Constituição Federal atual (1988) além de considerar os direitos originários dos povos indígenas sobre as terras que ocupam, exige ainda quatro mandamentos para que se possa realizar os procedimentos de demarcação, ou seja, para se dar o reconhecimento administrativo das Terras Indígenas por parte do Estado. Em seu Artigo 231 parágrafo $1^{\circ}$, considera "terras tradicionalmente ocupadas": - as por eles habitadas em caráter permanente; - as utilizadas para suas atividades produtivas; - as imprescindíveis à preservação dos recursos ambientais necessários ao seu bemestar; - as necessárias a sua reprodução física e cultural, segundo seus usos, costumes e tradições.

Assim esta Constituição prioriza no processo demarcatório a questão da " ocupação". Pressupõe a posse permanente, ou seja, as populações indígenas devem permanecer fisicamente no território, e, essa posse deve se dar de acordo com os costumes tradicionais, para assim poder ser identificada e demarcada, como terra tradicionalmente ocupada.

Porém, no caso dos Guarani do Oco’y, não se trata de identificar o atual território que ocupam, mesmo porque ele está demarcado, embora, paradoxalmente, não seja possível a essa população indígena reproduzir sua vida plenamente, conforme seus usos e costumes tradicionais, de acordo com os quatro mandamentos constitucionais; daí necessitarem de revisão desta ou Identificação de outras terras.

\footnotetext{
${ }^{7} \mathrm{O}$ mesmo se dá na Colômbia, agentes estadunidenses estão se instalando na região amazônica, outro grande potencial aquífero do mundo, com a suposta justificativa de apoiar o exército colombiano, visando combater as FARCs (Forças Armadas Revolucionárias Colombianas). A revista Carta Capital (nº 283/2004) denunciou a existência de vinte e uma bases da CIA já instaladas em território brasileiro, a maior parte na Amazônia. Assim os agentes dos EUA, vão reconhecendo o território, instalando bases, produzindo informações à Casa Branca, enquanto que no Brasil ainda não temos conhecimento quanto à política adotada pelo governo brasileiro com relação à questão.
} 
O que se observou é que houve no passado uma série de esbulhos de considerável porção do território indígena Guarani, inclusive com relação aos ocupados anteriormente pelos atuais Guarani do Oco’y. Foram identificadas preliminarmente por esta pesquisa 32 (trinta e duas) aldeias Guarani existentes no Oeste paranaense, as quais foram esbulhadas de seu território entre os anos 40 e 80 do século XX, apesar de haver legislação que defendia os direitos indígenas as terras, em cada época em que se deram os fatos. Assim a legislação que deveria ter sido aplicada e não foi, seriam as anteriores a 1988, a partir dos anos 40 do século XX. Dessa forma esse trabalho se propôs a refazer o histórico acontecido, visando esclarecer os fatos como se deram e buscar dessa forma, garantir o direito indígena ao território, provando a imemorialidade dessa ocupação.

As Constituições Federais anteriores a 1988 priorizavam de modo temporal, a garantia da posse indígena sobre a terra. $\mathrm{O}$ reconhecimento administrativo pelo governo das Terras Indígenas passava pela questão da "imemorialidade da ocupação", ou seja, na presença comprovadamente histórica dos indígenas nas terras por eles ocupadas.

$\mathrm{E}$ as constituições mais antigas ainda garantiram o direito à terra pelo simples fato de serem os índios os seus primeiros habitantes, ou seja, possuíam o direito consuetudinário as terras, o direito instituído pelo indigenato, que em resumo nada mais é que a institucionalização do direito sobre as terras ocupadas por serem os povos originários. Uma questão de Justiça com os primeiros habitantes, conceitos legais esses que nunca foram revogados.

Portanto, concluindo, se os Guarani não ocupavam hoje de forma extensiva o território é porque haviam sido no passado esbulhados dele. Diante dessa discussão teríamos que provar a imemorialidade da ocupação dos Guarani do Oco’y no território, para então haver o reconhecimento de seus direitos sobre as terras. É o que vamos fazer neste capitulo.

Era necessário provar ainda a ocupação imemorial Guarani em terras brasileiras, para também desmistificar algumas falácias que induziam a um pensamento que a alta concentração populacional no Oco’y se devia a emigração de índios Guarani do Paraguai para o Brasil. Desta forma era veiculado pela mídia dominante da região, que o problema era supostamente populacional e não fundiário, ou seja, o problema na visão destes era causado pelos próprios Guarani (a migração) e não pela falta de terras destinadas a eles como "compensação" pelo Estado, o que, como veremos, na maioria das aldeias antes existentes, a compensação não se deu, e na única em que se deu, realizou-se de forma precária, o Oco’y.

Quanto a questão “a”, se refere à imemorialidade da ocupação Guarani, primeiramente na região do Tekoa Guassu, e, mais especificamente, apontada em menor escala geográfica, na região de interesse desta pesquisa, o Oeste paranaense. 
Foi verificado a existência de uma certa dinâmica geopolítica acontecida na Tríplice Fronteira nos últimos 500 anos, na qual foi detectada a imemorialidade da ocupação territorial Guarani e os sucessivos processos históricos de esbulho seguidos de ocupação pela sociedade envolvente deste território indígena, como ainda revelou as sucessivas retomadas dos indígenas de parte de seus territórios no Oeste paranaense.

Este capítulo pretende desenhar assim os acontecimentos que culminaram na tomada da maior parte da banda brasileira (Oeste do Paraná) deste território Guarani, assim como apontar a retomada e a persistência de fixação na terra por alguns agrupamentos Guarani, tanto no passado como na atualidade, na mesma região.

Visando melhor compreensão do contexto a ser apresentado, subdividiremos o estudo das regiões geográficas a seguir em quatro fases históricas, que se iniciam no período relativo, desde a ocupação imemorial até o ano de 2006. Elas serão apresentadas de forma a verificarmos inicialmente o macroterritório Guarani, ou seja, o Tekoa Guassu e no decorrer do tempo ir afunilando a pesquisa sobre o território tradicionalmente ocupado pelos integrantes da Terra Indígena AváGuarani do Oco’y, localizados no sudoeste paranaense e sudeste paraguaio. Neste parte estarão incluídas todas as discussões acima referidas nos itens "a", "b" e "c". Dessa forma este capítulo apresenta-se subdividido em quatro partes que em resumo irão apresentar:

4.2. A Imemorialidade da Ocupação Guarani no Tekoa Guassu. As Reduções Jesuíticas nos séculos XVI e XVII. Os Ataques Bandeirantes no século XVII. A resistência indígena: os Guarani no Tape e os Cainguá ${ }^{8}$ (Gente da Floresta) do Itatin e Guairá.

4.3. A existência de 32 (trinta e duas) aldeias identificadas presentes nos anos 40 do século XX no Oeste do Paraná e 7 (sete) no Paraguai ${ }^{9}$ e os sucessivos processos de esbulho sofridos a partir da década de 40, 50, 60, 70 e 80 do século XX.

4.4. As formas pelas quais se deram os esbulhos das terras de onde os Guarani do Oco'y são provenientes, aldeias: "Guarani” (década de 40), “São João Velho” (década de 60), "ColôniaGuarani” (década de 70), e "Ocoy-Jacutinga” (década de 70 e 80).

4.5. Aponta por fim a persistência Guarani em se manter em seu território, no caso em terras brasileiras, localizado no oeste paranaense.

\footnotetext{
${ }^{8}$ Também denominados de Kaiuá e/ou Kainguá.

${ }^{9}$ Foram levantadas as aldeias no Paraguai limitadas aos locais onde existiam populações Guarani que mais se relacionavam com a população de Oco'y, ou seja, são as parentelas que mantêm tradicionalmente as relações de reciprocidade entre as famílias dos dois países.
} 
Estes esclarecimentos históricos e geográficos devem ser realizados, pois auxiliarão no entendimento de todo o processo referente à movimentação populacional sobre o território e fundamentalmente auxiliarão a entender a questão fundiária que vem se desenvolvendo hoje, principalmente com relação aos Guarani do Oco’y.

\subsection{A Imemorialidade da Ocupação Guarani no Tekoa Guassu. As Reduções Jesuíticas nos séculos XVI e XVII. Os Ataques Bandeirantes no século XVII. A resistência indígena: os Guarani no Tape e os Cainguá (Gente da Floresta) do Itatin e Guairá}

O subcapítulo 4.2. está subdividido em quatro sequências históricas a saber:

4.2.1. Levantamento geral, que compreende um plano macro histórico, geográfico e arqueológico no qual demonstra a imemorialidade da ocupação Guarani no Tekoa Guassu;

4.2.2. O processo histórico de ocupação não indígena da região no período colonial, referente à criação de algumas cidades importantes como também a criação das Reduções Jesuíticas estabelecidas no Itatin, Guairá e Tape, acontecidas no século XVI e XVII;

4.2.3. As ações do bandeirantismo paulista de destruição das Reduções Jesuíticas no século XVII;

4.2.4. A resistência indígena Guarani no Tape, assim como a volta dos Guarani que haviam se escondido nas Matas, os Cainguá (Gente da Floresta), para a região do Guairá (Oeste paranaense) e Itatin (Mato Grosso do Sul).

Esta pesquisa foi realizada em literatura etnográfica especializada na questão indígena, assim como em literatura histórica, geográfica e arqueológica não especializada na questão, estes últimos materiais bibliográficos produzidos no próprio estado do Paraná.

Cabe salientar que os levantamentos a seguir apresentados, foram pesquisados pelos integrantes da sociedade envolvente ao longo dos séculos, quando os mesmos incidiram suas atividades em determinadas regiões geográficas do amplo território indígena e aí nesse determinado momento e local encontraram os Guarani ou seus resquícios arqueológicos. Portanto, são fragmentos possíveis de serem pesquisados por nós, fundamentalmente por nossa visão, a visão do “outro" não guarani. Este "nós” compreende os levantamentos de viajantes, jesuítas, etnógrafos, historiadores, geógrafos, antropólogos e arqueólogos que puderam ter contato com a historiografia Guarani. 
Assim é um olhar da própria ação do "branco" sobre o território, a partir da história de como a sociedade envolvente dominou e/ou estudou este território, quando então, eventualmente encontraram integrantes desse agrupamento indígena. Assim não são os próprios Guarani que relatam sua história, e sim o "outro".

Portanto, não compreendem a totalidade da ocupação territorial Guarani, pois trata-se de uma reunião de fragmentos históricos, geográficos, arqueológicos e etnográficos que foram pinçados em alguns lapsos de tempo e espaço, os quais acabaram assim, por legitimar a ocupação Guarani em cada local descrito.

Este trabalho não pretende esgotar o assunto, pois provavelmente seria trabalho de pesquisa para uma vida inteira, diante do grande volume de bibliografia existente sobre esta etnia. Pretende somente caracterizar a área de ocupação desta população e as formas como se dão sua organização socioespacial.

\subsubsection{A imemorialidade da ocupação Guarani no Tekoa Guassu}

Segundo Saguier, citado por Ladeira, eles afirmam à respeito da antiguidade da ocupação Guarani na América Latina:

As fontes históricas mais antigas afirmam que "antes da chegada dos europeus, os Guarani integravam a grande família, ou a nação conhecida com o nome de Guarani-Tupi. A mesma ocupava uma vasta região que de maneira descontínua descia pelas costas do Oceano Atlântico desde a desembocadura do Amazonas até o estuário Platino, estendendo-se rumo ao interior até os contrafortes andinos, especialmente em volta dos rios. A família Guarani-Tupi habitava pois, grande parte dos atuais territórios do Brasil, Paraguai, Argentina, Uruguai, Bolívia, Peru, Equador e Guyana. $\underline{\mathrm{O} \text { núcleo }}$ Guarani propriamente dito se centrava entre os rios Paraná e Paraguai com certas prolongações; pode-se dizer que os Guarani habitavam a atual região oriental do Paraguai, o estado do Mato Grosso e Paraná, e parte da costa Atlântica no Brasil, e a província de Missiones na Argentina, com algumas fixações em território boliviano pelo noroeste e Uruguai pelo sudeste." (Saguier, 1980. Op. cit. LADEIRA: 1992:45).

Hèléne Clastres resume a ocupação Tupi-Guarani no século XVI sem contradizer a definição de Saguier, da seguinte forma: 
Os Tupis ocupavam a parte média e inferior da bacia do Amazonas e dos principais afluentes da margem direita. Dominavam uma grande extensão do litoral Atlântico, da embocadura do Amazonas até Cananeia. Os Guarani ocupavam a porção do litoral compreendida entre Cananeia (SP) e o

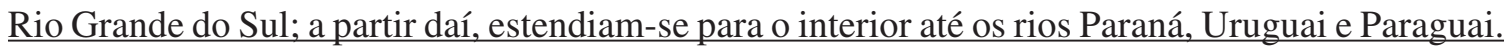
Da confluência entre o Paraguai e o Paraná, as aldeias indígenas distribuíam-se ao longo de toda a margem oriental do Paraguai e pelas duas margens do Paraná. Seu território era limitado ao norte pelo rio Tietê, a oeste pelo rio Paraguai. Separado deste bloco pelo Chaco, vivia outro povo Guarani. os Chiriguanos, junto as fronteiras do Império Inca (Clastres, 1978 op cit LADEIRA:1992:45-6).

Portanto, a grande região da Bacia do Prata, localizada entre as Bacias dos rios Paraguai, Paraná e Uruguai é a região geográfica tradicional, considerada de ocupação imemorial pela população Guarani, a qual eles próprios denominam desde tempos muito antigos de Tekoa Guassu. Esse fato foi estudado por inúmeros relatos históricos, geográficos e etnográficos. Separados pelo Chaco, que compreende hoje o norte paraguaio, o sudeste boliviano e o oeste dos estados de Mato Grosso e Mato Grosso do Sul, o denominado Pantanal brasileiro (mais úmido que o restante do Chaco), viviam os Chiriguanos, junto ás fronteiras do Império Inca, como Clastres se refere, outro povo Guarani. O Mapa da Bacia do Prata já foi apresentado anteriormente no Capitulo II.

A forma mais clara para se visualizar a totalidade do grande território Guarani e Chiriguano é demonstrada pelo caminho do Peabiru (Figura 47). Nele se pode observar horizontalmente que do oceano Atlântico até Porto Suarez na Bolívia é o Tekoa Guassu dos Guarani e a partir desta localidade em diante já é território Chiriguano, onde obtinham saída em Arequipa ou Tacna no Peru, para o oceano Pacífico.

A rede de caminhos denominada "Peabiru", era uma estrada Guarani, aberta a picadas em meio a floresta atlântica com 8 palmos de largura, nela os Guarani semeavam, espaçadamente, com gramíneas, que tinham extrema facilidade de se alastrar com a movimentação dos caminhantes. Na língua Guarani "Pe” significa caminho e "abiru” batido ou muito usado.

Segundo informa Chmyz:

O Peabiru compreendia pois, um caminho transcontinental, que partia de São Vicente (SP), acompanhava o curso do rio Tiête até a altura de Itú (SP). Tomava então direção sudoeste, atravessando os rios Paranapanema e Itararé até as cabeceiras do rio Ribeira do Iguape. Deste ponto, tomava uma direção geral leste-oeste, passando pelas nascentes dos rios Ivai e Cantu e o médio rio Piquiri (PR). Na margem direita do rio Paraná acompanhava o curso do Iguatemi, dobrando a seguir, para o noroeste, em direção as cabeceiras do rio Paraguai, cortando o Chaco paraguaio, e chegando ao planalto do Peru e ao oceano Pacífico. (CHMYZ:1976:70-1) 
Existiam vários caminhos secundários, ramais que se comunicavam com o Peabiru. As margens de todos estes caminhos encontravam-se inúmeras aldeias Guarani.

Este mapa (Figura 47) mais simplificado demonstra quase que apenas o caminho principal e alguns ramais no Brasil e no Peru.

Todo o Oeste paranaense e Leste paraguaio de Guairá ao rio Iguaçu eram provavelmente os ramais mais utilizados pelos ascendentes e pelos próprios Guarani do Oco’y.

Em termos temporais as ocupações Tupi-Guarani mais antigas, encontradas até o momento no estado do Paraná, foram realizadas pelas expedições arqueológicas denominadas PRONAPA (1965-1970) e Projeto Arqueológico Itararé (1965-68), de autoria do arqueólogo, Professor Doutor Igor Chmyz do Centro de Estudos e Pesquisas Arqueológicas da Universidade Federal do Paraná - CEPA/UFPR; localizam-se respectivamente nos arredores do rio Paranapanema e do rio Itararé; nestes locais foram encontrados objetos Tupi-Guarani que datam de 80 D.C. (Depois de Cristo). Assim são povos antigos, autóctones da região.

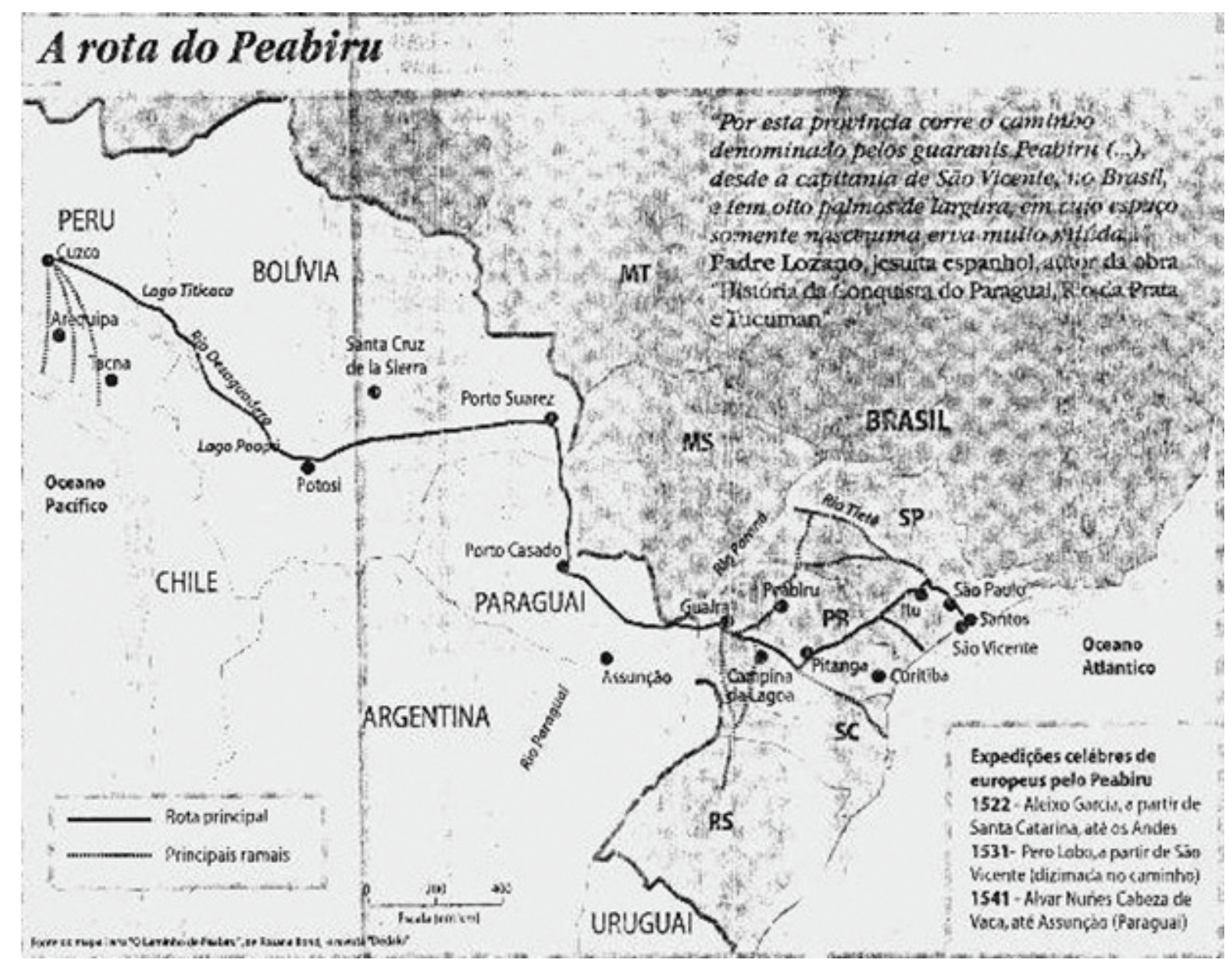

Figura 47. Mapa. O Caminho do Peabiru.

Fonte Secundária: Folha de São Paulo. Brasil 500. 20.02.2000. p1-18 Brasil. Extraído do livro "O caminho do Peabiru" de Rosana Bond. s/ data. 
Em termos geográficos o CEPA/UFPR, realizou levantamentos arqueológicos que atestam a presença Tupi-Guarani em várias regiões do estado do Paraná (Figura 48).

O texto a seguir apresenta os locais e suas respectivas datações, os extremos - a mais antiga e a mais recente datação encontrada. Deve-se salientar que estes locais, são os locais onde foram possíveis ao CEPA realizar as pesquisas ao longo dos anos, pois estas pesquisas em geral, tem sido desenvolvidas no rastro da iminente instalação de Grandes Projetos, ou seja, condicionadas a eles, antes que se destruam os ambientes para instalação de empreendimentos.

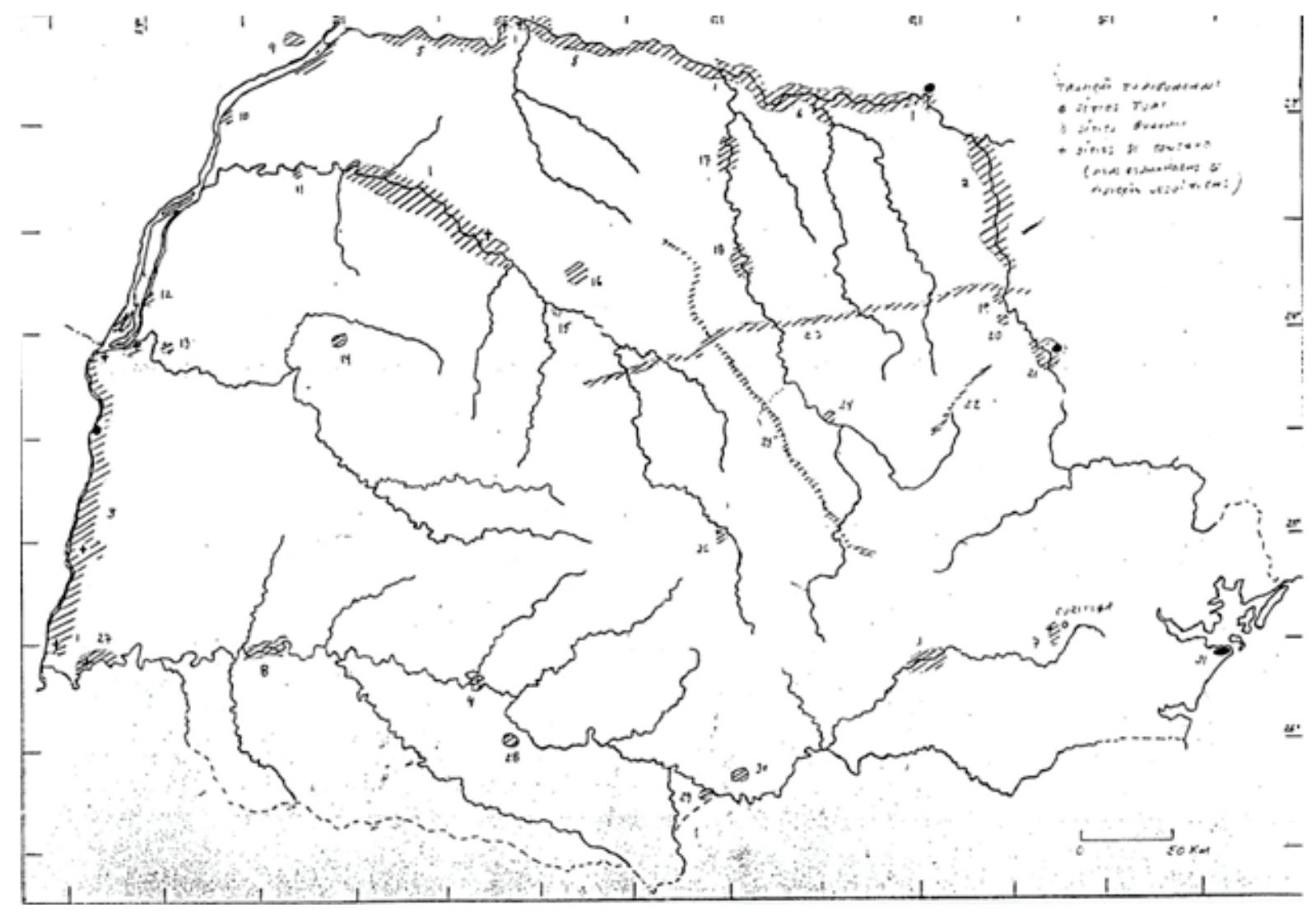

Figura 48. Mapa. Pesquisas Arqueológicas desenvolvidas pelo CEPA/UFPR no Estado do Paraná e adjacências, que revelaram sítios e fases da Tradição Tupiguarani.

Fonte: Igor Chmyz. A Arqueologia do Paraná (em elaboração/2002).

Legenda: Ponto negro = Sítios Tupi; Franchado = Sítios Guarani; Sinal $+=$ Sítios de Contato (Vilas Espanholas e Projeções Jesuíticas)

Se fosse possível a equipe do CEPA rastrear arqueologicamente amiúde a maior parte do estado do Paraná, acreditamos que certamente encontrariam na maior parte dele informações arqueológicas Tupiguarani, pois como veremos, referências a presença deste agrupamento indígena foram encontradas em grande parte do estado do Paraná através da literatura histórica e etnográfica da região, no decorrer dos últimos 500 anos. 
Chmyz informa em Arqueologia do Paraná (2002) a localização dos Projetos Arqueológicos e as respectivas datações dos períodos (os extremos) em que foram achados objetos Tupi-

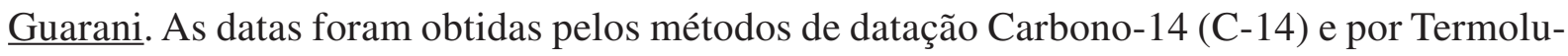
minescência (TL).

\section{PRONAPA (1965-1970).}

2. Projeto Arqueológico Itararé (1965/68).

Nas áreas dos projetos 1 e 2 (Rios Paranapanema e Itararé) as datas variam de 80 d.C. a 1190 d.C.

3. Projeto Arqueológico Itaipu (1975/83).

Na área 3 (Proj. Arq. Itaipu), variam de 325 d.C a 1895 d.C.

4. Projeto Arqueológico Santiago (1979/80).

Sem datação

5. Projeto Arqueológico Rosana-Taquaruçu (1983-1986/92).

Na área 5 (Rio Paranapanema), variam de 460 d.C. a 1650 d.C.

6. Projeto Arqueológico Canoas (1992/96).

Sem datação

7. Projeto Arqueológico Passaúna (1984/85).

$\mathrm{Na}$ área 7 (Curitiba): 1422 d.C.

8. EIA-RIMA UHE Salto Caxias (1993).

Sem datação

9. Porto São José (PR) e Bataiporã (MS) (1967).

Na área 9 (Mato Grosso do Sul), variam de 1475 d.C. a 1840 d.C.

10. Querência do Norte (BLASI), 1961)*

11. José Vieira (EMPERAIRE e LAMING, 1959)*

12. Lagoa Xambrê (1976).

13. Francisco Alves (1980).

14. Ubiratã (1970/71).

15. J. Lopes (1959).

16. Kaloré (1967).

17. Sertanópolis (1968).

18. Ibiporã (1966 e 1968).

19. Santana do Itararé (1965).

20. São José da Boa Vista (1973).

21. Sengés (PR) - Itararé (SP) (1968).

22. EIA-RIMA Rodovia PR-151 (2001). 
23. EIA-RIMA LT 750kv Ivaiporã-Itaberá (1999).

24. Conceição (NIGRO, 1970)*

25. EIA-RIMA BR-376 (2001).

26. Estirão Comprido (SILVA e BLASI, 1955)*

27. Plano de Manejo Parque Nacional do Iguaçu (1998).

28. Mangueirinha (1982).

Sem datação de $n^{\circ} 10$ a n 28 . “*” Referência a sítios trabalhados por outros pesquisadores.

29. União da Vitória (1967).

Na área 29 (Rio Iguaçu): 1450 d.C.

30. Mallet (1965).

Sem datação

31. Paranaguá (1979 e 1998).

Na área 31 (Paranaguá): 1549 d. C.

As áreas “3. Projeto Arqueológico Itaipu (1975/83)” e "27. Plano de Manejo Parque Nacional do Iguaçu (1998)", são regiões geográficas bastante próximas dos Guarani do Oco’y. Podese concluir através das informações de Chmyz que a ocupação Guarani foi extensiva sobre a região do estado do Paraná.

\subsubsection{As Reduções Jesuíticas nos séculos XVI e XVII}

Os Guarani vivem de forma independente, sob sua própria determinação histórica, até o período em que a América passa a ser colonizada pelos povos ibéricos no século XVI. A partir deste momento histórico, o território Tupi-Guarani passa a ser o palco onde se darão as disputas de fronteiras entre as Coroas portuguesa e espanhola.

Em 7 de junho de 1494, é firmado o Tratado de Tordesilhas (Figura 49) entre Portugal e Espanha. Este tratado constituía-se no traçar de uma linha vertical imaginária, que cortava a América aproximadamente de Belém no Pará, até Laguna em Santa Catarina. Os termos deste tratado ajustaram-se da seguinte forma: pertenceriam a Castela (Espanha) todas as terras descobertas a ocidente de uma linha tirada de polo a polo, trezentas e setenta léguas a oeste das ilhas de Cabo Verde; e a Portugal as descobertas a leste da mesma linha. (QUADROS \& ARINOS: 1967:167). 


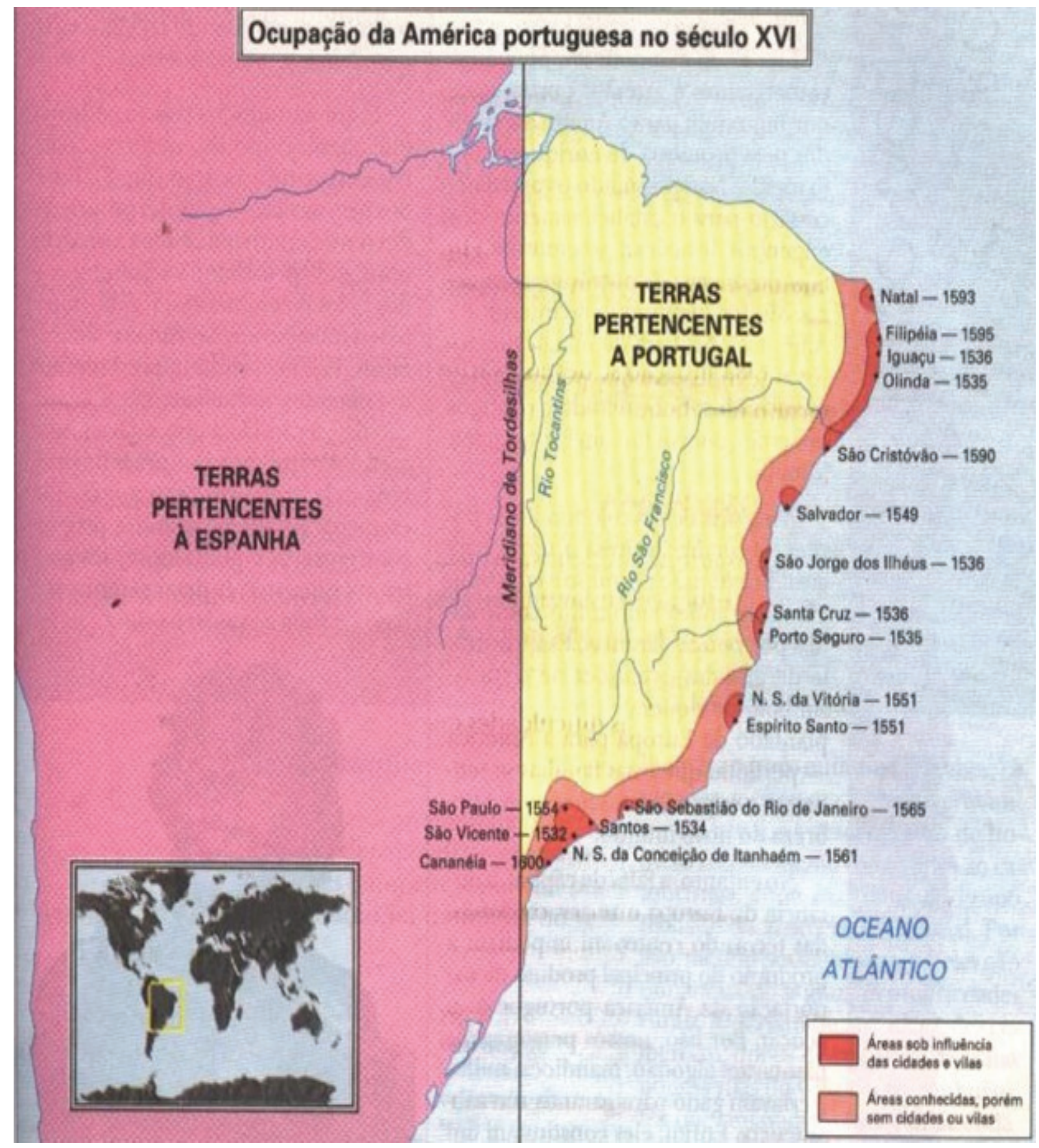

Figura 49. Mapa. Tratado de Tordesilhas. 1494.

Fonte: B. Bandecchi. História Econômica e Administrativa do Brasil. Ed. Didática, São Paulo, 1996. p. 80.

De acordo com este tratado, apenas um terço do atual território capitalista no Brasil ficou pertencendo à Coroa Lusa. Desta forma, no atual estado do Paraná, somente uma pequena faixa territorial à leste, junto ao litoral, era de domínio português, há referências históricas de que os portugueses ficavam como "caranguejos" no litoral paranaense, espreitando o que poderia haver em território espanhol; a oeste, metade do estado de São Paulo, praticamente todo o atual estado do Paraná, assim como todos os atuais estados de Santa Catarina, Rio Grande do Sul, Mato Grosso e Mato Grosso do Sul, além do Paraguai, Uruguai e Argentina ficaram sob domínio espanhol. 
Neste sentido os Guarani foram submetidos ao jugo das duas Coroas, tanto de um lado como de outro do território, porém, na atual região fronteiriça em que analisamos, os ascendentes dos Guarani do Oco’y inicialmente foram submetidos ao domínio espanhol. Estes limites estabelecidos, posteriormente ao domínio da Coroa Espanhola de Portugal e Espanha (1580 a 1640) pouco vigoraram, sendo com frequência, ultrapassados pela expansão territorial portuguesa no sul, a oeste e no vale amazônico. Na primeira metade do século XVIII, os Guarani da região oeste paranaense, passaram a estar submetidos territorialmente ao domínio português; porém, o estabelecimento mesmo de contatos sistemáticos dos Guarani com as populações da banda brasileira deste território, somente passou a se dar a partir da década de 40 do século XX. Assim como povos de fronteira é natural articularem-se, além de, na língua materna (guarani), também por ordem temporal, na língua espanhola e por fim portuguesa.

No início da exploração colonial, Portugal passa a ocupar a costa litorânea fundando o comércio do pau-brasil; implanta engenhos de cana-de-açúcar, em São Vicente/SP (em menor escala), como também na Bahia e em Pernambuco, estes locais irão necessitar de mão de obra, buscarão elas, em índios escravizados, os Guarani. Em São Paulo, colonos portugueses constituíam-se de população empobrecida, vivendo de economia de subsistência; neste contexto surge o bandeirantismo paulista de caça aos índios e metais preciosos, como forma de auferir renda.

Espanha inicia as entradas pela Bacia do Prata, através dos rios Paraguai, Paraná e Uruguai, em busca da exploração das minas na Serra da Prata nos Andes. Na atual região argentina, paraguaia e oeste do Paraná, à época sob domínio de Espanha, são fundados alguns povoados espanhóis, respectivamente Buenos Aires (1536), Assunção (1537), Ontiveiros (1554) e Ciudad Real de Guairá (1556).

Cabeza de Vaca, futuro Adelantado do Prata (governador) espanhol, vem à América em 1541, inicialmente com a missão de salvar seus compatriotas que haviam sido abandonados na região platina. Empreende viagem por terra, a partir da ilha de Santa Catarina, hoje a atual Florianópolis; segue pelo atual estado do Paraná, atravessa-o em toda extensão leste-oeste, fazendo uso do caminho utilizado pelos Guarani, o "Peabiru”, por fim atinge Assunção no Paraguai. No capitulo II, quando apresentamos o Peabiru, o fizemos através do mapa de Cabeza de Vaca. No diário de viagem, transformado em livro "Naufrágios e Comentários” (L\&PM Pocket:1999), Cabeza de Vaca narra uma postura amistosa com relação aos inúmeros e seguidos povoados Guarani que encontrou em toda extensão do Paraná, os quais por escambo teriam alimentado sua tropa. Observa-se que a grande maioria étnica na região é Guarani. Os Guarani inicialmente passam a ser aliados do governo espanhol. 
Durante o século XVI, os Guarani já habitavam a região das Cataratas do Iguaçu, conforme o curioso relato de Cabeza de Vaca, que em 1542 em busca de uma saída para o Rio da Prata quase desaparece com sua tripulação, prestes que estava a cair naquelas quedas d'água. Assim o autor-viajante descreve ${ }^{10}$ :

Depois de andarem oito jornadas (...) chegaram novamente ao rio Iguaçu, agora à altura de vinte $\mathrm{e}$ cinco graus e meio (...). Os nativos que encontraram por perto informaram que o rio Iguaçu entra no Paraná, que por sua vez entra no rio da Prata, e que, nesses rios, morreram muitos índios e portugueses que Martim Afonso de Souza enviou para descobrirem aquelas terras. Foram mortos pelos índios da margem do rio Paraná, quando atravessavam o rio em canoas. Assim, para prevenir-se dos ataques, o governador decidiu seguir por dois caminhos. Iria ele com uma parte do pessoal em canoas, rio Iguaçu abaixo, até encontrarem o rio Paraná. O restante do pessoal e os cavalos iriam por terra e se colocariam à margem do rio para proteger a passagem das canoas. Assim foi feito. $\mathrm{O}$ governador comprou algumas canoas dos índios e embarcou com oitenta homens rio Iguaçu abaixo, seguindo o restante por terra, devendo todos se juntarem no rio Paraná. Mas, ao irem rio Iguaçu abaixo, era tão forte a correnteza que as canoas corriam com muita fúria. Logo adiante do ponto onde haviam embarcado o rio dá uns saltos por uns penhascos enormes e a água golpeia a terra com $\underline{\text { tanta força que de muito longe se ouve o ruído. }}{ }^{11}$ De modo que foi necessário sair da água, tirar as canoas e conduzi-las por terra até passar aqueles saltos. Assim à força de braços, as conduziram por mais de meia légua passando grande trabalho. Vencido aquele obstáculo, voltaram a colocar no Paraná. Quis Deus que a gente que ia por terra com os cavalos e os que iam por água com as canoas chegassem todos ao mesmo tempo. Na margem do rio estavam postados um grande número de índios guaranis, todos enfeitados com plumas de papagaios e muito pintados de maneira multicolorida, com seus arcos e flechas na mão, formando um esquadrão que era maravilhoso de se ver. (CABEZA DE VACA: 2002:137-8)

De dezembro de 1552 a junho de 1553 Ulrich Schmidel, lansquenete da armada de Mendoza, realiza viagem em sentido contrário ao de Cabeza de Vaca; parte do interior de Assunção no Paraguai, e com guias Guarani atravessa o Estado do Paraná também através do Peabiru, chegando a São Vicente (SP). É produzido por Schmidel um mapa onde pode-se verificar a enorme concentração da ocupação Tupi-Guarani na região. (Figura 50)

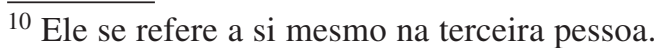

${ }^{11}$ Neste ponto o tradutor faz uma nota mencionando "Cabeza de Vaca foi o primeiro branco a contemplar a foz do Iguaçu".
} 
Observando-se a Figura 50, nota-se próximo a Assunção a ocupação dos Carios (Carijós), denominação dada também aos Guarani na época. Mais a frente em direção leste, nota-se a ocupação Tupi-Guarani nas duas margens do rio Paraná, onde hoje compreende as fronteiras Brasil e Paraguai, local onde atualmente continua a existir concentração de aldeias Guarani, como é o caso de Oco'y entre outras aldeias; um pouco acima lê-se Guarani-Tape, na região de Ontiveiros e Ciudad Real de Guairá, esta região compreende hoje o atual oeste paranaense, o sul do Mato Grosso do Sul e parte do Paraguai onde vive a parcialidade Tupi-Guarani, denominada Kaiowá. Indo em direção ao litoral encontra-se os Mbiazais-Tinguis, denominação da época para a atual parcialidade Tupi-Guarani denominada hoje de Mbyá, os quais continuam a habitar o litoral brasileiro.

A escravização de indígenas pela coroa espanhola era oficialmente proibida, o país já havia abolido a escravatura. A penetração espanhola da região platina passava pelas relações desenvolvidas com as populações nativas. No início da colonização do Paraguai, os espanhóis buscavam alianças com grupos locais, cimentadas através de casamentos entre os conquistadores e as filhas dos chefes indígenas. Segundo o historiador J. Monteiro as alianças visavam quatro objetivos: mobilização de guerreiros para a conquista de índios resistentes ao avanço espanhol; - apropriação dos excedentes agrícolas dos indígenas para o sustento da população espanhola; - estabelecimento de núcleo de povoamento espanhol, através da incorporação de mulheres guarani e a consequente emergência de uma população mestiça; - a exploração do trabalho indígena, inicialmente para construir os povoados coloniais, depois para tocar a economia agropastoril. (MONTEIRO: 1992:32)

Os Guarani tratavam de lidar com a situação transformando-se em "parentes" dos espanhóis, fenômeno que se cunhou na antropologia por Darcy Ribeiro, de relações de "cunhadismo". Consideravam vantajosas as relações de parentesco com os espanhóis, pois estes seriam aliados úteis no combate à inimigos tradicionais; esta aliança trazia também em forma de presentes ou de escambo, os cobiçados artigos estrangeiros, armas de fogo, produtos de ferro, espelhos etc. A perspectiva de alianças estáveis desmanchava-se face ao desenvolvimento de práticas e instituições espanholas que visavam maximizar a exploração de mão de obra nativa, assim ameaçando a liberdade e identidade dos Guarani, como relata Monteiro. Colonos espanhóis vieram a servir-se do trabalho escravo de índios Guarani, para o serviço pessoal e para o plantio da erva-mate. $\mathrm{O}$ contexto dá surgimento a figura de "encomenderos", caçadores espanhóis que apresavam os Guarani para destiná-los ao serviço pessoal nos povoados recém fundados. John Monteiro assim 

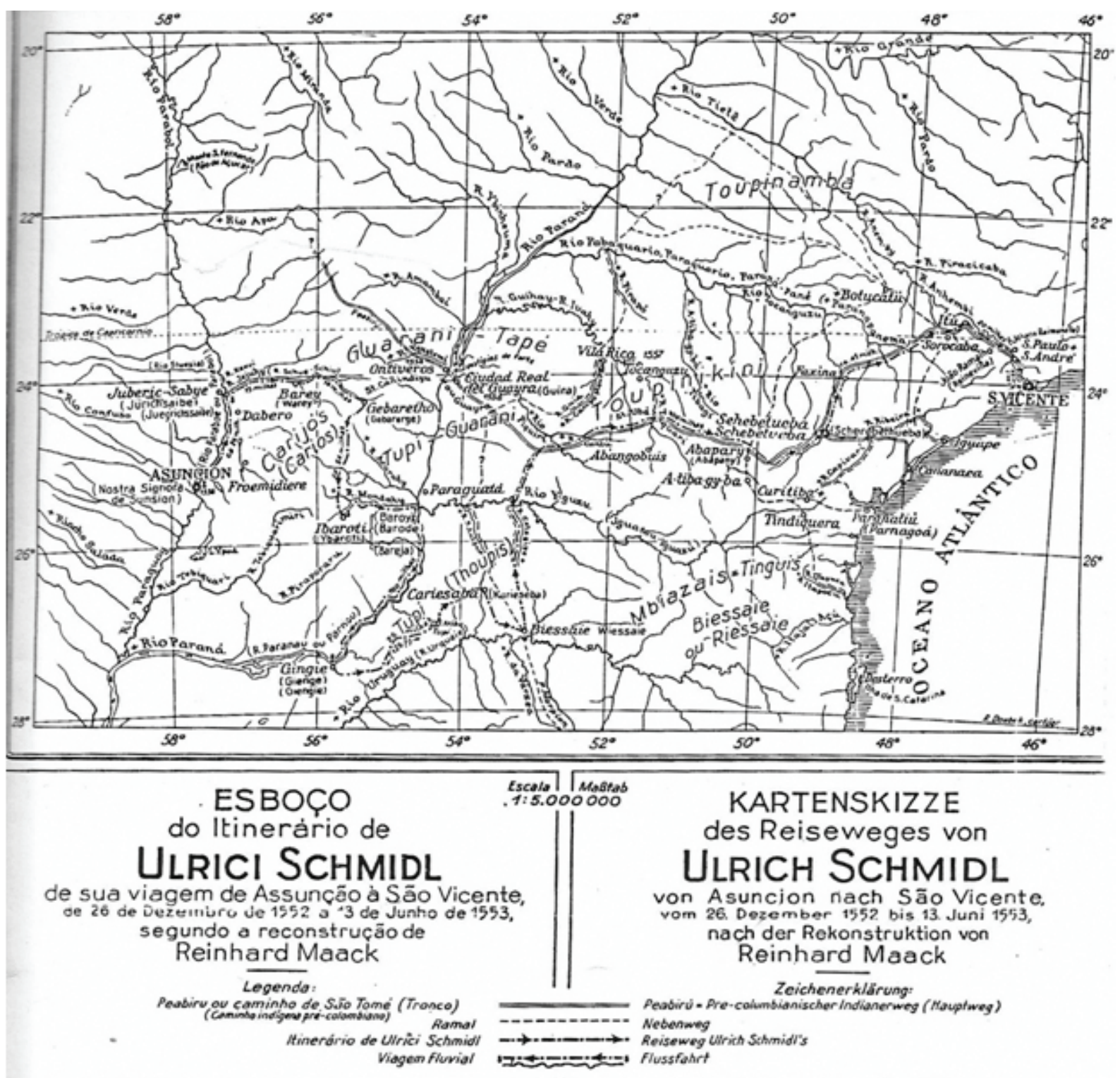

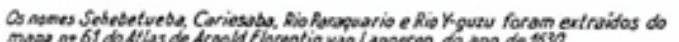

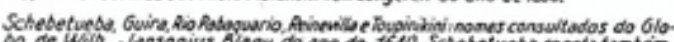

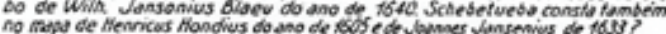

Os names Juberic Sabye e Gingie arovion do mapa de Levius Hulsius, do tivero de Ulrici Schmidl do ano de 1599.

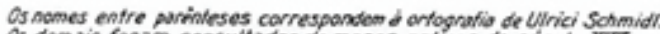
Ds demais foram consultados de mapas antigos do seicubo XVI

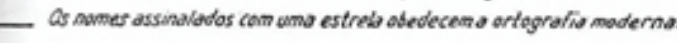

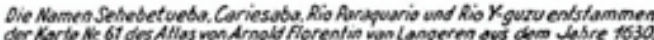

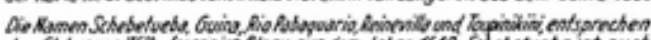

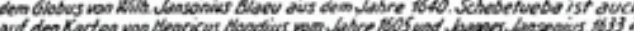

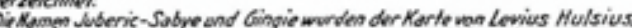
in der Ausgabe won Sedimidis Buch, ous dom Jatre 1599 , entnommen. Die Namen in Klammem entsprechen der Orthographie Urich Schmidts, alle anderen ous alten Karten des 17 Jabhimdert's.

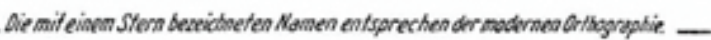

Retirulo de Banck, $1981,7.34$

CD-Figura 50. Viagem de Ulrich Schmidel ao Sul. 1552/1553.

Fonte: Reinhard Maack, 1981, p. 34. In: M. I. Ladeira. O caminhar sob a luz. O território Mbyá a beira do oceano. Mestrado. PUC-SP. 1992. p. 46.

se refere ao assunto: A principal recompensa dos conquistadores do Paraguai veio na forma de "encomienda", que apesar do serviço obrigatório para os índios ser formalmente proibido, aos poucos adquiriu a forma de "servicio personal" (MONTEIRO: 1992:23). Os jesuítas mostravam firme descontentamento com esta política local. 
Assim relata Chmyz sobre a ocupação dos estrangeiros em solo guarani:

Sob jurisdição de Espanha é fundada em 1554 a primeira comunidade espanhola do Guairá, Ontiveiros (CD-figura 51, triângulo $n^{\circ}$ 1), localizada numa povoação indígena guarani denominada Canideyú. (Chmyz:1976:70). (...) Em 1556 é fundada na foz do rio Piquiri com Paraná, a comunidade de Ciudad Real. Esta comunidade ocupou uma grande aldeia do Cacique guarani Guairá (CD- figura 51, triângulo $n^{\circ}$ 2), estando a três léguas ao norte de Ontiveiros. Ciudad Real de Guairá, cujos restos estão localizados no atual município paranaense de Terra Roxa do Oeste, foi disposta justamente na passagem do Peabiru do Paraná para o Mato Grosso (Chmyz:1976:71). (...) Em 1570 é fundada a comunidade espanhola de Vila Rica do Espírito Santo (CD- figura 51, triângulo no ${ }^{\circ}$ ), na foz do rio Corumbataí com o Ivaí, em terras do Cacique guarani Coraciberá (Chmyz:1976:73). № ano de 1630, segundo o governador Hernandarias, Vila Rica contava com uma população branca de 100 pessoas e Ciudad $\underline{\text { Real de } 30 \text { pessoas. Estimava ainda, que a população indígena Guarani, na área influenciada pelas }}$ duas comunidades, era de 150 mil pessoas (Chmyz:1976:75). (CD- figura 51).

No final do século XVI e início do século XVII são fundadas pelos jesuítas da Companhia de Jesus as Missões Jesuíticas no Itatin, Guairá e Tape. (Figura 52).

Talvez o período de maior projeção histórica da região que é nosso objeto de estudo, tenha sido a fundação das Reduções Jesuíticas do Guairá, composta em quase sua totalidade pela população Guarani. (Ver Figuras 51 e 52).

Segundo o historiador Erneldo Schallenberger o território do Guairá configurava-se da seguinte forma:

O Guairá compreendia, a região localizada entre o rio Paraná na vertente oeste, o Tiête e Anhembi ao norte, o Iguaçu ao sul e a leste a linha de Tordesilhas. Era uma região de bons solos, de abundantes rios e de um clima propício para o desenvolvimento de atividades agropecuárias, tendo boa distribuição de chuvas, com maior intensidade no verão, e uma temperatura média em torno de $23^{\circ}$ C. Nestas condições naturais vivia a parcialidade indígena Guarani que, segundo Cabeza de Vaca, eram abundantes e 'son labradores, que siembran dos veces en el año maíz, y asimismo siembran cazabi, crian gallinas a la manera de nuestra España, y patos: (...) tienen ocupada muy gran tierra, y todo es una lengua' (SCHALLENBERGER: 1997:174).

Se compararmos a Figura 45 (Ipardes 2005), veremos que as Reduções Jesuíticas do Guairá ocuparam a fração do Tekoa Guassu, que compreende as mesoregiões nº $105 ; 101 ; 102 ; 104$; 106; e 107. 


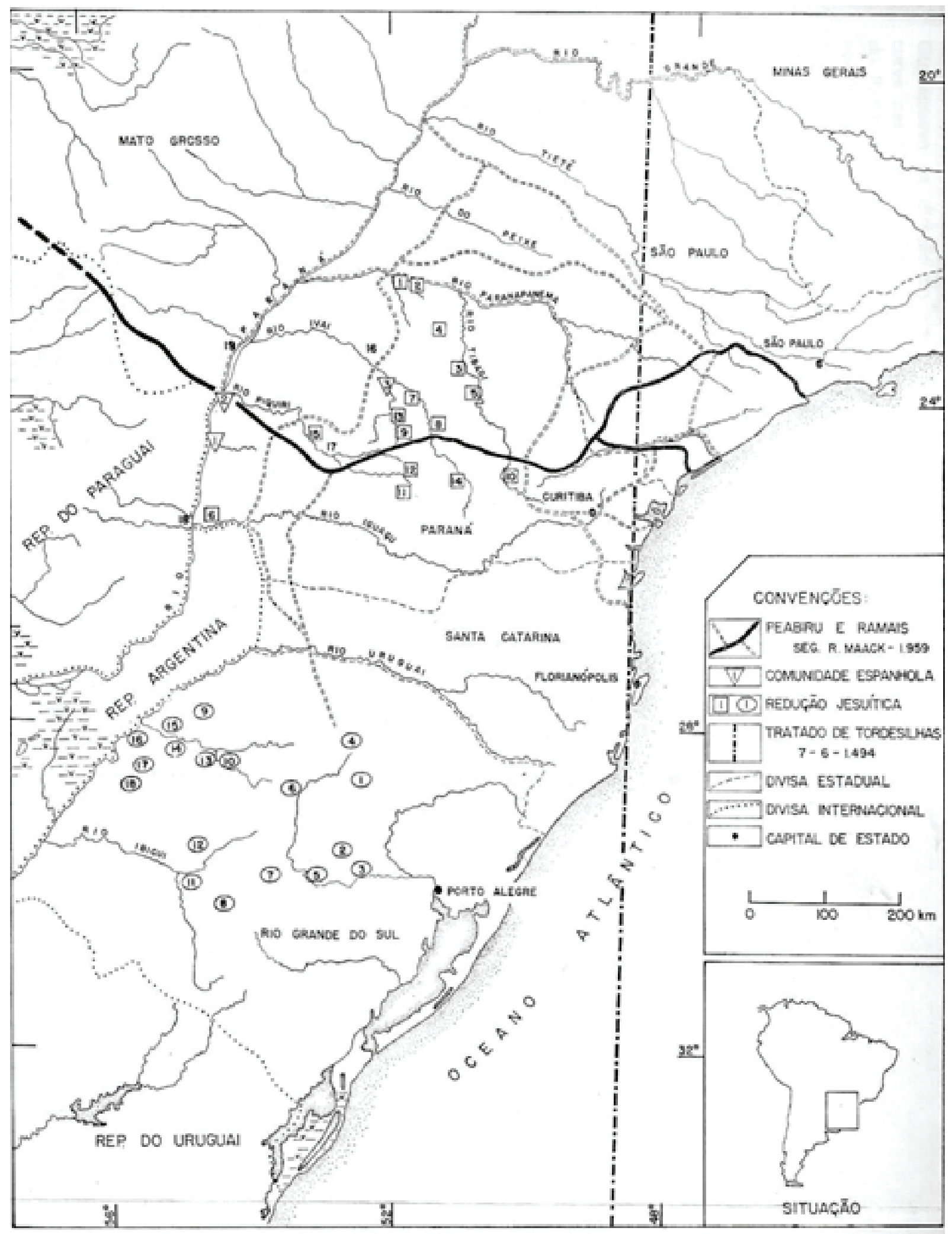

CD-Figura 51. Mapa. Peabiru e ramais. Comunidades espanholas e Reduções Jesuíticas dos séculos XVI e XVII no Guaíra/PR e no Tape/Sete Povos das Missões/RGS, localizadas em terras de tradicional ocupação TupiGuarani.

FONTE: CHMYZ, Igor. Arqueologia e História da Vila espanhola da Ciudad Real do Guairá. Cadernos de Arqueologia, n. ${ }^{\circ}$ 1, Ano I, 1976. Paraná - Brasil: UFPR,103 p, p. 70-5. 


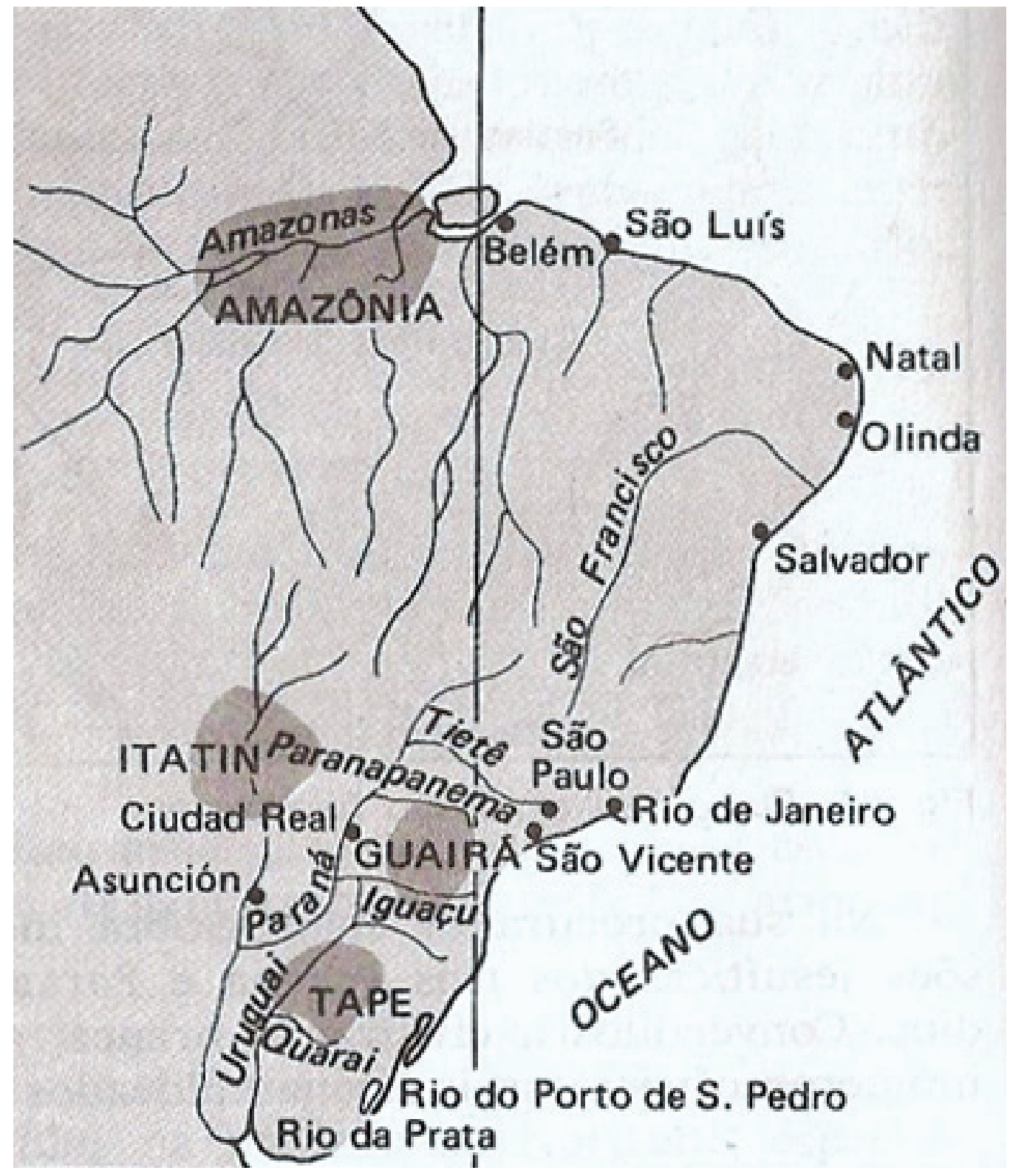

Figura 52. Mapa. Reduções Jesuíticas no Sul: Guairá, Tape e Itatin. Fonte: R. Campos. História do Brasil. Editora Atual. 1983, p. 54.

A clara intenção de incorporar o índio Guarani no processo de colonização, buscando adaptálo aos interesses que moviam os segmentos hegemônicos da sociedade colonizadora, basicamente representados pelos membros da hierarquia eclesiástica e do poder do Estado, acabou por definir uma política de segregação étnica. O Estado espanhol pretendia reduzi-los às Missões Jesuíticas, protegendo-os dos encomenderos e bandeirantes, mas ao mesmo tempo suprimindo grande extensão de seus territórios, ensinando-lhes os ofícios, para povoar a terra pelos colonizadores de forma "pacífica" e à seu serviço, ou seja, como mão de obra não assalariada, além de serem utilizados ainda, como guarda de fronteira nas Reduções. 
Assim concomitantemente, esta política de segregação étnica teve ao longo do tempo fundamentalmente um caráter de defesa da missão; segundo Schallenberger, os missionários buscavam:

Erradicar o mau exemplo dos espanhóis em meio aos índios, para que a mensagem da paz e a obra de cristianização não fossem contrastadas pelas práticas dos colonos cristãos. A opção preferencial pelos índios, por parte dos padres jesuítas começou a ser definida a partir da própria resistência dos encomenderos frente às tentativas de moralização dos costumes, das exigências de cumprimento dos princípios ético-cristãos e da observância da legislação do estado sobre o índio, que previa sua liberdade. (SCHALLENBERGER: 1997:178).

Desse modo as missões jesuíticas se caracterizaram, num primeiro momento, como um instituto pelo qual a Igreja e o Estado buscavam uma solução comum aos problemas de exploração que os encomenderos praticavam sobre os índios. A intervenção missionária teve, pois, segundo Schallenberger, como finalidade básica moralizar os costumes e cristianizar, ou seja, trazer uma solução humana e evangelizadora para os conflitos sociais do antigo território denominado Paraguai (Figura 53 e Figura 54). Isso reverteria numa política de colonização, que pretendia integrar o índio ao sistema colonial, fazendo com que ele se tornasse auto suficiente e se moldasse segundo os padrões do homem espanhol e cristão.

Como se pode notar grande região que hoje é o Sul brasileiro, foi Província do Paraguai. Assim todas as regiões onde estão localizadas a Itaipu, o PNI e o próprio Oco’y, eram regiões consideradas do Paraguai, onde se articulavam na língua guarani e espanhola.

Informa Schallenberger, que em 1589, os padres Ortega e Fields da Companhia de Jesus iniciavam seus trabalhos apostólicos na região, buscando frear os impulsos dos encomenderos e pacificar os índios Guarani revoltosos, através da evangelização (SCHALLENBERGER: 1997:175).

Em 1610, os padres italianos José Cataldino e Simão Maceta da Companhia de Jesus fundam no Guairá a primeira base para uma futura redução (Imagem nº1), que vem a ser a de Nossa Senhora de Loreto (Figura 51 de Chmyz, quadrado no 1), localiza-se um pouco adiante da foz do rio Pirapó, no Paranapanema. Essa manifestação contou com o apoio do governador espanhol Hernando Arias de Saavedra ou Hernandarias. Verificaram que nos arredores havia cerca de 25 aldeias guarani, cujo número de indígenas, calculado em 2000, poderia integrar uma redução (CHMYZ: 1976:77). O arqueólogo Chmyz relata que, em 1970, nesse mesmo local encontra 27 sítios arqueológicos, mais tarde englobados na fase Loreto. Todos os sítios, restos de pequenas aldeias Guarani estavam dispostos nas proximidades da redução de Loreto. (CHMYZ: 1976:77) 


\section{AS PROVÍNCIAS DO PRATA ANTES DO VICE-REINADO}
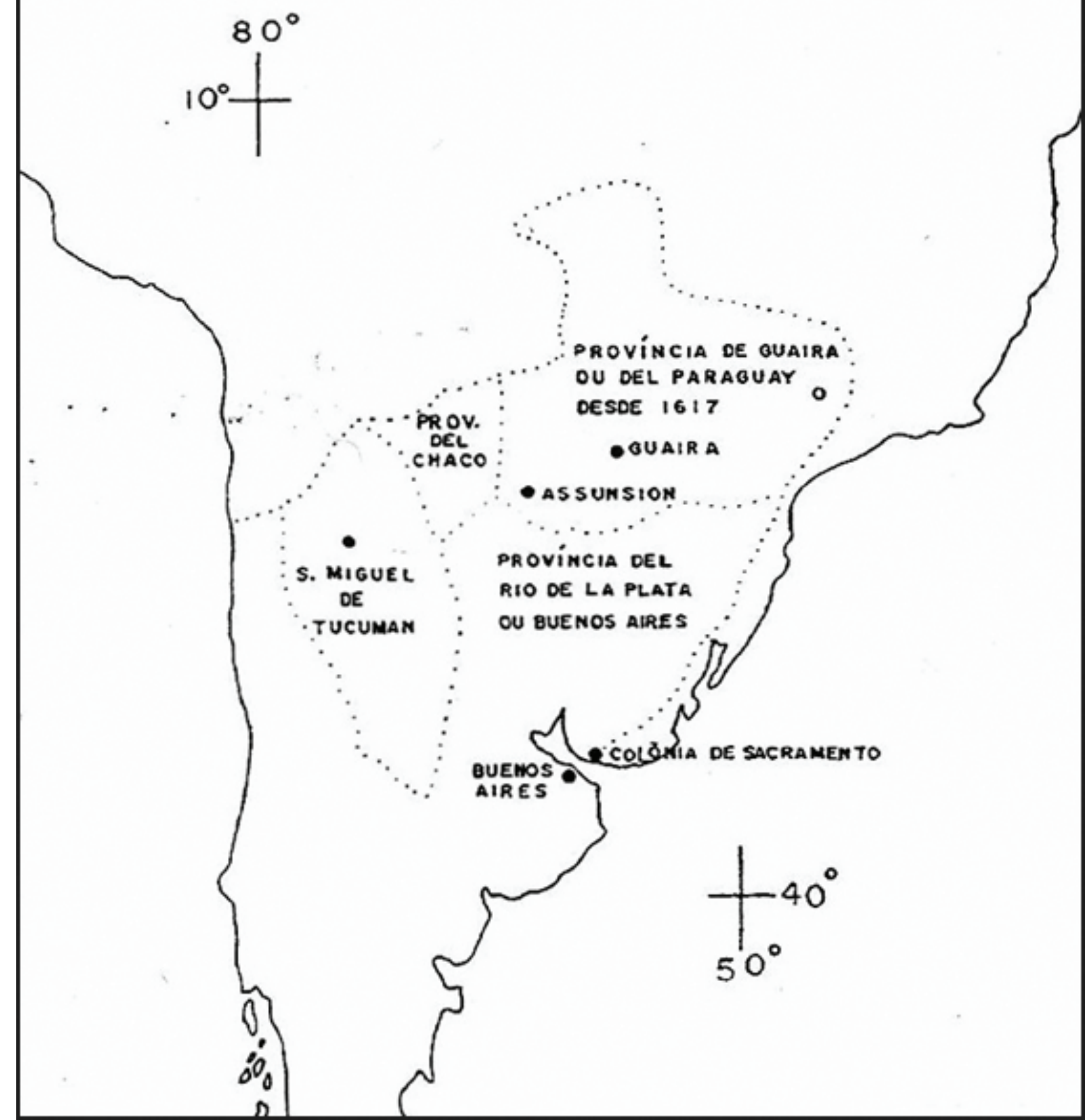

Figuras 53. Mapa. Província do Paraguai no início do século XVII.

Fonte: SCHALLENBERGER, Erneldo. A Integração do Prata no sistema colonial: Colonialismo interno e missões jesuíticas do Guairá. Toledo-Paraná: Editora Toledo, 1997, p 168. 


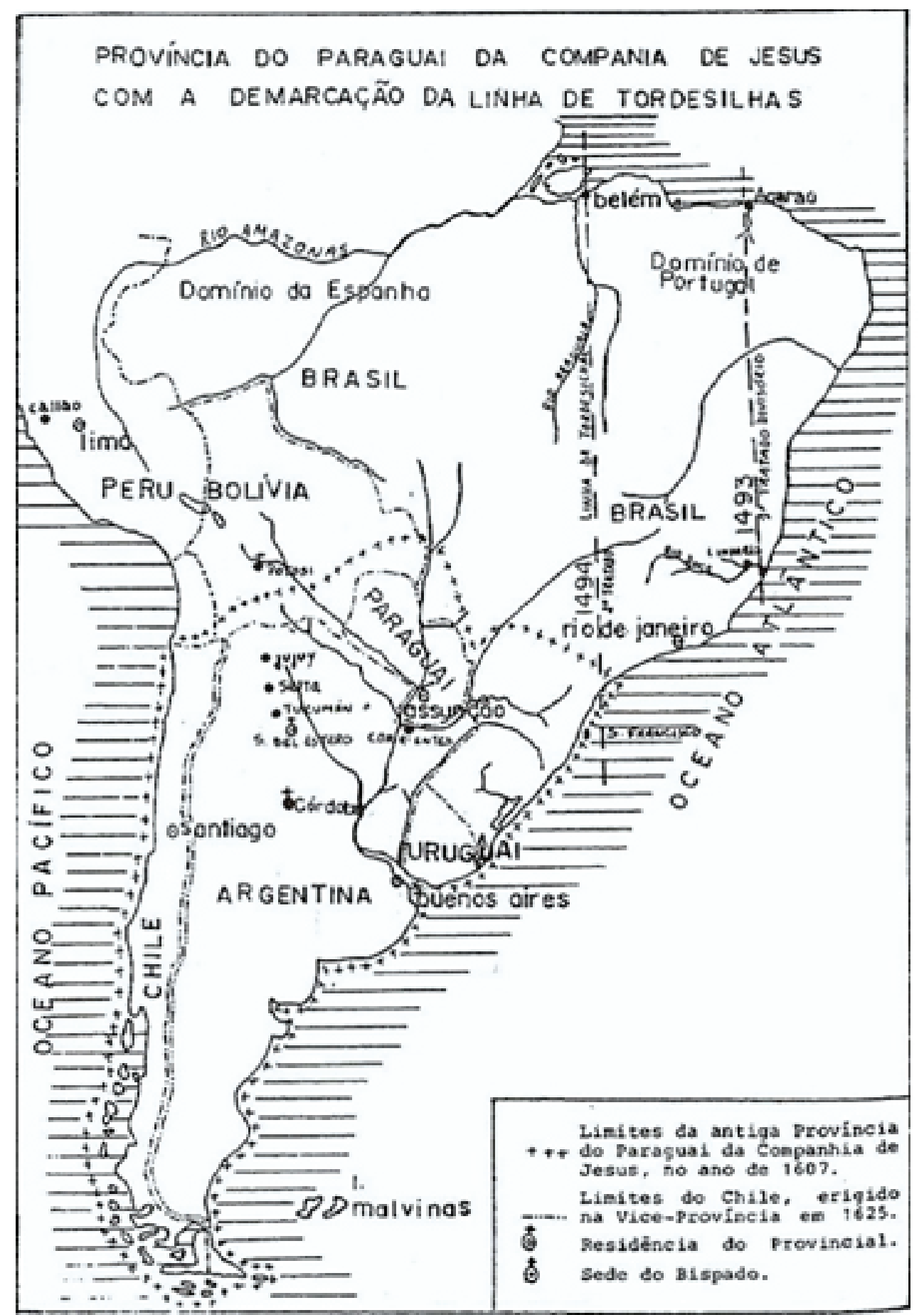

Figuras 54. Mapa. Província do Paraguai no início do século XVII.

Fonte: SCHALLENBERGER, Erneldo. A Integração do Prata no sistema colonial: Colonialismo interno e missões jesuíticas do Guairá. Toledo-Paraná: Editora Toledo, 1997, p. 146. 


\section{Montoya define o termo "Redução":}

Llamamos reducciones à los pueblos de indios, que viviendo à su antigua usanza en montes, sierras y valles, en escondidos arroyos, en tres, cuatro ó seis casas solas, separadas à légua, dos, tres y más unos de otros, los redujo la diligencia de los Padres à poblaciones grandes y à vida politica y humana. (MONTOYA:1892:29).

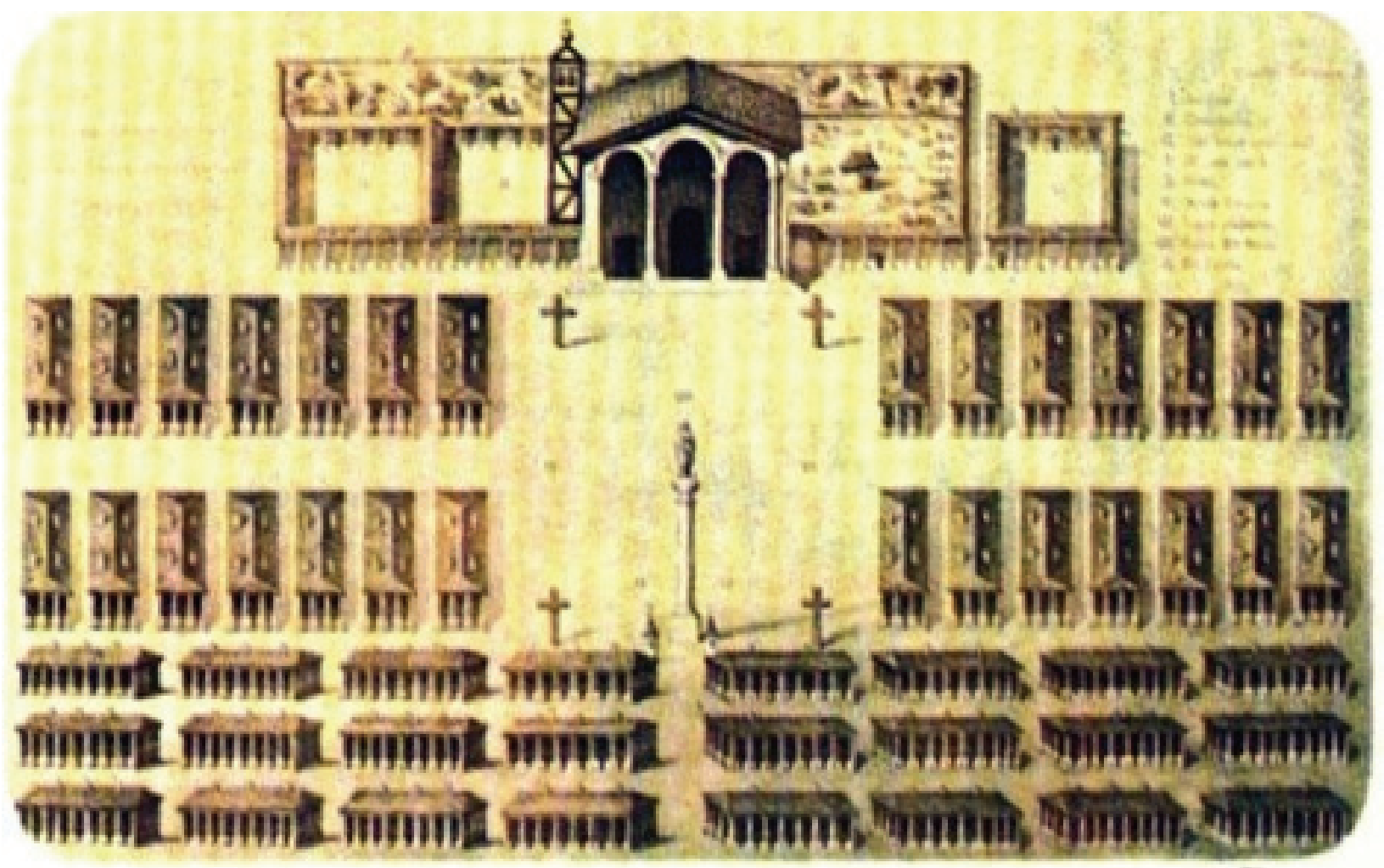

Figura 55. Imagem. Construção de uma redução jesuítica no Guairá.

Fonte: Grandes Personagens da Nossa História, Volume I, Abril Cultural, 1969, p. 166.

A Redução como o próprio nome indica transformava o espaço; a economia Guarani antes extensiva, transforma-se para uma economia intensiva, ocupando logicamente menores porções de terras, provocando dessa forma cada vez maior circunscrição territorial dos Guarani, e, portanto, liberação das terras indígenas que encontravam-se nas zonas periféricas da própria Redução.

O arqueólogo Igor Chmyz em seu livro Arqueologia e Historia da Vila espanhola de Ciudad Real de Guaíra ${ }^{12}$, levanta as seguintes informações, à respeito de quem ocupava as Missões Jesuíticas do Guaíra:

\footnotetext{
$\overline{12}$ CHMYZ, Igor. Arqueologia e História da Vila espanhola da Ciudad Real do Guairá. Cadernos de Arqueologia, n. ${ }^{\circ}$ 1, Ano I, 1976. Paraná - Brasil: UFPR, 103 p.
} 
Também pelos mesmos padres citados, em 1610 foi fundada a redução de Santo Inácio Menor ou do Ipaumbucu, às margens esquerdas dos rios Paranapanema e Santo Inácio (Figura 51 de Chmyz, quadrado $\mathrm{n}^{\circ}$ 2). Este local está situado cerca de $30 \mathrm{Km}$, rio Paranapanema acima, da redução de Nossa Senhora do Loreto, no atual município paranaense de Santo Inácio. A sua população indígena era, entre todas as reduções do Guairá, a mais numerosa. As estimativas variam de 2000 a 6000 índios guarani.

Cardiff citado por Chmyz, relata que, em 1617 a redução de Nossa Senhora de Loreto contava com 700 famílias de índios, sendo 450 as crianças que frequentavam a escola. Na de Santo Inácio Menor havia 850 famílias e 500 crianças em escola. Em 1620 a população das duas reduções era calculada em 8000 índios. (CHMYZ: 1976:78)

Em 1624, chefiados pelo Padre Antonio Ruiz de Montoya, é estabelecida a redução de São Francisco Xavier à margem esquerda do rio Tibagi (Figura 51 de Chmyz, quadrado $n^{\circ} 3$ ) em terras do cacique guarani Taiati ou Ibiritimbetá. (...) Montoya afirma que a população atingia cerca de 1500 famílias em vésperas do ataque bandeirante. (...) Localiza-se no atual município de Ibiporã (CHMYZ: 1976:81-2).

Os padres Simão Maceta, Montoya e Cristobal de Mendoza, fundam em 1625, nas terras do cacique guarani Tucuti, a redução de São José, nas nascentes de um pequeno afluente da margem esquerda do rio Tibagi, talvez o rio Abóbora (Figura 51 de Chmyz, quadrado no 4). (...) Sua população era calculada em 500 índios. (CHMYZ: 1976:82).

A redução de Nossa Senhora da Encarnação foi fundada em terras de Taiati, dominadas pelo cacique guarani Pindoviiú, à margem esquerda do rio Tibagi, em 1625, pelos padres Montoya e Mendoza (Figura 51 de Chmyz, quadrado ${ }^{\circ}{ }^{5}$ ). Em 1627 foi mudada por causa da ameaça da fome e da hostilidade de índios contrários à sua permanência. A definitiva distaria cerca de $60 \mathrm{Km}$ dali. (...) Sua população era estimada em $\mathbf{5 0 0}$ famílias. Localiza-se no atual município de Ortigueira. (CHMYZ: 1976:82-3).

A redução de Santa Maria foi fundada pelo padre Diego de Boroa em 1626, nas proximidades dos Saltos de Santa Maria no rio Iguaçu (Figura 51 de Chmyz, quadrado n ${ }^{\circ} 6$ ). Numa Carta Ânua do padre Durán, datada de 1628, há referências sobre a redução de Santa Maria: “...quatro léguas se navegan por el Parana desde la reduccion del Iguazu, hasta la de Natd, de N. Señora de Acaray...”. Nessa redução havia uma população indígena de $\mathbf{6 0 0}$ famílias. Segundo Chmyz, este local localizase no interior do Parque Nacional do Iguaçu. Em princípios de 1969, Chmyz efetua pesquisas no baixo rio Iguaçu, e ao prospeccionar o lado brasileiro dos Saltos de Santa Maria, encontra "um grande sítio arqueológico satisfatoriamente protegido pela mata e autoridades do Parque Nacional do Iguaçu. As evidências colhidas no local foram relacionadas a de outros sítios arqueológicos encontrados na mesma região. O conjunto foi denominado Fase Sarandi, pertencendo a sub-tradição Escovada Tupiguarani. (CHMYZ: 1976:83-4). 
A redução de São Paulo do Iniai fundada pelos padres Maceta e Montoya em 1627 (Figura 51 de Chmyz, quadrado $\mathrm{n}^{\circ}$ 7), chegou a reunir $\mathbf{5 0 0}$ famílias de índios. Localiza-se na margem esquerda do rio Ivaí, na confluência do rio Iniai, entre os municípios de São João do Ivaí e Jardim Alegre.

A redução de Santo Antonio (Figura 51 de Chmyz, quadrado no 8 ) deve-se a fundação ao padre Montoya, em 1627, na região do Ibiticoi. (...) 1500 índios teriam vivido ali. Localiza-se na margem direita do rio Ivaí na foz do rio das Antas. Hoje este ponto esta situado no município de Grandes Rios.

A redução de Sete Arcanjos de Taiaoba (Figura 51 de Chmyz, quadrado ${ }^{\circ}{ }^{9}$ ) foi fundada pelos padres Maceta e Montoya em 1627, na margem direita do rio Corumbataí quase nas suas cabeceiras. A região era dominada pelo cacique guarani Taiaoba. (...) População 1500 índios. (CHMYZ: 1976:84).

A redução de São Miguel (Figura 51 de Chmyz, quadrado $n^{\circ} 10$ ) foi fundada pelos padres Montoya e Mendoza em 1627, na região do Ibitiruzu ou Ibituruna. Localiza-se à margem esquerda do rio das Cavernas, um pouco acima de sua confluência com o rio Tibagi.

A redução de São Pedro (Figura 51 de Chmyz, quadrado $n^{\circ}$ 11) foi fundada em 1627 pelo padre Montoya, em terras dos índios gualachos, gualacos ou guaianases, nas nascentes do rio Piquiri. A redução de Conceição de Nossa Senhora dos Guanhanhos (Figura 51 de Chmyz, quadrado no 12), foi fundada pelo mesmo padre entre os anos de 1627/1628, localiza-se nas cabeceiras do rio Piquiri, composta pelos mesmos povos anteriormente citados. Essas duas reduções são as únicas não-guarani do conjunto das reduções do Guairá. (CHMYZ: 1976:85).

A redução de São Tomé foi fundada por Montoya em 1628 (Figura 51 de Chmyz, quadrado n 13). Localiza-se na margem direita do rio Corumbataí, no município de Jardim Alegre.

A redução de Jesus-Maria foi fundada pelo padre Maceta, por determinação de Montoya em 1628 (Figura 51 de Chmyz, quadrado $n^{\circ} 14$ ). (...) Estabelecida em terras do cacique guarani Guiravera, apresentava uma população de $\mathbf{2 0 0 0}$ índios. (...) Localiza-se nas cabeceiras do rio Ivaí, no município de Prudentópolis. (CHMYZ: 1976:86).

A redução de Nossa Senhora da Natividade do Acarai (Figura 51 de Chmyz, número isolado ${ }^{\circ}$ 18), fundada em 1619 pelo padre Diego de Boroa, à margem direita do rio Paraná, contou com o apoio do cacique guarani Arapindazu. (...) População 2000 índios. (CHMYZ: 1976:88)

O que se nota nas pesquisas do arqueólogo Chmyz é que a grande maioria étnica na região dos três povoamentos espanhóis e treze das quinze reduções jesuíticas do Guairá, eram compostas pela população Guarani; assim portanto, os estrangeiros estabeleceram-se em território da etnia. Chmyz confirma este fato através da seguinte assertiva final: 
Graças as pesquisas desenvolvidas em muitas partes do Estado, mas principalmente nas porções que sofreram a influência dos padres e militares, foram reconhecidas tradições ceramistas como a Itararé e Casa de Pedra, além da fase Icaraíma, contemporâneas da tradição Tupi-Guarani. Pelas citações daqueles europeus, percebe-se que fora o grande contingente indígena pertencente ao grupo linguístico Tupi-Guarani, com o qual a tradição arqueológica Tupiguarani está relacionada, havia outros, ligados a grupos linguísticos diferentes (CHMYZ: 1976:89).

Portanto, a referência histórica espacialmente mais próxima dos atuais Guarani do Oco’y é a Redução de Santa Maria, localizada no interior do Parque Nacional do Iguaçu.

Na conclusão do trabalho "Arqueologia e História da vila espanhola de Ciudad Real do Guairá”, o Prof. Igor Chmyz apresenta mapa do estado do Paraná referente às descobertas realizadas quanto à tradição arqueológica Tupiguarani até a publicação desse estudo, que se deu em 1976 (Figura 56). Comparado a Figura 48, do mesmo autor, datado de 2002, nota-se que 26 anos depois, o avanço da pesquisa demonstra que a ocupação Guarani do território era realmente extensiva, ou seja, quanto mais as pesquisas foram desenvolvidas, mais foram encontradas informações sobre a presença da etnia Guarani.

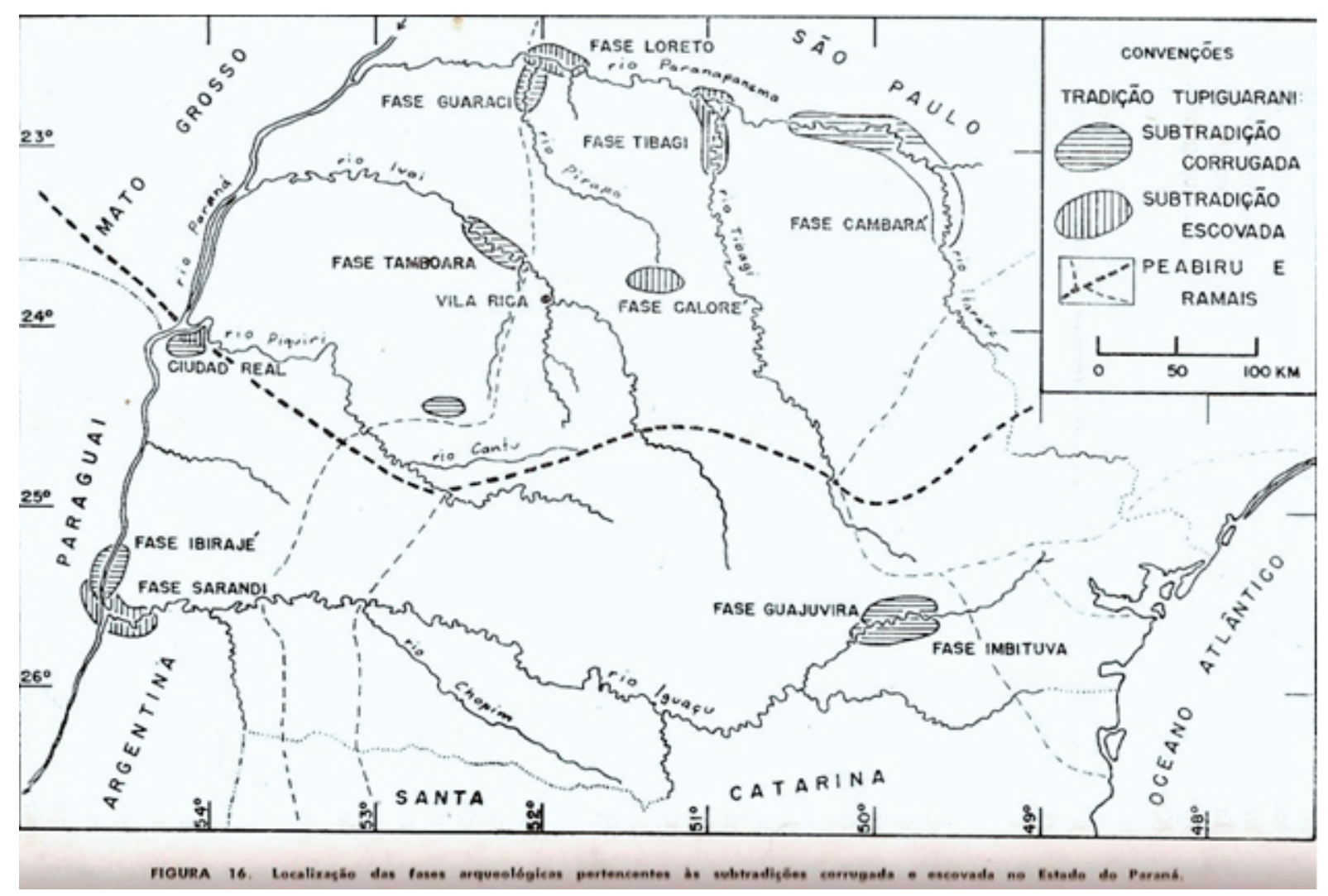

Figura 56. Tradição arqueológica Tupiguarani no estado do Paraná.

Fonte: I. Chmyz. Arqueologia e história da vila espanhola de Ciudad Real do Guairá. Cadernos de Arqueologia. Ano 1, no 1, Paraná. UFPR. 1976, p. 56. 
Continua Chmyz, relatando outras missões fundadas em território Guarani:

Em 1626 o padre Roque Gonzalez atravessa o rio Uruguai, onde é fundada em terras do cacique guarani Nienguiru, no Tape (onde hoje é fração do território do Rio Grande do Sul), a primeira redução neste local: São Nicolau (Figura 51 de Chmyz, elipse nº 16). No final de 1630 já eram mais quatro as reduções fundadas nesta região, a maioria também em terras de população Guarani (CHMYZ: 1976:93).

Em seguida Chmyz descreve outras inúmeras Reduções Jesuíticas no Tape. Foram fundadas também missões jesuíticas no Itatin, região localizada no atual Mato Grosso do Sul e norte paraguaio (Figura 52), da mesma forma em terras de população Guarani.

Todo esse território eminentemente ocupado tradicionalmente pela população Guarani, foi então até o século XVII jurisdição da "Província do Paraguai", o qual integrava os atuais estados do Paraná, Santa Catarina, Rio Grande do Sul e Mato Grosso do Sul, além dos atuais países Paraguai, Uruguai e Argentina (Figura 53 e Figura 54).

Assim não há sentido em não se reconhecer as terras ocupadas pelos Guarani, com afirmações de que são índios "paraguaios”, pois, grande parte do antigo território da Província do Paraguai foi incorporado ao Brasil (MT, MS, parte de SP, PR, SC e RGS) a partir do século XVII e, se antes ainda, estas mesmas porções eram extensivamente de posse imemorial da população Guarani. É fundamental a compreensão pelas autoridades estatais, de que os Guarani são um povo dividido por fronteiras nacionais, posteriores a sua ocupação, arbitrariamente definidas, exteriores a sua realidade.

\subsubsection{Os ataques bandeirantes no século XVII}

De 1580 a 1640 perdurou a dominação espanhola sobre esse território, período em que as duas Coroas de Portugal e de Espanha eram comandadas pelo rei espanhol. Esta união fez com que momentaneamente as questões de limites na América fossem esquecidas. A linha de Tordesilhas foi cortada em ambos os sentidos. Espanhóis estabeleceram-se em território português, enquanto luso-brasileiros através de entradas e bandeiras, penetraram em regiões castelhanas, conquistando dessa forma extensas áreas, tendo a posse sido ratificada mais tarde por vias diplomáticas.

As Cartas Régias de 30.07.1609 e a de 10.09.1611 promulgadas por Filipe III, afirmam o pleno domínio dos índios sobre seus territórios e sobre as terras que lhe são alocadas nos 
aldeamentos, estas são as primeiras leis promulgadas afirmando o direito sobre a posse das terras indígenas:

Os gentios são senhores de suas fazendas nas povoações, como o são na Serra, sem lhes poderem ser tomadas, nem sobre ellas se lhes fazer moléstia ou injustiça alguma; nem poderão ser mudados contra suas vontades das capitanias e lugares que lhes forem ordenados, salvo quando elles livremente o quizerem fazer..."(Carta Régia de 10.09.1611, in CARNEIRO DA CUNHA: 1987:58)

Porém, na prática a história é outra. Desde a fundação de São Vicente, um dos graves problemas enfrentados pelos colonizadores foi a falta de mão de obra. Sem condições de obter negros d'África, lançaram mão do trabalho escravo indígena. O mercado de captura de índios no Sul se restringia inicialmente às aldeias Guarani das imediações de Piratininga (SP), mas à medida que escasseavam, fugindo sertão a dentro, crescia o âmbito de ação dos "preadores", abrangendo até as terras espanholas do Prata. (Figura 57).

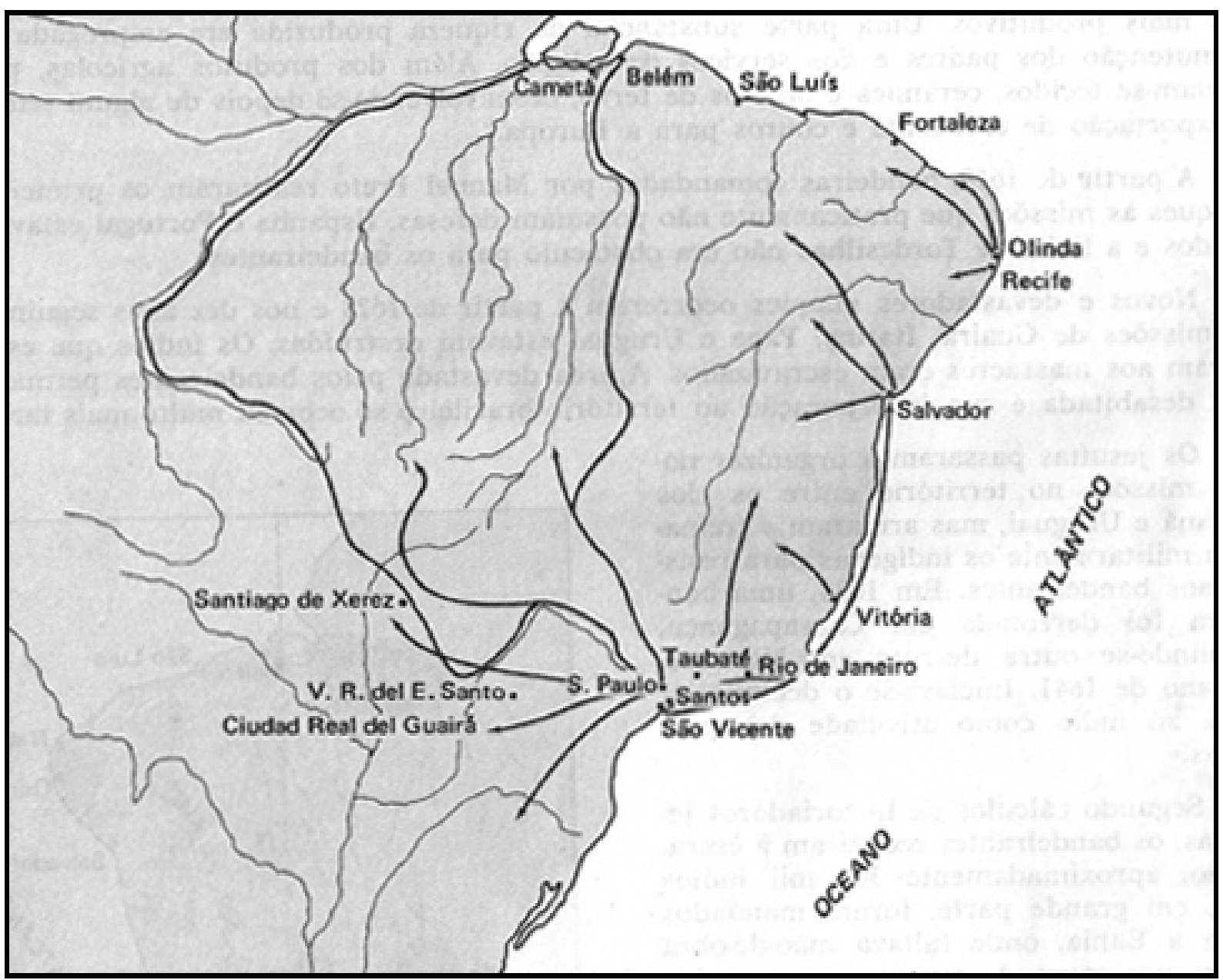

Figura 57. Mapa. Rumos da expansão bandeirante.

Fonte: R. Campos. História do Brasil. Editora Atual. 1983, p. 53. 
Desta forma, no período de 1610 a 1632, bandeirantes paulistas, em busca de mão de obra escrava, vinham em expedições para a região do Guairá, aprisionar índios Guarani, levando-os para São Paulo, afim de posteriormente vendê-los para os engenhos de cana-de-açúcar instalados na Bahia e Pernambuco (Figuras 58A; 58B; 58C). Neste contexto, encomenderos espanhóis passam também a apresar os Guarani, para vendê-los aos bandeirantes paulistas. Eram aprisionados em maior escala os que viviam nas Reduções Jesuíticas, pois além de estarem concentrados, facilitando o aprisionamento, também já estavam sedentarizados e treinados em ofícios, o que permitia melhores preços na venda.

Assim escreve Chmyz, sobre os ataques a Guaíra:

Entre 1610 e 1615 Sebastião Preto seria o bandeirante responsável pelos movimentos entradistas no Guaíra. Existem referências que teria induzido cinco caciques guarani a acompanhá-lo até São Paulo, juntamente com 3000 índios. Em 1618 Manuel Preto ameaça invadir Nossa Senhora de Loreto, ação que é evitada pelo padre Montoya. O bandeirante estabelece-se na foz do rio Tibagi, preando os índios dos arredores, capturando 900 índios. Atacado por uma onça Manuel e sua expedição voltam a São Paulo, e os índios Guarani que haviam sido capturados, são reconduzidos às reduções do Paranapanema. Manuel Preto volta a investir em 1623/24 contra as reduções do Paranapanema.

Uma grande investida contra as reduções do Guairá começa a ser preparada em 1627, dessa vez por Antonio Raposo Tavares; contava com quatro companhias, ao todo 4000 homens. Em 1629, estabeleceram-se nas proximidades da redução de Santo Antonio atacando e destruindo aquela redução. As reduções Encarnação de Nossa Senhora dos Guanhanhos, São Paulo, Sete Arcanjos e São Tomé pelo sucedido e temendo o mesmo fim, desfizeram-se. Os índios foram agrupados nas reduções do Paranapanema. Meses mais tarde são atacadas as reduções de Jesus-Maria e de São Miguel onde apesar da resistência indígena é desmantelada. Os portugueses voltam a São Paulo, com muitos índios escravizados e objetos saqueados.

Em 1631 apenas as reduções de Loreto e Santo Inácio Menor estavam intactas. Nela existiam 5000 índios. Os índios fugitivos, das reduções abandonadas ou destruídas, aproximadamente 7000, aglomeravam-se nas cercanias das restantes. Vendo a impossibilidade de manter a integridade das mesmas, os padres Trujilho e Montoya concordaram em abandoná-las. Houve muita relutância por parte dos Guarani. Canoas e jangadas são rapidamente confeccionadas, sendo nelas dispostas, os pertences dos índios, as crianças e pequenos animais. Segundo Montoya, escaparam 12.000 índios em 700 balsas e muitas canoas. Dois dias depois os portugueses atacam as duas reduções, destruindo-as e levando ainda muitos índios que lá haviam permanecido. Em 1632 são destruídas as comunidades de Vila Rica do Espírito Santo e Ciudad Real onde se dá a retirada final dos habitantes das Missões do Guaíra. (CHMYZ:1976:89 - 93). 


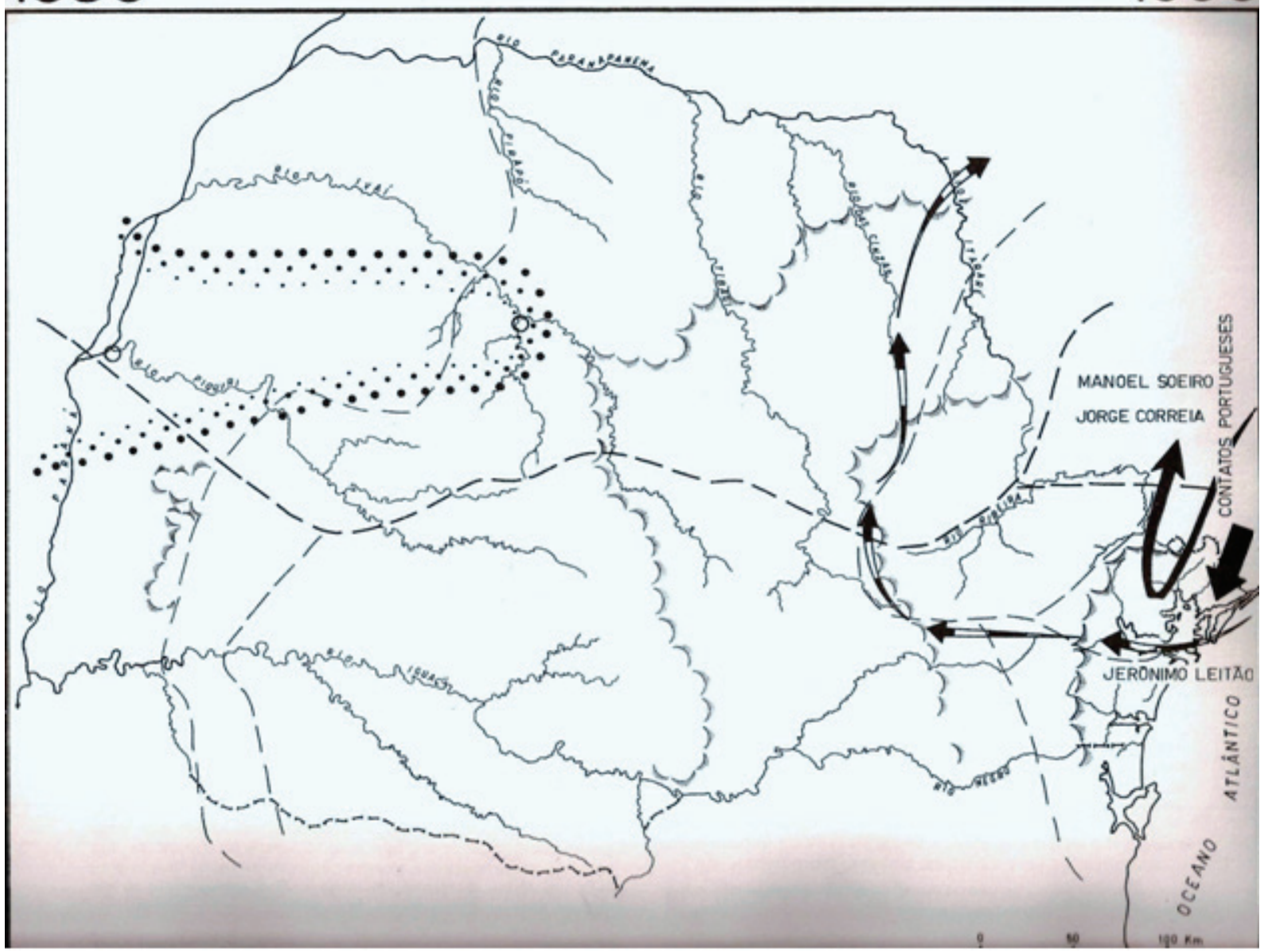

\section{Legendas}

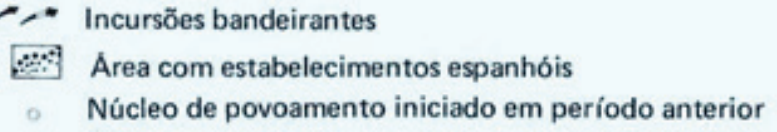

Figura 58A. Mapa. Ataques bandeirantes ao Paraná, especialmente no Guairá. Período de 1580-1600.

Fonte: J.A. Cardoso e C.M. Westphalen. Atlas Histórico do Paraná. Curitiba, Chain Editora, 1986, p 30-1. 


\section{0}

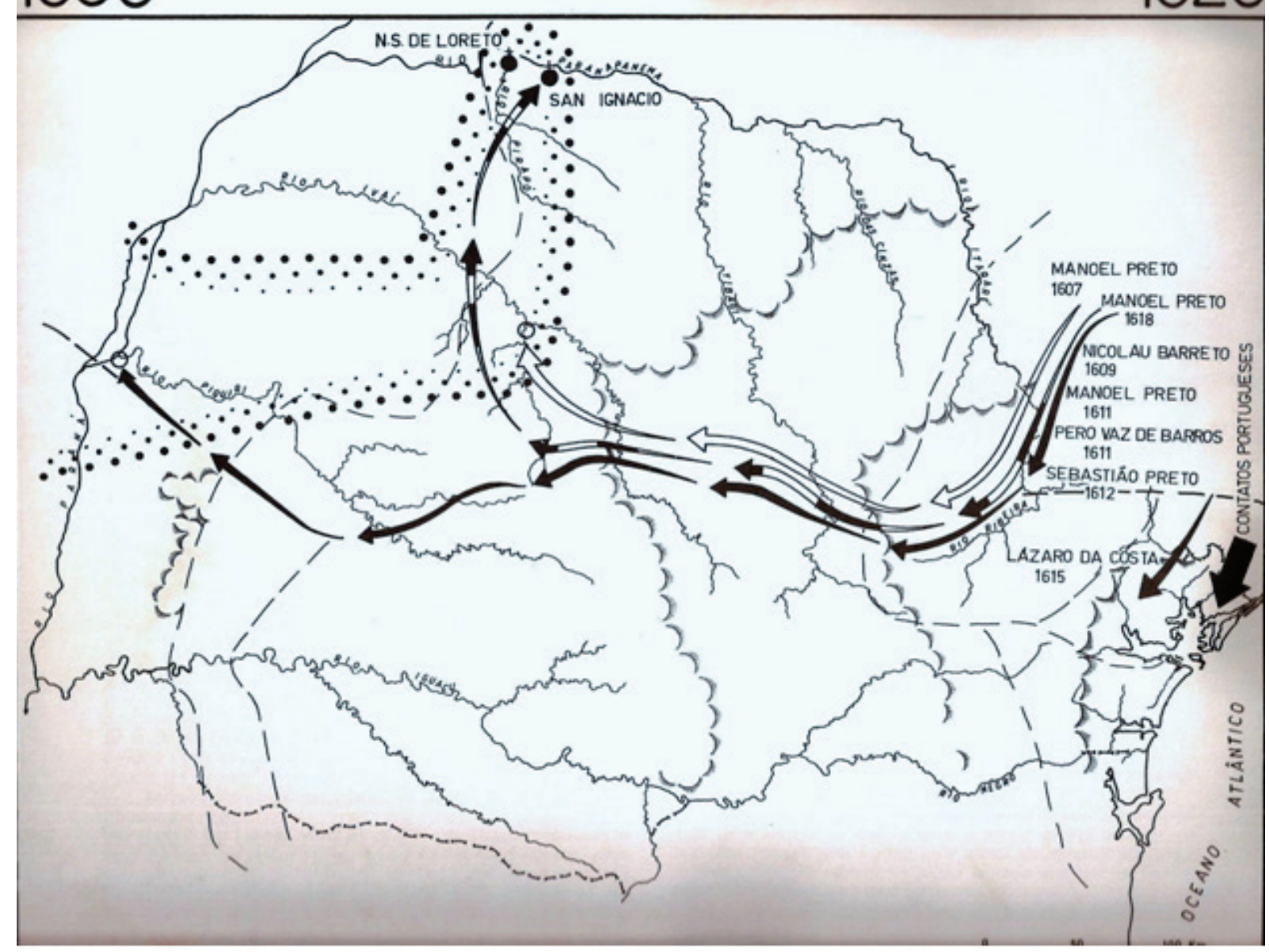

\section{Legendas \\ - Reduções jesuíticas espanholas criadas no periodo Núcleo de povoamento iniciado em período anterior C.* Incursões bandeirantes \\ fint Area com estabelecimentos espanhóis}

Figura 58B. Mapa. Ataques bandeirantes ao Paraná, especialmente no Guairá. Período de 1600-1620

Fonte: J.A. Cardoso e C.M. Westphalen. Atlas Histórico do Paraná. Curitiba, Chain Editora, 1986, p 33-4. 

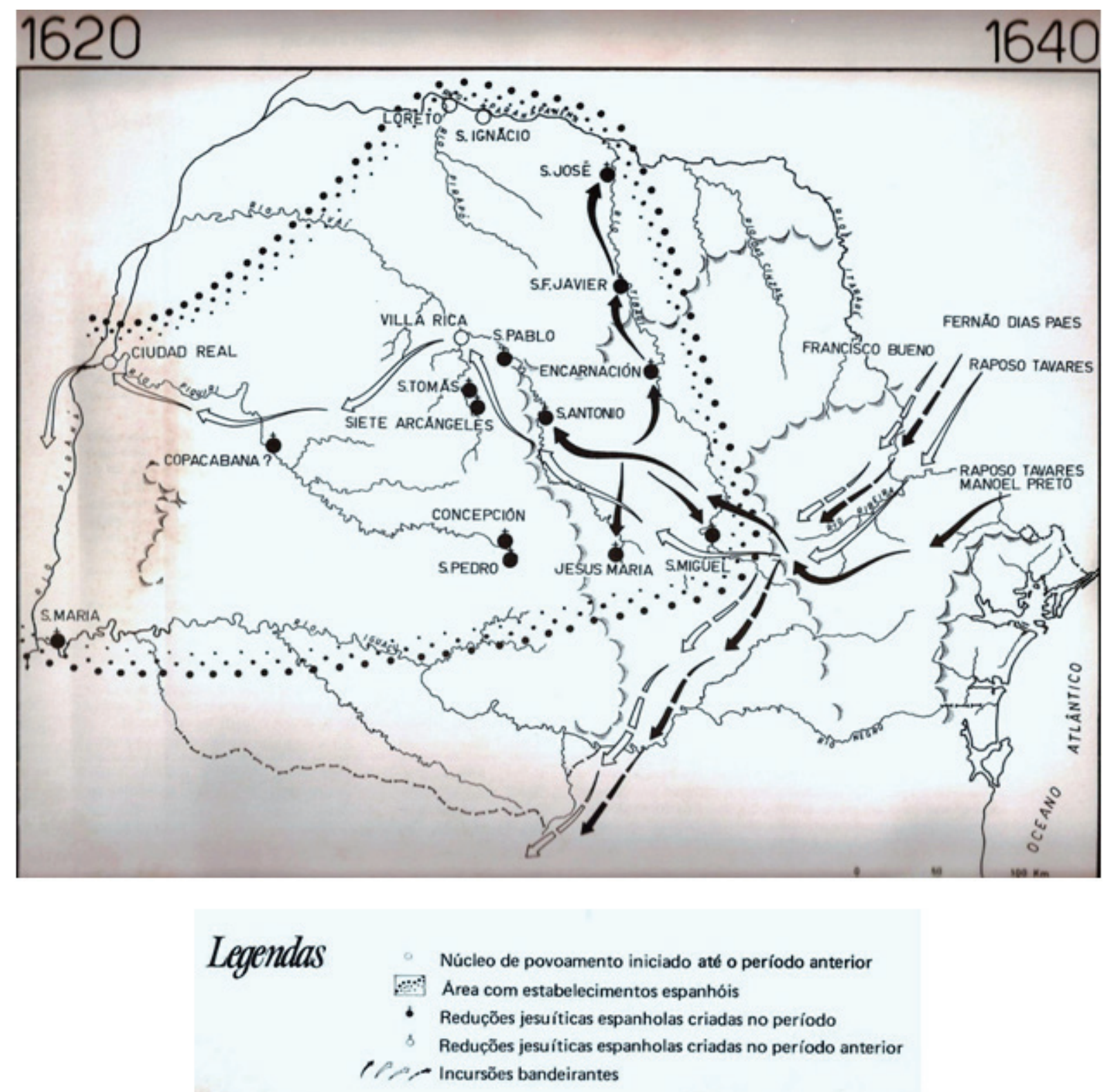

Figura 58C. Mapa. Ataques bandeirantes ao Paraná, especialmente no Guairá. Período de 1620-1640. Fonte: J.A. Cardoso e C.M. Westphalen. Atlas Histórico do Paraná. Curitiba, Chain Editora, 1986, p 34-5.

A destruição das reduções no Guairá motivou o êxodo de 12.000 índios Guarani que escaparam da ação dos bandeirantes, até as proximidades da atual cidade argentina de Posadas. Apenas 4000 conseguiram atingir aquele ponto. $\underline{O}$ padre Aires de Casal, descreve que a Província do Guairá era composta de $\mathbf{7 0 . 0 0 0}$ índios que viviam nas reduções, na época dos ataques dos bandeirantes.

Assim indaga-se para onde se dirigiram a maioria dos Guarani habitantes do Guairá? ${ }^{13}$

\footnotetext{
$\overline{13}$ Essa questão será respondida quando nos referirmos aos Cainguá (Gente da Floresta).
} 
Os jesuítas do Guairá e mais os novos vindos da Europa, aceleraram a fundação de outras reduções no Tape, no Rio Grande do Sul atualmente. Em 1636, o número de reduções atingia 18 (Figura 51 de Chmyz, elipses numeradas de 1 a 18). Em 1648 Raposo Tavares acaba por destruir o conjunto das missões do Itatin, fugindo grande parte dos Guarani, para o Tape.

Segundo Jânio Quadros, a geopolítica da região, foi em muito definida pela ação dos bandeirantes. Assim descreve:

As reduções cedo se constituíram em excelentes alvos para as atividades de caça ao índio. A partir de 1628 os ataques bandeirantes tornaram-se sistemáticos e se multiplicaram de tal modo que os inacianos viram-se obrigados a sucessivos recuos, em direção ao Sul, o que não só deteve o avanço dos jesuítas castelhanos sobre o Atlântico, mas possibilitou a conquista e o alargamento do espaço brasileiro (QUADROS: 1967:199).

Entre 1636 e 1641, investidas dos bandeirantes no Rio Grande do Sul, ocasionaram a destruição das primitivas reduções jesuíticas. Semelhantemente ao Guairá, também no Tape a destruição foi assistida passivamente pelas autoridades e espanhóis de Assunção e Buenos Aires.

Com a Restauração da Coroa em Portugal, em 1640, acabaram as incursões dos bandeirantes preadores de índios, a atividade deixa assim de influir no crescimento territorial. Os bandeirantes portugueses agora são impulsionados pela descoberta de metais e pedras preciosas na América espanhola, lançando-se da orla oceânica para o interior do continente. Daí por diante as buscas às minas desempenharão o papel nos avanços geográficos.

\subsubsection{A resistência Guarani no Tape e os Cainguá (Gente da Floresta) do Itatin e do Guairá}

Descrevemos a seguir de forma sucinta relatos de Janio Quadros e Afonso Arinos (1967) sobre a formação histórica das fronteiras no sul da America Latina. Sob a ótica dos indígenas Guarani pode-se dizer que é uma "historiografia da dominação do seu território". Nos documentos históricos os indígenas são citados apenas como coadjuvantes dessa história. Nesse período como em vários outros os Guarani são envolvidos com a questão de fronteiras, vivendo numa espécie de "corda bamba" onde são empurrados para aquém ou além dos limites estabelecidos pelos países fronteiriços. Essa é uma tônica na historia dos Guarani junto ao colonizador. Esta historiografia geral não entra no mérito do direito à terra pelos povos indígenas, porém, identifica 
os Guarani nas regiões provando sua imemorial ocupação sobre o território. Vejamos como são descritos os fatos.

A ocupação ibérica sobre o território Tupi-Guarani estabelece um contexto de disputa pela terra através de batalhas, acordos e por fim tratados entre Portugal e Espanha. Janio Quadros e Afonso Arinos (1967) descrevem que com a revolução restauradora de 1640 e a consequente emancipação de Portugal, tornou-se imperioso estabelecer os limites dos domínios de cada coroa. Em 1680 é fundada pelos portugueses a Colônia do Sacramento, no sul do atual Uruguai. Objetivava Portugal restabelecer os negócios com Buenos Aires, interrompidos com a separação dos dois países; com a fundação deste posto, permitiria que a prata de Potosi (Bolívia) chegasse à metrópole, quando já declinava o comércio açucareiro.

Ainda em 1680 é promulgado o Alvará de $1^{\circ}$ de abril, que declara que as sesmarias concedidas pela Coroa Portuguesa não podiam afetar os direitos originais dos índios sobre suas terras. "Primários e naturais senhores" de suas terras eram enquanto tais isentos de qualquer foro ou tributo sobre elas.

E para os ditos Gentios, que assim decerem, e os mais, que ha de presente, melhor se conservem nas Aldeas: hey por bem que senhores de suas fazendas, como o são no Sertão, sem lhe poderem ser tomadas, nem sobre ellas se lhe fazer moléstia. E o Governador com parecer dos ditos Religiosos assinará aos que descerem do Sertão, lugares convenientes para neles lavrarem, e cultivarem, e não poderão ser mudados dos ditos lugares contra sua vontade, nem serão obrigados a pagar foro, ou tributo algum das ditas terras, que ainda estejam dadas em Sesmarias e pessoas particulares, porque na concessão destas se reserva sempre o prejuízo de terceiro, e muito mais se entende, e quero se entenda ser reservado o prejuízo, e direito os Índios, primários e naturaes senhores dellas. (Alvará de $1^{\circ}$ de abril de 1680 descrito por CARNEIRO DA CUNHA: 1987:59)

Os índios na época tinham permissão para se defender com armas de fogo. Em 1680 começam a retornar às terras que haviam abandonado em consequência dos ataques portugueses. Funda-se novamente no Tape (atual extremo oeste do RGS), o local que viria a se chamar $\underline{\text { Sete Povos das }}$ Missões, reduções compostas majoritariamente pela população Guarani. São elas: São Francisco Borja, São Nicolau, São Luis Gonzaga, São Miguel Arcanjo, São Lourenço Mártir, São João Baptista e Santo Ângelo Custódio. (Figura 51 de Chmyz). Nesta região na verdade haviam 32 missões jesuíticas, compostas em sua maioria por Guarani e em menor parte por Kaingang e outras etnias. Historicamente, pelos fatos que sucederam em Sete Povos, essas são as mais conhecidas. 
Descrevem Quadros e Arinos que em 1715 é assinado o Tratado de Utrecht, onde se reconhecia mais uma vez os direitos portugueses sobre a Colônia do Sacramento. Porém, este tratado não pôs fim às disputas territoriais, pois provocava interpretações diferentes a cada uma das partes. Sob o ponto de vista espanhol apenas Colônia do Sacramento pertencia à Portugal, pertencendo à Espanha os territórios adjacentes. Os portugueses alegavam que o tratado lhe dera não apenas aquela posse, mas de extensa área que a circundava. Em 1737 o governador espanhol de Buenos Aires ataca a Colônia do Sacramento.

Os mesmos autores descrevem que em 13 de janeiro de 1750 é assinado o Tratado de Madrid. Este tratado propunha a troca da possessão portuguesa, Colônia do Sacramento (localizada a 60 km de Montevidéu) pela região onde habitavam os Guarani dos Sete Povos das Missões, atual oeste do Rio Grande do Sul (Figura 51 de Chmyz), na época possessão espanhola. Os índios Guarani deveriam abandonar seus povoados no Sete Povos, para fixar-se novamente em terras de Espanha, à margem direita do rio Uruguai. Cabe salientar que a leste de Sete Povos havia ainda cerca de vinte e cinco missões, compostas em sua maioria pelos Guarani, conforme se pode observar na Figura 51 de Chmyz.

Pelo acordo, os autores descrevem os limites entre as duas potências ficariam assim fixados: Começava em Castilhos Grande, na atual costa uruguaia; procurava as vertentes da lagoa Mirim e do rio Negro até alcançar o rio Ibicuí, e daí descia até o rio Uruguai, seguindo por este até a foz do Peperi-guaçu. Em seguida prolongava-se ao Iguaçu, até alcançar o Paraná. Dali ia ter ao Igureí. Subindo o rio pela contravertente, afluente do rio Paraguai, atingia o Jauru. Em linha reta tocava o Guaporé e, seguindo-o, a divisa continuava até o Mamoré. Daí contava-se meia distância da boca da foz do Madeira, no Amazonas, de onde se tirava outra linha até às nascentes do rio Javari, para buscar o Solimões e continuar até o Japurá. O rio Negro era atingido no ponto de separação da sua bacia com a do Orenoco, encontrando-se logo a seguir a serra do Paracaima, que servia de limite com a Guiana Holandesa (QUADROS \& ARINOS: 1967:207-8).

Janio Quadros e Afonso Arinos transcrevem o relato de Southey (1862), caracterizando os sofrimentos épicos a que os Guarani foram submetidos, compelidos à execução do decretado deslocamento:

Os missionários emigrariam das aldeias que a Espanha cedia ao oriente do Uruguai, levando consigo todos os seus bens e todos os seus índios, que iriam estabelecer algures dentro do território espanhol, e também os indígenas levariam toda a sua propriedade móvel e semovente, suas armas, pólvora e munições. Seriam as reduções entregues à coroa de Portugal com suas casas, igrejas e edifícios de 
toda espécie, propriedade e posse da terra. (...) A cessão da Colônia e dos estabelecimentos ao nascente do Uruguai se efetuaria dentro de um ano contado da assinatura do tratado. (...) Nas sete florescentes reduções situadas na área atribuída a Portugal, habitavam cerca de $\mathbf{3 0 . 0 0 0}$ guaranis.(...) Todos estes, com mulheres e filhos, com doentes e velhos, com cavalos e ovelhas e bois, tinham, como do Egito os filhos de Israel, de emigrar para o deserto, não fugindo à escravidão, mas obedecendo a uma das mais tirânicas ordens jamais emanadas do poder insensível (QUADROS \& ARINOS: 1967: 179-80-1).

Quadros e Arinos afirmam que a contragosto os índios Guarani da maioria das reduções intentaram um movimento de saída de Sete Povos, porém, todos retornavam vendo a impossibilidade da transferência, por diversas razões: - ao sair acabavam invadindo território de outros grupos indígenas inimigos, os charruas; - as terras ali não eram boas para o cultivo, desérticas; havia pouco espaço para a totalidade da população; - não havia tempo suficiente para preparar os cultivos (apenas três meses de prazo) para receber aquela multidão de população. Naquele momento mostrava-se a total inviabilidade da mudança. Os jesuítas entram com uma representação junto às autoridades, na qual declaravam impossível a transferência. Inicia-se assim, um movimento de resistência, caracterizado pela recusa dos Guarani em entregar as terras de Sete Povos das Missões. Da tentativa de emigração forçada resultou a insurgência uma a uma das sete reduções. A situação complicava-se, uma vez que as sete reduções atingidas pelo decreto de mudança receberam a adesão das não atingidas em número de vinte e cinco, dispostas a apoiá-las na resistência. Uma guerra avizinhava-se. Os Guarani firmes em seu propósito de não arredar pé do local, começam a voltar sua animosidade também contra os padres, conforme relato de Southey:

Publicamente se proclamava que esquecidos do amor devido aos guaranis como filhos seus, lhes tinham os jesuítas vendido aos portugueses as aldeias e as terras, e os magistrados recentemente eleitos, a todos proibiram sob pena de morte até o falar em obedecer, ou escutar sobre este assunto os jesuítas, não se sofrendo que pregassem os padres sobre outra matéria que não as leis de Deus. Pouco mais eram os jesuítas agora do que prisioneiros, onde pouco antes gozavam de absoluta autoridade, tão grande mudança produzira o ressentimento de uma injustiça (QUADROS \& ARINOS: 1967:186).

A direção da Companhia de Jesus ordena aos missionários que inutilizem a pólvora existente e impeçam o fabrico de arcos, flechas e outras armas. Vencido o prazo concedido aos rebeldes para que se conformassem com o tratado (...) e cuidassem de se recolher a Buenos Aires, a fim de não se comprometerem na sedição (QUADROS \& ARINOS: 1967:187). O provincial da região abre mão de seus poderes outorgados pela Coroa da Espanha, depondo-os em mãos do governador e do bispo 
de Assunção. Irromperam as hostilidades. Os guaranis de São Luis, São Miguel, São Lourenço e São João atacam no rio Pardo um destacamento português. Destaca-se na luta o alferes da redução de São Miguel, o índio guarani Sepé Tiaraiú. Mais tarde neste mesmo local os guaranis levam tropas de cavalos dos portugueses. (QUADROS \& ARINOS: 1967:188). O representante do governo português, Gomes Freire, junto aos trabalhos de demarcação, receando ter de sustentar, com seus únicos recursos militares essa situação, recusou receber os Sete Povos antes que os espanhóis os declarassem definitivamente pacificados. À responsabilidade de jesuítas espanhóis acabou sendo levada a insurreição dos índios missioneiros. As notícias acerca do estado de guerra no Sul, atribuído aos jesuítas espanhóis do Paraguai, e as acusações aos jesuítas portugueses que teriam oposto sérias dificuldades a missão de Mendonça Furtado no Norte, criavam então um ambiente carregado contra a Companhia de Jesus, à qual se imputava o propósito de projetar a organização de um império teocrático na Sul-América. Os incidentes registrados no Norte e no Sul seriam preliminares da ação militar em preparação. (QUADROS \& ARINOS: 1967:189)

Não se conseguia avançar na demarcação. Os negociadores de ambos os lados faleceram. O rei enlouquecera. O Marquês de Pombal tentou negociar modificações, sem êxito. A execução do tratado foi suspensa. Em 12 de fevereiro de 1761 o Tratado de Madrid é anulado pelo Tratado de El Pardo. "A ciência das cláusulas do tratado de Madrid, de 1750, causou grande dissabor em Lisboa e no Brasil, por causa da estipulada entrega do Sacramento; e desagradou, na Espanha, e no Prata, por causa da mutação de fronteiras na zona das Missões. Foi por causa dessa oposição, nos dois países, que D. José I e D. Carlos III resolveram anulá-lo através do tratado de El Pardo" (QUADROS \& ARINOS: 1967:193).

Os autores descrevem que Sete Povos continuam temporariamente em terras consideradas espanholas no mesmo local. Já em 1759 o Marques de Pombal conseguira a expulsão dos jesuítas de Portugal e suas colônias. Em 1767 na Espanha é adotada a mesma medida. Somente em 1768, por temor à reação indígena, o decreto de expulsão dos jesuítas foi aplicado nos Sete Povos das Missões.

Em 1767 a população de Sete Povos das Missões era estimada em 25.000 índios. Destes, em 1801, só restavam 14.000. Os jesuítas foram substituídos por padres de outras congregações e por administradores civis. Imediatamente iniciaram os atritos entre os índios e os novos administradores. Os índios passaram a ser explorados por ambas as partes. A decadência de Sete Povos foi imediata. Os Guarani começam a abandoná-la, espalhando-se pelos domínios agora portugueses ou em terras argentinas ou paraguaias. (QUADROS \& ARINOS: 1967:190) 
Em 1777, os espanhóis tomam pela quinta vez a Colônia do Sacramento. Em $1^{\circ}$ de setembro de 1777 é assinado em Santo Idelfonso um acordo de limites entre as duas Coroas referente as terras do Sul. Segundo Quadros e Arinos:

A tímida conduta portuguesa permitiu que o Tratado de Santo Idelfonso fosse favorável aos interesses castelhanos. Em linhas gerais mantinham-se os lindes traçados em 1750, no Tratado de Madrid, com exceção do Sul, onde se fizeram mudanças acentuadas. Por esse acordo incorporaram-se à Espanha o Sacramento e os Sete Povos das Missões. Os limites, agora, corriam no Chuí e não mais em Castilhos Grande, passando pela lagoa Mirim até o Peperi-Guaçu (QUADROS \& ARINOS: 1967:210).

Uma nova guerra pelas fronteiras no Sul é iniciada entre Portugal e Espanha em fevereiro de 1801. Jânio Quadros comenta que:

Esta guerra fez com que as tropas que guarneciam a fronteira do Rio Grande do Sul levassem de roldão a guarnição espanhola, e se não fora a prudência do Governador Veiga Cabral, seguramente os lusitanos teriam chegado até à margem esquerda do rio da Prata. Fortificaram-se os soldados de Portugal na barra do arroio Chuí, junto à costa, e firmaram definitivamente a fronteira brasileira pelo Chuí, margem esquerda da Lagoa-Mirim a Oeste, e o rio Jaguarão a Noroeste (QUADROS: 1967:194)

Em $\underline{6}$ de junho de 1801, é firmado entre as duas Coroas o Tratado de Badajoz, este pôs termo a guerra iniciada em fevereiro do mesmo ano entre Portugal e Espanha, não revalidou o Tratado de Santo Idelfonso, nem mandou restabelecer o status quo antes da guerra, continuando na posse dos portugueses os territórios conquistados no Rio Grande do Sul e definitivamente incorporados ao Brasil.

Quadros e Arinos assim definem a formação do povo do Rio Grande do Sul:

O Rio Grande resultou de correntes humanas diversas nos objetivos e na origem. De um lado os índios: guaranis das missões e charruas das planícies; de outro os espanhóis, que reivindicando a região aos portugueses, constituíram-se em elementos formadores da população. A par dos nativos e dos castelhanos, os jesuítas desempenharam notável papel missioneiro, enquanto que pelo interior, os paulistas, isto é, os mamelucos, incursionavam na faina preadora, radicando-se, muitas vezes no campo de criação. (QUADROS \& ARINOS: 1967:205) 
A despeito da política colonial, a rebelião armada por parte dos Guarani, constituía estratégia frequente no decorrer do século XVI e XVII. John Monteiro afirma à respeito:

Longe da imagem de índios pacíficos e submissos, grupos de índios Guarani inconformados com o caráter da dominação colonial, sublevaram-se pelo menos 25 vezes no período, segundo as estimativas de Louis Necker (1979). Motivos para semelhantes ações não faltavam: - o abuso da mão de obra; - a preferência pelo trabalho feminino junto à sociedade dominante, chocando-se com o privilégio poligâmico, inúmeras vezes, defendido por chefes e xamãs; - o gado dos espanhóis que destruía as roças dos índios... (...) Enfim diante da agressão permanente a seus costumes, algumas lideranças indígenas recorreram à violência como forma de contestação das injustiças da conquista. (...) Os movimentos revoltosos dispunham de articulação política e discursos elaborados de estrutura profética, mobilizados por líderes carismáticos; através de cantos e danças e discursos deveras subversivos, incitavam os índios a rechaçarem e abandonarem o modo de vida imposto pelos Karaí (cristãos). (MONTEIRO: 1992:26-7).

A disputa de territórios entre as duas coroas portuguesa e espanhola se dá sobre território Guarani, questão que a análise histórica oficial não reconhece, porém, é fato. Toda a região do Itatin, do Guairá até Sete Povos, foi e ainda é ocupada pela população Guarani. Como se vê a própria história oficial, mesmo não tendo a intenção, comprova a ocupação Guarani nessas regiões.

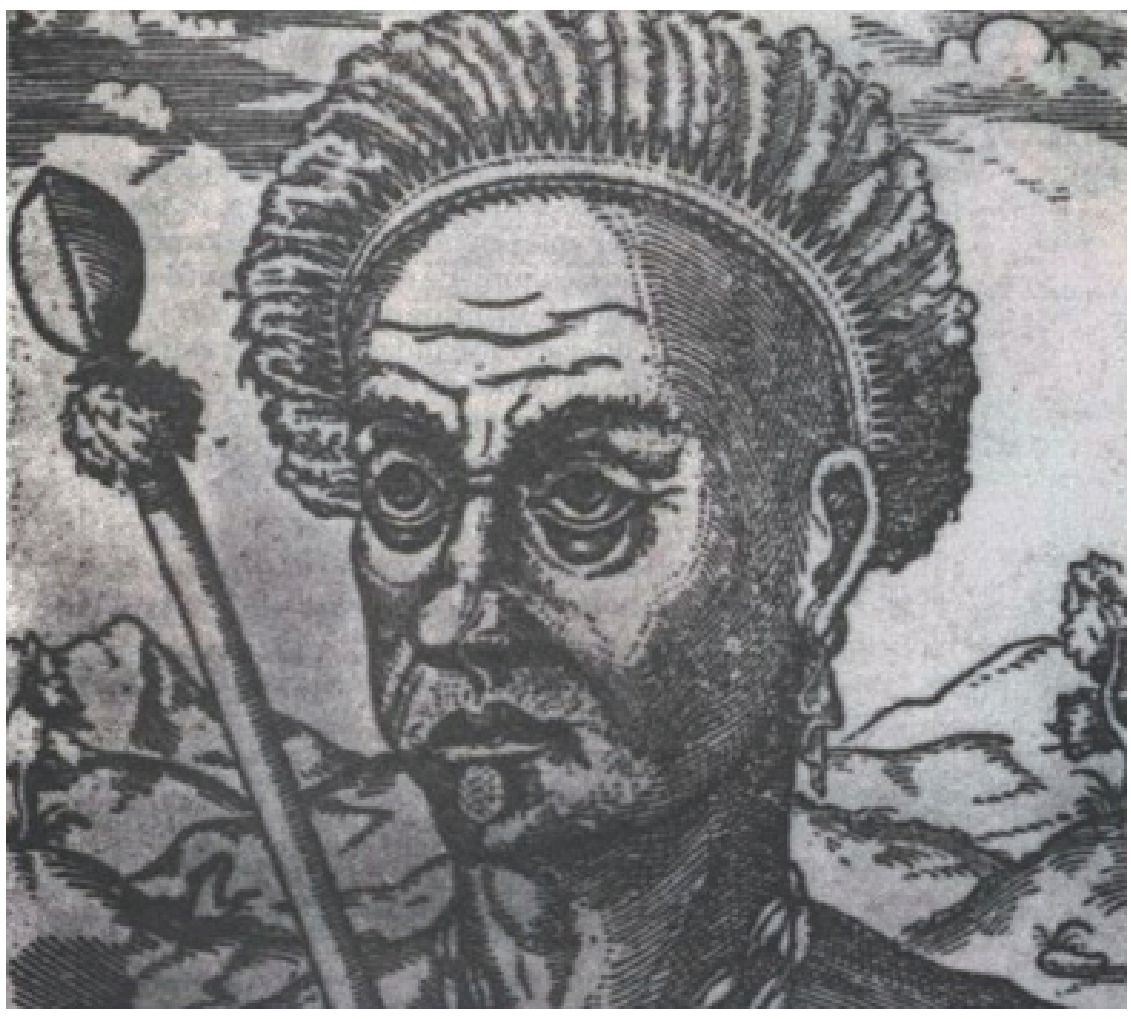

Figura 59. Imagem.

Cunhambebe, líder da Confederação dos Tamoios; simboliza a resistência indígena ao domínio europeu. Fonte: R. Dreguer e E. Toledo. História Cotidiano e Mentalidades. Vol. 3. Ed. Atual. 1995, p. 100. 
Quanto à população Guarani habitante das reduções jesuíticas do Guairá, foco de nossa pesquisa, após os ataques dos bandeirantes ocorridos no século XVII, dividiram-se em diversas situações: - muitos que viveram o processo de encomiendas e preação, foram mortos pelos encomenderos espanhóis e bandeirantes paulistas, seja pela guerra ou pelo contágio; os sobreviventes, escravizados, foram transferidos para São Paulo, Bahia e Pernambuco, para trabalhar na cana-de-açúcar; - outros Guarani, fugindo para o Paraguai, integraram-se à aldeias Guarani ali existentes ou ainda junto aos regionais, formando no futuro um país, em que a língua mais falada é o Guarani; - outra parte dirigiram-se a região do Tape no Rio Grande do Sul, acompanhando os missionários, juntando-se a outros grupos Guarani; por fim, outros grupos, compostos por partes das populações Guarani do Itatin e do Guairá, fugiram para as matas, juntando-se àqueles que já viviam de forma independente nas florestas, os quais anteriormente haviam se recusado à integrar as missões; estes últimos auto-denominavam-se "Cainguá” na língua Guarani significa "Gente da Floresta"; localizavam-se em floresta atlântica, as margens de rios do atual oeste paranaense, sudoeste matogrossense e leste paraguaio.

Helené Clastres refere-se à localização dos Cainguás: Os Cainguás (Gente da Floresta) denominação atribuída às tribos Guarani que não se submeteram às reduções jesuíticas nem aos colonos, viviam por volta de 1800, nas nascentes do rio Iguatemi, estendendo-se para o norte até a Cordilheira de São José, perto das nascentes do Ypané. (CLASTRES: 1978).

No entanto, o estudo histórico denominado “A Integração do Prata no Sistema Colonial: Colonialismo interno e Missões Jesuíticas do Guairá”, de autoria de Schallenberger ${ }^{14}$ (1997) apesar da excelência do mesmo quando se trata de retratar o processo histórico acontecido no passado, porém, quando finda seu livro, conclui, por meio da última frase, uma espécie de vaticínio sobre as populações Guarani habitantes do Guairá. Assim afirma: Contudo, em outra dimensão, mas não em menor sentido, a organização defensiva dos índios com as reduções e a projeção ofensiva das frentes colonialistas, contribuíram para um mesmo fim: a extinção do índio como cultura e como etnia, embora uma buscasse preservá-lo do consumo da outra. (SCHALLENBERGER: 1997:223)

Ao final desse processo histórico (século XVII) a que o autor se refere, ele indica claramente que as Comunidades Indígenas Guarani foram “extintas”, seja cultural ou fisicamente. Assim o historiador apesar de ser uma autoridade no assunto quando se trata do tema "passado", trabalha ao finalizar o estudo de modo não claro, referindo-se aos Guarani de modo equivocado, impri-

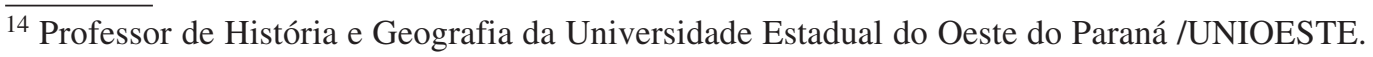


mindo ao leitor uma imagem de que os mesmos "foram" uma população existente no passado, assim como, se presentes hoje, seriam populações destituídas de suas características socioculturais.

Porém, como já vimos, após a destruição provocada na região pelo bandeirantismo, os Guarani-Cainguá refugiaram-se nas Matas. Como veremos a seguir, a partir desse período (século XVII) passaram a reconstruir mais uma vez suas aldeias, vindo novamente a habitar extensivamente a mesma região do Guairá até o século XX, aldeias nas quais mantiveram preservadas tanto a sua cultura como sua autodeterminação étnica. Ou seja, a informação de Schallenberger, não procede, e o que é grave, desinforma os leitores.

Inexplicavelmente o livro do historiador tem a marca símbolo da empresa Itaipu Binacional impressa na contracapa, o que se pode imaginar que o material foi encomendado e financiado pela citada empresa.

O autor em praticamente todo o seu livro, informa sobre o passado, tempo no qual só se pode refletir sobre o acontecido e não intervir diretamente. Ao mesmo tempo através dessa frase conclusiva, desinforma sobre o presente vivido pelos Guarani, na medida em que não os considera sequer existentes nos próximos séculos até o presente momento, como "cultura e etnia", negando assim, além da informação verdadeira, a possibilidade de intervenção na história; dessa forma portanto, confunde os estudantes da região paranaense da referida ciência, com uma imagem a respeito dos indígenas, inadequada, e o mais grave, irreal.

Ao contrário da informação do referido autor, verifica-se que a partir justamente dos grupos Cainguá-Guarani que mantiveram sua independência, ressurgiram no Brasil os três subgrupos Guarani que conhecemos na atualidade, a saber: Mbyá, Kaiowá e Ñandeva (Avá-Guarani); no Paraguai são denominados de Mbya, Aché Guayaki, Pai Tavyterá (corresponde aos Kaiowá) e Avá-Guarani ou Txiripá (corresponde aos Ñandeva). Os locais mencionados acima, representam o "berço histórico" dos Guarani contemporâneos.

A disputa de território entre as coroas portuguesa e espanhola dá-se a todo momento sobre território Guarani, questão que a análise histórica oficial não menciona diretamente, porém, como foi demonstrado, apesar de ser por meio da "historiografia da dominação", verificamos que é fato. Como vimos toda a região Guarani do Guairá a Sete Povos foi e ainda é, embora em menor proporção territorial, ocupada por esta população indígena. Sob a ótica dessa historiografia, os primeiros donos da terra são citados de forma pontual como meros coadjuvantes da história; porém, ela própria identifica os Guarani nestas regiões, provando dessa forma sua imemorial ocupação sobre o território em questão. Apesar da existência de legislação que reconhece os 
direitos indígenas às terras que ocupavam desde o período colonial, esta historiografia não entra no mérito deste direito em nenhum período da história.

Assim somente os intelectuais especializados, que são uma minoria, tem verdadeiro conhecimento sobre a presença Guarani no território na atualidade. Leigos, estudantes, professores não especializados, cidadãos comuns, apesar de alguns conviverem próximos aos Guarani, não possuem a dimensão da ocupação territorial dessa etnia. A mídia dominante realiza um trabalho de camuflar essa informação, por vários meios, por ex: através desse livro do historiador Schallenberger, através do Plano de Manejo do Parque Nacional do Iguaçu, através das varias atividades que a Itaipu divulga, envolvendo os indígenas, como veremos a frente.

\subsection{A existência de 32 aldeias identificadas presentes no século XX no Oeste do Paraná}

Os estudos apresentados neste subcapítulo foram inicialmente pesquisados por meio de "levantamentos etnográficos", a partir das informações colhidas junto à informantes Guarani, habitantes do Oco’y. Os informantes, apenas dois, o cacique e o pajé, deram conta de relatar a dimensão da ocupação por várias aldeias da etnia em pleno século XX, nessa parte do Tekoa Guassu, localizado no lado brasileiro, no oeste e sudoeste paranaense. A presença Guarani na banda paraguaia foi também pesquisada junto aos mesmos informantes, porém, em escala menor dada a dificuldade de acesso ao país vizinho. O procedimento realizado quanto a este último país, foi levantar de forma específica, as aldeias nas quais essas populações Guarani (PY) mantinham com esses Guarani do Oco’y no Brasil, as costumeiras relações de reciprocidade, assim quais aldeias eram visitadas pelos membros de Oco'y. Complementarmente foram pesquisadas também algumas informações arqueológicas, históricas e a localização geográfica o mais exata possível, à respeito da presença da etnia nessa região.

No final do século XIX, o oeste paranaense ainda era praticamente fechado à comunicação com o resto do continente brasileiro. A região possuía maior influência de população proveniente dos países vizinhos Argentina e Paraguai, os quais atuavam na extração do mate (ilex paraguaienses) e madeira, beneficiando-se do escoamento acessível pelo Rio Paraná, que juntando-se ao rio Paraguai, iria desaguar no rio da Prata, levando as mercadorias exportáveis ao porto de Buenos Aires.

A partir de 1880 a região passa a ser ocupada por projetos de colonização, através de concessão de terras pelo governo imperial do Brasil. Em 1889, antes da queda do governo 
imperial, este concede terras no extremo oeste paranaense à Estrada de Ferro São Paulo - Rio Grande, subsidiária da Brazilian Railways Company, com vistas à construção de ferrovia. No mesmo ano dá-se a fundação da Colônia Militar em Foz do Iguaçu, projetos os quais tentavam estabelecer o domínio brasileiro sobre o território. Jose Maria Brito, cronista da fundação da Colônia Militar, refere-se aos índios Kaiuá ou Kainguá (Guarani) encontrados pelas picadas de penetração na região.

É interessante detalhar neste ponto, alguns dados arqueológicos pesquisados na região de Foz do Iguaçu/Paraná. Limitaremos a reproduzir algumas partes do texto de Chmyz, existentes no Relatório Técnico sobre Arqueologia e a Etno-História da Área do Parque Nacional do Iguaçu ${ }^{15}$. Ele inicia informando sobre as primeiras pesquisas arqueológicas existente na região:

Os primeiros dados arqueológicos sobre a ocupação indígena do oeste do Paraná são devidas ao naturalista argentino Juan B. Ambrosetti. Nas duas últimas viagens que realizou pelo rio Paraná, entre os anos de 1892 e 1894, coletou e escavou artefatos indígenas antigos nas margens do Brasile $\underline{\text { Paraguai. Ao visitar as Cataratas do Iguaçu encontrou fragmentos de recipientes cerâmicos junto }}$ aos detritos vegetais acumulados na margem do rio, julgando-os transportados pela caudal a partir de terrenos erodidos no interior. (CHMYZ: 1999:28).

Em outro trabalho também de Chmyz, denominado Pesquisas arqueológicas na área brasi$\underline{\text { leira de Itaipu }}^{16}$, reafirma: Juan B. Ambrosetti, arqueólogo pioneiro na região, entre 1892 a 1894, assinalou os índios Kainguá em ambas as margens do rio Paraná, desde o rio Iguaçu até as proximidades do rio Bela Vista (CHMYZ: 1987:2) (Figura 60).

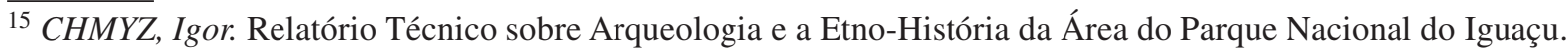
Curitiba: CEPA/UFPR, 1999, 81p.

${ }^{16}$ CHMYZ, Igor. Pesquisas arqueológicas na área brasileira de Itaipu. $2^{\circ}$ Seminário da Itaipu Binacional sobre Meio-Ambiente. Foz do Iguaçu: CEPA/UFPR, 1987. 4 p.
} 


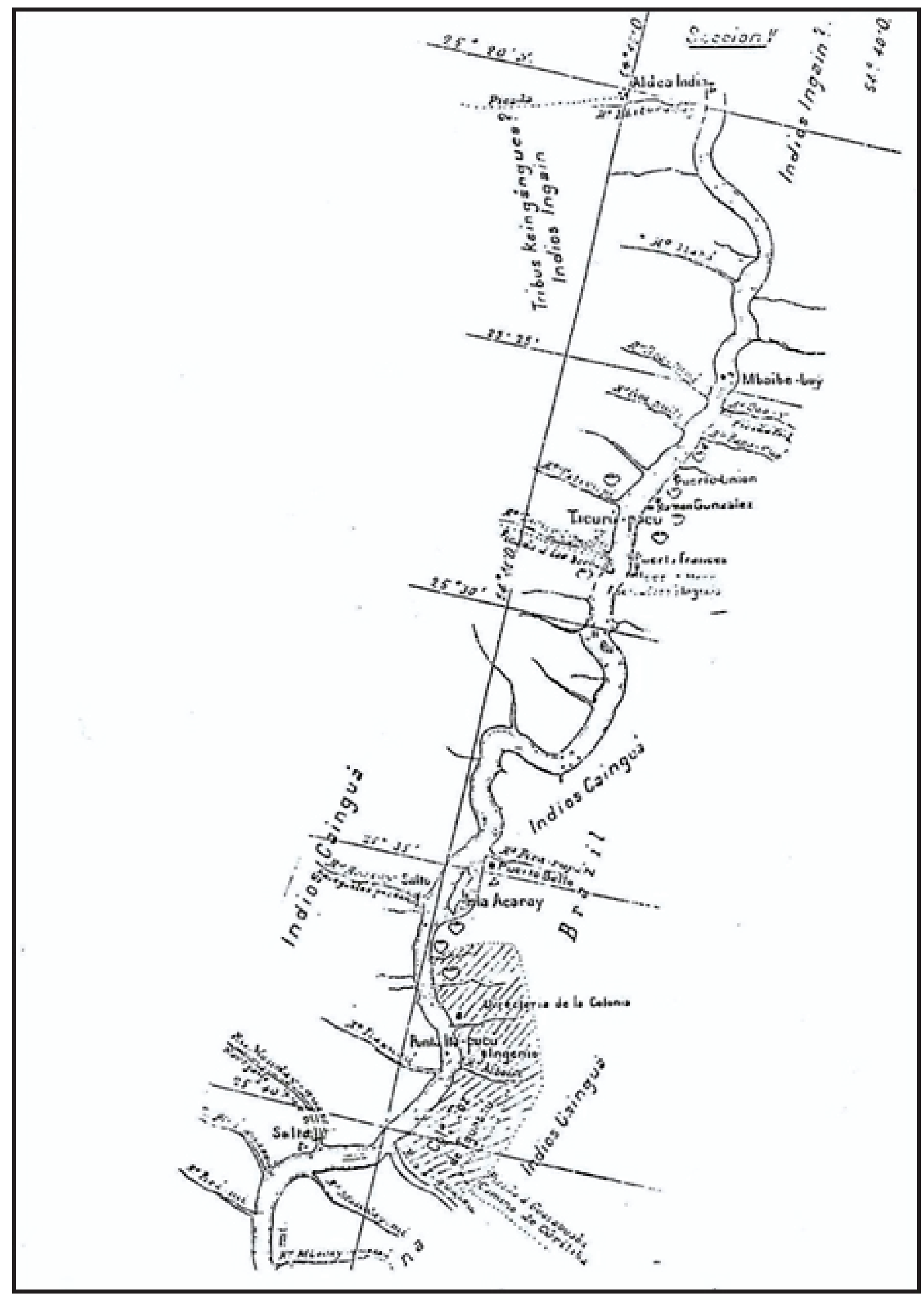

Figura 60. Mapa. Urnas assinalando os pontos de coleta arqueológica nas proximidades da Colônia Militar de Foz do Iguaçu, entre 1892 e 1894. (mapa extraído de Ambrosetti, 1895.)

Fonte: I. Chmyz. Relatório Técnico sobre Arqueologia e Etno-história da área do Parque Nacional do Iguaçu/ CEPA/UFPR, Curitiba: 1999, p. 29. 
Segundo Chymz, o trabalho de Ambrosetti mais profícuo foi nos espaços da recém instalada Colônia Militar de Foz do Iguaçu e dos portos situados mais ao norte, ao longo do rio Paraná.

\begin{abstract}
Nos trechos desmatados Ambrosetti registrou recipientes cerâmicos, principalmente grandes urnas, e artefatos de pedra como lâminas de machados e mãos de pilões. O achado de tembetás de resina no interior das urnas possibilitou comparações com os produzidos pelos índios Cainguá dos arredores. Estudados também pelo naturalista argentino, foi esclarecido que os Cainguá comunicavam-se através de uma língua que os relacionava a família Tupi-Guarani. (CHMYZ:1999:28).
\end{abstract}

Como já vimos anteriormente, os Cainguá (Gente da Floresta) são os próprios Guarani, aqueles que se refugiaram mata adentro, fugindo tanto inicialmente da ação jesuítica, como mais tarde outros de juntaram aos primeiros, fugindo da ação bandeirante. No mapa, nota-se além da pesquisa arqueológica de Ambrosetti, a presença dos índios Cainguá na época, em ambas as margens do rio Paraná, brasileira e paraguaia.

Sete décadas depois Chmyz inicia suas pesquisas na área. Apontou o vandalismo sobre as áreas de patrimônio arqueológico da região, no período em que ocorreu maior incremento populacional, a partir da década de 40, na medida em que avançava o desmatamento e a ocupação do solo. O autor relata:

(...) Quando o CEPA/UFPR realizou as prospecções no sítio PR FI 8: Cataratas do Iguaçu, em janeiro de $\underline{1969}$, os pesquisadores foram guiados por um paraguaio designado para esse fim, pela administração do Parque (PNI). O guia conhecia o local desde 1942 e havia presenciado a retirada, por outros visitantes, de várias urnas contendo restos ósseos humanos. Os buracos constatados na ocasião por toda a área corroboravam a informação. (CHMYZ:1999:30).

Os trabalhos de 1969, integrado ao Programa Nacional de Pesquisas Arqueológicas, foram originalmente estruturados para abranger um trecho do rio Paraná, ao norte da Cidade de Foz do Iguaçu. $\underline{A}$ incursão ao Parque foi ocasional e em função das notícias recolhidas sobre a existência de abundante material indígena nas proximidades das Cataratas. Pensava-se que o local poderia estar relacionado com a redução de Santa Maria, que teria sido fundada pelos jesuítas da década do século XVII nas cercanias. Descartada essa possibilidade, tendo em vista que as estruturas constatadas no sítio PR FI 8 referiam-se a um estabelecimento indígena não influenciado pelos europeus, os procedimentos adotados limitaram-se à obtenção de pequenas amostras de material para estudo comparativo (CHMYZ:1999:30-1).

As pesquisas então desenvolvidas na margem do rio Paraná, desde as imediações da ilha de Acaraí até o rio Bela Vista, embora dificultadas pela ainda densa vegetação ribeirinha, possibilitaram a 
descoberta de 18 sítios arqueológicos. Foram mais comuns os sítios cerâmicos e relacionados à tradição Tupiguarani. Mostrando tendências diferenciadas na tipologia e morfologia de sua cerâmica, esses sítios foram agrupados em fases denominadas Ibirajé e Sarandi. Esta, à qual está vinculado o sítio PR FI 8 estudado no Parque, revelou-se como a mais recente da tradição na área. (CHMYZ: 1999:31).

Por fim Chmyz descreve o resultado geral da pesquisa efetuada:

(...) Como resultado das pesquisas efetuadas na área de Foz do Iguaçu, foram definidas dez fases arqueológicas. As mais antigas, consideradas pré-ceramicas e vinculadas a grupos caçadores e coletores generalizados, receberam as denominações Vinitu, Pirajuí, Ipacaraí e Tatuí. As mais recentes, atribuídas a grupos que tinham em comum a produção de cerâmica e a horticultura, foram denominadas como fases Itacorá, Ibirajé, Sarandi, Icaraima, Cantu e Asssuna. Foram percebidos, ainda, indícios de outras ocupações que, por apresentarem traços diferentes, não puderam ser incluídas nas fases estabelecidas. (CHMYZ:1999:32).

Aqui nos interessa a fase cerâmica, onde são já identificadas as tradições, entre elas a Tupiguarani. Depois de longa descrição do tipo de cerâmica produzida, Chmyz afirma:

\section{Entre os grupos ceramistas, os mais numerosos foram os pertencentes à tradição arqueológica}

Tupiguarani. Os seus grupos foram agrupados nas fases Itacorá, Ibirajé e Sarandi. Esta divisão, que se baseou em vários traços diagnósticos, entre os quais a frequência de decorações cerâmicas, tem conotação cronológica, sendo a mais antiga a primeira. (CHMYZ:1999:36).

Os sítios dessas fases eram superficiais, tinham áreas que chegavam a $13.000 \mathrm{~m} 2$, e eram normalmente constituídos por concentrações de material espaçadas. As concentrações, frequentemente acentuadas por manchas de terra preta, correspondiam às bases das habitações e informavam sobre o padrão de implantação das aldeias. Conforme a fase, as concentrações dispunham-se em círculo, semi-círculo e alinhadas em forma de L e T. (CHMYZ: 1999:36).

As datações obtidas para as fases Itacorá, Ibirajé e Sarandi cobrem uma faixa temporal que vai de 1190 d.C. até 1695 d.C. (CHMYZ: 1999:37).

Em alguns sítios das fases Ibirajé e Sarandi foram encontradas peças originárias do contato inicial com os europeus a partir da primeira metade do século XVI. Quatro sítios mostraram inclusive alterações na sua cerâmica em consequência do contato. (CHMYZ: 1999:38).

A fase Cantu, não há datação absoluta para esta fase, mas a sua cerâmica ocorreu de forma intrusiva em sítios Tupiguarani, indicando a sua contemporaneidade. (CHMYZ: 1999:39). 
Chymz informa ainda que além das pesquisas acima resumidas, existem informações de outras desenvolvidas pelo Museu paranaense, ao lado do Parque, no município de Capanema, quando cinco urnas funerárias da tradição Tupiguarani foram expostas pela erosão da margem esquerda do rio Iguaçu. Assim ele relata: Apesar da depredação causada por moradores locais, uma das peças foi resgatada intacta pelos arqueólogos. Esta media cerca de $80 \mathrm{~cm}$ de altura e continha restos ósseos humanos e oferendas constituídas por recipientes, peças líticas e resíduos alimentares. (CHMYZ: 1999:41). Chmyz finaliza:

Os dados produzidos pelas abordagens arqueológicas desde o final do século passado no interior e nas proximidades do Parque comprovaram a intensa ocupação do espaço por grupos indígenas através de milênios. Permitiram, também, a avaliação das características culturais das estruturas dos diferentes estabelecimentos, corroborando o relato etno-histórico a partir do século XVI. (...) Diante desse quadro, a área do Parque Nacional do Iguaçu, por encerrar sítios em grande parte preservados, mostra-se muito importante também para estudos arqueológicos futuros. (CHMYZ: 1999:42).

Retomando novamente a historicidade, a densidade demográfica do Paraná da população não indígena na década de 30 era de 5 a 10 habitantes por km2 (Dreguer \& Toledo:1995:112). No ano de 1939 é instalado o primeiro Grande Projeto na região, o Parque Nacional do Iguaçu de responsabilidade do Instituto Brasileiro de Desenvolvimento Florestal/IBDF, hoje IBAMA, com área atualmente de 185.000 hectares.

Se no final do século XIX foi instalada a Colônia Militar em Foz do Iguaçu, a partir da década de 40 do século XX, é que o governo brasileiro começa a estabelecer realmente seu domínio geopolítico sobre o oeste paranaense, por meio da promoção pelo Estado do povoamento da região, camponeses são incentivados a ocupar a região. A importância geopolítica desta região para o governo federal se resumia a tentar neutralizar a força político-econômica argentina, de norte ao sul da região sul-americana, a qual monopolizava o comercio regional e internacional através do escoamento da maioria, senão todos, os produtos provenientes dos países da Bacia Platina para o porto de Buenos Aires, única saída para o Atlântico na região. Nas próximas décadas o Brasil irá reverter essa situação, redirecionando o escoamento em sentido oeste-leste para os portos de Santos e Paranaguá, através da criação de obras de infraestrutura na região como pontes e estradas que irão se ligar ao litoral atlântico brasileiro, como veremos a frente, no capitulo 7 . 
O Paraná na década de 40 passa a ser ocupado ao norte, pela influência paulista, pelos plantio de café. O sul e sudoeste são ocupados por gaúchos e imigrantes de várias nacionalidades (alemães, italianos, poloneses e ucranianos), os quais extraem a erva-mate. Os Guarani aparecem em alguns momentos da história, como apenas “coadjuvantes”, citados no já referido Atlas Histórico do Paraná (1986), como plantadores de erva-mate.

A presença Guarani é novamente confirmada na primeira metade do século XX na região do Tekoa Guassu, através do Mapa Etno-Histórico confeccionado pelo etnógrafo alemão Curt “Nimuendajú" Unkel em 1944. Neste período "Nimuendaju” (presenteado com nome Guarani, vindo a adotá-lo oficialmente), percorreu grande parte da América do Sul, identificando as populações indígenas nas regiões em que habitavam. Os Guarani foram apontados inclusive na região que compreende o foco de nossos estudos, na Tríplice Fronteira (Figura 61). A Figura 62, confirma mais uma vez, a "mancha” da tradicional ocupação Guarani na região.

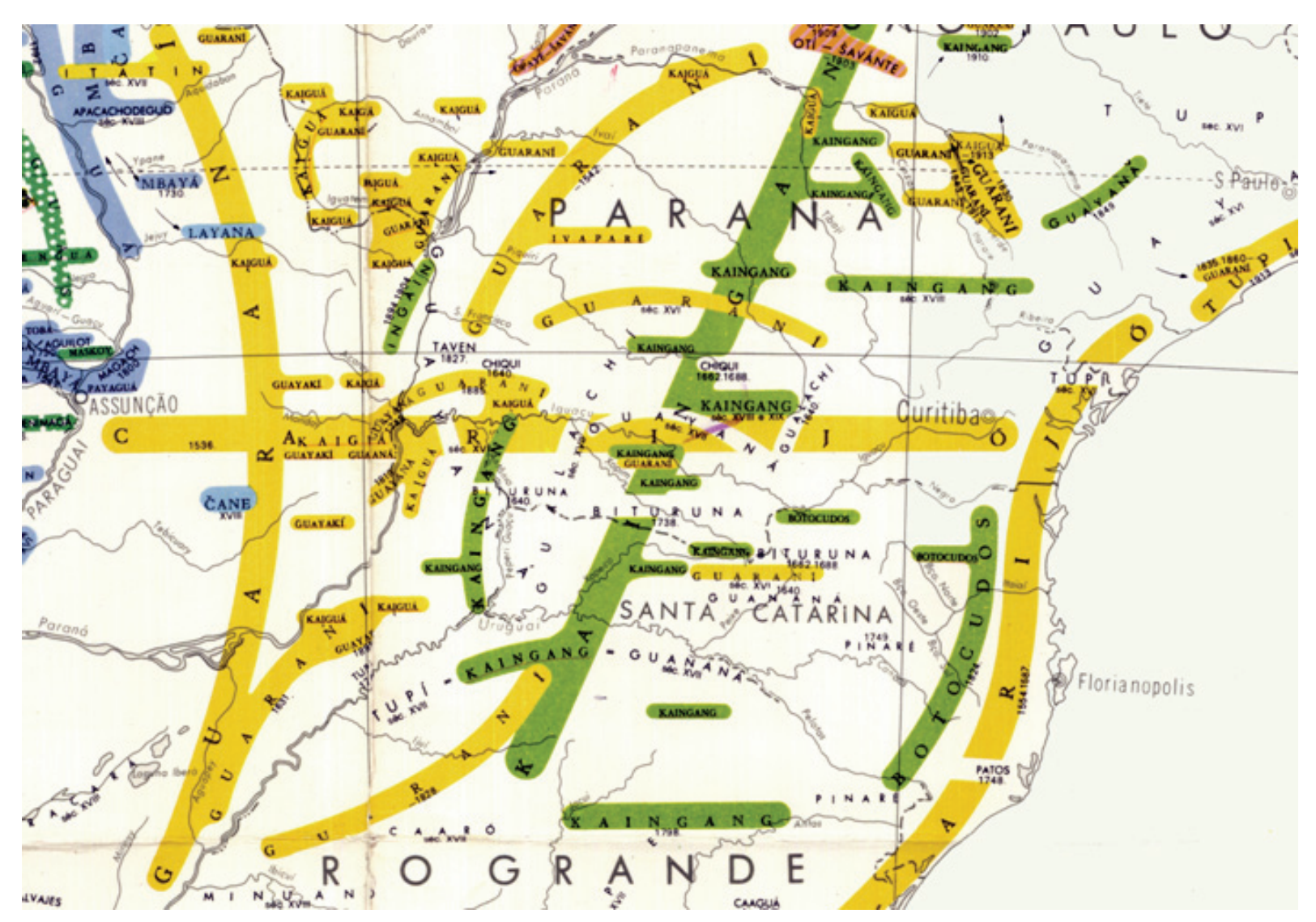

CD-Figura 61. Mapa. Mapa etno-histórico do Brasil apontando a presença tradicional Guarani inclusive na região de interesse desta pesquisa, Oeste do Paraná. 1944. (Região do Tekoa Guassu).

Fonte: IBGE. Mapa etno-histórico do Brasil e regiões adjacentes adaptado do Mapa de Curt Nimuendaju Unkel, 1944. Secretaria do Planejamento e Coordenação da Presidência da República, IBGE. 


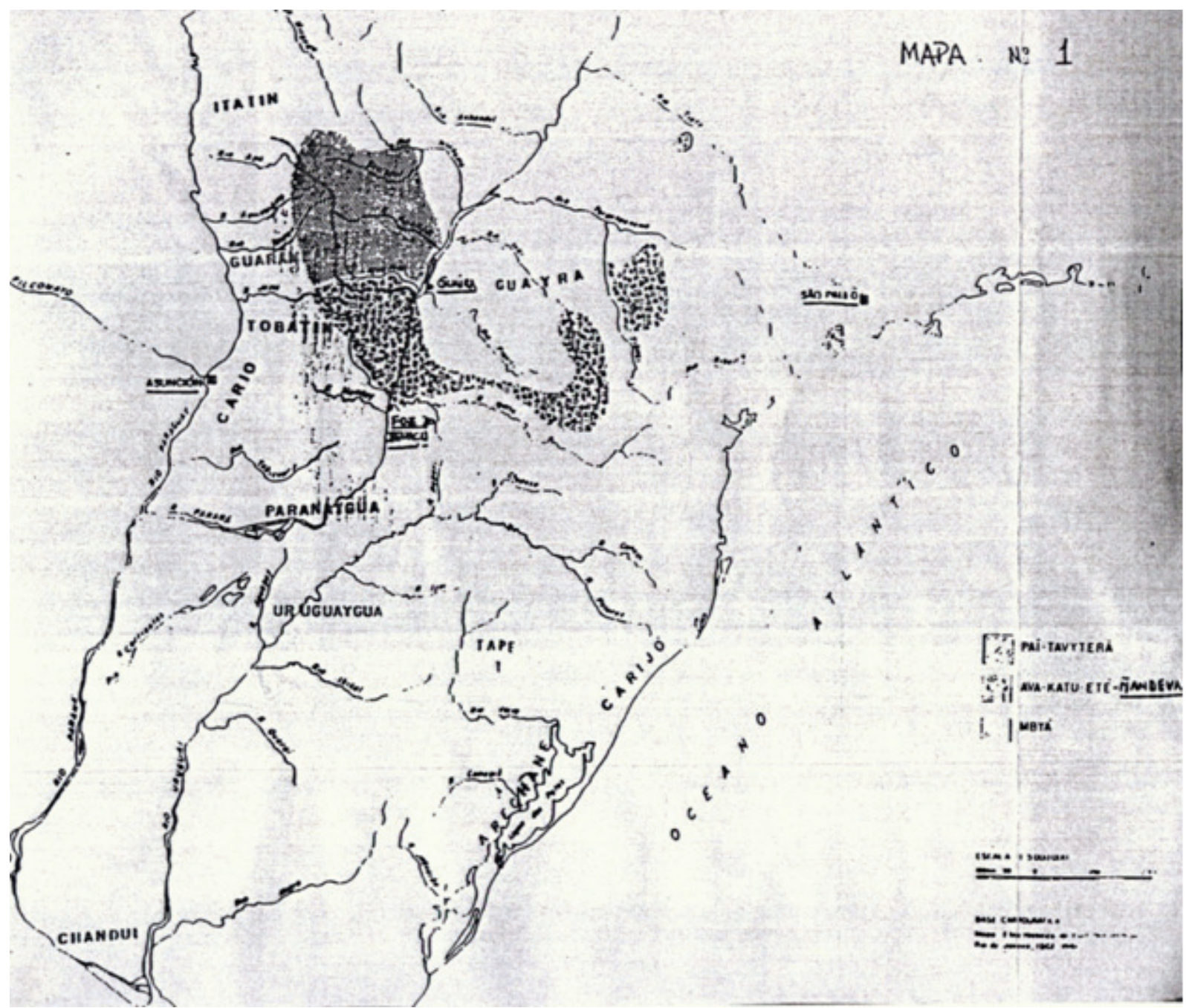

Figura 62 $\mathbf{2}^{17}$. Mapa. Ocupação territorial Ñandeva (Txiripá), Mbya e Kaiowá (Paí-Tavyterã) na região de confluência entre as três fronteiras, Brasil, Paraguai e Argentina.

Fonte Secundária: R.T. Almeida. Laudo Antropológico sobre a comunidade Guarani-Ñandeva do Oco’y-JacutingaPr. Rio de Janeiro. 1995.

Os Avá-Guarani mais idosos da atual Terra Indígena do Oco’y, afirmam que desde os anos 40 passaram a sentir a pressão da entrada de imigrantes nas terras do oeste paranaense. Que algumas vezes neste período o INCRA, já havia tentado retirá-los da região. Um idoso Guarani, Seu Honório, habitante do Oco’y, a esse respeito afirma:

Já em 1948 o INCRA, querendo nossa terra, escreveu carta para o SPI (antigo Serviço de Proteção ao Índio) e eles levaram todo o povo da aldeia Colônia-Guarani (área ocupada atualmente por colonos que foram obrigados a sair do Parque Nacional do Iguaçu em Foz do Iguaçu) $e$ de Toledo

\footnotetext{
${ }^{17}$ Infelizmente neste mapa a mancha Guarani Mbyá está apagada, impossível de visualizar. A mancha Guarani Ñandeva, também autodenominados Ava Katu Ete são os vários pontos e a mancha Guarani Kaiowa também denominados Pai Tavy Tera é a mancha uniforme. Os Avá-Guarani de Oco’y são Guarani Ñandeva, também denominado de Txiripá.
} 
para a aldeia do Rio das Cobras (Município de Nova Laranjeiras e Espigão Alto do Iguaçu). Alguns não querendo ir, fugiram para o Paraguai. Eles davam tiro na perna de quem fugia! Muitos voltaram ...

O avanço dos projetos de colonização continuaram ao longo dos governos republicanos até a década de 60 do século XX da seguinte forma (Figuras 63. Mapas A, B, C, D e E).

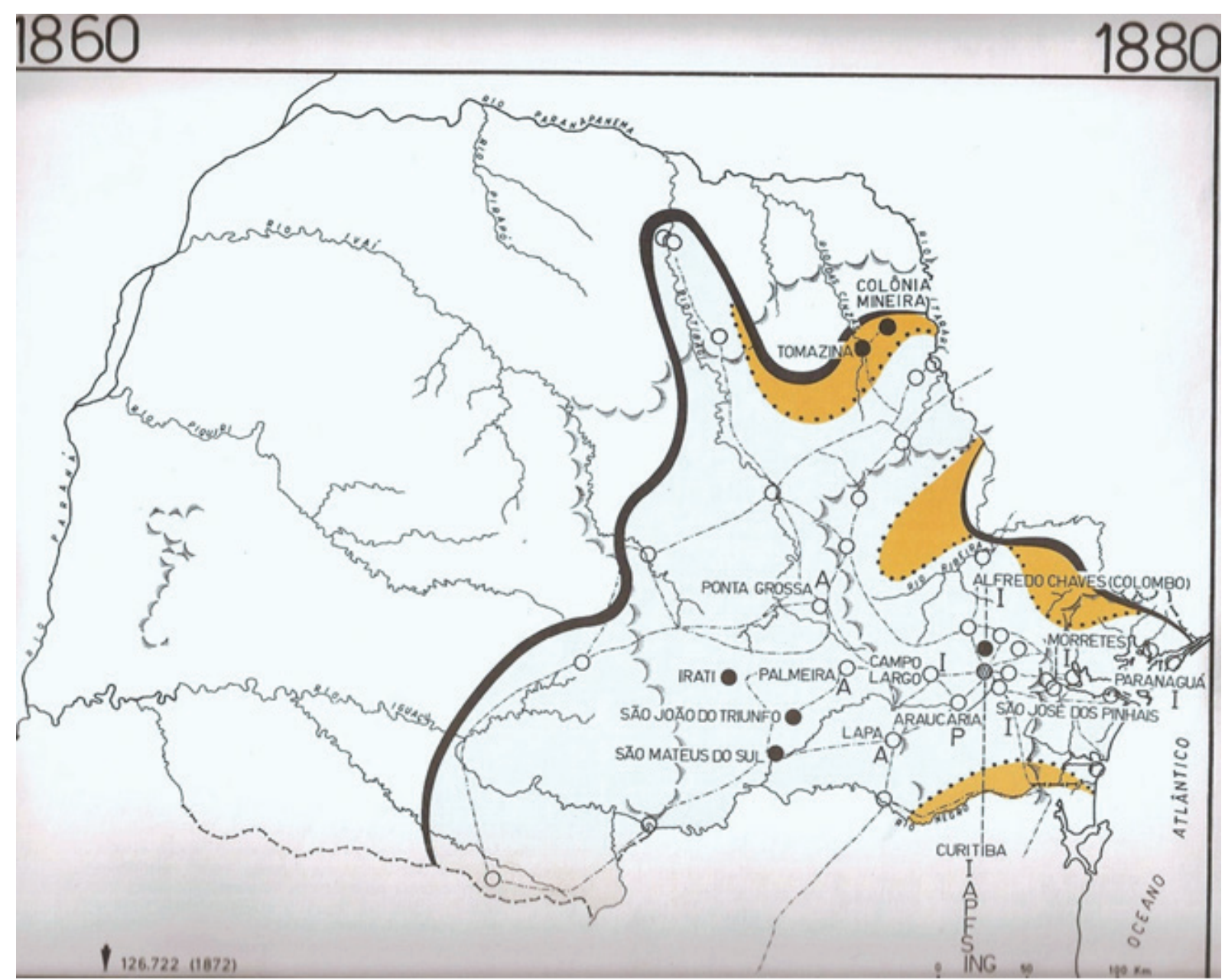

\section{Legendas

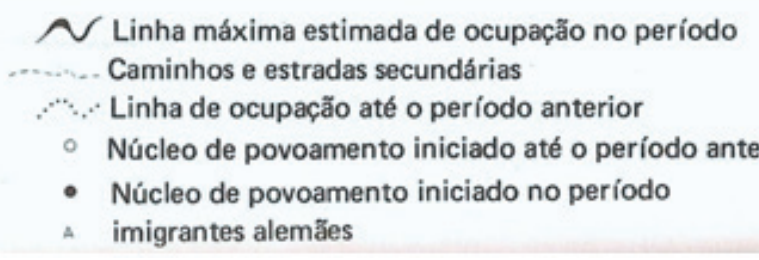 \\ (1) imigrantes italianos \\ p imigrantes poloneses \\ F .imigrantes franceses \\ $s$ imigrantes suiços \\ No imigrantes ingleses \\ A imigrantes alemães}

Figura 63. Mapa A. Chegada da colonização no oeste paranaense do período de 1860 a 1880, incidindo sobre as terras de ocupação tradicional Guarani.

Fonte: Cardoso, J.A. e Westphalen, C.M. Atlas Histórico do Paraná. 2a ed. amp., Chain Editora, 1986, p. 58-59. 


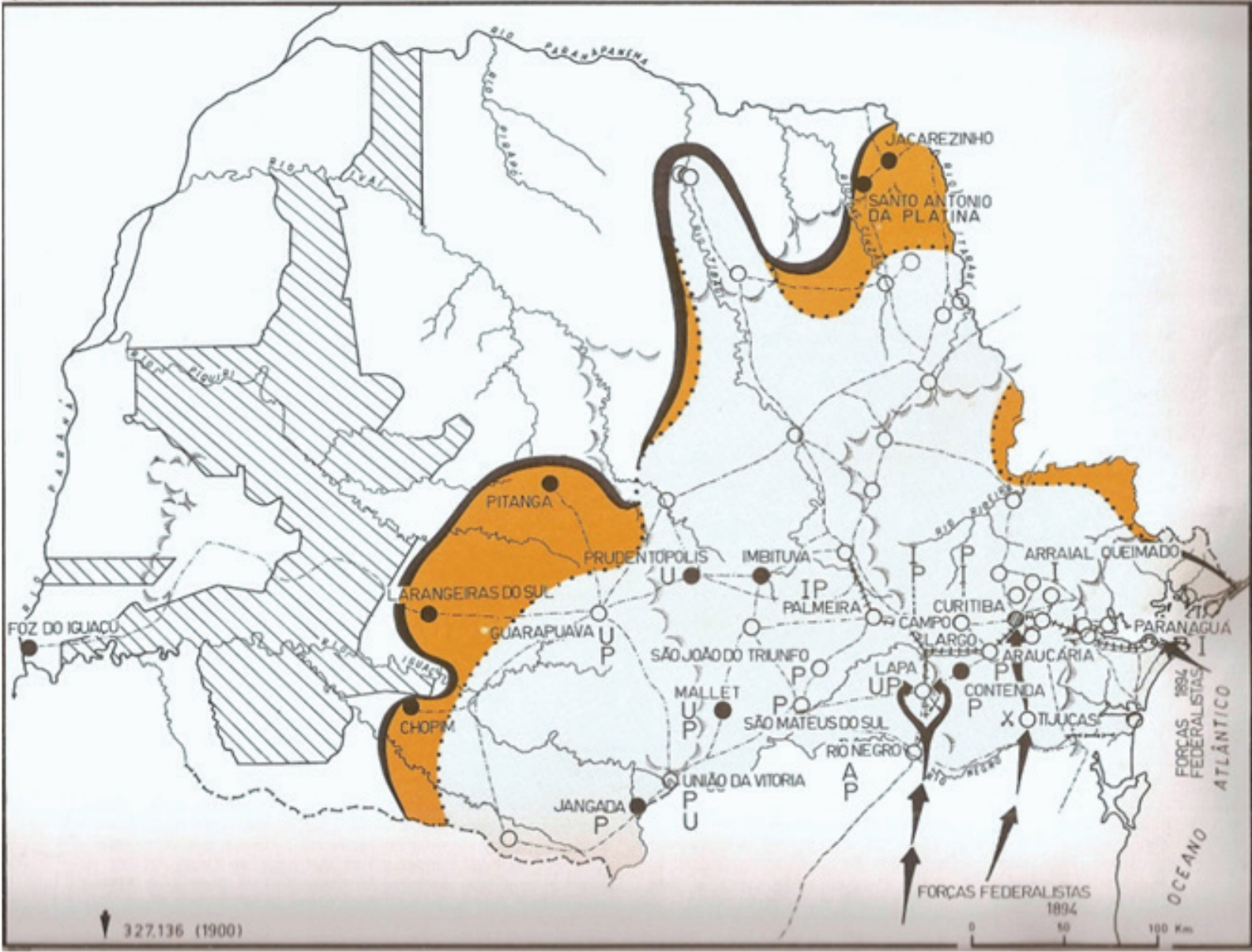

\section{Legendas}

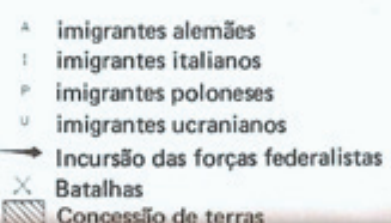

-nstrada de ferro

$\sim$ Linha máxima estimada de ocupaçăo no período - Caminhos e estradas secundárias " Linha de ocupaçăo até o período anterior

- Núcleo de povoamento iniciado até o período anterior

- Núcleo de povoamento iniciado no período

Figura 63. Mapa B. Chegada da colonização no oeste paranaense do período de 1880 a 1900, incidindo sobre as terras de ocupação tradicional Guarani.

Fonte: Cardoso, J.A. e Westphalen, C.M. Atlas Histórico do Paraná. 2ª ed. amp., Chain Editora, 1986, p.60-61.

A denominada Tríplice Fronteira entre o Brasil, o Paraguai e a Argentina mediada pelo rio Paraná é a região foco de nossa pesquisa, onde os Guarani do Oco’y que ali habitam, se referem a ela, como tendo sido ocupada extensivamente nas três margens, por várias aldeias Guarani, até recentemente, ou seja, ela se constituí como parte do grande território do Tekoa Guassu.

Em pesquisa etnográfica de campo, consultamos um idoso Guarani, o pajé, que viveu toda sua vida na região do extremo oeste paranaense, onde teve a oportunidade de percorrer aldeias entre o noroeste e o meio-oeste do estado; consultamos também o cacique, homem de seus 45 anos, que também tendo vivido toda a sua vida na região do extremo oeste, percorreu-a, conhecendo grande parte da região do meio-oeste ao sudoeste do Paraná. 


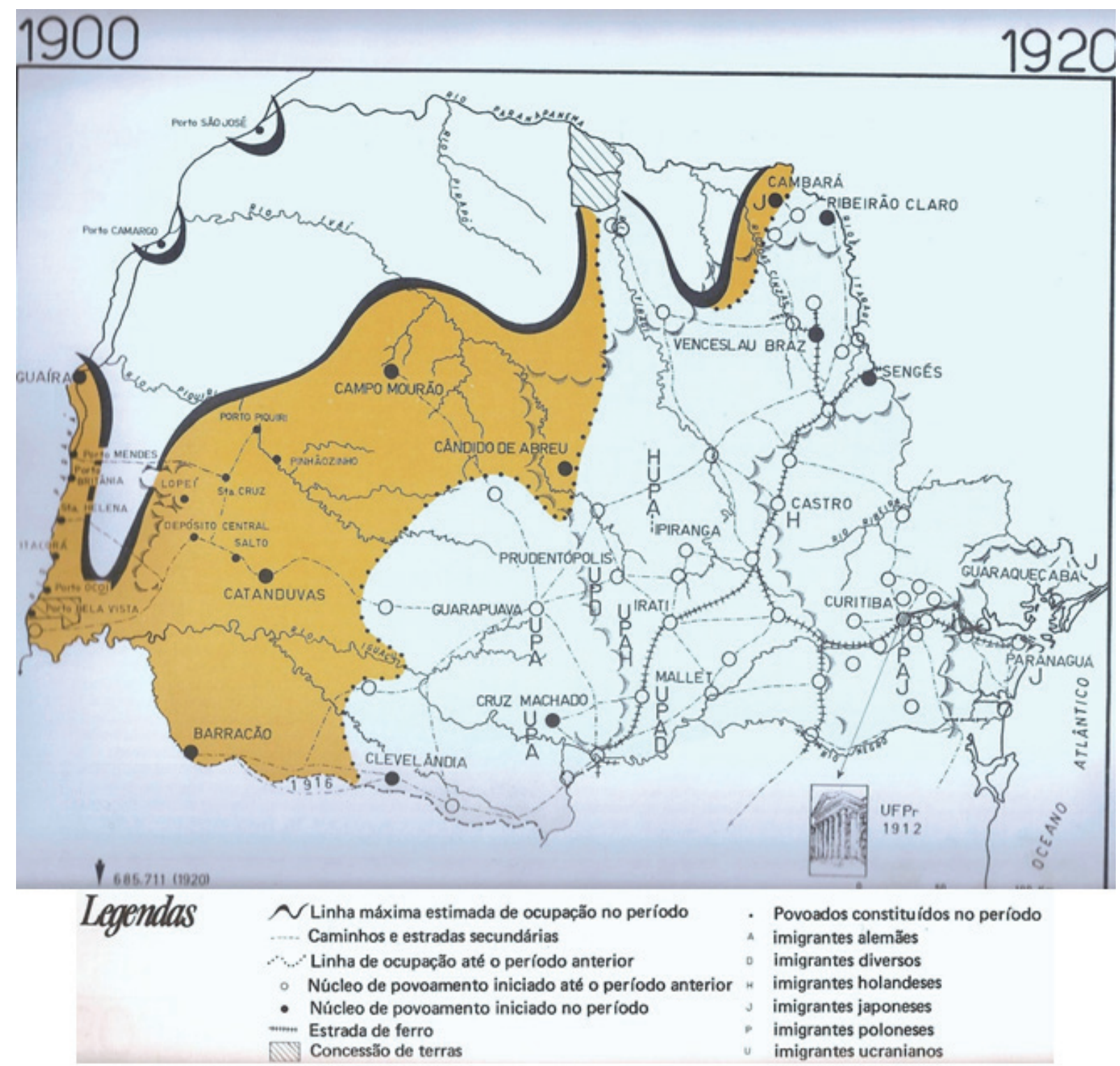

Figuras 63. Mapa C. Chegada da colonização no oeste paranaense do período de 1900 a 1920, incidindo sobre as terras de ocupação tradicional Guarani.

Fonte: Cardoso, J.A. e Westphalen, C.M. Atlas Histórico do Paraná. 2a ed. amp., Chain Editora, 1986, p. 62-63.

Perguntei-lhes quantos "tekoas" (aldeias) eles haviam conhecido e/ou vivido nestas duas regiões do oeste do Paraná, de norte ao sul, limitando inicialmente a pesquisa a somente a porção brasileira. A conversa durou toda uma tarde. A pesquisa etnográfica realizada por meio da história oral, contada por apenas esses dois informantes Guarani, levantou 32 aldeias existentes nesta região brasileira do oeste do estado do Paraná, na língua guarani 32 Tekoas, os quais os informantes tiveram a oportunidade de visitar, conviver ou mesmo morar.

Contaram com detalhes alguns momentos, encontros familiares, as visitas a parentes - por meio de casamentos entre seus habitantes que propiciaram a união de vários de seus familiares; a troca de produtos, a participação em cerimônias, às mudanças de residência, as reuniões de 


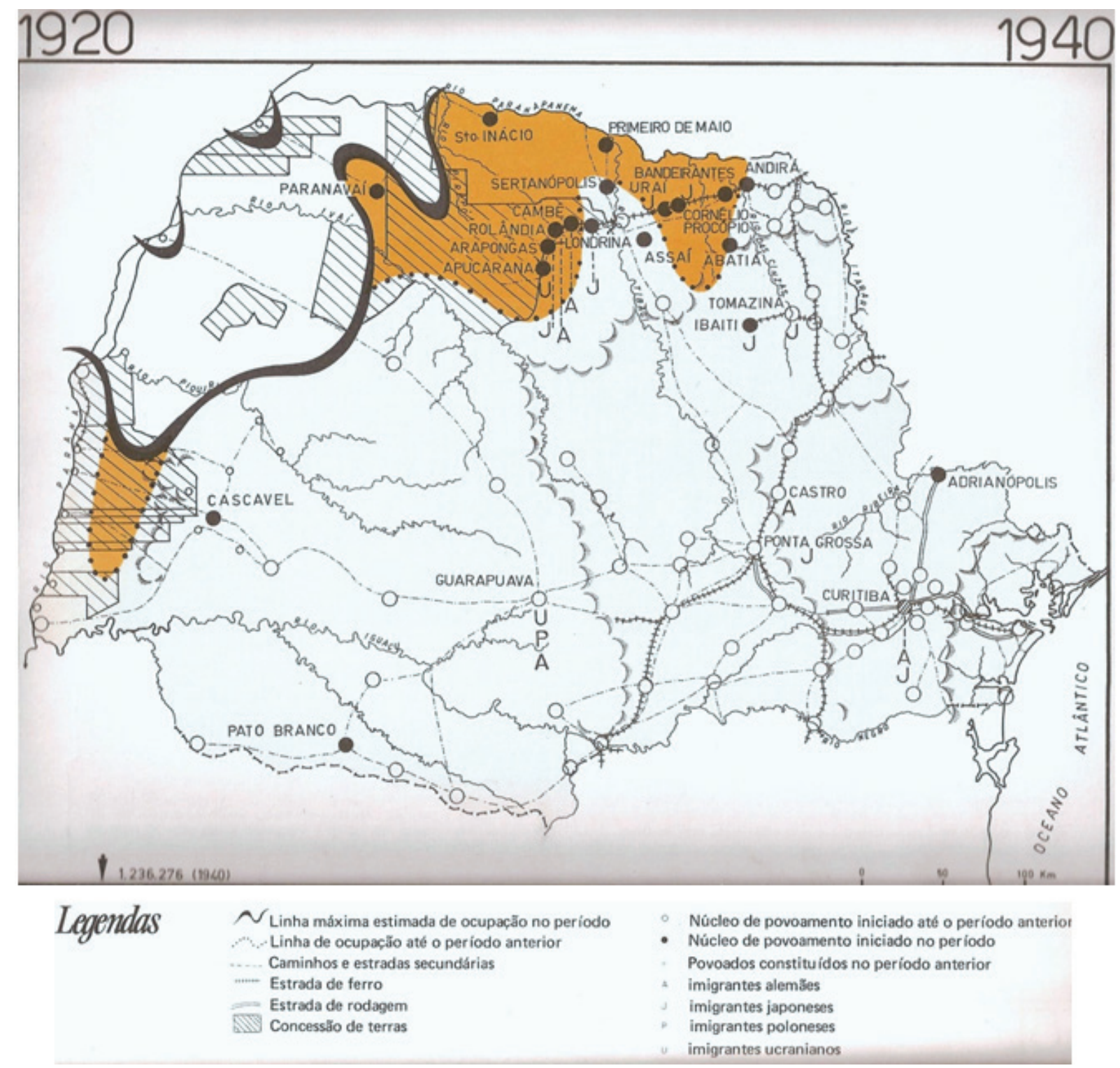

Figura 63. Mapa D. Chegada da colonização no oeste paranaense do período de 1920a 1940, incidindo sobre as terras de ocupação tradicional Guarani.

Fonte: Cardoso, J.A. e Westphalen, C.M. Atlas Histórico do Paraná. 2a ed. amp., Chain Editora, 1986, p. 64-65.

líderes, e com pesar, contaram como essas aldeias desapareceram, por conta da invasão de terceiros, muitas vezes matando sua gente, obrigando a população Guarani a fugir, a andar..., a juntarse aos parentes em outras aldeias mais escondidas e protegidas, a reconstruir suas necessidades de subsistência noutros territórios, novamente serem invadidos, a fugir, a andar... .

Por certo haviam mais aldeias nessa parte do Tekoa Guassu, sendo as 32 aldeias referidas, localidades estas, com as quais estes dois informantes efetivamente conviveram, mantendo suas tradicionais relações de reciprocidade.

Assim esta pesquisa, focou com maior precisão as aldeias pertencentes ao Tekoa Guassu localizadas na banda brasileira, banhadas pelos grandes rios, Paraná e seus afluentes, do Piquiri 


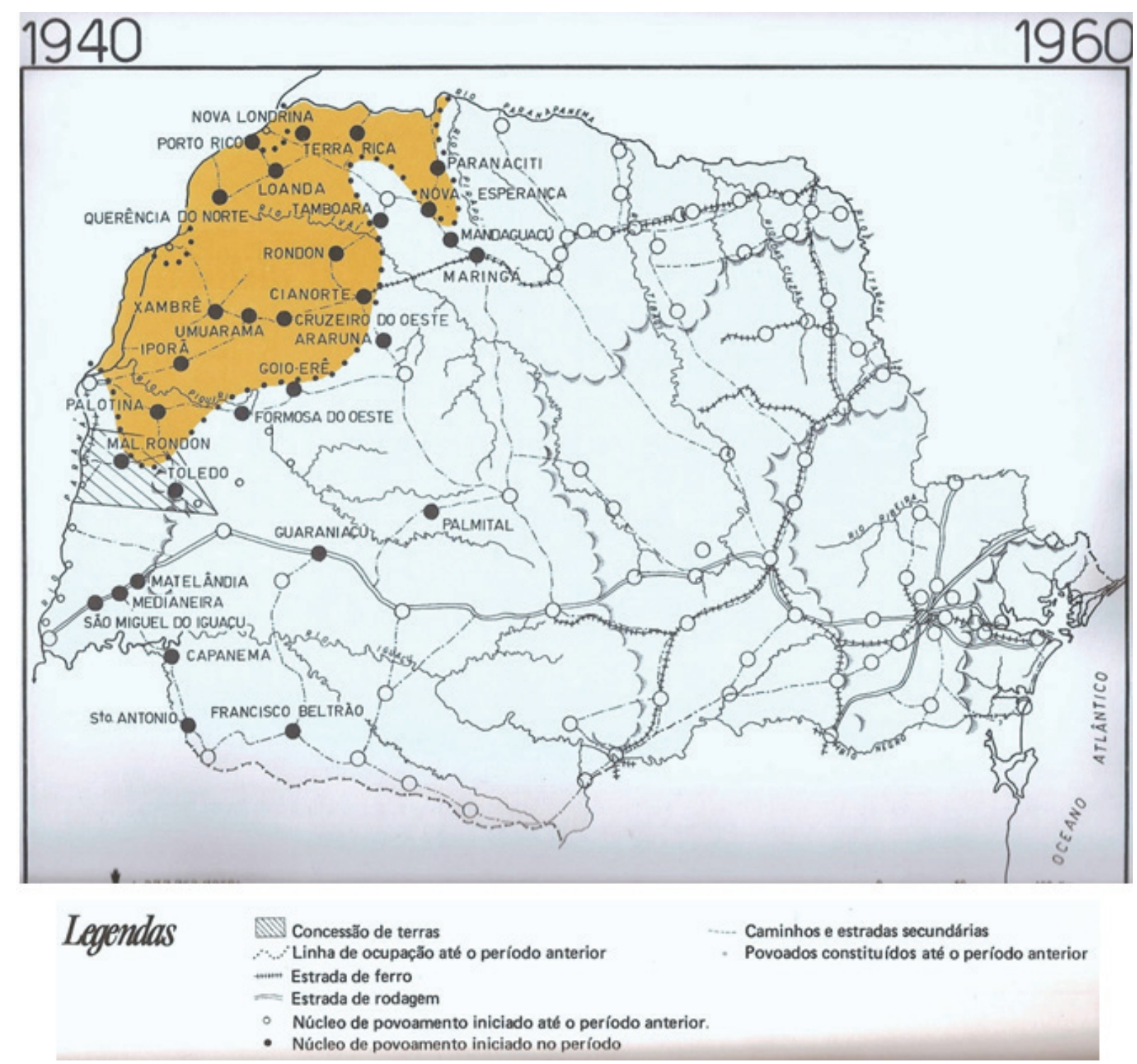

Figura 63. Mapa E. Chegada da colonização no oeste paranaense no período de 1940 a 1960 , incidindo sobre terras de ocupação tradicional Guarani, porém, ficando livre Oco’y-Jacutinga e aldeias próximas.

Fonte: Cardoso, J.A. e Westphalen, C.M. Atlas Histórico do Paraná. 2a ed. amp., Chain Editora, 1986, p. 66-67.

para o sul, ou seja, as aldeias também localizadas nos rios Ivaí, Guaçu, São Francisco, Ocoí e Iguaçu, e em seus tributários menores, todos no extremo oeste paranaense. Estas regiões constituíam-se nos principais locais de perambulação das parentelas Guarani do atual Oco’y na banda brasileira.

Porém, as aldeias não se limitam às fronteiras territoriais, estaduais ou federais da nação brasileira. Atingem também outros países, regiões que se configuram como de tradicional ocupação Guarani até a atualidade. Assim existiam/existem aldeias Guarani ao sul, ao norte e a leste deste território no Brasil, assim como em direção ao oeste, onde alcança a nação paraguaia, como também há aldeias em direção ao sudoeste, na Argentina. O que estaremos descrevendo 
aqui, primeiramente refere-se às aldeias mais conhecidas, visitadas e ocupadas no lado brasileiro pela população Guarani, que vive atualmente na Terra Indígena do Oco’y.

Quanto as aldeias ocupadas no Paraguai serão descritas também, porém, consideramos que para um melhor levantamento etnográfico, seria necessário nos dirigir a região, o que não se mostrou possível atravessar a fronteira. Assim foram descritos apenas as aldeias que existiam no Paraguai, os quais as famílias de Oco’y mantinham/mantêm laços mais estreitos de reciprocidade, segundo a visão dos próprios Guarani do Oco’y, os dois informantes.

São elas as 32 aldeias, descritos à frente em detalhe sua localização, ano da invasão, número aproximado de famílias existentes quando da invasão e por quem as invadiu em cada aldeia:

- Aldeias Campina, Britador, Lope’y, Yvy-u ou Barro Preto, Paraje, Jabuticaba (todas os seis localizadas no município de Toledo);

- Memória e Paková (as duas em Corbélia);

- M’Boi-Picuá (Cascavél);

- Rio Branco e Quatro Pontes (as duas em Marechal Rondon);

- Yvyrá-petei ou Iguaçuzinho (Campo Mourão);

- Rio Tapera (Laranjeira do Sul);

- São João Velho, Guarani, Colônia-Guarani, M'Boicy e Sanga-Funda (as cinco em Foz do Iguaçu);

- Camba'i (Porto Britânia/Porto Mendes);

- Rio Guavirá, Passo-Kuê, Takuá-Pindaí, Mborevy, Ipiranga, Mocoitadji ou Dois Ipês e Arroyo Leon (as sete em Santa Teresinha);

\section{- Oco’y-Jacutinga (antigo município de Criciúma hoje São Teresinha de Itaipu);}

- Vitorace (Tres Lagoas);

- Tati-Jupi (Céu Azul);

- Três Irmãs e Santa Rosa (as duas em Santa Helena);

- Yvá-Karetã ou Mato Queimado (Espigão Alto).

As 32 aldeias ocuparam no Brasil as mesorregiões 105, 101 e 107, localizadas na "Figura 45. Mapa. Estado do Paraná. Mesorregiões Geográficas”, (Ipardes: 2005), primeira figura deste capitulo. Treze (13) delas tinham como região central as terras localizadas no entorno da cidade de Foz do Iguaçu.

Os habitantes dessas 32 aldeias possuíam interligações de parentesco e consideravam-se ocupando um mesmo território, praticamente contínuo. Com as informações fornecidas pelos Avá-Guarani, produzimos junto à Diretoria de Assuntos Fundiários/DAF/FUNAI um mapa, que 
didaticamente pretende representar este contexto fundiário, tendo como base territorial, apenas as terras do oeste do estado do Paraná no Brasil (Figura 64). Esta área media, segundo cálculos efetuados pela DAF, aproximadamente 132.000 hectares (DAF/FUNAI: 2002).

O mapa a seguir apresentado demonstra três situações: o levantamento etnográfico realizado por nós, das 32 (trinta e duas) aldeias Avá-Guarani que foram extintas e ocupadas por terceiros; - a situação fundiária indígena geral, atualmente no estado do Paraná; na legenda há indicativos da situação fundiária atual da subfamília Avá-Guarani no Paraná, todos levantamentos realizados em 2002.

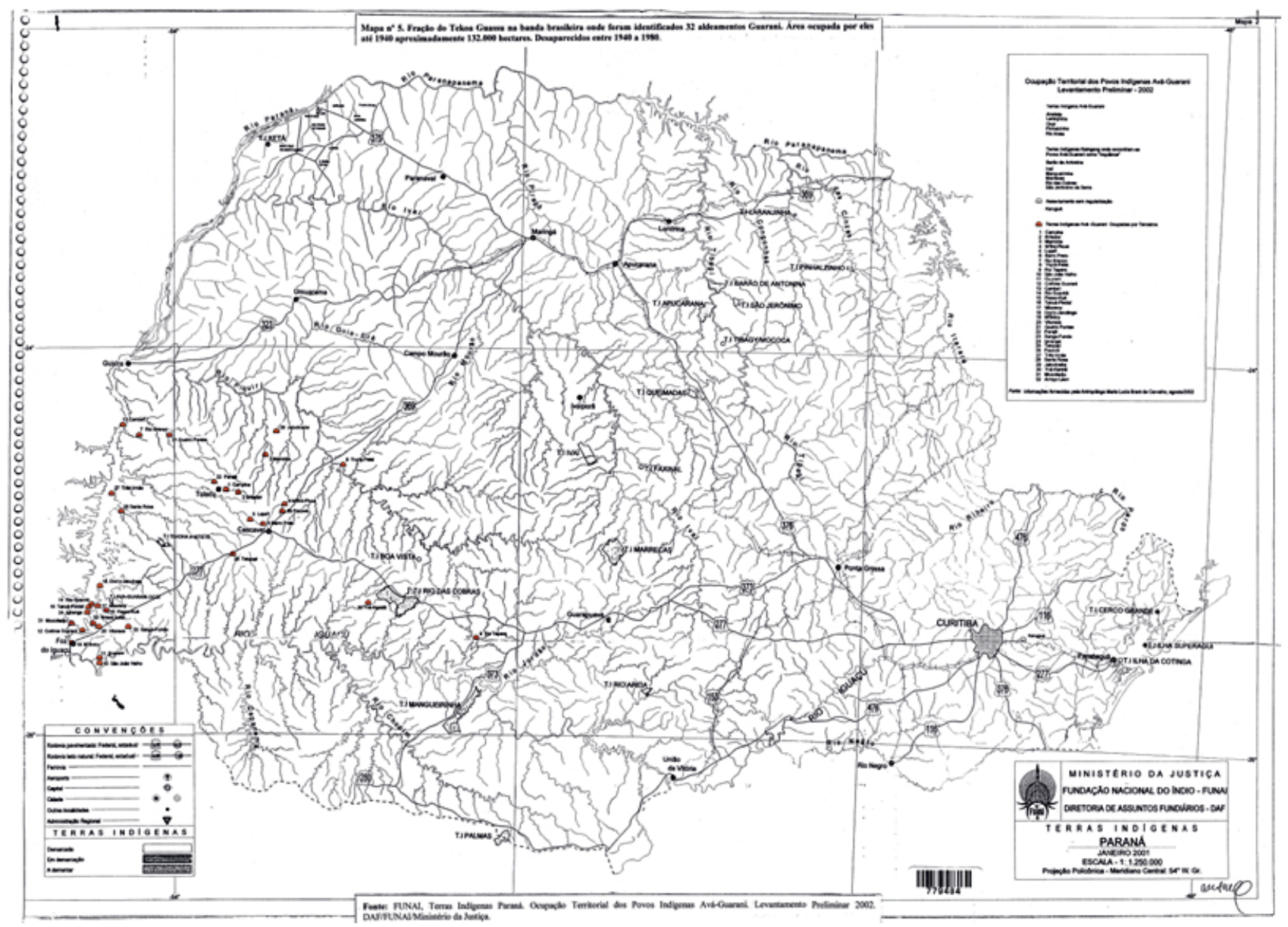

CD-Figura 64A. Mapa. Identificação de 32 aldeias Guarani desaparecidas no oeste paranaense (em vermelho) a partir de 1940 até 1982, em fração do Tekoa Guassu, território na banda brasileira. Situação fundiária indígena geral, atualmente no estado do Paraná (2002); Indicativos da situação fundiária atual da subfamília Avá-Guarani no Paraná (2002). Mapa original somente em CD-Figura 64B.

Fonte: FUNAI, Terras Indígenas Paraná. Ocupação Territorial dos Povos Indígenas Avá-Guarani. Levantamento Preliminar 2002. Antropóloga responsável Maria Lucia Brant de Carvalho. DAF/FUNAI/Ministério da Justiça. 
Portanto, o que se pode perceber a partir desses novos levantamentos etnográficos, é que após a invasão e destruição pelos bandeirantes do Guairá (como também do Itatin) no século XVII, os Guarani-Cainguá pertencentes aquelas Reduções se dispersaram pela região, refugiando-se nas Matas, e, assim que consideraram ser possível, voltaram a reocupar as terras antes tradicionalmente habitadas. Espalharam-se novamente pelo território de forma maciça, reconstruindo durante os três séculos seguintes um novo conjunto de aldeias na região do oeste paranaense (como também no sul matogrossense, onde habitam atualmente os Guarani-Kaiowá). Durante os últimos dois séculos até a década de 40 do século XX passaram, ao que tudo indica, por um período histórico de relativa paz, já que quase não há referencias nesse período de ocupação maciça "branca" na região, pelo menos proveniente do Brasil, fato que propiciou a retomada territorial. Dessa forma é notória a persistência desses grupos Guarani de fixarem-se em terras imemorial e tradicionalmente ocupadas, nesta banda brasileira do território. A existência dessas aldeias em pleno século XX põe por terra a informação de Schallenberger anteriormente citada, a qual supunha erroneamente que os Guarani teriam desaparecido como "cultura e etnia" no século XVII, demonstrando dessa forma, total inconsistência histórica.

Segundo os mesmos dois informantes, a partir de 1940, se inicia de forma acelerada novos e sucessivos processos de esbulho de suas terras, que culminaram na perda de todas as 32 aldeias que compunham essa fração territorial do Tekoa Guassu, existente no oeste paranaense. Esse processo perdurou até o ano de 1982.

Segundo descrição dos informantes indígenas, a população indígena foi sendo novamente esbulhada de seu território de ocupação imemorial, sendo obrigada a migrar para outros aldeias, localizadas tanto no Brasil como no Paraguai e Argentina. A região foi sendo paulatinamente tomada pelos "brancos", população composta inicialmente por colonos imigrantes, através da formação de pequenas propriedades, vilarejos e cidades, épocas em que concomitantemente instalaram-se na região os dois Grandes Projetos de Estado, o Parque Nacional do Iguaçu (1939) e a Usina Hidrelétrica de Itaipu (1971-1982 ${ }^{18}$ ). Como pode-se observar, os fatos deram-se em passado recente, ao contrário do que é afirmado pelos representantes da "historiografia da dominação", em que insistem em afirmar que supostamente os Guarani desapareceram no século XVII.

Após tomarem o poder de Estado na década de 60, os militares brasileiros iniciaram a política denominada de "O Milagre Brasileiro". O lema nacional destes governos resumia-se

\footnotetext{
$\overline{18}$ Em 1971 ocorre o acordo de construção da hidrelétrica entre Brasil e Paraguai, denominado "Tratado de Itaipu”. Em 1982 ocorre a inundação formando o reservatório.
} 
ao slogan "Exportar é o que Importa". Objetivaram substituir as importações, criando indústrias de grande porte no país. No Paraná, ocorre a espoliação dos camponeses e indígenas, a apropriação privada da terra por meio de grilagem, os primeiros vão sendo substituídos pela grande propriedade, concentradora de terras e de renda, mecanização da agricultura, produção de monoculturas, fundamentalmente a de soja, visando à exportação de produtos, para inicialmente criar divisas em dólares, para pagar a divida externa contraída no processo de desenvolvimento. Assim nesse contexto de crescimento econômico contraíram a dívida externa brasileira, uma das maiores do mundo. Em 1971 é assinado o “Tratado de Itaipu” objetivando a construção da hidrelétrica que viria gerar a energia para impulsionar a industrialização crescente. Assim nesse período dá-se início ao segundo Grande Projeto Estatal da região. Todas estas questões serão exploradas no capitulo 7.

Nessa medida ocorreu a conjunção de dois fatores no oeste do Paraná, que culminaram na transfiguração do território indígena, surgindo uma nova configuração geopolítica sobre ele. Somadas as terras que foram evacuadas para a instalação dos dois Grandes Projetos federais na região, cerca de 320.000 hectares e a vinda de 40.000 trabalhadores e suas famílias, no início dos anos 70 para a construção da hidrelétrica, ocorreu dessa forma, uma inversão: houve um considerável aumento populacional na região, e, ao mesmo tempo, grande diminuição das terras disponíveis à ocupação, provocando assim uma crescente movimentação populacional e, portanto, crescente também disputa sobre as terras.

Na escala social os Guarani foram, conforme indica Carvalho (1981), os primeiros a serem esbulhados de suas terras, em parte delas são instalados os próprios Grandes Projetos, assim como em outras frações de suas terras são utilizadas para a instalação de outras populações não indígenas, que foram remanejadas das próprias áreas evacuadas.

Estas áreas foram sendo tomadas gradativamente, o que ocasionava a dispersão de cada agrupamento indígena em direção a outras aldeias, tanto no Brasil como no Paraguai, num movimento circular sobre o território e de crescente diminuição do numero de aldeias; até que foram por fim, grande parte dos indígenas, definitivamente expulsos do Brasil. É o caso, como veremos adiante, de todas as aldeias anteriormente habitadas pela maioria da população da atual Terra Indígena Avá-Guarani do Oco’y, grande parte da população dessas anteriores aldeias encontramse hoje no Paraguai, os que resistiram, concentraram-se no Oco’y/Brasil.

Inúmeras famílias de pequenos posseiros e proprietários, respectivamente perdem ou são obrigados a vender suas terras, tornando-se boias-frias ou meeiros. Muitos deles após vender as 
terras no Brasil buscam terras mais baratas no Paraguai, dando surgimento a uma grave questão social, na qual passam a ser conhecidos como "brasiguaios". Da mesma forma muitos Guarani do Brasil, fogem para aldeias existentes nesse país vizinho. Assim em nome do "desenvolvimento nacional", houve uma migração forçada de indígenas e agricultores do Brasil para o Paraguai.

Em seguida de forma textual, apresentamos as 32 terras indígenas invadidas e tomadas do lado brasileiro no estado do Paraná, sua localização, município, referências regionais, o número de famílias aproximadas existentes quando da expulsão, ano aproximado da expulsão e por quem passou a ser ocupada em cada aldeia. Observar a concentração de aldeias desaparecidas na região de Foz do Iguaçu. Atenção a aldeia desaparecida nº 18 (Oco'y-Jacutinga), território indígena ocupado anteriormente a inundação da Itaipu, pelos Guarani do atual Oco’y.

Quanto as aldeias antigamente ocupadas do lado paraguaio, o critério utilizado foi indagar aos próprios Guarani do Oco'y, quais populações e de quais aldeias, que mais se relacionavam e/ ou relacionam com os grupos familiares do Oco'y, que estavam localizados próximos a região sudoeste do Paraná/Brasil.

Esta descrição justifica-se, pois, estas regiões, margem esquerda e direita do rio Paraná, pertencentes aos dois países, são de circulação tradicional da população Guarani do Oco’y.

Foi obtido por meio do relato dos Guarani do Oco’y, informações sobre 7 (sete) aldeias do lado paraguaio que desapareceram neste mesmo período. A maior parte delas se encontravam no Departamento de Alto Paraná/Paraguai, exatamente na mesma direção das aldeias encontradas no lado brasileiro. Obteve-se informações sobre estas aldeias, sua localização, departamento e número de famílias, porém em termos de mapeamento, foi possível colher apenas o mapa das parcialidades indígenas existentes no Paraguai, os quais em termos étnicos encaixam-se exatamente em área de perambulação correspondente à subfamília Avá-Guarani da banda brasileira. 


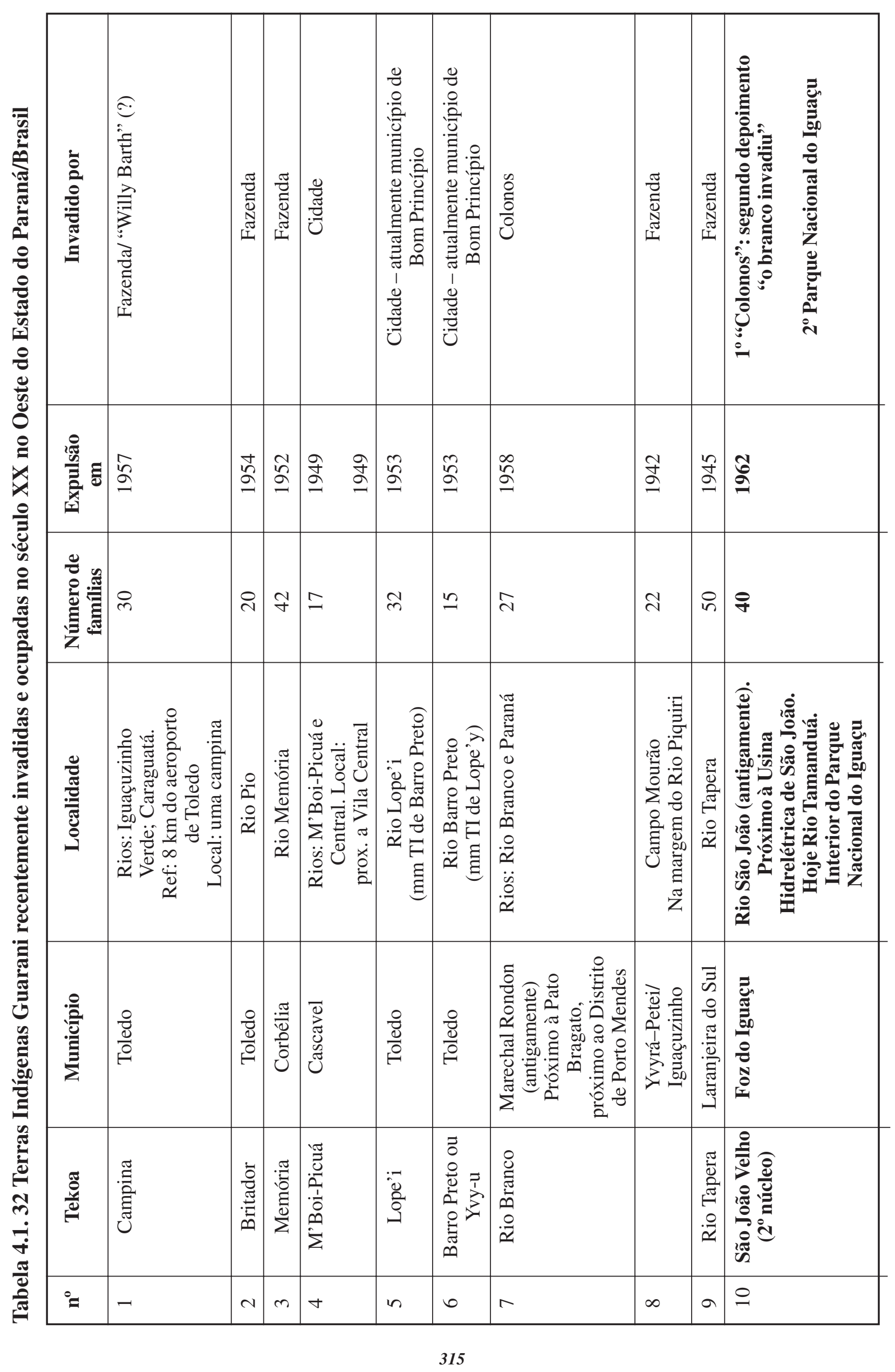




\begin{tabular}{|c|c|c|c|c|c|c|c|}
\hline 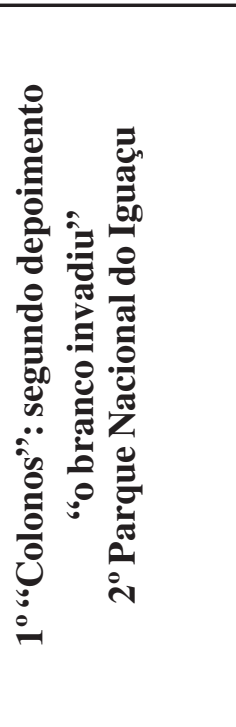 & 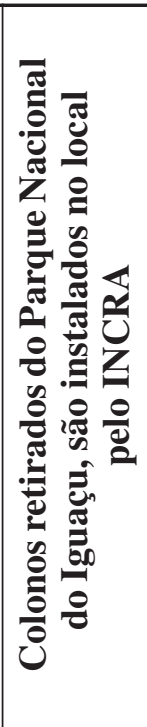 & 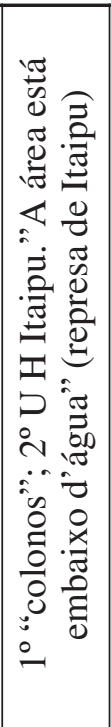 & 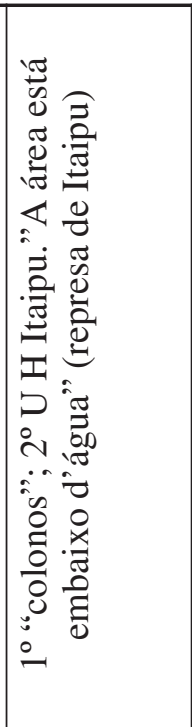 & 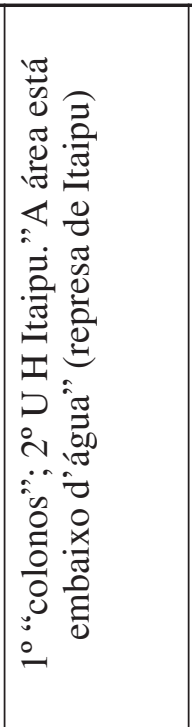 & 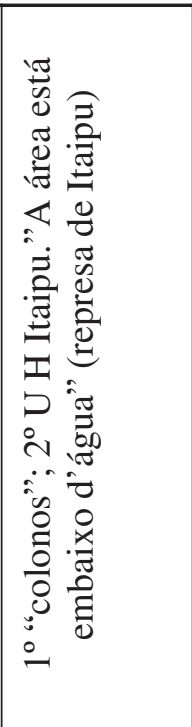 & 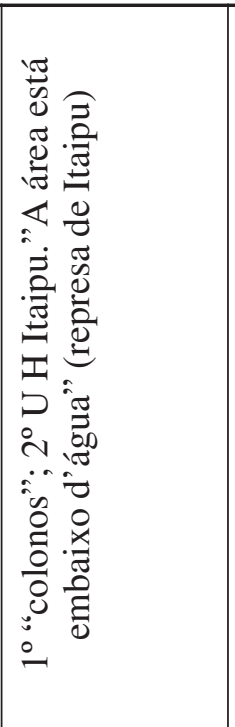 & 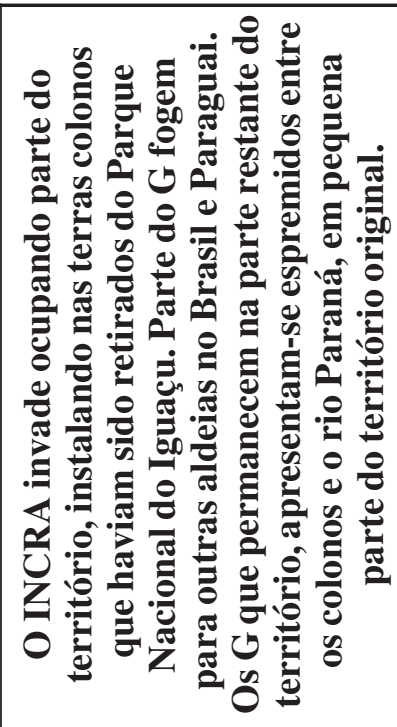 \\
\hline$\stackrel{7}{\Xi}$ & 点 & $\frac{\Delta}{\sigma}$ & $\stackrel{\stackrel{一}{2}}{2}$ & 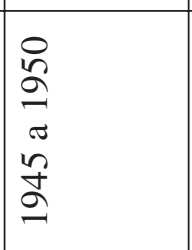 & $\stackrel{\circ}{2}$ & $\stackrel{\wp}{2}$ & 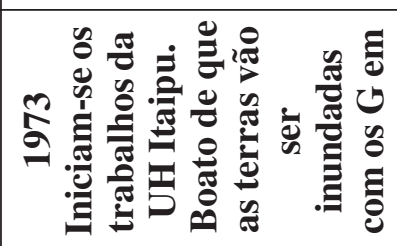 \\
\hline in & in & \pm & ㄱ. & $\stackrel{\infty}{=}$ & $\simeq$ & $\simeq$ & 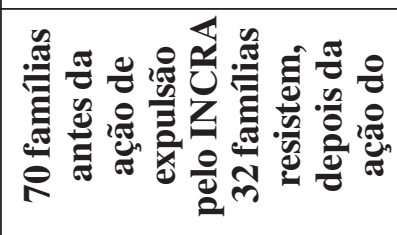 \\
\hline 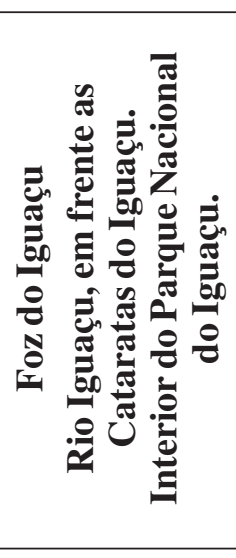 & 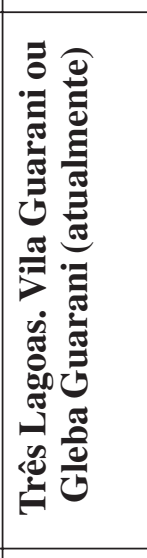 & 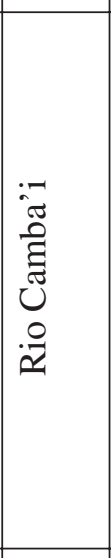 & 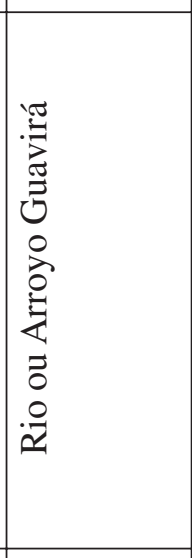 & 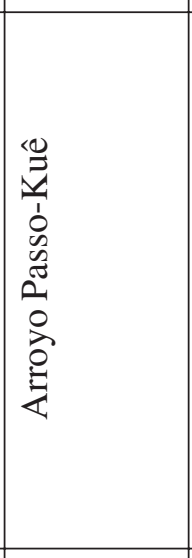 & 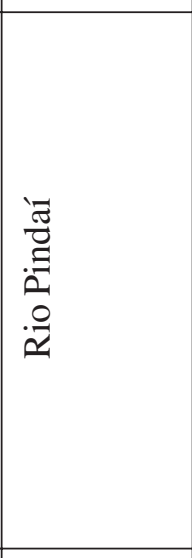 & 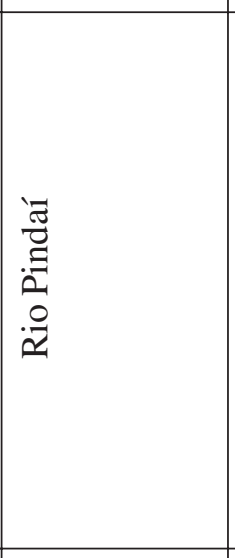 & 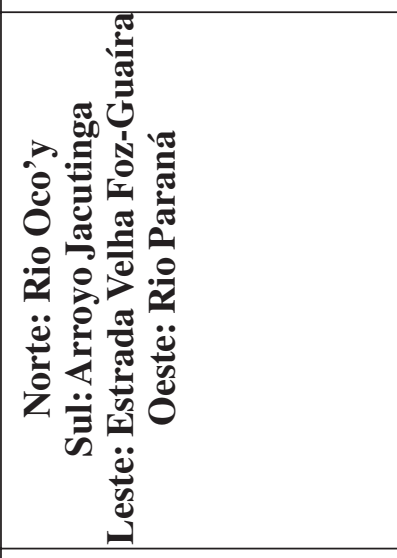 \\
\hline \multirow[t]{2}{*}{ 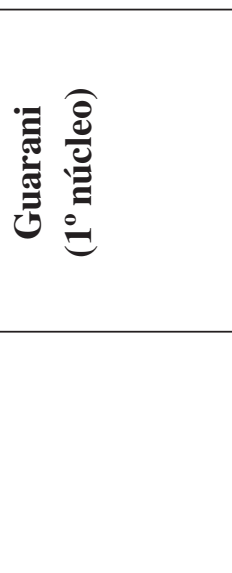 } & 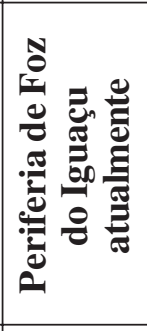 & 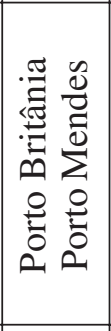 & 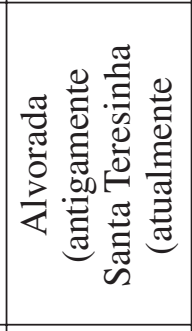 & 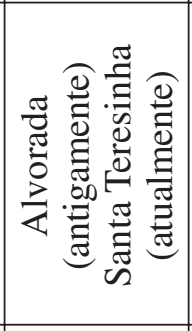 & 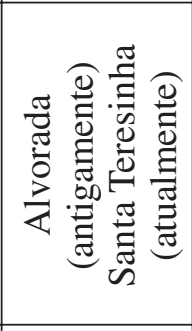 & 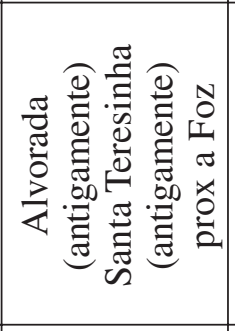 & 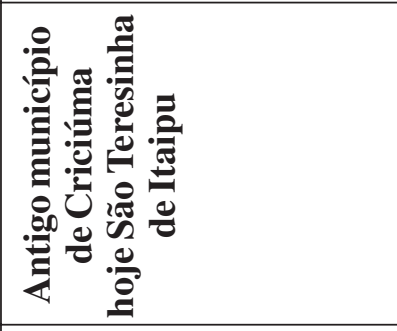 \\
\hline & 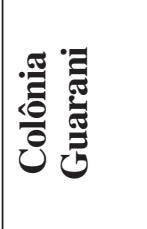 & $\begin{array}{l}:= \\
\tilde{ే} \\
\text { है } \\
\text { Uี }\end{array}$ & 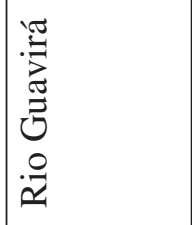 & 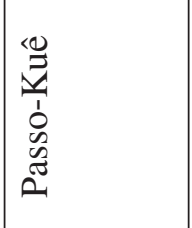 & 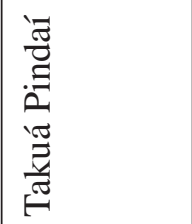 & 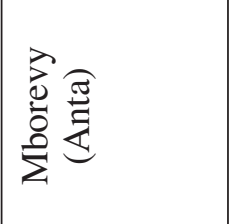 & 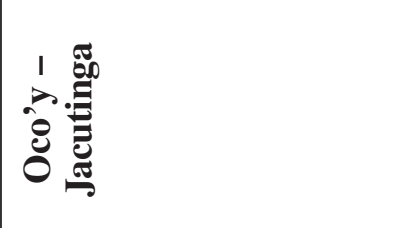 \\
\hline$=$ & $\simeq$ & $\stackrel{m}{2}$ & \pm & $\because$ & 0 & 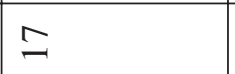 & $\stackrel{\infty}{\infty}$ \\
\hline
\end{tabular}




\begin{tabular}{|c|c|c|c|c|c|c|c|c|c|c|c|}
\hline & 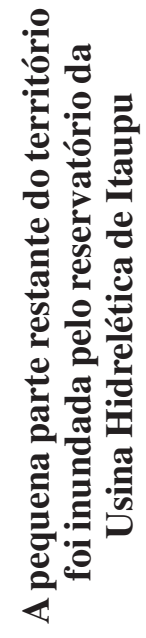 & 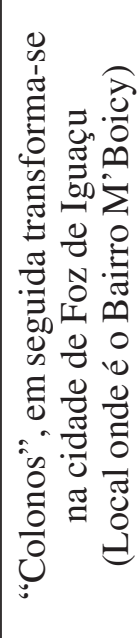 & 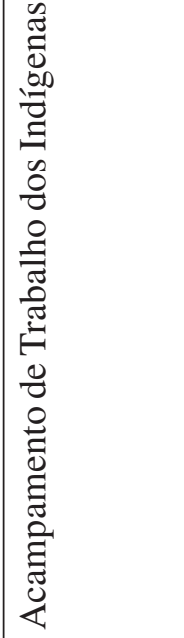 & 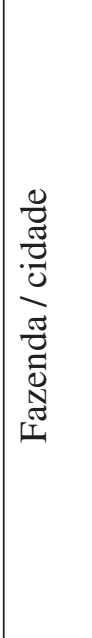 & 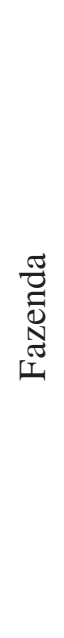 & 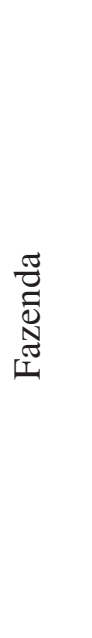 & 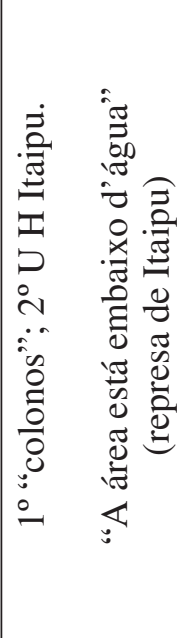 & 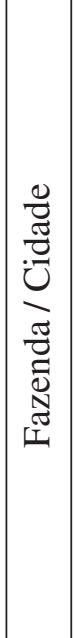 & 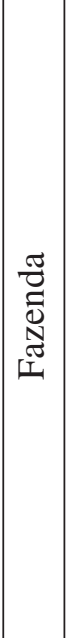 & 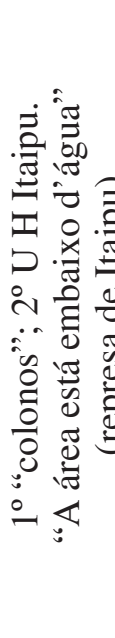 & 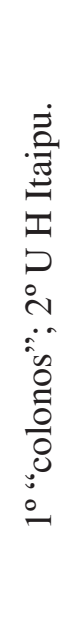 \\
\hline 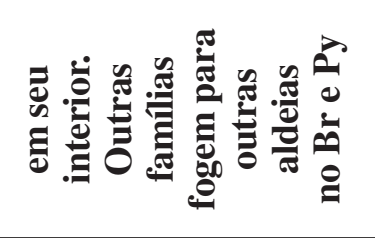 & $\stackrel{\mathscr{\sigma}}{\sigma}$ & 옹 & $\begin{array}{l}\infty \\
\stackrel{0}{0}\end{array}$ & $\stackrel{8}{\circ}$ & $\underset{\Xi}{\varnothing}$ & $\Xi$ & 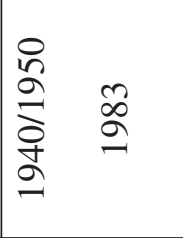 & 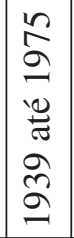 & $\stackrel{f}{2}$ & 号 & $\begin{array}{l}\frac{9}{9} \\
\frac{2}{2} \\
\frac{\sigma}{2}\end{array}$ \\
\hline \multirow[t]{5}{*}{ 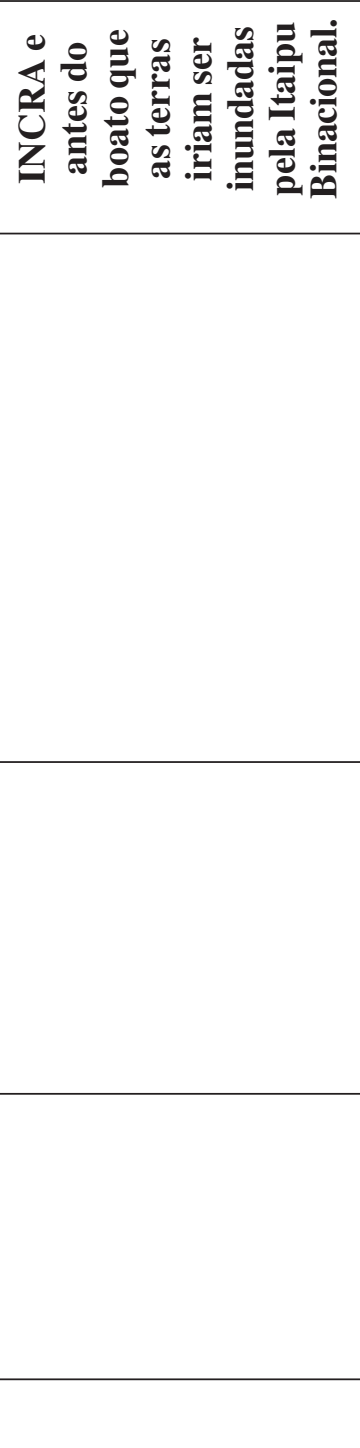 } & 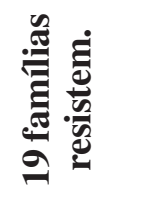 & $\simeq$ & ㄱ. & $\stackrel{\sim}{\sim}$ & $\stackrel{0}{0}$ & $\infty$ & 2 & $\stackrel{\infty}{\sim}$ & \pm & 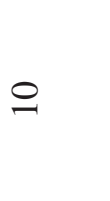 & \pm \\
\hline & & 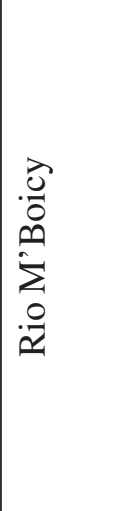 & 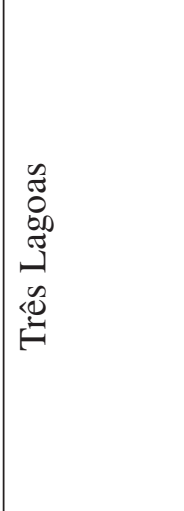 & 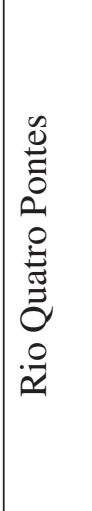 & 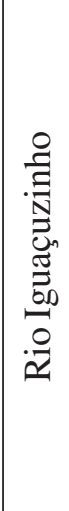 & 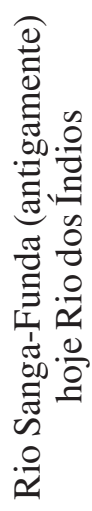 & 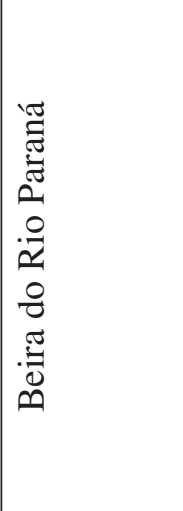 & 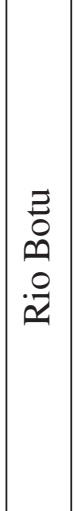 & 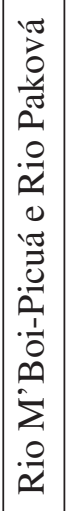 & 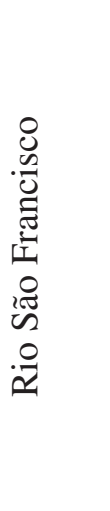 & 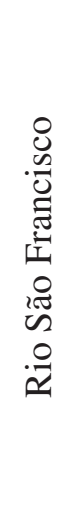 \\
\hline & & 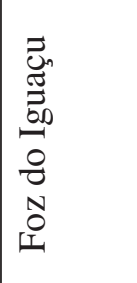 & 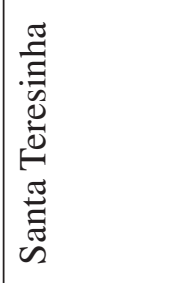 & 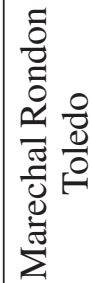 & $\frac{\stackrel{8}{0}}{\frac{0}{0}}$ & 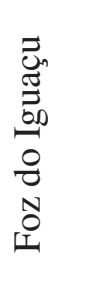 & 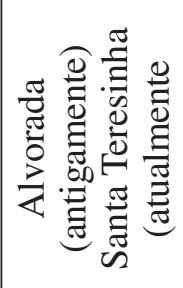 & 题 & 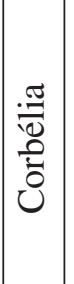 & 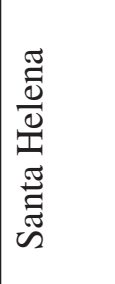 & 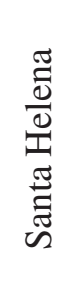 \\
\hline & & 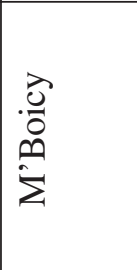 & 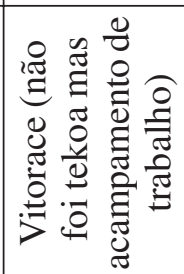 & 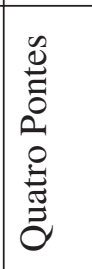 & 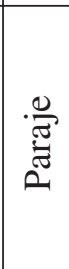 & 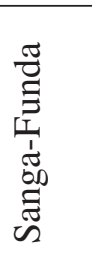 & 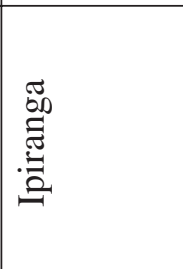 & 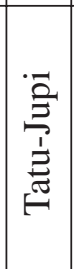 & 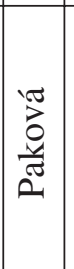 & 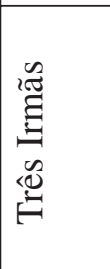 & 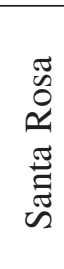 \\
\hline & & 2 & ¿ & $\bar{\lambda}$ & ส & $\theta$ & $\underset{d}{J}$ & 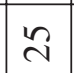 & i & $\hat{\imath}$ & $\stackrel{\infty}{\sim}$ \\
\hline
\end{tabular}




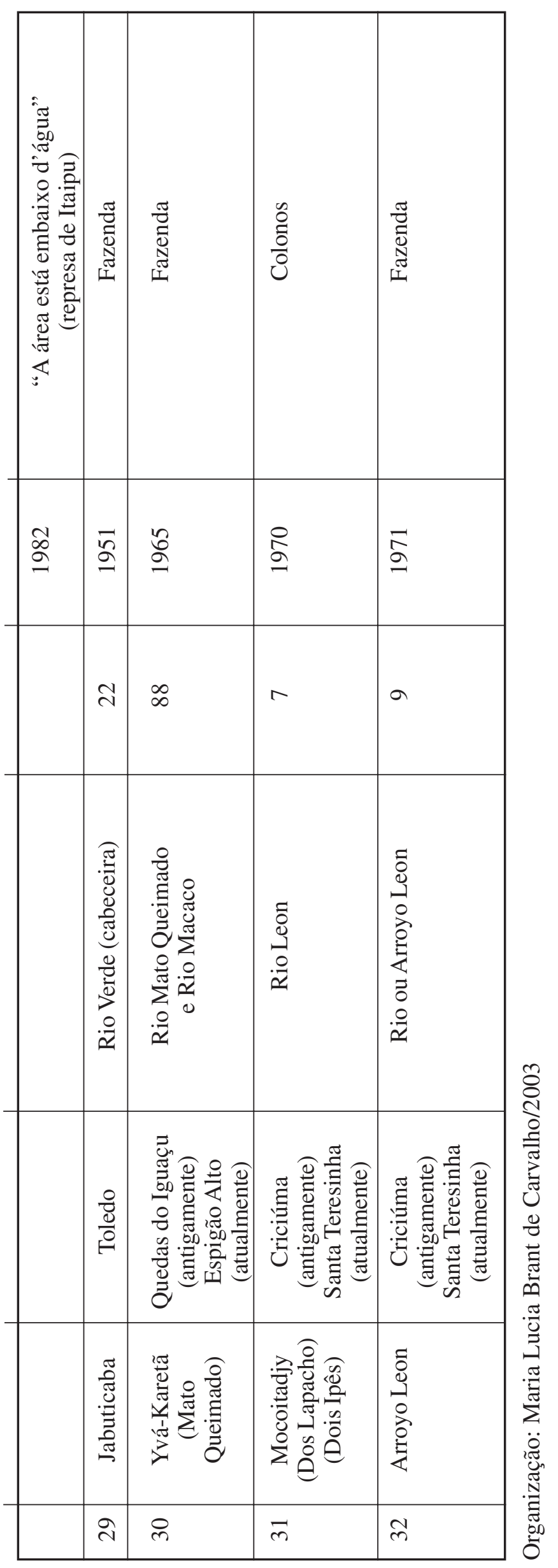


MAPA DE LAS PARCIALIDADES INDIGENAS DEL PARAGUAY

FAMILIAS LINGÜÍSTICAS DEL PARAGUAY

REGIÓN ORIENTAL Y OCCIDENTAL
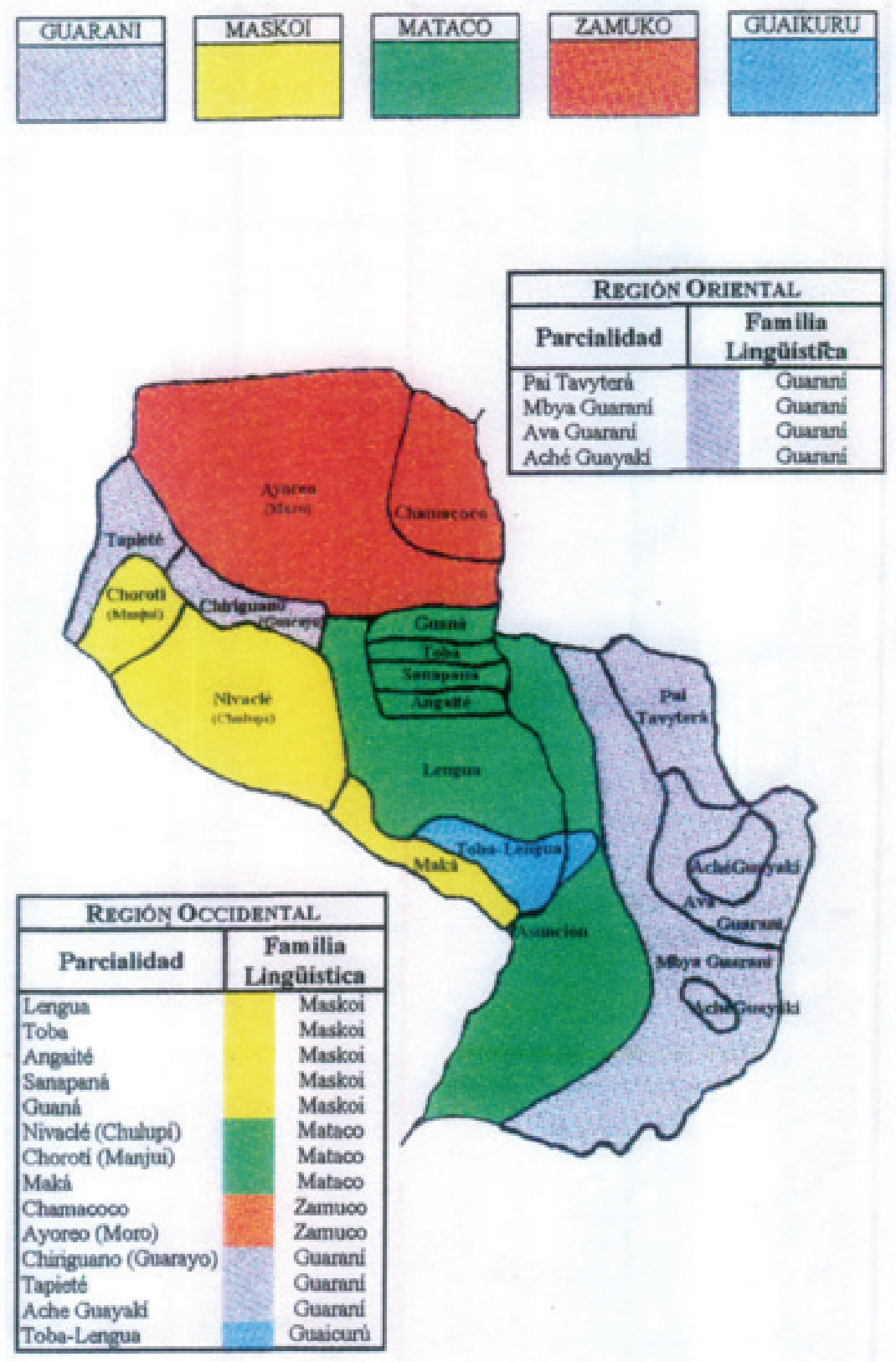

Fuente: CENSO DE ESTUDIO DE LA POBLACION INDIGENA DEL PARAGUAY. Instituto Paraguayo del Indigena.

Don Bosco 745. Asunción-Paraguay. la Edición. 1982. INDI.

Figura 65. Mapa. Mapa de las parcialidades indígenas del Paraguay. 


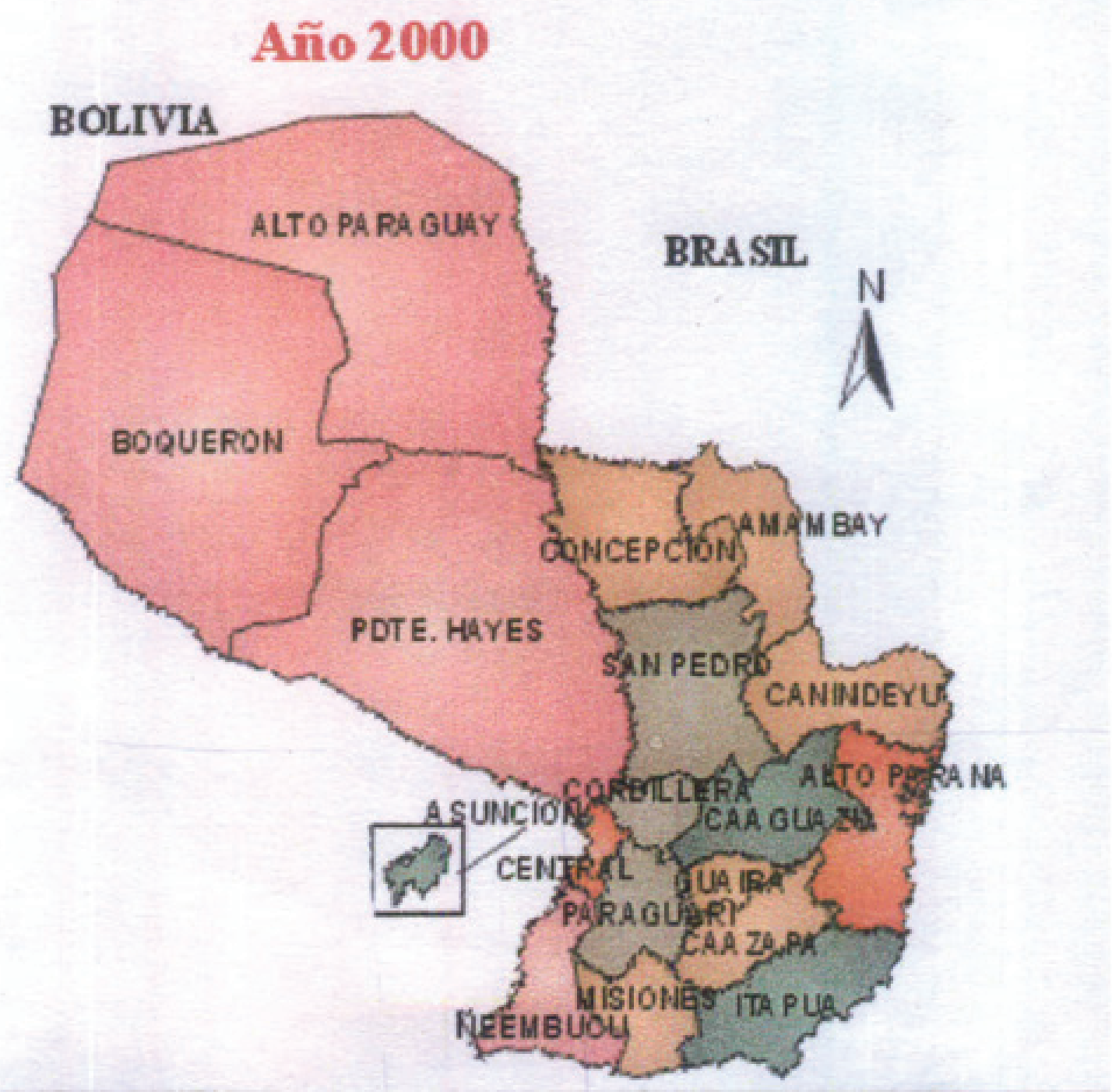

Figura 66. Mapa. Mapa dos Departamentos (estados) do Paraguai.

Fonte: Internet: Site do governo paraguaio. 2001. 


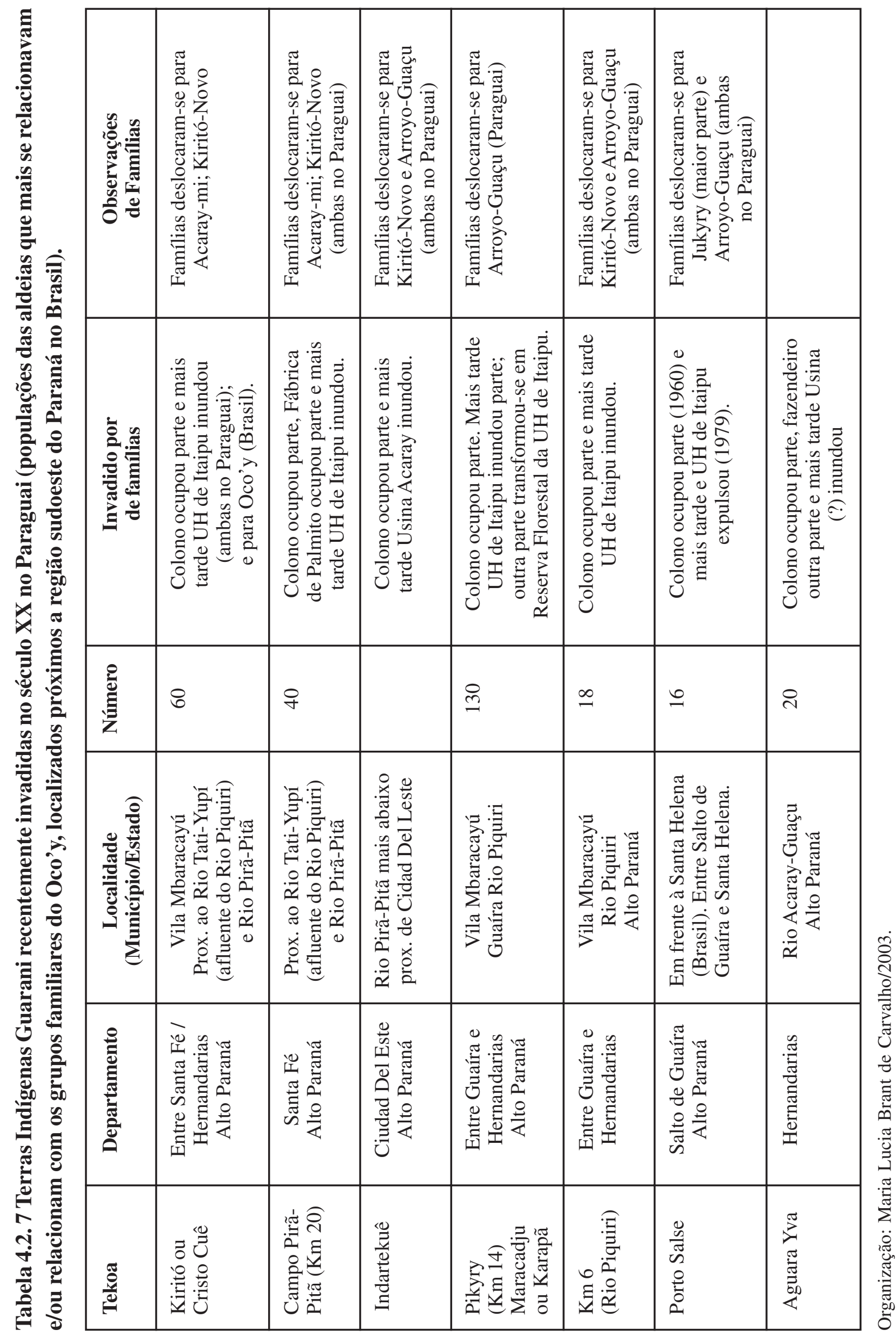


"Colono" referido nas Tabelas anteriores no entendimento dos Guarani é todo "representante da sociedade envolvente", portanto, muitas vezes eles não sabem dizer exatamente se a invasão se deu em função do interesse particular do colono ou se este mesmo pressuposto "colono" agia em função do poder estatal.

Pela descrição dos Guarani as 32 aldeias foram invadidas pelos seguintes membros da sociedade nacional:

- 11 (onze) pela invasão de fazendeiros;

- 2 (duas) pela invasão de fazendeiros, que em seguida transforma-se em cidade;

- 3 (três) pelo transbordamento de cidades;

- 2 (duas) pela ação de colonos;

- 1 (uma) pela ação de "colonos" que em seguida transforma-se em cidade;

-2 (duas) pela ação de "colonos" que caracterizaram como sendo a "invasão dos brancos", se instalando no local o Parque Nacional do Iguaçu;

- 1 (uma) pela ação do INCRA para instalação de colonos que haviam sido retirados do Parque Nacional do Iguaçu;

- 1 (uma) pela ação do INCRA para instalação de colonos que haviam sido retirados do Parque Nacional do Iguaçu; mais tarde seguida da inundação pelo reservatório da Usina Hidrelétrica de Itaipu;

- 7 (sete) pela ação de “colonos”, seguida da ocupação pelo reservatório da Usina Hidrelétrica de Itaipu;

- 1 (uma) pela ação de "fazendeiro" seguida da ocupação pelo reservatório da Usina Hidrelétrica de Itaipu;

- 1 (uma) se caracterizava como "acampamento de trabalho" dos indígenas na fazenda Vitorace.

Em todas elas o Governo Federal tinha a obrigação legal de defender o território indígena. Em 13 (treze) delas foram ocupadas em razão dos interesses do próprio Governo Federal a título de instalação dos dois Grandes Projetos, sem que houvessem as devidas compensações em 12 (doze) delas. Em apenas 1 (uma) o Oco'y-Jacutinga, apesar de haver compensação, foi realizada de forma inadequada e irreal como veremos adiante.

Vejamos a seguir, a dimensão territorial da ocupação Guarani que foram pesquisadas arqueologicamente no espaço que veio a se tornar o reservatório da Usina Hidrelétrica de Itaipu. 
De 1975 a 1983 foram desenvolvidas pelo Prof. Dr. Igor Chmyz/ CEPA/UFPR ${ }^{19}$ pesquisas arqueológicas nas margens brasileiras do rio Paraná, as quais seriam atingidas pelo reservatório da Usina Hidrelétrica de Itaipu. O reservatório veio a ocupar uma área de $835 \mathrm{Km} 2$ do lado brasileiro. Através do Projeto Arqueológico Itaipu foram descobertos e trabalhados 237 sítios arqueológicos, dos quais 89 eram pré-cerâmicos e 148 cerâmicos. $\mathrm{O}$ estudo permitiu a reconstituição das etapas de ocupação humana na área, abrangendo um período compreendido entre 6000 A. C. e 1920 D. C. Quanto aos sítios pré-cerâmicos, foram agrupados nas fases Vinitu, Pirajuí, Ipacaraí e Tatuí; não foram avaliadas ainda há quais tradições culturais pertencem. Quanto aos cerâmicos, integraram as fases Itacorá, Ibirajé, Sarandi, Icaraíma, Cantu, Pacitá e Assuna. Destes sítios cerâmicos, 116 pertencem a tradição Tupiguarani, ou seja, 78,37\% das amostras, conforme classificação arqueológica.

Fase Itacorá: Fase da sub-tradição Pintada Tupiguarani representada por 42 sítios em toda área, mas de forma concentrada nas suas porções superiores e medianas.(...) Os caçadores-coletoreshorticultores desta fase ter-se-iam movimentado no sentido norte-sul, no trecho pesquisado do rio Paraná. Existe uma datação de A. D. 1250 +- 55 para um de seus sítios.

Fase Ibirajé: Fase da tradição Corrugada Tupiguarani representada por 36 sítios, sendo mais expressiva nas porções inferiores da área de Itaipu. (...) a seriação das coleções cerâmicas indica a movimentação dos integrantes da fase no sentido norte-sul da área pesquisada. Muitos dos seus sítios foram datados, cobrindo um período que vai de A. D. 1190 +- 40 a A. D. 1696 +- 80.

Fase Sarandi: Os 15 sítios desta fase da tradição Escovada Tupiguarani limitaram-se às porções medianas e inferiores da área estudada. (...) Há indícios de que esta fase tenha se dispersado do sul para o norte na calha do rio Paraná. Datações situam-na entre A. D. 1300 +- 40 e A. D. $1805+-70$. Outros sítios pertencentes à tradição Tupiguarani, por apresentarem características próprias, não foram incluídos nas fases relacionadas acima, como o PR TO 62, encontrado no extremo norte da área. Pertence à subtradição Pintada da fase Condor que foi estabelecida no médio Ivaí, e poderia representar uma extensão desta no rio Paraná. A fase Condor possui datações que vão de A .D. 885 +- 150 até A. D. $1410+-60$.

O sítio PR FI 82, localizado próximo a Foz do Iguaçu, e o PR FO 24, ao lado de Guairá, apresentam fortes indícios de contato com os espanhóis que atuaram na área no século XVI e XVII. A estrutura dos sítios é tipicamente indígena porém entre seus objetos aparecem alguns modificados (peças metálicas) devido a presença espanhola.

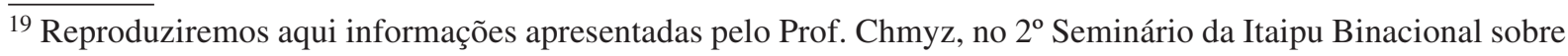
Meio-Ambiente, realizado em Foz do Iguaçu em 1987, nos limitando as referências citadas apenas da Tradição Tupi-Guarani.
} 
Um dos sítios deve corresponder a vila de Ontiveiros, fundada em 1554 por Garcia Rodrigues de Vergara. Essa vila foi estabelecida sobre uma aldeia indígena Guarani denominada Canideyú. Igualmente apresentando indícios de contato com o europeu, mais três sítios da tradição Tupiguarani foram registrados ao longo do rio Ocoí. Está relacionada às reduções que os jesuítas fundaram no Paraná a partir de 1610.

Nas proximidades do extremo sul da área de Itaipu existem duas referências históricas sobre reduções jesuíticas: a de Santa Maria, fundada em 1626 ao lado das Cataratas do rio Iguaçu e a de Nossa Senhora da Natividade do Acaraí, estabelecida em 1619 na margem direita do rio Paraná, no Paraguai, nas imediações do rio Acaray, todas as duas Tupiguarani.

Ainda ligado ao movimento espanhol dos séculos XVI e XVII, está o sítio PR FO 42 ao lado do porto de travessia fluvial de Guaíra. Este local não foi atingido pelo reservatório de Itaipu e é formado por dois muros paralelos com mais de 200 m de extensão, com base larga e que atingem 1 $m$ de altura. Tais estruturas seriam uma fortificação que eles teriam erigido para impedir a passagem dos índios guarani e jesuítas que, em 1631, fugindo dos ataques dos bandeirantes às reduções de Santo Inácio Menor e de Nossa Senhora de Loreto no rio Paranapanema, haviam navegado até a altura dos Saltos de Sete Quedas. Neste ponto teriam desembarcado e tentado prosseguir viagem por terra, sendo bloqueados pelos espanhóis. Numericamente superiores, os índios acabaram forçando a passagem. Informações históricas existem sobre uma fortificação espanhola coincidindo com a localização do sítio PR FO 42.

Também foi possível detectar a intrusão de traços da fase Cantu em sítios da fase Itacorá, Ibirajé e Sarandi, da tradição Tupiguarani, inferindo contemporaneidade.

O sítio cerâmico PR FI 145: os índios Guayaki, tidos como pertencentes à família linguística TupiGuarani e que foram observados no começo deste século (XX) nas proximidades da margem direita do rio Paraná, no Paraguai, produziam uma cerâmica comparável a do sítio PR FI 145, embora pareça que essa prática seja recente.

Fase Assuna: Os oito sítios dessa fase foram descobertos na metade inferior da área pesquisada e pertencem a tradição Neobrasileira. Mostra a fusão de tecnologias indígenas e portuguesa; se percebe nesta fase, a incidência de grande parte dos traços diagnósticos da fase Sarandi, da subtradição Escovada Tupiguarani. Cronologicamente esta fase pode ser situada entre a metade do século XIX até as primeiras décadas da atual (sec. XX), quando a região sofreu profundas mudanças sociais e econômicas. No momento da fundação da Colônia Militar de Foz do Iguaçu em 1889 havia na margem esquerda do rio Paraná, até $27 \mathrm{Km}$ ao norte de sua confluência com o rio Iguaçu, habitantes brasileiros, indígenas (guarani) e estrangeiros.

No município de Guaira, em uma área florestada e reservada para a instalação de um estaleiro, foram encontradas peças cerâmicas, onde revelou-se vários sítios : um pré-cerâmico da fase Vinitu 
e três cerâmicos pertencentes a tradição Tupiguarani. As escavações revelaram características da estrutura habitacional da antiga aldeia indígena, além de peças ósseas bem conservadas. Entre estas destacam-se anzóis, artefatos até agora não registrados em nenhum sítio arqueológico Tupiguarani no território nacional. A outra área que está recebendo atenção é a do futuro Centro Náutico e Recreativo do Guaira. Nela foram localizados três sítios, dois pertencentes à tradição Tupiguarani.

Essas pesquisas demonstram a forte e vasta imemorialidade da ocupação Guarani na região, sendo comprovada por nós também, a ocupação indígena até a instalação dos Grandes Projetos, portanto, é inegável seus direitos fundiários sobre estas terras.

Quanto ás terras indígenas Guarani invadidas no Paraguai que estavam localizadas próximas a região sudoeste do Paraná/ Brasil, as quais eram pertencentes ás populações que viviam em aldeias que mais se relacionavam/relacionam com os grupos familiares do Oco’y, estes perderam suas terras pelas seguintes razões:

- 5 (cinco) aldeias colonos invadiram parte e em seguida houve ocupação pelo reservatório da Usina Hidrelétrica de Itaipu;

- 1 (uma) aldeia colono invadiu parte e em seguida houve ocupação pelo reservatório da Usina Hidrelétrica de Acaray:

- 1 (uma) colono invadiu parte, fazendeiro invadiu outra parte e em seguida houve ocupação pelo reservatório da Usina Hidrelétrica de ... (gravação ininteligível).

Portanto, no Paraguai a história se repete, todas as aldeias foram perdidas em nome da instalação de projetos governamentais, sem que os direitos indígenas fossem considerados.

Dos quadros apresentados anteriormente podemos concluir que somente na faixa sudoeste paranaense haviam 32 aldeias Avá-Guarani, as quais foram extintas entre as décadas de 40 e 80 do século XX. Elas desapareceram por meio de invasões, que segundo relato dos indígenas, cada uma das aldeias foi invadida de forma a tomarem parte ou todo do território indígena. Apesar da existência de legislação que protegia o direito à terra dos indígenas, as terras originais não foram reconhecidas, para que então se procedesse a remoção dessas populações, garantindo o direito delas à terra de igual dimensão e ambientalmente semelhante.

Essas populações foram obrigadas a ocupar outras aldeias, tanto no Paraguai quanto em outras terras Guarani em solo brasileiro, afastadas da fronteira. Também foram obrigadas a ocupar terras de outra etnia (Kaingang) no Brasil. Esse processo ocasionou a diminuição em grande proporção, do conjunto das terras habitadas pelos Guarani, havendo no oeste paranaense um verdadeiro processo de desterritorialização da população indígena. 
Os 39 aldeamentos (Br e Py) descritos, localizavam-se regionalmente nas cercanias do próprio atual Oco’y. Eram formados por parentelas próximas ou mesmo eram parte da própria população do atual Oco’y, que foram se deslocando na medida em que suas terras eram invadidas. Como veremos a seguir, ao longo deste período (1940 a 1982) muitas das famílias destas aldeias deslocaram-se para o Oco'y-Jacutinga, um dos últimos redutos a ser invadido, porque mais afastado da área de interesse maior (Foz do Iguaçu), como foi relatado pelos habitantes do Oco’y. Ao ser invadido definitivamente o Oco’y-Jacutinga em 1982, parte das famílias foram reassentadas no Oco’y.

Por todo o exposto pode-se concluir que:

De 1500 a 1940 apesar das pressões da sociedade envolvente, fundamentalmente no decorrer do período colonial (século XVI e XVII), os Guarani por fim resistiram em seu território, voltando a habitá-lo de forma extensiva, dada a presença dos 32 aldeamentos no decorrer do século XX, quando demonstrou-se que eles haviam reocupado grande parte do oeste e sudoeste paranaense, conforme informações apresentadas.

De 1940 a 1982 foram novamente esbulhados de forma extensiva de seu território tradicional, período em que se instalaram os Grandes Projetos estatais na região, apesar de haver clara legislação que defendia os direitos indígenas ao território. Assim a perda real de território por parte dos Guarani contemporâneos, ocorre em termos históricos recentemente, em pleno século XX.

Desta forma a extensiva presença indígena Guarani nessa região é indiscutível. Aparecem documentados em inúmeros relatos históricos, arqueológicos e etnográficos, ocupando extenso espaço geográfico desde o século I Depois de Cristo, atravessando os períodos pré-colonial, colonial, imperial e republicano, atestando a presença dos mesmos contemporaneamente no século XX.

Pode-se concluir que esses inúmeros registros confirmam a imemorialidade da ocupação Guarani na região localizada na Tríplice Fronteira, entre o Brasil, Paraguai e Argentina.

Portanto, os Guarani são os povos autóctones do lugar. Assim eles obtêm o direito consuetudinário, de obter a posse dos territórios que ocupavam/ocupam, por serem, justamente, os povos originários do lugar. Este direito é assegurado independentemente de estar ou não demarcada a aldeia, conforme o Estatuto do Índio, Lei Federal n. 6001 de 1973, Artigo 25, já citado. Complementarmente é importante lembrar o que o ex-presidente da FUNAI, o advogado Júlio Gaiger, afirma:

Os direitos indígenas sobre suas terras, porém, não dependem da demarcação. A demarcação é providência administrativa que visa identificar com maior precisão as terras indígenas, mas não tem 
o condão de constituir ou desconstituir direitos. O preceito constitucional de maior importância sobre as terras tradicionalmente ocupadas pelos índios, todavia, é o que reconhece que o direito dos índios sobre eles é originário (artigo 231 caput).(GAIGER:1989).

É o caso de todas essas aldeias, elas muito provavelmente não estavam demarcadas. Vejamos a seguir como se deram os esbulhos das aldeias nas quais a maioria da população Guarani do Oco'y eram provenientes.

\subsection{As formas pelas quais se deram os esbulhos das terras de onde os Guarani do Oco’y são provenientes, Aldeias: “Guarani” (década de 40), “São João Velho” (década de 60), “Colô- nia-Guarani”" (década de 70), e “Ocoy-Jacutinga (década de 70 e 80)"}

A parte aqui descrita refere-se à história recente dos anos 40 a 1982. Como se utilizássemos de uma "lente de aumento", demonstraremos de que forma ocorreram os processos de esbulho das terras de quatro aldeias, as quais partes de suas populações eram parentelas compostas pelos ascendentes e pelos próprios formadores do atual contingente populacional da Terra Indígena Avá-Guarani do Oco'y. Dessa forma descreveremos sua origem territorial e populacional, verificando como se deu a perda dos territórios habitados pela maioria desta população Guarani, que hoje vive no Oco’y.

A pesquisa foi realizada por meio de levantamentos etnográficos junto a alguns informantes Guarani do Oco'y, associando a história narrada à documentação oficial disponível, contida no processo n 1053/1976, referente a própria Terra Indígena Avá-Guarani do Oco’y. O material é proveniente do Centro de Documentação/CEDOC da FUNAI, em Brasília. Neste acervo, foram levantados os materiais produzidos institucionalmente à respeito do agrupamento, pelos seguintes órgãos governamentais: FUNAI, INCRA, Itaipu Binacional e IBDF/IBAMA, os quais durante 30 anos trocaram informações a respeito desses agrupamentos Guarani. Foram acessados também materiais de pesquisa arqueológica do CEPA/UFPR e outros de Organizações Não Governamentais, os quais participaram dos processos vividos junto aos índios, à época.

Estas aldeias estavam localizadas antes das invasões ocorridas no século XX, na mesoregião geográfica 105 - Oeste (Figura 45. Mapa. Estado do Paraná. Mesorregiões Geográficas: Ipardes 2005). Duas delas, Aldeia “Guarani”” e Aldeia “São João Velho” (CD-Figura 64. Mapa. Identificação de 32 aldeias Guarani desaparecidas no oeste paranaense...: aldeias no 11 e 10), estavam em áreas contíguas, ás margens do rio Iguaçu, próximo as Cataratas do Iguaçu; a terceira aldeia, 
“Colônia-Guarani” (CD-Figura 64: aldeia n 12) localizava-se à margem esquerda do rio Paraná, na periferia da atual cidade de Foz do Iguaçu; a quarta aldeia, “Oco'y-Jacutinga” (CD-Figura 64: aldeia $\mathrm{n}^{\circ} 18$ ) localizava-se também à margem esquerda do rio Paraná, em local mais distante de Foz do Iguaçu.

A Figura 60, mapa do século XIX (Ambrosetti:1895), demonstra achados arqueológicos sobre a presença Kainguá-Guarani nessa mesma região, onde viviam ainda no século XX também as populações das quatro aldeias, “Guarani”, “São João Velho”, “Colônia-Guarani” e “Oco’y-Jacutinga”.

Os Guarani pertencentes à essas quatro aldeias, estavam situados em rota secundária, vertical em relação ao caminho principal do Peabiru (CD-Figura 51. Mapa de Chmyz). Especificamente esta rota se comunicava com aldeias Guarani de norte a sul, desde o rio Tietê (SP), passando pelos rios Peixe, Paranapanema (divisa SP/PR), Ivaí, Piquiri, Iguaçu (regiões dos quatro últimos rios que compreendem a área onde se estabeleceram as Reduções Jesuíticas do Guairá); e continuando na rota do Peabiru em direção sul, atravessando o rio Uruguai, encontrava ao final, o local onde foi estabelecida a Redução Jesuítica de Santa Teresa no Tape (RGS).

Vejamos atualmente quem as ocupa, quem foram os responsáveis pelo esbulho e em que época:

- Aldeia Guarani e Aldeia São João Velho; localizadas em área atualmente ocupada por Unidade de Conservação, o Parque Nacional do Iguaçu, administrado pelo IBDF, sucedido hoje pelo IBAMA. Foram esbulhados da Aldeia Guarani, segundo depoimento de indígena por "invasão de brancos por meio de massacre" em 1943. Considerando que o parque foi criado em 1939 e que justamente a área habitada pelos Guarani era a área de maior interesse do IBDF (antecessor do IBAMA), pois constituía-se do próprio local das Cataratas do Iguaçu, e que ainda, o Parque em torno das Cataratas foi criado nesta data em uma extensão inicial de 1.008 hectares, tudo leva a crer que foram os próprios responsáveis pelo Parque, ou seja, os funcionários do Governo Federal, os autores da expulsão através de massacre dos indígenas; em 1962 são expulsos novamente por "invasão de brancos por meio de expulsão" da Aldeia São João Velho, segundo relatos dos indígenas, esta aldeia se localizava logo atrás da Aldeia principal a Aldeia Guarani.

-Aldeia Colônia Guarani; localizada na antiga região de Três Lagoas, hoje Santa Teresinha, subúrbio/bairro periférico de Foz do Iguaçu. As terras dessa aldeia foram invadidas em 1971 por representantes do INCRA, que armados, expulsaram do local, os Guarani. Foram reassentados nesse local pelo INCRA, colonos que haviam sido obrigados a se retirar da área do Parque Nacional do Iguaçu (os parques brasileiros são de uso indireto). Assim novamente a invasão ocorreu pelo próprio Governo Federal, em razão de interesses indiretos do mesmo Parque. 
- Aldeia do Oco’y-Jacutinga; As terras dessa aldeia foram invadidas em dois momentos, em 1973 e 1982. Em 1973 parte das terras dessa aldeia foram invadidas novamente por representantes do INCRA, armados, nos quais expulsaram os Guarani, sendo no seu lugar, ali reassentados colonos que haviam sido obrigados a se retirar também da área do Parque Nacional do Iguaçu. A parte restante do território, onde os Guarani ficaram reduzidos, entre o rio Paraná e os colonos que ocuparam suas terras, foi mais tarde coberta pelas águas do reservatório da Usina Hidrelétrica de Itaipu em 1982; assim novamente os responsáveis pela invasão, foram ás instituições do Governo Federal, obviamente pelos interesses do mesmo Parque e Hidrelétrica.

Os quatro casos mencionados contaram com a omissão do SPI e depois da FUNAI, órgãos de governo encarregados da defesa dos direitos de seus tutelados, os povos indígenas. Vejamos caso a caso como ocorreram:

- Aldeia Guarani e Aldeia São João Velho; Há indivíduos vivos no Oco’y, que viveram nestas aldeias, sendo todos hoje idosos. Dona Narcisa, é uma senhora de 83 anos (2007) que vive no Oco'y ${ }^{20}$. O depoimento dela traz informações históricas importantes, referente à ocupação tradicional deste território pela população Avá-Guarani. Pelo depoimento pode-se verificar também um misto de razões (indígena e fundamentalmente governamental) para a "mobilidade espacial” das famílias Guarani sobre o território.

A seguir o depoimento da Senhora Narcisa Tacua Catu de Almeida, sendo solicitado a ela que no seu relato tentasse lembrar os locais e datas por onde passou:

Nasci no Oco'y-Jacutinga em 1924. Fui mora na Aldeia Guarani em 1934. Morei ali até 1943. Morava umas 50 família na aldeia Guarani, perto do Rio Iguaçu, lá onde hoje é o Parque Nacional do Iguaçu. Afirma que na década de 1940, houve um massacre, que ela e sua família assistiram escondidos, emocionada, descreve: (...) guerra com os índio para tira os Guarani da terra: Eu vi, eu vi, mataram tudo! Jogavam os índios nas Catarata, abriam a barriga com facão e jogava depois nas Catarata (do Iguaçu). Enquanto falava, demonstrava com as mãos, o corte a facão que era feito, do baixo ventre ao coração. Indagada do porque o corte dessa forma, ela afirma: era para o corpo não boiá, pra afunda! O cacique da aldeia Guarani (Téve) e a mulher dele (Aispis) foram tudo morto, e jogado nas Catarata. Nesse massacre, tinha quatro padre: dois era amigo dos índio e dois que era contra os índio, um de cada lado, que era "irmãos", brigaram muito e se mataram ali. A Catarata é cemitério Guarani.

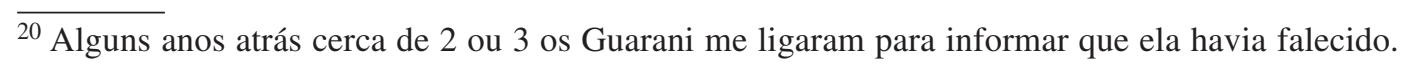


Em 1944 fui mora na aldeia São João Velho. Moravam umas 40 família na aldeia São João Velho, perto da antiga Usina (Hidrelétrica) São João (hoje desativada), perto do Rio São João. Eu morei lá de 1944 a 1962. Depois tivemo que saí de lá também, os branco expulsou os Avá-Guarani. Tem o cemitério lá, minha sogra, Siriaka Coronel Martinez, foi enterrada ali.

Em 1962 fui mora na aldeia Colônia Guarani. Os branco do INCRA expulsou os Guarani dali também. Em 1967 nasceu Laureano (seu filho). Em 1981 voltei a mora no Oco'y-Jacutinga. Quando inundaram o Oco'y-Jacutinga, depois vim mora aqui na aldeia do Ocoy, isso foi no ano de 1982.

Apesar de idosa, ainda pretende ir residir em outra aldeia, ela afirma: quero vive num lugar mais tranquilo... .

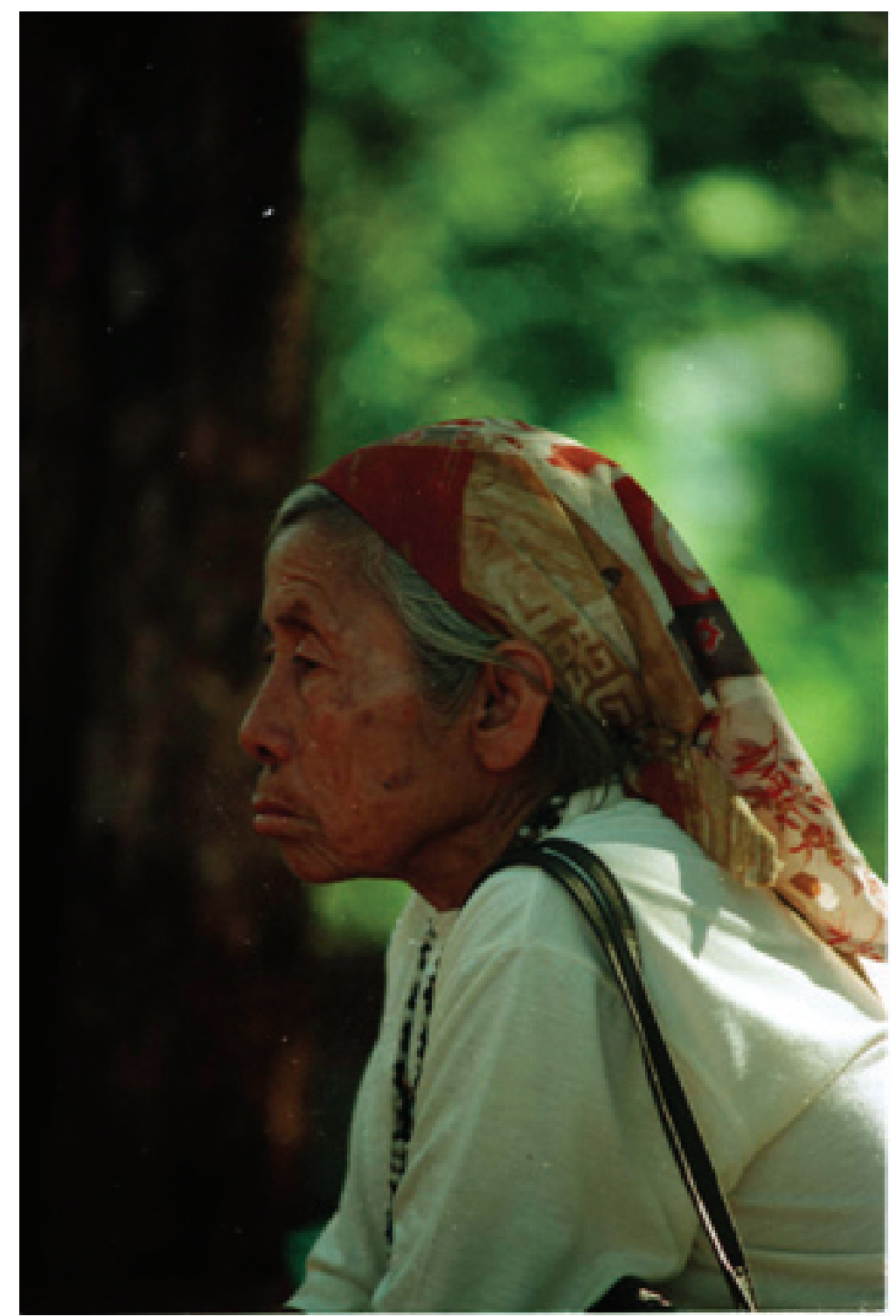

Figura 67. Foto. Homenagem a Dona Narcisa Tacua Catu de Almeida (in memoriam).

Autora: Maria Lucia Brant de Carvalho. 2001. 
O que se passou na Aldeia Guarani, a respeito do massacre, ela conta que havia ido com a família para o "mato" e na volta para a aldeia viram de certa distancia o que estava acontecendo. Sua família ficou "escondida no mato", assim protegida, mas vendo o que ocorria. Ela informa que a Aldeia São João Velho ficava atrás da Aldeia Guarani, e esta última localizava-se em frente as Cataratas do Iguaçu.

O depoimento de Dona Narcisa, comprova a evidente habitação Guarani em alguns locais da região de tradicional ocupação da etnia, e ainda, suas várias e obrigatórias retiradas. Somente quando ela se transferiu do lugar onde nasceu, foi por motivação interna própria (mudança das famílias de uma aldeia para outra), todas as outras mudanças espaciais foram realizadas através de coibição e esbulho pelo próprio Governo Federal, pontuando, em 1943 foram expulsos por meio de massacre da Aldeia Guarani; e em 1962 foram expulsos por meio de coibição da Aldeia São João Velho.

Durante esse depoimento esta senhora solicitou a nós que gostaria de visitar esses locais onde existiam as antigas aldeias. Ao providenciar transporte para a finalidade, quando chegamos à entrada do referido Parque, fomos obrigados a utilizar o transporte interno do mesmo, o ônibus circular. Adiantamos a ela que não sabíamos se conseguiríamos ir até os locais onde estavam as aldeias, já que as visitas internas são dessa forma, guiadas por caminhos pré-estabelecidos pelo Parque. Quando chegamos as Cataratas, saltamos ali mesmo. Ao indagar a ela qual a direção das aldeias, ela apontou para o Hotel de luxo existente em frente ás Cataratas e afirmou: É aqui mesmo. Aqui era a Aldeia Guarani. Nesse momento da visita Dona Narcisa permaneceu um longo tempo olhando para o local, muito constrita, séria e calada. Um senhor Guarani que também acompanhava a visita e também foi antigo morador da atual UC, revelou sua tristeza ao visitar a referida Unidade de Conservação: Os branco usa a terra (da UC) para brincar, passear e ganhar dinheiro, enquanto que nós precisamo da terra para viver...

Dessa forma esses Guarani do Oco’y, eram os próprios, os antigos habitantes das

\section{Cataratas do Iguaçu ${ }^{21}$ !}

Assim a atual Unidade de Conservação administrada pelo IBAMA, Parque Nacional do Iguaçu é local tradicional, habitado imemorialmente pelos Guarani. Como vimos anteriormente, vários fatos comprovam a presença desses índios nesse mesmo local, ao longo dos 500 anos de colonização, a saber: Cabeza de Vaca se deparou com eles quando chegou ás Cataratas do Iguaçu (século XVI); o arqueólogo Chmyz identificou a Redução de Santa Maria fundada nas proxi-

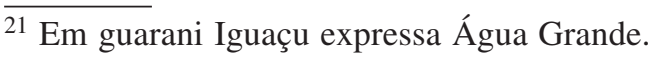


midades do denominado a época de "Saltos de Santa Maria" no rio Iguaçu (CD-Figura 51 de Chmyz, quadrado $n^{\circ}$ 6), ou seja, nas próprias Cataratas do Iguaçu, resgatando relatos jesuíticos em que informavam que nesta Redução habitavam 600 famílias Guarani, em 1628; Os Cainguá, ou também denominados Kaiuá e Kainguá, são identificados pelo cronista da fundação da Colônia Militar Jose Maria Brito em 1889 nas proximidades desse local, assim como o arqueólogo Ambrosetti realiza o mesmo, entre 1892 e 1894, assinalando os Kainguá em toda região pertencente a estas quatro aldeias aqui citadas (Figura 60); Nimuendajú os identifica nesse local em seu mapa de 1944 (CD-Figura 61); por fim, este levantamento etnográfico realizado por nós (a entrevista e a visita a área com Dona Narcisa e os levantamentos antes realizados com outros informantes Guarani), demonstra o mesmo, sendo esse local atualmente localizado no interior do Parque Nacional do Iguaçu, habitado pela última vez na Aldeia Guarani até o ano de 1943 e na Aldeia São João Velho até o ano de 1962. (CD-Figura 64).

Portanto, não se trata de apenas uma "longínqua antiguidade" a presença indígena Guarani na área administrada pelo IBAMA. Ao contrário do que a mídia dominante na região veicula os Guarani só foram definitivamente expulsos da Unidade de Conservação recentemente, no século XX. Nesse sentido vejamos como duas publicações referentes ao pólo turístico das Cataratas do Iguaçu, relatam para o grande público a presença indígena na região:

O primeiro texto contido no "Resumo Executivo do Plano de Manejo do Parque Nacional do Iguaçu" elaborado e publicado pelo IBAMA/MMA (2000), assim se refere na parte sobre o "Histórico" (p. 8), quanto a presença dos Guarani na área:

Os primeiros registros históricos da existência da região do Iguaçu datam do século XVI, com as expedições exploratórias realizadas pelos colonizadores espanhóis na Bacia do Prata.

Alvar Nuñez Cabeza de Vaca foi o primeiro a chegar as Cataratas do Iguaçu, em 1547. Mais tarde o local foi cenário das missões jesuíticas espanholas, que tentavam catequizar os índios Tupi-Guarani, e das incursões bandeirantes, para reconhecimento da região.

Nos séculos seguintes, a região tornou-se alvo de disputa entre espanhóis e portugueses. Todas as tentativas de domínio fracassaram, no entanto, por causa da presença de populações indígenas do ramo $\underline{\mathrm{J}}$, que demonstraram forte resistência ao assédio dos colonizadores.

A colonização da área só se tornou possível pouco antes da Proclamação da República. O povoamento foi motivado pela atividade comercial ligada à extração da erva-mate Ilex paraguaiensis e de madeira, então abundantes na região.

Em 1916, Santos Dumont, em visita às Cataratas, ficou impressionado com a beleza cênica do lugar e sugeriu que as terras da margem direita do Iguaçu se tornassem de domínio público. Três anos depois, a área foi declarada de utilidade pública pelo governo do estado do Paraná. 
A extensão territorial originalmente decretada, de 1008 ha, sofreu vários acréscimos e tornou-se objeto de inúmeras demandas judiciais, por causa dos problemas fundiários gerados. Em 1930, foi doado ao Governo Federal, que a transformou em Parque Nacional em 1939. (PNI: 2000:8)

Assim a presença Guarani por este texto ficou limitada ao século XVI, quando ela se dá na verdade até o século XX. Objetiva dar a entender que ocorreu uma sequência linear de substituição e eliminação de povos em passado muito antigo, quando na verdade, a história é mais dinâmica, complexa e mais recente do que é apresentado por este trabalho.

Uma segunda publicação denominada “Iguaçu Cataratas/Falls Brasil” de Werner Zotz (2000), voltada para finalidade turística, editada em colaboração conjunta do "IBAMA", "Paraná Turismo", "Iguassu Convention \& Visitors Bureau", "Itaipu Binacional" e "Cataratas do Iguaçu", a presença Guarani é assim referida:

Uma História de Índios: Há muito, muito tempo, quando apenas os índios perambulavam pelo novo mundo, então ainda desconhecido, esta região era habitada por povos guaranis e caingangues. (ZOTZ: 2000:11)

Um Pouco de História. Os primeiros europeus a palmilharem estas terras faziam parte de uma expedição que buscava aumentar os domínios espanhóis na América do Sul. Liderados por Alvar Nuñes Cabeza de Vaca, saíram do litoral de Santa Catarina, cruzaram o território paranaense para, finalmente, chegarem a região do Iguaçu, em fevereiro de 1542.

Em 1609, bandeirantes paulistas tentam colocar a região sob o domínio de Portugal. As fronteiras definitivas só foram estabelecidas em 1750, com a assinatura do Tratado de Madrid, entre Portugal e Espanha, confirmando o domínio português sobre a região.

Nos séculos XVII e XVIII, os missionários da Companhia de Jesus organizaram diversas povoações guaranis, em moldes semelhantes às reduções jesuíticas mais famosas do Rio Grande do Sul e da Argentina.

Em 1917, Iguassu passa a comarca. No ano seguinte, recebe o nome de município de Foz do Iguaçu. (ZOTZ: 2000:13)

Assim a história aqui contada limita-se a atuação dos povos ibéricos, seja ele explorador, jesuíta ou bandeirante, quando toda a ação dava-se em solo habitado pelos Guarani, neles participando como ativos atores sociais. Apesar de citar a presença dos Guarani, quando o faz, limitase a uma longínqua presença, omitindo a informação quanto as Missões Jesuíticas ali estabelecidas do "Guairá", e especificamente nesse local, sobre a redução de Santa Maria. Omite ainda a pre- 
sença dos mesmos nas Cataratas, terras tradicionais dessa população até o século XX, quando os representantes desse mesmo parque ali se estabeleceram, expulsando dessa forma os Guarani.

Vejamos os resultados obtidos pelas pesquisas arqueológicas realizadas na área do Parque Nacional do Iguaçu pelo CEPA/UFPR. Neste parte nos limitaremos a reproduzir os trabalhos dessa Universidade com algumas observações nossas.

Em 1969 o Centro de Estudos e Pesquisas Arqueológicas/CEPA/UFPR já havia identificado um sítio arqueológico de tradição Tupiguarani no interior do Parque Nacional do Iguaçu/ PNI. Convidado pelo IBAMA para participar das discussões sobre o Plano de Manejo do PNI, o CEPA, em 1997, inicia novo trabalho arqueológico junto ao Parque ${ }^{22}$. Chmyz relata:

\begin{abstract}
A pesquisa, programada para restritos 15 dias (dezembro de 1997), previa enfoques amostrais em três espaços daquela Unidade de Conservação: o primeiro na margem direita do rio Iguaçu, nas proximidades das Cataratas; outro ao longo da estrada do Colono e o último junto aos formadores do rio Floriano.(CHMYZ: 1999:43)
\end{abstract}

Chmyz em seguida descreve que o início da pesquisa foi pelo menos duas vezes postergado; quando finalmente, inicia-se a pesquisa, junto as Cataratas do Iguaçu, em seguida os trabalhos são interrompidos. As duas propostas seguintes de pesquisa, já previstas, sofrem alterações em sua programação original. Somente em abril/98, na tentativa de se dar sequência aos trabalhos, durante 13 dias apenas, foi permitido a pesquisa, porém, em outra região, na fronteira com o $\underline{\text { meio externo, na divisa seca do Parque, do rio Represinha até o rio Benjamin Constant. As áreas }}$ previstas anteriormente não puderam ser pesquisadas. Desta forma, pontuada por idas e vindas, interrupções e censura de áreas, foi realizada em curto período de tempo pesquisa arqueológica no interior, e, nos limites externos do Parque Nacional do Iguaçu. Foram identificados 28 sítios arqueológicos (CD-Figura 68). Novamente foram paralisadas as pesquisas, agora laboratoriais. Foram retomadas somente em outubro de 1998, quando é então retomado o relatório técnico, o qual consultamos.

\footnotetext{
${ }^{22}$ I. Chmyz. Relatório Técnico sobre Arqueologia e a Etno-História da Área do Parque Nacional do Iguaçu/ CEPA/UFPR, Curitiba: 1999. 81p.
} 


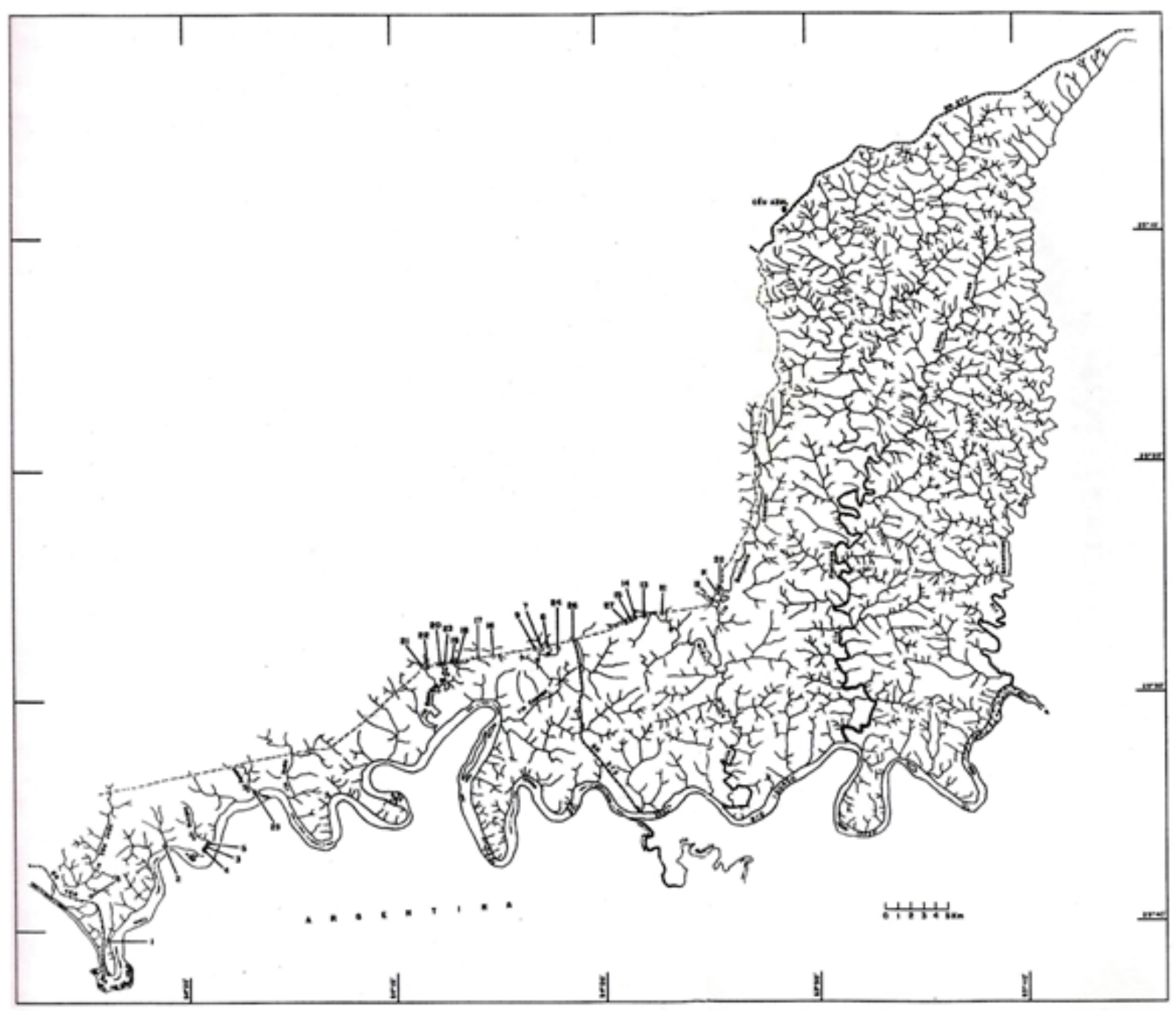

CD-Figura 68. Mapa. Indícios arqueológicos localizados na área do PNI.

Fonte: I. Chmyz. Relatório Técnico sobre Arqueologia e a Etno-História da Área do Parque Nacional do Iguaçu/ CEPA/UFPR, Curitiba: 1999, p. 46.

Neste trabalho intitulado Relatório Técnico sobre Arqueologia e a Etno-História da Área do Parque Nacional do Iguaçu/CEPA/UFPR, Curitiba, 1999, Chmyz relata:

As prospecções foram realizadas em dois curtos períodos, no primeiro semestre de 1998 (...). O projeto previa três enfoques: um na margem direita do rio Iguaçu, nas proximidades das Cataratas, outro ao longo da estrada do Colono e o último junto as formadores do rio Floriano. O primeiro trecho foi acessado através das trilhas existentes e pelo rio principal. Na mata foram abertas picadas acompanhando cursos fluviais. Além da visualização superficial do terreno pequenos cortes-experimentais foram praticados espaçadamente para a localização de traços arqueológicos. Na margem do rio Iguaçu situada entre as corredeiras da Irene e a foz da Sanga Boqueirão, as picadas foram intensificadas para o interior, à procura de elementos relacionados à redução de Santa Maria. Nesse 
trecho, na cartografia jesuítica do século XVII, está assinalada "S. Maria". Tal referência poderia ser apenas alusiva às Cataratas, assim como ao "Salto Grande", que foi destacado no mesmo mapa, no rio Paraná. A diferença entre as nominações é a cruz acompanhando de $\underline{\text { Santa Maria, convenção }}$ presente nas demais reduções marcadas no mapa jesuítico. Vários dias foram empregados nessa procura e, as picadas abertas, muito difíceis e vagarosas, não foram suficientes para se vasculhar $\underline{\text { todo espaço pretendido. As possíveis ruínas da redução de Santa Maria }}{ }^{23}$ não foram encontradas. Na sequência, as pesquisas sofreram alterações quanto à programação original. (CHMYZ: 1999:44).

Apesar dos atropelos e falta de tempo hábil para os procedimentos necessários à pesquisa, foram identificados vários sítios, entre eles os PNI-01, PNI-02, PNI-04 e PNI-05 todos classificados como pertencentes à tradição Tupiguarani e localizados no interior do Parque. (CD-Figura 68. Achados arqueológicos nos pontos PNI: 01-02-04-05). Em especial o ponto PNI-01 localizava-se próximo ás Cataratas; nesse local Chmyz conseguiu fazer breve pesquisa; posteriormente foi proibido o desenvolvimento da pesquisa nesse local, pela direção do Parque. Porém, Chmyz ainda teve tempo hábil, para encontrar um recipiente cerâmico da tradição Tupiguarani nesse mesmo ponto, o PNI-01, apresentado a seguir. (Figura 69 A e B).

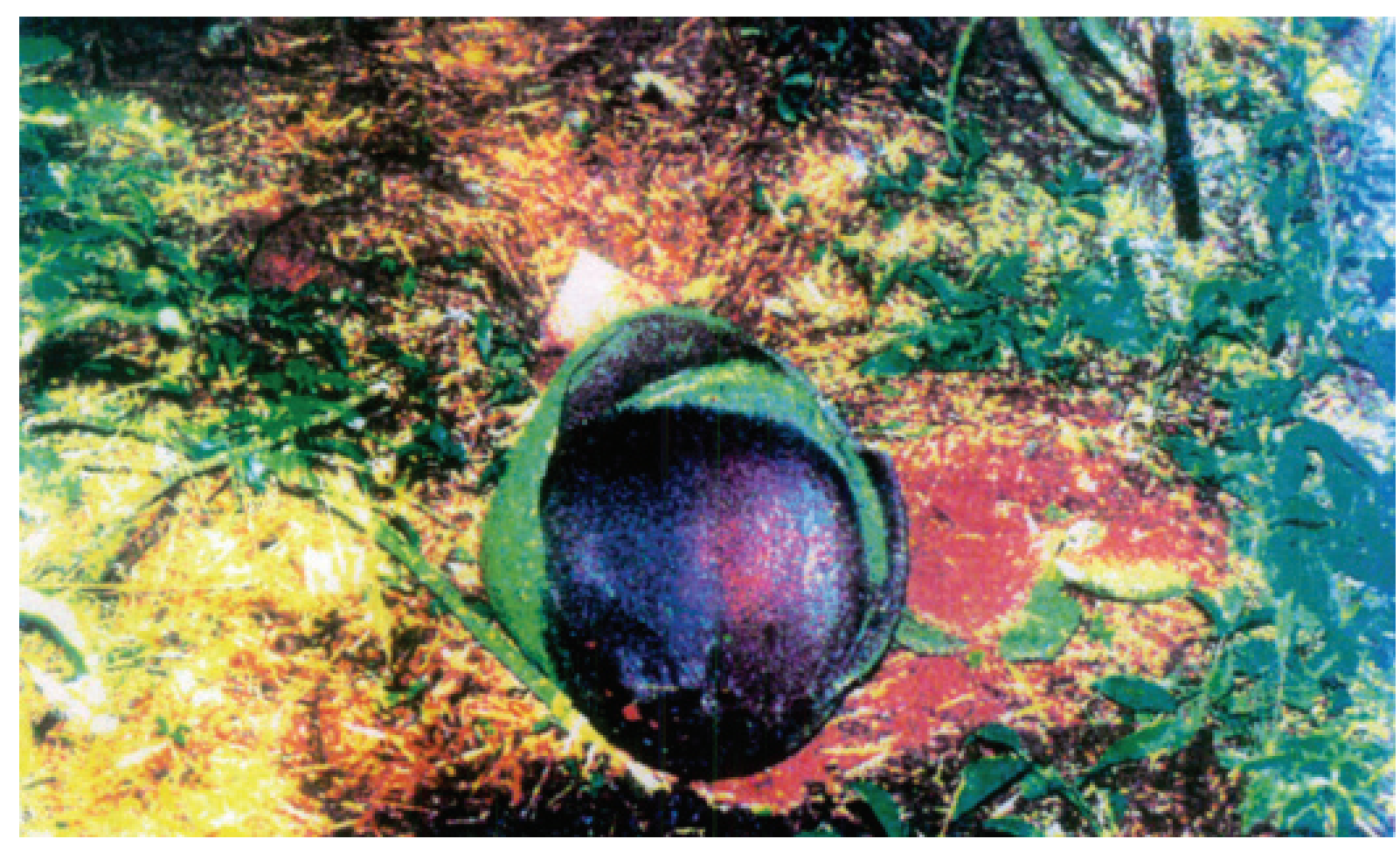

Figura 69A. Foto. Recipiente cerâmico da tradição Tupiguarani removido da área do Parque Nacional do Iguaçu. Fonte: I. Chmyz. Relatório Técnico sobre Arqueologia e a Etno-História da Área do Parque Nacional do Iguaçu/ CEPA/UFPR, Curitiba: 1999, p. 48.

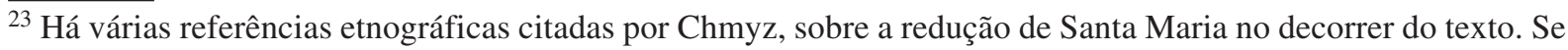
houver interesse em aprofundá-las estão contidas nas páginas 72 e 73 do trabalho citado.
} 


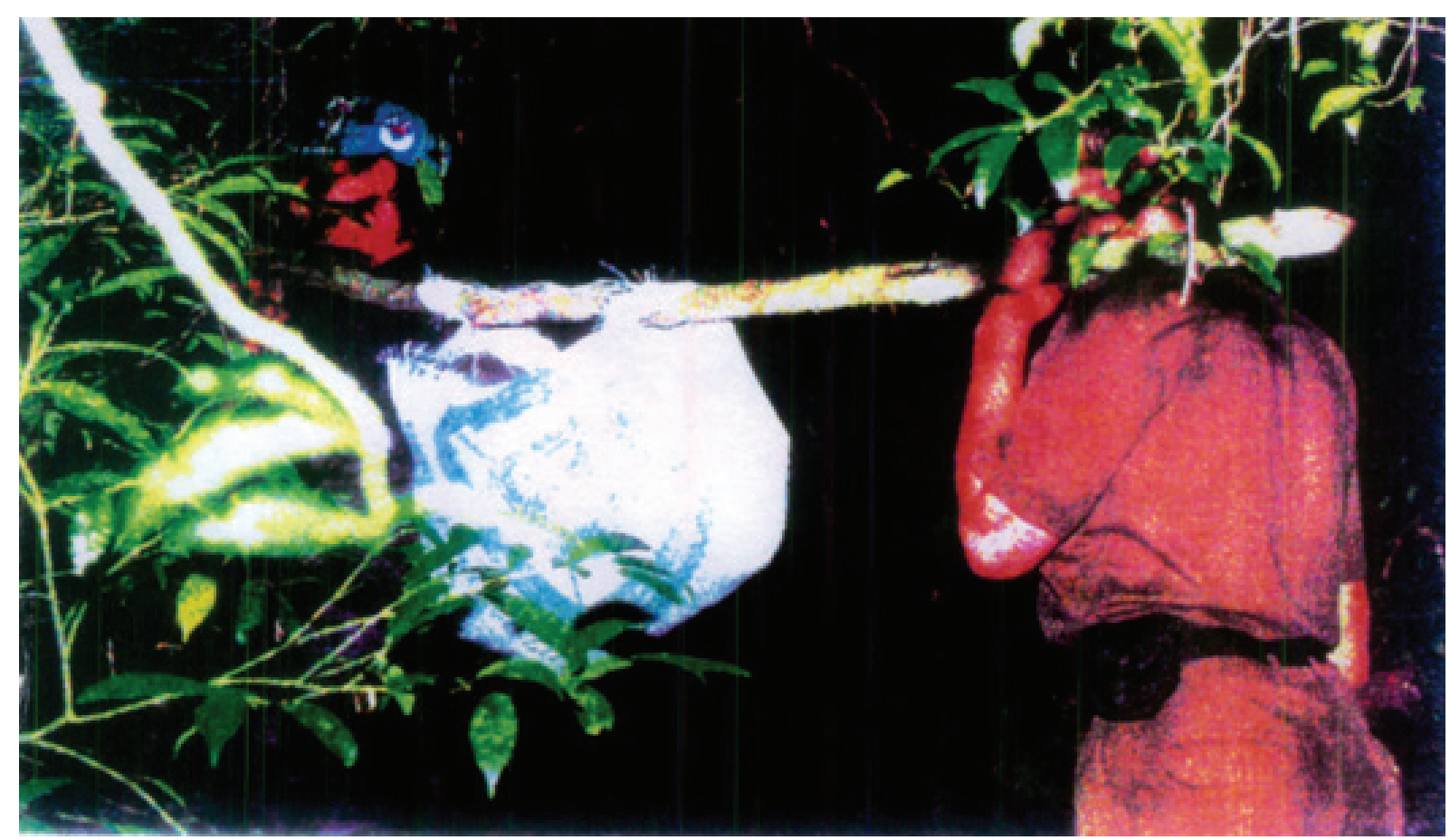

Figura 69B. Foto. Recipiente cerâmico da tradição Tupiguarani removido da área do Parque Nacional do Iguaçu. Fonte: I. Chmyz. Relatório Técnico sobre Arqueologia e a Etno-História da Área do Parque Nacional do Iguaçu/ CEPA/UFPR, Curitiba: 1999, p. 48.

Chmyz assim relata: (...) verifica-se que a tradição Tupiguarani instalou-se preferencialmente na margem do rio Iguaçu. (...) as demais ocorrências da tradição tupiguarani não puderam ser filiadas as fases devido à pequena amostragem (CHMYZ:1 999:71). Mais adiante Chmyz se ressente novamente quanto ao tempo de pesquisa: (...) os traços arqueológicos referentes aos outros grupos indígenas identificados pelas pesquisas anteriores na região de Foz do Iguaçu, não foram detectados nas atuais. Tal resultado deve-se unicamente ao curto período de tempo dispendido na avaliação (CHMYZ: 1999:72).

A seguir as recomendações e sugestões de Chmyz ao final do trabalho. Selecionamos as que apresentam correlação com os Tupi-Guarani:

Tendo em vista os resultados da presente pesquisa arqueológica na área do Parque Nacional do Iguaçu, recomenda-se:

3. a realização de um projeto de pesquisa arqueológica na margem do rio Iguaçu, no trecho compreendido entre o córrego do Mingau e a rodovia BR-467, a das Cataratas. A pesquisa deve ser sistemática, possibilitando a localização de todos os sítios arqueológicos; deve incluir a topografia dos sítios descobertos e a coleta de amostras que permitam a sua filiação cultural. Objetiva-se principalmente, a identificação do sítio Tupiguarani que serviu de base para o estabelecimento da redução de Santa Maria, em 1626. 
4. que o sítio identificado com a redução de Santa Maria seja pesquisado intensamente e que, com os resultados desta, se desenvolva um projeto de reconstrução das estruturas que o compunham. para fins turísticos-culturais.

6. a localização do sítio Tupiguarani existente na margem do rio Iguaçu, junto ao porto de balsa da estrada do Colono, contando com a indicação de guarda florestal (policial Rubens Luiz Barreto). 12. que sejam arrolados os documentos históricos de posse do parque com a avaliação do estado de conservação para serem devidamente acondicionados.

13. a promoção de pesquisa de história-oral junto aos moradores vizinhos ao Parque, especialmente àqueles mais idosos e aos que de alguma forma atuaram na área.

15. a produção de um documentário histórico sobre a ocupação indígena antes e após a chegada dos europeus na região para fins educativos e turísticos-culturais. Deverá ter o assessoramento de especialista nas áreas de história, arqueologia e antropologia. (CHMYZ: 1999:75-6)

De todo estes materiais disponíveis: etnográficos produzidos por mim e por outros autores, arqueológicos produzidos por Ambrosseti e Chmyz, históricos por todos citados e Jose Maria de Britto e turísticos produzidos pelo Parque, podemos inferir algumas questões:

- que os Guarani habitavam a área que hoje é considerada como parte do Parque Nacional do Iguaçu, fundamentalmente nas margens do rio Iguaçu, próximo às Cataratas;

- a certeza de que existiu ali, a partir de dados históricos e etnográficos, a redução jesuítica denominada Santa Maria, ocupada pelos Tupi-Guarani, não tendo sido localizado o sítio arqueológico unicamente por falta de disponibilidade da direção do Parque de oferecer ao arqueólogo tempo hábil para a pesquisa;

- um claro descontentamento do pesquisador com o trabalho realizado, tanto pela falta de tempo hábil disponibilizado, quanto pela restrição de áreas para proceder a pesquisa; apesar disso o Professor Chmyz havia já encontrado urna funerária Tupi-Guarani no interior do Parque, e posteriormente quando foi autorizado somente a realizar suas pesquisas nos limites externos do Parque, ao fazê-lo encontrou inúmeros sítios Tupi-Guarani nas bordas do referido Parque. Assim a presença Guarani foi constatada no interior e nas bordas do Parque de forma evidente. $\underline{O}$ Professor Chmyz relatou em contato pessoal, que este material produzido sobre o PNI, foi o único material produzido por ele, que não pode ser publicado.

- Quanto ao material de divulgação turística do Parque Nacional do Iguaçu está claro a omissão quanto a presença Guarani recente no interior do Parque, o que nos leva a crer, a intenção de tentativa de apagar a imagem Guarani associada ao Parque para o publico em geral, assim 
como a intenção de não levantar nenhuma questão, que possa levar a relacionar algum direito indígena sobre as terras ocupadas pelo Parque.

Quando o IBDF (atual IBAMA) ocupou os territórios Guarani na região que hoje é o Parque Nacional do Iguaçu, já vigorava legislação federal que defendia o direito à posse das terras pelos indígenas: Quanto a Aldeia Guarani ocupada no início da década de 40 vigorava a Constituição de 1937, artigo 154, em que determinava: Será respeitada aos silvícolas a posse das terras em que se achem localizados em caráter permanente, sendo-lhes, no entanto, vedado aliená-las. Quanto a Aldeia São João Velho, ocupada no início da década de 60 vigorava a Constituição de 1946, artigo 216, o qual determinava: Será respeitada aos silvícolas a posse das terras onde se acham permanentemente localizados, com a condição de não a transferirem (CARNEIRO DA CUNHA: 1987:901). Assim está claro o abuso de poder, culminando em esbulho da população indígena.

Quanto as aldeias Colônia-Guarani e Oco'y-Jacutinga, os indígenas de Oco’y informaram a respeito de ter havido em suma, também esbulho. Porém, informações pertinentes à estas duas aldeias, passaram a ser registradas a partir de 1976 em documentação, os quais perfazem quase 30 anos de informações trocadas entre as instituições envolvidas. Estes materiais se encontram no Centro de Documentação da FUNAI. Assim esses materiais foram pesquisados, e novamente foi aberta outra "lente de aumento" sobre o tema, no qual irão ser relacionados as informações dos indígenas com a documentação institucional envolvida. Estes materiais serão descritos no próximo capítulo, Capítulo 5. Ainda neste capitulo iremos dar um breve relato dos acontecimentos nestas duas aldeias, para depois relatar em detalhe no próximo capítulo.

- Aldeia Colônia-Guarani: Esta aldeia localizada na antiga Três Lagoas, hoje Santa Teresinha, periferia da cidade de Foz do Iguaçu, atualmente é um bairro, denominado paradoxalmente de “Vila Guarani”. Há muitos indivíduos vivos no Oco’y, que viveram em Colônia-Guarani, foram colhidos seus depoimentos, assim como depoimentos de não índios, antigos moradores da região, os quais comprovam a ocupação indígena no local.

Segundo relato dos indígenas antigos habitantes de Colônia-Guarani, as famílias Guarani foram expulsas à força por funcionários do INCRA, os quais para isso atearam fogo em suas casas, atiraram seus pertences na estrada, ameaçando-os com armas, obrigando desta forma e ao final, a retirada em caminhões "disponibilizados" pelo INCRA. Os fatos se deram no ano de 1971, sem qualquer intervenção da FUNAI. Foram reassentados pelo INCRA em seu território, colonos, antigos moradores do atual Parque Nacional do Iguaçu. Estes últimos haviam sido desapropriados em função do estabelecimento da Unidade de Conservação/UC, que é de uso indireto, ou seja, não pode haver indivíduos morando na UC. 
- Aldeia Oco’y-Jacutinga: Segundo informam os depoimentos dos indígenas Guarani, sendo eles expulsos sucessivamente dessas terras, Aldeia Guarani, Aldeia São João Velho e Aldeia Colônia-Guarani, muitos dos habitantes dessas terras, como é o exemplo da própria Dona Narcisa, juntaram-se aos parentes na aldeia do Oco'y-Jacutinga, local este, que ainda era mais afastado dos interesses da sociedade envolvente, interesses que estavam concentrados em torno de Foz do Iguaçu. Outras famílias dessas antigas aldeias, dirigiram-se compulsoriamente, obrigados pelo governo, para aldeias Guarani localizadas no Paraguai.

A população do Oco'y-Jacutinga passou a ser também esbulhada por funcionários do INCRA em 1973, por meio dos mesmos métodos e motivos acima relatados, com relação a ColôniaGuarani. Foram reassentados pelo INCRA na parte Leste de seu território, mais colonos, antigos moradores do atual Parque Nacional do Iguaçu. A Terra Indígena restante à Oeste, junto, às margens do rio Paraná, a população indígena ficou restrita. Após 1973 vários grupos de famílias da população indígena dessa antiga aldeia, foram sendo expulsos sucessivamente para o Paraguai, sendo assustados por indivíduos, que afirmavam que a área seria alagada pela hidrelétrica e se não saíssem iriam morrer afogados. Esta parte do território indígena restante foi coberta pelas águas do reservatório da Usina Hidrelétrica de Itaipu em 1982. Cabe informar que o INCRA desde 1971 já tinha conhecimento que esta parte do território indígena à Oeste seria inundada, o que fica claro a má fé.

Apenas uma parte diminuta da população indígena que ainda restava no Oco’y-Jacutinga foi reconhecida como indígena, e esta composta de apenas 4 famílias, foram reassentadas na atual Terra Indígena Avá-Guarani do Oco’y. As outras famílias não reconhecidas como indígenas, somadas a famílias que estavam sem terra perambulando na região, assim como famílias que haviam sido obrigadas a ir para o Paraguai, quando ficou definida a "compensação" com a terra de Oco’y, se dirigiram também para a área nova. O que causou uma superpopulação num território bastante reduzido, território de dimensões e qualidade ambiental, que como veremos a seguir, não foram observadas as normas legais para a transferência da população indígena.

\subsection{A persistência Guarani em se manter em seu território localizado no oeste paranaense}

Segundo relato dos indígenas aconteceu de forma semelhante o desaparecimento das outras 28 (vinte e oito) aldeias Guarani existentes no Brasil, já citadas (Figura CD-Figura 64. Mapa. 
Identificação de 32 aldeias Guarani...) neste capítulo, “os brancos tomaram”. Ao se observar o oeste paranaense no mapa citado, nota-se a presença entre 1940 a 1982 das 32 (trinta e duas) aldeias, levantadas por esta pesquisa, segundo depoimento de dois indígenas. Comparando com a situação na atualidade, como se vê nas Figuras anteriores (CD-Figura 9. Mapa. Dispersão geográfica atual Guarani no Brasil, Paraguai e Argentina (2004) e CD-Figura 10. Mapa. Os Guarani na fronteira Brasil, Paraguai e Argentina/2008 apresentadas no capítulo 2), desapareceram todas as 32 aldeias do local. Ao mesmo tempo pode-se observar nestes últimos dois mapas a existência de grande concentração de aldeias Guarani na região fronteiriça, no Leste do Paraguai, para onde se dirigiram nesse período, segundo relato dos indígenas por coibição no Brasil, muitas famílias indígenas, que nascidas no Brasil, foram então no período, expulsas de suas terras.

Essas expulsões se deram através de violência e fraude, em detrimento dos direitos dos Guarani: houveram massacres, coibição com armas, ocorrendo desrespeito em todas as épocas à legislação que defendia os direitos indígenas sobre as terras que tradicionalmente ocupavam.

Após o desaparecimento das 32 aldeias existentes no oeste paranaense, acreditávamos que apenas um agrupamento indígena Guarani havia resistido na região brasileira, pelo menos no sul do oeste do Paraná essa era a realidade, o agrupamento que resistiu era parte da população do Oco'y-Jacutinga, a qual se dirigiu para a Terra Indígena Avá-Guarani do Oco’y, se reestabelecendo em aldeia em 1982, no município de São Miguel do Iguaçu.

Dada a impossibilidade dessa população de se manter nestas terras, por motivos já expostos no capítulo 3, que se resume a expressiva falta de terras, acrescido do fato de que é população indígena que em geral apresenta altas taxas de crescimento demográfico, esses Guarani através de árdua luta pacífica, foram retomando territórios nessa região, assim um grupo de famílias de Oco’y formou o Tekoa Ãnetete em 1997, no município de Diamante D’Oeste, posteriormente surgiu a Terra Indígena Itamarã, dissidência de Ãnetete em 2006, também no município de Diamante D’Oeste. Assim nesta região suldoeste do Paraná já eram três as aldeias.

Em nossos trabalhos no Oco'y, os Guarani vez ou outra se referiam também à outras comunidades Guarani existentes mais a norte, distantes dali do Oco’y, na região de Guaíra. Estávamos concentrados com a atenção no Oco’y e naquela altura dos acontecimentos não tínhamos muito conhecimento a respeito dos Guarani da região de Guaíra. Foi então quando um grupo de famílias dos Guarani do próprio Oco’y foi viver em Guaíra, próximo a outras comunidades ali existentes. Posteriormente esse mesmo grupo de famílias voltou para Ãnetete, e mais tarde formaram aldeia própria, a Aldeia de Itamarã. 
Somente em anos recentes, dado o conflito de terras, fomos chamados para prestar serviços na região de Guaíra. Até então, dado que estas terras indígenas não estão demarcadas ainda, como tantas outras da etnia, elas não constavam em mapas oficiais, portanto não tínhamos conhecimento claro a respeito delas, até a ida a região. Encontramos 13 (treze) aldeias Guarani na região, todas sofrendo graves embates em torno da legitimação de suas terras, preconceito, novamente sendo acusados de que são "paraguaios" por parte da população da região, conflitos de terras com colonos, conflitos com Itaipu e assim por diante. São elas:

Tabela 4.3. População Indígena vinculada a Coordenação Técnica Local/CTL Costa Oeste do Paraná subordinada a Coordenação Regional da FUNAI de Chapecó/SC

\begin{tabular}{|l|l|}
\hline Terra & Município \\
\hline Tekoha Porã & Guaíra \\
\hline Tekoha Karumbey & Guaíra \\
\hline Tekoha Marangatu & Guaíra \\
\hline Tekoha Yy Hovy & Guaíra \\
\hline Tekoha Jevy & Guaíra \\
\hline Tekoha Mirim & Guaíra \\
\hline Tekoha Guarani & Guaíra \\
\hline Tekoha Araguaju & Terra Roxa \\
\hline Tekoha Nhemboete & Terra Roxa \\
\hline Tekoha Vy'a Renda & Santa Helena \\
\hline Tekoha Avá Guarani do Ocoy & São Miguel do Iguaçu \\
\hline Tekoha Anetete & Diamante D'Oeste \\
\hline Tekoha Itamarã & Diamante D’Oeste \\
\hline
\end{tabular}

Fonte: Maria Lucia Brant de Carvalho/Antropóloga/CTLSP/FUNAI. Informação Técnica nº 009/ CTLSP/FUNAI. SP 20.04.2012 dirigida ao Sr Aluísio Azanha/DPT/FUNAI/Bsb.

Portanto, envolve esta CTL, 13 terras indígenas no Oeste paranaense, a saber: 7 terras no município de Guaíra com população em torno de 900 indígenas; 2 em Terra Roxa; 1 em Santa Helena com população de 93 indígenas; 2 em Diamante D’Oeste; e 1 em São Miguel do Iguaçu com população em torno de 800 indígenas. Portanto, deve existir quase 3 mil índios Guarani na disputada costa oeste do Paraná, atualmente.

Foi a respeito deles o recente pronunciamento da Ministra da Casa Civil Gleisi Hoffmann, em decidir interromper os processos de Identificação da FUNAI em andamento. 
Assim apesar das pressões para expulsá-los do Brasil, há visível resistência indígena em direção à manutenção de seu território tradicional no Brasil.

Por fim um cântico Guarani, cantado às noites na casa de Reza no Oco’y:

\title{
Cântico Guarani entoado pelo coral infanto-juvenil na Casa de Reza da Terra Indígena Avá-Guarani do Oco'y. Grupo TAPE VY'A
}

\author{
Canto 1: Nhanderuete \\ Nhanderuete nhandexy ete amba'i re \\ Nhanema'endu' a mavy jaje'oi opy'i re \\ Nharoporandu nhaderete'i, Nharoporandu nhaderete' $i$ \\ Jaguata ma vy tape miri re Nhavae aguã jaexa \\ Aguã para rovai yvy ku'iju re Javy' a aguã \\ Aguã para rovai yvy ku'iju re Javy' a aguã \\ yvy ku' iju, yvy ku' iju
}

Tradução Canto 1: Nosso Deus

Nosso Deus, Nossa Mãe eterna, quando lembramos do nosso altar sagrado

Vamos para a nossa Casa de Reza

Para fortalecer o nosso espírito, Para fortalecer o nosso espírito

Quando caminhamos pela estrada infinita para chegar ao outro lado do oceano

E na Terra sem Mal seremos felizes

E na Terra sem Mal seremos felizes

Terra sem Mal, Terra sem Mal

Canto 2:

Mba'e puja'i kuery

Mba'e puja'i kuery

Mba'e puja'i kuery

Tanhapu a pave nhambojerojy xondaro' $i$

Tanhanebaraete, Tanhanebaraete

Nhamandu rexaka vy, nhamandu rexaka vy 


\section{Tanhapu'apave jajerojy}

Joupiveguai, Joupiveguai

\section{Tradução Canto 2:}

Tocador, vamos nos levantar todos os que estão aqui Tocador, vamos nos levantar todos os que estão aqui Tocador, vamos nos levantar todos os que estão aqui

Para tocando a dança do xondaro os soldadinhos marcharem Para nos fortalecer, Para nos fortalecer

Quando o sol nascer, quando o sol nascer Vamos nos levantar e marchar Todos os que estão aqui juntos, Todos os que estão aqui juntos. 


\section{CAPÍTULO 5 \\ O PROCESSO OFICIALMENTE REALIZADO DE DESTERRITORIALIZAÇÃO DA POPULAÇÃO INDÍGENA AVÁ-GUARANI DA TERRA DE OCUPAÇÃÓ TRADICIONAL OCO'Y-JACUTINGA E A RETERRITORIALIZAÇÃO NA ATUAL TERRA INDÍGENA AVÁ-GUARANI DO OCO'Y. ASPECTOS ANTROPOLÓGICOS E JURÍDICOS}

\subsection{Primeiras palavras}

Neste capítulo procuramos caracterizar de que forma se deu o processo, de população autóctone da região, que teria todos os direitos garantidos sobre as terras que ocupava, para a situação presente, de uma população vivendo em terras inadequadas sob o ponto de vista fundiário e ambiental, sofrendo riscos sérios de saúde, enfim, sendo colocada em risco a própria sobrevivência física e cultural desses indígenas. Assim se fez necessário verificar como se deu o oficialmente processo de transferência da população indígena, do território tradicional que ocupavam no Oco’y-Jacutinga, para o atual território no Oco’y.

O trabalho de pesquisa foi realizado com base na análise da documentação oficial existente nos arquivos do Centro de Documentação da Fundação Nacional do Índio/ CEDOC/FUNAI, processo $n^{\circ} 1053 / 1976$, documentação esta, trocada fundamentalmente a partir de 1976, entre as Instituições FUNAI, INCRA e Usina Hidrelétrica de Itaipu. Em suma visaram o reconhecimento da população indígena, os procedimentos adotados de desterramento e assentamento da mesma, assim como alguns outros procedimentos paralelos. Foi considerada ainda, a própria história oral contada pelos Guarani, relato fundamental sobre como os conflitos ocorreram. É documentação vasta e complexa, que compreende o período de 1976 a 2005, ou seja, 29 anos de procedimentos.

Foram entregues após a pesquisa concluída, cópia do material utilizado para a pesquisa, a totalidade dos documentos oficiais contidos nos arquivos da FUNAI, o próprio processo $\mathrm{n}^{\circ}$ 1053/1976, ao Procurador da Republica Dr Jorge lrajá Louro Sodré para análise competente do Ministério Publico Federal de Foz do lguaçu, no ano de 2004, assim como o Laudo Antropológico - Parte II, correspondente a esta parte da pesquisa ${ }^{1}$. Os outros Laudos Antropológicos já

\footnotetext{
${ }^{1}$ Este capítulo toma em parte informações do seguinte trabalho. BRANT DE CARVALHO, Maria Lucia. LAUDO ANTROPOLÓGICO. $2^{\text {a }}$ Parte: O processo de desterramento da população indígena Avá-Guarani da região do Oco’y-Jacutinga e o reassentamento na Terra Indígena do Oco'y: Aspectos antropológicos e jurídicos. Vol. III-III. Ref: Comunidade Indígena AVÁ-GUARANI. TERRA INDÍGENA OCO'Y. Município de São Miguel do Iguaçu. Estado do Paraná. Brasil. São Paulo: AERBAURU/SP/FUNAI/MJ. 2005. Vol I. 174 p.
} 
haviam sido entregues, a todos as instituições envolvidas, Presidência da FUNAI, o próprio Ministério Publico Federal de Foz do lguaçu, a Justiça Federal de Foz do Iguaçu e a VI Câmara de Coordenação e Revisão do Ministério Público Federal em Brasília. Assim o Laudo Antropológico II e seu anexo, tema deste capitulo, também foram entregues a todas as Instituições citadas.

Afirmávamos que através deste Laudo (Laudo Antropológico Parte II), os peritos dessas instituições citadas, poderiam de posse da documentação oficial dos arquivos da FUNAI, verificar a veracidade das informações aqui contidas, assim como em que bases legais se deram os fatos descritos, os quais havíamos cotejado com a legislação indigenista respectiva de cada época.

Refazendo o itinerário histórico e geográfico vivido pela população Guarani, a população indígena Avá-Guarani (Guarani-Nhandeva) do Oco’y-Jacutinga teve seu território de ocupação tradicional invadido por funcionários do INCRA em 1973. Dessa forma, ela foi compulsoriamente deslocada para pequena parcela do próprio território indígena à margem esquerda do rio Paraná. Em 1982 essa área restante foi inundada pela represa da Usina Hidrelétrica de Itaipu. Cabe registrar que o INCRA, desde 1971, conhecia o traçado das áreas que seriam inundadas pela hidrelétrica. Dessa forma deu-se a perda total do território indígena. Os dois processos de desterramento, da forma como se deram, sob o ponto de vista do direito indígena constituído, foram marcados pela ilegalidade.

Reassentada a população em 1982 na Terra Indígena Avá-Guarani do Ocoy, São Miguel do Iguaçu, Paraná, encontrou um local muito menor que o original, inexistindo condições ambientais semelhantes ao território anterior, questões que deveriam ter sido garantidas pelas normas constitucionais, no decorrer do processo de transferência. As terras indígenas são de uso exclusivo e, no entanto, os Guarani “dividem” a área com a APP da Itaipu, como também com algumas glebas de colonos, que foram antes desapropriados e não indenizados pelo INCRA, instituição a qual na época reservara a área para ser APP de Itaipu. Passados três décadas vivendo nesta situação, a análise dos fatos demonstra que o atual território caracteriza-se como espaço insuficiente em extensão e, sob o ponto de vista ambiental, inadequado, tendo como consequência inúmeros prejuízos à saúde e a sobrevivência física e cultural da população indígena, fatos que, como vemos, também contraria a legislação indigenista.

O material existente nos arquivos da FUNAI sobre este agrupamento indígena demonstra que os direitos indígenas constitucionalmente consagrados pela Iegislação de todas as épocas, foram utilizados de forma equivocada, deturpada seria a palavra correta, pelos representantes do poder executivo, culminando no repasse de um espaço geográfico extremamente inadequado aos 
Índios Guarani. Apontamos assim os “erros" cometidos durante os governos militares pelas agencias do Estado brasileiro, a saber, FUNAI, INCRA, IBDF/IBAMA e Usina Hidrelétrica de Itaipu e as consequências desastrosas advindas desses fatos, para a população Guarani, as quais, já vimos no Capitulo 3.

Desta forma, a reavaliação do processo, referente aos procedimentos adotados pelos representantes do Estado Nacional, no processo de desterramento da população Guarani do Oco'yJacutinga e reassentamento na Terra Indígena do Oco'y, deve ser examinada a luz do direito constitucional. O material legislativo é o substrato científico e legal, que baseado na Antropologia e no Direito Indígena, foi consolidado pela Iegislação federal. Portanto, estes materiais devem ser revistos e analisados a luz dos fatos acontecidos, relatados pelos próprios Guarani, cobertos amplamente através da documentação oficial da época pela FUNAI, sendo cotejados com os direitos indígenas constitucionalmente estabelecidos. Os três conjuntos de materiais são norteadores de todo os encaminhamentos possíveis, para que se possa destinar solução fundiária ao grupo indígena Avá-Guarani do Oco’y sendo, portanto, o tema deste capítulo.

\subsection{O processo histórico de esbulho ocorrido nas terras indígenas da região}

No final do século XIX, o Oeste paranaense ainda era praticamente fechado à comunicação com o resto do país. O acesso dava-se pelo Rio da Prata, Rio Paraná, tendo a região ainda, maior influencia das populações provenientes da Argentina e do Paraguai.

A partir de 1880 a região passa a ser ocupada por projetos de colonização, através de concessão de terras pelo governo imperial do Brasil. Em 1889, antes da queda do governo imperial, este concede terras no extremo oeste paranaense à Estrada de Ferro São Paulo - Rio Grande, subsidiária da Brazilian Railways Company, com vistas à construção de ferrovia.

$\mathrm{O}$ avanço dos projetos de colonização na região continua ao longo dos governos republicanos, temos registros mapeados até a década de 60 do século XX, como vimos no capítulo anterior (Figuras 63. Mapa A B, C, D e E).

O Paraná passa a ser ocupado ao norte, pela influência paulista, no plantio de café. O sul e sudoeste são ocupados por gaúchos e imigrantes de várias nacionalidades (alemães, italianos, poloneses e ucranianos), os quais passam a trabalhar também com erva-mate e desmatamento para exploração de madeira. Os Guarani aparecem em alguns momentos da história, como ape- 
nas coadjuvantes, citados no referido Atlas Histórico do Paraná (1986), como trabalhadores da erva-mate, nenhuma referencia é feita sobre as terras indígenas.

Os Avá-Guarani da atual Terra Indígena do Oco’y, afirmam que desde os anos 40 passaram a sentir a pressão da entrada de imigrantes nas terras do oeste paranaense. Que algumas vezes neste período o Instituto Nacional de Colonização e Reforma Agrária/ INCRA, já havia tentado retirá-los da região. Um idoso Guarani, habitante do Oco’y, a esse respeito afirma:

Já em 1948 o INCRA, querendo nossa terra, escreveu carta para o SPI (antigo Serviço de Proteção ao Índio) e eles levaram todo o povo da aldeia Guarani (área ocupada hoje pelo Parque Nacional do Iguaçu em Foz do lguaçu) e de Toledo para a aldeia do Rio das Cobras (Município de Nova Laranjeiras e Espigão Alto do lguaçu/Pr). Alguns não querendo ir, fugiram para o Paraguai.

Eles davam tiro na perna de quem fugia! Muitos voltaram... .

Assim com o levantamento feito junto aos informantes Guarani pode-se verificar que até 1940 havia no Tekoa Guassu um conjunto de aldeias Guarani, tendo como ponto central a região da Foz do lguaçu. Os habitantes dessas aldeias possuíam interligações de parentesco e consideravam-se ocupando um mesmo Território, praticamente continuo. Nele haviam, segundo puderam visitar e conhecer dois informantes Guarani, cerca de 32 aldeias na língua guarani 32 Tekoas $^{2}$. Esta área media, segundo cálculos efetuados pelo Departamento de Assuntos Fundiários/DAF FUNAI/Bsb, aproximadamente 132.000 hectares (DAF/FUNAI: 2001).

Entre os anos 40 e 80 do século XX, as 32 aldeias Guarani, incluindo a aldeia do Oco’y Jacutinga desapareceram por força dos impactos das frentes de expansão. A população indígena foi esbulhada de seu território de ocupação imemorial, sendo obrigada a migrar para outras aldeias localizadas tanto no Brasil como no Paraguai e Argentina. Esta região foi sendo paulatinamente tomada pelos "brancos", através da formação de posses e pequenas propriedades, vilarejos, cidades, propriedades maiores e por projetos governamentais. Isto se deu, apesar da existência de legislação na época, que poderia defender os direitos indígenas sobre a posse dos territórios que ocupavam.

Entre as aldeias mais significativas para a população do atual Oco’y, em que havia maior envolvimento de suas populações, pela proximidade física das parentelas, são aquelas já mencionadas:

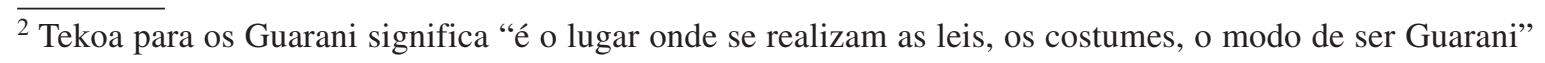


- Aldeia Guarani e Aldeia São João Velho; localizadas em atual Unidade de Conservação (Parque Nacional do lguaçu) administrada pelo IBAMA. Esbulhados pelo IBDF, antecessor do IBAMA;

- Aldeia Colônia Guarani; localizada na antiga região de Três Lagoas, hoje Santa Teresinha, subúrbio/bairro periférico de Foz do lguaçu. O local da aldeia hoje é denominado "Vila Guarani". Esbulhados pelo INCRA;

-Aldeia Oco’y-Jacutinga; localizada hoje, parte em assentamento de colonos, terras em que tivemos a informação recente que estão inclusive as terras do Diretor-geral da Itaipu Jorge Miguel Samek (a ser confirmado), outra parte coberta pelas águas do reservatório da Usina Hidrelétrica de Itaipu; Esbulhados respectivamente, pelo INCRA e pela Usina Hidrelétrica de Itaipu.

Os quatro casos mencionados contaram com a omissão do SPI e depois da FUNAI, órgãos de governo encarregados da defesa dos direitos de seus tutelados, os povos indígenas.

Quanto às aldeias Guarani e São João Velho, perdidas pelos indígenas respectivamente nas décadas de 40 e 60 do século XX, já foram descritas em capitulo anterior os fatos narrados pelos indígenas idosos de Oco’y. Eles eram os habitantes originais das Cataratas do Iguaçu. Sobre eles infelizmente não há documentação registrada na FUNAI. Os registros da FUNAI sobre a região do oeste paranaense começam a aparecer somente na década de 70 , precisamente no ano de 1976, os quais se referem no tempo, desde 1971, quando a Aldeia Colônia-Guarani estava em jogo. Assim vejamos inicialmente qual foi o tratamento institucional dado pelas instituições a esta aldeia Colônia-Guarani e em seguida o tratamento dado pelas mesmas instituições ao Oco'yJacutinga.

\subsubsection{Aldeia Colônia Guarani}

Os habitantes indígenas de Colônia-Guarani foram esbulhados, obrigados a ceder o lugar em função do assentamento de colonos pelo INCRA, no local. Os colonos estavam sendo obrigados a se retirar da área que se tornou o Parque Nacional do Iguaçu, Unidade de Conservação de uso indireto destinado somente à pesquisa e turismo, assim foi proibido "moradores", mesmo que antigos habitantes como os próprios indígenas e esses colonos. Há muitos indivíduos ainda vivos no Oco’y, que viveram em Colônia-Guarani, foram colhidos seus depoimentos, assim como depoimentos de não índios, antigos moradores da região, os quais comprovam a ocupação indígena 
no local. Segundo relato dos indígenas, antigos habitantes de Colônia-Guarani, as famílias Guarani foram expulsas a força por funcionários do INCRA, os quais para isso atearam fogo em suas casas, atiraram seus pertences na estrada, ameaçando-os com armas, obrigando desta forma, a retirada. Os fatos se deram no inicio da década de 70, provavelmente em 1971, sem qualquer intervenção da FUNAI.

Por outro lado, começam a surgir relatos da FUNAI de Curitiba, somente em 1976, sobre os índios da região do oeste paranaense, especificamente relativos ás aldeias de Colônia-Guarani e do Oco’y-Jacutinga. Como os documentos são inúmeros, tentaremos reter o que de mais importante descrevem, inclusive grifando as informações mais importantes. Os documentos fazem parte de processo $n^{\circ}$ 1053/76, do Centro de Documentação/CEDOC da FUNAI/Bsb, sendo sumamente esclarecedores do contexto em questão.

Em ofício do Delegado Regional da FUNAI em Curitiba $/ 4^{\circ} \mathrm{DR} / \mathrm{FUNAI}$, dirigido ao Presidente da FUNAI, (Anexo 1a) são colocados os seguintes argumentos:

Em 1971, esta DR (FUNAI) foi alertada pelo Comando do $1^{\circ}$ Batalhão de Fronteiras e pelo Chefe do DFZ-01, Distrito de Terras do PR e SC do IBRA, a respeito da existência de grupo tribal e da conveniência de regularização da área de terras por ele ocupado e localizado no município de Foz do Iguaçu, assuntos esses encaminhados à apreciação da administração central da FUNAI. No início do ano passado (1975), a FUNAI solicitou a Coordenadoria Regional do INCRA/PR esclarecimentos acerca da Colônia Guarani, situada na localidade Santa Teresinha ou Três lagoas, nas proximidades da rodovia que demanda a Foz do Iguaçu, tendo esta DR, pelo ofício no 110/75Gab/4 DR, de 25.04.75 após ligeiro histórico, proposto a constituição de Equipe FUNAI-INCRA para efetivação de diligências necessárias à localização e reunião de grupos tribais, à delimitação da Colônia Guarani e de outras áreas indígenas existentes na região e à efetiva ocupação das mesmas pelas comunidades silvícolas.

As dificuldades na consecução de recursos financeiros e viatura, bem como de servidores habilitados retardaram a composição dessa equipe, até que, em vista do ofício n ${ }^{\circ}$ INCRA-4 (09) nº 247/76. de 23.01.76, da Coordenadoria Regional do INCRA, que aludia à expedição de títulos em favor de 55 ocupantes da Colônia Guarani, foi necessário recorrer aos préstimos ... de que resultou o anexo relatório do servidor Nelson Silva (FUNAI):

(...) a Colônia Guarani foi demarcada pelo Distrito de Terras do Paraná e Santa Catarina do INCRA. dentro das terras da primitiva área ocupada por grupo tribal Guarani, onde viviam na década de 30. cerca de 40 famílias indígenas, algumas numerosas, chegando até a contar com 17 membros.

Informou também, o Cel Belo, atual Diretor do Parque Nacional do Iguaçu, que há uns dez anos 
(1966), quando no Comando do $1^{\circ}$ Batalhão de Fronteiras em Foz do Iguaçu, existiam famílias indígenas nessa área, também conhecida por Três Lagoas, com os quais manteve contato por intermédio do Sargento Orcídio A. Dias, o qual pessoalmente confirmou a informação.

Esse grupo tribal vivia quase que exclusivamente da caça e pesca e de alguma lavoura.... foi quase totalmente dizimado por epidemia de maleita no período de 48/50, tendo os remanescentes na década de 50/60, sob pressão dos civilizados, se retirado da área.

A área está toda cultivada, é toda cortada por estradas e ocupada por civilizados, não possui mais matas. (...) encontrei cerâmica Guarani.

(...) A área está toda intrusada, ...estando o INCRA com os títulos de 70 lotes prontos para ser entregues aos ocupantes.

Consta que não vive família indígena alguma na área, pois os índios remanescentes devem estar espalhados na região de Foz do Iguaçu e Paraguai, a que depende de mais minuciosa e demorada verificação.

$\underline{\text { Se, mediante tais diligências, se apurar a existência de famílias Guarani, talvez fosse possível localizá- }}$ los no Parque Nacional do Iguaçu/PNI, cujo Diretor, todavia, afirmou inexistirem índios no interior do mesmo. (Curitiba. 20.02.76. of. $n^{\circ} 045 / 76 / G a b / 4^{\circ}$ DR/FUNAI p/ Presidente/ FUNAI)

Portanto, em 1971 a FUNAI é alertada sobre a existência de agrupamento indígena no local pelo Comando do $1^{\circ}$ Batalhão de Fronteiras de Foz do Iguaçu, bem como da conveniência de se fazer uma diligência imediata para regularizar a área de terras por ele ocupada. Mas, somente após cinco anos, em 1976, a FUNAI realiza tal diligência, a partir de informação do INCRA referente à expedição de títulos em favor de 55 ocupantes não índios das terras de ColôniaGuarani. Assim, somente após a ocupação da área pelo INCRA e a consequente expulsão dos Guarani da mesma, a FUNAI se dirige ao local. O funcionário designado pela FUNAI confirma a existência recente de grupo indígena no local e também sua expulsão, atestando a intrusão da área. Mas, ao invés de trabalhar pela desintrusão destinando-a novamente aos Guarani, conforme o Estatuto do Índio vigente na época, tal funcionário não procura os índios na região, sugerindo que, se encontrados, fossem colocados no Parque Nacional do Iguaçu.

O próximo documento - ofício do INCRA para o Delegado Regional de Curitiba/FUNAI (Anexo 1b) indica que as famílias Guarani de Colônia-Guarani, foram encontradas pelo INCRA:

(...) comunicamos a consulta procedida por esta CR (INCRA) junto à DR do IBDF, sobre a possibilidade de localização das famílias Guarani na área do Parque Nacional do Iguaçu... .

Tendo em vista as constantes pressões que vem sofrendo esta CR, para que se proceda a titulação 
daquela área a seus ocupantes, sendo do inteiro conhecimento público que todo processo administra$\underline{\text { tivo encontra-se concluído }}$, faltando somente a liberação da área por esse Orgão (FUNAI) para a outorga dos títulos, vimos, nesta oportunidade, reiterar a Vossa Senhoria o valioso empenho no sentido de ser procedida a liberação da gleba para os fins propostos. (Curitiba 24/05/1976 ofício/ INCRA - 4(09) $n^{\circ} 1733 / 76$ p/ Del Reg. Curitiba/FUNAI)

Objetiva assim o INCRA assentar a população indígena de Colônia-Guarani no Parque Nacional do Iguaçu. Medida que é negada pelo IBDF. O INCRA solicita então a liberação da área pela FUNAI, ou seja, que atestasse que ali não havia índios.

Em ofício do Delegado Regional da $4^{\circ}$ DR/ Curitiba /FUNAI para o Presidente da FUNAI General Ismarth de Araujo Oliveira, (Anexo 1c) é afirmado:

Primeiramente refere-se à área de Colônia Guarani:

(...) apesar de o IBDF pronunciar-se contrariamente ao assentamento dos índios no PNI, insiste o INCRA na liberação das terras da Colônia-Guarani, para fim de titulação das mesmas em favor dos civilizados que as invadiram e as vêm ocupando, razão por que solicito decisão final de V. Exa.

Em seguida refere-se ao Oco’y-Jacutinga:

De outra parte, informa o INCRA que as terras ocupadas por famílias indígenas na região do Ocoi $\underline{\text { serão totalmente inundadas por efeito de instalação da hidrelétrica de Itaipu, motivo porque rogaria }}$ a V. Exa, entender-se com a administração central do INCRA no sentido de que determine à Coordenadoria Regional a manutenção das citadas famílias nas terras remanescentes do PIC-OCOI, em local próximo a represa a ser construída. (Curitiba 28/05/76 ofício n ${ }^{\circ}$ ilegível/76/Gab/4 $\mathrm{DR} /$ FUNAI p/ Pres FUNAI Gen. Ismarth de Araujo Oliveira)

O Delegado Regional da FUNAI/Curitiba dirige-se ao Presidente da FUNAI colocando dois problemas: 1) O IBDF nega o assentamento dos índios de Colônia-Guarani no Parque Nacional do Iguaçu/PNI. O INCRA insiste na liberação da área Colônia-Guarani em favor dos colonos ocupantes. Solicita decisão final do Presidente da FUNAI. 2) O INCRA informa que as terras habitadas pelos índios Guarani do Oco’y-Jacutinga serão totalmente inundadas pela represa da hidrelétrica de Itaipu. Porém, o próprio INCRA, é que havia desalojado também estes índios de seu território, empurrando-os para esse mesmo local referido, ainda em território indígena, que seria alagado por Itaipu, como veremos a frente quando dos depoimentos indígenas. 
Em documento interno do INCRA, (Anexo 1e) é afirmado (primeiramente refere-se à área da Colônia Guarani):

A Colônia Guarani localizada.... encontra-se totalmente ocupada por famílias de agricultores, já demarcada pelo PFP/ INCRA, no aguardo de apenas autorização da FUNAI, para que seja entregue os títulos a 70 ocupantes. Não existem famílias indígenas ocupando a área.

Em seguida refere-se ao Oco’y-Jacutinga, e ao seu próprio procedimento (INCRA) com relação aos Guarani desta localidade.

Acreditamos na deturpação dos informes chegados à Pres/FUNAI, referente ao procedimento hostil que estariam tendo as 8 famílias de remanescentes indígenas que habitam às margens do rio Paraná na área do PIC-OCOI I, por parte de servidores daquele Projeto. (Curitiba. 29.06.76. Doc. interno do INCRA)

O Presidente da FUNAI em ofício ao Presidente do INCRA, (Anexo 1d) primeiramente refere-se à área da Colônia Guarani:

Dirijo-me a V. Sa. em face dos problemas existentes na área da Colônia Indígena Guarani situada na localidade de Santa Teresinha ou Três Lagoas, na proximidade da rodovia que leva à Foz do Iguaçu, onde existe grupo tribal.

Dos entendimentos realizados junto ao CR/INCRA/PR, ficou patente a necessidade de imediata remoção do grupo para outro local, em face da preemência na liberação da área, em favor dos civilizados que a habitam e que terão seus lotes titulados por este Instituto.

Procurando solução para o problema... o INCRA encaminhou ao IBDF, expediente consultando aquele órgão sobre a viabilidade de instalar o referido grupo no Parque Nacional do Iguaçu/PNI. O IBDF responde negativamente, apoiando-se no princípio de desalojamento total de famílias nos parques nacionais.

Em seguida refere-se aos Guarani do Oco’y-Jacutinga:

Por outro lado os remanescentes Guarani, que residem na barra do rio Ocoi, Rio Paraná, onde o INCRA desenvolve o PIC-OCOI I, estão sendo ameaçados de despejo sumário, por parte de elementos desta entidade, sob a alegação que esta região será inundada por força das obras da Usina Hidrelétrica de Itaipu. 
Em face de problemas de tão significativa relevância, que vem preocupando sobremodo esta Presidência, solicito de V. SA um pronunciamento sobre a real situação daquelas áreas e das alternativas que poderão ser oferecidas, para equacionamento da situação que se apresenta realmente grave para as comunidades indígenas ali residentes. Tendo em vista que o IBDF não pode permitir a transferência dos índios para o PNI, consulto-lhes sobre a possibilidade do INCRA determinar uma área para a sua localização, onde possam exercer atividades para sobrevivência (caça, pesca e agricultura de subsistência). (Ofício no ${ }^{\text {ilegível/ junho/1976/PRES/FUNAI/BSB p/ PRES/INCRA) }}$

O pronunciamento do Presidente da FUNAI de então, é paradoxal, pois ao mesmo tempo em que afirma à respeito da atitude do INCRA para com os índios, que "estão sendo ameaçados de despejo sumário, por parte de elementos desta entidade", afirma em seguida: "consulto-lhes sobre a possibilidade do INCRA determinar uma área para a sua localização".

A FUNAI, técnica e legalmente, deveria intervir de antemão, afirmando sua responsabilidade institucional de defesa das Terras Indígenas, isto é, não permitir por princípio Constitucional uma "ação de despejo sumária" por parte de terceiros sobre terras de posse tradicional das Comunidades Indígenas. A responsabilidade de reconhecimento territorial era da FUNAI. O caso “de possível remoção do grupo tribal para outra área" - era ilegal. Não poderia assim, o Presidente da FUNAI à época, solicitar à terceiros uma incumbência técnica que era sua, e ainda solicitar área para a instalação dos índios ao próprio INCRA, órgão que os havia expulsado de $\underline{\text { suas terras. }}$

Em resumo, no caso de Colônia-Guarani, funcionários da FUNAI indicam inicialmente, de forma correta, que se deve proceder a demarcação, para que os índios não percam suas terras. Nada é realizado neste sentido. A FUNAI se "atrasa", não vai a busca dos Guarani que haviam sido expulsos da região. O INCRA ocupa a área, provocando a expulsão violenta segundo testemunho dos Guarani. Em seguida, com os 70 títulos de terras já prontos, o INCRA pressiona a FUNAI com o fato consumado: o assentamento de "civilizados" em área tradicional de ocupação Guarani. A FUNAI, por seu turno, não requer a área em favor dos índios conforme a legislação em vigor na época, Artigo nºs 25 e 38/Estatuto do Índio/1973.

Assim, o Território Indígena Colônia-Guarani, de posse dos índios, é perdido através de autorização do Presidente do próprio órgão indigenista, FUNAI, que afirma "a necessidade de imediata remoção do grupo para outro local em face da preemência na liberação da área, em favor dos civilizados". A autorização do Presidente da FUNAI se dá através de certidão negativa, a qual afirma que Colônia-Guarani não era local de habitação tradicional indí- 
gena. Portanto, solução em desacordo com a legislação. Em 21 de dezembro de 1976, são emitidos pelo INCRA, 62 títulos aos ocupantes, colonos da área indígena Colônia-Guarani. Os documentos comprobatórios dos fatos aqui arrolados, pertencentes ao processo $n^{\circ}$ 1053/1976/ FUNAI, estão em anexo (Anexo n⿳01).

Outro depoimento significativo é o do empresário Sr Silvio, atual proprietário de hotéis em São Miguel do Iguaçu (Marcom e Letto de Fiori). Ao informar ter visitado algumas vezes a referida aldeia Colônia-Guarani, a título de ajuda humanitária, relata ter batizado crianças com freiras da região. Apresentou fotos do fato narrado, feitas por ele mesmo e seus familiares, em 1958 na própria aldeia Colônia-Guarani. As fotos provas contundentes da ocupação tradicional Guarani no local, são apresentadas em anexo (Anexo n 2: Fotos de A a K). Afirmou ainda que os colonos que atualmente residem no local, são provenientes do Parque Nacional do Iguaçu, quando no início dos anos 70, foram obrigados a se retirar do local. O depoimento é comprovado pelos colonos que residem na região.

Assim, o INCRA e o Presidente da FUNAI à época, acabaram descumprindo os seguintes artigos legais, então em vigor, no caso de Colônia-Guarani:

Emenda Constitucional $n^{\circ} 1$ de 17. 10. 1969: Art. 198. As terras habitadas pelos silvícolas são inalienáveis nos termos que a lei federal determinar, a eles cabendo a sua posse permanente e ficando reconhecido seu direito ao usufruto exclusivo das riquezas naturais e de todas as utilidades nelas existentes.

Parágrafo $1^{\circ}$. - Ficam declaradas a nulidade e a extinção dos efeitos jurídicos de qualquer natureza, que tenham por objeto o domínio, a posse ou a ocupação das terras habitadas pelos silvícolas.

Parágrafo $2^{\circ}$ - A nulidade e a extinção de que trata o parágrafo anterior não darão aos ocupantes direito a qualquer indenização ou ação contra a União e a Fundação Nacional do Índio.

Vejamos o Estatuto da Terra, Lei $\mathrm{n}^{\circ} 4504$ de 30/11/1964, lei que rege a maioria dos atos relativos ao órgão governamental INCRA.

Título I. Capítulo I. Artigo $2^{\circ}$. É assegurado a todos a oportunidade de acesso à propriedade da terra, condicionada pela sua função social, na forma prevista nesta lei.

Parágrafo $4^{\circ}$. É assegurado às populações indígenas o direito à posse das terras que ocupam ou que $\underline{\text { lhes sejam atribuídas de acordo com a legislação especial que disciplina o regime tutelar a que estão }}$ sujeitas. 
Vejamos o Estatuto do Índio, Lei no 6001 de 19/12/1973. Os Artigos $2^{\circ}$, item V e IX, o Artigo 18, 25 e 38:

Artigo $2^{\circ}$. Cumpre à União, aos estados e Municípios, bem como aos órgãos das respectivas administrações indiretas, nos limites de sua competência, para a proteção das comunidades indígenas e a preservação de seus direitos; V- garantir aos índios a permanência voluntária no seu habitat, proporcionando-lhes ali recursos para seu desenvolvimento e progresso; IX - garantir aos índios e comunidades indígenas, nos termos da Constituição, a posse permanente das terras que habitam, reconhecendo-lhes o direito ao usufruto exclusivo das riquezas naturais e de todas as utilidades naquelas terras existentes;

Art. $18^{\circ}$. As terras indígenas não poderão ser objeto de arrendamento ou de qualquer ato ou negócio jurídico que restrinja o pleno exercício da posse direta pela comunidade indígena ou pelos silvícolas. Artigo $25^{\circ}$. O reconhecimento do direito dos índios e grupos tribais à posse permanente das terras por eles habitadas, nos termos do artigo 198, da Constituição federal, independerá de sua demarcação, e será assegurado pelo órgão federal de assistência aos silvícolas, atendendo à situação atual e ao consenso histórico sobre a antiguidade da ocupação, sem prejuízo de medidas cabíveis que, na omissão ou erro do referido órgão, tomar qualquer dos Poderes da República.

Artigo $38^{\circ}$. As terras indígenas são inusucapíveis e sobre elas não poderá recair desapropriação, salvo o previsto no Artigo 20.

Está claro que o Presidente da FUNAI da época, agiu ilegalmente, através de soluções políticas e não técnicas, em detrimento dos interesses e direitos indígenas na região.

Aconteceu de forma semelhante com as outras 31 aldeias Guarani, ver capitulo anterior. Esta tese analisa profundamente como ocorreu um destes trinta e dois processos de desterramentos, forçados e ilegais, acontecido em território tradicional de habitação Guarani, no denominado Oco'y-Jacutinga, a partir dos depoimentos indígenas, a documentação oficial e as leis vigentes na época.

\subsubsection{Aldeia Oco'y-Jacutinga: o processo de desterramento}

Até os anos 70 do século XX, o agrupamento Guarani, hoje aldeado na Terra Indígena do Oco’y, habitava o território do Ocoy-Jacutinga, um dos últimos redutos territoriais a desaparecer. O local, segundo depoimento dos indígenas, apresentava mata alta, preservada, situando-se 
no extremo oeste paranaense, entre o rio Oco’y ao norte e o córrego (denominado pelos Guarani de Arroio) Jacutinga ao sul, tendo como fronteira oeste o rio Paraná. (Figuras 70 A e B). Este território, segundo o INCRA, denominado mais tarde de TERRENO OCOI (1971), possuía extensão de 12.500 hectares. Os Guarani o identificam como "parte" de seu território de ocupação tradicional.

Os Guarani haviam delimitado o contorno de seu território entre-rios, os quais faziam fronteira com outras terras de população também Guarani. Esta pesquisa na tentativa de delimitar precisamente esse território, indagou aos Guarani a localização precisa do limite leste. Para eles a indagação pouco fazia sentido. A resposta dada foi: “Aqui tudo era Guarani, todas as aldeias fazia parte do Tekoa Guassu, não tinha limite". Realmente constatou-se impossível circunscrever uma "área" de terras isolada de outras terras da etnia, pois o macro território como um todo era de posse do conjunto de aldeias Guarani. É o que Ladeira se refere no inicio desta tese, não se pode confundir a noção de "terras" situadas em áreas geográficas delimitadas por nós "brancos", com a noção que os Guarani possuem de seu "território original", que é muito maior.

Explicam os Guarani que sendo eles expulsos dos três locais citados, aldeia São João Velho e aldeia Guarani, localizadas no atual Parque Nacional do Iguaçu, pelo IBDF atual IBAMA, e, da aldeia Colônia-Guarani, localizada hoje na "Vila "Guarani”" subúrbio/bairro de Foz do Iguaçu, pelo INCRA, muitos dos habitantes dessas aldeias, foram juntando-se em sucessivas levas aos parentes na aldeia Oco’y-Jacutinga, que estava mais afastada do centro de interesses dos "brancos" em Foz do Iguaçu. Quando a população do Oco’y-Jacutinga passou a ser esbulhada pelo INCRA em 1973, ficaram restritos à margem oeste de seu território, junto ao rio Paraná, a parte leste foi ocupada por colonos. A área então restante foi coberta pelas águas do reservatório da Usina Hidrelétrica de Itaipu em 1982, e após esse período esta população passou a viver na atual Terra Indígena do Oco’y, nas condições que vimos anteriormente. Convém lembrar que a expulsão dos Guarani de Colônia-Guarani e Oco'y-Jacutinga, pelo INCRA, foi em ambas aldeias, com o objetivo de assentar colonos que haviam sido retirados da área do Parque Nacional do Iguaçu. 


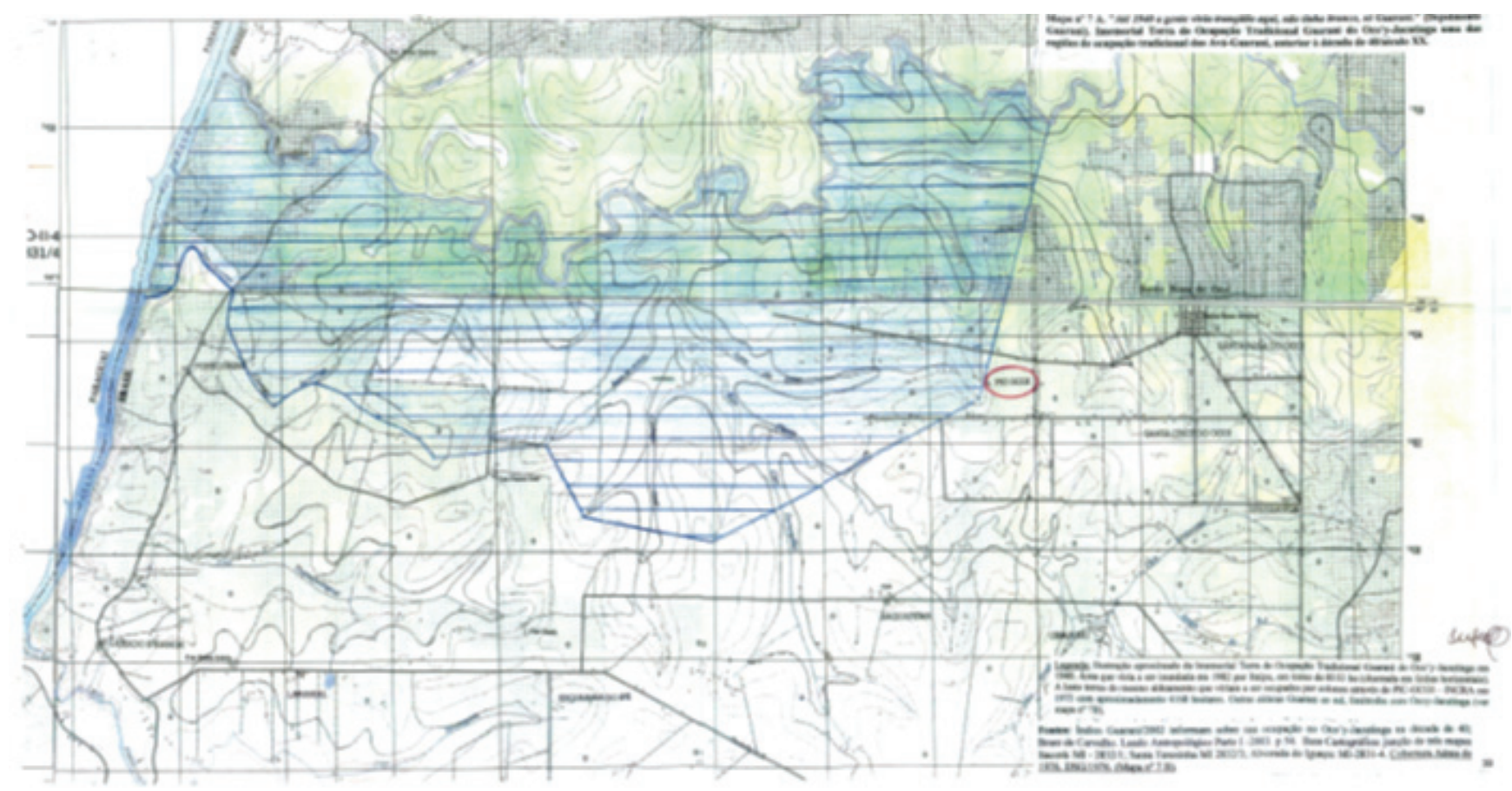

CD-Figura 70. Mapa A. Imemorial Terra de Ocupação Tradicional Guarani do Oco’y-Jacutinga uma das regiões de ocupação tradicional dos Avá-Guarani, anterior à década de 40/século XX.

Legenda: Ilustração aproximada da Imemorial Terra de Ocupação Tradicional Guarani do Oco’y-Jacutinga em 1940. Área que viria a ser inundada em 1982 por Itaipu, em torno de 8332 ha (chureada em linhas horizontais). A leste terras do mesmo aldeamento que viriam a ser ocupados por colonos através do PIC-OCOI - INCRA em 1973 com aproximadamente 4168 hectares. Outras aldeias Guarani ao sul, limítrofes com Ocoy-Jacutinga (ver mapa $\left.n^{\circ} 7 \mathrm{~B}\right)$.

Fontes: Índios Guarani/2002 informam sobre sua ocupação no Oco’y-Jacutinga na década de 40; Brant de Carvalho. Laudo Antropológico Parte I -2003, p. 54. Base Cartográfica: junção de três mapas Itacorá: MI - 2832/1; Santa Teresinha MI 2832/3; Alvorada do Iguaçu: MI-2831-4. Cobertura Aérea de 1976. DSG/1976. (CD-Figura 70. Mapa 7 B). 


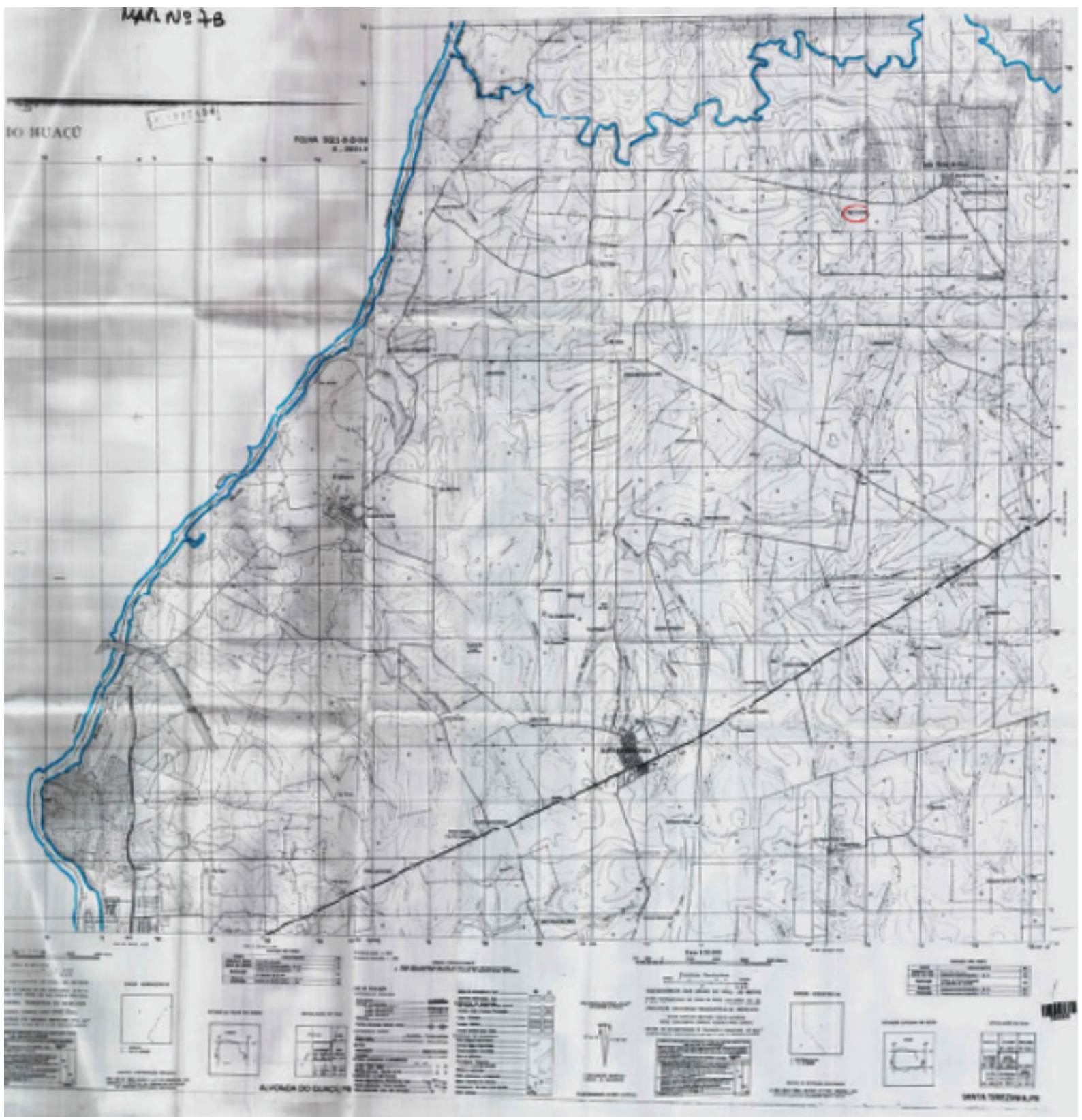

CD-Figura 70. Mapa B. Base Cartográfica que indica a presença limítrofe ao Ocoy-Jacutinga de outras nove aldeias Guarani, entre o Rio Ocoí e o Rio Paraná correspondente as Imemoriais Terras de Ocupação Tradicional Guarani.

Legenda: A Imemorial Terra de Ocupação Tradicional Guarani do Oco’y-Jacutinga. Limite leste indicado por aproximação. Aproximadamente 12500 hectares. Cálculo do "Terreno OCOI", considerado "área útil” para o PIC-OCOI / INCRA (1971) vir a ocupar: 4168 ha (quatro mil cento e sessenta e oito mil hectares) correspondente a $1 / 3$ do Terreno (à leste). Cálculo de área para Itaipu vir a inundar 8332 ha (oito mil trezentos e trinta e dois hectares) correspondente a $2 / 3$ do Terreno (a oeste).

Fontes: Índios Guarani/2002 informam sobre sua ocupação no Oco’y-Jacutinga na década de 40 e de outras 9 (nove) aldeias; Base Cartográfica: junção de três mapas Itacorá: MI - 2832/1; Santa Teresinha MI 2832/3; Alvorada do Iguaçu: MI-2831-4. Cobertura Aérea de 1976. DSG/1976. Pesquisa Laudo Antropológico - Parte II/ 2005 de Maria Lucia Brant de Carvalho. 
A respeito deste ultimo mapa pode-se verificar: A antiga aldeia de Oco'y-Jacutinga; A atual Terra Indígena Avá-Guarani do Oco’y localiza-se no antigo Córrego Santa Clara ao lado de Santa Rosa do Ocoy. As duas terras estão no mesmo paralelo.

As 10 (dez) terras Guarani que foram esbulhadas em décadas próximas. Associar o mesmo espaço do CD-Figura 70. Mapa B a Figuras 63. Mapa E. Cap IV. O autor deste ultimo mapa não considerou as áreas ocupadas por "população indígena”, porém indica o mesmo espaço, na mesma época, como local "não ocupado"; na verdade, era ocupado por dez (dez) aldeias Guarani. Associar este CD-Figura 70. Mapa B também ao CD-Figura 64A Cap IV, observando o mesmo local, ocupado pelas 10 (dez) aldeias.

Tabela. 5.1. Pelo menos 10 aldeias Guarani existiam ainda em 1940

\begin{tabular}{|l|c|l|}
\hline Tekoa & Época da Invasão & Quem as invadiu \\
\hline 12. Colônia-Guarani & 1940 e 1971 & $1^{\circ}$ colonos com o INCRA \\
\hline 14. Rio Guavira & 1950 & $1^{\circ}$ colonos; $2^{\circ}$ Usina Hidrelétrica de Itaipu \\
\hline 15. Passo Kuê & $1945-1950$ & $1^{\circ}$ colonos; $2^{\circ}$ Usina Hidrelétrica de Itaipu \\
\hline 16. Takuá Pindaí & 1950 & $1^{\circ}$ colonos; $2^{\circ}$ Usina Hidrelétrica de Itaipu \\
\hline 17. Mborevy & 1950 & $1^{\circ}$ colonos; $2^{\circ}$ Usina Hidrelétrica de Itaipu \\
\hline 18. Ocoy-Jacutinga & $1940-1973-1982$ & $1^{\circ}$ estrada; $2^{\circ}$ colonos/INCRA $3^{\circ}$ U. H. de Itaipu \\
\hline 20. Vitorace & 1968 & $1^{\circ}$ colonos \\
\hline 24. Ipiranga & $1940-1950-1983$ & $1^{\circ}$ colonos; $2^{\circ}$ Usina Hidrelétrica de Itaipu \\
\hline $\begin{array}{l}\text { 31. Mocoitadjy (Dos } \\
\text { Lapachos ou Dois Ipês) }\end{array}$ & 1970 & $1^{\circ}$ colonos \\
\hline 32. Arroyo Leon & 1971 & Fazenda \\
\hline
\end{tabular}

Fonte: Brant de Carvalho. Laudo Antropológico Parte I -2003. Páginas 54, 55, 56 e 57.

Na década de 40 do século XX, os Guarani que viviam na aldeia Colônia-Guarani/ bairro/ periferia atual de Três Lagoas/Foz do Iguaçu, serviram como mão de obra aos militares brasileiros - os Guarani lembram-se ainda do nome do representante militar responsável, "Sargento Dias" (o mesmo referido na documentação sobre Colônia-Guarani anteriormente) - para auxiliar na abertura da estrada de terra que ia de Foz do Iguaçu à Guaíra, a chamada atualmente Estrada Velha Foz-Guaíra, hoje submergida pelas águas do reservatório da Hidrelétrica de Itaipu/UHI. Os Guarani ajudaram a abrir com facão e terçado o matagal do trecho que ia de Foz do Iguaçu até Santa Helena. Paradoxalmente, ajudaram a iniciar uma das condições para a ocupação das 
frentes de expansão da sociedade nacional em suas terras, a estrada. Os Avá-Guarani afirmam: "Até 1940 a gente vivia tranquilo aqui, não tinha branco, só Guarani."

Os Guarani de Colônia-Guarani/Foz, tinham parentes próximos, que ocupavam o Oco’yJacutinga. Com a abertura da estrada, o território indígena do Oco’y-Jacutinga foi cortado de ponta a ponta. Como "compensação" ao trabalho realizado, os militares reservaram para os Guarani a própria área do Oco’y - Jacutinga, já habitada, de posse indígena e, agora, cortada pela estrada. A "compensação pelo trabalho" foi assim negativa.

Os Guarani mais idosos relembram algumas passagens referentes a este momento de sua história: "Os militares falaram: aqui é de vocês, ninguém pode entra; (...) os militares falavam para não ocupa os primeiro 100 metro do rio Paraná; (...) levava mais ou menos umas 10 hora a pé para atravessar do corrégo Jacutinga ao rio Oco'y”. Iniciando o processo de colonização da região, esta estrada, cortou transversalmente o território do Oco’y-Jacutinga (Figuras 71. Croqui A e Mapa B), restando aos Guarani 1.500 hectares. Há informações não acessíveis de que durante o governo Getulio Vargas, os Guarani teriam recebido garantias sobre a ocupação desse território. 


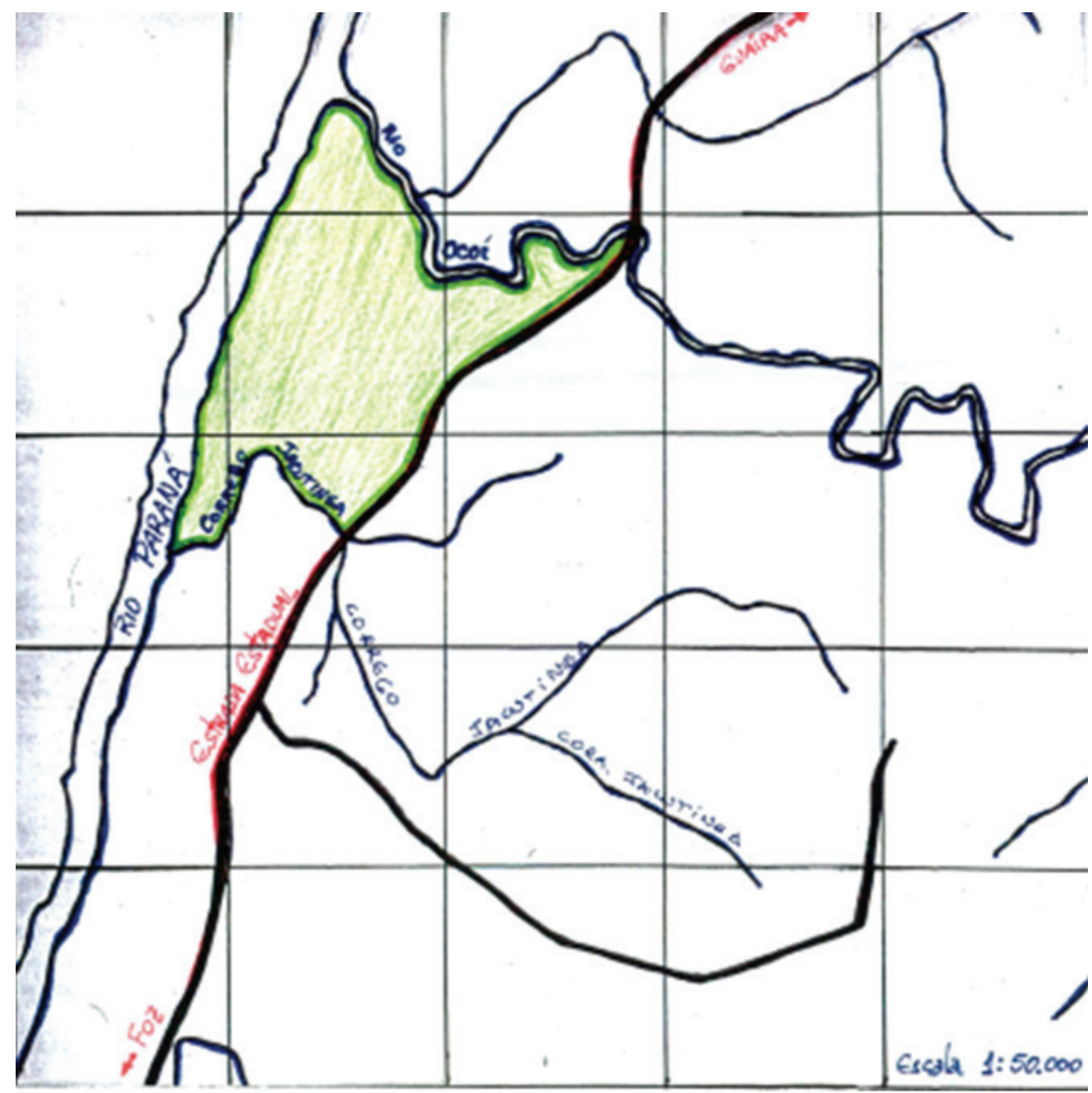

Figura 71. Croqui A. Território do Oco’y-Jacutinga, cortado pela estrada estadual Foz-Guaíra. Década de 40. Reduzido à 1500 ha.

Fontes: Índios Guarani/2002 informam sua ocupação no Oco’y-Jacutinga (década de 40); Carvalho, E de A. AváGuarani do Ocoí-Jacutinga. Parecer Antropológico ABA. CIMI-Sul, CJP e ANAÍ/Pr: 1981; Base Cartográfica: junção de três mapas Itacorá: MI - 2832/1; Santa Teresinha MI 2832/3; Alvorada do Iguaçu: MI-2831-4. Cobertura Aérea de 1976. DSG/1976. Organização Maria Lucia Brant de Carvalho. 


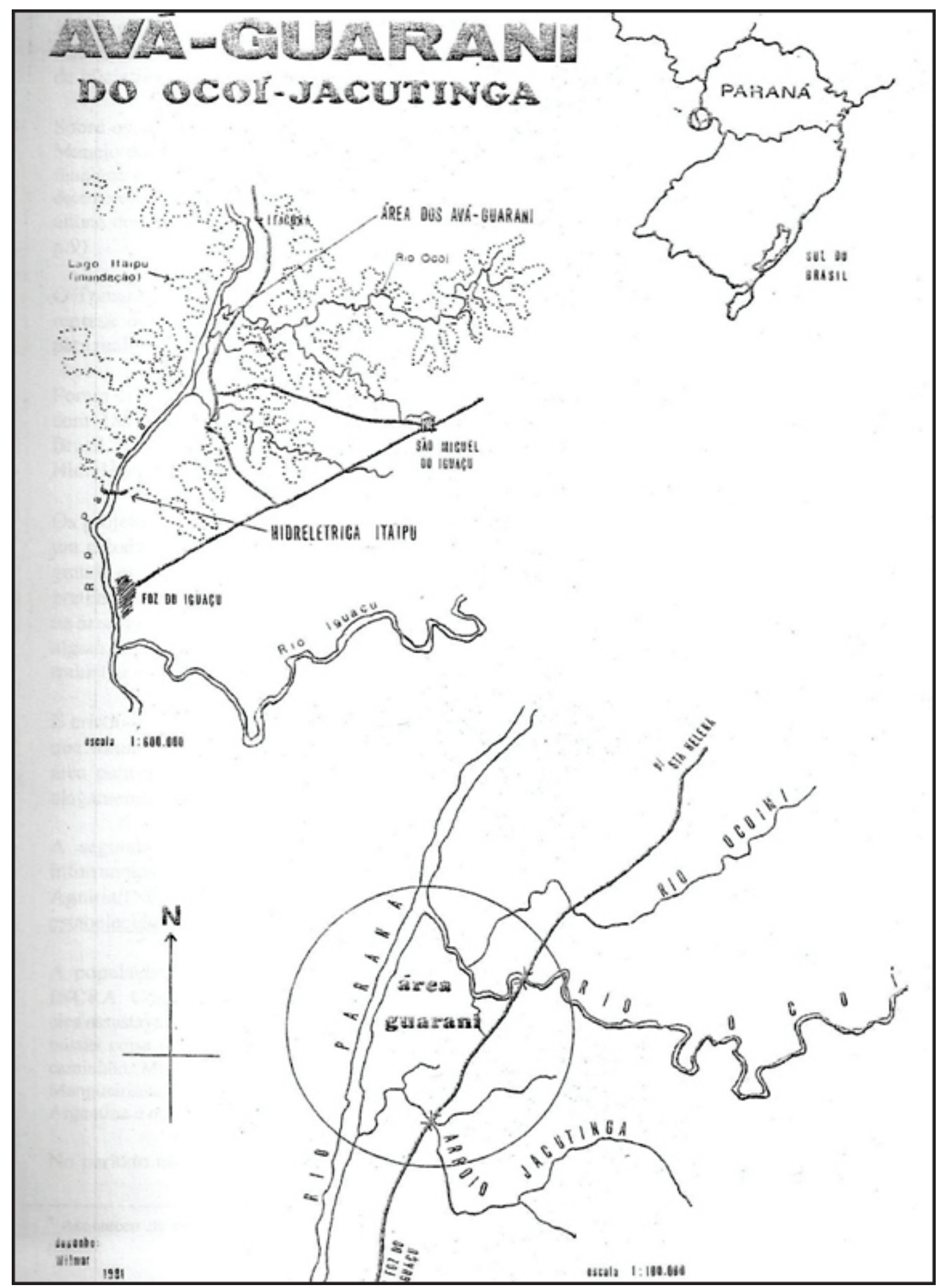

Figura 71. Mapa B. O território de ocupação do Oco’y-Jacutinga segundo a ABA (1981).

Fonte: Carvalho, E de A. Avá-Guarani do Ocoí-Jacutinga. Parecer Antropológico da Associação Brasileira de Antropologia/ABA. CIMI-Sul, CJP e ANAÍ - Pr: 1981. p 11. 


\subsubsection{O INCRA promove a invasão do território indígena (1973)}

Em 1973, Oco’y-Jacutinga abrigava cerca de 70 famílias Guarani, muitas delas refugiadas pois haviam sido obrigadas a se retirar de outras aldeias já invadidas pelas frentes de expansão. O número apresentava-se alto para a composição de um Tekoa. Isso tem uma explicação, fornecida pelos Guarani: quando todos os outro tekoa foram invadido, as família vieram procurar abrigo no Oco'yJacutinga, região mais afastada do "branco" e que tinha mata alta, ainda bom para viver. Era um dos tekoas mais afastados do centro de interesse maior, que constituía Foz do Iguaçu.

Fizeram parte da composição da população desta área vários indivíduos provenientes de aldeias próximas, localizadas tanto nas cercanias de Foz do Iguaçu, como mais distantes, de várias regiões vizinhas. De Foz do Iguaçu, vieram a compor a população do Oco’y-Jacutinga, indivíduos de antigas aldeias, como M’Boicy/ hoje centro de Foz do Iguaçu, de São João Velho e Guarani, localizadas no atual Parque Nacional do Iguaçu, da aldeia Colônia-Guarani, localizada no atual bairro/periferia de Santa Teresinha, próximo à Foz de Iguaçu. Das aldeias mais distantes vieram indivíduos da Aldeia Lope’y/ Mun. de Toledo, da Aldeia Rio Branco/ Mun. de Marechal Rondon, de Passo Kuê/antigo Alvorada, hoje Santa Teresinha, de Santa Helena/Santa Helena, de Yvá-Karetã/ Quedas do Iguaçu.

Deve-se entender que a composição populacional de uma aldeia indígena, principalmente Guarani, não pode ser vista como sendo um núcleo circunscrito em si, fechado ou imóvel; ao contrário, a organização social Guarani no território, deve ser analisada como um complexo de aldeias que se interrelacionam, as quais vivem num complexo territorial considerado como próprio e que naquele momento, se ajudavam reciprocamente, diante da invasão do colonizador sobre suas terras.

Desta forma, após a primeira invasão territorial pela estrada, até 1973 habitavam na região do Ocoy-Jacutinga 70 famílias, segundo depoimento dos indígenas. No período do governo militar no país, elas tiveram seu território de uso tradicional invadido por mais duas frentes de expansão atuando conjuntamente. Essas frentes não eram de iniciativa privada, mas sim orientadas por instituições do próprio Governo da época.

Sobre os acontecimentos no decorrer da década de 70 na região, assim relata o documento "Plano de Manejo do Parque Nacional do Iguaçu/IBAMA/MMA/2000:

Os trabalhos de demarcação e regularização fundiária só foram iniciados em 1967. Em 1972 ainda

viviam na região do Parque cerca de 457 famílias entre os detentores de títulos do Governo do 
estado, posseiros, arrendatários e empregados rurais. Apenas em 1978, o último dos colonos passível de desapropriação desocupou a área do Parque. (Plano de Manejo/PNI: 2000:9)

O Tratado de Itaipu havia sido assinado em 1971. A Usina Hidrelétrica de Itaipu havia projetado um reservatório de grandes dimensões, $1.350 \mathrm{Km}^{2}$, sendo $580 \mathrm{~km}^{2}$ do lado paraguaio e $770 \mathrm{~km}^{2}$ do lado brasileiro.

Foram criados dois Grandes Projetos na mesma área do oeste paranaense, Parque Nacional do Iguaçu com 185.000 hectares e Usina Hidrelétrica de Itaipu com 770 km² de áreas a serem ocupadas no Brasil. Os dois projetos previam, na mesma época, a evacuação de populações de seu interior. A Hidrelétrica, recebeu cerca de 40.000 trabalhadores de fora da região, no mesmo período.

Os projetos de assentamento de colonos promovidos pelo INCRA na região, nessa época sofreram de um razoável estreitamento de seus objetivos primordiais. Os dois Grandes Projetos passaram a ocupar grande superfície, encurtando assim a margem de manobra para os assentamentos populacionais pretendidos originalmente. O INCRA tinha como missão retirar grande número de população residente na área do Parque Nacional do Iguaçu e na área da futura Usina Hidrelétrica de Itaipu, e assentá-las em algum lugar, como também prever o assentamento de novas populações que haviam chegado para trabalhar no Projeto da Hidrelétrica, na pequena, então, Foz do Iguaçu.

É criado o "Decreto Federal nº 69.412 de 22.10.1971" do INCRA, que então dividiu porções de terras que foram reservadas para assentamento de colonos, em função das três populações a assentar. Esta área para assentamento de colonos denominou-se "PIC-OCOI I-INCRA". A área destinada para o alagamento do grande reservatório de Itaipu denominou-se "PIC-OCOI II-INCRA”.

A segunda invasão ao Oco'y-Jacutinga, que pudemos acompanhar em detalhe pelo relato dos informantes Guarani, deu-se em 1973, realizada por funcionários do Instituto Nacional de Reforma Agrária/INCRA, com o objetivo de assentar colonos que haviam sido recém evacuados do já estabelecido Parque Nacional do Iguaçu.

A população indígena, como já havia acontecido antes na região ${ }^{3}$, foi expulsa com violência pelo INCRA. Conforme a descrição dos Guarani:

\footnotetext{
$\overline{3}$ Aconteceu da mesma forma em Colônia-Guarani em 1971, portanto, já era prática Institucional este tipo de ação na região.
} 
Em 1973 o INCRA chega aqui, expulsando a gente da terra, eles assustava a gente, ameaçava, mandava embora, botando fogo nas casa, queimando nossa plantação, atirava nossas coisa na estrada, expulsando a gente daqui... ameaçava dar tiro na perna, quem não queria subir no caminhão. Muita gente fugiu para outra aldeia, do Guarani mesmo, aqui no Paraná, lá pra Rio das Cobras, Mangueirinha... foi pra aldeia em outro estado, em São Paulo, Rio de Janeiro..., foi também para aldeia na Argentina e no Paraguai. Foram se junta aos parente. Não tinha FUNAI aqui... . Os mais corajoso ficou!

No período não havia representação da FUNAI na região, o escritório mais próximo localizava-se em Curitiba. Porém, ela havia sido chamada para verificar a questão já em 1971. Não foi. A população Guarani do Oco’y-Jacutinga, ao ser expulsa, foi forçosamente deslocada pelo INCRA para uma pequena parcela, ainda no interior do próprio território indígena, próximo à margem esquerda do rio Paraná, permanecendo encurralada, entre o rio Paraná e as frentes colonizadoras (Figura 72. Croqui A e B). Esta área, já estava predestinada a ser inundada mais tarde pela represa da Usina Hidrelétrica de Itaipu, fato que era de conhecimento do próprio INCRA.

O denominado “Terreno OCOI” segundo o PIC-OCOI I-INCRA/ $\underline{1971}$, perfazia 12.500 hectares. Ele era habitado originalmente pelos índios Guarani inclusive do Oco’y-Jacutinga como “imemorial terra de ocupação tradicional”. Segundo o INCRA, com o advento da instalação da hidrelétrica, esse Terreno OCOI veio a perder $\underline{2 / 3}$ de sua superfície original, antes destinada aos assentamentos, em decorrência do reservatório da Itaipu que veio a se formar. Assim, a área considerada "útil" para o PIC-OCOI I do INCRA, aonde vieram a fixar-se as famílias de colonos procedentes do Parque Nacional do Iguaçu, ficou reduzida a 1/3 de seu tamanho original. Foi considerada uma das poucas áreas "livres" na região.

Parte da população indígena obrigada a sair do Oco’y-Jacutinga dispersou-se para outras regiões, a maioria para aldeias no Paraguai, outros para aldeias em várias regiões do sul e sudeste brasileiro. Trinta e duas (32) famílias resistiram no pequeno pedaço de terra, às margens do rio Paraná, segundo depoimento dos indígenas. Segundo relato de idoso: "Nessa época o INCRA ocupou toda nossa terra. O Guarani ficou cercado pelo colono na barranca do Paraná. Sem terra pra planta nós trabalhava plantando hortelã pros colonos". Assim cercados e quase sem área para plantio, passaram a trabalhar em atividades intermitentes, como boias-frias para os próprios colonos que invadiram seu território. O INCRA pela ação e a FUNAI pela omissão contrariavam, portanto, tanto a legislação federal vigente na época, a Emenda Constitucional/EC de 1969 na Constituição de 1967, quanto o Estatuto da Terra de 1964, citados anteriormente. 


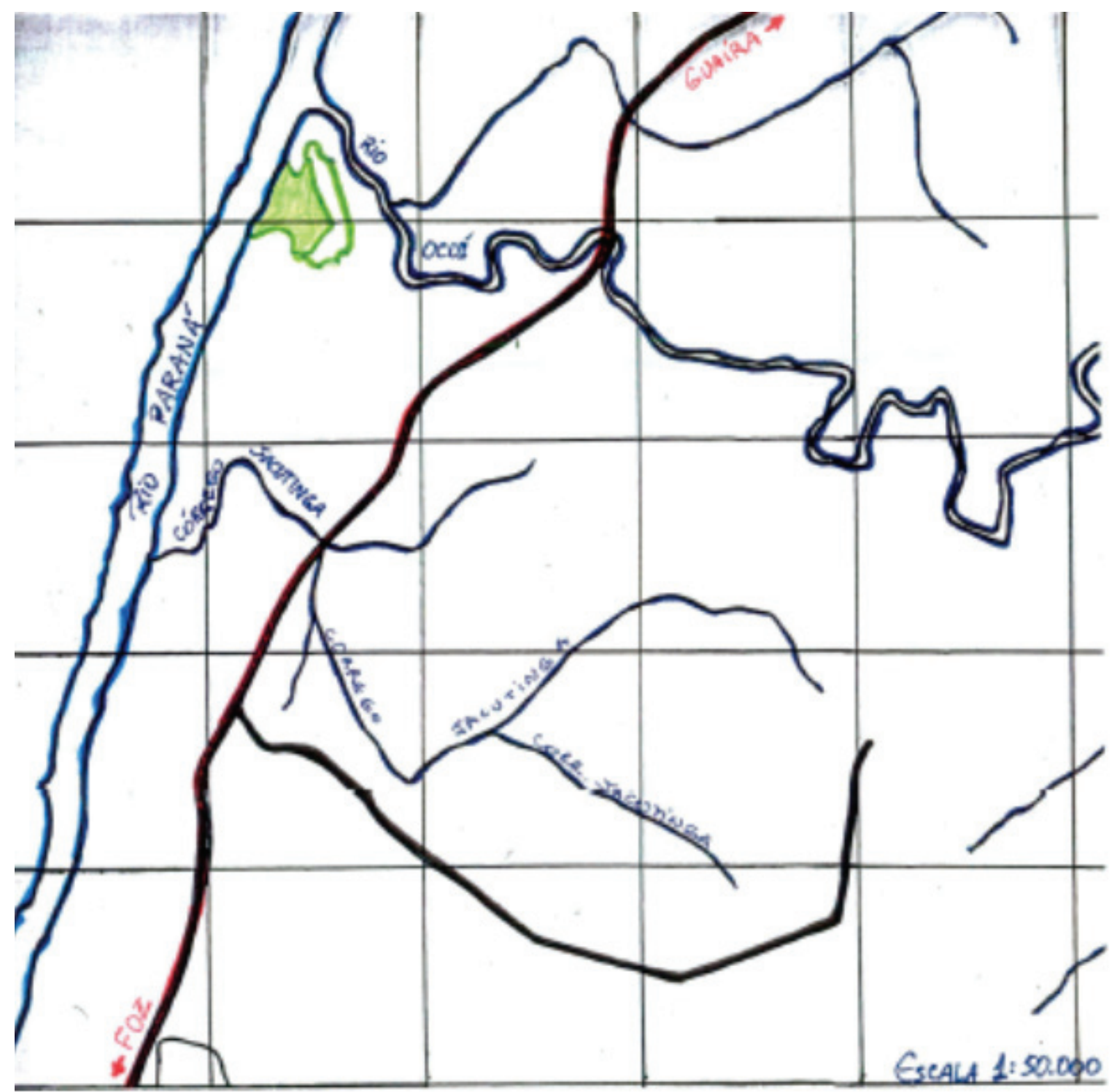

CD-Figura 72. Croqui A. Os Guarani são empurrados pelo PIC OCOI I-INCRA para beira do rio Paraná, ainda parte do território indígena, local previsto para ser inundado pela Itaipu pelo PIC-OCOI II - INCRA (Decreto de 1971). Ver área prevista para ser inundada na Figura 71. Mapa B.

Fontes: Índios Guarani/2002 informam sobre sua ocupação no Oco’y-Jacutinga em 1973; Base Cartográfica: Junção de três mapas Itacorá: MI - 2832/1; Santa Teresinha MI 2832/3; Alvorada do Iguaçu: MI-2831-4. Cobertura Aérea de 1976. DSG/1976. Org: Maria Lucia Brant de Carvalho. 


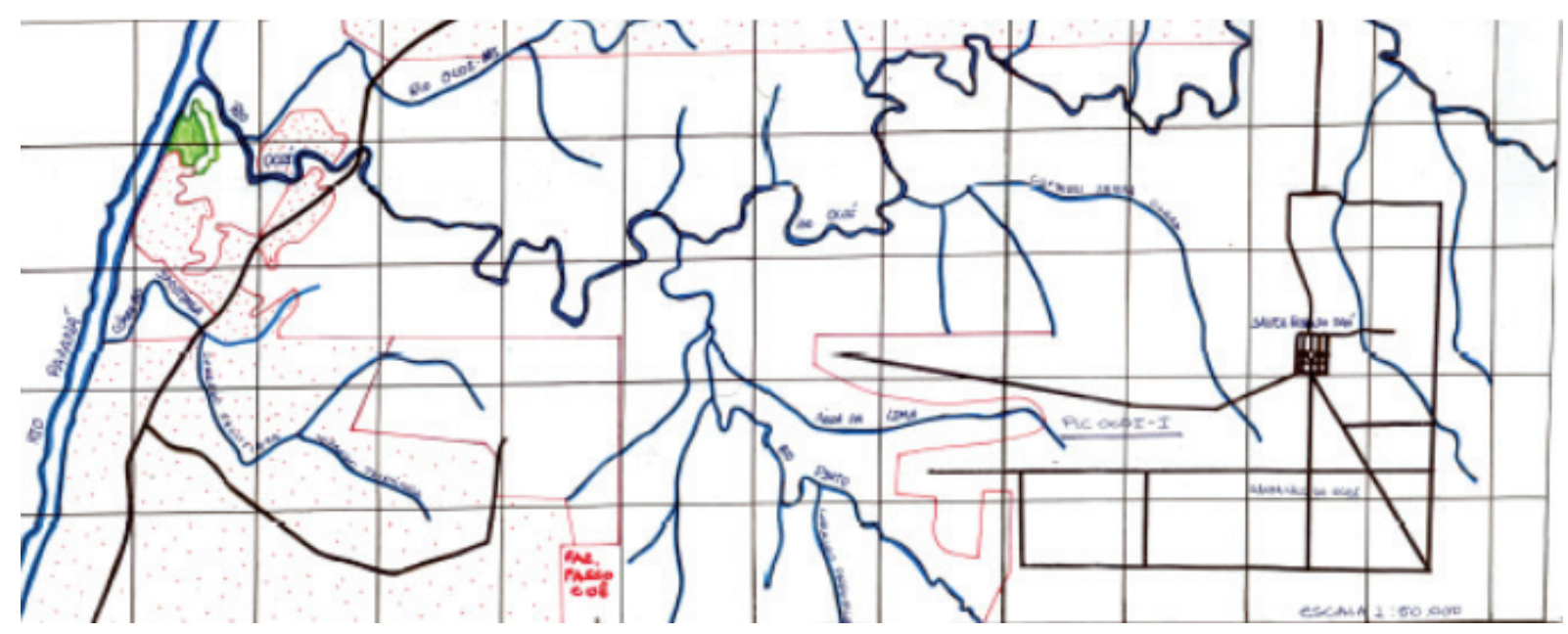

CD-Figura 72. Croqui B. O Oco’y-Jacutinga invadido pelo INCRA (1973) e tomado pelos colonos (1976), recém retirados do PNI. 1/3 (4168 ha) do "Terreno OCOI" (12500 ha), denominado de "área útil" pelo PICOCOI I-INCRA é ocupado pelos colonos à leste. A presença indígena próxima ao rio Paraná, ainda em território indígena (1976) à oeste. A Funai chega ao local em 1977 e não reconhece o "território de imemorial ocupação Guarani”. Segundo Itaipu os Guarani ocupavam 100 ha neste local.

Fontes: Índios Guarani/2002 relatam sobre sua localização em 1976. Base Cartográfica: Idem. Org: Maria Lucia Brant de Carvalho.

O Estatuto do Índio, Lei n. ${ }^{\circ} 6001$ de 19/12/1973, publicado no mesmo ano da invasão promovida pelo INCRA, nos seus Artigo $2^{\circ}$, item V e IX, Artigos $18^{\circ}, 25^{\circ}$ e o $38^{\circ}$ (ver anteriormente), também foi desrespeitado, pois não se garantiu a posse permanente e o direito de usufruto exclusivo das terras ocupadas tradicionalmente pelos indígenas, bem como não se observou que essas terras são "inusucapíveis e sobre elas não poderá recair desapropriação".

A legislação que então vigorava demonstra, por si só, que tal ocupação do Oco'y-Jacutinga era ilegal. Vigorava lei semelhante, Constituição de 1934, artigo 129; Constituição de 1937, artigo 154 (Carneiro da Cunha:1987:32) quando o Parque Nacional do Iguaçu ocupou território Guarani na região. Vigoravam a mesma EC de 1969 e o Estatuto da Terra quando o INCRA invadiu Colônia-Guarani. Os sucessivos órgãos indigenistas (SPI e FUNAI) foram omissos em relação aos direitos indígenas sobre as terras que ocupavam.

Em posterior relatório da FUNAI (1994) é afirmado:

A comunidade indígena Guarani da margem esquerda do rio Paraná na região de influência de Itaipu foi localizada na década de 70, na barra do rio Jacutinga, afluente do rio Paraná. Ainda em 1976 a $\underline{\text { FUNAI foi informada sobre o desterramento destes índios, vítimas de uma política que os confundia }}$ com invasores de terras. Suas casas eram queimadas, o que os obrigava a emigrar. Antes mesmo do início da construção da UHE de Itaipu, já sofriam diferentes formas de violência, com a acelerada ocupação "branca" no Oeste paranaense. A partir dos meados deste século, foram promovidas mui- 
tas investidas no sentido de afugentar os índios das terras que ocupavam. (FUNAI - ITAIPU BINACIONAL. Relatório do Grupo de Trabalho. Protocolo de Intenções. 20/maio/94. Processo Funai/Bsb no 0178/94. Foz do Iguaçu. 20/julho/1994).

\subsubsection{A Usina Hidrelétrica de Itaipu inunda o restante do território indígena (1982)}

Quanto ao planejamento da hidrelétrica de Itaipu, a Ata de Iguaçu foi realizada em $\underline{1966}$ e o Tratado de Itaipu foi assinado em 1973. em seguida começaram as obras.

Os projetos de assentamento de colonos promovidos pelo INCRA naquela região, como vimos, sofriam de um razoável estreitamento de seus objetivos primordiais, pela evacuação das populações da áreas do Parque Nacional do Iguaçu e daquelas que viviam na área da futura Hidrelétrica de Itaipu. Milhares de imigrantes chegaram a região para trabalhar no projeto da hidrelétrica.

Desta forma, em 1973, quando o INCRA invade o Oco'y-Jacutinga, já conhecia o traçado do projeto da Usina Hidrelétrica de Itaipu, planejado para a região, tanto é que já havia elaborado os Projetos Integrados de Colonização (Decreto Federal n. ${ }^{\circ} 69412$ de 22.10.1971), denominados $\underline{\text { PIC-OCOI I e II, }}$, separando áreas de terras que iriam ser destinadas à assentamentos de população, as quais correspondem ao PIC-OCOI I, das áreas reservadas para Itaipu (a área do reservatório somado a Área de Preservação Permanente/APP do entorno), as quais juntas, comporiam o $\underline{\text { PIC-OCOI II. }}$.

Portanto, o INCRA em 1973, obriga a retirada dos Guarani de seu território tradicional, o Oco’y-Jacutinga, empurra-os para local diminuto do próprio território indígena, junto ao rio Paraná, permanecendo os Guarani, encurralados entre os colonos e o rio, justamente em local que estava previsto pelo PIC-OCOI II /INCRA já em 1971, para vir a ser coberto pelas águas da represa da Usina Hidrelétrica de Itaipu.

Segundo os Guarani, o INCRA dizia a eles em 1973, que deveriam se retirar de seu território, pois a área viria a ser inundada por Itaipu. Mais tarde os Guarani perceberam que o INCRA os expulsara para assentar colonos em local da terra indígena que não seria alagada, deslocandoos para a área junto ao rio Paraná, justamente aquela predestinada a ser inundada pela represa de Itaipu. Em documentos da FUNAI, acima já citados, o INCRA informa à FUNAI que os índios devem ser retirados da pequena área, pois será alagada por Itaipu. (Ver Figura 72. Croqui B).

Assim, verifica-se que já no ano de $\underline{\mathbf{1 9 7 1}}$ já havia ocorrido o esbulho do Oco'y-Jacutinga, por fraude. O mesmo "Decreto Federal nº 69.412 de 22.10.1971, o PIC-OCOI I-INCRA" havia 
expropriado ilegalmente a “área de ocupação tradicional” Guarani do Oco’y-Jacutinga, o chamado, a partir daquele momento "Terreno OCOI - antiga Gleba 84". Verificou-se também que a população de colonos, que veio a ocupar as terras Guarani do Oco’y-Jacutinga que não seriam alagadas, era composta por indivíduos que haviam sido desapropriados, também provenientes do interior do Parque Nacional do Iguaçu. Informações essas constantes no Anexo no 5 A.

Portanto, no caso da “terra de ocupação tradicional” Oco’y-Jacutinga, mais uma vez os Guarani foram esbulhados, primeiro em função do Parque Nacional do Iguaçu, e depois pela Hidrelétrica de Itaipu, como veremos a seguir. Assim, o oficial "Decreto Federal no 69.412 de 22.10.1971 referente ao PIC-OCOI I-II /INCRA”, contrariava, como já citamos acima, a Emenda Constitucional de 1969, artigo 198, parágrafos $1^{\text {o }}$ e $2^{\text {o}}$; e o Estatuto da Terra. Lei n 4504 de 30/11/1964. Título I. Capítulo I. Artigo $2^{\circ}$.

Em 1976, quando começaram as obras de construção da Usina Hidrelétrica de Itaipu, os Guarani passaram a ser alvo de nova investida de desterramento. Itaipu fez saber publicamente que grande extensão da região seria inundada, inclusive a totalidade daquela pequena área para onde os Guarani haviam sido deslocados pelo INCRA.

Diante da ameaça de inundação, nova leva de famílias Guarani dispersou-se pela região, com medo do dilúvio. Pela sua ótica cultural, a inundação tomava o significado de um dilúvio. A mitologia Guarani da Terra Sem Males inclui a ideia que o mundo vai acabar num dilúvio, "as águas vão cobrir toda a terra". As famílias amedrontadas fugiam e aconselhavam os parentes a fugir, como de fato se deu. Resistiram no local apenas 19 familias. Segundo relato do Cacique Reroyvyju, cuja família permaneceu na área: "os mais corajoso ficou, a gente não podia sair da nossa terra".

Os Guarani são obrigados a se retirar definitivamente de seu território em maio de 1982, sem que nenhum procedimento legal quanto a "remoção de indígenas" tenha sido realizado. Foram reassentados em terras de colonos, na beira do Córrego Santa Clara (ver Figura 72. Croqui B), ao lado do vilarejo de Santa Rosa do Ocoí, local onde veio a se constituir a atual Terra Indígena Avá-Guarani do Oco’y. O novo local estava previsto pelo PIC-OCOI II - INCRA para ser desapropriado dos colonos, para vir a constituir parte da Área de Preservação Permanente/ APP do lago de Itaipu. Os colonos foram desapropriados e não indenizados pelo INCRA, segundo seus depoimentos. O local passou a ser tanto Terra Indígena como APP de Itaipu. Os colonos não indenizados pelo INCRA invadem desde sempre a área, que com razão consideram como suas propriedades. Desde o início a mesma área apresenta três superposições, Terra de Colonos, Terra Indígena e APP de Itaipu. Índios e colonos perderam suas terras e foram colocados numa situação em que o confronto pelas terras era inevitável. Graças a paciência Guarani isso não se 
deu, o confronto, mas os colonos invadem a todo momento as franjas externas do Oco'y. Estes fatos citados serão analisados detalhadamente adiante.

Em outubro de 1982, o que restou do território indígena é inundado pela represa de Itaipu. Dessa forma deu-se a perda total do Território Indígena do Oco’y-Jacutinga. Fato que se deu, como no caso anterior do INCRA, também de forma ilegal. Nas duas ocasiões, a FUNAI pouco ou nada fez para defender os direitos indígenas sobre o território. Pelo contrário.

O texto Constitucional que vigorava à época (1982), e que garantia os direitos indígenas, era o mesmo citado no caso do INCRA, artigo 198, parágrafo $1^{\circ}$, da Emenda Constitucional de 1969 (já citado). Ainda, esse tipo de situação vivida, desterramento em função de obra pública, já estava detalhado na Lei n. ${ }^{\circ} 6001$ - Estatuto do Índio de 19.12.1973, como descrito abaixo:

“Título I. Dos Princípios e Definições. Artigo 2. Cumpre à União, aos estados e Municípios, bem como aos órgãos das respectivas administrações indiretas, nos limites de sua competência, para a proteção das comunidades indígenas e a preservação de seus direitos;

$\mathrm{V}$ - garantir aos índios a permanência voluntária no seu habitat, proporcionando-lhes ali recursos para seu desenvolvimento e progresso;

IX - garantir aos índios e comunidades indígenas, nos termos da Constituição, a posse permanente das terras que habitam, reconhecendo-lhes o direito ao usufruto exclusivo das riquezas naturais e de todas as utilidades naquelas terras existentes;

Art. $18^{\circ}$. As terras indígenas não poderão ser objeto de arrendamento ou de qualquer ato ou negócio jurídico que restrinja o pleno exercício da posse direta pela comunidade indígena ou pelos silvícolas.

Art. $20^{\circ}$. Em caráter excepcional e por qualquer dos motivos adiante enumerados, poderá a União intervir, se não houver solução alternativa, em área indígenas, determinada a providência por decreto do Presidente da República.

Parágrafo $1^{\circ}$. A intervenção poderá ser decretada: (...) d) para a realização de obras públicas que interessem ao desenvolvimento nacional.

Parágrafo $2^{\circ}$ : A intervenção executar-se-à nas condições estipuladas no decreto e sempre por meio $\underline{\text { suasórios, dela podendo resultar, segundo a gravidade do fato, uma ou algumas das medidas seguin- }}$ tes: (...) c) remoção de grupos tribais de uma para outra área.

Parágrafo $3^{\circ}$ : Somente caberá a remoção de grupo tribal quando de todo impossível ou desaconselhável a sua permanência na área sob intervenção, destinando-se à comunidade indígena removida área equivalente a anterior, inclusive quanto às condições ecológicas.

Parágrafo $5^{\circ}$ : $\mathrm{O}$ ato de intervenção terá assistência direta do órgão federal que exercita a tutela do índio." 
Portanto, já existiam leis que asseguravam os direitos indígenas às terras que ocupavam. Se a remoção fosse inevitável, deveria ser controlada, e assim garantidos os direitos indígenas sobre futura terra substituta, com extensão equivalente à anterior, e ainda, ecologicamente semelhante. Por fim, tal providência de remoção de grupo tribal de uma para outra área, só poderia ser determinada, na época, por Decreto Presidencial. Tanto Itaipu como o INCRA desconsideraram a lei que protege os direitos indígenas. A Itaipu reconhece oficiosamente como área de ocupação dos Guarani apenas aquela parcela mínima que foram obrigados a ocupar junto ao rio Paraná, por força da ação ilegal anterior do INCRA, declara que ocupavam apenas "100 hectares". Mas, na prática, a área que foi inundada é bem superior a esses números, pois inclui parte da anterior área Guarani tomada pelo INCRA ocupada por colonos que também foram obrigados a se retirar, a área ao sul do que restou da aldeia às margens do rio Paraná, e se considerado a totalidade do território original do Oco’y-Jacutinga, esse foi inundado em 2/3 de sua extensão original.

Como vimos, segundo documento da FUNAI (Anexo $\mathbf{n}^{\mathbf{0}} 5$ A), que descrevia informações prestadas pelo INCRA, o denominado “Terreno OCOI” pelo PIC-OCOI I-INCRA/1971, perfazia 12.500 hectares; terras as quais eram ocupadas originalmente pelos índios Guarani do Oco'yJacutinga, em “terras de ocupação tradicional”. Segundo o INCRA, com o advento da instalação da hidrelétrica, esse Terreno OCOI veio a perder $2 / 3$ de sua superfície original, antes destinada aos assentamentos, em decorrência do reservatório da Itaipu que veio a se formar. Assim, a área considerada "útil" para o PIC-OCOI I do INCRA, onde ele veio a fixar as famílias procedentes do Parque Nacional do Iguaçu, ficou reduzida a 1/3 de seu tamanho original. Portanto, na verda$\underline{\text { de, as terras originais dos Guarani do Oco'y-Jacutinga foram inundadas em 2/3 pela hidrelétrica }}$ o que perfaz 8332 hectares, e ocupadas em 1/3 pelos colonos o que perfaz 4168 hectares. (Figuras 73. Imagens A, B, C e D).

O Laudo do antropólogo Edgard de Assis Carvalho (1981), contratado pela Associação Brasileira de Antropologia/ABA, para relatar este caso à Associação, em passagem onde cita matéria de jornal "O Estado de São Paulo" de 08.11.78, assim descreve:

O fato - reitera o jornal - é que a Itaipu Binacional agirá com os índios da mesma forma que com os posseiros das áreas a serem inundadas pela barragem em abril de 1982. Quem tiver documentos de propriedade de terras será indenizado em primeiro lugar; depois, os que possuem somente títulos provisórios, por estarem pagando as terras; e finalmente posseiros e ocupantes diversos. Nesta última condição é que estão os índios. (Carvalho: Avá-Guarani do Ocoí Jacutinga. Parecer Antropológico. ABA/CIMI/CJP/ANAI. 1981) 
De fato, apesar dos povos indígenas serem detentores de direitos especialmente protegidos por todas as Constituições Nacionais, foram tratados pela Itaipu, juridicamente de forma ilegal, como simples "posseiros".

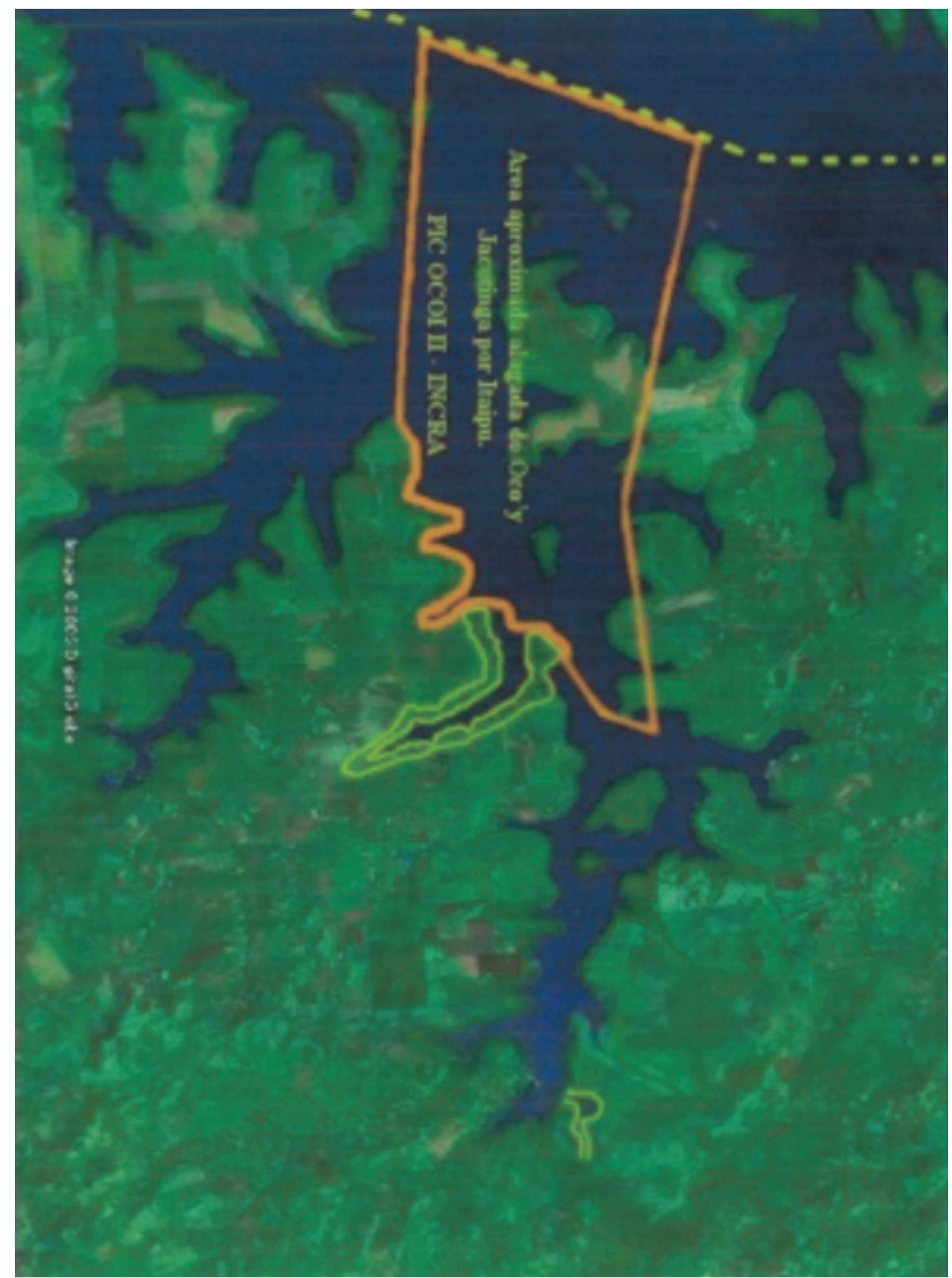

Figuras 73. Imagem A. A Oeste a região original do Oco’y-Jacutinga que foi inundado pela represa da Usina Hidrelétrica de Itaipu. 1982. Área superior aos 100 ha informados pela mesma. Na verdade 2/3 do território indígena original, conforme previsto pelo PIC-OCOI II-INCRA, 8.332 hectares aproximadamente. No centro a Terra Indígena do Oco’y (1982), com 231,88 hectares. Detalhe da ilha (100 ha) onde Itaipu pretendia reassentar os Guarani. No extremo leste, o rio Ocoí desaguando na represa da hidrelétrica.

Fonte: Google. Image 2005 Digital Globe. Organização: Maria Lucia Brant de Carvalho, 2005. 


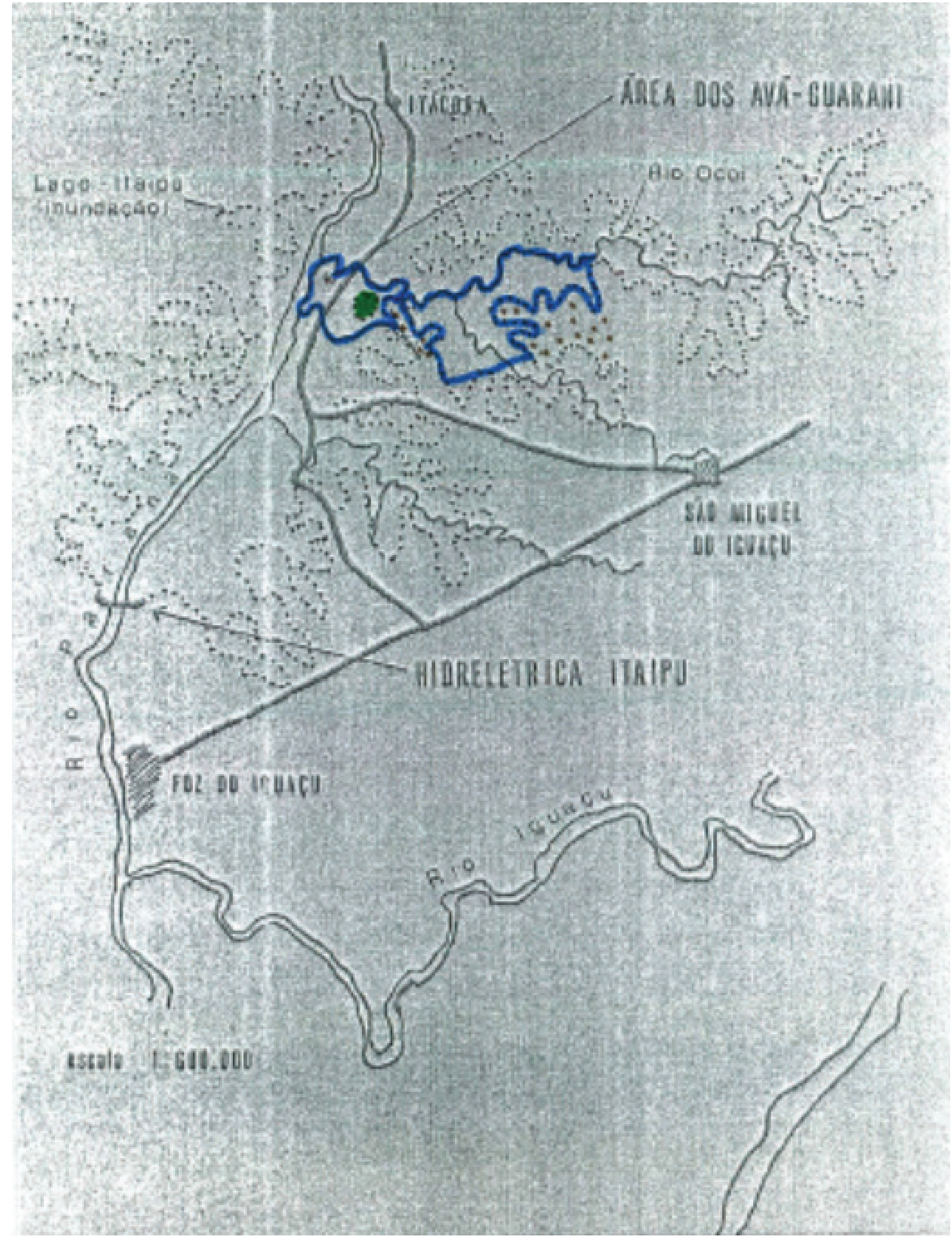

Figuras 73. Imagem B. Área original do Ocoy-Jacutinga prevista pelo PIC-OCOI II -INCRA para ser inundada por Itaipu, aproximadamente 8332 ha. Detalhe da ilha (100 ha) onde Itaipu pretendia reassentar os Guarani. Área original do Ocoy-Jacutinga que foi ocupada pelos Colonos através do PIC OCOI I-INCRA em 1973, aproximadamente 4168 ha.

Fonte: Carvalho, E de A. Avá-Guarani do Ocoí-Jacutinga. Parecer Antropológico da Associação Brasileira de Antropologia/ABA. CIMI-Sul, CJP e ANAÍ - Pr: 1981. p 11; Conclusões deste Laudo Antropológico - Parte II/ 2005. Organização Maria Lucia Brant de Carvalho, 2005. 


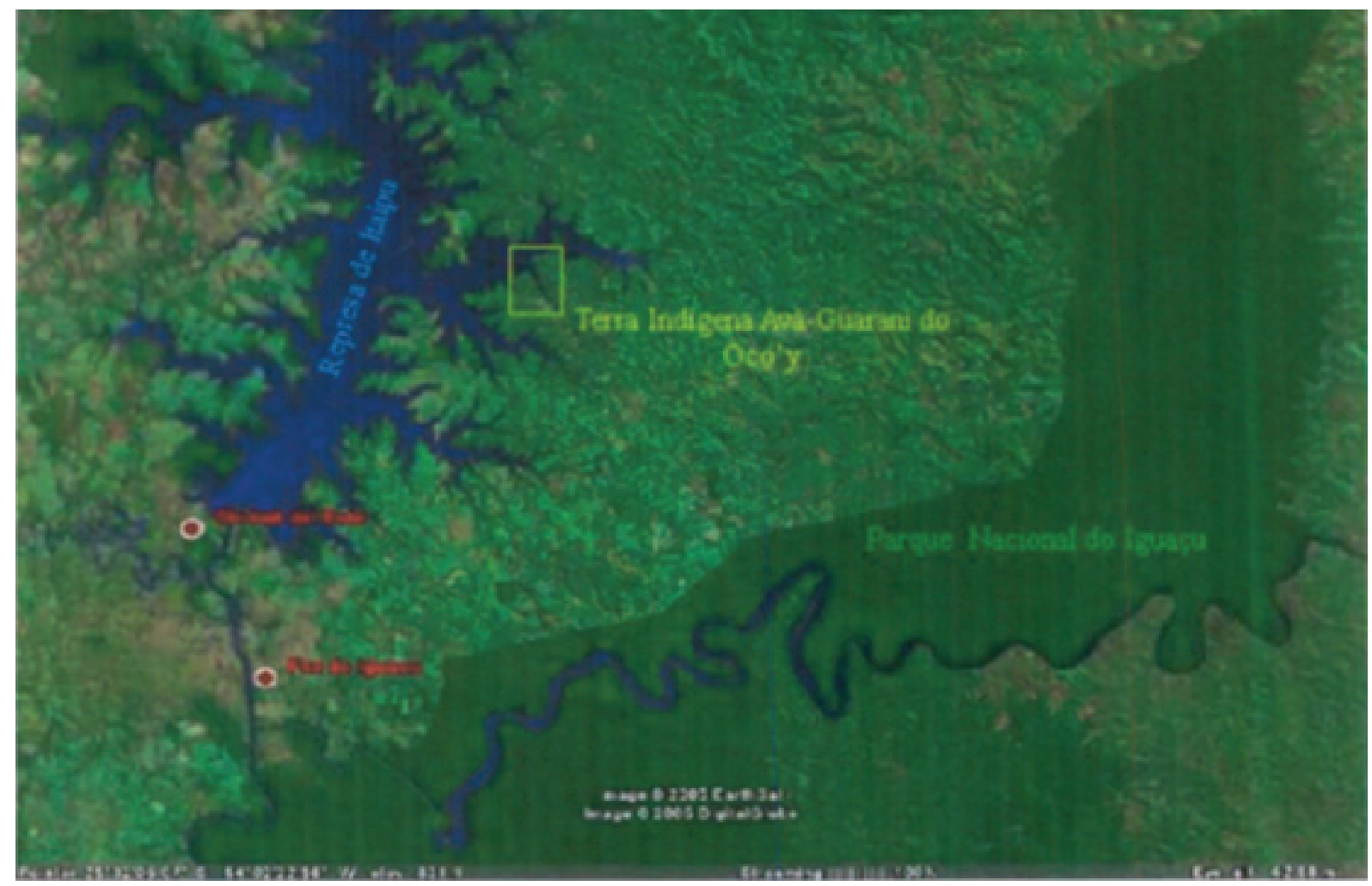

Figuras 73. Imagem C. Visão do conjunto das áreas lago de Itaipu, Terra Indígena do Oco’y e Parque Nacional do Iguaçu.

Fonte: Google.Image 2005 Digital Globe. Organização: Maria Lucia Brant de Carvalho, 2005.

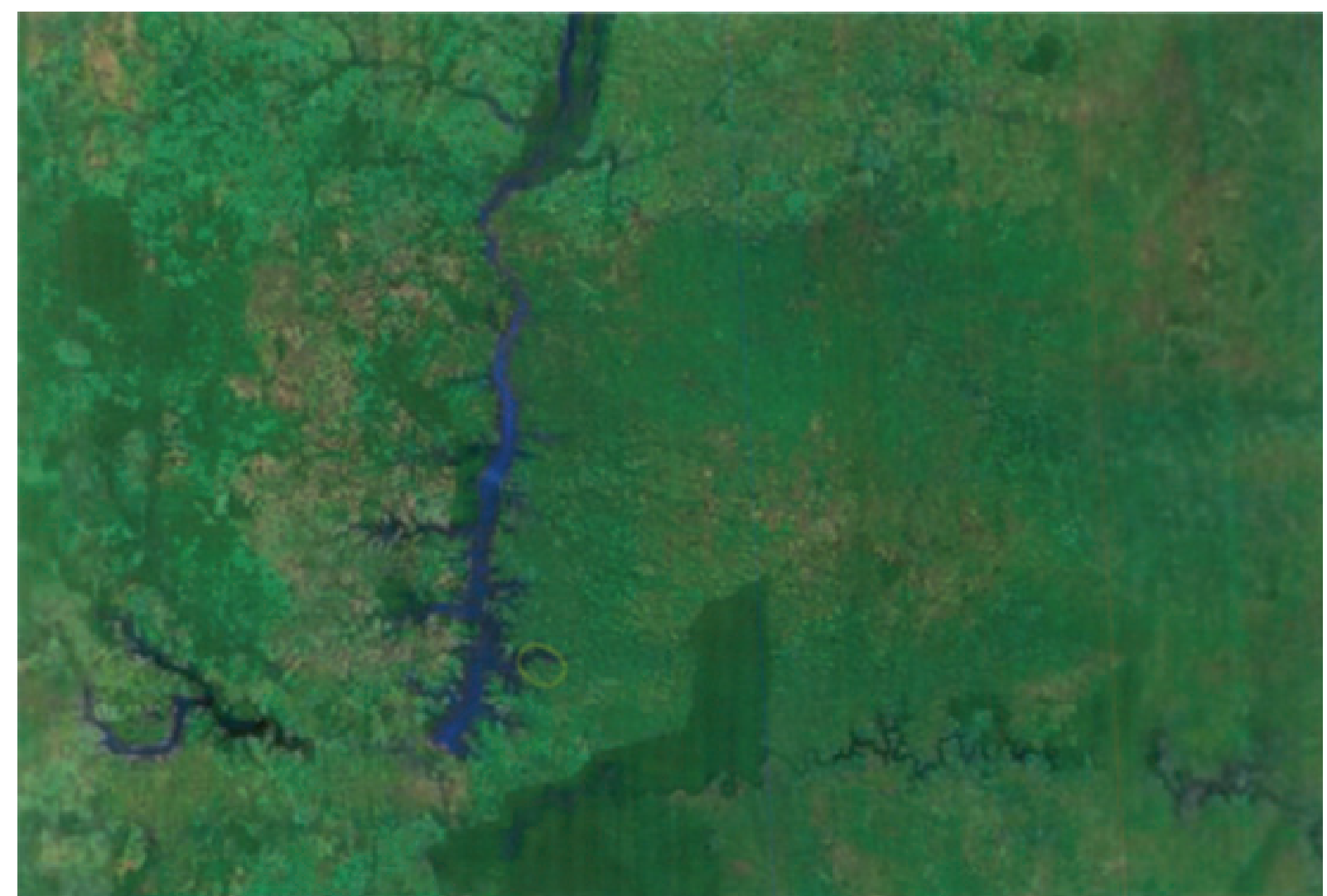

Figuras 73. Imagem D. Visão do conjunto das áreas lago de Itaipu, Terra Indígena do Oco’y e Parque Nacional do Iguaçu.

Fonte: Google. Image 2005 Digital Globe. Organização: Maria Lucia Brant de Carvalho, 2005. 


\subsubsection{O papel institucional da FUNAI}

Em casos de desterramento de população indígena há normas administrativas legais para o cumprimento do ato. São necessários: 1) Laudo Antropológico/LA caracterizando a situação do grupo indígena; 2) em seguida, é formado Grupo de Trabalho/GT, visando buscar área adequada para transferência do grupo, estudo este, baseado no Laudo Antropológico anteriormente realizado; 3) por fim autorização - na época, da Presidência da República para proceder o desterramento.

O Laudo Antropológico/LA visaria na época realizar a Identificação e Delimitação de Terra Indígena, comprovando a imemorialidade da ocupação indígena na área; identificaria por meio de dados socioculturais e econômicos, a área de uso tradicional que ocupavam, descrevendo o perímetro do território, as características do ambiente, bem como a forma como os índios a utilizam: áreas de caça, pesca, coleta, agricultura, reservas de matéria-prima, habitação, locais sagrados etc; cabe ao Laudo recensear a população, entre outras medidas. O Laudo deve ser realizado por técnico competente na área, ou seja, por antropólogo.

Formatado o Laudo Antropológico, em seguida é formado Grupo de Trabalho/GT, que visa a partir das indicações antropológicas do Laudo identificar área adequada, ou seja, semelhante em extensão e qualidade ambiental, como reza a lei, para o reassentamento dos indígenas; via de regra, o GT é coordenado pelo antropólogo que realizou o Laudo Antropológico.

O processo passa por diversas instâncias de aprovação, FUNAI, Ministério da Justiça e Presidência da República. Ao final é necessário em qualquer caso de procedimento de desterramento, autorização - atualmente - do Congresso Nacional. Na época (1982) a legislação determinava que a autorização seria proveniente da Presidência da República.

Nada disso ocorreu quando do desterramento dos Guarani do Oco’y-Jacutinga. O INCRA ocupou grande parte das terras desta aldeia em 1973. O órgão tutor foi omisso, sem prestar qualquer assistência aos Guarani na região. A FUNAI nomeia diretamente um GT que passa a participar das negociações. Quando a Usina Hidrelétrica de Itaipu, em 1982, pretende retirar os Guarani da pequena área restante, onde haviam sido colocados pelo INCRA, a fim de inundar a região, prestes a fazê-lo, a FUNAI nomeia diretamente outro GT, que passa a participar das negociações. Os dois GTs sem antropólogo.

Assim, de forma irregular, num primeiro momento houveram dois GTs, que definem a situação contra os direitos indígenas, e somente depois aparece um relatório, de bases científicas 
questionáveis, apresentado como "Laudo Antropológico”, sem preencher os requisitos obrigatórios para Identificação e Delimitação de Terra de Ocupação Tradicional e ainda, recenseando a população através de critérios não previstos Constitucionalmente, os Critérios de Indianidade.

\subsubsection{As ações dos Grupos de Trabalho/ GTs}

O General Ismarth de Araújo Oliveira, presidente da FUNAI à época, designa o "Sub-Grupo de Trabalho XV" em 23.03.1977 (Anexo n 3), composto por um funcionário do DGO/FUNAI/ Bsb e por um engenheiro agrônomo do INCRA, nenhum antropólogo. O segundo GT produziu um "Relatório de Viagem: FUNAI", sem data, constante mais tarde do processo n. o 1053/1976/ FUNAI, fls 143/44/45, também sem nenhum antropólogo. (Anexo no 6).

\subsection{As ações do primeiro Grupo de Trabalho/ GT FUNAI-INCRA (1977)}

Cerca de 4 (quatro) anos após a invasão do INCRA ao Oco’y-Jacutinga, em 1973, Itaipu ainda não havia inundado a área, a FUNAI forma um Grupo de Trabalho/GT misto, FUNAI-INCRA, composto por Saul Lopes/Coordenador do DGO/FUNAI e Wilson Kaniak/advogado do INCRA, o Sub-Grupo de Trabalho XV, que conclui seus trabalhos em 19.04.1977 (Anexo no 5A).

Este GT não realiza qualquer pesquisa junto aos índios, como seria de obrigação institucional ao menos da FUNAI. Relatam os Guarani que, apesar de tentativas de esclarecimentos e apelos sobre o que de fato havia acontecido (expulsão pelo INCRA e tomada de seu território pelos colonos), os técnicos os ignoram.

Na prática, o GT recebe de antemão a definição de quem seria índio ou não, dos próprios técnicos do INCRA ${ }^{4}$, órgão que, como vimos, estava diretamente implicado contra os interesses indígenas na região. Informa então o INCRA à FUNAI que a composição demográfica do grupo indígena era de 11 famílias. (Anexo no 4). Competiria legalmente à FUNAI e apenas a ela recensear a população indígena.

\footnotetext{
${ }^{4}$ O levantamento deveria ser feito por Laudo Antropológico da FUNAI, através do reconhecimento da população indígena e do território de uso tradicional, fatos via de regra a serem reconhecidos legal e exclusivamente pelo órgão indigenista; deveria ser realizado por funcionário profissionalmente especializado para tanto, a saber antropólogo; Assim não é o GT que realiza estes procedimentos.
} 
Contudo esse GT constata a presença indígena às margens do rio Paraná, anexando fotos dos Guarani habitando o local. O que demonstra que eles ainda estavam presentes, mesmo que em parte diminuta de seu território original (Anexo $\mathbf{n}^{\mathbf{0}} \mathbf{5 A}$ ), acuados pela ocupação dos colonos que já haviam plantado a soja. Por ter chegado tarde demais ao local, ou seja, depois de invadido, constatando também a presença de colonos, a FUNAI ignora o recente histórico vivenciado pelos Guarani, aceitando as informações do INCRA e limitando-se a endossar as mesmas.

Reproduzimos abaixo parte do texto do GT (Anexo no 5A), para entendermos o contexto fundiário naquele momento. Em apenas um dia de visita a área em 06/04/1977 o Subgrupo de Trabalho XV declara:

(...) No dia 6/IV/77, dirigimo-nos ao Município de São Miguel do Iguaçu, onde se encontra a sede do Projeto Integrado de Colonização Ocoí, mais conhecido pela sigla de PIC-OCOÍ.

a) Sinopse Histórica:

Este Projeto, especificamente criado pelo Instituto Nacional de Colonização e Reforma Agrária, sobre o TERRENO OCOÍ (antiga Gleba 84), situa-se sobre os municípios de Foz do Iguaçu e de São Miguel do Iguaçu.

Foi havido, pela Autarquia, através de ato expropriatório Decreto Federal no 69.412 de 22/10/ 1971, para o fim exclusivo de assentar famílias de colonos que, então, seriam retirados do Parque Nacional do Iguaçu.

O terreno, inicialmente, abrangia uma área de 12500 hectares que com advento da Usina Hidrelétrica de Itaipu, viria a perder 2/3 (dois terços) de sua superfície originária, em decorrência da inundação do reservatório a se formar.

Consequentemente, a área útil onde iriam se fixar as famílias de colonos procedentes do Parque Nacional do Iguaçu, ficou reduzida em apenas 1/3 (um terço) de seu tamanho inicial, gerando, inclusive, dificuldades para a própria Autarquia, que se viu cerceada em executar, na íntegra, o plano originário de assentamento dos referidos colonos.

Essa área que denominamos de útil, e que corresponde a 1/3 do terreno originário, foi denominada de PIC-OCOÍ-I, cujo esquema de colonização de Projetos Integrados do INCRA foi, apesar das novas e reduzidas dimensões devidamente cumprido, cujos lotes medidos e demarcados já foram titulados a seus ocupantes.

Os 2/3 (dois terços) que serão submersos com a formação do reservatório, receberam a denominação de PIC-OCOÍ-II e ficaram, em decorrência deste fato, fora do esquema aplicado ao PICOCOÍ-I, pelo INCRA.

Dialogando com o Executor, em exercício do PIC-OCOÍ-I. (...) fomos, pelo mesmo, atendidos, com a designação de um servidor, com pleno conhecimento do terreno e da atuação do Projeto, para nos acompanhar no desempenho da $2^{\mathrm{a}}$ etapa do trabalho. 
A área que compreende o PIC-OCOÍ-I, já se encontra em fase final de emancipação, isto é, com lotes demarcados e titulados aos colonos, que os cultivam através de processo de mecanização e cuja prosperidade se faz notória. Não há, aí, qualquer resquício de elementos indígenas. Adentrando mais além, pela porção que integra o PIC-OCOÍ-II, especialmente às margens do Rio Paraná, no local assinalado na xerocópia da fotografia aérea 273030325 (doc de fl 12), constatamos a existência de 11 famílias indígenas já identificadas pela Administração do PICOCOÍ-I (rel anexa doc fl 13), em processo de aculturação e cuja subsistência obtêm da pesca, efetuada no Rio Paraná e de produtos agrícolas extraídos das lavouras que cultivam ao redor de suas moradias.

Contatos estabelecidos:

Tendo em vista que o local onde se encontram as famílias indígenas, anteriormente descrito como PIC-OCOÍ-II, será objeto de inundação, para dar lugar ao reservatório d'água, procuramos dialogar com o pessoal técnico de Itaipu, em busca de esclarecimentos que determinassem uma possível solução, para o caso das aludidas famílias, vez que, o domínio das áreas utilizáveis pela Usina, passará a responsabilidade daquela Empresa Binacional de Itaipu.

Nos dias 14 e 15, nos ocupamos em contatos verbais com técnicos encarregados de diversos setores, os quais nos atenderam, fornecendo mapas e informações que o presente subsidiam, à guisa de ilustração, bem como induzem a fazer sugestões, conforme abaixo nos propomos. (Sub-Grupo de Trabalho XV: 21.12.76)

Item I: ${ }^{5}$. Este texto do Sub-Grupo de trabalho XV, também referia-se a solucionar os problemas existentes em Colônia-Guarani, área tradicionalmente ocupada pelos Guarani. Ver rodapé a solução apresentada para essa terra de ocupação tradicional.

ÍTEM II- ÁREA OCUPADA PELAS FAMÍLIAS INDÍGENAS NO PIC-OCOÍ-II, QUE FUTURAMENTE SERÁ INUNDADA:

Oferecemos duas sugestões para o assentamento que deverá se processar:

1) Localizá-las em uma das ilhas que se formarão a longo do reservatório (...) .

2)Assentá-las às margens do lago a ser formado pela represa, na zona destinada à faixa de proteção, que abrangerá além da quota máxima estabelecida por Itaipu, uma extensão de 100 $\underline{\text { metros }}$ e excepcionalmente, 500 metros em sentido horizontal, a partir da margem (vide gráfico esboço-doc fl 15), de caráter meramente ilustrativo, pois as plantas definitivas consignando tais faixas se encontram em fase de elaboração.

Observação: O assentamento dessas famílias deverá se processar em local não distante que ora

\footnotetext{
${ }^{5}$ Soluções apresentadas pelo Sub-Grupo de Trabalho da FUNAI: "Item I: Colônia Guarani. Liberação da área pela FUNAI ao INCRA, afim de que se concretize a titulação definitiva, ansiosamente aguardada pelos seus ocupantes." Também um dia de trabalho, o dia anterior.
} 
ocupam, relevando-se, para tanto, os hábitos de sobrevivência que mantém e o aspecto sócio-cultural que os vincula àquela localidade, fato constatado pela existência de cemitério indígena, nas proximidades. (Subgrupo de Trabalho XV. 19.04.19776) (Anexo no 5A).

Note-se que, em primeiro lugar, o Sub-grupo de Trabalho não se deu ao trabalho básico de reconhecimento e determinação da área tradicionalmente ocupada pelos Guarani, medida que deveria ter sido fundamental no processo e que cabia legalmente à FUNAI.

O INCRA com problemas de espaço declara à FUNAI, que por sua vez relata: a área útil onde iriam se fixar as famílias de colonos procedentes do Parque Nacional do Iguaçu, ficou reduzida em apenas 1/3 (um terço) de seu tamanho inicial, gerando, inclusive, dificuldades para a própria Autarquia, que se viu cerceada em executar, na íntegra, o plano originário de assentamento dos referidos colonos.

Portanto, dois terços (2/3) da região seriam destinados a Itaipu para inundação (PIC-OCOI II/INCRA/1971). Um terço (1/3) para assentamento de população, colonização (PIC-OCOI I/ INCRA/1971). O local encontrava-se apertado, para o INCRA solucionar o assentamento de todos os colonos, planejamento que havia previsto anteriormente e que teve que ser reequacionado.

O decreto de expropriação do INCRA do suposto “TERRENO OCOI”, na verdade terra de ocupação tradicional Guarani, é de 1971. Quando os funcionários do INCRA, expulsam a força os Guarani do Oco’y-Jacutinga, em 1973, em direção às barrancas do rio Paraná, já haviam realizado oficialmente então, em 1971, a ilegal expropriação da terra indígena. Assim, fica claro que ao expulsar os Guarani para as barrancas do rio Paraná, através do PIC-OCOI I /INCRA, esta Autarquia tinha conhecimento de que este local iria ser inundado, pois o mesmo fazia parte dos seus próprios planos, firmados junto ao PIC-OCOI II /INCRA/1971, ou seja, áreas destinadas à utilização de Itaipu.

Após tratativas com Itaipu, a "solução" apresentada pelo GT, para a questão dos indígenas se resume a assentar os Guarani na Área de Preservação Permanente /APP do reservatório de Itaipu, local que vem tornar-se superposto à Terra Indígena do Oco’y.

No histórico que analisamos, para além do desrespeito à legislação federal pertinente aos povos indígenas, verifica-se que o esbulho dos Guarani, de todos os sucessivos locais ocupados, deu-se de forma circular pelo território, sendo eles sempre os primeiros e maiores prejudicados. Os interesses que são privilegiados na ocupação do território, provocando o remanejamento das

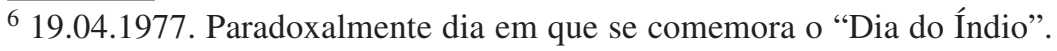


populações, dão-se na seguinte ordem de importância decrescente: 1) Grandes Projetos: Parque Nacional do Iguaçu e Itaipu Binacional; 2) Colonização - Assentamentos de populações não índias; 3) Povos Indígenas.

\subsection{Tratativas entre as Instituições FUNAI - ITAIPU. Período de 19.05 .77 a $22.06 .77^{7}$}

Reproduzimos abaixo trechos fundamentais de documentos que reportam a relação institucional entre a FUNAI e Itaipu no período.

\section{Anexo $n^{\circ} 5$ B. Em documento interno do Diretor do Departamento Geral de Opera- ções para o Presidente da FUNAI Gerson da Silva Alves, of. no (apagado) /DGO/77 de} 19.05.77 tece algumas considerações equivocadas, sobre as famílias Guarani encontradas:

Existem famílias Guarani na margem do rio Paraná, exatamente na área compreendida pelo Projeto de Colonização do INCRA - Projeto OCOI.

Quando o ponto de vista correto seria ao contrário: existe Projeto de Colonização do INCRA - Projeto OCOI exatamente na área compreendida pelas terras de ocupação tradicional Guarani.

As citadas famílias ocupam áreas individuais de aproximadamente de 5 a 10 hectares.

Nenhuma terra indígena pode ser considerada lotes de terras "individuais", mas sim de posse coletiva da Comunidade Indígena e de propriedade da União, portanto não há sentido na afirmação sobre áreas individuais.

...pelo fato de serem pescadores os Guarani ali localizados têm mesmo preferência por áreas ribeirinhas.

Excessiva insistência nesse argumento, em todos os documentos. Seria para justificar em futuro próximo o assentamento da população indígena à beira do reservatório, APP de Itaipu, onde a área já seria mesmo desapropriada pelo INCRA em função do interesse de Itaipu. A “compensação" pela hidrelétrica, devida aos Guarani, seria assim irrisória.

\footnotetext{
${ }^{7}$ Documentos constantes do processo no 1053/1976/ FUNAI em posse do MPF de Foz do Iguaçu. Anexado aqui resumos elaborados anteriormente. Anexados desta forma, por falta de tempo hábil para terminar as análises, por exigência da presença deste documento "Laudo Antropológico parte II", pela Justiça Federal e Ministério Público Federal de Foz do Iguaçu. Em novembro/2005.
} 
A $4^{\text {a }}$ DR propôs ao INCRA, através do Of. $86 / 4^{\mathrm{a}} \mathrm{DR}$, a outorga gratuita de títulos de posse da terra às famílias Guarani localizadas na área do Projeto Ocoi.

A medida era ilegal, não poderia o INCRA destinar "títulos de posse individuais" de terra à indivíduos “indígenas”. Assim, consideravam não sendo “Terras Indígenas” reconhecidas como tal, evitar-se-ia todo o processo de remoção legal junto ao órgão, definido pelo Artigo 20 do Estatuto do Índio e pela Constituição Federal. Realizado desta forma, seria rápido o processo, inclusive dispensando autorização do Presidente da República.

Essa área será também inundada futuramente pela Barragem de Itaipu o que ocasionará uma possível indenização dos lotes titulados pelo INCRA.

Considerando as "terras indígenas" como "lotes individuais de terra pelo INCRA", facilitaria os procedimentos, dispensando todos os trâmites legais, para o desterramento. Em nenhum momento foi considerada a "área de ocupação tradicional" Guarani, procedimento fundamental. Os índios, com este procedimento ilegal, viriam a perder definitivamente suas terras, inexistindo os procedimentos a que tinham legalmente o direito.

Anexo n 5 C. Em documento do servidor Saul Carvalho Lopes de junho de 1977 ao Chefe da DR de Curitiba/FUNAI, afirma-se novamente com insistência:

Os índios Guarani são agricultores e pescadores pelo que opinamos, sejam acentados (sic) as margens da represa formada pela Binacional Itaipu afim de que seus padrões alimentares não sofram solução de continuidade.

O objetivo era, evidentemente, o de baratear o custo da área na qual os indígenas seriam assentados. Como vimos no capítulo 3, essa ação, a princípio preocupada com o bem-estar dos índios Guarani, trouxe consequências nefastas à saúde dos mesmos. Assentados à beira do reservatório de Itaipu, águas praticamente paradas, contraem malária de forma epidêmica. Alimentam-se de peixes do mesmo lago, contaminados por agrotóxicos, carreados das terras de propriedade dos colonos lindeiros, extremamente próximas à Terra Indígena.

Anexo $n^{\circ} 5$ D. Em ofício do Presidente da FUNAI, General Ismarth de Araújo Oliveira para o Presidente de Itaipu General Jose Costa Cavalcanti ofício n 285/PRES/BSB de 01/ 06.1977 afirma:

Enviado a área Subgrupo de Trabalho para proceder estudo e levantamento do problema obtive a 
certeza de estarem essas famílias indígenas em local a ser inundado e que a solução desse problema seria $\underline{o \text { assentamento dos índios às margens do lago a ser formado pela represa, na zona destinada à }}$ faixa de proteção que, segundo ficou evidenciado, abrangerá, além da quota máxima estabelecida por Itaipu, uma extensão de 100 metros e excepcionalmente de 500 metros em sentido horizontal a partir da margem. Esse assentamento deverá se processar em local não distante do que ora ocupam em virtude dos hábitos de sobrevivência que mantêm e o aspecto sócio-econômico que os vincula àquela localidade, existência de seu cemitério e outros.

Novamente, a insistência no assentamento às margens do lago de Itaipu, na APP.

Anexo no 5 E. Em ofício complementar nº 04(?)6/GAB/P de 22.06.1977 do presidente da FUNAI para o presidente da Itaipu:

-a solicitação é para atender a 11 famílias indígenas num total de 27 pessoas;

-a área total necessária para o reassentamento dessas famílias é de 265 ha, na base de 15 hectares por família;

Cálculo irreal, não técnico, desconhecedor da organização social indígena sobre o território.

Como os índios Guarani são agricultores e pescadores, encareço a V. Exa., $\underline{\text { o assentamento dos }}$ mesmos às margens da represa, a fim de que seus padrões alimentares não sofram solução de continuidade.

Afirmavam os Guarani que o número de famílias era mais alto (70) inicialmente, que suas terras haviam sido invadidas pelo INCRA, obrigando-os a ocupar a pequena área em que foram localizados. A FUNAI chegou após esses fatos acontecidos, e segundo os Guarani, não deu ouvidos a eles. Não foi feito o reconhecimento de área original de ocupação. Não foi feito um recenseamento pela FUNAI da população do local. Não foi levado em conta o ato de expulsão dos indígenas pelo INCRA de seu território original para o local que seria inundado e ainda se propõe assentá-los na futura APP de Itaipu, com um custo muito baixo para a Hidrelétrica.

Pode-se concluir que a FUNAI não cumpriu sua obrigação de realizar a "Identificação do Território Tradicionalmente ocupado pelos Guarani”, através de "Laudo Antropológico". A informação sobre território ocupado pelos Guarani, nunca apareceu realmente. A informação sobre o número de população existente no local, pelos documentos vai decrescendo com o tempo, mas nunca condizem com as informações prestadas pelos Guarani. Esses dados populacionais e territoriais transformam-se nos "dados oficiais", que no futuro serão ainda mais reduzidos. 
A questão encaminhava-se, como os documentos acima demonstram, no sentido de titular individualmente através do INCRA, "as terras de ocupação tradicional de posse comunal da Comunidade Indígena e de propriedade da União", o que caracteriza ilegalidade, segundo o Estatuto do Índio e Constituição Federal.

\subsection{As ações do segundo Grupo de Trabalho FUNAI-INCRA antes da inundação do local por Itaipu (sem data) ${ }^{8}$}

Do segundo GT FUNAI-INCRA participaram, ao lado de funcionários do INCRA, outros dois funcionários da FUNAI nos trabalhos de campo, um engenheiro agrônomo e um indigenista. O trabalho não se configura oficialmente como GT constituído, porém, encaminha oficialmente resoluções a partir dos dados do primeiro GT. Após dirigirem-se a área, os servidores da FUNAI produziram documento, sem data, sem número de memorando, denominado apenas de RELATÓRIO de VIAGEM. (Battistelli. Relatório de Viagem: FUNAI, sem data, s/nº, documento constante mais tarde do processo n. ${ }^{\circ}$ 1053/1976/FUNAI, fls 143/44/45). (Anexo no 6). Os objetivos da viagem:

Objetivo: Acompanhar servidores do INCRA/Pr, numa vistoria realizada na área daquele Projeto. local habitado por doze famílias indígenas às quais serão destinados individualmente mediante titulação, uma quantidade de área de acordo com levantamento efetuado pelo INCRA. (Battistelli. Relatório de Viagem: FUNAI, sem data, processo n. ${ }^{\circ}$ 1053/1976, fls 143/44/45).

Primeiramente como funcionários da FUNAI, eles não deveriam estar visitando a área daquele Projeto do INCRA, mas sim vistoriando terras ocupadas tradicionalmente pelos indígenas, isto é, Terras Indígenas de posse coletiva de Comunidade Indígena, propriedade da União. Em segundo lugar não é o INCRA que reconhece as populações indígenas, mas a FUNAI, como já comentado anteriormente. Em terceiro lugar, pretendia-se titular individualmente as terras ocupadas pela Comunidade Indígena, utilizando-se procedimentos de acordo com as normas do INCRA. Evidentemente, o tratamento deveria ter sido outro, de acordo com as devidas normas específicas contidas no Estatuto do Índio e Constituição Federal. No Relatório de Viagem é afirmado:

\footnotetext{
${ }^{8}$ Curiosamente o texto inteiro deste GT não possui qualquer data, portanto, de difícil localização no tempo, mas contextualizado historicamente, nesta época, deve ser em torno de 1981.
} 
Os indígenas em questão pertencem a tribo Guarani e residem às margens do rio Paraná, distante $31 \mathrm{Km}$ da cidade de São Miguel do Iguaçu. Para o Instituto Nacional de Colonização e $\underline{\text { Reforma Agrária - INCRA, estes indígenas são moradores da gleba na localidade de Ocoi-2 }}$

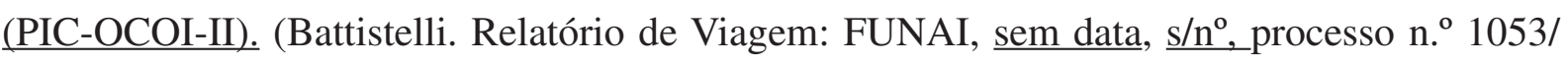
1976, fls 143/44/45)

Seria o caso de se perguntar: e para os servidores da FUNAI, onde habitavam esses indígenas?

As afirmações feitas no Relatório de Viagem dão continuidade à mesma linha de raciocínio do GT anterior: O tempo de habitação destas terras por estas famílias variam muito, chegando até a 49 anos, como existe um caso. (Battistelli. Relatório de Viagem: FUNAI, sem data, $\underline{\mathrm{s} / \mathrm{n}^{\mathrm{o}}}$, processo n. ${ }^{\mathrm{o}} 1053 / 1976$, fls 143/44/45).

Qual a competência de um engenheiro agrônomo para analisar o tempo de habitação da população indígena no local? O trabalhoso levantamento antropológico sobre o consenso histórico sobre a antiguidade da ocupação (Art. 25, Lei n. ${ }^{\circ}$ 6001) dos índios Guarani na região, foi determinado sumariamente - numa frase, sem qualquer pesquisa, por um engenheiro agrônomo, tecnicamente desabilitado para este tipo de análise.

É público e notório que a região é de ocupação imemorial da população Guarani desde antes da colonização. Inúmeros documentos históricos e arqueológicos provam o fato. Em pesquisa arqueológica ficou demonstrado que os Guarani ocupam a região a pelo menos 80 Depois de Cristo. Inúmeras são as passagens históricas descritas sobre a região em que os Guarani participam como atores sociais: as viagens de Cabeza de Vaca junto aos Guarani pelo Peabiru (1541), as Missões Jesuíticas do Guairá composta em sua maioria pelos Guarani (século XVI e XVII), as prisões de Guarani como escravos junto aos bandeirantes (século XVII), os mapas de Schmidel (século XVI), Nimuendajú (início do século XX), Chmyz (final do século XX) e muitos outros dados que atestam a presença Guarani ao longo dos séculos nesta região.

Demonstra ainda o documento, que ali mesmo, já estavam iniciando os procedimentos ilegais de titulação aos índios:

No momento da vistoria, preencheram parte dos processos individuais, visando a expedição de títulos definitivos aos indígenas. A maioria destes doze silvícolas beneficiados não possuem documentação, e cujo problema ofereceu dificuldades parciais ao INCRA na coletânea de dados. Mas estes dados são dispensados por se tratarem de pessoas não emanciapadas e sujeitas a tutela.

Cabe ao INCRA a destinação e a formalização dos títulos em nome dos indígenas que vivem naquela área, para o que, vem fazendo todo o empenho e, à FUNAI cabe assistir esta titulação 
como órgão tutor. (Battistelli. Relatório de Viagem: FUNAI, sem data, processo n. ${ }^{\circ}$ 1053/1976, fls $143 / 44 / 45)$.

É certo que não cabe ao INCRA este tipo de procedimento, pois povos indígenas são regidos pelo Estatuto do Índio, justamente criado para atender às especificidades indígenas de posse e uso coletivo da terra de toda a Comunidade Indígena em seu conjunto; ao passo que o INCRA aplica o Estatuto da Terra, na forma de titulação individual para outras populações, colonos, os quais possuem a "propriedade individual" da terra, fazendo uso da terra diferenciado dos indígenas. Outra afirmação decisiva proferida pelos funcionários da FUNAI:

Como estes indígenas ocupam por mais de dez anos áreas inferiores a 50 hectares de terra o “Estatuto do Índio" Lei 6001 de 19/12/1973 no Artigo 33 lhe dá o direito de propriedade plena. (Battistelli. Relatório de Viagem: FUNAI, sem data, processo n. ${ }^{\circ}$ 1053/1976, fls 143/44/45).

O Estatuto do Índio, Lei n. ${ }^{\circ} 6001$ de 19.12.1973 no Capítulo IV - Das Terras de Domínio Indígena, em seu Artigo $33^{9}$, afirma na verdade:

Artigo 33: O índio, integrado ou não, que ocupe como próprio, por dez anos consecutivos, trecho de terra inferior a cinquenta hectares, adquirir-lhe-à a propriedade plena.

Porém vem em seguida o Parágrafo Único, fazendo ressalva importante, o qual no caso se fez questão de omitir:

\footnotetext{
Parágrafo Único: O disposto neste artigo não se aplica às terras de domínio da União, ocupadas por grupos tribais, às áreas reservadas de que trata esta lei, nem as terras de propriedade coletiva de grupo tribal.
}

No caso, as terras eram de domínio da União e ocupadas por grupo tribal. Portanto, os técnicos da FUNAI, não levaram em conta este Parágrafo Único do Artigo 33, o qual seria contraditório com aquela situação.

\footnotetext{
${ }^{9}$ Este Artigo destina-se àqueles casos onde se encontra uma ou duas famílias indígenas, apenas, isoladas em local distante, em que já não são componentes de um Grupo Tribal, eventualmente vivendo na periferia de qualquer lugar.
} 
Não eram indivíduos isolados que ali foram encontrados, mas sim uma coletividade indígena, em processo de desterramento de suas terras em função de obra pública, que anteriormente sofreram, ainda, invasão de suas terras originais pelo INCRA. Tentou-se descaracterizar a existência de coletividade indígena, de grupo tribal, que viviam em terras da União, para uma falsa visão de poucos indivíduos isolados, últimos remanescentes, que supostamente viveriam em um ínfimo pedaço de terra, inferior a cinquenta hectares.

Assim, os técnicos da FUNAI consideraram, erroneamente, que os Guarani poderiam receber terras inferiores a cinquenta hectares como "propriedade particular", como se fossem posseiros beneficiados por usucapião. Battistelli continua:

Porém, como o orgão tutor é a FUNAI quem representa o índio juridicamente, por isso, Sugiro: IQue doravante o Setor Jurídico desta DR/FUNAI acompanhe a titulação e a entrega dos títulos a estes silvícolas beneficiados.(idem)

II - Após tituladas, esta área ficará contida na Bacia Hidrográfica da Hidroelétrica, então, deverá a FUNAI contactar com a Itaipu-Binacional para requerer a indenização. (idem)

Portanto, posteriormente à ilegal titulação individual dos indígenas, pretendia-se que Itaipu viesse a pagar a indenização pelas terras de ocupação tradicional como se fossem terras de colonos. Para a empresa isso possibilitaria retirar rapidamente a população indígena da área que viria a ser inundada, em detrimento dos direitos indígenas.

III - Que a indenização seja feita com outra área de igual tamanho, fértil e produtiva, de preferência as margens do lago para reassentamento dos índios.(idem)

Pergunta-se qual tamanho de área, se a terra não foi identificada? A de lotes individuais? Fica claro também que se pretendia reassentar a população indígena nas margens da Área de Preservação Permanente/APP do lago de Itaipu. Portanto, o remanejamento não haveria custos para Itaipu, já que a APP viria a ser de propriedade da mesma.

IV - Que o reassentamento destas famílias seja assistido pela FUNAI até a sua concretização. (idem)

A seguir o servidor Battistelli faz a relação das famílias consideradas pelo INCRA como "legítimas" recebedoras de títulos individuais de terras: 
Relação das doze famílias a serem tituladas e indenizadas, posteriormente, número e área dos lotes que ocupam num total de 91,1313 (noventa e um hectares treze ares e treze centiares).

$\begin{array}{lrr}\text { Nome } & \mathbf{N}^{\mathbf{o}} \text { do lote } & \text { Área (ha) } \\ \text { Nicolas Fernandes } & 571 & 25,8626 \\ \text { Saturino Fernandes } & 573 & 8,0000 \\ \text { João Lopes } & \mathbf{5 7 4} & \mathbf{5 , 5 9 5 7} \\ \text { Ovilon Venite } & \mathbf{5 7 5} & \mathbf{4 , 8 7 0 4} \\ \text { Fernando Martins_ } & \mathbf{5 7 6} & \mathbf{4 , 8 1 9 2} \\ \text { Julião Fernandes_ } & 577 & 4,6037 \\ \text { Clementino Rodrigues } & 578 & 9,7920 \\ \text { Balbino Venite_ } & 581 & 4,2950 \\ \text { Idalécio de Cordeiro_ } & 582 & 9,9648 \\ \text { Valdemar Floriano_ } & 590 & 10,2157 \\ \text { Máximo Vilialva } & 592 & 6,1336 \\ \text { Salécio Rosa_ } & & 9,8782 \\ \text { Total_ } & & 91,1313\end{array}$

(12 famílias)

Desta relação supra discriminada contactamos com oito indivíduos sem títulos, dois já estão titulados (Idalécio de Cordeiro e Valdemar Floriano), dois estão no Paraguai (João Lopes e Salécio Rosa) e o último (Máximo Vilialva) mudou-se para a área indígena Rio das Cobras.

Existem problemas nos lotes de $\mathrm{n}^{\circ} \mathrm{s} 590$ e 592 pertencentes aos índios e foram destinados a terceiros. De acordo com informações locais os dois índios constantes da já mencionada relação, ocupam estas terras a já muito tempo, porém cabe ao INCRA destinar os lotes aos verdadeiros titulados, de acordo com os critérios padronizados para tal, no PIC-OCOI. (idem)

Portanto, "reconhecidas" as terras indígenas como lotes individuais, elas poderiam ser desapropriadas em favor de Itaipu, conforme acontecia com colonos, em procedimento junto ao INCRA. A descaracterização das terras indígenas contornaria os procedimentos legais decorrentes, a saber: - autorização da Presidência da República; - os direitos indígenas sobre as terras, decorrentes da Constituição Federal e Artigo 20 do Estatuto do Índio, que estabelece normas para remoção de população indígena, com a expressa determinação de destinar-lhes terras em extensão igual a anterior e ambientalmente semelhante. 
Iniciou-se dessa forma a formalização da passagem de direitos coletivos da "comunidade indígena" que possuíam interesses comuns, consignados em extensa legislação para a situação de indivíduos isolados, semelhante à situação legal de colonos. Os direitos indígenas às especificidades socioculturais, assim como os direitos às terras que ocupavam, através deste procedimento desapareceram.

\subsubsection{O Laudo Antropológico de Célio Horst: os Critérios de Indianidade (1981)}

Como a FUNAI necessitasse da chancela de um antropólogo na documentação produzida de antemão, pelos GTs, foi escalado um funcionário da FUNAI, chamado Célio Horst ${ }^{10}$. Ele dirige-se a área, depois de tudo já acordado pelos GTs, e numa perícia inaceitável de apenas um dia em campo, não reconhece a maioria dos indivíduos "indígenas", como "indígenas" (Anexo no 7).

Nesse trabalho de Horst, repleto de equívocos, informações truncadas, erros de interpretação, contradições, se omite a devida análise antropológica e não se observa a legislação pertinente. Após breve relatório, Horst aplica ao final, critérios de "raça", os conhecidos "Critérios de Indianidade" ${ }^{11}$, que nunca foram utilizados por antropólogos, dentro ou fora da FUNAI, a não ser por ele mesmo.

A explanação de Horst contradiz o afirmado no Relatório de Viagem do engenheiro agronômo Battistelli, sobre que os Guarani estavam ali a não mais de 49 anos (sic). Uma das poucas afirmativas corretas de Horst é que ele confirma a imemorialidade da habitação Guarani na região às

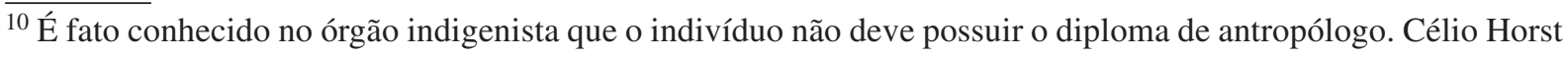
mantinha ligações com meios militares na época. Segundo relatos de funcionários da FUNAI, era filho de criação do ex-Presidente da República Ernesto Geisel. A FUNAI conhece bem o papel que este indivíduo desempenhou durante o Governo Militar na questão indígena. Mais recentemente, no caso dos YANOMAMI/Roraima, Horst propôs a demarcação de várias "ilhas" no entorno das aldeias, proposta mais tarde desfeita, pois, desconsiderava áreas fundamentais de perambulação, onde estes indígenas obtinham os recursos ambientais necessários à sobrevivência. Este tipo de informação "área de perambulação" é de conhecimento básico de qualquer antropólogo. A área YANOMAMI foi posteriormente demarcada em território contínuo.

${ }^{11}$ Os critérios de indianidade foram criados administrativamente na FUNAI, sob as ordens do coronel Ivan Zanoni, em 1981, para "classificar quem é ou não índio", sob a recomendação de que tais indicadores não precisavam ser justificados, mas simplesmente listados. O documento apresentado faz menção à comunidade científica, mas esta jamais sequer foi consultada. Os antropólogos, por sua vez dentro e fora da FUNAI, sentiram-se indignados perante tal absurdo e simplesmente ignoraram os tais critérios, por acreditarem que não existem 'indicadores' para detectar indianidade, assim como não se pode medir o quantum de indianidade tem uma pessoa. (Faria: 1997:124). Os critérios de indianidade deixaram de ser utilizados na FUNAI, após as críticas provenientes da comunidade científica. Os critérios legalmente estabelecidos pelo Estatuto do Índio, já válidos na época são utilizados até hoje.
} 
margens do rio Paraná, baseando-se em informações de outros autores. Refere-se assim ao conjunto de aldeias Guarani existentes na região brasileira e paraguaia, como território tradicional da etnia Guarani.

Horst lança mão de textos sobre as Forças Armadas brasileiras, para ilustrar a participação de "índios em geral" na Guerra do Paraguai e "um" Guarani em cena, na Batalha de Tuiuti, o que em nada contribui para a reflexão antropológica sobre os indígenas do Oco’y-Jacutinga. Quanto à história mais recente, confirma também a existência de famílias Guarani em Colônia-Guarani/ Três Lagoas, quando a FUNAI havia fornecido antes certidão negativa ao INCRA, afirmando, indevidamente, que o local não era de habitação indígena:

(...) Esta migração continuou com a expansão das frentes pioneiras no oeste paranaense e na década de 30, cerca de 40 famílias viviam em Colônia-Guarani em Três Lagoas. Estas terras teriam sido demarcadas pelo Distrito de Terras do Paraná e Santa Catarina, do INCRA.

Como antropólogo da FUNAI em campo, Horst deveria ter questionado em seu relato a ocupação não indígena, de um local que ele próprio caracterizava como imemorial terra de ocupação tradicional indígena, a Colônia-Guarani, e sua posterior demarcação para colonos feita pelo INCRA. Não fez menção à questão, e continua:

A maioria dos Guarani de Três Lagoas foi dizimada por epidemia de maleita no período de 1948-50, tendo seus remanescentes se retirado da área, na década de 50/60, sob a pressão da sociedade envolvente.

Hoje eles se encontram dispersos pelas margens do rio Paraná em fazendas, em ilhas próximas a Guairá, em alguns Postos Indígenas, e na Área do Projeto Integrado de Colonização OCOI, cuja área ficará contida na Bacia Hidrográfica da Hidrelétrica de Itaipu-Binacional. (HORST:1981:3-4).

Horst inverte os valores ao afirmar que os índios Guarani estão na Área do Projeto Integrado de Colonização OCOI, cuja área ficará contida na Bacia Hidrográfica da Hidrelétrica de Itaipu-Binacional (HORST: 1981:4). Ora, é justamente o contrário: a Área do Projeto Integrado de Colonização OCOI, cuja área ficará contida na Bacia Hidrográfica de Itaipu, é que estava sobreposta à Terra de Ocupação Tradicional Guarani, o Oco’y-Jacutinga.

Horst continua, confirmando mais uma vez a imemorialidade da ocupação Guarani na área, agora referindo-se sem saber ao Tekoa Guassu: 
Nesta área, objeto da Instrução técnica nº 023/81-AGESP, as famílias identificadas como sendo indígenas são originárias de Três Lagoas ou de Porto Irene.

Os Guarani do OCOI estão numa região que é território tradicional Xiripá (Avá)-Guarani. Esta região se estende pelas margens do rio Paraná, da foz do rio Iguaçu até a foz do Paranapanema, estando incluída nela, as duas localidades supracitadas. (HORST: 1981:4)

Apesar de reconhecer a imemorialidade da ocupação Guarani em toda a região, surpreendentemente Horst sequer faz menção sobre o devido reconhecimento antropológico da antiga área de ocupação, Colônia-Guarani, assim como sequer menciona o devido reconhecimento antropológico sobre a situação atual, do Oco’y-Jacutinga. Horst sequer nomeou a terra como “'Oco’yJacutinga", como os Guarani sempre o fizeram.

Omitindo-se em defender os interesses indígenas sobre as terras na área, indica como solução da problemática, a remoção do grupo para outra terra indígena, Posto Indígena Rio das Cobras:

Que as famílias identificadas como sendo indígenas possam residir na área Guarani do PINHAL (PI Rio das Cobras), conforme seu próprio desejo. (HORST: Relatório de Viagem. ITE nº 023/81AGESP:1981:7)

Assim sugere que os Guarani sejam transferidos para o PI Rio das Cobras, através de um suposto - e que testemunhas Guarani negam ter dado - aval dos próprios índios. Há várias Cartas Indígenas juntadas ao processo no 1053/76/FUNAI que provam o contrário: os Guarani do Oco'yJacutinga pretendiam permanecer e reivindicar os direitos sobre suas terras. Horst propunha transferir a população indígena Guarani para terra já demarcada de posse de etnia diversa, Kaingang, o que provocaria superpovoamento de terras já ocupadas, ao mesmo tempo que subtrairia terras das populações indígenas, cujo direito à manutenção da posse era garantindo constitucionalmente. Sugere ainda:

Que a FUNAI acompanhe o processo de indenização (LOTE 574, 575, 576, 590 e 592) e que esta importância seja aplicada em benefício das famílias a serem removidas (construção de casas, abertura e preparo de novas roças etc). (HOSRT: 1981:7)

Descreve a terra coletiva de posse indígena como se fossem "lotes" do INCRA. Nos fatos, auxilia o invasor INCRA a se estabelecer, retirando da área os verdadeiros ocupantes imemoriais. 
Nota-se pelo discurso de Horst que os índios Guarani do Oco’y-Jacutinga, já haviam sido titulados individualmente, que o processo de indenização estava em curso, e nem ao menos os valores monetários que seriam transferidos em nome dos índios pela "perda das terras", seriam aplicados em aquisição de "novas terras", mas sim para a instalação das famílias que perderam as suas, em área já demarcada para outra população indígena. Se fosse obrigado a gerenciar a remoção, que o fizesse de acordo com o Artigo 20 do Estatuto do Índio e Constituição Federal.

A FUNAI, como tutora, tem o dever de resguardar os interesses e direitos indígenas, diante de sua capacidade relativa de compreensão dos mecanismos de funcionamento da sociedade nacional. A FUNAI, com base na legislação federal, tem o dever de complementar a vontade do

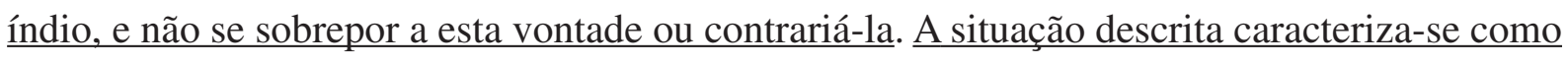
abuso da tutela, indo frontalmente contra os interesses indígenas e seus direitos territoriais protegidos por lei.

Pelas contas do INCRA a população do Oco'y-Jacutinga somava 11 famílias, pelas contas dos próprios Guarani haviam permanecido 19 famílias. Horst, por seu lado, em campo, submete somente 9 famílias ao estudo realizado, afirmando, o que é inadmissível do ponto de vista antropológico, que apenas 4 (quatro) famílias seriam verdadeiramente "indígenas". As restantes, afirma são não-indígenas ou remanescentes indígenas que não se auto-identificam como sendo indígenas. (HORST:1981: 4-5-6).

Um detalhe que chama a atenção: na página 4 do texto de Horst, no final do $4^{\circ}$ parágrafo, está escrito:

Para a identificação étnica dos habitantes do PIC-OCOI, utilizei como roteiro os Indicadores de Indianidade, elaborado por técnicos desta AGESP, sendo este aplicado a cada família que foi anteriormente conscientizada da realidade de sua condição de indígena ou não indígena e sobre as condições de uma família não assumir sua identidade étnica, chegando ao seguinte quadro:

O detalhe: as palavras não assumir foram escritas no texto posteriormente..., a mão. O Artigo $3^{\circ}$, item I do Estatuto do Índio, Lei no 6001 de 19/12/1973, afirma:

I - Índio ou Silvícola -É todo indivíduo de origem e ascendência pré-colombiana que se identifica e é identificado como pertencente a um grupo étnico cujas características culturais o distinguem da sociedade nacional; 
Aí está legalmente a forma como se realiza a identificação das populações indígenas, não é qualquer indivíduo que o faz, mas sim é uma auto-identificação realizada pelo próprio indígena, que ao mesmo tempo é identificado pelo seu grupo étnico. A lei bastava, não era necessária uma medida administrativa da FUNAI, nos moldes dos "Critérios de Indianidade". O trabalho foi realizado junto somente aos "chefes" de família indígena, porém, mulheres, filhos e netos foram “julgados” também pelo mesmo “critério", sem passar por qualquer crivo.

Antropólogos, objetivando pesquisar dados com relação às famílias indígenas de certo local, costumam realizar as pesquisas através do levantamento de árvores genealógicas, visando verificar as relações de afinidade e/ou consanguinidade das parentelas entre si, bem como a composição das famílias extensas. No documento de Horst é apresentada apenas uma listagem individual de cada chefe de família e seus parentes, como se fossem famílias nucleares sem qualquer relação entre si.

Os "Critérios de Indianidade" são apresentados por Horst em três subgrupos de pesquisa. A seguir reproduzimos em itálico os critérios e os comentamos em seguida: (Anexo n⿳0 8).

1) Indicadores apontados pela sociedade nacional - por si mesmo indicador absurdo, pois quem são esses representantes da sociedade nacional que opinam? Os vizinhos dos índios, que geralmente concorrem pelas terras dos mesmos ? É muito subjetivo e impreciso tal critério.

a) denominação pejorativa - encampa como indicador lugares comuns provenientes de indivíduos membros da sociedade nacional, provavelmente vizinhos, sobre as populações indígenas.

b) origem étnica - como indivíduos comuns provenientes da sociedade nacional, podem opinar sobre a "origem étnica" de populações indígenas, dado muito específico, se mal sabem na verdade quem são essas populações, no máximo, em geral, que são apenas índios.

c) elementos culturais representativos - como indivíduos comuns provenientes da sociedade nacional, podem opinar sobre "elementos culturais representativos" se não convivem com estas populações? E se este dado por acaso referir-se à cultura material, é um dado bastante relativo, pois depende do ambiente em que esta população está inserida, se há ou não disponibilidade de material da flora e fauna no local, para reproduzir a vida material.

d) características qualitativas e pigmentares - o que vem a ser características qualitativas? Não se sabe! quanto à características pigmentares, de há muito esta discussão já havia sido superada, pois é o critério cultural que é considerado válido, ou seja, se o indivíduo comunga usos e costumes de determinado grupo, que são provenientes de cultura indígena específica; é este o critério, cultural, que os definem como indígenas. 
e) Mestiçagem - o próprio Horst não entende os indicadores dos critérios de indianidade (sic) por ele utilizado! Os índios que ele admite serem índios verdadeiros, levaram a nota máxima de mestiçagem. Os que ele nega serem índios verdadeiros, levaram a nota mínima de mestiçagem, o que demonstra a má qualidade do material apresentado.

2) Indicadores apontados pelo Índio:

f) identidade histórica - em apenas um dia de trabalho não seria possível todos os índios dali levantarem sua “identidade histórica”. E mais, este é um tema que não é tratado individualmente.

g) índios identificados - índios não fazem observações sobre “ índios identificados”, índios realizam a auto-identificação.

h)Língua - Horst deixa escapar que todos falam a língua Guarani, o que por si só já é sinal de identificação mais do que provada, pois se todos utilizam a língua materna, comungam todos os valores da cultura Guarani ali presente.

i) arte indígena - valor relativo, pois as áreas Guarani em geral são pobres em cultura material, porque os ambientes são pobres em biodiversidade.

j) alimentação - valor relativo, pois as áreas Guarani em geral são pobres em cultura material, porque os ambientes são pobres em biodiversidade.

Indicadores apontados pela FUNAI - pela lei os povos indígenas se auto-identificam e são identificados pelo agrupamento, nem haveria sentido neste indicador.

k) critério histórico e geográfico - mal foi realizado pois em apenas um dia de trabalho não seria possível Horst levantar esta informação junto aos índios, tanto é que não existe a informação em detalhe no relatório realizado por ele. Este dado relacionado a um indivíduo isolado, pouco ou nada faz sentido.

l) critério cultural - mal foi realizado, em apenas um dia de trabalho, nada se refere ao tema no relatório.

m) auto-identificação - Horst inverte os termos novamente, pois não é a FUNAI que faz a auto-identificação, são os próprios índios.

n) identidade tribal - objetivo impreciso?

o) identidade de caráter - não se sabe sequer o que pretendia dizer com isso?

Legenda: Média 75 0-75 pontos = não índio $\quad 76-150=$ índio

0 - nenhuma característica 5 -algumas características 10 -todas as características

Ao final indica o "total de pontos" que cada indígena fez. Descontente com a forma de auferir da Legenda, em seguida remodela para:

1-Fraco 2-Médio 3-Forte 
Os critérios utilizados para definir quem são ou não índios, aponta indicadores equivocados do tipo grau de indianidade: fraco, médio, forte. Não se sabe o que vem a ser a característica identitária de um indígena "Fraco, Médio ou Forte"?

A linguagem do laudo não caracteriza abordagem antropológica. Apresenta juízos de valor preconceituosos, adjetivação pejorativa, imprecisa e não justificada, encampa lugares comuns da sociedade nacional sobre os índios, manipula desajeitadamente fontes históricas, demonstrando desconhecimento da dinâmica histórica Guarani na região, além de observações empíricas mal feitas. Enfim, trabalho extremamente falho, formalmente viciado, caracterizado por ideias cientificamente não pertinentes e em desacordo com a legislação.

Ironicamente denominados como "indiômetro", segundo Castro, os "Critérios de Indianidade" são resumidos por este autor, da seguinte forma:

Um documento non sense, que consiste basicamente em listar, indexar indicadores com números, palavras, expressões tiradas de manuais de antropologia e textos obscuros. Estão impregnados de fundamentos racistas, pois procuram classificar o índio a partir de sinais físicos - contidos na listagem de características biológicas (mancha mongólica, forma dos olhos, pelos do corpo) e indicadores de ordem psicológica (mentalidade primitiva), é um documento inqualificável do ponto de vista antropológico, mas perfeitamente qualificável do ponto de vista político. (CASTRO:1982:57)

Os "Critérios de Indianidade" tiveram como finalidade política extinguir a proteção legal às Comunidades Indígenas, as quais seriam consideradas “ex-índios”, após terem supostamente absorvido padrões culturais da sociedade nacional envolvente. Uma emancipação ex-ofício, emancipar o índio independentemente da sua vontade, como é observado por Faria (1997).

É ainda Faria (1997) que afirma que a FUNAI, na época, esperava alcançar dois objetivos imediatos com os Critérios de Indianidade:

O primeiro político tinha como meta interromper a rebeldia ou mesmo atos considerados pela FUNAI, como subversivos de lideranças indígenas que se opunham à política indigenista oficial da época. Isto se dava através do controle das lideranças indígenas que incomodavam e criticavam a política oficial, ou seja, só seria índio quem o governo quisesse e, na qualidade de ex-índios, estas lideranças não poderiam mais falar em nome de todo o grupo; o segundo objetivo era econômico, no sentido de liberar as terras indígenas do nordeste, sul e sudeste do Brasil.(FARIA:1997:127) (grifos nossos). O resultado do Laudo de Horst: afirma que apenas 4 indivíduos e suas respectivas famílias, 
são "verdadeiros indígenas". Das 11 famílias "reconhecidas" anteriormente pelo INCRA, agora apenas 4 famílias terão o direito às terras. (Anexos $\mathbf{n}^{0} \mathbf{s} 7$ e 8).

Os indígenas que foram reconhecidos como tais foram: Fernando Martine e família; Ovilon Venite e família; Máximo Vilhalva e família; e Salício Rosa.

Os indígenas que não foram reconhecidos como tais foram: Nicolas Fernandes e família; Saturnino Fernandes e família; Balbino Benitez e família; Julião Fernandes e família; e Clementino Rodrigues e família. Os outros indígenas, segundo depoimentos dos próprios Guarani, "não existiram" na ótica de Horst.

O Laudo de Horst dá a entender que os "poucos" indígenas encontrados na região seriam apenas os remanescentes da população de outrora, sobras de um passado remoto..., o que vem a calhar com a brecha aberta por seus antecessores do GT anterior, ao suprimir o parágrafo único do Artigo no 33 do Estatuto do Índio. (Anexo n⿳0 6).

Assim, este posterior "Laudo Antropológico" é reconhecido, vindo a legitimar a ação anterior dos GTs, de forma irregular, como já demonstramos ${ }^{12}$. Portanto, quanto menor o número de indivíduos reconhecidos como indígenas e quanto menor a área de ocupação (deveria ser inferior a 50 hectares), mais fácil seria aplicar o Artigo 33 do Estatuto do Índio (suprimido logicamente seu Parágrafo Único). Outra “vantagem” obtida com esse procedimento ilegal seria a possibilidade de transferir as poucas famílias reconhecidas como "indígenas" para outra aldeia já habitada, e se, no limite, houvesse resistência à essa transferência e se tornasse necessário destinar terras para estes indígenas - como veio a ocorrer, estas seriam destinadas na forma de "lotes familiares" (o que a legislação impede), em menor número, ou seja, apenas 4 (quatro) lotes, despendendo menos recursos para a obtenção de terras.

Os dados do LA de Célio Horst foram amplamente contestados por 6 (seis) outros Laudos Antropológicos. Dentre estes, um Laudo era da antropóloga Rosane Cossich Furtado da própria FUNAI (Anexo no 10). Ou seja, pareceres diametralmente contrários, foram realizados e um foi encaminhado por funcionário da mesma FUNAI. Mas esses seis laudos não foram acatados.

As 19 famílias indígenas, apesar das tentativas da FUNAI de transferi-las para a Terra Indígena Rio das Cobras, permaneceram resistindo no Oco’y-Jacutinga, pois se consideravam possuidoras de legítimo direito sobre as terras. A Itaipu, FUNAI e INCRA não tiveram outra saída a não ser adquirir terras para os 4 ( quatro) grupos familiares. Dessa forma, a solução

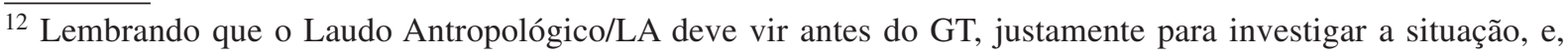
depois o GT executar o que foi estipulado pelo LA.
} 
dada por essas Instituições, mais uma vez se deu em total desacordo com as leis do país ("módulos rurais" do INCRA para “indígenas").

5.2.5.3. As tentativas de titulações individuais de terra aos indígenas pelos órgãos INCRA e FUNAI. Tratativas entre as Instituições Governamentais: FUNAI - INCRA - ITAIPU. E não governamentais: CJP e ANAI. Laudos Antropológicos e Cartas dos Guarani. Período de 19/06/81 a 05/02/82

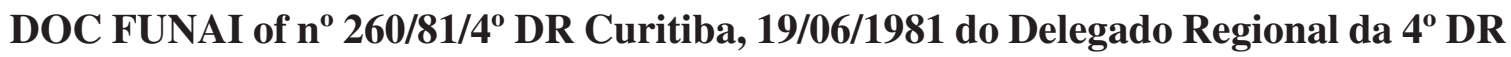
Harry L. Ávila Teles para o Coord. Geral da Coordenadoria Regional do INCRA- Curitiba. Dr. José Guilherme Lobo Cavagnari. Anexo n9 A

Subtítulo: À Comissão de Emancipação do PIC-OCOÍ, para as demais medidas inerentes à titulação.

De acordo com nossos entendimentos anteriores a respeito das famílias indígenas localizadas na área do Projeto Integrado de Colonização do Ocoí -PIC-OCOÍ, em Foz do Iguaçu -PR, cujas terras serão atingidas pelo reservatório da Usina Hidrelétrica de Itaipú, considerando o levantamento antropológico realizado pela FUNAI junto àquela região, informamos a relação dos indivíduos considerados como índios.

Inversão completa de valores: as famílias indígenas não estavam localizadas na área do Projeto Integrado de Colonização do Ocoí -PIC-OCOÍ, em Foz do Iguaçu -PR, mas ao contrário, o Projeto Integrado de Colonização do Ocoí -PIC-OCOÍ que instalou-se ilegalmente em área das famílias indígenas. O local era área tradicional de ocupação dos Guarani, o Oco’y-Jacutinga. O PIC OCOÍ-I se sobrepôs à Terra Indígena, como vimos anteriormente, empurrando os Guarani para a beira do rio Paraná, área ainda do território indígena, porém, área essa última, que o INCRA já tinha conhecimento que seria inundada pela Itaipu. Está claro a má fé do INCRA. Está claro a má fé do delegado regional da FUNAI.

Através de Laudo Antropológico, ficou identificado como sendo indígenas as famílias de Fernando Martine, Ovilon Venite, Máximo Vilhalva e Salício Rosa. Segundo consenso geral dos habitantes da área, o indivíduo João Lopes também é considerado índio, porém não se encontrava no local por ocasião do levantamento efetuado. Os lotes a serem titulados são os de nºs 574, 575, 576, 590 e 592. Assim sendo esta fundação assistirá oficialmente a titulação dos lotes aos índios acima relacionados, de acordo com o que dispõe a Lei n ${ }^{\circ} 6001$, de 19/12/73, em seu artigo 33. 
Diante do até aqui exposto, solicitamos a essa Coordenadoria Regional sejam adotados as medidas necessárias e cabíveis para a consecução do que acima se propõe.

Como vimos, eram ao todo 70 famílias que viviam no Oco’y - Jacutinga. Após a ação do INCRA, através da expulsão à força para dar lugar aos colonos provenientes do Parque Nacional do Iguaçu, restaram 32 famílias, as outras dispersaram pela região e/ou foram obrigadas a ocupar aldeias já ocupadas por outros indígenas. Os Guarani foram empurrados para a margem do rio Paraná, local que seria inundado pela Itaipu. Embora não seja sua função institucional, o INCRA faz um reconhecimento de 11 famílias indígenas. A FUNAI endossa, sem qualquer pesquisa, essas 11 famílias. Em seguida é feito o Laudo Antropológico de Célio Horst, que afirma que são 4 e mais uma família que está dispersa, um total de 5 famílias, os verdadeiros indígenas. Tratavase, assim, de diminuir ao máximo o número de famílias indígenas, para se utilizar da brecha relativa existente no Artigo 33 do Estatuto do Índio.

Com esse procedimento, pretendeu-se destinar às 5 famílias indígenas, "lotes" de terras, procedimento este ilegal, populações indígenas são regidas pelo seu próprio estatuto, o Estatuto do Índio, não configuram-se como "colonos", que são regidos pelo Estatuto da Terra. Com isso todos os direitos indígenas cairiam por terra.

Outros documentos resumidos, mas não comentados:

Ofício INCRA - 4 (09) no 445 de 10/07/81 do Coordenador Regional do INCRA/PR, José Guilherme D. Cavagnari, para o Presidente da FUNAI.Anexo no 9 B

Em atenção aos ofícios no 170/PRES., de 06/05/81 e nº 260/81/4DR., de 19/06/81, protocolados nesta Coordenadoria Regional sob números 1204/81 e 1589/81 respectivamente, estou encaminhando a Vossa Senhoria, cópia das plantas, memoriais descritivos e Títulos Definitivos de Propriedade, outorgados à indígenas residentes no Projeto Integrado de Colonização OCOI, situado em Foz do Iguaçu-PR.

A expedição do Título Definitivo à Máximo Vilialva, ocupante do lote $n^{\circ} 590$, está dependendo da aprovação pelo Departamento de Recursos Fundiários do INCRA, bem como, da anuência prévia da Secretaria Geral do Conselho de Segurança Nacional. Oportunamente será encaminhada a esta Fundação, cópisa do referido Título. 
É enviado em anexo o documento a seguir.

4 (quatro) documentos referentes à TÍTULO DEFINITIVO DE PROPRIEDADE DE $\mathrm{N}^{\circ} \mathrm{S}$ 1) 4(09)92(02) 831 2) 4(09)92(02) 832 3) 4(09)92(02) 835 4) 4(09)92(02) 837 emitidos pelo Ministério da Agricultura -INCRA. Curitiba 06/07/1981. Anexo nº 9 C

São expedidos 4 documentos de igual teor, destinando "Títulos Definitivos de Propriedade" aos “indígenas"(???), são eles:

Doc 1) 4(09)92(02) 831 Indígena Fernando Martins - imóvel com área de 4,9892 ha - Lote 576

Doc 2) 4(09)92(02) 832 Indígena João Lopes - imóvel com área de 5,5957 ha - Lote 574

Doc 3) 4(09)92(02) 835 Indígena Ovilon Benite - imóvel com área de 4,8704 ha - Lote 575

Doc 4) 4(09)92(02) 837 Indígena Salecio Rosa - imóvel com área de 6,8782 ha - Lote 592

Os quatro títulos somam irrisórios 22,3335 hectares. Por serem idênticos os termos dos Títulos, reproduziremos apenas um, a título de exemplo de como foi o procedimento realizado.

Pelo presente Título Definitivo mediante condição resolutiva, o INCRA (...) por seu Presidente e tendo em vista as disposições dos artigos 24 da Lei n 4.504, de 30/11/1964, arts. 25 alínea "g" e 51 do Decreto n ${ }^{\circ} 68153$ de 1\%/02/1971, concede a Fernando Martins, brasileiro, indígena, solteiro, agricultor, filho de (...) o lote n⿳0 576 do Projeto Integrado de Colonização OCOÍ - Município de São Miguel do Iguaçu-PR.

O imóvel tem área de 4,8192 ha (quatro hectares oitenta e um ares e noventa e dois centiares), com os limites e confrontações seguintes: (...) cuja planta e memorial descritivo integram este Título, conforme Processo Administrativo CR (09) no 711/79, e mediante as seguintes condições:

CLÁUSULA PRIMEIRA - O INCRA é o senhor e legítimo possuidor da área integrante do Projeto supramencionado conforme transcrição no Registro de Imóveis da Comarca de Foz do Iguaçu sob o n ${ }^{\circ} 18.586$ às fls 239 do Livro 3-P.

CLÁUSULA SEGUNDA - O presente título é concedido graciosamente, ex-vi do Art.33 da Lei no 6001, de 19/12/1973 “ESTATUTO DO ÏNDIO”.

CLÁUSULA TERCEIRA - Fica preservada a destinação da área com a obrigatoriedade do OUTORGADO cumprir as exigências estipuladas neste Título, sendo-lhe vedada a alienação sem prévia anuência do INCRA, excluindo-se dessa inalienabilidade, qualquer negócio jurídico a ser pactuado com órgão governamental ou entidade delegada, visando efeitos expropriatórios, sob pena de nulidade absoluta. 
CLÁUSULA QUARTA - O não cuprimento de qualquer disposição legal aplicável à espécie, bem como das condições estipuladas neste Título, autoriza a adjudicação do imóvel pelo INCRA, mediante pagamento das benfeitorias realizadas pelo Outorgado, com resilição de pleno direito do domínio ressalvados os créditos hipotecários, se existentes.

O presente título é firmado em três vias, aceitando o Outorgado, expressamente, as cláusulas e condições dele integrantes, eleito o foro de Brasília-DF, com renúncia a qualquer outro, para dirimir quaisquer questões que resultarem deste.

Assina o documento em nome do Presidente do INCRA, José Guilherme D. Cavagnari, Coordenador Regional do INCRA/PR (Delegação de Competência -Port 588(?) / 79.

A $2^{\text {a }}$ via deste Título, acompanhada da planta e memorial descritivo da área, constituirão Folha de Livro Fundiário da Divisão de Terras Públicas do Departamento de Recursos Fundiários do INCRA.

Ministério do Interior. FUNAI. Ofício no 122/DGPI BSB, 12/08/1981. De Claúdio H. Pagano de Mello/ Diretor do Departamento Geral do Patrimônio Indígena - DGPI para Dr Odair Zanatta /Diretor do INCRA -DF Departamento de Recursos Fundiários. Anexo n 9 D

Tendo em vista a conclusão dos entendimentos entre esse Instituto e esta Fundação, com vistas à titulação definitiva dos remanescentes indígenas “Guarani”, situados nos lotes ns 574, 575, 576 e 592, da Gleba 04, do imóvel do OCOÍ (...), cumpre-nos informar a V. As, quanto à necessidade de cancelamento dos TDs já preparados pela Coordenadoria Regional do Paraná - CR-09, desse órgão, a fim de que os títulos definitivos a serem outorgados àqueles indígenas se ajustem às exigências legais contidas no Estatuto do Índio.

Os beneficiários dos lotes acima referidos são os indígenas João Lopes, Fernando Martins, Salecio Rosa eOvilon Benite, todos solteiros e antropologicamente identificados pelo órgão próprio desta Fundação, como remanescentes indígenas Guarani, estando assim, sob proteção legal do Estatuto do Índio.

Desse modo, consoante entendimento do Setor de Regularização Dominial deste Departamento, aprovado pela Procuradoria Geral desta Fundação, passamos às mãos de V. Sa, para as necessárias providências, o modelo do título definitivo que deverá ser adotado sempre que seu beneficiário for índio, integrado ou não, nos termos do Artigo 33, da Lei nº 6001/73.

Modelo de Título definitivo que o DGPI/FUNAI faz para o INCRA. Sem data. Anexo $\underline{\mathbf{n}^{0} 9 \mathbf{E}}$

Pelo presente Título Definitivo, o INCRA, (...) tendo em vista as disposições dos Artigos 24 da Lei n 4.504 , de 30/11/1964, arts. 25 alínea "g” e 51 do Decreto no 68153 de 1\%02/1971, combinados 
com o disposto no Artigo 33, da Lei n ${ }^{\circ}$ 6001, de 19/12/1973 (Estatuto do Índio) - concede a brasileiro, indígena , agricultor, o lote $\mathrm{n}^{\circ}$, do Projeto (est civil) Integrado de

Colonização OCOÍ, Município de São Miguel do Iguaçu-PR, do qual é legítimo senhor e possuidor conforme transcrição no registro de Imóveis da Comarca de Foz do Iguaçu -PR, sob nº 18586 , fls.239, do Livro 3-P, reconhecendo assim, ao beneficiário do presente título, o domínio pleno do referido lote.

O imóvel tem...

O presente título, que é concedido graciosamente por força do que preceitua o Artigo 33 do Estatuto

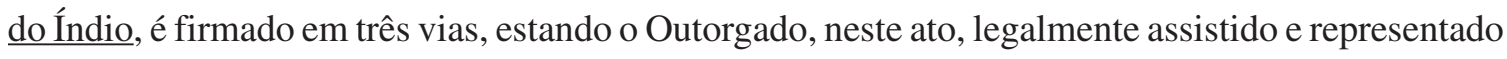
pelo órgão federal encarregado da tutela, conforme preceito contido no artigo 426, I, do Código Civil.

Curitiba -PR, em de de 1981.

PRESIDENTE DO INCRA PRESIDENTE DA FUNAI

TESTEMUNHA TESTEMUNHA

A $2^{\mathrm{a}}$ via deste Título, acompanhada da planta e memorial descritivo da área, constituirão Folha de Livro Fundiário da Divisão de Terras Públicas do Departamento de Recursos Fundiários do INCRA.

\section{Ofício E/DG/ 0337/81 Itaipu Binacional. RJ, 20/08/1981. Do Diretor Geral José Costa}

\section{Cavalcanti para Presidente da FUNAI João Carlos Nobre da Veiga. $\underline{\text { Anexo n }}{ }^{0} 9$ F}

Em atenção ao ofício 169/PRES, informamos a V. Sa. que até o momento a Itaipu Binacional não procedeu a qualquer pagamento aos elementos indígenas que ocupam a área do Reservatório pelos motivos abaixo:

Em 04/09/78 remetemos à FUNAI expediente, oferecendo uma ilha que se formará no Reservatório e que fica próximo a área, hoje ocupada pelos elementos indígenas, como modo de pagamento da indenização, uma vez que as áreas se equivalem. Até a presente data não houve, entretanto, qualquer pronunciamento por parte desse órgão.

O INCRA ainda não expediu os títulos definitivos de propriedade para os indígenas. Tão logo os indígenas recebam seus títulos de propriedade, entraremos em contato com o SR Harry Avila Teles, representante desta Fundação na $4^{\mathrm{a}}$ Delegacia para os entendimentos finais, quando então poderá ficar definida a forma de pagamento se a permuta de terras, ou o pagamento da indenização, se for o caso. 


\title{
OFÍCIO Nº 357/PRES BSB 10/09/1981 Do Presidente da FUNAI/MI Octavio Ferreira
}

\author{
Lima p/ Diretor Geral de Itaipu Binacional Gen. José Costa Cavalcanti. Anexo nº 9 G
}

Ao acusar recebimento de Ofício E/DG/0337/81, de 20/08/1981, cumpre-nos informar a V. Sa. que esta Fundação já concluiu os estudos antropológicos de identificação e caracterização dos índios, em número de 05 (cinco) famílias, localizadas na área de interesse da empresa Itaipu Binacional. Consoante entendimentos firmados entre esta Fundação e o INCRA, aos indígenas ali localizados, $\underline{\text { serão outorgados títulos definitivos de propriedade, relativos aos imóveis por eles ocupados na área }}$ de interesse dessa empresa.

Regularizadas suas situações na área em apreço, com o consequente pagamento das indenizações por benfeitorias existentes, os mesmos serão remanejados para área sob jurisdição da FUNAI, no município de Laranjeira do Sul, no estado do Paraná.

Quanto ao oferecimento da ilha, que se formará no citado Reservatório, como forma de pagamento aos índios atingidos em suas ocupações pela cota da inundação da barragem de Itaipu, esta Fundação não reunia na época, condições para um pronunciamento conclusivo, face sua dependência às conclusões dos estudos antropológicos de identificação e caracterização do grupo indígena.

Diante dos exposto, consumados os entendimentos com os índios e com o INCRA, resta manifestar a V. Sa., o desinteresse desta Fundação pelas terras da citada ilha, já que as famílias indígenas identificadas manifestaram o desejo de serem transferidas para área sob jurisdição desta Fundação, no município de Laranjeiras do Sul, no estado do Paraná.

\section{Ofício INCRA/32/n ${ }^{0}$ 547/81 BSB, 05/10/1981 Do Diretor Substituto do DF Milton San-}

tos de Amorim para o Diretor do Departamento Geral do Patrimônio Indígena -DGPIFUNAI Dr Cláudio H. Pagano de Mello. Anexo no 9 H

Em atenção ao Ofício n 122/DGPI, de 12/08/1981, transmito ao conhecimento de V. Sa., o teor de $\underline{\text { título de reconhecimento do domínio que deverá ser emitido por esta Autarquia para os indígenas }}$ localizados no imóvel OCOÍ, no município de Foz do Iguaçu, estado do Paraná.

Destaco que o instrumento de titulação em comento foi oferecido pela Procuradoria Geral do INCRA e aprovado por esta Diretoria.

Comunico que estou encaminhando a Coordenadoria Regional deste órgão no estado do Paraná as informações pertinentes para a oportuna outorga de títulos. 
Ref Ofício INCRA/32/n 547/81 - Modelo de Título de Reconhecimento de Domínio

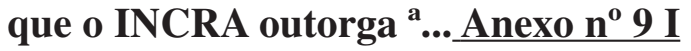

O INCRA, autarquia federal criada pelo Decreto-Lei n ${ }^{\circ} 1110$, de 9 de julho de 1970, com sede e foro na Capital Federal, neste ato representado pelo seu Presidente, na forma do Artigo 25 alínea "g", do regulamento Geral aprovado pelo Decreto n 68153 de 1\%02/1971, com fundamento no Artigo 33 , da Lei ${ }^{\circ} 6001$, de 19/12/1973, pelo presente TÍTULO DE RECONHECIMENTO DE DOMÍNIO. com plena força e validade de escritura pública, a teor do artigo 51, do citado Regulamento geral, reconhece o domínio de

, silvícola, , neste ato assistido pela Fundação Nacional do Índio -FUNAI, na forma dos artigos $6^{\circ}$, item III, e 84 do Código Civil, art. $7^{\circ}$, parágrafo $2^{\circ}$, da Lei 6001, de 19/12/1973, e art. $\underline{1^{\circ} \text {, item I, do estatuto da Fundação Nacional do Índio aprovado pelo Decreto n }{ }^{\circ} 84.638 \text {, de } 16 \text { de }}$ abril de 1980, sobre o imóvel rural denominado, com há (

), compreendido na Gleba

do Projeto Integrado de Colonização do OCOÏ, situado no município de estado , com as metragens limites e confrontações seguintes:

cuja planta e memorial descrito integra este Título.

O imóvel acima descrito está registrado, em maior porção em nome do INCRA, no Registro de Imóveis da Comarca de no Livro , a fls. , matrícula , sob o $n^{\circ} \mathrm{R}-$

reconhecendo assim, ao beneficiário do presente título, o domínio pleno do referido lote.

Este ato conta com o assentimento prévio da Secretaria Geral do Conselho de Segurança Nacional, conforme o que consta do Ofício.

O presente Título é firmado em três vias, de igual teor e forma, na presença das testemunhas abaixo, ficando eleito o Foro do Distrito Federal, com renúncia de qualquer outro, para dirimir quaisquer questões que resultarem deste.

, de de 19 .

PRESIDENTE DO INCRA TITULAR DE DOMÍNIO

\section{PRESIDENTE DA FUNAI}

\section{TESTEMUNHA}

TESTEMUNHA

A $2^{\circ}$ via deste Título, acompanhada da planta e memorial descrito Do imóvel, constituirá folha do Livro Fundiário do INCRA. 
Doc Interno /FUNAI. REF: Processo INCRA/BR/No 5759/81. Interessado: FUNAI. Informação PJR n 337/81. Do Procurador Autárquico Sérvulo TB Costa para a Chefe da PJR Maria Jovita Wolney Valente $\underline{\text {Anexo }^{\circ} 9 \mathrm{~J}}$

O procurador não concorda com a documentação produzida: Não se trata de reconhecimento de domínio, como quer esta Autarquia.

\section{Carta: Guarani do Oco’y para o Presidente da FUNAI Paulo Moreira Leal (02/12/81) $\underline{\text { Anexo no } 9 \mathrm{~K}}$}

Nós índios e em nome da comunidade Guarani da Barra do rio Ocoí, localidade de Jacutinga, município de Foz do Iguaçu, no estado do Paraná, vimos expor e requerer:

Nossas terras de posse imemorial, que estão localizadas abaixo (sul) da foz do rio Ocoí, que deságua no rio Paraná, no lugar do Arroio Jacutinga, município paranaense de Foz do Iguaçu, estão dentro da área demarcada para formação do reservatório da Hidrelétrica de Itaipu Binacional, devendo ser totalmente alagadas quando do fechamento das comportas daquela usina no próximo ano.

Não é de hoje que procuramos demonstrar nossa preocupação com a situação e a incerteza de nosso futuro. Já no início desse ano pudemos contatar com o Conselho Indigenista Missionário/CIMI SUL, Comissão de Justiça e Paz do Paraná e a Associação Nacional de Apoio ao Índio/ANAI-PR, e, junto com essas entidades que passaram a nos dar apoio, alguns líderes de nossa comunidade indígena estiveram em Curitiba, no dia 23 de março, apresentando ao Dr Delegado Regional da FUNAI informações a nosso respeito e solicitando uma solução de acordo com nossos interesses. Naquela ocasião, a própria Delegacia Regional da FUNAI perguntou se gostaríamos de ser removidos para a Reserva de Rio das Cobras, e nossos representantes disseram que, na realidade, se temos de sair de nossas terras, queremos continuar vivendo como comunidade que somos, em área equivalente a que ocupamos hoje, e que procedem de nossos pais e avós, sem sofrermos as restrições que teremos nas áreas da FUNAI que já são habitadas por outros grupos indígenas.

De março para cá, apesar de toda a nossa movimentação e das entidades que nos tem apoiado, nosso problema continua sem solução, tampouco recebemos qualquer resposta oficial nesse sentido. Agora, aproximando-se o prazo para conclusão da represa de Itaipu, nossas preocupações são ainda maiores: logo teremos que deixar nossa terra e até agora ninguém, FUNAI ou ITAIPU, nos ofereceu área idêntica à que iremos perder, contra nossa vontade.

Razões pelas quais, requeremos a V. Exa., como novo presidente desse organismo destinado a zelar pela causa indígena, para que a FUNAI providencie imediata destinação de nova área, com igual dimensão e qualidade às que hoje ocupamos, nela assentando nossa comunidade, incluso com a remoção por conta da FUNAI (segundo nos assegura o art. 20, parágrafos $3^{\circ}$ e $4^{\circ}$, do estatuto do 
índio), medidas essas que devem ser tomadas com a máxima urgência, face o cronograma da Itaipu Binacional impedir permanência na área do alagamento no próximo ano.

Barra do Ocoí Foz do Iguaçu 02/12/1981

Assinam a rogo :

Fernando Martines Parãrãwypóty Odilon Benites Tupapotyry

Santiago Centurião Mamangáwypy Balbino Benites

Euzébio Peralta João Martines

Os mesmos indígenas fazem Escritura Pública em Cartório do Registro Civil e Tabelionato - Distrito de Itacorá - Município e Comarca de São Miguel do Iguaçu Livro 2I fls 150 4/12/1981. Anexo no 9 L

Os mesmos indígenas fazem Escritura Pública do documento acima dirigido ao Presidente da FUNAI.

FUNAI - Informação no 16/81/4 DR. Delegado Regional da $4^{\circ}$ DR Curitiba/FUNAI Harry Luiz Ávila Teles informa ao Superintendente Administrativo da FUNAI sobre reunião havida entre ele/FUNAI, Comissão de Justiça e Paz, ANAÍ, e os repórteres dos jornais O Estado de São Paulo, O Estado do Paraná, Gazeta do Povo, O Globo, Canal 4 TV Iguaçu/ Curitiba. Curitiba 23/12/1981. Anexo no 9 M

O objetivo da reunião, segundo o Dr Wagner D'Angelis/CJP, era o de colocar este titular a par dos assuntos tratados junto à Administração Central da FUNAI, em Bsb, em reunião de encontro que manteve com o Sr Presidente da Fundação, Sr. Superintendente Administrativo, Sr procurador e Sr Diretor do DGPI, no dia 14 próximo passado.

Em tal encontro foi discutida a situação das famílias indígenas ocupantes da região do Ocoí, em Foz do Iguaçu, durante o qual foi entregue à Presidência da FUNAI um requerimento assinado por seis indígenas da região (em anexo).

O Dr D'Angelis informou-nos que a FUNAI teria se "comprometido a apresentar uma solução teórica para o caso em 30 dias".

Disse ainda ter pedido revisão dos laudos antropológicos elaborados pelo antropólogo Célio Horst, o qual disse, teria sido "manipulado" pelo indivíduo chamado Nicolas Fernandes (não-índio). Para tal na próxima reunião do Conselho Indigenista, o assunto seria levado à discussão, "pois o próprio Presidente da FUNAI, Cel Paulo Moreira Leal, teria concordado que um dos indivíduos presentes à reunião era índio, não tendo sido porém, classificado como tal através de Laudo Antropológico elaborado pelo Dr Horst". 
Afirmou também, o Dr D'Angelis que o Sr Presidente da FUNAI lhe teria “CONFIDENCIADO"ser muito pouca a área de 5 a 8 hectares que cada indígena de Ocoí ocupa, e mais, que tentaria obter em torno de 15 hectares para cada família.

Declarou outrossim que a FUNAI se comprometia a contactar com o INCRA e ITAIPU BINACIONAL, objetivando obter área de terras, na própria região onde os índios estão. Se isto não fosse possível, seria tentado junto ao Governo do Paraná a indicação de possíveis locais de reassentamento daquelas famílias.

Dentro desta solicitação pediu-nos para oficializar consulta com o Instituto de Terras e cartografia do Paraná-ITC, afim de saber onde existiriam terras devolutas no estado e possíveis de serem doadas aos índios. Tal pedido lhe foi negado na hora, quando lhe informamos que somente adotaríamos tal medida mediante orientação de Bsb.

Entregou-nos também "em caráter confidencial", uma cópia de certidão de declaração efetuada pelos indígenas em Cartório de Registro Civil e Tabelionato de São Miguel do Iguaçu (em anexo). Para seu conhecimento, anexamos também, recortes de jornais locais com reportagem sobre o caso.

\section{Memo no 22/82/GAB/4 ${ }^{\circ}$ DR de 07/01/82 do Delegado Regional Harry L. A. Teles p/ o} Diretor do Depto Geral de Patrimônio Indígena. Anexo no 9 N

Atendendo solicitação desse Depto, a respeito das famílias indígenas existentes no PIC-OCOI, município de Foz do Iguaçu, cujas áreas ocupadas serão inundadas pela represa de Itaipu, temos a informar que:

1. O INCRA informa que a fazenda Britânia com 170 ha... já tem destinação certa. Será ocupada por colonos não-índios, egressos das áreas a serem inundadas por Itaipu.

2. Informou ainda o Dr Schigueru, que no Paraná não existem áreas da União disponíveis e desocupadas possíveis de serem destinadas a reassentamento de indígenas;

3. Das famílias ocupantes da área de PIC-OCOI, cinco foram identificadas pelo antropólogo Célio Horst, da AGESP, como indígenas:

a) Fernando Martines - ocupa 4,8 ha (?)

b) Odilon Benites - ocupa 4,8 ha (?)

c) Máximo Vilialba - ocupa 6,1 ha (?) (já no PI Rio das Cobras)

d) Salésio Rosa - ocupa 6,8 ha (?)

e) João Lopes - ocupa 5,5 ha (?)

2. A Comissão de Justiça e Paz - CIMI, identificou como indígenas as famílias de:

a) Fernando Martines

b) Odilon Benites 
c) Santiago Centurião

d)Balbino Benites - (ocupa 4,2 ha) (?)

e) Euzébio Peralta

f) João Martins

5. As famílias 4c, 4e e 4f, não constam da relação elaborada pelo INCRA em 15/6/77, que foi o primiero levantamento efetuado naquela área. (Ver ofício INCRA/PIC OCOI, nº 218/77, de 15/6/77).

\section{Carta: Guarani de Barra do Ocoí - Jacutinga, Foz do Iguaçu/PR de 05/02/82 dirigida ao Presidente da FUNAI Coronel Paulo Moreira Leal e ao Presidente de Itaipu Binacional General Costa Cavalcanti. Anexo no 90}

Senhor Presidente,

A FUNAI e a Itaipu fez proposta para nossa gente de dar 20 hectares de terras em Santa Helena (PR) e mais 80 hectares de Faixa de Segurança da represa em troca das nossas terras que vão ficar embaixo da água.

Nós achamos que não ia dar pro Guarani aceitar isso porque como é que nossa comunidade vai poder viver nesses 20 ou nesses 100 hectares? Porque nós somos mais de 20 casal, e com muitas famílias.

E também não dava pra o Guarani aceitar porque nossa terra sempre foi desde o Jacutinga até o Rio Ocoí; e vai da estrada de Foz para Santa Helena, no lado que o sol levanta, até o rio Paraná, no lado que o Sol se esconde. Então como é que o Guarani vai trocar tudo isso com os 20 ou os 100 hectares de Itaipu?

Mas nós aceitamos de ir conhecer a terra que a FUNAI mandou dizer, pra ver se o Governo entendeu o que o Guarani está falando.

O Guarani está falando que ele quer o mato, porque o Nosso Pai foi o primeiro que abriu essa terra, e ele deu o mato para o Guarani. E o Guarani não vive no limpo, ele gosta o mato onde tem os bichinhos, tem passarinho, e o nosso sistema é esse. O sistema do Guarani é viver aonde tem o mato. Por isso nós quer o mato. Tem que arrumar o mato. E aumenta a família. E se depois não tem mais lugar?

Essa terra de Itaipu é boa para plantar, mas não dá para o Guarani, não tem mato, é pouca terra. Tem que procurar o mato. Não precisa ser tudo mato, mas ao menos um pouco de mato tem que ter, mas pode ter um pouco de limpo. Mas o mato não pode ser só um pedacinho, porque depois acaba a lenha, não tem bichinho. E precisa o mato prá fazer a casa. Como vai fazer a casa? De capim não dá. Vai fazer a casa de terra? Da terra não dá. Precisa procurar o mato aonde passa o rio prá ter o peixe. 
Depois, prá achar outro lugar tem que ser logo também, porque o tempo de planta vem vindo, e já vai passar o tempo da planta. E tem que primeiro fazer um ranchinho, prá fazer depois a planta. E depois já faz uma casa melhor. E na terra de Itaipu vai morrer de frio, não tem lenha, não tem nada ali.

E o Guarani costuma fazer um NHEMBO'E, e tá fazendo e o português não gosta. Então não adianta ficar pertinho do português.

Essa terra da Itaipu o Guarani não quer. Tem que procurar o mato. FUNAI precisa vim falar com o Guarani prá entender o nosso sistema. Nós não queremos viver como o Karaí.

Nós viajamos muito longe, andamos bastante prá dizer pro Governo que nós não queremos sair do nosso lugar, porque aqui sempre viveram os nossos pais e os pais dos nossos pais, e nós nascemos e se criamos aqui. Mas como vai essa água de Itaipu o guarani tem que deixar essa terra. Então nós queremos um lugar prá viver com a nossa gente. Prá fazer as nossas plantinhas e seguir nosso sistema. Mas não queremos ir longe do nosso lugar e dos parentes. Nós queremos umas terras aqui perto, e a terra de mato. Tem o Parque do Iguaçu, tem muitas fazendas aqui perto que tem mato, e até encostado no Parque.

Essa terra de Santa Helena nós não vamos querer, nem outras terras desse jeito. Não gostamos terra sem mato, e não pode ser pequena.

O Guarani está com pressa, porque o tempo de fazer roça vem vindo, e a Itaipu está mandando sair no fim de Abril, e não queremos sair sem outro lugar.

Assinam

Fernando Martines Parãrãwypoty

Odilon Benites Tupápotyry

José da Costa

Balbino Benites

Inácio Floriano

Antonio da Costa

Lucas Vilhalva

\subsubsection{O espaço físico que foi oficializado ilegalmente da atual Terra Indígena Avá-Guarani do Oco’y}

Neste item veremos como foi elaborada "oficialmente", porém de forma ilegal, a formação do território da atual Terra Indígena Avá-Guarani do Oco’y. 


\subsubsection{A ilegal passagem de "4 lotes individuais" de terras pelo INCRA, para somente 4 famílias indígenas $(\mathbf{1 7 7 , 5 6 0 1} \mathrm{ha})$}

Em 06/05/82 os Guarani redigiram Carta Aberta (Anexo n 11 A), onde solicitavam reunião na aldeia, para resolver o problema da terra. Eles alegavam ser a área oferecida por Itaipu muito pequena (200 ha), que necessitavam de local maior como possuíam antes no Oco’y-Jacutinga. Afirmavam que o que havia saído em jornal, não teria sido a resposta dada por eles, porque até aquele momento não haviam dado resposta alguma para Itaipu, e também que não haviam dado resposta nem ao INCRA, nem a FUNAI. Eles aceitariam se Itaipu oferecesse área maior, igualmente a que possuíam antes (referiam-se as terras nas dimensões que possuíam no Oco’y-Jacutinga antes do INCRA invadi-las e tomá-las em 1973). Assinaram os representantes da Comunidade Indígena.

Assim, a Comunidade Indígena reivindicou seus legítimos direitos, de acordo com a Constituição, a uma terra em extensão igual e qualidade ambiental semelhante às que possuíam anteriormente. Porém, nenhuma Instituição, INCRA, ITAIPU e principalmente a própria FUNAI, reconheceu esse legítimo direito.

Em 07/05/82, portanto, já no dia seguinte, no escritório regional da Itaipu em Curitiba, aconteceu "Reunião para tratar de reassentamento do grupo indígena Avá-Guarani”. (Anexo no 11 B). Dela participaram o Delegado Regional Harry Luiz Ávila Teles da 4DR/FUNAI, a Dra Maria Ângela Sommer do INCRA, Dr Paulo José Nogueira da Cunha - Procurador Jurídico da ITAIPU, Dr Wagner Rocha D’ Angelis da Comissão de Justiça e Paz/CJP, Darli Machado Santana da ANAÍ e Wilmar da Rocha Dángelis do CIMI.

A "Memória de Reunião" é escrita pelo Procurador Jurídico da Itaipu. Assim, não se trata de uma "Ata de Reunião" em que todos os participantes assinam em concordância ao que é dito. Nota-se pela argumentação colocada, que Itaipu chama os defensores dos direitos indígenas para a reunião, com a finalidade precípua de verificar o que estão pensando à respeito do caso, e, não exatamente para negociar a questão.

Destaque-se alguns pontos suscitados nessa "Memória de Reunião", transcritos em itálico abaixo, acompanhados de comentário:

Definição das áreas para reassentamento dos índios, cerca de 200 ha. Apesar da Carta anteriormente enviada pelos índios, em 06/05/82, não aceitar os 200 ha, pois a área em que habitavam era maior. 
Processo de legalização das áreas com sugestões a respeito do assunto. É de se supor que a CJP, a ANAÍ e o CIMI tenham colocado na reunião questões sobre a ilegalidade da forma como Itaipu estava abordando o problema, pois foram posições reafirmadas ao longo de todo o processo verificado na documentação disponível (processo $\mathrm{n}^{\circ}$ 1053/76/FUNAI) a saber: o reassentamento da população indígena, através de "títulos individuais do INCRA", para somente algumas poucas famílias em número de 5 (cinco) até então, e a pouquíssima terra oferecida, que não condizia com os termos legais do Artigo 20 do Estatuto do Índio e com a Constituição Federal.

Áreas efetivamente livres e áreas a serem preservadas. No contexto, “áreas livres” correspondem a área da Terra Indígena do Oco’y que os Guarani passariam a ocupar. "Áreas a serem preservadas" correspondem às áreas às margens do reservatorio de Itaipu, ou seja, a própria APP de Itaipu. Note-se que no local limitando-se com a Terra Indígena do Oco’y, a APP de Itaipu possui apenas 100 metros de distância da borda do reservatório, no restante do perímetro do reservatório, ela possui em média 200 metros de largura. Note-se também que não é permitido por lei que seja habitada qualquer APP. Este fato já foi discutido em Laudo Antropológico anterior, enviado a VI Câmara/MPF, que demonstra a ilegalidade da superposição dessas áreas, dado que tanto Terra Indígena quanto APP, são de uso exclusivo de seus possuidores. Dessa forma, a própria Itaipu estaria legalmente impedida de fazer tal proposta. Mas fez.

Recapitulação dos nomes dos índios que já receberam os títulos, segundo reunião anteriormente realizada. 5 (cinco) índios receberam, ou pelo menos Itaipu e INCRA tentou-lhes destinar 5 (cinco) ilegais títulos de propriedade de terras, quando o procedimento correto, como já vimos, seria o de que os índios devem deter a posse e não a propriedade de terra, e que a mesma é coletiva e não individual.

Referência ao critério da indenização de benfeitorias, tratado em reunião anterior. A indenização ao invés de incidir sobre a questão fundiária, ou seja, "pagamento por terras de extensão e qualidade ambiental semelhante às anteriores", conforme Artigo 20 Estatuto do Índio e Constituição Federal, reduzia-se apenas a pagar as "benfeitorias existentes" nas terras indígenas a inundar, e mesmo assim, este recurso ilegalmente repassado, seria utilizado pela FUNAI apenas para a "instalação da população em outro local".

Apresentação da carta dos índios, não aceitando as áreas que lhes foram designadas. A carta dos índios de 06/05/82 não aceitando os 200 ha de terras, então, era de conhecimento dos membros da referida reunião. 
Continuação de diálogos com os índios, para acerto de eventuais discordâncias. Os índios discordavam tanto da proposta da quantidade de terras, quanto do número de famílias consideradas, o que, portanto, não era um detalhe "eventual."

Referência a legislação relativa aos índios, a qual apresenta aspectos muito especiais. De acordo com o que vinham afirmando coerentemente neste caso, supõe-se que a CJP, a ANAI e o CIMI tenham apresentado na reunião a legislação federal, demonstrando a ilegalidade em se destinar aos "indígenas", "títulos individuais de terras", aquela "mínima quantidade de terras", e que ainda, todas as famílias deveriam ser reconhecidas como de fato eram, como um "Grupo Tribal" que obtinha a posse da terra em terras de propriedade da União, conforme Constituição Federal e Estatuto do Índio.

\section{O problema do uso coletivo da terra pelos índios, fato que contraria o critério da titulação}

individual. A própria forma como é colocada textualmente a questão já denuncia a inversão de valores e as pretensões ilegais de Itaipu. O “problema” para a Itaipu resumia-se às determinações da legislação federal em vigor, que se constituía no procedimento legal a fazer sem mais discussões; o ilegal era a proposta da hidrelétrica, a "titulação individual”. Desta forma, Itaipu, FUNAI e INCRA pretendiam fazer a população indígena passar por “colonos", o que evitaria o cumprimento da legislação federal específica (Artigo 20/EI) e da Constituição Federal. Inclusive, dessa forma, se evitaria a solicitação de autorização do Presidente da República para a remoção de população indígena de suas terras originais.

Necessidade de ajuda e compreensão de todas as entidades envolvidas no problema. Quem na verdade necessitava de ajuda e compreensão eram os próprios Guarani.

Examinada a hipótese de a Itaipu doar a União, a área destinada aos índios, através do INCRA, parecendo esta a solução ideal, no consenso dos participantes da reunião, anulando-se os títulos individuais com a concordância dos índios. Ao invés de agir legalmente, isto é, reconhecer as terras dos índios e as famílias que ali habitavam, opta a Itaipu por mais um artifício ilegal: substituir as titulações que ela mesma propunha pela transferência das mesmas e insuficientes quantidade de terras pelo INCRA aos indígenas. Como veremos adiante a Itaipu não doa os 4 (quatro) lotes à União. O INCRA, por sua vez, não recebe estas terras da Itaipu, apenas desapropria terras dos colonos, sem pagar-lhes a devida indenização, repassando-as aos índios. A mesma terra da qual o INCRA desapropriou os colonos estava prevista para servir de APP da represa de Itaipu. Daí a superposição, irregular, de TI e APP no Oco’y. 
Eventual possibilidade do livre trânsito dos índios nas áreas ribeirinhas, reserva de Itaipu. Diante da pouca terra que estava sendo oferecida aos índios, a APP de Itaipu seria autorizada, mesmo que ilegalmente, a ser também ocupada pelos índios, como de fato o foi.

Conclusão: Levar aos índios, em nova reunião, proposta objetiva para a solução definitiva do problema, em termos de 200 ha já referidos, eventualmente uma área maior a ser tentada.

Ainda a eventual possibilidade do livre trânsito dos índios (item 12). Ou seja essa "área maior" a ser tentada seriam as terras da APP de Itaipu, que como se verifica, apertando daqui e dali, reduzindo a APP de 200 para 100 metros, seriam colocados os índios.

Nova reunião: dia 12/05.82 às 14:00 hs no Ocoí.

Os próximos documentos a serem analisados, a saber: Anexos n's 11 C - D - E - F (F1, F2, F3 e F4) e G, deverão ser analisados necessariamente em seu conjunto.

Em 10.05.82, a Itaipu recebe uma consultoria especializada, através de Carta do advogado especialista em direito indígena Carlos Frederico Marés de Souza Filho, contratado como consultor pela Itaipu, o qual veio posteriormente a ser Presidente da FUNAI e hoje é Procurador do Estado do Paraná. Esta carta é de fundamental importância. As declarações do Dr Marés reafirmam de forma contundente todas as determinações legais expostas nesta tese. Afirmávamos: Ela deve ser levada em conta para a avaliação das decisões posteriormente tomadas pelas Instituições envolvidas neste caso.

Sob o título "SOBRE A FORMA DE TRANSMISSÃO DA PROPRIEDADE E POSSE AOS ÍNDIOS AVA-GUARANI DO RIO OCOÍ DA NOVA ÁREA A LHES SER DESTINA-

DA." (Anexo no 11 C), a Carta do Dr Marés assim nos explica sobre o contexto proposto por Itaipu:

Independentemente da quantidade de terra a ser destinada ao grupo indígena em questão, e partindo do princípio de que a terra por eles ocupada atualmente faz parte de seu território de posse imemorial e histórica - e por isso mesmo coletiva -, entendemos que não há porque se falar em titulações familiares ou individuais, qualquer terra que se lhes destine há de ser coletiva, isto é, para a comunidade - ou grupo - indígena dos avá-guarani do rio Ocoí. Partindo desta base, apresentamos a seguir alguns aspectos e propostas para transmissão da propriedade e posse aos índios avá-guarani do rio Ocoí da nova área a lhes ser destinada:

1. Os cinco títulos individuais de propriedade entregues aos índios pelo INCRA na região do rio Ocoí são nulos porque: 
a-os títulos podem ter sido dados ou como se fossem para colonos/posseiros, ou fundados no artigo 33 do estatuto do índio (usucapião indígena), se foi dado como se os índios fossem colonos (legitimação de posse ou venda) são nulos porque não pode se tratar dessas figuras jurídicas por não ter competêncio o Poder Público para "titular" a colonos área com posse indígena.

b- se foi aplicado o usucapião indígena (citado art.33) também são nulos porque este artigo exige que o índio ocupe a área como própria e o que havia, e há, na região é ocupação coletiva. O parágrafo único daquele artigo veda esta especialíssima modalidade de usucapião em terras ocupadas por grupos tribais. Além desta contrariedade à lei, há a discussão doutrinária da existência deste usucapião reconhecido administrativamente (via de regra a usucapião é declarada judicialmente).

_c-A ocupação da área pelos índios avá-guarani às margens do rio Ocoí, por si só, caracteriza a área como bem da União (art. 4 VI da Constituição Federal) destinada a posse e usufruto exclusivo das riquezas aos próprios índios e atribuindo-lhe a qualidade de inalienável (art. 198, caput, CF), ficando declarada a nulidade e extinção de efeitos jurídicos de qualquer ato que tenha como objeto o domínio ou posse desse imóvel (art. 198, parag $1^{\circ}, \mathrm{CF}$ ). $\underline{\text { São assim, nulos, todos os atos praticados }}$ pelo INCRA - ou qualquer outro orgão, ou ainda particulares, na área."

2.Os atos (titulações) não são passíveis de convalidação. Assim, mesmo que os beneficiados individuais e a FUNAI os aceitem e os levem ao Registro Público Imobiliário competente, os atos continuam nulos porque o direito ofendido é o direito da comunidade ou grupo. Tanto é verdade que, ainda que sem personalidade jurídica, a lei concede ao grupo ou comunidade indígena, nestes casos, capacidade processual para deduzir em juízo sua defesa (art. 37, EI).

3. Portanto, devem os títulos ali emitidos serem anulados pelo próprio INCRA, antes de a FUNAI os levar a Registro, porque a administração pode anular seus próprios atos. É importante frisar que por força do artigo 198, parag. $1^{\circ}, \mathrm{CF}$, mesmo levado a registro os títulos são nulos - como acima se disse -, mas criaria a necessidade de intervenção judicial para desconstituir, não os títulos, mas o registro.

Mesmo que realizado o ato pela FUNAI, ele continuaria nulo, dado o direito da Comunidade Indígena ofendido. Além de ter descartado a validade dos cinco títulos individuais de propriedade, que haviam sido entregues aos índios pelo INCRA na região do rio Ocoí, o Dr Marés os declarou nulos, pelas mesmas razões que esta tese advoga. Ou seja, índios não podem ser considerados como colonos, e mais o Artigo 33/EI não se aplica ao caso, pois o Oco’y-Jacutinga se caracaterizava como ocupação coletiva de grupo tribal, propriedade da União. Ainda afirmou Marés que as terras de ocupação tradicional indígena não podem ser alienadas, e se o fossem, deveria ser imediatamente declarada sua nulidade, assim como a extinção de efeitos jurídicos dos atos que teriam por objeto o domínio ou posse dessas terras. Mesmo que realizado o ato pela 
FUNAI, ele continuaria nulo, dado o direito da Comunidade Indígena ofendido. ${ }^{13}$ Continua o Dr. Marés:

4. Nos documentos de transferência da nova área, a ser destinada aos guarani, não deve haver, assim, qualquer referência aos cinco títulos emitidos pelo INCRA.

5. A transferência da nova área poderá ser feita da seguinte forma:

a. área de propriedade da Itaipu Binacional pode ser transferida de duas formas:

a1. Ser passada por escritura pública, diretamente da Empresa à comunidade indígena, sendo recebida pelos representantes dos guaranis - como determina o costume - assitido pela FUNAI (art. 32 combinado com 7, parag. $2^{\circ}-$ EI). A escritura pública pode ser de permuta, doação ou venda simbólica. Esta primeira forma oferece dois problemas de difícil solução: 1. Existem impostos a pagar assim como custas de cartório; 2. Possivelmente haverá problema no registro. A comunidade indígena não tem personalidade jurídica e a lei dos registros Públicos exige isto, embora possa ser superado, esta superação quase com certeza será via judicial. $\underline{\text { A interpretação da lei está vedada }}$ aos tabeliões e entregues com exclusividade aos juízes.

a2. A empresa transfere a área diretamente para a União, por escritura pública, estabelecendo a destinação específica - posse e usufruto exclusivo da comunidade indígena dos guarani do rio Ocoí - e a origem da obrigação (art. 20, parág $1^{\circ}$, d, e parag. $2^{\circ}$, c, e parag. $3^{\circ}$ ) - entrega de novas terras para a comunidade que viu as suas perdidas.

b. área de propriedade da União sob administração do INCRA. Deve simplesmente, por ato administrativo do INCRA, ser destinado a posse e usufruto exclusivo da comunidade avá-guarani de Ocoí, passando o processado de medição da área à FUNAI para que esta providencie o registro no SPU e no registro imobiliário competente, conforme artigo 19 do Estatuto do Ïndio." (Marés: 10.05.1982)

A partir do documento do Dr Marés não seria necessário dizer mais nada sobre o caso, a orientação jurídica feita por ele bastaria. Orientação que desde o inicio dos trabalhos solicitamos e não fomos atendidos. Porém, Itaipu, que havia solicitado a consultoria, utiliza seus resultados não como procedimento legal a ser seguido, mas como procedimento a ser preventivamente utilizado, para na verdade, contornar as exigências legais.

\footnotetext{
${ }^{13}$ Os sucessivos atos praticados pelo INCRA sobre as terras Colônia-Guarani e Oco'y-Jacutinga, configuram esbulho da população Guarani de terras tradicionalmente ocupadas. O fato da FUNAI haver fornecido falsas certidões negativas sobre essas terras, não implica em qualquer validade legal, devendo os atos praticados serem nulos.
} 


\title{
Em documento de ATA DE REUNIÃO realizada em 12/05/82, assinado por represen- tantes da FUNAI, CJP, CIMI/SUL, CIMI, ANAI e ITAIPU, reunião realizada na aldeia “Jacutinga-Ocoi. Acampamento dos índios Ava-Guarani”, se afirma: (Anexo no 11 D).
}

\begin{abstract}
"Dando continuidade aos entendimentos entre Itaipu, FUNAI, INCRA, CIMI, ANAI, CJP e comunidade indígena que se encontra na área do reservatório de Itaipu Dr Paulo Cunha/Itaipu iniciou os trabalhos ...mostrou a área que está sendo oferecida para relocação da comunidade, com aproximadamente 253 ha, conforme planta apresentada. A Itaipu informou ainda que será pago o valor das benfeitorias e benefícios feitos na terra através da Funai. A Funai por sua vez informou que esse valor será aplicado integralmente na implantação do novo acampamento, ou seja, aquisição de fer$\underline{\text { ramentas, utensílios, alimentos e outras necessidades. .... ficou acertado que a comunidade indígena }}$ Ava-guarani, concordou com a nova área de aproximadamente 253 ha, tendo inclusive aposto suas impressões digitais na referida planta; que tão logo a área esteja demarcada será feito o reassentamenro da comunidade."
\end{abstract}

Ora, não é a Comunidade Indígena que se encontra na área do reservatório de Itaipu e sim, ao contrário, o reservatório de Itaipu é que se encontra na área da Comunidade Indígena. $\mathrm{O}$ Procurador Jurídico se refere à "Comunidade Indígena", o que supõe uma coletividade. Já o Laudo de Horst afirmava que não existia uma "Comunidade Indígena", mas tão somente 4 (quatro) famílias. Estavam ali sendo pagos valores por benfeitorias, como se os índios fossem realmente colonos, quando na verdade o que deveria ser indenizado era sobre "terras", de tamanho igual a que possuíam anteriormente bem como as benfeitorias existentes. A FUNAI usa o recurso financeiro para comprar ferramentas, ao invés de terras, o valor devia ser tão irrisório, que talvez só desse para comprar artigos do gênero ali referido. Os Guarani em depoimento contam que, nessa ocasião, Itaipu e FUNAI só levavam os velhinhos da aldeia para as reuniões, ou seja, aqueles que não entendiam bem o português e que não sabiam ler e escrever, acabando por "concordar" assim, com as resoluções tomadas.

Os índios Guarani afirmam que contra a sua vontade foram remanejados para o Oco'y. Os documentos históricos comprovam que esta saída se deu sem que qualquer trâmite legal fosse acionado. Os Guarani foram obrigados a sair de seu território original em maio de 82. Em seguida, em outubro Itaipu fecha as comportas e inunda o território.

No mapa em anexo “CROQUI DA ÁREA DA RESERVAAVA-GUARANI", (Anexo n” 11 E) é apresentada a atual área da Terra Indígena do Oco’y, com a seguinte legenda: 
Incra 177,5501 ha ( 4 lotes de terras repassadas individualmente aos indígenas pelo INCRA)

Itaipu 73,5925 ha (várias pequenas parcelas de terras "vendidas" simbolicamente por Itaipu aos índios, e coladas aos 4 lotes do INCRA)

área da reserva 251,1526 ha (área su-

postamente total da Terra Indígena Avá-Guarani do Oco’y, na realidade apresenta 231,88 ha).

Esta planta demonstra claramente como foram destinadas as terras aos índios. O INCRA cede 177,5501 ha para as 4 famílias indígenas "reconhecidas" por Horst. Esta área será Terra Indígena, e, ao mesmo tempo, APP do lago de Itaipu. Itaipu, segundo o Croqui, adquiriria pedaços de terra num total de 73,5925 ha, limítrofes à área cedida pelo INCRA, que seriam repassados aos índios Guarani. Esta seria a limitada compensação de terras, em função da inundação prevista, oferecida por Itaipu aos indígenas Guarani.

A planta delimitava a atual área da Terra Indígena do Oco’y. Uma área que iria ser destinada, obrigatoriamente, pelo PIC OCOI II/INCRA para a Itaipu como Área de Preservação Permanente/APP do reservatório.

No mapa da demarcação da TI do Oco’y/ FUNAI, também em anexo (Anexo no 11 J), encontra-se a referência, escrita no interior do lago, LINHA DE INUNDAÇÃO DA BACIA DE ACUMULAÇÃO DO RIO PARANÁ -HIDRELÉTRICA DE ITAIPU. Assim as áreas, Terra Indígena do Oco’y e APP de Itaipu, estarão desta forma, desde a sua criação, superpostas, o que, como já vimos, é ilegal, pois tanto TI como APP são de uso exclusivo.

\section{Em PORTARIA No 444/P DE 29 DE JUNHO DE 1983, MINISTÉRIO DO INTE- RIOR/MINTER - FUNAI GABINETE DO PRESIDENTE, o Presidente da FUNAI Paulo Moreira Leal, determina: (Anexo no 11 Fo)}

O PRESIDENTE DA FUNDAÇÃO NACIONAL DO ÍNDIO - FUNAI, no uso das atribuições que lhe conferem os estatutos e tendo em vista o que consta do RD $1.180 / 4^{\circ}$ DR de 24 de junho de 1983 , RESOLVE

DELEGAR competência a HARRY LUIZ ÁVILA TELES, Delegado da $4^{\circ}$ Delegacia Regional FUNAI, observadas as formalidades legais, assinar, em nome desta Fundação, Títulos definitivos de terras destinados à Comunidade Indígena, AVA-GUARANI, em SÃO MIGUEL DO IGUAÇU, Estado do Paraná. 
O presidente da FUNAI, dessa forma, ignora o documento anteriormente mencionado " $\mathrm{SO}$ BRE A FORMA DE TRANSMISSÃO DA PROPRIEDADE E POSSE AOS ÍNDIOS AVAGUARANI DO RIO OCOÍ DA NOVA ÁREA A LHES SER DESTINADA” do Dr. Marés, que demonstrava a ilegalidade de se tratar o processo na forma de titulação individual. Cabe registrar que tal documento está anexado ao processo no 1053/76 no CEDOC/FUNAI.

Em 14/07/83, o MINTER - FUNAI - DGPI Brasília, em documento MEMORIAL DESCRITIVO DE DELIMITAÇÃO, é realizado o referido memorial descritivo de delimitação da área de Oco’y, onde atualmente os índios vivem, com uma área de 232,3276 ha (duzentos e trinta e dois hectares, trinta e dois ares e setenta e seis centiares). Ou seja, não seriam os 253 ha que Itaipu afirmou em acordo com os índios, e como é registrado em documentação exposta a seguir, e o mais importante, muito menos corresponde à área de ocupação tradicional dos índios, que de direito deveriam receber.

Em 25.08.83, o Delegado Sr Harry Luiz Ávila Teles da $4^{\circ}$ Delegacia Regional de Curitiba FUNAI, de posse da PORTARIA No 444/P de 29 de junho de 1983, do Presidente da FUNAI, Sr Paulo Moreira Leal, acompanha os Guarani em Cartório local, para realizar os procedimentos de "Títulos definitivos de terras destinados à Comunidade Indígena, AVA-GUARANI, em SÃO MIGUEL DO IGUAÇ, Estado do Paraná”.

De propriedade do INCRA, foram repassados os "Títulos definitivos de terras destinados à Comunidade Indígena, AVA-GUARANI” foram realizados individualmente para cada uma das “4 (quatro) famílias indígenas”. (Anexos ns 11: F1 (2- duas folhas); F2 (2- duas folhas); F3 (2- duas folhas); e F4 (2- duas folhas)).

São realizados os procedimentos em Cartório de propriedade de ARLEI COSTA - Oficial de Registro de Imóveis no MUN. SÃO MIGUEL DO IGUAÇU - ESTADO PARANÁ, mesmo à despeito das orientações jurídicas do Dr Marés, onde frisa em documento de 10.05.82 (Anexo $\mathbf{n}^{\mathbf{0}}$ 11C), portanto um ano antes da ação se dar, assim com conhecimento de causa, de que $\underline{\boldsymbol{a}}$ interpretação da lei está vedada aos tabeliões e entregues com exclusividade aos juízes.

Descrição literal dos documentos (Anexos ns 11: F1 (2- duas folhas); F2 (2- duas folhas); F3 (2- duas folhas); e F4 (2- duas folhas). Grifo nosso somente no primeiro objetivando destacar, em seguida os comentários:

\footnotetext{
“ARLEI COSTA (TABELIÃO RESPONSÁVEL) - OFICIAL DO REGISTRO DE IMÓVEIS SÃO MIGUEL DO IGUAÇU - PARANÁ
} 
REGISTRO GERAL MATRÍCULA No 8933 LIVRO No 2 (Anexos nº 11: F1 - 2-duas folhas). Imóvel rural denominado como Reserva Florestal n 06-Parte C-1, com 45,8570 ha, compreendido na Gleba no 84 do Projeto Integrado de Colonização Ocoí, situado neste Município e Comarca, com as metragens, limites e confrontações seguintes: ao Norte, com a Reserva Florestal $n^{\circ}$ 06-Parte B; a Este, com a Reserva Florestal no 06-Parte A e lotes 118, 117, 116, 115 e 114 (canto); ao Sul, com a Reserva Florestal ${ }^{\circ}$ 06-Parte C-2; e, ao Oeste, com a Reserva Florestal ${ }^{\circ}$ 06-Parte B. Havido pela transcrição imobiliária no $18.586, L^{\circ} 3-P$, do Cartório de Registro de Imóveis da Comarca de Foz do Iguaçu-PR. O referido é verdade. São Miguel do Iguaçu, 25 de agosto de 1983.

PROPRIETÁRIO: INSTITUTO NACIONAL DE COLONIZAÇÃO E REFORMA AGRÁRIA - INCRA - inscrito no CGC-MF sob nº 00.375.972/0011-32

R-01/8933 - TITULADO o imóvel presente, em favor de FERNANDO MARTINES, brasileiro, silvícola, agricultor, neste ato assistido pela Fundação Nacional do Índio - FUNAI, na forma dos Artigos nº 6, item III, e 84 do Código Civil, Art. No $7^{\circ}$, parágrafo $2^{\circ}$ da Lei 6001, de 19/12/1973, e Art. $1^{\circ}$ item I, do Estatuto da Fundação Nacional do Índio, aprovado pelo Decreto 84638, de 16 de abril de 1980; de conformidade com o TÍTULO DE RECONHECIMENTO DE DOMÍNIO, expedido pelo Instituto Nacional de Reforma Agrária, na Cidade de Curitiba, capital deste Estado, em data de 22 de agosto de 1983, sem valor declarado. Demais condições constantes do referido Título. D/ C\$3.000,00=0,300VRC. O referido é verdade. São Miguel do Iguaçu, 25 de agosto de 1983.

AV-02/8933 - Certifico e dou fé, que o Título de Reconhecimento de Domínio, a que se refere a R01 da presente Matrícula, tem seu registro no INCRA sob no 4 (09)92(02) 06. O referido é verdade. São Miguel do Iguaçu, 25 de agosto de 1983.

R-03/8933: Doado, o imóvel da presente, em favor da COMUNIDADE INDÍGENA AVÁGUARANI, integrada pelos índios: - Cacique FERNANDO MARTINES e família; JOÃO CENTURION e família; PEDRO ALVES e família; TORÍbio PALÁCIO e família; JOSÉ ACOSTA e família; ANTONIO ACOSTA e família; ALÉCIO VOGADO e família; JERÔNIMO VAZ e família; CASEMIRO PEREIRA e família; JORGE VOGADO e família; ANGELO BENITE e família; MÁXIMO VILIALBA e família; FELIPE ROMERO e família; TERESO CENTURION e família; SILVINO VAZ e família; INOCÊNCIO ACOSTA e família; SEBASTIÃo VOGADO e família; SANTIAgo CENTURION e família; LOSSANTO PEREIRA e família; de conformidade com a Escritura Pública de Doação, lavrada às folhas 125/126 do livro 
número 18-N, em data de 25 de agosto de 1983, nas Notas do Escrivão Distrital designado, Sr João Cornella Fagion, do Distrito de Aurora do Iguaçu, neste Município e Comarca, doação essa sem valor declarado. No ato da escritura, outorgante e outorgada foram devidamente assistidos pela FUNAI, com sede em Brasília DF, na forma do Art. $7^{\circ}$, parágrafo $2^{\circ}$ da Lei 6001 , de 19.12.1973, do Estatuto da Fundação Nacional do Índio, representada pelo Delegado Regional da $4^{\circ}$ DR Dr Eng ${ }^{\circ}$ Agronômo Harry Luiz Ávila Teles, brasileiro, casado, residente em Curitiba PR, portador da CI/1049722-PR e CPF/MF n ${ }^{\circ}$ 073.343.979/91, de acordo com a delegação de competência da Presidência da FUNAI n 444/P, de 29.06.1983. Compareceu no ato da escritura, a mulher do outorgante doador, Izidora Vilialba, brasileira, silvícola, agricultora, casada conforme Registro de Casamento $\mathbf{n}^{\circ}$ 09, da Comunidade Indígena Avá-Guarani, deste Município e Comarca. Estando os doadores e donatária isentos de obrigações tributárias, conforme preceitua o Art. 60 da Lei n ${ }^{\circ}$ 6001, de 19.12.73 (Estatuto do Índio). Demais condições, constantes da escritura. D/C \$3000,00=300VRC.O referido é verdade. São Miguel do Iguaçu, 29 de agosto de 1983.

Data assinada pelo Cartório 26.07.85, ou seja dois anos depois.

Repete-se documento semelhante de igual teor em mais três vias:

\section{REGISTRO GERAL MATRÍCULA Nº 8934 LIVRO No 2 (Anexos nº 11: F2 -2 duas folhas).} Imóvel rural denominado como Reserva Florestal n 06 -Parte C-2, com 45,3255 ha, compreendido na Gleba n ${ }^{\circ} 84$ do Projeto Integrado de Colonização Ocoí, situado neste Município e Comarca, com as metragens, limites e confrontações seguintes: ao Norte, com a Reserva Florestal n ${ }^{\circ}$ 06-Parte C-1; a Este, com os lotes 115 (canto) 114, 113-A, 113, 112, 111, 110, 109, 108 e 126; ao Sul, com o lote 73, separado pela estrada; e, ao Oeste, com a Reserva Florestal n ${ }^{\circ}$ 06-Parte B. Havido pela transcrição imobiliária n ${ }^{\circ} 18.586$, L 3 3 -P, do Cartório de Registro de Imóveis da Comarca de Foz do IguaçuPR. O referido é verdade. São Miguel do Iguaçu, 25 de agosto de 1983.

PROPRIETÁRIO: INSTITUTO NACIONAL DE COLONIZAÇÃO E REFORMA AGRÁRIA INCRA - inscrito no CGC-MF sob n ${ }^{\circ} 00.375 .972 / 0011-32$

R-01/8934 - TITULADO o imóvel presente, em favor de JOÃO CENTURION, brasileiro, silvícola, agricultor, neste ato assistido pela Fundação Nacional do Índio - FUNAI, na forma dos Artigos n ${ }^{\circ} 6$, item III, e 84 do Código Civil, Art. № $7^{\circ}$, parágrafo $2^{\circ}$ da Lei 6001, de 19/12/1973, e Art. $1^{\circ}$ item I, do Estatuto da Fundação Nacional do Índio, aprovado pelo Decreto 84638, de 16 de abril de 1980; de conformidade com o TÍTULO DE RECONHECIMENTO DE DOMÍNIO, expedido pelo Instituto Nacional de Reforma Agrária, na Cidade de Curitiba, capital deste Estado, em data de 22 de 
agosto de 1983, sem valor declarado. Demais condições constantes do referido Título. D/ C \$3.000,00=0,300VRC. O referido é verdade. São Miguel do Iguaçu, 25 de agosto de 1983.

AV-02/8934 - Certifico e dou fé, que o Título de reconhecimento de Domínio, a que se refere a R-01 da presente Matrícula, tem seu registro no INCRA sob no 4 (09)92(02) 07. O referido é verdade. São Miguel do Iguaçu, 25 de agosto de 1983.

R-03/8934: Doado, o imóvel da presente, em favor da COMUNIDADE INDÍGENAAVÁ-GUARANI, integrada pelos índios: - Cacique FERNANDO MARTINES e família; JOÃO CENTURION e família; PEDRO ALVES e família; TORÍBIO PALÁCIO e família; JOSÉ ACOSTA e família; ANTONIO ACOSTA e família; ALÉCIO VOGADO e família; JERÔNIMO VAZ e família; CASEMIRO PEREIRA e família; JORGE VOGADO e família; ANGELO BENITE e família; MÁXIMO VILIALBA e família; FELIPE ROMERO e família; TERESO CENTURION e família; SILVINO VAZ e família; INOCÊNCIO ACOSTA e família; SEBASTIÃO VOGADO e família; SANTIAGO CENTURION e família; LOSSANTO PEREIRA e família; de conformidade com a Escritura Pública de Doação, lavrada às folhas 125/126 do livro número 18-N, em data de 25 de agosto de 1983, nas Notas do Escrivão Distrital designado, Sr João Cornella Fagion, do Distrito de Aurora do Iguaçu, neste Município e Comarca, doação essa sem valor declarado. No ato da escritura, outorgante e outorgada foram devidamente assistidos pela FUNAI, com sede em Brasília DF, na forma do Art. $7^{\circ}$, parágrafo $2^{\circ}$ da Lei 6001, de 19.12.1973, do Estatuto da Fundação Nacional do Índio, representada pelo Delegado Regional da $4^{\circ}$ DR Dr Eng ${ }^{\circ}$ Agronômo Harry Luiz Ávila Teles, brasileiro, casado, residente em Curitiba-PR, portador da CI/1049722-PR e CPF/MF nº 073.343.979/91, de acordo com a delegação de competência da Presidência da FUNAI n ${ }^{\circ}$ 444P, de 29.06.1983. Compareceu no ato da escritura, a mulher do outorgante doador, Vergínia da Cunha Centurion, brasileira, silvícola, agricultora, casada conforme Registro de Casamento n 11 , da Comunidade Indígena Avá-Guarani, deste Município e Comarca. Estando os doadores e donatária isentos de obrigações tributárias, conforme preceitua o Art. 60 da Lei $\mathrm{n}^{\circ}$ 6001, de 19.12.73 (Estatuto do Índio). Demais condições, constantes da escritura. D/ C $\$ 1.500,00=150$ VRC.O referido é verdade. São Miguel do Iguaçu, 29 de agosto de 1983.

Data assinada pelo Cartório 26.07.85, ou seja dois anos depois.

\section{REGISTRO GERAL MATRÍCULA No 8935 LIVRO No 2. (Anexos nº 11: F3 -2 duas folhas).}

Imóvel rural denominado como Reserva Florestal nº 06-Parte D-1, com 46,6823 ha, compreendido na Gleba no 84 do Projeto Integrado de Colonização Ocoí, situado neste Município e Comarca, com as metragens, limites e confrontações seguintes: ao Norte, com a Reserva Florestal n ${ }^{\circ}$ 06-Parte B; a 
Este, com a Reserva Florestal n ${ }^{\circ}$ 06-Parte B; ao Sul com a com a Reserva Florestal no 06-Parte D2 e, lotes, 173, 180, 180 $, 180 \mathrm{~B}, 180 \mathrm{C}$ e174 (canto); e, ao Oeste, com os lotes 173 e540. Havido pela transcrição imobiliária n 18.586, L $^{\circ} 3-\mathrm{P}$, do Cartório de Registro de Imóveis da Comarca de Foz do Iguaçu-PR. O referido é verdade. São Miguel do Iguaçu, 25 de agosto de 1983.

PROPRIETÁRIO: INSTITUTO NACIONAL DE COLONIZAÇÃO E REFORMA AGRÁRIA INCRA - inscrito no CGC-MF sob nº 00.375.972/0011-32

R-01/8935 - TITULADO o imóvel presente, em favor de MÁXIMO VILIALBA, brasileiro, silvícola, agricultor, neste ato assistido pela Fundação Nacional do Índio - FUNAI, na forma dos Artigos n ${ }^{\circ}$ 6, item III, e 84 do Código Civil, Art. No $7^{\circ}$, parágrafo $2^{\circ}$ da Lei 6001, de 19/12/1973, e Art. $1^{\circ}$ item I, do Estatuto da Fundação Nacional do Índio, aprovado pelo Decreto 84638, de 16 de abril de 1980; de conformidade com o TÍTULO DE RECONHECIMENTO DE DOMÍNIO, expedido pelo Instituto Nacional de Reforma Agrária, na Cidade de Curitiba, capital deste Estado, em data de 22 de agosto de 1983, sem valor declarado. Demais condições constantes do referido Título. D/ C\$3.000,00=0,300VRC. O referido é verdade. São Miguel do Iguaçu, 25 de agosto de 1983.

AV-02/8935 - Certifico e dou fé, que o Título de reconhecimento de Domínio, a que se refere a R-01 da presente Matrícula, tem seu registro no INCRA sob no 4 (09)92(02) 08. O referido é verdade. São Miguel do Iguaçu, 25 de agosto de 1983.

R-03/8935: Doado, o imóvel da presente, em favor da COMUNIDADE INDÍGENAAVÁ-GUARANI, integrada pelos índios: - Cacique FERNANDO MARTINES e família; JOÃO CENTURION e família; PEDRO ALVES e família; TORÍBIO PALÁCIO e família; JOSÉ ACOSTA e família; ANTONIO ACOSTA e família; ALÉCIO VOGADO e família; JERÔNIMO VAZ e família; CASEMIRO PEREIRA e família; JORGE VOGADO e família; ANGELO BENITE e família; MÁXIMO VILIALBA e família; FELIPE ROMERO e família; TERESO CENTURION e família; SILVINO VAZ e família; INOCÊNCIO ACOSTA e família; SEBASTIÃO VOGADO e família; SANTIAGO CENTURION e família; LOSSANTO PEREIRA e família; de conformidade com a Escritura Pública de Doação, lavrada às folhas 125/126 do livro número 18-N, em data de 25 de agosto de 1983, nas Notas do Escrivão Distrital designado, Sr João Cornella Fagion, do Distrito de Aurora do Iguaçu, neste Município e Comarca, doação essa sem valor declarado. No ato da escritura, outorgante e outorgada foram devidamente assistidos pela FUNAI, com sede em Brasília DF, na forma do Art. $7^{\circ}$, parágrafo $2^{\circ}$ da Lei 6001, de 19.12.1973, do Estatuto da Fundação Nacional do Índio, representada pelo Delegado Regional da $4^{\circ}$ DR Dr Eng ${ }^{\circ}$ Agronômo Harry Luiz Ávila Teles, brasileiro, casado, 
residente em Curitiba - PR, portador da CI/1049722-PR e CPF/MF n ${ }^{\circ}$ 073.343.979/91, de acordo com a delegação de competência da Presidência da FUNAI nº 444/P, de 29.06.1983. Compareceu no ato da escritura, a mulher do outorgante doador, Catarina Duarte Vilialba, brasileira, silvícola, agricultora, casada conforme Registro de Casamento n 10, da Comunidade Indígena Avá-Guarani, deste Município e Comarca. Estando os doadores e donatária isentos de obrigações tributárias, conforme preceitua o Art. 60 da Lei $\mathrm{n}^{\circ}$ 6001, de 19.12.73 (Estatuto do Índio). Demais condições, constantes da escritura. D/C $\$ 1.500,00=150$ VRC.O referido é verdade. São Miguel do Iguaçu, 29 de agosto de 1983.

Data assinada pelo Cartório 26.07.85, ou seja dois anos depois.

\section{REGISTRO GERAL MATRÍCULA No 8936 LIVRO N² 2. (Anexos n 11: F4 - 2duas folhas).}

Imóvel rural denominado como Reserva Florestal nº 06-Parte D-2, com 39,6953 ha, compreendido na Gleba n ${ }^{\circ} 84$ do Projeto Integrado de Colonização Ocoí, situado neste Município e Comarca, com as metragens, limites e confrontações seguintes: ao Norte, com a Reserva Florestal nº6-Parte D-1;

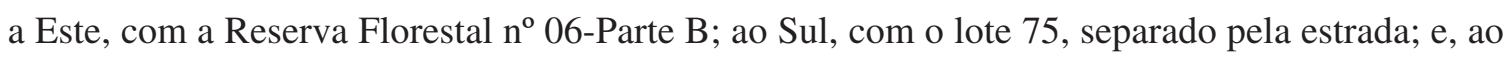
Oeste, com os lotes 84, 83, 85, 178, 177, 176, 175, 174 e 173 (canto). Havido pela transcrição imobiliária nº 18.586, L³-P, do Cartório de Registro de Imóveis da Comarca de Foz do Iguaçu-PR. O referido é verdade. São Miguel do Iguaçu, 25 de agosto de 1983.

PROPRIETÁRIO: INSTITUTO NACIONAL DE COLONIZAÇÃO E REFORMA AGRÁRIA INCRA - inscrito no CGC-MF sob no 00.375.972/0011-32

R-01/8936 - TITULADO o imóvel presente, em favor de PEDRO ALVES, brasileiro, silvícola, agricultor, neste ato assistido pela Fundação Nacional do Índio - FUNAI, na forma dos Artigos n ${ }^{\circ} 6$, item III, e 84 do Código Civil, Art. $N^{\circ} 7^{\circ}$, parágrafo $2^{\circ}$ da Lei 6001, de 19/12/1973, e Art. $1^{\circ}$ item I, do Estatuto da Fundação Nacional do Índio, aprovado pelo Decreto 84638, de 16 de abril de 1980; de conformidade com o TÍTULO DE RECONHECIMENTO DE DOMÍNIO, expedido pelo Instituto Nacional de Reforma Agrária, na Cidade de Curitiba, capital deste Estado, em data de 22 de agosto de 1983, sem valor declarado. Demais condições constantes do referido Título. D/ C\$3.000,00=0,300VRC. O referido é verdade. São Miguel do Iguaçu, 25 de agosto de 1983.

AV-02/8936 - Certifico e dou fé, que o Título de reconhecimento de Domínio, a que se refere a R-01 da presente Matrícula, tem seu registro no INCRA sob no 4 (09)92(02) 09. O referido é verdade. São Miguel do Iguaçu, 25 de agosto de 1983. 
R-03/8936: Doado, o imóvel da presente, em favor da COMUNIDADE INDÍGENAAVÁ-GUARANI, integrada pelos índios: - Cacique FERNANDO MARTINES e família; JOÃO CENTURION e família; PEDRO ALVES e família; TORÍBIO PALÁCIO e família; JOSÉ ACOSTA e família; ANTONIO ACOSTA e família; ALÉCIO VOGADO e família; JERÔNIMO VAZ e família; CASEMIRO PEREIRA e família; JORGE VOGADO e família; ANGELO BENITE e família; MÁXIMO VILIALBA e família; FELIPE ROMERO e família; TERESO CENTURION e família; SILVINO VAZ e família; INOCÊNCIO ACOSTA e família; SEBASTIÃO VOGADO e família; SANTIAGO CENTURION e família; LOSSANTO PEREIRA e família; de conformidade com a Escritura Pública de Doação, lavrada às folhas 125/126 do livro número 18-N, em data de 25 de agosto de 1983, nas Notas do Escrivão Distrital designado, Sr João Cornella Fagion, do Distrito de Aurora do Iguaçu, neste Município e Comarca, doação essa sem valor declarado. No ato da escritura, outorgante e outorgada foram devidamente assistidos pela FUNAI, com sede em Brasília DF, na forma do Art. $7^{\circ}$, parágrafo $2^{\circ}$ da Lei 6001, de 19.12.1973, do Estatuto da Fundação Nacional do Índio, representada pelo Delegado Regional da $4^{\circ}$ DR Dr Eng ${ }^{\circ}$ Agronômo Harry Luiz Ávila Teles, brasileiro, casado, residente em Curitiba PR, portador da CI/1049722-PR e CPF/MF nº 073.343.979/91, de acordo com a delegação de competência da Presidência da FUNAI n 444/P, de 29.06.1983. Compareceu no ato da escritura, a mulher do outorgante doador, Bernarda Centurion, brasileira, silvícola, agricultora, casada conforme Registro de Casamento $\mathrm{n}^{\mathrm{0}}$ 12, da Comunidade Indígena Avá-Guarani, deste Município e Comarca. Estando os doadores e donatária isentos de obrigações tributárias, conforme preceitua o Art. 60 da Lei no 6001 , de 19.12.73 (Estatuto do Índio). Demais condições, constantes da escritura. D/C $\$ 1.500,00=150$ VRC.O referido é verdade. São Miguel do Iguaçu, 29 de agosto de 1983.

\section{Data assinada pelo Cartório 26.07.85, ou seja dois anos depois.}

Comentários quanto aos 4 (quatro) documentos: Os documentos Anexos no 11 F1 - F2 F3- F4 são quatro REGISTROS GERAIS MATRÍCULAS Nºs 8933, 8934, 8935 e 8936, em que o INCRA repassou os imóveis de sua propriedade, a saber: RF $n^{\circ} 6$ - parte $\mathrm{C}-1 ; \mathrm{RF} \mathrm{n}^{\mathrm{o}} 6$ parte C-2; RF n ${ }^{\circ} 6$ - parte D-1; e RF n 6 - parte D-2, em 25.08.83, para as respectivas 4 (quatro) famílias indígenas, a saber: Cacique FERNANDO MARTINES e família; JOÃO CENTURION e família; MÁXIMO VILIALBA e família; PEDRO ALVES e família, que recebem estas terras como 4 (quatro) TÍTULOS DE RECONHECIMENTO DE DOMÍNIO. 5 (cinco) dias depois, em 29.08.83, os 4 (quatro) indígenas citados, repassam os 4 títulos individuais de terra para 19 famílias, o que inclui as próprias 4 famílias antes tituladas, denominadas, a partir deste momento, como "Comunidade Indígena", que passaram a ter a "posse coletiva" dessas terras. (Tabela 5.2.) Em resumo o documento coloca as seguintes questões explicitadas na Tabela 5.2. 


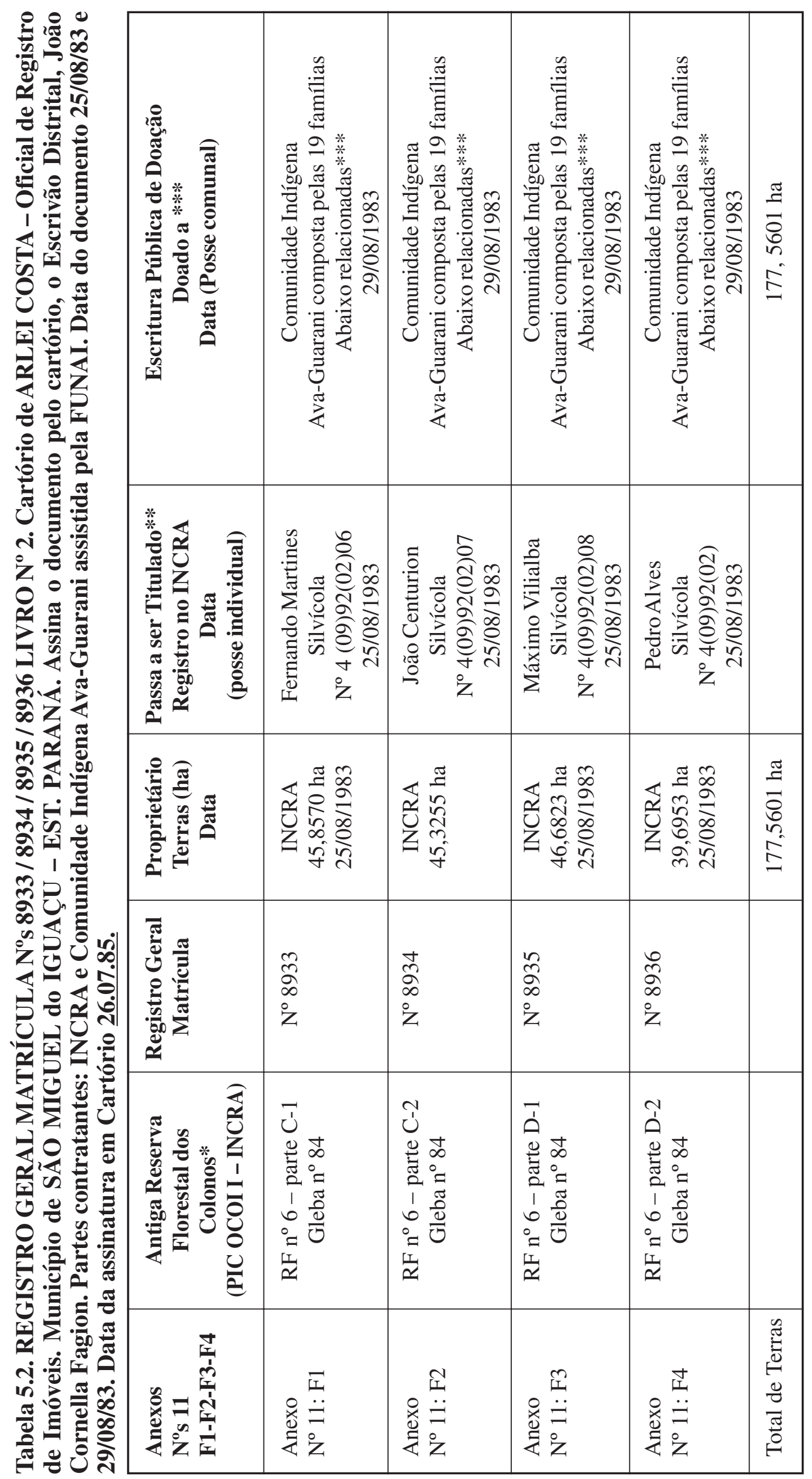

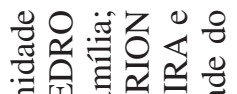
편 돈

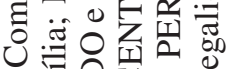
* 更过

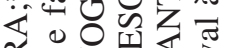

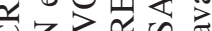

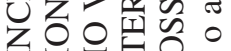
of

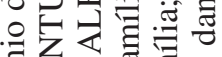

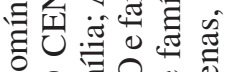
$\circ \bigcirc$

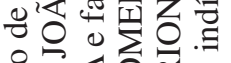

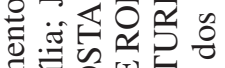

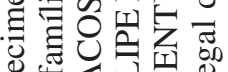
政还记

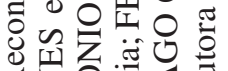
$\simeq$ Z

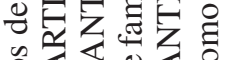
की $40<0$ 至溇约的 으를 추ㅇㅝㅔ 过

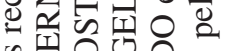
跣记安造

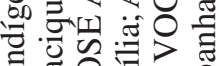
ฮ음

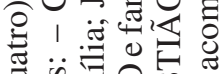

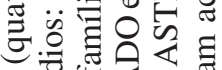

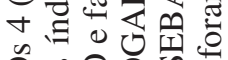

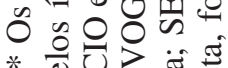

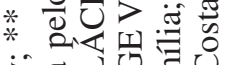

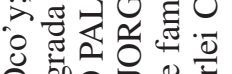

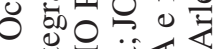
을. 불

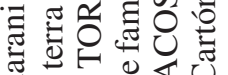
$5 \%$.

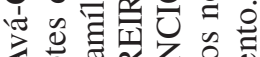
의 证 .00 80 \%

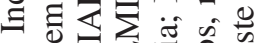
远国完

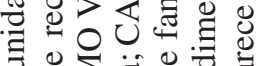

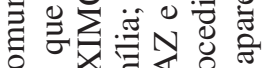

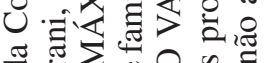

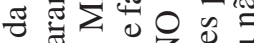

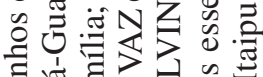

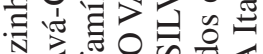

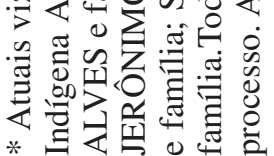




\section{$1^{\circ}$ ilegalidade: Titulação individual de terras para indígenas}

Remetemos ao documento já citado pelo Dr. Carlos Frederico Marés de Souza Filho, que anteriormente a esses procedimentos serem efetivados, colocou para os advogados de Itaipu, que a transferência de títulos individuais de propriedade de terra pelo INCRA, destinado à povos indígenas, é medida ilegal. Em razão disso, 5 (cinco) indígenas já haviam recebido títulos individualmente e a proposta foi posteriormente desfeita, por não encontrar acolhida na Consultoria Jurídica dos órgãos INCRA e FUNAI em Brasília. Então, o procedimento passou a ser feito junto aos funcionários destes mesmos órgãos, só que localmente, sendo efetivados, não junto à Juiz Federal, mas também localmente, em Cartório de São Miguel do Iguaçu.

Assim Dr Marés já apontava os procedimentos corretos, conforme legislação federal, em 10.05.82, um ano antes de serem novamente realizados de forma irregular em 25.08.83.

Em resumo, em 25 de agosto de 1983, na Comarca de São Miguel do Iguaçu, no Cartório do Registro de Imóveis, de propriedade do Tabelião Arlei Costa, o INCRA, assistido pela FUNAI, através de legislação inapropriada, que não condiz com a legislação federal, titula quatro lotes de terra, "módulos rurais", em nome de quatro famílias indígenas. Todos os procedimentos ilegais.

\section{$2^{\circ}$ ilegalidade: os 4 indígenas titulados não são exatamente os 4 indígenas indicados por Horst}

Em todos os quatro documentos (Anexos n ${ }^{\circ} 11$ F1 - F2 - F3 e F4), são mencionados apenas as 4 (quatro) famílias: Cacique FERNANDO MARTINES e família; JOÃO CENTURION e família; PEDRO ALVES e família; MÁXIMO VILIALBA e família; que passaram a ser os 4 (quatro) "proprietários de terras" ilegalmente constituídas. Eram 4 (quatro) porque haviam sido

somente 4(quatro) famílias, que o Laudo de Horst (Anexos no 7 e 8), havia reconhecido como verdadeiros "indígenas".

Mas, as 4 (quatro) famílias reconhecidas por Horst como indígenas eram as seguintes: Fernando Martine e família; Máximo Vilhalva e família; Ovilon Venite e família; e Salício Rosa. Note-se que não são essas exatamente as 4 (quatro) famílias tituladas na documentação elaborada em 1983 (Anexo n ${ }^{\circ} 11$ F1,2,3,4), quando aparecem os nomes de João Centurion e Pedro Alves e família ao invés de Ovilon Venite e Salicio Rosa. Ou seja, nesta nova documentação, duas novas famílias indígenas, que não haviam sido sequer citadas anteriormente por Horst, apesar de sempre terem estado no Oco’y-Jacutinga, aparecem como destinatários das terras.

Conclui-se que se tratava de reduzir "artificialmente" o número de famílias a serem reconhecidas como indígenas, para que o tratamento dado coubesse dentro dos estreitos termos do 
Artigo 33 do Estatuto do Índio, pouco importando o fato de que os índios Guarani constituíam uma Comunidade Indígena com então 19 (dezenove) famílias, compondo um Grupo Tribal, assentado em terras da União, como é reafirmado também pelo Dr Marés.

\section{$3^{\circ}$ ilegalidade: 4 famílias indígenas tituladas "individualmente" doam para as 19 famílias agora na forma “comunal”, os mesmos 177,5601 hectares}

O número de famílias indígenas, na realidade, era maior no interior da Comunidade Indígena desde o início de todo o processo, como comprovam os documentos (Anexo n ${ }^{\circ} \mathrm{s} 11 \mathrm{~F} 1$ F2-F3-F4). Mas, somente agora, é admitida a existência de mais 15 (quinze) famílias, totalizando 19 (dezenove) famílias, como "Comunidade Indígena". O que, concretamente, desmente o Laudo de Horst.

As 4 (quatro) famílias indígenas "remanescentes" que receberiam 4 títulos de propriedade da terra como usucapião, de acordo com aplicação errônea do artigo 33/EI, do dia 25 para o dia 29 de agosto de 1983, num "passe de mágica", passaram a ser um "Grupo Tribal”, uma Comunidade Indígena de 19 (dezenove) famílias possuidoras de "posse coletiva" da terra, agora, no "formato legalmente aceito". Ressalte-se que as terras atribuídas à Comunidade Indígena são os mesmos e irrisórios 177,5601 (cento e setenta e sete hectares e cinquenta e seis ares) antes atribuídos às 4 famílias individualmente. Essas 4 famílias doaram para si mesmas terras, o que faz pouco sentido, e ainda para outras 15 famílias.

Assim, Cacique FERNANDO MARTINES e família; JOÃO CENTURION e família; MÁXIMO VILIALBA e família; PEDRO ALVES e família; os quatro recebem os módulos rurais do INCRA como se fossem colonos, proprietários rurais e 5 (cinco) dias depois doam para eles próprios e ainda, para as outras 15 (quinze) famílias a seguir: TORÍBIO PALÁCIO e família; JOSÉ ACOSTA e família; ANTONIO ACOSTA e família; ALÉCIO VOGADO e família; JERÔNIMO VAZ e família; CASEMIRO PEREIRA e família; JORGE VOGADO e família; ANGELO BENITE e família; FELIPE ROMERO e família; TERESO CENTURION e família; SILVINO VAZ e família; INOCÊNCIO ACOSTA e família; SEBASTIÃO VOGADO e família; SANTIAGO CENTURION e família; LOSSANTO PEREIRA e família.

Está claro que já seriam insuficientes as terras para as 4 famílias, pois o modelo não é adequado ao uso indígena, que deve-se basear no Estatuto do Índio e Constituição Federal, mais sim, modelo apropriado para "módulo rural", conforme Estatuto da Terra. Logo elas seriam ainda mais insuficientes para as 19 famílias da Comunidade Indígena. 
Assim, os 4 "proprietários" indígenas, receberam no dia 25.08.83, 4 (quatro) "lotes individuais do INCRA" com a seguinte extensão: 45,8570 ha, 45,3255 ha, 46,6823 ha e 39,6953 ha, que somam 177,5601 hectares. As 19 famílias receberam a seguir no dia 29.08.82, por “doação", os mesmos 177,5601 hectares, agora como "posse comunal". Portanto, as dimensões das terras permaneceram exatamente as mesmas, e, o que se modifica é apenas a posse "individual" para a posse "comunal", com o claro objetivo de adaptação posterior ao que os direitos indígenas e a legislação federal determinavam.

Deve-se lembrar de que no início de todo o processo, em 1973, quando o INCRA invade as terras da população indígena no Oco'y-Jacutinga, ela era composta de 70 famílias. Estas passam por todas as agruras aqui descritas e finalmente, no momento em que Itaipu vai inundar a área (1982), permaneciam ainda na área 19 (dezenove) famílias.

\section{$4^{0}$ ilegalidade: os 4 lotes individuais repassados aos índios são os mesmos lotes dos colonos} lindeiros ao Oco’y, que não receberam indenização pela desapropriação de suas terras; e $5^{\circ}$ ilegalidade: as mesmas terras dos colonos (PIC-OCOI I - INCRA) estavam destinadas a ser Área de Preservação Permanente/APP do lago de Itaipu (PIC-OCOI II - INCRA)

O INCRA desapropriou terras de colonos, a saber, de acordo com a Escritura citada acima: $\mathrm{RF} \mathrm{n}^{\circ} 6$ - parte C-1; RF n ${ }^{\circ} 6$ - parte C-2; RF n ${ }^{\circ} 6$ - parte D-1; e RF n 6 - parte D-2, assume a propriedade por algum tempo, e repassa em seguida as mesmas terras para os 4 indígenas titulados. Os colonos lindeiros ao Oco’y sempre reclamaram não haver recebido qualquer indenização pela desapropriação de suas terras, conforme os depoimentos dos indígenas. Tal fato explica-se pela impossibilidade dos funcionários do INCRA justificarem indenizações aos colonos por terras que foram ilegalmente repassadas para os "indígenas".

Foram destinados às 19 famílias Guarani, 4 lotes de terras contíguos, uma pequena faixa de terras de 240 metros em média de largura, por $7 \mathrm{Km}$ de comprimento. Onde os 100 metros primeiros é faixa de APP de Itaipu e os restantes 140 metros de largura sobrantes foram destinados aos índios. Assim, descontada a APP, a diferença que restou destinou-se à acomodar os índios Guarani. Portanto, os índios Guarani perderam a totalidade de suas terras, sendo acomodados num espaço irrisório, ilegal, sem possibilidades de sobrevivência minimamente digna. Sua reprodução física e cultural está neste local em muito comprometida.

Esta terra apresentava as seguintes características: A área havia sido destinada anteriormente aos colonos, pelo INCRA, parte da Reserva Florestal n 6 através do PIC OCOI I. A parte que seria 
destinada aos índios, portanto, desapropriada dos colonos, consistia em área obrigatória destes últimos (dos colonos) de Reserva Florestal, os $20 \%$ obrigatórios de preservação ambiental junto ao antigo Córrego Santa Clara exigidos pelo IBDF, atual IBAMA. Mais tarde, esse córrego também sofre inundação (1982) pela hidrelétrica, tornando-se um braço do reservatório de Itaipu, que atualmente localiza-se, não em frente às terras dos colonos, mas em frente à Terra Indígena do Oco’y.

Entretanto, estas áreas ocupadas por colonos (PIC OCOI I / INCRA), já estavam destinadas pelo INCRA à desapropriação, para tornar-se uma franja florestada, parte da Área de Preservação Permanente/APP de um dos braços do reservatório da Itaipu, àquele braço acima citado. Desapropriadas, essas terras viriam a constituir a Área de Preservação Permanente /APP das margens do reservatório de Itaipu. Ou seja, área destinada através do projeto PIC-OCOI-II/ INCRA, para uso exclusivo de Itaipu, que teria que ser adquirida dos colonos, indenizadas, através do INCRA, para usufruto de Itaipu.

Como já vimos, estas terras são destinadas aos índios Guarani (os 4 lotes individuais), o que gera a superposição da Terra Indígena do Oco’y e da Área de Preservação Permanente /APP de Itaipu. Superposição de duas áreas, tecnicamente inadequada, pois, são mutuamente exclusivas, sendo assim o procedimento ilegal.

Segundo informação dos colonos desapropriados, eles nunca receberam indenização do INCRA por essas terras. Fato que está na base da disputa entre índios e colonos pela posse das mesmas terras, que acontece até hoje no local. Ao perderem esta fatia de suas terras sem receber indenização por elas, os colonos avançam com seus tratores sobre suas legítimas terras, as bordas externas, já da mínima terra que é considerada também, Terra Indígena do Oco’y.

O "muro natural de proteção" que os Guarani mantinham através de vegetação em estado primário, nestas bordas externas da Terra Indígena, já não existe mais, assim como os marcos divisórios, também já não existem mais, frequentemente são recolocados pelo poder público, em seguida retirados pelos colonos. Em seu lugar é plantado soja ou trigo, com agrotóxicos pesados.

Os colonos pulverizam agrotóxicos a menos de 5 metros das casas indígenas, quando a legislação determina pelo menos 500 metros de distância. Consequentemente intoxicam famílias Guarani, lavouras, produtos dessas lavouras, peixes, águas, áreas de coleta etc. O fato tem como agravante que esses agrotóxicos, muitos deles comprados ilegalmente no Paraguai, incluem produtos como 24D (agente laranja), já há muito proibidos de utilização no Brasil.

O Instituto Ambiental do Paraná/ IAP/Pr, apesar de ter visitado a área por várias vezes, não registrou tal ocorrência de proximidade excessiva de aspersão de agrotóxicos junto a agrupamento populacional, conforme determina a legislação estadual. 
Os cultivos Guarani, que já não possuem quase espaço físico para se dar visando a sustentação de todas as famílias, ficam assim, também comprometidos, dado que os agrotóxicos não são apropriados a eles, gerando mais uma vez comprometimento da subsistência Guarani, seguidos de casos de subnutrição ou até desnutrição.

Assim ao colocar a Comunidade Indígena em área de APP de Itaipu, não lhes foi destinada praticamente nenhuma terra como compensação, mas tão somente liberada a sua moradia em local proibitivo. Ou seja, INCRA e Itaipu, ao fazerem esta transposição de áreas, não despenderam quase nenhum recurso financeiro para realocar os índios. As terras destinados aos índios, era de responsabilidade de Itaipu compensar. Tirou-se as terras dos colonos em número de 4 fatias de lotes, e elas foram atribuídas aos índios, colocando-os, as instituições INCRA, FUNAI e Itaipu, frente a frente, os dois grupos de vizinhos para disputarem as mesmas terras. Ao mesmo tempo Itaipu recebeu sem custos para o INCRA, a sua necessária APP.

Daí também a insistência de todos, FUNAI, INCRA e ITAIPU, conforme os vários documentos citados anteriormente em anexo, de colocar os indígenas nas margens do reservatório de Itaipu.

Os índios Guarani passaram a viver num local em que, pelas bordas externas os colonos fazem pressão para retomar suas terras perdidas e não indenizadas pelo INCRA. Aspergem agrotóxicos há menos de 5 metros das residências indígenas. Pelas bordas internas, a Itaipu mantém área superposta à Terra Indígena, o que traz também uma série de problemas para os Guarani, como a presença do mosquito anópheles, transmissor da malária à beira do reservatório ou o consumo de peixes contaminados por agrotóxicos, do reservatório. A nenhuma população é permitido viver às margens do reservatório de Itaipu em qualquer parte dessa APP. Curiosamente apenas os índios Guarani ali habitam.

Para os Guarani restaram, entre o lago e as áreas ocupadas por colonos, uma irrisória porção de terra de apenas 140 metros de largura para realizarem todas as suas atividades de subsistência. Esse espaço mínimo não comporta atividades de coleta e agrícolas, umas competem com as outras: ou seja, para os Guarani manterem a rarefeita biodiversidade, devem deixar de plantar; se plantam, então devem retirar as pequenas sobras de Matas, diminuindo assim a rarefeita biodiversidade; sendo fundamentalmente necessária, as duas atividades, para a sobrevivência indígena.

Constitui-se assim a Terra Indígena do Oco’y com 231,88 hectares, numa superposição incompatível de áreas, APP de Itaipu e Terra Indígena, que contraria o uso exclusivo pelos indígenas, previsto no Estatuto do Índio (Artigo 22), conforme também indica Dr Marés.

Portanto, de terras dos colonos (PIC OCOI I - INCRA) transforma-se em Terra Indígena/ TI Guarani e/ou Área de Preservação Permanente/APP de Itaipu (PIC OCOI II - INCRA). 
A FUNAI, acompanhando os índios, parte para o segundo documento (Anexo $\mathbf{n}^{\mathbf{0}} \mathbf{1 1} \mathbf{~ G}$ ), desdobramento do primeiro, realizados os dois no mesmo dia 25/08/83 e no mesmo Cartório, sem que o primeiro documento (Anexos $\mathrm{n}^{\mathrm{o}} 11 \mathrm{~F}$ 1-2-3-4) esteja assinado pelo Cartório, o que vem a acontecer apenas 2 (dois) anos depois, no dia 26.07.85, pelo escrivão distrital João Cornella Fagion.

O segundo documento ESCRITURA PÚBLICA DE DOAÇÃO QUE FAZEM PEDRO ALVES E OUTROS, EM FAVOR DE COMUNIDADE INDÍGENA AVÁ-GUARANI, COMO ABAIXO SE DECLARA: (Anexo nº $11 \mathrm{G}$ ) é o que segue.

REPÚBLICA FEDERATIVA DO BRASIL

DISTRITO AURORA DO IGUAÇU - MUN. SÃO MIGUEL DO IGUAÇU - ESTADO PARANÁ COMARCA DE SÃO MIGUEL DO IGUAÇU

ARLEI COSTA E ALTAIR COSTA (TABELIÕES RESPONSÁVEIS)

ASSINA O DOCUMENTO O TABELIÃO JOÃO CORNELLA FAGION

DATA $25 / 08 / 1983$

ESCRITURA PÚBLICA DE DOAÇÃO QUE FAZEM PEDRO ALVES E OUTROS, EM FAVOR DE COMUNIDADE INDÍGENA AVÁ-GUARANI, COMO ABAIXO SE DECLARA:

Saibam quantos esta pública escritura de doação virem, que aos $25.08 .1983 \ldots$, neste distrito de Aurora do Iguaçu, município e comarca de São Miguel do Iguaçu, estado do Paraná, República Federativa do Brasil, em cartório, perante mim Tabelião Designado e duas testemunhas adiante nomeadas e no final assinadas, compareceram partes entre si justas e contratadas, a saber: -como outorgantes doadores: PEDRO ALVES e sua mulher BERNARDA CENTURION ALVES, casados conforme Registro Administrativo nº 12 da Comunidade Indígena Avá-Guarani de São Miguel do Iguaçu, expedido pela Fundação Nacional do Índio - FUNAI - Ministério do Interior; MÁXIMO VILIALVA e sua mulher CATARINA DUARTE VILIALVA, casados conforme Registro Administrativo $\mathbf{n}^{\circ} 10$ da Comunidade Indígena Avá-Guarani de São Miguel do Iguaçu, expedido pela Fundação Nacional do Índio - FUNAI - Ministério do Interior; JOÃO CENTURION e sua mulher VERGÍNIA DA CUNHA CENTURION, casados conforme Registro Administrativo ${ }^{0} 11$ da Comunidade Indígena Avá-Guarani de São Miguel do Iguaçu, expedido pela Fundação Nacional do Índio - FUNAI - Ministério do Interior; e, FERNANDO MARTINES e sua mulher IZIDORA VILIALVA, casados conforme Registro Administrativo no 9 da Comunidade Indígena Avá-Guarani de São Miguel do Iguaçu, expedido pela Fundação Nacional do Índio - FUNAI - Ministério do Interior; todos brasileiros, silvícolas, agricultores, casados segundo a Tradição Indígena, anotada nos registros administrativos da Comunidade Indígena Avá-Guarani de São Miguel do Iguaçu, neste ato assistidos pela FUNAI - Fundação Nacional 
do Índio, com sede em Brasília DF, na forma do Art. $7^{\circ}$, parágrafo $2^{\circ}$ da Lei 6001, de 19/12/1973, do Estatuto da Fundação Nacional do Índio, representada pelo Delegado Regional da $4^{\circ}$ DR Dr Eng $^{\circ}$ Agronômo Harry Luiz Ávila Teles, brasileiro, casado, residente em Curitiba - PR, portador da CI/1049722-PR e CPF/MF n ${ }^{\circ}$ 073.343.979/91, de acordo com a delegação de competência da Presidência da FUNAI n ${ }^{\circ}$ 444/P, de 29.06.1983; e, como outorgada donatária, a Comunidade Indígena Avá-Guarani, integrada pelos índios: - Cacique FERNANDO MARTINES e família; JOÃo CENTURION e família; PEDRO ALVES e família; TORÍBIO PALÁCIO e família; JOSÉ ACOSTA e família; ANTONIO ACOSTA e família; ALÉCIO VOGADO e família; JERÔNIMO VAZ e família; CASEMIRO PEREIRA e família; JORGE VOGADO e família; ANGELO BENITE e família; MÁXIMO VILIALBA e família; FELIPE ROMERO e família; TERESO CENTURION e família; SILVINO VAZ e família; INOCÊNCIO ACOSTA e família; SEBASTIÃO VOGADO e família; SANTIAGO CENTURION e família; LOSSANTO PEREIRA e família; neste ato assistida pela FUNAI - Fundação Nacional do Índio, com sede em Brasília DF, representada pelo Delegado Regional da $4^{\circ}$ DR Dr Eng ${ }^{\circ}$ Agronômo Harry Luiz Ávila Teles, acima qualificado, de acordo com a delegação de competência da Presidência da FUNAI n 444/P, de 29.06.1983; Os presentes, reconhecidos como os próprios por mim Tabelião Designado e pelas duas testemunhas referidas, do que dou fé. E, perante essas mesmas testemunhas, pelas partes, falando cada uma por sua vez, me foi declarado o seguinte: $1^{\circ}$ ) Que, os outorgantes doadores, sendo senhores e legítimos possuidores, livre e desembaraçado de quaisquer dúvidas, bem como ações reais e pessoais, dos seguintes imóveis: -a) RESERVA FLORESTAL No 6 - PARTE D-2 , com área de 39,6953 ha., compreendido na Gleba ${ }^{0} 84$ do Projeto Integrado de Colonização Ocoí, situado neste Município e Comarca de São Miguel do Iguaçu, com os limites e confrontações seguintes: ao Norte, com a Reserva Florestal nº6-Parte D-1; a Este, com a Reserva Florestal no 06-Parte B; ao Sul, com o lote 75, separado pela estrada; e, ao Oeste, com os lotes 84, 83, 85, 178, 177, 176, 175, 174 e 173 (canto). Imóvel esse havido por PEDRO ALVES, por força do TÍTULO DE RECONHECIMENTO DE DOMÍNIO, no 4 (09)92(02) 09, expedido pelo INCRA, na Cidade de Curitiba,Pr, em data de 22 de agosto de 1983, devidamente registrado sob o $\mathrm{n}^{\circ}$ 01, na Matrícula no— do livro no 02, do Cartório de Registro de Imóveis desta Comarca de São Miguel do Iguaçu; b) RESERVA FLORESTAL No 6 - PARTE D1, COM ÁREA DE 46,6823 ha. , compreendido na Gleba ${ }^{\circ} 84$ do Projeto Integrado de Colonização Ocoí, situado neste Município e Comarca de São Miguel do Iguaçu, com os limites e confrontações seguintes: ao Norte, com a Reserva Florestal n ${ }^{\circ}$ 06-Parte B; a Este, com a Reserva Florestal n ${ }^{\circ}$ 06-Parte B; ao Sul com a com a Reserva Florestal no 06-Parte D-2 e, lotes, 173, 180, $180^{\mathrm{A}}, 180 \mathrm{~B}, 180 \mathrm{C}$ e174 (canto); e, ao Oeste, com os lotes 173 e540. Imóvel esse havido por MÁXIMO VILIALBA, por força do TÍTULO DE RECONHECIMENTO DE DOMÍNIO, ${ }^{\circ}$ 
4 (09)92(02) 08, expedido pelo INCRA, na Cidade de Curitiba, Pr, em data de 22 de agosto de 1983, devidamente registrado sob o $\mathrm{n}^{\circ} 01$, na Matrícula $\mathrm{n}^{\circ}$ , do livro no 02, do Cartório de Registro de Imóveis desta Comarca de São Miguel do Iguaçu; c) RESERVA FLORESTAL No 6 - PARTE C-2, COM ÁREA DE 45,3255 ha., , compreendido na Gleba nº 84 do Projeto Integrado de Colonização Ocoí, , situado neste Município e Comarca de São Miguel do Iguaçu, com os limites e confrontações seguintes: ao Norte, com a Reserva Florestal $n^{\circ} 06-P a r t e ~ C-$ 1; a Este, com os lotes 115 (canto) 114, 113-A, 113, 112, 111, 110, 109, 108 e 126; ao Sul, com o lote 73, separado pela estrada; e, ao Oeste, com a Reserva Florestal n ${ }^{\circ}$ 06-Parte B. Imóvel esse havido por JOÃO CENTURION, por força do TÍTULO DE RECONHECIMENTO DE DOMÍNIO, no 4 (09)92(02) 07, expedido pelo INCRA, na Cidade de Curitiba, Pr, em data de 22 de agosto de 1983, devidamente registrado sob o $\mathrm{n}^{0}$ 01, na Matrícula $\mathrm{n}^{\circ}$

, do livro no 02, do Cartório de Registro de Imóveis desta Comarca de São Miguel do Iguaçu; d)RESERVA FLORESTAL Nº 6 - PARTE C-1, COM ÁREA DE 45,8570 ha., compreendido na Gleba no 84 do Projeto Integrado de Colonização Ocoí, situado neste Município e Comarca de São Miguel do Iguaçu, com os limites e confrontações seguintes: ao Norte, com a Reserva Florestal $\mathrm{n}^{\circ}$ 06-Parte B; a Este, com a Reserva Florestal nº6-Parte A e lotes 118, 117, 116, 115 e 114 (canto); ao Sul, com a Reserva Florestal n ${ }^{\circ}$ 06-Parte C-2; e, ao Oeste, com a Reserva Florestal n ${ }^{\circ}$ 06-Parte B. Imóvel esse havido por FERNANDO MARTINES, por força do TÍTULO DE RECONHECIMENTO DE DOMÍNIO, no 4 (09)92(02) 06, expedido pelo INCRA, na Cidade de Curitiba, Pr, em data de 22 de agosto de 1983, devidamente registrado sob o $\mathrm{n}^{\circ} 01$, na Matrícula ${ }^{\circ}$

—— , do livro $\mathbf{n}^{\circ}$ 02, do Cartório de Registro de Imóveis desta Comarca de São Miguel do Iguaçu; e, estão justos e contratados para doá-los a outorgada donatária; $\mathbf{2}^{\circ}$ ) Que em razão desta doação, os outorgantes doadores transferem neste ato à outorgada donatária, pela claúsula CONSTITUTI, todo domínio, posse, uso, gozo, direitos e ações que tinham e exerciam, sobre os referidos imóveis, podendo desde já a outorgada donatária, fazer das áreas ora doadas, o uso que melhor lhe convier; $3^{\circ}$ ) Que a presente DOAÇÃO, é feita em caráter irrevogável e irretratável, não assistindo as partes o direito arrependimento, a qualquer título, obrigando-se os outorgantes doadores por si ou seus herdeiros, a fazer a presente doação e esta escritura, sempre boa firme e valiosa, em Juízo ou fora dele, respondendo pela evicção de direito quando chamados a autoria; $4^{\circ}$ ) Pela outorgada donatária na forma integrada e assistida me foi dito que aceitava a presente doação e esta escritura em todos os seus expressos termos. Os outorgantes doadores e a outorgada donatária de acordo com o Art. 60, da Lei $\mathbf{n}^{0}$ 6001, de 19 de dezembro de 1973 (Estatuto do Índio) estão isentos de obrigações tributárias. E de como assim disseram e me pediram, lavrei-lhes a presente escritura, a qual feita, lida em voz alta e achada conforme, outorgaram, aceitaram e assinaram-na, fazendo-o a rogo dos outorgantes doadores por declararem 
não saber ler nem escrever, o sr. João Vanderlei de Souza, brasileiro, casado, funcionário da ItaipuBinacional, residente e domiciliado em Foz do Iguaçu, Pr, justamente com as testemunhas ao ato presentes e que são: Idalino José Norgan e Léo Schmitz, ambos brasileiros, casados, do comércio, meus conhecidos e aqui residentes. Eu, João Cornella Fagion, Tabelião Designado, a datilografei, conferi, subscrevo e dou fé. Aurora do Iguaçu, Pr, 25 de agosto de 1983. (aa) João Vanderlei de Souza, Harry Luiz Ávila Teles, Idalino José Norgan e Léo Schmitz. Ao lado, vê-se as impressões digitais dos outorgantes doadores, por não saberem ler nem escrever. NADA MAIS.

Aurora do Iguaçu, Pr. 25/agosto/1983

João Cornella Fagion

Recorde-se que os Guarani foram retirados ilegalmente de suas "terras de ocupação tradicional" em maio de 1982, as terras de Oco'y foram nesse mesmo ano demarcadas pela FUNAI, e somente agora em agosto de 1983, portanto, 15 meses depois, são providenciados os documentos relativos à resolução das questões fundiárias, a transferência oficial, mas feita de forma ilegal, à população indígena (Anexos nº s 11 F1, 2, 3 e 4 e Anexos nº 11 G).

Através de uma escritura de "doação", no mesmo dia 25.08.83, perante o mesmo tabelião JOÃO CORNELLA FAGION e duas testemunhas (um funcionário da Itaipu Binacional, o outro Delegado da FUNAI), os 4 indígenas chefes de família são levados a doarem as terras recém recebidas para a Comunidade Indígena, composta de 19 famílias.

Neste segundo documento (Anexo $\mathrm{n}^{\circ} 11 \mathrm{G}$ ) não aparece a origem das terras destinadas aos Guarani (“titulação individual pelo INCRA”). Registra-se apenas “Títulos de Reconhecimento de Domínio", o que significa "legitimação de posse" realizada pelo INCRA, o que, conforme apontado pelo Dr Marés (Anexo $\mathrm{n}^{\circ} 11 \mathrm{C}$ ) configura ilegalidade.

Em documentação reelaborada no mesmo Cartório, agora só com participação da FUNAI, repete-se o mesmo procedimento: foram reconhecidos os "direitos" de mais 15 famílias indígenas às terras, além das 4 famílias anteriores, na posse das mesmas e insuficientes terras, os mesmos quatro lotes destinados às 4 famílias, os mesmos 177,5601 ha. De "posse individual" das 4 famílias passou-se à "posse coletiva" das 19 famílias, sem que as dimensões das terras fossem alteradas. (Anexo n⿳ 11 F1,2,3,4; G; H; I).

Novamente há um procedimento incorreto, pois as 19 famílias são nominadas, uma a uma, na documentação, quando o correto seria conferir a posse a todos os sucedâneos pertencentes da “Comunidade Indígena”. 
Dessa forma foi contornada a questão do desterramento de população indígena de território tradicional, não sendo realizada a Identificação do Território Tradicional do Oco'yJacutinga, com suas dimensões reais e qualidade ambiental. Também se evitou a necessária autorização do Presidente da República quando se tratava de desterramento de uma área para outra, através de subterfúgios já demonstrados. O resultado é que se destinou terras irrisórias e inadequadas aos Guarani.

Outras questões a observar: nos documentos pertencentes ao Anexo $\mathrm{n}^{\circ} 11 \mathrm{~F}(1,2,3$ e 4$)$ e $\mathrm{n}^{\mathrm{o}}$ $11 \mathrm{G}$, aparecem diferentes valores em hectares para a mesma área; não se vê as impressões digitais dos doadores indígenas; não há assinatura dos outros presentes, só a do escrivão Fagion.

O que se pode depreender da análise em conjunto destes dois últimos documentos Anexos $\mathrm{n}^{\circ} \mathrm{s} 11: \mathrm{F} 1 ; \mathrm{F} 2 ; \mathrm{F} 3$; e F4 e Anexo ${ }^{\circ} 11 \mathrm{G}$ :

O INCRA, a FUNAI e a Itaipu Binacional, baseados na consultoria do Dr Marés, a utilizaram, não para respeitar seu "conteúdo legal", mas apenas para encontrar formas e caminhos que mascarassem os atropelos à legislação, cometidos por esse órgãos contra os direitos indígenas.

Assim, não é permitido destinar "Títulos de Propriedade da Terra" ou "Títulos de Reconhecimento de Domínio" à "Comunidade Indígena”, a qual obtém a "posse comunal” de "território tradicionalmente ocupado", sendo esta terra de "propriedade da União".

Pode-se notar que nos documentos (Tabela 5.3 ou Anexos no 11 F1, 2, 3, 4) não aparece a origem das terras que seriam destinadas aos índios (os 4 lotes). A forma como o INCRA recebe a propriedade destas terras, encontra-se transcrito da seguinte forma: "Havido pela transcrição imobiliária $n^{o}$ 18.586, L'3-P, do Cartório de Registro de Imóveis da Comarca de Foz do Iguaçu$P R$ ”; não há qualquer referência a quem seria seu proprietário original e nem a qualquer data.

Porém, é evidente que são as terras dos colonos lindeiros à Terra Indígena do Oco’y. São as Reservas Florestais: RF no 06 Parte C1; RF nº 06 Parte C2; RF no 06 Parte D1; RF no 06 Parte D2; desapropriadas dos colonos pelo INCRA, porém não indenizadas pela mesma Autarquia, conforme reclamos dos próprios colonos lindeiros.

Comparando os dois documentos Anexo n⿳ 11 F 1 (tomando um Registro Geral de Matricula $\mathrm{n}^{\mathrm{o}} 8933$, como exemplo) e Anexo $\mathrm{n}^{\mathrm{o}} 11 \mathrm{G}$ vejamos as origens destas terras, de como foram repassadas aos Guarani. Tabela 5.3. e Tabela 5.4. respectivamente. 
Tabela 5.3. Incra titula terras para 4 famílias indígenas. Registro Geral de Matrícula $\mathbf{n}^{\circ}$ 8933 (tomado um registro como exemplo). (Anexo $\mathrm{n}^{0} 11 \mathrm{~F} 1$ )

\begin{tabular}{|c|c|}
\hline Proprietário & Forma da Passagem da Propriedade \\
\hline $\begin{array}{l}1^{\circ} \text { ) Colono lindeiro à Terra } \\
\text { Indígena do Oco'y da Reserva } \\
\text { Florestal no } 06 \\
\text { Parte C1 c/ } 45,8570 \text { ha }\end{array}$ & $\begin{array}{l}\text { Sem qualquer referência da passagem da propriedade do colono } \\
\text { para o INCRA, obviamente sem data. }\end{array}$ \\
\hline $\left.2^{\circ}\right)$ INCRA & $\begin{array}{l}\text { "Havido pela transcrição imobiliária } \mathbf{n}^{\mathbf{0}} \mathbf{1 8 . 5 8 6}, \mathbf{L}^{\mathbf{0}} \mathbf{3}-\mathbf{P} \text {, do } \\
\text { Cartório de Registro de Imóveis da Comarca de Foz do } \\
\text { PR." Sem data. }\end{array}$ \\
\hline $\begin{array}{l}\left.3^{\circ}\right) \text { R-01/8933 Titulado } \\
\text { Silvícola Fernando Martines }\end{array}$ & $\begin{array}{l}\text { “...de conformidade com o TÍTULO DE RECONHECIMEN- } \\
\text { TO DE DOMÍNIO, expedido pelo INCRA, na Cidade de } \\
\text { Curitiba, capital deste Estado, em 22.08.1983. AV-02/8933 - } \\
\text { Certifico e dou fé, que o Título de Reconhecimento de Domínio, } \\
\text { a que se refere a R-01 da presente Matrícula, tem seu registro no } \\
\text { INCRA sob n } 4 \text { (09)92(02) 06.” }\end{array}$ \\
\hline $\begin{array}{l}4^{\circ} \text { ) R-03/8933: Doado à } \\
\text { Comunidade Indígena } \\
\text { Avá-Guarani (19 famílias) }\end{array}$ & 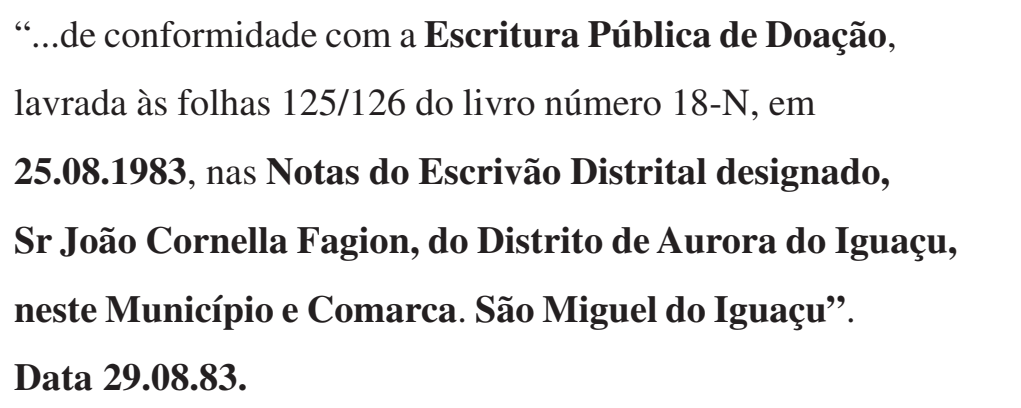 \\
\hline
\end{tabular}

Este documento F1 e os demais F2, F3 e F4 são assinados pelo Escrivão Distrital João Cornella Fagion, do Cartório Arlei Costa, de São Miguel do Iguaçu, somente dois anos depois, em 26.07.85. 
Tabela 5.4. Escritura Pública de Doação que fazem Pedro Alves e Outros, em favor de Comunidade Indígena Avá-Guarani. (Anexo nº 11G)

\begin{tabular}{|l|l|}
\hline Outorgantes doadores em 25.08.83 & Outorgada donatária em 25.08.83 \\
\hline Pedro Alves (39,6953ha); & Comunidade Indígena Avá-Guarani (19 famílias) \\
Máximo Vilialva (46,6823ha); & \\
João Centurion (45,3255ha); & \\
Fernando Martines (45,8570ha) & \\
\hline
\end{tabular}

Assinado pelo Escrivão Distrital João Cornella Fagion, do Cartório Arlei Costa, de São Miguel do Iguaçu, em 25.08.83.

- Imóvel esse havido por PEDRO ALVES, por força do TÍTULO DE RECONHECIMENTO DE DOMÍNIO, no 4 (09)92(02) 09, expedido pelo INCRA, na Cidade de Curitiba,Pr, em data de 22 de agosto de 1983, devidamente registrado sob o $\mathrm{n}^{\circ} 01$, na Matrícula $\mathrm{n}^{\circ}$ __ do livro $\mathrm{n}^{\circ}$ 02, do Cartório de Registro de Imóveis desta Comarca de São Miguel do Iguaçu;

- Imóvel esse havido por MÁXIMO VILIALBA, por força do TÍTULO DE RECONHECIMENTO DE DOMÍNIO, no 4 (09)92(02) 08, expedido pelo INCRA, na Cidade de Curitiba, Pr, em data de 22 de agosto de 1983, devidamente registrado sob o $\mathrm{n}^{\circ}$ 01, na Matrícula $\mathrm{n}^{\circ} \longrightarrow$, do livro $\mathrm{n}^{\circ}$ 02, do Cartório de Registro de Imóveis desta Comarca de São Miguel do Iguaçu;

- Imóvel esse havido por JOÃO CENTURION, por força do TÍTULO DE RECONHECIMENTO DE DOMÍNIO, $\mathbf{n}^{\circ} 4$ (09)92(02) 07, expedido pelo INCRA, na Cidade de Curitiba, Pr, em data de 22 de agosto de 1983, devidamente registrado sob o $\mathrm{n}^{\circ}$ 01, na Matrícula $\mathrm{n}^{\circ} \_$_ do livro $\mathrm{n}^{\circ}$ 02, do Cartório de Registro de Imóveis desta Comarca de São Miguel do Iguaçu;

- Imóvel esse havido por FERNANDO MARTINES, por força do TÍTULO DE RECONHECIMENTO DE DOMÍNIO, no 4 (09)92(02) 06, expedido pelo INCRA, na Cidade de Curitiba, Pr, em data de 22 de agosto de 1983, devidamente registrado sob o $\mathrm{n}^{\circ}$ 01, na Matrícula $\mathrm{n}^{\circ} \longrightarrow$, do livro $\mathrm{n}^{\circ}$ 02, do Cartório de Registro de Imóveis desta Comarca de São Miguel do Iguaçu.

No segundo documento Tabela 5.4., a passagem dos 4 lotes individuais para as 19 famílias deu-se no mesmo dia 25/08/83. Neste documento não é citado o INCRA como proprietário original das terras, mas apenas que este órgão lhes havia reconhecido um suposto "Título de Reconhecimento de Domínio".

“Imóvel esse havido por PEDRO ALVES, por força do TÍTULO DE RECONHECIMENTO DE DOMÍNIO, no 4 (09)92(02) 09, expedido pelo INCRA, na Cidade de Curitiba, Pr, em data de 22 de agosto de 1983, devidamente registrado sob o n 01 , na Matrícula n ${ }^{\circ}$ , do livro ${ }^{\circ} 02$, do

Cartório de Registro de Imóveis desta Comarca de São Miguel do Iguaçu;” (Anexo nº 11 G).

A forma como os 4 (quatro) indígenas recebem estas terras, na forma de "TíTULO $\boldsymbol{D E}$ RECONHECIMENTO DE DOMÍNIO, expedido pelo INCRA”, ainda “na cidade de Curitiba”, é datado em "22.08.1983" na Tabela 5.3. Documento AV-02/8933 - que o escrivão distrital João Cornella Fagion certifica como "Título de Reconhecimento de Domínio, a que se refere a $R$-01 
da presente Matrícula”, matrícula essa que não foi realizada em Curitiba em 22.08.83 e sim em 25.08.83 em São Miguel do Iguaçu, conforme tabela 5.4. e tabela 5.3., respectivamente.

$\mathrm{Na}$ Tabela 5.3., as 4 (quatro) famílias que detinham ali a propriedade individual das terras na data de 25.08.83, repassam por doação as mesmas 4 (quatro) terras, para a Comunidade Indígena, composta pelas 19 famílias em 29.08.83. Já o cartório, representado pelo escrivão Fagion, só assina o documento dois anos depois, em 26.07.85. ${ }^{14}$ Entretanto, na Tabela 5.4., o mesmo fato, a passagem dos 4 lotes para as 19 famílias, se dá na mesma data de 25.08.83. Por isso que neste documento (tabela 5.4.) não aparece o $\mathrm{n}^{\circ}$ de matrícula do cartório, pois ele ainda não existia. Depois de "resolvido" o problema fundiário (tabela 5.3.), a documentação (Tabela 5.4.) endossa legalmente a posse coletiva, como a legislação determinava. Sempre os mesmos 177, 5601 hectares.

Assim, o INCRA cede às 4 famílias indígenas através de titulação individual da terra, 45,8570 ha, 45,3255 ha, 46,6823 ha e 39,6953 ha, que somam 177,5601 hectares, que se transformam na posse coletiva de 19 famílias da Comunidade Indígena. População essa que ainda não é a totalidade do atual Oco'y.

\title{
5.2.6.2. A passagem de pequenas parcelas de terras pela Itaipu Binacional para os índios Guarani: 88,5941 ha ou 73,5925 ha, ou na verdade 54,3199 hectares? Única compensação em terras, realizada pela hidrelétrica.
}

Realizada no mesmo dia 25.08.83 que as outras escrituras, no mesmo cartório, sendo os índios Guarani acompanhados pelo mesmo delegado da FUNAI é feita uma escritura de compra e venda simbólica de pequenas parcelas de terras entre Itaipu e a Comunidade Indígena, que destinou aos Guarani supostamente um total de 88,5941 ha (oitenta e oito hectares, cincoenta e nove ares e quarenta e um centiares).

\author{
“REPÚBLICA FEDERATIVA DO BRASIL \\ DISTRITO AURORA DO IGUAÇU - MUN. SÃO MIGUEL DO IGUAÇU - ESTADO PARANÁ \\ COMARCA DE SÃO MIGUEL DO IGUAÇU, ARLEI COSTA E ALTAIR COSTA (TABELIÕES \\ RESPONSÁVEIS)
}

\footnotetext{
$\overline{14}$ A documentação (Anexos no 11 F1, F2, F3 e F4) supõe-se que é "guardada" pelos seus proponentes e somente 2 (anos) anos depois, quando a situação se "acalmou" na região, o então documento é assinado pelo Cartório, no dia 26.07.85. Fato de toda forma também ilegal, pois o Cartório não possuía competência legal para realizar qualquer um dos procedimentos aqui referidos, com relação aos dois documentos e aos próximos que virão.
} 


\section{ASSINA O DOCUMENTO O TABELIÃO JOÃO CORNELLA FAGION, DATA 25.08.1983", Denominada ESCRITURA PÚBLICA DE COMPRA E VENDA QUE FAZEM ITAIPU- BINACIONAL E COMUNIDADE INDÍGENA AVÁ-GUARANI, COMO ABAIXO SE DECLA- RA: - VALOR C\$1,00 (Anexo no 11 H).}

Foi então elaborada em 1983, nas escrituras existentes em Cartório, a Terra Indígena AváGuarani do Oco’y com um total de $\mathbf{2 6 6 , 1 4 4 2}$ ha, que corresponde à soma dos 4 lotes “módulos rurais" do INCRA com 177,5601 ha, somados às áreas simbolicamente vendidas por Itaipu, num total de 88,5941 ha, que é composto dos seguintes pequenos lotes:

a) Área 0,2501 ha (vinte e cinco ares e um centiare)

b) Área 0,7878 ha (setenta e oito ares e setenta e oito centiares)

c) Área 0,9942 ha (noventa e nove ares e quarenta e dois centiares)

d) Área 2,6591 ha (dois hectares, sessenta e cinco ares e noventa e um centiares)

e) Área 15,0016 ha (quinze hectares e dezesseis centiares)

f) Área 10,6214 ha (dez hectares, sessenta e dois ares e quatorze centiares)

g) Área 28,1878 ha (vinte e oito hectares, dezoito ares e setenta e oito centiares)

h) Área 12,7755 ha (doze hectares, setenta e sete ares e cinquenta e cinco centiares)

i) Área 8,8666 ha (oito hectares, oitenta e seis ares e sessenta e seis centiares)

j) Área 8,1539 ha (oito hectares, quinze ares e trinta e nove centiares)

k) Área 0,2961 ha (vinte nove ares e sessenta centiares)

Porém, no acordo apresentado anteriormente em 1982, (Anexo ${ }^{\circ}$ 11D), estava estabelecido que o INCRA cedia 177,5601 ha, e Itaipu repassaria 73,5925 ha, o que perfazia um total de 251,1526 ha (Ver croqui Anexo no 11 E). Além disso, como se nota no Mapa da Demarcação da Terra Indígena Avá-Guarani do Oco’y (Anexo nº 11 J), ela havia sido demarcada em 31.07.82, um ano antes desta documentação ser realizada em Cartório, com os atuais $\mathbf{2 3 1 , 8 8}$ ha. Concluise que apesar da documentação em cartório local registrar 266,1442 ha, na realidade foram destinados 231,88 ha. Uma diferença de 34,2642 ha, que não se sabe onde estão. Pode ser a fração inundada por Itaipu, a diferença.

A Terra Indígena do Oco’y possui 231,88 hectares, soma de terras repassadas pelo INCRA, num total de 177,5601 hectares, àquelas repassadas por Itaipu, num total, na realidade, de 54,3199 hectares. Cabe salientar que, atualmente, a Terra Indígena do Oco'y é menor ainda que os referidos 231,88 ha. O reservatório de Itaipu, com seu assoreamento eleva o nível das águas, o que faz com que inunde a Terra Indígena pelas bordas internas. Fato que tem relação direta com a 
superposição dos dois usos: Terra Indígena/TI e Área de Preservação Permanente/APP de Itaipu. Pelas bordas externas, os colonos invadem a área que os Guarani mantinham como "muro" de vegetação naturalmente preservado, protegendo-os da incidência de aspersão de agrotóxicos, sobre eles próprios e suas terras. Atualmente este "muro" não existe mais, os colonos plantam por cima da terra que é considerada indígena.

Outra escritura ainda é feita, no mesmo Cartório em 17.11.1983, para abrir Servidão de Passagem (estrada), "Escritura Pública de Servidão de Passagem que fazem: Marcelino Leitchweis e sua mulher, em favor da Comunidade Indígena Ava-Guarani” (Anexo no 11 I). Esta estrada, ao invés de passar entre as áreas dos colonos e da Comunidade Indígena, local que seria o lógico, inclusive para o estabelecimento claro de limites, passa por dentro apenas da Terra Indígena, diminuindo ainda mais o seu já irrisório espaço territorial. As margens externas da estrada, onde os Guarani mantinham o referido "muro natural” com vegetação, ficaram expostas à exploração dos colonos, que ao derrubarem-na encurtaram mais ainda as terras indígenas. Hoje refletindo, talvez foi um meio utilizado de forma subreptícia de devolver parte das terras não indenizadas aos colonos. Ver Figura 13. Foto Aérea. TI Avá-Guarani do Oco’y no Capitulo III e comparar a Figura 74. Croqui, a seguir e fotos $\mathbf{n}^{0}$ 25-26-27A-27B-41-42-43-44-47 do Volume III do Laudo Antropológico em anexo.

O que se tentou demonstrar nesse croqui se resume a seguinte situação: Os Guarani foram reassentados em maio/82 no Oco’y às margens do Córrego Santa Clara. Em outubro/82 a Itaipu inundou a área, inclusive essa mesma região do Córrego e fração de terras no seu entorno. Portanto, os Guarani observam novamente suas novas terras serem reduzidas. Deve estar aqui a diferença das terras repassadas aos Guarani. Assim as terras foram subtraídas pelo lado interno (Itaipu) e externo (pelos colonos). 


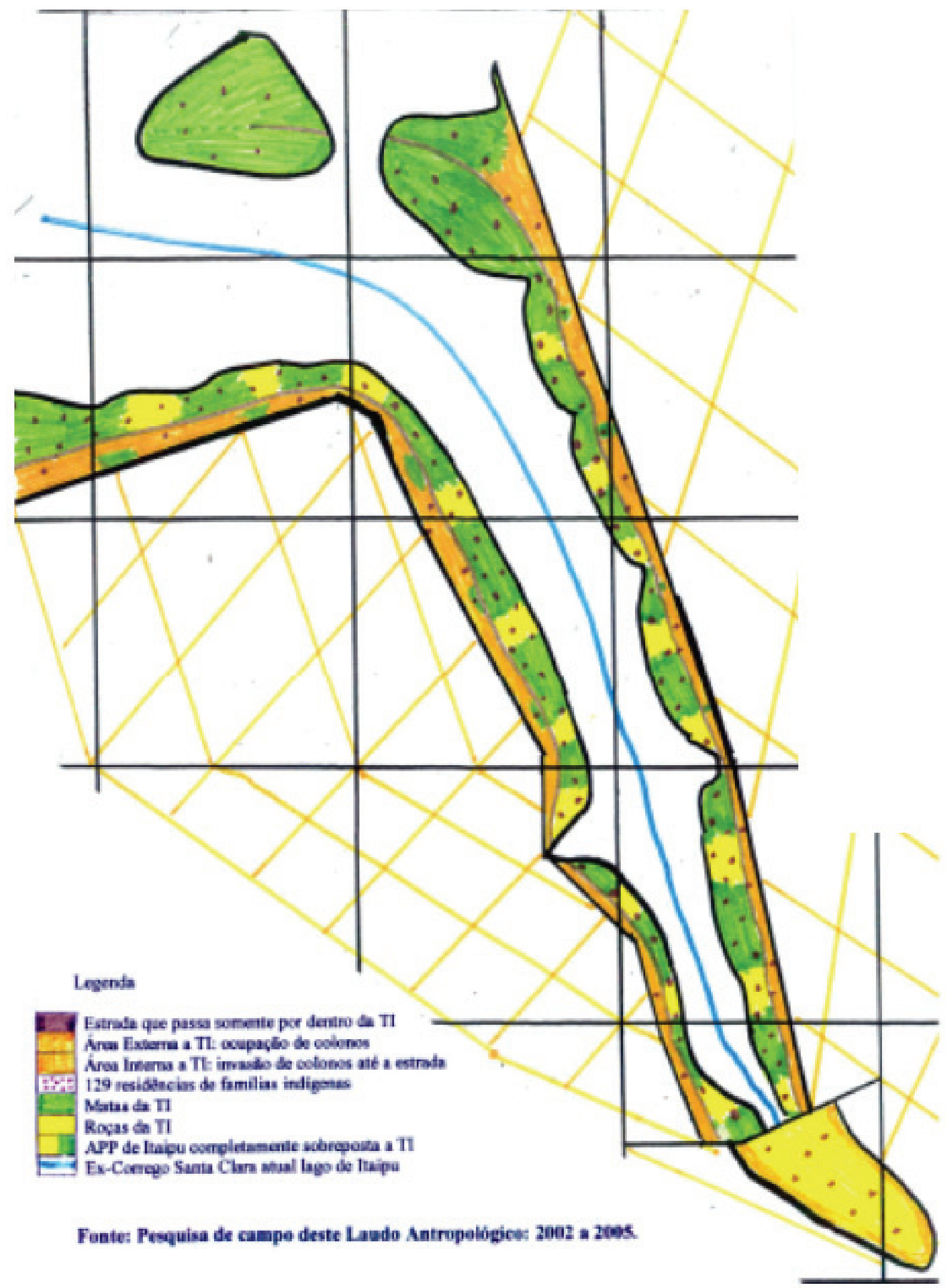

Figura 74. Croqui. Simulação aproximada do que acontece atualmente na TI do Oco’y com referencia as três áreas superpostas: Terra de Colonos; Terra Indígena; e Área de Preservação Permanente de Itaipu. Fonte: Laudo Antropológico 2005. Maria Lucia Brant de Carvalho. 


\subsection{População versus território: muita gente para pouca terra}

No decurso inicial dos fatos, a FUNAI tentou transferir a todo custo a população indígena da região que seria inundada, o Oco’y-Jacutinga, para outras aldeias, como Rio das Cobras/PR e Itariri/SP, como se pode depreender do texto de Célio Horst (1981) (Anexo no 7 e 8).

Alguns indígenas foram transferidos, outros resistiram na terra, outros ainda foram em busca de parentes do outro lado da fronteira, no Paraguai. Diante da resistência Guarani, reivindicando suas terras que haviam sido perdidas, ao final 19 famílias puderam se estabelecer na Terra Indígena do Oco’y, nos 4 lotes do INCRA somados aos 54,3199 hectares de Itaipu.

As outras famílias restantes, que também tinham direito à essas terras, superpovoaram terras de outras aldeias, já demarcadas ou não, tanto Guarani como de outras etnias (Kaingang), contribuindo para o desequilíbrio entre grande número de população em cada vez menor numero de terras indígenas. Como vimos, somente nesta área haviam trinta e duas aldeias e atualmente em todo o oeste paranaense restam treze aldeias. Apesar de tudo, a população Guarani continua a existir, e mais, a crescer demograficamente na região e em todo o país.

A superpopulação também veio a ocorrer na própria Terra Indígena do Oco’y. Esta terra já era insuficiente para as necessidades de sustentação das 19 famílias, às quais foram atribuídas. Outras famílias que faziam parte do Oco’y-Jacutinga (aquelas que haviam fugido da violência perpetrada pelo INCRA e da "futura" inundação), encontravam-se dispersos em outras regiões circunvizinhas, não aldeados ou aldeados precariamente. Quando foi estabelecida a Terra Indígena do Oco’y, essas famílias dispersas vieram nela juntar-se, buscando reatar seus laços de parentesco e, como era de seu direito, reocupar uma área que lhes pertencia, conforme é relatado pelos indígenas. Com a volta desses parentes, agravou-se ainda mais o desequilíbrio população-território. Na medida em que geram filhos, a sobrevivência no local torna-se cada vez mais dificultada. Assim, acabou ocorrendo superpopulação no Oco’y. Na medida em que a população aumenta em termos demográficos, consequentemente, a situação tem levado à degradação das condições de vida e saúde da população indígena como um todo.

A política oficial que a direção da FUNAI no período do Governo Militar vinha norteando com relação a esta população, era, na medida em que seus territórios eram invadidos, ao invés de lutar pela sua manutenção, através de leis já aprovadas na época como o próprio Estatuto do Índio/1973 e Constituição Federal, acabava por ceder às pressões ou a contribuir mesmo para a instalação dos Grandes Projetos e dos Projetos de Colonização, transferindo a população indíge- 
na de uma aldeia para outra, esta ultima já habitada, tornando-a forçosamente superpovoada. Outra forma, grave e mais pontualmente realizada, foi “não reconhecer" a real identidade indígena do agrupamento. A população indígena Guarani aqui analisada sofreu as consequências dessa política em suas duas vertentes, resultando na perda da grande maioria de suas terras, o que compromete a sua sobrevivência física de modo adequado.

\subsubsection{Análise demográfica da população sobre o território}

Com base em análise exposta em trabalhos anteriores ${ }^{15}$ pode-se depreender algumas características demográficas e fundiárias que vem ocorrendo na região:

Que ocorre atualmente no Oco’y migração, tanto emigração quanto imigração. Os índices de migração mantêm certo equilíbrio, assim como atraem indivíduos para o Oco’y, cedem da mesma forma membros do Oco'y para outras áreas. Quanto às “benesses sociais”, se no Brasil apresenta algumas vantagens como possuir assistência social (Posto de Saúde, escola etc), no Paraguai existe terras ambientalmente mais adequadas ao modo de vida indígena. Assim, a reciprocidade populacional interaldeias se dá de forma equilibrada.

Que os índices de fecundidade entre as mulheres Guarani são altos, apresentando em final de idade reprodutiva a média de 8 a 9 filhos per capita.

Que as gerações entre os Guarani se sucedem em curto período de tempo. Como todos casam-se cedo e passam assim a ter filhos em seguida, as gerações entre os Guarani, se comparadas à sociedade nacional, se sucedem em curto período de tempo, gerando crescimento populacional rápido, em média surgindo uma nova geração a cada 15 anos.

Que o crescimento populacional entre os Guarani é alto. Altos índices de fecundidade, somado ao fato de que o decorrer das gerações se dar em curto período de tempo, as duas taxas agregadas resultam em crescimento populacional acelerado e alto. A população Guarani cresce demograficamente, conforme o padrão de toda e qualquer população indígena Guarani. Esta é uma das razões pelas quais o Oco’y apresenta-se superpovoado, mas não é a única, e muito menos a fundamental, o problema maior é a quantidade irrisória de terras a eles destinadas, de forma ilegal.

\footnotetext{
$\overline{15}$ Brant de Carvalho: O Relatório Antropológico da FUNAI em resposta a carta colocada à $\mathrm{VI}^{\circ}$ Câmara do Ministério Público Federal, pelo antropólogo Rubem Thomaz de Almeida, antropólogo contratado pela Usina Hidrelétrica de Itaipu. 2004.
} 
Que ocorreu o desaparecimento de muitas aldeias na região entre os anos 40 e 80 do século XX, por pressão fundamentalmente dos dois Grandes Projetos, PNI e Itaipu. Somente no oeste paranaense, de 32 (trinta e duas) aldeias extintas por pressão colonizadora, ressurgiram no sul do oeste apenas 2 (duas) aldeias, Oco’y e Ãnetete e depois mais uma Itamarã. Na região de Guaíra há 11 aldeias já citadas. No Paraguai de 9 (nove) aldeias extintas, ressurgiram 4 (quatro) aldeias.

No caso específico do Oco’y, a razão principal que justifica grande número de população nesta aldeia é o de terem sido destinadas terras a apenas 4 (quatro) famílias, quando na verdade eram inicialmente 70 famílias quando se iniciou a intervenção do INCRA em 1973. Ainda, a forma como foram cedidas as terras foi inadequada, 4 (quatro) módulos rurais para as 4 famílias, como já foi demonstrado nesta tese ("Módulo rural" corresponde ao Estatuto de Terra, "Posse Comunal" ao Estatuto do Índio). Mais tarde definida a terra, outras famílias também se reassentaram no Oco'y.

Portanto, conclui-se que historicamente vem ocorrendo uma grave inversão nas taxas. Enquanto o crescimento demográfico da população Guarani é positivo e acelerado, a situação fundiária caminha de forma decrescente com cada vez menor número de terras, demarcadas ou não, sendo assim insuficientes ao desenvolvimento da vida da população indígena.

Verifica-se que as Instituições envolvidas, tanto a Itaipu quanto a FUNAI, vem "culpabilizando" a população Guarani pelo problema. No caso de Itaipu, com um discurso de que as aldeias estão superpovoadas porque migram indivíduos Guarani de outras aldeias do Paraguai para o Brasil. No caso da FUNAI, muitas vezes foi utilizado um falso discurso de que os Guarani não necessitam de terras demarcadas porque estão constantemente migrando, quando, na prática, muitas vezes os obrigou a migrar para aldeias já habitadas. Essas Instituições centram o foco na questão migração, culpando os Guarani pelo excesso demográfico, quando na verdade, agiram de forma a suprimir ilegalmente as terras tradicionais de ocupação Guarani, fato que está na base da situação fundiária extremamente crítica da etnia.

Deve-se ponderar ainda que existem alguns aspectos que se devem analisar quanto ao crescimento populacional. Se por um lado é saudável a população crescer, em termos socioculturais é sinal que os Guarani lutam para sobreviver enquanto povo e etnia. Por outro lado, se este crescimento não é acompanhado de políticas públicas nas quais sejam consideradas a resolução da questão fundiária, como se verifica ser o caso, nos quais vêm permanecendo grande número de população Guarani em pequenos territórios, fixos sem possibilidade de expandir-se como é o caso de Oco’y ou ainda, em cada vez menor número de aldeias, estará a população assim sendo 
"asfixiada" e inviabilizadas suas formas de sobrevivência costumeiras e tradicionais, gerando portanto, a destruição de seus meios de vida por "constrição territorial". Assim, a permanecer esta tendência de crescimento populacional positivo e situação fundiária decrescente, pelo menos no Paraná, as duas taxas se distanciando cada vez mais, são motivos de preocupação.

O fato demonstra a urgência em se buscar a resolução fundiária para a população indígena Guarani do Oco’y, considerando a destinação de terras adequadas para a população indígena existente e a que está por vir, já que o crescimento demográfico é alto (deve-se considerar que grande parte da atual população da Terra Indígena do Oco'y é constituída de crianças de até 14 anos) e a demanda por terras se encontra reprimida há muito tempo.

\subsubsection{Censo demográfico do Oco’y a partir de fontes históricas variadas}

A seguir a partir do histórico populacional pesquisado sobre a população indígena Guarani do antigo Oco’y-Jacutinga que foi reassentada no Oco’y, podemos apontar na Tabela 5.5. o seguinte censo demográfico contido em dados históricos vários, cruzando-se desde a informação indígena, como também a informação oficial das várias instituições envolvidas.

\section{Tabela 5.5. Censo demográfico do Oco’y a partir de fontes históricas variadas}

\begin{tabular}{|l|c|c|l|}
\hline Ano & $\mathbf{N}^{\mathbf{0}}$ de famílias & $\mathbf{N}^{\mathbf{0}}$ de indivíduos & Observações históricas \\
\hline 1973 & 70 famílias* & ? indivíduos & $\begin{array}{l}\text { A população existente no território tradicional Oco'y- } \\
\text { Jacutinga, segundo os Guarani. Período anterior a } \\
\text { expulsão do INCRA. }\end{array}$ \\
\hline 1973 & 32 famílias* & ? indivíduos & $\begin{array}{l}38 \text { famílias são expulsas da maior parte de suas terras } \\
\text { pelo INCRA para dar lugar a assentamento de colonos, } \\
\text { dispersando pela região. 32 famílias permanecem em } \\
\text { pe quena parte do TI mesmo, noOco'y-Jacutinga, beira } \\
\text { do rio Paraná, acuadas por todos os lados, pela } \\
\text { presença de colonos. }\end{array}$ \\
\hline 1976 & 19 famílias* & $?$ indivíduos & $\begin{array}{l}\text { Mais 13 famílias fogem do local com medo da } \\
\text { vindoura inundação pela construção da hidrelétrica } \\
\text { de Itaipu. Permanecem 19 famílias. } \\
\text { Dado histórico comprovadamente falso, o INCRAfez } \\
\text { o recenseamento parcial (que não lhe cabia), } \\
\text { desconsiderando a população existente no } \\
\text { território tradicional do Oco’y-Jacutinga, o qual esta }\end{array}$ \\
\hline
\end{tabular}




\begin{tabular}{|c|c|c|c|}
\hline & & & $\begin{array}{l}\text { mesma instituição havia invadido. A FUNAI } \\
\text { endossou apesar dos reclamos dos índios. } \\
\text { Permaneciam ainda as } 19 \text { famílias. }\end{array}$ \\
\hline 1981 & 4 famílias $* * *$ & ? indivíduos & $\begin{array}{l}\text { As Terras destinadas aos Guarani por Itaipu/INCRA } \\
\text { e FUNAI são } 4 \text { módulos rurais para } 4 \text { Famílias. } \\
\text { Ilegalidade no modo (módulo rural) e na contagem do } \\
\text { total de população que tinha direito às Terras. } \\
\text { Deveriam ser contados as } 70 \text { famílias desde o início. } \\
\text { Responsável: Laudo Antropológico falso de Célio } \\
\text { Horst, o qual desconsiderou outros indivíduos } \\
\text { indígenas, como “indígenas". } \\
\text { Permaneciam ainda as } 19 \text { famílias. }\end{array}$ \\
\hline 1982 & 19 famílias $* * * *$ & ? indivíduos & $\begin{array}{l}\text { As que puderam ser assentadas inicialmente } \\
\text { no Oco'y,foram as } 4 \text { reconhecidas como indígenas; } \\
\text { após resolvida a questão fundiária (4 modulos rurais) } \\
\text { mais } 15 \text { famílias,não reconhecidas antes, por Horst } \\
\text { como “indígenas", puderam se assentar. O que } \\
\text { demonstra a falsidade do LA de Horst. }\end{array}$ \\
\hline 1994 & 60 famílias***** & 310 indivíduos & $\begin{array}{l}\text { GT da FUNAI (1994) faz a contagem, ressalvando } \\
\text { os dispersos pela região, que voltaram agora que } \\
\text { a terra foi destinada aos índios, o Oco’y. } \\
\text { A população também cresce demograficamente. }\end{array}$ \\
\hline 2001 & 80 famílias $* * * * * *$ & 449 indivíduos & $\begin{array}{l}\text { Outras famílias que estavam dispersas continuaram } \\
\text { vindo pois tinham direito às terras do Oco’y apesar do } \\
\text { não reconhecimento do Laudo Antropológico falso, } \\
\text { que destinou módulos rurais à somente } 4 \text { famílias. } \\
\text { Censo do Posto de Saúde da aldeia/FUNASA. A } \\
\text { população em termos demográficos continua } \\
\text { crescendo. }\end{array}$ \\
\hline 2002 & 113 famílias $* * * * * *$ & 482 indivíduos & $\begin{array}{l}\text { Censo do Posto de Saúde da aldeia/FUNASA. } \\
\text { A população em termos demográficos continua } \\
\text { crescendo. }\end{array}$ \\
\hline 2004 & 125 famílias $* * * * * *$ & 600 indivíduos & $\begin{array}{l}\text { Censo do Posto de Saúde da aldeia/FUNASA. A } \\
\text { população em termos demográficos continua crescendo. }\end{array}$ \\
\hline 2004 & -25 famílias $* * * * * *$ & 64 indivíduos & $\begin{array}{l}\text { Imigraram: retiraram-se do Oco’y em jan/04, saíram } \\
\text { com Teodoro Alves para Ãnetete /Diamante D’Oeste. }\end{array}$ \\
\hline 2004 & 134 famílias****** & ? indivíduos & $\begin{array}{l}\text { Parte da população que estavam com Teodoro voltou. } \\
\text { Constituição de novas famílias. }\end{array}$ \\
\hline
\end{tabular}

Fontes variadas, reunião dos dados e montagem Maria Lucia Brant de Carvalho. 2004.

Legenda: Informação respectivamente fornecida por : * Índios Guarani; ** INCRA e FUNAI; *** Laudo Antropológico de Célio Horst/FUNAI; **** Itaipu e FUNAI; ***** GT da FUNAI; ****** Posto de Saúde/ FUNASA. 
É visível que na época das tratativas com as instituições de governo referentes ao período de desterramento e reassentamento, houve uma redução artificial do número real de famílias indígenas, reduzindo-as paulatinamente de: 70 para 32 famílias - invasão pelo INCRA/1973; de 32 para 19 famílias - restantes fogem com medo da ameaça de inundação por Itaipu; existentes 19 contadas pelo INCRA 11 famílias - recenseamento do INCRA; existentes 19 contadas pelo INCRA, Itaipu e FUNAI, 4 famílias para lhes destinar 4 módulos rurais 1981/1982. Posteriormente quando a informação é real e não provêm destas instituições, nota-se que a população indígena cresce normalmente. 


\section{CAPÍTULO 6 \\ O INSTITUTO AMBIENTAL DO PARANÁ/IAP PRETENDEU PROIBIR OS GUARANI DE PLANTAR NA PRÓPRIA TERRA INDÍGENA AVÁ-GUARANI DO OCO'Y}

\subsection{Palavras iniciais}

Este capítulo discute a questão a respeito das contradições criadas pelo próprio Estado, no sentido de ter estabelecido os Guarani em parcela imprópria do território, o Oco’y.

Após a entrega do Laudo Antropológico referente ás condições de vida dos Guarani do Oco'y (Brant de Carvalho:2002) descritos na tese no capitulo 3, e, concomitantemente, após os reclamos dos indígenas sobre a falta de terras para prover sua subsistência, em seguida a Itaipu Binacional e a FUNAI/Bsb no ano de 2003 solicitaram um trator da Prefeitura de São Miguel do Iguaçu e inadvertidamente suprimiram de vez, os poucos remanescentes florestais existentes passando o trator em grande extensão da Terra Indígena (80ha), inclusive na APP de Itaipu, o que resultou no desnudamento da pouca diversidade florestal que ainda existia, como ainda deu margem a compactação futura da terra desnudada. Segundo as instituições a ação visava "liberar" mais áreas de roças para a agricultura indígena. Portanto, não se mencionou a necessidade de resolução do problema da exígua terra destinada aos Guarani. Em seguida o Instituto Ambiental do Paraná/IAP em 08.10.2003 multou os três órgãos e pretendeu proibir os Guarani, de estabelecer seus cultivos na própria Terra Indígena Avá-Guarani do Oco’y, considerando assim, ser ela, "somente APP de Itaipu".

No bojo desta ação institucional estabeleceram outra ação; ao passar a patrol pelas áreas florestadas e derrubadas, ao final, com as sobras de terras revolvidas, haviam instalado dois tipos de "murundus" (montes de terra) como denominam os Guarani, ao longo de toda a Terra Indígena criando com eles assim duas barreiras, a primeira na "divisa da estrada"1 entre os colonos e os Guarani (Figura 75A) - local no qual, na verdade, deveria ter sido fiscalizado pela FUNAI os

\footnotetext{
1 "Divisa da estrada" em termos porque a estrada como vimos antes passava somente pelo interior da Terra Indígena; a instalação da estrada somente no interior da Terra Indígena possibilitou aos colonos invadir com seus cultivos até à margem da estrada, diminuindo o território indígena e aumentando suas glebas, glebas tais que haviam sido perdidas e não indenizadas pelo INCRA, desapropriadas em função da instalação do reservatório e da APP de Itaipu, glebas nas quais além da APP de Itaipu, também foram colocados os Guarani.
} 
limites entre as duas áreas; a segunda barreira foi instalada na "divisa" entre o reservatório da Itaipu e a Terra Indígena (Figura 75B); tentavam dessa forma evitar de forma sofrível, a contaminação dos Guarani e das águas do reservatório de Itaipu, com os agrotóxicos provenientes das glebas dos colonos (apontados em Laudo de 2002 e que estão apontados no capitulo III da tese), visando provavelmente não serem responsabilizados pelo fato e terem que arcar com os problemas criados.

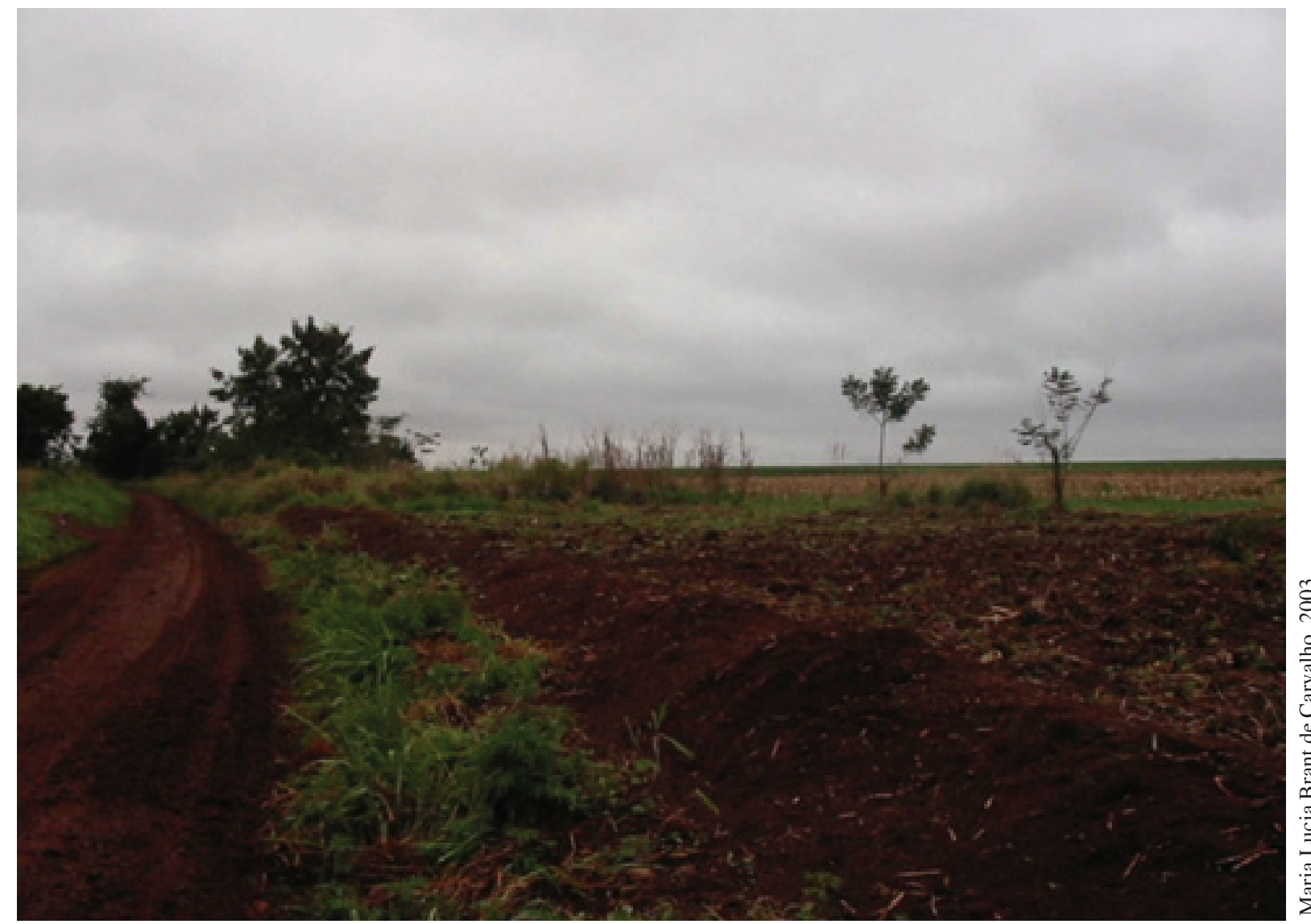

Figura 75A. Foto. Murundu criado pela Itaipu, FUNAI e Prefeitura de São Miguel do Iguaçu na "divisa" entre os colonos e os Guarani.

Os exames solicitados a fim de verificar os níveis de contaminação, fundamentalmente na população indígena e nas águas, em suma, não foram encaminhados pelas autoridades competentes (FUNAI e FUNASA), o projeto de pesquisa da UFRJ não conseguiu financiamento, enfim barreiras políticas impediram o desenvolvimento das pesquisas sobre a contaminação. A problemática questão fundiária do Oco’y permaneceu sem questionamento pelas instituições apesar de nossos Laudos.

Assim a ação de supressão de vegetação da TI e APP por parte das três instituições citadas teve como consequência uma questão paradoxal: além de multa ás Instituições, houve a proibição pelo IAP do plantio pelos Avá-Guarani na própria Terra Indígena por considerá-la somente 


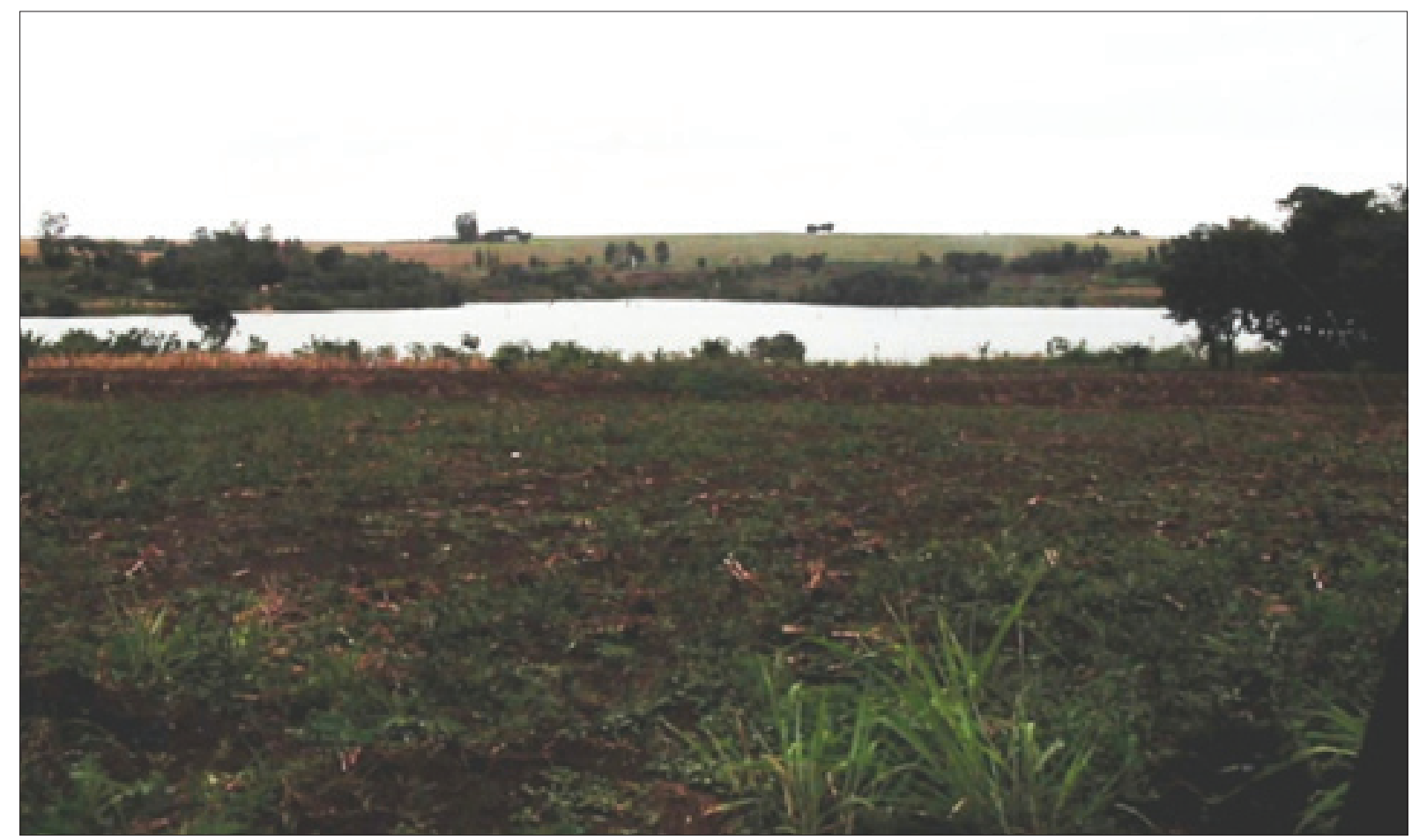

Figura 75B. Foto. Murundu na "divisa" entre o reservatório e os Guarani e terra desmatada na TI.

APP de Itaipu. O órgão responsável no caso seria na verdade o IBAMA, pois as duas áreas APP e TI, são federais, esse jamais se pronunciou a respeito.

\section{2. $O$ contexto da questão}

Em 2004 produzimos um Relatório Antropológico denominado “Relatório Antropológico da FUNAI em resposta a Carta enviada à VI ${ }^{\circ}$ Câmara do Ministério Público Federal, pelo antropólogo Rubem Thomaz de Almeida, antropólogo contratado pela Usina Hidrelétrica de Itaipu"2. O Relatório tratava de dois contextos vividos na Terra Indígena Avá-Guarani do Oco’y.

O primeiro se refere ao tema deste capítulo. Segundo carta enviada em 13.04.2004 pelo antropólogo Rubem Thomaz de Almeida/ consultor da Usina Hidrelétrica de Itaipu e carta dos Guarani (Anexo 1) à Procuradora da República Dra Deborah Duprat ${ }^{3}$ da VI ${ }^{\mathrm{a}}$ Câmara de Coorde-

\footnotetext{
${ }^{2}$ Este capítulo toma emprestado informações de: BRANT DE CARVALHO, Maria Lucia. Relatório Antropológico. O Relatório Antropológico da FUNAI em resposta a carta colocada à $\mathrm{VI}^{\circ}$ Câmara do Ministério Público Federal, pelo antropólogo Rubem Thomaz de Almeida, antropólogo contratado pela Usina Hidrelétrica de Itaipu. População Indígena Avá-Guarani (Ñandeva). Terra Indígena do Oco’y. Município de São Miguel do Iguaçu. Paraná. Brasil. São Paulo: AERBAURU/SP/FUNAI/MJ. 2004. 150 p.

${ }^{3} \mathrm{Na}$ verdade a Carta foi enviada a Dra Ela Wiecko Wolkmer de Castilho que se aposentou e foi substituída pela Dra Deborah Duprat.
} 
nação e Revisão/VI ${ }^{\circ} \mathrm{CCR}$ Populações Indígenas e Minorias da Sub-Procuradoria Geral da República, o Instituto Ambiental do Paraná/IAP estaria proibindo os Guarani de plantarem na própria Terra Indígena do Oco'y. A VI Câmara de Coordenação e Revisão enviou a mesma carta à Coordenadoria Geral de Patrimônio Indígena e Meio Ambiente/CGPIMA/FUNAI, solicitando esclarecimentos sobre a razão pela qual o Instituto Ambiental do Paraná/IAP estaria impedindo os Guarani de plantar na própria Terra Indígena do Oco'y. Por sua vez o CGPIMA/FUNAI encaminhou a questão a nós, para prestar o esclarecimento, já que éramos responsável pelo Laudo Antropológico da Terra Indígena Avá-Guarani do Oco’y.

O segundo contexto a esclarecer se referiu a uma solicitação do Ministério Público Federal de Foz do Iguaçu para prestar esclarecimentos quanto ao comportamento demográfico dos Guarani, especificamente quanto ao crescimento populacional e migração, já que a população indígena Guarani tradicionalmente encontra-se em faixa de fronteira, ocupando terras tanto no Brasil, como no Paraguai e na Argentina. A Itaipu Binacional afirmava que, o problema fundiário existente no Oco’y, tinha como causa suposta “a emigração de famílias Guarani provenientes do Paraguai para o Brasil, tornando assim esta Terra Indígena superpopulosa, daí então, a falta de terras". Houve, antes da entrega desse trabalho, um debate entre os dois antropólogos, da Itaipu e da FUNAI, no Departamento de Meio Ambiente da Usina Hidrelétrica de Itaipu, em que, não havendo consenso, o MPF de Foz do Iguaçu, na mesma ocasião, determinou aos dois antropólogos, que se procedesse então, o referido estudo demográfico. O estudo foi realizado somente pela antropóloga da $\mathrm{FUNAI}^{4}$.

O trabalho apresentado anteriormente foi elaborado para atender às solicitações relativas aos dois temas citados, os quais, tanto em um como em outro, em discussões anteriores, houve divergência de análise entre nós e o antropólogo Rubem Thomaz de Almeida, consultor contratado pela Itaipu.

Assim afirmávamos de início:

O Relatório Antropológico da FUNAI sobre a Terra Indígena do Oco’y ora apresentado, visa responder às questões da forma como foram pautadas pelo antropólogo contratado pela Usina Hidrelétrica de Itaipu, Rubem Thomaz de Almeida, em carta dirigida à VI ${ }^{\circ}$ Câmara do Ministério Público Federal em 13 de abril de 2004.

\footnotetext{
$\overline{4}$ Tema que infelizmente não será apresentado nesta tese por completo por falta de tempo hábil para a explanação.
} 
Neste documento são discutidas algumas questões que, na realidade, são vistas de ângulos diferentes pelos dois antropólogos, o da Usina Hidrelétrica de Itaipu e a da FUNAI. Como o documento deverá passar por diversas instâncias interessadas, FUNAI, VI Câmara/MPF/Bsb, Justiça Federal e Ministério Público Federal de Foz do Iguaçu, optamos por estabelecer através deste, um diálogo aberto entre as análises antropológicas, cujas instâncias de decisão referidas acima poderão analisar seu mérito. (BRANT de CARVALHO: 2004:4)

Este trabalho foi entregue aos representantes das seguintes instituições na época:

Sra Procuradora da República Dra Ela Wiecko Volkmer de Castilho e/ou Dra Deborah Duprat/ VI ${ }^{\circ}$ Câmara de Coordenação e Revisão/VI ${ }^{\circ} \mathrm{CCR}$ Populações Indígenas e Minorias da Sub-Procuradoria Geral da República;

Ao Juiz Federal Dr Rony Ferreira / $2^{\circ}$ Vara da Justiça Federal de Foz do Iguaçu - Seção Judiciária do Paraná;

Ao Senhor Procurador da República Dr Jorge Irajá Louro Sodré / Ministério Público Federal de Foz do Iguaçu;

Ao Presidente e Antropólogo Sr Mercio Pereira Gomes / Presidente da FUNAI;

Ao Procurador Geral Dr Luiz Soares de Lima / Procuradoria Jurídica da FUNAI;

Ao Indigenista Sr Coordenador Guilherme Carrano / Coordenadoria Geral de Patrimônio Indígena e Meio Ambiente;

Ao Diretor e Antropólogo Sr Artur Nobre Mendes / Departamento de Assuntos Fundiários.

\subsection{Os fatos que envolvem o contexto referente ao IAP proibir que os Guarani plantem na própria Terra Indígena Avá-Guarani do Oco’y}

Foi justificado inicialmente por nós que quanto ao caso da proibição de plantio, a Comunidade Indígena necessita de mais espaço físico, diante da insuficiência de terras destinadas à ela no Oco’y, questão já colocada em todos os volumes do Laudo Antropológico realizado e entregue. Especialmente como vimos no capitulo anterior desta tese foram cedidos de forma ilegal 4 (quatro) lotes individuais de terras pelo INCRA para apenas 4 famílias indígenas, num total de 177,5601 hectares, que somados aos 54,3199 hectares cedidos pela Itaipu, perfazem 231,88 hectares. Se este montante de terras já era diminuto para as necessidades dos indígenas, considerando o assoreamento do reservatório de Itaipu agravado com o desmatamento promovido pelas institui- 
ções somado a "invasão" da Terra Indígena pelos colonos lindeiros, este montante de terras se apresentava menor ainda.

Considerando também, tanto no que diz respeito à realidade do numero de famílias que vieram a se estabelecer no Oco’y, quanto à extensão do território original, não eram esses os dados em 1982, quando Itaipu inundou parte das terras desses Guarani no Oco’y-Jacutinga. Tampouco eram esses mesmos dados quando, em 1973, o INCRA invadiu o Oco’y-Jacutinga, que na época continha em torno de 70 famílias e cuja área, que não havia sofrido processo de Identificação Fundiária, era maior. De início foram instaladas nas terras de Oco’y 19 famílias, posteriormente outras que estavam dispersas retornaram. Ainda somado a estes fatos, em novembro de 2004 o Oco'y apresentava um quadro de crescimento populacional alto e acelerado, natural da etnia, com 129 famílias, cerca de 600 indivíduos, habitando a reduzida área de 231,88 hectares ou menor, dada as "invasões".

Assim, faltavam terras. Especialmente para a agricultura, visando prover as necessidades básicas de subsistência de todas as famílias. Como já nos referimos antes, a Comunidade Indígena encontra-se no seguinte dilema: se mantiver as já poucas áreas florestadas no Oco’y, não há como suprir a subsistência através das roças familiares existentes; se estas roças, que são insuficientes para a demanda das famílias, forem ampliadas, decresce a pouca área florestada, prejudicando a igualmente necessária atividade extrativa, que também faz parte da subsistência Guarani.

Em seguida no Relatório entregue às autoridades explicávamos introdutoriamente toda a questão já vista no capitulo III desta tese, de forma resumida, apresentando o Depoimento de Seu Guilherme, pajé mais velho do Oco’y e suas impressões a respeito da exiguidade da terra; em seguida buscamos explicitar a conformação, a morfologia geográfica da Terra Indígena do Oco’y, sua localização, extensão, características ambientais, entorno e relevo; A finalidade daquela mata ciliar da APP, ou seja, se era um refúgio biológico de biodiversidade de espécies importantes para os indígenas ou se era apenas uma área de proteção das margens do reservatório da Usina Hidrelétrica de Itaipu. O problema de limites com os colonos vizinhos.

Diante de área tão exígua cedida aos indígenas, observávamos também que a própria Itaipu acabou "cedendo" às pressões socioeconômicas dos Guarani por mais terras, permitindo que eles ocupassem os 100 metros da Área de Preservação Permanente /APP5 ${ }^{5}$ junto à Terra Indígena do

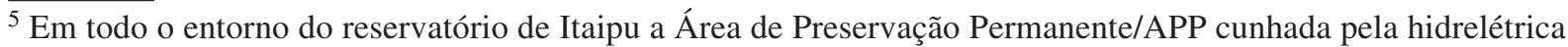
como Faixa de Proteção ela apresenta 210 metros de largura. Somente junto ao Oco’y a APP possui "100 metros" de largura. Está claro portanto, que as duas áreas estão superpostas.
} 
Oco’y. Assim, de forma técnica e legalmente incorreta, as áreas estavam há muito tempo, já superpostas, dado que os Guarani desde sua instalação no local já se utilizavam da APP, como Terra Indígena. Por fim chegamos ao que segue.

\subsection{O problema colocado, origens e razões, segundo Rubem Thomaz de Almeida, antropó- logo contratado pela Usina Hidrelétrica de Itaipu}

A seguir iremos rever os problemas colocados em carta dirigida à Dra Ela Wiecko Volkmer de Castilho, Procuradora da República da VI Câmara do Ministério Público Federal em Brasília, pelo antropólogo Rubem Thomaz de Almeida, contratado pela Itaipu Binacional, para dirimir questões junto à comunidade indígena Guarani habitante da Terra Indígena do Oco’y, afetada pelo reservatório da Usina Hidrelétrica de Itaipu. Em seguida teceremos alguns comentários.

Colocação do problema, segundo o antropólogo de Itaipu:

Em recente visita (10.03.2004) ao tekoha Guarani-Chiripa de Okoy, fazendo-me acompanhar pelo Sr Artur Nobre Mendes, Diretor do Departamento de Assuntos Fundiários da FUNAI, os índios do local nos apresentaram problema que consideram "grave": estão impossibilitados de plantar em boa parte de suas terras.

Origem do problema, segundo ele:

A origem disso, como contam, foi um procedimento do Instituto Ambiental do Paraná - IAP que autuou a FUNAI, a Prefeitura de São Miguel do Iguaçu e a Itaipu Binacional por terem viabilizado máquinas agrícolas para o preparo da terra na aldeia; teriam com isso cometido "crime ambiental" e foram impedidos de continuar o trabalho. Isto deixou os índios indignados porque, afirmam, têm utilizado aquelas terras no cultivo de roçados há décadas e não haveria razão para autuação e multa. Dizem os índios que na área trabalhada predominava o capim colonião, muito difícil de vencer na enxada.

Razões pelas quais os problemas foram desencadeados, segundo ele:

A vistoria do IAP, de outro lado, originou-se em denúncia apresentada por vizinhos dos índios. Há décadas que colonos e índios mantêm relações relativamente beligerantes. Os índios são considera- 
dos "vagabundos", "bêbados" e outros qualificativos inerentes à uma concepção de mundo calcada na intolerância face ao diferente. Os índios informam que, impossibilitados de atingi-los por outras vias, os vizinhos buscaram no IAP um "aliado" para obstruir as instituições que vinham oferecendo apoio a sua agricultura, eliminando a principal alternativa para a realização de sua economia de subsistência.

Estas são as razões colocadas pelo antropólogo de Itaipu, como ele enxerga o problema, sua origem e as razões pelas quais foi desencadeado. Nossa interpretação é outra dos fatos. Em seguida discutiremos sob nosso ponto de vista, a ação das instituições que culminaram no problema, a relação entre índios e colonos na região, assim como as razões do IAP ter multada as instituições e por fim o que o IAP deixou de observar na área.

\subsection{A ação das instituições Usina Hidreéetrica de Itaipu, FUNAI e Prefeitura de São Miguel do Iguaçu que culminaram no problema}

Os fatos devem necessariamente ser revistos através da memória histórica que cerca os índios Guarani da região. Apesar de trabalhar para Itaipu pelo menos desde 1995 no acompanhamento destes índios, R. T. Almeida demonstra não conhecer em profundidade a história dos mesmos. Suas análises primam pela falta de observância com relação ao tempo e ao espaço que os envolvem, realizando análises estritamente limitadas ao âmbito cultural, desprezando dados de realidade fundamentais para o caso.

Vejamos, primeiramente duas de suas afirmações:

- ... autuou a FUNAI, a Prefeitura de São Miguel do Iguaçu e a Itaipu Binacional por terem viabilizado máquinas agrícolas para o preparo da terra na aldeia; teriam com isso cometido "crime ambiental" e foram impedidos de continuar o trabalho.

- ...os vizinhos buscaram no IAP um "aliado" para obstruir as instituições que vinham oferecendo apoio a sua agricultura, eliminando a principal alternativa para a realização de sua economia de subsistência.

Os antropólogos tem a obrigação de conhecer o manejo indígena sobre seus territórios. A partir desta afirmativa, veremos que o ocorrido foi tanto ambientalmente inadequado quanto antropologicamente incorreto. Vejamos a seguir. 
Não se deve desnudar o solo da Terra Indígena com máquinas agrícolas, pois em se passando o trator de maneira uniforme, como foi feito por iniciativa de Itaipu, numa área considerável de 80 ha no Oco'y, deixou-se o solo totalmente exposto, tornando a pouca biodiversidade existente no ambiente praticamente inexistente, biodiversidade esta, imprescindível à subsistência indígena. O solo desta forma revolvido, estará exposto à degradação do tempo pela insolação que irá sofrer e a curto prazo poderá ficar inutilizado em termos de fertilidade. Os Guarani realizam seus plantios em clareiras abertas em áreas de capoeira, para justamente evitar de eliminar a biodiversidade do entorno, preservando assim, a terra e seus componentes diversificados, que fazem uso.

O que contribui ainda para agravar a situação - e quem conhece a Terra Indígena do Oco’y fica claro - é que não há possibilidade de os Guarani alternarem no sistema de uso e pousio de ambientes, para este espaço desnudado se recuperar (daqui a 20 ou 30 anos), pois não há área possível para tanto no Oco’y. A terra em si é demasiado pequena.

Além disso, os Guarani socioculturalmente não acessam e não possuiriam meios financeiros para se utilizarem de meios tecnológicos exógenos, ou seja, do "branco", visando repor a qualidade do solo degradado, através de adubação química. Isto é completamente estranho a eles e desaconselhável no futuro.

Desta forma, através das medidas tomadas por Itaipu, influenciaram os Guarani por meio de orientação equivocada, não prevendo riscos futuros, culminando no aprofundamento da crise em torno da satisfação da subsistência, anteriormente já existente.

Desta forma, ao contrário do que possa parecer, as instituições citadas, $\underline{n a \tilde{o} o \text { estão oferecen- }}$ do apoio à agricultura indígena, estão sim, elas próprias, eliminando a principal alternativa para a realização de sua economia de subsistência, através da eliminação da pouca biodiversidade existente no Oco'y, restando ao longo do tempo, um solo certamente mais empobrecido. Portanto, as próprias instituições, que Almeida cita o auxílio aos índios, deram margem à multa do IAP, na medida em que geraram situação ambientalmente inadequada e antropologicamente incorreta, cometendo assim realmente, crime ambiental.

Já em reunião com a socióloga Rosângela da Silva, funcionária da Itaipu para assuntos referentes às Comunidades Indígenas, em dezembro de 2003, tentamos alertá-la para o fato, colocando a inadequação do procedimento (desnudar a terra no trator), mas esta, pouco familiarizada com a questão indígena, justificou que do contrário, “os índios não teriam o que comer". Pretendia assim dar a entender, que a insuficiência alimentar no Oco’y, ocorria em razão da 
tecnologia agrícola empregada pelos índios. Tentamos argumentar que a falta de condições para que os Guarani realizem sua subsistência, redundando "na falta de alimentos", não estaria relacionado ao tipo de tecnologia utilizada pelos índios - que continuamos à afirmar, é a mais adequada ao ambiente, mas sim à falta absoluta de espaço físico na Terra Indígena, para prover as necessidades de subsistência dos Guarani. A funcionária não teria condições de decidir medida de tal gravidade, mesmo porque não é antropóloga nem indigenista. Mas infelizmente, ela ou seus superiores decidiram desta forma.

Em diagnóstico realizado por nós em Laudo Antropológico de 2002 (capítulo 3), entregue ao MPF-Foz do Iguaçu e FUNAI, já apontávamos a insuficiência de terras para a sobrevivência da comunidade indígena, assim como sua extrema inadequação ambiental.

Verificamos que a Terra Indígena do Oco'y, quanto às condições territoriais e ambientais para prover à subsistência dos indígenas, apresentava-se: Quanto ao Extrativismo (coleta, caça e pesca): Insuficiente área de Mata destinada à coleta de artigos fundamentais à subsistência indígena, inexistindo inúmeros elementos necessários à subsistência indígena; Quanto às atividades de caça, não há possibilidade de animais viverem ali, pelo diminuto tamanho da área, pela alta densidade demográfica e pela falta de condições ambientais, biodiversidade rarefeita na Terra Indígena, e ainda, inexistência absoluta de biodiversidade em todo o entorno da Terra Indígena, nas áreas vizinhas dos colonos, assim não há animais a serem caçados; Quanto a pesca, a existente no reservatório de Itaipu é contaminada por agrotóxicos provenientes dos plantios dos colonos lindeiros à Terra Indígena, apresentando-se como um produto alimentício contaminado. Durante as chuvas de verão, em janeiro e fevereiro, segundo os Guarani, os peixes boiam mortos no reservatório de Itaipu, devido ao carreamento das águas poluídas proveniente dos vizinhos para o mesmo.

No que se refere às Atividades de Agricultura: A área destinada aos plantios por família é em média em torno de 0,5 hectare, pequeno espaço em frente às moradias, fixo há três décadas. Neste espaço, não é possível plantar mais que 3 (três) cultivos por temporada, sendo logicamente insuficiente para prover as necessidades de subsistência das famílias. Também os plantios indígenas são contaminados pelo uso de agrotóxicos pulverizados pelos colonos lindeiros, que perpassa a Terra Indígena, desaguando no reservatório. Não sendo os agrotóxicos apropriados para as espécies plantadas pelos Guarani, seu desenvolvimento fica comprometido. Em nenhuma hipótese é possível aos Guarani alternarem de ambientes, para que esses possam se recuperar ambientalmente, como é o costume econômico indígena, uso e pousio, agricultura itinerante; não há espaço físico no local, assim plantam nos mesmos espaços há cerca de três décadas, comprometendo desta forma, a produtividade da terra. O correto seria alternarem de espaços depois de 
2 ou 3 plantios anuais. Neste quadro precário de subsistência, a Itaipu passa o trator sobre essas terras já desgastadas, zerando mais ainda a rarefeita biodiversidade, contribuindo para agravar mais a situação. Tudo indica que pessoas, animais de criação, roças, áreas de coleta e fauna do reservatório (peixes), são todos sem exceção, contaminados pelos agrotóxicos provenientes das terras dos colonos lindeiros ao Oco’y.

Este é o quadro que faz com que se apresente insuficiência alimentar junto aos Guarani do Oco’y, tanto em termos fundiários (quantitativos) quanto em termos ambientais (qualitativos). Ao contrário do que funcionários da Itaipu afirmam, não é a tecnologia empregada pelos índios o problema, ela é a mais correta para o ambiente. Também o foco do problema não é a falta de sementes, como deu a entender o prefeito de São Miguel em jornal local.

O problema na verdade é a falta absoluta de terra para a população indígena poder sobreviver de forma digna. O fato de estas terras terem sido cedidas da forma como o foram aos Guarani, apresentando esta conformação, contraria toda a Legislação existente à respeito dos povos indígenas no Brasil. Os Guarani não receberam área equivalente a anterior, inclusive quanto às condições ecológicas, como preconiza o Estatuto do Índio em seu Artigo 20 parágrafo $3^{\circ}$, quando do desterramento de suas terras originais em função do alagamento do reservatório de Itaipu.

Diante de todo este quadro extremamente sofrível para satisfazer às necessidades de subsistência dos Guarani do Oco’y, consequentemente fica comprometida seriamente a saúde dos mesmos, já que as condições para prover a alimentação são com o passar do tempo, cada vez mais difíceis, caminhando em direção a uma curva descendente.

Desta forma, o próprio manejo indígena, ainda é o mais adequado para o ambiente, embora a quantidade e qualidade das terras oferecidas por Itaipu sejam insuficientes.

O Decreto n ${ }^{\circ} 1141$ de 19.05.1994, que dispõe sobre as ações de proteção ambiental, saúde e apoio às atividades produtivas para as comunidades indígenas, em seu capítulo III, Do Apoio às Atividades Produtivas, no Artigo $10^{\circ}$, afirma:

As ações voltadas para o apoio às atividades produtivas das comunidades indígenas dar-se-ão somente quando estiver ameaçada a sua auto-sustentação ou houver interesse manifesto dos índios, evitando-se a geração de dependência tecnológica e econômica.

Parágrafo Único. As ações de que trata o caput deste artigo serão fundamentadas em diagnóstico sócio-ambiental, e contemplarão: I - utilização racional dos recursos naturais das terras indígenas; II- incentivo ao uso de tecnologia indígena e de outras consideradas apropriadas do ponto de vista ambiental e antropológico. 
Com base no texto acima, é certo que está ameaçada a auto-sustentação dos Guarani no Oco’y, este fato é colocado por eles à própria Itaipu há bastante tempo, desde sua instalação no local.

Por estas medidas tomadas por Itaipu, o uso do trator desnudando a terra, gerou-se utilização de uma tecnologia inadequada ambientalmente e ainda, desnecessária, como também aprofundou-se ainda mais a crise vivenciada naquelas terras, resultando na eliminação da biodiversidade de boa parte do território indígena, comprometendo ainda mais a sustentação alimentar presente e futura dos Guarani.

Gerou-se também a dependência econômica, através do recebimento de cestas básicas ao longo do tempo, antes e depois deste fato, cestas básicas estas, de entrega na história desta população, periodicamente irregular.

Nós já afirmávamos o problema da insuficiência tanto quantitativa quanto qualitativa dessas terras, já em 2002. Fato este somente em agosto/2004 admitido por Itaipu. Já se passaram quase três décadas nesta situação, sendo o passivo indígena considerável em perdas materiais e socioculturais, pois, quem nasceu no Oco’y vivendo nesta situação precária foi impedido de apreender o modo como vivem tradicionalmente os Guarani. Somente a geração mais velha, que já apresentava cerca de 20 a 25 anos quando foram desterrados do Oco'y-Jacutinga é que possuem os conhecimentos associados ao ambiente, necessários à subsistência indígena. Das gerações seguintes foi-lhes suprimido autoritariamente a possibilidade de sobreviver conforme conheciam sobreviver. Este é um direito indígena previsto em toda a legislação brasileira, do qual pouco se deu importância. A situação foi e é dramática.

Indagávamos se existia algum diagnóstico socioambiental realizado pelo antropólogo contratado por Itaipu R. T. Almeida ou pela funcionária de Itaipu, socióloga Rosângela da Silva, aconselhando a Itaipu a realizar a ação de desmate para o plantio, por trator?

Nesta medida os funcionários de Itaipu, a saber, o antropólogo R. T. Almeida e a socióloga Rosângela da Silva, não estão considerando o interesse em assegurar as condições de subsistência à comunidade indígena, na medida em que a área destinada aos Guarani, o Oco’y, como compensação pelo seu antigo território, o Oco’y-Jacutinga que foi inundado pelo reservatório de Itaipu, está provado, que nela não é possível desenvolver as atividades tradicionais de subsistência, diante do território/ambiente disponibilizado. Os Guarani teriam direito à território em extensão equivalente ao anterior, inclusive quanto às condições ecológicas, segundo Estatuto do Índio, Lei 6001, Artigo 20, parágrafo $1^{\circ}$, letra d, parágrafo $2^{\circ}$, letra c, parágrafos $3^{\circ}$ e $4^{\circ}$. Não foi 


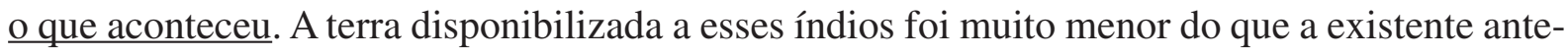
riormente, contrariamente a lei em vigor, na época e hoje.

Em julho-agosto/2004 estivemos na Terra Indígena do Oco’y. Fomos verificar a ação in loco do trator na Terra Indígena. Para nosso espanto, além do desmate, ao longo de toda a "obra" foram feitos vários murundus, como os índios denominam. Perguntei para os Guarani para quê? Eles também não sabiam o porquê daquilo. Sabiam que os murundus, diminuíam ainda mais a área de plantio deles próprios, somente. Eram dois tipos de murundus, um deles localizava-se nas bordas externas da área, vizinhos aos colonos lindeiros. Outro acompanhava, como uma parede, as margens do reservatório da Itaipu. Somente nos demos conta, posteriormente. Os murundus serviriam para duas finalidades: - aqueles ao longo de toda a área da TI, vizinhos aos colonos lindeiros, serviria para barrar os agrotóxicos provenientes das próprias áreas dos colonos, porém estava localizado na Terra Indígena; Itaipu propiciou a barragem para quem contamina os índios, na própria Terra Indígena. O outro murundu maior em altura, as margens do reservatório, servia para de alguma forma proteger as águas do próprio reservatório de Itaipu, seja dos agrotóxicos provenientes dos colonos lindeiros, se os primeiros murundus não fossem suficientes, seja do acesso dos Guarani a ele.

De toda forma toda condução do caso está incorreta; como veremos adiante, também deveria existir uma distância mínima de 500 a 250 metros conforme o caso, entre a pulverização de agrotóxicos e o núcleo populacional (no caso indígena), conforme determina a lei estadual, referente aos agrotóxicos. Ali não há sequer uma distância de 5 metros, entre os Guarani e a pulverização de agrotóxicos. Na verdade Itaipu aproveitou a obra supostamente "em favor dos índios" para minimizar sua responsabilidade sobre os efeitos dos agrotóxicos sobre os mesmos, já apontados por nós em 2002, na forma de impactos sobre a saúde da população indígena; para tanto, minimizou mais ainda as áreas de uso dos próprios Guarani. Quanto ao reservatório, tentou proteger sua propriedade dos efeitos nefastos dos agrotóxicos, novamente suprimindo mais ainda áreas de uso dos Guarani.

Para concluir a ação de Itaipu, da Prefeitura de São Miguel do Iguaçu que emprestou o trator e a concordância da FUNAI, resultaram em uma ação, sob o ponto de vista técnico, ambientalmente inadequada e antropologicamente incorreta. Está correto o IAP tê-los multado. 


\subsection{A beligerância entre índios Guarani e colonos: INCRA desapropria terra de colonos em função do reservatório e APP de Itaipu, coloca no local os Guarani e não indeniza os colonos}

Outra afirmação do antropólogo da Itaipu, sobre as razões pelas quais os problemas foram desencadeados:

A vistoria do IAP, de outro lado, originou-se em denúncia apresentada por vizinhos dos índios. Há décadas que colonos e índios mantêm relações relativamente beligerantes. Os índios são considerados "vagabundos", "bêbados" e outros qualificativos inerentes à uma concepção de mundo calcada na intolerância face ao diferente.

A beligerância existente entre índios e colonos não se dá exatamente e circunscrita à questões relativas ao preconceito racial, mas sim, porque na história local desses dois grupos humanos, eles foram colocados estrategicamente uns contra os outros, pelas próprias instituições governamentais, através do INCRA, em função de interesses regionais, a saber, instalação da hidrelétrica de Itaipu e criação do Parque Nacional do Iguaçu/PNI, contando para isso com a conivência da FUNAI.

Os índios Guarani a partir dos anos 40 do século XX foram expulsos de suas áreas de ocupação tradicional, em favor das instituições locais. Foram levantados ainda em pesquisa 32 (trinta e duas) aldeias situadas no entorno de Oco'y, que desapareceram entre os anos 40 e 80 do século XX, por força da pressão das frentes de expansão no oeste paranaense. O INCRA teve um papel fundamental nesta verdadeira "limpeza étnica" feita na região.

A região em foco, margens do rio Paraná e rio Iguaçu é o berço da cultura Guarani, existindo ali tradicionalmente inúmeras aldeias. Em 2004 só existia o Oco’y e Ãnetete, em todo o sul do oeste paranaense; mesmo estas duas aldeias, surgiram após 1982, quando do conflito desencadeado por Itaipu. Todo o resto desapareceu contando com a conivência da política adotada pelo órgão tutor. Nas 32 aldeias não houve menção do SPI e depois da FUNAI de suas respectivas épocas, em defender os territórios indígenas, papel esse que se constituía em sua obrigação institucional primeira e fundamental. Ao invés de defendê-los e as suas terras, o encaminhamento dado, reduzia-se a superlotar outras aldeias já habitadas. É o caso do encaminhamento de parte da população Guarani do Oco’y-Jacutinga, também para outras aldeias Guarani (TI Rio das Cobras/PR, TI Itariri/SP, TI Sapucai/RJ, entre outros), assim como para aldeias Kaingang (Pr), o 
qual se constitui em etnia diversa, permanecendo os Guarani em terras de outros, a título de “inquilinos", portanto, com as partes menores e piores do território Kaingang.

Neste contexto, alguns Guarani do antigo Oco'y-Jacutinga, assim como outros Guarani das outras aldeias invadidas, dirigiram-se para outras aldeias, dispersando-se pela região, indo em busca de parentes também do outro lado da fronteira, no Paraguai. Hoje os Guarani estão sufocados territorialmente, apresentando na maioria das aldeias, superpopulação, em condições de sobrevivência muito precárias. Um verdadeiro crime, um genocídio, cabível na Lei no 2889 de $1^{\circ} .10 .1956$, artigo $1^{\circ}$, letra c, Artigos $2^{\circ}, 4^{\circ}$ e $5^{\circ}$.

Ao que parece, há uma política deliberada em favorecer no país, somente as populações indígenas que habitam áreas "ricas" em recursos naturais, como a Amazônia Legal e a eles cabem projetos especiais como o Projeto Integrado de Proteção às Populações e Terras Indígenas da Amazônia Legal/PPTAL. As populações indígenas restantes, fora dessa orla, estão sendo paulatinamente abandonadas pela política pública federal, ficando a mercê das conjunturas políticas locais. É o caso dos Guarani nas mãos de Itaipu. Em detalhe vejamos em que condições os Guarani foram finalmente instalados no Oco'y.

- anos 40/60 - são expulsos das aldeias Guarani e São João, área que veio a se tornar a Unidade de Conservação administrada pelo IBAMA, o Parque Nacional do Iguaçu/PNI;

- anos 70, (1971) são expulsos por funcionários do INCRA da aldeia Colônia-Guarani, localizada no atual bairro de Três Lagoas/Foz do Iguaçu, para dar lugar à assentamentos de colonos, colonos esses que também haviam sido retirados da Unidade de Conservação PNI;

- anos 70, (1973) são expulsos por funcionários do INCRA da parte leste da aldeia Oco'yJacutinga, localizada no atual município de São Miguel do Iguaçu, para dar lugar à assentamentos de colonos, colonos esses que também haviam sido retirados da Unidade de Conservação PNI; neste momento histórico, os Guarani habitantes do Oco'y-Jacutinga são expulsos a força pelo INCRA, este colocando fogo em roças, casas e pertences dos índios, empurrando-os para uma parte mínima de seu próprio território, às margens do rio Paraná, área esta, em que o INCRA tinha conhecimento de antemão, através do Projeto Integrado de Colonização (PIC-OCOI I-II), que seria inundada pela Usina Hidrelétrica de Itaipu. Está claro a má fé.

- Os Guarani são novamente expulsos da parte restante (Oeste) de seu território de origem (Oco’y-Jacutinga), em 1982, agora por Itaipu, e são obrigados a se instalar por meio de procedimento incorretos do INCRA, FUNAI e Itaipu, nas margens do futuro reservatório de Itaipu, no atual Oco’y. O processo de desterramento e reassentamento dos Guarani do Oco’y-Jacutinga, foi 
realizado de forma totalmente ilegal, sendo destinados a eles "população indígena", as terras no Oco’y, na forma de 4 “módulos rurais”, para somente 4 famílias indígenas, repassadas individualmente pelo INCRA. As terras do Oco’y eram a própria APP às margens do reservatório de Itaipu, área esta que estaria sendo mesmo desapropriada pelo INCRA em função da Usina Hidrelétrica (parte reservatório, parte faixa de proteção do reservatório - APP); elas foram "cedidas" como "compensação de terras" aos Guarani. Anteriormente esta área ás margens do reservatório, eram parte das áreas de Reserva Ambiental Legal dos colonos, ali lindeiros ao futuro reservatório. Estes foram desapropriados em função do reservatório e APP de Itaipu e não foram indenizados pelo INCRA; Em seu lugar foram reassentados os Guarani. Esta aqui a razão da beligerância entre as partes, colonos e Guarani.

Os Guarani contam que "pacificaram" os colonos lindeiros, pois estes, justificam, manifestavam muita raiva deles, porque o INCRA desapropriou área deles para nós, sem ter pago para eles a desapropriação. Portanto, foi uma maneira eficaz promovida pelo INCRA, para colocar índios e colonos, uns contra os outros. Segundo os Guarani eles “amansaram” os colonos, colocando a eles, que nem eles e nem os colonos, tinham culpa do acontecido, era o governo, através do INCRA que provocava este desentendimento entre eles.

Em período anterior presenciamos junto ao Procurador da República Dr. Porciúncula/MPFFoz do Iguaçu, a invasão dos colonos lindeiros sobre a área da Terra Indígena do Oco’y, através da derrubada com o trator dos marcos das divisas em parte de área florestada, situada na divisa entre as duas áreas. Hoje esta área florestada, já desapareceu e foi tomada pelos colonos com seus plantios. Esta área era no passado parte do que sobrou da Reserva Ambiental Legal dos colonos, que veio a fazer parte da Terra Indígena. Em relação ao fato, segundo o Procurador, seria gerado documento enviado ao IBAMA, colocando o flagrante da invasão, cobrando os marcos das divisas, assim como o licenciamento ambiental para a atividade de pulverização de agrotóxicos, já que estava situada ilegalmente junto, muito próximo, à núcleo populacional. Não temos conhecimento sobre o resultado do procedimento. $O$ fato é que ainda continua a acontecer invasão dos colonos sobre a Terra Indígena.

A invasão dos colonos se dá constantemente, por diversas vezes pudemos verificar em praticamente todas as viagens que fizemos ao Oco’y. Observa-se plantios de soja, milho e trigo já em Terra Indígena. Também aqui os colonos seriam passíveis de multa pelo IAP, por destruir floresta de Preservação Permanente em Terra Indígena, Artigo 38, da Lei no 9605 de 12.02.1998, no entanto o IAP não observou o fato, omitindo-se. 
Assim não é exatamente por um preconceito racial que os colonos tratam como tratam os Guarani, como afirma R. T. Almeida, mas sim porque o próprio INCRA, criou situação estratégica para torná-los inimigos, na medida em que, segundo os Guarani, os primeiros não foram indenizados pelas terras desapropriadas, em favor dos índios, na região do Oco’y.

\subsection{Razões colocadas pelo IAP para multar as três instituições}

A afirmação do antropólogo de Itaipu, sobre a situação em que culminou multa do IAP:

Em recente visita (10.03.2004) ao tekoha Guarani-Chiripa de Okoy, fazendo-me acompanhar pelo Sr Artur Nobre Mendes, Diretor do Departamento de Assuntos Fundiários da FUNAI, os índios do local nos apresentaram problema que consideram "grave": estão impossibilitados de plantar em boa parte de suas terras.

Neste contexto, em 08.10.2003 o Instituto Ambiental do Paraná/IAP da Secretaria de Estado do Meio Ambiente, aplicou o Auto de Infração Ambiental no 20793/IAP/SEMA sobre a Usina Hidrelétrica de Itaipu, FUNAI e Prefeitura de São Miguel do Iguaçu, no valor de R\$ 160.000,00 (cento e sessenta mil reais) para cada uma das instituições. As razões colocadas pelo IAP para realizar a multa e as leis correspondentes:

Supressão de Vegetação e Movimentação do Solo, com uso de máquinas, em Área considerada de Preservação Permanente (Lei Federal no 4771/65, Artigo $2^{\circ}$ alínea b, Artigo $3^{\circ}$ alínea g, parágrafo $2^{\circ}$ ) sem licença ambiental conforme estabelece o Artigo $3^{\circ}$, parágrafo $1^{\circ}$, lei federal 4771/65, área correspondente, aproximadamente 80 hectares. Co-reponsável - Artigo 2º lei 9605/98.

Infração de acordo com o Artigo 70, da Lei Federal n 9605/98, Artigo $2^{\circ}$ da Lei Federal nº 9605/98, Artigo $25^{\circ}$ do Decreto Federal n ${ }^{\circ} 3179 / 99$.

Em detalhe, o que essas leis exprimem:

Lei Federal no 4771/65, Código Florestal: Artigo $2^{\circ}$ : Consideram-se de preservação permanente, pelo só efeito desta lei, as florestas e demais formas de vegetação natural situadas: alínea b: $\underline{\text { ao redor }}$ das lagoas, lagos ou reservatórios d'água, naturais ou artificiais; Artigo $3^{\circ}$ : Consideram-se, ainda, de preservação permanente, quando assim declaradas por ato do Poder Público, as florestas e demais formas de vegetação natural destinadas; alínea g: a manter o ambiente necessário à vida das 
populações silvícolas; Parágrafo $2^{\circ}$ : As florestas que integram o Patrimônio Indígena ficam sujeitas ao regime de preservação permanente (letra g) pelo só efeito desta Lei.

A multa foi aplicada em função do desmatamento de 80 hectares, com uso de máquinas agrícolas, pelas Instituições citadas, nas duas áreas superpostas. Tanto na APP de Itaipu quanto na Terra Indígena/TI, são áreas legalmente consideradas de Preservação Permanente que não podem ser desmatadas.

Lei Federal n 4771/65, Código Florestal: Artigo $3^{\circ}$ : Consideram-se, ainda, de preservação permanente, quando assim declaradas por ato do Poder Público, as florestas e demais formas de vegetação natural destinadas: Parágrafo $1^{\circ}$ : A supressão total ou parcial de florestas de preservação permanente só será admitida com prévia autorização do Poder Executivo Federal, quando for necessária a execução de obras, planos, atividades ou projetos de utilidade pública ou interesse social.

Assim, estaria correto o IAP de multar as Instituições, pois a forma utilizada - supressão total através de trator, naquela área, não poderia ser admitida. Sequer obra de interesse social dos indígenas era, pois a medida resultou em eliminação total em um considerável de terra, da pouca biodiversidade existente no Oco'y. Os Guarani tradicionalmente plantam em capoeiras, em clareiras abertas na Mata.

Lei Federal n 9605/98: Dispõe sobre as sanções penais e administrativas derivadas de condutas e atividades lesivas ao meio ambiente, e dá outras providências Artigo $70^{\circ}$ : Considera-se infração administrativa ambiental toda ação ou omissão que viole as regras jurídicas de uso, gozo, promoção, proteção e recuperação do meio ambiente.

Lei Federal no 9605/98, Artigo 2 ${ }^{\circ}$ : Quem, de qualquer forma, concorre para a prática dos crimes previstos nesta lei, incide nas penas a estes cominadas, na medida da sua culpabilidade, bem como o diretor, o administrador, o membro de conselho e de orgão técnico, o auditor, o gerente, o preposto ou mandatário de pessoa jurídica, que, sabendo da conduta criminosa de outrem, deixar de impedir sua prática, quando podia agir para evitá-la.

A Itaipu realizou a ação, a Prefeitura de São Miguel do Iguaçu ajudou emprestando o trator e a FUNAI, ciente da conduta ilegal da Itaipu, não agiu para evitá-la.

Decreto Federal n 3179/99: Dispõe sobre a especificação das sanções aplicáveis às condutas e atividades lesivas ao meio ambiente, e dá outras providências. Artigo $25^{\circ}$ : Destruir ou danificar 
floresta considerada de preservação permanente, mesmo que em formação, ou utilizá-la com infringência das normas de proteção: Multa de R \$ 1500,00 a R \$ 50.000,00, por hectare ou fração.

Está claro que as Instituições erraram e por isso foram multadas. Porém, a determinação do IAP foi multar e posteriormente impedir a continuidade das tarefas de "plantio" dos índios. Portanto, os Guarani, diante desse acordo anterior entre as Instituições, foram novamente penalizados, prejudicando ainda mais a sua já sofrível subsistência.

A Terra Indígena é, por princípio constitucional, de uso exclusivo dos índios, Artigo nº 231, parágrafo $2^{\circ}$ da Constituição Federal. Porém, como já insistimos exaustivamente, a Terra Indígena está superposta à APP de Itaipu, o que confirma a ilegalidade do processo de reassentamento dos índios Guarani no local.

Se na APP é proibido suprimir vegetação, na Terra Indígena é necessário plantar para a subsistência. Tal fato foi ignorado pelo IAP, a despeito de conhecer a existência de Comunidade Indígena no local em área inclusive demarcada. Se o IAP não permitiu plantar ali, é porque considerou a área como sendo somente APP do reservatório da Itaipu. Portanto, estava o IAP na ocasião defendendo apenas o ambiente intacto, pois se os Guarani plantassem ali se correria o risco de assorear o reservatório de Itaipu. Assim, o IAP contornou o fato de que os Guarani foram colocados ali contra a sua vontade e por responsabilidade das próprias Instituições, Itaipu e FUNAI.

Conforme o Artigo 231, \#1 ${ }^{\circ}, \# 2^{\circ}$ e $\# 6^{\circ}$ da Constituição Federal:

Capítulo VIII - Dos Índios. Art. 231. São reconhecidos aos índios sua organização social, costumes, línguas, crenças e tradições, e os direitos originários sobre as terras que tradicionalmente ocupam. competindo à União demarcá-las, proteger e fazer respeitar todos os seus bens.

Neste caso, os direitos originários, organização social, costumes, línguas, crenças e tradições, não foram reconhecidos, nem sobre as terras que tradicionalmente ocupavam, o antigo Oco’y-Jacutinga, nem na atual Terra Indígena do Oco’y.

Paragráfo $1^{\circ}$ : São terras tradicionalmente ocupadas pelos índios as por eles habitadas em caráter permanente, as utilizadas para suas atividades produtivas, as imprescindíveis à preservação dos recursos ambientais necessários ao seu bem-estar e as necessárias a sua reprodução física e cultural. segundo seus usos, costumes e tradições. 
As terras do Oco’y desde o início de sua ocupação, nunca reuniram as condições descritas quanto à serem as imprescindíveis à preservação dos recursos ambientais necessários ao seu bem-estar e as necessárias a sua reprodução física e cultural, segundo seus usos, costumes e tradições.

Paragráfo $2^{\circ}$ : As terras tradicionalmente ocupadas pelos índios destinam-se à sua posse permanente, cabendo-lhes o usufruto exclusivo das riquezas do solo, dos rios e dos lagos nelas existentes.

Assim como nunca, na prática, foram terras de uso exclusivo dos Guarani.

Parágrafo $6^{\circ}$ : São nulos e extintos, não produzindo efeitos jurídicos, os atos que tenham por objeto a ocupação, o domínio e a posse das terras a que se refere este artigo, ou a exploração das riquezas naturais do solo, dos rios e dos lagos nelas existentes, ressalvado relevante interesse público da União, segundo o que dispuser lei complementar, não gerando a nulidade e a extinção direito à indenização ou a ações contra a União, salvo, na forma da lei, quanto às benfeitorias derivadas da ocupação de boa-fé.

Não foi nulo nem extinto, produziu efeitos jurídicos a própria demarcação do Oco'y como terra indígena, a ocupação e a posse das terras antigas foi totalmente realizada de forma ilegal, e assim por diante. Daí as contradições de todo o processo. A própria realidade dos indígenas tem, historicamente, demonstrado que o resultado desses procedimentos se deu mais uma vez em seu próprio e único prejuízo.

\subsection{O que o IAP não observou, deixando de fiscalizar}

Apesar de os técnicos do IAP terem realizado fiscalização "in loco" na área em questão, Oco’y e APP de Itaipu, e apesar de seus fiscais serem preparados em termos legais para tanto, não apontaram que os Guarani estão submetidos à três situações ambientalmente ilegais:

- A APP de Itaipu deveria ter uma largura semelhante ao estabelecido no entorno de todo o reservatório de Itaipu, 210 metros. Junto ao Oco’y ela possui 100 metros, único local em todo o reservatório que possui esta medida. Em nenhum momento o IAP colocou em questão em termos legais, sobre a existência de ocupação humana na APP, questão que também é proibida; só se limitaram a apontar a supressão de vegetação em local proibitivo, na APP; é fato que os indígenas 
estão ocupando uma área que deveria ser em toda sua extensão, apenas Área de Preservação Permanente/APP do reservatório de Itaipu; daí que levaria a responsabilidade das instituições que realizaram os procedimentos de reassentamento dos indígenas no local, na própria APP, constituindo ali indevidamente o Oco’y; Por qual razão será que o IAP não levantou estas questões?

- os indígenas encontram-se passíveis de contaminação por agrotóxicos, utilizados pelos colonos lindeiros, em toda a extensão do entorno da Terra Indígena; deveria haver de 250 a 500 metros de distancia a pulverização de agrotóxicos próximo à núcleo populacional, no caso o núcleo é composto por indígenas;

- por estarem os indígenas assentados em local impróprio ambientalmente, na APP, estão expostos à malária, únicos sujeitos no estado do Paraná com a doença; bem como estão sujeitos ao produto tóxico borrifado para debelar o mosquito anófheles, transmissor da doença, existente no reservatório de Itaipu, localizado às margens da APP, local onde estão assentados os indígenas.

A conduta do IAP foi omissa com relação aos indígenas, por não ter fiscalizado fatos de natureza ambiental de tal gravidade, os quais seriam também de sua responsabilidade e do IBAMA fiscalizar. A partir daí desenvolvemos toda a argumentação já exposta anteriormente no capitulo III quanto aos três contextos referidos. Não cabe repeti-los, mas somente apontar as leis existentes, sobre as quais o IAP poderia ter se apoiado, mas não o fez.

\subsubsection{A determinação legal quanto à extensão da Área de Preservação Permante/APP do reservatório de Itaipu e a verdadeira extensão existente}

A orientação que os Guarani receberam de Itaipu, quando passaram a viver no Oco'y é que os primeiros 100 metros internos (a APP), a partir do reservatório de Itaipu, nas duas margens do reservatório, não poderiam ser utilizados pela Comunidade Indígena. Como a área do Oco’y em largura é muito estreita, descontando os "oficiais" 100 metros de APP de Itaipu, possui em média apenas 138 metros de largura, estando os Guarani literalmente espremidos entre o reservatório e os colonos, eles acabaram também por utilizar a APP para as finalidades de subsistência, e a Itaipu com relação a isso, não se manifestou. Porém, estes primeiros 100 metros do reservatório considerado pela Itaipu sua APP, destina-se as finalidades já descritas anteriormente: - Faixa de Segurança com relação às cotas de volume d'água da represa; - Proteção da Mata Ciliar, contra possível assoreamento. Assim esta área não pode ser de forma alguma ocupada, muito menos desmatada, 
pois esta Mata Ciliar assegura através de suas raízes, às margens firmes do reservatório, evitando que este assoreie. Desta forma o IAP preocupado com a Preservação Permanente das margens do reservatório de Itaipu, tomou a atitude de multar as Instituições, em detrimento, portanto, da subsistência indígena. Porém, o fato que nos chama a atenção, é que o IAP deveria observar também, qual é a distância de margem de APP legalmente determinada pela legislação e não observou.

Se observarmos a lei, naquele local, o correto não seriam os 100 metros de comprimento transversal ao reservatório, o espaço destinado a Área de Preservação Permanente/APP do reservatório de Itaipu. Foram medidos por nós (os guarani e a autora), a largura de vários pontos do reservatório de Itaipu, em frente a Terra Indígena do Oco’y. As medidas tomadas de pontos em mapa anexo demonstram as várias larguras tomadas: a) 795 metros; b) 510 metros; c) 417 metros; d) 369 metros; e) 199,5 metros.

O Código Florestal, Lei no 4771, de 15.09.1965, afirma à esse respeito:

Artigo $2^{\circ}$ - Consideram-se de preservação permanente, pelo só efeito desta lei, as florestas e demais formas de vegetação natural situadas:

- ao longo dos rios e de qualquer curso d'água desde o seu nível mais alto em faixa marginal cuja largura mínima seja:

3) de 100 (cem) metros para os cursos d'água que tenham 50 (cinquenta) metros a 200 (duzentos) metros de largura;

4) de 200 (duzentos) metros para os cursos d'água que tenham 200 (duzentos) metros a 600 (seiscentos) metros de largura;

5) de 500 (quinhentos) metros para os cursos d'água que tenham largura superior a 600 (seiscentos) metros.

Portanto, somente a largura "e" de 199,5 metros, faixa de largura do reservatório mais estreita, localizada na ponta mais próxima a estrada que corta a Terra Indígena, é que estaria dentro da determinação legal item “3” de 100 metros de preservação permanente; todas as medidas restantes se encaixam entre os itens "4" e "5", o que demonstra que a Área de Preservação Permanente/APP do reservatório da Itaipu, deveria apresentar de 200 a 500 metros de largura. Se fosse realmente cumprida a lei, praticamente a totalidade da área considerada Terra Indígena do Oco'y, deveria legalmente ser considerada como APP do reservatório de Itaipu, inclusive ainda, partes das áreas dos colonos lindeiros. Portanto, a população indígena não poderia ter sido ali estabelecida. Provavelmente isso se deu, também porque a Itaipu não teve Licenciamento Ambiental, como não tem até hoje. 


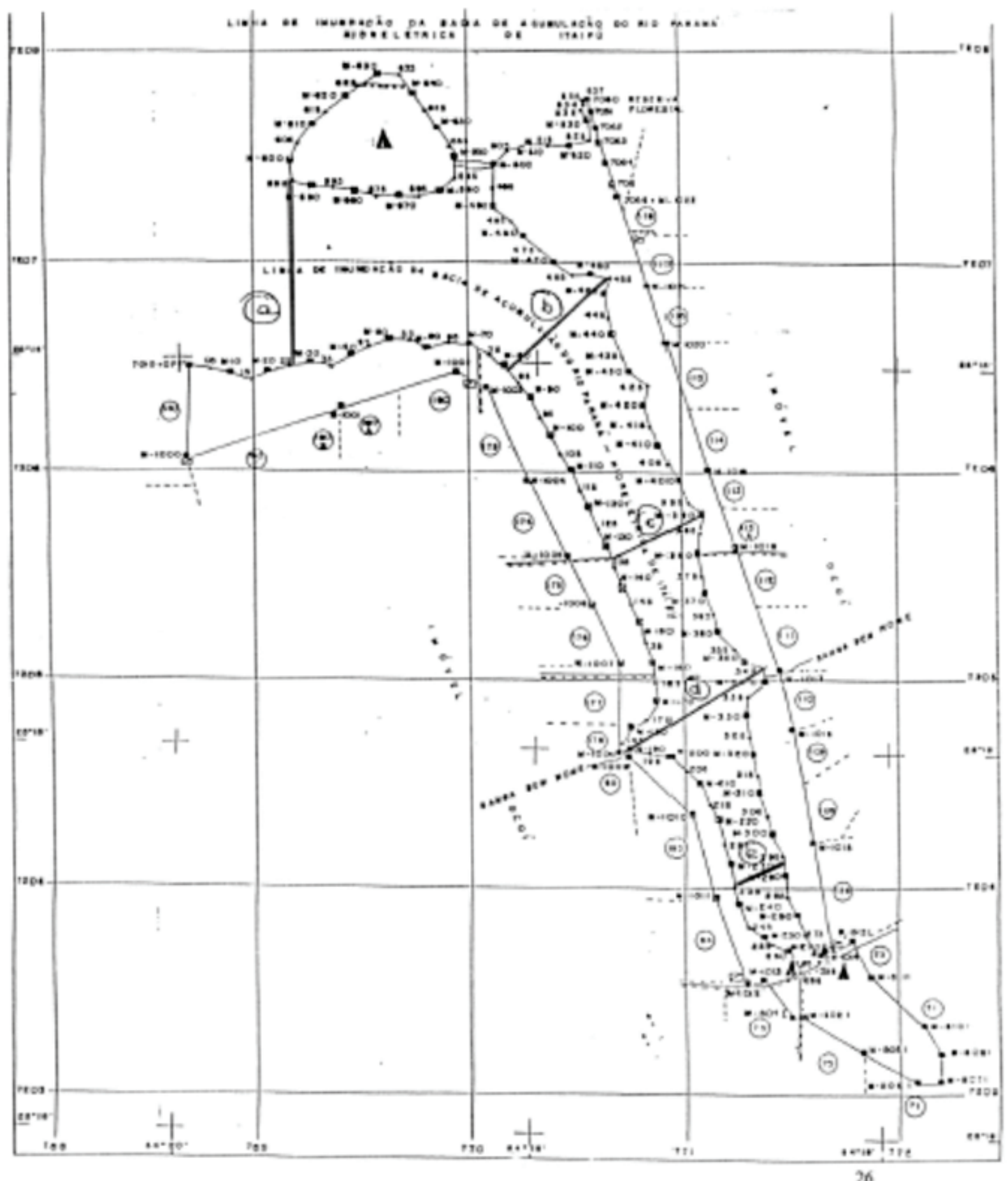

Figura 75C. Mapa. Larguras do reservatório da Usina Hidrelétrica de Itaipu em frente a Terra Indígena do Oco'y.

Fonte: Os Guarani de Oco’y e Maria Lucia Brant de Carvalho, 2002.

Desta forma, a Terra Indígena do Oco’y, em termos legais, nem poderia existir naquele espaço, pois na verdade ali deveria constar apenas como Área de Preservação Permanente do reservatório da Itaipu. A lei deveria ser aplicada a própria Itaipu, por não ter cumprido a legislação quanto às larguras mínimas que deve apresentar a APP, conforme lei já descrita anteriormente, Artigo $2^{\circ}$ do Código Florestal. Quanto a isso o IAP "não observou”. 
Aplica-se também a Lei no 4771, Código Florestal (15/09/2004), a outras questões que o IAP não observou.

Aos colonos lindeiros por ter destruído ao longo de todos estes anos, as Áreas de Preservação Permanente, suas próprias e as dos índios Guarani, no limite entre áreas, plantando seus cultivos sobre elas; a legislação é clara a esse respeito:

Artigo $26^{\circ}$ : Constituem contravenções penais, puníveis com três meses a um ano de prisão simples ou multa de uma a cem vezes o salário-mínimo mensal do lugar e da data da infração ou ambas as penas cumulativamente:

destruir ou danificar a floresta considerada de preservação permanente, mesmo que em formação, ou utilizá-la com infringência das normas estabelecidas ou previstas nesta Lei;

cortar árvores em florestas de preservação permanente, sem permissão da autoridade competente;

g) impedir ou dificultar a regeneração natural de florestas e demais formas de vegetações;

O Artigo 29, letra a e c, o Artigo 31, letra b, o Artigo 32, desta lei prevê ainda, sobre as penalidades a serem aplicadas sobre os autores do crime ambiental, acima descrito.

Poderia ser aplicado ao INCRA, Itaipu e FUNAI por terem destinado terras aos Guarani, em Área que deveria ser de Preservação Permanente, o próprio Oco’y; a legislação é clara:

Artigo $8^{\circ}$ : Na distribuiçãa de lotes destinados à agricultura, em planos de colonização e de reforma agrária, não devem ser incluídas as áreas florestadas de preservação permanente de que trata esta

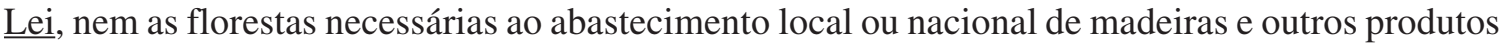
florestais.

O que se observa no local, é que os Guarani foram assentados ali de forma ilegal, através de arranjos da Itaipu e do INCRA, sob os auspícios da própria FUNAI, da época. A Itaipu instalou os Guarani ali, a título de compensação, por ter inundado suas terras originais, o Oco’y-Jacutinga, quando da formação do reservatório. Ou seja, além de não compensar os índios em terras de igual tamanho e qualidade ambiental, que era sua obrigação legal, os assentou ainda em terras territorial e ambientalmente inapropriadas, submetendo-os aos mais variados impactos ambientais e sanitários, ao mesmo tempo que subtraia nestas últimas três décadas, as condições necessárias para reprodução sociocultural desses indígenas, até o limite da fome; Neste caso o descumprimento da Lei por Itaipu, caberia no Estatuto do Índio, Artigo 20 parágrafo $3^{\circ}$ e Constituição Federal, artigos 231 e 232. Mas como sabemos Itaipu se coloca acima da lei. 


\subsubsection{A contaminação de todo ser vivente na Terra Indígena do Oco’y, em razão dos agrotóxicos utilizados pelos colonos lindeiros}

Outra questão que o IAP não observou é a questão da contaminação da Comunidade Indígena pelos agrotóxicos. Desde os primeiros trabalhos entregues à FUNAI e MPF-Foz, Laudo Antropológico (2002), (capítulo 3 da tese) assim como o Relatório de Campo (18.03.2004), entregue este ao MPF-Foz, já havíamos apontado a gravidade do fato.

O local se constituí numa Bacia Hidrográfica, onde os colonos encontram-se no alto, os índios Guarani no meio e o reservatório da hidrelétrica na parte baixa desta Bacia. Pode-se imaginar para onde escoam as águas das chuvas, e com elas, os agrotóxicos sendo carreados logicamente para baixo, perpassando pela Terra Indígena, em seguida pela APP, escoando o produto tóxico no reservatório de Itaipu.

O Relatório de Campo de 18.03.2004 entregue ao MPF-Foz já afirmava:

Outra questão importante que o IAP não se refere e como esteve presente no local certamente obteve a oportunidade de verificar é a distância entre as moradias indígenas e a pulverização de agrotóxicos praticadas pelos colonos lindeiros, em muitos casos a menos de 5 metros de distância. O fato já observado por mim no Capítulo III do Laudo Antropológico entregue em 2002, na época já apontava a ilegalidade do fato, através da clara descrição da lei. Isso não foi relatado apesar de nosso pronunciamento incisivo sobre o caso, indicando que o fato é de responsabilidade do IBAMA e/ou IAP, ao MPF-Foz. Alertamos também que a cabeceira do Córrego Santa Clara que abastece a Terra Indígena do Oco'y, está em meio ao plantio de soja/milho, portanto também exposta à contaminação por agrotóxicos. (BRANT DE CARVALHO. M. L. Terra Indígena do Oco’y. Relatório de Campo. FUNAI/MJ. São Paulo. 18.03.2004, p. 6)

Não é necessário apontarmos todas as observações a respeito já realizadas. Elas estão contidas no capitulo III desta tese. Apontaremos aqui apenas as leis que o IAP deveria ter observado.

Lembrando antes que em entrevista em dezembro de 2001 com especialistas em agrotóxicos do Departamento de Fiscalização/DEFIS da Secretaria de Estado da Agricultura e do Abastecimento - SEAB/PR, e com a Secretaria Estadual da Saúde/ Departamento Estadual de Saúde no Trabalho/ PR ao levarmos duas listas dos agrotóxicos utilizados na região, ao analisarem as listas e ao descrevermos a situação vivida pelos Avá-Guarani, estes mostraram-se apreensivos, levantando uma série de problemas:

- verificaram a utilização de produtos proibidos como o 2-4-D; 
- levantaram a questão da aspersão dos agrotóxicos sobre as roças de subsistência dos índios, inapropriada para este tipo de lavoura, comprometendo a produção da mesma, além da própria intoxicação provocada na população.

- verificaram a falta de distância mínima entre as duas áreas, dos colonos e da comunidade indígena, em função do uso destes produtos; a distância mínima legal deveria ser de pelo menos 250 metros, não há sequer 5 metros de distância na melhor das hipóteses, em outros pontos das duas áreas elas estão literalmente coladas;

- a contaminação de águas, solos e dos recursos neles existentes;

- o comprometimento da saúde das populações humanas e animais que habitam a área;

- descreveram que em populações com deficiências nutricionais, como é o caso desta população indígena, a questão se torna bastante mais grave, tendo efeitos seriamente comprometedores da saúde. Há casos na aldeia de crianças com síndrome de down, nascidas anecéfalas, as quais foram a óbito e o caso de câncer de esôfago (Seu Guilherme);

Pelas informações colhidas através de terceiros, os agrotóxicos são usados com atomizadores e pulverizadores.

Vejamos agora o que a Legislação Estadual específica de responsabilidade do IAP afirma sobre o tema. A Resolução no 22/85 - SEIN, que regula a poluição do meio ambiente por agrotóxicos e biocidas, criada visando aperfeiçoar as normas vigentes relativas ao controle da poluição por agrotóxicos e outros biocidas, de acordo com o artigo $5^{\circ}$, inciso II, do decreto estadual $\mathrm{n}^{\circ} 857$, de 18.07.1979, resolve:

5. Nas áreas agricultáveis, deverão ser adotadas medidas específicas de controle contra a erosão, de modo a diminuir a carreação de partículas do solo, onde se encontram absorvidos agrotóxicos, principalmente os organoclorados, para as coleções de água e áreas circunvizinhas.

6. Os tratamentos fitossanitários deverão ser feitos com rigorosa observância dos cuidados e das recomendações técnicas, no sentido de garantir a eficiência do tratamento, e não ocasionar danos à saúde pública, ao meio ambiente e às explorações agropecuárias circunvizinhas, bem como, à qualidade dos produtos obtidos.

7. Não é permitida a aplicação aérea de agrotóxicos e outros biocidas em áreas situadas a uma distância mínima de 500 metros adjacente a mananciais de captação de água para abastecimento de populações, núcleos populacionais, escolas, habitações e locais de recreação, e, de 250 metros adjacentes a mananciais de água, moradias isoladas e agrupamento de animais e culturas susceptíveis a danos.

7.1. Será permitida, porém, a aplicação de agrotóxicos e biocidas nas lavouras, se efetuada por atomizadores ou canhões, numa distância mínima de 250 metros, e, por aparelhos costais ou 
tratorizados de barra, numa distância mínima de 50 metros, dos locais mencionados no item 7.

7.2. Em todos os casos as aplicações somente poderão ser feitas quando a direção do vento for tal que não leve resíduos de agrotóxicos e biocidas para os locais referidos no item 7.

18. No caso de lançamento culposo ou doloso de agrotóxicos e/ou biocidas de qualquer espécie nos rios, córregos ou reservatórios d'água, configurando crime contra a saúde pública, tal como previsto nos Artigos 270 e 271 do Código Penal, caberá à SUREHMA (atual IAP), sem prejuízo da aplicação de penalidades administrativas, comunicar o fato à autoridade policial competente para instauração de inquérito, apuração da infração e sua autoria.

$\mathrm{O}$ artigo $20^{\circ}$ explicita o valor da multa a ser pago pelo infrator seja ele pessoa jurídica ou física. Nenhum destes cuidados foram observados pelo IAP, a evidente contaminação dos índios Guarani, pelos agrotóxicos pulverizados pelos colonos.

O mesmo tipo de omissão ocorreu com as técnicas da FUNASA, nada responderam à respeito da contaminação, claramente verificada ali, dado a legislação relativa à saúde, que referiase a procedimentos desta natureza.

Vejamos agora o que a Legislação Nacional de responsabilidade do IBAMA e/ou seu órgão vinculado IAP, afirma sobre o tema. A Lei n ${ }^{\circ}$ 9605, de 12.02.1998 denominada Lei da Vida ou Lei dos Crimes Ambientais, afirma em seu Artigos:

Artigo $33^{\circ}$ : Provocar, pela emissão de efluentes ou carreamento de materiais, o perecimento de espécimes da fauna aquática existentes em rios, lagos, açudes, lagoas, baías ou águas jurisdicionais brasileiras: Pena - detenção, de um a três anos, ou multa, ou ambas cumulativamente.

Artigo 54ㅇ: Causar poluição de qualquer natureza em níveis tais que resultem ou possam resultar em danos à saúde humana, ou que provoquem a mortandade de animais ou a destruição significativa da flora: Pena - reclusão, de um a quatro anos, e multa.

Parágrafo $1^{\circ}$ : se o crime é culposo: Pena - detenção, de seis meses a um ano, e multa. Parágrafo $2^{\circ}$ : Se o crime:

I - tornar uma área, urbana ou rural, imprópria para a ocupação humana:

II - causar poluição atmosférica que provoque a retirada, ainda que momentânea, dos habitantes das áreas afetadas, ou que cause danos diretos à saúde da população;

III - causar poluição hídrica que torne necessária a interrupção do abastecimento público de água de uma comunidade;

V - ocorrer por lançamento de resíduos sólidos, líquidos ou gasosos, ou detritos, óleos ou substâncias oleosas, em desacordo com as exigências estabelecidas em leis ou regulamentos; 
Parágrafo $3^{\circ}$ : Incorre nas mesmas penas previstas no parágrafo anterior quem deixar de adotar, quando assim o exigir a autoridade competente, medidas de precaução em caso de risco de dano ambiental grave ou irreversível.

Artigo $58^{\circ}$. Nos crimes dolosos previstos nesta Seção, as penas serão aumentadas:

de um sexto a um terço, se resulta dano irreversível à flora ou ao meio ambiente em geral;

de um terço até a metade, se resulta lesão corporal de natureza grave a outrem;

até o dobro, se resultar a morte de outrem;

Parágrafo Único: as penalidades previstas neste Artigo somente serão aplicadas se do fato não resultar crime mais grave.

Artigo $60^{\circ}$. Construir, reformar, ampliar, instalar ou fazer funcionar, em qualquer parte do território nacional, estabelecimentos, obras ou serviços potencialmente poluidores, sem licença ou autorização dos órgãos ambientais competentes, ou contrariando as normas legais e regulamentares pertinentes: Pena- detenção, de um a seis meses ou multa, ou ambas as penas cumulativamente.

Artigo $70^{\circ}$. Considera-se infração administrativa ambiental toda ação ou omissão que viole as regras jurídicas de uso, gozo, promoção, proteção e recuperação do meio ambiente.

Parágrafo $1^{\circ}$ São autoridades competentes para lavrar auto de infração ambiental e instaurar processo administrativo os funcionários de órgãos ambientais integrantes do SISNAMA, designados para as atividades de fiscalização, bem como os agentes das Capitanias dos Portos, do Ministério da Marinha.

Parágrafo $3^{\circ}$. A autoridade ambiental que tiver conhecimento de infração ambiental é obrigada a promover a sua apuração imediata, mediante processo administrativo próprio, sob pena de co-responsabilidade.

Assim a Lei n 9605, de 12.02.1998, não foi observada pelo IAP, novamente.

O Decreto nº 3159 de 21.09.1999, deveria também ser aplicado pelo IAP, novamente não se deu conta sobre o que a legislação suscita. Com base no decreto citado, o IAP é responsável também na medida em que se omite ainda, com relação aos agrotóxicos, quanto à:

Artigo $1^{\circ}$ : Toda ação ou omissão que viole as regras jurídicas de uso, gozo, promoção, proteção e recuperação do meio ambiente é considerada infração administrativa ambiental e será punida com as sanções do presente diploma legal, sem prejuízo da aplicação de outras penalidades previstas na legislação.

Artigo $2^{\circ}$ : As infrações administrativas são punidas com as seguintes sanções:

VII - embargo de obra ou atividade;

IX - suspensão parcial ou total das atividades; 
$\mathrm{X}$ - restritiva de direitos;

XI - reparação dos danos causados.

Parágrafo $1^{\mathrm{o}}$ : se o infrator cometer, simultaneamente, duas ou mais infrações, ser-lhe-ão aplicadas, cumulativamente, as sanções a elas cominadas.

Parágrafo $2^{\circ}$ : A advertência será aplicada pela inobservância das disposições deste decreto e da legislação em vigor, sem prejuízo das demais sanções previstas neste artigo.

Parágrafo $3^{\circ}$ : A multa simples será aplicada sempre que o agente, por negligência ou dolo:

advertido, por irregularidades, que tenham sido praticadas, deixar de saná-las, no prazo assinalado por orgão competente do SISNAMA... .

Parágrafo $6^{\circ}$ : A apreensão, destruição ou inutilização, referidas nos incisos IV e V do caput deste artigo, obedecerão ao seguinte:

VII- tratando-se de apreensão de substâncias ou produtos tóxicos, perigosos ou nocivos à saúde humana ou ao meio ambiente, as medidas a serem adotadas, seja destinação final ou destruição, serão determinadas pelo orgão competente e correrão às expensas do infrator;

Parágrafo $7^{\circ}$ : As sanções indicadas nos incisos VI, VII e IX do caput deste artigo serão aplicadas quando o produto, a obra, a atividade ou o estabelecimento não estiverem obedecendo às determinações legais ou regulamentares.

Parágrafo $9^{\circ}$ : As sanções restritivas de direito aplicáveis a pessoas físicas ou jurídicas são:

suspensão de registro, licença, permissão ou autorização;

cancelamento de registro, licença, permissão ou autorização;

perda ou restrição de incentivos ou benefícios fiscais;

perda ou suspensão de participação em linhas de financiamento em estabelecimentos oficiais de crédito; $\mathrm{e}$

proibição de contratar com a Administração Pública, pelo período de até três anos.

Artigo 6 $6^{\circ}$ O agente autuante, ao lavrar o auto de infração, indicará a multa prevista para a conduta, bem como, se for o caso, as demais sanções estabelecidas neste Decreto, observando:

I - a gravidade dos fatos, tendo em vista os motivos da infração e suas consequências para a saúde pública e para o meio-ambiente;

Artigo $17^{\circ}$ : Praticar ato de abuso, maus tratos, ferir ou mutilar animais silvestres, domésticos ou domesticados, nativos ou exóticos.

Artigo $18^{\circ}$ : Provocar, pela emissão de efluentes ou carreamento de materiais, o perecimento de espécimes da fauna aquática existentes em rios, lagos, açudes, lagoas, baías ou águas jurisdicionais brasileiras: Multa de $\mathrm{R} \$ 5000.00$ (cinco mil reais) a $\mathrm{R} \$ 1.000 .000,00$ (um milhão de reais).

Artigo $25^{\circ}$ : Destruir ou danificar floresta considerada de preservação permanente, mesmo que em formação, ou utilizá-la com infringência das normas de proteção: Multa de R \$ 1.500,00 (mil e quinhentos reais) a $R \$ 50.000,00$ (cincoenta mil reais), por hectare ou fração. 
Artigo $26^{\circ}$ : Cortar árvores em floresta considerada de preservação permanente, sem permissão da autoridade competente: Multa de $\mathrm{R} \$ 1.500,00$ (mil e quinhentos reais) a $\mathrm{R} \$ 5.000,00$ (cinco mil reais), por hectare ou fração, ou $\mathrm{R} \$ 500,00$ (quinhentos reais) por metro cúbico.

Artigo $41^{\circ}$ : Causar poluição de qualquer natureza em níveis tais que resultem ou possam resultar em danos à saúde humana, ou que provoquem a mortandade de animais ou a destruição significativa da flora: Multa $\mathrm{R} \$ 1.000,00$ (mil reais) a $\mathrm{R} \$$ 50.000.000,00 (cincoenta milhões de reais), ou multa diária.

Parágrafo $1^{\circ}$ - Incorre nas mesmas multas, quem: I - tornar uma área, urbana ou rural, imprópria para a ocupação humana; II - causar poluição atmosférica que provoque a retirada, ainda que momentânea, dos habitantes das áreas afetadas, ou que cause danos diretos à saúde da população; III- causar poluição hídrica que torne necessária a interrupção do abastecimento público de água de uma comunidade; $\mathrm{V}$ - lançar resíduos sólidos, líquidos ou gasosos ou detritos, óleos ou substâncias oleosas em desacordo com as exigências estabelecidas em leis ou regulamentos; e VI- deixar de adotar, quando assim o exigir a autoridade competente, medidas de precaução em caso de risco de dano ambiental grave ou irreversível.

Artigo $43^{\circ}$ : Produzir, processar, embalar, importar, exportar, comercializar, fornecer, transportar, armazenar, guardar, ter em depósito ou usar produto ou substância tóxica, perigosa ou nociva à saúde humana ou ao meio ambiente, em desacordo com as exigências estabelecidas em leis ou em seus regulamentos: Multa de $\mathrm{R} \$ 500,00$ (quinhentos reais) a $\mathrm{R} \$ 2.000 .000,00$ (dois milhões de reais). Parágrafo $1^{\circ}$ : Incorre nas mesmas penas, quem abandona os produtos ou substâncias referidas no caput, ou os utiliza em desacordo com as normas de segurança.

Artigo $44^{\circ}$ : Construir, reformar, ampliar, instalar ou fazer funcionar, em qualquer parte do território nacional, estabelecimentos, obras ou serviços potencialmente poluidores, sem licença ou autorização dos órgãos ambientais competentes, ou contrariando as normas legais e regulamentos pertinentes: Multa de $\mathrm{R} \$ 500,00$ (quinhentos reais) a $\mathrm{R} \$ 10.000 .000,00$ (dez milhões de reais).

Artigo $45^{\circ}$ : Disseminar doença ou praga ou espécies que possam causar dano à agricultura, à pecuária, à fauna, à flora ou aos ecossistemas: Multa de $\mathrm{R} \$ 5000,00$ (cinco mil reais) a $\mathrm{R} \$ 2.000 .000,00$ (dois milhões de reais).

Artigo 50 : Alterar o aspecto ou a estrutura de edificação ou local especialmente protegido por lei, ato administrativo ou decisão judicial, em razão de seu valor paisagístico, ecológico, turístico, artístico, histórico, cultural, religioso, arqueológico, etnográfico ou monumental, sem autorização da autoridade competente ou em desacordo com a concedida: Multa de R $\$ 10.000,00$ (dez mil reais) a $\mathrm{R} \$ 200.000,00$ (duzentos mil reais).

Artigo $51^{\circ}$ Promover construção em solo não edificável, ou no seu entorno, assim considerado em razão de seu valor paisagístico, ecológico, turístico, artístico, histórico, cultural, religioso, ar- 
queológico, etnográfico ou monumental, sem autorização da autoridade competente ou em desacordo com a concedida: Multa de $\mathrm{R} \$ 10.000,00$ (dez mil reais) a $\mathrm{R} \$ 100.000,00$ (cem mil reais). Artigo 53: Deixar de obter o registro no Cadastro Técnico Federal de Atividades Potencialmente Poluidoras ou Utilizadoras de Recursos Ambientais, as pessoas físicas e jurídicas, que se dedicam às atividades potencialmente poluidoras e à extração, produção, transporte e comercialização de produtos potencialmente perigosos ao meio ambiente, assim como de produtos e subprodutos da fauna e flora: Multa de $\mathrm{R} \$ 500,00$ (quinhentos reais) a $\mathrm{R} \$ 20.000,00$ (vinte mil reais).

Artigo $60^{\circ}$ : As multas previstas neste Decreto podem ter a sua exigibilidade suspensa, quando o infrator, por termo de compromisso aprovado pela autoridade competente, obrigar-se à adoção de medidas específicas, para fazer cessar ou corrigir a degradação ambiental.

Parágrafo $1^{\circ}$ : A correção do dano de que trata este artigo será feita mediante a apresentação de projeto técnico de reparação do dano.

Desta forma, os colonos derrubaram toda a área de Preservação Permanente de suas próprias terras, assim como derrubam, na medida em que plantam nas divisas e além dela, também na área de Preservação Permanente da Terra Indígena do Oco’y. Obtivemos ainda, informação fidedigna de que muitos dos agrotóxicos utilizados ali são comprados pelos colonos no Paraguai e proibidos pela legislação brasileira, é o caso do 2-4-D.

Pode-se concluir pelo extenso rol de leis aqui expostas que o IAP não cumpriu nenhuma das recomendações que as leis estadual e federal ordenam, as quais a princípio deveria fiscalizar, omitindo-se do caso. Assim, ele é co-responsável à toda situação encontrada ali.

\subsubsection{A proximidade da população indígena ao reservatório da U. H. de Itaipu, razão pela qual os Guarani são contaminados pelo mosquito anófheles, transmissor da malária}

O mesmo se dá novamente quanto à omissão do IAP, no que se refere a não fiscalizar como se dá a transmissão da malária na Terra Indígena. A população indígena do Oco’y é a única população a apresentar epidemia de malária no estado do Paraná. Assim como é a única população a habitar às margens do reservatório de Itaipu. A malária quando chegamos ali, apresentava-se de forma epidêmica. Se o fato é concernente ao âmbito das instancias de saúde, também é decorrente de uma situação ambiental incorreta. Juridicamente é ilegal, qualquer núcleo populacional viver às margens do reservatório da Usina Hidrelétrica de Itaipu, já que ali obrigatoriamente deve ser uma Área de Preservação Permanente/APP, objetivando não assorear as 
margens do reservatório de Itaipu. Assim aplica-se a Lei nº 4771, Código Florestal (15/09/2004), pesquisado à época que o IAP deveria ter fiscalizado, mas "não enxergou" o problema:

Artigo $8^{\circ}$ : Na distribuição de lotes destinados à agricultura, em planos de colonização e de reforma agrária, não devem ser incluídas as áreas florestadas de preservação permanente de que trata esta Lei, nem as florestas necessárias ao abastecimento local ou nacional de madeiras e outros produtos florestais.

Artigo $26^{\circ}$ : Constituem contravenções penais, puníveis com três meses a um ano de prisão simples ou multa de uma a cem vezes o salário-mínimo mensal do lugar e da data da infração ou ambas as penas cumulativamente:

- destruir ou danificar a floresta considerada de preservação permanente, mesmo que em formação, ou utilizá-la com infringência das normas estabelecidas ou previstas nesta Lei;

- cortar árvores em florestas de preservação permanente, sem permissão da autoridade competente;

g) impedir ou dificultar a regeneração natural de florestas e demais formas de vegetações;

O Artigo 29, letra a e c, o Artigo 31, letra b, o Artigo 32, desta lei prevê ainda sobre as penalidades a serem aplicadas sobre os autores do crime ambiental, acima descrito. No caso aqui o IAP deveria aplicar a legislação ao INCRA e a Itaipu, por terem assentado a população indígena em local inapropriado, e a própria FUNAI por ter permitido.

Quanto a ação do IAP, o órgão esteve certo em autuar as três Instituições mencionadas inicialmente. Porém, age de forma tendenciosa na medida em que impede os índios de plantar e não observa a exposição dos mesmos à malária, ao agrotóxico, culminando as duas ações, de permanência de assentamento dos Guarani, respectivamente, ao lado do reservatório e muito próximo aos colonos, na contaminação de águas e solos, plantios e áreas de coleta indígenas, pessoas, animais de criação e peixes. Deixa de observar também os espaços superpostos da APP e da TI, que além de ilegais são inapropriados à utilização.

\subsection{O IAP quer apenas a terra intacta, livre da ocupação humana}

Afirma por fim Rubem Thomaz de Almeida em sua carta:

A interferência do IAP, além de inviabilizar a subsistência de inúmeras famílias, veio acentuar um sentimento, manifesto por muitos indígenas, de querer sair do lugar: "se não podemos plantar o IAP que fique com a terra"; 
Talvez deva ser mesmo essa a intenção do IAP, deseja que os índios saíam das terras, por considerá-las apenas Área de Preservação Permanente/APP do reservatório da Itaipu, mantendoa assim, “intacta", livre de ocupação humana, no caso indígena.

As leis até então postas em prática pelo IAP com relação aos Guarani, só contribuíram para aprofundar a crise entre eles, na medida em que a Instituição proíbe de os índios plantarem na própria Terra Indígena; todas as outras questões acima arroladas que o IAP deveria fazer também cumprir a lei, que traria benefícios aos Guarani, na medida em que poderia proteger suas terras contra violações ambientais, como no caso dos agrotóxicos ou da malária, o IAP se omitiu. Estão assim sujeitos os funcionários do próprio IAP, quanto a omissão praticada, no que se refere às próprias leis que deveriam fiscalizar em seu âmbito institucional e não fiscalizaram, sendo coresponsáveis à toda situação ali encontrada.

Ao desencadear toda esta situação, contribui o IAP, mais uma vez, para demonstrar a insuficiência territorial e a inadequação ambiental apresentada no local para satisfazer as necessidades de subsistência da comunidade indígena. 


\title{
CAPÍTULO 7 \\ A GEOPOLÍTICA DA TRÍPLICE FRONTEIRA: \\ O PROCESSO HISTÓRICO DE COMO A SOCIEDADE HEGEMÔNICA CONSTRUIU A REGIÃO EM FUNÇÃO DOS INTERESSES DO CAPITAL
}

\begin{abstract}
A informação por si só é de pouca importância. Em qualquer sociedade que alegue estar baseada na participação democrática de seus cidadãos, a informação deve ser traduzida em estratégias para a ação pública, a responsabilidade e a mudança.
\end{abstract}

Shelton Davis/ abril de $1977^{1}$

Darcy Ribeiro alegava no contexto da ditadura militar: Muito mais do que as garantias da lei, é a falta de interesse econômico que garante ao índio a posse do nicho em que vive. A descoberta de qualquer coisa que possa ser explorada é sinônimo do dia do juízo final para os índios, que são pressionados a abandonar suas terras, ou chacinados dentro delas. $\mathrm{E}$ as descobertas econômicas não precisam ser excepcionais para que os índios sejam saqueados.

Darcy Ribeiro/1962²

\subsection{O processo de desconstrução do território indígena visando o domínio geopolítico} estatal através da implantação da economia de mercado na região da Tríplice Fronteira

Desde a colonização do Cone Sul da América Latina, parte do território capitalista mundial que veio a se tornar parte dos Estados Nacionais, Brasil, Paraguai, Argentina, Bolívia e Uruguai, os Guarani seus habitantes imemoriais, vêm sendo ao longo dos séculos, inúmeras vezes dele esbulhados, e também, retornam a ele, outras tantas vezes. Seu território original, o Tekoa Guassu, foi totalmente recortado e ocupado, restando aos indígenas poucos espaços no interior dele.

O presente capítulo dedica-se a compreender a geopolítica estabelecida na região da Tríplice Fronteira, através do processo histórico de como a sociedade hegemônica construiu a região, em

\footnotetext{
${ }^{1}$ DAVIS, Shelton. Vítimas do Milagre: O desenvolvimento e os índios do Brasil. Rio de Janeiro: Zahar, 1978, p. 22.

${ }^{2}$ RIBEIRO, Darcy. A Política Indigenista Brasileira. Rio de Janeiro, 1962, p . 101.
} 
função dos interesses do capital. Esse processo foi estruturado de tal forma, que acabou por refletir num processo de desconstrução do imemorial território indígena Guarani. Trata-se de apontar quais mecanismos foram e ainda são usados, pelo Estado brasileiro, para expulsar as populações indígenas de seu território e estabelecer sua dominação sobre ele.

A partir da década de 40 do século XX, passou a haver uma bem-sucedida "limpeza étnica" na região do oeste do Paraná, promovida por instituições que representavam o governo brasileiro em todo esse período. Poucos agrupamentos indígenas resistiram a essa investida, entre eles os Guarani da Terra Indígena Avá-Guarani do Oco’y. Acrescentamos que resistiu e continua sendo constantemente atacado, através de ações estatais, ora ativas, ora passivas, para que não permaneçam no local, dada as condições de vida a que foram submetidos, como vimos anteriormente ao longo desse trabalho.

Uma das razões que nos levaram ao estudo tratado neste capítulo especificamente foi compreender porque os governos brasileiros, passado e atual, insistem em não respeitar os direitos indígenas na região do oeste paranaense, próximos a Tríplice Fronteira. Após verificado o esbulho por parte de Itaipu Binacional e Parque Nacional do Iguaçu, os Guarani deveriam ser indenizados, preferencialmente em novas terras, como acontece hoje na instalação de empreendimentos que afetam as comunidades indígenas, com o respectivo Licenciamento Ambiental. Já que no período dos esbulhos não havia leis ambientais que cobrissem os danos causados, seria o caso de se fazer um Termo de Ajuste de Conduta/TAC, visando cobrir essa lacuna. Isso sequer foi considerado.

Tudo leva a crer que essa motivação atual tem relação com motivações anteriores, as várias e bem-sucedidas ações de "limpeza étnica" promovidas na região de fronteira pelo Estado nacional, com a intenção deliberada de expulsão dos indígenas em direção ao Paraguai e criação de impedimentos de retorno dos mesmos, ao Brasil.

Dessa forma, como veremos ao longo deste capitulo, a situação vivenciada pelos Guarani tanto no passado como hoje, tem raízes profundas, influenciadas, ou melhor, causadas, pelas ações implementadas fundamentalmente a partir dos governos militares, no decorrer da ditadura militar no Brasil. Elas caracterizam-se pelo modelo geopolítico militar traçado para a região da Bacia Platina objetivando o domínio estatal brasileiro dessa região, bem como pelo modelo econômico "desenvolvimentista" implementado, visando ampliar na região a economia capitalista.

Esses modelos (geopolítico e econômico) subentendiam que para assegurar sua implantação, era necessário ocupar o território Guarani, estabelecer o domínio geopolítico estatal brasileiro na região da Tríplice Fronteira, alterando a primazia de forças estabelecidas, bem como 
estender a ela, uma base de infraestrutura energética importante para o desenvolvimento econômico brasileiro, base a qual seria também "os olhos e ouvidos" do Estado Nacional na região, bem como ainda, desenvolver a economia regional, ainda insipiente, sustentada pela constituição da propriedade privada.

Nesse contexto os governos brasileiros que foram se sucedendo, acabaram por subjugar os povos indígenas e camponeses, que viviam na região, por meio da tomada de suas terras, de forma tal, que reprimiu como pode iniciativas de reivindicação de direitos, bem como inibiu o quanto pode manifestações contra a repressão vivida. A política indigenista da época, como veremos, de caráter integracionista, estava subordinada a política maior de desenvolvimento, a um custo social alto para os indígenas.

\subsection{Conceitos fundamentais}

Para o bom entendimento deste capítulo é necessário refletir sobre o significado dos seguintes conceitos fundamentais: cultura, língua, nação, Estado, território e fronteira. Tanto mais interessante se pensarmos esses conceitos, em relação à ambas sociedades, aqui neste trabalho justapostas, indígena e nacional.

A antropóloga Carmem Junqueira, define em seu livro “Antropologia Indígena” o que vem a ser o termo cultura: em antropologia, convencionou-se que os padrões de comportamento, as instituições, os valores materiais e espirituais de um povo são a sua cultura $^{3}$.

O Brasil sem duvida é um país composto de vários povos, de sociedades e culturas distintas, de nações diferentes, somente de indígenas há mais de 200 nações atualmente, apresentando o país um leque variado de múltiplas nacionalidades, composta posteriormente com a colonização, por imigrantes: portugueses, africanos, franceses, italianos, japoneses, alemães, poloneses, ucranianos, holandeses..., caracterizando assim, ao longo da historia, por ser uma sociedade de formação pluriétnica e pluricultural.

O geógrafo Claude Raffestin, em seu livro "Por uma geografia do poder", na "Segunda Parte. A população e o poder. Capítulo II - Língua e poder. I- As funções da linguagem”, afirma sobre o significado da linguagem e da língua:

\footnotetext{
3 JUNQUEIRA, Carmen. Antropologia Indígena. São Paulo: EDUC,1991, p. 17.

${ }^{4}$ RAFFESTIN, Claude. Por uma geografia do poder. Serie Temas. Vol. 29. Geografia e Política. São Paulo: Editora Ática. 1993. 269 p.
} 
Uma linguagem referencial, ligada às tradições culturais, orais ou escritas e que assegura a continuidade dos valores por uma referência sistemática às obras do passado (RAFFESTIN:1993:98).

Uma língua determina um modelo de representação do "universo". Em outros termos, privilegiar uma língua é impor um modelo de representação única e é, por isso mesmo, homogeneizar o sistema de informação. (RAFFESTIN: 1993:117)

Porém, para a política territorial do Estado, ele a quer uma sociedade homogênea, una, indivisível, uma única nação, cultura e língua, uma nacionalidade determinada, "a brasileira", dedicada à causa da unidade nacional, visando manter assim a integração territorial.

Em direito, o advogado Paulo Bonavides, em seu livro "Ciência Política" define com bastante clareza o que vem a ser o conceito de nação e nacionalidade ${ }^{5}$ :

A Nação vem a ser, em suma, um plano de vida, uma linha de conduta coletiva, uma identidade de crença, costumes, tradições, aspirações, ideais, reivindicações, ao redor dos quais, determinada coletividade humana faz a sua historia, vive o presente por já ter vivido o passado e viverá o futuro pelas mesmas aspirações que a impelem a preservar-se como tal. São laços de solidariedade, vínculos de aproximação cultural, quase toda uma consciência global nos destinos sociais; aquela coesão interna que cifra no passado um núcleo de reminiscências e sugestões validas, de experiência renovada no presente, intentando projetar-se de forma independente ou autônoma para o futuro, enfim, um sentimento de inquebrantável solidariedade, operado por larga convivência em comum e por imperativo de adesão aos valores e padrões culturais da coletividade. Quando nós descobrimos no meio social a presença amadurecida dessa consciência, podemos dizer que aí esta a Nação, a nacionalidade. Cada um desses fatores já perquiridos, a língua, a religião, a raça pode concorrer com maior ou menor importância ou intensidade para que esta consciência se forme, se avigore, se venha a estruturar definida numa concreção autônoma.

Qual desses elementos - língua, religião, raça - se afigura de maior importância? A língua. Porque a língua é instrumento de comunicação, na verdade o meio de que o homem melhor se serve para comunicar ideias, sentimentos e formas de pensar, estabelecendo o diálogo, e, através do diálogo, dando resposta e solução aos problemas do presente.

Enquanto muitos povos abrasileiraram-se pelo convívio mútuo, apesar de conservarem muitas vezes a língua da pátria mãe e varias de suas tradições e costumes originais, convencionou-se a se chamar esses povos bastante diversificados na origem, de "cultura nacional", participantes de uma mesma sociedade industrial moderna, que mesclada, é "a brasileira”.

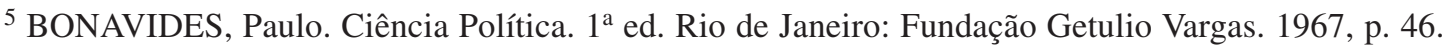


Outros se vêm como povos ainda realmente diferentes, de peculiaridades únicas, como é o caso dos indígenas, sociedades as quais tem o direito de se autodeterminarem enquanto nações ${ }^{6}$ diferenciadas, social e culturalmente, apesar de se sentirem e serem realmente, sua "segunda" nacionalidade, também brasileiros.

Sobre o assunto, comenta o antropólogo Rinaldo Arruda, em seu artigo "Imagens do Índio: Signos da Intolerância"7:

O Estado e os governos que tem representado os povos indígenas relutam em aceitar a realidade pluricultural e multiétnica da sociedade brasileira. As sociedades indígenas têm sido vistas como um problema de segurança nacional e como entraves ao progresso (ARRUDA:2001:46).

A ocupação pelos indígenas de seus territórios desde sempre foi e é ainda, o tema central, o "pano de fundo", para o qual converge toda a problemática, no que concerne a disputa por terceiros, sejam eles provenientes de instancia publica ou privada, desses territórios para convertêlos em parte do território capitalista mundial. Assim o conceito de território é fundamental nesta discussão.

O geógrafo Wanderley Messias da Costa em sua Tese de Doutorado denominada “Geografia Política e Geopolítica. Discursos sobre o território e o poder"8 assim reflete sobre o conceito de território. Antes porém, lembro de início, que se voltará a discutir esse conceito mais a frente nesta tese.

Estão em questão processos sociais reais que se desenvolvem no amplo quadro de relações que se estabelecem entre a sociedade e o espaço ao longo do desenvolvimento histórico (...) (1990:17).

(...) toda sociedade, em qualquer tempo e lugar, define formas particulares de relações com o seu espaço de vivencia e produção; em outras palavras valoriza-o ao seu modo; (1990:18).

Toda sociedade que delimita um espaço de vivencia e produção, delimita ao mesmo tempo um espaço político, uma dada projeção territorializada das suas relações econômicas, sociais, culturais e políticas (1990:21).

\footnotetext{
${ }^{6}$ Historicamente têm causado "arrepios" aos militares, denominar as sociedades indígenas, de nações indígenas, como se elas fossem uma ameaça à integridade territorial do Estado nacional, dado que elas pudessem se constituir em Estados separados e diferenciados do Brasil, questão essa, fora de cogitação.

${ }^{7}$ ARRUDA, Rinaldo S. V. Imagens do Índio: Signos da Intolerância. In: Grupioni, L.D.B., VIDAL. L., FISCHMANN, R. (orgs). Povos Indígenas e Tolerância: construindo praticas de respeito e solidariedade. São Paulo: EDUSP, 2001.

${ }^{8}$ COSTA, Wanderley Messias da. Geografia Política e Geopolítica. Discursos sobre o território e o poder. Tese de Doutorado. Departamento de Geografia Humana. FFLCH/USP. São Paulo, 1990. 477p
} 
O geógrafo Costa, argumenta a respeito do que significa o território para os povos indígenas:

Uma estrutura de domínio no que se refere às relações territoriais, que se expressa no sentimento tribal como língua comum, cultura comum e território comum; não são manifestações de propriedades, mas de apropriação de um espaço de vivencia e recursos, um espaço ecológico territorializado (1990:20).

Diante da histórica "fragilidade cultural” dos povos indígenas, em não dominar claramente as regras, noções, conceitos, acessos políticos etc, da sociedade nacional majoritária, na história do Brasil e do mundo, os povos autóctones vem pagando um preço alto, muitas vezes com a própria vida, na luta por manter seus territórios, ou melhor, as terras a que foram confinados.

Contextualizando a questão em termos fundiários, há nesta região do Cone Sul, como vimos, superposições entre o território histórico dos indígenas Guarani e as parcelas território capitalista historicamente convertidos nos Estados que foram se sucedendo e modificando suas fronteiras nacionais de contato, ampliando-a ou reduzindo-a conforme o caso.

Os povos indígenas originalmente são povos sem organização de Estado. A partir da colonização passaram a estar submetidos aos Estados Nacionais a que passaram a estar inseridos.

No caso tratado, os Guarani, povos que imemorialmente habitavam um grande território localizado no Cone Sul da America Latina, o Tekoa Guassu, já descrito anteriormente, passaram a estar submetidos, no inicio da colonização, às Coroas de Espanha e Portugal. Ao longo da história, na região que hoje é a Tríplice Fronteira, ela inicialmente se constituiu como parte da porção espanhola de território capitalista mundial, mais tarde como parcela da Província do Paraguai, e mais tarde ainda, como região subdividida entre os Estados Nacionais, Brasil, Paraguai e Argentina, como vimos, em capítulos anteriores.

Somente a partir da década de 40 do século XX, o oeste paranaense passou a ser ocupado de fato por povos considerados "brasileiros", apesar de ser oficialmente já considerado domínio jurídico do Brasil. Anteriormente a essa época, índios Guarani ocupavam essa fração do território em ambos os lados da fronteira, e povos paraguaios e argentinos exploravam a erva-mate, juntamente com os Guarani que às colhiam, em toda a região da Tríplice Fronteira, inclusive no lado que se encontra hoje, o oeste paranaense.

Dessa forma o governo brasileiro da época viu a necessidade de ocupar com população "brasileira" (embora à época, tenha sido ocupado por brasileiros, foi também ocupado por imigrantes de outras nacionalidades italianos, alemães, poloneses e ucranianos), uma parcela do território que corria risco de ser incorporado por argentinos e paraguaios. Assim, como por outros Estados Nacionais. 
Com relação à questão voltada aos indígenas, o território que os Guarani consideram como seu próprio, o Tekoa Guassu, apesar de não ser mais ocupado por eles de forma exclusiva em toda a sua extensão, ele transborda os limites dos Estados Nacionais, que foram impostos a eles, no decorrer da historia da colonização. Portanto, a identidade Guarani ela é supranacional, ela é, antes de qualquer coisa, Guarani, que vivem hoje em solo brasileiro, argentino e paraguaio, para ficarmos somente na região de foco de nosso estudo.

Dessa forma as fronteiras entre esses países, criada posteriormente a ocupação primeira dos Guarani, para eles próprios, ela não tem muito significado, aqui, como acolá, sempre foram terras ocupadas por eles; até então, a fronteira sempre foi porosa à ida e vinda dos Guarani, que ali desde sempre habitaram.

Diante dessas colocações, se faz necessário que se discuta os conceitos de Estado, território, território do Estado, e, de fronteira.

Vejamos o conceito de Estado, sob a visão do direito, da economia e da geografia.

Segundo o eminente jurista Dalmo Dallari, em seu livro "Elementos de Teoria Geral do Estado"9, ele apresenta a seguinte definição de Estado:

Estado. A ordem jurídica soberana que tem por fim o bem comum de um povo situado em determinado território. Nesse conceito se acham presentes todos os elementos que compõem o Estado, e só esses elementos. A noção de poder está implícita na de soberania, que, no entanto, é referida como característica da própria ordem jurídica. A politicidade do Estado é afirmada na referencia expressa ao bem-comum, com a vinculação deste a um certo povo e, finalmente, a territorialidade, limitadora da ação jurídica e política do Estado, está presente na menção a determinado território.

Esta definição nos parece proveniente da visão da "social-democracia"; talvez o que Dallari expôs é o que ele gostaria que o Estado fosse, ou ainda, que seus alunos devam aprender o que o Estado “deveria ser", porém, não consideramos que seja realmente o que o Estado representa.

Segundo outro eminente jurista, Paulo Bonavides, em seu livro "Ciência Politica"10 ele afirma sobre o conceito de Estado:

O emprego moderno do nome Estado remonta a Maquiavel, quando este inaugurou o Príncipe com a frase celebre: “Todos os Estados, todos os domínios que tem tido ou tem império sobre os homens são Estados, e são republicas ou principados”. (1967:36)

\footnotetext{
${ }^{9}$ DALLARI, Dalmo de Abreu. Elementos de Teoria Geral do Estado. 29a ed. São Paulo: Saraiva, 2010. 314 p., p. 119.

${ }^{10}$ BONAVIDES, Paulo. Ciência Política. $1^{a}$ ed. Rio de Janeiro: Fundação Getulio Vargas. 1967. 339 p.
} 
Em seguida ele tece uma serie de comentários à respeito das várias visões de Estado:

Há pensadores que intentam caracterizar o Estado segundo posição predominantemente filosófica; outros realçam o lado jurídico e, por ultimo, não faltam aqueles que levam mais em conta a formulação sociológica de seu conceito. (1967:36)

Optamos por apresentar a visão sociológica, que Bonavides expõe:

A posição sociológica de Duguit com respeito ao Estado não varia consideravelmente da de Oppenheimer. Considera o Estado coletividade que se caracteriza apenas por assinalada e duradoura diferenciação entre fortes e fracos, onde os fortes monopolizam a força, de modo consciente e organizado. (DUGUIT. L’État, I, Paris, 1901, p 615-6);

Define o Estado, em sentido geral, como toda sociedade humana na qual há diferenciação entre governantes e governados, e, em sentido restrito, como "grupo humano fixado em determinado território, onde os mais fortes impõem aos mais fracos sua vontade". (DUGUIT. Manuel de Droit Constitutionnel, Quatrième édition, Paris, 1923, p 14-5).

Do mesmo cunho sociológico, é o conceito marxista de Estado. Marx e Engels explicam o Estado como fenômeno histórico, passageiro, oriundo da aparição da luta de classes na Sociedade, desde que, da propriedade coletiva se passou à apropriação individual dos meios de produção. Instituição, portanto, que nem sempre existiu e que nem sempre existirá. Fadado a desaparecer, o poder político, como Marx o definiu, é “o poder organizado de uma classe para a opressão da outra”. (MARX. Das Kommunistisches Manifest. In: Die Fhrueschriften. Stuttgart, 1953, p. 548). (1967:38).

Da mesma forma, assinala Engels que a presente Sociedade, como Sociedade de classes, não pode dispensar o Estado, isto é, "uma organização da respectiva classe exploradora para manutenção de suas condições externas de produção, a saber, para a opressão violenta das classes exploradas". (ENGELS. Die Entwicklung des Sozialismus von der Utopie zur Wissenschaft. Frankfurt, 1946, p. 41). (1967:39).

Assim Bonavides, apresenta entre outras visões, uma visão marxista do Estado.

A visão do economista, o Professor Luiz Carlos Bresser Pereira, em seu livro "Estado e subdesenvolvimento industrializado" 11 , assim conceitua o que considera ser o Estado:

O Estado é uma parte da sociedade. É uma estrutura jurídica e organizacional que se sobrepõe a ela, dela fazendo parte. Quando determinado sistema social passa a produzir um excedente econômico,

\footnotetext{
${ }^{11}$ BRESSER PEREIRA, Luiz Carlos. ESTADO e subdesenvolvimento industrializado. São Paulo: Brasiliense, 1977. $420 \mathrm{p}$.
} 
a sociedade divide-se em classes. Para que a classe dominante que então surge tenha condições políticas de exercer seu domínio e apropriar-se do excedente econômico ela institucionaliza o Estado. A partir desse momento a sociedade, além de ser dividida em classes, passa a se compor de uma sociedade civil e do Estado. (1977:75)

Em seguida ele lança mão da definição de Engels:

Observa assim Engels: “O Estado não é, pois, de modo algum, um poder que se impôs à sociedade de fora para dentro; tampouco é a 'realidade da ideia moral', nem a 'imagem e a realidade da razão' como afirma Hegel. É, antes, um produto da sociedade quando esta chega a determinado grau de desenvolvimento; é a confissão que essa sociedade se enredou numa irremediável contradição com ela própria e esta dividida por antagonismos irreconciliáveis que não consegue conjurar. Mas para que esses antagonismos, essas classes com interesses econômicos colidentes não se devorem e não se consumam a sociedade em uma luta estéril, faz-se necessário um poder colocado aparentemente acima da sociedade, chamado a amortecer o choque e a mantê-lo dentro dos limites da 'ordem'. Este poder, nascido da sociedade, mas posto acima dela, e dela se distanciando cada vez mais, é o Estado" (ENGELS, Friedrich. A Origem da Família, da Propriedade e do Estado. (primeira edição alemão 1884) Rio de Janeiro: Vitoria, 1964, p. 135-6). (1977:75-6)

Neste texto clássico Engels resume a origem do Estado e ao mesmo tempo o conceitua: trata-se de um poder, ou seja, de uma estrutura organizacional destinada a manter a ordem dentro da sociedade, ou seja, a manter o sistema de classes vigentes. Nestes termos Engels acrescenta: "Como o Estado nasceu da necessidade de conter o antagonismo das classes, e como, ao mesmo tempo, nasceu em meio ao conflito delas, é, por regra geral, o Estado da classe mais poderosa, da classe economicamente dominante, classe que por intermédio dele se converte também em classe politicamente dominante e adquire novos meios para a repressão e exploração da classe oprimida" (ENGELS, Friedrich. A Origem da Família, da Propriedade e do Estado. (primeira edição alemão 1884) Rio de Janeiro: Vitoria, 1964, p. 137. (1977:76).

Bresser Pereira informa ainda sobre como o Estado se estrutura:

O Estado é assim uma estrutura de dominação, é um poder estruturado e organizado, que permite à classe economicamente dominante tornar-se também politicamente dominante e assim garantir para si a apropriação do excedente. São seus elementos constitutivos: a) uma elite política, que geralmente se confunde com a própria classe dominante e nela se recruta; b) uma burocracia ou tecnoburocracia, ou seja, de um corpo de funcionários hierarquicamente organizados, que se ocupa da administração; e, c) uma força publica, que se destina não apenas a defender o país contra o inimigo externo, mas 
principalmente a manter a ordem interna. Por outro lado, essa estrutura de poder assim estruturada dispõe ainda do monopólio da violência institucionalizada, que se traduz em dois direitos ou poderes básicos: a) o poder de estabelecer leis, de montar um ordenamento jurídico impositivo que obrigue coercitivamente os cidadãos; e b) o poder de tributar. Finalmente, o Estado exerce seu poder ou soberania sobre um ambiente que o circunda e do qual faz parte, constituído por (a) um território e (b) uma população. Território e população não são elementos constitutivos do Estado, mas objetos sobre os quais se exerce a soberania estatal. (1977:76)

\section{Por fim Bresser Pereira sintetiza da seguinte forma:}

O Estado é, portanto, uma estrutura de dominação, constituída de uma elite dirigente, de uma burocracia e de uma força publica, dotado de poder de legislar e tributar, estrutura através da qual a classe dominante no plano econômico torna-se também dominante no plano político, e assim se assegura da apropriação do excedente. O controle do Estado e a apropriação do excedente mantêm entre si uma relação dialética. Determinada classe é dominante não apenas porque controla os fatores de produção mas também porque controla o Estado. O controle do Estado reforça o seu controle sobre os meios de produção e vice-versa. Por outro lado, a apropriação do excedente daí resultante também reforça a posição da classe dominante. (1977:76-7)

Essa estrutura de dominação, que é o Estado, constitui-se na superestrutura jurídico-institucional da sociedade. Em cada modo de produção, definido em termos de suas relações de produção e do grau de desenvolvimento das forças produtivas, temos uma correspondente superestrutura jurídico-institucional, da qual o Estado é o elemento fundamental. Esta superestrutura jurídico-institucional, mais a superestrutura ideológica, irão garantir e legitimar as relações de produção vigente, assegurando à classe ou às classes dominantes sua posição na estrutura social (1977:77).

\section{Sobre a relação entre Estado e Sociedade Civil, Bresser Pereira assim afirma:}

O caráter mais ou menos democrático do sistema social fará com que a população do Estado se transforme ou não em povo, ou seja, no conjunto de cidadãos com direitos políticos efetivos.(...). O Estado é uma estrutura organizada de poder, constituída de uma elite política, de um corpo de funcionários e de uma força publica, a qual exerce o poder de tributar e legislar sobre a população de determinado território. Nestes termos, o Estado distingue-se claramente do povo, sobre o qual exerce poder e do qual deriva, em menor ou maior grau, o mesmo poder. (1977:77)

O Estado surge da dissolução da comunidade primitiva e da formação da sociedade de classes. Através da historia, sua função básica será sempre a de garantir a apropriação do excedente econômico para as classes dominantes, e em seguida estabelecer as regras básicas para a divisão desse excedente no seio 
da classe dominante. Para realizar essa tarefa ele revestir-se-á de formas mais ou menos autoritárias e intervirá no sistema econômico em maior ou menor grau. (...) A ponte formal entre a sociedade civil e o Estado, nos Estados modernos, será representada pelos partidos políticos. (1977:77-8)

(...) O Estado é, assim, um sistema de poder organizado que se relaciona dialeticamente com outro sistema de poder difuso, mas efetivo - a sociedade civil. A sociedade civil, é, em ultima analise, a forma pela qual a classe dominante (ou as classes dominantes) se organiza(m) fora do Estado para controlá-lo e pô-lo ao seu serviço. A sociedade civil não se confunde, portanto, com a população ou com o povo. O Estado exerce seu poder sobre a sociedade civil e sobre o povo. Por outro lado, a sociedade civil é uma fonte de poder do Estado e ao mesmo tempo estabelece limites e condicionamentos para o exercício desse poder. (1977:78)

Para o geógrafo Claude Raffestin, em seu livro "Por uma geografia do poder" a definição de Estado é assim expressa:

Para Ratzel, o elemento fundador, formador do Estado, foi o enraizamento no solo de comunidades que exploraram as potencialidades territoriais. (1993:13)

Se há um conceito sobre o qual os geógrafos concordam é com certeza a de definição de Estado: "O Estado existe quando uma população instalada num território exerce a própria soberania". Portanto, três sinais são mobilizados para caracterizar o Estado: a população, o território e a autoridade. Toda a geografia do Estado deriva dessa tríade (1993:22-3).

Assim, após todas estas exposições, pode-se concluir como o discurso jurídico, legitima a ordem jurídico-institucional do Estado, o qual, ele mesmo, é produto da organização das classes dominantes.

Vejamos o conceito de território, sob a visão do direito e da geografia.

Dallari, no mesmo livro citado, "Elementos de Teoria Geral do Estado", afirma que o Território é o espaço ao qual se circunscreve a validade da ordem jurídica estatal (2010:87). Ele também cita Ranelletti: O território é o espaço dentro do qual o Estado exerce seu poder de império. Este poder se exerce sobre tudo, pessoas e coisas, que se encontre no território (RANELLETTI, Oreste. Instituzioni di Diritto Pubblico. Parte Geral. Milão: Ed Giuffrè, 1955. P55-6). (2010:88)

Assim Dallari considera o território, fundamentalmente como sendo, o território do Estado.

O geógrafo Claude Raffestin, define território da seguinte forma. Na introdução de seu livro, "Por uma geografia do poder", o geógrafo já demonstra como a questão da formação de 
qualquer que seja o território, ele está intrinsecamente ligado à questão do poder, que os homens atribuem a si próprios, ao se estabelecer em um território:

A geografia humana consiste em explicitar a consciência do conhecimento e da pratica que os homens têm dessa realidade, que é denominada "espaço". Explicitar o conhecimento e a pratica que os homens têm das coisas é, involuntariamente, desnudar o poder que esses mesmos homens se atribuem ou procuram se atribuir sobre os seres e as coisas. O poder não é uma categoria nem espacial nem uma categoria temporal, mas está presente em toda "produção" que se apoia no espaço e no tempo. O poder não é fácil de ser representado, mas é, contudo, decifrável. Falta-nos somente saber fazê-lo, ou então poderíamos sempre reconhecê-lo. (RAFFESTIN:1993:6) (grifo nosso)

O território(...), não poderia ser nada mais que o produto dos atores sociais. São esses atores que produzem o território, partindo da realidade inicial dada, que é o espaço. Há, portanto, um "processo" do território, quando se manifestam todas as espécies de relações de poder, que se traduzem por malhas, redes e centralidades cuja permanência é variável, mas que constituem invariáveis na qualidade de categorias obrigatórias. O território é também um "produto" consumido, ou, se preferirmos, um produto vivenciado por aqueles mesmos personagens que, sem haverem participado de sua elaboração, o utilizam como meio. É então todo o problema da territorialidade que intervém permitindo verificar o caráter simétrico ou dissimétrico das relações de poder. A territorialidade reflete, com muita segurança, o poder que se dá ao consumo por intermédio de seus "produtos". (1993:7/8) (grifo nosso)

É importante ressaltar no processo de construção do território, o que visa o poder, na visão de Raffestin:

O poder visa o controle e a dominação sobre os homens e as coisas. Pode-se retomar aqui a divisão tripartida em uso na geografia política: a população, o território e os recursos.

Na população residem as capacidades virtuais de transformação; ela constitui o elemento dinâmico de onde precede a ação.

O território é a cena do poder e o lugar de todas as relações, mas sem a população, ele se resume a apenas uma potencialidade, um dado estático a organizar e a integrar numa estratégia.

Os recursos determinam os horizontes possíveis da ação. Os recursos condicionam o alcance da ação. Uma relação pode privilegiar um dos trunfos: a população, o território ou os recursos. De fato eles sempre são mobilizados simultaneamente em diversos graus. O conflito de dois Estados pela posse de uma região não é apenas um conflito pela aquisição de um pedaço de território, mas também pelo que ele contém de população e/ou de recursos. (1993:58) 
Transpondo para o tema desta tese: O poder de Estado na região da Tríplice Fronteira, por meio dos Grandes Projetos implementados, Itaipu Binacional (1973) e Parque Nacional do Iguaçu (1939), pretendeu dominar e controlar a região da Tríplice Fronteira: Quanto à população: Ocorreu o esbulho dos Guarani de grande parte do território que ocupavam e sua substituição por população “brasileira”, preferencialmente branca, na região do oeste paranaense, que irá exercer uma economia de mercado, capitalista. Quanto ao território capitalista em formação: a estratégia de interesses no território Guarani foi ocupá-lo efetivamente com população "brasileira" (branca), estabelecer os Grandes Projetos, gerar energia e atrair turismo, marcar presença e controlar a fronteira e os Estados vizinhos, ampliar a economia capitalista, no interior do território Guarani. Quanto aos recursos: no caso os recursos, que em sua maioria eram de posse dos Guarani, que deles foram esbulhados, para dar lugar aos Grandes Projetos: As águas para Itaipu gerar energia e estabelecer o controle de Estado na fronteira, as águas do Parque para atrair turistas para as Cataratas do Iguaçu, e gerar renda, as terras extremamente férteis, para plantio de monoculturas de soja e trigo para os agricultores (brancos) capitalizarem, ao colocar seus produtos na economia de mercado agroexportadora e no mercado interno.

Continua Raffestin:

Qualquer organização é caracterizada por seres e coisas, seja porque os possui, os controla ou os domina. (1993:59)

O território é um trunfo particular, recurso e entrave, continente e conteúdo, tudo ao mesmo tempo. O território é o espaço político por excelência, o campo de ação dos trunfos. (1993:59/60)

Ainda Raffestin, no mesmo livro citado, na “Terceira Parte. O Território e o Poder. Capítulo I. O que é o território? I- Do espaço ao território.” ele conceitua mais detalhadamente a noção de território:

É essencial compreender bem que o espaço é anterior ao território. O território se forma a partir do espaço, é o resultado de uma ação conduzida por um ator sintagmático (ator que realiza um programa) em qualquer nível. Ao se apropriar de um espaço, concreta ou abstratamente (por exemplo, pela representação), o ator "territorializa" o espaço. Lefebvre mostra muito bem como é o mecanismo para passar do espaço ao território: “A produção de um espaço, o território nacional, espaço físico, balizado, modificado, transformado pelas redes, circuitos e fluxos que aí se instalam: rodovias, canais, estradas de ferro, circuitos comerciais e bancários, auto-estradas e rotas aéreas etc.”. $\underline{\mathrm{O}}$ território, nessa perspectiva, é um espaço onde se projetou um trabalho, seja energia e informação, 
e que, por consequência, revela relações marcadas pelo poder. $\mathrm{O}$ espaço é a "prisão original", o território é a prisão que os homens constróem para si. (1993:143/144) (grifos nossos)

O espaço é, portanto, anterior, preexistente a qualquer ação. O espaço é, de certa forma, "dado" como se fosse uma matéria-prima. Preexistente a qualquer ação. "Local" de possibilidades é a realidade material preexistente a "qualquer conhecimento e a qualquer prática dos quais será o objeto a partir do momento em que um ator manifeste a intenção de dele se apoderar. Evidentemente, o território se apoia no espaço, mas não é o espaço. É uma produção, a partir do espaço. Ora, a produção, por causa de todas as relações que envolve, se inscreve num campo de poder. Produzir uma representação do espaço já é uma apropriação, uma empresa, um controle portanto, mesmo se isso permanece nos limites de um conhecimento. Qualquer projeto no espaço que é expresso por uma representação revela a imagem desejada de um território, de um local de relações.

Todo projeto é sustentado por um conhecimento e uma prática, isto é, por ações e/ou comportamentos que, é claro, supõem a posse de códigos, de sistemas sêmicos. É por esses sistemas sêmicos que se realizam as objetivações do espaço, que são processos sociais. É preciso, pois, compreender que o espaço representado é uma relação e que suas propriedades são reveladas por meio de códigos e de sistemas sêmicos. Os limites do espaço são os do sistema sêmico mobilizado para representá-lo. Unimo-nos aqui ao pensamento de Wittgenstein ("The limits of my language mean the limits of my world").(1993:144).

Sobre as políticas territoriais dos Estados, Raffestin afirma:

Na sua vontade de atingir o mar, de preservar o acesso às rodovias, de implantar cidades, de fazer coincidir uma fronteira com uma linha de cristas ou um rio, os Estados modularam suas políticas segundo uma axiomática não claramente assumida, mas bem presente e bem real. (1993: 146)

A representação proposta aqui é, portanto, um conjunto definido em relação aos objetivos de um ator. Não se trata pois do "espaço", mas de um espaço construído pelo ator, que comunica suas intenções e a realidade material por intermédio de um sistema sêmico. Portanto, o espaço representado não é mais o espaço, mas a imagem do espaço, ou melhor, do território visto e/ou vivido. É, em suma, o espaço que se tornou o território de um ator, desde que tomado numa relação social de comunicação. (1993: 147)

Por exemplo, está bastante claro a proteção da fronteira oeste do Paraná, pelo Estado brasileiro. Inicialmente com a criação do Território Federal do Iguaçu, o Estado pretendeu tamponar essa área (extremo oeste do Paraná e Santa Catarina), através de um domínio jurídico, em relação aos Estados vizinhos, Paraguai e Argentina. Dada a sua curta duração, em seguida o Estado 
criou na mesma região dois Grandes Projetos, o Parque da Ilha Grande e a Itaipu Binacional, o Estado fechou assim, as comunicações terrestres, respectivamente com o Mato Grosso do Sul e com o Paraguai, tendo como passagem de comunicação terrestre entre os dois projetos, no fim do Parque e no começo da hidrelétrica, o município de Guaíra/BR e Saltos Del Guaira/PY; e, ao sul, ao fim da hidrelétrica, a cidade de Foz do Iguaçu, na qual foram estabelecidas duas pontes com os Estados Nacionais vizinhos; a Ponte da Amizade/Brasil-Paraguai e a Ponte Internacional da Fraternidade (oficialmente Ponte Tancredo Neves)/Brasil-Argentina, nas quais foram estabelecidas controle alfandegário, sendo as duas fronteiras legais, fiscais e de controle. Dessa ultima forma o Estado passou a exercer o domínio econômico sobre a região.

É interessante observar como Raffestin conceitua a formação do sistema territorial. A definição encontra-se no mesmo livro citado, na "Terceira Parte. O Território e o Poder. Capítulo I. O que é o território? II- O sistema territorial":

Toda pratica espacial, mesmo embrionária, induzida por um sistema de ações ou de comportamentos se traduz por uma "produção territorial" que faz intervir tessitura, nó e rede. É interessante destacar a esse respeito que nenhuma sociedade, por mais elementar que seja, escapa à necessidade de organizar o campo operatório de sua ação (1993:150).

Os indivíduos ou os grupos ocupam pontos no espaço e se distribuem de acordo com modelos que podem ser aleatórios, regulares ou concentrados. São, em parte, respostas possíveis ao fator distancia e ao seu complemento, a acessibilidade. Sendo que a distancia pode ser apreendida em termos espaciais (distancia física ou geográfica), temporais, psicológicos ou econômicos. A distancia se refere a interação entre os diferentes locais. Pode ser uma interação política, econômica, social e cultural que resulta de jogos de oferta e procura, que provém dos indivíduos e/ou dos grupos. Isso conduz a sistemas de malhas, de nós e redes que se imprimem no espaço e que constituem, de algum modo, o território. Não somente se realiza uma diferenciação funcional, mas ainda uma diferenciação comandada pelo principio hierárquico, que contribui para ordenar o território segundo a importância dada pelos indivíduos e/ou grupos às suas diversas ações (1993:150/151).

Esses sistemas de malhas, de nós e redes organizadas hierarquicamente permitem assegurar o controle sobre aquilo que pode ser distribuído, alocado e/ou possuído. Permitem ainda impor e manter uma ou varias ordens. Enfim, permitem realizar a integração e a coesão dos territórios. Esses sistemas constituem o invólucro no qual se originam as relações de poder. Tessituras, nós e redes podem ser muito diferentes de uma sociedade para outra, mas estão sempre presentes. Quer sejam formadas a partir do principio da propriedade privada ou coletiva, nós os encontramos em todas as praticas espaciais. Se insistimos nesse fato é porque estamos em presença, sem duvida nenhuma, de "universais" ou de invariáveis propriamente geográficas (1993:151). 
A partir daí, é possível construir uma matriz que justifique esse conjunto estrutural que toma, uma vez exteriorizado, uma infinidade de imagens (1993:151).

As "imagens" territoriais revelam as relações de produção e consequentemente as relações de poder, e é decifrando-as que se chega a estrutura profunda. Do Estado ao individuo, passando por todas as organizações pequenas ou grandes, encontram-se atores sintagmáticos que "produzem" o território. De fato, o Estado esta sempre organizando o território nacional por intermédio de novos recortes, de novas implantações e de novas ligações. O mesmo se passa com as empresas ou outras organizações, para as quais o sistema precedente constitui um conjunto de fatores favoráveis ou limitantes (1993:152).

Essa produção de território se inscreve perfeitamente no campo do poder de nossa problemática relacional. Todos nós combinamos energia e informação, que estruturamos com códigos em função de certos objetivos. Todos nós elaboramos estratégias de produção, que se chocam com outras estratégias em diversas relações de poder (1993:152/153).

Quando o geógrafo é posto diante de um sistema territorial, ele descobre uma produção já elaborada, já realizada. Produção suscetível de mudanças, contudo suficientemente fixa para ser analisada.

Falar de território é fazer uma referencia implícita à noção de limite que, mesmo não sendo traçado, como em geral ocorre, exprime a relação que um grupo mantêm com uma porção do espaço. A ação desse grupo gera, de imediato, a delimitação. Sendo a ação sempre comandada por um objetivo, este é também uma delimitação em relação a outros objetivos possíveis.

Delimitar é, pois, isolar ou subtrair momentaneamente ou, ainda, manifestar um poder numa área precisa. $\mathrm{O}$ desenho de uma malha ou um conjunto de malhas é a consequência de uma relação com o espaço e, por conseguinte, a forma mais elementar da produção de território (1993:153).

A definição que consideramos mais completa do conceito de território é a do geógrafo Ariovaldo Umbelino Oliveira. Em artigo denominado a "A Geografia Agrária e as transformações territoriais recentes no campo brasileiro" ${ }^{12}$, ele situa o termo concretamente em sua atualidade histórica, demonstrando a lógica da construção do território sob o modo de produção em vigor, o capitalista:

Meus trabalhos refletem essa corrente que tem no estudo do território o tema central da investigação na geografia. Sigo autores como Lefèbvre, Calabi e Endovina, Raffestin, Gottdiner, Coraggio, Quaini, Chesnais e Lacoste, entre outros. Parto da concepção de que o território deve ser apreendido como síntese contraditória, como totalidade concreta do processo/modo de produção/distribuição/circula-

$\overline{12}$ OLIVEIRA, Ariovaldo Umbelino. A Geografia Agrária e as transformações territoriais recentes no campo brasileiro. p. 63 a 110. In: FANI, A., CARLOS, A.,(orgs). Novos Caminhos da Geografia. São Paulo: Contexto, 1999. 
ção/consumo e suas mediações e articulações supraestruturais (políticas, ideológicas, simbólicas etc) em que o Estado desempenha a função de regulação. $\underline{\text { O território é assim produto concreto da }}$ $\underline{\text { luta de classes travada pela sociedade no processo de produção de sua existência. Sociedade capita- }}$ lista que esta assentada em três classes sociais fundamentais: proletariado, burguesia e proprietários de terra (1999:74) (grifo nosso).

O processo de construção do território é simultaneamente construção/destruição/manutenção/transformação. Em síntese, é a unidade dialética, portanto contraditória, da espacialidade que a sociedade tem e desenvolve. Logo, a construção do território é contraditoriamente o desenvolvimento desigual, simultâneo e combinado, o que quer dizer: valorização, produção e reprodução (1999:74/75). A lógica do desenvolvimento do modo capitalista de produção é gerada pelo processo de produção propriamente dito (reprodução ampliada/extração da mais-valia/produção do capital/extração da renda da terra), circulação, valorização do capital e reprodução da força de trabalho. É essa lógica contraditória que constrói/destrói formações territoriais em diferentes partes do mundo ou faz com que frações de uma mesma formação territorial conheçam processos desiguais de valorização, produção e reprodução do capital, conformando as regiões. Trabalhamos com o principio contraditório de que ao mesmo tempo que o capital mundializou-se, mundializando o território capitalista, a terra nacionalizou-se. A partir desta contradição nasce a possibilidade histórica do entendimento das diferentes formações territoriais e das regiões como territorialidades concretas, portanto totalidades históricas, da espacialização contraditória do capital (produção/reprodução ampliada) e suas articulações com a propriedade fundiária, ou seja, a terra. Volto a insistir que o capital, em sua essência, é internacional, porém, a lógica que envolve a terra é essencialmente nacional (1999:75). Vejamos o conceito de território do Estado, sob a visão do direito.

Tanto Dallari quanto Bonavides compartilham a mesma visão de território do Estado, dado que o primeiro cita as concepções do segundo, em seu livro "Elementos de Teoria Geral do Estado":

Quatro concepções fundamentais sobre o território do Estado:

Território-patrimônio, característica do estado Medieval e com alguns reflexos em teorias modernas. Essa teoria não faz diferenciação entre imperium e dominium, concebendo o poder do Estado sobre o território exatamente como o direito de qualquer proprietário sobre um imóvel.

Território-objeto, que é a que concebe o território como objeto de um direito real de caráter público. Embora com certas peculiaridades, a relação do Estado com seu território é sempre e tão só uma relação de domínio.

Território-espaço, teoria segundo a qual o território é a extensão espacial da soberania do Estado. A base dessa concepção é a ideia de que o Estado tem um direito de caráter pessoal, implícito na 
ideia de imperium. Alguns adeptos dessa orientação chegam a considerar o território como parte da personalidade jurídica do Estado, propondo mesmo a expressão território-sujeito.

Território-competência, teoria defendida sobretudo por Kelsen, que considera o território o âmbito de validade da ordem jurídica do Estado.(BONAVIDES, Paulo. Ciência Politica. Rio de Janeiro: Ed FGV, 1967, p. 50-8). (2010:89)

\section{Dallari somente, continua:}

Sintetizando todos os aspectos fundamentais que tem sido objeto de considerações teóricas, podemse estabelecer algumas conclusões de caráter geral, sobre as quais se pode dizer que praticamente não há divergência:

a) Não existe Estado sem território. No momento mesmo de sua constituição o Estado integra num conjunto indissociável, entre outros elementos, um território, de que não pode ser privado sob pena de não ser mais Estado. A perda temporária do território, entretanto, não desnatura o Estado, que continua a existir enquanto não se tornar definitiva a impossibilidade de se reintegrar o território com os demais elementos. O mesmo se dá com as perdas parciais de território, não havendo qualquer regra quanto ao mínimo de extensão territorial.

b) O território estabelece a delimitação da ação soberana do Estado. Dentro dos limites territoriais a ordem jurídica do Estado é a mais eficaz, por ser a única dotada de soberania, dependendo de ela admitir a aplicação, dentro do âmbito territorial, de normas jurídicas provindas do exterior. Por outro lado, há casos em que certas normas jurídicas do Estado, visando diretamente à situação pessoal dos indivíduos, atuam além dos limites territoriais, embora sem a possibilidade de concretizar qualquer providência externa sem a permissão de outra soberania.

c) Além de ser elemento constitutivo necessário, o território, sendo o âmbito de ação soberana do Estado, é objeto de direitos deste, considerado no seu conjunto. Assim, é que caso haja interesse do povo, o Estado pode até alienar uma parte do território, como pode também, em circunstâncias especiais, usar o território sem qualquer limitação, até mesmo em prejuízo dos direitos de particulares sobre porções determinadas.

Em face destes aspectos é que se diz, em primeiro lugar, que a ordem jurídica estatal, atuando soberanamente em determinado território, está protegida pelo principio da impenetrabilidade, o que significa reconhecer ao Estado o monopólio de ocupação de determinado espaço, sendo impossível que no mesmo lugar e ao mesmo tempo convivam duas ou mais soberanias. Além disso, ressalte-se que o território tem uma significação jurídica negativa, enquanto exclui outras ordenações e cria para o Estado a obrigação de agir sempre que no seu âmbito se verifiquem certas circunstancias. E tem uma significação positiva, enquanto assegura ao Estado a possibilidade de agir soberanamente no seu campo de ação. (2010:89/90) 
Quanto ao conceito de território do Estado, sob a visão da geografia, veremos exemplificada aqui na prática, ao longo dos subcapítulos subsequentes, a visão geopolítica aplicada para a região da Bacia Platina, pelo Estado brasileiro.

Vejamos enfim, o conceito de fronteira, nas visões da geografia e da sociologia:

O geógrafo Demetrio Magnoli em seu livro "O que é geopolítica"13, começa por definir o significado de fronteira, como fronteira de Estado, e caracteriza-a como produto da história humana:

Fronteiras e países (...) são (...) construções da historia humana, resultado e expressão de processos sociais. Seu significado atual é fruto recente da história humana, com raízes fincadas na Europa pós-medieval, matriz dos Estados nacionais. (...) A dimensão planetária que adquiriram ainda é mais recente: liga-se à projeção colonial e imperialista dos Estados nacionais europeus, sobre todos os continentes, nos últimos quatro séculos. (...) Confrontados com mapas políticos, frequentemente perdemos de vista o caráter histórico das realidades que eles espelham. (...) Na prática cotidiana, insensivelmente naturalizamos esses fenômenos que são políticos. (MAGNOLI: 1988:8)

Magnoli define fronteira como limite, separação entre territórios Estatais diferentes, portanto soberanias diferentes, que possuem cada um, características especificas e singulares, relativas a sua própria historia de formação econômica, política e legal:

Mas o que são fronteiras... ? Limites terrestres, elas tem repercussões marítimas (o mar territorial) e aéreas (o espaço aéreo). São chamadas naturais quando oceanos, mares, montanhas, rios surgem como evidencias físicas de seu traçado, e artificiais quando unicamente representadas por linhas geodésicas. Em qualquer caso parecem cumprir uma função clara: separar territórios. Elas circunscrevem espaços, limitando-os. Isolam o "meu” do "teu”. Evidenciam empiricamente a existência de um espaço distinto dos outros que o rodeiam. Um território dotado de características singulares: uma determinada organização social da produção, distribuição e consumo de bens e serviços; - um regime político, consubstanciado em instituições particulares, tecido ao longo de uma historia comum; - um conjunto de leis, normas, regimentos e regulamentos que ordenam a existência do conjunto social em suas relações internas. (MAGNOLI: 1988:9)

Magnoli discute que, antes de separar pelo Estado, a fronteira une realidades diversas:

Fronteiras são a delimitação espacial do Estado, a sua evidencia territorial. Estado: a realidade

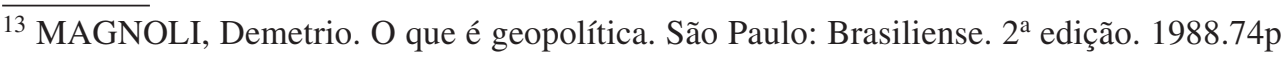


invisível que se eleva por trás dos espaços assimétricos visíveis no planisfério político, impropriamente chamados países.

Estados sempre souberam que as fronteiras, mais que linhas divisórias, são ponto de contato com o espaço exterior. Antes de separar, elas aproximam. Antes de segregar, viabilizam fluxos e influências. São superfícies porosas de contato do território estatal com outros territórios, outros Estados. Com outras realidades sociais, econômicas e políticas. Testemunhas da existência do Outro.

Segundo o geógrafo francês Jacques Ancel, "fronteira é uma isóbara política que fixa o equilíbrio entre duas pressões". Isóbara, em mapas e cartas, é a linha que separa áreas de pressão atmosférica diferente; ao longo de seu traçado, a pressão é constante. (MAGNOLI: 1988:10)

Raffestin ${ }^{14}$, demarca o conceito fronteira, como limite sagrado do Estado moderno:

Quando a fronteira se tornou um sinal? Tornou-se um sinal quando o Estado moderno atingiu um controle territorial "absoluto" e tornou unívoca a mensagem fronteira = limite sagrado. (RAFFESTIN: 1993:166)

A geógrafa Maria Lucia Torrecilha, em seu trabalho “A Gestão compartilhada como espaço de integração na fronteira. Ponta Porã (Brasil) e Pedro Juan Caballero (Paraguai)"15, discute o conceito de fronteira, ampliando seu significado, de limite para zona de fronteira, ainda no âmbito do Estado. Assim ela afirma sobre os vários aspectos do termo:

\section{Fronteira:}

a) Aspecto simbólico, cultural e formal da fronteira denominada de limites;

b) Aspecto como zona, uma área entre territórios diferentes, submetida a um regime jurídico, político, econômico especial de direito interno e de direito internacional;

c) Dimensões políticas e institucionais no Estado Moderno, a fronteira-linha, marcando a separação entre Estados-Nação e cumprindo um papel de instrumento para sua unificação ideológica;

d) Conceito de fronteira-zona, na contemporaneidade, privilegiam a integração e a interação entre essas áreas, muitas vezes contiguas entre países (...), do que a fratura e a fragmentação. (2010:37-8)

\footnotetext{
${ }^{14}$ RAFFESTIN, Claude. Por uma geografia do poder. Terceira Parte. O Território e o Poder. Capítulo II - As quadrículas do poder. I - Limites e fronteiras. 1993.

${ }^{15}$ TORRECILHA, Maria Lucia. A Gestão compartilhada como espaço de integração na fronteira. Ponta Porã (Brasil) e Pedro Juan Caballero (Paraguai). São Paulo: Relatório de Qualificação. Departamento de Geografia Humana/FFLCH/USP, 2010.
} 
Quanto a discussão de zona de fronteira, a geógrafa Torrecilha, discute o tema da seguinte forma:

O que é limite, linha ou zona de fronteira. Fronteira é linha ou zona. Pensar fronteira como zona amplia o seu conceito, pois nele estão embutidos os fatores comuns que podem ser culturais, sociais, físicos, geográficos, ambientais ou econômicos, aos Estados que pertencem. Com a instalação dos Estados modernos, a definição de fronteiras e limites foi fundamental para a estruturação das soberanias (...). (2010:63)

Em seguida ela nos oferece a visão de vários geógrafos à esse respeito, distinguindo limite e zona de fronteira:

Mattos (1990:7) considera limite a linha natural ou artificial que contorna o extremo do território físico do Estado. A fronteira é faixa contigua a linha limite; usualmente os Estados estabelecem a extensão desta faixa. (2010:64)

Machado (1988:42) diz que a fronteira pode ser "um fator de integração, na medida em que for uma zona de interpenetração mutua e de constante manipulação de estruturas sociopolíticas e culturais distintas". Já o limite é um “fator de separação, pois separa unidades políticas, soberanas". (2010:64) As fronteiras podem ser áreas de trocas privilegiadas, de cooperação transfronteiriças, áreas dinâmicas, estagnadas, assimétricas, em transformação ou que apresentam disfunção e ainda, lugares de obstáculos que impedem ou dificultam a passagem. (2010:68-9)

Segundo Melo (1997:69) “as fronteiras são (...) elementos simbólicos carregados de ambiguidades, pois, ao mesmo tempo que impedem, permitem ultrapassar".

Milton Santos afirma que "as fronteiras não são algo acabado, são momentos de um processo e construções históricas, resultantes de força entre os grupos, classes sociais ou povos”. (2010:74)

Fronteiras étnicas, religiosas, políticas, culturais e outras, tem construído através de muros, verdadeiras barreiras que delimitam desencontros e vitimam populações. (2010:75) (grifo nosso)

Conceito de fronteira para o migrante, do padre Alfredo Jose Gonçalves: é o lugar onde ele "já não é" (do país de origem) e "já não é” (do país destino). (...) É um não lugar onde o migrante é um não cidadão. $(2010: 85)$

No caso de nosso trabalho, a fronteira entre os Estados Brasil e Paraguai, tem assumido um, dentre tantos significados, para os sucessivos governantes do Brasil, de ser local onde se pode realizar a expulsão de indígenas, verdadeira "limpeza étnica" no país, para assentar em seu lugar (nos territórios originais indígenas), formas de exploração capitalista da terra, apropriando-se dessa forma delas. Assim tem sido realizado um fluxo de uma mão só, para migrarem do Brasil para o Paraguai. Quando os indígenas Guarani (os próprios indivíduos que foram daqui para lá, 
seus filhos e netos) querem voltar ao Brasil, para junto de seus parentes que ainda restaram em solo brasileiro, o Estado (através da FUNAI local) os mantêm na ilegalidade, na medida em que não fazem os procedimentos de documentação; o indígena permanece assim, como um não cidadão. Outra forma de manter os grupos indesejáveis fora do país é limitar o numero de famílias que irão residir na Terra Indígena, como vimos é o caso que acontece em Tekoa Anetete/Diamante D’Oeste/Paraná, sob controle da Itaipu Binacional. Dessas formas, os Guarani tem sido contidos por barreiras na fronteira, que impedem que exerçam sua cidadania no Brasil.

A geógrafa Torrecilha ao explorar o conceito de fronteira como zona, nos oferece uma outra conotação do conceito:

Turner (1893) em seu ensaio O Significado da Fronteira na Historia Americana cria uma nova conotação para o termo fronteira: "fronteira de assentamento ou colonização". (2010:61) (grifo nosso). (...) o que as colocações de Turner vêm gerar é uma extensão do conceito de limite como linha divisória, para a noção de zonas ou faixas de fronteira que incluem a dimensão econômica e social resultante da necessidade de conquista do território americano. (2010:62)

Em seguida, Torrecilha, afirma:

No Brasil, as "fronteiras de assentamento" são chamadas de fronteiras agrícolas e representam áreas de expansão da colonização agrária e agrícola em espaços vazios, que sofreram alterações ambientais, produtivas e demográficas em suas regiões. (2010:62) (...)

Integração das Margens, remete a teoria de Turner, das frentes pioneiras de colonização, que se referia a progressão dos pioneiros nas áreas ainda incultas ou não colonizadas.

No século XIX o avanço se realizou nos Estados da América e no século seguinte na América do Sul, África e Ásia Oriental. De acordo com este modelo, a identidade nacional se formava a partir das franjas do território não dominado ou em processo de colonização. (TORRECILHA: 2010:69)

O aspecto que mais nos chamou a atenção no trabalho da geógrafa Torrecilha é o significado ideológico de "vazio demográfico, de áreas incultas..." embutido no conceito de fronteira de assentamento, de colonização, agrícola ou pioneira, como queira.

O problema que assim como Turner, Torrecilha, Jayme Antonio Cardoso, Cecília Maria Westphalen ${ }^{16}$ e outros, quase todos entendem de maneira generalizada, que à frente das frontei-

\footnotetext{
16 Jayme Antonio Cardoso e Cecília Maria Westphalen são autores do Atlas Histórico do Paraná. Ver: Cardoso, J.A. Atlas Histórico do Paraná. Curitiba: Chain, 1986.
} 
ras de assentamento em todas as Américas, não havia/não há - supostamente - ninguém! Os domínios dos Estados nacionais seriam, a princípio, supostamente, apenas "um grande vazio demográfico" a ser ocupado pelos antigos e novos colonizadores. Essa é uma postura claramente ideológica e não científica, por parte dos geógrafos, em não considerar a existência de sociedades indígenas, o que implica em desconsiderar, por fim, como territórios ocupados, os territórios habitados pelos indígenas.

Se para uma parte da geografia a zona de fronteira de assentamento ou pioneira é vista da forma acima exposta, para a antropologia a zona de fronteira é vista como "frente de expansão da sociedade nacional" por sobre territórios indígenas habitados, portanto, territórios ocupados, que passam a sofrer alterações várias, por meio de relações sociais impostas, que geram modificações ambientais, produtivas, demográficas, em suas regiões.

Para esta discussão, vamos lançar mão dos trabalhos do sociólogo Jose de Souza Martins, denominado "O tempo da fronteira: retorno a controvérsia sobre o tempo histórico da frente de expansão e da frente pioneira." 17

Martins ao discutir o tema fronteira trabalha justamente com o encontro de sociedades diversas, em um mesmo território:

A fronteira é, simultaneamente, lugar da alteridade e expressão da contemporaneidade dos tempos históricos. A Unidade do diverso, pressuposto metodológico da dialética, encontra aí o lugar mais adequado e mais rico para a investigação científica. (MARTINS: 1996:25)

O tema fronteira remete a realidade de frentes de deslocamento da população civilizada e das atividades econômicas de algum modo reguladas pelo mercado; isso traz duas concepções de referencia: “Zona ou frente pioneira”, concepção da geografia (anos 40) e "frente de expansão", concepção da antropologia (anos 50). Constituem as fronteiras da civilização.

A frente de expansão expressa a concepção de ocupação do espaço de quem tem como referencia as populações indígenas, enquanto que a concepção de frente pioneira não leva em conta os índios e tem como referencia o empresário, o fazendeiro, o comerciante e o pequeno agricultor moderno e empreendedor.

Modos de ver a fronteira diferentes entre si, porque são diferentes os lugares sociais a partir dos quais a realidade é observada: o do chamado pioneiro empreendedor e o do antropólogo preocupado com o impacto da expansão branca sobre as populações indígenas. A expressão dos geógrafos "frente pioneira" mal viam os índios no cenário construído por seu olhar dirigido. (MARTINS:1996:28)

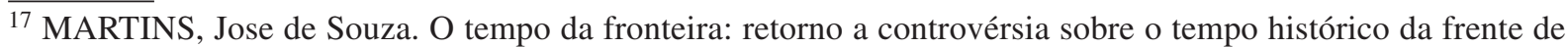
expansão e da frente pioneira. Tempo Social. Revista de Sociologia. USP. São Paulo, 8(1): 25-70, maio de 1996.
} 
(...) essas distintas e, de certo modo, desencontradas perspectivas, levam a ver diferentes coisas porque são expressões diferentes da mesma coisa. (MARTINS: 1996:29)

Essas visões são produtos de observações feitas em desiguais lugares sociais. Esses lugares sociais correspondem a própria realidade da fronteira. Eles viram a partir do vinculo que tinham com a fronteira na pesquisa científica. Viram o que a fronteira lhes mostrava e o que estavam dispostos a ver profissionalmente. Essencialmente expressão da contraditória diversidade da fronteira, mais do que produto da diversidade de pontos de vista da fronteira. Diversidade que é, sobretudo, diversidade de relações sociais marcadas por tempos históricos diversos e, ao mesmo tempo, contemporâneos. (MARTINS: 1996:30)

Nas concepções implícitas nos termos frente de expansão e frente pioneira, elas se referem a realidades sociais substantivas, modos singulares de organização da vida social, de definição dos valores e das orientações sociais.

frente pioneira - mais do que o deslocamento de população sobre territórios novos, na fronteira se cria o novo, nova sociabilidade, fundada no mercado, é a situação espacial e social que convida e induz a modernização, à formulação de novas concepções de vida, à mudança social. Ela constitui o ambiente oposto ao das regiões antigas, esvaziadas de população, rotineiras, tradicionalistas e mortas. (MARTINS: 1996:29/30)

É com este binômio que os generais brasileiros vão trabalhar na fase da arrancada "desenvolvimentista" no Brasil, nos anos, 40, 50, 60 e 70 do século XX, transformar as regiões "antigas", criando uma nova sociabilidade, pautada pelas relações de mercado; de início, como primeiro mandamento, usurpar a terra de seus antigos ocupantes e transformá-la em propriedade privada, em renda capitalizada, que produz mercadoria, que gera lucro.

Voltando a Martins:

É (...) uma das faces da reprodução ampliada do capital: a sua reprodução extensiva e territorial, essencialmente a conversão de terra em mercadoria e, portanto, em renda capitalizada, como indicava e indica a proliferação de companhias de terras e negócios imobiliários nas áreas de fronteira.... nesse sentido se refere a uma das dimensões da reprodução capitalista do capital. (MARTINS: 1996:29/30) Frente de expansão - aquilo com que se defronta o índio. Sobre os territórios tribais se move a fronteira populacional e cultural dos brancos, expansão da fronteira da civilização. Expansão da sociedade nacional, da frente econômica, a expansão do capitalismo, ou ainda, a expansão do modo de produção capitalista. (MARTINS: 1996:29)

Martins ao citar os manuscritos do antropólogo Roberto Cardozo de Oliveira afirma: 
A frente de expansão não deve se reduzir aos seus aspectos meramente econômicos da vida na fronteira, mas sim pela situação de contato, pressuposto metodológico da totalidade, como é próprio da situação dialética. Aí as relações interétnicas são relações de fricção interétnica, o equivalente lógico, mas não ontológico, da luta de classes. (MARTINS: 1996:29)

Assim, momento de uma totalidade dialética e, portanto, momento de tensão, de fricção, de contradição, lugar de conflito. Por fim, Martins conclui: A categoria mais rica e apropriada para a reflexão sociológica é a frente de expansão porque ela se refere a lugar e tempo de conflito e de alteridade. (MARTINS: 1996:33)

\subsection{A Geopolítica brasileira na região da Bacia Platina}

\subsubsection{Definição dos conceitos de Geografia Política e Geopolítica}

Costa, em tese de doutorado citada, afirma que cabe a Geografia Política examinar a Política de Estado, ou mais precisamente a Política Territorial dos Estados (1990:3); Ou seja, cabe a ela, examinar e interpretar os modos de exercício do poder estatal na gestão dos negócios territoriais e a própria dimensão territorial nas fontes e nas manifestações do poder em geral (1990:4). O autor afirma ainda, que parte da tradição do setor (geográfico) identifica como geografia política aquele conjunto de estudos sistemáticos mais afetos à geografia e restritos às relações entre o espaço e o Estado, questões relacionadas à posição, situação, características das fronteiras, etc. (COSTA: 1990:5-6). (grifo nosso)

Costa coloca, que enquanto para a Geopolítica:

Caberia a formulação das teorias e projetos de ação voltados às relações de poder entre os Estados e às estratégias de caráter geral para os territórios nacionais e estrangeiros, de modo que esta última estaria mais próxima das ciências políticas aplicadas, sendo deste modo mais interdisciplinar e utilitarista que a primeira. (COSTA: 1990:6) (grifo nosso)

O autor afirma: Enquanto definições estanques mais encobrem que explicam a real natureza do que está envolvido. (COSTA: 1990:6)

Ele explica que tanto uns quanto outros se servem das mesmas fontes bibliográficas; a produção da primeira se dá na academia, a da segunda se dá no meio militar, porém não de forma 
exclusiva, pois também pode se dar na academia. Segundo o autor o melhor critério para diferenciálas seria o critério do 'nível de engajamento' do estudo aos objetivos estratégicos nacionaisestatais. (COSTA: 1990:6) (grifo nosso)

$\mathrm{Na}$ tentativa de demonstrar diferenciação entre os dois conceitos, Costa afirma:

A Geopolítica “envolve os estudos explicita e assumidamente geopolíticos, naquele sentido de produzir formulações mais diretamente envolvidas com as estratégias do poder estatal, tem sido em geral realizados fora do sistema precipuamente acadêmico, sendo assim, no mais das vezes, identificados com as atividades dos "Estados-Maiores" das forças armadas e centros de estudos direta ou indiretamente a eles ligados". (COSTA:1990:7) (grifo nosso)

Magnoli, em livro citado, nos oferece as origens do termo, Geopolítica:

O primeiro a utilizar o termo Geopolítica (1916) foi o professor de ciência política da Universidade de Upsala, o sueco germanófilo Rudolf Kjéllen, (...) assim ele define: "Geopolítica é a ciência que concebe o Estado como um organismo geográfico ou como um fenômeno no espaço". Mas foi na Alemanha do Reich nazista que a nova doutrina institucionalizou-se (...). Seus maiores expoentes reuniram-se em torno do general e conselheiro de Hitler, Karl Haushofer. Fundado e presidido por ele, o Instituto de Geopolítica de Munique sintetizou: “A Geopolítica deve ser e será a consciência geográfica do Estado”. (MAGNOLI: 1988:12)

Torrecilha, em artigo citado anteriormente, nos apresenta a definição de Geopolítica dos redatores da ZEITSCHRIFT FÜR GEOPOLITIK, Revista de Geopolítica alemã de 1927: A ciência que indaga os liames que ligam os eventos políticos à Terra e quer indicar as diretrizes da vida política dos Estados, deduzindo-as de um estudo geográfico-histórico dos fatos políticos, sociais e econômicos e de sua conexão (TORRECILHA: 2010:59).

Magnoli informa sobre as raízes intelectuais da Geopolítica:

As raízes intelectuais da Geopolítica residem no pensamento geográfico do alemão Friedrich Ratzel (1844-1904). Intelectual de Estado, engajado no Projeto de Unificação da Alemanha sob hegemonia da Prússia, concebido e executado pelo chanceler Otto von Bismarck, publica em 1882 seu principal livro: Antropogeografia - Fundamentos da Aplicação da Geografia à História. Influenciado pelo organicismo de fundo biológico, concebia o Estado como emanação natural da sociedade destinada à defesa do território. Ao formular suas "leis de expansão espacial dos Estados" define o progresso como crescimento territorial. Dessas "leis" origina-se o conceito de Lebensraum (espaço vital), razão de 
equilíbrio entre a população de determinada sociedade, seus recursos naturais e seu território potencial. Lebensraum reapareceria na obra programática de Hitler, Mein Kampf (MAGNOLI: 1988:13).

\subsubsection{O estado da arte da Geografia Política e da Geopolítica no Brasil}

Costa afirma nos anos 90, que a Geografia Política até então, praticamente não existia no Brasil: Não há como avaliar uma "geografia política brasileira”. (...) Esse ramos da geografia, tal como desenvolvido em alguns países da Europa e nos EUA, não logrou ainda firmar-se no país. (COSTA: 1990:237)

Costa acrescenta que o que seria a "geografia política" existente no Brasil, se afastou de suas relações propriamente com o Estado. Assim ele relata:

Houve uma desestatização do objeto da geografia política, com análises muito mais centradas nos problemas relativos ao poder em geral e às suas formas de manifestação e exercício, do que exclusivamente no poder estatal, como no passado. São importantes as formas de distribuição do poder no espaço nacional, regional, etc e os modos de repartição desse poder no interior da sociedade, cada vez mais territorializada em suas práticas sociais cotidianas. (COSTA: 1990:16/17)

Ao final do subcapitulo dedicado a questão da geopolítica no Brasil, Costa coloca os estudos de Berta Becker, como os trabalhos que estão dando um novo rumo à geografia política.

Com relação à Geopolítica desenvolvida no Brasil, Costa tece severas críticas, classificando-a de características pífias, não acadêmicas, de corte e cola, etc.

Os estudos geopolíticos encontram-se hoje praticamente restritos aos meios especializados oficiais ou para-oficiais de estudos estratégicos, cujas publicações raramente ultrapassam os círculos diretamente envolvidos ou dos iniciados no tema. (COSTA: 1990:16) (grifo nosso)

(...) quando se examina a evolução dos estudos que abordaram explicitamente o amplo campo de relações entre a política e o território, observa-se de imediato que a opção preferencial da esmagadora maioria dos que aqui se dedicaram a eles foi pela geopolítica, tal qual formulada por Kjéllen e desenvolvida por Haushofer, isto é, a manipulação de alguns conhecimentos ditos "geográficos" para a formulação de esquemas interessantes ao poder. (COSTA: 1990:237) (grifo nosso)

No Brasil, assim como em outros países da América Latina (Arg e Chile por ex:) importou-se prontamente e exclusivamente a geopolítica, desde os seus primeiros movimentos na Europa. Como veremos mediante operação engenhosa de nossos geopolíticos, autores clássicos como Ratzel e Mackinder - sempre referidos - foram devidamente internalizados e adaptados, procurando-se no 
amplo conjunto de suas concepções geográficas pinçar aquelas teorias que mais se ajustassem como "bases científicas" - às suas formulas, algumas delas autênticos devaneios de "engenharia política" dos círculos conservadores do poder político nacional. (1990: 240) (grifo nosso)

Aspecto da geopolítica aqui desenvolvida, ela representa um inegável atraso cultural, teórico e téc$\underline{\text { nico (...). Aqui, os estudos geopolíticos tiveram a hegemonia do pensamento militar e das suas }}$ instituições. Por isso, pode-se afirmar que não há no Brasil, um pensamento geopolítico, e muito menos geográfico-político, que possa ser referido como produto de um ambiente de reflexão acadêmico especificamente universitário. Por consequência, as possibilidades de uma avaliação crítica das teorias da área aqui desenvolvidas ficam drasticamente reduzidas... . Em geral, tratam-se de adaptações, frequentemente diretas e por vezes grosseiras, do que já fora produzido e exaustivamente discutido em outros centros. Sob ângulo diverso, porém, se o interesse é o de examinar justamente o modo pelo qual essas adaptações tornaram-se instrumentos de analises e "formulas" interessando à "realidade geopolítica" do país, ou mesmo a sua operacionalização em ideologias e políticas, então justificam-se estudos até mesmo exaustivos sobre o pensamento geopolítico brasileiro. (COSTA: 1990:240-1) (grifo nosso)

Portanto, é nesse sentido último, crítico, caracterizado pelo não cientificismo da matéria, colocado por Costa, que devemos olhar a geopolítica desenvolvida no Brasil. Ainda a esse respeito, Costa coloca a posição dos geógrafos brasileiros:

Quanto aos geógrafos brasileiros "procuraram rejeitar com o silencio o que identificavam como pseudo-ciência, ou ideologias perigosas, doutrinas, etc. (...) diante do que consideravam 'desvios' da autentica ciência geográfica e o seu uso como instrumento de opressão." (COSTA: 1990: 241-2)

Raffestin, em obra citada, faz crítica a abordagem da geopolítica, como sendo ela, unidimensional, pois considera somente o poder do Estado, e esse para fins de dominação. Assim ele afirma:

O expediente geopolítico..., o inconveniente é que se trata de um método que encerra uma concepção de poder que descende em linhas direta de um determinismo geográfico. A geopolítica vê o poder territorial hierarquizado: o poder vem do alto e o poder se apoia em áreas, cujas posições relativas permitem ao Estado controlar o meio. O Estado, com maiúscula, é o único ator que a geopolítica leva em consideração. Retomar o expediente geopolítico sem outra forma de processo é negar, de antemão, as possibilidades de a população encontrar o seu próprio poder. A geopolítica só confronta organizações para as quais o poder vem do alto para baixo. Há pouca possibilidade de se utilizar esse método unidimensional fora da pequena escala. 
Em tudo isso se expressa, em pequena escala, uma concepção geográfica do poder único e unidimensional.

É de fato uma concepção militar do poder. A geopolítica é unidimensional na exata medida em que constitui o suporte ideal para desenvolver estratégias cuja a finalidade é a dominação, como demonstram muito bem as proposições mordazes citadas acima. Não é por acaso que a geopolítica continua a ser ensinada em muitas escolas militares ou de guerra. A geografia política do poder pode propor um antídoto contra essa unidimensionalidade. (RAFFESTIN: 1993:199) (grifo nosso)

Dessa forma vamos analisar aqui, o que a geopolítica militar exercida no Brasil, reservou ao país, e mais a frente, especificamente na região foco de nosso estudo, para a Bacia Platina.

\subsubsection{Preocupação geral da geopolítica brasileira desde os anos 20 do século XX: o arranjo interno da unidade nacional e da integração territorial}

Antes de qualquer coisa é preciso estar ciente do contexto politicoeconomico do Brasil a partir dos anos 20. Com a crise na Bolsa de Valores de Nova York em 1929 e com a Revolução de 30 no Brasil, introduziram-se grandes transformações na economia brasileira. A crise de 29

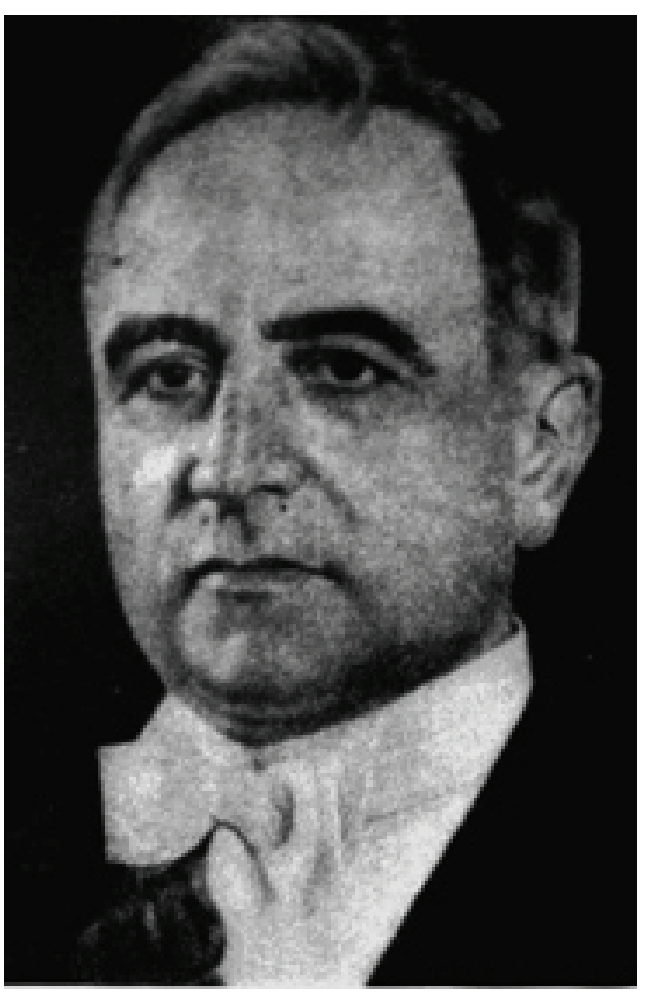

Figura 76. Presidente da Republica do Brasil: Getulio Vargas. Fonte:

http://upload.wikimedia.org/wikipedia/ commons/1/1d/Getulio.gif abalou a economia de exportação cafeeira do Brasil e seu poder de compra, com as exportações, caiu pela metade, o que fez impulsionar o desenvolvimento da indústria nacional, ainda dependente das importações de bens intermediários e de capital. Com a crescente industrialização surgiu uma correspondente demanda por energia. Foi necessário que o Estado passasse a orientar as importações em prol do desenvolvimento industrial. Getúlio Vargas no poder a partir de 1930, o Brasil experimentou uma fase desenvolmentista, caracterizada pelo intervencionismo de Estado na produção industrial e por ter um governo extremamente centralizado e nacionalista.

Costa afirma que a Geografia Política, enxerga como determinante para a história dos Estados, ser a capacidade que eles demonstram em construir sua uni- 
dade nacional interna do ponto de vista da organização política do território, e de transformar esse dado em poder de Estado, a fim de projetá-lo em sua política externa. (COSTA:1990:12-3) Miyamoto, crítico da geopolítica, citado por Costa (1990), observa na leitura de algumas das principais obras dos geopolíticos brasileiros e as resume da seguinte forma:

A absorção imediata das ideias geopolíticas que privilegiam a necessidade de unidade nacional$\underline{\text { territorial e, ao nível do ambiente ideológico interno, a transposição para as formulas geopolíticas }}$ das principais ideias do conservadorismo nacional (antirrepublicanas, antidemocráticas e antifederativas), como as expressas por Alberto Torres e Oliveira Viana. Finalmente, como traço marcante, a predominância dos militares nos principais estudos geopolíticos. (COSTA: 1990:242-3) (grifo nosso)

Miyamoto, afirma que o poder político dos anos 20 e 30, advogava a centralização do poder político e da gestão territorial, culpabilizando a Republica, por ter dado autonomia aos estados. Dado que já vimos os conceitos de "nação" e "território", vejamos como eles se apresentam articulados pela elite política brasileira desde sempre:

O pensamento conservador brasileiro, desde o período colonial, passando pelo império e, de certo modo, até os dias atuais, sempre tendeu a expressar um conceito de nação articulado ao de território, de tal maneira que, frequentemente, a ideia de unidade nacional confunde-se com integridade territorial. (COSTA: 1990:245)

O Estado quer ver a questão da unidade nacional, como uma única nação, a brasileira, preferencialmente de maioria branca, enlaçada pela economia de mercado, visando dessa forma, manter a integridade territorial, através dos fluxos que a movimentação do capital estabelece. Raffestin comenta a respeito da questão da existência ou não, de homogeneidade entre a população:

A composição da população quer seja considerada do ponto de vista étnico, linguístico ou religioso, é com frequência abordada por meio da categoria homogeneidade versus heterogeneidade. $\underline{\mathrm{A}}$ homogeneidade é, nesse caso, percebida como uma condição favorável à sobrevivência do Estado, enquanto a heterogeneidade é tida como uma condição mais desfavorável. Em outras palavras a estratégia do Estado visa a homogeneidade, e é este o motivo da adequação dos índices de diferenciação. Trata-se é certo, de uma "leitura estatal". O Estado que procura unificar, tornar idêntico por todos os meios. $\underline{\text { O Estado teme as diferenças e, em consequência, só quer ver uma face das coisas. }}$ (1993: 27-8) (grifos nossos) 
Dada a diferença étnica e cultural dos povos indígenas podemos imaginar em que situação ficam esses povos, perante os interesses do Estado, interesses esses que são os mesmos interesses das elites dominantes, ou seja, o lucro e/ou o poder que possa advir de cada região.

Raffestin, afirma que, o Estado brasileiro no século XIX - um século marcado por disputas fronteiriças - foi fortemente marcado pela preocupação com a dimensão. (RAFFESTIN: 1993:23)

Costa coloca a questão da desarticulação a nível nacional, do país, como o grande problema considerado pelos geopolíticos do país:

O problema da coesão interna, tão exaustivamente debatido pela geografia política, desde Ratzel, e eleito pelos geopolíticos como um dos principais alvos da ação dos Estados em geral, adquire no Brasil um caráter particular. A imensidão do território, o povoamento disperso e o fraco poder de articulação inter-regional da economia agrário-exportadora, ao lado de um poder central baseado na composição política com as oligarquias locais e regionais, mação do Estado nacional, em 1822, um quadro distante do federalismo clássico (como o norteamericano) e mais próximo de um conjunto politico-administrativo-territorial unitário extremamente desarticulado em nível nacional.

Esse era o pano de fundo para as ideias de integração nacional que, sob vários matizes, marcaram o discurso politico-territorial de muitos setores do poder estatal ou próximo deste. Daí porque a base técnico-científica fornecida pela geografia tornou-se elemento importante para a formulação dessas políticas. (COSTA: 1990:246) (grifos nossos)

Gustavo Capanema/Ministro da Educação e Saúde (1934 a 1945) do governo Vargas, em varias ocasiões ilustrou essa ideia de unidade nacional. Ao justificar a "Revolução de 30", afirma, por ex:, da necessidade então inadiável de colocar um fim "aos regionalismos desenfreados (que) comprometiam a todo o momento a integridade nacional.” (COSTA: 1990:246-7) (grifo nosso)

No inicio do governo Vargas, a partir de 30, verifica-se a ação modernizante do Estado brasileiro, com o fim de sistematizar informações sobre o território nacional. Em 1931 são criados o Conselho Nacional de Estatística e os Serviços Geográficos; Em 1932, foi organizado o Serviço Geográfico e Histórico do Exército; Em 1934 foi instituído o Conselho Brasileiro de Geografia, mais tarde Conselho Nacional de Geografia; Em 1938, ambos, o Conselho Nacional de Estatística e o Conselho Nacional de Geografia, vieram a se tornar o Instituto Brasileiro de Geografia e Estatística/IBGE; foram criados ainda, os Planos de Viação visando a integração territorial, para superar a "falta de visão estratégica", segundo Capanema (COSTA: 1990:247). 
Costa afirma sobre as intenções dessa política de gestão territorial:

Instrumento de ação modernizante do Estado, que incluía um novo tipo de gestão territorial ou, como diz Capanema, que pudessem promover estudos para "um conhecimento melhor e sistemático do território do país" e, como conclui adiante, contribuir para o cumprimento de determinações governamentais que fixavam "normas precisas para a racionalização do quadro territorial brasileiro".

A ideia de unidade nacional, enquanto integração territorial foi exposta pelo próprio Getulio Vargas de maneira eloquente:

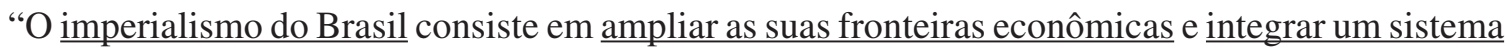
coerente em que a circulação das riquezas e utilidades se faça livre e rapidamente, baseada em meios $\underline{\text { de transporte eficientes, que aniquilarão as forças desintegradoras da nacionalidade. }} \underline{\mathrm{O} \text { sertão, } \mathrm{O}}$ isolamento, a falta de contato são os únicos inimigos terríveis para a integridade do país. Os localismos, as tendências centrífugas, são o resultado da formação estanque de economias regionais fechadas. Desde que o mercado nacional tenha a sua unidade assegurada, acrescendo-se a sua capacidade de absorção, estará solidificada a federação política. A expansão econômica trará o equilíbrio desejado entre as diversas regiões do país, evitando-se que existam irmãos ricos ao lado de irmãos pobres. No momento nacional só a existência de um governo central, forte, dotado de recursos suficientes, poderá trazer o resultado desejado. “(Getulio Vargas citado por COSTA: 1990:247) (grifos nossos)

Daí retira-se vários conceitos marcados pelo então presidente: A intenção de Vargas de ver o Brasil como potencia imperialista na região latino-americana; abrir o país para circulação da economia capitalista; a expansão econômica como articuladora da federação política; combater economias regionais fechadas; instituir um governo centralizado.

Nesta visão, pode-se concluir que os povos indígenas e camponeses autossuficientes, são os representantes máximos do "sertão, do isolamento, da falta de contato, inimigos terríveis para a integridade do país. Representantes, nessa visão ideológica, dos localismos, das tendências centrífugas, são o resultado da formação estanque de economias regionais fechadas".

Costa avalia sobre o discurso de Getulio Vargas:

Esse discurso geográfico e político (...) a partir dos anos 20 (do século XX) ele passou a integrar os círculos de pensamento oficiais e para-oficiais de modo cada vez mais sistemático. O desenvolvimento dos estudos geográficos, combinados com esse tipo de "ideologia nacional" é que resultaria no que foi rotulado de pensamento "geopolítico brasileiro". (COSTA: 1990:247) 
O brasileiro Everardo Backheuser, não-militar, professor do Colégio Militar nos anos 20, participante da Sociedade de Geografia do Rio de Janeiro e após os anos 30, integrante dos círculos oficiais, pioneiro na área da geopolítica no Brasil, era um antirrepublicano e antifederalista radical, para quem era mister "manter e solidificar a unidade nacional”, a fim de fazer frente à “temível doença do separatismo". Essa era a posição política geral nos anos 30. (MAGNOLI: 1988:10; COSTA: 1990:249).

A ideia de integração territorial novamente aparece ligada a ideia de unidade nacional, preferencialmente encaminhada para o "embranquecimento" da "raça" brasileira:

Em Backheuser, a ideologia conservadora aparece também na sua "equação Brasil”, (...) em que "repõe o racismo de Henning e Korholz, sugerindo medidas destinadas a "selecionar" os imigrantes estrangeiros, de modo a permitir um progressivo "branqueamento" da "raça" brasileira. (COSTA: 1990:250-1)

Em contraponto, quanto aos povos indígenas, o antropólogo Shelton Davis em seu Livro "Vitimas do Milagre"18, dá mostras do pensamento da elite política do inicio do século XX, quanto ao destino daqueles, no contexto do desenvolvimento nacional:

No Congresso brasileiro, muitos legisladores argumentavam que seria conveniente, tendo em vista o desenvolvimento nacional, usar as mesmas táticas de extermínio que os militares americanos praticaram contra os índios na ocupação de quase toda a America do Norte. (Ver os artigos de Hermann von Ihering, diretor do Museu Paulista: “A antropologia do estado de São Paulo”, Revista do Museu Paulista, 7 (1907), 202-57; e “A questão dos índios no Brasil”, Revista do Museu Paulista, 8 (1911), 112-40). (DAVIS: 1978:24) (grifo nosso)

Voltando a Backheuser, Costa, refere-se ao pensamento dele da seguinte forma:

Suas elucubrações "geopolíticas" são todas desse gênero: criticas a aceitação "servil" pelo país do federalismo norte-americano, que seria impróprio às características brasileiras; o exemplo edificante da "unidade alemã" e do pangermanismo; a "superioridade dos paulistas e sulistas" em relação aos de outras regiões; defesa da centralização geográfica da capital no planalto goiano, etc.

São ideias esparsas e por vezes desconexas, (...) que expressam manifestações de uma concepção fortemente conservadora ao nível do pensamento político, e inegavelmente confusas no que toca à Geografia enquanto "base cientifica" para seus discursos. (COSTA: 1990:251)

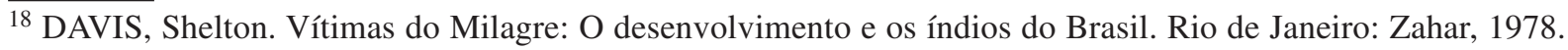
$208 \mathrm{p}$.
} 
Costa identifica Backheuser ideologicamente com o alemão Hanshofer e seu grupo, portanto, com os nazistas.

As propostas de Backheuser, segundo Costa:

Os riscos potenciais de uma desagregação politico-territorial do país constituem verdadeira obsessão para Backheuser. Em seu livro de 1933 (...) ele adianta duas estratégias principais: a redivisão territorial e nova localização da capital. (COSTA:1990: 251) (grifo nosso)

Trata-se da antiga ideia geopolítica de que a grande extensão territorial só se torna vantagem política e econômica quando associada à ocupação e povoamento adequados, ao mesmo tempo em que o poder central, bem localizado, possa estabelecer relações de coesão eficazes, no todo territorial. (COSTA: 1990: 251-2) (grifo nosso)

Quanto à redivisão, (...) estabelece como método "o principio da equipotência", (...) formula antiregionalista, pois subordina a constituição das unidades político-administrativas a um imperativo político-estatal de natureza "unitarista", isto é, por cima da divisão regional advinda do curso normal do povoamento "espontâneo" do território. (...) O autor propõe uma redivisão que resultaria em 64 "unidades fundamentais", agrupadas em 16 estados e 6 territórios, traçados no mapa no sentido dos paralelos e meridianos, sem prender-se, salvo poucas exceções, aos chamados limites naturais. Com esse modelo geopolítico de redivisão territorial, Backheuser estilhaça as regiões e, consequentemente, o peso relativo das oligarquias regionais na política nacional. Em outros termos tratava-se de dividir para centralizar. (COSTA: 1990: 252-3)

Magnoli cita como as ideias de Backheuser caracterizam as fronteiras e os territórios federais, os quais estes últimos, ele foi o seu mentor.

Backheuser, caracteriza as fronteiras como a "epiderme do organismo estatal". É essa ordem de ideias que justifica a existência dos antigos territórios federais (Amapá, Roraima, Acre, Ponta Porá, Iguaçu...) diretamente subordinados ao poder central. Eles cumprem a função de conduzir "para o cérebro as impressões colhidas pela epiderme do corpo territorial”, na expressão do general Mario Travassos, discípulo de Backheuser. (MAGNOLI: 1988:10)

Segundo Costa, a proposta de Backheuser no tocante a localização da capital manifesta também esta tendência à centralização:

(...) ele vê o papel das capitais como essencial para os mecanismos promotores da coesão do todo nacional-territorial. Por isso, defende a centralização geográfica e geopolítica da capital brasileira, de modo que, a partir de nossa posição, pudesse fazer frente aos desafios da integração interna e às exigências da defesa estratégica em relação ao meio externo. Desse modo, e refletindo o ponto de 
vista dos setores militares do período, defende uma localização que situe a capital no "centro de gravidade do sistema geopolítico".(COSTA: 1990:253) (grifos nossos)

Argumentos de estadistas desde o Império defendiam uma nova localização da capital em terras do Planalto Central.

Costa acrescenta sobre alguns dos interesses na mudança da capital:

(...) Mais do que promover o desenvolvimento e a integração de porções do interior brasileiro, a mudança da capital visava sobretudo "impedir o crescimento dos movimentos populares", ao deslocar a sede do poder político de um centro de lutas populares como o Rio de Janeiro.

O processo de construção de Brasília, durante o governo JK, é caracterizado pelo autor (Vesentini) como parte de um amplo movimento de centralização e racionalização de tipo capitalista do Estado brasileiro, cuja direção era dada pela burguesia nacional, pelo capital estrangeiro e pela ação planejadora. A ideologia desse processo, onacional-desenvolvimentismo. (COSTA: 1990:256) (grifo nosso)

(...) Brasília seria o símbolo de uma ideologia nacional autoritária e burguesa, legitimada pelo discurso racionalizador e até mesmo "dito" progressista. (COSTA: 1990:257)

As ideias sobre unidade nacional do Brigadeiro Lysias A. Rodrigues (1947):

As ideias geopolíticas brasileiras, de inspiração francamente militar e sempre obcecadas com o problema da unidade nacional, também foram desenvolvidas pelo Brigadeiro Lysias A. Rodrigues. Em seu trabalho (...) o autor enfoca a questão da unidade nacional desde o período colonial, entendendo-a como tema estratégico de primeira grandeza. Para ele, todas as medidas dos governos imperiais e republicanos, no tocante as redes de circulação, procuraram, cada uma ao seu modo, enfrentar essa questão crucial.

No período republicano (...) assinala que as tendências desagregadoras ganharam vigor, especialmente o municipalismo, a desagregação dos estados e os "regionalismos de caráter separatista". Como Backheuser, "seu mestre", Rodrigues mostra-se ardoroso defensor da centralização pós-30 e especialmente durante o Estado Novo. Para ele, nesse período o Estado finalmente assumiu o poder dirigente na construção do todo nacional-territorial. (COSTA: 1990:254)

Também como Backheuser, Rodrigues propõe uma redivisão territorial do país, (...) com a criação de territórios federais nas porções setentrionais (estados de Mato Grosso, Para e Amazonas). Costa citando Rodrigues: (...) Os critérios a serem seguidos deverão ser definidos exclusivamente pelo poder central, de modo "a neutralizar quaisquer condicionamentos do regionalismo, da tradição histórica ou dos sentimentos arraigados, de todo inaceitáveis quando se trata de unidade nacional". (COSTA: 1990:255) 
Segundo o economista Jadison Luis Rebelo Porto, em artigo denominado, "Os Territórios Federais e a sua evolução no Brasil" ${ }^{19}$, ele relata o processo de como se deu a instalação e evolução dos territórios federais brasileiros; como mentor do processo, Backheuser. É interessante ver estas afirmações, sob o ponto de vista de seus tradicionais moradores, os povos Guarani, que habitam entre outras regiões, a fronteira oeste do Paraná:

Efetivamente, a instalação dos Territórios Federais, sob a orientação de um processo legal, deram-se à luz da Constituição de 1937.

Esta Carta Magna apresentou melhores diretrizes que a anterior, pois segundo o seu art. $6^{\circ}:$ a) houve uma justificativa para a sua criação: A União poderá criar, no interesse da defesa nacional: b) determinou que as suas áreas fossem oriundas de partes desmembradas dos Estados: e c) a sua administração seria regulada por lei especial.

A fim de melhor organizar o espaço brasileiro, no inicio da década de 30 foi realizado um estudo que se preocupou em rever a divisão territorial no Brasil, por uma Comissão Nacional de Redivisão Territorial, presidida por Everardo Backheuser. Esta Comissão sugeriu que a instalação de Territórios Nacionais seria providência de primeira urgência, para atender as justificativas de povoamento adequado, nacionalização e defesa de fronteiras (MEDEIROS. 1944. p. 398) e, com isso, indica a criação de dez dessas novas entidades administrativas federais no Brasil assim estabelecidas (MIYAMOTO, 1995, p. 192): um originado das terras dos Estados do Paraná e Santa Catarina (Iguaçu); três no Mato Grosso (Maracajú, Guaporé e Jaru); quatro no Amazonas (Rio Branco, Rio Negro, Acre e Solimões): e dois no Pará (Óbidos e Amapá). Apesar das propostas dessa Comissão, o Presidente Getúlio Vargas sancionou o Decreto-lei n 311, de 02 de março de 1938, que determinou critérios para a delimitação dos municípios, sua denominação, corno também foi estabelecido um período sem mudanças na divisão territorial de cada Estado. De acordo com o art. $16^{\circ}$, deste diploma legal, a programação das modificações do quadro territorial só poderiam ser feitas após leis gerais, e no $3^{\circ}$ deste mesmo artigo, específica que essa alteração seria efetuada por leis quinquenais. Mesmo com tais diretrizes, os Territórios Federais foram implantados sob a ideologia da defesa nacional, em época de guerra, com Fernando de Noronha (arquipélago desmembrado do estado de Pernambuco), Amapá, o Rio Branco (hoje constitui o Estado de Roraima), no Guaporé (atualmente constitui o Estado de Rondônia), de Ponta Porã e o Iguaçu. No que se refere à sua origem política, deu-se a partir de Decreto-lei, sem consulta à população por plebiscitos, nem às Assembleias Legislativas, ou seja, foram impostos pelo Governo Central sobre as regiões fronteiriças do Brasil.

\footnotetext{
$\overline{19}$ PORTO, Jadison Luis Rebelo. Os Territorios Federais e a sua evolução no Brasil. Universidade Federal do Amapá, Doutorando do Instituto de Economia da UNICAMP. REVISTA DE EDUCAÇÃO, CULTURA E MEIO AMBIENTE- Març.- $\mathrm{N}^{\circ}$ 15, Vol III, 1999.
} 
Este período histórico relaciona-se à primeira gestão de Getúlio Vargas (1937-1945), quando governou o Brasil com a participação de interventores, sem discussões no Congresso Nacional dos seus projetos, pois esta instituição foi dissolvida por sua determinação.

Vários objetivos foram traçados com a criação e instalação desses Territórios, dentre os quais se destacam: proteger as regiões fronteiriças de vazio demográfico; garantir a atuação do governo em regiões longínquas e criar condições jurídicas e econômicas para reorganizar o espaço brasileiro, de acordo com as orientações constitucionais e com um programa para sua organização e desenvolvimento que preconizava sanear, educar e povoar.

Neste contexto, NUNES (1951, p. 140) identifica a criação dos Territórios Federais como a etapa inicial e a primeira execução de valorização econômica (...) com emprego de medidas que serviriam de base para uma política territorial brasileira. Essas medidas, entre outras, deveriam ser: $\underline{\text { maiores }}$ recursos; ação planificada, Redivisão territorial; imigração e colonização econômica com as áreas internacionais vizinhas; efetivo domínio e recuperação das áreas mortas; formação de administrado$\underline{\text { res territoriais; preparação de núcleos civilizadores que mantenham os atuais limites e preparem as }}$ populações que se encontrarão com os grupos vindos do litoral na ocupação dos desertos do centro. (PORTO: 1999:3-4-5)

Ao se verificar a história dessas áreas especiais, é possível notar que o cotidiano político das mesmas estava intimamente ligado ao Poder Central e, com isso, essas mudanças, sempre estiveram vinculadas à decisão final do Governo Central. Ao que indica, a sua população não foi consultada sobre essa possibilidade, como também se preferia ter suas terras reincorporadas aos Estados que os originaram. (PORTO: 1999:7)

Esses Territórios funcionavam, basicamente, como um Departamento do Ministério do Interior. (PORTO: 1999:9)

Em especial, para o interesse dessa tese, o Território Federal do Iguaçu foi criado pelo Decreto-Lei lei n. ${ }^{\circ}$ 5.812, de 13 de setembro de $1943^{20}$, durante o governo de Getúlio Vargas, e extinto em 18 de setembro de 1946, pela Constituição de 1946.

O cientista social Sergio Lopes, em artigo denominado "Raízes do Movimento Pró-Criação do "Estado do Iguaçu"21 informa-nos sobre a caracterização do Território do Iguaçu:

\footnotetext{
${ }^{20}$ Decreto-Lei N. $^{\circ}$ 5.812, de 13 de setembro 1943: cria os territórios federais do Amapá, do Rio Branco, do Guaporé, de Ponta Porã e do Iguassú. Presidência da República.

${ }^{21}$ LOPES, Sérgio (2004). Raízes do Movimento Pró-Criação do "Estado do Iguaçu”. III Seminário do Centro de Ciências Sociais Aplicadas, 18 a 22 de Outubro de 2004, Unioeste, Cascavel, PR. http://www.unioeste.br/campi/ cascavel/ccsa/IIISeminario/artigos/Artigo\%2020.pdf
} 


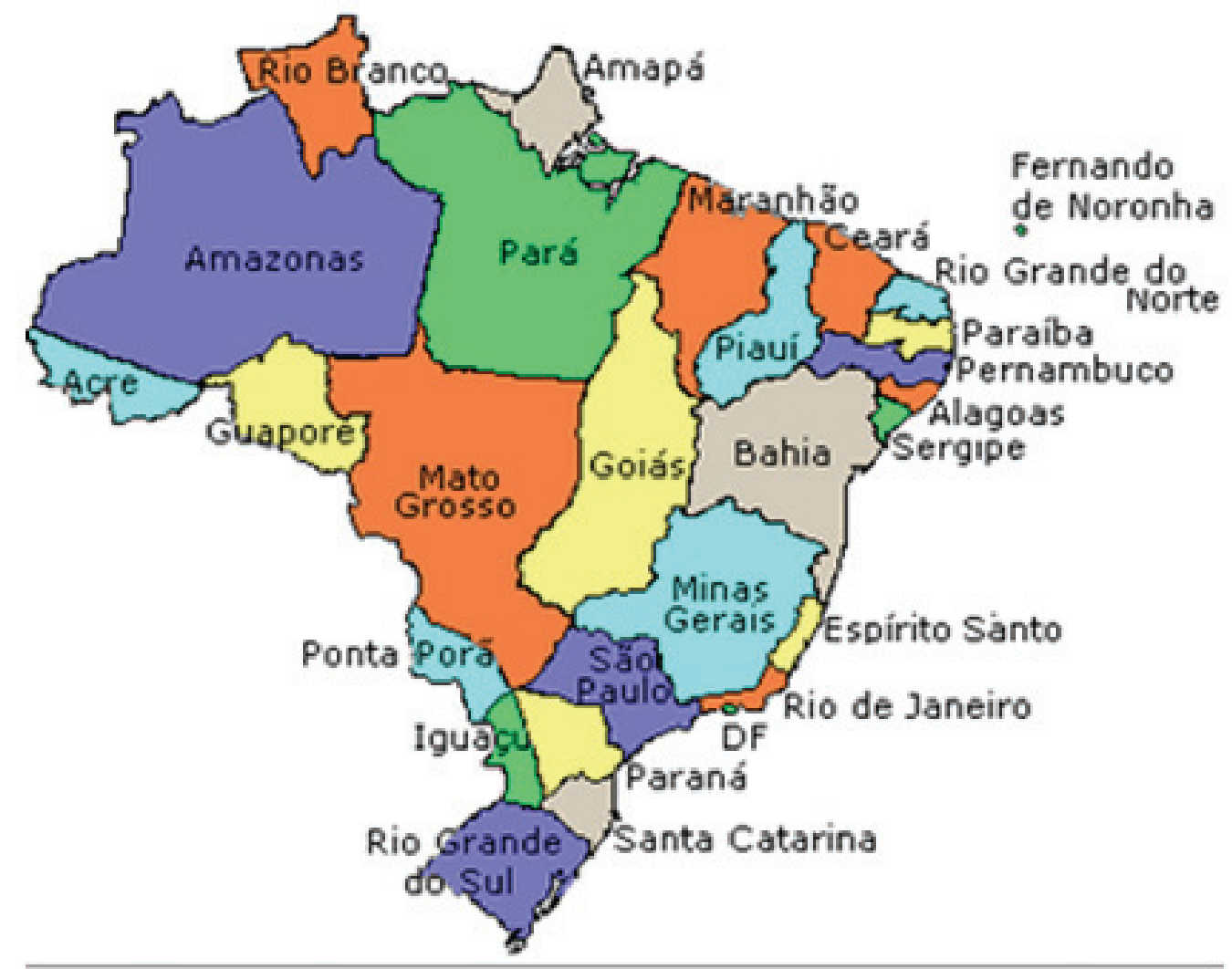

BRASIL - Divisäo Politico-Administrativa em 1943

Figura 77. Mapa Territórios Federais. Iguaçu, Ponta Porã, Guaporé, Rio Branco, Amapá e Fernando de Noronha. Fonte: IBGE (2002) Divissão Territorial Brasileira. Mapa 8 República dos Estados Unidos do Brasil - 1945, pg. 25. http://www1.ibge.gov.br/home/estatistica/populacao/censo2000/metodologia/anexos/desenho/ Anexo_C_6_3_1_1_DTB.doc

Com a entrada do Brasil na Segunda Guerra Mundial o governo decidiu desmembrar seis territórios em regiões estratégicas da fronteira do país para administrá-los diretamente como Territórios Federais: Amapá, Rio Branco, Guaporé, Ponta Porã, Iguaçu e o arquipélago de Fernando de Noronha. Nesse período a decisão do Presidente Getúlio Vargas de criar novos territórios federais estava relacionada principalmente com a soberania nacional sobre as regiões de fronteira. A ideia era permitir ao governo federal ocupar mais diretamente regiões fronteiriças de baixa densidade demográfica, com pequena rede urbana e reduzida presença do poder público. Na região em que foram criados os estados de Iguaçu e Ponta Porã, comissões do governo haviam notado a presença de grandes contingentes de indígenas e registrou a presença de grupos de paraguaios e argentinos vivendo ali, que não falavam português e que utilizavam as moedas de seus países de origem como moeda corrente. Este fato já havia aumentado a preocupação do governo em relação à garantia da soberania sobre estas regiões. Apesar da determinação da Constituição de 1937 da criação de uma faixa próximo à fronteira com controle direto do governo federal, a organização do Território de Iguaçu enquanto tal, só ocorreu em 1943. (LOPES: 2004: 1-2) 
Os Guarani relatam exatamente este contexto vivido nos anos 30 e 40, na região de fronteira do oeste do Paraná. Eles afirmam que não havia brasileiros nesta região, "não tinha estrada, só morava nós aqui"; acrescentam que paraguaios e argentinos vinham negociar a compra de ervamate, a qual era extraída pelos próprios Guarani. "Eles não moravam aqui, só vinham pegar a erva-mate", afirmam.

Continua Lopes:

O Decreto-Lei n. ${ }^{\circ} 6.550$, de 31 de maio de 1944, estabelecia que o território era dividido em cinco municípios: Foz do Iguaçu, Clevelândia, Iguaçu, Mangueirinha e Chapecó. Nesta época, a capital do Território do Iguaçu era a cidade de Iguaçu, atual Laranjeiras do Sul.

Com a redemocratização em 1946, os estados de Santa Catarina e Paraná, que durante 2 anos lutaram para reincorporar o território, conseguiram sua re-anexação. A extinção do Território do Iguaçu deu-se em através do ato das disposições transitórias da Constituição Brasileira de 1946, em decorrência de articulações de políticos paranaenses com capacidade de influência na Assembleia Nacional Constituinte. Assim, a área do antigo território do Iguaçu retornou aos estados de Paraná e Santa Catarina.

Nesse periodo houve intensificação da migração de populações vindas de outras regiões do Paraná, Santa Catarina e Rio Grande do Sul, no fim do processo conhecido como "Marcha para o Oeste" (dos anos 1940 aos 1950). (LOPES: 2004: 2) (grifo nosso)

É interessante notar que a abrangência geográfica do Terrritorio Federal do Iguaçu, coincide em grande medida por terras tradicionalmente habitadas pelas populações indígenas Guarani. Em nota abaixo apontamos a lista de municípios que comporiam o Território Federal se o mesmo se encontrasse nos dias atuais. Estão grifados os municípios paranaenses que pudemos conhecer ou saber (nos limites de nossa pesquisa que não tinha exatamente este objetivo), aonde existiam populações Guarani ${ }^{22}$.

\footnotetext{
${ }^{22}$ Abrangência Geográfica: Mesorregião do Oeste Catarinense:

Microrregião de Chapecó: Águas de Chapecó, Águas Frias, Bom Jesus do Oeste, Caibi, Campo Erê, Caxambu do Sul, Chapecó, Cordilheira Alta, Coronel Freitas, Cunha Porã, Cunhataí, Flor do Sertão, Formosa do Sul, Guatambu, Iraceminha, Irati, Jardinópolis, Maravilha, Modelo, Nova Erechim, Nova Itaberaba, Novo Horizonte, Palmitos, Pinhalzinho, Planalto Alegre, Quilombo, Saltinho, Santa Terezinha do Progresso, Santiago do Sul, São Bernardino, São Carlos, São Lourenço do Oeste, São Miguel da Boa Vista, Saudades, Serra Alta, Sul Brasil, Tigrinhos e União do Oeste.

Microrregião de Concórdia: Alto Bela Vista, Arabutã, Arvoredo, Concórdia, Ipira, Ipumirim, Irani, Itá, Lindoia do Sul, Paial, Peritiba, Piratuba, Presidente Castelo Branco, Seara e Xavantina.

Microrregião de Joaçaba: Água Doce, Arroio Trinta, Caçador, Calmon, Capinzal, Catanduvas, Erval Velho, Fraiburgo, Herval d'Oeste, Ibiam, Ibicaré, Iomerê, Jaborá, Joaçaba, Lacerdópolis, Lebon Régis, Luzerna, Ma-
} 
O que se pode notar é que a partir da década de 1940, os Guarani passaram a enfrentar vários focos de disputa pelas terras que habitavam, e essa disputa não se dava somente entre pessoas físicas, mas também por pessoa jurídica, o próprio Estado, a União.

Como vimos neste subcapitulo, até então, houve uma preocupação geopolítica a nível interno, com o objetivo primordial de manutenção da unidade nacional e da integração territorial, pretendendo implantá-la de modo a estender a economia de mercado capitalista, a todos os cantões possíveis do país.

cieira, Matos Costa, Ouro, Pinheiro Preto, Rio das Antas, Salto Veloso, Tangará, Treze Tílias, Vargem Bonita e Videira.

Microrregião de São Miguel do Oeste: Anchieta, Bandeirante, Barra Bonita, Descanso, Dionísio Cerqueira, Guaraciaba, Guarujá do Sul, Iporã do Oeste, Itapiranga, Mondaí, Palma Sola, Paraíso, Princesa, Riqueza, Romelândia, Santa Helena, São João do Oeste, São Miguel do Oeste e Tunápolis.

Microrregião de Xanxerê: Abelardo Luz, Bom Jesus, Coronel Martins, Entre Rios, Faxinal dos Guedes, Galvão, Ipuaçu, Jupiá, Lajeado Grande, Marema, Ouro Verde, Passos Maia, Ponte Serrada, São Domingos, Vargeão, Xanxerê e Xaxim.

Abrangência Geográfica: Mesorregião do Sudoeste Paranaense

Microrregião de Capanema : Ampére, Bela Vista da Caroba, Capanema, Pérola d'Oeste, Planalto, Pranchita, Realeza e Santa Izabel do Oeste.

Microrregião de Francisco Beltrão: Barracão, Boa Esperança do Iguaçu, Bom Jesus do Sul, Cruzeiro do Iguaçu, Dois Vizinhos, Enéas Marques, Flor da Serra do Sul, Francisco Beltrão, Manfrinópolis, Marmeleiro, Nova Esperança do Sudoeste, Nova Prata do Iguaçu, Pinhal de São Bento, Renascença, Salgado Filho, Salto do Lontra, Santo Antônio do Sudoeste, São Jorge d'Oeste e Verê.

Microrregião de Pato Branco: Bom Sucesso do Sul, Chopinzinho, Coronel Vivida, Itapejara d'Oeste, Mariópolis, Pato Branco, São João, Saudade do Iguaçu, Sulina e Vitorino.

Abrangência Geográfica: Mesorregião do Noroeste Paranaense

Microrregião de Cianorte: Cianorte, Cidade Gaúcha, Guaporema, Indianópolis, Japurá, Jussara, Rondon, São Manoel do Paraná, São Tomé, Tapejara e Tuneiras do Oeste.

Microrregião de Paranavaí: Alto Paraná, Amaporã, Cruzeiro do Sul, Diamante do Norte, Guairaçá, Inajá, Itaúna do Sul, Jardim Olinda, Loanda, Marilena, Mirador, Nova Aliança do Ivaí, Nova Londrina, Paraíso do Norte, Paranacity, Paranapoema, Paranavaí, Planaltina do Paraná, Porto Rico, Querência do Norte, Santa Cruz de Monte Castelo, Santa Isabel do Ivaí, Santa Mônica, Santo Antônio do Caiuá, São Carlos do Ivaí, São João do Caiuá, São Pedro do Paraná, Tamboara e Terra Rica.

Microrregião de Umuarama: Alto Paraíso, Alto Piquiri, Altônia, Brasilândia do Sul, Cafezal do Sul, Cruzeiro do Oeste, Douradina, Esperança Nova, Francisco Alves, Icaraíma, Iporã, Ivaté, Maria Helena, Mariluz, Nova Olímpia, Perobal, Pérola, São Jorge do Patrocínio, Tapira, Umuarama e Xambrê.

Abrangência Geográfica: Mesorregião do Oeste Paranaense

Microrregião de Cascavel: Anahy, Boa Vista da Aparecida, Braganey, Cafelândia, Campo Bonito, Capitão Leônidas Marques, Cascavel, Catanduvas, Corbélia, Diamante do Sul, Guaraniaçu, Ibema, Iguatu, Lindoeste, Nova Aurora, Santa Lúcia, Santa Tereza do Oeste e Três Barras do Paraná.

Microrregião de Foz do Iguaçu: Céu Azul, Foz do Iguaçu, Itaipulândia, Matelândia, Medianeira, Missal,

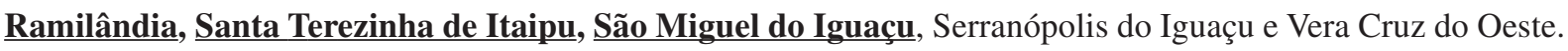
Microrregião de Toledo: Assis Chateaubriand, Diamante d'Oeste, Entre Rios do Oeste, Formosa do Oeste, Guaíra, Iracema do Oeste, Jesuítas, Marechal Cândido Rondon, Maripá, Mercedes, Nova Santa Rosa, Ouro Verde do Oeste, Palotina, Pato Bragado, Quatro Pontes, Santa Helena, São José das Palmeiras, São Pedro do Iguaçu, Terra Roxa, Toledo e Tupãssi. 


\subsubsection{Primeiras preocupações com as projeções externas do poder de Estado brasileiro - As ideias do General Mario Travassos}

O que é mais significativo demonstrar é qual a articulação mantida na estratégia territorial durante o período de 30 em diante, no que se refere ás manobras geopolíticas exercidas pelos militares brasileiros no país. Estes pretendiam entre outras coisas, alçar o país à condição de supremacia sub-continental, frente ao domínio argentino na região da Bacia Platina. Veremos assim neste subcapítulo, as propostas do General Mario Travassos para o contexto.

Desde a Primeira Guerra, Argentina, Brasil e Chile já contavam com alguma industrialização e modernização. No continente latino-americano se desenhou sobre a região da Bacia Platina, ações de disputa por hegemonia regional entre o Brasil e a Argentina, em torno de áreas de influencia próximas, Uruguai, Paraguai, Bolívia e Peru.

Assim Costa define os interesses geopolíticos estratégicos do Brasil na Bacia Platina, na visão do General Mario Travassos:

Além dos problemas de arranjo interno, a geopolítica de inspiração militar também tratou das projeções externas do poder nacional. O pioneiro nesses estudos foi o General Mario Travassos, cuja obra mais conhecida foi publicada em $1931^{23}$ e que influenciou sobremaneira as doutrinas estratégicas posteriores. Como Backheuser e Lysias Rodrigues, também Travassos deriva a sua geopolítica da geografia, mais especificamente da geografia política. Interessa-lhe sobretudo a posição brasilei$\underline{\text { ra face ao conjunto de terras e Estados sul-americanos, e especialmente a projeção do país na região, }}$ "vis-avis" a presença e a influencia aí exercidas pela vizinha Argentina. (COSTA: 1990:258-9)

O General Mário Travassos publicou a obra "Projeção Continental do Brasil"24 (2a edição) em 1935. No caso de nosso estudo, interessa verificar especificamente o projeto que o autor traçou para os interesses brasileiros na região da Bacia Platina. A obra parte de um estudo geográfico do relevo do continente sul-americano, visando verificar como se dá o seu aproveitamento, descreve a infraestrutura de comunicações que a Argentina apresentava à época, para o escoamento de mercadorias produzidas no continente, e assim, aconselha os governantes brasileiros,

\footnotetext{
$\overline{{ }^{23} \text { Em } 1931}$ Mario Travassos publicou o livro denominado "Aspectos Geográficos Sul-Americanos”. Em 1935 publicou a segunda edição do mesmo livro, alterando seu nome para "Projeção Continental do Brasil". É neste ultimo livro que pesquisamos material para esta tese. (Nota da autora da tese).

${ }^{24}$ TRAVASSOS, Mario. Projeção continental do Brasil. São Paulo: Companhia Editora Nacional. 1935. $2^{\mathrm{a}}$ edição ampliada. 206 p.
} 
como viabilizar esse escoamento, geopoliticamente melhor, de forma que o país tirasse melhor proveito, em benefício de sua hegemonia, e portanto, em detrimento do país vizinho, a Argentina.

Com base no aproveitamento da natural potencialidade geográfica do país, objetiva indicar ações geopolíticas coordenadas, por parte do governo brasileiro, no sentido de sistematizar por meio de eixos de penetração de Leste para Oeste, o escoamento de mercadorias para os portos brasileiros; assim, busca indicar uma racionalidade no estabelecimento de corredores econômicos por meio dos transportes (terrestre, fluvial, marítimo e aéreo), visando desviar à circulação de mercadorias, inclusive de outros países (Bolívia e Paraguai), antes realizada pela Argentina, neutralizando dessa forma sua força comercial, redirecionando o fluxo da economia continental por caminhos mais curtos, por terra, para vir a ser realizado o escoamento pelos portos brasileiros do Atlântico, favorecendo dessa forma, um maior poder de influencia do Brasil na Bacia Platina.

Quanto ao conjunto do país, Travassos subdivide o Brasil em quatro grandes regiões naturais, em que na sua visão se poderá utilizá-las de modo mais adequado, em termos geopolíticos, são elas: Brasil Amazônico, Brasil Platino, Nordeste Sub-Equatorial e Vertente Oriental dos Planaltos.

Nesse sentido as regiões a oeste, o Brasil Amazônico e o Brasil Platino são as mais valorizados economicamente, e que, portanto, devem ser desenvolvidas as ações de penetração tendo como base de ligação o litoral atlântico.

Quanto ao Nordeste Sub-Equatorial e a Vertente Oriental dos Planaltos, segundo o autor, o papel funcional dessas regiões é de ligar, homogeneizar, amarrar os dois brasis essenciais, do ponto de vista continental, o platino e o amazônico (TRAVASSOS: 1935:116). O segundo conjunto de regiões, Travassos afirma, contém mais de $2 / 3$ das costas e das terras da vertente atlântica, cujo dinamismo hidrográfico se manifesta decisivo segundo seus dois formidáveis compartimentos o platino e o amazônico. (TRAVASSOS: 1935:105)

Criadas as possibilidades viatórias, o Brasil terá a capacidade coordenadora do litoral atlântico em relação a ambas essas altas manifestações de potencial econômico e político (TRAVASSOS: 1935:107). Esses são seus objetivos geopolíticos. Travassos discorre sobre as possibilidades viatórias em direção ao Atlântico:

O Brasil Amazônico se comunica de modo mais direto com o Oceano, por isso que dispõe do rio Amazonas como via natural. E sua capacidade de penetração é mais ampla, pois o vale amazônico é o grande coletor do formidável anfiteatro que se arqueia de Caracas a La Paz. O Brasil Platino, apesar que exija meios artificiais para ligar-se ao Oceano, dispõe de portos com suficiente capacida- 
de de atração na costa e dos estímulos de dois países mediterrâneos que naturalmente reagem contra a força centrípeta do Prata: - o sul de Mato Grosso, prolongando os territórios paulista e paranaense, representa a sua força de penetração. (TRAVASSOS: 1935:113-4)

Referia-se ele, a Bolívia e ao Paraguai, países sem saída para o mar que reagiam contra a força do porto argentino de Buenos Aires. Ele sugere saídas de Oeste a Leste, que virão se concretizar.

Tendo em mente estas constatações e objetivos, Travassos antes expõe geograficamente, dois antagonismos formais no continente: - o primeiro refere-se à oposição das duas vertentes continentais, os oceanos, Pacífico e Atlântico; - o segundo, interessando ao Atlântico, é a oposição das duas grandes bacias: a do Amazonas e do Prata.

Quanto à primeira oposição descreve as características de aproveitamento de cada um dos oceanos e terras correspondentes. No que se refere à vertente pacífica, localizada no oeste do continente, ele a descreve como:

Um mar solitário, oceano de feixes de circulação regionais, das extensões sem fim, (...) nenhum grande rio, as terras descem bruscamente de alterosos planaltos e píncaros, preferindo as águas o sentido dos meridianos, percorrendo, como torrentes, os vales longitudinais andinos antes de abordarem o litoral. Ao litoral, pobre em articulações (enseadas, bacias e golfos), isento de ecúmeno marítima, corresponde a um interior caracteristicamente montanhoso pela altitude, tão bem como pela produção mineira dos tratos e a mentalidade estática de suas populações. (TRAVASSOS: 1935:2022) (...) Litoral muitas vezes inóspito e excêntrico as grandes vias de comunicação marítima. Interior sistematicamente montanhoso, convidativo, pelo clima e pela produção. Comunicações longitudinais, paralelas ás cristas das grandes massas integrantes da Cordilheira. (TRAVASSOS: 1935:51)

No que se refere à vertente atlântica e suas terras correspondentes, localizada a leste do continente, descreve-a, como:

As águas mais frequentadas do globo, em cujas costas a ecúmeno marítima se encontra magnificamente definida e onde o "planalto continental" é dos mais piscosos. (...) Tudo harmonizado com o oceano que lhe banha o litoral. As terras, e com elas as águas, se alongam desde os confins mediterrâneos, até alcançarem, tranquilas, o oceano. Imensos rios navegáveis prolongam, terra adentro, todas as magnificências atlânticas, vinculando destarte o interior aos grandes feixes de circulação marítima. Atividade pastoril e agrícola, espírito dinâmico. (TRAVASSOS: 1935:20-22). Longas e vastas bacias hidrográficas, imensos rios navegáveis, mesmo nos confins mediterrâneos. Litoral fortemente 
articulado, bordando extenso e rico planalto continental. Costas de condensação próximas a importantes feixes de comunicação marítima. (TRAVASSOS: 1935:50-1)

Em resumo na vertente do Pacífico, segundo o autor há: isolamento marítimo relativo, produção e comunicações que aconchegam características montanhosas, mentalidade mineira, tendências estáticas. Por outro lado, na vertente atlântica, há: imensa superfície de contato com os mais possantes centros da civilização mundial, vias de penetração naturais, estendendo-se do oceano às próprias fraldas andinas, mentalidade agrícola, tendências dinâmicas (TRAVASSOS: 1935:51).

Sobre isso o autor pré-conclui:

(...) o formidável antagonismo demarcado pelas cumiadas dos Andes, porque da maneira de ser da oposição entre as vertentes andinas pode-se concluir da influência decisiva da vertente atlântica sobre a vertente pacífica, da sorte de sucção econômica que o sistema hidrográfico daquela, acionada como se encontra pelas correntes de transportes marítimos mais importantes do globo, há de exercer sobre esta. (TRAVASSOS: 1935:52)

É interessante ter em mente, o papel geopolítico da localização dos portos para seus países. Assim Travassos os define: Um porto se define pela configuração geral da costa que ele articula com o Oceano, por sua configuração particular (condições de acesso, proteção etc) e também pela configuração da região litorânea, que lhe é tributária. (TRAVASSOS: 1935:201)

Assim Travassos conclui sobre a supremacia dos portos brasileiros no Atlântico, por sobre os portos do Pacífico; e mais a frente, como veremos também, conclui sobre a supremacia dos portos atlânticos brasileiros, por sobre o porto de Buenos Aires.

É interessante também notar, a visão que Travassos desenvolve a respeito das bacias hidrográficas: Nada neutraliza as ações concêntricas, engendradas pela rede hidrográfica, pela própria Bacia. Uma sorte de fatalismos arrasta todas as coisas (TRAVASSOS: 1935:120). Os grandes vales são verdadeiros eixos de compartimentos econômicos (TRAVASSOS: 1935:49).

Quanto ao segundo antagonismo, Travassos irá descrever as características geográficas da bacia amazônica e da bacia platina.

Se partirmos do planalto boliviano para leste, sobre o divorcio aquário que emerge dos contrafortes andinos e se estende pelo planalto central brasileiro, repartindo as águas entre as bacias amazônica e a platina, até se fundir na barreira orográfica que, por sua vez, reparte águas entre essas bacias e as do São Francisco e Paranaíba, constataremos nova oposição.

Ao norte, o Amazonas; ao sul, o Prata. 
Seus mais longínquos formadores se opõem sistematicamente. O maior volume d'águas de um corre na direção geral do norte; as águas do outro, na do sul. Apenas concordam em decidir na direção geral de leste o curso inferior de seus caudais. Ainda assim fazem-no após percurso de regiões que se contradizem pelo clima e pela produção: o Amazonas, recebendo em seu longo curso, afluentes repartidos ao N. e ao S. do Equador; o Prata, em seu curto desenvolvimento, enfeixando toda uma extensa bacia homogeneizada pelo tropico meridional.

Ao passo que o Amazonas esbarra com o oceano na extremidade N.E. do litoral da grande vertente,

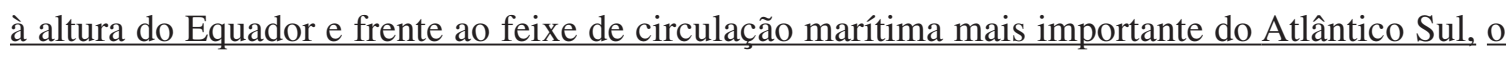
Prata fá-lo muito abaixo do Capricórnio, frente a feixes secundários de circulação marítima.

(...) pode-se concluir (...) esse antagonismo como que agrava o criado pelo divisor andino, por isso que as reações da vertente atlântica sobre a do Pacífico se vão processar através de dois compartimentos também antagônicos. É por esses compartimentos que a vertente do Pacífico vai procurar neutralizar suas insuficiências ou sejam, as insuficiências de seu litoral (ausência de ecúmeno) e do oceano que o banha (circulação regional).

Ainda é por essas duas formidáveis válvulas de segurança, em contato direto com a civilização europeia, é que a vertente pacífica vai escapar a influencias estranhas que seus vales longitudinais possam atrair e canalizar. (TRAVASSOS: 1935:23-4-5) (grifos nossos).

Portanto, as saídas de escoamento de mercadorias mais importantes se encontram no Atlântico, pelo rio Amazonas no Brasil, e pelo Rio da Prata na Argentina. Esta ultima condição pode ser mudada, segundo Travassos, trazendo as mercadorias, inclusive de países mediterrâneos (Bolívia e Paraguai) por via terrestre pelo Brasil, na direção Oeste - Leste, encontrando saída no Atlântico mais interessante, pelos portos brasileiros mais a norte, portanto, melhor localizados em relação ao hemisfério norte, assim pelos portos brasileiros de: Rio Grande, Paranaguá, Santos e São Francisco.

O aproveitamento do curso natural dos rios encravados na bacia hidrográfica amazônica, assim como a rede de comunicações terrestres por fazer, e, a posição dos portos no Atlântico, são as pontas que irão interligar os principais eixos econômicos, que Travassos irá descrever, trazendo para o Brasil as vantagens políticas de maior influencia econômica, que esse sistema irá criar; portanto, o Brasil irá prejudicar o sistema de escoamento existente na Bacia Platina, armado pela Argentina.

Costa, assim resume a visão de Travassos sobre o contexto:

O esquema básico de Travassos está assentado na posição peculiar do território brasileiro no continente sul-americano, marcado, como diz, por dois antagonismos principais: Atlântico versus Pacifi- 
co e Prata versus Amazonas. Esses antagonismos, de natureza geográfica, mas com resultantes geopolíticos, determinam, em sua opinião, os desdobramentos das políticas de expansão das áreas de influencia dos dois principais estados (Brasil e Argentina), em inevitável disputa hegemônica (pelas suas posições e importância econômica). Dadas essas condições gerais, observa que a política de comunicações platina, levada a cabo pela Argentina, voltava-se naturalmente para a captura das terras a montante do Prata, estendendo a sua influencia até o Pacifico e aos limites da bacia amazônica. (COSTA: 1990:259) (grifo nosso)

Travassos descreveu o funcionamento das comunicações argentinas (fluvial e ferroviária), o possível domínio argentino do heartland boliviano, notando que se o Brasil não tomar as rédeas desse sistema, a Argentina poderia vir a ter a hegemonia sobre os outros países do continente sulamericano.

Travassos fica bastante impressionado com a organização da rede de comunicações platinas, leia-se a organizada pela Argentina, a saber, a fluvial e a ferroviária. Primeiramente ele discorre sobre as vias fluviais que engendram a bacia platina, terminando no porto de Buenos Aires no Atlântico:

No caso particular das comunicações platinas essa atuação se mostra por demais interessante, posto que aquelas vias se vão condensar no próprio coração de um dos países da bacia platina, de Buenos Aires, a distribuidora à beira mesmo do Prata, à borda do Atlântico. (TRAVASSOS: 1935:28)

Em seguida Travassos discorre sobre a rede ferroviária existente na Bacia Platina:

Tudo isso se compreende e sente quando se toma conhecimento do caráter expansionista da política de comunicações platinas (...). Como se vê, Buenos Aires está ligada, diretamente, por estrada de

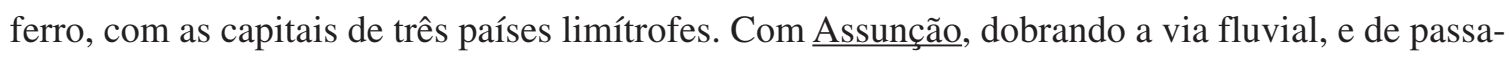
gem, assegurando o contato (Concordia-Salto), entre as redes argentinas e uruguaia. Com $\underline{\text { Santiago }}$ (e Valparaíso) por meio da via férrea de montanha que vincula a riqueza andina com o Atlântico. Com La Paz, pela soldagem em Tupiza, da via argentina, com as linhas bolivianas, após seus trilhos percorrerem até La Quiaca a bagatela de $1795 \mathrm{~km}$. (TRAVASSOS: 1935:30-32)

Ou seja, a Argentina havia feito ligações ferroviárias com as três capitais sul-americanas, Paraguai, Chile e Bolívia, e ainda, estabeleceu comunicações por via férrea e fluvial com os dois oceanos, Atlântico e Pacífico, e teria por fim, a supremacia do heartland boliviano, que poderia fazer comunicação fluvial com a bacia amazônica. 
Costa assim interpreta, corroborando com a interpretação do próprio Travassos:

É com essa ultima articulação terrestre (Buenos Aires - La Paz) que Travassos está mais preocupado, pois a extensão da influencia sobre a Bolívia - "zona de transição entre dois antagonismos" garantiria à Argentina o controle do "heartland" sul-americano, opondo-se assim a uma possível e natural influencia brasileira na área. O comentário de Mello, a respeito, aponta a evidente influencia de Mackinder nessa tese de Travassos:

No campo intelectual, a geopolítica de Travassos sofreu uma influencia determinante de Mackinder, com sua teoria sobre o poder terrestre. Essa teoria foi reelaborada e aplicada de forma criadora às condições peculiares do continente sul-americano, com o planalto boliviano assumindo o papel de área-chave com importância análoga à do heartland euro-asiático. Para Travassos, o controle da Bolívia, região-pivo do continente, outorgaria ao Brasil o domínio político-econômico sul-americano. (COSTA: 1990:259-260) (grifos nossos)

Costa assim interpreta, a posição que Travassos toma diante desses fatos:

Como medida destinada a conter esse domínio argentino, Travassos propõe a plena utilização, pelo Brasil, das potencialidades das vias fluviais amazônicas para uma rede de circulação que articulasse esse heartland boliviano à costa atlântica brasileira (a começar pela utilização do rio Madeira), apoiada pela ferrovia Madeira-Mamoré. Em suma, tratava-se, em seu esquema, de opor a "espontaneidade viária da Amazonia" ao "artificialismo da atração ferroviária platina". (COSTA:1990:260) Quanto ao antagonismo natural entre as vertentes pacífica e atlântica, o autor está certo de que as vantagens naturais desta última certamente transformar-se-ão em vantagens geopolíticas, de modo que o essencial, no caso, é apenas o de se descobrir a melhor estratégia para estender a circulação oriental até a borda do Pacífico. Para ele, é inevitável o desencadeamento da "influencia decisiva da vertente atlântica sobre a pacífica", que dependerá sobretudo da capacidade da circulação terrestre de estender-se por sobre os Andes, através das "linhas naturais de circulação", ou "as abertas nas linhas de cumeada" (passos e nudos). $\underline{O}$ coroamento dessa estratégia brasileira no continente seria de fato a captura do "heartland" para a sua área de influencia:

"Quando as possibilidades carreadoras da Amazônia se verificarem a pleno rendimento e conjugadamente com as abertas andinas, excluindo apenas o Paso de Uspalata, as bocas do Amazonas despejarão no Atlântico grande parte da riqueza do centro e da vertente ocidental do continente." (COSTA: 1990:260-1)

Quanto à situação do porto de Buenos Aires na Argentina, o autor o interpreta como uma verdadeira calha coletora em favor do Prata, e muito bem organizada. É aí que a geopolítica brasileira irá também atuar, procurando desviar, através de suas próprias palavras, por meio de 
ações neutralizantes do Brasil Platino ${ }^{25}$ sobre a força concêntrica da bacia do Prata ${ }^{26}$. Deve-se considerar, analisa ele, está a má posição da foz do Prata, quando sugere ao Brasil tirar partido desse fato, pois a posição de sua latitude a torna secundária, notadamente quanto aos portos de Santos e São Francisco.

O autor levanta o problema da situação geográfica da Bolívia e do Paraguai, países os quais não possuem saída para o mar. Refere-se ele a Bolívia, como triste situação de país mediterrâneo, que se sujeitou a influência argentina pela saída pelo Rio da Prata, mas que quer sua saída para o Pacífico, ao mesmo tempo que apela para o Brasil, visando um porto em correspondência mais direta com seu planalto central, os portos de Santos ou São Francisco. Quanto ao Paraguai, descreve-o de forma semelhante: sorte de prolongamento de toda a angústia concentrada na território boliviano (TRAVASSOS: 1935:168) 27.

Constatando o domínio da bandeira argentina em águas da bacia platina, Travassos sugere que, os países mediterrâneos (Paraguai e Bolívia) gostariam de dispor de novos caminhos para o Atlântico...; portanto, o autor propõe desviar, a rota de escoamento fluvial desses países (Bolívia

\footnotetext{
${ }^{25}$ O Brasil Platino engloba a costa ou contra-vertente oceânica (entre o Atlântico e a Serra do Mar) a Região Serrana (Serra do Mar e Geral) a região do Planalto (alternação de campos e matas, região suporte dos afluentes orientais do Paraná) a campanha riograndense e a baixada matogrossense.

${ }^{26}$ Segundo Magnoli acrescenta: Os rios Paraná, Paraguai e Uruguai vertebram a bacia, que drena três milhões de quilômetros quadrados em terras argentinas, uruguaias, paraguaias, brasileiras e bolivianas. O conjunto da rede fluvial assemelha-se a um triângulo de base invertida, formada pelas nascentes dos rios principais localizadas em território brasileiro. A foz comum dos três rios, no estuário da Prata, demarca o vértice do enorme triângulo. A disposição espacial dessa rede de rios torna o porto de Buenos Aires, no estuário platino, pólo natural de atração de toda área da bacia. Ao longo do período colonial, essa posição geográfica privilegiada conferiu à cidade de Buenos Aires um dinamismo contrastante com a economia ganadera da pampa. (MAGNOLI:1 988:34) ${ }^{27}$ Acrescenta Magnoli: Paraguai, Bolívia e Uruguai vivem histórias marcadas pela fatalidade geopolítica de estarem situados na hinterlândia das duas potências platinas, o Brasil e a Argentina. O Paraguai e a Bolívia, Estados interiores, tem as suas existências determinadas pela necessidade de acessos para o mar. O Uruguai, Estado-tampão, nasce do impasse entre as pretensões territoriais brasileiras e argentinas e da intervenção inglesa no conflito platino (MAGNOLI:1988:34). A decadência paraguaia inicia-se precisamente com a derrota sofrida na guerra desigual travada contra o Brasil, a Argentina e o Uruguai, entre 1865 e 1870. Movido pelo sonho de conquista de um pulmão oceânico, Solano Lopez lança o prospero Paraguai na empresa impossível de anexação do Mato Grosso, da mesopotâmia argentina e do Uruguai. O fracasso militar da empreitada significou a ruína econômica e demográfica do país, circunscrevendo toda a possibilidade de desenvolvimento futuro. A Bolívia é a síntese de uma contradição regional aparentemente insolúvel. As suas planícies tropicais do oriente, fracamente povoadas e atraídas pela amazônia e pelo Chaco, encontram-se drasticamente isoladas do altiplano e dos vales interandinos de ocidente, voltados naturalmente para a vertente do Pacífico. Em 1884 o país viu o seu corredor para o Pacifico anexado pelo Chile, perdendo os portos de Arica e Antofagasta. Mesmo reivindicando a devolução da preciosa faixa perdida, a diplomacia boliviana foi obrigada a voltar-se para soluções alternativas, direcionadas ora para o Pacífico, ora para o Atlântico. O Uruguai era parte da Argentina em 1828, quando é desmembrado e surge como Estado independente. Nasce da estratégia inglesa de dominação sobre o Atlântico Sul que presidira a anexação britânica da Colônia do Cabo, no sul da África, em 1806 e das ilhas Malvinas em 1832. Intervindo na Guerra Cisplatina com o objetivo de conter simultaneamente a expansão brasileira na região e a posse argentina das duas margens do Prata, a Inglaterra completa o seu tripé hegemônico sul-atlântico. Estado-tampão entre o Brasil e a Argentina, o Uruguai desenvolveria uma diplomacia pendular, fator de equilíbrio e tensão entre os vizinhos poderosos. (MAGNOLI: 1988:36)
} 
e Paraguai) que se dava por meio do porto do país vizinho (Argentina), agora em direção ao Brasil, através da criação de rodovias e ferrovias, que tanto encurtariam o caminho a ser percorrido de Oeste a Leste, quanto ao encontrarem os portos brasileiros, Paranaguá, Santos, São Francisco, estariam em melhor posição para exportação, em águas do Oceano Atlântico mais a norte, mais próximo dos grandes centros da Europa e EUA, que o porto de Buenos Aires. Assim ele explora a vantagem econômica brasileira sobre a Argentina, com a seguinte assertiva: (...) pelas energias neutralizantes produzidas pelo litoral atlântico e que recaem sobre a Bacia do Prata, devido a má posição de sua foz (TRAVASSOS: 1935:149).

Por fim Travassos ressalta a importância de o Brasil desenvolver as comunicações ferroviárias, neste período ainda em inicial estágio, o que ele reclama por aceleramento, existindo somente à época, na região da Bacia Platina brasileira, a ferrovia São Paulo - Rio Grande. Ele refere-se que a sua existência possui vantagens sobre a Argentina, na medida em que, dobrando a via marítima e as ligações ferroviárias com o litoral (São Paulo-Santos; Ponta Grossa - Paranaguá; Porto da União - São Francisco) pelo menos impedem a influência platina de exercer-se livremente em território brasileiro. (TRAVASSOS: 1935:124).

Costa, referindo-se as estratégias de comunicação elaboradas por Travassos, afirma:

Todas as propostas do autor, em especial as referentes a uma necessária estratégia de comunicações para o país, giram em torno da influencia brasileira na porção ocidental do continente, com repercus-

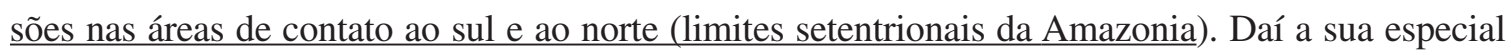
atenção para as vias terrestres de articulação: entre Santa Cruz de la Sierra e o porto de Santos (ferrovia Noroeste do Brasil), a Madeira-Mamoré, as pontes Brasil-Paraguai e as transcontinentais orientadas segundo paralelos. Particularmente a ligação com Santa Cruz, ao lado da melhoria das vias navegáveis amazônicas, constitui para ele a possibilidade do país cumprir o seu "destino geopolítico". Finalmente, e fazendo eco à geopolítica do período, Travassos defende com veemência o movimento de integração nacional em direção a oeste: "Se bem que possa vir a ser a reprodução das 'entradas' e das 'bandeiras', a marcha para oeste, hoje, não terá a mesma espontaneidade daqueles movimentos que a atração litorânea acabou por estagnar. Agora, um movimento dessa ordem terá todo o sentido de uma contra-ofensiva de larga envergadura no terreno político, econômico e social”'. (COSTA: 1990:261-2)

Para concluir, Costa analisa o significado do trabalho de Travassos, para a geopolítica brasileira:

A análise geopolítica de Travassos é não apenas pioneira, como original nesse tipo de discurso no país. Ao contrario dos demais desse período, ela parte de uma minuciosa descrição das condições geográficas primárias do continente e do território brasileiro. 
Além disso, ele deriva daí um projeto geopolítico que está centrado não na unidade interna "stricto sensu", mas na repercussão externa do movimento de integração interna, subordinando este àquele objetivo maior. Nesse sentido, na mais pura tradição inaugurada por Mackinder, Travassos empresta ao chamado "poder nacional" uma dimensão nova no contexto da geopolítica brasileira. Assim, não é de se estranhar - como aponta Melo em seu trabalho - a grande repercussão da sua obra em países sul-americanos, e especialmente, como era de se esperar, entre os seus colegas geopolíticos argentinos. (COSTA: 1990:262)

Mario Travassos concebeu assim nos anos 30 uma manobra geopolítica de peso, a qual para sua concretização ainda iria durar muitos anos, manobra que objetivava a consolidação da hegemonia do Brasil na America do Sul.

\subsubsection{O Imperialismo norte-americano e a geopolítica de Golbery}

Os fatos que irão explicar o processo histórico de como a sociedade hegemônica construiu a região da Tríplice Fronteira em função dos interesses do capital, podem ser explicados por duas questões principais: pelo intervencionismo norte-americano na America Latina e o consequente modelo de desenvolvimento econômico capitalista, de característica "desenvolvimentista", imposto pelo imperialismo norte-americano e assumido pelas elites e pelo Estado, brasileiros; e o quadro de disputas por hegemonia regional no continente sul-americano entre os Estados do Brasil e da Argentina, nos conflitos que se sucederam pela supremacia político-econômica na Bacia do Prata; e, assim, poderemos compreender por fim, as políticas adotadas pelos sucessivos governos do Brasil, para fazer face a estas duas situações, explicadas, fundamentalmente a segunda questão, através dos estudos do General Golbery do Couto e Silva.

Nesse sentido é preciso entender inicialmente como se deu, em linhas gerais, o intervencionismo norte-americano sobre a América como um todo.

\subsubsection{O intervencionismo norte-americano sobre a América}

O intervencionismo norte-americano sobre a própria América do Norte vem ocorrendo desde o inicio de sua colonização. Weinberg $(1976)^{28}$ se refere a colonização dos Estados Unidos,

\footnotetext{
${ }^{28}$ WEINBERG, Albert Katz. Manifest Destiny: A Study of Nationalist Expansionism in American History. Ams Pr Inc; 1st AMS ed edition (June 1976), ISBN 9780404147068, p. 28.
} 
que inicialmente eram treze colonias. Ao se libertar da Inglaterra, com o comércio e a indústria em crescimento, houve a necessidade de aumentar os limites territoriais de atuação. Daí a expansão para o Sul e para o Oeste. Estradas de ferro foram construidas visando alcançar o Oeste. Este avanço gerou o massacre e o extermínio de diversas nações indigenas, que viviam a milenios naquelas terras. A cada vitoria, firmava-se um sentimento de superioridade sobre os outros povos, realimentando um sentimento de patriotismo expansionista. Nesse contexto, pode-se citar Benjamin Franklin quando afirmava: Se faz parte dos desígnios da Providência extirpar esses $\underline{\text { selvagens para abrir espaço aos cultivadores da terra, parece-me oportuno que o rum seja o }}$ instrumento apropriado. Ele já aniquilou todas as tribos que antes habitavam a costa ${ }^{29}$.

Segundo ainda Weinberg, este sentimento de superioridade acabou se transformando com o tempo na ideologia do Destino Manifesto, que se realimentou, gerando a ideia fixa da prédestinação dos estadunidenses da época, sobre os outros povos americanos descendentes de indígenas, hispânicos, e escravos negros. Capítulo à parte era o sentimento de superioridade racial dos estadunidenses sobre os negros - estes, segundo muitos estudiosos da época, eram considerados um elo entre os animais e os seres humanos. Em 1821, o senador por Massachusetts, Edward Everett, demonstrando o pensamento estadunidense sobre os seus vizinhos da América Latina declarou: Nem com todos os tratados que possamos fazer, nem com todo o dinheiro que emprestarmos, poderemos transformar seus Bolívares em Washington ${ }^{30}$.

O intervencionismo norte-americano com relação a America Central e America do Sul iniciou-se a partir do século XIX, através das políticas adotadas pelos sucessivos governos norteamericanos, políticas essas de conquista e dominação política e territorial, como também de intervenção política e econômica e criação de dependência econômica, políticas as quais foram se sucedendo, criando um círculo virtuoso que perdura até nossos dias, através da conquista por meio da política e da economia e de financiamentos a outros países e endividamentos deles para com os EUA; fornecimento de matérias-primas dos países sob o comando político dos EUA; sujeição destes países ao mercado de consumo norte-americano; ou da guerra aberta (indústria armamentista), uma bola de neve de enriquecimento norte-americano, que se retroalimenta incessantemente, com uma industria armamentista e um poder econômico, cada vez mais fortes e poderosos. Assim os ataques norte-americanos aos outros países se deram ora com intervenções militares, ora com intervenções econômicas, políticas ou ideológicas. Ao longo do tempo essas

\footnotetext{
${ }^{29}$ (org.) J. A. Leo Lemay, Wrintings. Library of America, New York, 1987, p. 1.422 apud Losurdo, Domenico in Contra-História do Liberalismo, 2006, p. 30
} 
políticas foram desenvolvidas e simbolicamente cunhadas como: "Destino Manifesto"; "Doutrina Monroe”; "Big Stick”; “Corolário Roosevelt”; “Diplomacia do Dólar”; "Política de Boa Vizinhança"; "Escola das Américas"; “Aliança para o Progresso" e, assim por diante.

\section{A Doutrina Monroe (1823):}

Quando os estadunidenses referem-se a si mesmos como americanos somente repetem a frase mais conhecida do presidente James Monroe (1817 a 1825), proferida no congresso estadunidense em 1823: A América para os americanos (estadunidenses). A esta linha de pensamento denominou-se Doutrina Monroe, que é seguida até a atualidade.

A mensagem ao Congresso em 02.12.1823 anunciada pelo presidente Monroe, chamada de Doutrina Monroe ${ }^{\mathbf{3 1}}$ foi a seguinte, (reproduzimos parte dela):

Julgamos propícia esta ocasião para afirmar, como um princípio que afeta os direitos e interesses dos Estados Unidos, que os continentes americanos, em virtude da condição livre e independente que adquiriram e conservam, não podem mais ser considerados, no futuro, como suscetíveis de colonização por nenhuma potência europeia.

A frase famosa que resume a doutrina, dita em seguida por Monroe: "A América para os americanos", os criticos acrescentam ironicamente,... "do Norte".

O pensamento político de Monroe consistia em três pontos: - a não criação de novas colônias nas Américas por países europeus; - a não intervenção nos assuntos internos dos países americanos por países europeus; - a não intervenção dos Estados Unidos em conflitos relacionados aos países europeus como guerras entre estes países e suas colônias.

A Doutrina reafirmava a posição dos Estados Unidos contra o colonialismo europeu, inspirando-se na política isolacionista de George Washington, segundo a qual a Europa tinha um conjunto de interesses elementares sem relação com os nossos ou senão muito remotamente (Discurso de despedida do Presidente George Washington, em 17.09.1796), e desenvolvia o pensamento de Thomas Jefferson, segundo o qual a América tem um Hemisfério para si mesma, o qual tanto poderia significar o proprio continente americano, como para o seu próprio país.

À época, a Doutrina Monroe representava uma séria advertência não só à Santa Aliança, como também à própria Grã-Bretanha, embora seu efeito imediato, quanto à defesa dos novos Estados americanos, fosse puramente moral, dado que os interesses econômicos e a capacidade

\footnotetext{
30 Idem: Weinberg, 1976, p 29.

${ }^{31}$ http://pt.wikipedia.org/wiki/Doutrina_Monroe. Pesquisado em março de 2013.
} 
política e militar dos Estados Unidos não ultrapassassem a região do Caribe. De qualquer forma, a formulação da Doutrina ajudou a frustrar os planos europeus de recolonização da América e permitiu que os Estados Unidos continuassem a dilatar as suas fronteiras na direção do Oeste, dizimando as tribos indígenas que lá habitavam. Essa expansão no continente americano teve como pressuposto o Destino Manifesto, e marcou o início da política expansionista do país no continente.

A interpretação no Brasil da Doutrina Monroe, segundo Burns ${ }^{32}$ :

A Doutrina Monroe teve na América Latina acolhidas distintas. As nações hispânicas nunca a reconheceram oficialmente, nem lhe deram legitimidade. O Brasil, pelo contrário, demonstrou receptividade cordial com a doutrina. Logo após o Presidente James Monroe ter recomendado aos europeus que se afastassem dos assuntos internos do Hemisfério Americano, o governo brasileiro reconhecia a doutrina e já declarava apoio aos EUA. O Brasil via nessa doutrina uma forma de defesa de sua recente independência e uma proteção de sua soberania contra agressões europeias. A partir de então, a Doutrina Monroe tornou-se presente nas declarações dos governos brasileiros. $\mathrm{O}$ país, entretanto, tinha sua própria interpretação da doutrina, dando acepção multilateral ás palavras de Monroe, já que na concepção original, a Doutrina Monroe era afirmação unilateral dos EUA, proibindo a interferência europeia nos assuntos do "condomínio" norte-americano (grifos nossos).

Weinberg acrescenta que entre 1820 e 1830, os estadunidenses começaram a invadir lentamente o Texas que pertencia à República do México, comprando terras, a preços muito baratos.

Grandes latifundiários, levaram consigo as oligarquias e o trabalho escravo. No México não havia escravatura, era proibida pela Constituição. Em 1835, o governo mexicano aprovou a Constituição Centralista Mexicana, reforçando a proibição da escravidão em território daquele país. Os grandes oligarcas estadunidenses "donos" daquelas terras financiaram então uma revolução e proclamaram a independência do Texas em 1836. Formou-se então a República da Estrela Solitária, que passou a ser um protetorado dos Estados Unidos. Reconhecida a independência da República do Texas pelos estadunidenses, fez-se um pedido formal de anexação à nação vizinha, sob a alegação de que os laços raciais do povo texano eram mais estreitos com os Estados Unidos do que com o México. Desta forma, em 1845, o Texas foi anexado ao território estadunidense. Segundo informações coletadas da Biblioteca do Congresso estadunidense, que após a "libertação do Texas", o povo mexicano da região de fronteira era muito "violento", aumentando o índice de criminalidade. Foram necessárias

\footnotetext{
$\overline{32}$ BURNS, E. Bradford. A Aliança não Escrita: O Barão do Rio Branco e as Relações Brasil-Estados Unidos. Rio de Janeiro: EMC, 2003, p. 185-186.
} 
portanto, "medidas drásticas de contenção contra os criminosos e bandos de bandidos hispanoamericanos". Estas "medidas de contenção do banditismo" geraram desentendimentos entre os dois países. Em 1846, houve novamente conflito de fronteira entre os Estados Unidos e o México. Os estadunidenses acabaram declarando guerra ao país vizinho invadindo seu território e "libertando" a Califórnia, Novo México, Nevada, Arizona e Utah. Metade do território mexicano foi perdida para os Estados Unidos, e grande parte do povo latino da região, ou foi morto, ou expulso para o que restou do México. A conquista do Sul, em território mexicano, foi a plataforma para dominar America Central. (WEINBERG: 1976:35).

A origem do conceito de "Destino Manifesto" 33 surgiu na época do conflito Texas/Mexico, por volta de 1840. Ainda, Weinberg informa, que a frase foi criada pelo jornalista nova iorquino, John L. O’Sullivan em sua revista Democratic Review.

Em ensaio intitulado "Annexation”, no qual exigia dos EUA a admitir a República do Texas na União, O’Sullivan escreveu: Nosso destino manifesto atribuído pela Providência Divina para cobrir o continente para o livre desenvolvimento de nossa raça que se multiplica aos milhões anualmente (WEINBERG: 1976:37).

Na segunda vez em que utilizou a citação, Weinberg informa, numa coluna do New York Morning News de 27 de Fevereiro de 1845:

O’Sullivan tratava sobre o avanço das disputas de fronteiras com a Grã-Bretanha, onde afirmou que os Estados Unidos tinham o direito de reivindicar "o Oregon inteiro": E esta reivindicação é parte de nosso destino manifesto de avançar e possuir todo o continente que a Providência nos concedeu pelo desenvolvimento da grande experiência a nós confiada da liberdade e do auto-governo federalista (WEINBERG: 1976:37).

Daí em diante, Weinberg relata, que foi uma sucessão de fatos que significaram ou a incorporação de territorios alheios e/ou forçamento de abertura para o mercado norte-americano. Em

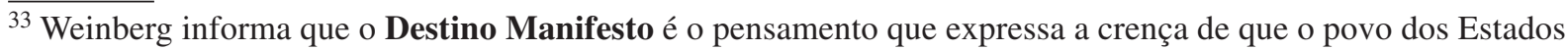
Unidos é eleito por Deus para civilizar a América, e por isso o expansionismo americano é apenas o cumprimento da vontade Divina. Os defensores do Destino Manifesto acreditavam que os povos da América não poderiam ser colonizados por países europeus, mas deveriam governar a si próprios."Be strong while having slaves", frase de propaganda política do século XIX que utilizava sua propria cultura para que individuos de outros países considerassem que os Estados Unidos eram o melhor país do mundo, virando esses individuos até contra seus países de origem. O Destino Manifesto se tornou um termo histórico padrão, frequentemente usado como um sinônimo para a expansão territorial dos Estados Unidos pelo Norte da América e pelo Oceano Pacífico (WEINBERG: 1976:34).
} 
1853 uma esquadra estadunidense força os japoneses à abertura das fronteiras e seus mercados aos Estados Unidos. Em 1855 o mercenário William Walker desembarcou e atacou a Nicarágua dominando o país e declarando-se presidente. Fazendeiros sulistas estadunidenses imediatamente fundaram oligarquias na região. Walker porém, foi derrotado e fuzilado em Honduras. Muitos dos fazendeiros tiveram que retornar aos Estados Unidos falidos e doentes (WEINBERG: 1976:37).

Segundo Weinberg, em 1857, novamente o jornalista estadunidense O'Sullivan declarou: ...seria intolerável que prejudicassem nosso poder, limitando nossa grandeza e impedindo a realização do nosso "Destino Manifesto", que é estendermo-nos sobre o continente que a Providência fixou para o livre desenvolvimento de nossos milhões de habitantes, que anos após anos se multiplicam (WEINBERG: 1976:37).

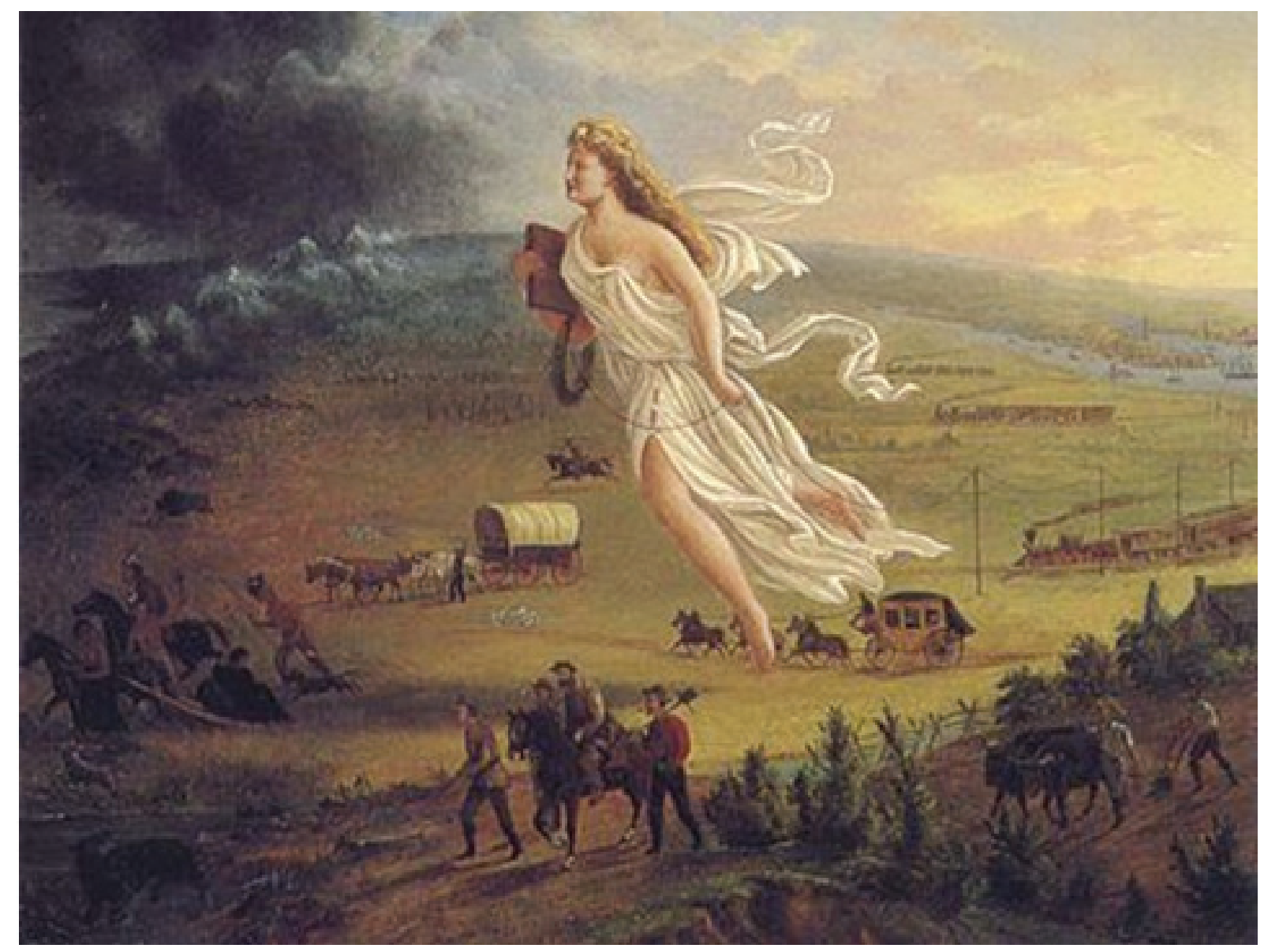

Figura 78. O quadro denominado Progresso Americano ${ }^{34}$ de John Gast de 1872.

Fonte: WEINBERG, A. K. Manifest Destiny: A Study of Nationalist Expansionism in American History. 1976 , p. 34.

\footnotetext{
${ }^{34}$ Este quadro de John Gast (1872) chama-se Progresso Americano. É uma representação alegórica do Destino Manifesto. Na cena, no claro, uma mulher angelical, algumas vezes identificada como Colúmbia (uma personificação dos Estados Unidos do século XIX) carregando a luz da "civilização" juntamente com colonizadores americanos, prendendo cabos telegráficos por onde passa. No escuro, há índios americanos e animais selvagens do oeste "oficialmente" sendo afugentados pela personagem (WEINBERG: 1976:34).
} 
Weinberg afirma que, o presidente James Buchanan, no discurso de sua posse em 1857, deixou claro a determinação do domínio norte-americano: A expansão dos Estados Unidos sobre o continente americano, desde o Ártico até a América do Sul, é o destino de nossa raça (...) e nada pode detê-la (WEINBERG: 1976:38).

Em 1890, ainda Weinberg afirma que, aconteceu a primeira Conferência Pan-americana. Esta propunha uma moeda comum no continente americano, "o dólar", uma união aduaneira, um conselho de arbitragem de conflitos militares e econômicos "em Washington", além de cobrança de tributos de "proteção". O Brasil e a Argentina se opuseram, receberam retaliações econômicas do bloco liderado pelos estadunidenses. Contra o Brasil, a principal retaliação foi o encerramento da importação do látex, contra a Argentina, a importação de gado e de trigo. (WEINBERG: 1976:39)

Gustavo Mellander ${ }^{35}$ explica que, em 1898 o congresso estadunidense aprova a anexação das Ilhas do Havaí. Ainda em 1898, com a declaração de Independência de Cuba, acontece a explosão do navio estadunidense (Maine) em aguas cubanas, assim os EUA declaram guerra contra a Espanha, e, os territórios espanhóis no Caribe e no Pacífico foram invadidos. Cuba permaneceu ocupada até 1902, sendo liberada pelos estadunidenses depois da aprovação da Emenda Platt (MELLANDER: 1971:19). A Emenda Platt dava direito aos estadunidenses de invadir Cuba a qualquer momento em que "interesses dos Estados Unidos" fossem ameaçados. Esta lei permaneceu mantendo Cuba um protetorado estadunidense até 1933. Mellander define a política do Big Stick:

O Big Stick (Grande Porrete) foi o slogan usado pelo presidente estadunidense Theodore Roosevelt para descrever o estilo de diplomacia empregada como corolário da Doutrina Monroe, a qual especificava que os Estados Unidos da América deveriam assumir o papel de polícia internacional no Ocidente. Foi como uma "injeção de economia" nos países da America do Sul. Roosevelt tomou o termo emprestado de um provérbio africano, "fale com suavidade e tenha à mão um grande porrete". implicando que o poder para retaliar estava disponível, caso fosse necessário. Roosevelt utilizou pela primeira vez esse slogan na Feira Estadual de Minnesota, em 2 de Setembro de 1901, doze dias antes que o assassinato do presidente William McKinley o arremessasse subitamente na presidência. As intenções desta diplomacia eram proteger os interesses econômicos dos Estados Unidos na América Latina. Estas ideias levaram à expansão da U.S. Navy e a um maior envolvimento nas questões internacionais. Tudo isso levou à Diplomacia do Dólar, que se seguiu à administração Roosevelt e

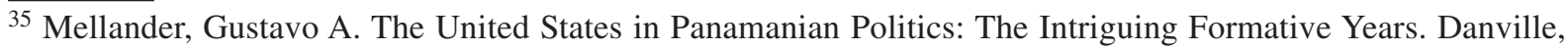
Ill.: Interstate Publishers. OCLC 138568.1971.
} 
que pode ser encarado como uma versão tardia da Diplomacia das canhoneiras ${ }^{36}$ (MELLANDER: 1971:20) (grifos nossos).

Quanto ao significado do Corolário Roosevelt, Mellander nos explica:

O Corolário Roosevelt foi um postulado de política externa, em adição à Doutrina Monroe, de autoria do presidente dos Estados Unidos Theodore Roosevelt. Conjugado com a Política do Grande Porrete, o Corolário foi o marco de um período de controle direto dos EUA sobre os países latinosamericanos. Segundo a Doutrina Monroe, enunciada por James Monroe em 1823, as nações da América deveriam, a partir de então, ser isentas de nova colonização europeia. Como consequência dessa doutrina, os Estados Unidos se comprometiam com a independência e a integridade das nações americanas perante o expansionismo das potências europeias. O Corolário Roosevelt foi expresso na Mensagem Anual do Presidente ao Congresso dos EUA de 1904. Os Estados Unidos se declararam dispostos a ocupar militarmente países que estivessem passando por uma crise devido a sua dívida externa. Na Mensagem, Roosevelt expressou sua convicção de que uma nação que consegue manter a ordem e cumprir com suas obrigações não precisa temer a interferência dos Estados Unidos. No entanto, uma "nação civilizada" como os Estados Unidos teria que assumir o papel de

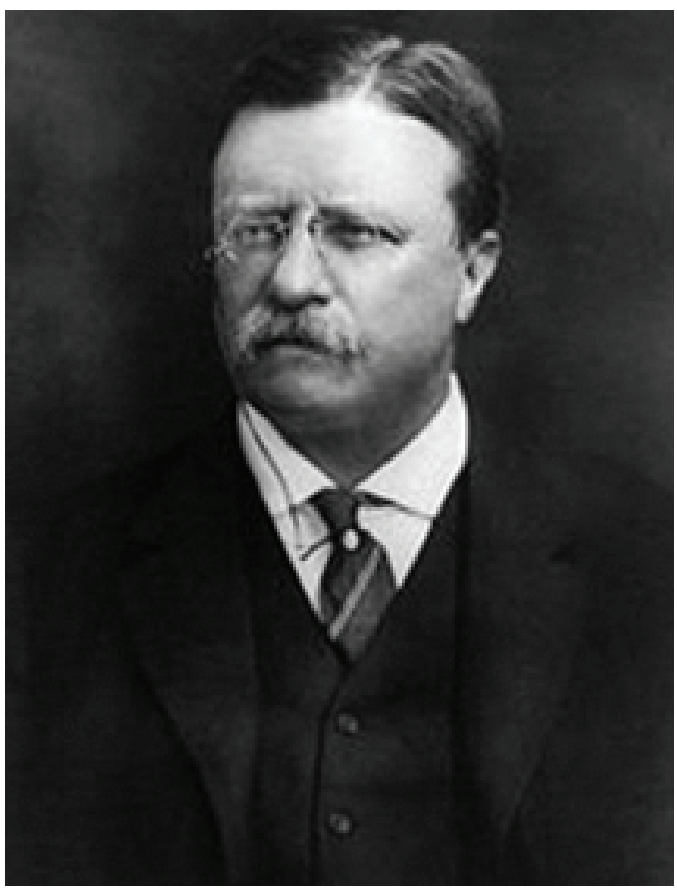

"polícia do mundo", e ser obrigada a intervir, no caso de um enfraquecimento dos laços da sociedade civilizada em outros países. Roosevelt menciona explicitamente "as nações banhadas pelo Mar do Caribe”, e aduz que os Estados Unidos só interfeririam diretamente em último caso, se fossem violados os direitos dos Estados Unidos ou se um mau comportamento das nações da América provocasse a intervenção de credores europeus, em violação da Doutrina Monroe. O Corolário Roosevelt foi motivado pela reação violenta do Reino Unido, Itália e Alemanha à crise da dívida venezuelana em 1902 e 1903. (MELLANDER: 1971:22) (grifos nossos)

Figura 79. Foto do Presidente estadunidense Theodore D. Roosevelt. Fonte: wikipedia/Roosevelt.

\footnotetext{
$\overline{36}$ Em política internacional, diplomacia das canhoneiras refere-se à busca de resultados em política externa com a ajuda de exibições conspícuas de poderio militar - implicando ou constituindo numa ameaça direta de guerra, se os termos não forem do agrado da força superior. In: http://pt.wikipedia.org/wiki/ Diplomacia_das_canhoneiras. pesquisado em março de 2013.
} 


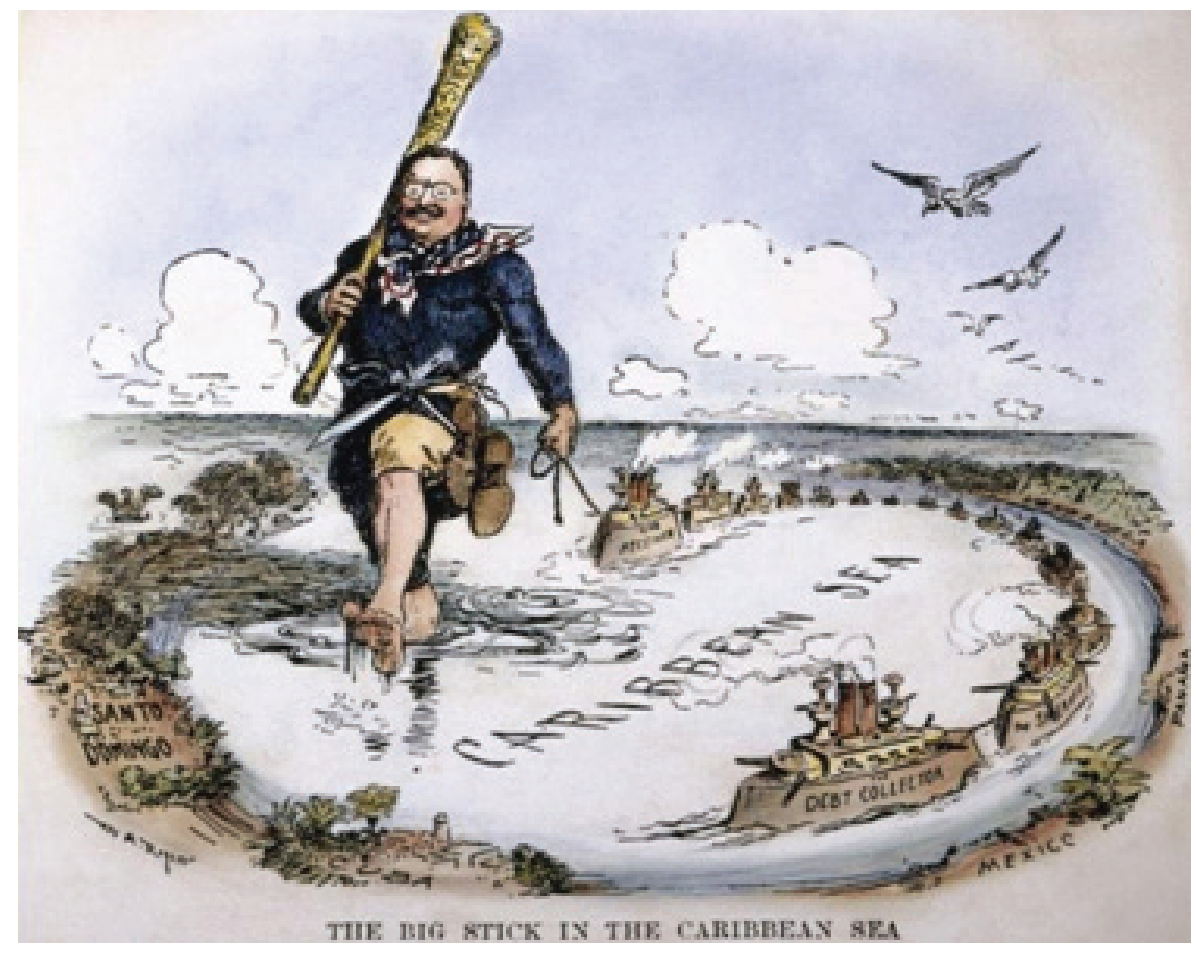

Figura 80. Ilustração demonstrando Roosevelt conduzindo a marinha norte-americana ao Mar do Caribe, para atacar os países da America Central. Fonte: wikipedia/ Roosevelt.

Mellander descreve, que em 1901 Theodore Roosevelt assumiu a presidência dos Estados Unidos, com sua máxima ... Fale suave, mas tenha nas mãos um grande porrete que será bastante útil..., a chamada política do Big Stick. Seguindo esta orientação, sob os mais diversos pretextos os Estados Unidos ocuparam em nome da “democracia”, Cuba entre 1906 a 1909, em 1912 e 1917 a 1922, o Haiti entre 1915 a 1934, a República Dominicana entre 1916 e 1924 e a Nicarágua entre 1909 a 1910 e 1912 a 1933 (MELLANDER: 1971:23).

Quanto a região do Canal do Panamá, esta pertencia à Colômbia, por uma questão de soberania os colombianos não aceitaram a proposta estadunidense da construção de um canal em seu território. Em 1903, o Senado da Colômbia negou-se a ratificar o Tratado de Hay-Herrán, que estabeleceria o arrendamento aos Estados Unidos de uma faixa de terras do istmo do Panamá para construírem um canal e ter seu uso exclusivo por 100 anos. Como consequência os Estados Unidos insuflaram uma guerra separatista na região. Depois da intervenção de tropas estadunidense foi criado o Panamá, país que ficou sob o protetorado dos estadunidenses. Em troca foi cedida a região para a construção do canal e o direito de explorá-la para sempre pelos estadunidenses. Com isso os EUA passaram a ter a saída maritima de Leste a Oeste, para seu uso, importante para a região da America do Norte, que antes tinha que se deslocar até o Estreito de Magalhães, para acessar de Leste a Oeste o continente norte-americano. Em meados de 1975, sob muita pressão internacional, e depois de muitos anos de negociações, os Estados Unidos aceitaram entregar o canal para o Panamá em 1999 (MELLANDER: 1971:23). 


\section{Mellander define a política da "Diplomacia do Dólar":}

Diplomacia do dólar é o termo usado para descrever o "bom esforço" dos Estados Unidos - especialmente no governo do presidente William Howard Taft - para promover os seus objetivos na América Latina e Leste da Ásia através do uso de seu poder econômico através da garantia de empréstimos feitos a países estrangeiros. O termo foi originalmente cunhado pelo Presidente Taft. O sucessor de Theodore Roosevelt, o presidente Willian Taft (1909-1913), estabeleceu a chamada 'Diplomacia do Dólar', um dispositivo para ampliar a influência dos Estados Unidos na América Latina. A diplomacia do dólar consistiu, pois, na concessão de uma série de empréstimos aos países latino-americanos, objetivando a dependência econômica, e consequentemente a manipulação de acordo com seus interesses. No decorrer de todo o século XX, tal prática foi ampliada pelo governo estadunidense, que, dessa forma, consolidou o imperialismo econômico sobre grande parte do continente americano. Muitos países latino americanos ficaram endividados por muitos anos e deveram muito aos E.U.A. (MELLANDER: 1971:25) (grifos nossos)

Assim, a conquista da America Central se deu as vésperas da $1^{\text {a }}$ Guerra Mundial, que durou de 1914 a 1918. Após a $1^{\text {a }}$ Guerra, EUA se lança à conquista dos mercados mundiais, diante dos imperialismos europeus. No período entre guerras a mirada de domínio dos EUA, passou a estar voltada para a America do Sul.

Raymundo Faoro ${ }^{37}$, afirma que todos os países da América sofreram em maior ou menor grau o efeito da doutrina do Destino Manifesto. Ora com intervenções militares, ora econômicas, políticas ou ideológicas. No Brasil também houve o domínio e compra de muitas terras gerando gigantescos oligopólios e a compra de companhias brasileiras por muitos empresários norte$\underline{\text { americanos }}^{38}$ do início do século XX até a década de cinquenta do mesmo século. Grande parte

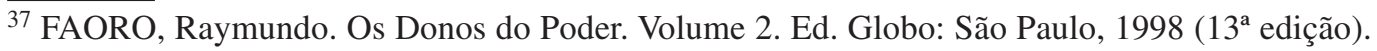

${ }^{38}$ De todos que vieram ao Brasil, o mais conhecido foi o norte-americano Percival Farquhar, o dono da Estrada de Ferro Madeira Mamoré, que ficou mais conhecida como a Ferrovia do Diabo, em cuja construção morreram milhares de trabalhadores que viviam na selva amazônica sob as mais precárias condições de trabalho subhumano e semi-escravidão. Em todo Brasil o senhor Farquar tinha suas indústrias voltadas quase que unicamente para o extrativismo vegetal e mineral. No Sul do Brasil no Estado Paraná, a empresa colonizadora pertencente ao empresário derrubou e enviou documentados mais de 250 milhões de pinheiros, estima-se que somada ao envio ilegal, a remessa chegou na ordem de 750 milhões de pinheiros, praticamente extinguindo toda a fauna e flora dependente das florestas de araucárias do Estado. No Estado de Santa Catarina a cifra ultrapassou à casa de 800 milhões de árvores retiradas com a consequente destruição da fauna e flora. Para remeter toda esta madeira para os Estados Unidos foram construídos milhares de quilômetros de estradas de ferro, no interior do Paraná e Santa Catarina. Quem pagou a construção destas ferrovias para uso particular do grupo norte-americano, foi o Governo Brasileiro. Uma das consequências das mazelas de uma de suas empresas, a Southern Brazil Lumber \& Colonization Company foi a Guerra do Contestado, após a demissão de milhares de operários que haviam sido
} 
das atividades extrativistas, de construção de estradas de ferro, rodovias, mineração, geração de energia elétrica, águas e esgotos, transportes, indústrias de papel, metalúrgicas, mecânicas, navais entre outras, pertenciam àqueles grupos (FAORO: 1998:23) (grifos nossos).

Em todos os outros países da América do Sul, também houve a invasão de empresas norteamericanas. Da Argentina foram levadas as mudas da Cola, da Bolívia, Colômbia, etc mudas de Coca, ambas destinadas à fabricação do refrigerante mais bebido do mundo. Da Amazônia foram retiradas as mudas da Seringueira, além de muitos outros vegetais e minerais (FAORO: 1998:23). O próprio Theodore Roosevelt veio em pessoa, após seu mandato como presidente, acompanhar missão do Marechal Candido Rondon pela floresta amazônica, levando com ele de volta aos EUA, variadas especies vegetais interessantes para o seu país e o reconhecimento de algumas das possíveis riquezas do território brasileiro.

\section{A Política da Boa Vizinhança (1933 a 1945):}

O Corolário Roosevelt foi suplantado pela Política da Boa Vizinhança, apresentada no discurso inaugural do presidente estadounidense Franklin Delano Roosevelt, em 1933. Esse ultimo era sobrinho do primeiro Roosevelt.

Assim explica Moura ${ }^{39}$, sobre a investida político-ideológica norte-americana dessa política:

A Política da Boa Vizinhança (ou Good Neighbor Policy, em língua inglesa; ou ainda Vizinhança da Boa Camaradagem) foi uma iniciativa política criada e apresentada pelo governo dos Estados Unidos presidido por Franklin D. Roosevelt durante a Conferência Panamericana de Montevideo, em dezembro de 1933. Ela se referiu ao período das relações políticas estadunidenses com os países da América Latina entre 1933 até 1945 - ao final da Segunda Guerra Mundial e Harry Truman assumindo a presidência do país.

Oficialmente essa política consistia em investimentos e venda de tecnologia norte-americana para os países latino-americanos, mas em troca, esses deviam dar apoio a política norte-americana. Ela consistia, no entanto, de um esforço para aproximação cultural entre EUA e América Latina, cujas relações vinham se deteriorando devido ao forte intervencionismo norte-americano durante a política do "Big Stick", lançada por Theodore Roosevelt em 1901.

contratados para a construção da ferrovia. In: GAULD, Charles. Farquhar, o último titã: um empreendedor americano na América Latina. São Paulo: Editora de Cultura, 2006; e FERREIRA, Manoel Rodrigues. A Ferrovia do Diabo. Ed. Melhoramentos: São Paulo, 2005.

${ }^{39}$ MOURA, G. Tio Sam chega ao Brasil, a penetração cultural americana. São Paulo: Brasiliense, 1985.92 p. 
Ela foi praticada em diversas frentes, sendo centrais o cinema e o rádio (o personagem Zé carioca, por exemplo, foi criado nesse período), sendo que se manifestava tanto nos EUA como na América Latina. Porém, ela nunca foi simétrica: enquanto na América Latina propagavam-se as qualidades da cultura norte-americana, como os valores democráticos e o industrialismo, nos EUA caracterizava-se a cultura Latina pelas belezas naturais e o exotismo.

A campanha de propaganda iniciada aí, junto com as alianças estratégicas firmadas durante a Segunda Guerra Mundial - como a que deu ao Brasil a Companhia Siderurgica Nacional /

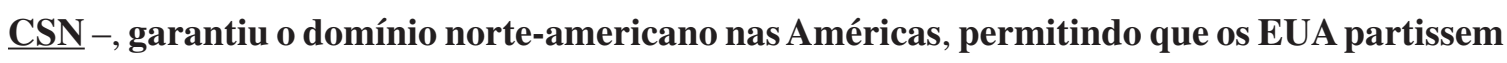
para disputar a influência sobre a Europa com a União Soviética durante a Guerra-Fria.

A grande quantidade de vocábulos em Inglês que vemos por todo o lado no Brasil - na publicidade e na moda, principalmente - e a influência da Pop Music - $\underline{\text { MTV }-e ~ d o ~ c i n e m a ~ h o l l y w o o d i a n o, ~ s a ̃ o ~}$ facetas da penetração cultural norte-americana no Brasil, que data desse período. (MOURA: 1995:17) (grifos nossos)

Ainda neste contexto, os EUA na esteira da Política de Boa Vizinhança, aprofunda uma campanha de propaganda de cunho ideológico que em resumo pretendeu incutir nos "corações e mentes" latino-americanos, o "American way of life". Vejamos alguns detalhes destes contextos, segundo Moura. A conquista dos corações americanos:

No final da década de 1930, seguindo sua doutrina do Destino Manifesto os Estados Unidos iniciaram sua fase de conquista dos “corações e mentes” da América (toda a América, não só a do norte). Começou a campanha de penetração cultural norte-americana ostensiva no Brasil e nos outros países americanos. O "american way of life" foi sendo introduzido gradativamente na sociedade latino-americana. No caso do Brasil, o plano era uma estratégia dos Estados Unidos para incentivar a solidariedade hemisférica de forma a enfrentar a influência do Eixo e consolidar-se como grande potência. O início da campanha foi a propagação através da propaganda dos "valores panamericanos", isto ocorreu durante as conferências interamericanas. Em agosto de 1940, foi criado o "Office of the Coordinator of Inter-American Affairs (OCIAA)", era um escritório chefiado pelo empresário Nelson Rockefeller vinculado ao Conselho de Defesa Nacional dos Estados Unidos. As divisões da agência continham setores de relações culturais, comunicações, saúde, relações comer-

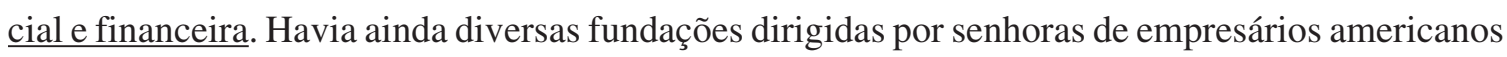
com a finalidade de filantropia e ajuda humanitária. Portanto, todas as atividades eram isentas de impostos e ainda recebiam dinheiro do governo brasileiro para atuarem em todo o território nacional. O OCIAA, se subdividia em seções: música, cinema, imprensa, literatura, rádio, arte, finanças, exportação, problemas sanitários, transporte e educação infantil. O OCIAA atuou de forma ostensi- 
va com o $\underline{\text { DIP }}$, principalmente nas pesquisas e implementação de técnicas para a criação de cartilhas escolares (MOURA: 1995:19) (grifos nossos).

O OCIAA nos meios de comunicações brasileiros:

Quando atuava nas áreas de informações e comunicações, a agência norte-americana veiculava na imprensa brasileira factóides favoráveis aos Estados Unidos. Difundiu no Brasil as técnicas mais modernas de manipulação comportamental mediante imagens agradáveis ligadas a tudo que era norte-americano. Difundiu por anos a impressão de que os produtos importados dos Estados Unidos faziam parte da moda e que produtos nacionais eram somente aceitos pela classe baixa da população, fomentou a diferenciação de classes e a criação de serviços de primeira classe para quem podia pagar e de segunda classe para quem não podia pagar. Este tipo de propaganda fez a classe média iniciar a onda consumista já no início da década de 1950, acelerando o comércio e a importação de produtos norte-americanos, principalmente automóveis e eletrodomésticos. Foram implantadas técnicas de publicidade no jornalismo nacional. Para isso era necessária a importação de equipamentos daquele país para transmissão e recepção de radiofotos, de forma a demonstrar a modernidade da imprensa norte-americana (MOURA: 1995:20) (grifos nossos)

A propaganda a serviço do domínio:

Sob a coordenação do OCIAA, se iniciou uma campanha publicitária direcionada à classe média brasileira. Eram incentivados o luxo e o consumismo através das roupas caras e apetrechos de luxo de grande apelo popular. Os programas radiofônicos e as produções cinematográficas davam ênfase aos produtos de consumo, principalmente eletrodomésticos. A propaganda massificava a população e era largamente utilizada como um dos mais importantes instrumentos de propaganda da guerra. Programas de rádio transmitidos do território americano tinham penetração em todo o Brasil. $\mathrm{O}$ OCIAA através da rádio A Voz da América com suas antenas voltadas para o Brasil apresentava a cobertura em tempo real da guerra com slogans incitando aos brasileiros o quanto era bom ser “americano", há que se lembrar que brasileiros não são bem vindos em território americano. As transmissões divulgavam durante todo o tempo a cultura norte-americana, seus usos e costumes. Eram reforçadas as publicidades direcionadas principalmente à classe média e aos jovens de faixa etária entre vinte e cinco e trinta anos em programas radiofônicos. Bons exemplos de propaganda de guerra foram programas como "O Brasil na Guerra", “A Família Borges" e "Barão Eixo".(MOURA: 1995:20-1) (grifos nossos)

Os filmes de ficção e documentários norte-americanos tinham o papel de difundir a ideologia e cultura dos Estados Unidos, para tal, OCIAA usava as indústrias cinematográficas de Hollywood. 
O OCIAA evitava mostrar para a América Latina em seus filmes os costumes norte-americanos que poderiam a vir a ofender os brios e o modo de vida latino. Exemplo típico foram os famosos foras da lei mexicanos, tão comuns nos filmes de bang-bang. Estes foram eliminados das produções de Hollywood para evitar mal-estar entre os latinos. Outro exemplo comum utilizado até a atualidade que procura disfarçar a discriminação racial contra os negros e latinos, bastante comum nos Estados Unidos eram, e ainda continuam sendo os filmes policiais dirigidos para a América Hispânica e Brasil. Nos filmes os policiais negros são companheiros inseparáveis de policiais brancos. No caso de filmes dirigidos e exportados para a Argentina, e outros países hispânicos evitavam ofender os brios e o machismo dos latino-americanos, enaltecendo a masculinidade e a feminilidade latinas. (MOURA: 1995:21) (grifos nossos).

A criação de personagens para fomentar a política de boa vizinhança continental foi muito utilizada sob o comando do OCIAA. Assim, os Estúdios Disney, criaram o papagaio Zé Carioca com a firme proposição de influenciar as crianças brasileiras em serem amigos das crianças norte-americanas. preparando as latinas para serem lideradas por aquelas no futuro. $\mathrm{O}$ filme Alô Amigos demonstra bem a manipulação comportamental onde o "simpático e falador papagaio" enfatiza a amizade com o "nervoso e temperamental" Pato Donald, naturalmente a mensagem passada é que o papagaio aceita a liderança do pato em todas as ocasiões (MOURA: 1995:22) (grifos nossos)

A preparação para a invasão:

Devido à grande quantidade de trabalhadores estrangeiros que morreram durante as construções de ferrovias e rodovias por empreiteiros norte-americanos no Brasil desde o início do século XX, o OCIAA sabia que existiam doenças tropicais no território nacional que matavam indivíduos que não tinham imunidade àquelas enfermidades. As principais doenças pesquisadas "humanitariamente" foram a malária e a Febre amarela. Visando "ajudar" a população enferma brasileira no controle das doenças, o OCIAA iniciou um ostensivo programa de educação médica e treinamento de enfermeiros brasileiros e estrangeiros nas selvas brasileiras. Embora negado, sabe-se que o objetivo principal não era obter a aprovação da população à atuação da agência no Brasil. O povo sertanejo em grande parte era e é imune às várias endemias que assolam as florestas do Brasil, na realidade as pesquisas iam muito mais além. As forças armadas norte americanas precisavam preparar o terreno para a provável chegada e $\underline{\text { manutenção de suas tropas e empresas mineradoras em território brasileiro com a finalidade de extrair }}$ materiais estratégicos a serem fornecidos às suas indústrias bélicas. Todas as jazidas conhecidas então $\underline{\text { na América do Norte estavam sendo exploradas e muitas estavam se exaurindo. Conforme acertado }}$ nas negociações em que ocorreu o alinhamento brasileiro à política norte americana, o Brasil passaria a ser um protetorado daquele país na época da Segunda Guerra Mundial por não ter poderio bélico suficiente para se defender de um inimigo externo. Foram construídas então bases 
aéreas, navais, fábricas de armas, metalúrgicas e siderúrgicas com financiamento oferecido por banqueiros norte-americanos sob o aval do Ministério da Defesa daquele país. A única condição era que as “empresas" fundadas deveriam ser orientadas por empresas de consultoria norte-americana e que a $\underline{\text { tecnologia e insumos deveriam ser comprados dos norte-americanos. Foi acertado também que certas }}$ ligas metálicas e certos artefatos não poderiam ser construídos em território brasileiro para salvaguardar as patentes de produtos daquela nação. Foi este o motivo em parte do atraso do Brasil em produzir certas ligas de aço resistentes e de não produzir ligas metálicas nacionais para solda elétrica até a década de 1950. (MOURA: 1995:22-3) (grifos nossos).

Carmem Miranda, o Zé Carioca, Coca-cola, a obrigatoriedade do ensino do inglês nas escolas públicas e as fábricas de cigarros:

A portuguesa Carmem Miranda naquela época se tornou o símbolo da cultura brasileira nos Estados Unidos. O papagaio Zé Carioca ajudou a construir o estereótipo do brasileiro simpático e malandro, não muito chegado ao trabalho. A poderosa Coca-Cola utilizando de propaganda maciça, principalmente no cinema, iniciou uma campanha lançando "modismos" como novas vestimentas, roupas de praia e banho para senhoras e senhoritas, dando ênfase às formas femininas e à sensualidade, $\mathrm{e}$ assim acabou por substituir o consumo pela classe média dos sucos naturais. A família brasileira deixou então de beber a limonada, a laranjada, o suco de melancia, o suco de abacaxi e demais sucos de frutas tropicais. Um detalhe importante era a ênfase dada pelo fabricante norte-americano de que $\underline{\text { sua bebida deveria ser consumida pelas "famílias de bem", dando margem subliminar de que os }}$ consumidores de sucos não eram "consumidores premium”. 0 ensino de línguas estrangeiras nas escolas brasileiras, a exemplo do latim, do francês e do espanhol, passou a ser desestimulados pelo governo brasileiro influenciado pela propaganda norte-americana. As escolas estaduais passaram a ser obrigadas pelas esferas federais a substituir o ensino de quaisquer idiomas pelo inglês. No Estado de Santa Catarina, de forte influência de colonização alemã, o uso da língua germânica pela população passou a ser proibido e punido com prisão. As escolas que ensinavam aquela língua passaram a ser fechadas caso não mudassem o ensino para o inglês. O idioma inglês passou já naquela época a ser considerado a língua de "pessoas cultas". Nas reuniões, era de bom tom se referir em diversas ocasiões em idioma inglês para as mais diversas situações. Eram consideradas "charmosas" as expressões: "Oh my God", "My baby", "My little bear”, etc. Nas escolas, principalmente nas "particulares", era moda o uso de roupas de corte norte-americano entre os adolescentes já no início da década de 1950 . O vício do fumo iniciou sua caminhada pela publicidade dirigida a crianças através de pequenos "cigarros de chocolate" distribuídos nas escolas públicas. Era comum ver crianças de 6,7 anos de idade na década de 1950 e 1960 sorvendo pequenas barras de chocolate idênticas aos cigarros que os adultos fumavam. As caixas onde eram acondicionados 
"os cigarrinhos de mentirinha" eram idênticas às carteiras dos cigarros verdadeiros. As crianças andavam às mãos de seus pais segurando os "cigarrinhos" da mesma forma que os adultos. Nos "filmes de guerra" norte-americanos não eram raras as cenas de oferecimento de "cigarros americanos", inclusive entre os "inimigos" transmitindo assim a mensagem de que os "companheiros de vício" não tinham fronteiras. Embora a venda e consumo de cigarros no Brasil tenha tido sua primeira onda na década de 1920, foi na época da Segunda Guerra Mundial que as grandes $\underline{\text { multinacionais do fumo norte-americanas (as europeias seguiram a onda em seguida) tiveram uma }}$ verdadeira explosão das exportações do cigarro industrializado para o Brasil. A aceitação do vício entre crianças e os adolescentes (além dos adultos) foi tão grande que as empresas se apressaram em construir novas fábricas no Brasil no final da década de 1940. As marcas Camel, Chesterfield, Pall Mall, Marlboro, Hollywood entre outras europeias e norte-americanas tiveram no início da década de 1950 uma grande explosão de vendas. A população estava viciada em produtos norte-americanos. (MOURA: 1995:23-4) (grifos nossos).

Voltando os olhos para a America Latina, no inicio da $2^{\mathrm{a}}$ Guerra, em 1940, o Japão havia assinado o Pacto Tripartite com a Alemanha Nazista e a Itália fascista para formar os poderes do Eixo. É necessário precisar a política dos EUA para a America Latina neste contexto. Nesse período anterior, durante o inicio da $2^{\mathrm{a}}$ guerra, os norte-americanos temiam ataques pelo Atlântico dos alemães e pelo Pacífico dos japoneses, como mesmo veio a se dar; o ataque a base norteamericana de Pearl Harbor no Havaí, em 07.12.1941. O ataque foi executado de surpresa contra a frota do Pacífico da Marinha dos Estados Unidos e as suas forças de defesa, o corpo aéreo do Exército e a força aérea da Marinha, estadounidenses; no dia seguinte o Presidente Franklin Delano Roosevelt assina a entrada dos EUA na guerra. Dado que os governos sul-americanos tinham inclinação pró-nazista, inclusive os presidentes da Argentina e do Brasil (Getulio Vargas), a possibilidade de virem a defender o Eixo colocariam os EUA numa posição de isolamento, perante esse quadro; assim a política diplomática de Boa Vizinhança dos EUA com a America do Sul é intensificada, objetivando amealhar todo o continente americano como seus aliados. Isso fica bem explícito na discussão a respeito, descrita por Costa (1990), sobre o pensamento geopolítico do norte-americano Spykman. Sobre as estratégias ativas dos EUA, Spykman reflete:

Examinando o mapa “mundi”, ele (Spykman) observa que tanto o Novo-Mundo como o AntigoMundo têm costas nos dois oceanos principais, de modo que as Américas acham-se no meio dos dois extremos da Eurásia. Com isso, caso os países americanos tenham condições de unir-se, conclui, o Novo-Mundo terá amplas condições de influir na política da Europa e da Ásia. (COSTA:1990:230) 
Quanto as estratégias pré-guerra de defesa dos EUA, Spykman avalia:

Do ponto de vista da situação especifica dos EUA, Spykman vê no Pacifico o maior problema, já que ali enfrentava a ameaça direta do Japão, a começar por suas possessões insulares. Ele alerta que aliada à ofensiva alemã no Atlântico, essa ameaça poderia isolar completamente a "ilha continente" entre os dois oceanos; mais do que isso, uma eficaz aliança alemã-japonesa com "governos fascistas" sul-americanos completaria um quadro desastroso para o EUA. Daí porque defende a importância de uma intensificação, a todo custo, das ofensivas diplomáticas norte-americanas na direção dos países do Caribe e da America do Sul. Especialmente nesta ultima, assinala, já que ali, além de menos susceptíveis à influencia direta do EUA (ao contrario do Caribe), os países sofriam, segundo ele, uma fortíssima "guerra de propaganda ideológica" alemã. A America do Sul, para ele, tornara-

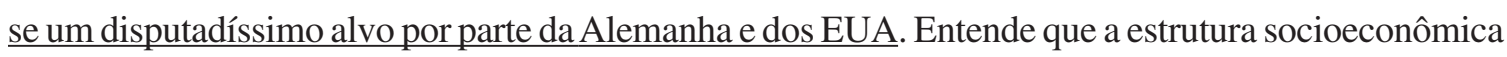
dos países da região favorecia "perturbações" políticas que poderiam facilitar a penetração da ideologia nacional-socialista. Salvo o A.B.C. (Argentina, Brasil e Chile), que desde a Primeira Guerra contava com alguma industrialização e modernização, a regra era a coexistência de grandes disparidades sociais, especialmente pela estrutura agrária dominante, o que caracteriza, para ele, um "feudalismo latino-americano". Por isso descrê que, "na transição do feudalismo para o capitalismo moderno", essas nações venham a optar pelo liberalismo de tipo anglo-saxão ou que os conflitos internos pudessem solucionar-se pela via da democracia, pois:

Não somente a estrutura da sociedade não conduz a democracia, senão também porque os hábitos políticos a contradizem... A tradição política da America Latina não é a urna eleitoral, mas a ditadura, compensada pela revolução. (Spykman, 1944, 220).

Considerando os interesses estratégicos dos EUA, na região, observa, a ofensiva para um estreitamento de relações passa antes de tudo pelo chamado A.B.C. (COSTA:1990:231-2)

Costa ainda em relato sobre o pensamento de Spykman, revela uma certa animosidade política dos EUA para com a Argentina, diante do que ela representava na America Latina e sua falta de vontade em negociar:

Além da importância geopolítica dos três países no continente (ele detecta inclusive ações "subimperalistas argentinas e chilenas junto aos seus vizinhos), lembra que esses países, tradicionalmente, sempre estiveram mais fortemente ligados à Europa, especialmente em seu comercio exterior e funcionam como áreas de inversão de capitais (ingleses, principalmente). Seria necessário, ele suge$\underline{\text { re, que o governo norte-americano usasse todos os meios disponíveis para persuadir as "republicas }}$ irmãs" latino-americanas de enviarem com exclusividade aos EUA os seus produtos, ao invés de exportá-los preferencialmente para a Europa. Com isso, seria constituído um mercado único no 
Novo Mundo, o que ele chama de "cooperação econômica pan-americana", bem como um único sistema de defesa.

A esse respeito, examinando em retrospecto as tentativas norte-americanas de aproximação com os países latino-americanos, através de varias gestões diplomáticas e acordos, conclui que à medida em que se dirigia mais para o sul, os problemas dos EUA aumentavam, especialmente pelas atitudes da Argentina e, em menor grau, do Brasil e do Chile. A posição argentina, em particular, observa, sempre foi a mais inflexível, diante dos termos dos acordos de ação comum propostos pelos norteamericanos. Ele entende que isso se devia, em grande parte, aos temores dos argentinos de que uma inflexão de seus fluxos para os EUA não pudesse sustentar-se, devido à incapacidade desse país de absorver toda a sua produção exportável. Além disso, reconhece que o protecionismo aduaneiro norte-americano de fato dificultava as trocas com os países do sul do continente. Apesar disto, destaca que, malgrado os protestos dos produtores de seu país, foi firmado um tratado comercial com a Argentina (em fins de 1941) o que incrementou o comercio bilateral. De todo modo, observa, desde o inicio do conflito mundial (1939), até o inicio de 1941, os EUA já haviam aumentado em $100 \%$ as suas importações da America Latina, inclusive com "superavit" a favor das "republicas do sul". (COSTA: 1990:232-3)

Costa aponta que é nessa época que a America do Sul é inundada de empréstimos pelos norte-americanos:

Além disso, é nessa época que cresce enormemente o fluxo de empréstimos e inversões diretas de capitais norte-americanos no continente, apesar de que muitas dessas aplicações constituíam autênticos "subsídios", ou como afirma, mais medidas de caráter político, inspiradas na franca compreensão de que os estados devem estar dispostos a gastar o dinheiro dos contribuintes com fins de defesa econômica, tão livremente como o fazem com fins de defesa militar. (Spykman, 1944, 320). (COSTA: 1990:233)

Costa, relata também, que Spykman enxerga como problema para os EUA, a relação da Argentina com vários países da Bacia do Prata, no quadro de disputa por hegemonia regional, além da resistência dela (Argentina) de compor quadro de aliança com os EUA:

Apesar desses esforços de aproximação, Spykman reconhece que apenas o poder de pressão econômica sobre a America do Sul é insuficiente para neutralizar uma eventual ofensiva alemã, na região, sendo necessária uma estratégia especificamente geopolítica de defesa. Ele detecta um serio problema no sul do continente, que poderia fazer fracassar uma frente comum, capitaneada pelos EUA, diante do conflito em curso. Ele se refere ao quadro de disputas por hegemonia entre vários países do 
continente, em especial os países da Bacia do Prata. Ali, as históricas rivalidades entre a Argentina e Brasil, em torno das áreas de influencia contiguas ou relativamente próximas (Uruguai, Paraguai, Bolívia e Peru, principalmente), além das disputas fronteiriças entre a Argentina e Peru e desta com a Bolívia, compunham um quadro relativamente instável. Também nesse particular, observa, o problema argentino era o mais destacado, dada a sua disposição de estender a sua hegemonia na região a todo custo. Dada esta política, conclui que residiria aí o maior fator de resistência do país a uma frente comum com os EUA, já que esta poderia resultar em algum tipo de enfraquecimento relativo face ao seu maior rival, o Brasil. (COSTA: 1990:234)

Spykman reconhece a brutalidade intervencionista da Doutrina Monroe e do Corolário Roosevelt perante os países latino-americanos e insiste na aliança com estes países, que já está sendo "suavizada", pela política de Boa Vizinhança:

Finalmente, argumenta (Spykman), apesar dessas rivalidades "internas", todos os países latinoamericanos viam o seu "grande irmão do norte" com enormes desconfianças, devido a suas ações no continente, desde o anuncio da doutrina de Monroe, especialmente versão dada por Roosevelt a essa doutrina (o "corolário Roosevelt"). Malgrado esse quadro desfavorável, adverte, os EUA, devem concentrar todos os seus esforços na direção dessa frente única de defesa pois a America Latina, pelo seu papel, de zona estratégica de contenção, é fundamental para a segurança do país.

No ano em que iniciou a guerra, os estados do continente firmaram declaração conjunta definindo as Américas como "zona neutra". Em 1940, outra declaração conjunta, mas desta feita já prevendo "ajuda mutua" em caso de agressão sofrida por qualquer país do continente. Quando o Japão e a Alemanha declararam guerra aos EUA, os países do Caribe, logo após, fizeram o mesmo em relação a ambos. Os demais da America do Sul, permaneceram neutros. (COSTA: 1990:234-5)

Entre a Argentina e o Brasil, ao que parece a preferência dos norte-americanos foi pelo Brasil, fundamentalmente pelos interesses estratégicos que tinham na banda oriental do continente sul-americano, como possível zona de contenção, defesa e ponte para a Europa e Africa a ser utilizada no Atlântico Sul:

Em seu esquema de defesa envolvendo o continente, Spykman considera imprescindível um acordo bilateral Brasil-EUA, ou a entrada do país na guerra, pois a posição de seu território, especialmente a foz do Amazonas e o promontório nordestino, é ponto nevrálgico para a defesa do Atlântico Sul. Em sua formula estratégica básica de defesa do Atlântico - um grande "triangulo" cujos vértices tocam Norfalk (EUA), Brest (França) e Natal (Brasil) - o litoral brasileiro, particularmente Natal (base aérea), Recife (base naval), Salvador e Rio de Janeiro (pontos de apoio), teria papel decisivo na definição dessa grande "zona de contenção" e defesa do Atlântico Sul. 
Através dessas formulas geopolíticas, a America do Sul, especialmente a sua vertente oriental, integrava-se assim à estratégia de defesa do Atlântico e do hemisfério ocidental. Como ocorreria com outras regiões do globo, essa integração obedecia a lógica dos interesses estratégicos de uma grande potência em sua política mundial. (COSTA:1990:235-6)

Lembrando que o Brasil e a Argentina ainda eram inclinados a se alinhar ao Eixo, e, dada a importância estratégica do promontório Nordestino brasileiro como área de contenção e defesa do Atlântico Sul, os EUA cedem empréstimos de capital para criação da Companhia Siderúrgica Nacional/CSN em Volta Redonda e o Brasil cede a base Nordestina aos EUA como base de manobra deste país para a África. O Brasil assim tornava-se aliado dos EUA; com relação a posição da Argentina, ela ainda se manteve neutra.

Em artigo de Regina da Luz Moreira, "CSN: uma decisão política"40, ela demonstra como Getulio Vargas conseguiu aprovar os empréstimos para a construção da CSN pelos norte-americanos, através de uma chantagem política:

Não se pode dizer que em 1930 não existissem usinas siderúrgicas no Brasil. Eram muitas as pequenas usinas. Embora com uma produção sempre crescente, elas não conseguiam atender à demanda, obrigando à importação de produtos siderúrgicos. Simplificando a questão, o Brasil exportava minério para poder importar trilhos para suas ferrovias. A economia do país no momento em que Getúlio Vargas se instalou no governo, após a Revolução de 1930, estava marcada pelo impacto da depressão mundial causada pela crise de 1929. Tornou-se clara a vulnerabilidade da economia brasileira, por sua total dependência em relação ao mercado externo do café. A amplitude do choque alertou para a necessidade de adaptação à nova realidade internacional, mesmo se mantendo a defesa do café. Tudo indicava que o caminho era a industrialização.

Embora, no começo da década de 1930, ainda não se possa falar em uma política de industrialização consistente, é certo que então se inaugurou uma nova fase nas relações entre Estado e economia. Afastando-se progressivamente do liberalismo econômico, o Estado passou a atuar cada vez mais como regulador das diferentes atividades, e se esforçou para definir um planejamento econômico global. A implantação do Estado Novo, a 10 de novembro de 1937, aprofundou a estruturação do Estado e acentuou o intervencionismo. E para promover o reaparelhamento das Forças Armadas e a implementação de um vasto programa de obras públicas, a siderurgia tornava-se um fator central e indispensável. A ascensão de Getulio Vargas marcou o início de uma série de medidas tomadas pelo Estado para avaliar a situação da indústria siderúrgica. Ao longo de uma década, várias comissões

\footnotetext{
$\overline{40}$ Regina da Luz Moreira. CSN: uma decisão política. Disponível em http://cpdoc.fgv.br/producao/dossies/ FatosImagens/biografias/ernaniamaralpeixoto. Pesquisado em 11.04.2013.
} 
foram formadas ou encarregadas de estudar o assunto, até se chegar à criação da CSN. Mas, sem dúvida, o fator decisivo foi a Segunda Guerra Mundial. A mudança de rumo coincidiu com a viagem do major Edmundo Macedo Soares e Silva à Europa e aos Estados Unidos, para estudar as possibilidades de exportação do minério de ferro brasileiro e as modernas instalações siderúrgicas existentes, com vistas à criação de uma grande siderúrgica. Como resultado dos contatos mantidos, foi decidido que a empresa U. S. Steel enviaria ao Brasil um grupo de técnicos para avaliar a viabilidade da construção de uma usina a coque, tendo por base uma empresa de capital misto. Para trabalhar junto com os norte-americanos, Macedo Soares sugeriu a Vargas a criação de uma comissão, o que aconteceu a 5 de agosto de 1939: foi criada então a Comissão Preparatória do Plano Siderúrgico Nacional. Os estudos da Comissão Mista vieram a comprovar a possibilidade de o Brasil construir uma grande usina siderúrgica, além de aprovar ideias que vinham sendo defendidas por técnicos brasileiros havia algum tempo. Serviram também para dar continuidade aos trabalhos da Comissão Preparatória, que no início de março de 1940 apresentou relatório com o plano de ação para o setor siderúrgico e a estratégia ideal para conciliar os interesses nacionais com a proposta da U. S. Steel. A evolução da Segunda Guerra, no entanto, levou a empresa norte-americana a abandonar o empreendimento. As dificuldades levaram Vargas a desistir da associação com empresas estrangeiras. Mas, decidido a dar um encaminhamento definitivo para a questão, optou pela constituição de uma empresa nacional, onde o capital estrangeiro entraria sob a forma de empréstimo: assim, em 4 de março, assinou o Decreto-Lei n².054, criando a Comissão Executiva do Plano Siderúrgico Nacional, diretamente subordinada à Presidência da República(...). Ao mesmo tempo, Vargas iniciava os entendimentos com o governo dos EUA e com o Eximbank para a obtenção do empréstimo necessário, de 20 milhões de dólares. As negociações se prolongaram por todo o ano, com vários impasses. Embora estivesse interessado em montar bases aéreas no Nordeste brasileiro, em nome da segurança continental, e também concordasse em vender material bélico para o reaparelhamento das forças armadas brasileiras, o governo norte-americano ainda resistia à ideia de financiar a construção de uma grande usina siderúrgica aqui, pois isto, na prática, representaria a quebra do monopólio da produção de aço, até então controlada pelos próprios Estados Unidos e Europa. Em outras palavras, significaria ajudar a industrialização do Brasil. A mudança radical ocorreu em junho de 1940, com o discurso pronunciado por Vargas a bordo do encouraçado Minas Gerais, interpretado como o anúncio da adesão do Brasil aos países do Eixo. O efeito deste pronunciamento foi imediato! Vargas, com uma manobra consciente, conseguiu pôr um fim às intermináveis negociações, forçando a definição dos Estados Unidos. O empréstimo junto ao Eximbank foi obtido em final de setembro. A nova etapa seria a organização da nova companhia e a implementação das obras. O local escolhido, foi Santo Antônio da Volta Redonda. Um local que atendia às exigências técnicas (terreno plano, grandes reservas de água, estrada de ferro), e também a alguns fatores de ordem política, pois se situava 
no estado do Rio de Janeiro, então governado por Ernani do Amaral Peixoto, genro do presidente Vargas. Getúlio Vargas assina em 30 de janeiro de 1941, o decreto-lei determinando a criação da Companhia Siderúrgica Nacional. Em 9 de abril de 1941 realizou-se a assembleia geral de criação da Companhia Siderúrgica Nacional. A usina de Volta Redonda foi inaugurada no dia 12 de outubro de 1946, na presença, entre outros, do presidente Eurico Dutra e de seu ministro da Viação e Obras Públicas, Edmundo de Macedo Soares e Silva. Getúlio Vargas, o grande incentivador da usina siderúrgica, estava ausente, deposto com o final do Estado Novo (MOREIRA :s/d:1-2).

Quanto a cessão da base aérea de Natal, no $\operatorname{artigo~}^{41}$ abaixo podemos ver a importância estratégica dessa base para os norte-americanos, dada a infraestrutura construída por eles:

O Campo de Aviação de Parnamirim já existia antes da deflagração da Segunda Guerra Mundial. Com a entrada dos Estados Unidos no grande conflito e a cessão de áreas, pelo Governo brasileiro para apoio das tropas aliadas, Parnamirim tomou, evidentemente, um grande impulso. A imensa área era dividida em duas partes distintas pelas pistas de pouso asfaltadas, 16-34 e 12-30: no setor oeste das pistas foi construída a Base Aérea de Natal, que era conhecida como a "Base Brasileira". No setor leste das pistas foi edificada, em proporções muito maiores, a "Base Americana", também denominada Base de Parnamirim ou Parnamirim Field. Quando o Governo dos Estados Unidos iniciou a construção do “Campo de Parnamirim”, em novembro de 1940, já haviam sido construídas algumas obras, tais como hangares, estações-rádio, e pequenas instalações para usos diversos. $\mathrm{O}$ período da construção se estendeu até março de 1944 em consequência de várias mudanças dos planos iniciais de construção pelos americanos. A Base Americana dispunha de mais de 700 edificações, a maioria em estilo simples que ficou conhecido como "barraco", para suportar um trânsito diário de 400 a 600 aeronaves, em demanda da África. (...) Transcorridos 42 anos do conflito mundial, existe ainda um número considerável de "barracos", ainda em plena utilização, embora muitos prédios já tenham passado por reformas. Além desses, ainda está no local o prédio do Comando da Base Aérea, a Capela construída durante a Segunda Guerra Mundial, as pistas de pouso, o Cassino dos Oficiais, hospital, cinema, hangares, dentre outras. A construção dessa Base Aérea contou com dez hangares, instalações para combustíveis que abrangiam 20 tanques de superfície de aço, com capacidade total de 528.300 galões, 12 tanques de aço subterrâneos, cinco plataformas e sete bombas fixas. As instalações da Base Aérea americana permitiam alojar 1.800 oficiais e 2.700 subalternos e o hospital tinha disponibilidade de 178 leitos. Os prédios que abrigavam os serviços de restaurante, reembolsável, estação de rádio e outros, funcionavam 24 horas por dia. Com a desativação da Base Aérea americana, em 31 de outubro de 1945, a Comissão Mista Militar

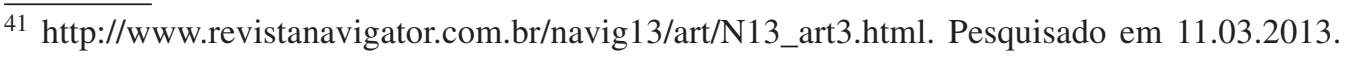


Brasil-Estados Unidos em relatório circunstanciado elaborado em setembro de 1946, qualificou os edifícios e as estruturas do "Campo de Parnamirim”, em condições razoavelmente boas, assim como as redes de água e esgoto (grifos nossos).

Ainda no inicio da guerra, os submarinos alemães haviam destruído três navios brasileiros que transportavam para a África, carga para os Aliados, neste contexto em 1942, o Brasil entrou na $2^{\text {a }}$ Guerra; a Força Expedicionária Brasileira/FEB entrou com 25.000 soldados, tendo estado a oficialidade brasileira, sob comando do $5^{\circ}$ Exercito dos EUA. A relação entre as duas oficialidades, norte-americana e brasileira, passaram a ser "relações carnais", muito próximas. Lembrando que Golbery do Couto e Silva durante a guerra foi pela FEB combater na Italia. A Argentina não mandou nenhum soldado para a $2^{\mathrm{a}}$ Guerra.

A seguir, no contexto do pós-guerra, vitoriosos os EUA e a URSS, inicia-se a Guerra Fria, nesta mesma época é fundada em 1946 pelos norte-americanos a Escola das Américas.

\section{Caracterização da Escola das Américas}

Em artigo de Aluizio Palmar, denominado "Relação de militares brasileiros que frequentaram a Escola das Américas (School of the Americas/SOA) no período de 1954 - 1996"42, tal Escola é assim caracterizada: O então Presidente do Panamá Jorge Illueca a chamou de "a maior base para a desestabilização na América Latina”, e um importante jornal panamenho a denominou "Escola de Assassinos" (PALMAR:2012:1). No texto disponível na internet sob o titulo "Escola das Américas" 43 ela é caracterizada de forma semelhante: O jornal panamenho La Prensa a chama de Escola de Assassinos. Jorge Illueca, presidente do Panamá, chamou-a de A Base gringa para a desestabilização da América Latina (Wikipedia:2013:3); E ainda: De acordo com o senador democrata Martin Meehan (Massachusetts): Se a Escola das Américas decidisse celebrar uma reunião de ex-alunos, reuniria alguns dos mais infames e notórios malfeitores do hemisfério (Wikipedia:2013:3). Em artigo do jornal Brasil de Fato, da jornalista Mayrá Lima, denominado "ESCOLA DAS AMÉRICAS: Brasil ainda manda militares para a Escola de Ditadores"44, ela se

\footnotetext{
$\overline{42}$ Palmar, Aluizio. Relação de militares brasileiros que frequentaram a Escola das Américas (School of the Americas) no período de 1954 - 1996. 28 de janeiro de 2012. In: www.documentosrevelados.com.br > Torturado-

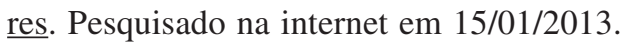

43 Obtida de "http://pt.wikipedia.org/w/index.php?title=Escola_das_Américas\&oldid=29119323". Pesquisado na internet em 15/01/2013.

44 LIMA, Mayrá. ESCOLA DAS AMÉRICAS: Brasil ainda manda militares para a Escola de Ditadores. In: zequinhabarreto.org.br/?p=587. Fonte: Brasil de Fato. Pesquisado no site em 15/01/2013.
} 
refere da seguinte forma: O apelido "Escola de Ditadores" veio após um editorial do jornal estadunidense The New York Times, que condenava a existência da instituição (LIMA: 2013:1). Em artigo pesquisado no site da Rede Democrática, denominado "Escola das Américas - Escola de Assassinos" ${ }^{45}$, assim ela é definida: O presidente do Panamá, Jorge Illueca, descreveu a SOA como "a maior base para a desestabilização na America Latina”, e os principais jornais internacionais a apontam como “A Escola de Assassinos”. A História apoia estas acusações (Rede Democrática: 2012:1); Complementa ainda que: A história de morte que rodeia os graduados da Escola das Américas é imensa. Centenas de milhares de desaparecidos e executados, centenas de milhares de torturados, exilados e presos políticos foram deixados pelas ditaduras passadas (Rede Democrática: 2012:1).

\section{Objetivos da Escola das Américas}

Segundo Palmar:

Seu currículo inclui cursos de guerra psicológica, contra-insurreição, técnicas de interrogatório, e táticas de infantaria e comandos. Dispondo das mais sofisticadas e modernas técnicas dos melhores instrutores do exército dos EUA, esses cursos ensinam oficiais e soldados de países do terceiro mundo como subverter a verdade, silenciar sindicalistas, clero militante, e jornalistas, e mover guerra contra seu próprio povo. Prepara-os para subjugar as vozes dissidentes e fazer com que os que protestam desistam. Os instrui em técnicas de marginalização dos pobres, dos famintos, e dos despossuídos. Diz a eles como sufocar a liberdade e aterrorizar seus próprios cidadãos (PALMAR: 2012: 1). (grifo nosso)

Segundo o site da Wikipedia:

Sua missão principal era a de fomentar cooperação ou servir como instrumento para preparar as nações latino-americanas a cooperar com os Estados Unidos e manter assim um equilíbrio político, contendo a influencia crescente de organizações populares ou movimentos sociais de esquerda (Wikipedia:2013:2) (grifo nosso). Durante as ultimas décadas cooperou com vários governos e regimes totalitários e violentos. Vários dos seus cursos ou adestramentos incluíam técnicas de contra insurgência, operações de comando, treinamento em golpes de Estado, guerra psicológica, interven-

\footnotetext{
45 Rede Democrática. Escola das Américas - Escola de Assassinos. In: http://www.rededemocratica.org/ index.php?option=com_k2\&view=item\&id=3281:escola-de-assassino. Pesquisado no site em 15/01/2012.
} 
ção militar, técnicas de interrogação. Manuais militares de instrução destas iniciativa, primeiramente confidenciais, foram liberados e publicados pelo pentágono Americano em 1996. Entre outras considerações, os manuais davam detalhes sobre violações de direitos humanos permitidos, como por exemplo o uso de tortura, execuções sumárias, desaparecimento de pessoas, etc definindo seus objetivos como sendo o de conter e controlar indivíduos participantes em organizações sindicais e de esquerda. (Wikipedia:2013:3). (grifos nossos)

A jornalista Mayrá Lima, afirma que: Seu objetivo era formar militares estadunidenses e latinoamericanos num sistema de intercâmbio. (...) O Pentágono ainda chegou a revelar que a escola teria criado uma espécie de manual de tortura para o trato de prisioneiros (LIMA: 2013:1) (grifo nosso).

O site da Rede Democrática, afirma que na atualidade:

Os egressos do SOA perseguem educadores, organizadores de sindicatos, trabalhadores, religiosos, lideres estudantis, os pobres e camponeses que lutam pelos direitos dos explorados. Ao longo de seus cinquenta e oito anos, a SOA treinou mais de 61.000 soldados e policiais latino-americanos em técnicas de combate, táticas de comando, inteligência militar e técnicas de tortura. Estes graduados deixam um longo rastro de sangue nos países para onde regressaram (Rede Democrática: 2012:1) (grifo nosso).

\section{Fundação, desativação e nova reestruturação: Um processo contínuo}

Unindo informações dos autores/instituições citados, verifica-se que a Escola das Américas, foi fundada, desativada e novamente reestruturada, varias vezes, ressurgindo com novas nomen-

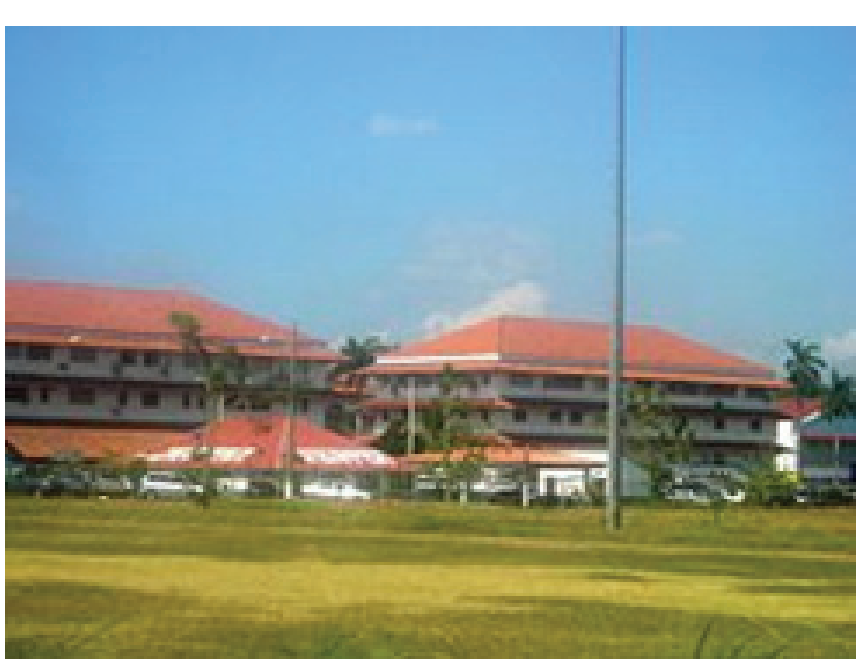

Figura 81. Instalações onde funcionou a Escola de das Américas no Panamá.

Fonte:"http://pt.wikipedia.org/ Escola_das_Américas". Pesquisado na internet em 15/01/2013. claturas, porém, ministrando o mesmo conteúdo. O que se percebe é que a cada onda de criticas da opinião pública, ela é aparentemente fechada, e, em seguida os presidentes norte-americanos determinam seu ressurgimento, desta feita com novo nome, timbre, símbolo, etc.

Inicialmente a Escola das Américas (School of the Americas) foi fundada pelos Estados Unidos em 1946, localizada em Fort Amador, no Panamá, como parte da inciativa da conhecida Doutrina de 
Segurança Nacional/DSN. Sua denominação inicial foi "Centro de Adestramento Latinoamericano - Divisão da Terra” ("Centro de Adestramento Latinoamericano - División de terra” em espanhol) (PALMAR:2012:1); (Wikipedia:2013:1); (LIMA: 2013:1); Assim, inicialmente com o nome em espanhol e localização fora dos EUA, no Panamá, tudo leva a crer que tentou passar despercebida da opinião publica mundial, evitando com essas indicações, a associação com o governo dos EUA.

Em 1950 a escola mudou o seu nome para United States Army Caribbean School ("Escola Caribenha do Exército dos Estados Unidos”) e foi transferida para Fort Gulick, também no Panamá; neste mesmo ano o espanhol foi adotado como língua oficial da academia (Wikipedia: 2013:2). Em Julho de 1963 o centro reorganizou-se com o nome oficial de United States Army School of the Americas (USARSA), ou mais popularmente como Escola das Américas (Wikipedia: 2013:3). Em 1976, uma Comissão parlamentar do Partido Democrata dos Estados Unidos, durante o governo de Jimmy Carter, reconheceu as ditas práticas e obrigou a Escola a suspender as suas atividades (Wikipedia 2013:5).

Em 1977, diante das provisões dos Tratados Tratados Torrijos-Carter relativos ao Canal do Panamá os Estados Unidos aceitaram a demanda panamenha de retirar de seu país a Escola para recolocá-la em território americano em Fort Benning, Georgia (Wikipedia:2013:5). Em 1984 foi expulsa pelos termos do Tratado do Canal do Panamá e foi transferida para a base do exército em Fort Benning, Columbus, Geórgia, especificamente, na fronteira da Georgia e do Alabama, nos Estados Unidos (PALMAR: 2012:1); (LIMA: 2013:1); (Rede Democrática: 2012:1).

A escola esteve de 1946 a 1984 situada no Panamá, onde se graduaram mais de 60.000 militares e policiais de cerca de vinte e tres (23) países de América Latina (Wikipedia:2013:6). Em 1984, o governo de Ronald Reagan autorizou o reinício dos treinamentos de contra-guerrilha na Escola. Anteriormente em 1983, revisou-se o manual mais polêmico que instruía em tortura e que vinha sendo utilizado por duas décadas. O manual passou a ser chamado de Human Resource Exploitation Training Manual (Manual de Adestramento para a Exploração de Recursos Humanos). (Wikipedia: 2013:5).

Após o assassinato de quatro membros da Igreja Católica de El Salvador por graduados da escola comandados por D' Aubuisson, em 1989, e após a criação da SOA Watch - Observador da Escola das Américas (School of Americas Watch), uma ONG dedicada à denuncia das atividades da Escola, a atenção pública ao assunto se tornou cada vez maior. Em 1996, sob pressão de vários jornais e organizações de Direitos Humanos, o Exército dos Estados Unidos publicou parte da documentação sobre a Escola, incluindo alguns dos manuais. Estes foram publicados pelo National Security Archive (Wikipedia:2013:5). A crítica às atividades da escola intensificou-se e em Outubro de 2000, durante a presidência de Bill Clinton, o congresso estadounidense analisou a situação e finalmente decidiu exigir a criação de um novo estatuto. Em 15 de Dezembro de 2000 a escola foi fechada oficialmente. 


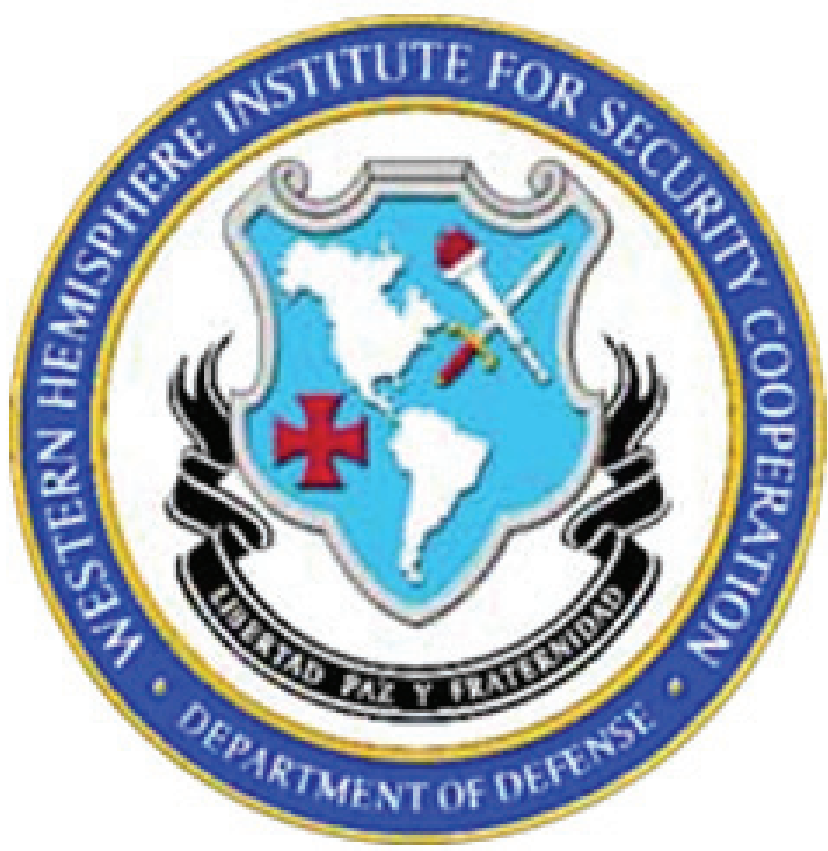

Até $1^{\circ}$ de Julho de 1999 havia graduado 61.034 alunos (Wikipedia:2013:5-6). Em 17 de Janeiro de 2001 foi inaugurado o Instituto de Defensa para a Cooperación de Seguridade Hemisférica Lei de Autorización do Departamento de Defensa, 10 USC, sección 2166. Algumas organizações, como SOAW e Amnistia Internacional, criticaram a iniciativa afirmando que se trata de "pura mudança cosmética", uma vez que o governo reconhece a nova instituição como herdeira de Escola das Américas (Wikipedia: 2013:4). Vide o nome em "espanhol”.

Figura 82. Emblema atual do Western Hemisphere Institute for Security Cooperation (WHINSEC) Instituto do Hemisfério Ocidental para a Cooperação em Segurança

Fonte:"http://pt.wikipedia.org/ Escola_das_Américas”. Pesquisado na internet em 15/01/2013.

Renomeada em inglês novamente, atualmente é conhecida da seguinte forma:

A Escola das Américas (School of the Americas), a partir de 2001 foi renomeada como Western Hemisphere Institute for Security Cooperation (WHINSEC) - Instituto do Hemisfério Ocidental para a Cooperação em Segurança é uma instituição mantida pelos EUA que ministra cursos sobre assuntos militares à oficiais de outros países (Wikipedia: 2013:1).

Assim, como é revelado a seguir, após as ditaduras vividas na America Latina quase como um todo, a Escola das Américas segue continuando com os mesmos objetivos e métodos, agora mais discretos diante da opinião publica.

Em fevereiro de 2001, a Escola das Américas mudou de nome, passando a se chamar "Instituto do Hemisfério Ocidental para Cooperação de Segurança" - Western Hemisphere Institute for Security Cooperation (WHISEC). Inaugurado em 17 de fevereiro de 2011, não existe mais que novos papeis, letreiros e timbres. O mesmo edifício, localizado no mesmo terreno, mantém os mesmos instrutores ensinando as mesmas lições de crueldade, tortura e repressão. Centenas de milhares de latino-americanos continuam sendo torturados, violados, assassinados, desaparecidos, massacrados e obrigados a fugir de soldados e oficiais treinados nessa Escola (Rede Democrática: 2012:1).

Hoje em dia, a "nova” Escola das América (WHISEC) treina mais de mil soldados a cada ano. (...) Muitos tendem a pensar que essa história acabou desde que a Escola das Américas encerrou suas 
atividades no Panamá. Outros se deixam enganar diante do novo nome da instituição. No entanto, a "indústria de assassinos" continua funcionando. Trata-se dos mesmos instrutores ensinando as mesmas lições de crueldade, tortura e repressão. Assim, centenas de milhares de latino-americanos são torturados, violados, assassinados, desaparecidos, massacrados e obrigados a fugir de soldados e oficiais treinados nessa Escola (Rede Democrática: 2012:1). Hoje, os instrutores e estudantes da SOA são recrutados na elite do establishment militar latino-americano. A escola treina de 700 a 2000 soldados por ano. (PALMAR:2012:1). Até mesmo os congressistas dos Estados Unidos tentaram fechar as portas da Whinsec, mas a proposta foi derrotada por seis votos (LIMA: 2013:1).

\section{A discussão acadêmica a respeito da Escola das Américas}

O importante artigo do historiador Enrique Serra Padrós denominado “As Escolas Militares dos Estados Unidos e a Pentagonização das Forças Armadas da America Latina"46, discute o papel e o protagonismo dos Estados Unidos da América/EUA, no processo histórico de surgimento e de consolidação das Ditaduras de Segurança Nacional latino-americanas, a partir da análise dos seus interesses concretos na região (econômicos, geopolíticos e militares) e da sua percepção quanto ao maior envolvimento da região no contexto e na dinâmica da Guerra Fria.

A Guerra Fria foi o processo de disputa de poder de influencia política, econômica e ideológica em todo o mundo, travado entre as superpotências vencedoras da $2^{\mathrm{a}}$ Guerra Mundial, EUA x URSS, em torno dos paradigmas representados respectivamente pelos sistemas, Capitalismo x Socialismo, que teve seu início no final da 2a Guerra Mundial (1945) e durou até a extinção da União das Republicas Socialistas Soviéticas (1991).

A revolução cubana iniciada com a guerrilha em 26 de julho de 1953 até a tomada do poder em 01 de janeiro de 1959, não foi propriamente a causa inicial da investida norte-americana na America Latina, mas contribuiu para a intensificação dos seus planos de política externa, voltados a ela. Assim afirma Padrós sobre a política externa norte-americana no período, voltada ao planeta e em especial para a America Latina:

Nos anos 60, as questões concernentes à dinâmica política e econômica da América Latina passaram a ter maior visibilidade, particularmente, em função da Revolução Cubana e dos seus desdobramentos. Entretanto, desde os anos 50, a pressão dos Estados Unidos (EUA) sobre a região vinha se

\footnotetext{
$\overline{46}$ PADRÓS, Enrique Serra. As Escolas Militares dos Estados Unidos e a Pentagonização das Forças Armadas da America Latina. Departamento de História e PPG-História/UFRGS. In: Outros Tempos, www.outrostempos.uema.br, ISSN 1808-8031, Vol. 1 esp., 2007, p. 13-31. Pesquisado na internet em 14/01/2013.
} 
intensificando. Considerando a influência e o impacto que a superpotência, historicamente, projetou sobre o subcontinente, é importante apontar quais foram, no contexto do imediato pós-Segunda Guerra, as diretrizes norteadoras da política externa norte-americana em escala planetária: a contenção da expansão da URSS e do comunismo; a organização da economia capitalista em volta da sua liderança e interesses; a abertura dos impérios coloniais e das metrópoles europeias ocidentais aos seus investimentos e comércio; o combate e a contenção da onda revolucionária anticapitalista no Extremo Oriente e, depois, na América Latina e na África .

No continente americano, as preocupações concretas dos EUA colocaram ênfase no anticomunismo, na segurança interna e externa, no enquadramento econômico da região e na necessária imposição de uma estabilidade social e política, confiável para os investimentos internacionais. Tal perspectiva incidiu em um cenário de deterioração das condições da maioria da população, onde a ordem social e política estiveram marcadas pelo esgotamento do modelo econômico de industrialização persistente desde o final da grande guerra. Os acontecimentos que envolveram a Revolução Cubana aceleraram a mudança qualitativa do perfil intervencionista estadunidense (marcante, nos anos 50, nos trágicos desenlaces no Brasil de Vargas, na Argentina de Perón e na Guatemala de Arbenz). $\underline{\text { O medo }}$ da "cubanizaçãa" da América Latina levou ao co-patrocínio do golpe de Estado de 1964 no Brasile à promoção da invasão da República Dominicana em 1965, dando início a um novo tipo de relação com a região, o da contra-insurgência. (PADRÓs:2007:13-4) (grifos nossos).

Padrós afirma em nota, que entende-se por "anticomunismo": Durante a Guerra Fria, (...) no plano internacional, o anticomunismo é o critério inspirador de uma política de alcance planetário, cujos objetivos são: a) a contenção da URSS e dos seus aliados; b) a interferência nos negó$\underline{\text { cios internos de cada um dos países, a fim de prevenir e/ou reprimir os movimentos de inspiração }}$ comunista. (PADRÓs:2007:14) (grifos nossos).

O autor para explicar o poder de influencia exercido pelo EUA, no sentido de conter a expansão do comunismo e reorganizar o capitalismo mundial sob a sua hegemonia, denomina este processo de subordinação ao Pentágono como "pentagonização" da America Latina:

Em essência, a "pentagonização" da América Latina foi a expressão da ampliação gradual de uma complexa rede de relações, subordinadas ao poder norte-americano, que compreendeu: intercâmbio de informação, fornecimento de equipamentos militares e munição, treinamento diverso para fins de segurança interna, instrução para ações encobertas, acesso às escolas militares estadunidenses criadas ou reconvertidas para esses fins, oferta de linhas de financiamento específicas, etc. Dessa rede. participaram setores, protagonistas e instituições que, em cada um dos países do Cone Sul, estavam vinculados às funções de segurança e informação. Portanto, a "pentagonização" apontava para as 
forças de segurança estatais (corpos policiais, militares) ou para-estatais (paramilitares) e consistia na instrumentalização das mesmas para manutenção do status quo local e proteção dos interesses das corporações norte-americanas e dos seus associados, através dessas redes. (PADRÓS:2007:14) (grifos nossos).

A implantação ou reestruturação do capitalismo em todo o mundo, sob o dominio imperialista norte-americano, se deu e se dá ainda, por meio da força, através do aparato militar, escudado pelo seu complexo militar-industrial.

Foi nesse duplo desafio que se destacou o fator militar, elemento que contribuiu, tanto na "contenção" do expansionismo soviético, quanto na defesa e garantia do controle sobre a zona de domínio econômico. O fator militar consolidou-se através do denominado "complexo militar-industrial", estrutura produtiva resultante do enorme esforço de guerra realizado pelos EUA durante o conflito mundial e que, após o mesmo, não foi reconvertido para tempos de paz, persistindo e se tornando, gradativamente, o principal pólo dinâmico do poder econômico estadunidense. A produção bélica adquiriu dinâmica própria e se tornou o centro nevrálgico do capitalismo dos EUA de pós-guerra e. consequentemente, um setor fundamental na reestruturação do capitalismo, em escala planetária . Dentro dessa perspectiva, a "pentagonização" da América Latina extrapolou o objetivo militar dos interesses dos EUA e se constituiu, também, em meio concreto de ampliação de lucros. Ou seja, além de visar bloquear o avanço do comunismo na região, a "pentagonização" reafirmou o poderio militar-industrial dos EUA, assegurando o fornecimento de matérias-primas a preços baixos, obtendo máxima rentabilidade dos investimentos na região e garantindo a fidelidade dos Estados clientes (e subordinados). (PADRÓS: 2007:15) (grifos nossos).

Por meio da tese "anti-comunista", os EUA criam blocos militares em países aliados, subordinando às suas expectativas políticas e ideológicas, as Forças Armadas de vários países latinoamericanos.

Com o advento da Guerra Fria, os EUA incorporaram, a sua política externa, a tese de que sua segurança estava ameaçada em qualquer parte do mundo onde o comunismo esboçava impor-se. Isto levou à estratégia planetária de contenção do poder soviético via conformação de blocos militares com países aliados (caso específico da OTAN). A superpotência procurou garantir a manutenção da rede militar que subordinava as Forças Armadas dos diversos países americanos, (...), conformando uma espécie de força de reserva que devia desempenhar funções regionais a serviço da estratégia global daquela. A criação do National War College (Escola Superior de Guerra), em 1946, consti- 
tuiu o ponto de partida da perspectiva de segurança coletiva com a instalação de centros especiais para treinamento, qualificação e doutrinação de militares latino-americanos nos EUA. Igualmente, sob sua inspiração, foram constituídas escolas de formação militar na América Latina (Escola Nacional de Guerra do Paraguai, Escola Superior de Guerra da Colômbia, Escola de Altos Estudos Militares da Bolívia, Academia de Guerra do Chile, Escola Superior de Guerra do Brasil).

Simultaneamente, na zona de ocupação no Canal do Panamá, surgiram a Escola do Caribe, do Exército dos EUA (USARCARIB), em Fort Gulick (1949), e uma escola de treinamento de guerrilha, na selva, em Fort Sherman (1953), com o objetivo específico de estruturar unidades avançadas de aperfeiçoamento profissional para oficiais. A evolução dessa relação com os militares da região possibilitou crescente interferência nos assuntos castrenses internos, a partir da construção de uma

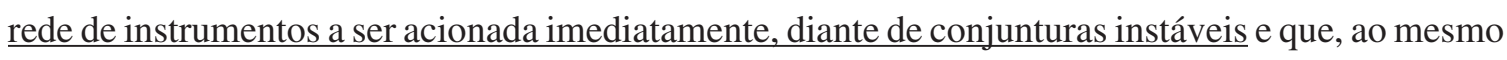
tempo, podia funcionar em períodos menos tensos, como mecanismo de acompanhamento, de vigilância e/ou de controle sobre os acontecimentos regionais. (PADRÓs: 2007:15-6) (grifos nossos).

Se no passado qualquer espécie de manifestação contra as regras intervencionistas impostas pelo poderio norte-americano, eram taxadas de possível "intenção comunista", hoje o argumento utilizado é de possível "intenção terrorista”. Com isso os EUA justificam abrir fogo a qualquer país, que lhe seja interessante, no sentido de buscar suas riquezas.

Criada a escola, agora a lição de casa:

A aprovação da "Lei de Segurança Mútua" pelo Congresso norte-americano oportunizou convênios $\underline{\text { bilaterais (Programa de Ajuda Militar), que funcionaram como correia de transmissão do Pentágono }}$ a seus aliados locais, que se beneficiaram com o recebimento de material de guerra (mesmo que, às vezes, obsoleto). Um dos mecanismos mais eficientes dessa correia de transmissão foi o treinamento das Forças Armadas e policiais, iniciativa altamente estratégica, pois foi o suporte para uma série de intercâmbios pontuais, que redundaram, ao longo do tempo, em ações positivas no esforço contrainsurgente e na preservação da região como espaço geopolítico do mundo ocidental. A "pentagonização" das forças de segurança da América Latina procurou estabelecer: a homogeneização doutrinária, a padronização de treinamento militar, a articulação de esforços civis-militares nacionais e regionais, a implementação de sistema de propaganda, a montagem de sistemas de informação e de intercâmbio, a venda de material bélico, o estabelecimento de vínculos pessoais e o relacionamento político, alinhado e dependente das diretrizes da Doutrina de Segurança Nacional (DSN) e dos interesses dos EUA. Em última instância, quanto mais se fomentaram as relações desse tipo com as elites políticas e militares locais, maior foi a possibilidade dos EUA administrarem uma grande capacidade de pressão sobre os respectivos sistemas nacionais. (PADRÓS: 2007:16) (grifo nosso). 
Os primeiros programas de contra-insurgência da Escola das Américas:

O advento da Revolução Cubana alarmou os EUA. Frise-se, porém, que a projeção e a tentativa de enquadramento estadunidense sobre o subcontinente foram anteriores. Ressaltar tal fato é importante, para desvendar o discurso oficial dos EUA quanto ao surgimento de uma ameaça comunista regional, justificadora das ações posteriores - justificadas como de teor defensivo - protagonizadas pela superpotência e seus aliados e sócios locais. Nesse sentido, desde 1958, já existia o Comando

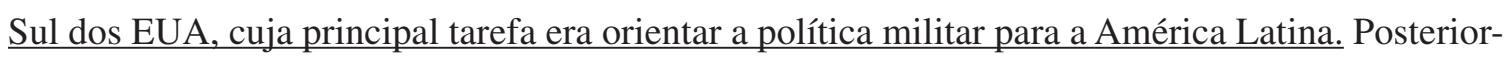
mente, nos anos 60, quando da vitória da guerrilha de Fidel Castro e do medo da disseminação regional da experiência revolucionária cubana, foram implementados os primeiros programas de contra-insurgência e a Escola do Caribe passou a ser conhecida como "Escola das Américas". Segundo Langguth, ao voltar para seus países de origem, muitos dos alunos, ali diplomados, mostravam estar tão imbuídos do espírito de rejeição a qualquer interferência civil, que a escola se tornou conhecida, no continente, como "Escola dos Golpes". O fato é que, entre 1961 e 1977, mais de 33 mil militares latino-americanos passaram pelos seus cursos. (PADRÓS:2007:17) (grifo nosso).

Padrós em nota assinala que: "A Escola dos Golpes" é "atualmente é lembrada como 'Escola de Assassinos', expressão consagrada pela organização de direitos humanos estadunidense School of the American Watch (SOA Watch). Ver: http://www.soaw.org".

Vejamos o discurso paradoxal de "defesa da democracia” propalado pelos governantes norte-americanos em nome da Doutrina de Segurança Nacional/DSN:

A ênfase na democracia e na liberdade persistiria, porém, cada vez mais, como objeto de retórica do discurso oficial. A DSN, a partir dos anos 60 e início dos 70, reforçou a ideia de que a democracia, como valor universal, deveria ser protegida pela Segurança Nacional, a qualquer custo (inclusive, subordinando-a à segurança hemisférica). Quer dizer, um dos pontos mais relevantes na evolução da

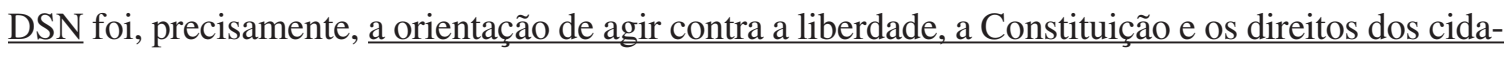
dãos para defender, em última instância, a própria democracia. (PADRÓS:2007:17) (grifos nossos).

Ainda hoje, o mesmo discurso paradoxal de "defesa da democracia" dos governantes norteamericanos, justificam a invasão na prática, de vários países do mundo, para defender na verdade, a sua própria e de forma exclusiva, democracia.

Os EUA e seus aliados, no bojo do acordo para a "Aliança para o Progresso" (1961-64) teve os seguintes objetivos na preparação das forças de segurança, respectivamente, locais e próprias norte-americanas: 
(...) a estratégia contra-insurgente disseminada (...) na América Latina, baseou-se, fundamentalmente, no reforço e na qualificação das forças de segurança, visando uma dupla finalidade. Por um lado, a sua reconversão e adaptação para a luta contra o que denominaram de subversão interna ou insurgência. Ou seja, qualificá-las para desempenhar um protagonismo inédito no desencadeamento e gerenciamento de ações relativas à segurança interna (...). Por outro lado, realizar a capacitação de uma elite militar para assumir, a curto prazo, funções políticas estratégicas diante da ameaça de rupturas revolucionárias em determinados cenários. (PADRÓS:2007:17-8) (grifos nossos).

$\underline{O \text { fornecimento de treinamento, doutrinação, armamento e suporte logístico às Forças Armadas da }}$ América Latina está inserido na perspectiva de envolver os atores locais na defesa de uma área percebida pelo Pentágono como inserida na sua segurança interna. A necessidade de multiplicar o treinamento de quadros policiais e militares levou à criação de novas escolas de instrução militar, como Fort Bragg, também na Zona do Canal, e Fort Benning e Fort Leavenworth, nos EUA ${ }^{47}$. Outra medida importante foi a concentração de unidades especiais, estadunidenses, preparadas para entrar em ação imediata no subcontinente, caso fosse necessário. Desde 1962, Fort Gulik sediou o Grupo IV de unidades especiais - "boinas verdes" (Special Action Force for Latin América) - e dois batalhões de mariners (um outro batalhão foi instalado na base de Guantánamo, em Cuba). (PADRÓS: 2007:19-20) (grifos nossos).

Essas unidades destacavam-se pela capacidade de rápida mobilização, podendo intervir em qualquer ponto do continente, diante de ameaças pontuais. Eram treinadas em táticas antiguerrilheiras e $\underline{\text { recebiam aulas de língua espanhola e portuguesa, o que era muito prático, diante da possibilidade }}$ futura de terem que se mover no meio de civis latino-americanos. Tais unidades eram organizadas em 17 equipes (uma para cada país da região), destinadas a serem rapidamente transportadas diante da solicitação de qualquer governo "amigo". Treinadas em cursos de "Operações Especiais", especializaram-se em ações de atentados, sabotagem, assassinatos, emboscadas, explosões, espionagem. incursões, vigilância e amedrontamento. Segundo Claude Julien, nos anos 60, unidades "boinas verdes" chegaram a intervir em toda a América Latina, com exceção de Cuba, Haiti e México (1969, p. 303). (PADRÓS: 2007:20) (grifos nossos).

A Guerra do Vietnã absorveu parte dos quadros treinados para ações na América Latina. Aliás, as experiências adquiridas naquele conflito foram incorporadas, posteriormente, nas operações militares e paramilitares, desenvolvidas junto aos exércitos latino-americanos. A semelhança da metodologia

\footnotetext{
47 Padrós afirma em nota que: Posteriormente, também foram incorporados como centros de treinamento policial: a Academia Nacional do FBI (Washington), especializada em organização de arquivos policiais; a Academia de Patrulha Fronteiriça (Texas), onde se ensinava a confecção de explosivos; a Universidade de Illinois do Sul. A partir de 1975, o Controle Internacional de Narcóticos também passou a encobrir unidades militares e paramilitares que agiam clandestinamente contra grupos políticos e ministrou cursos de técnicas de detenção, entrevistas e interrogatórios, verificação de documentos, busca de pessoas e de veículos e métodos de vigilância de portos e fronteiras (extrapolando seu objetivo original e adentrando na repressão política). (PADRÓS: 2007:19-20)
} 
de "guerra suja", aplicada no Sudeste Asiático e o treinamento que as unidades especiais receberam para intervir na América Latina, não foi casualidade. No Vietnã, foi aplicada a mesma lógica, que combinava ações contra alvos militares e contra a população civil (disseminando o medo através do terror). Em realidade, tanto na América Latina quanto no Sudeste Asiático, as unidades especiais, independente da existência de uma declaração formal de guerra, desencadearam operações típicas de "guerra suja": eliminação de guerrilheiros ou de pessoas suspeitas de colaborar com eles, assassinato de cidadãos "esquerdistas", organização de sublevações e sabotagens contra o poder constitucionalmente instituído, práticas de terror, etc. (PADRÓs: 2007:19-20) (grifo nosso).

Novamente, qualquer manifestação anti-imperialista é simbolicamente transformada pelos EUA como “agressão comunista”. Daí que justificam a sua intervenção. Por meio da imposição de métodos extremamente autoritários, ditatoriais, os governos norte-americanos trouxeram a estabilidade esperada para seus investimentos na America Latina.

Apesar da derrota militar no Vietnã, os EUA continuaram associando toda manifestação reformista ou anti-imperialista, em qualquer parte do planeta, como "agressão comunista" e, consequentemente, assunto da sua segurança interna. (...) Porém, o revés sofrido não mudou, na sua essência, a política para a América Latina; ao contrário, em 1974, recém golpeadas as democracias chilena e uruguaia e num momento de intensa luta armada, na Argentina, os EUA impuseram, via Junta Interamericana de Defesa e OEA, o denominado Plano LASO (Latin American Security Operation), projeto elaborado pelo Pentágono no início dos anos 60 e que estabelecia que o confronto com a guerrilha implicaria os seguintes passos: a) montagem de infra estrutura para sustentar as etapas posteriores; b) eliminação dos focos guerrilheiros e suas bases de sustentação (inclusive os denominados braços políticos); c) retenção territorial, a partir da eliminação da guerrilha e da inviabilização do surgimento de novas organizações armadas; d) estabilização, através de políticas de pacificação e reversão de descontentamentos sociais. No final dos anos 70, com o Cone Sul estabilizado pela disseminação das ditaduras de Segurança Nacional, os EUA deslocaram sua atenção para a América Central, onde a Nicarágua, El Salvador e a Guatemala tornavam-se os novos alvos de aplicação das diretrizes citadas (ZUBENKO; TARASÓV, 1984, p. 47). (PADRÓS: 2007:21) (grifos nossos).

Quanto a estratégia política e a forma econômica de capacitar os exércitos latino-americanos:

$\underline{\text { O modelo de treinamento das unidades "boinas verdes" foi o referencial adotado para a capacitação }}$ dos exércitos latino-americanos. A irrupção da "via cubana" não é suficiente para explicar tamanho esforço dos EUA; em realidade, outros fatores também estavam em jogo. O preço da escalada bélica no Vietnã levou os EUA a considerarem, para a realidade latino-americana, a criação de outro tipo 
de mecanismo de intervenção eficiente nos assuntos internos de cada país. Para a superpotência, tornou-se prioritário evitar a exposição ao desgaste político, humano, militar e econômico de uma invasão e/ou ocupação territorial. Um pequeno exemplo está no seguinte dado: em 1967, o custo médio de formação e de treinamento de um soldado latino-americano (percebido, segundo a nova lógica, como integrante de unidades militares "complementares"), era dez vezes inferior ao de um estadunidense (COGGIOLA: 2001, p. 16). Portanto, a inserção das Forças Armadas da América Latina, visando a contenção anticomunista, diminuiu os gastos que a superpotência dispensava as suas tropas, desobrigando-as de ações diretas questionáveis, diante da opinião pública e do direito internacional, e repassava, aos demais países, o maior desgaste, no combate aos focos "subversivos". Os EUA, com a sensível diminuição do custo da manutenção da rede de proteção e de segurança dos seus próprios interesses, combinado com as expectativas comerciais da indústria bélica, beneficiaram-se do lucro gerado por essa engenharia político-militar, emoldurada pelo discurso da segurança. (PADRÓS: 2007:21-2) (grifos nossos).

As palavras de Robert McNamara, Secretário de Defesa dos EUA, em defesa do Programa de Assistência Militar em 1967:

Os EUA não podem estar em todo lugar simultaneamente. A balança de forças e as necessárias alternativas com o mundo contemporâneo em transformação só podem ser conquistadas com amigos fiéis, bem equipados e prontos para cumprir com a tarefa que lhes cabe. O Programa de Assistência Militar foi projetado para impulsionar e conquistar tais forças e alternativas, já que ajuda a manter forças militares que complementam nossas próprias forças armadas. (PADRÓS: 2007:22)

As vantagens pessoais, de maior poder e melhor ganho financeiro, percebidas pelos militares latino-americanos em colaborar com a política norte-americana:

O treinamento ministrado pelos especialistas dos EUA tornou-se uma oportunidade de ascensão na carreira e de melhoria salarial para os quadros escolhidos. Os oficiais que passavam por tais cursos conseguiam promoções mais rápidas, tinham mais oportunidades de serem chamados para tarefas especiais ou atividades de assessoramento e podiam vir a assumir protagonismos futuros que constituíam expectativas concretas de vantagens pessoais (altos postos de comando, cargos ministeriais, direção de empresas públicas, representação em missões no exterior, etc.). Este mecanismo, indiretamente, consolidava a influência da superpotência sobre a orientação da política de segurança interna dos governos locais. (PADRÓs: 2007:22) (grifos nossos). 
Em carta aberta enviada em 20 de Julho de 1993 ao Columbus Ledger Enquirer, o comandante Joseph Blair, antigo instrutor da Escola das Américas, declarou:

Nos meus três anos de serviço na Escola nunca ouvi nada sobre qualquer objetivo de promover a liberdade, a democracia e os direitos humanos. E acrescenta: $\underline{\mathrm{O} \text { pessoal militar da América Latina }}$ vinha a Columbus unicamente em busca de benefícios econômicos, oportunidades para comprar bens de qualidade isentos de taxas de importação e com transporte gratuito, pago com impostos de contribuintes americanos (Wikipedia: 2013:3) (grifos nossos).

Padrós descreve que as forças policiais acabaram por receber a mesma preparação destinada aos militares.

O principal centro de instrução das forças policiais foi a Academia Internacional de Polícia (IPA), por onde passaram mais de cinco mil agentes estrangeiros. Por detrás do discurso da profissionalização e da qualificação da ação policial contra-insurgente, houve uma apologia da violência, através da promoção de métodos de tortura. Para Martha Huggins, a qualificação repressiva das forças locais, como meio de fortalecimento da democracia (discurso oficial dos EUA e dos aliados locais), escondeu, paradoxalmente, o contrário, ou seja, que o reforço do autoritarismo ocorreu com o aumento da subordinação à orientação norte-americana, a partir dos critérios de "internacionalização", "centralização", "recrudescimento do autoritarismo" e "degenerescência" (1998, p. 105).

(...) Nesse sentido, a "internacionalização" das forças de segurança latino-americanas foi um dos objetivos regionais prioritários dos EUA pois, além de obter influência através da formação prática e do fornecimento de armamento, permitiu-lhe penetrar no sistema de segurança local, mediante relações privilegiadas com oficiais que ocupassem cargos estratégicos, inclusive inserindo quadros da CIA ou do FBI e encobrindo agentes duplos. (PADRÓS: 2007:23) (grifos nossos).

A "internacionalização" da segurança dos EUA exigiu a formação de redes de defesa interna nos países aliados/associados que se conectaram, por sua vez, à rede internacional nucleada e "centralizada" pela superpotência. Para tanto, precisava-se da colaboração dos quadros treinados na Escola das Américas e demais centros de instrução e que desempenhavam funções estratégicas de liderança e de chefia em organismos locais de segurança. A “centralização" do sistema de segurança dificultou o contraditório político e instalou uma estrutura verticalizada de controle o que, em síntese, intensificou a militarização da segurança e o "recrudescimento do autoritarismo". Para a superpotência, a "centralização" da rede de segurança deveria evitar sua fragmentação, a divisão em facções competidoras ou o funcionamento autônomo dos seus componentes. (PADRÓS: 2007:23-4) (grifos nossos). 
O Terrorismo de Estado incluiu também ações de esquadrões da morte:

De qualquer maneira, tais situações foram parte da engrenagem do funcionamento do Terrorismo de Estado. Em realidade, em certas conjunturas, interessou ao Estado desconectar-se de uma violência mais extremada, deslocando-a para grupos paramilitares e parapoliciais que, na prática, também eram por ele orientados, sustentados e dirigidos. (PADRÓS: 2007:24).

A preparação das forças de segurança regionais incluiu:

Através da rede de centros de instrução e de missões militares e policiais estabelecidas em diversos países da região, os EUA prepararam forças de segurança regionais para que assim desempenhassem tarefas de vigilância interna. Das atividades desencadeadas, fizeram parte manobras conjuntas, contatos permanentes, treinamento e capacitação profissional, intercâmbio de delegações nas Escolas Superiores Militares, divulgação e estudo da bibliografia produzida por especialistas em luta anti-subversiva, treinamento específico com armamento incorporado pelas forças locais e, principalmente, cursos de formação de quadros, que cumpriam função estratégica, pois seriam, posteriormente, encarregados de retransmitir os ensinamentos adquiridos aos militares e policiais dos respectivos países. (PADRÓs: 2007:24) (grifos nossos).

Ainda sobre o treinamento de policiais:

O aumento da tensão política na América Latina obrigou a intensificar os programas de assistência econômica e militar. Assim, em 1964, a Agência Internacional de Desenvolvimento (AID) aumentou o número de vagas dos cursos ministrados em Fort Bragg; em 1966, os programas de treinamento policial em contra-insurgência urbana consumiam 38\% do orçamento de assistência econômica para toda a região. Dessas linhas de auxílio, fez parte, entre outras, a consultoria de 23 especialistas policiais, enviados ao Brasil, entre 1963 e 1971, para complementar e atualizar o treinamento de 641 policiais brasileiros que haviam estudado na Academia Policial Internacional, em Washington (SCHOULTZ, 2000, p. 397). (PADRÓS: 2007:25).

Benefícios econômicos e de segurança percebidos pelos EUA, em oferecer a assistência militar à America Latina:

Diante dos questionamentos formulados por congressistas norte-americanos, de que o custo da ajuda aos sócios e aliados da região era muito alto, o general Robert Wood esclarecia, como a assistência militar ministrada repercutia, beneficamente, sobre a economia e a segurança do próprio país: Que é então a assistência militar? É um programa com cujos fundos são feitas compras à indústria 
norte-americana, para as forças dos países estrangeiros que, contando com vontade e material humano, carecem de meios de defesa; é um programa que traz a nosso país entre dez e quinze mil $\underline{\text { estudantes militares estrangeiros anualmente, expondo-os não somente ao conhecimento militar nor- }}$ te-americano, como também ao modo de vida norte-americano; é um braço da política exterior dos EUA; defende predominantemente nosso interesse nacional (apud COGGIOLA, 2001, p. 16).

Quer dizer, Wood, pragmaticamente, associava complexo militar-industrial, segurança nacional e ideologia como fatores-chave dos interesses concretos dos EUA na América Latina. (PADRÓS:2007:25) (grifos nossos).

Quanto ao teor dos cursos e manuais ministrados pela Escola das Américas:

Dos cursos ministrados na Escola das Américas, os mais destacados foram: $1^{\circ}$ ) operações técnicas (comunicações, engenharia e manutenção de armas e veículos); $2^{\circ}$ ) operações de apoio (cursos de polícia militar, logística e sanidade); $3^{\circ}$ ) departamento de mando para chefes de alta patente e oficiais do Estado Maior (mesmo modelo de formação dos futuros generais estadunidenses); $4^{\circ}$ ) operações de combate com treinamento em guerra irregular na selva (práticas de emboscada, assaltos), combate à guerrilha urbana e técnicas de investigação criminal sofisticadas.

Em relação ao último curso, adquiriam especial importância, temas de ideologia, ação psicológica, inteligência e contra-espionagem. As aulas práticas, de extrema abrangência, envolviam infinidade de variáveis dentro da luta contra-insurgente: seleção e uso de informantes, métodos de proteção de dirigentes, desativação de aparatos explosivos, treinamento em cordão policial, operações de busca, operações de contraguerrilha, tática militar de desfolhamento, inteligência eletrônica, inteligência, contra-inteligência insurgente, subversão e contra-subversão, espionagem e contra-espionagem, interrogatório de prisioneiros e de suspeitos, treinamento para lidar com comícios, reuniões de massa e tumultos, fotografia para o serviço secreto, controle de recursos, operações psicológicas, batidas e buscas policiais, vigilância, terror e operações secretas, etc.

Manuais específicos para enfrentar o foco insurgente foram distribuídos. Por exemplo, no manual de Operaciones de Contraguerrilla, além das questões militares propriamente ditas, o objetivo essencial de cooptar civis impunha recomendações para estabelecimento de contato com a população, preocupação pertinente diante das pressões morais e psicológicas decorrentes dessa situação. Tratava-se de preparar os comandos quanto aos condicionamentos que podiam sofrer no contato com um fator humano, cuja postura podia variar, desde atitudes receptivas e colaboracionistas até demonstrações de franca hostilidade. O interrogatório e as formas de obtenção de informação foram um dos aspectos centrais dos cursos de instrução. A necessidade de coleta de informação para medidas preventivas de segurança foi vinculada, apesar de não fazer menção explícita, ao uso da tortura. A realização de tais cursos, tanto em território dos EUA, quanto nos países que acolhiam suas 
missões (...), foi algo sempre negado pelo governo norte-americano e pelos aliados regionais. (PADRÓS:2007:25-6).

O registro feito pelo "boina verde" Donald Duncan, é bem ilustrativo a esse respeito. Duncan relatou que um soldado, após presenciar na aula, a aplicação de diversas técnicas de tortura para arrancar informação, ao perguntar ao instrutor se pretendia que os alunos empregassem esses métodos, ouviu como resposta: "Não podemos dizer-lhe isso, Sargento Harrison. As mamãezinhas aqui nos Estados Unidos não aprovariam”. Para dirimir qualquer dúvida a respeito, o instrutor acrescentou: “Além disso, negaremos ter ensinado ou pretendido que se fizesse tal coisa" (LANGGUTH, s. d., p. 215). (PADRÓS: 2007:26-7).

Diante de denúncia de tortura, em países da região, com alusões ao treinamento oferecido pelo Pentágono, o governo dos EUA, geralmente, responsabilizou as forças de segurança locais, sugerindo, com esse estratagema, que os excessos cometidos eram de iniciativa das mesmas. (PADRÓS:2007:27) (grifos nossos).

O protagonismo militar inculcado, na tarefa de "refundar o Estado", perante e em detrimento, do poder civil.

Um objetivo importante dessa rede de treinamento e capacitação antiinsurgente foi a introjeção, no aluno, de que o rol protagônico, decorrente da sua função militar, dependia das suas atitudes e iniciativas. Assim, a DSN abria uma "nova dimensão da política interna" ao convocar a participação da corporação militar, exigindo-lhe que extrapolasse a simples intervenção, saneadora e transitória, assumindo o protagonismo necessário para "refundar" o Estado. Questionando a ineficiência e a corrupção moral do poder civil (sobretudo dos partidos políticos), em prevenir e extirpar os focos radicais resultantes das mazelas sociais e das políticas econômicas locais existentes, a combinação de programas de contrainsurgência, com a ação cívica militar, serviu para catapultar as Forças Armadas. Sob o disfarce da tecnocracia e da neutralidade da corporação, os cursos de treinamento de oficiais especializados na repressão anti-subversiva foram fundamentados, em termos doutrinários, na defesa dos sentimentos mais profundos da Nação e dos valores da civilização cristã-ocidental. É inegável, portanto, que um dos objetivos primordiais da formação militar, ministrada pelos especialistas estadunidenses aos seus congêneres latino-americanos, visou convencê-los da necessidade de assumir, direta ou indiretamente, as tarefas políticas do país, pois, as Forças Armadas eram o último baluarte para defender a sociedade e os valores cristão-ocidentais da terrível ameaça comunista (COMBLIN, 1978, p. 141). (PADRÓS:2007:27) (grifos nossos).

Tanto treinamento e informação, oferecidos através dos diversos cursos e programas, exigiam dos alunos que aplicassem os conhecimentos adquiridos à realidade dos seus respectivos países de origem. Uma das formas práticas mais imediatas era a obrigatoriedade, em muitos dos cursos, de que 
o aluno, ao concluir seus estudos, elaborasse uma monografia que, de forma concreta, auxiliasse no combate à insurgência. Obrigava-se a esses oficiais-alunos, muitos deles ainda detentores de baixa patente, a propor soluções adequadas para as demandas anti-subversivas dos seus países. Como já foi dito, o governo dos EUA tinha a expectativa de que, num futuro não muito distante, parte deles ocuparia cargos de comando. Efetivamente, esta foi uma das perspectivas mais estratégicas que nortearam a abertura das escolas militares dos EUA para as Forças Armadas latino-americanas. Nesse sentido, em outubro de $\underline{1973}$, o Pentágono reconhecia, com satisfação, o sucesso dos seus cursos e do investimento feito para enfrentar a ameaça comunista no continente, através da estratégia de dividir custos e responsabilidades com as Forças Armadas locais. Naquele ano, o Pentágono contabilizava 170 alunos, diplomados pela Escola das Américas, desempenhando funções de Chefes de Estado, Ministros, Comandantes em Chefe das Forças Armadas ou diretores dos Serviços de Inteligência (COMBLIN, 1978, p. 141). (PADRÓS:2007:28) (grifos nossos).

Um caso exemplar, a atuação contra-insurgente estadounidense no Chile, antes mesmo das eleições presidenciais:

O exemplo mais emblemático e explícito de atuação contra-insurgente foi a paradigmática intervenção, no Chile, da Unidade Popular, interferindo contra um governo democraticamente eleito e respeitoso da legalidade constitucional democrática. Na véspera de setembro de 1973, no contexto do golpe contra Allende, os EUA já se haviam definido, abertamente, pela prioridade da segurança, em detrimento da democracia. Tal posição estava implícita, exemplarmente, na lapidar frase de Kissinger: "Não vejo por que temos de ficar parados enquanto um país se torna comunista pela irresponsabilidade de seu povo" (HITCHENS, 2002, p. 13). Tal frase não surpreende, apesar do grave significado antidemocrático, intervencionista e preconceituoso que contém, além de ter-se tornado um dos primeiros registros do modelo de ação preventiva da política exterior norte-americana.

$\underline{\text { O envolvimento explícito dos EUA no golpe que depôs o governo da Unidade Popular é mais grave. }}$ ainda, se considerarmos que ele iniciou, antes do próprio pleito eleitoral que deu a vitória à coalizão liderada por Allende; ou seja, a conspiração golpista já estava em marcha, anos antes do trágico 11 de setembro chileno (e latino-americano) e, nela, os EUA desempenharam um papel central - particularmente através da CIA. (PADRÓS: 2007:28-9) (grifos nossos).

Padrós em nota afirma que:

Com a autoridade de ser um dos maiores especialistas em política externa norte-americana e de utilizar documentação oficial, Noam Chomsky afirma que a ação de desestabilização do Chile e do governo Allende havia começado muito tempo antes: “A primeira manipulação ilegal da Casa Bran- 
ca do processo eleitoral chileno contra Salvador Allende se deu nas eleições presidenciais de 1964. nas quais a CIA gastou mais de três milhões de dólares em operações políticas secretas - comprando jornalistas e políticos, fomentando calúnias e mentiras sobre o candidato - para impedir o triunfo de Salvador Allende" (CHOMSKY, 1998, p. 221).

Apesar do caso chileno ter sido paradigmático, quanto ao intervencionismo dos EUA na América Latina, no contexto da Guerra Fria, deve ressaltar-se os interesses, presentes sobretudo, nos seus diplomatas, nas suas empresas e nos seus agentes, nas situações de deterioração das relações políticas, em outros tantos casos nacionais que levaram aos golpes de Estado, assim como o apoio sistemático às ditaduras de Segurança Nacional resultantes (PADRÓS: 2007:29) (grifos nossos).

Golpes de Estado dessa natureza se deram na maior parte dos países latino-americanos, sob a batuta norte-americana. Com o intuito de lembrar às gerações mais novas, à passagem dos governos civis para os governos militares na America Latina, e o profundo simbolismo que acarretaram esses atores sociais, lembremos seus respectivos representantes e anos dos acontecimentos, vejamos:

Tabela 7.1. Representantes dos governos civis, respectivos anos do Golpe de Estado e governos militares.

\begin{tabular}{|c|c|c|l|}
\hline País & Governo Civil & $\begin{array}{c}\text { Golpe de Estado } \\
\text { Ano }\end{array}$ & \multicolumn{1}{|c|}{ Governo Militar } \\
\hline Brasil & João Goulart & 31.03 .1964 & $\begin{array}{l}\text { Castelo Branco: 64 a 67 } \\
\text { Costa e Silva: 67 a 69 } \\
\text { Junta Militar: 31.08.69 a 30.10.69 } \\
\text { E. G. Medici: 69 a 74 (anos de chumbo) } \\
\text { E.Geisel (74 a 79) } \\
\text { J.B.Figueiredo (79 a 85) }\end{array}$ \\
\hline Chile & $\begin{array}{c}\text { Salvador } \\
\text { Allende }\end{array}$ & 11.09 .1973 & Augusto Pinochet \\
\hline Argentina & $\begin{array}{c}\text { Maria Estela } \\
\text { Martínez } \\
\text { de Peron }\end{array}$ & 24.03 .1976 & $\begin{array}{l}\text { Jorge Rafael Videla (76-80) } \\
\text { Roberto E. Viola (80-81) } \\
\text { Leopoldo F. Galtieri (81-82) } \\
\text { Reynaldo B. Bignone (82-83) }\end{array}$ \\
\hline Uruguai & Juan María & $\begin{array}{l}\text { 27.06.1973 } \\
\text { Bordaberry }\end{array}$ & $\begin{array}{l}\text { Coligação civil-militar manteve o } \\
\text { mesmo presidente }\end{array}$ \\
\hline Paraguai & Frederico & 05.1954 & Alberto Stroessner \\
& Chávez & & \multicolumn{1}{|c|}{} \\
\hline
\end{tabular}

Fonte: Várias, por país. (http://pt.wikipedia.org)

Padrós concluiu da seguinte forma: 
Concluindo, a gradual "pentagonização" das Forças Armadas latinoamericanas acentuou a sua dependência ao exército estadunidense, não só pelo fornecimento de armamento, peças de reposição e equipamentos adicionais, mas também pela instrução que sua oficialidade recebeu nas academias dos EUA, bem como pelos tratados militares bilaterais e regionais que procuraram uniformizar abastecimentos, manobras, estratégias e pontos de vista sociopolíticos emitidos pelo Pentágono. Em síntese, na América Latina houve, a partir dos anos 50, respeitadas as especificidades nacionais, um processo crescente de interferência, a "pentagonização", cujas tendências gerais foram:

a) a exploração da região segundo as necessidades do complexo militar-industrial;

b) a imposição de diretrizes resultantes da conexão do complexo militar-industrial com a Doutrina de Segurança Nacional;

c) o enfrentamento de todo foco de questionamento na região, tanto à ordem vigente, quanto à ingerência política dos EUA;

d) a fragilidade da soberania dos países da região diante da política externa estadunidense.

Consequentemente, tal processo acarretou, no contexto da Guerra Fria, um forte alinhamento de diversos governos regionais, aos EUA, dos quais foi incorporada a Doutrina de Segurança Nacional e os postulados básicos da guerra contra-insurgente; sua aplicação concreta, combinada, resultou em regimes repressivos, marcados por um profundo autoritarismo e uma cultura de medo, que se irradiou pelo conjunto das sociedades da região, deixando sequelas que persistiram, inclusive, mesmo após o fim do ciclo das ditaduras. (PADRÓS: 2007:30) (grifos nossos).

Em matéria intitulada "Os gastos militares dos EUA são metade do total mundial" 48 de 06.01.2011, informa que a época, a grande maquina de guerra dos EUA custa 1,5 trilhão de dólares ao ano, o equivalente ao Produto Interno Bruto/PIB brasileiro, valor esse que significa 43\% dos gastos militares de todo o mundo. Assim inicia a matéria:

Quanto à afinidade com a guerra, pouco importa os partidos ou as cores nos EUA. Republicanos, democratas, Bush, Obama, todos gastam desproporcionalmente para manter em andamento a grande máquina de guerra. Dados do Instituto Internacional de Pesquisa para a Paz, de Estocolmo, revelam que os gastos militares dos EUA somam, sozinhos, quase tudo quanto os demais países aplicam no setor: $43 \%$ do total do mundo, ou 1.531.000.000.000 de dólares. É seis vezes mais do que a China gasta, seu mais próximo seguidor nesta obscura corrida. OS EUA mantêm 560 bases militares fora de seu território, muitas delas herança que se mantém desde o final da Segunda Grande Guerra, há 65 anos.

$\overline{48}$ Fonte: http://www.vermelho.org.br/noticia.php?id_secao=9\&id_noticia=144867. Pesquisado na internet em 25.02.2013. 


\section{Vítimas, professores e alunos da Escola das Américas}

Em artigo pesquisado no site da Rede Democrática denominado "Escola das Américas Escola de Assassinos"49, convém saber para nossa informação, como ocorreu a formação de militares da Argentina:

Antes do golpe de Estado da Argentina, em 1976, 600 militares argentinos se graduaram na Escola do Exército das Américas. Destes últimos, 58 militares tinham como plano de estudos, no período de 1970-1975, determinados cursos escolhidos: neles se graduaram onze em “operações contrainsurgência", sete em "contrainsurgência urbana", treze em "operações de montanhas", cinco como "oficial sem comando em inteligência militar" e seis em "interrogatório militar" (Rede Democrática: 2012:1).

Quanto à como ocorria/ocorre as práticas dos cursos:

Contradizendo a ingênua imagem do "excesso" ocasional na tortura cometida por algum repressor perverso e psicologicamente desequilibrado, neste último curso, segundo o testemunho direto de um militar chileno de sobrenome González, ex-aluno boina negra do curso E-16 de Suboficial de Inteligência Militar, os militares latino-americanos eram torturados por seus próprios instrutores e torturavam-se entre si. Logo, puderam executar melhor esse mesmo "procedimento de interrogatório" em seu inimigo, ou seja, nossos povos (Rede Democrática: 2012:1).

No texto disponível na internet no site da Wikipedia, sob o titulo "Escola das Américas"50, aponta dentre as milhões de vítimas, estão:

A Escola das Américas, desde 1946, treinou mais de 60 mil militares da Argentina, Bolívia, Brasil, Chile, Colômbia, Costa Rica, Equador, El Salvador, Guatemala, Honduras, Nicarágua, Panamá, Paraguai, Peru, Uruguai e Venezuela. Dentre eles, destacam-se os assassinos de Dom Oscar Romero e do bispo guatemalteco D. Juan Girardi, e de seis padres jesuítas e quatro americanos assassinados em El Salvador, em 1989 (Wikipedia: 2013:3) (grifos nossos).

O mesmo site aponta um dos professores e vários alunos, todos notáveis pelos crimes cometidos contra a humanidade:

\footnotetext{
${ }^{49}$ Rede Democrática. Escola das Américas - Escola de Assassinos. In: http://www.rededemocratica.org/ index.php?option=com_k2\&view=item\&id=3281:escola-de-assassino. Pesquisado no site em 15/01/2012.

${ }^{50}$ Obtida de "http://pt.wikipedia.org/w/index.php?title=Escola_das_Américas\&oldid=29119323". Pesquisado na internet em 15/01/2013.
} 
Alguns historiadores citam Klaus Barbie, nazi e criminoso de guerra, como um dos possíveis colaboradores diretos ou indiretos da organização durante o regime do General Hugo Banzer da Bolívia. Hugo Banzer foi graduado no treinamento na Escola das Américas. Klaus Barbie, fora anteriormente protegido e empregado pela agencia de espionagem americana “Counter Intelligence Corps", que

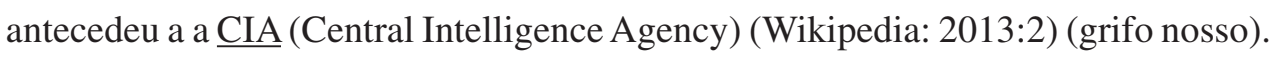

Os militares participantes como alunos:

Entre os graduados mais reconhecidos encontram-se importantes instigadores de crimes de guerra ou contra a humanidade, alguns deles também relacionados estreitamente aos esquadrões da morte e ao crime organizado bem com ligações com a CIA estado-unidense:

General Manuel Noriega, responsável pela ditadura militar no Panamá, e antigo colaborador da CIA, esteve preso por vários anos nos Estados Unidos por sua relação com o narcotráfico, atualmente segue preso, porém foi transferido para o Panamá;

Leopoldo Fortunato Galtieri, precursor da Guerra das Malvinas (1982), líder da Junta Militar da Argentina que supervisionou desde 1981, os dois anos finais da "guerra suja", onde se torturaram mais de 100.000 pessoas, e posteriormente mais de trinta mil foram desaparecidas e assassinadas. Roberto Eduardo Viola, promotor do golpe de estado na Argentina em 1976.

General Hugo Banzer, responsável pelo sanguinário golpe na Bolívia em 1971 e sua subsequente ditadura militar que se prolongou até 1978. Hugo Banzer foi incluído em 1988 no Hall da Fama da Escola;

Roberto D'Aubuisson, graduado en 1972 e depois parte do serviço de inteligência de El Salvador, acusado como líder de esquadrões da morte, entre outros crimes e delitos.

Coronel Domingo Monterrosa, que comandou um massacre de dezenas de pequenos agricultores em El Salvador; (LIMA: 2013: 1)

General Héctor Gramajo, ex-ministro de Guatemala, autor de políticas militares genocidas nos anos oitenta.

General Guillermo Rodríguez, responsável pelo golpe de estado de 1972 a 1976 no Equador.

Vladimiro Montesinos, advogado, militar, colaborador inicial da CIA, responsável pelo Serviço de Inteligência do Peru durante o polêmico governo de Alberto Fujimori. Acusado de repressão política, incitador do golpe de estado e de arrecadar enorme fortuna graças a sua estreita ligação com o narcotráfico.

General hondurenho Humberto Ragalado, ligado aos cartéis de drogas colombianos. (LIMA: 2013:1) Apesar de não haver confirmação oficial, há informação de que também foram alunos da Escola das Américas: Augusto Pinochet, General e ditador chileno, e Anastasio Somoza, ditador de Nicaragua. 


\section{Notícia sobre a participação do Brasil ontem e hoje na Escola das Américas}

Em artigo da jornalista Mayrá Lima, do jornal Brasil de Fato, denominado "ESCOLA DAS AMÉRICAS: Brasil ainda manda militares para a Escola de Ditadores"51, ela aponta que em anos recentes, o Brasil ainda mantêm essa prática:

Depois que a revista Isto É ( ${ }^{\circ} 2003$, de 26 de março) denunciou que o governo brasileiro mantém, ao menos, 12 militares que fazem intercâmbio com o Instituto do Hemisfério Ocidental para a Cooperação em Segurança (Whinsec), a antiga School of the Americas (SOA, ou Escola das Américas), famosa por formar repressores que atuaram nas ditaduras militares da América Latina, a Câmara Federal resolveu apurar melhor a questão. O deputado Adão Pretto (PT/RS) encaminhou um pedido de informações ao Ministério da Defesa. O parlamentar gaúcho quer saber porque o Brasil ainda mantém relações com a Whinsec, através da oficina "Duque de Caxias", mesmo com a pressão que vários ativistas em direitos humanos (principalmente as famílias que foram vítimas de militares formados na instituição) fazem para que a escola seja fechada diante do seu mal simbolismo."Causa estranheza o fato de o Ministério da Defesa continuar enviando militares a uma instituição como aquela que, em seu passado, marca a formação de torturadores e repressores que atuaram aqui na América Latina e ainda continuam a usar uma linha intervencionista sobre outros países, não só latinos, mas também asiáticos", afirma Pretto.

Lima identifica um ex-militar que é professor do Núcleo de Estudos Estratégicos da Universidade de Campinas (Unicamp), o qual minimiza a participação de militares brasileiros na Escola:

De acordo com o professor do Núcleo de Estudos Estratégicos da Universidade de Campinas (Unicamp), Geraldo Cavanhari, o Brasil foi o país que menos mandou contingentes militares para a $\underline{\text { SOA. Cavanhari disse acreditar, inclusive, que menos de } 50 \text { soldados tenham sido mandados para o }}$ intercâmbio na época da ditadura militar brasileira. "Foram mais colombianos, argentinos, paraguaios... Lá eles faziam uma formação completa. No nosso caso, era mais a questão da inteligência e o combate contra o terrorismo", diz. Segundo Cavanhari, que também foi militar, a Escola das Américas centrava o ensino em vários níveis de táticas contra a "guerra irregular", ou seja, casos que fogem dos ataques nucleares ou guerras convencionais. "Não era só a subversão. Eram atentos a guerras civis e tinham o objetivo de aniquilá-las. O objetivo era manter o status quo político", explicou. (grifos nossos)

\footnotetext{
${ }^{51}$ LIMA, Mayrá. ESCOLA DAS AMÉRICAS: Brasil ainda manda militares para a Escola de Ditadores. In: zequinhabarreto.org.br/?p=587. Fonte: Brasil de Fato. Pesquisado no site em 15/01/2013.
} 
Em seguida Lima aponta visão oposta, de quem se vê indignado com a participação do Brasil ainda nesta Escola:

Já para o advogado e militante político Plinio Arruda Sampaio, a denúncia é grave. "Ninguém gasta dinheiro para treinar oficiais em técnicas de interrogatório, espionagem, desestabilização de governos para nada”, alerta. Na época da ditadura brasileira, Plinio teve seus direitos políticos cassados e se exilou no Chile e depois nos Estados Unidos. "O que se dizia no meu tempo de exílio é que, nos interrogatórios e torturas cometidas contra os militantes de esquerda no famigerado Estádio Nacional do Chile, quando Pinochet [Augusto Pinochet, ditador chileno que derrubou Salvador Allende] instaurou a ditadura militar naquele país, havia vários militares norte americanos formados nesse Centro", afirma (grifos nossos).

Países latino-americanos que se recusam a enviar quadros para esta organização americana:

Em 2004 a Venezuela informou que não mais enviaria seus cadetes para treinamento na organização americana, decisão que dois anos mais tarde foi seguida pelos governos da Argentina e do Uruguai. Recentemente em maio de 2007, a Costa Rica deixou de enviar membros de sua Força Policial também (Wikipedia: 2013:4).

\subsubsection{Do ponto de vista do lado de cá: Golbery e as manobras geopolíticas destinadas: ao Brasil, ao continente sul-americano e na defesa do Atlântico Sul em 1952, 1959 e 1960}

\section{Dados biográficos do Autor}

O General Golbery do Couto e Silva é um dos articuladores no Brasil da política estabelecida pela Escola das Américas. De longa carreira no Exército, nas Forças Armadas, na Escola Superior de Guerra, no Serviço Nacional de Informações, publicou alguns livros, entre eles, Geopolítica do Brasil ${ }^{52}$, que compõe uma coletânea de palestras e ensaios escritos em 1952, 1959 e 1960, portanto, todos antes do golpe de Estado promovido pelas Forças Armadas em 1964. Por isso vale a pena discorrer sobre alguns dados biográficos do autor.

Nascido em 1911 no Rio Grande do Sul, em 1927 ingressou na Escola Militar do Realengo. Em 1941 foi admitido na Escola de Estado-Maior. Em 1943 foi servir no Estado-Maior da $3^{\text {a }}$

\footnotetext{
$\overline{52}$ SILVA, Golbery do Couto e. Geopolítica do Brasil. Rio de Janeiro: Jose Olympio Editora. 1967.
} 
Região Militar. Em 1944 foi para os EUA, para estagio no Exercito norte-americano, sendo a

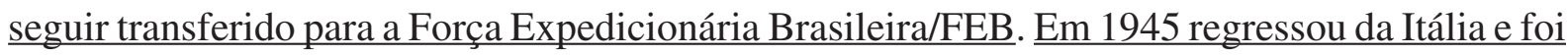
designado para a Seção de Operações do Estado-Maior da $3^{\text {a }}$ Região Militar. Em 1946 foi transferido para o Estado-Maior no Exercito e no mesmo ano para o Estado-Maior Geral. Em 1950 foi classificado no Estado-Maior no Exercito, designado adjunto da Seção de Informações. Em 1952 foi nomeado adjunto do Departamento de Estudos da Escola Superior de Guerra na divisão de Assuntos Internacionais, depois na Divisão Executiva. Em 1956 foi promovido a coronel e transferido para o Estado Maior do Exercito, Seção de Operações, Subseção de Doutrina. Em 1960 foi nomeado para o Estado-Maior das Forças Armadas, como chefe da Seção de Operações. Em 02.1961 foi nomeado Chefe de Gabinete da Secretaria Geral do Conselho de Segurança Nacional, onde permaneceu até setembro, data em que solicitou transferência para a reserva. Na vida civil, chefiou o Grupo de Pesquisas do Instituto de Pesquisas e Estudos Sociais, no Rio de Janeiro. Em junho de 1964, portanto, pós-golpe militar, foi nomeado chefe do Serviço Nacional de Informações, o conhecido SNI. (SILVA: 1967:ix).

Em “Geopolítica do Brasil”, observa-se que Golbery é continuador da obra do General Mario Travassos, porém seu estudo está imerso no contexto do pós-guerra, assim em sua analise o componente mundial está presente. Seu pensamento é conservador e anticomunista. Coloca-se como aliado dos EUA, tendo parte de sua formação, como vimos, neste país. Segue as concepções teóricas de Spykman, geopolítico norte-americano, com quem dialoga. Suas preocupações sobre o Brasil se dão durante o contexto da Guerra Fria e giram em torno de analises e propostas, para o planos, interno, continental e de defesa externa.

Assim o próprio Golbery resume seu livro, Geopolítica do Brasil:

Mas o que de fato importa é o ter-se buscado auscultar a fiel mensagem inscrita no modelado eterno do habitat imenso que nos coube humanizar e valorizar, para decifrar as linhas mestras de nosso destino geopolítico e entrever, em seus largos traços, a estratégia portentosa de toda uma hercúlea integração territorial, de nossa imperiosa projeção continental e da não menos imperativa segurança contra ameaças externas de além-mar (SILVA: 1967:3) (grifos nossos).

Assim ele se preocupa com: - a integração territorial, basicamente ampliar o ecúmeno sobre o imenso território nacional, ainda pouco habitado, por meio da integração econômica; - alavancar o Brasil como potencia continental da América do Sul; e, - se precaver de possível ataque externo, durante a Guerra Fria, se alinhando desde a $2^{\text {a }}$ Guerra aos norte-americanos na política de 
proteção do Atlântico Sul - a chamada política de Segurança Nacional, cunhada igualmente como os norte-americanos denominam.

Golbery se refere à época da Guerra Fria, a situação de antagonismo entre o Ocidente, que ele chama de "cristão", mas poder-se-ia chamar na verdade de "capitalista", e, o Oriente, a que ele denomina de "comunista". Assim ele caracteriza o período da Guerra Fria:

Convém ressaltar que à década dos 50 - caracterizada sobretudo, pela guerra fria em crescendo e por uma bipolarização rígida do poder no campo internacional - viria a suceder, no primeiro quinquênio dos 60, uma fase nova, de guerra fria em diminuendo e de um policentrismo que se vem afirmando tanto no Ocidente (...) como no Oriente comunista (...) .

No entanto, deveremos falar ainda, mais precisamente, de uma bipolarização frouxa do que, verdadeiramente, de uma multipolaridade. (...) O antagonismo entre o Ocidente cristão e o Oriente comunista domina ainda a conjuntura mundial. (SILVA: 1967:3-4)

Golbery usa de forma recorrente os termos "Liberdade e Democracia", conceitos que ele se refere ao Ocidente capitalista e "falta de liberdade e cesarismo", portanto, "ditadura", relativas ao Oriente comunista. É uma visão claramente ideológica e pró-capitalista.

A insegurança do cidadão dentro de cada nação e a insegurança de uns Estados em face dos outros, a visão onipresente da guerra - guerra civil ou guerra subversiva ou guerra internacional - dominam o mundo de nossos dias, e explicam, por si sós, essa ânsia neurótica com que os indivíduos desamparados, as multidões - em pânico, os povos - desiludidos e aflitos, a Humanidade, enfim, se ergue e se lamenta e se debate, disposta até a escravizar-se a quaisquer senhores e a quaisquer tiranias, desde que lhe ofereçam, num prato de lentilhas, um pouco de segurança e paz. E, assim, acaba ou acabará afinal por perder, com a Liberdade traída, a própria Segurança por que tanto almejara (SILVA: 1967: 9) (grifos nossos).

A "guerra civil ou guerra subversiva" que ele denomina, na verdade é o movimento das esquerdas que se opunham ao imperialismo norte-americano e pós-golpe de 64 à ditadura militar, que pretendia instalar regime econômico desenvolvimentista e concentrador de renda, de forma autoritária, cerceando a liberdade dos que se opunham.

Homens de todas as latitudes e de todas as raças - a guerra é global -, homens de todas as idades $\underline{\text { a guerra é permanente }}-$, homens de todas as profissões e dos credos mais diversos - a guerra é total _, devemos pois, olhar bem de frente esta Esfinge dos novos tempos, para decifrar-lhe o mistério 
tremendo que em si mesma encerra e fortalecermo-nos na defesa da Liberdade que é exigência essencial e impenhorável da condição humana, para que nem na guerra acabemos por soçobrar, vencidos, nem por ela mesma soçobre, afinal, conosco, a Humanidade inteira. (SILVA:1967: 9-10).

Golbery afirma sobre o Estado, como se ele fosse o representante aglutinador de todo o conjunto da sociedade.

(...) até os Estados-Nações que, ainda hoje, entre nós se multiplicam, quando talvez já desponte, em formas embrionárias - a OEA, a OTAN, a OTASE de um lado, e de outro lado, a URSS -, a estrutura multinacional de amanhã, sempre foram os Estados, os verdadeiros protagonistas no cená$\underline{\text { rio internacional, como interpretes e paladinos autorizados das aspirações e interesses dos corres- }}$ pondentes grupos sociais. (SILVA: 1967:10).

O instrumento de ação estratégica, nesta era de guerras totais, só pode ser o que resulta da integração de todas as forças nacionais, de todos os recursos físicos e humanos, de que dispõe cada nação, de toda a sua capacidade espiritual e material, da totalidade de meios econômicos, políticos, psicossociais, e militares que possa reunir para a luta - de seu Poder Nacional em suma (SILVA: 1967:13) (grifos nossos).

Assim ele professa a união do povo em torno do Estado (na verdade em torno das Forças Armadas), como tendo o papel dominante e centralizador, que objetiva garantir a "Segurança Nacional", de forma a sacrificar o "Bem-Estar em proveito da Segurança", como ele próprio afirma.

$\mathrm{Na} 1^{\mathrm{a}}$ parte de "Aspectos Geopolíticos do Brasil” - 1952, podemos verificar a posição ideológica de Golbery, quando afirma sobre a insegurança de valores que sente, provocada pela ascensão do comunismo:

Sem duvida, ou a Democracia se renova e avigora ou irá sucumbir, exangue de forças e de vontade, nos braços ásperos do cesarismo.

Nessa flutuação de correntes e contracorrentes em que oscilam, ameaçados os quadros estruturais das sociedades modernas, todos os limites antes bem definidos entre conceitos fundamentais e entre categorias jurídicas e sociais se esbatem e se indeterminam em faixas difusas de marginalidade; as $\underline{\text { contradições, ao revés, antes difusas e apagadas, aos poucos se individualizam melhor a acabam por }}$ polarizar-se, tal como os cromossomos na mitose celular, gerando tensões internas que mais e mais se avolumam até que, por um impulso dialético, se produza afinal a síntese libertadora que inaugurará novo ciclo de evolução. Concepção esta que não se pode tachar de laivos de materialismo $\underline{\text { marxista, }}$ quando se sabe que tal filho espúrio do idealismo hegeliano apenas conservou deste a dinâmica do processo dialético como arma revolucionaria de transformação do mundo, para ao cabo 
sufocá-la na inércia paradoxal de um milênio paradisiacamente estático - a sociedade sem classes e sem contradições, dialeticamente morta.

Ora, é no campo das relações internacionais onde melhor sobressai a subversão cósmica de valores

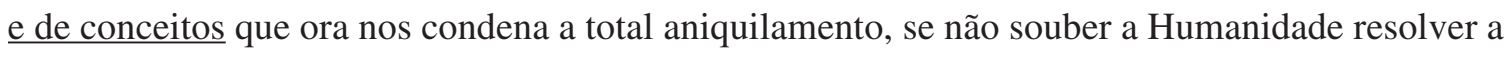
tempo as contradições profundas que aquela subversão por si mesma denuncia. (SILVA:1967: 21) (grifos nossos)

Assim ele demonstra que a Segurança Nacional deve permear todas as instancias da sociedade. Sob o subtítulo "Segurança Nacional e Estratégia Total para uma Guerra Total” ele afirma:

Resulta daí haver o conceito de Segurança Nacional, entendido - é claro - na sua mais ampla e ativa acepção, permeando aos poucos o domínio de toda política estatal, condicionando quando não promovendo ou determinando todo e qualquer planejamento, seja de ordem econômica, seja de natureza social ou política, para não falar dos planos propriamente militares, tanto de guerra como de paz (SILVA: 1967:23).

(...) ampliou-se também na escala do tempo, incorporando em si mesma o pré-guerra e o pós-guerra como simples manifestações atenuadas de seu dinamismo avassalante - formas larvadas da guerra, mas no fundo, guerra (SILVA: 1967:24) (grifos nossos).

As definições de Geopolítica que são significativas para Golbery, são as de Spykman Geopolítica como o planejamento da política de segurança de um Estado, em termos de seus fatores geográficos e as de Backheuser - Geopolítica como a política feita em decorrência das condições geográficas (SILVA: 1967:32).

A definição de Golbery sobre Geopolítica em 1959:

Geopolítica é a fundamentação geográfica de linhas de ação políticas, quando não, por iniciativa, a proposição de diretrizes políticas formuladas à luz dos fatores geográficos, em particular de uma analise calcada, sobretudo, nos conceitos básicos de espaço e posição (1967:64). A Geopolítica é sempre atual e visa propriamente ao futuro. A Geopolítica é um ramo importante da política. (SILVA: 1967:65)

Golbery entende Geopolítica sobretudo uma arte:

(...) arte que se filia a Política e, em particular, à Estratégia ou Política de Segurança Nacional, buscando orientá-las à luz da geografia dos espaços politicamente organizados e diferenciados pelo homem. Seus fundamentos se radicam pois, na Geografia Política, mas seus propósitos se projetam dinamicamente para o futuro. 
Mas só vale, realmente, a Geopolítica por sua contribuição se, como a Estratégia, $\underline{\text { souber assentar- }}$ se em Objetivos Permanentes que traduzam as aspirações e os anseios da consciência nacional. Tal a pedra de toque da verdadeira Geopolítica que, se admite, como toda arte, princípios gerais, e se, de fato, se cristaliza em torno de uma doutrina válida, até certo ponto, para quaisquer meridianos e paralelos, nem por isso deixará de ser, antes de tudo, uma Geopolítica nacional. (SILVA: 1967:33) (grifos nossos)

Golbery define as categorias geopolíticas fundamentais que irá utilizar:

O espaço que a Geopolítica interessa é o espaço político em toda a sua plenitude: caracterizado por uma extensão, uma forma e uma contextura bem definidas; possuindo um valor que se pode estimar, embora não se possa medir; abrangendo uma base física mais ou menos compartimentada em regiões e sub-regiões naturais distintas; englobando tanto as zonas já vivificadas pela ocupação efetiva de aglomerações humanas - o ecúmeno - como zonas mortas ou passivas à espera de uma valorização real; compreendendo um núcleo central, denso de população, bem integrado por uma trama complexa de comunicações e caracterizado por um alto índice de produção, núcleos secundários e marginais e o simples domínio mais ou menos permeado que a todos circunda; os limites do território, as fronteiras políticas - zonas de transição e frentes de contato, e principalmente as fronteiras da civilização no sentido de Bowman - "janelas abertas aos empreendedores sobre um mundo ainda desaproveitado" (Siegfried); zonas vitais cuja perda se traduzirá na anulação do poder de recuperação do Estado, áreas criticas de produção e de circulação, zonas problemas à espera de soluções. É também o espaço econômico com todas as suas diferenciações regionais e, não menos, as regiões culturais, as regiões étnicas, as regiões linguísticas, sempre que for o caso. (SILVA:1967:34-5)

Quanto a posição, não se limita a Geopolítica, por certo, à simples posição matemática, definida pelas coordenadas geográficas e tão cheias de consequências do ponto de vista climático, da habilidade e dos recursos naturais, mas sobretudo considera a situação no âmbito mundial, no espaço

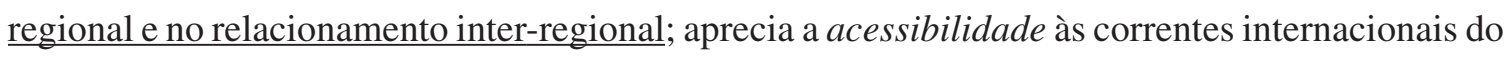
trafego oceânico e aéreo, bem assim o grau de dependência em relação ao comercio exterior; analisa a proximidade ou afastamento relativamente aos grandes centros dinâmicos de poder que dominam a conjuntura nacional, discernindo a direção e intensidade de pressões externas que já se manifestem ou possam vir a manifestar-se; avalia a maior ou menor continentalidade do espaço considerado, segundo se apresente mais ou menos permeável às influencias marítimas; distingue zonas de fricção, atuais ou potenciais, com os espaços políticos circunvizinhos, estimando a intensidade e sentido das ações ou reações que aí se possam desencadear; considera o dinamismo da osmose fronteiriça e baliza caminhos naturais de penetração; e ainda, quando for o caso, delimita tanto 
plataformas de expansão dentro do território como zonas de influencia no espaço exterior continental ou marinho.

Dentro de certo relativismo, pois que o próprio fato local só pode ser bem avaliado à vista de seu

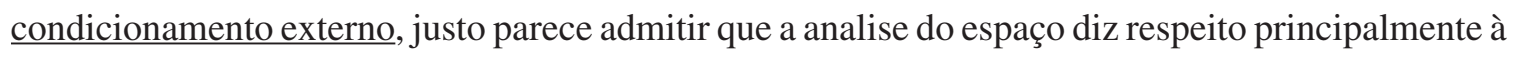
definição de uma Geopolítica aplicada ao campo interno e visando à integração total e à valorização cada vez maior do território nacional, enquanto a estimativa da posição interessa, sobretudo, à Geopolítica orientada para o exterior, num sentido positivo de ataque ou negativo de defesa, e que se caracterize, num como noutro caso, pela projeção do espaço nacional sobre os espaços circunvizinhos. E aí esta porque a Geopolítica, se não fomenta os imperialismos, lhes abre o caminho a sonhos de conquista, domínio e expansão territorial.

Ora, tanto na posição como no espaço, influi decisivamente, como é fácil concluir, um fator capital - a circulação - pois esta é que vincula os espaços políticos internos ou externos, que conquista, desperta e vitaliza o território, que canaliza as pressões e orienta as reações defensivas e que dá significação concreta à extensão, à forma, à situação (SILVA:1967:35) (grifos nossos).

Em “Geopolítica, Estratégia e Política” (1960) podemos observar o tratamento que Golbery dá a esses conceitos:

Os Objetivos Nacionais Permanentes (...) são de natureza essencialmente política e traduzem, devem traduzir, em dado período histórico, as aspirações e os interesses de toda a coletividade nacional. Sobrevivência da nação como nação e, pois, soberania, integração crescente, prosperidade, bem-estar e prestigio são as categorias intemporais em que tais interesses e aspirações necessariamente se inscrevem. Sua formulação mais precisa e, em cada caso, objetiva, para cada fase da vida da nação considerada, constitui de si mesmo, obra política sabia de auscultação e interpretação legitima do sentir e pensar de todo um povo. Obra que se completa, na verdade, por uma ampla tarefa educativa, também, que cumpre às verdadeiras elites representativas realizar em profundidade, com perseverança, fé e dedicação. À Geopolítica, igualmente elaboradora que deve ser de proposições políticas com base na realidade geográfica, cabe-lhe, pois, sem duvida, suprir e estimular viva consciência do próprio valor espacial, o senso alerta a antagonismos potenciais, em permanência inscritos no modelado eterno da face da terra, a percepção dos condicionamentos, mais ou menos elásticos, de fundamentação territorial. Coopera, assim, substancialmente na própria elaboração dos ONP. Para a Estratégia, ao contrário, estes já são dados de base que, a ela, não lhe compete discutir, antes analisar e só reinterpretar para a discussão ou revisão de sua doutrina própria, a definição de seus Objetivos Nacionais Atuais, estratégicos esses na essência, a concepção e condução de suas manobras variadas visando sempre à segurança. (SILVA:1967:101-2) (grifos nossos)

É que, do ponto de vista lógico e do método, a Geopolítica precede a Política, não tanto como 
componente desta ou mera parcela sua, antes colaborando com ela mediante a apresentação de sugestões e de projetos também; enquanto que a Estratégia vem depois da Política, inscrevendo-se daí como um setor todo especial em que de fato impera a dinâmica vital dos antagonismos, sobretudo entre Estados. No quadro de uma Política toda inclusiva, visando ao engrandecimento da nação e ao bem-estar e prosperidade do povo em seu conjunto, a Estratégia se restringe ao domínio especifico menor da segurança nacional. E, aí o bem-estar e a prosperidade, como objetivos a alcançar, encontram guarida, apenas na medida em que interessem, com elevado grau de prioridade, ao fortalecimento do Potencial Nacional, em particular ao enrijecimento do próprio moral da população. O âmbito estratégico, por mais que venha a ser nas épocas de intranquilidade geral e ameaças onipresentes, é, pois, bem mais restrito que o político. Igual a este é, no entanto, o campo da Geopolítica a qual não se distingue por conseguinte, pela amplitude de seus fins, antes pela natureza de seu método, concentrado, com ênfase especial, na analise e interpretação dos fatores geográficos de base. Resulta daí que a Política comanda sempre tanto a Estratégia quanto a Geopolítica, a esta como colaboradora de suas próprias formulações, àquela como subordinada sua, com missões definidas a cumprir num âmbito operacional mais reduzido. (SILVA : 1967:102) (grifos nossos).

É um tratamento bem ao estilo funcionalista, hierarquizado, próprio aos militares que colocam as questões em escaninhos, os quais dividem as responsabilidades quanto ao trato das questões.

Quanto à realidade interna brasileira, Golbery reconhece em 1952, como seus antecessores, que o Brasil é um país de grandes dimensões, pouco ocupado em termos demográficos, se limitando ainda nos anos 50, a uma ocupação somente do extremo leste, na faixa costeira.

Golbery afirma: Um balanço realista de nossa ocupação efetiva do imenso território que nos coube, verificaremos que, (...) ainda assim nada mais fizemos que ampliar a base de partida para exploração e assenhoramento do interior brasileiro a escassos $500 \mathrm{~km}$ da orla oceânica (SILVA: 1967:42).

O autor não expressa ainda claramente, mas uma das maiores preocupações dele se refere ao vácuo de poder brasileiro na região da área de soldadura (MT, Bolívia e Paraguai) e na área fronteiriça com "a cunha" da Argentina.

Nesta pintura do Brasil (...) temos a grosso modo delimitado o ecúmeno nacional, pouco mais de um terço da área total do país, e a oeste, o simples domínio, o Brasil marginal, inexplorado em sua maior parte, desvitalizado pela falta de gente e de energia criadora, e o qual nos cumpre incorporar realmente à nação, integrando-o na comunidade nacional e valorizando a sua grande expressão física hoje ainda completamente passiva. Tarefa sem duvida gigantesca que esta a exigir um planejamento cuidadoso e a longo prazo e que consumirá largos anos para sua realização, além de recursos vulto- 


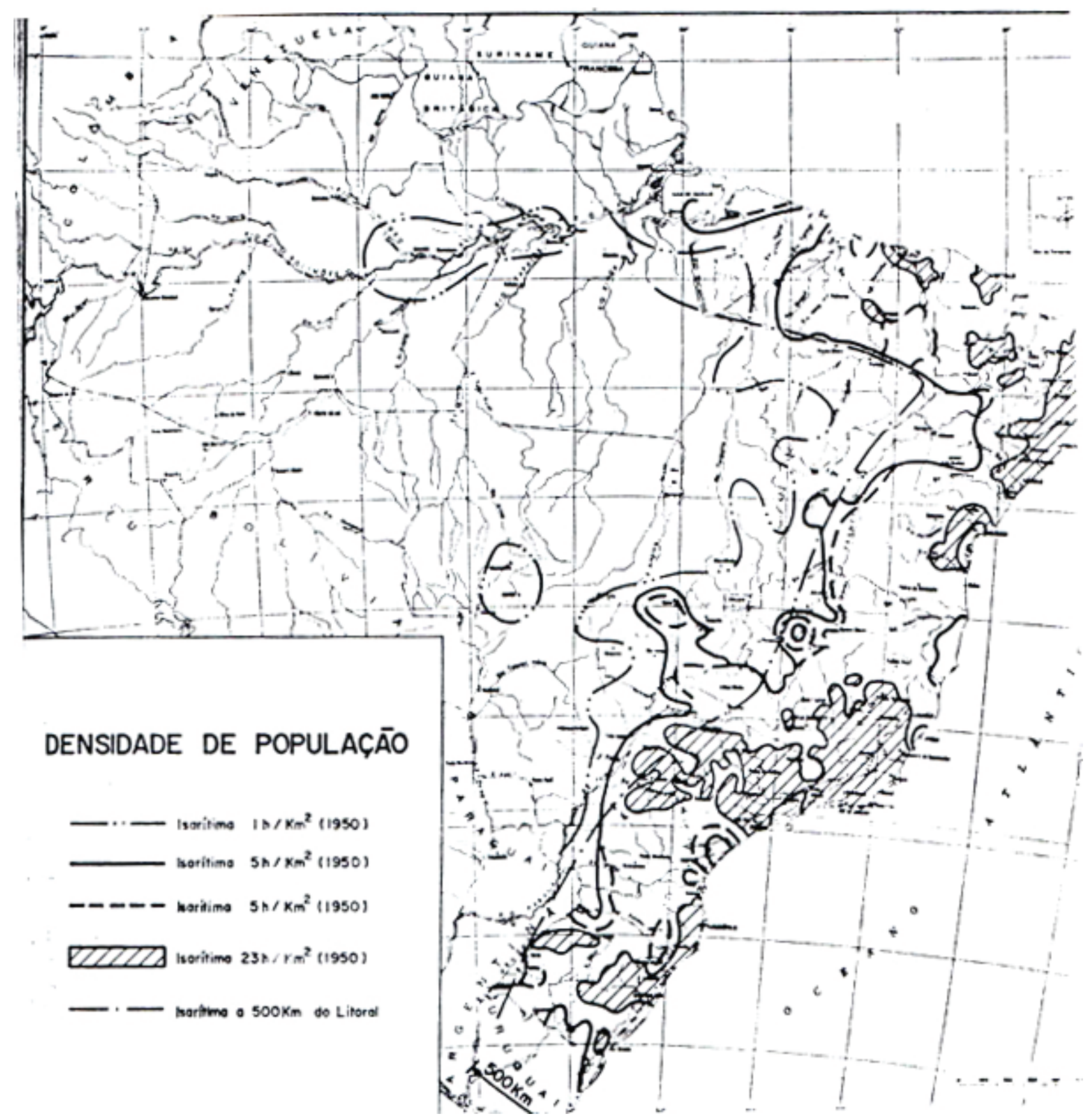

Figura 83. Realidade do ecúmeno brasileiro em 1950.

Fonte: Golbery do Couto e Silva. Geopolítica do Brasil. 1967. Esquema 5, p. 41.

sos e de toda ordem. Mas é preciso que não esqueçamos que o vácuo de poder, como centro de baixas pressões, atrai de todos os quadrantes os ventos desenfreados da cobiça. E, portanto, se larga é a empresa e sobremodo difícil, impõem-se pelo menos dispor sem tardança, na cintura dessa imensa área vazia, postos avançados de nossa civilização, convenientemente equipados para que possam testemunhar a posse indiscutível da terra, à espera dos melhores dias de uma integração e valorização contínuas e totais, e estejam em condições de opor-se a quaisquer veleidades alienígenas de penetração. O que urge fazer, em outra escala e com outros meios, é ainda a mesma ideia velha em circunstâncias novas. É preciso tamponar o deserto (SILVA: 1967:43) (grifos nossos). 
Frente ao quadro exposto, pretendendeu estender ao máximo o ecúmeno para todos os sentidos do Brasil, estabeleceu um plano racional de ocupação, que em resumo tratou-se de, a partir de um núcleo central, composto por São Paulo - Rio de Janeiro - Belo Horizonte, estender a ocupação através de "istmos de circulação", para Nordeste e Sul, o que nesse caso contribuiria para a defesa do Atlântico Sul. Assim ele se referia a esta região:

É o núcleo central do Brasil, seu verdadeiro coração (...); onde se concentra a maior massa de população e de riquezas do país, onde a circulação é muitíssimo mais intensa, onde a produção se acumula, onde estão sediadas as mais importantes indústrias de base, onde o dinamismo é mais poderoso e enérgico. Sobre a base de articulação Rio - São Paulo, materializada pelas comunicações rodoviárias e ferroviárias ao longo do providencial vale do Paraíba, esse núcleo central de estrutura em amplo setor que, de um modo geral, é balizado de Santos ou um pouco mais ao sul ao vale do Rio Doce, pelos vales do Paranapanema, do Paraná e do Paranaíba, cruzando depois o São Francisco para despontar as cabeceiras do Jequitinhonha. Aí se encontram quase todo São Paulo, a maior parte de Minas Gerais, o Distrito Federal (Rio de Janeiro) e o Estado do Rio de Janeiro, mais a metade sul do Espírito Santo (SILVA: 1967:44-5).

Desde logo ressalta à simples inspeção, em torno do triângulo Rio - São Paulo - Belo Horizonte, um notável adensamento demográfico servido por trama rica de comunicações ferroviárias e rodoviárias. No Nordeste, em derredor dos núcleos secundários do recôncavo baiano, de Recife e Fortaleza, condensa-se uma segunda área ecumênica, também unificada por uma apreciável trama de ferrovias e rodovias; como, no Sul, a que se estende pelo Paraná e Santa Catarina, alargando-se depois para englobar todo o território do Rio Grande do Sul.

Escassas comunicações que, além de escassas, são precárias, conectam debilmente essas áreas ecumênicas do Nordeste e do Sul ao grande núcleo central, através de verdadeiros istmos de circulação (SILVA:1967:45) (grifos nossos).

Num segundo momento propõe estender a ocupação através de istmo de circulação para o centrooeste, tudo indica a fim de dominar a área de soldadura descrita por Travassos (composta por frações de Mato Grosso, Paraguai e Bolívia). Assim ele se refere a esta região:

Por outro lado, no Brasil centro-oeste, Cuiabá e a região circunvizinha que lhe é tributária, Campo Grande e o Sul de Mato Grosso, Goiânia e o Sul de Goiás se integram em vasta área ainda não ecumênica, mas que já se articula ao núcleo central por um istmo bem delimitado, de fraca densidade de circulação. (SILVA: 1967:45). 
E, por fim, estender a ocupação através de istmo de circulação para a Amazônia, que tratase na época, como ele mesmo diz, de um deserto. Assim ele se refere: E, mais a noroeste ainda, a Hileia - isolada, tributaria do caudal amazônico e nitidamente dependente das ligações marítimas (SILVA: 1967:45) (grifos nossos).

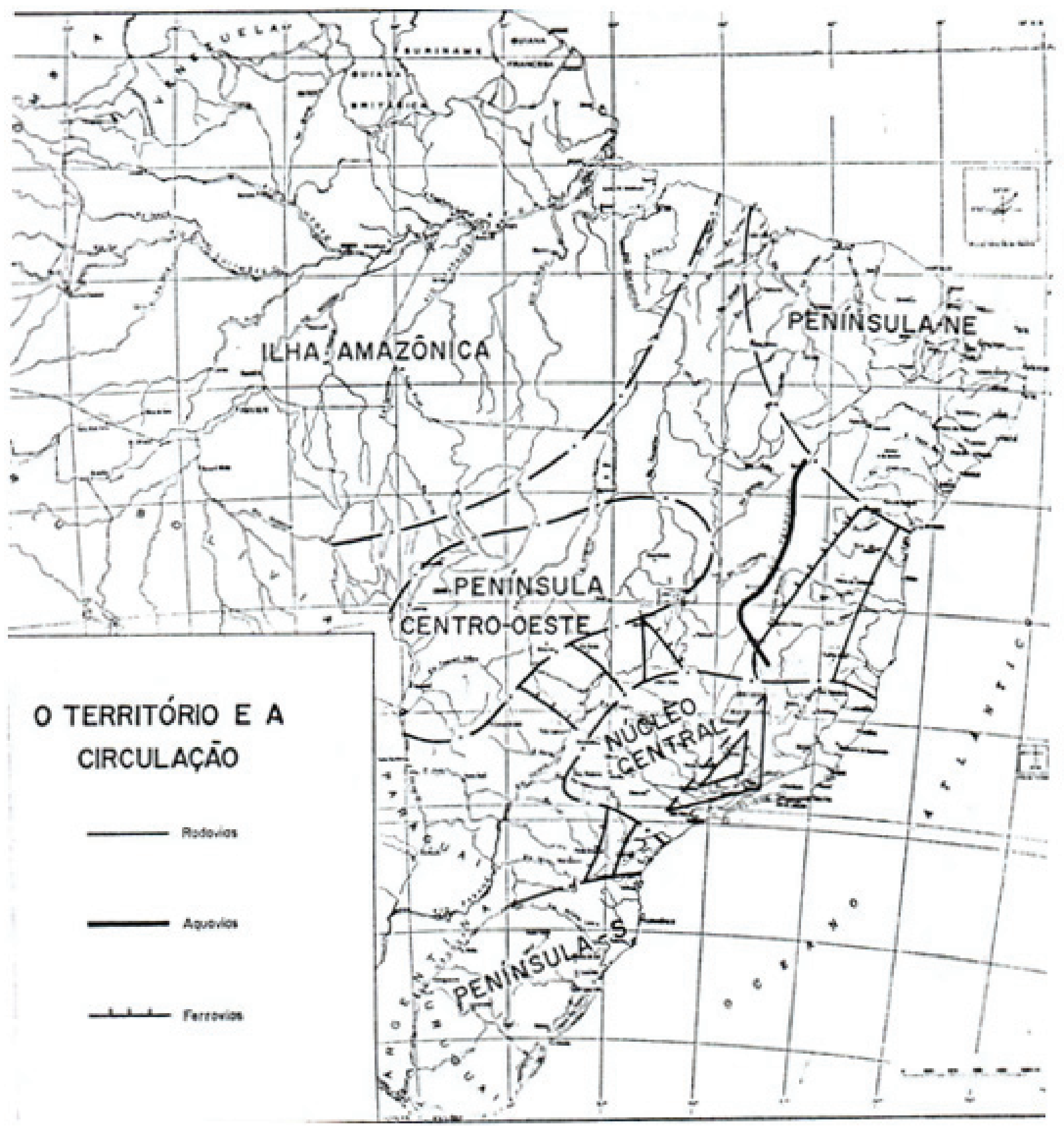

Figura 84. A ideia de manobra geopolítica para a integração e valorização do território nacional. Fonte: Golbery do Couto e Silva. Geopolítica do Brasil. 1967. Esquema 6, p. 44. 
Golbery por fim avalia a situação do país:

$\underline{\text { O Brasil sob o ponto de vista da circulação é um vasto arquipélago - imagem sugestiva que faz }}$ $\underline{\text { ressaltar a pobreza de nossas comunicações interiores e a triste e perigosa contingencia em que nos }}$ encontramos ainda como escravos dos transportes marítimos periféricos. (...) partindo do núcleo central do país três grandes penínsulas que se projetam para nordeste, para o sul e para noroeste. apenas ligadas por precários istmos de circulação - zonas criticas de transportes - e, mais longe ainda, inteiramente isolada, uma vasta ilha perdida.

A primeira tarefa, pois, visando a integração e valorização do território nacional, há de ser a de vitalizar esses três istmos de circulação, de maneira a, de um lado, articular solidamente de norte a $\underline{\text { sul a nossa atual base ecumênica e de outro lado, consolidar o avanço já esboçado para noroeste, a }}$ partir do núcleo central que, geográfica e historicamente, é a verdadeira plataforma para penetração e conquista do interior. Somente a seguir, depois de nos havermos debruçado sobre a Hileia amazônica, poderemos pensar em conquistar a grande ilha brasileira de noroeste por uma manobra concêntrica que combine o avanço do sul para o norte, ao longo dos afluentes da margem direita do grande

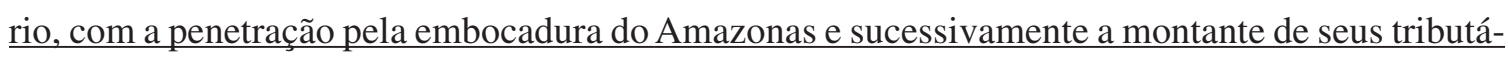
rios de uma e outra margem (SILVA: 1967:45-6) (grifos nossos).

Enquanto não se ocupam essas áreas, sua estratégia é criar tamponamento dos extremos a Oeste, com postos avançados ou territórios federais, até que as populações brasileiras provenientes de Leste encontrem esses núcleos a Oeste; demonstra preocupação menor com possível invasão da Bacia Amazônica, dada a grande floresta que a protege e a separa de outros países latinoamericanos; sua preocupação maior é com o domínio argentino da Bacia Platina.

Em linhas gerais a ideia de Golbery de manobra geopolítica para integração do território nacional, trata-se de:

$1^{\mathrm{a}}$. Articular firmemente a base ecumênica de nossa projeção continental, ligando o Nordeste e o Sul ao núcleo central do país; ao mesmo passo que garantir a inviolabilidade da vasta extensão despovoada do interior pelo tamponamento eficaz das possíveis vias de penetração;

$2^{\mathrm{a}}$. Impulsionar o avanço para noroeste da onda colonizadora, a partir da plataforma central, de modo a integrar a península centro-oeste no todo ecumênico brasileiro (para o que se combinarão o processo da mancha de azeite preconizado por Lyautey e o dos núcleos avançados atuando como pontos de condensação);

$3^{\mathrm{a}}$. Inundar de civilização a Hileia amazônica a coberto dos nódulos fronteiriços, partindo de uma base avançada constituída no Centro-Oeste, em ação coordenada com a progressão E-O, segundo o eixo do grande rio (SILVA: 1967:47) (grifos nossos). 


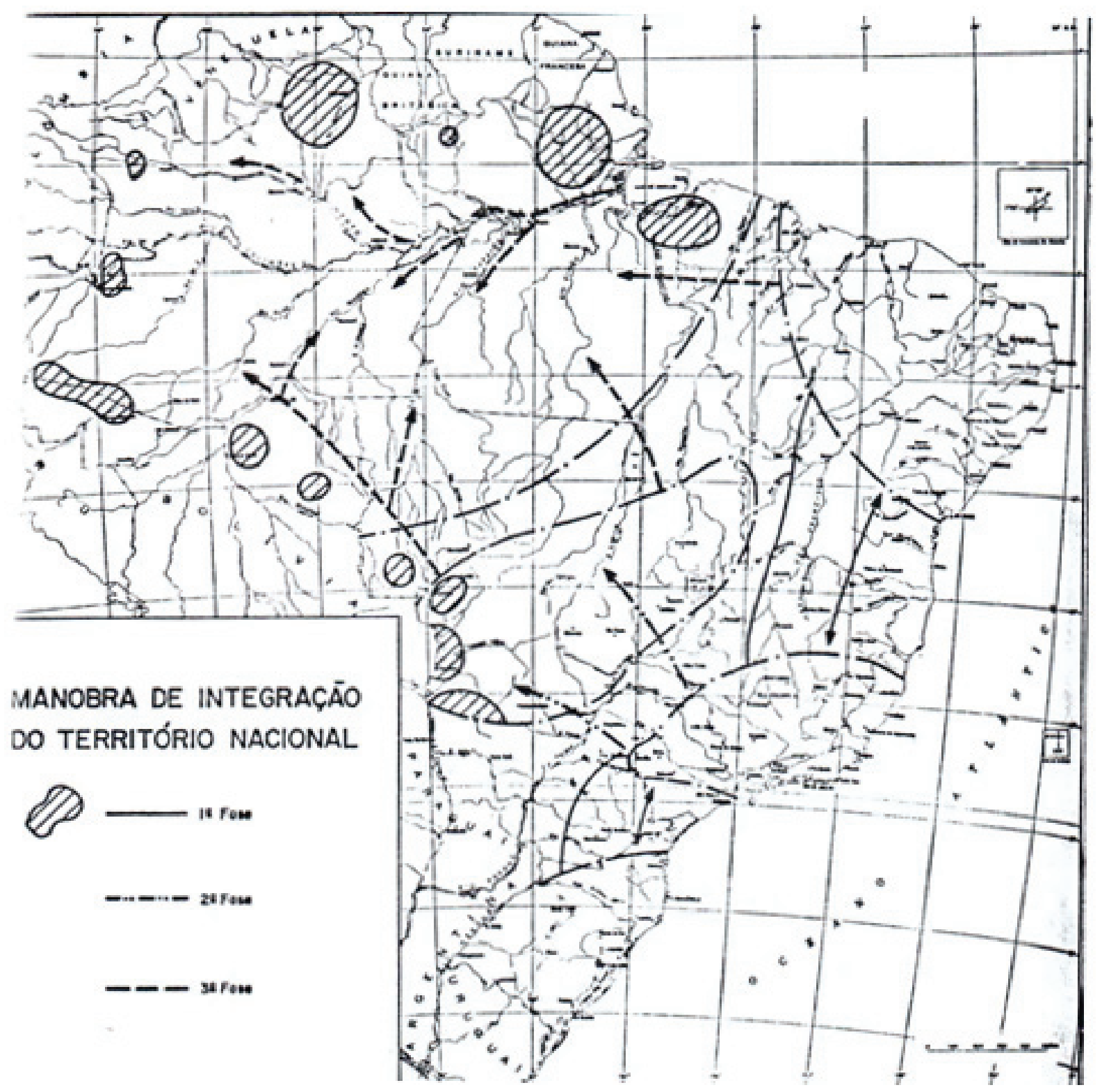

Figura 85. Manobra geopolítica para integração do território nacional de Golbery. Fonte: Golbery do Couto e Silva. Geopolítica do Brasil. 1967. Esquema 7, p. 46.

No plano externo, trata-se do contexto pós-guerra (Golbery escreve em 1952), período da Guerra Fria, onde se verifica a hegemonia norte-americana sobre o continente sul-americano. Trata-se de verificar a posição dos três países, EUA, Brasil e Argentina durante esse conflito; Aos EUA interessa manter aliança com o Brasil, entre outras razões para utilizar o promontório nordestino (Natal - base aérea, Recife - base naval), como plataforma de transporte, ataque e defesa, distancia mais curta para atravessar o oceano atlântico em direção aos continentes, africano e europeu; também interessa aos EUA a proteção pelo Brasil, em função de seus interesses, da embocadura do rio Amazonas com seu tampão, a Ilha de Marajó, caso os soviéticos viessem atacar os EUA, esse local seria a plataforma mais próxima de ataque. Por seu turno o Brasil, 
representado pelo pensamento geopolítico de Estado, de Golbery, demonstra estar alinhado à luta anticomunista e pró-capitalista, e concorda ceder as bases descritas aos norte-americanos; demonstra a necessidade de proteger a integridade territorial do país e o Atlântico Sul (base de nossa prosperidade e sobrevivência, como ele diz), temendo a ameaça de avanço soviético; por tudo isso, pelos deveres que se impõe ao Brasil neste contexto, e por conta disso, considera que o Brasil se envolveu numa trama, na verdade criada e aprofundada pelos dois antagonistas (EUA x URSS), os quais criaram certo ônus ao país, propõe ceder o promontório nordestino, mas com reservas... e acrescenta então, cobranças de ajuda mutua aos EUA, alegando os laços de amizade que unem os dois países. Quanto à Argentina, Golbery demonstra tentativa de depreciá-la em sua não aliança (posição inicial de Neutralidade) durante a Guerra ou aliança inexpressiva aos EUA, e, cobra desse país (EUA), uma postura menos ambígua (de duas frentes) e acomodada em relação ao Brasil e Argentina.

A seguir, nota-se que Golbery indica a posição argentina frente ao conflito mundial, como de Terceira Posição ou de Neutralidade; assim o autor coloca aquele país, frente aos EUA de forma pouco amistosa; por seu turno Golbery se adianta, ao colocar o Brasil como o grande e maior aliado na America do Sul dos EUA. Tudo indica que, além de haver uma disputa entre os dois países nesse período da Guerra Fria pelas atenções dos EUA, esse ultimo, por seus interesses estratégicos e econômicos, acaba por privilegiar o Brasil, em detrimento da Argentina.

Ora, em tais circunstancias, quando entre nossos vizinhos hispano-americanos recrudesce indisfarçável uma oposição aos Estados Unidos da America que se mascara de Terceira Posição ou que outro rotulo tenha, aproveitando-se exatamente daquela enfocação para além Atlântico e além Pacífico dos interesses primaciais dos norte-americanos, o Brasil parece estar em condições superiores, pela sua economia não competitiva, pela sua larga e comprovada tradição de amizade e, sobretudo, pelos trunfos de que dispõe para uma barganha leal - o manganês, as areias monazíticas, a posição estra$\underline{\text { tégica do Nordeste e da embocadura amazônica com seu tampão da Marajó - de negociar uma }}$ aliança bilateral mais expressiva que não só nos assegure os recursos necessários para concorrermos substancialmente na segurança do Atlântico Sul e defendermos, se for o caso, aquelas áreas brasileiras tão expostas a ameaças extracontinentais, contra um ataque envolvente ao território norte-americano via Dacar-Brasil-Antilhas, mas uma aliança que, por outro lado, traduza o reconhecimento da real estatura do Brasil nesta parte do Oceano Atlântico, posto um termo final a qualquer política bifronte e acomodatícia em relação ao nosso país e à Argentina, ambas nações, por exemplo, igualmente aquinhoadas, contra todas razões e todas as evidencias, em armas de guerra naval (SILVA:1967:50-1) (grifos nossos). 
Golbery ressalta novamente a importância do Nordeste brasileiro para os norte-americanos:

(...) de forma alguma pode desmerecer a importância estratégica do Nordeste brasileiro, não para nós que nada queremos do outro lado do Atlântico, mas para o EUA que já se engajaram a fundo na defesa da Europa, como plataforma de ataque ou simplesmente de salto por sobre o oceano ao continente africano desde já se situa, ao norte, o cinturão de importantes bases aéreas das quais se espera deter qualquer avanço comunista para oeste e martelar o coração industrial da Russia. Além do mais o nosso Nordeste é um amplo e inigualável porta-aviões que permitirá aos comboios norteamericanos que demandem a África e a Europa, a segurança da travessia oceânica, na parte mais estreita e, portanto, menos vulnerável do Atlântico (1967:51-2) (grifos nossos).

Golbery demonstra que no contexto da Guerra Fria, que defender a integridade territorial brasileira e a segurança do Atlântico é uma obrigação do Estado brasileiro, apesar de considerar que isso vem ocorrendo, muito em função do conflito entre EUA e URSS, assim deve ceder o espaço aos EUA, mas não de graça, indica que terá de alguma forma custos para os EUA:

Ora, se assim considerarmos a realidade dos fatos e a posição singular do território brasileiro no grande conflito da hora presente em que se defrontam, (...) os EUA e a Russia, forçoso é reconhecer que a segurança e a defesa do Nordeste, do estuário amazônico e do Atlântico Sul são ônus que recaem em nós muito acrescidos agora em consequência daquele antagonismo tremendo. Não há para nós alternativa outra senão aceitá-los e aceitá-los conscientemente - pois de forma alguma poderíamos abrir mão de deveres que são exclusivamente nossos, como o da defesa da integridade do território nacional e não menos da segurança do Atlântico Sul, ao qual estão vinculadas a nossa prosperidade e, sem duvida, a nossa sobrevivência. Mas, por outro lado, o direito de utilização de nosso território, seja para o que for, é um direito exclusivo de nossa soberania que não devemos de forma alguma, ceder por um prato de lentilhas. Se a geografia atribuiu à costa brasileira e ao seu promontório nordestino um quase monopólio de domínio no Atlântico Sul, esse monopólio é brasileiro, deve ser exercido por nós exclusivamente, por mais que estejamos, sem tergiversações, dispostos a utilizá-los em beneficio de nossos irmãos do norte, a que nos ligam tantos e tão tradicionais laços de amizade e de interesses, e em defesa ao mesmo tempo da civilização cristã, que é a nossa, contra o imperialismo comunista de origem exótica. (SILVA:1967:52) (grifos nossos).

No plano continental, a maior preocupação de Golbery em 1952 é com a hegemonia argentina verificada sobre os países da Bacia do Prata; para Golbery o Brasil deve temer essa hegemonia como séria concorrente, dada a importância do dinamismo econômico argentino, verificado pelo porto de Buenos Aires, pelas regiões próximas urbanizadas de Rosário, Córdoba e Tucumã 
e pelas ferrovias instaladas que se comunicam com La Paz/Bolívia e o porto de Arica/Chile no Pacífico, com Assunção/PY, com Santiago e o porto de Valparaíso/Chile. Considera os dois países mediterrâneos, Bolívia e Paraguai, como "prisioneiros geopolíticos dos argentinos”, dada a única saída desses países para o atlântico, ser pelo porto de Buenos Aires ${ }^{53}$. Dada a proximidade destas ferrovias com os locais citados, outra preocupação de Golbery, é com o possível domínio argentino também da "área de soldadura” (MT/BR, Paraguai e Bolívia) referida por Travassos, que levaria aquele país a ter acesso a Bacia Amazônica, dominando, portanto, o ponto divisor das duas bacias, amazônica e do Prata, ponto geopolítico estratégico da America do Sul.

Uma terceira preocupação é com a região de Misiones na Argentina, a “cunha de Misiones...”, Golbery inicialmente não entra em detalhes, mas possivelmente se incomoda com dinamismo econômico da região argentina, em áreas próximas já urbanizadas, como também com o fato (já apontado aqui antes), de que na Tríplice Fronteira, havia indígenas (Guarani) trabalhando com erva-mate, os quais comercializavam com argentinos e paraguaios em moeda desses países, a língua castelhana era de forma recorrente falada na região, ou seja, o perigo da dominação pelos "castelhanos" dessa parte do país.

Os três fatos são vistos como ameaças a hegemonia continental do Brasil na America do Sul; a época (1952), nestas regiões, como vimos a pouco, o país não tinha mais que o domínio jurídico, parafraseando o próprio Golbery, nesta região o país apresentava “vácuo de poder, como centro de baixas pressões, atrai de todos os quadrantes os ventos desenfreados da cobiça”". Assim o Brasil e a Argentina, se encontravam em disputa pela hegemonia continental; estão como vimos a pouco também, em disputa pela atenção dos EUA, e este, está voltado para as questões da Guerra Fria.

Portanto, Golbery tem três intenções: a) dominar a área de soldadura MT, Paraguai e Bolívia, impedindo o avanço argentino para a Bacia Amazônica; b) dominar a área próxima de Misiones/ Argentina; c) enfraquecer o domínio argentino sobre os outros países da America Latina; Isso se dará por meio da seguinte estratégia: criar saídas para o Oceano Atlântico para a Bolívia (ferrovia) e para o Paraguai (rodovia) e assim livrá-los do domínio argentino, até então, como afirma o

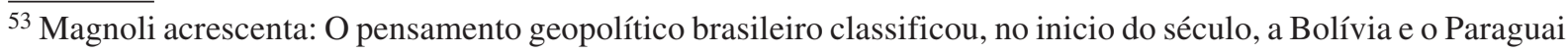
como "prisioneiros geopolíticos" da Argentina. Esta caracterização apoiou-se num circuito de fatos econômicos, culturais, históricos e geográficos: a colonização espanhola comum do Vice-reinado do Prata, a disposição da rede fluvial platina sobre um eixo norte-sul polarizado por Buenos Aires e seu porto, a influencia do arco urbano formado por Buenos Aires - Rosário - Córdoba - Tucuman em território argentino... A tese dos "prisioneiros geopolíticos" está na raiz da manobra estratégica de larga envergadura posta em marcha pelo Brasil na região do Prata (MAGNOLI:1988:36-7) (grifo nosso).
} 
autor "prisioneiros geopolíticos, reféns dos argentinos"; dessa forma, o Brasil irá satelizar esses países para área de sua influencia, enfraquecendo a hegemonia argentina e fortalecendo a sua própria hegemonia no continente, fundamentalmente na área de soldadura. Na visão geral dos militares, o Brasil seria "futura potencia mundial”, a ser construída na America do Sul.

Vejamos desde o inicio, a visão de Golbery a respeito do Brasil, frente aos outros países da America Latina:

Quanto à paisagem política continental, onde os perigos intrínsecos à nossa inefetiva, descontínua e mesmo, mais a noroeste, ganglionar, para não dizer nula, ocupação do território nacional já foram antes apontados o que vemos nos circundando é uma cintura de nações a que unem, acima de quaisquer dissensões, a mesma origem hispânica, tradições históricas semelhantes e entrelaçadas e, sobretudo, a unidade linguística, quando não tanto os costumes e a cultura hoje bastante diferenciados pela desigual contribuição dos contingentes nativos e a força modeladora do meio físico diverso. Velhas desconfianças e litígios antigos, sem duvida, as separam, mas não parecem de molde a impedir uma composição de interesses e uma conjugação de esforços, quando se trate de satisfazer todas as ambições e todos os ressentimentos à custa do vizinho exótico, rico demais hoje em virtude de seu imperialismo prepotente, que nem pode aproveitar devidamente suas terras imensas e cuja a vontade se julga a andar um tanto alquebrada pela contribuição em alta dose de sangue escravo inferior... (SILVA: 1967:53) (grifos nossos).

Acrescente-se, que o racismo de Golbery é escancarado.

Os países latino-americanos que o autor enxerga que possa fazer frente ao Brasil:

Dentre essas nações, três avultam pelo seu potencial superior, evidenciado, em comparação com o Brasil, (...) com base no efetivo populacional, na produção de carvão, aço e petróleo e no potencial hidrelétrico instalado: a Argentina ao sul, a Colômbia a noroeste e o Peru a oeste, para não falar do Chile que não tem fronteiras conosco.

Mesmo constituídos em blocos regionais - o antigo Vice-Reinado do Prata contando com o recurso da economia chilena, a Colombia acrescida da Venezuela e do Equador - seu potencial, no momento, apresenta-se ainda bastante inferior ao do Brasil cuja maior deficiência se acha indiscutivelmente em nossa quase completa dependência do petróleo estrangeiro. Consideremos a posição relativa desses centros continentais de poder, felizmente tão isolados uns dos outros (SILVA:1967:53) (grifos nossos).

Vide a importância da energia. 
Quanto a Colômbia e o Peru, Golbery não teme invasão por conta da muralha florestal, mas recomenda o tamponamento dos caminhos naturais de penetração que conduzem a Amazônia, até que possa levar a cabo, como afirma, quando oportuno, tranquila e metodicamente, um plano de integração e valorização daquele imenso mundo ainda perdido (SILVA:1967:53).

Para o interesse dessa tese, vale descrever a situação do Brasil com relação à Argentina e seus reféns geopolíticos, Bolívia e Paraguai. Golbery assim descreve:

Ao sul e S.O., a situação é bem outra. Aqui se nos defronta o poder argentino, concentrado num evidente núcleo central que, a grosso modo, abarca a grande capital-tentáculo de Buenos Aires e a província do mesmo nome, mais parte de La Pampa e Santa Fé, e que se articula a N.E. com a Mesopotâmia $^{54}$, a N.O. com um núcleo marginal importante englobando Córdoba, Mendoza e Tucumã ${ }^{55}$, e ao S. em condições precárias, com a região não-ecumênica da Patagônia cuja a expressão se cifra quase que inteiramente no petróleo de Comodoro Rivadávia e no carvão de Rio Túrbio. Mais ou menos tributários da Argentina, oscilando entre a desconfiança, o ressentimento e a admiração e jungidos pela dependência econômica indiscutível - o Paraguai e a Bolívia, "prisioneiros geopolíticos" muito mais o primeiro que a segunda, valem muito pela sua posição geográfica no flanco aberto e vulnerável do Brasil meridional e central e constituem, sobretudo por sua instabilidade política e econômica, indisfarçáveis zonas de fricção externas onde podem vir a contender, quer queiram quer não, os interesses brasileiros e argentinos (SILVA: 1967:55) (grifos nossos).

Golbery coloca frases encobertas, como um "manto" pouco transparente. Vejamos aqui sua avaliação sobre as condições do Paraguai e da Bolívia e a proposta do Brasil frente a questão.

Muito se tem escrito desde Badia Malagrida e Mario Travassos sobre a oposição das duas grandes bacias do Amazonas e do Prata que nessa região central, reforçada de um e de outro lado pela

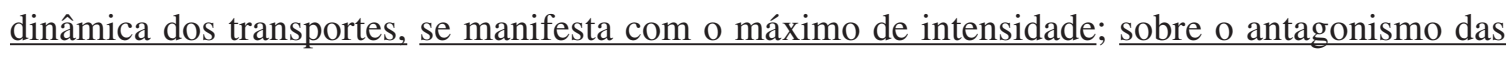
atrações do Pacífico e do Atlântico que, através dos nudos e pasos andinos, dissociam a Bolívia,

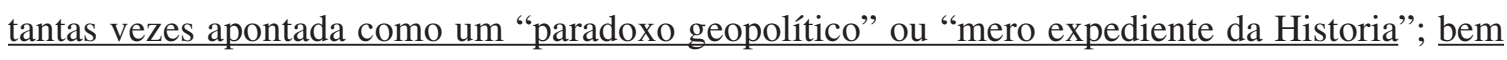
assim sobre a eterna aspiração paraguaia de poder "respirar por dois pulmões" - para que nos detenhamos agora a reexaminar tais aspectos, sem duvida relevantes, da geografia política sulamericana. Baste com repetir que será a vitalização e integração no ecúmeno nacional, do centrooeste brasileiro, especialmente o Mato Grosso - placa-giratória superiormente situada nas cabecei-

\footnotetext{
54 "La Pampa e Santa Fé, e que se articula a N.E. com a Mesopotâmia". A referida Mesopotâmia é a região que esta situada entre os rios Paraguai e Paraná, na Argentina. Estas três regiões são as mais férteis da Argentina. 55 “Córdoba, Mendoza e Tucumã”. Áreas na época mais urbanizadas juntamente com Buenos Aires na Argentina.
} 
ras comuns das duas grandes bacias hidrográficas - que permitirá afinal tudo esclarecer e definir neste jogo múltiplo de forças que trabalham incansavelmente o coração do continente (SILVA: 1967:558) (grifos nossos).

Assim, sua proposta é vitalização e integração no ecúmeno nacional do centro-oeste brasileiro. Esta região, especificamente área do Mato Grosso de relevo mais elevado, esta próxima das áreas mais elevadas também do relevo paraguaio e boliviano. Segundo Magnoli ela representa:

O enorme divisor de águas das duas bacias, encravado em posição central e elevada, determina Área Continental de Soldadura: ela abrange a Bolívia, o Paraguai e parte do Centro-Oeste brasileiro. Vértice de toda a América do Sul, a Área de Soldadura contém a heartland continental, o triangulo estratégico Santa-Cruz - Cochabamba - Sucre. Coração sul-americano, ele magnetiza influencias vitais: de Cochabamba, próximo a um nudo, recebe vibrações andinas; de Sucre, vizinha de outro nudo, apropria-se de eflúvios platinos; de Santa Cruz, na planície oriental boliviana, acolhe impressões amazônicas. (MAGNOLI: 1988:31)

Portanto, movimentar, criar ocupação..., assim em futuro próximo, serão criadas ali, a ferrovia que comunica a Bolívia com o Brasil, se ligando ao porto de Santos e a rodovia que comunica o Paraguai com o Brasil, se ligando ao porto de Paranaguá, ambos no litoral atlântico brasileiro. Questões as quais veremos a frente.

Golbery indica a região onde considera ser a linha de tensão máxima sul-americana:

Mas é bem mais ao sul, onde o Uruguai, meio brasileiro meio platino, continua a viver e prosperar galhardamente em seu histórico papel de estado-tampão, é aí onde Las Misiones $\underline{\mathbf{5 6}} \underline{\text { avançam como }}$ uma cunha para nordeste modelando o gargalo de Santa Catarina, que se define a linha de tensão máxima no campo sul-americano, reforçada como é pela proximidade maior dos centros de força potencialmente antagônicos, seu dinamismo e potencial superiores, a tradição de choques e conflitos que vêm desde o passado colonial e, por fim, se bem não menos importante, uma aspiração hegemônica alimentada além do Prata por uma propaganda tenaz e incansável desde os dias já longínquos de Rosas. Aí, onde não há barreiras que valham, se encontra pois nossa verdadeira fronteira viva - a única "realmente sentida que serve de testemunho à enorme abstração da quase totalidade das linhas divisórias do imenso Brasil”, como escreveu o Embaixador Macedo Soares (SILVA:1967:58) (grifos nossos).

${ }^{56}$ Las Misiones é na Argentina. Novamente a frases encobertas de Golbery, dão a impressão ao leitor pouco atento que ela se localiza no Uruguai. Será de propósito?! 
Para enfrentar a questão das Misiones argentinas, a solução geopolítica encontrada pelo Brasil, para entestar de frente, foi também ocupar, vitalizar, integrar esta região ao país, por meio de um Grande Projeto, uma grande hidrelétrica, a Itaipu Binacional, questão que também veremos a frente.

Golbery afirma posteriormente que para o norte, a tensão vai gradativamente decrescendo até anular-se ao ultrapassar o paralelo de Corumbá.

O autor conclui sobre a análise da posição do país, afirmando que ela nos conduz à seguinte configuração geral:

- um núcleo central de importância capital, altamente sensível tanto ás ações externas vindas do mar como a perturbações internas instigadas de fora e cuja segurança é absolutamente indispensável à $\underline{\text { estrutura toda do sistema }}{ }^{57}$, relativamente bem protegido pela barreira natural da grande escarpa litorânea e sujeito a ataques, senão de grande importância, pelo menos de alto efeito moral;

- no Nordeste, $\underline{\text { uma zona de vulnerabilidade máxima a ações extracontinentais, }}$, as quais se preveem em futuro não imediato e apenas no caso em que os EUA não consigam, na eventualidade de uma $3^{\text {a }}$ Guerra Mundial, impedir que a Rússia transborde por sobre o continente europeu e a África Ocidental, circunstancias essas em que sempre teremos assegurado o concurso inigualável daquela potencia $\underline{\text { na defesa de área cuja importância é, antes de tudo, mundial }} \underset{58}{ }$;

- ao Sul, estendendo-se até Mato Grosso, uma zona também de vulnerabilidade máxima, mas a possíveis ações adversas de origem regional, às quais, embora sejam menos potentes, nos teremos de opor, exclusivamente, com os meio próprios que consigamos mobilizar

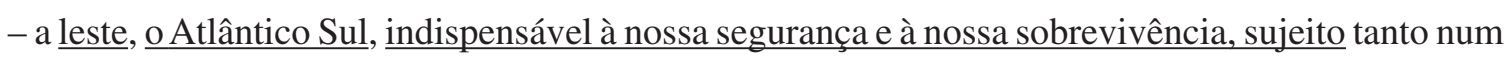
como noutro caso a possíveis ações adversas que dificultam, e talvez mesmo impeçam, nossas comunicações litorâneas com o sul atacado ou, na hipótese extracontinental, ameacem seriamente não só a navegação de cabotagem, mas até nossas ligações marítimas com os EUA, embora se conte seguramente, em tal emergência, com poderoso auxilio exterior ${ }^{60}$.

(...) resta na periferia amazônica uma fronteira passiva a policiar e a guarnecer pela barragem dos caminhos históricos de penetração.

\footnotetext{
$\overline{57}$ O núcleo central é a "cabeça" que comanda a economia do país.

${ }^{58}$ Nordeste, o promontório nordestino, sujeito a um ataque soviético; aliança do Brasil com os norte-americanos que redundam em projetos de ajuda mutua, o Brasil apoia a política norte-americana e os EUA investem no Brasil, oferecendo recursos financeiros (empréstimos de monta que resultarão em divida externa alta), venda de tecnologia e assistência técnica.

${ }^{59}$ O Brasil dominar a área de soldadura (MT, Bolívia e Paraguai) e entestar frente a região das Misiones argentinas.

${ }^{60}$ Teme pela segurança do Atlântico Sul, seja por uma investida argentina, seja por uma investida soviética, para no caso da ultima, conta com o apoio norte-americano.
} 
Com relação àquelas ameaças, mais ou menos prementes, de maior ou menor vulto, interessando somente a nós ${ }^{61}$ ou também a um poderoso aliado ${ }^{62}$, o núcleo central brasileiro, centro dinâmico do país, está superiormente situado, (...): mais distante do arco amazônico onde a ameaça é de pouca monta; menos distante do Nordeste, onde o perigo se avoluma, mas é certo o concurso norte-americano; e muito mais próximo do Sul, principal área de friç̧ão sul-americana dada a sua vulnerabilidade maior a ameaças mais diretas, mais próximas e mais imediatas. Quanto a possíveis ações marítimas adversas, a localização daquele núcleo, por exposto que se considere, é a melhor que se nos oferece em todo nosso litoral.

De maneira que o que mais importa é articulá-lo convenientemente ao Sul, ao Nordeste e ao CentroOeste para que fique o Brasil em condições de realizar, se as circunstâncias o exigirem, a gigantesca manobra em posição central que a geografia traçou no território nacional (SILVA:1967:59-60) (grifos nossos).

Há um autoquestionamento de Golbery sobre se o Brasil está preparado para essa grande tarefa:

Atendem as comunicações existentes a essa finalidade? Dispomos ao pé da obra, em cada uma das regiões vulneráveis, de recursos suficientes para assegurar o êxito de uma manobra essencialmente baseada em uma mecânica de espaço e tempo? A massa de manobra central é suficiente? Estamos em condições de decidir a tempo o encaminhamento de reforços para onde se faça mister, à luz de informes que nos permitam desvendar o sinal da tormenta que se aproxima? Poderemos assegurar em condições satisfatórias nossas comunicações marítimas com o Sul e para o Norte? Achamo-nos prevenidos contra ações da sabotagem, contra a quinta-coluna ${ }^{63}$, contra as praticas derrotistas nas zonas vitais do país? Está o povo psicologicamente preparado para as eventualidades de guerra que se preveem? (SILVA:1967:60).

Golbery ainda em 1952 refletindo um pouco mais sobre a geopolítica nacional visando à integração do território, e à sua segurança, delimita novamente as três fases, da seguinte forma:

$1^{\mathrm{a}}$ - equipamento e reforço de nossa base ecumênica, articulando-a solidamente de norte a sul, $\underline{\text { com }}$ prioridade para o sul;

- constituição de potenciais regionais que garantam o mínimo de segurança à realização da manobra estratégica considerada, potenciais esses proporcionais à importância das ameaças que se preveem

\footnotetext{
$\overline{61}$...a nós significa: Brasil x Argentina;

62 ...também a um poderoso aliado significa: Brasil e EUA x Soviéticos

${ }^{63}$ A quinta coluna comunista de Luis Carlos Prestes.
} 
(volume, proximidade no tempo e no espaço, jogo de alianças que motivem) - máximo face ao Prata, médio no Nordeste (um arcabouço reforçável a tempo), mínimo na periferia amazônica; $2^{\text {a }}$ - Integração da península do centro-oeste brasileiro, equipando-a de meios que lhe permitam desempenhar seu duplo papel de solida plataforma para um transbordamento sobre a Hileia ou para ações visando a contrapor-se ao avanço para o norte de um imperialismo platino, sub-reptício ou virulento;

$3^{\text {a }}$ - Incorporação da Amazônia (SILVA:1967:60-1) (grifos nossos).

Nota-se claramente que a preocupação maior do autor é com o Sul, com a região do Prata, com o avanço para o norte do "imperialismo"platino, ou seja, com o fortalecimento geopolítico da Argentina na região do Prata.

Golbery enxerga como dilema e qual deles dar prioridade de atenção: a geopolítica interna de valorização do espaço nacional, que deve concentrar esforços para Oeste, considerando inclusive o balanço de forças no continente sul-americano (Brasil-Argentina); ou a realidade nacional em face da conjuntura mundial, portanto a geopolítica externa atenta ao problema da segurança e da defesa que deve reforçar presença de Nordeste a Sul, em toda faixa litorânea do Atlântico Sul.

O ecúmeno brasileiro é ainda, como vimos, faixa relativamente estreita ao largo do litoral atlântico de leste e, pois, o Brasil é hoje, e sê-lo-à ainda mais no momento culminante em que haja concluído a articulação dessa sua base para futuras projeções, um grande país-charneira, indeciso entre dois destinos. De um lado, a vasta hinterlândia, quase deserta ainda, à espera de vitalização, riquezas desconhecidas que (...) a alma popular sempre (...) imaginou portentosas, um espaço cujo potencial de atração vem acrescido da continentalidade de outros países mediterrâneos e até mesmo de imensas áreas cisandinas de nações do Pacífico, ameaças atuais ou potenciais que só se poderão afirmar cada vez mais com o tempo e, (...) uma geomorfologia que faz do Brasil, (...) um país voltado para dentro e onde grandes rios e divisores indefinidos conduzem naturalmente ao coração do continente.

Do outro lado está o mar (...) o oceano mais vivificado do mundo, caminho sem igual das civilizações modernas, que nos liga aos centros de produção e de cultura do hemisfério norte, de onde nos vêm e virão os impulsos mais fortes de renovação e progresso, toda a técnica moderna, as ciências e as artes, do qual dependerão sempre a nossa prosperidade e, talvez em grau muito maior no futuro, a nossa segurança, e onde o vasto litoral favorável e o dominante promontório nordestino, sem falar nas duas avançadas de Fernando de Noronha e Trindade, nos abrem, sem duvida, amplas perspectivas não só de alicerçar em bases solidas aquela prosperidade, libertando-nos de uma deplorável escravização às frotas de bandeiras estranhas, mas, além disso de garantir por nós mesmos, contra quaisquer ameaças extracontinentais, nossas extensas costas vulneráveis (SILVA: 1967:61-2) (grifos nossos). 
Golbery encerra a analise de 1952, com a seguinte assertiva: É que ao Brasil, na hora presente, só há uma escolha: engrandecer-se ou perecer. E para não perecer é necessário aceitar aquele sábio conselho de Washington:

Deveis ter sempre em vista que é loucura o esperar uma nação favores desinteressados de outra; e que tudo o que uma nação recebe como favor terá de pagar mais tarde com uma parte de sua independência (SILVA:1967: 62).

Golbery avaliava justamente a questão da relação dos EUA com o Brasil naquele momento; O Brasil em seguida a esta fase, passa a viver um desenvolvimento econômico sem precedentes baseado em empréstimos norte-americanos, para pagamento a longo prazo; fato que veio a se transformar em uma dívida externa altíssima, a qual gerou o comprometimento do bem-estar social do povo brasileiro, na medida em que com o dinheiro publico, ou se paga a dívida e juros cobrados, ou se faz as necessárias reformas sociais por exemplo, na educação, saúde etc, obras de interesse do povo, mas não das elites.

A próxima análise, realizada por Golbery em 1959, se dá durante o período de governo do Presidente Juscelino Kubitschek/JK (31.01.56 a 31.01.61). Cabe aqui nos determos antes, sobre as características da política econômica desse governo.

\section{Os anos JK}

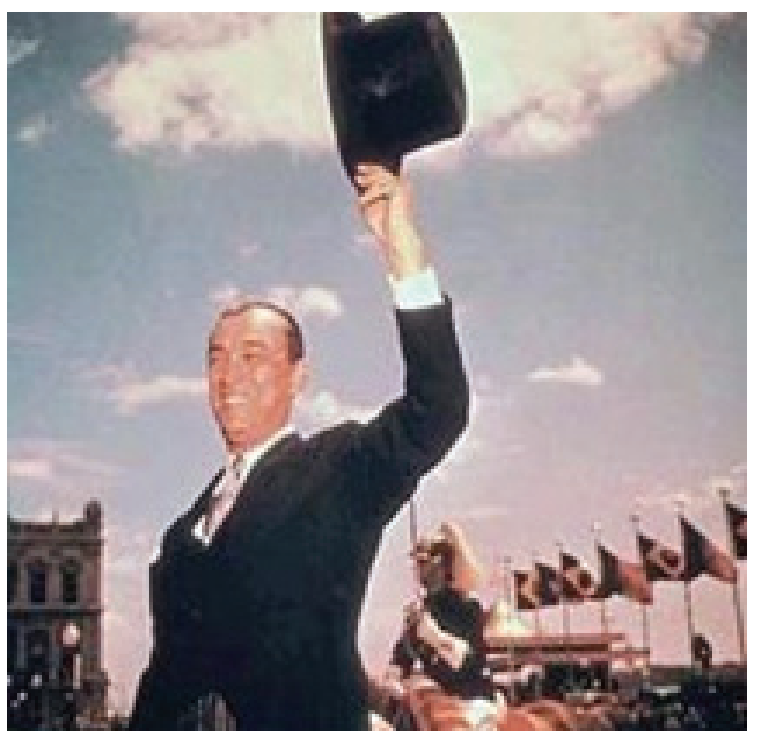

Ao anunciar seu programa de governo - " $\underline{50}$ anos de progresso em 5 anos de realizações", esse ideal desenvolvimentista foi consolidado num con-

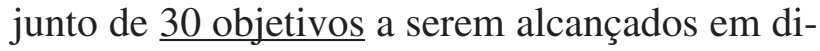
versos setores da economia, que se tornou conhecido como Plano de Metas. Ao final de sua elaboração o plano incluiu mais uma meta, a $31^{\mathrm{a}}$, chamada de meta-síntese: a construção de Brasília e a transferência da capital federal, da cidade do Rio de Janeiro para o Planalto Central.

Figura 86. JK eleito Presidente do Brasil em 1956. Fonte: Iasmin da Costa Marinho ${ }^{64}$.

\footnotetext{
$\overline{64}$ http://educacao.uol.com.br/historia-brasil/ult1689u64.jhtm. Pesquisado em 10.03.2013.
} 
Segundo o artigo, "O Brasil de JK. 50 anos em 5: O Plano de Metas" ${ }^{65}$ os analistas da época, assim viam a questão econômica brasileira do período:

O Plano de Metas de Juscelino foi elaborado com base em estudos e diagnósticos realizados desde o início da década de 1940 por diversas comissões e missões econômicas. Oúltimo grande esforço de diagnóstico dos entraves ao crescimento econômico brasileiro fora feito pela Comissão Mista Brasil - Estados Unidos entre 1951 e 1953, ainda no governo Vargas. Os estudos da Comissão Mista, assim como os do Banco Nacional de Desenvolvimento Econômico (BNDE) e os da Comissão Econômica para a América Latina e Caribe (CEPAL), indicavam a necessidade de eliminar os "pontos de estrangulamento" da economia brasileira. Tratava-se de setores críticos que não permitiam um adequado funcionamento da economia. A premissa do Plano de Metas, esboçado pouco antes da posse de JK por uma equipe do BNDE, era, assim, a superação desses obstáculos estruturais. As metas deveriam ser definidas e implementadas em estreita harmonia entre si, para que os investimentos em determinados setores pudessem refletir-se positivamente na dinâmica de outros. O crescimento ocorreria em cadeia. A meta de mecanização da agricultura, por exemplo, indicava a necessidade de fabricação de tratores, prevista na meta da indústria automobilística.

Para os analistas da época, o Brasil vinha passando, desde a década de 1930, por um processo de substituição de importações não-planejado, e a falta de planejamento seria a causa dos constantes desequilíbrios no balanço de pagamentos. O Plano de Metas pretendia suprir essa falta. A introdução de uma meta de consolidação da indústria automobilística no país tinha como objetivo, entre outras coisas, a redução planejada e gradativa da importação de veículos.

Talvez pela consciência que tivesse das dificuldades inerentes à burocracia estatal e dos obstáculos permanentes e inevitáveis impostos pela oposição, JK traçou uma estratégia de ação que se mostraria acertada com relação à administração e à operacionalização do Plano de Metas. Já na primeira reunião de seu ministério, em $1^{\circ}$ de fevereiro de 1956, criou um órgão diretamente subordinado à Presidência da República, o Conselho do Desenvolvimento, que iria coordenar o detalhamento e a execução do plano. Tendo como secretário-executivo o presidente do BNDE, e reunindo todos os ministros, os chefes dos gabinetes civil e militar e o presidente do Banco do Brasil, o conselho constituiria uma administração paralela com autonomia de decisão suficiente para viabilizar a realização dos projetos. O Conselho do Desenvolvimento recorria a especialistas dos diversos setores previstos no Plano de Metas e também a economistas oriundos de órgãos do governo, como a Superintendência da Moeda e do Crédito (Sumoc). Atuava através de grupos executivos, aos quais cabia a responsabilidade pela concessão de incentivos ao setor privado para que as metas de que tratavam fossem atingidas. O mais conhecido de todos foi o Grupo Executivo da Indústria Automobilística (GEIA). A coordenação dos investimentos do setor público era atribuição do BNDE. (cpdoc.fgv.br:1-2) (grifos nossos).

\footnotetext{
$\overline{65}$ http://cpdoc.fgv.br/producao/dossies/JK/artigos/Economia/PlanodeMetas. Pesquisado em 10.03.2013.
} 
O Plano de Metas (31 metas) apresentava como principal objetivo acelerar o crescimento econômico do Brasil, ou seja, pautava-se em um conjunto de medidas que atingiria o desenvolvimento econômico de vários setores, priorizando a dinamização do processo de industrialização do Brasil. O Plano consistia de investimento em áreas prioritárias para o desenvolvimento econômico, principalmente as voltadas à infraestrutura: rodovias, hidrelétricas e aeroportos, e indústria.

Vejamos a importância para o Estado e para as elites dominantes, dos investimentos feitos:

O Plano de Metas mencionava cinco setores básicos da economia, abrangendo várias metas cada um, para os quais os investimentos públicos e privados deveriam ser canalizados. Os setores que mais recursos receberam foram energia, transportes e indústrias de base num total de $93 \%$ dos recursos alocados. Esse percentual demonstra por si só que os outros dois setores incluídos no plano, alimentação e educação, não mereceram o mesmo tratamento dos primeiros. A construção de Brasília não integrava nenhum dos cinco setores. O crescimento das indústrias de base (bens de consumos duráveis), fundamentais ao processo de industrialização, foi de praticamente $100 \%$ no quinquênio 1956-1961 (cpdoc.fgv.br:2) (grifos nossos).

O desenvolvimentismo econômico que o Brasil viveu durante o mandato de JK priorizou o investimento nos setores de transportes e energia, na indústria de base, destacando aqui a ascensão da indústria automobilística.

Segundo Carvalho ${ }^{66}$, assim ele discorre sobre as obras realizadas no período anterior:

Os setores de energia e transporte foram considerados fundamentais para o desenvolvimentismo econômico, ressalta-se a importância do governo Vargas neste processo, com a criação da Companhia Siderúrgica Nacional em Volta Redonda-RJ no ano de 1946 e da Petrobras no ano de 1953. No setor energético, construiu as usinas hidrelétricas de Paulo Afonso no rio São Francisco e as barragens de Furnas e Três Marias. (Carvalho:s/d:2) (grifos nossos).

Sobre os capitais que foram investidos na indústria automobilística, significaram a desnacionalização da economia brasileira:

Foi na área do desenvolvimento industrial que JK teve maior êxito. Abrindo a economia para o capital internacional, atraiu o investimento de grandes empresas. Foi no governo JK que entraram no país grandes montadoras de automóveis como, por exemplo, Ford, Volkswagen, Willys e

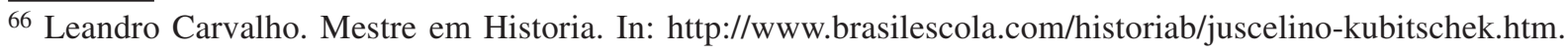
Pesquisado em 10.03.2013.
} 
GM (General Motors). Estas indústrias instalaram suas filiais na região sudeste do Brasil, principalmente, nas cidades de São Paulo, Rio de Janeiro e ABC (Santo André, São Caetano e São Bernardo). As oportunidades de empregos aumentaram muito nesta região, atraindo trabalhadores de todo Bra$\underline{\text { sil. Este fato fez aumentar o êxodo rural e a migração de nordestinos e nortistas de suas regiões para }}$ as grandes cidades do Sudeste ${ }^{67}$.

Quanto a construção de Brasília e a transferência da capital federal.

Em fins de 1956, depois de o Congresso Nacional ter aprovado a transferência da capital, iniciaramse as obras da construção de Brasília. Juscelino Kubitschek não foi o primeiro a falar sobre a possibilidade da transferência da capital do Brasil, desde 1891 a Constituição Federal, no seu artigo $3^{\circ}$, já almejava a transferência. (Carvalho:s/d:2).

Além do desenvolvimento do Sudeste, a região Centro-Oeste também cresceu e atraiu um grande número de migrantes nordestinos. A grande obra de JK foi a construção de Brasília, a nova capital do Brasil. Os trabalhadores que a construíram, grande parte migrantes da região nordeste do Brasil, se tornaram seus primeiros moradores, ficando conhecidos como "Candangos". Com a transferência da capital do Rio de Janeiro para Brasília, JK pretendia desenvolver a região central do país e afastar o centro das decisões políticas de uma região densamente povoada, por população que estava sempre a protestar. Com capital oriundo de empréstimos internacionais, JK conseguiu finalizar e inaugurar Brasília, em 21 de abril de 1960. Com a construção de Brasília o interior do Brasil passou a ser parte do avanço do ecúmeno sobre a área do centro-oeste, tão importante e indicada como sumamente necessária por Golbery.

Quanto a consequências da política econômica desenvolvimentista de Juscelino, vários autores assim comentam:

Para ampliar o desenvolvimentismo econômico brasileiro, JK considerava impossível o progresso da economia sem a participação do capital estrangeiro. Para alcançar os objetivos do Plano de Metas era necessária uma intervenção maior do Estado na economia, priorizando, então, a entrada de capitais estrangeiros no país, principalmente pela indústria automobilística. Ressalta-se que nesse período o Brasil iniciou o processo de endividamento externo. Contudo, tais mudanças empreendidas por JK ocasionou a acentuação da industrialização do país com um aumento do Produto Interno Bruto (PIB) anual em 7\%, mas não superando a inflação da dívida externa. ${ }^{68}$

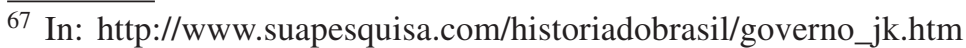

${ }^{68}$ Idem, Leandro Carvalho, p. 2
} 
A entrada de multinacionais gerou empregos, porém, deixou o país mais dependente do capital externo. O investimento na industrialização deixou de lado a zona rural, prejudicando o trabalhador do campo e a produção agrícola. O país ganhou uma nova capital, porém a dívida externa, contraída para esta obra, aumentou significativamente. A migração e o êxodo rural descontrolados fez aumentar a pobreza, a miséria e a violência nas grandes capitais do sudeste do país. ${ }^{69}$

Ao final dos anos JK, o Brasil havia mudado. Muitos foram os avanços, e muitas foram as críticas à opção de JK pelo crescimento econômico com recurso ao capital estrangeiro, em detrimento de uma política de estabilidade monetária. O crescimento econômico e a manutenção da estabilidade política, apesar do aumento da inflação e das consequências daí advindas, deram ao povo brasileiro o sentimento de que o subdesenvolvimento não deveria ser uma condição imutável. Era possível mudar, e o Brasil havia começado a fazê-lo. ${ }^{70}$

Com a abertura ao mercado estrangeiro, a ampliação e investimentos na indústria se tornaram ainda mais fáceis, porém, não era viável aos cofres brasileiros. A emissão monetária, um dos recursos utilizados por JK, causou graves danos ao processo inflacionário. Com o uso dos recursos estrangeiros, o governo abriu portas para desnacionalização, as influências das empresas estrangeiras se tornaram ainda mais fortes e presentes no país, controlando grande parte da economia

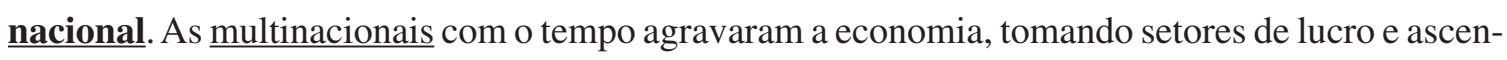
são, como as indústrias automobilísticas, de cigarros, farmacêutica e mecânica. Com isso o investimento aparentemente rentável para a gestão presidencial mudou de configuração, as empresas estrangeiras dominavam o mercado brasileiro garantindo grandes lucros, muitas vezes, mais altos que o que eles investiam no Brasil. Embora, esses procedimentos fossem opostos às Leis locais, as multinacionais burlavam. Concluímos, portanto, que o Plano de Metas iniciou com grandes avanços, porém foi responsável pelo nascimento de uma dívida externa para o Brasil que percorreu por muitos anos, por isso, fora tão criticado, esta possibilidade de crescimento arriscou a dependência econômica brasileira. ${ }^{71}$

O que se pode concluir sobre os anos JK é que o Brasil deu uma grande arrancada em termos de crescimento econômico, articulando entre si algumas regiões do país. Porém isso se deu às custas de desnacionalização da economia do país, endividamento com os empréstimos externos e dependência econômica, de inflação e de comprometimento do capital publico com a dívida externa, fundamentalmente com os bancos e governo dos EUA. Avançou o ecúmeno para a

\footnotetext{
${ }^{69}$ Idem In: http://www.suapesquisa.com/historiadobrasil/governo_jk.htm, p. 2.

${ }^{70}$ Idem O Brasil de JK. 50 anos em 5: O Plano de Metas. p. 3

${ }^{71}$ Iasmin da Costa Marinho. http://educacao.uol.com.br/historia-brasil/ult1689u64.jhtm, p. 1.
} 
região centro-oeste, com a construção de Brasília, estando dessa forma mais próximo da área de soldadura (MT/BR, Bolívia e Paraguai) a ser conquistada.

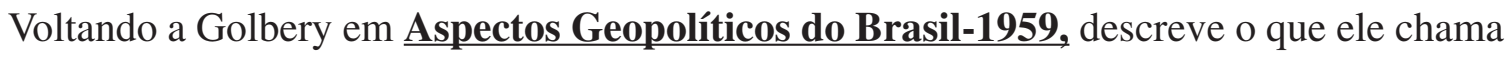
de Geistoria (uma mistura de Geografia com Historia); ao analisar as fronteiras naturais brasileiras ele se refere a "faixas ou centros formadores de fronteira". Ele cita e expõe mapa do historiador Jaime Cortesão:

Sobre este espaço continental, situado nos trópicos úmidos e rodeado insularmente pelo sistema hidrográfico platino-amazônico, de traços muito vigorosos, destacavam-se, envolvendo-o num arco de circulo irregular, certas zonas de relevo áspero, declive abrupto ou profunda depressão, que opunham forte obstáculo à expansão humana (...) Apontemos as mais características: ao Norte (...); a Noroeste (...); a Oeste, o trecho encachoeirado do Madeira, as vastas depressões alagadiças da planície de Santa Cruz de La Sierra e do Grande Pantanal; finalmente, mais ao Sul, o Salto das Sete Quedas sobre o Paraná, o Salto do Iguaçu e o Salto Grande do Uruguai. (Jaime Cortesão citado por SILVA: 1967:66) (grifos nossos).

Dessa forma ao analisar as potencialidades naturais do Brasil em função de proteção de suas fronteiras, podemos notar que ele aponta como uma delas, a região ao Sul, de interesse desta tese, o Salto das Sete Quedas sobre o Paraná e o Salto do Iguaçu.

Em seguida Golbery demonstra conhecimento sobre a presença indígena, assim como os territórios que ocupavam (ocupam) assim afirmando:

Por mais que, em sua incrível mobilidade de nômades superiormente afeitos à navegação em quaisquer rios, os Aruaques e, também, os Tupis-Guaranis fôssem capazes, graças ao seu inato senso geográfico e de orientação, de desprezar todos esses marcos formidáveis, desbordando-os ou transpondo-os mercê de quase miraculosa continuidade das bacias hidrográficas riquíssimas de afluentes e subafluentes, a verdade é que, completado vasto circuito pelo interior platino-amazônico e muito avançada a migração de norte a sul, ao longo do litoral atlântico, os aborígenes, já agora mal ou bem unificados pelo poder aglutinante da "língua geral" e da cultura tupi-guaranítica, "ao começar o século de Quinhentos (...) prefiguravam sobre o território, ainda que sob forma ondulante, a fundação colonial dos portugueses, na America do Sul" - como assinala ainda, o mesmo Cortesão. A unidade geográfica, econômica e humana precedia, assim, o império lusitano da America, superando, graças às facilidades de tradicionais comunicações pelo geossinclinal aberto do interior... (SILVA: 1967:66-7) (grifos nossos). 


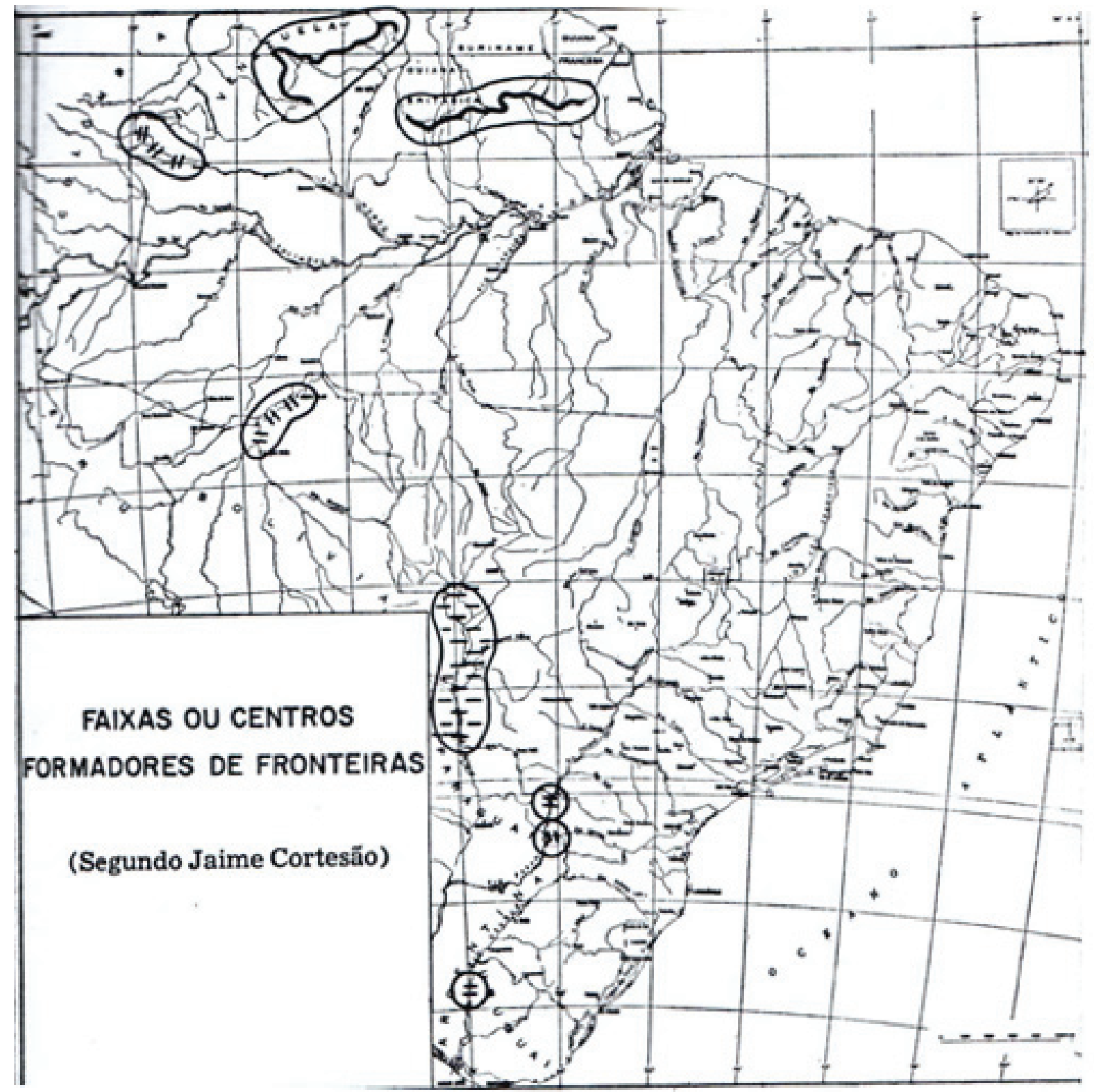

Figura 87. Faixas ou Centros Formadores de Fronteira.

Fonte: Golbery do Couto e Silva. Geopolítica do Brasil. 1967, p. 67.

Assim, os portugueses utilizaram-se dos caminhos criados pelos índios, no sul o Peabiru, dos Guarani. O problema dessas afirmações é que Golbery tende a ver o assunto de forma evolucionista e linear. “Antes eram os índios, depois os portugueses...", e assim por diante. Como se os indígenas tivessem desaparecido no Brasil-Colonial, fizessem parte apenas do passado. É o que as elites sempre tendem a assinalar, o suposto "desaparecimento dos indígenas" em tempos anteriores e muito, muito, antigos. Essa premissa é falsa na medida em que estamos aqui tratando de povos indígenas Guarani que ocupam atualmente a Tríplice Fronteira, apesar do recorrente esbulho dessas mesmas elites sobre as terras indígenas. 
Referindo-se a formação da "unidade territorial brasileira" assim o autor afirma, com respeito ao Sul:

Não poderíamos, aqui, pretender resumir sequer todo o longo processo de formação e paulatina afirmação da consciência coletiva dessa unidade territorial, que romperia, ao cabo de séculos e peripécias mil, o minguado cárcere do meridiano de Tordesilhas. Em si mesmo, condensa ele todo o sentido imanente da historia colorida e agreste desse surpreendente Brasil colonial, surpreendente mantido uno e coeso sob as mais perigosas investidas - de (...) e ao arrepio dos formadores do Prata -, (...), até o Brasil reino o Brasil Império, vigorosas projeções em que se radicam, afinal, os seculares embates em torno da Cisplatina, as intermináveis questões do Prata e não menos o trágico esmagamento do Paraguai de Solano Lopez. (SILVA: 1967:68).

Golbery enaltece a figura do bandeirante Raposo Tavares, como alargador de fronteiras, aquele mesmo que em capítulos anteriores, vimos como o destruidor do Guairá, que massacrou os índios Guarani dessa fronteira paranaense. Por fim refere-se a diplomacia portuguesa no Prata, possivelmente se refere a questão da disputa entre espanhóis e portugueses pela Colônia do Sacramento, tema já tratado nesta tese.

Em seguida Golbery ressalta a significação geopolítica de varias regiões, entre elas, ressaltamos quatro, as mais importantes para o conteúdo desta tese:

- a salvaguarda de fronteiras distantes e a afirmação aí da soberania territorial, mediante a sábia disposição de núcleos defensivos, tamponando estrategicamente todas as abertas à penetração desde o exterior;

- a sensibilidade ao valor geopolítico capital das regiões interiores do Guairá, do Itatim, de PotosiChiquitos - o Oeste paranaense, o Sudoeste do Mato Grosso e os contrafortes andinos no divortium aquarum entre o Amazonas e a bacia do Prata - que flanqueiam do sul para o norte, o planalto coração do Brasil e barram o caminho do médio e alto Paraná por uma e outra de suas margens ou dominam o talvegue do Guaporé-Mamoré que, cumprido seu papel de divisória, leva diretamente ao mundo amazônico do Madeira;

- o comercio intensivo tanto com o Prata e Tucumã como, a oeste, com as populações andinas da Bolívia e do Peru, a despeito mesmo das fortes barreiras opostas por um ciumento e feroz monopólio da Espanha; (SILVA: 1967:69)

- o espírito do pan-americanismo, alicerçado no reconhecimento de uma unidade continental que os perigos externos ameaçadores deste nosso século conturbado põem, cada vez mais, na categoria das realidades indiscutíveis, e sem cessar triunfante, até hoje, de inúmeras e graves divergências, de 
agudos choques de interesses e dos receios, não de todo infundados, por certo, contra interferências descabidas e prepotentes dos mais fortes; (SILVA:1967:70) (grifos nossos)

No item "3. Principais modificações estruturais da sociedade brasileira em face da evolução do ambiente mundial e, em particular, do panorama americano", Golbery demonstra novamente a visão etnocêntrica, evolucionista e integracionista a respeito das sociedades indígenas, visão essa compartilhada pelas elites (estatal e civil) em geral, à época e ainda hoje:

(...) A complexidade deste universo brasileiro em que coexistem, lado a lado, formações sociais e complexos culturais diversos, em grau muito distinto de evolução, como que oferecendo ao observador uma recapitulação viva, ao largo do espaço territorial imenso, da própria seriação temporal desigualmente concluída. No campo econômico, ultrapassadas, embora nunca de todo, as formas pré-capitalistas, a partir das mais rudimentares - a caça e a pesca primitivas, a simples coleta dos frutos da terra, a lavoura itinerante e predatória com todo o seu complexo da queimada... (SILVA: 1967:70-1) (grifos nossos)

Bastaria acessar hoje os estudos, por exemplo, do etnobôtanico Posey, para se verificar que a técnica utilizada pelos indígenas no Brasil, nada tem de rudimentar, primitivo ou simples, pelo contrario são técnicas que aliam uso e preservação ambiental, criação de banco de germoplasma..., que a lavoura itinerante nada tem de predatória, pelo contrario ela não exaure as terras e criam vários nichos em diferentes locais, com produtos interessantes ao consumo de homens e animais, e por fim, que há estudos que afirmam que a queimada é benéfica ao solo e ao plantio, desde que se faça de forma a utilizar vários espaços de lavoura, ou seja, não seguidamente no mesmo local.

O ápice para Golbery desta linha evolucionista é termos atingido "o grau", de sociedade de economia capitalista industrial:

(...) A sociedade brasileira vai atingindo agora os mais elevados tipos estruturais, pela industrialização intensiva, não confinada aos meros bens de consumo, mas alicerçada na grande indústria de base, com vistas às inegáveis potencialidades amplas de um mercado interno faminto de produtos de toda ordem e, não menos, às possibilidades de uma concorrência, se bem que ainda muito dificultada de inicio, no próprio campo internacional. Não mais a exclusiva produção de bens primários, de matérias-primas e outros produtos de exportação, sujeitas a todas as escorchadoras imposições do exterior e jungida inteiramente, nos moldes das clássicas plantations, aos interesses imediatistas de empresários e capitalistas estrangeiros. Não mais a secular renovação de ciclos econômicos - o pau-brasil, o açúcar, o ouro, a borracha, o café agonizante - conduzindo afinal à estagnação e ao desalento, após um período, mais ou menos efêmero, de euforia e riqueza (SILVA: 1967:71) (grifos nossos). 
O contexto da época revela descompassos vários no setor produtivo, como vimos ao citar o governo JK:

É certo que o desenvolvimento econômico acelerado, $\underline{\text { na ânsia de queimar etapas, }}$ pode gerar, por si

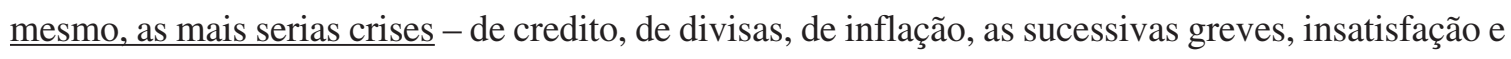
motins; agrava, em muitos casos, fundamentais pontos de estrangulamento do sistema - o cons-

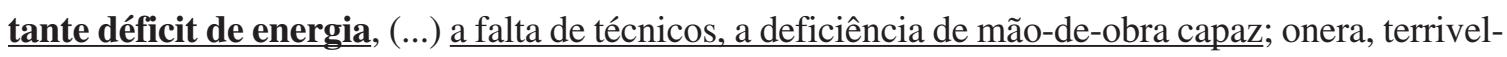
mente, as sempre reduzidas disponibilidades de um equipamento de circulação constantemente em $\underline{\text { forte retardo com relação à demanda; } \text { aumenta cada vez mais o alarmante descompasso entre uma }}$ agricultura atrasada, de rendimento ainda muito baixo, e uma industria em promissor avanço, a despeito mesmo dos gravames iniciais que lhe tolham a produtividade; (SILVA:1967:71) (grifos nossos)

Como veremos mais adiante esses problemas vão ser equacionados, com os empréstimos fundamentalmente norte-americanos, para a construção de ferrovias e rodovias, a construção de varias hidrelétricas de grande porte, como Itaipu, assessoria técnica, industrialização da agricultura e a produção, ainda para exportação de produtos primários, de soja, de laranja etc, inicialmente, para pagar a dívida externa.

Golbery continua:

(...) aumenta, dramaticamente, o perigoso desnível entre as varias regiões do país, exacerbando os contrastes e criando zonas marginais e áreas-problemas - uma periferia nitidamente subdesenvolvida em derredor de alguns núcleos vigorosos de elevado ritmo de expansão econômica. (SILVA:1967:71-2)

Assim a riqueza não é para todos.

Continua Golbery:

Mas, no que mais importa, esse desenvolvimento pela industrialização faz prenunciar, afinal, uma libertação mais efetiva aos grandes centros externos, motores do dinamismo econômico mundial, e implicará, em benefício da unidade e da coesão nacionais, na articulação cada vez mais solida das diversas porções do amplo domínio, mesmo as mais distantes ou mais excêntricas, a núcleos propulsores radicados no próprio território e, sobretudo, orientados por genuínos propósitos nacionais. (SILVA: 1967:72) (grifos nossos)

Quanto ao desenvolvimento nacional pela industrialização apesar de haver de fato certa libertação mais efetiva aos grandes centros externos de produção, porém, o país acabou por cair em outro tipo de "escravização", com relação aos países desenvolvidos, a dependência econômica e a dívida externa, que reduz direitos sociais do povo, em nome de seu pagamento. 
No campo político Golbery vê no final da década de 50, a ascensão da burguesia comercial e industrial:

(...) a republica federativa e o regime representativo e presidencial que aí temos, o que mais vale assinalar - por sobre a dinâmica partidária, o estilo tão criticado e tão criticável da vida publica, o funcionamento precário do sistema de opinião publica-governo e propaganda, a ingerência tão poderosa e sutil do poderio econômico - é o inegável processo de maturação política das massas, cada vez mais adensadas nos grandes e médios centros populacionais (...). O velho senhor de engenho, patriarca todo-poderoso, já de há muito se foi, como vai também passando a historia do passado a figura tradicional do "coronel" do interior; as velhas e orgulhosas aristocracias rurais cederam inteiramente as novas elites - a burguesia comercial, os "bacharéis", os barões industriais (...).

No campo psicossocial, a despeito de enormes tropeços e de muitos erros de orientação, a educação ganha novos impulsos, difundindo-se em âmbito cada vez mais amplo e desviando-se de um academicismo de ostentação para formas mais técnicas e bem mais produtivas, em geral; (SILVA: 1967:72) (grifos nossos).

Ou seja, não criar massa critica e sim técnica, voltada apenas à produtividade ${ }^{72}$. Na questão demográfica o autor vê relativo avanço do ecúmeno:

No setor demográfico, em particular, registra-se um crescimento quase explosivo da população e, a despeito do tumultuar irrequieto das migrações internas descontroladas e do persistente êxodo rural, avança para o interior, lenta, desordenada, irregular, mas constantemente, a vaga vitalizadora do povoamento, cobrindo hoje, quase sem grandes lacunas que o valham, embora com densidade média ainda bastante fraca, toda uma faixa litorânea de seus $500 \mathrm{~km}$ de largo, do Rio Grande do Sul ao Maranhão. Evoluímos, pois - e não pouco - da tênue colonização periférica que caracterizava ainda o Brasil nos começos do século XVII, para a ocupação de ampla base de partida, favorável à manobra que teremos de realizar, da incorporação real do imenso domínio do interior, praticamente ainda o desertão, à comunidade nacional (SILVA: 1967:73) (grifos nossos)

Quanto a política das Grandes Potências, afirma:

(...) enquanto progredíamos, (...) o mundo que nos rodeia sofria o impacto tremendo de duas revoluções industriais que acabariam por alterar-lhe profundamente todos os padrões dimensionais, a escala toda do espaço e do tempo, avizinhando as mais distantes paragens e pondo em intimo contato

\footnotetext{
$\overline{72}$ Política adotada também pelo Presidente Fernando Henrique Cardozo ao propror a retirada das matérias de humanas (sociologia e antropologia), dos curriculuns de graduação no Brasil. Sendo ele próprio, sociólogo de formação.
} 
com as mais apartadas culturas. Submergiram, nos cataclismos de duas grandes guerras de projeções mundiais, as Grandes Potencias orgulhosas de outrora e os polos da dinâmica econômica, política e militar que galvaniza o mundo todo, transferiram-se bruscamente a regiões novas, inaugurando estilos completamente diversos nas relações internacionais (SILVA: 1967:73) (grifos nossos).

\section{Referindo-se a política dos EUA para a America Latina:}

Dissensões velhas e tradicionais desconfianças varias esbatem-se aos poucos e afirma-se um sentimento de solidariedade continental, sob o calor das praticas de uma "boa-vizinhança" 73 compreensiva e sem subterfúgios. A America Latina toma consciência de fato de sua inegável expressão geopolítica, não só potencial, mas já atual, enquanto a sombra projetada pelos Estados Unidos da America, elevados estes, agora, à categoria de superpotência líder reconhecida do Ocidente e de responsabilidades, portanto, ampliadas a uma escala universal, deixa aos poucos de gerar os mesmos receios que tanto vicejaram em épocas anteriores. E ressentimentos - que os há, e fortes - são até de outra ordem: reclama-se hoje, neste particular, uma ajuda e uma assistência que, em verdade, nem mesmo seriam sequer consideradas em épocas mais distantes (SILVA: 1967:74) (grifos nossos).

Refere-se ele, aos ressentimentos do passado, a Doutrina Monroe, a política de Roosevelt do Big Stick e do Corolário Roosevelt; embora anunciassem para o mundo que os países de todas as Américas seriam livres de colonização por parte da Europa, se colocavam assim os EUA, como policiais do mundo, dando-se ao direito de intervir nesses países, e nesta esteira, por fim dominá-los economicamente, para os seus próprios fins.

Golbery propõe em 1959, os “Objetivos Nacionais Permanentes do Brasil”, uma receita que deveria inspirar toda a ação geopolítica, tanto no âmbito interno como no campo internacional. São eles:

- a salvaguarda intransigente de nossa independência política, admitidas, embora, autolimitações, nunca essenciais, da soberania nacional, em beneficio da cooperação e da paz internacionais: $:{ }^{74}$

\footnotetext{
${ }^{73}$ É notória a influencia dos conceitos criados pelos norte-americanos no discurso de Golbery: "política de boa vizinhança"; "uma geopolítica sul-americana, uma estratégia do Ocidente, uma política pan-americana"; Unidade Continental; "Segurança Nacional"; "Defesa da Democracia e da Liberdade"; "Engrandecimento, Progresso, Subdesenvolvimento/Desenvolvimento"; Na mesma linha de raciocínio mas por conta do próprio Golbery: "imperialismo moscovita" contraponto "as democracias do Ocidente"; o "Sacro Império Romano do Ocidente"; se refere ao comunismo da seguinte forma (sic): corruptora histeria demagógica e bloqueará por fim, a endemia desvitalizante da teorização balofa e inatual (1967:101).

${ }^{74}$ Ele considera pequenas, as limitações impostas pelos EUA.
} 
- a manutenção de um estilo de vida democrático, com bases cada vez mais amplas na participação efetiva e consciente do povo, ${ }^{75}$

- a garantia das liberdades regionais (sentido federativo) e da autonomia local (municipalismo); ${ }^{76}$

- a consolidação da unidade do grupo nacional, através de crescente integração social, com fundamentação nos princípios da justiça social e da moral cristã $;{ }^{77}$

- a incorporação efetiva de todo o território nacional, humanizando-se e valorizando-se os largos espaços ainda vazios;

- o fortalecimento equilibrado da estrutura econômica, de modo a assegurar elevados níveis de bemestar e cultura a todo o povo, em todas as regiões do país, e garantindo-se o grau de autossuficiência realmente indispensável ao pleno exercício da própria soberania nacional;

- a manutenção do status quo territorial na America do Sul, contra quaisquer tendências revisionistas ou a formação de blocos regionais, políticos ou simplesmente econômicos, que possam vir a constituir ameaça à própria paz do continente $;{ }^{78}$

- o robustecimento da solidariedade e cooperação entre os povos da America, para o progresso geral e a defesa continental;

- o fortalecimento do prestigio nacional no âmbito externo, com base no principio da igualdade jurídica dos Estados, e a crescente projeção do país no exterior com vistas à salvaguarda eficaz de seus próprios interesses e em beneficio também da própria paz internacional (SILVA: 1967:74-5) (grifos nossos).

No item “5. O Brasil de hoje no mundo contemporâneo” (página 75), Golbery faz uma apreciação do panorama do Brasil de hoje: “- numa perspectiva brasileira do mundo; - na vizinhança latino-americana; no império brasileiro".

Quanto a "uma perspectiva brasileira do mundo" o autor discorre sobre a Segurança Nacional do Brasil frente ao mundo, dado o possível ataque que esperava dos soviéticos e cria sua estratégia defensiva por meio da teoria dos hemiciclos:

Esse é, pois, o hemiciclo perigoso (o exterior) contra o qual a America do Sul terá de solidamente estruturar a sua própria segurança. (Moscou-Pequim). (...) Tamponadas as brechas de nordeste e sudeste (...) a fortaleza sul-americana permanecerá quase que inexpugnável, se contra a infiltração quinta-colunista $^{79}$, a agressão disfarçada em subversão insuflada de longe, a penetração ideológica

\footnotetext{
$\overline{75}$ Golbery vai ser um dos articuladores da repressão pós-golpe dos militares.

76 idem.

${ }^{77}$ Ibidem.

${ }^{78}$ Deve-se referir ele, a Argentina.

${ }^{79}$ Refere-se ele a infiltração comunista da Quinta-Coluna de Luiz Carlos Prestes.
} 
emoliente e sutil, forem tomadas, com oportunidade e sabedoria, justas medidas preventivas e, se necessário, repressivas.

Empenhar-se a America do Sul, e com ela, o Brasil, decidida e perseverantemente, na preservação, em mãos amigas ${ }^{80}$, das terras do hemiciclo interior representa o mínimo que podemos, que devemos fazer para segurança da fortaleza sul-americana, que precisa desenvolver-se e criar riquezas e realizar plenamente os seus destinos, nesta época de vertiginoso progresso das técnicas e das armas, arrasadoras ou insidiosas, de ataques realizados por sobre distancias intercontinentais.

Ora no momento atual, lança suas sombras pressagas, sobre o mundo todo, um antagonismo de proporções nunca vistas e que arregimenta o Ocidente democrático e o Oriente comunista em dois blocos já empenhados em interminável e porfiosa pendência (SILVA: 1967:82-3-4).

Sobre a "Vizinhança Latino-Americana" Golbery afirma em tom reconciliador, discurso certamente voltado para a rival Argentina.

Superados em grande parte muitos dos focos de atrito tradicionais que convulsionaram, em épocas passadas (...) o panorama sul-americano e, por vezes, ainda afloram bruscamente à tona em desconfianças mutuas, receios mais ou menos infundados e raros choques esporádicos, prontamente contidos; fortalecido o sentimento de uma natural comunidade latino-americana que terá tudo a ganhar de uma união sincera e ativa de energias na luta contra o subdesenvolvimento e a fraqueza econômica; vivamente provada a unidade continental em face de ameaças externas que se manifestam, dia a dia, mais próximas e mais tremendas - nem por isso perde um sentido objetivo a compartimentação do continente em áreas estratégicas distintas, antes ganha cada vez maior significação, entendidas estas, realmente, mais como zonas de integração geopolítica com vistas a uma conjunção voluntaria de esforços nacionais para tarefas construtivas de paz (SILVA: 1967:87) (grifos nossos).

Objetivando orientar a ação geopolítica do Brasil no continente sul-americano, Golbery repete formula passada, agora mais atualizada, e com certo viés de país hegemônico na região:

Na sua imensidão territorial que se desdobra por quase todos os meridianos e paralelos da America do Sul e em virtude mesmo das responsabilidades de cooperação internacional a que não saberia furtar-se, pelo seu potencial muito superior de recursos materiais em mobilização acelerada, o Brasil participa, em verdade, de todas essas áreas geopolíticas do continente, em cada uma delas integrando porções inegavelmente expressivas de seus amplos domínios (SILVA: 1967:87) (grifos nossos).

Assim ele analisa, por meio do mapa a seguir, por ele criado.

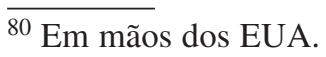


Ele afirma que, o núcleo central brasileiro - Rio - SP - BH, tende a incorporar todo o estado de MG e o Sul de Goiás. Ele é a zona de reserva geral ou plataforma central de manobra;

Duas outras grandes áreas geopolíticas terrestres: noroeste e sul.

A Noroeste: Peru, Equador, Colômbia e Venezuela, as três Guianas, a hileia brasileira (Amazonas, Pará, Acre, Amapá, Rio Branco (atual Roraima) e Norte de Goiás);

Ao Sul: A Argentina, o Chile, o Uruguai e o Brasil platino (RGS, SC, PR);

Ao centro, articulando entre si essas duas áreas e ligando-as, por outro lado, à zona central do núcleo ecumênico brasileiro - uma área geopolítica de soldadura, caracterizada pelo seu notório caráter ambivalente amazônico-platino e que abrangeria, a grosso modo, a Bolívia e o Paraguai, mais o estado do Mato Grosso e o Território do Guaporé (atual Rondônia).

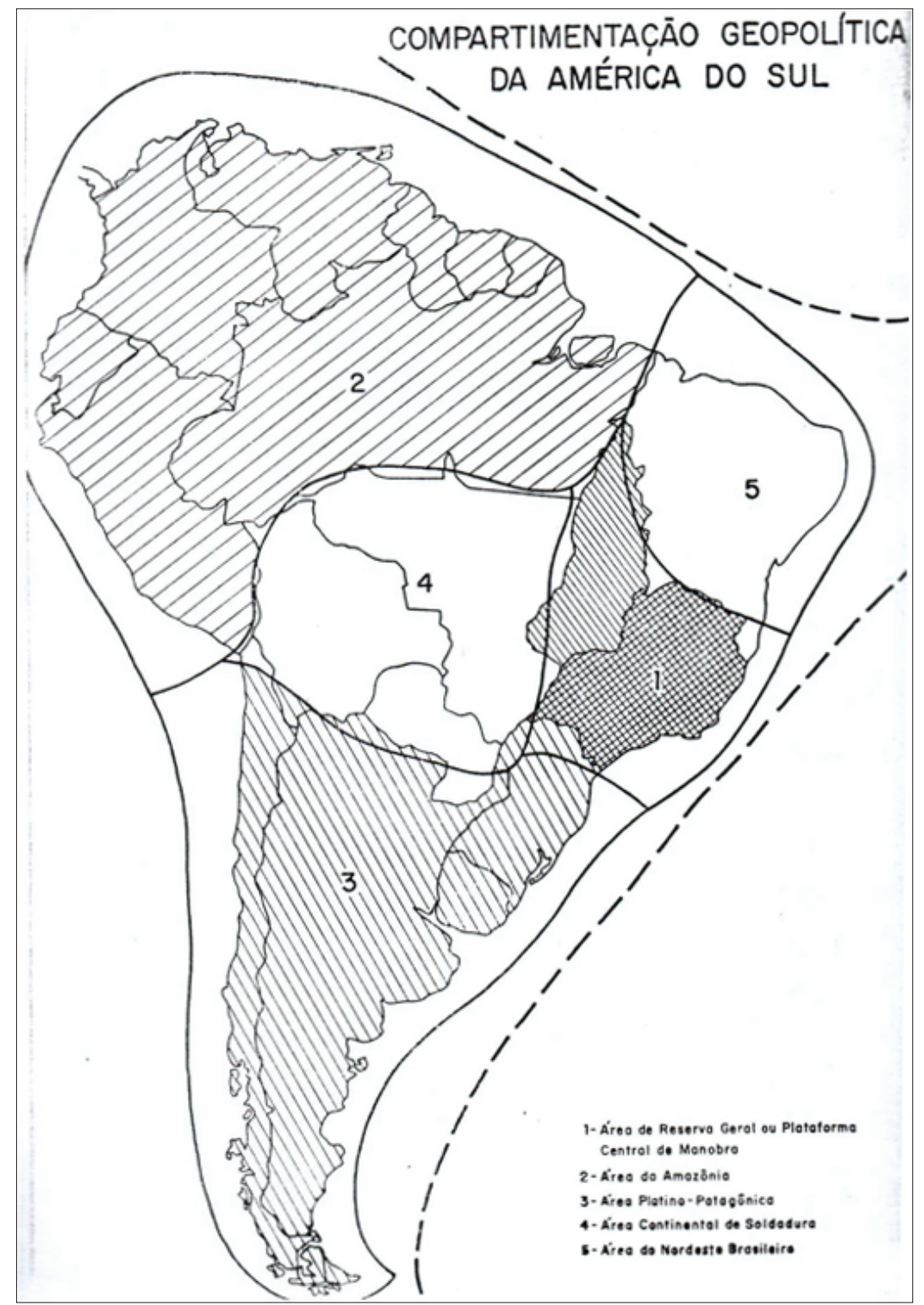

Figura 88. Mapa. Compartimentação Geopolítica da America do Sul.

Fonte: Golbery do Couto e Silva. Geopolítica do Brasil. Esquema 20, p. 88. 
Nota-se que além dele incorporar o Mato Grosso, a Bolívia e o Paraguai na área 4, ele margeia a fronteira sul dessa área, incluindo da Tríplice Fronteira apenas áreas do Brasil (oeste paranaense) e do Paraguai, e, entestando de frente com Las Misiones argentinas. Ao que parece desde daí, o plano geopolítico para essa área já estava acertado.

Continua Golbery:

(...) $\mathrm{Na}$ banda oriental duas vastas, áreas geopolíticas ou estratégicas marítimas, correspondente ao Atlântico centro-norte e ao Atlântico centro-sul e as quais serviria de soldadura a área geopolítica nordestina, aí incluindo necessariamente, todo o arco que vai de São Luis a Salvador (o chamado Nordeste Oriental e o Nordeste ocidental, e ainda a Bahia). (SILVA: 1967:89) (grifos nossos)

Ele acrescenta ao final: (...) assegurando co-participação expressiva e indispensável de nosso ecúmeno no equacionamento e solução integrada das varias problemáticas regionais, das quais nunca poderíamos nos alhear. Entende-se assim o pensamento de Raffestin quando define o conceito de Estado. Sem população não há Estado.

Assim são os mesmos problemas de outrora, antes apontados e agora atualizados.

Quanto ao que o autor denomina de “O Império Brasileiro” em 1959, ele enxerga o ecúmeno avançar na região do Núcleo Central, ancorado nas cidades do Rio de Janeiro, São Paulo e Belo Horizonte, e que abarca todo o estado de São Paulo, grande parte de Minas Gerais e Espírito Santo, todo o estado do Rio de Janeiro, mais o atual Distrito Federal (ainda Estado da Guanabara). Enxerga com pesar que: - articulam-se por istmos de circulação infelizmente ainda precários, três grandes penínsulas: a nordestina, a do extremo sul e a goiano-matogrossense; - mais a noroeste a hileia, ainda isolada; (SILVA: 1967:89-90)

Em seguida Golbery detalha, caracterizando o estágio atual de cada uma, das que ele denomina de "núcleo-central e penínsulas", apoiado no mapa a seguir.

O núcleo central ecumênico do Brasil amplia-se para uma área geopolítica de manobra central, que incorporará necessariamente em futuro não muito remoto, a totalidade de Minas Gerais e o restante de Espírito Santo, espraiando-se, ao impulso da interiorização da Capital, por todo o sul de Goias (...) estirando-se ainda mais para Noroeste para fincar seu vértice interior na região de Brasília, possibilitando afinal a articulação que faltava, com a atual ilha amazônica, ao longo do rio Tocantins e do traçado paralelo da BR-14 (atual Belém-Brasília BR-153).

A península nordestina interioriza-se também, já como área geopolítica, para englobar todo o Nordeste ocidental, de um lado, a Bahia, de outro, de modo a poder consolidar-se naturalmente (...) a sua base diagonal de Salvador a São Luis, por Juazeiro - Petrolina, Picos e Teresina, e objetivar-se a revitalização do tradicional meridiano fluvial do São Francisco (...). 
A península meridional comprimida sem remédio em espaço bem mais reduzido, ganhará apenas em maior organicidade em derredor do quadrilátero de articulação básica, demarcado por Curitiba Porto Alegre - Santa Maria e Irati.

Ao revés, a atual península do centro-oeste, amputada da banda oriental, avança, como área geopolítica plenamente individualizada, reorientando-se de sudeste a noroeste para entestar completamente com a Bolívia e o Paraguai, de cujo caráter indeciso e ambivalente participa também, a cavaleiro das duas grandes bacias hidrográficas do Amazonas e do Prata. Cuiabá no próprio paralelo de equipotencia das atrações do Norte e do Sul, esta fadada a ser o grande centro de articulação de toda a área, cuja potencial base de circunvalação fronteiriça, de Porto Velho a Campo Grande e Ponta Porã, acabará se tornando uma realidade concreta na soldadura mais avançada entre o Brasil Amazônico e o Brasil Platino (SILVA: 1967:91) (grifos nossos).

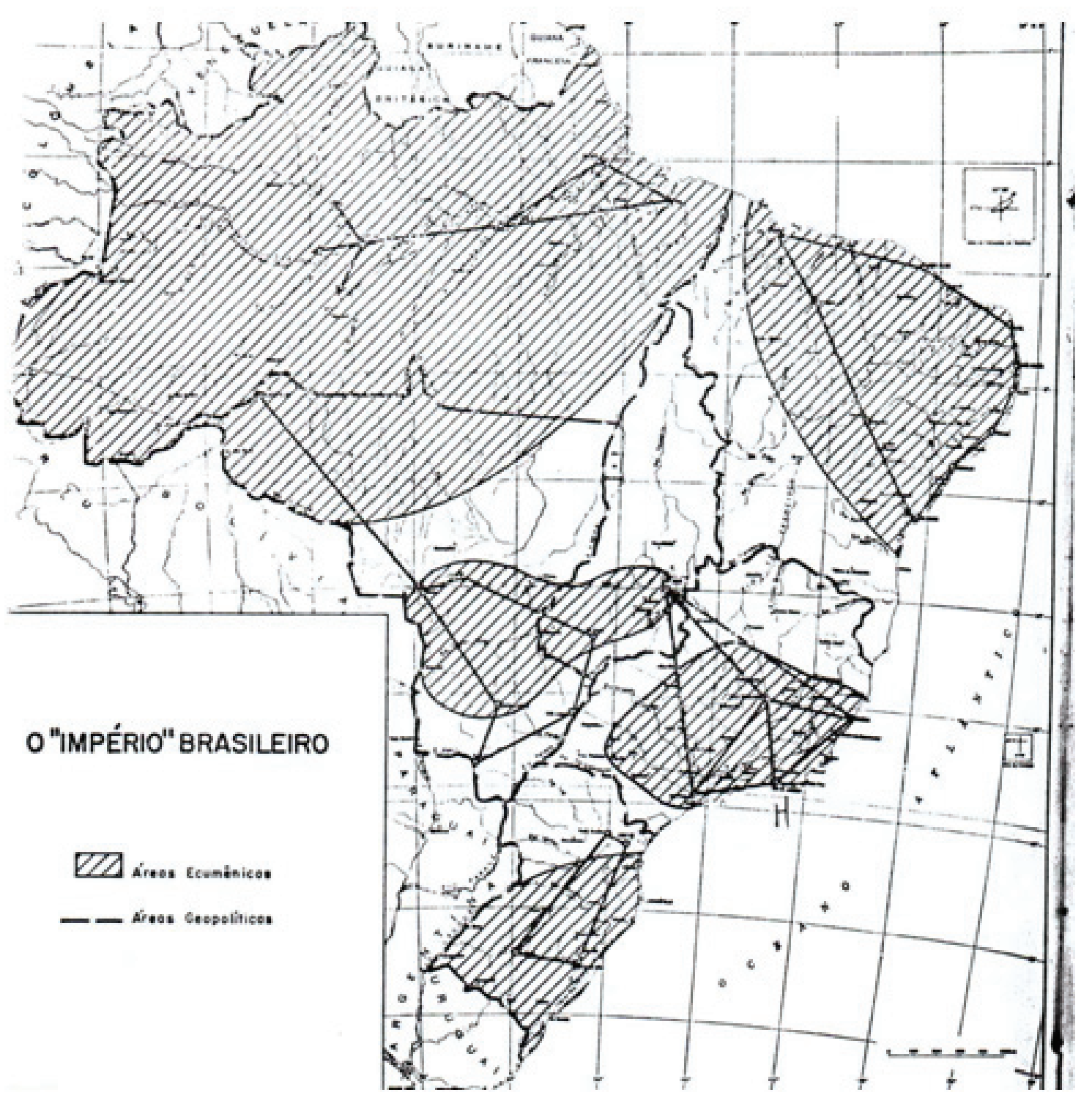

Figura 89. O "Império Brasileiro". Áreas Ecumênicas e Geopolíticas.

Fonte: Golbery do Couto e Silva. Geopolítica do Brasil. Esquema 21, p. 90. 
A ilha amazônica (...) continuará como área geopolítica, eixada segundo o leito do rio formidável, onde Manaus permanecerá o fulcro do sistema, por mais que se articule e adense e vitalize o vasto estuário, no triangulo Belém-Amapá-Santarém (SILVA: 1967:91-2)

Assim, para o que é importante reter para esta tese, portanto, o ecúmeno esta avançando em direção a região centro-oeste, para a proteção da área de soldadura frente à Argentina e o sul está ganhando maior organicidade, frente ao mesmo país. Porém, a região da cunha de Las Misiones, junto a Tríplice Fronteira, como se vê no mapa exposto, continua ainda a descoberto.

Concluindo os estudos de 1959, Golbery traça “Possíveis diretrizes de uma geopolítica brasileira".

No campo interno ainda é o problema da vitalização do ecúmeno:

No campo interno, a problemática geopolítica resume-se na incorporação efetiva e vitalização de todo o amplo domínio, em grande parte ainda vazio do homem e da civilização fecundadora. Três fases de forma alguma estanques no tempo:

$1^{\text {a }}$. Articular firmemente a base ecumênica de nossa projeção continental, ligando o Nordeste e o Sul ao núcleo central do país; ao mesmo passo que garantir a inviolabilidade da vasta extensão despovoada do interior pelo tamponamento eficaz das possíveis vias de penetração;

$2^{\mathrm{a}}$. Impulsionar o avanço para noroeste da onda colonizadora, a partir da plataforma central, - a atual região nuclear do país - de modo a integrar a península centro-oeste no todo ecumênico brasileiro; $3^{\mathrm{a}}$. Inundar de civilização a Hileia amazônica, a coberto dos nódulos fronteiriços, partindo de uma base avançada constituída no Centro-Oeste, em ação coordenada com a progressão E-O, segundo o eixo do grande rio (SILVA:1967:92) (grifos nossos).

No âmbito externo são dois os problemas a enfrentar: - a salvaguarda da inviolabilidade territorial frente a ameaça comunista que exige o fortalecimento do ecúmeno de norte a sul e, a presença no centro-oeste visando dominar a área de soldadura frente aos argentinos:

No âmbito externo, o problema fundamental da geopolítica é, em primeiro plano, de natureza propriamente estratégica e não poderia deixar de objetivar a salvaguarda da inviolabilidade territorial, ante ameaças externas de quaisquer origens que sejam, por pouco prováveis mesmo que se nos afigurem. Ora, ainda sob tal aspecto, avultam de importância na frente continental, o fortalecimento de nossa base ecumênica, a exigir uma solida e permanente articulação de norte e sul, bem assim a integração do Centro-Oeste, área de soldadura de inigualável importância estratégica no coração do continente e capaz de permitir reação eficaz a qualquer aventura expansionista, ostensiva ou mascarada, que venha a surgir por estas bandas, ao influxo mesmo de espúrias influencias de além-marcapaz até de prevení-las (SILVA: 1967:93) (grifos nossos). 
Golbery não diz claramente, mas ele sugere acima, provavelmente influencias comunistas sobre os argentinos.

Continua Golbery afirmando, que não se pode esquecer das áreas geográficas 2, 3 e 4 do mapa anteriormente apresentado, "Compartimentação Geopolítica da America do Sul”:

Tudo isso, sem prejuízo, é evidente, de uma adequada estruturação das três áreas geopolíticas $\underline{\text { transfronteiriças, }}$, constituindo-se em cada uma delas, potenciais regionais de valor proporcional à importância, periculosidade, grau de urgência e de probabilidade das ameaças que se antevejam (SILVA: 1967:93) (grifos nossos).

Quanto a frente atlântica o autor se refere:

- num circulo restrito a circunvizinhança imediata ${ }^{81}$ e considerados, sobretudo, os compromissos recíprocos entre o Brasil e os EUA para a defesa do hemisfério, o fortalecimento e articulação de nossa base ecumênica, extensa charneira anfíbia, permanece ainda em primeira urgência, acrescendo-se mais ainda agora, a significação dentro dela ${ }^{82}$, da área nordestina de soldadura entre os dois amplos setores oceânicos opostos pelo vértice (SILVA: 1967:93) (grifos nossos).

O autor retoma a tese dos hemiciclos e sua correspondente vigilância:

- (...) mas num raio bem mais avantajado (...) devemos impor-nos vigilante observação do que se processa em toda a fachada arqueada da Africa fronteira, em cuja preservação contra o domínio por forças imperialistas agressivas nos incumbe, por interesse próprio e ate por tradição, colaborar eficazmente, da forma que afinal se tornar mais conveniente (SILVA: 1967:93).

Nos estudos de Aspectos Geopolíticos do Brasil - 1960, Golbery, retoma os mesmos esquemas de apresentação da questão. Em "Perspectiva Geopolítica Brasileira”, vai apresentar "O Império Brasileiro"; "A moldura continental"; e "O mundo ameaçador e tumultuado de além mar".

Em o "Império Brasileiro", Golbery faz um amplo discurso caracterizando as varias regiões brasileiras, ora de modo objetivo e claro, ora de modo subjetivo. Assim ao invés de reproduzir o pensamento de Golbery a respeito de todo o Brasil, já exaustivamente contextuado aqui, iremos fazer uma analise do discurso do autor, sobre pontos que são significativos para esse trabalho.

Referindo-se a fronteira amazônica Golbery afirma:

\footnotetext{
${ }^{81}$ Refere-se a questão frente a Argentina.

${ }^{82}$ Significação como área de manobra para os EUA.
} 
(...) sucedem-se as "marcas" semidesertas, instáveis ainda, quase de todo abandonadas, abertas a penetrações de grupos sem bandeira definida e a correrias de nômades sem lei e onde, em torno de um arremedo de organização política pouco adequado e um rudimentar sistema de guarnições militares tão esparsas quanto débeis, se cristalizam nódulos de população ativa, desprevenidos inteiramente do grande, do enorme, do vital papel, que de fato lhes incumbe, e incumbirá por longo tempo, de colônias de povoamento pioneiro, mas, igualmente, de postos dinâmicos e agrestes de defesa. (SILVA: 1967:108-9) (grifos nossos)

Refere-se aos povos indígenas dessa forma, "penetrações de grupos sem bandeira definida e a correrias de nômades sem lei", o que revela assim, o pensamento das elites conservadoras. Essas elites não consideram essas populações culturalmente diferentes, portanto, "nações diferentes", que vivem num mesmo país, como povos que devem ser incluídos como parte da sociedade brasileira. Só caberiam, nessa lógica, se fossem integrados a sociedade nacional, perdendo assim sua cultura e suas terras, tornando-se então mão de obra desqualificada e barata, a serviço das classes dominantes. Como vimos antes, para a política territorial do Estado, ele quer uma sociedade homogênea, una, indivisível, uma única nação, uma nacionalidade determinada, a brasileira, preferencialmente branca, dedicada à causa da unidade nacional, visando manter assim a integração territorial. Tratando-se ainda de zona de fronteira é comum que os representantes das classes dominantes (Estado, burguesia e proprietários de terras) tentem a todo custo expulsar essas populações "para o lado de lá", desincumbindo-se de qualquer tratamento aos problemas comuns à essa população, fundamentalmente o reconhecimento das terras que ocupam. A questão fundiária é claro, é o maior nó de tensão entre as populações indígenas e as classes dominantes, dada a disputa por elas. Apesar de se referir neste parágrafo acima aos habitantes indígenas do norte, seu pensamento não seria diferente com os habitantes do sul, caso desta tese.

Com relação a região sul e Mato Grosso, justamente região densamente ocupada pelos Guarani, inclusive os de Oco’y, Golbery afirma:

Frentes pioneiras ativas conjugando-se espontaneamente, em amplas manobras de envolvimento para incorporação de fragmentos do deserto ainda próximo - no oeste de Santa Catarina e Paraná (...) no norte do Paraná com a onda avassaladora do café, na metade sul do Mato Grosso como natural prolação da própria expansão paulista para oeste (SILVA: 1967:109) (grifos nossos).

Já discutimos antes a diferença conceitual entre os termos "frente pioneira" e "frente de expansão”. Ou seja, no parágrafo anterior ele reconhece presença indígena, mas no seguinte, ao 
afirmar a existência de "frente pioneira... num deserto", subtende-se, "área que não existe qualquer população", portanto, não leva em consideração a existência dos indígenas na região, e, muito menos, seus direitos sobre as terras que ocupam, apesar das leis vigentes.

Sobre a situação dos transportes Golbery afirma sobre as grandes dificuldades que ainda nos anos 60 se apresentam:

Verdadeiras vias imperiais - estradas de rodagem, sobretudo, e rotas aéreas, a contrastarem com o ronceiro avanço ferroviário e o lamentável descaso para com inigualáveis eixos fluviais - mal ou bem implantadas, esboçadas apenas muitas como meros, mas sem duvida, significativos atos de afirmação e vontade mais do que realidades tangíveis e fecundas, buscam, a duras penas por certo, desde o núcleo central nitidamente delineado, para o sul, para o norte, para o oeste distante e o noroeste ainda mais longínquo, interligar o conjunto heterogêneo, bravio, ganglionar e imenso._(SILVA:1967:109).

Esta claro que o maior interesse na criação das vias de transporte são para interligar e atender a demanda econômica, o transporte de cargas. Assim veremos, no contexto aqui tratado, a criação e ou extensão de ferrovia e de rodovia, que irão ligar desde a Bolívia e o Paraguai, até os portos, respectivamente, de Santos e Paranaguá.

O autor discorre sobre a movimentação da população:

E, por sobre tudo isso, uma dinâmica migratória surpreendente e trepidante, a manifestar-se, já secularmente, em pulsações irregulares, segundo inconstantes direções das mais entrecruzadas e através de raios desmedidos, a atestar a ausência real de barreiras internas decisivas e a consolidar, mal ou bem, a própria unidade nacional pela aculturação incessante e niveladora e a miscigenação indiscriminada; (SILVA: 1967:109-10) (grifos nossos).

Portanto, os territórios ocupados pelos indígenas sequer são considerados barreiras; vê com certo pesar, carregado de preconceito, que a consolidação da unidade nacional vem se dando através da miscigenação e da aculturação, que nivela à todos. Como já vimos anteriormente ele considera os negros “inferiores” e os índios, sequer existem como população com direitos. Assim em seus textos, fica explicito, a consideração sobre a "superioridade da raça branca" e a preferência desta, sobre o país.

Quanto ao desenvolvimento econômico reconhece que:

Um desenvolvimento econômico e social, em ritmo, embora ainda inferior ao que seria desejável, dependente sem duvida, em muito, de contribuições maciças do exterior, mas que apresenta já, de 
fato, apreciável grau de autonomia em certas áreas progressistas de elevado índice de poupança, amplas economias externas, forte propensão para investir; e, demais, um indiscutível espírito imperialista, alerta e vigoroso. (SILVA: 1967:110) (grifos nossos)

Assim, a formação econômica e social capitalista do país, se deu com base em dependência externa, sobretudo dos EUA. Do conceito de país "subdesenvolvido" passamos a ser "dependentes". O antropólogo Rodolfo Stavenhagem em artigo denominado "Etnodesenvolvimento: Uma dimensão ignorada do pensamento desenvolvimentista" 83 discute esse contexto, o que ele denomina de "o destino mutável da teoria do desenvolvimento".

A palavra (termo, conceito) "desenvolvimento" por si mesma é cheia de implicações de valor das mais intensas, e, no entanto, até hoje, ninguém parece ter encontrado uma substituição adequada. "Desenvolvimento" significa mudança, evolução, crescimento, metamorfose. Mas devemos perguntar: desenvolvimento de onde para onde, e de que para que?; de pequeno a grande?; de atrasado a adiantado?; de simples a complexo?; de jovem a velho?; de estático a dinâmico?; de tradicional a moderno?; de pobre a rico?; de inferior a superior?; As questões são muitas e complexas e, no entanto, aceitamos o termo "desenvolvimento" como instrumento de trabalho da ciência social, realizamos estudos de desenvolvimento, e até praticamos "desenvolvimento" enquanto economistas e sociólogos do desenvolvimento, ou planejadores e agentes de desenvolvimento. Termos similares e também amplamente usados, não são menos problemáticos. Falamos de subdesenvolvimento, ou países em desenvolvimento (em relação a quê, ou a quem?).

As Nações Unidas dispõe de uma longa lista de países menos desenvolvidos, aos quais dedicam cuidado especial... e pouco mais do que isso. Vários cientistas sociais falam de "maldesenvolvimento" ou desenvolvimento "perverso", com a implicação de algum tipo de patologia que seria desviante de um tipo ideal de desenvolvimento válido e sadio que não estaria sendo observado. Assim, nossos valores implícitos já aparecem, mesmo antes de começarmos a discutir a questão do desenvolvimento.

Tais questões nunca foram colocadas tão claramente quanto durante as três décadas, do inicio dos anos 50 até fins dos anos 70, quando predominou, com algumas exceções notáveis, uma concepção linear evolucionista no pensar o desenvolvimento. O ponto de partida era o reconhecimento de que algumas regiões do mundo (na maior parte colônias ou ex-colônias das potencias europeias) eram “atrasadas" econômica, social, cultural, e, acrescentariam alguns, politicamente. O atraso, tal como era entendido na época, significava pobreza, fome, produto nacional baixo, baixa renda per capita, e, em geral, baixos padrões de vida para grandes parcelas da população. O remédio para o atraso

\footnotetext{
83 STAVENHAGEM, Rodolfo. Etnodesenvolvimento: Uma dimensão ignorada do pensamento desenvolvimentista. Anuário Antropológico 84. Rio de Janeiro: Tempo Brasileiro, 1985.
} 


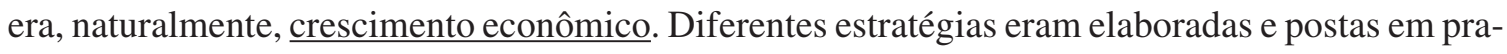
tica em diferentes contextos, visando acelerar o crescimento econômico. Algumas enfatizavam a necessidade de recursos naturais, outras sustentavam que o elemento chave era o capital, e outras ainda elegiam a tecnologia, ou a educação. Logo tornou-se claro que nem todos estes fatores juntos poderiam resolver o problema do atraso. Dizia-se, então, que o crescimento é uma questão de estágios pelos quais os países devem, necessariamente, passar e que, dificilmente podem ser pulados. Fez-se uma importante distinção entre crescimento econômico enquanto tal (aumento do produto nacional e da renda per capita) e desenvolvimento entendido numa perspectiva mais ampla e institucional. O desenvolvimento social e institucional tornou-se um componente importante. Na década de 60 a palavra chave era modernização.

Obviamente, encontramos aqui, diretamente, as premissas básicas de valor daqueles que, sejam cientistas sociais ou planejadores, lidam com as questões de desenvolvimento. O modelo implícito, ou, muitas vezes, explícito, da chamada sociedade moderna só poderia ser alcançado se os países em questão seguissem certas estratégias de mudança social e econômica. O modelo segundo o qual se esperava que os países subdesenvolvidos encontrassem seu próprio futuro vinha do mundo industrializado. O progresso através da escala de desenvolvimento era medido, julgado e avaliado por uma nova casta de especialistas internacionais. Os países eram classificados numa hierarquia de acordo com seu desempenho, como atletas numa pista, orientando a distribuição ou a suspensão dos recursos das agencias internacionais de financiamento e ajuda.

Pratica-se muito, nesse período, o exercício de identificar os chamados obstáculos a mudança: instituições sociais tradicionais, economia não monetária, ausência de espírito empreendedor, visão de mundo particularista e não universalista, e assim por diante. $\mathrm{O}$ crescimento e o desenvolvimento deveriam ser alcançados através da introdução de inovações e de uma mudança cultural

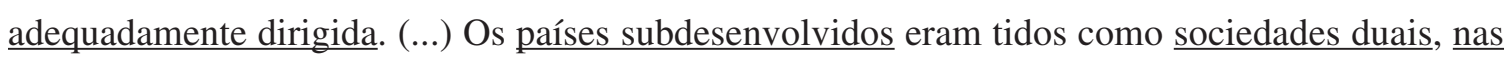
quais um setor moderno e progressista chocava-se com outro, tradicional e atrasado, e este ultimo deveria ser ultrapassado.

O fraco desempenho da maioria dos países subdesenvolvidos, $\underline{\text { o aumento da distancia entre pobres e }}$ $\underline{\text { ricos no mundo, }}$ a persistência e, de fato, o aumento da pobreza da massa no Terceiro Mundo tornaram claro, por volta dos anos 60 , que esta abordagem não produzia bons resultados. A critica às teorias sociais e conceitos subjacentes a esta orientação, por parte de cientistas sociais radicais, tornou-se cada vez mais intensa. Muitos especialistas começaram a perceber que o "subdesenvolvimento" não se deve tanto a ausência deste ou daquele fator, e que vários países subdesenvolvidos, tomados individualmente, não conseguiriam, por mais que se esforçassem, superar essa condição. Não se procurava mais as causas históricas do subdesenvolvimento, simplesmente nos contextos locais ou nacionais, mas sim no sistema econômico internacional vigente desde os tempos colo- 
niais. Passou-se a reconhecer que o subdesenvolvimento era resultante de certos tipos de relações econômicas estabelecidas entre o centro e a periferia. Estes novos conceitos, centro e a periferia (ou suas variantes como metrópole e satélite), tornaram-se objeto de analise e debate. Muitos cientistas sociais dedicaram-se ao estudo do sistema mundial e de seu impacto sobre diferentes regiões e nações, no quadro da agora chamada teoria da dependência.

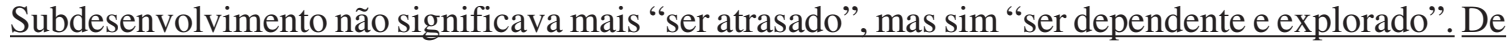
um conceito linear, transformou-se em um conceito relacional. Em termos metodológicos, pode-se dizer que houve uma mudança no paradigma: em contraste com o período anterior, começaram a ser colocadas outras questões, criados outros conceitos e outras respostas.

O debate logo passou dos círculos acadêmicos à arena pública. Na metade dos anos 70, o sistema das Nações Unidas tornou-se o fórum das reivindicações do Terceiro Mundo por uma nova ordem econômica internacional. Afirmava-se que o subdesenvolvimento só poderia ser combatido e alcançado o desenvolvimento, se ocorressem mudanças drásticas nos padrões de comercio internacional, nos preços das matérias primas e dos produtos industrializados, nos fluxos de capital e nas transferências de financiamento de tecnologia etc. Os países industriais eram agora apontados como responsáveis pela situação do Terceiro Mundo, e passaram a arcar com o ônus da mudança. Na verdade, nenhum país industrializado admitiu esta responsabilidade histórica, embora algumas vozes prudentes expressassem preocupação a respeito de suas implicações (por ex: o Relatório Brandt). Até agora, as assembleias especiais das Nações Unidas, o diálogo Norte-Sul, as várias tentativas fracassadas de negociações globais, não ofereceram resultados significativos. $\underline{\text { O sistema internacio- }}$ nal, pelo menos no que se refere às relações Norte-Sul, continua mais firme do que nunca, mesmo mergulhando numa crise cada vez mais profunda. (STAVENHAGEM: 1985:12-5)

Golbery observando o Sul do Brasil, aponta algumas características que mais lhe chamam a atenção, sobre a área foco de nosso estudo; as informações vão formando um mosaico de dados históricos, geográficos e políticos, sobre as quais, vamos tendo noção da compreensão do autor sobre a região, em termos de sua prioridade, a expansão do ecúmeno: (...) por Guarapuava até o vale do Iguaçu, seguindo o traçado muito batido de imemorável trilha dos indígenas (SILVA:1967:116); portanto, demonstra conhecer o traçado do Peabiru, praticamente único caminho existente até então, e, por decorrência, possui noção da presença dos Guarani. (...) elevado potencial hidrelétrico, seja bem junto a escarpa costeira, seja nos rápidos, corredeiras e saltos dos rios volumosos que demandam o sinclinal paranaense (SILVA: 1967:119); reconhece assim o potencial hidrelétrico do Oeste do Paraná. Se referindo à conflitos anteriores no sul, durante o século XVII, que formaram as históricas relações entre brasileiros e argentinos, afirma: A presença ativa dos castelhanos ao sul, os problemas que se agravam, de Sacramento e do Continente de 
São Pedro ${ }^{84}$ - esse novo teatro de operações que se inaugurava - atraíam também fortemente os interesses da metrópole (SILVA: 1967: 120); Ainda sobre à época colonial, demonstra a tímida possibilidade de expansão de São Paulo para o Paraná: A expansão natural de São Paulo, orientada segundo as grandes linhas de penetração que o território oferecia, não levaria mais que a Curitiba e Paranaguá, como já tivemos oportunidade de ver (SILVA: 1967:120); Demonstra o autor, no final do século XIX, inicio do XX, como se deu a expansão do ecúmeno nessa região:

Seria, na verdade, o surto cafeeiro, responsável por toda uma apreciável infraestrutura de transporte e de disponibilidade de capitais para outros investimentos, o que condicionaria, bem mais tarde, a implantação de um parque industrial poderoso, a mola real do avanço povoador para o interior do estado de São Paulo, processado há cerca de meio século (...) do espraiamento final, em ambas as alas, no Espírito Santo e Paraná. (SILVA: 1967:121-2) (...) Enquanto isso, no Sul como no Nordeste, os núcleos de povoamento mais densos situam-se ainda, em grande parte, na periferia das grandes massas continentais (...) (SILVA: 1967:123).

Preocupado em ocupar a zona de soldadura do centro-oeste, o autor afirma: O segundo heartland interior é todo ele ainda um desertão incógnito, exceção do pequeno avanço que se faz sentir logo ao norte de Cuiabá (SILVA: 1967:123).

Quanto ao núcleo central vê com satisfação sua condensação e alargamento:

Passados quatro séculos e meio de nossa historia, somente o heartland central, portanto, vai atingindo, em pleno, o seu destino geopolítico de vasta área de condensação ecumênica, centro de propulsão econômica, encruzilhada complexa de caminhos, nó de amarração natural de todo o bloco continental, plataforma essencial ao futuro expansionismo para o interior. Aí, se vai, ultimando, assim, aquela coincidência fundamental dos espaços físico, demográfico, econômico e político que ancora o poder no centro de base compacta, possibilitando-lhe atuar dinamicamente e em potencia. (SILVA: 1967:123).

Quanto a hinterlandia do Sul, vê com pesar, muito atrasada, frisando a desvitalização do uso fluvial, as fracas ligações rodoviárias e ferroviárias:

O bloco do Sul, em fase muito mais retardada, nem mesmo se articula ainda, solida e seguramente, ao heartland central, justamente pela debilidade de sua própria ocupação interior. Mantêm, assim, a primazia as ligações periféricas e estas mesmas, da banda do Oriente, dado o atraso - talvez dir-se-

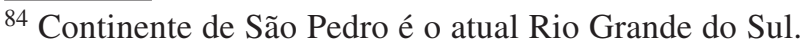


ia melhor até retrocesso - da vitalização das grandes linhas fluviais do interior, o Paraná, o Paraguai $\underline{\text { e o Uruguai. Fracos liames rodoviários e ferroviários, inadequados e até inseguros, através de angustos }}$ istmos de circulação ainda precária e irregular, tornam-nos meras penínsulas mal evoluídas ainda de seu inicial status insular. (SILVA: 1967:123-4).

Conclui por fim que quase nada mudou de 1950 para 1960, em termos de avanço do ecúmeno: Ao esboçar, anos faz, um panorama geopolítico do Brasil, à vista de um mapa demográfico com o traçado das isaritmas de 1, de 5, de 23 habitantes por Km2, distinguíramos já (esquema 5) a mesma estrutura geral de uma cunha avançando para o interior, assinaladas, em torno de um núcleo central, propriamente ecumênico, as três penínsulas do Sul, Nordeste e Centro-Oeste e, bem mais para além, a vasta e despovoada ilha da Amazônia. Essa é uma pintura demográfica, o quadro ecumênico de 1950, possivelmente não modificado ainda hoje em seus contornos mais essenciais. (SILVA: 1967:124).

Golbery vislumbra a ação geopolítica para o Brasil, fundamentalmente demarcando os limites políticos entre os Estados do Brasil e da América espanhola:

Com vistas à própria ação estratégica ou geopolítica, e considerando, portanto, o necessário reajustamento de minúcias que leve na devida conta o traçado dos limites políticos entre Estados, isto é, a organização administrativa do território e busque a coincidência, na linha da fronteira, com os marcos da compartimentação internacional da America espanhola - realidades políticas, umas e outras, que se não poderiam de forma alguma subalternizar, pois, no quadro das mesmas, é que se terá de desenvolver aquela ação - resulta a mesma delimitação objetiva das áreas geopolíticas brasileiras a que tivemos a oportunidade de nos referir em estudo antecedente (esquema 29): (SILVA: 1967:125-6)

Em resumo, o autor vislumbra as aproximações necessárias e possíveis à época, do estender do ecúmeno, da seguinte forma:

- uma área geopolítica de reserva geral ou de manobra central - São Paulo, Rio de Janeiro e Guanabara, Espírito Santo, Minas Gerais e o sul de Goiás, com o Distrito Federal - estruturada politicamente sobre o próprio heartland central, projeção natural, em dias próximos, do atual núcleo central ecumênico, e onde "o triangulo de potencia, que já se vai alargando firmemente para o quadrilátero tão bem dotado de SP - Rio - Vitoria - BH, acabará por estirar-se ainda mais a noroeste para fincar seu vértice interior na região de Brasília, possibilitando a articulação que faltava, com a atual ilha amazônica, ao longo do rio Tocantins e do traçado paralelo da BR-14 (atual BR153 - Belém - Brasília)"; 


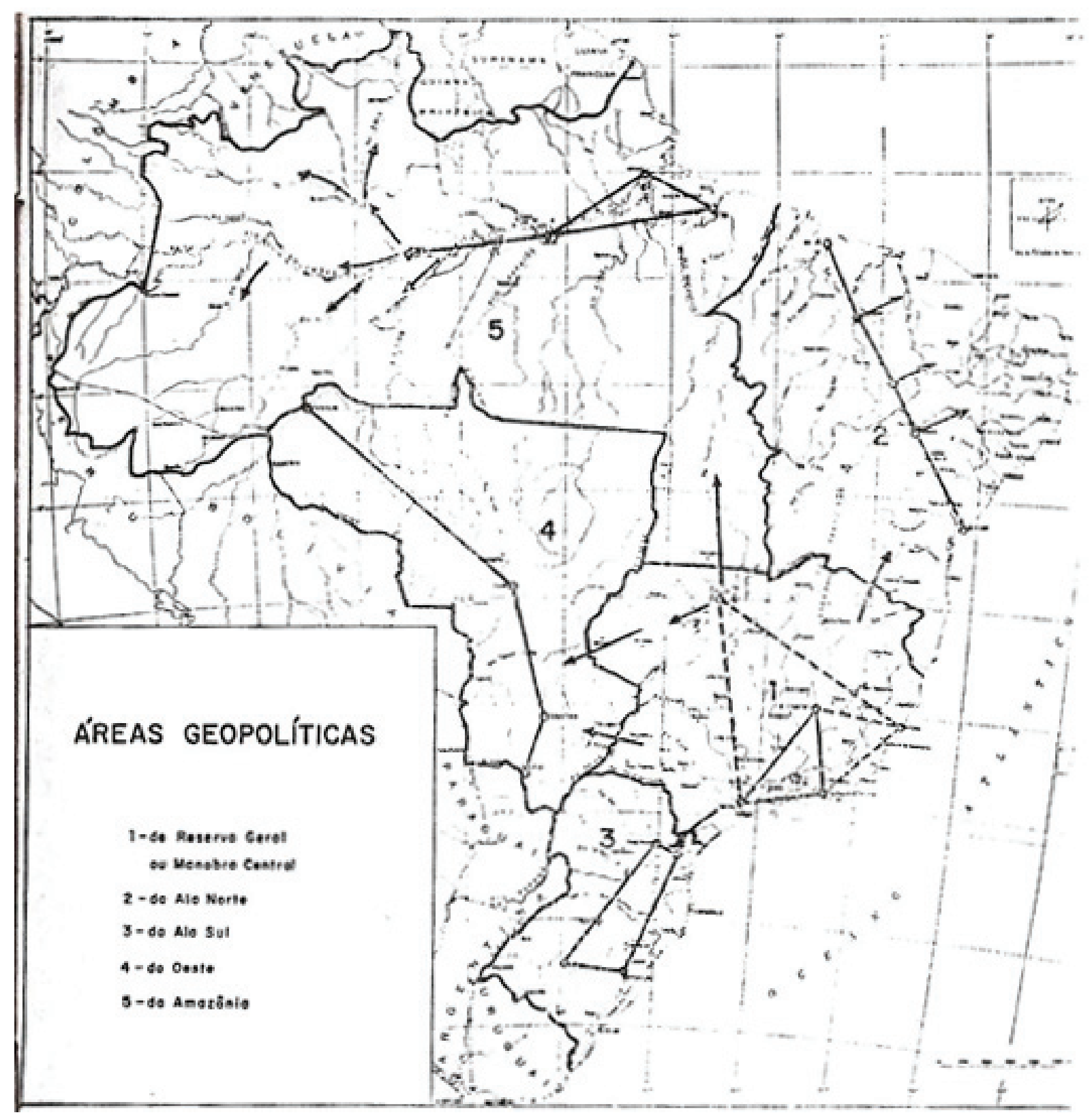

Figura 90. Áreas Geopolíticas

Fonte: Golbery do Couto e Silva. Geopolítica do Brasil. Esquema 29, p. 125.

- uma área geopolítica da área Norte, abarcando todos os Estados do Grande Nordeste, desde a Bahia inclusive ao Maranhão, e aglutinando, assim, ao escudo nordestino todo o seu pontão baiano do sul, por simples distensão da atual península do Nordeste, tudo "de modo a poder consolidar-se naturalmente a sua esplendida base diagonal de Salvador a São Luis, por Juazeiro, Petrolina, Picos e Teresina, e objetivar-se a revitalização do tradicional meridiano fluvial do São Francisco - Rio Preto - Parnaguá - Rio Gurgueia - Parnaíba - Itapicuru. E o mero istmo de circulação balizado pela BR-4 (atual BR-116 Rio-Bahia) e o TPN, de incidência deseixada para o extremo sudeste da área, poderá evoluir francamente para a ampla faixa de soldadura da divisa mineira"; 
- uma área geopolítica da área Sul - Paraná, Santa Catarina e Rio Grande - ancorada no núcleo maciço de terras entre o Paranapanema e o Jacuí-Ibicuí, por ampliação espontânea da península ecumênica do Sul, a qual, assim, "ganhará apenas maior organicidade em derredor do quadrilátero de articulação básica, demarcado por Curitiba - Porto Alegre - Santa Maria - e Irati”;

- uma área geopolítica do Oeste, reajustada aos contornos do Mato Grosso mais o território do Guaporé (Rondônia) e incorporando, portanto, quase todo o segundo heartland do interior, além de grande parte da amputada península atual do Centro-Oeste, isso tudo de forma a reorientar-se de

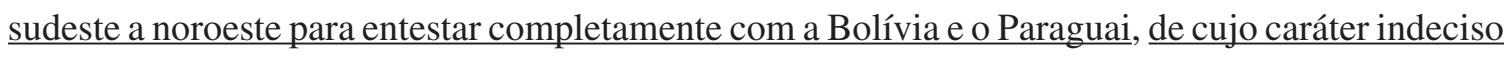
e ambivalente participa também, a cavaleiro das duas grandes bacias hidrográficas do Amazonas e do Prata. Cuiabá no próprio paralelo de equipotência das atrações do Norte e do Sul, está fadada a $\underline{\text { ser o grande centro de articulação de toda a área, cuja potencial base de circunvalação fronteiriça, de }}$ Porto Velho a Campo Grande e Ponta Porã - a BR-29 (atual BR-364) em construção, prolongada de Cuiabá para o sul por Rondonópolis e Coxim (BR-31 e BR-16 atualmente BR-163 e BR-463). "acabará se tornando uma realidade concreta na soldadura mais avançada entre o Brasil amazônico e o Brasil Platino";

- finalmente uma área geopolítica da Amazônia - Amazonas, Pará e os Territórios do Acre, Amapá e Rio Branco (hoje Roraima) - o que restará da ilha original e amplíssima do esquema ecumênico, com os dois nódulos gêmeos de terras maciças da região guaianense e uma parte ainda do segundo heartland interior, a cavaleiro de um e outro lado do geossinclinal este-oeste; área geopolítica que, por muitos e muitos anos, “continuará (...) eixada segundo o leito do rio formidável, onde Manaus permanecerá o fulcro do sistema, por mais que se articule, adense e vitalize o vasto estuário, no triangulo Belém - Amapá - Santarém.” (SILVA:1967:126-7)

Quanto à moldura continental em 1960, tendo em mente a compartimentação geopolítica de toda a America do Sul (esquema 20 de Golbery), Golbery assim vê:

- (...) a área geopolítica nuclear do Brasil evidentemente mantém, em toda a sua plenitude, o mesmo papel capital de zona de reserva geral ou plataforma central de manobra.

- A noroeste, uma área geopolítica continental da Amazônia americana, caracterizada pela bacia imensa do grande rio (Amazonas), (...), e emoldurada a oeste pelos arcos imponentes dos Andes, ao norte pelo escudo guianense, amplia nada mais que a área geopolítica da Amazônia Brasileira, englobando, assim, a Grã Colômbia, enquadrada, em seus extremos, pelo Peru e as Guianas.

Ao sul, uma área geopolítica continental platino-patagônica prolonga a área geopolítica do Brasil meridional, através do Uruguai e do território argentino, até o estirado anteparo abrupto dos Andes chilenos que incorpora também a si. 
E, entre as duas, indecisa entre as atrações provindas das duas grandes bacias dinâmicas do Amazonas e do Prata, nítida área geopolítica continental de soldadura, abarca a área geopolítica brasileira do Mato Grosso e do Guaporé (Rondonia), englobada também nesta o Paraguai e a Bolívia. Na primeira entrecruzam-se: de leste a oeste, o antagonismo tanta vezes apontado entre o Pacifico e o Atlântico, preponderando largamente a influencia deste ultimo, graças a penetração profunda e quase onipresente do portentoso caudal, em face da dinâmica ainda pobre que se esboça através dos pasos e dos nudos andinos; e, do norte para o sul, a oposição continental-marítima entre a influencia do golfão do Caribe, francamente permeável a vigorosa pressão exterior da America do Norte, e a atração do coração do continente. Fraca por si mesma, dado o intenso trabalho dissociador que neste, de todos os quadrantes, se produz, e a falta de potencial demográfico e econômico, esta ultima força arregimenta, entretanto, em seu favor a densidade muito superior e a maior penetração dos afluentes meridionais do Amazonas e mesmo, através da própria instabilidade natural da área de soldadura, incorpora ainda algo do dinamismo platino que pulsa bem mais ao sul. Ante a influência que vem do hemisfério norte, mais distante, a Grã-Colombia e, em menor grau as Guianas desempenham, como já foi assinalado, o papel geopolítico de enormes estados-tampões. Mas o que mais importa, é que, num caso, a atração atlântica, no outro, a influencia continental são favoráveis ao Brasil. $\mathrm{Na}$ segunda área, platino-patagônica, continua ainda a manifestar-se a oposição, onipresente em toda a America, entre o Pacifico e o Atlântico, com indiscutível predominância para este em toda a seção setentrional, dada a potente força atrativa integradora do Prata. Como se exerce, também, de norte a sul, um antagonismo continental-marítimo em moldes semelhantes ao que permeia a Amazônia, contrabalançando-se aqui, porém, a maior proximidade e o dinamismo efetivo do Prata, com a presença também, mais imediata e superiormente localizada, do núcleo central brasileiro. E este nunca atuará isoladamente, pois estará sempre em condições de apoiar e coordenar ações convergentes, graças a participação ponderável do Brasil, em espaço senão em termos demográficos, ainda, na própria área de soldadura que fica ao norte.

É, nesta afinal, que se refletem, a fundo, como se vê, todos esses antagonismos e oposições dos mais distintos quadrantes e de natureza vaária, a tal ponto que a solidez dessa área capital sobreleva de importância, estratégica, como verdadeiro penhor da própria estabilidade continental. Nem de admirar seria que, em geopolítica, o compartimento mais instável, justo por sê-lo assim, possa vir a tornar-se mesmo o garante de toda a estabilidade na área maior circunjacente. E, pois, a presença brasileira na área de soldadura continental, sendo - não há duvida alguma - um trunfo de valor sem igual, traduz uma responsabilidade que nunca poderemos esquecer nem sequer menosprezar.

Resta ainda por situar a área geopolítica do nordeste brasileiro, neste conjunto de toda a America Latina, para o qual continua a desempenhar, como para o Brasil, em escala apenas diferente, o 
mesmo papel sensível de bastião avançado de defesa contra as ações extra-continentais provindas do Atlântico ou de mais além, senão o de essencial plataforma de projeção para oriente. E sua importância queda melhor ressaltada se o caracterizarmos, muito de justiça, como área também de soldadura entre as duas grandes áreas geopolíticas ou estratégicas do Atlântico Sul e do Atlântico Norte (SILVA: 1967:127-8-9) (grifos nossos).

Em “O Mundo de além-mar” de 1960, ainda muito presente no imaginário de Golbery um possível ataque soviético, ele desenvolve a tese dos hemiciclos interior e exterior, visando se precaver de possíveis futuras investidas:

Ressaltemos pois, a imagem centrada no próprio coração de nossa America do Sul, em dois hemiciclos de terras que nos defrontam:

- o hemiciclo interior, a uma raio médio de $10.000 \mathrm{~km}$ de vai desde a Ilha norte-americana, potente, sobretudo na sua ampla borda do oriente até a Antartida, deserta e glacial, ao sul, passando, pelo ao largo, pelo continente intranquilo da África, semipovoada e retardada;

- e o hemiciclo exterior balizando, a grosso modo, por um arco de $15.000 \mathrm{~km}$ de raio e onde avulta a Eurásia, tentacular e envolvente, com densas massas de população concentradas de uma e outra banda de um quase deserto intermédio, com seus fulcros formidáveis de poder, atual ou apenas potencial escalonados desde a península avançada da Europa Ocidental até o coração do Império Soviético e, mais além, ao Japão ultradenso, a espantosa imensidade da China, a mole e compacta da Índia, ao arco insular estirado na Indonésia, pululante de uma humanidade sofredora e irrequieta. A Austrália progressista, entre Nova Guiné e Nova Zelandia, demarca o extremo, para lá do polo sul, desse colossal hemiciclo exterior que, em sua frente central, chega a morder quase o arco interior, flaqueando o costado setentrional da África. (SILVA: 1967:129-30)

Do hemiciclo exterior o autor teme o ataque comunista, do hemiciclo interior ele o considera a fronteira de segurança da America do Sul:

Se algo de positivo nos ensina a historia de séculos, é que esse hemiciclo exterior constitui, para a America do Sul, o hemiciclo perigoso, de onde lhe tem advindo, época trás época, as ameaças, mais graves, mais duradouras, continuadas e potentes. Enquanto isso, o hemiciclo interior, sobretudo nessa nossa era agigantada de ampliadíssimo raio de ação geopolítico e estratégico que não respeita nem oceanos nem quaisquer massas continentais, avulta no dispositivo geral, como fronteira decisiva da segurança sul-americana.

Coberta, na ala norte, pelo escudo da America do Norte e o arco antilhano adjacente e, no flanco sul, pelo bastião inóspito da Antártida; com a África maciça em sua primeira linha capital de defesa; 
barradas as duas entradas atlânticas pelo complexo insular dos Açores, das Canárias e do Cabo Verde, ao norte, e pelas ilhas esparsas que dominam as saídas do Indico, ao sul; dispondo de uma favorável longitudinal intermediaria ao longo do Atlântico Sul, desde a ascensão a Ilha Bouvet e ao arquipélago das Sanduiches do Sul; protegida, a oeste, pela vastidão do Pacifico onde mergulha, de chofre, a formidável dos Andes - a fortaleza sul-americana é de si mesma um conjunto estratégico $\underline{\text { natural bem equilibrado e disposto. O que se impõe é estruturá-lo solidamente, assegurando uma }}$ articulação firme entre as suas diversas massas componentes, cada uma destas tornadas invulneráveis a toda espécie de ataques sub-reptícios ou diretos.

Golbery mais uma vez avalia a situação mundial sob o prisma de aliado do Ocidente, que ele qualifica como "democrático e cristão".

Situando, nesta perspectiva geral e, por assim dizer, subjacente e algo mais permanente do mundo, tal como visto desde o Brasil e, pois, da America do Sul, o quadro do atual antagonismo dominante entre o Ocidente democrata e cristão e o Oriente comunizado e materialista podemos distinguir e qualificar, além dos dois grandes centros de poder que cristalizam em seu derredor os dois blocos em contenda (esquema 19).

- um cinturão de verdadeiras áreas-esplanadas, na vasta fronteira do domínio soviético, traduzindo a estratégia dos espaços periféricos propugnada por Spykman, áreas essas em diferentes estágios de integração como bastiões avançados da defesa Ocidental da OTAN, e da OTASE e do CENTO ou em grau variável de instabilidade - o Oriente Médio, o Sudeste Asiático, sobretudo caminho estes muito mais favoráveis a uma progressão, seja pela força, seja, mais provavelmente, pela infiltração insidiosa e mascarada, da ideologia e do poder comunista;

- e, bem mais atrás, constituindo um triangulo que circunda e protege o vasto lago interior do Atlântico Sul, chave das comunicações marítimas mais seguras a serviço do ocidente, três áreas

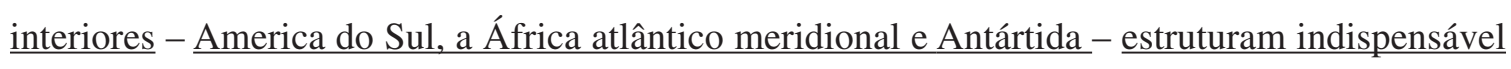
placa giratória de manobra para qualquer estratégia decisiva de contenção ou contra-ataque, em ampla escala, em face do expansionismo sino-moscovita. (SILVA: 1967:130-31)

Por fim as "Diretrizes Geopolíticas" do autor em 1960. "O Brasil e sua hinterlândia"; "O Brasil no arquipélago sul-americano"; e, "O Brasil em pleno mundo".

O Brasil e sua hinterlandia:

Com vistas à humanização, integração e valorização do território imenso, ainda em grande parte inaproveitado e deserto (...):

$1^{\mathrm{a}}$. Articular firmemente a base ecumênica de nossa projeção continental, ligando o Nordeste e o Sul 
ao núcleo central do país; ao mesmo passo que garantir a inviolabilidade da vasta extensão despovoada do interior pelo tamponamento eficaz das possíveis vias de penetração;

$2^{\mathrm{a}}$. Impulsionar o avanço para noroeste da onda colonizadora, a partir da plataforma central, - a atual região nuclear do país - de modo a integrar a península centro-oeste no todo ecumênico brasileiro; $3^{\mathrm{a}}$. Inundar de civilização a Hileia amazônica, a coberto dos nódulos fronteiriços, partindo de uma base avançada constituída no Centro-Oeste, em ação coordenada com a progressão E-O, segundo o eixo do grande rio. (SILVA: 1967:131-2)

Acrescenta algumas medidas para cada uma das fases.

Quanto a $1^{\mathrm{a}}$ fase ele indica o tamponamento a noroeste e oeste do país, o travamento de norte a sul por meio de ligações rodoviárias e ferroviárias e o aproveitamento da navegabilidade fluvial e marítima:

- (...) o tamponamento a realizar-se sem tardança, ao largo de toda a fronteira desde o corte do Paraná ao território do Amapá, medida de segurança, indispensável e pendente para que se possa levar a cabo, metodicamente, o conjunto ordenado da manobra - consistirá sobretudo:

- no travamento solido do núcleo sulino e, através do pontão da Bahia, do escudo do Nordeste, ambos ao hinterland central, o que importa, principalmente, no estabelecimento de ligações rodoviárias e ferroviárias de elevado rendimento, utilizáveis sob quaisquer condições de tempo, suficientemente resguardadas e oferecendo a possibilidade de alternativas para o caso de emergências; $\mathrm{e}$

- na incorporação desde logo, a esse sistema de circulação, do espaço pericontinental e fluvial e marítimo, ou seja, a revitalização de nossa abandonada navegação de cabotagem lada, portos assoreados, organização portuária ineficiente e caótica sob o signo das reivindicações irresponsáveis, até de caráter político e nitidamente subversivos, e de lamentáveis medidas pedagógicas - seja o inestimável aproveitamento da navegabilidade natural dos muitos rios favoráveis, passadeiras rolantes que aí jazem por incúria toda nossa, completamente relegadas como se até inexistentes, mesmo quando tenham visto outrora breves períodos de salutar florescimento (SILVA: 1967:132).

Assim a ocupação e a integração das partes do território, em termos da movimentação que gera, o valoriza também enquanto medida de defesa.

Quanto a $2^{\text {a }}$ fase ele indica que deve o Brasil em tendo se assenhorado do núcleo central impulsionar o povoamento para o centro-oeste por meio de circulação rodoviária, ferroviária e fluvial: 
A $2^{\mathrm{a}}$ fase corresponderá ao assenhoreamento, pela ocupação efetiva e o desenvolvimento econômico, de todo o hinterland central, impulsionando-se a onda de povoamento, desde o núcleo atual, decisivamente ao interior; e isso compreenderá:

- de um lado a ultimação de uma adequada articulação interna, pela circulação tanto rodoferroviária como também fluvial, não esquecido de forma alguma o papel extraordinário que poderão desempenhar, com algumas adaptações, transversais do Tiete - Paraíba e do Rio Grande - Alto São Francisco; e

- de outro lado a incorporação, também, da periferia circulatória do segundo cinturão interior onde ressalta o papel integrador do Paraguai e seus maiores afluentes, do Tocantins e do Araguaia (SILVA: 1967:132-3).

Quanto a $3^{\text {a }}$ fase ele indica, em tendo vitalizado o centro-oeste, povoar para noroeste, e a seguir a partir de Manaus para o sul, aproveitando-se dos cursos d'água:

A $3^{\text {a }}$ fase, de conquista da Amazonia, exigirá que se tome pé firme no segundo heartland do interior, para a concretização do grande esquema de manobra, concêntrico em todo um largo e importante primeiro tempo, e a seguir divergente a partir do polo capital de Manaus. A valia inigualável dos cursos de água nem precisa ai ser ressaltada, desde o Guaporé, demarcando lateralmente a fronteira, até os múltiplos afluentes penetrantes do Amazonas. A Transacreana (BR-29 hoje BR-364) antevista por Euclides da Cunha, merece aqui especial referencia, não seja acaso possível considerá-la como elemento essencial do próprio tamponamento inicial da fronteira (SILVA: 1967:133-4).

Quanto ao tema “O Brasil no arquipélago sul-americano" em resumo, Golbery indica:

- quanto a possíveis antagonismos entre Estados, o Brasil deve intervir para prevenir, limitar ou abrandar, fazer cessar com o objetivo de assegurar a paz, a unidade continental e manter o status quo; - não ao revisionismo de fronteiras;

- a manobra de integração territorial delineada: a) peso superior incorporado a nossa área de manobra central; b) participação brasileira muito mais efetiva na área vital e decisiva da soldadura continental cuja instabilidade natural sempre poderá constituir um perigo a exigir pronto remédio;

- tamponamento do extenso arco fronteiriço a noroeste;

- sólida articulação entre o Nordeste, o heartland central e o núcleo sulino;

- participação eficaz no desenvolvimento conjunto desta vasta America do Sul, dado que o Brasil é integrante com parcela significativa de território e de população, de todas as áreas geopolíticas do continente; 
- vitalização dos rios navegáveis de toda a faixa fronteiriça, fazendo-se o Brasil não só presente mas assíduo;

- ligações aéreas e marítimas entre os principais centros populosos dos países sul-americanos;

- mercado comum dará maior unidade continental e um desenvolvimento econômico mais acelerado e coerente exige base física de sistema adequado de circulação em toda a America do Sul (SILVA: 1967:134-5).

Por fim quanto a visão sobre "O Brasil em pleno mundo" em resumo, Golbery enxerga como maior ameaça de todas, um possível ataque soviético, comunista:

- proveniente do hemiciclo exterior, ameaças graves e armas terrificantes: desde a sutil propaganda ideológica até modernos engenhos termonucleares, capaz de inaugurar a guerra intercontinental; daí a vulnerabilidade do Brasil na faixa litorânea: os mais populosos centros do país; principais núcleos industriais; mais importantes eixos de circulação rodoviária e ferroviária;

- Nordeste, posição dominante em relação ao estrangulamento Natal e Dacar, grande significação estratégica;

- Atlântico Sul, dificilmente interdito à penetração de submarinos atômicos dotados de engenhos nucleares de longo alcance, perde cada vez mais em real significação como fosso protetor de nosso centro de potencia;

- Numa primeira fase, porém, de uma guerra geral desencadeada entre o Ocidente e o Oriente, os ataques de intimidação ou de represália a que podemos ser submetidos - e por mais destruidores e tremendos que venham a ser - nunca deixarão de ser esporádicos, intermitentes, localizados por certo e de curta duração. Somente o domínio, pelos soviéticos, de importantes bases no litoral fronteiriço da África permitir-lhes-á atuar decisivamente, em continuidade e potencias combinadas, contra algum ponto do território brasileiro. E, portanto, na grande batalha de manutenção da invulnerabilidade de toda essa África atlântico-meridional a penetrações e, sobretudo, à radicação aí do poder soviético, jogar-se-á afinal o próprio destino do Brasil.

O hemiciclo interior (...) constitui para o continente sul-americano, a fronteira decisiva de sua segurança. Assim também (...) a borda do Atlântico.

Ora, de toda essa dilatada fronteira, a África vem a ser, por sua própria posição estratégica entre os dois blocos antagônicos, pelas vias de acesso naturais que a ela conduzem, pela instabilidade em que se debate, a porção mais vulnerável e, ao mesmo tempo, mais valiosa - mais cobiçada, portanto. A Antártida, na quadra atual, é ainda um vasto deserto excêntrico; a America do Norte, inclusive o México, o centro poderoso de todo o sistema defensivo do Ocidente, o ponto forte decisivo, a cidadela difícil de abordar e de reduzir e que, tudo o indica, muito mais valerá desbordar, levá-la aos poucos ao isolamento, à asfixia e ao acerco, antes de qualquer imprudente investida direta. 
Mesmo com relação à fachada atlântica da plataforma africana, muito distante ainda da periferia do mundo comunista, mal ou bem contido êste, demais, pela cercadura de bastiões avançados da defesa ocidental, a estratégia da aproximação indireta, (...), será sem duvida alguma, a mais rendosa, de efeitos mais imediatos e, além disso, muito menos perigosa. Relegada a ação militar ostensiva ao plano meramente secundário das ameaças e das ostentações de prestigio e de força, todo o amplo e variado espectro das táticas sutis de infiltração, do terrorismo, da guerrilha, da propaganda ideológica que compõem esse complexo moderno da guerra insurrecional ou subversiva, oferece perspec$\underline{\text { tivas muito mais promissoras de êxito, }}$ sobretudo onde já se manifestem tensões sociais das mais graves e se eternize um padrão intolerável de vida, tal como o demonstraram, na pratica, Mao Tse Tung e Ho Chi Min.

Eis por que não estará a America Latina, ela própria afinal, imune a ataques solertes desse tipo, tanto mais de temer quanto mais perdurem a estagnação econômica, a corrupção, a miséria, a ignorância e a fome.

Combater o subdesenvolvimento nas áreas nacionais retardadas e no restante do continente, coope-

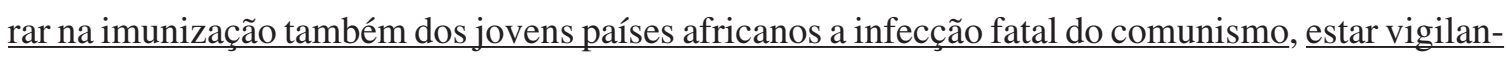
te e atento a qualquer progressão soviética na direção dessa África atlântica onde se situa a fronteira avançada e decisiva da própria segurança nacional, colaborar por todos os meios em mantê-la total$\underline{\text { mente livre do domínio comunista - eis aí, mais ou menos, bem delineadas, numa tentativa de ordem }}$ de prioridade decrescente, as diretrizes principais que nos afiguram em declináveis, de uma geopolítica brasileira adequada a atual época agitada e cataclísmica, ante um mundo que se debate e agoniza no mais brutal encontro de civilizações antagonistas (SILVA: 1967:136-7).

Quando Cuba se alinha a URSS, daí se entende melhor, após os golpes de Estado acontecidos na America Latina, as razões da reação repressora, com relação ás esquerdas constituídas. O temor que as elites conservadoras têm da possibilidade de se abolir a propriedade privada dos meios de produção, desmoronaria todo o sistema capitalista, esse é o fulcro do antagonismo, a possibilidade de lucros exorbitantes por uma classe em detrimento da outra. Daí também toda a propaganda ideológica para a manutenção desse sistema econômico.

Por fim, Golbery tece algumas conclusões sobre as características dominantes de uma geopolítica brasileira:

A geopolítica para os três campos sucessivamente mais amplos - o interno, o continental e o mundial -, condicionada muito perto pelos contornos dominantes da conjuntura atual, caracteriza-se como geopolítica de:

- integração e valorização espaciais; 
- expansionismo para o interior e, também de projeção pacifica no exterior;

- contenção, ao longo das linhas fronteiriças;

- participação na defesa da Civilização Ocidental que também é a nossa;

- colaboração continental;

- colaboração com o mundo subdesenvolvido de aquém e além mar;

- segurança ou geoestratégia nacional, em face da dinâmica própria dos grandes centros externos de poder ( SILVA: 1967:137-8).

\subsubsection{As ditaduras militares e o modelo econômico desenvolvimentista implantado na América Latina}

Vimos assim o discurso "oficial” de Golbery do Couto e Silva. Nele, está camuflado todo aparato repressivo que viria a ser instalado no país, no período subsequente. A historiadora Camila Nehring Belo em artigo denominado "Supremacia Regional no Cone Sul: A Usina de Itaipu como instrumento da luta diplomática entre Brasil e Argentina na década de 70"85 introduz a cena do contexto político da época na America Latina. Mais à frente iremos utilizar do desenvolvimento de seu trabalho, para explicar o contexto das negociações entre Brasil e Argentina, quanto a construção da hidrelétrica de Itaipu e os conflitos existentes na Bacia Platina. Por ora vejamos a introdução do trabalho da historiadora.

Este artigo tem por objetivo tratar de alguns aspectos que nortearam as relações internacionais na região do Cone Sul no decorrer da década de 1970, mais precisamente a disputa diplomática entre a Argentina e o Brasil pela supremacia regional e o papel da usina de Itaipu nesse processo.

Para que tal objetivo seja alcançado, temos que primeiramente compreender quais eram os contextos internacionais político e econômico desde o início da década de 1960, quando a peculiar situação criada com a revolução cubana delineou um novo cenário continental, onde as relações se tornaram extremamente conflitivas, substancialmente após o alinhamento de Cuba ao bloco soviético. Nesse sentido, quando redirecionou sua política exterior, Fidel Castro criou um grande problema para o Pentágono e para o Departamento de Estado norte-americano, conforme afirmam Amado Luiz Cervo e Mario Rapoport no livro História do Cone Sul.

\footnotetext{
85 BELO, Camila Nehring. Supremacia Regional no Cone Sul: A Usina de Itaipu como instrumento da luta diplomática entre Brasil e Argentina na década de 70. Pós-graduação em Historia/PPGH. Dourados: Universidade Federal da Grande Dourados/UFGD. Obtido em www.pph.uem.br/cih/anais/trabalhos/373.pdf. Pesquisado em fevereiro de 2013.
} 
Assim, em contra partida ao alinhamento cubano ao bloco soviético e à expansão do comunismo na América Latina, o "Presidente norte-americano Jonh F. Kennedy (1961-1963) lançou a Aliança para o Progresso (ALPRO), que nada mais era do que um conjunto de programas econômicos e sociais destinados aos países latino-americanos e financiados pelos Estados Unidos.” (CERVO e RAPORT,1998, p.278). Não esquecendo que para além das questões econômicas e sociais os governos estadunidenses investiram maciçamente em intervenções militares nessa região. Um exemplo foi o episodio da invasão de Cuba por forças contrarevolucionárias, formadas segundo Voltaire Schilling, “[...] por integrantes da ditadura de Batista exilados em Miami, na Flórida" (1991, p.48) que foram treinados em campos da CIA. O conflito se estendeu ao ponto de aviões B-16 bombardearem a cidade de Havana. Além de medidas como a fundação no ano de $1961^{86}$ da School of the Americas, no Forte Gulick, na Zona do Canal do Panamá.

Neste contexto, a prioridade norte-americana, em impedir a expansão do comunismo, se estendeu a uma política de interiorização do seu combate nos países sul-americanos. Essa política objetivava o apoio, tanto militar quanto financeiro, a golpes militares de direita. Nesse sentido, os exemplos mais expressivos são os golpes civil-militares no Brasil, que foram encabeçados pelo General Humberto de Alencar Castelo Branco, deflagrados no ano de 1964 e, na Argentina, pelo General Juan Carlos Onganía em junho de 1966. Essas intervenções na região possibilitaram a abertura de um novo jogo político e diplomático: a busca pelo status de satélite norte-americano no Cone Sul, lembrando que tais intervenções já existiam, o que mudou foi a natureza pelas quais eram justificadas. Nesse sentido, Schilling afirma que "na América Latina, entre 1964 a 1978, apenas a Colômbia e a Venezuela permaneceram com regimes constitucionais" (1991, p. 59).

Assim, Amado Luiz Cervo afirma no Livro Relações Internacionais da América Latina que, Cuba prosseguia sendo uma das ocupações das diplomacias americanas durante a década de 1960 [...]. Não, havia, contudo, uniformidade de ação e de pensamento entre as chancelarias do continente para enfrentar o desafio de esquerda. $\underline{\text { A intromissão desenfreada da guerra fria no continente levantava }}$ ciúmes e suspeitas entre os países, grandemente governados por militares que buscavam o tratamento privilegiado dos Estados Unidos em troca de envolvimento político contra a guerrilha e Fidel Castro. No Cone Sul, essas circunstancias acenderam as rivalidades entre a Argentina e o Brasil. mesmo porque o Brasil irrompeu como campeão do anticomunismo pan-americano. (2007, p.103). Portanto, podemos compreender que a busca pela supremacia regional foi pautada pelas políticas norte-americanas. (BELO: s/d:1353-4) (grifos nossos).

\footnotetext{
$\overline{86}$ Belo comete um pequeno engano: a Escola das Americas (School of the Americas) foi fundada pelos Estados Unidos em 1946, em Fort Amador, no Panamá. Assim a repressão já estava estudada e elaborada desde então, para ser posta em pratica, quando fosse conveniente.
} 
Moniz Bandeira em artigo denominado "A CIA e a técnica do golpe de Estado" 87 , nos auxilia a clarear mais ainda, o contexto vivido, uma cascata de golpes militares em toda a America Latina, desde o fim inclusive da era Vargas:

Golpes militares começaram a derrubar presidentes dos vários países das Américas. Foi derrubado Jacobo Arbens na Guatemala e Vargas no Brasil, entre outros.

Em 1962, Cuba foi excluída da OEA. Em 1964 com o apoio da Operação Brother Sam houve o Golpe Militar de 1964 no Brasil. Em seguida, diversos países da America Latina tiveram seus governos derrubados por golpes e contra-golpes.

Devido a estes movimentos revolucionários e contra-revolucionários, os países da região perderam completamente o controle econômico, a região se transformou num caos, e as populações começaram a ser massacradas pelas diversas ditaduras militares.

$\mathrm{Na}$ América do Sul, o empobrecimento real transformou economias de países em meras dívidas externas impagáveis.

À cada revolução, golpe e contra-golpe, sempre havia "alguém” pronto para emprestar o dinheiro necessário à conquista da "liberdade democrática" .

Atrás disso vieram os empréstimos para o "desenvolvimento" dos países do bloco americano, estes se endividaram novamente e tiveram que contrair mais empréstimos para pagar as dívidas geradas pelos golpes. Necessitavam de novos e novos empréstimos para pagar os juros que explodiram com as "crises" internacionais, como a do petróleo.

Com a queda da União Soviética, os norte-americanos continuaram acreditando na sua doutrina do destino manifesto. Agora como maior potência militar e econômica do Planeta iniciaram a aculturação de outras nações sob o pretexto de combater o "terrorismo internacional". (BANDEIRA: 2006:28) (grifos nossos)

No plano da conjuntura econômica é a ordem capitalista que precisa acumular capital para constituir e manter o sistema em todos os cantos do país, e, no plano político é a expansão econômica que vai ser a articuladora da unidade da federação política, fato que, dadas as políticas adotadas irão resultar na expulsão de indígenas e camponeses das terras, em nome do estabelecimento dos Grandes Projetos de infraestrutura (transporte e energia), do estabelecimento de "proprietários de terras" com extensas monoculturas para exportação, na exploração por empresas multinacionais do solo (madeira etc) e subsolo (minerais) no Brasil.

\footnotetext{
$\overline{87}$ BANDEIRA, Luiz Alberto Moniz. A CIA e a técnica do golpe de Estado. Revista Espaço Acadêmico, ${ }^{\circ} 58$, ano V, março de 2006, ISSN 1518.6186.
} 
Como vimos anteriormente, apesar da excelência do trabalho de Padrós, ele foca sua atenção prioritariamente voltada a questão das "formas políticas" utilizadas para a conquista dos países americanos pelos EUA, de características extremamente repressivas, ditatoriais, à base da tortura, utilizando o próprio aparato militar dos países que iriam dominar, visando o estabelecimento de sua exploração capitalista, no caso, no Brasil.

O antropólogo Shelton Davis em seu livro "Vítimas do Milagre"88 publicado em 1978, documenta um período da historia brasileira, centrado no pós-golpe militar e nos projetos de desenvolvimento econômico, deflagrados pela injeção de grande capital externo, no país. Ele demonstra o processo histórico de como a sociedade hegemônica (Estado e burguesia nacional e internacional) construiu a região da Bacia Amazônica, em função dos interesses do capital nacional e internacional. Apesar de Shelton Davis não tratar da questão do Sul do Brasil, foco de nosso estudo, ele demonstra as "praticas econômicas" adotadas em "campo" na Bacia Amazônica brasileira, nos anos 70. Seu estudo se dá no mesmo período histórico em que também trabalhamos, no decorrer do processo vivido pelos indígenas do Oco’y no Sul, durante a ditadura militar e da necessidade de expansão econômica pelo capital, por isso o trabalho de Davis é exemplar, no sentido de demonstrar as estratégias utilizadas por aqueles grupos econômicos, fundamentalmente norte-americanos, em utilizar os militares para abrir caminho como "testas-de-ferro", garantindo a ordem autoritária imposta, visando a implantação de uma economia tipicamente capitalista, que veio a espoliar os originais ocupantes das terras. Assim é interessante compreender a lógica utilizada pelo governo brasileiro no período, a lógica do "milagre econômico".

Shelton Davis faz a triangulação entre o desenvolvimento do capitalismo no Brasil, de economia dependente, por meio da força bruta dos militares no comando do Estado, inclusive determinando a política (anti)-indigenista imposta no período, e, a consequente situação vivida pelos indígenas, bem como por camponeses, na apropriação de suas terras e riquezas pelo capital. Tentaremos absorver assim, fundamentalmente a estrutura montada pela associação do capital internacional e nacional ao governo militar, para ocupação e exploração do país (na verdade aqui restrito a Bacia Amazônica) e o modelo de política indigenista adotado no período, descrevendo o padrão de relações que foram ali estabelecidas, por meio do relato de Davis.

Altos investimentos na forma de empréstimos dos EUA e dos bancos (Banco Mundial/BM, Banco Interamericano de Desenvolvimento/BIRD, assim como bancos privados) foram feitos

\footnotetext{
$\overline{88}$ DAVIS, Shelton. Vítimas do Milagre: O desenvolvimento e os índios do Brasil. Rio de Janeiro: Zahar, 1978. 208 p.
} 
em nome da "Aliança para o Progresso", acordo realizado entre EUA x Brasil, para financiar a infraestrutura de base, abertura de terras, desmatamento, energia e transporte, instalação de hidrelétricas e construção de rodovias, ferrovias, aeroportos e portos, inundando dessa forma o país de empréstimentos. No período a taxa de crescimento econômico do Brasil era alta, comparada as taxas de crescimento do EUA no final do século XIX e do Japão da época. O processo fez com que o Brasil se tornasse devedor de empréstimos contraídos a longo prazo de bancos internacionais e de bancos particulares, que seriam pagos no futuro, redundando numa das maiores dívidas externas contraídas por qualquer país.

Altos investimentos de empresas multinacionais, sobretudo norte-americanas, no Brasil, na investigação de recursos, esquadrinhando o território, de modo a identificar a localização dos recursos existentes, seguidas de compra de enormes quantidades de terras no país pelos estrangeiros. Foram utilizadas tecnologias sofisticadas, não existentes ainda no país, para a prospecção de riquezas minerais, resultando na exploração e exportação por essas empresas, com altíssimos lucros.

Davis demonstra como os EUA se utilizaram de nosso próprio aparato militar para ir contra a nossa própria população, trazendo "a estabilidade política" esperada, na base do autoritarismo, para abrir caminho para o capital, notadamente norte-americano. A estrutura disciplinar e hierárquica militar, em que não são permitidos "subalternos" questionarem "superiores" e apenas "cumprir ordens", foi a tônica e pretenderam estendê-la à todo o país.

Assim tudo isso se deu por meio de "assistência militar norte-americana", "transferência de tecnologia" e "ajuda econômica".

Em especial, quanto a atuação do governo brasileiro no período da ditadura militar na Amazônia, Davis demonstra que o comando das ações se deu sob ordens do Ministério do Interior, na época era Ministro, o General Jose Costa Cavalcanti, representante do governo que ao mesmo tempo, em que era o ordenador dos negócios do desenvolvimento econômico do interior do país, era também o Ministro superior à FUNAI, a instituição estava subordinada a este Ministério. Assim esses representantes governamentais não titubearam em prejudicar os interesses fundiários e consequentemente de vida, dos indígenas, como também dos camponeses, em nome do desenvolvimento econômico. É justamente desta época a campanha política de integração dos índios à comunidade nacional. Imaginavam os generais que só assim os indígenas poderiam servir aos propósitos do capital, desinstalados de suas terras e como mão de obra desqualificada e barata. Davis demonstra como a "política indigenista" do período, atrelada ao Ministério do Interior, era conivente também com a chacina de comunidades indígenas. Os novos colonizadores estabelece- 
ram um sistema de dominação, em que as terras e os direitos territoriais de camponeses e indígenas, eram desrespeitados ao ponto de exterminar populações que se colocavam no caminho dos projetos desenvolvidos. O impacto social e ambiental dos programas de desenvolvimento foram desastrosos. Os lucros tremendos.

A propósito, o General Jose Costa Cavalcanti ao deixar o cargo de Ministro, em seguida passou a assumir o cargo de primeiro Diretor-Geral da Itaipu. Assim os indígenas Guarani do Oco’y e demais indígenas do Paraná, vão receber tratamento semelhante ao dispensado às comunidades indígenas da Amazônia, pelo referido General, repressão e expulsão de suas terras.

Em seu livro Davis relacionou documentos sobre a política econômica do Brasil, o alcance da ajuda e do investimento externo, e a natureza da política indigenista e de desenvolvimento no Brasil e apontou a necessidade de ação internacional para deter as atrocidades cometidas contra os índios na America do Sul. Vejamos o próprio discurso de Davis a respeito do contexto exposto, pois nada mais esclarecedor do que o relato de quem viu os acontecimentos:

Davis de inicio aponta uma denuncia:

Dezembro/1973. Bispos e padres da Amazônia Brasileira divulgaram um documento intitulado YJuca-Pirama: O Índio, Aquele que Deve Morrer. Esse documento descreveu o modelo de destruição étnica que foi deflagrado contra as tribos indígenas brasileiras a partir da construção do sistema rodoviário da Transamazônica em 1970. Caso por caso, o documento do clero demonstrou como a terra e os direitos territoriais do índio foram sacrificados em prol da rodovia e dos programas de desenvolvimento no Brasil. "Em todo o país", declararam os bispos da região Oeste, "as terras pertencentes aos índios estão sendo invadidas e gradualmente expropriadas. Os direitos humanos das populações indígenas são virtualmente ignorados, acarretando seu rápido extermínio cultural e biológico, como já aconteceu a tantas outras tribos brasileiras." (DAVIS: 1978: 11)

O autor aponta que é o modelo de desenvolvimento escolhido pelo Brasil, o "Milagre Brasileiro", que estava resultando nessas consequências:

O Brasil fornece um dos mais claros exemplos modernos de um país onde os direitos das comunidades indígenas foram sacrificados em nome dos interesses maiores do desenvolvimento nacional. Gigantescos projetos rodoviários, de mineração de pecuária foram planejados para atravessar territórios dos índios na Amazônia brasileira, e em seu rastro trouxeram doenças, morte e destruição cultural para as tribos indígenas. A partir de 1974, a FUNAI tentou proteger algumas dessas terras indígenas contra as invasões de estranhos, mas foi substancialmente frustrada em seus esforços pela carência de recursos e as diretrizes econômicas mais amplas de outros órgãos governamentais no 
Brasil. No presente livro, argumento que nada havia de inevitável nesses processos de destruição étnica. A Amazônia brasileira é uma área geográfica de tamanha vastidão que parques e reservas indígenas poderiam ter sido protegidos sem estorvar o desenvolvimento nacional do Brasil. Uma das razões por que essas áreas indígenas foram criadas, mas depois não protegidas está, creio eu, no “modelo de desenvolvimento" especifico que está sendo adotado pelo Governo do Brasil.

Existe um vasto acervo bibliográfico sobre a natureza dependente do desenvolvimento no Brasil. Conquanto o Governo brasileiro formule políticas desenvolvimentistas, poucas dúvidas subsistem de que essas politicas dependem, para sua implementação, de capital, assistência técnica e empréstimos estrangeiros. Desde fins da década de 1960, centenas de milhões de dólares têm entrado no Brasil, provenientes de bancos estrangeiros, empresas e instituições internacionais de empréstimo. Na Amazônia, grandes empresas estrangeiras juntaram-se a firmas brasileiras de propriedade privada ou estatal a fim de explorar os vastos recursos minerais, florestais e agrícolas da região; empréstimos externos são contraídos para financiar estradas, portos e usinas hidrelétricas; e assistência técnica estrangeira é fornecida para pesquisas de engenharia, minérios e levantamentos aerofotográficos. Em todos esses sentidos, as instituições internacionais também são responsáveis, direta ou indiretamente, pelas consequências sociais da política desenvolvimentista na Amazônia brasileira. Neste livro documento a grande extensão do envolvimento internacional no programa do Governo brasileiro para abrir e desenvolver a região amazônica (DAVIS: 1978: 12-3) (grifos nossos).

O autor associa os fatores políticos e econômicos do chamado "milagre brasileiro" ao extermínio dos indígenas e a molestação de outras comunidades:

Este livro difere de todos os relatos anteriores, na medida em que acentua os fatores políticos e econômicos que estão provocando o extermínio das tribos indígenas brasileiras. A tese central desse livro é que as doenças, a morte e o sofrimento humano, que se desencadearam maciçamente sobre os índios brasileiros nos últimos anos, são o resultado direto da política de desenvolvimento econômico dos Governos militares do Brasil. Em termos mais genéricos, pretendo demonstrar que a situação atual dos índios brasileiros, vincula-se estruturalmente ao "milagre econômico" do Brasil, muito aclamado, mas pouco conhecido. Para tanto, centralizo a atenção nas políticas de desenvolvimento econômico do regime militar brasileiro. (...) Um tipo de progresso econômico que molesta, (...) os índios, os trabalhadores nas plantações e nas estradas da Amazônia, milhares de miseráveis migrantes rurais do Nordeste, e milhões de pessoas pobres e famintas que vivem nas grandes cidades de São Paulo e Rio de Janeiro.

(...) este livro tenta analisar o que ocorre quando as modernas formas de desenvolvimento capitalista começam a penetrar na ultima e maior região inexplorada das Américas. (...) A noção de "desenvolvimento", tornou-se algo que é visto hoje como um bem necessário por quase todos os governos, 
planejadores e públicos. A mística que cerca a noção de "desenvolvimento econômico" é tão grande que praticamente todos acreditam no beneficio que trará aos povos, regiões e nações do mundo inteiro. Em parte alguma essa aceitação cega é tão dominante quanto no Brasil de hoje. A impressionante taxa de crescimento da economia brasileira, superando a dos EUA no final do século XIX e a do Japão no pós-guerra, é aceita por quase todos os observadores estrangeiros como um bem positivo para o povo do Brasil. Por isso, poucos analisaram a estrutura institucional da politica econômica brasileira: as alianças que surgiram no Brasil entre capitalistas nacionais e firmas multinacionais, $\underline{\text { o }}$ papel dominante de um Governo militar repressivo na origem da formação do capital e do crescimento econômico, e a importância das transferências de tecnologia e da ajuda internacional para que acontecesse o "milagre econômico" brasileiro. Do mesmo modo, os observadores de fora têm passado ao largo das implicações e do custo, em termos sociais, desse crescimento econômico (DAVIS: 1978:15). Poucos, por exemplo, perguntaram quem se beneficia com o "milagre" e que setores sociais tem necessariamente sofrido e perdido (DAVIS: 1978:17) (grifos nossos).

Em conversa com o médico indigenista Noel Nutels, ele indicou a Davis que se deveria protestar contra o Estatuto do Índio, dada a proposição integracionista e centrar atenção na política indigenista brasileira. Assim Davis primeiramente vai buscar um apanhado histórico sobre a política indigenista brasileira. É aí que ele levanta as propostas iniciais da burguesia brasileira, muito semelhantes às ações da burguesia norte-americana, com relação aos indígenas:

No Congresso brasileiro, muitos legisladores argumentavam que seria conveniente, tendo em vista o desenvolvimento nacional, usar as mesmas táticas de extermínio que os militares americanos praticaram contra os índios na ocupação de quase toda a America do Norte ${ }^{89}$ (DAVIS: 1978:24).

A política indigenista do período pós-guerra em diante, foi se tonando cada vez mais ligada à politica regional e nacional. (...) No final dos nãos 50, um novo grupo de oficiais do Exercito e funcionários públicos começaram a assumir posições de poder no SPI. (DAVIS:1978:30)

Uma onda de corrupção burocrática infestou então a administração do SPI. A nova direção pôs fim a Seção de Estudos Antropológicos, que Darcy Ribeiro havia ajudado a criar, no inicio dos anos 50. Vários postos indígenas foram confiados a missionários religiosos. Expedições de pacificação, prejudiciais ao bem-estar e à segurança das tribos indígenas, foram toleradas, e praticamente deixou de haver controle sobre as atividades dos agentes do órgão nas áreas pioneiras. Em termos simples, considerações econômicas e não mais humanitárias passaram a formar a base da política indigenista do Brasil (DAVIS: 1978:32) (grifos nossos).

\footnotetext{
89 Indica Davis: Ver os artigos de Hermann von Ihering, diretor do Museu Paulista: "A antropologia do estado de São Paulo", Revista do Museu Paulista, 7 (1907), 202-57; e “A questão dos índios no Brasil”, Revista do Museu Paulista, 8 (1911), 112-40.
} 
É nesta contradição mesma, que os órgãos indigenistas, SPI e FUNAI, sempre, em todos os tempos viveram, de forma pendular, entre considerações indigenistas humanitárias e antropológicas e considerações anti-indigenistas de controle das comunidades, de cunho e imposição econômica. Infiltrados na instituição, até hoje, convivem em luta, os dois modelos.

Davis cita o "Relatório Figueiredo", que hoje está sendo pauta da Comissão da Verdade:

Em 1967 (...), o Ministro do Interior, General Albuquerque Lima, encarregou o Procurador-Geral Jader Figueiredo de investigar as acusações de corrupção contra os funcionários do Serviço de Proteção aos Índios. De acordo com um repórter presente à entrevista, a Comissão Figueiredo “descobriu provas de ampla corrupção e sadismo, indo desde o massacre de tribos inteiras a dinamite, metralhadoras e açúcar misturado com arsênico, até a remoção de uma garota de 11 anos da escola para servir de escrava de um funcionário do Serviço". O mesmo repórter informou que dos 700 empregados do SPI, 134 eram acusados de crimes, 200 haviam sido demitidos, e 38, fraudulentamente contratados, haviam sido afastados (DAVIS: 1978:33) (grifos nossos).

Um dos observadores estrangeiros, Patrick Braun, adido médico do Depto Frances dos Territórios de Ultramar, em artigo publicado no Medical Tribune and Medical News (Nova York), intitulado "Denuncia de Guerra de Germes contra os Índios no Brasil". Confirmavam as denuncias de que agentes do SPI e latifundiários haviam usado armas biológicas e convencionais para exterminar tribos indígenas. Indicavam a introdução deliberada de varíola, gripe, tuberculose e sarampo entre tribos da região de Mato Grosso, entre 1957 e 1963. Além disso, os arquivos do Ministério do Interior sugeriam ter havido a introdução consciente de tuberculose entre as tribos do Norte da Bacia Amazônica entre 1964 e 1965. Braun afirmou ter visto provas de que organismos infecciosos "foram deliberadamente levados aos territórios indígenas por latifundiários e especuladores utilizando um mestiço previamente infectado". Sem imunidade contra essas doenças introduzidas, de acordo com Braun, um número incontável de índios morreu rapidamente. O jornalista britânico Normam Lewis, publicou em fevereiro de 1969 artigo no Sunday Times de Londres intitulado "Genocídio - de Fogo e Espada a Arsênico e Balas, a Civilização mandou Seis milhões de Índios para a Extinção”. O artigo traçava a historia das relações entre índios e brancos no Brasil e dava provas que o SPI era um dos principais cumplices em vários crimes contra os índios (DAVIS: 1978:34) (grifos nossos).

De acordo com Lewis, mais de 100 indigenistas, incluindo dois dos recém-empossados diretores do SPI, se haviam aliado a latifundiários e especuladores para roubar e matar sistematicamente os índios. Lewis informou que o Major Luis Neves, ex-chefe do SPI, fora acusado de 42 crimes, inclusive cumplicidade em vários assassinatos, roubo e venda ilegal de terras dos indígenas, e um desfalque de 300 mil dólares. Citando o Procurador-Geral Figueiredo, Lewis escreveu que "não é apenas pela malversação de fundos, mas pela admissão de perversões sexuais, assassinatos, e todos os outros crimes enumerados no código penal contra os índios e suas propriedades, que se pode ver 
que o SPI foi, durante anos, um antro de corrupção e assassinatos indiscriminados" (DAVIS: 1978:345) (grifos nossos).

Os relatos de Braun e Lewis, assim como vários pronunciamentos de sociedades antropológicas e cientificas, tornaram-se grandes fontes de problemas para o novo Governo militar do Brasil e produziram momentaneamente uma onda de protesto no mundo inteiro. Vários jornais acusaram o Governo brasileiro de consentir numa politica de genocídio contra as tribos indígenas remanescentes e exigiram uma investigação imediata pelas Nações Unidas (DAVIS: 1978:35).

Em resposta às descobertas da Comissão Figueiredo, Albuquerque Lima tomou três decisões. 1) Fechou o SPI e conseguiu estabelecer um novo órgão de Governo, a FUNAI. 2) Prometeu que todos os criminosos envolvidos no escândalo do SPI seriam punidos e que as terras vendidas ilegalmente ou tomadas dos índios seriam devolvidas. 3) Convidou varias organizações internacionais, como a Cruz Vermelha Internacional, a enviar missões de investigação ao Brasil para testemunhar em primeira mão as condições dos índios.

Todas essas medidas levaram a um enfraquecimento do protesto internacional contra a politica indigenista brasileira, e não houve investigação do Governo brasileiro pelas Nações Unidas. Em 1969, ocorreram três fatos, que tiveram importantes implicações para o destino das tribos indígenas remanescentes no Brasil. 1) A morte do presidente Arthur da Costa e Silva e sua substituição pelo General Emilio Garrastazu Médici. 2) O desparecimento do General Albuquerque Lima da politica brasileira, e sua substituição no Ministério do Interior pelo Coronel Jose Costa Cavalcanti. 3) Anúncio de que o novo Governo brasileiro planejava investir 500 milhões de dólares na construção de uma nova rodovia transcontinental na Bacia Amazônica (DAVIS: 1978:36) (grifos nossos).

Assim o plano de construção da Transamazônica e os subsequentes planos de desenvolvimento, como parte do tão aclamado "milagre econômico" brasileiro.

Em 1971, artigo do New York Times (...) dizia que o país tinha "dado largos passos econômicos" no ano anterior, quebrando todos os recordes estatísticos no comercio e na indústria. (DAVIS: 1978:37) O milagre econômico só despertou a atenção em 1968, quando a partir dai o PIB deu saltos de crescimento altos. O crescimento das exportações brasileiras apresentou uma curva semelhante. (...) Essa fantástica performance econômica levou vários observadores estrangeiros a apontarem o Brasil como um caso clássico de modelo do desenvolvimento capitalista de "livre empresa". No auge do entusiasmo pelo "milagre econômico" brasileiro, por ex: a Business International Corporation (BIC) publicou um relatório intitulado Brasil: Nova Potencia Comercial na America Latina. A BIC observava que o Brasil estava no seu estagio critico de seu desenvolvimento. Durante séculos o país fora chamado de "o gigante adormecido das Américas", mas no inicio da década de 70 ele finalmente “acordava e se erguia". De acordo com a BIC, o Brasil possuía uma "base industrial solida e varia- 
da" e se estava "acelerando para o segundo estagio da industrialização"(DAVIS: 1978:38). Essa nova fase de desenvolvimento industrial, segundo o relatório, tornaria o Brasil "competitivo nos mercados mundiais e talvez, no final da década de 70, o transforme numa potencia econômica de peso, pelos padrões globais.” (DAVIS: 1978:39) (grifos nossos).

Para compreender a situação dos índios brasileiros, é necessário examinar a história econômica da Região Amazônica e discutir o seu recente crescimento na economia politica do Brasil. (...) Analisar as relações que existem entre as politicas indigenistas e a estratégia de desenvolvimento mais global para a ocupação da Bacia Amazônica. (...) A situação atual dos índios, assim como de vários outros setores sociais, esta intimamente vinculada a fatores institucionais responsáveis por aquilo que vários observadores batizaram de "milagre econômico" do Brasil (DAVIS: 1978:40).

Os Planos de desenvolvimento no período pós-guerra:

Vargas deixou claro que convidaria representantes dos EUA para qualquer conferencia que discutisse o futuro econômico dos países amazônicos. (...) No final de 1940, diplomatas brasileiros viajavam para Washington para discutir um acordo militar de defesa mutua. Em outubro de 41, os EUA assinaram com o Brasil um acordo de empréstimos que prometia 100 milhões de dólares em armas e discutia o possível estacionamento de tropas norte-americanas no Nordeste brasileiro. Em 1942, novas negociações elevaram o acordo para 200 milhões de dólares em armas e abriram caminho para a exploração pelos americanos dos ricos recursos minerais do Brasil. Bancos americanos oferecem empréstimos para o governo militar do Brasil, e fazem programas de exploração mineral no Brasil. (DAVIS: 1978:47)

(...) Hanson afirmava que os interesses políticos e econômicos, e não os obstáculos naturais, é que determinariam o curso do desenvolvimento econômico da Bacia Amazônica. Segundo ele, a tecnologia moderna e o planejamento racional podiam superar os problemas do clima tropical, da baixa fertilidade do solo, das miseráveis condições sanitárias e dos índios hostis. E escrevia: "O sonho do desenvolvimento amazônico já esta hoje firmemente enraizado em alguns países sul-americanos." (Hanson, 1944, p. 81). De acordo com Hanson, vários fatores poderiam tornar esse sonho uma realidade. Um deles seria a "Politica de Boa Vizinhança”" dos EUA que, após a guerra forneceriam aos vários países sul-americanos ajuda financeira e assistência técnica para o desenvolvimento sistemático da Bacia Amazônica. Outro fator seria o grande excedente de capital que estaria disponível para ser investido na Bacia Amazônica no pós-guerra. E, por fim, havia o interesse cada vez maior dos militares pelos recursos da região amazônica. Hanson lembrava que vários lideres militares americanos, preocupados com questões de "defesa hemisférica", também se interessavam em ter fontes de borracha, e outros suprimentos essenciais num lugar mais próximo do que a Ásia. Seja qual for a divisão do mundo no pós-guerra, continuará sendo mais fácil proteger as linhas de fornecimento vindas da 
Amazônia do que aquelas que atravessam o Pacifico. Por fim Hanson argumentava que a Bacia Amazônica assumiria uma nova importância geopolítica após a guerra. Até recentemente, segundo ele, o "mundo expandiu-se na direção Leste-Oeste", mas "logo iniciará uma vigorosa expansão" para as áreas inexploradas que existem ao Norte e ao Sul (DAVIS: 1978:49-50) (grifos nossos).

Assim os planos de conquista através da "Política de Boa Vizinhança" dos EUA de fornecer aos países sul-americanos ajuda financeira e assistência técnica, visavam a criação da dependência político-econômica brasileira, aos norte-americanos. Foram postos em ação, alguns planos prévios para essa conquista, quando dessa forma vão fechando o cerco:

1942 - acordo bilateral Brasil e EUA - programa de saúde publica e controle de endemias na BA. Entre 42 e 60 o Governo americano forneceu 16,8 milhões de dólares ao programa SESP. Mais de 200 técnicos e conselheiros de saúde foram enviados ao Brasil. Em 1960 o programa SESP foi encampado pelo governo brasileiro. (DAVIS: 1978:51-2)

Crescimento da aviação/1940, com assistência técnica dos EUA; treinamento de pilotos e fornecimento de aviões para o Brasil. Resultou num Programa Cooperativo de Aviação.

Criação em 1943 da Fundação Brasil Central; trabalhava com a FAB e o SPI; final dos anos 40 construiu uma rede de campos de pouso e de estradas de acesso em MT e GO, marcando a primeira penetração na BA; Anos 40 e 50 - grande corrente de migrantes para a BA; 1960 - fim da construção de Brasília; Começa a construção da rodovia Belém - Brasília; 1960 - MT, GO e PA já são as maiores áreas agrícolas e pastoris do Brasil (DAVIS: 1978:53)

A importância do movimento militar de 1964 em abrir para investimentos a Amazônia. Segundo a publicação "The Amazon: Its Treasures are being revealed," in Brazilian Trends: Economic Development in Brazil (1972), ela assim descreve:

A Região Amazônica representa um vigésimo da área deste planeta, um quinto de sua água e um terço de suas florestas. A importância da floresta amazônica é decisiva, sobretudo para o Brasil. Nem tanto por seu atual papel econômico, - no momento contribui com menos de $4 \%$ do PIB brasileiro - mas por sua riqueza em potencial: possui 79,7\% das reservas madeireiras do país, $81 \%$ da agua doce, metade dos depósitos de minério de ferro, quase 100\% do estanho, 93\% de alumínio, e o maior deposito de sal-gema do mundo, calculado em 10 bilhões de toneladas. A Região Amazônica também possui o que se imagina ser o maior deposito de petróleo do mundo...

Contudo, só recentemente foram tomadas medidas efetivas para abrir esse grande tesouro, com a decisão do Governo federal de dar passos reais para a ocupação e a "conquista” da região. Até recentemente os problemas e as dificuldades da Região Amazônica, embora longamente discutidos, de fato 
nunca foram enfrentados, concretamente, pelos sucessivos governos. Mas algumas das maiores companhias mundiais, especialmente nos campos da mineração, extração de madeira e pecuária, partiram para o trabalho pratico, confiantes em que os projetos serão altamente lucrativos (DAVIS:1978:57).

Aqui vemos claramente os planos geopolíticos de Travassos e Golbery, sendo postos em ação, em direção ao norte, à Amazônia:

Esse estudo alegava que os novos projetos rodoviários e de colonização, tal como a construção da capital federal em Brasília no fim da década de 50, aliviariam os desequilíbrios regionais e redirigiriam a vida econômica do país das regiões litorâneas do Centro-Sul para a imensa área inexplorada do Norte. A longo prazo, argumentavam os planejadores do Governo, esses programas criariam condições para integração econômica do Brasil.

Ao inaugurar a construção das novas estradas, em outubro de 70, o presidente Médici disse que a "Rodovia Transamazônica será um caminho aberto para permitir aos habitantes do Nordeste colonizar o grande deserto demográfico e começar a utilizar esse potencial ate agora inacessível”. Durante os cinco anos seguintes, revelou o Presidente, o Governo brasileiro gastaria mais de um bilhão de dólares num programa maciço de construção de estradas, colonização rural, exploração mineral e construção de hidrelétricas e portos na BA. O novo programa, já então denominado Plano de Integração Nacional (PIN), substituiria a "Operação Amazonas" anunciada em 1966.

Embora alguns membros do regime militar enfatizassem o aspecto "segurança" contido no PIN, a maioria via o plano como o primeiro passo para a integração econômica da região mais atrasada e subdesenvolvida do Brasil. Em janeiro de 1973, por exemplo, o Ministro do Planejamento Joao Paulo dos Reis Velloso publicou um artigo que descrevia o programa para a Amazônia como capaz de provocar uma "transformação dramática da sociedade" brasileira. Isso incluiria a abertura das ultimas "fronteiras econômicas" do país, e o desenvolvimento de uma área "economicamente tênue", cobrindo 5 milhões de KM2 de terra. Segundo Reis Velloso, o Governo federal estava gastando U\$ 1.500.000 por ano em novas tecnologias para desenvolver os recursos da área e levando em conta o equilíbrio ecológico da região. Mais importante que isso segundo ele, era que: "Grandes contingentes hoje engajados em simples atividades de subsistência entrarão progressivamente na economia de mercado através de programas destinados a dar, aos pequenos produtores rurais, o acesso à terra" (DAVIS: 1978:66) (grifos nossos).

A dependência econômica a financiamentos externos:

As diretrizes introduzidas pelo Governo brasileiro após 1970 começaram a transformar toda a estrutura econômica da BA. Para entender a natureza dessas diretrizes, é importante salientar dois pon- 
tos. Primeiramente, de modo a financiar seus programas de desenvolvimento, o Governo se viu forçado a pedir grandes somas a instituições internacionais de empréstimos e a bancos estrangeiros. Entre o movimento militar de 1964 e o mês de junho de 1971, o Governo dos EUA e suas varias instituições internacionais de empréstimos forneceram ao Governo brasileiro mais de U\$3.500.000 em ajuda bilateral e empréstimos internacionais. Em 1972, o Brasil ultrapassou o Japão como o maior tomador de empréstimos do Export-Import Bank dos EUA e tornou-se a maior nação deve-

\section{dora do Banco Mundial.}

Nesse período, o Governo brasileiro também tomou grandes empréstimos de bancos privados estrangeiros. Em 1970, um estudo da Comissão Econômica para a América Latina (CEPAL), indicava que a taxa anual de aumento de empréstimos a médio e curto prazo para o Brasil triplicaria entre 1965 e 1969. Nesse período a taxa anual de obrigações a curto prazo do Brasil crescera oito vezes, atingindo um nível de 388 milhões de dólares em 1969.

Em segundo lugar, na época de divulgação do PIN, corporações estrangeiras e multinacionais con$\underline{\text { trolavam os postos de comando da economia brasileira. Esse controle externo aumentou de modo }}$ $\underline{\text { significativo ao longo da década de } 60}$. Um estudo de 1962, revelava que 29 dos 55 maiores "grupos econômicos" do Brasil eram controlados por capitais externos, e que a maioria dos grupos controlados por brasileiros possuía estreitos vínculos com firmas estrangeiras.

Nos últimos anos da década de 60, a principal revista econômica do Brasil informava que dois terços das 50 maiores firmas em suas "500 maiores firmas brasileiras" eram subsidiárias de companhias estrangeiras. Em 1969, 90\% da indústria automobilística, 87\% da indústria farmacêutica, $73 \%$ da maquinaria pesada, $65 \%$ da química e dos plásticos, e $33 \%$ da siderurgia estavam em mãos estrangeiras no Brasil.

Dados mais recentes para o inicio da década de 70 dão um quadro semelhante. Um estudo (...) de 1972 verificou que firmas americanas e de outros países respondiam por 158 das 500 maiores empresas, excluídas as financeiras. No setor manufatureiro, as corporações estrangeiras respondiam por 147 das 300 maiores firmas, e 59 das 100 maiores. "O comportamento das corporações multinacionais", afirmava esse relatório, "é um determinante critico do desempenho da economia brasileira. Se a desnacionalização e a concentração do mercado de produtos continuarem a crescer. a economia brasileira se tornará cada vez mais vulnerável diante do poder dos árbitros externos, nas matrizes das corporações multinacionais."

Na ultima década, surgiu no Brasil uma nova associação entre as instituições internacionais de credito, as corporações multinacionais e o regime militar brasileiro. A força dessa associação tem sido um fator primordial para a rápida abertura da Amazônia brasileira.

(...) em seguida pesarei o significado dessa associação para as tribos indígenas da BA. Iremos demonstrar que, de varias maneiras, a politica indigenista contemporânea está comprometida com a 
politica, mais abrangente, de desenvolvimento econômico, adotada pelo regime militar brasileiro (DAVIS: 1978: 67-69) (grifos nossos).

Os irmãos Villas Boas, o médico Noel Nutels e a política indigenista no Brasil:

"Todo o meu trabalho como medico entre os índios do Brasil foi orientado por uma única ideia: que o processo rápido de civilizar o índio é a forma mais eficaz de matá-lo.” Noel Nutels

"Estamos exterminando o índio, e da pior maneira possível, - convencendo-nos de que somos grandes humanistas, estendendo ao índio as asas da proteção. Mas que espécie de proteção podemos realmente oferecer a ele? Talvez o que nos interesse na verdade seja o pedacinho de terra que o índio ainda possui. Ou, talvez, estejamos procurando uma fonte de mão de obra barata. É assim que se pode interpretar todo o humanitarismo que temos imposto ao índio." Orlando Villas Boas (DAVIS: 1978:73) (grifos nossos).

Na criação da FUNAI (1967) novamente os dois modelos opostos de política indigenista no Brasil:

Quando a FUNAI foi criada em 1967, dois modelos opostos de politica indigenista existiam no Brasil. Um desses modelos, de natureza radicalmente protecionista, foi posto em pratica, pelos irmãos VB no Parque Nacional do Xingu. De acordo com esse modelo, as tribos indígenas deveriam ser protegidas pelo Governo federal contra as intromissões nas áreas pioneiras nos parques e reservas indígenas, e ser preparadas gradualmente, como grupos étnicos independentes, para se integrarem à sociedade e à economia do Brasil. Em oposição à filosofia dos irmãos VB havia um segundo modelo de política indigenista desenvolvido pelo SPI nos seus últimos anos de existência, e mais tarde assumido pela FUNAI. De natureza desenvolvimentista, baseava-se na premissa de que os grupos indígenas deveriam ser rapidamente integrados, como força de trabalho de reserva ou como produtores de mercadorias, às economias regionais em expansão e às estruturas de classe rurais do Brasil. A importância desses dois modelos para a politica indigenista contemporânea do Brasil será examinada neste capitulo (DAVIS:1978:73-4) (grifos nossos).

Rondon e irmãos Villas Boas reavaliam a política indigenista:

Em contato com o velho Rondon (que morreu em 1958) e o que restava de seu pequeno e dedicado circulo de indigenistas, os irmãos VB começaram a reavaliar a historia e as consequências da politica indigenista no Brasil. Eles descobriram que o pior aspecto desta politica era a sua tendência a fazer contato com as tribos indígenas para mais tarde descobrir que elas eram varridas pelos interesses econômicos mais poderosos ao longo das fronteiras econômicas do Brasil. Assim, decidiram que era 
necessário um programa positivo de proteção aos índios - um programa que desse aos índios uma base territorial para manter seus modos tradicionais de subsistência econômica, além de assistência medica contra doenças exógenas.

Os irmãos VB alegavam ainda que era da responsabilidade do Governo federal fornecer um tampão protetor seguro, entre os índios e a sociedade nacional, sob a forma de parques e reservas indígenas fechados. Com o tempo, os índios se integrariam a sociedade nacional brasileira. Esse processo de integração, contudo, deveria ser gradual, e garantir a sobrevivência, as identidades étnicas e os estilos de vida dos índios.

Em 1952, essa nova filosofia indigenista tornou-se realidade quando o Vice-presidente do Brasil convocou uma mesa-redonda para debater a criação de um parque nacional indígena na Bacia do Alto Xingu. Na época estavam maduras as condições para uma discussão como essa no Brasil. De 1950 a 1954, o SPI esteve sob a direção de um dos mais dedicados indigenistas do país, Jose Maria da Gama Malcher. Além disso, havia durante esse período um forte sentimento nacionalista no Brasil e a crença de que um sistema de parques nacionais protegeria o patrimônio natural e histórico do país. (DAVIS: 1978:76-7) (grifos nossos).

Os primórdios “politicamente corretos” da FUNAI de inicio, 1967:

Quando a Funai foi criada, em dezembro de 1967, parecia que esse novo órgão iria seguir as experiências postas em pratica pelos irmãos VB no Parque Nacional do Xingu/PNX. Quando do estabelecimento da FUNAI, o General Albuquerque Lima era Ministro do Interior. Num de seus primeiros atos ele autorizou o aumento da área do PNX de 22 para 30 mil KM2. Ao mesmo tempo, O ministro reclamava o estabelecimento de varias reservas indígenas (áreas reconhecidas pelo governo federal como ocupadas por uma única tribo) e a criação de três novos Parques indígenas: o Parque Indígena Tumucumaque, no extremo norte do Pará, o Parque Indígena Aripuanã em Rondônia e no Oeste do Mato Grosso, e o Parque Indígena Araguaia, na ilha do Bananal. (DAVIS:1978:81)

Em termos de política formal, a reorganização da administração indigenista parecia ser um passo na direção correta. O primeiro artigo do estatuto que estabelecia a FUNAI, incluía as seguintes disposições:

1. Respeito pelas instituições e comunidades tribais;

2. Garantia de posse permanente das terras que os índios habitam, e o uso exclusivo dos recursos naturais nas mesmas, de acordo com a Constituição brasileira;

3. Preservação do equilíbrio biológico e cultural das comunidades indígenas em contato com a sociedade nacional; e

4. Defesa da aculturação espontânea das comunidades indígenas em vez de sua aculturação rápida e forçada. 
O estatuto acima foi aprovado em 31/01/1969 e emendado em 02/05/1969. (...) Na época de sua aprovação, tudo indicava que haveria uma grande mudança na natureza da política indigenista no Brasil (DAVIS: 1978:82-3) (grifos nossos).

Já na vigência da ditadura militar ocorre profunda mudança de direção na administração e na filosofia da FUNAI:

Em 1970, porém, houve uma importante mudança de direção na administração e na filosofia da FUNAI. Em junho desse ano, um ex-oficial da inteligência militar, o General Oscar Jeronimo Bandeira de Mello, foi nomeado para presidir a FUNAI. Ao assumir o cargo, ele anunciou que a politica indigenista seria conduzida dentro do quadro do Plano de Integração Nacional (PIN). O general afirmou que a FUNAI, na qualidade de órgão do Ministério do Interior, daria proteção às tribos indígenas, mas essa proteção seria coordenada ao programa mais global para a ocupação e colonização da Amazônia. Num de seus primeiros discursos públicos, o General teria dito que "minorias étnicas como os índios brasileiros devem ser orientadas para um processo de planejamento bem definido, levando em conta sua participação no progresso nacional e sua integração como produtores de bens". Durante seu primeiro ano a frente da FUNAI, Bandeira de Mello introduziu duas medidas importantes para implementar essa nova visão de politica indigenista na administração da FUNAI. A primeira foi a reintrodução da chamada "renda indígena", uma instituição especial criada nos últimos anos do SPI. No final da década de 50 e inicio da de 60, uma mentalidade empresa-

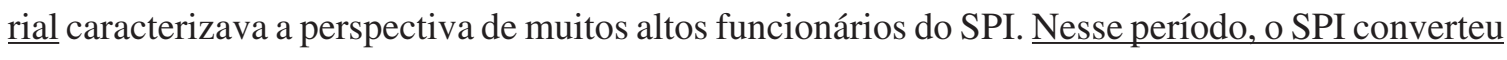
vários postos indígenas em empresas econômicas onde os índios eram forçados a vender o produto do seu trabalho aos agentes do órgão, e onde as terras e recursos indígenas eram arrendados à estranhos através de direitos à exploração mineral, madeireira ou pecuária. Ao mesmo tempo o SPI criou um fundo especial, a chamada renda indígena, que representava a renda auferida nas terras dos índios, e que servia para pagar os salários dos agentes indigenistas e aliviar os custos das atividades do SPI. Essas práticas econômicas foram criticadas no Relatório Figueiredo de 1968, e estavam entre as principais razões para a desmoralização e o colapso do SPI.

Em 1970, o General Bandeira de Mello apoiou a reintrodução do fundo da renda indígena na administração da FUNAI. Com base num complicado sistema de contabilidade, $\underline{\text { a FUNAI criaria um }}$ fundo estatal especial formado pela renda ganha na venda dos produtos indígenas e no arrendamento das terras dos índios. Segundo o general, o dinheiro desse fundo iria financiar projetos agrícolas e industriais do Governo, nas reservas indígenas, e seria coordenado com outros esquemas de desenvolvimento regional no Brasil. A longo prazo, argumentava o general, esses programas transformariam as economias nativas de caça, pesca e agricultura, e lançariam as bases para a integração dos índios na economia de mercado e na estrutura de classes no Brasil. 
A segunda medida do novo regime da FUNAI foi o anuncio de que a politica indigenista seria coordenada ao programa de maciça construção de estradas, planejado para a Região Amazônica. Em outubro/70, o Presidente Médici anunciou que a FUNAI estava prestes a assinar um contrato com a Superintendência de Desenvolvimento da Amazônia (SUDAM) para a pacificação de quase

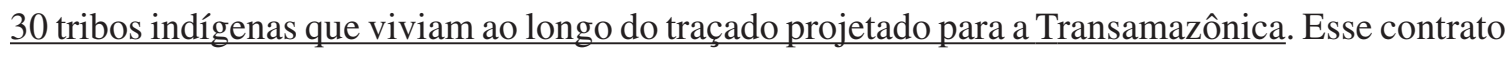
estabelecia que equipes da FUNAI seriam responsáveis pelo contato com tribos hostis e sua pacificação. O mais importante era que os agentes da FUNAI teriam duas obrigações: 1) garantir que os índios não serviriam de obstáculo à rápida ocupação da Amazônia; e 2) dar aos operários da estrada proteção contra uma suposta ameaça indígena.

Ao anunciar esse contrato, o presidente Médici também revelou que um novo Estatuto do Índio estava sendo formulado para fornecer diretrizes à politica indigenista na BA. O esboço original foi dado a publico em outubro/70 e continha vários dispositivos que punham em risco a integridade territorial das tribos indígenas. Umas das seções mais extensas e claras do novo Estatuto do índio, dava poderes ao Presidente do Brasil, assessorado pela FUNAI, para intervir em áreas indígenas e deslocar as tribos fisicamente, com vistas a seis objetivos:

1. Cessar lutas entre tribos rivais;

2. Combater surtos graves de epidemias que possam levar ao extermínio da comunidade nativa ou qualquer doença que ponha em risco a integridade do silvícola ou grupo tribal;

3. Manter a segurança nacional;

4. Realizar obras públicas no interesse do desenvolvimento nacional;

5. Reprimir a desordem generalizada ou a grilagem; e

6. Explorar depósitos do subsolo de interesse relevante para a segurança e o desenvolvimento nacionais.

O significado dessas medidas tornou-se claro na primavera de 1971. Foi então que o Governo brasileiro revelou que uma estrada ligando a pequena cidade isolada de Xavantina à colônia do Cachimbo em Mato Grosso (BR-080) deveria passar por um trecho de $40 \mathrm{~km}$ na parte norte do PNX. Originalmente os mapas mostravam que essa estrada passaria fora dos limites do Parque. O novo plano exigia uma invasão territorial do mesmo (DAVIS:1978:83-6) (grifos nossos).

Ocorre um choque entre os Villas Boas e protestos em todo o Brasil. Ao contrario os altos funcionários da FUNAI alegam:

Altos funcionários da FUNAI responderam a esses protestos alegando que o parque era uma "falsa experiência" que estava bloqueando "o progresso e desenvolvimento" do Brasil. De acordo com uma nota oficial da FUNAI, o PNX era um "exemplo típico de isolacionismo". A rodovia, segundo a nota, seria um "elo terrestre vital para o desenvolvimento e segurança do país" e "levaria os índios a uma participação mais intensa" na economia nacional. 
O presidente da FUNAI, general BM, resumiu a importância da construção da BR-080 com as seguintes palavras:

"O índio não é cobaia, nem propriedade de meia dúzia de oportunistas. Não se pode deter o desenvolvimento do Brasil por causa do Parque do Xingu" (DAVIS: 1978:86-7) (grifos nossos).

Davis afirma que um grupo de Txukahamãe chefiados por Krumari mudou-se para perto dos trabalhadores da estrada; pegaram sarampo e broncopneumonia, se encontravam em estado critico de subnutrição e foram encaminhados a hospitais que não tinham remédios para tratá-los. O resultado: quase todos morreram.

Novo modelo de política indigenista foi institucionalizado, cada vez mais atrelado às políticas de desenvolvimento, com as seguintes bases:

A administração de BM durou de junho de 1970 a março de 1974. Nesse período, um novo modelo de politica indigenista foi institucionalizado no Brasil. Seus principais objetivos eram: 1) integrar os índios, o mais rápido possível, à economia de mercado em expansão e à estrutura de classes no Brasil; e 2) garantir que os índios não ofereceriam obstáculos à ocupação e colonização da Amazônia (DAVIS: 1978:88) (grifos nossos).

“O Índio e a ocupação da Amazônia” documento assinado por 80 etnólogos, antropólogos, sociólogos e historiadores brasileiros (14/julho/1971), declarava:

Ao longo de toda a historia do Brasil, das épocas coloniais mais distintas ao dia de hoje, os esforços de "integração" do índio constituíram o objetivo essencial e quase único da politica indigenista oficial. Em todas as épocas, a "integração" do índio foi promovida por meio de guerras justas e pacificação forçada, por dizimação, trabalho forçado, conversão religiosa e muitas outras técnicas que foram ou continuam a ser imaginadas ou sugeridas pelos setores interessados.... O índio continua a ser, hoje como sempre, objeto dos mesmos esforços “integracionistas”(DAVIS:1978:89).

O contexto da construção da rede rodoviária transamazônica e os grupos indígenas:

Vários fatores explicam a rapidez com que o Brasil foi capaz de construir essa rede de estradas através da BA. (...) O papel que o DNER assumiu no planejamento do maciço programa brasileiro de construção de estradas. O DNER foi reorganizado em 1969 e imediatamente, começou a traçar planos para a integração de toda a rede rodoviária federal. Construção de estradas e linhas de comunicação: principal objetivo do DNER, segundo o Ministro dos Transportes: era "formar uma rede unificada de estradas na qual seriam levados em conta os interesses civis e militares visando a 
integração nacional". Batalhões de engenharia do Exercito brasileiro construíram as estradas... (DAVIS:1978:90) (grifos nossos).

(...) nos últimos anos o Governo brasileiro tem sido extremamente bem-sucedido na obtenção de empréstimos internacionais para financiar seu programa de construção de rodovias federais. Os recursos são provenientes do Fundo do Brasil e da Agencia para o Desenvolvimento Internacional (US AID).

No final da década de 60, porém, o Governo brasileiro começou a depender mais de empréstimos internacionais para seu programa de construção de estradas. Entre 68 e 72, o DNER recebeu um total de 400 milhões de dólares em empréstimos do BIRD e BM. Esses foram os maiores empréstimos já feitos a qualquer país para a construção de estradas na historia do BM, sendo um fator decisivo para o rápido crescimento da rede rodoviária brasileira.

(...) A assistência técnica estrangeira foi extremamente importante na construção da rede rodoviária transamazônica. Uma das principais áreas dessa assistência técnica foi o fornecimento de técnicas modernas de fotografia aérea e reconhecimento por satélite. Já em 1968, a US AID fornecia uma subvenção de 8,4 milhões de dólares ao governo brasileiro para que este participasse do Programa de Satélites de Observação de Recursos da Terra (Earth Resources Observation Sattelite Program EROS) dos EUA. Em 1970, o Governo brasileiro anunciou o Projeto RADAM (Radar Amazônia), um gigantesco esforço para fotografar e mapear a BA. A maior companhia estrangeira envolvida no projeto RADAM era a Divisão de Serviço Aéreo da Litton Industries dos EUA (DAVIS:1978:91) (grifos nossos).

Em colaboração com a Goodyear Corporation e vários órgãos governamentais e firmas brasileiras, a Litton realizou um mapeamento aéreo detalhado de toda a hidrologia, geologia, geografia, distribuição de florestas e vegetação da BA. Realizou em menos de um ano o que levaria um quarto de

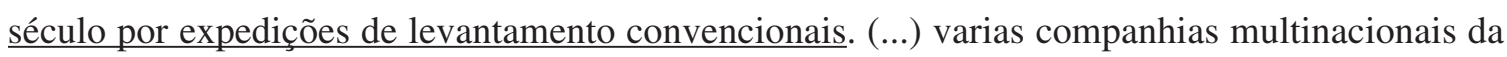
Europa e dos EUA forneceram ao governo brasileiro equipamento pesado de terraplanagem para a construção de estradas amazônicas. Um executivo da Caterpillar do Brasil disse a um repórter (...) que "nosso mercado crescerá, (...) mais rápido que o PNB de um país, dependendo de como esse país aloca seus recursos. Isso é particularmente verdadeiro no Brasil, onde tanto está sendo feito em estradas, aeroportos, mineração e projetos hidrelétricos.” (DAVIS: 1978:92) (grifos nossos).

Em contrapartida a situação vivida pelos Parakanan. Davis afirma a esse respeito, por meio da declaração de Cotrim, um dedicado indigenista da FUNAI, que vivia o contexto da construção da Rodovia Transamazônica: que nos primeiros contatos (anos 50), contexto anterior, o da construção da Rodovia do Tocantins, com os índios Parakanan, 50 índios morreram de gripe (...); em 1970 o governo brasileiro revelou que a rodovia transamazônica atravessaria o território 
Parakanan (...); após a pacificação mais 40 índios foram atacados por gripe (...) (DAVIS:1978:93); em 1971, (...) os trabalhadores da transamazônica invadiam o território Parakanan, embora uma reserva indígena tivesse sido supostamente decretada, para protegê-los (...). Os trabalhadores deram presentes aos homens e violentaram varias índias. (...) Agentes da FUNAI também teriam praticado violência sexual contra as índias; Em 1971, o medico Antonio Madeiros visitou uma aldeia Parakanan (...) e relatou que havia um quadro de promiscuidade entre os índios e gente de fora; (...) descobriu que 35 índias e 2 agentes da FUNAI tinham doenças venéreas; (...) 8 crianças nasceram cegas e 6 morreram de disenteria; (...) Em 1972 outra epidemia de gripe atacou a tribo (...); Uma equipe medica foi levada às pressas para a aldeia, mas foi de pouca valia pela falta de remédios e suprimentos suficientes, e vários índios morreram(1978:94);Em maio de 1972 um dos mais dedicados agentes indigenistas do Brasil Antonio Cotrim Soares abandonou a FUNAI. (...)(1978:94). Cotrim tinha uma posição importante na frente da Transamazônica, mas se aborreceu com a falta de apoio da FUNAI a ele a outros experientes agentes indigenistas. declarou a imprensa que a infecção da tribo Parakanan não foi um incidente isolado. Representava, segundo ele, parte de um quadro brutal que passara a caracterizar a situação de quase todas as tribos recentemente contatadas ao longo de estradas transamazônicas. (...) O mais importante é que as denuncias de Cotrim destacavam as diretrizes econômicas que passavam cada vez mais a caracterizar a política indigenista do Brasil. "Estou cansado", disse Cotrim ao se demitir da FUNAI, em maio de 1972, “de ser um coveiro de índios... Não pretendo contribuir para o enriquecimento de grupos econômicos à custa da extinção de culturas primitivas." Segundo Cotrim, os direitos dos índios estavam sendo sacrificados no Brasil em prol de projetos rodoviários e de desenvolvimento. Afirmava ser impossível proteger esses direitos quando o Ministério do Interior tinha a responsabilidade pelo desenvolvimento do interior, sendo ao mesmo tempo a autoridade que controlava os assuntos indígenas. Os Parakanan foram reduzidos a 80 pessoas. (1978:95) (grifos nossos).

Um breve relance com os Kréen-Akaróre e a atitude dos militares brasileiros:

A primeira tentativa seria de contato com a tribo ocorreu em 1967, quando um pequeno bando Kréen-Akaróre foi visto perto da Base Aérea do Cachimbo. A presença dos índios causou uma onda de histeria no pessoal militar da base e uma esquadrilha de caças vasculhou a selva à procura da tribo. Essa atitude deixou Orlando Villas Boas furioso. Ele explicou que o medo dos militares diante dos índios era totalmente infundado. Os Kréen-Akaróre aproximaram-se da base por curiosidade, como indicava o fato de estarem acompanhados por mulheres e crianças, e haverem deixado arcos, 
flechas e cestos numa das extremidades da base. Foi citada na época a seguinte declaração de Orlando Villas Boas: Basta gritar “Índio!” e todo mundo enlouquece. Os civilizados atiram. Voam de avião sobre a selva toda. Um brigadeiro é fotografado atrás de uma metralhadora... . (DAVIS: 1978:97).

Por fim Davis demonstra como foram dizimados os Kréen-Akaróre.

Acelerando o processo da denominada "integração nacional":

A dizimação das tribos Parakanãn e Kréen-Akaróre descrita neste capitulo foi um conjunto de incidentes isolados, mas fez parte de um esquema mais amplo de destruição étnica que desde 1970 incluía toda a Região Amazônica do Brasil. Entre 1970 e 1974, o Governo brasileiro tentou acelerar o processo de "integração nacional" construindo uma serie de estradas que cortavam os parques e reservas indígenas. Os efeitos traumáticos e desastrosos desse programa de "integração", sobre as tribos indígenas, foram documentados nos relatórios da Cruz Vermelha Internacional, da Survival International, e da Aborigenes Protection Society (APS) sobre a politica indigenista do Brasil (DAVIS:1978:101) (grifos nossos).

Estradas planejadas para passar propositalmente por dentro de quase todas terras indígenas: Mais recentemente, Edwin Brooks, geografo e um dos membros da equipe da APS, publicou vários artigos sobre o alcance e as consequências das invasões, pelas estradas, de áreas indígenas da BA. Um desses artigos intitulava-se "A Estrada Brasileira para o Etnocídio". Continha uma serie de mapas federais, estaduais e territoriais mostrando estradas planejadas para passar dentro de quase todos os parques e reservas indígenas da Amazônia brasileira. Repetindo as conclusões do relatório da APS, Brooks escreveu que "quando estão em jogo os interesses do desenvolvimento, as Reservas Indígenas mal valem os mapas nos quais estão traçadas" (DAVIS: 1978:103) (grifos nossos).

Crescimento econômico x Destruição das populações aborígenes:

Para muitos jornalistas e escritores populares, a expulsão de tribos indígenas causada por essas estradas era o custo trágico, mas inevitável, do "progresso econômico" do Brasil. De acordo com esses escritores, a destruição das populações aborígenes da BA era uma consequência triste, mas necessária, de uma sociedade tecnológica extremamente avançada, experimentando um rápido crescimento econômico.

Infelizmente, essa posição, que só contém uma parcela de verdade, tem obscurecido qualquer compreensão genuína, pelo publico em geral, da natureza da política indigenista do Brasil. O exemplo do 
Parque Nacional do Xingu é um caso concreto em que, até recentemente, mais de uma dúzia de tribos indígenas foram protegidas contra os perigos das frentes de expansão, e na qual os índios encontraram condições medicas e uma base territorial para viver. A BA é uma área geográfica tão vasta que outros parques e reservas indígenas poderiam ter sido criados seguindo o modelo do $\underline{\text { Parque Nacional do Xingu. O Governo brasileiro, em outras palavras, poderia ter intervido para }}$ proteger essas áreas indígenas contra intromissões externas, e poderia ter planejado as estradas e projetos de desenvolvimento de modo a não ameaçar a integridade territorial das tribos indígenas. Durante um breve período em 1968, parecia que esta seria politica da FUNAI. Em 1970, porém, novas diretrizes de natureza integracionista e desenvolvimentista começaram a dominar a política indigenista brasileira, e varias tribos, tais como os Parakanãn e Kréen-Akaróre, foram expulsas e destruídas.

Entre 70 e 74 , a política indigenista brasileira tornou-se cada vez mais comprometida com a política global de desenvolvimento econômico do regime militar brasileiro. Durante esse período, a FUNAI passou a ser a principal cumplice nos processos de etnocídio desencadeados contra as tribos da BA. $\underline{\text { Para definir a situação nos termos mais simples, pode-se dizer que sua politica indigenista "reforma- }}$ da" acelerou, em vez de deter, os processos de destruição étnica que caracterizam tão amargamente a historia das frentes de expansão do Brasil.

Obviamente, é necessário fazer uma analise mais profunda dos motivos subjacentes às políticas indigenista e de desenvolvimento da Região Amazônica do Brasil. Pode-se perguntar por que o Governo brasileiro optou pela construção dessas estradas a um custo humano, social e cultural tão elevado. Ou, mais concretamente, para quem essas novas estradas estavam realmente sendo construídas, e por que era necessário que elas cortassem os parques e as reservas indígenas (DAVIS: 1978:103-4) (grifos nossos).

Eduardo Galvão, antropólogo brasileiro, citado em "Progress, Indians Collide in Brazill", Los Angeles Times, 26 de abril de 1973, citado por Davis afirma:

A invasão do Parque Indígena Aripuanã

A área do Parque Indígena Aripuanã possui um dos mais ricos depósitos de estanho do mundo, e há grandes companhias nacionais e internacionais de mineração ansiosas para entrar nele. Não estão dispostas a esperar 5, 10 ou 20 anos enquanto os índios são contatados, pacificados e preparados para a integração em nossa sociedade. O Brasil esta tentando acelerar o processo de contato com os índios, mas não sabemos para onde ir.

Em relatório da Aborigines Protection Society (APS) de Londres, (...) é descrita uma seria ameaça aos índios que resultava da ausência de uma politica territorial coerente por parte da FUNAI. $\underline{\mathrm{O}}$ relatório da APS observava que o sistema de reservas da FUNAI tendia a diminuir as terras indígenas e ameaçava a integridade biológica e cultural das tribos. Pela lei, lembrava o relatório da APS, 
os parques e reservas indígenas pertenciam ao Governo brasileiro como parte do chamado Território Indígena e não podiam ser vendidos ou arrendados pela FUNAI. Além disso, muitas tribos nem sequer viviam em parques e reservas indígenas bem definidos, e estavam sendo expulsas por companhias agrícolas e de mineração interessadas em conquistar a posse das terras dos índios. "A não ser que se faça cumprir uma lei salvaguardando suas terras de origem", escrevia a equipe da APS em 1973, "os índios serão varridos pela frente de avanço da colonização e da exploração econômica" (DAVIS: 1978:105-6) (grifos nossos).

Antes da construção da Transamazônica, os principais agentes econômicos que ameaçavam a integridade territorial das tribos indígenas eram pequenos seringueiros, castanheiros, garimpeiros, roceiros, caçadores e negociantes. $\underline{\mathrm{O} \text { novo programa rodoviário e de desenvolvimento da Amazônia }}$ introduziu dois elementos econômicos adicionais ao longo das frentes de expansão do Norte e Oeste do Brasil. O primeiro foi o próprio Governo brasileiro, o qual, como vimos anteriormente, iniciou um programa maciço de construção de estradas, exploração mineral, e colonização agrícola na $\underline{\text { Região Amazônica. O segundo elemento foi um bom numero de empresas privadas, estatais e }}$ multinacionais que queriam ganhar acesso aos grandes recursos agrícolas, minerais e madeireiros da região. A presença de ambos elementos refletia uma transformação econômica mais ampla que estava acontecendo em todo o Brasil. Devido a essa transformação, houve varias mudanças importantes na politica da FUNAI quanto às terras e recursos indígenas.

Um das principais áreas em que a FUNAI acomodou sua politica de terras aos interesses desses novos elementos econômicos foi na vasta região de selva ao longo dos rios Aripuanã e Roosevelt. De acordo com os relatos etnológicos, em certa época havia mais de 10 mil nativos nessa área, vivendo em mais de 100 aldeias. Durante quase um século, as tribos dessa região haviam lutado com sucesso contra os seringueiros e garimpeiros que, de tempos em tempos, tentavam invadir suas terras. № inicio da década de 60, grandes companhias imobiliárias brasileiras começaram a se interessar pelas terras da região do Aripuanã. Uma delas era a firma de borracha Arruda e Junqueira, que mantinha muitos postos no território de Rondônia.

Em 1963, um homem chamado Francisco de Brito, que trabalhava para a Arruda e Junqueira, organizou um bando de garimpeiros e pistoleiros para expulsar os Cintas-Largas de suas terras. Esse incidente (...) ficou conhecido como o "Massacre do Paralelo Onze", Brito alugou um avião para atacar as aldeias Cintas-Largas. (...) O avião com Brito e seus capangas (...) jogou pacotes de açúcar sobre os índios. Em seguida, o avião deu uma rasante e começou a dinamitar a aldeia. Ninguém sabe exatamente quantos índios foram mortos nesse ataque. Alguns, porem, escaparam, e outra expedição foi organizada para exterminar a tribo.

Os detalhes sangrentos dessas tentativas de extermínio dos Cintas-largas, assim como a rápida e infrutífera investigação do massacre pelo Governo, foram descritos no artigo de Norman Lewis, "Genocídio - de Fogo e Espada a Arsênico e Balas, a Civilização extinguiu Seis Milhões de Índios”. 
Valiosos depósitos minerais foram o motivo de dizimação da tribo. Lewis escreveu que a tragédia dos Cintas-largas "era a de que depósitos de metais raros estivessem sendo descobertos na área. Não estava claro que metais eram esses. Foi imposto um gênero de silencio de segurança, só esporadicamente atravessado por vagas noticias sobre as atividades de companhias americanas e europeias, e sobre o contrabando de cargas dos mesmos metais raros para os EUA" (DAVIS: 1978:107-8) (grifos nossos).

(...) Ataide Pereira que fez parte da expedição com Brito, contou os detalhes a um padre jesuíta: Levamos seis semanas para achar os Cintas-Largas e uma semana para voltar... Chico (apelido de Brito) encontrou alguns minérios e os levou de volta para agradar à companhia. $\underline{O}$ fato é que os

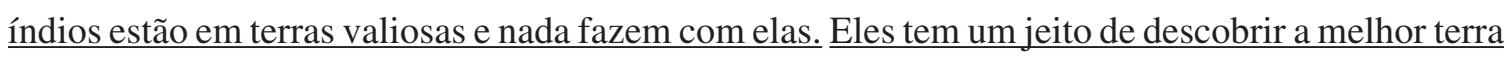
para plantar e também estão ali todos aqueles minérios valiosos. É preciso convencê-los a ir embora, e se nada mais resolver, então terá que ser pela força.

Outra testemunha afirmou: Não é a primeira vez que a firma Arruda e Junqueira comete crimes contra os índios. Várias expedições foram organizadas no passado. Essa firma age como fachada para outras empresas interessadas em adquirir terras, ou que planejam explorar os ricos depósitos minerais existentes nessa área.

Fins da década de 60 (...) grandes depósitos de cassiterita, elemento chave na produção de estanho, haviam sido descobertos no Território de Rondônia. Em 1967, por exemplo, o Christian Science Monitor publicou um artigo intitulado "Brasil torna-se autossuficiente em estanho". Esse artigo descrevia como, na década anterior, uma vasta frente de mineração fora aberta no Território de Rondônia. Segundo a mesma fonte, grandes companhias internacionais haviam instalado modernas operações de mineração mecanizada em Rondonia, e aos poucos estavam tornando o Brasil autosuficiente em estanho. Várias empresas estavam explorando, uma das maiores era americana. Em 1968, um grande incentivo foi dado a essa frente de mineração quando o Batalhão de Engenharia do Exercito completou uma estrada de $300 \mathrm{~km}$ entre Cuiabá e Porto Velho. A principal ajuda financeira e técnica veio da Agencia para o Desenvolvimento Internacional dos EUA(US AID) que emprestou ao Brasil 2,6 milhões de dólares, como parte da "Aliança para o Progresso", a fim de construir 14 pontes permanentes ao longo da estrada. No final da década de 60, informava-se que 50 veículos pesados entravam e saiam de Porto Velho diariamente. Eram, na maioria, caminhões carregando cassiterita para as fabricas e fundições de estanho no Sul do Brasil. (DAVIS: 1978:108-9) (grifos nossos).

A reserva de mercado às grandes corporações:

Desde o inicio do boom do estanho em Rondônia uma serie de problemas começou a surgir entre as novas companhias de mineração e os garimpeiros que antes dominavam a economia da região. Até o final da década de 60, o Território de Rondônia era uma típica frente de expansão brasileira, relati- 
vamente livre de controle policial e governamental, e infestada de crimes, prostituição e fraudes imobiliárias. Em abril de 1970, o Departamento Nacional de Produção Mineral (DNPM), agencia que coordena as licenças de mineração no Brasil, obteve um decreto que tornava ilegal a prospecção individual em Rondônia. Em consequência desse decreto, em março de 1971 todas as atividades de mineração no Território já estavam nas mãos de grandes firmas nacionais e internacionais. 1500 garimpeiros, em Rondônia, eram empregados dessas novas companhias, e mais de 2000 foram intimados pelo Governo federal a deixar o Território.

Em outras palavras, no inicio da década de 70 já haviam ocorrido varias mudanças importantes na estrutura econômica de Rondônia. Essas mudanças faziam parte de uma transformação mais ampla no $\underline{\text { setor de mineração do Brasil e refletiam a nova simbiose, a nível nacional, entre Governo militar e }}$ grandes corporações multinacionais. Os efeitos dessas mudanças foram imediatamente sentidos pelos membros remanescentes das tribos Cinta-Larga e Suruí (DAVIS: 1978:109-10) (grifos nossos).

Dá com uma mão e tira com a outra: Reúnem os indígenas no Parque Indígena Aripuanã e os massacram:

Em seguida a publicidade em torno do "Massacre no Paralelo Onze", o Governo brasileiro prometeu que iria intervir no Território de Rondônia para proteger as tribos indígenas. Em 1967, (...) o Governo anunciava a criação do Parque Indígena Aripuanã/PIA, (...) para proteção dos Suruí e Cinta-Larga. Numa carta oficial ao Presidente do Brasil, após a criação do PIA, o Ministro do Interior Jose Costa Cavalcanti, afirmou que esses depósitos minerais eram de "grande importância" para o desenvolvimento nacional, mas estavam sendo ameaçados por exploradores individuais que realizavam atividades de prospecção dentro dos limites do Parque. A carta do ministro alegava que, sob a direção da FUNAI, os direitos de propriedade dos índios seriam respeitados, mas sem o abandono daquelas importantes fontes de riqueza mineral.

Então em dezembro de 1971, a imprensa brasileira publicou uma serie de matérias sobre um suposto "levante indígena" no PIA. Quando surgiu a primeira informação sobre esse incidente, sabia-se que dois funcionários da FUNAI haviam sido mortos.

O presidente da FUNAI, General Oscar Jerônimo Bandeira de Mello, culpou certos membros "hostis" da tribo Cinta-Larga pelos assassinatos. De acordo com o general, os agentes indigenistas haviam tentado varias vezes contatar e pacificar os Cinta-Larga, mas os índios recusaram os presentes e tomavam uma atitude beligerante contra a presença de agentes do governo em suas terras. Numa entrevista coletiva especial sobre o ataque dos Cinta-Larga, o Ministro Costa Cavalcanti fez as mesmas alegações. Os índios segundo ele eram por natureza um "povo nômade" e o incidente resultara de sua "ignorância geográfica" da região. Uma unidade militar especial revelou o ministro, havia sido despachada para manter a ordem e proteger os colonos na área do entorno do PIA. 
No período entre dezembro de 1971 e a primavera de 1972, uma historia inteiramente diferente do incidente surgiu nas paginas da imprensa brasileira. Parece que, desde a criação do PIA, em 68, a FUNAI e outros órgãos do Ministério do Interior autorizaram companhias de prospecção mineral e de colonização a entrarem no parque. Uma grande companhia, a firma Itaporanga, propriedade da

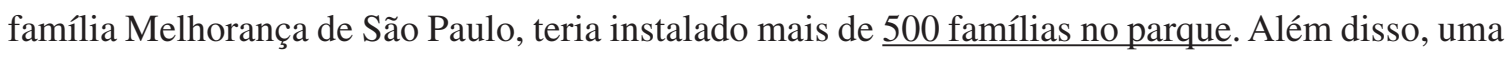
companhia de exploração mineral recebera licença para fazer prospecção na área. Durante meses, antes do suposto "levante indígena", de acordo com os relatos na imprensa brasileira, os chefes $\underline{\text { Cinta-Larga comunicaram aos agentes indigenistas seu descontentamento com essas usurpações em }}$ seu território, e varias mensagens haviam sido enviadas aos escritórios centrais da FUNAI em Brasília, rogando pela proteção do parque.

Em março de 72, Apoena Meirelles, diretor do PIA, enviou uma carta formal a FUNAI descrevendo como os colonos haviam invadido o parque, causando choques sangrentos com os índios e levando doenças infecciosas. Meirelles contou a imprensa brasileira que a FUNAI nada fez para remover esses colonos do parque, nem deu permissão para que ele, como seu diretor, o fizesse. Meirelles afirmou: "Em menos de 4 anos, as terras dos Cinta-Larga e Suruí foram alienadas. As epidemias já deixaram sua marca, e as tribos já deram os primeiros passos na longa estrada para a miséria, a fome e a prostituição de suas mulheres... . Eu prefiro morrer lutando ao lado dos índios em defesa de suas terras e seus direitos do que viver para amanha vê-los reduzidos a mendigos em suas terras" (DAVIS: 1978:111-3) (grifos nossos).

\section{Outros depoimentos:}

Em agosto de 72, a equipe da APS visitou o posto de atração Sete de Setembro da FUNAI, no PIA. $\underline{\text { A }}$ equipe descobriu que os limites originais do parque haviam sido severamente reduzidos, que sua antiga fronteira meridional estava sendo ocupada por uma nova estrada, e que uma companhia paulista de desenvolvimento estava levando colonos para a região. Em seu relatório, a APS escreveu:

"A cessão dessa imensa fatia de terra excelente parecia ser o exemplo mais recente de abandono de $\underline{\text { terras indígenas a colonizadores de fora. Só descobrimos isso comparando vários mapas. O caso }}$ parecia tão ruim quanto os piores exemplos da pratica que alcançou proporções escandalosas nos últimos dias do SPI."

Outro relatório de Jean Chiappino, medico francês que passara vários meses entre os Cinta-larga e Surui, numa mensagem que enviara a $8^{\circ}$ Delegacia Regional da FUNAI em Porto Velho, Chiappino afirmava que os Surui (...) estavam em situação extremamente critica e haviam sido praticamente dizimados pela tuberculose. Desde julho de 72, observava, 20 índios haviam morrido, e muitos outros, inclusive Dikboba, o chefe da tribo, estavam em estado grave. Mais de $40 \%$ da tribo sofriam de infecções pulmonares, e muitos índios haviam fugido para a selva a fim de escaparem das condi- 
ções opressivas do posto indígena. Chiappino salientava a necessidade de uma ação medica por parte da FUNAI e rogava que se procurasse ajuda da Cruz Vermelha Internacional.

O mais serio, assinalava Chiappino em novembro de 72 , era que sete grandes companhias desenvolviam atividades de exploração mineral no PIA, lançando uma ameaça critica, do ponto de vista $\underline{\text { social e medico, à tribo dos Cinta-larga, a mais numerosa. }}$

Todas essas companhias tentavam lucrar com o novo boom da cassiterita em Rondônia e haviam recebido autorização da FUNAI para fazer prospecção no PIA.

Outro relatório mais detalhado de Chiappino, mostra que, apesar de suas advertências à FUNAI, a epidemia de tuberculose que ele inicialmente detectara havia atingido todos os grupos etários na tribo Suruí, matando os índios no curto espaço de 2 meses. (...) Chiappino alega que a expansão dessa epidemia "desesperava, desorientava e destruía” as famílias indígenas e o grupo social. De acordo com seus cálculos, só essa epidemia afetou mais de $60 \%$ da população Suruí observada.

Em seu relatório, Chiappino também descreve suas tentativas de controlar a epidemia ministrando um $\underline{\text { tratamento antituberculose, mas conta como o pequeno e incompetente staff medico da FUNAI o }}$ atrapalhava. Ele alega que a presença de certos casos de hepatite entre os Suruí era devida ao pessoal medico da FUNAI, que não tomava sequer as mínimas precauções para aplicar injeções nos índios. (...) O mais significativo, segundo Chiappino, é que na época de sua despedida do Brasil não havia indícios de que a FUNAI houvesse criado uma política para a proteção dos recursos e das terras dos índios. Ao contrario, os colonos e as companhias de mineração continuavam a invadir o PIA. Vários campos de pouso haviam sido construídos na área. A escassez de caça estava chegando a um ponto critico. De acordo com Chiappino, a existência de tais condições era um resultado lógico das políticas de terras e de arrendamento da FUNAI (DAVIS: 1978:113-6) (grifos nossos).

O olhar da mídia especializada, das empresas e do governo brasileiro sobre a questão:

Em fevereiro de 1972, o Engineering and Mining Journal, luxuosa publicação mensal da indústria internacional de mineração, trazia um artigo intitulado: "A Bacia Amazônica - Nova Província Mineral para os anos 70". De acordo com esse artigo, mais de 50 corporações internacionais já $\underline{\text { estavam envolvidas em projetos de desenvolvimento de mineração na BA, atraídas pelos incentivos }}$ fiscais, pela estabilidade política do Brasil e pela ajuda do Governo brasileiro à prospecção. $\mathrm{O}$ mesmo artigo afirmava:

A BA do Brasil, virtualmente impenetrável e intocada pela tecnologia moderna, está hoje entrando em cena como uma das mais promissoras províncias minerais não-desenvolvidas do mundo... . Embora a maioria dos grandes empreendimentos de mineração provavelmente vá terminar sob o controle brasileiro, estatal ou privado, as companhias estrangeiras em geral estão ávidas por qualquer fatia do bolo que puderem conseguir (DAVIS: 1978:116-7) (grifos nossos). 


\section{Conclui Davis:}

O novo boom da Amazônia serve como base para entender a recente política indigenista do Brasil. Quando o programa Transamazônica foi iniciado, em 1970, o papel da FUNAI era sobretudo pacificar as tribos indígenas. Mais recentemente, com essas rodovias prontas, ou quase, a FUNAI foi requisitada, em geral contra os desejos de suas lideranças e de vários agentes indigenistas dedicados, para abrir caminho às companhias multinacionais e estatais interessadas em ganhar acesso aos recursos naturais da BA. Basicamente, a resposta da FUNAI a esse novo desafio foi simples. Nos últimos anos ela institucionalizou uma política, semelhante àquela praticada pelo Escritório de Assuntos Indígenas dos EUA, de arrendar os ricos recursos minerais contidos nas terras dos índios. (...) Atualmente essa política de arrendamento constitui uma das maiores ameaças à permanência da integridade territorial e à sobrevivência das tribos brasileiras. (DAVIS: 1978:117).

Em maio de 1973 (...) num artigo de Max White, intitulado "Sondando a desconhecida BA - Uma investigação de 21 programas de exploração mineral no Brasil" apareceu na revista Engineering and Mining Journal. O artigo descrevia 21 projetos geológicos e de mineração iniciados na BA como parte de um programa de cooperação entre o DNPM, a Cia. de Pesquisa de Recursos Minerais e o Geological Survey dos EUA, sob o patrocínio do Governo brasileiro e da Agência para o Desenvolvimento Internacional dos EUA(US AID). De acordo com White, naquela data, já havia 225 geólogos e engenheiros realizando investigações minerais na Amazônia (DAVIS: 1978:118).

A herança social da relação simbiótica entre Grupos Econômicos e Estado Militar foi a resultante Política Indigenista implementada pela FUNAI, no período da ditadura militar. As praticas desenvolvidas pela sociedade dominante à respeito das populações indígenas, fundamentalmente os implicados com interesses nas terras de ocupação indígena, acabaram por desenvolver, utilizando "o aparato de imposição da ordem" do Estado, uma "política indigenista de Estado", que se resumiu declaradamente a integrar o índio à sociedade nacional, e, no entanto, as práticas efetivamente adotadas, foram de exterminar cultural e fisicamente ou expulsar das terras de interesse, e quando na fronteira, como o caso dos Guarani, foi de expulsar do território nacional.

Dessas visões, todas marcadas pelo etnocentrismo, derivaram as seguintes alternativas: $\mathrm{Ou}$ a tentativa de integração à sociedade nacional, política indigenista de Estado, em que imaginavam que integrar-se-iam os indígenas à sociedade majoritária, perdendo dessa forma seus direitos à terra, liberando-as, portanto, e os tornariam mão de obra barata a serviço do capital; essa alternativa representa o etnocídio, ou seja, contribuir para eliminar os laços culturais que mantêm coeso o agrupamento social indígena, ou seja, dispersá-los da convivência intra-grupal no interior de suas próprias terras. 
Essa alternativa representou a política indigenista "declarada" no período da ditadura militar. Shelton Davis (1978:118) sob o subtítulo a "A política indigenista e a frente de expansão da mineração na Amazonia", descreve respectivamente os discursos dos responsáveis pela política indigenista estatal no período:

Minha tarefa será de integrar o índio a sociedade nacional porque é impossível deter o processo de desenvolvimento do país com o argumento de que os índios deveriam ser protegidos e mantidos em seu estado puro. (Declaração do General Ismarth de Araujo Oliveira, Presidente da FUNAI).

Esta é uma promessa que posso fazer com firmeza: vamos criar uma política de integração da população indígena na sociedade brasileira o mais rapidamente possível (...). Pensamos que os ideais de preservação da população indígena em seu próprio habitat são muito bonitos, mas irreais. (Declaração de Mauricio Rangel Reis, Ministro do Interior do Brasil, março 1974).

A FUNAI no período descrito era subordinada ao Ministério do Interior, ou seja, a mesma instituição publica responsável pela condução dos projetos de desenvolvimento. Daí para subordinar a política indigenista aos interesses econômicos, foi um passo, ou melhor, uma estratégia.

Integrar o índio á sociedade nacional, implicava juridicamente pelo Estatuto do Índio - Lei n. 6001 de 19.12.1973, lei criada sob o regime da ditadura militar, a sua liberação do regime tutelar $^{90}$, o qual protegeria os indígenas, inclusive quanto aos seus direitos territoriais. Não poucas vezes, indígenas que se rebelaram contra a ordem estabelecida durante a ditadura militar, eram considerados por decreto, "integrados".

Outra alternativa efetivamente utilizada foi conduzir o processo por meio do extermínio físico, apelando para o genocídio, que segundo o dicionário Aurélio ${ }^{91}$ informa, significa no caso:

Crime contra (...) um grupo étnico, que consiste em destruir total ou parcialmente, cometendo contra ele, atos como: matar seus membros, causar-lhes graves lesões à integridade física ou mental, submeter o grupo à condições de vida capazes de, os destruir fisicamente, no todo ou em parte, adotar medidas que visem evitar nascimentos no seio do grupo.

Exemplos disso não faltaram, Davis (1978) cita vários casos nesse sentido, desde a: sugestão desta pratica no Congresso brasileiro no início do século XX; ás suas próprias declarações (1978) por ex: a decisão de certas mulheres indígenas de abortar a ter que sujeitar os filhos ao que

\footnotetext{
$\overline{{ }^{90} \text { Sobre o }}$ assunto ver Estatuto do Índio - Lei n. 6001 de 19.12.1973 Artigos: 4: parágrafos II e III, 7., 9., 10. e 11.

${ }^{91}$ FERREIRA, Aurélio Buarque de Holanda. Novo Dicionário Aurélio. Rio de Janeiro: Editora Nova Fronteira. $2^{\mathrm{a}}$ edição, 1986, p. 845.
} 
estavam vivendo; aos dados levantados pelo Relatório Figueiredo; ao caso do "Massacre no Paralelo Onze"; a declaração dos bispos da Amazônia etc.

Outra alternativa efetivamente utilizada foi expulsar os indígenas de suas terras e/ou território, e aí é uma solução que apela para o esbulho, como foi o caso dos Guarani em todo Oeste paranaense, o que significou redução de terras e/ou território e expulsão de parte da população para o Paraguai.

A Bacia Amazônica: implicações para a política externa dos Estados Unidos no Brasil

Estamos em desacordo com as repetidas declarações do Ministro do Interior, de que "o problema indígena é um problema do Brasil", e que "outros países nada tem a ver com o problema do índio brasileiro". O erradamente chamado "problema do índio" é um problema da humanidade, um problema cujas causas e motivações talvez sejam mais conhecidas em países onde há liberdade de discussão e de informação do que no Brasil.

Em última analise, há milhões de seres humanos nas Américas, e centenas de milhares no Brasil, que, por séculos, vêm sofrendo a mais grave das injustiças inflingidas por uma "raça" que se diz superior. $\underline{\text { Se a consciência da humanidade fosse igual ao volume de informação, uma situação tão iníqua não }}$ $\underline{\text { seria mais tolerada. }}$ O "problema do índio" no Brasil não pode ser compreendido, e muito menos resolvido, se não for situado em seu contexto internacional. (DAVIS: 1978:191) (grifos nossos).

Por fim Davis analisa o contexto internacional:

Três novos fatores transformaram a natureza do fenômeno das frentes de expansão no Brasil desde o movimento militar de 1964 e o anuncio da Rodovia Transamazônica, em 1970. O primeiro deles é o papel estratégico que o Governo brasileiro vem desempenhando na abertura e na colonização da

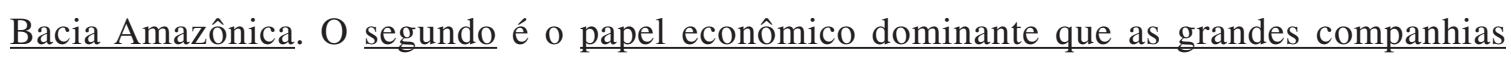
multinacionais e estatais têm assumido na exploração dos ricos recursos minerais, madeireiros e

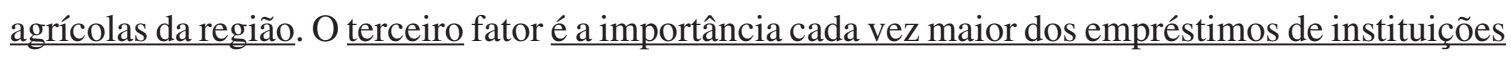
internacionais de credito e bancos estrangeiros no financiamento de projetos de infraestrutura na Amazônia (DAVIS:1978:192-3) (grifos nossos).

Ao longo da ultima década, surgiu no Brasil uma nova associação entre um Governo militar altamente repressor, mas voltado para o desenvolvimento, várias firmas multinacionais e estatais, e diversas instituições internacionais de credito, tais como o Export-Import Bank, o Banco Interamericano de Desenvolvimento e o Banco Mundial. Essa nova associação, que não é exclusividade no Brasil, acelerou o ritmo da expansão econômica para as ultimas áreas de refugio habitadas por tribos indígenas, e começou a substituir as várias fronteiras econômicas, diversas, mas todas relativamente atrasadas, as quais Darcy Ribeiro foi o primeiro a analisar em seu ensaio de 1957. (...) 
Três consequências importantes resultaram da presença desses novos parceiros na parte brasileira da Bacia Amazônica (DAVIS:1978:193) (grifos nossos).

Em primeiro lugar, desde 1970 a Fundação Nacional do Índio vem institucionalizando um novo tipo de política indigenista consistentes com os objetivos mais amplos de desenvolvimento econômico traçados pelo regime militar brasileiro, embora tais objetivos tenham um efeito devastador para as $\underline{\text { tribos indígenas brasileiras. Na qualidade de órgão do Ministério do Interior, as metas principais da }}$ politica da FUNAI tem dois aspectos: primeiro, integrar as tribos indígenas à sociedade nacional brasileira o mais rápido possível; e, segundo, garantir que essas tribos não sirvam de obstáculo ao progresso nacional e ao desenvolvimento econômico. Talvez a principal área em que essas metas se refletem seja o Estatuto Brasileiro do Índio. Transformado em lei em dezembro de 1973, ele dá à FUNAI o direito de deslocar índios para fora de seus territórios tribais tradicionais, por motivos de segurança nacional e desenvolvimento. Além disso, autoriza esse órgão oficial do Governo, sob a $\underline{\text { rubrica de "renda indígena", a arrecadar reservas minerais, madeireiras e agrícolas pertencentes aos }}$ índios. (DAVIS: 1978:193-4) (grifos nossos).

Apesar de a Constituição Federal de 1988 ter suplantado varias determinações do Estatuto do Índio, fundamentalmente as de características integracionistas, o próprio Estatuto do Índio não foi até hoje revisto, apesar de inúmeras proposições ao Congresso Nacional. Não é raro, juízes se "agarrarem" às normas antiquadas desse Estatuto.

Davis ainda concluindo:

Em vários casos, mostramos como a FUNAI foi forçada a sacrificar os direitos dos índios sobre a terra, em beneficio dos grandes interesses econômicos, dos programas rodoviários estatais, dos projetos de mineração em larga escala, e de empresas agroindustriais na Amazônia. Essa expropriação irrefreada de terras nativas tem levado à expulsão e destruição de dezenas de tribos. Sem uma grande mudança politica, só é possível prever que um destino semelhante espera outras tribos no Brasil. (DAVIS: 1978:194).

Davis também se refere a substituição do minifúndio camponês, pelo mesmo processo de apropriação pelo capital:

Em segundo lugar, as recentes mudanças econômicas na região amazônica tendem a piorar, em vez de aliviar, os sérios problemas agrários do Brasil. (...) Ao longo da última década, a criação de gado em grande escala substituiu o minifúndio camponês como padrão básico de ocupação da terra em Mato Grosso e no Brasil Central. A introdução dessas fazendas tem tido todo o apoio do Governo Militar, $\underline{\text { recebendo importantes influxos financeiros de capitalistas industriais e agroindustriais do Sul do Bra- }}$ 
sil. Entre as companhias estrangeiras hoje envolvidas em empresas agroindustriais na Amazônia estão as seguintes: King Ranch, do Texas, (...) a Liquigás, da Itália, e a Volkswagen alemã.

Um dos principais resultados desse novo padrão de colonização tem sido a expulsão de grande numero de camponeses pobres que anteriormente formavam o elemento pioneiro no Brasil Central. Deve-se afirmar categoricamente que a situação de posse da terra desses pequenos agricultores não é menos precária do que a dos grupos indígenas na Bacia Amazônica. Além disso, todas as tentativas de procurar proteção legal para as reivindicações de terra dessas populações camponesas, por iniciativa de instituições como a Igreja Católica brasileira, enfrentam uma severa repressão por parte das autoridades locais, estaduais e federais no Brasil. O resultado é que, nos últimos 10 anos, o protesto e a violência no campo alcançaram proporções epidêmicas em varias áreas de Mato Grosso e do Brasil Central (DAVIS:1978:194-5) (grifos nossos).

(...) Modelo de desenvolvimento econômico adotado pelo regime militar brasileiro. (...) Criou um "surto econômico espetacular". (...) A maior parte desse crescimento, esta confinada às regiões do Sul e do Centro do Brasil. "O Nordeste, se mudou", (...) "foi para uma pobreza ainda maior" (DAVIS: 1978:196).

Davis faz considerações ambientais:

Por fim, as recentes mudanças econômicas no Brasil vem devastando a delicada ecologia da floresta pluvial amazônica. (...) As causas para a destruição voraz da floresta pluvial amazônica devem ser procuradas no mesmo conjunto de fatores que estão expulsando as populações indígenas e camponesas do Brasil. Ou seja, há alguns anos o Governo brasileiro tem sido extremamente bem sucedido na obtenção de uma ampla gama de tecnologias modernas para desobstruir terras e derrubar florestas na Bacia Amazônica. Entre essas tecnologias encontram-se novos tipos de tratores usados para a construção de estradas na selva, herbicidas químicos jogados de aviões a baixas altitudes para manter pastagens, e varias tecnologias de derrubada e corte, levadas à Amazônia por firmas internacionais de madeira, papel e polpa.

A racionalidade ambiental dessas novas tecnologias de desobstrução de terras é questionável até mesmo nos países de clima temperado onde foram produzidas. No caso do Brasil, contudo, o uso de tais tecnologias tem se mostrado economicamente lucrativo, e por isso existe pouca inclinação, por parte do Governo militar, para avaliar seu impacto ecológico ou fixar padrões de controle ambiental. (DAVIS: 1978:196) (grifos nossos).

Robert J.A. Goodland, citado por Davis, ecólogo do Cary Arboretum do Jardim botânico de Nova York, resume as questões envolvidas na destruição ecológica da Amazônia nos seguintes termos: 
"O que está em jogo na Amazônia é o futuro de uma área de mais de um milhão de quilômetros quadrados, maior do que toda a Europa e contendo um terço das florestas que ainda existem no mundo... . Sob as atuais diretrizes de desenvolvimento do Brasil, ela está sendo eliminada. Os ridículos ganhos a curto prazo, que se estão buscando, serão suplantados por irreparáveis problemas a longo prazo, a não ser que algo seja feito, e logo, para remediar o mal."

Infelizmente, a maioria dos dirigentes da politica externa americana tendeu a negligenciar essas consequências sociais e ambientais do modelo de desenvolvimento brasileiro, dando o apoio oficial a companhias dos Estados Unidos com grandes investimentos no Brasil. Em maio de 1976, por exemplo, Willian Simon, então Secretário do Tesouro dos Estados Unidos, manteve uma serie de encontros importantes com o Ministro da Fazenda do Brasil, Mario Henrique Simonsen. Ostensivamente, tais encontros destinavam-se a preparar alguns acordos comerciais, dentro dos quais o Brasil se comprometeria a retirar os incentivos às exportações de sapatos, artigos de couro e óleo de soja. Mas vários outros assuntos importantes também foram discutidos, entre eles a necessidade de au$\underline{\text { mentar o investimento das companhias norte-americanas no Brasil. De acordo com um informe, } \mathrm{o}}$ Ministro do Planejamento, João Paulo dos Reis Velloso, presenteou o Secretario Simon com uma lista de oportunidades para investimentos privados totalizando mais de 77 bilhões e 200 milhões de dólares nos cinco anos seguintes. Entre os itens estavam novos projetos de mineração, polpa, madeira e petróleo, e um grande numero de usinas hidrelétricas, cuja construção na Bacia Amazônica ainda não havia sido anunciada (DAVIS: 1978:197) (grifos nossos).

\section{A posição do Congresso norte-americano:}

Em maio de 1971, por ex:, a Subcomissão do Senado dos Estados Unidos para Assuntos do Hemisfério Ocidental manteve uma serie de inquéritos sobre as politicas e programas dos Estados Unidos com relação ao Brasil. (DAVIS: 1978:198)

Nos inquéritos, focalizou-se atenção especial sobre a posição dos órgãos federais americanos com relação às questões da repressão politica e da tortura no Brasil. Mas alguns membros da subcomissão do Senado também mostraram interesse pela economia brasileira e pelo programa brasileiro para abrir e explorar a Região Amazônica. (DAVIS: 1978:199)

Uma segunda iniciativa importante do Congresso americano foi uma serie de inquéritos sobre a proteção internacional dos direitos humanos. Foram conduzidos pela Subcomissão da Câmara sobre Organizações e Movimentos Internacionais, de agosto a dezembro de 1973. Um relatório divulgado por oito dos 11 membros da subcomissão afirmava que a atitude predominante na politica externa americana era a de favorecer a politica de poder em detrimento dos direitos humanos. Nas relações tais como Vietnã do Sul, Espanha, Portugal, União Soviética, Brasil, Indonésia, Grécia, Filipinas e Chile, o relatório da Subcomissão acusava os Estados Unidos de "negligencia quanto aos direitos 
humanos, em beneficio de outros interesses assumidos", e, "adesão a governos que praticam a tortu-

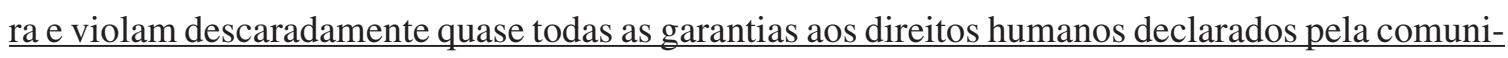
dade mundial" (DAVIS: 1978:200) (grifos nossos)

Por fim, Davis conclui:

Um impacto devastador que os recentes programas de desenvolvimento econômicos estão tendo sobre as populações indígenas, os camponeses, os trabalhadores rurais, e a própria Terra. Neste momento, está sendo travada uma guerra silenciosa contra povos aborígenes, contra camponeses inocentes e contra o ecossistema da floresta pluvial na Bacia Amazônica. Para muitos leitores, poderá parecer que o imenso sofrimento e o enorme dano causados à Bacia Amazônica fazem parte do custo inevitável que deve ser assumido por qualquer país que deseje experimentar um rápido crescimento econômico. Acredito ser essa uma posição equivocada. Nada há de inevitável no que está se passando na Amazônia brasileira. Nem há razoes imperiosas para acreditar que o programa de desenvolvimento da Amazônia venha a beneficiar a vasta maioria do povo brasileiro. A guerra silenciosa travada contra o povo e o meio ambiente da Bacia Amazônica é resultado de um "modelo de desenvolvimento" muito especifico. Hoje, esse "modelo de desenvolvimento" está sendo implantado em outras áreas de expansão econômica do mundo. Uma contraofensiva de sentimento público, que questione as prioridades da politica de desenvolvimento internacional, e que torne os autores da politica externa, as instituições internacionais de credito e as companhias multinacionais responsáveis por suas atividades nessas áreas pioneiras seria um grande passo para terminar com essa e com outras guerras (DAVIS: 1978:202).

Assim o que se deduz é que os povos indígenas, os povos autóctones e o ambiente, são a ponta inicial, mais fragilizadas de um processo de espoliação pelo capital, o qual é colocado à frente de expansão, em geral posseiros, os que vem a desmatar e preparar a terra, "amansar a terra", disputar a terra com os indígenas, para então esses últimos serem novamente espoliados, por empresas colonizadoras, governo e seus projetos, grileiros de todo o gênero, para enfim a propriedade privada, "proprietários de terras e de capital", e o Estado, tomarem as terras ao final.

Shelton Davis foi um dos antropólogos que veio ao Brasil para verificar as condições a que os Guarani do Oco’y estavam sendo submetidos. Apesar de produzir um importante relatório, este novamente não foi levado em conta. 


\subsubsection{As manobras estratégicas da geopolítica brasileira no Prata}

As manobras estratégicas de larga envergadura postas em marcha pelo governo brasileiro na região do Prata, tanto na área de soldadura (MT, Bolivia e Paraguai), quanto na área de tensão máxima, Las Misiones (Argentina), objetivaram a alçá-lo a país hegemônico na America do Sul, em detrimento da Argentina. Para tanto, "resgatar os prisioneiros geopolíticos argentinos", Bolívia e Paraguai, atraindo-os para o "campo magnético" do Brasil, era a meta. Dessa forma, foi criada superposição de um novo eixo de orientação, de direção terrestre oeste-leste, sobre o tradicional eixo fluvial norte-sul. A Estrada de Ferro Brasil-Bolívia e o Porto de Santos; a "Ruta n.7" no Paraguai, a Ponte da Amizade, a Rodovia BR-277 e o Porto de Paranaguá; a hidrelétrica de Itaipu; e, o porto de Rio Grande; foram as formas utilizadas pela geopolítica brasileira, para se contrapor a hegemonia argentina no Prata. Houve grande mobilização governamental no Brasil e muitos recursos financeiros foram gastos nestas operações.

\section{A Estrada de Ferro Brasil-Bolívia e o Porto de Santos}

A ferrovia Brasil-Bolívia já era fruto de um antigo acordo entre o Brasil e Bolívia. Magnoli assim explica:

O Tratado de Petrópolis, firmado em 1903 por brasileiros e bolivianos, estabelecia a responsabilidade compartilhada dos dois Estados na construção de uma ferrovia que ligasse o oriente boliviano ao porto de Santos, compensação para a anexação, pelo Brasil, do Acre e dos ricos seringais que pertenceram à Bolívia (1988:38).

O governo brasileiro retomou o referido Tratado, provavelmente dada ás indicações de ação geopolítica de Golbery, custeou toda a construção da ferrovia no trecho de 680 km que interligou Corumbá - Santa Cruz de La Sierra, portanto, toda ela em território boliviano, vindo a inaugurála em 5 de janeiro 1955. Magnoli assim comenta:

Em 1955, a inauguração do trecho Corumbá-Santa Cruz consubstanciava o antigo tratado: interligado ao sistema férreo Sorocabana-Noroeste do Brasil, ele unia os 2.550 quilômetros que medeiam Santos a Santa Cruz. (1988:38).

Foi um acontecimento tão importante que mereceu uma pagina inteira do Jornal do Brasil de 8 de janeiro de 1955, como se pode ver a seguir. 
A função de articulação da integração territorial, que a economia promove, assim é verificada:

As planícies tropicais do leste boliviano, isoladas do coração do país pela muralha andina, escondem no seu subsolo preciosas reservas de gás natural e petróleo. Com a Estrada de Ferro Brasil-Bolívia, essa região tende a soldar-se economicamente a vertente atlântica e ao território brasileiro, orientando-se sobre o eixo geopolítico oeste-leste. Além da maconha e da cocaína transportadas clandestinamente nos vagões do "trem da morte", passaram por seus trilhos, em 1982, mais de dois milhões de toneladas de petróleo, produtos siderúrgicos, animais, minérios e cereais. (MAGNOLI: 1988:38).

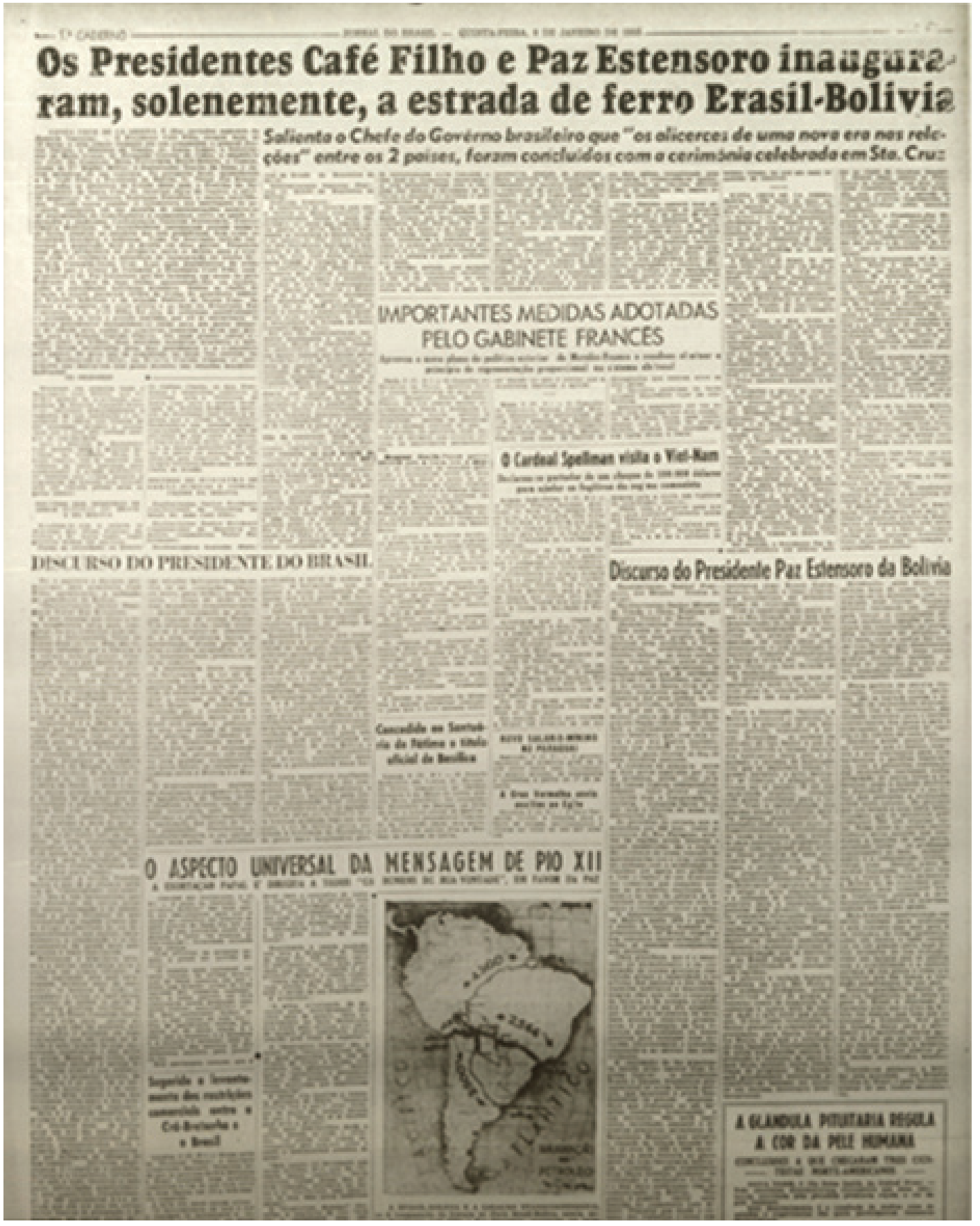

Figura 91. Inauguração da Estrada de Ferro Brasil-Bolivia em 05.01.1955 Fonte: Jornal do Brasil. Rio de Janeiro. 08.01.1955 
Em fins do século XX, foi inaugurado o trecho ferroviário Santa Cruz - Cochabamba. Assim escreveu a respeito Magnoli:

Aproxima-se a inauguração do último trecho da ferrovia, que ligará Santa Cruz a Cochabamba subindo os contrafortes escarpados da cordilheira. Com ele, o velho projeto de interligação de Santos, no Atlântico, ao porto chileno de Arica, no Pacífico, será finalmente realidade. Na perspectiva geopolítica brasileira, estará aberta uma via de acesso ao Pacifico, dissolvendo a tradicional compartimentação do continente nas suas vertentes atlântica e pacífica. É a satelização da Bolívia que explica a postura do Itamaraty, de apoio à reivindicação de devolução do corredor para o Pacifico anexado pelo Chile no século passado. (MAGNOLI: 1988:39-40)

\section{A MANOBRA ESTRATÉGICA DO PRATA}

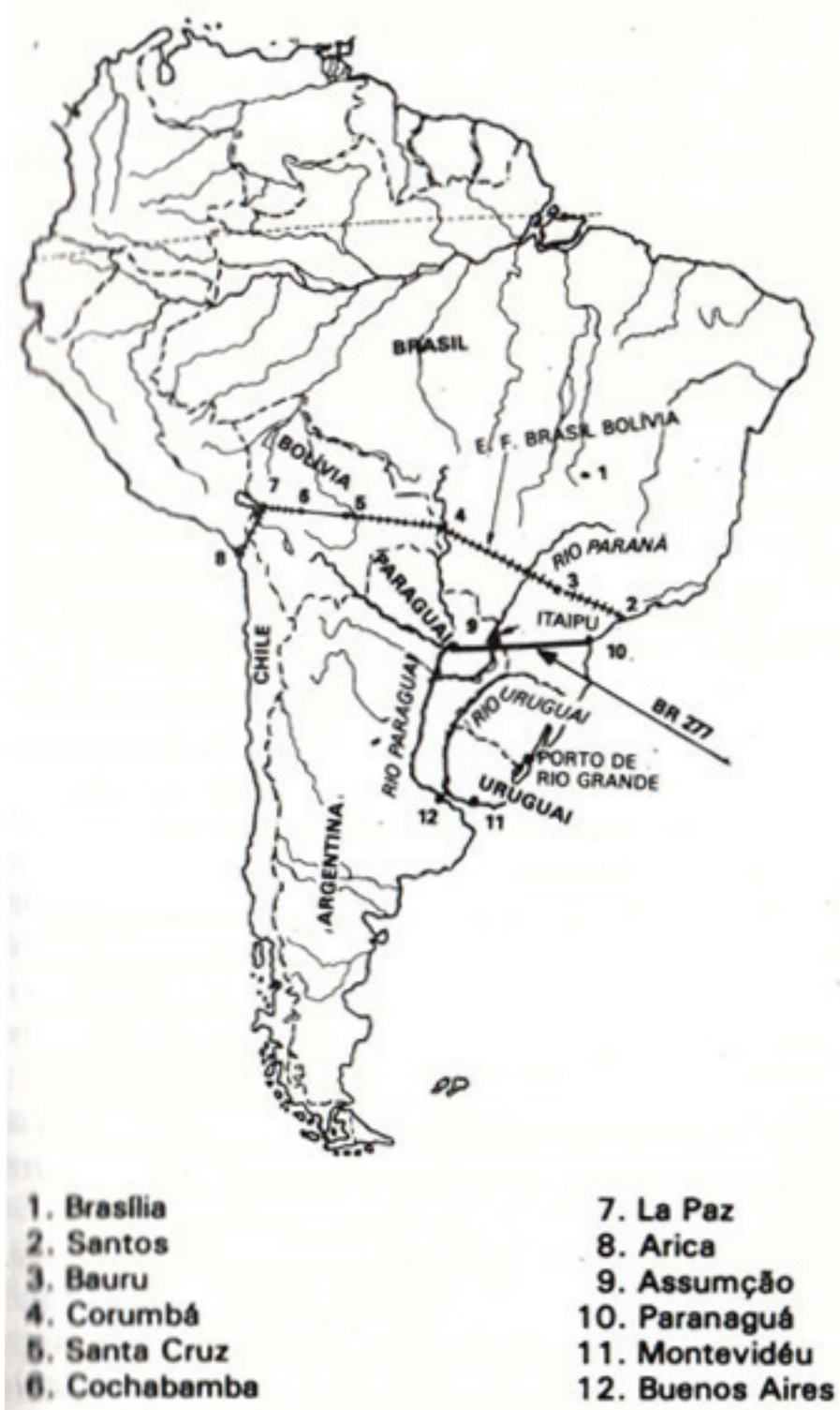

Figura 92. Mapa. A manobra estratégica do Prata

Fonte: Demetrio Magnoli. O que é geopolítica, 1988, p 39. 
Explicando o último parágrafo, assim a diplomacia brasileira no final do século XX, considerando que o Brasil satelizou a Bolívia para seu campo de ação, em acordo de ajuda mútua, apoiou a Bolívia, na reivindicação de devolução do corredor para o Pacífico, onde estava o porto boliviano de Arica, que foi anexado anteriormente pelo Chile no século XIX.

Em 2010 foi anunciado o projeto de construção do trecho de La Paz/Bolívia - Arica/Chile, em consorcio técnico e financeiro entre o Brasil e a Bolívia. Assim os acordos de auxilio mútuo continuaram firmes, pois interessa ao país a comunicação com o Pacífico visando trazer e levar mercadorias percorrendo varias regiões de oceano a oceano, assim como interessa fortalecer os laços entre os dois países, excluindo novamente a participação argentina.

Por fim, a ferrovia é transoceânica, pois, vai do porto de Santos no Atlântico, até a cidade de São Paulo (Estação Julio Prestes no bairro da Luz), são 70 km; de São Paulo, passando pelos municípios de Sorocaba/SP, Bauru/SP (até aqui trecho da antiga estrada de ferro Sorocabana) até Corumbá/MT (trecho da antiga estrada de ferro Noroeste) são mais 2000 km; de Corumbá/MT/BR a Santa Cruz de La Sierra/Bolívia, trecho inaugurado em 1955, são mais 680 km; De Santa Cruz de La Sierra, ela passa pelas cidades de Cochabamba, La Paz e termina no porto de Arica/Chile no Oceano Pacífico.

O Porto de Santos de propriedade do governo brasileiro é considerado o primeiro porto mais importante do Brasil e da America Latina.

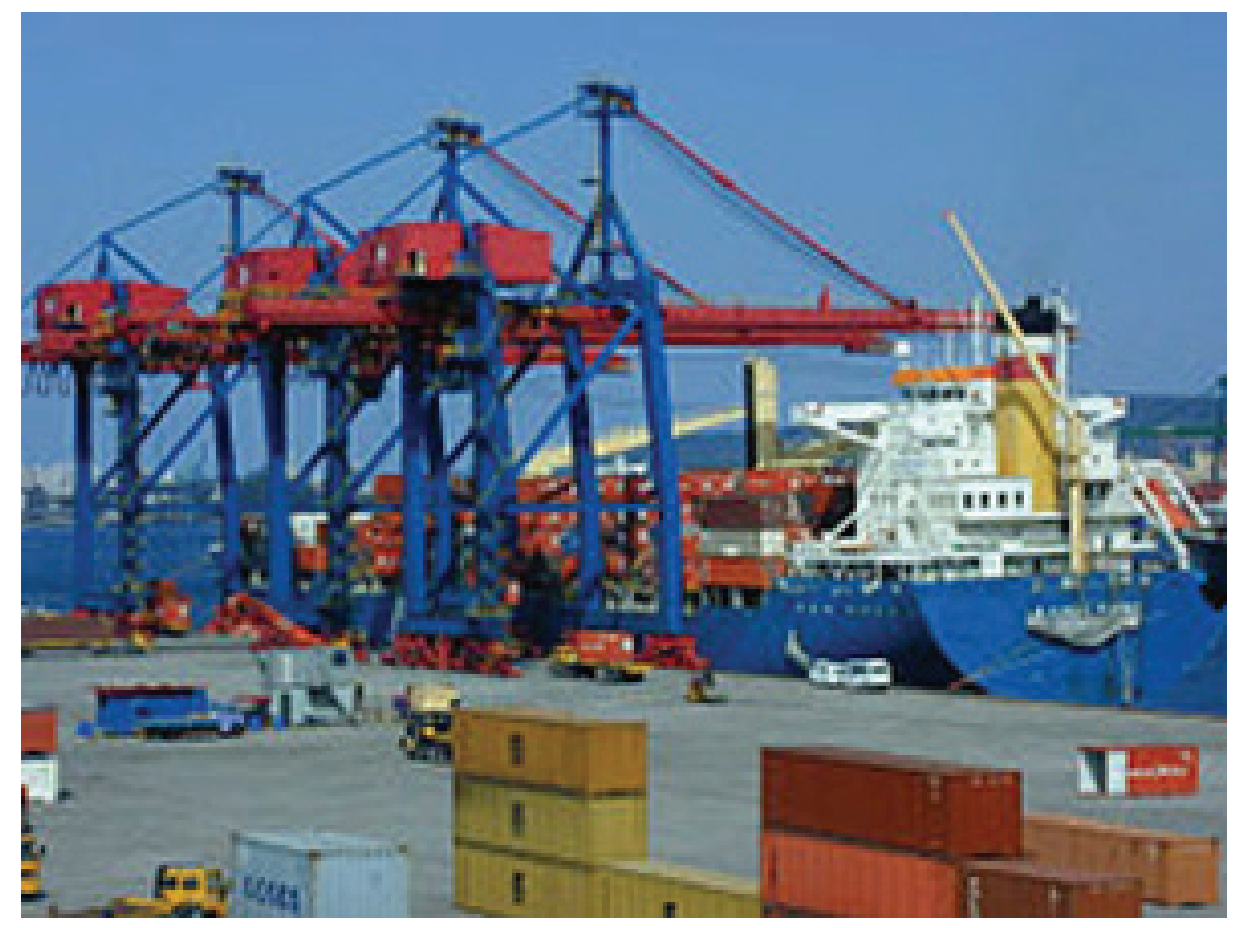

Figura 93. Terminal de contêineres do Porto de Santos, o maior da América do Sul. Fonte: www.portodesantos.com.br 
Segundo informa o site do Porto de $\operatorname{Santos}^{92}$, eis porque ele é o principal porto brasileiro:

A área de influência econômica do porto concentra mais de 50\% do produto interno bruto (PIB) do país e abrange principalmente os estados de São Paulo, Minas Gerais, Goiás, Mato Grosso e Mato Grosso do Sul.

O Complexo Portuário de Santos responde por mais de um quarto da movimentação da balança comercial brasileira e inclui na pauta de suas principais cargas produtos como o açúcar, soja, cargas conteinerizadas, café, milho, trigo, sal, polpa cítrica, suco de laranja, papel, automóveis, álcool e outros granéis líquidos.

Distante cerca de 70 quilômetros da terceira maior cidade do mundo, a cidade de São Paulo, o porto é servido por duas ligações ferroviárias (Ferroban e MRS) e duas estradas (Anchieta e Imigrantes) que ligam à capital e uma estrada para o sul do país. Aproximadamente $90 \%$ da base industrial paulista está localizada a menos de 200 quilômetros do porto santista.

A estrutura ferroviária, iniciada ainda no período do Império, garantiu o afluxo de cargas, destinados ao comércio exterior. Liderando o mercado nacional portuário, o Porto de Santos atende também vários países latino-americanos que fazem as cargas serem embarcadas e desembarcadas.

Em 2007, o Porto de Santos foi considerado o $39^{a}$ maior do mundo por movimentação de contêineres pela publicação britânica Container Management, sendo o mais movimentado da América Latina. Hoje é o maior porto da América Latina. Em 2006 a sua estrutura foi considerada a mais moderna do Brasil. Sua administração é feita pela Companhia Docas do Estado de São Paulo (CODESP) empresa do Governo Federal, vinculada à Secretaria de Portos da Presidência da República.

Concluindo, estavam consolidados, os objetivos de Golbery na satelização da Bolívia pelo Brasil. Aárea de soldadura foi dominada pela interação econômica entre Brasil e Bolívia, via ferrovia que ocupa a espinha dorsal das duas bacias; interrompem-se assim, as intenções de domínio e de ultrapassagem na área de soldadura para a Bacia Amazonica, pela Argentina. O Brasil cedendo à Bolívia saída para o porto de Santos no Atlântico, melhor localizada em termos de latitude, mais próxima dos grandes centros comerciais mundiais, vem a ser mais interessante economicamente para a Bolívia, se comparado com o porto de Buenos Aires; A Argentina perde assim as taxas alfandegárias de exportação sobre a Bolívia e o poder político que antes obtinha sobre aquele país, seu "prisioneiro geopolítico", dada a dependência anterior, de única alternativa de saída para o Atlântico. A Argentina sai enfraquecida deste processo. O Brasil ao satelizar a Bolívia, contribui para trazer para si a hegemonia no continente sul-americano. Toda produção boliviana, ao ser escoada pelo Brasil, vêm agregar valor ao Brasil, através de novos acordos mútuos.

\footnotetext{
$\overline{92}$ Informações obtidas em www.portodesantos.com.br. Pesquisado em 15.03.2013
} 


\section{A Interligação Brasil-Paraguai: A Ruta Nacional No 7 'Dr. José Gaspar Rodríguez de Francia” Paraguay, a Ponte da Amizade, a BR-277 e o Porto de Paranaguá}

Quem convive na região da Tríplice Fronteira sente de perto o envolvimento entre Brasil e Paraguai em varias solenidades, reuniões, acordos envolvendo a Itaipu e o país vizinho. Ao contrario isso não é sentido de forma alguma entre Brasil e Argentina. Isso foi calculado pelo governo brasileiro. Magnoli (1988) a esse respeito demonstra a política de fronteiras vivas, integração e cooperação com o país vizinho:

A manobra estratégica montada para capturar o Prata para a influencia brasileira introduz o conceito geopolítico de fronteiras vivas, em substituição à ideia de fronteiras mortas, áreas de vazios demográficos e econômicos, domínios jurídicos limítrofes passivamente defendidos por territórios federais subordinados ao poder central. Ponta-Porã é reabsorvido pelo estado de Mato Grosso e Iguaçu pelos estados de Santa Catarina e Paraná. Uma política exterior ativa substitui as ideias de demarcação e separação pelas noções de integração e cooperação (1988:37).

A situação de transporte e transbordo de carga feita entre o Paraguai e o porto de Buenos Aires, já era extremamente difícil, como demonstra Magnoli:

A captura do Paraguai fundamentou-se na constatação da precariedade da saída fluvial através do porto de Buenos Aires e das águas do rio Paraguai. O rio só é plenamente navegável durante três meses, na época das cheias, sendo singrado unicamente por chatas no resto do ano. Em Buenos Aires, as cargas têm de ser transferidas para navios de grande calado, onerando ainda mais o comercio já submetido às taxas portuárias argentinas. O Brasil irá fornecer um pulmão oceânico alternativo para o Paraguai. (1988:40)

Dessa forma, o Brasil facilita enormemente o transporte de cargas para o Paraguai com as seguintes medidas, segundo argumenta Magnoli:

Em 1965, um convênio internacional transforma o porto de Paranaguá em área franca para as importações e exportações paraguaias. Quatro anos depois é inaugurada a rodovia BR-277, unindo por asfalto Assunção a Paranaguá: o trajeto fluvial de duas semanas até o porto de Buenos Aires pode ser evitado através de uma viagem de apenas vinte horas para o porto brasileiro. Em 1971, o movimento se completa com reforma de Paranaguá, que passa a receber navios de grande calado. Em 1984, os paraguaios finalizam a construção de dois imensos armazéns graneleiros no porto livre, capazes de abrigar toda a soja exportada pelo país e ainda excedentes de grãos brasileiros. (MAGNOLI: 1988:40) 
Na verdade o Brasil ofereceu um porto franco, Paranaguá, ao Paraguai em $1956^{93}$, período em que Golbery estaba refletindo e colocando em pratica as manobras geopolíticas a respeito do tema aqui tratado. E nesse mesmo ano de 1956, o Brasil realizou convenio com o Paraguai, período a partir do qual financiou e ofereceu auxilio técnico para criar a "Ruta n. 7" (Rota n.7) que iria ligar Coronel Oviedo a Porto Presidente Stroessner (atual Ciudad del Leste), as margens do Rio Paraná.

Já havia sido construída antes a rodovia "Ruta Nacional n 2, denominada "Mariscal José Félix Estigarribia”, a qual interligava Assunção, capital do Paraguai, as margens do rio Paraguai, com Coronel Oviedo, capital do Departamento de Caaguazú, no Paraguai. Um trecho de $132 \mathrm{~km}$.

A partir da cidade de Coronel Oviedo, a Rota n.2 continuou como Rota n. 7, "Dr. José Gaspar Rodríguez de Francia” a qual terminou em Porto Presidente Stroessner (atual Ciudad del Leste)/Departamento de Alto Paraná, às margens do rio Paraná. Trecho de 193 km.

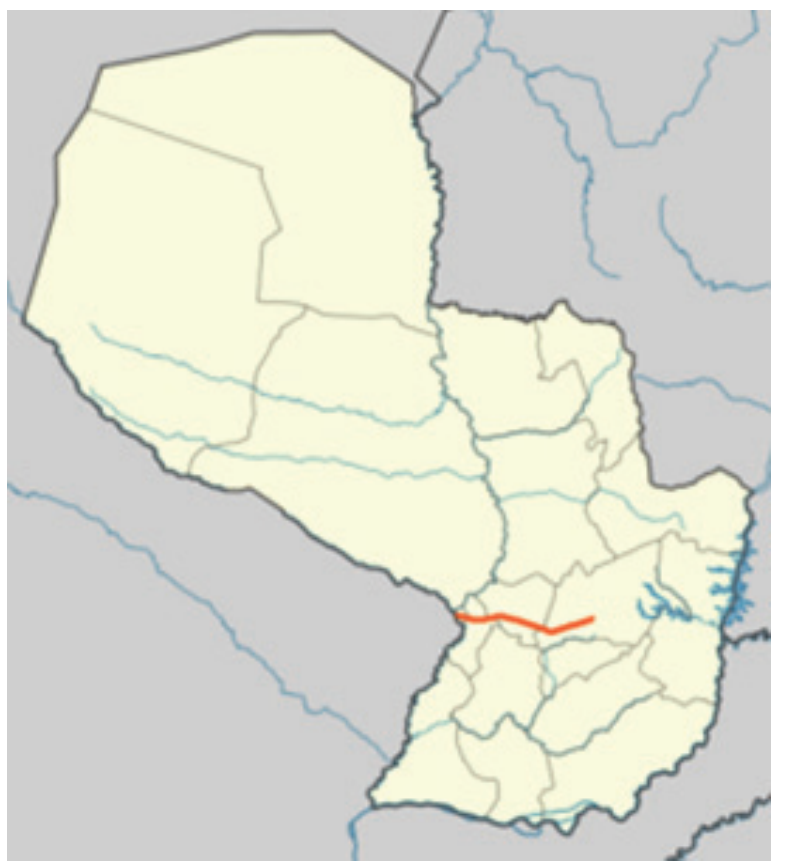

Figura 94. Ruta Nacional $N^{\circ}$ 2. "Mariscal José Félix Estigarribia". Assunção - Cel Oviedo.

Fonte: http://es.wikipedia.org/wiki/Ruta 2 (Paraguay). Pesquisado em 15.03.2013

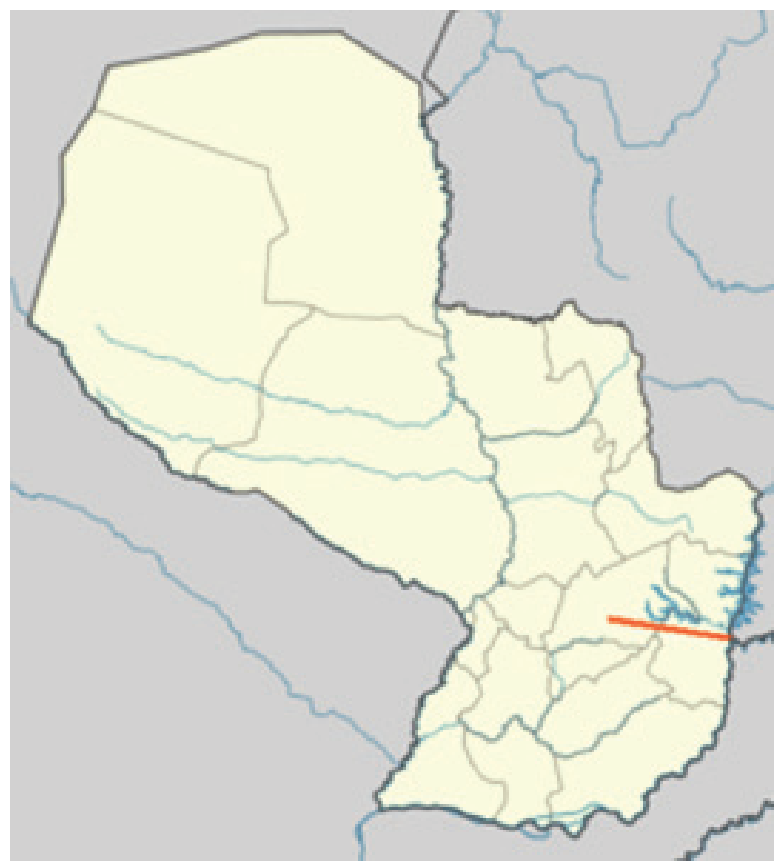

Figura 95. Ruta Nacional $N^{\circ}$ 7. "Dr. José Gaspar Rodríguez de Francia”. Cel Oviedo - Ciudad Del Leste. Fonte: http://es.wikipedia.org/wiki/Ruta 7 (Paraguay). Pesquisado em 15.03.2013

\footnotetext{
$\overline{93}$ Talvez Magnoli tenha invertido sem querer os números, 1956 para 1965.
} 
O Coronel Dom Indalecio Colmán ${ }^{94}$, que participou como membro da Comissão Mixta Paraguaya - Brasileira para a construção da rodovia "Ruta n.7", assim discorre sobre as condições da construção, aqui resumida:

De tiempo muy lejano viene la idea de la construcción de un camino Oeste-Este, ligando Asunción con el litoral Atlántico. Evolucionado poco a poco, naturalmente de un emprendimiento internacional de larga envergadura técnico-financiera, poco a poco, la idea fue concretándose en amalgama de los intereses recíprocos entre Paraguay y Brasil.

En enero de 1956, el Gobierno Brasileño había concedido un Puerto Franco en Paranagua. Esto hizo que el gobierno paraguayo acelerara la integración de las redes camineras de ambos países. Esto también se hizo posible mediante un crédito del Banco do Brasil y ayuda técnica para las obras de ingeniería del tramo Cnel. Oviedo-Río Paraná, según acuerdo respectivo del 29 de mayo de 1956. Inmediatamente, contingentes del Comando de Ingeniería con máquinas pesadas abrieron el sendero hasta el Río Paraná, cuyo terraplén fue completado en el año $\underline{1959}$.

Hasta entonces el "desierto verde" no ofrecía ningún atractivo para asentamiento humano. Ciudad Pte Strossner, la ruta 7 y el puente, transformaron radicalmente dicha percepción y los pioneros brasileños. Eran gentes que en su mayoría llegaban con conocimientos mejores de la siembra y cosecha que el campesino paraguayo.

Volviendo a la construcción de la ruta, el 20 de enero de 1956, firmaron el Paraguay y el Brasil, por cambios de notas, el convenio para la construcción del camino carretero Cnel Oviedo-Pte. Strossner, $\underline{\text { siendo entonces reconocida por el "Superior Gobierno" }}$ " la creación de la Comisión Mixta ParaguayoBrasileña. Con los estudios preliminares ya entonces adelantados, que fueron iniciados por Comisiones anteriores, fueron definitivamente asentadas las condiciones técnicas y financieras para la construcción. El camino carretero de Cnel. Oviedo a Puerto Pte. Strossner, tiene una extensión de $195 \mathrm{~km}$. El costo total de dicha obra fue presupuestado de Gs.150.000.000 y el tiempo de construcción duró aproximadamente 3 años. En mayo de 1956 comenzó la entrega a la Comisión Mixta de los fondos para la construcción, previstos en el convenio. Y en los pequeños trabajos que hasta entonces se había realizado, fueron recibiendo un desarrollo adecuado. El camino auxiliar de servicio que liga los dos extremos, fue costoso dadas las condiciones de un monte virgen y la absoluta falta de recursos locales. La realización de los trabajos camineros fue contratada por la Empresa Brasileña "TH. Marinho de Andrade Constructora S.A." de larga tradición en la construcción de caminos carreteros en aquel país. Iniciados

\footnotetext{
${ }^{94}$ Informe del Cnel. D. Indalecio Colmán, Miembro de la Comisión Mixta Paraguayo Brasileña. Em http:// es.wikipedia.org/wiki/Ruta_7_(Paraguay). Pesquisado em 15.03.2013.

95 "Superior Governo" tem relação com as decisões das "Altas Partes", que Itaipu sempre se refere, respondendo que não tem a obrigação de cumprir as leis do país, dado o acordo Binacional entre as "Altas Partes" do Brasil e do Paraguai.
} 
efectivamente los trabajos en octubre de 1956, después de largo y penoso viaje con los equipos de máquinas, se realizó la obra caminera en el monte virgen del Alto Paraná y Caaguazú.

La construcción de este camino carretero se realizó siguiendo el sendero (picada) trazada previamente por nuestros hermanos indígenas, pioneros, rolliceros, etc. en el monte virgen y tierra despoblada, llena de sacrificios, por ello, vale un merecido homenaje y un reconocimiento por su batallar constante, con tenacidad y con verdadero esfuerzo, han ido transformando en los marcos de un ideal, en el que hoy, Dios mediante, el camino se ha convertido en una verdadera realidad ${ }^{96}$.

Assim o governo brasileiro acenou em 1956, provavelmente pelas ordens de Golbery, com uma serie de benesses voltadas ao Paraguai: porto livre no Atlântico, financiamento e assistencia técnica para a rodovia "Ruta 7", a qual interligaria com a futura "Ponte da Amizade", construida também por mesmo acordo entre ambos os países, interligando dessa forma ao territorio brasileiro.

Em 23 de janeiro de 1959 a inauguração da rodovia (ainda não asfaltada) pelo ditador paraguaio Presidente General Stroessner, autoridades varias, Embaixada Brasileira e a Comissão Mixta Brasil-Paraguai, responsavel pela construção. Um acontecimento:

\section{En histórica jornada se incorporó ayer la ruta Oviedo - Pte. Stroessner a la red caminera de la república. El Presidente de la República y una extraordinaria comitiva recorrió la importante Obra. (Diario PATRIA, viernes 23 de enero de 1959):}

A primera horas de la mañana de ayer, el Pte. de la Rca. Gral. de Ejército Don Alfredo Stroessner, acompañado de ministros del Poder Ejecutivo, el Pte. de la Junta de Gobierno del Partido Colorado y miembro de la misma, el Pte. de la Corte Suprema de Justicia, miembro de la Honorable Cámara de Representantes, Pte. y miembros de seccionales partidarias, numerosos Jefes de la FF.AA, altos funcionarios de la administración pública y otros invitados especiales, entre los que se notó la presencia de la Embajada del Brasil y de la Comisión Mixta Paraguayo Brasileña a cargo de la construcción de la importante carretera, procedió a recorrer en toda su extensión la ruta Cnel. Oviedo a Pto. Pte. Stroessner, cuyo terraplenado había sido completado el día anterior, produciéndose la unión de los dos sectores, el que avanzaba desde el Río Paraná, con el que iba a su encuentro desde la capital ovetense. El punto de unión se produjo en el lugar denominado "Mburica" zona de Zanja Pypuku - Maracaná97.

\footnotetext{
${ }^{96}$ Mais uma vez se utilizaram dos caminhos Guarani, o Peabiru.

${ }^{97}$ Mora Martínez, Eliodoro. "Campo 9, un polo de desarrollo en la Marcha hacia el Este". Editorial El Lector, Asunción 2008. ISBN 978-99953-1-059-2.
} 
Em fevereiro de 1962 se inicia as obras para o asfaltamento da Ruta n.7:

\section{Se asfaltará totalmente la Ruta VII que une Cnel. Oviedo con Pto. Presidente Stroessner. (Diario}

PATRIA $1^{\circ}$ de febrero de 1962 Pag. 3): En el despacho del Ministro de Obras Públicas y Comunicaciones, Arq. Tomás Romero Pereira se efectuó en la tarde del martes últimos la ceremonia de suscripción de contratos en virtud de la cual la empresa Morrison Knusen se encarga de los trabajos de pavimentación asfáltica de la Ruta VII'

Dessa forma percorrendo apenas $325 \mathrm{~km}$, estava realizada em parte a manobra política de Golbery, ligar a capital de Assunção com a fronteira brasileira, em eixo oeste-leste.

Os governos do Brasil e do Paraguai realizaram no mesmo acordo de 29 de maio de 1956, que visava construir a Rota 7, também a construção da ponte que interligaria os dois países. Foi criada então uma Comissão Especial para Construção da futura Ponte da Amizade.

A Ponte Internacional da Amizade, inaugurada pelos Presidentes Castelo Branco, do Brasil, e Alfredo Stroessner, do Paraguai, em 27 de março de 1965, possui uma extensão de 552,40 metros e um vão livre de 303 metros, o maior do mundo em obra de concreto, com 13,50 metros de largura e altura de 78 metros.

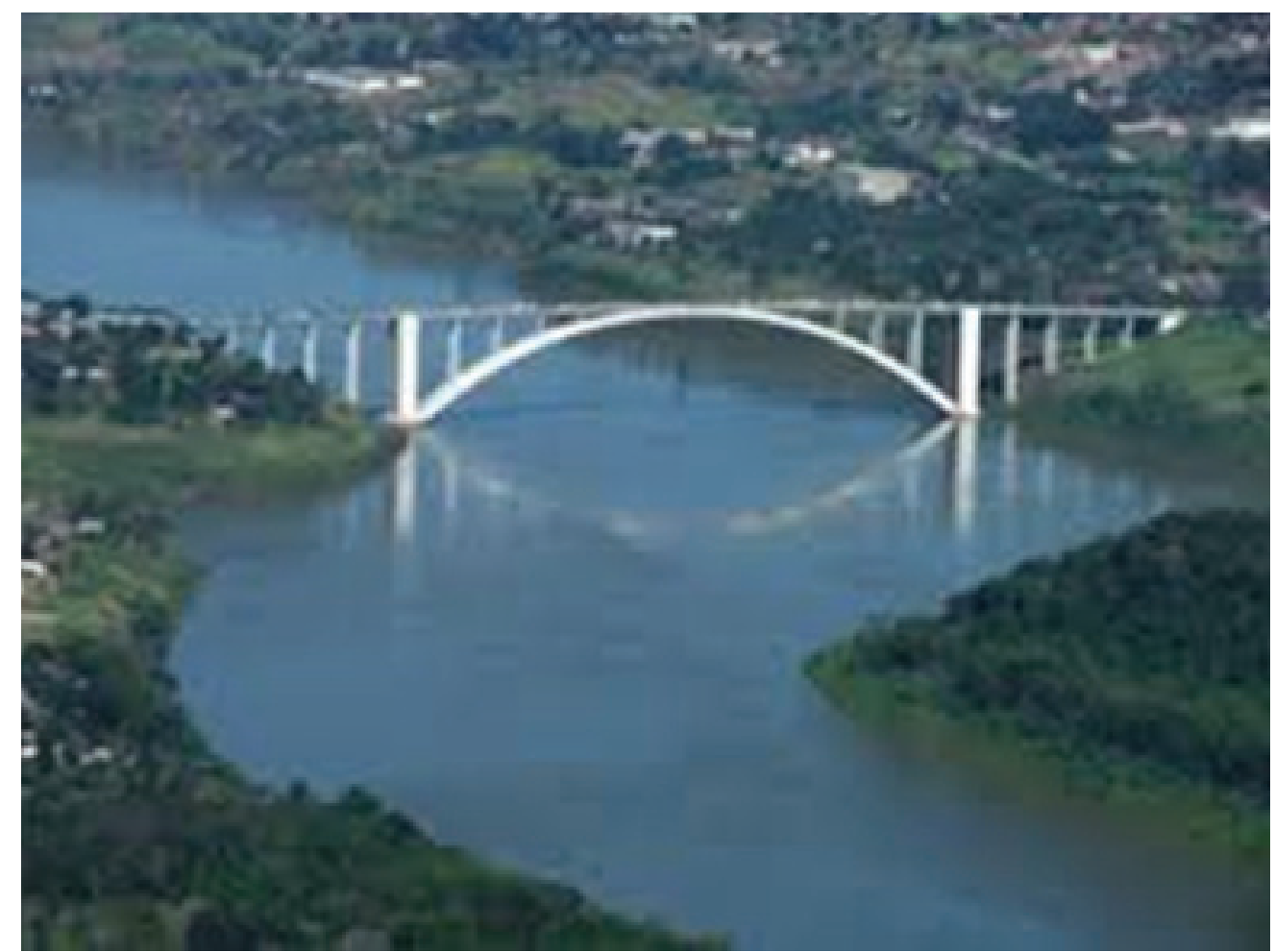

Figura 96. A ponte da Amizade Brasil-Paraguai.

Fonte: http://pt.wikipedia.org/wiki/Ponte_Internacional_da_Amizade

98 Idem. 
Vejamos algumas informações sobre a Ponte da Amizade:

O local onde se encontrava o canal entre Sete Quedas e Foz do Iguaçu era estreito, profundo e com águas revoltas. Suas variações de nível em condições normais chegavam (antes da construção da Barragem de Itaipu) até dez metros em 36 horas, resultando uma oscilação $30 \mathrm{~cm}$ por hora. Em função da rapidez de variações do rio Paraná foi definido que a ponte deveria ter vão livre de 18 metros acima do nível da água mesmo em grandes cheias ${ }^{99}$.

O local prenunciava também, como ideal para a construção de uma hidrelétrica.

O rio Paraná, devido a sua extensão continental, sofre duas cheias por ano, sendo a primeira em junho ou julho e a segunda no fim do ano, entre novembro e dezembro. Esta variação não está relacionada com as estações do ano, e sim com o regime de chuvas nas regiões em que passa. Em função das chuvas, da grande velocidade das águas, estreiteza e profundidade do canal (em torno de 71 metros de profundidade na época das cheias e nunca menor que de $28 \mathrm{~m}$ ), as variações de nível do rio em sua caixa são extremamente rápidas e perigosas. Portanto, chegou-se a conclusão que a ponte deveria ter 77 metros de altura (e nunca menos) a partir do fundo do rio. Na época de maior cheia deveria estar a 32 metros acima do nível de água. O canal, o leito e as barrancas do rio são formados por basalto e siltito cuja resistência mecânica é muito elevada. A velocidade de vazão é de aproximadamente 2 a 3 metros por segundo.

A principal condição preestabelecida no projeto da ponte era de que o tráfego fluvial não poderia ser interrompido. Desta forma foi projetada uma estrutura com 553 metros de comprimento, sustentada sobre arco com vão livre de 290 metros. Estruturas e materiais metálicos eram buscados em São Paulo, Volta Redonda e Rio de Janeiro. Para a construção do arco de sustentação da obra, a Companhia Siderúrgica Nacional, de Volta Redonda, montou um cimbre de aço carbono com 157,300 metros de comprimento e que tinha uma massa de 1.200 toneladas. A imensa estrutura de aço foi montada em Volta Redonda, testada, e desmontada para ser transportada ao seu destino a 1.700 quilômetros de distância, uma epopeia no final da década de 1950, início da década de 1960. Isto representou um grande desafio na época, pois o transporte dos componentes metálicos foi executado por carretas em estradas de traçado antigo. Em muitos trechos as peças não passavam, obrigando a alteração rápida de muitos pontos das estradas, além do reforço emergencial de pontes e viadutos. Foram utilizados em sua construção:

- Concreto armado: $43.000 \mathrm{~m}^{3}$ de concreto.

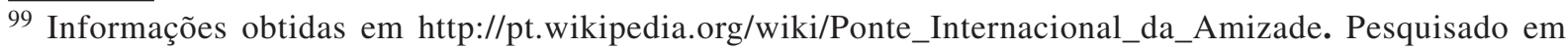
15.03.2013
} 
- Cimento: 14.000 toneladas.

- Aço: 2.900 toneladas de aço.

- Madeira: $120.000 \mathrm{~m}^{2}$ para formas, escoras e andaimes.

- Cubagem em madeira: $6.000 \mathrm{~m}^{3}$.

- Pregos: 50 toneladas de pregos de 20 fábricas situadas nos Estados do Paraná, Santa Catarina e São Paulo.

- Parafusos provindos de metalúrgicas de São Paulo, Minas Gerais e Rio de Janeiro: 12.000 toneladas.

- Arame de Construção: 33 toneladas da Siderúrgica Guaíra de Curitiba (Atual Gerdau).

- Aço em laminados, cabos, rebites e parafusos de alta tensão metálica para a peça metálica do cimbre: 1.300 toneladas vindos da Companhia Siderúrgica Nacional.

- Quantidade de operários: mil homens.

- Quantidade de famílias deslocadas para o local: 600 famílias instalados na Vila Operária. ${ }^{100}$

Assim se estabeleceu um povoado na região, o ecúmeno foi ocupado.

Foi desmatada uma área de 14 hectares de mata atlântica virgem e realizada 139.000 metros quadrados de terraplanagem. Para abastecimento com água potável na vila operária foi executada a perfuração de um poço artesiano de 117 metros de profundidade. Para a concretagem foi necessária a instalação de uma usina de britagem com capacidade de produzir $100 \mathrm{~m}^{3}$ de pedra brita por dia. O material foi retirado das margens do Rio Paraná. A areia também foi retirada do próprio leito do rio. Toda a madeira utilizada foi retirada da floresta atlântica da região. Foram construídas para a construção da ponte diversas serrarias da região, que vieram a destruir imensas reservas de mata natural que não foi replantada. O cimento utilizado veio de Curitiba e de São Paulo.

A Ponte Internacional da Amizade foi inaugurada em 27 de março de 1965 por Castelo Branco, presidente do Brasil e Alfredo Stroessner, presidente do Paraguai. No Brasil, foi chamada de Ponte da Amizade e no Paraguai, ponte Presidente Alfredo Stroessner.

Em função da construção da ponte surgiu o comércio exportador e importador de Foz do Iguaçu. Se iniciou a colonização e inauguração da cidade de Puerto Stroessner, atualmente chamada de Ciudad del Este, cidade que ocupa o posto de segundo maior centro urbano do Paraguai e é a terceira maior zona franca de livre comércio do mundo, depois de Miami e Hong Kong, seus clientes na maioria são brasileiros atraídos pelos baixos preços dos produtos vendidos na cidade ${ }^{101}$.

\footnotetext{
${ }^{100}$ Idem.

${ }^{101}$ Ibidem.
} 
Criada as relações comerciais com Foz do Iguaçu pelos habitantes de Puerto Stroessner, inicia-se sua colonização. Visando criar ocupação, movimento, nada melhor do que criar uma zona franca de comercio.

A BR-277 foi inaugurada em março de 1969 sendo rodovia federal, transversal, do Brasil. Ela possui 730 km de extensão, com início no Porto de Paranaguá e término na Ponte da Amizade, em Foz do Iguaçu. Esta rodovia corta o Estado do Paraná no sentido leste-oeste, ao longo do paralelo 25³0', ligando o Porto de Paranaguá a Curitiba, Campo Largo, Irati, Ponta Grossa, Guarapuava, Laranjeiras do Sul, Cascavel e Foz do Iguaçu, quando então interliga-se com a Ponte da Amizade e depois a "Ruta 7" (Rodovia Transparaguaia).

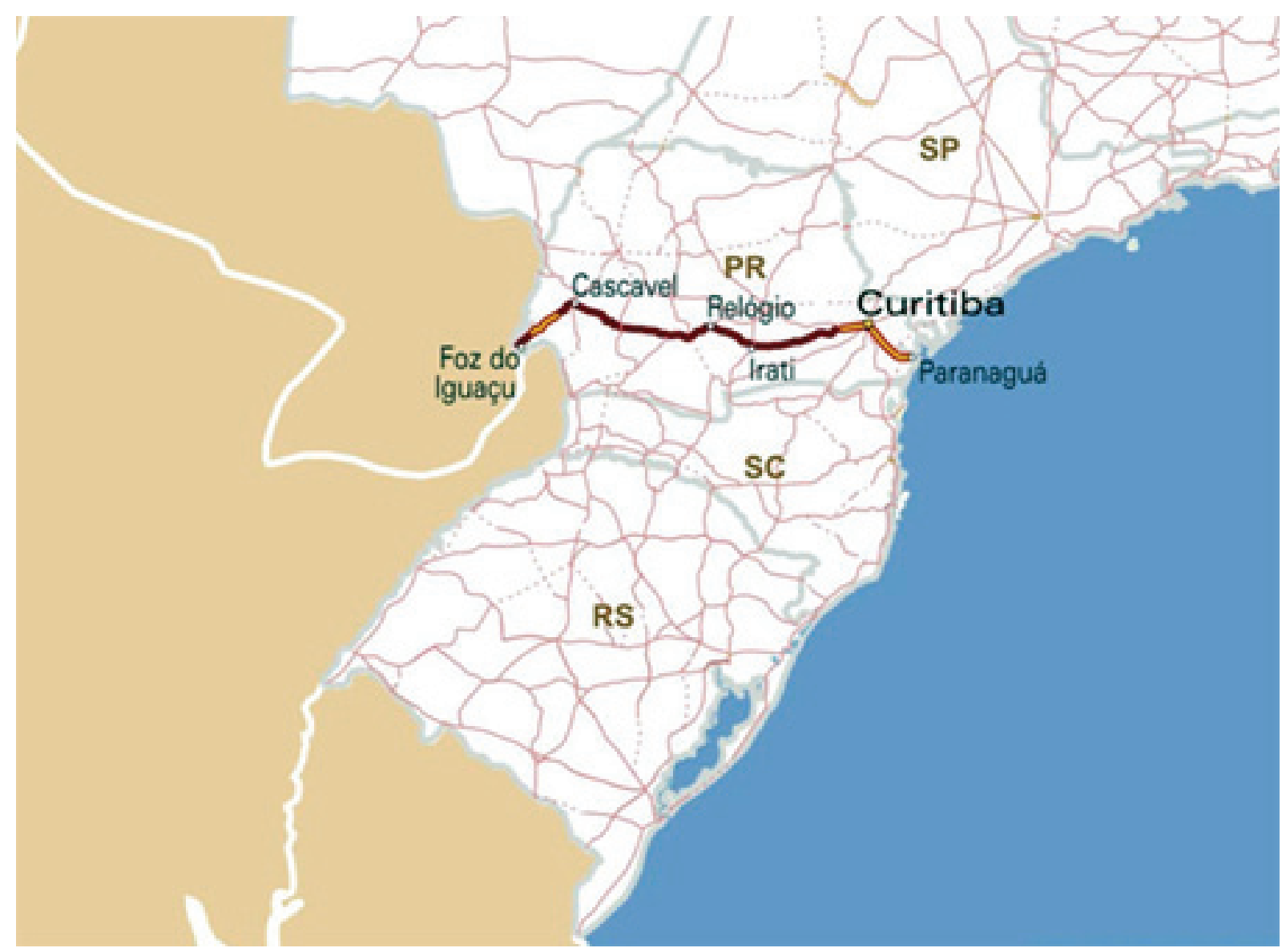

Figura 97. BR-277. Porto de Paranaguá a Foz do Iguaçu. Brasil.

Fonte: http://pt.wikipedia.org/wiki/BR-277. Pesquisado em 15.03.2013

Em Ciudad del Leste esta rodovia, obedecendo à mesma orientação Leste-Oeste e estendendo-se através de 325 km, alcança Assunção. Daí em diante a rodovia segue rumo à Cañada de Oruro, fronteira com a Bolívia, atravessa por Santa Cruz de La Sierra, Cochabamba e La Paz. É a "Ruta 33” da Bolívia. Por fim, interliga Cuzco, Nazca e Lima, no Peru. Assim, a BR-277 é parte integrante da Rodovia Panamericana que de Lima, capital do Peru, praticamente as margens do 
Pacífico, atinge o Porto de Paranaguá no Atlântico, após atravessar a Bolívia e o Paraguai. Assim o Peru também foi enfeixado na estrategia geopolítica brasileira, este país como os outros, também pode ter a sua disposição uma saída para o Atlântico.

Vejamos a importância do Porto de Paranaguá. Ele está localizado na cidade de Paranaguá no estado do Paraná. É o maior porto exportador de produtos agrícolas do Brasil, com destaque para a soja em grão e o farelo de soja. No ano de 2007, o Porto de Paranaguá, movimentou 38,5 milhões de toneladas e gerou uma receita cambial de US\$11,8 bilhões. O Porto de Paranaguá é o quarto maior porto do mundo e o maior porto graneleiro da América Latina. Sendo também o $3^{\circ}$ maior porto de conteineres do Brasil, perdendo só para Itajaí e Santos. É o maior porto do Brasil em exportação de grãos. Exporta e importa grãos, fertilizantes, contêineres, líquidos, automóveis, madeira, papel, sal, açúcar, entre outros. A maioria dos navios orindos de outros paises são provenientes dos Estados Unidos, China, Japão e Coreia do Sul.

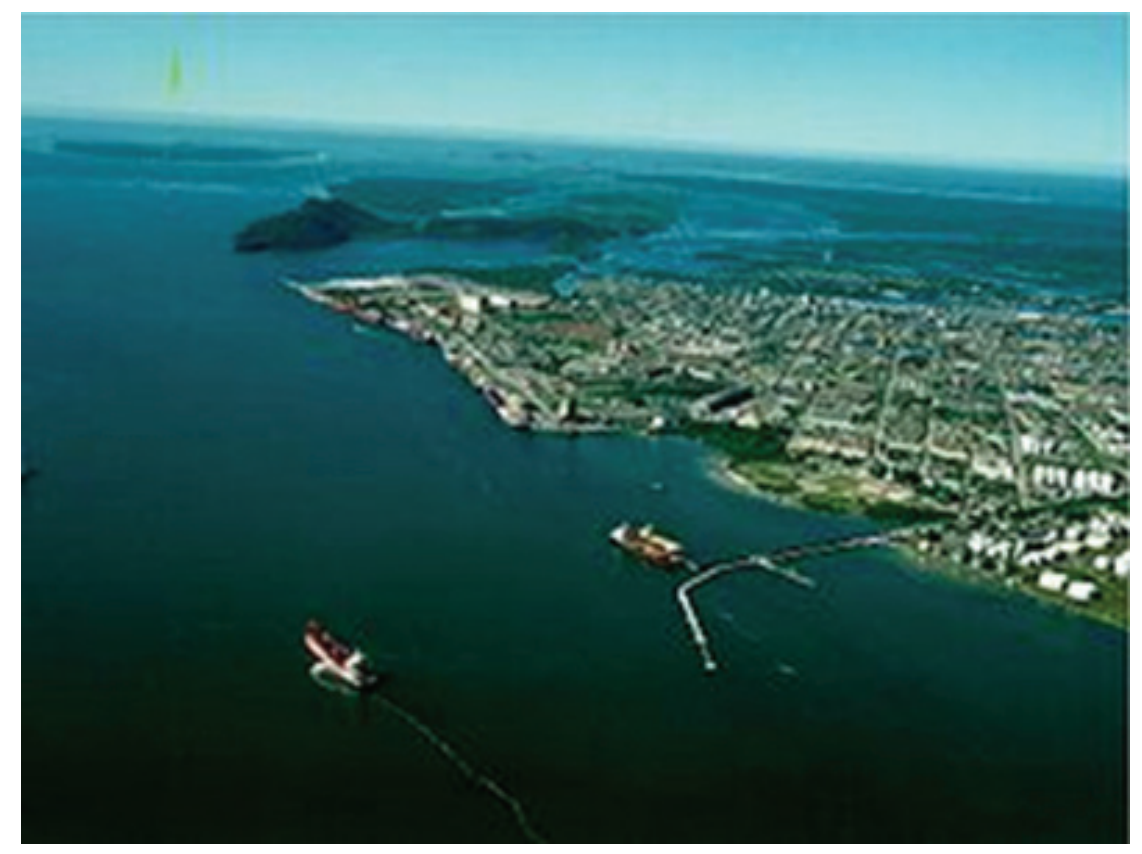

Figura 98. Porto de Paranaguá na Baía de Paranaguá.

Fonte: http://pt.wikipedia.org/ wiki/Porto_de_Paranagua.

O Porto de Paranaguá tem sua área de influência formada pelos estados de Mato Grosso do Sul, Mato Grosso, Santa Catarina, Rio Grande do Sul, Paraná, Paraguai, Minas Gerais e parte de São Paulo ${ }^{102}$.

Assim estava cumprido o projeto de Golbery por meio de criação de rodovias, no Paraguai e no Brasil, nos quais percorridos apenas 1055 km, de Assunção, se alcançou o porto de Paranaguá no Atlântico.

$\overline{102}$ Pesquisa obtida em http://pt.wikipedia.org/wiki/Porto_de_Paranagua. Pesquisado em 15.03.2013. 
Da mesma forma que ocorreu com a Bolívia, o Brasil satelizou o Paraguai lhe dando uma saída para o Atlântico, com isso enfraqueceu econômica e politicamente a Argentina, na medida em que retirou dela o controle sobre seu segundo "prisioneiro geopolítico", toda a produção do Paraguai viria a ser exportada também pelo Brasil, e não mais por Buenos Aires.

Ao criar essas rodovias podemos ver no mapa de Magnoli, “A manobra estratégica do Prata", apresentado anteriormente, que elas entestam com Las Misiones na Argentina, assim os dois países estabeleceram uma "linha de fronteira", as rodovias, com a cunha argentina, na qual iniciase a movimentação do ecúmeno na área paraguaia em Puerto Stroessner e maior vitalização em Foz do Iguaçu, áreas essas todas delineadas antes por Golbery, como podemos constatar no mapa denominado "Compartimentação Geopolítica da America do Sul”.

Todas as rotas criadas tanto para o Paraguai como para a Bolívia, viriam desaguar no atlântico brasileiro; o Brasil livrou-os de serem "reféns geopoliticos" da Argentina, e portanto, ao sairam da dependencia político-economica argentina, enfraqueceram a economia desse país e sua possivel hegemonia politica no sub-continente, transferindo ou reforçando, portanto, o fortalecimento da hegemonia política e economica do Brasil na America do Sul.

\section{A Usina Hidreletrica de Itaipu ou o Consorcio Brasil-Paraguai: A Itaipu Binacional}

\section{O contexto histórico}

Antes de mais nada vejamos o contexto histórico em que se desenvolveu a matriz energética brasileira. Uma analise retrospectiva da política energética brasileira no período que vai de 1945 a 1990, teve como elemento diretor o desenvolvimento da infraestrutura de oferta de derivados de petróleo e de eletricidade, visando aumentar rapidamente o grau de acesso da indústria e a cobertura geográfica de suprimento. Esse desenvolvimento foi definido e implementado por empresas estatais que tiveram como pilar financeiro, além do aval do Estado para alavancar recursos de terceiros, significativos aportes de recursos fiscais, para-fiscais e através da renuncia fiscal.

O artigo "Política Energética Brasileira: Mudança de Rumo?"103 de João Lizardo Rodrigues Hermes de Araujo e Adilson de Oliveira, ambos do Instituto de Economia da Universidade Federal do Rio de Janeiro, demonstra como caminhou a política energética no Brasil.

\footnotetext{
$\overline{103}$ ARAUJO, João Lizardo Rodrigues Hermes de. \& OLIVEIRA, Adilson de. Política Energética Brasileira: Mudança de Rumo? Artigo apresentado no Colóquio Internacional "Energia, Reformas Institucionales y Desarrollo en America Latina". Universidad Nacional Autónoma de México - Université PMF de Grenoble, México, DF, 5 a 7 noviembre de 2003.
} 
A crise de 1929 e a Revolução de 1930 tiveram um papel relevante para a industrialização brasileira e, por conseguinte para o problema petrolífero. A crise de 1929 tinha deteriorado o poder de compra das exportações brasileiras; (...) este foi reduzido em 50\%. Nestas condições orientar as importações tornava-se imperioso para manter funcionando o parque industrial e avançar no desenvolvimento industrial. Esta pauta tinha no petróleo um elemento importante e a tendência era que o seu consumo seria ascendente devido ao processo de industrialização.

O elemento novo no universo econômico brasileiro era o aumento do poder político do Governo Central. Ao contrario da etapa anterior, onde aquele era fragmentado pela política dos governadores, a importância política da União consubstanciou-se numa participação crescente do Estado no aparelho produtivo.

Os anos de 1920 a 1950 foram décadas em que se introduziram profundas mudanças na economia brasileira. A crise da economia cafeeira de exportação acelerou a divisão do trabalho nacional com a implantação de um setor manufatureiro no país. A incipiente base técnico-produtiva industrial persistia dependente das importações de bens intermediários e de capital. Mesmo de caráter restrito, o surgimento de novas indústrias havia provocado uma transformação profunda das estruturas do consumo energético nacional, sobretudo depois da Segunda Guerra Mundial: de 1944 a 1955 o consumo de carvão mineral, derivados de petróleo, hidroeletricidade, cresceu a uma taxa media de $14 \%$ ao ano provocando pressões cada vez mais fortes no precário aparelho produtivo energético $\underline{\text { nacional. }} \underline{\text { O binômio "transporte e energia" ameaçava a expansão industrial; e a superação destes }}$ pontos de estrangulamento foi a preocupação dominante do segundo Governo Vargas.

O problema era que o desenvolvimento industrial do Brasil tinha que fazer uma transição direta da lenha para o petróleo e eletricidade, e a construção deste sistema energético moderno esbarrava na incapacidade do capital privado nacional de mobilizar volumosos recursos financeiros necessários a empreendimentos de longa maturação e risco elevado, como é o caso do setor energético. Só o capital internacional ou o Estado estavam em condições de promover aqueles investimentos.

Desde de 1930 existia no país uma consciência da necessidade de criar mecanismos de centralização de recursos financeiros e técnicos, que viabilizassem investimentos de grande porte na industria siderúrgica e na refinação de petróleo. A centralização do poder comandada por Vargas, havia gerado uma serie de órgãos públicos entre eles o Conselho Nacional de Petróleo e o Conselho Nacional de Água e Energia, voltados para o planejamento do desenvolvimento industrial brasileiro (Araujo \& Oliveira: 2003: 628) (grifos nossos).

Vejamos a importância dos investimentos estatais em infraestrutura, e sua defesa e controle nacional, para a dinamização da industrialização brasileira:

O processo de industrialização em curso tinha gerado intenso debate entre nacionalistas e privatistas desde os anos 30, que se intensificou no pós-guerra. O nacionalismo econômico havia ganhado uma 
nova dimensão e empolgava cada vez mais a sociedade, crescendo a proposta de defesa e controle nacional dos recursos naturais e a visão de que a industrialização só seria viável através do apoio

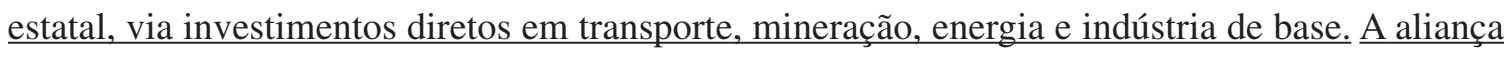
entre militares e quadros técnicos havia feito nascer nos anos 30 as bases de uma política ao mesmo $\underline{\text { tempo estatizante e nacionalista. (...) A indústria do petróleo e a eletricidade de origem hidráulica }}$ formavam a base da estrutura de consumo requerida pelo avanço do processo de urbanização/industrialização. O monopólio surgiu como solução racional que garantiria a otimização dos recursos escassos, viabilizando ganhos de escala em um mercado que era incipiente (Araujo \& Oliveira: 2003: 628-9) (grifos nossos).

Em 1953 com a campanha nas ruas “O Petróleo é nosso” foi criada a Petrobrás. A Eletrobrás depois de muitos esforços do governo Vargas, na verdade foi criada oficialmente em 1961, já durante o governo JK. Vejamos a importância destas duas instituições:

O ano de 1954 representou um marco na historia política brasileira. O suicídio de Vargas representou a derrota de um projeto governamental de desenvolvimento nacional autônomo. $\mathrm{O}$ fracasso do visionário projeto nacionalista teve, no entanto, algumas das suas utopias plenamente realizadas através da constituição das empresas energéticas (Petrobrás e Eletrobrás).

Na realidade a vigorosa evolução da economia brasileira colocava exigências crescentes de participação do Estado no sentido de superar os gargalos causados pela deficiência na infraestrutura econômica do país. No que diz respeito ao Governo, a intervenção do Estado limitou-se ao reaparelhamento da infraestrutura de transporte e energia.

O nacionalismo de Vargas nunca ameaçou a participação do capital estrangeiro na economia nacional: "Não nos opomos, como se costuma insinuar, à vinda de capitais estrangeiros para o Brasil. Ao contrario, desejamos que venham.” (Vargas, G. 1951, 303). Entendia que o Estado devia preservar a soberania nacional nos setores considerados estratégicos "Somos contrários, sim, à entrega de nossos recursos naturais, de nossas reservas ao controle de companhias estrangeiras, em geral a serviço do capital cosmopolita... o que constitui alicerce de nossa soberania, não pode ser entregue a interesses estranhos;" (Vargas, G. 1951, 303).

Os principais argumentos em favor da visão de que o segundo governo Vargas buscou o desenvolvimento nacional autônomo foram os projetos de criação da Petrobrás e Eletrobrás. Estas duas empresas e a simbólica morte com um tiro no peito em 24.08. 1954 fixaram no imaginário nacional a figura de Vargas como o paladino do desenvolvimento brasileiro.

A Petrobrás e a Eletrobrás, em suas trajetórias, organizaram o mercado energético nacional e tem um saldo histórico positivo para a sociedade brasileira. A primeira porque criou uma estrutura técnico gerencial importante capaz de operar globalmente e capacitou tecnologicamente a Nação a 
extrair petróleo em águas profundas, possibilitando a descoberta de vastas reservas num país considerado parcamente dotado em óleo. A segunda estruturou dois sistemas interconectados que permi$\underline{\text { tiram o aproveitamento racional do potencial hidrelétrico brasileiro, e organizou o mercado de for- }}$ necedores, de modo a induzir a emergência de um conjunto de grandes firmas de engenharia nacionais competitivas internacionalmente (Araujo \& Oliveira: 2003: 630) (grifos nossos).

Vejamos os antecedentes que determinaram especificamente o desenvolvimento do setor elétrico nacional:

A eletricidade foi inicialmente desenvolvida por capitais privados. Até os anos 30, dois grupos dominavam o crescente mercado de eletricidade. Um era o grupo americano-canadense Light, que dominava a oferta de energia elétrica no Sudeste. O segundo era a American Foreign Power Company (AMFORP), responsável pelo fornecimento de eletricidade a cidades menores nos estados de São Paulo e Rio de Janeiro, além de outros centros como Porto Alegre, Pelotas, Curitiba, Salvador, Natal e Vitoria. Além destes grandes grupos, muitas empresas públicas e privadas forneciam energia em pequena escala a regiões mais pobres. $\underline{\mathrm{O} \text { capital internacional controlou até a década de } 70 \mathrm{a}}$ distribuição nas duas maiores cidades brasileiras ( $\mathrm{SP}$ e RJ), e consequentemente no polo industrial do país. No que se refere à produção, ainda em 1950 mais de $81 \%$ da potencia instalada estava na atual região Sudeste e era propriedade do capital privado internacional.

Foi nas administrações Vargas que se deu a irrupção do Estado na geração de energia elétrica ao lado de grandes sociedades estrangeiras que abasteciam a região mais rica do país. Desde o final do século passado a hidroeletricidade era utilizada no Brasil, sendo responsável pela maior parte da geração de eletricidade no país. O elevado potencial hidroelétrico, próximo a principal região consumidora, levou o primeiro governo Vargas a promulgar uma legislação (o Código de Águas) ${ }^{104}$ em 1934, e criar um órgão regulador (Conselho Nacional de Águas e Energia Elétrica) em 1939 para orientar a exploração desses recursos. A coexistência do Estado e de empresas estrangeiras atuando conjuntamente no setor imprimiu uma dualidade, tanto de ordem técnico financeiro como política à industria de energia elétrica. No processo de evolução histórica do setor de energia elétrica brasileiro se estabeleceu uma divisão de trabalho que legou ao Governo federal os processos de geração e transmissão de energia elétrica, que exigem maiores investimentos e tem longos prazos de maturação, modificando a estrutura da propriedade setorial. A distribuição, inicialmente a cargo de empresas estrangeiras, foi progressivamente sendo estadualizada. (Araujo \& Oliveira: 2003: 636-7) (grifos nossos).

$\overline{104} \mathrm{O}$ autor em nota afirma: O Código de Águas foi até a década de 90 a base de toda a regulamentação do setor. Previa a fixação de tarifas pelo custo de serviço, remunerando o investimento a uma taxa justa sobre o valor histórico dos ativos (custo contábil). Estipulou a propriedade publica dos recursos hídricos e restringiu a exploração econômica, sob concessão do governo federal, a cidadãos brasileiros (Araujo \& Oliveira: 2003: 637). 
A perspectiva de colapso de abastecimento de energia elétrica nos anos 1959/1960 no Brasil era uma realidade:

No pós-guerra, a evolução da indústria de energia elétrica foi fruto da superposição de um setor publico nascente, não mais constituído de pequenas centrais municipais, mas de grandes empresas estaduais e federais que se formaram para executar os grandes projetos de aproveitamentos hidráulicos, ao lado de setores estrangeiros instalado no país. A perspectiva de colapso rondava o setor elétrico quando Vargas assumiu o mandato constitucional de 1951. O prognostico era de que por volta de 1959/1960 o país enfrentaria uma grave crise de abastecimento de energia elétrica de consequências imprevisíveis, caso os grandes aproveitamentos hidráulicos e as interconexões entre as zonas de concessão não fossem realizadas. Ao retornar ao poder, o governo Vargas tinha nessa questão um problema prioritário (Araujo \& Oliveira: 2003: 639) (grifos nossos).

Covre $^{105}$ acrescenta que O Código de Águas assegurava ao Estado o controle total sobre as concessionárias de energia elétrica. Ele estabeleceu o regime de concessões (com prazo determinado) e autorizações, ambas concedidas pela União e determinando a fiscalização técnica, financeira e contábil de todas as empresas do setor.

Araujo e Oliveira, afirmam que até então a presença do Estado no setor elétrico era dispersa, fruto de iniciativas pioneiras de alguns estados: Rio Grande do Sul, Paraná e Minas Gerais. Minas criou a CEMIG (Centrais Elétricas de Minas Gerais SA) e São Paulo, duas sociedades de economia mista, a USELPA (Usinas Elétricas de Paranapanema SA) e a CHERP (Companhia Hidrelétrica do rio Pardo); e em 1951 as Centrais Elétricas de Urubupungá SA para explorar o potencial hidráulico de um trecho do rio Paraná na fronteira com Mato Grosso, a futura hidrelétrica Ilha Solteira - Jupiá.

Assim a evolução da oferta de energia elétrica foi descontínua, cada projeto sendo encarado como uma unidade isolada, não integrada num sistema de projetos interligados. Esta diversidade entre projetos e empresas acentuou a descontinuidade, institucional e organizacional do setor. (...) Diante desta situação o segundo governo Vargas enviou ao Congresso Nacional o Plano Nacional de Eletrificação e o projeto de criação da Eletrobrás (Mensagem 134/135). Esta seria uma empresa publica responsável pela gestão de todos os empreendimentos estatais no setor. 0 Plano Nacional de Eletrificação previa a duplicação da capacidade instalada, interligação dos sistemas regionais e a unificação das correntes elétricas em dez anos (Araujo \& Oliveira: 2003: 639-40) (grifos nossos).

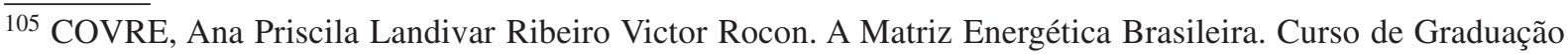
em Engenharia Química. Departamento de Engenharias e Computação. Centro Universitário Norte do Espírito Santo. Universidade Federal do Espírito Santo. 2011, p. 2. 
O Congresso Nacional acabou por criar inúmeros entraves ao Projeto de Vargas e finalmente em 1961 a Congresso aprovou a criação da Eletrobrás, porém numa versão menos ambiciosa do que o projeto original.

As Centrais Elétricas Brasileiras SA (Eletrobrás ) (...) não tinha o monopólio da produção e transmissão de energia elétrica, mas apenas o papel de coordenador do setor. Desta forma, a presença do capital privado na indústria de energia elétrica não foi alterada; $\underline{\text { entretanto, o Estado pretendia assu- }}$ mir a liderança do processo de expansão. As empresas privadas continuariam participando através de suas instalações existentes, basicamente na distribuição. É importante notar que, como estas empresas estavam concentradas no eixo Rio/São Paulo, elas eram responsáveis por cerca de $50 \%$ da distribuição de energia elétrica do país. (...) A formação da Eletrobrás alterou rapidamente a estrutura de propriedade do setor. Expandiu-se a participação publica, estagnou o setor privado (...) (Araujo \& Oliveira: 2003: 640-1) (grifos nossos).

Assim nota-se o esforço em que os governos brasileiros trouxeram para o domínio estatal o controle da geração, transmissão e distribuição da energia elétrica.

Vejamos a evolução da capacidade instalada de energia elétrica no país no período anterior à construção da Itaipu:

Em 1940, a capacidade instalada de energia elétrica do Brasil era de 1.250 MW. A partir da década de 40, várias empresas estatais foram criadas para a exploração dos recursos energéticos brasileiro, principalmente do seu potencial hídrico. Em 1950, a capacidade instalada passou para 1.900 MW. O Brasil tinha presenciado uma fase de intenso desenvolvimento econômico e industrial nos anos seguintes, principalmente durante o governo liberal de Juscelino Kubitschek (1956-1961). Com isso, a capacidade energética instalada no ano de 1960 deu um salto para 4.800 MW. Em 1961 foi criado o Ministério de Minas e Energia (MME) e, em 1962, a Eletrobrás. Apesar do desenvolvimento dos anos anteriores, até meados dos anos 60, a malha de transmissão do país ainda era ainda bastante isolada e pouco eficiente. Essa situação começou a mudar em 1969, com a intervenção do MME, que criou o Comitê Coordenador de Operações Interligadas (CCOI), abrangendo as empresas geradoras e distribuidoras da região sudeste, de forma que a malha de transmissão passasse gradativamente a funcionar de forma integrada, aproveitando de forma mais racional as fontes energéticas e melhorando a qualidade do serviço (COVRE: 2011:2).

Covre acrescenta, as inúmeras vantagens em ter o país energia elétrica disponível, por meio de hidrelétricas. Ela afirma que:

A matriz energética brasileira é baseada em recursos renováveis presentes em seu território, isso 
torna o país menos vulnerável a crises mundiais envolvendo o preço do petróleo. É nesse cenário em que a matriz energética brasileira se destaca. Enquanto a maior parte do mundo gera sua energia com base em combustíveis fósseis, altamente poluentes e de valor econômico variável conforme a economia global, o Brasil possui uma matriz energética baseada em recursos renováveis e existentes em seu território. Enquanto a média mundial é de apenas 13\% de energia proveniente de fontes renováveis, no Brasil essa taxa é de $46 \%$, e a comparação se torna mais desigual se apenas considerar a produção de energia elétrica, em que a média mundial é de $13 \%$ e a do Brasil alcança $87 \%$ de energia elétrica renovável. O segundo aspecto se apresenta nos momentos de crise econômica mundial. Enquanto a elevação dos preços dos insumos energéticos, principalmente do petróleo, afeta o custo da produção de energia dos demais países e, consequentemente, prejudica a indústria, a geração no Brasil não sofre tanto impacto, pois não é tão dependente do petróleo. Dessa forma, a indústria brasileira ganha em competitividade no cenário mundial (COVRE: 2011:1).

Atualmente, a participação das energias renováveis representa $46 \%$ de toda a matriz energética nacional, em contraste com a média de $13 \%$ da matriz mundial. Ao mesmo tempo em que o Brasil se torna menos dependente dos combustíveis fósseis, o país se descobre ser autossuficiente em petróleo, o que reduz consideravelmente os efeitos ocasionados pelas flutuações internacionais no preço do petróleo. A matriz brasileira se destaca da matriz mundial pela presença de energia proveniente de fontes renováveis. A matriz energética nacional é bem mais limpa que a matriz mundial (COVRE: 2011:2).

A diminuição dos combustíveis fósseis se deve atualmente pelo aproveitamento da cana de açúcar (álcool e bagaço), que já representa 16\% da matriz, a segunda maior fonte de energia. Se compararmos a produção de energia elétrica à dependência do petróleo é menor ainda, o índice de uso de fontes renováveis para geração de energia elétrica é de $87 \%$ atualmente. Isso se deve ao aproveitamento do imenso potencial hídrico existente no território nacional. Outro diferencial da matriz energética brasileira é a segurança do sistema elétrico. A vulnerabilidade energética é uma das grandes preocupações dos países industrializados. O Brasil possui uma posição bastante favorável quanto a esse aspecto, pois como já mencionado é autossuficiente em petróleo e em energia, e ainda conta com o Sistema Interligado Nacional (SIN), único em âmbito mundial. Devido ao recente processo de reestruturação do setor elétrico brasileiro, a geração é feita de maneira descentralizada, de modo a valorizar as fontes nãoconvencionais. Nesse cenário as pequenas centrais hidrelétricas desempenham um papel de extrema importância. A parcela de participação da energia hidroelétrica na matriz brasileira é de $14,7 \%$ e, se tratando de geração de energia elétrica, representa 68,28\%. Apesar do crescente aumento de outras fontes e a existência de restrições socioeconômicas e ambientais de projetos hidrelétricos, tudo indica que a energia hidroelétrica ainda será por muitos anos a principal fonte geradora de energia elétrica, isso porque apenas 70\% do seu potencial é explorado (COVRE: 2011:3).

Apesar do grande potencial, a geração hidroelétrica possui ainda outras vantagens como ser renovável e ser extremamente barata. Além disso, o Brasil possui um equilíbrio na sua matriz energética, sendo 
composta por variados tipos de fontes e desenvolvida de forma sustentável, aproveitando a atividade de setores da economia, como na produção dos biocombustíveis (COVRE: 2011:4).

Dada a constatação que a energia elétrica obtida por hidrelétricas apresenta tantas vantagens, energia renovável, limpa, barata, não vulnerável às flutuações do preço do petróleo, porque não compensar de forma justa o meio ambiente e as populações afetadas pela sua construção? Covre toca no problema, mas não cita claramente as populações que perdem suas terras:

A busca por geração de energia a qualquer custo é tão grande a ponto de poder ser observado, em todo o mundo, impactos ambientais causados, seja pela busca de recursos naturais como o carvão e o petróleo, seja pela falta de gerenciamento de resíduos dos processos de produção como no caso de gases de efeito estufa nas termoelétricas, ou ainda pela própria construção das usinas. É necessário repensar a composição da matriz energética para que se possa conciliar desenvolvimento industrial e preservação do meio ambiente (COVRE: 2011:1).

A composição da matriz energética de uma nação deve visar o menor custo possível, aproveitando os recursos naturais existentes. Contudo não é aceitável a geração de energia a qualquer custo, é necessário pensar no bem-estar social e na preservação da natureza. A matriz brasileira aproveita bem os seus recursos hídricos, uma fonte renovável e de baixíssima produção de poluentes, além de investir no desenvolvimento de fontes não-convencionais tais como a biomassa e a energia eólica (COVRE: 2011:4).

Voltando as observações de Golbery, dado o crescente desenvolvimento econômico que o Brasil vinha apresentando desde os governos de Vargas e de Juscelino Kubitschek, visando a continuidade de operação e o crescimento dos empreendimentos industriais naquela altura de 1959, Golbery chegou a afirmar, como vimos antes, duas questões:

- que, nesse período, o sistema econômico em desenvolvimento revelou descompassos no setor produtivo, apresentando falhas, entre eles, déficit de energia:

É certo que o desenvolvimento econômico acelerado, na ânsia de queimar etapas, pode gerar, por si mesmo, as mais serias crises - de credito, de divisas, de inflação, as sucessivas greves, insatisfação e motins; agrava, em muitos casos, fundamentais pontos de estrangulamento do sistema - o constante déficit de energia... (SILVA: 1967:71) (grifos nossos).

- que, ao citar e expor o mapa do historiador Jaime Cortesão, Golbery, analisando o Salto das Sete Quedas em Guaíra e o Salto do Iguaçu em Foz do Iguaçu, os apontou como importantes "faixas ou centros formadores de fronteira": 
Sobre este espaço continental, situado nos trópicos úmidos e rodeado insularmente pelo sistema hidrográfico platino-amazônico, de traços muito vigorosos, destacavam-se, envolvendo-o num arco de circulo irregular, certas zonas de relevo áspero, declive abrupto ou profunda depressão, que opunham forte obstáculo à expansão humana (...). Apontemos as mais características: ao Norte (...); a Noroeste (...); a Oeste (...); finalmente, mais ao Sul, o Salto das Sete Quedas sobre o Paraná, o

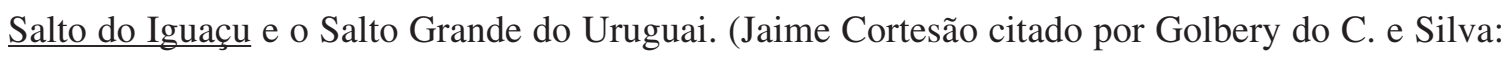
1967:66) (grifos nossos).

Dessa forma a hidrelétrica de Itaipu viria a cobrir em parte o alto déficit de energia existente no país, sendo a maior hidrelétrica do mundo em termos de potencia energética instalada (14.000 MW), assim como viria também a marcar nitidamente o controle da fronteira, por meio da instalação de um grande reservatório, que separa ainda mais em termos territoriais o Brasil do Paraguai, dada a grande dimensão de largura desse reservatório ${ }^{106}$, ao mesmo tempo que veio a unir politicamente por longo período os dois países, dado o projeto em conjunto, em território considerado por Golbery, um dos "centros formadores de fronteira".

\section{Início das negociações entre Paraguai e Brasil visando a construção da hidrelétrica de Itaipu}

Finalizada a Ponte da Amizade BR-PY, em 27 de março de 1965, e objetivando ainda, em termos geopolíticos a ocupação cada vez maior desse ecúmeno, próximo a área de "tensão máxima” citada por Golbery, "Las Misiones” na cunha argentina, a reorientação dos fluxos paraguaios, sobre o eixo oeste-leste magnetizado pelo Brasil, se combinaria com outro Grande Projeto. O governo autoritário embalava o sonho do "Brasil Grande" e a sua concepção se encaixava nos objetivos estratégicos da visão geopolítica militar do Brasil. Entestando de frente com o território Las Misiones, foi construída a Usina Hidrelétrica de Itaipu. (figura a seguir)

A barragem da hidrelétrica de Itaipu está localizada sobre o Rio Paraná, no trecho de fronteira entre o Brasil e o Paraguai, $14 \mathrm{~km}$ ao norte da Ponte da Amizade. A área do projeto se estende desde Foz do Iguaçu/Brasil e Ciudad del Este/Paraguai, ao sul, até Guaíra/Brasil e Salto del Guairá/Paraguai, ao norte. Ocupa superfície de dimensões de 1400 km2 $(800$ km² no Brasil e $600 \mathrm{~km}^{2}$ no Paraguai) sendo que $1350 \mathrm{~km} 2$ possui somente o reservatório criado.

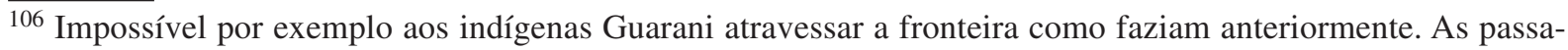
gens terrestres ficaram restritas a Foz do Iguaçu e Guaíra.
} 
Itaipu é resultado de intensas negociações entre os dois países, que ganharam impulso na década de 60. Em 2 de junho de 1966, os ministros das Relações Exteriores do Brasil, Juracy Magalhães, e do Paraguai, Sapena Pastor, assinaram a “Ata de Iguaçu”, uma declaração conjunta que manifestava a disposição para estudar o aproveitamento dos recursos hidráulicos pertencentes em condomínio aos dois países no trecho do Rio Paraná. Em fevereiro do ano seguinte, foi criada a Comissão Mista Brasil-Paraguai para a implementação da "Ata de Iguaçu”, relativa ao estudo sobre o aproveitamento do Rio Paraná.

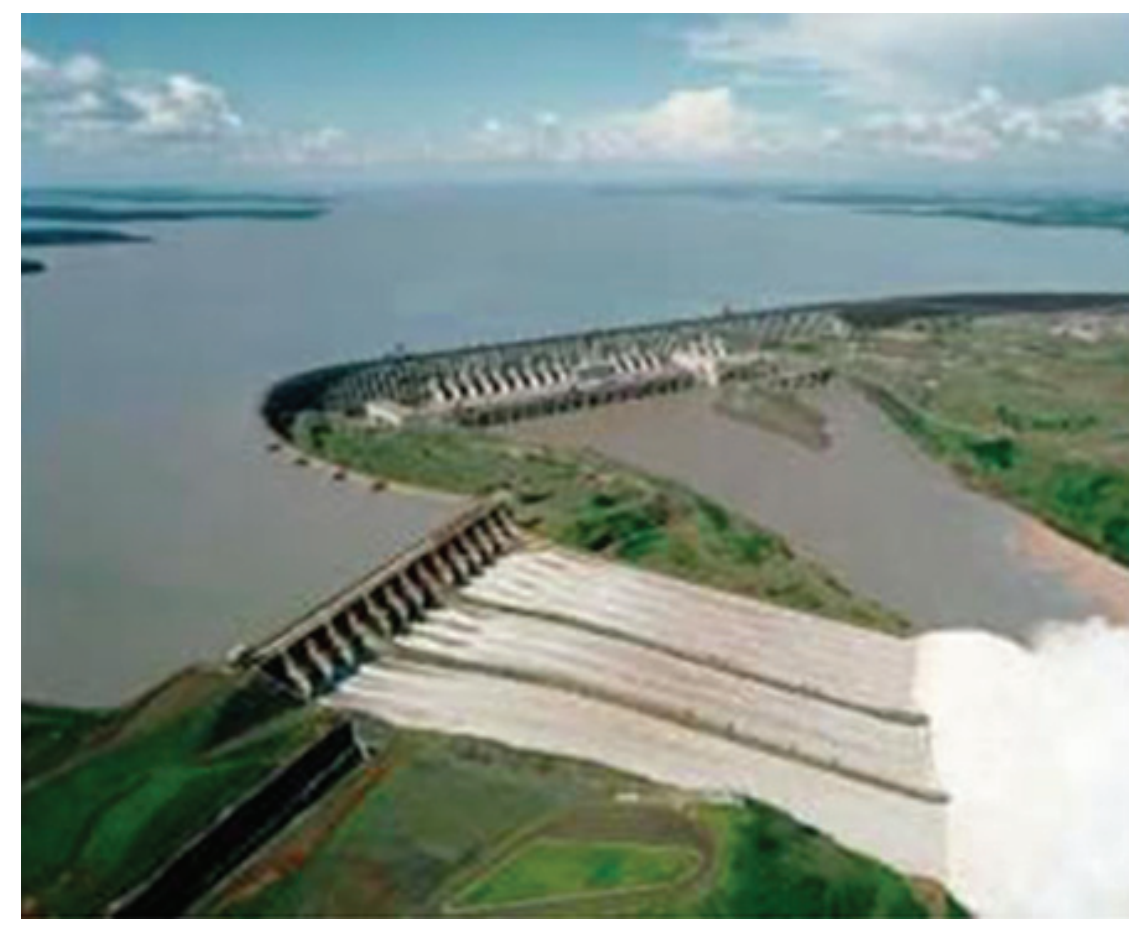

Figura 99. Rio Paraná, a Usina Hidreletrica de Itaipu e o vertedouro.

Fonte: http://www.brasilescola.com/brasil/o-impasse-sobre-usina-itaipu.htm

Vale a pena verificar a composição desse acordo realizado entre os embaixadores do Brasil e do Paraguai, a "Ata de Iguaçu”, e como eles atendem as perspectivas geopolíticas dos militares brasileiros.

\section{ATA DE IGUAÇU ${ }^{107}$ DE 22.06.1966. BRASIL - PARAGUAI. ATA FINAL}

Aos vinte e um e vinte e dois dias do mês de junho de mil novecentos e sessenta e seis, reuniram-se nas cidades de Foz do Iguaçu e de Porto Presidente Stroessner, o Ministro das Relações Exteriores dos Estados Unidos do Brasil, Embaixador Juracy Magalhães, e o Ministro das Relações Exteriores

\footnotetext{
$\overline{107}$ Informação obtida em http://www.itaipu.gov.br/institucional/documentos-oficiais. Pesquisado em 1.05.2013. Também publicado no "Diário Oficial da União" de 08.08.1966, pg. 9.061/62.
} 
da República do Paraguai, Doutor Raúl Sapena Pastor, com o objetivo de passar em revista os vários aspectos das relações entre os dois países, inclusive aqueles pontos em torno dos quais têm surgido ultimamente divergências entre as duas Chancelarias.

Após terem mantido várias entrevistas de caráter pessoal e outras com a presença de suas comitivas, os Ministros das Relações Exteriores dos Estados Unidos do Brasil e da República do Paraguai chegaram às seguintes conclusões, que fazem constar da presente Ata:

I - MANIFESTARAM-SE acordes os dois Chanceleres em reafirmar a tradicional amizade entre os dois Povos irmãos, amizade fundada no respeito mútuo e que constitui a base indestrutível das relações entre os dois países;

II - EXPRIMIRAM o vivo desejo de superar, dentro de um mesmo espírito de boa-vontade e de concórdia, quaisquer dificuldades ou problemas, achando-lhes solução compatível com os interesses de ambas as Nações;

III - PROCLAMARAM a disposição de seus respectivos governos de proceder, de comum acordo, ao estudo e levantamento das possibilidades econômicas, em particular os recursos hidráulicos pertencentes em condomínio aos dois países, do Salto Grande de Sete Quedas ou Salto de Guaira; IV - CONCORDARAM em estabelecer, desde já, que a energia elétrica eventualmente produzida pelos desníveis do rio Paraná, desde e inclusive o Salto Grande de Sete Quedas ou Salto do Guaira até a foz do rio Iguaçu, será dividida em partes iguais entre os dois países, sendo reconhecido a cada um deles o direito de preferência para a aquisição desta mesma energia a justo preço, que será oportunamente fixado por especialistas dos dois países, de qualquer quantidade que não venha a ser utilizada para o suprimento das necessidades do consumo do outro país;

V - CONVIERAM, ainda, os Chanceleres em participar da reunião dos Ministros das Relações Exteriores dos Estados ribeirinhos da Bacia do Prata, a realizar-se em Buenos Aires a convite do Governo argentino, a fim de estudar os problemas comuns da área, com vistas a promover o pleno aproveitamento dos recursos naturais da região e o seu desenvolvimento econômico, em beneficio da prosperidade e bem-estar das populações; bem como a rever e resolver os problemas jurídicos rela$\underline{\text { tivos à navegação, balizamento, dragagem, pilotagem e praticagem dos rios pertencentes ao sistema }}$ hidrográfico do Prata, a exploração do potencial energético dos mesmos, e à canalização, represamento ou captação de suas águas, quer para fins de irrigação, quer para os de regularização das respectivas descargas, de proteção das margens ou facilitação do tráfego fluvial;

VI - CONCORDARAM em que as Marinhas respectivas dos dois países procederão, sem demora à destruição ou remoção dos cascos soçobrados que oferecem atualmente riscos à navegação internacional em águas do Rio Paraguai;

VII - EM RELAÇÃO aos trabalhos da Comissão Mista de Limites e Caracterização da Fronteira Brasil-Paraguai, convieram os dois Chanceleres em que tais trabalhos prosseguirão na data que ambos os Governos estimarem conveniente; 
VIII - CONGRATULARAM-SE enfim, os dois Chanceleres, pelo espírito construtivo que preva$\underline{\text { leceu durante as conversações e formularam votos pela sempre crescente e fraternal união entre o }}$ Brasil e o Paraguai, comprometendo-se ainda a não poupar esforços para estreitar cada vez mais os laços de amizade que unem os dois países.

A presente Ata, feita em duas cópias nos idiomas português e espanhol, depois de lida e aprovada, foi firmada em Foz do Iguaçu, pelos Ministros das Relações Exteriores dos Estados Unidos do Brasil e da República do Paraguai, em vinte e dois de junho de mil novecentos e sessenta e seis. Juracy Magalhães, Ministro de Estado das Relações Exteriores dos Estados Unidos do Brasil, Raúl Sapena Pastor, Ministro das Relações Exteriores da República do Paraguai.

Assim, nota-se o profundo atrelamento geopolítico do Paraguai ao Brasil, exclusão do processo da Argentina e no item V, se pode notar "arestas" a serem aparadas entre os países-sócios e a Argentina.

Em 1970, o consórcio formado pelas empresas IECO - International Engeenering Company, de São Francisco /Estados Unidos e ELC - Eletroconsult, de Milão/Itália, venceram a concorrência internacional para a realização dos estudos de viabilidade e para a elaboração do projeto da obra. O início dos trabalhos se deu em fevereiro de 1971.

Vejamos o contexto político-econômico na época no Brasil, por imposição externa:

Nos anos 50, o debate sobre a condução do processo de desenvolvimento econômico foi favorável a corrente que preconizava um papel ativo para o Estado. (...) a intervenção do setor publico, para viabilizar ou acelerar o processo de desenvolvimento econômico. O Estado envolvia-se fortemente na infraestrutura, em particular no setor energético; no Brasil, este debate foi especialmente agudo no segundo governo Vargas, e culminou com a criação da Petrobras e da Eletrobrás. Entretanto, a partir dos anos 70 esta visão passou a sofrer ataques cerrados, que culminaram com a reforma das indústrias de infraestrutura num ambiente pró-mercado, no qual o papel do Estado passa a ser visto como regulador e provedor de direitos básicos, sem interferência direta nas atividades produtivas. Esta postura é conhecida como "Consenso de Washington" e suas componentes ideológicas são bem conhecidas (Araujo \& Oliveira: 2003: 644) (grifos nossos).

Pode-se detectar aqui novamente a interferência nos assuntos internos do país pelos norteamericanos. Consenso de Washington foi um conjunto de medidas, que se compõe de dez regras básicas, formulado em novembro de 1989 por economistas de instituições financeiras de Washington D.C., como o FMI, o Banco Mundial e o Departamento do Tesouro dos Estados Unidos, fundamentadas em um texto do economista John Williamson, do International Institute for 
Economy, e que se tornou a política oficial do Fundo Monetário Internacional em 1990, quando passou a ser "receitado" para promover o "ajustamento macroeconômico" dos países em desenvolvimento, que passavam por dificuldades. Na verdade foi um receituário de caráter neoliberal caracterizado como um esforço ideológico destinado a impor o neoliberalismo, e o fundamentalismo de livre mercado, aos países emergentes. As dez regras básicas são: - Disciplina fiscal; Redução dos gastos publicos; - Reforma tributaria; - Juros de mercado; - Câmbio de mercado; - Abertura comercial; - Investimento estrangeiro direto, com eliminação de restrições; Privatização das estatais; Desregulamentação das leis econômicas e trabalhistas; - e, Direito à propriedade intelectual.

Em fins do período do "Milagre Brasileiro", 1973, ditadura militar, governo Médici, ocorreu a Crise do Petróleo, os preços subiram as alturas. Em consequência desse fato os militares criaram vários programas buscando alternativas nacionais no campo da energia:

No início da década de 70, o mundo enfrentou um grande impacto na economia. O fator responsável pela grande penetração do petróleo era o baixo preço do barril, contudo, no ano de 1973, a OPEP aumentou significativamente o seu preço. Essa ação repercutiu de diferentes formas em cada país. No Brasil, os militares que estavam no poder reagiram com programas e ações, como o incentivo a extração de petróleo em águas profundas; a grande intensificação da construção de hidrelétricas para reduzir a dependência do petróleo, entre elas a construção de Itaipu Binacional; a associação com a Alemanha no desenvolvimento de tecnologia nuclear, que resultaram na construção de Angra I e Angra I; e o programa Proálcool, incentivando a energia renovável. O resultado disso foi que o ano de 1980 terminou com 31.300 MW de capacidade instalada de energia elétrica. (COVRE: 2011:2) (grifos nossos)

Araujo \& Oliveira, comenta a esse mesmo respeito e como vinha "bem" o modelo estatal de política energética:

Durante muitos anos, o modelo de política energética centrado na Petrobrás e na Eletrobrás funcionou muito bem. Graças a significativas economias de escala e de integração, e ao fácil acesso a financiamento domestico e internacional, não tiveram dificuldade em financiar a expansão da infraestrutura. Em meado dos anos 70, as tarifas elétricas e os preços de combustíveis foram equalizados em todo território nacional. O modelo parecia triunfante. A situação começou a mudar nos anos 70 . após o primeiro choque do petróleo. Pressionado a reduzir importações de petróleo, o governo sub$\underline{\text { sidiou a produção local de energia. A política energética centrou-se na substituição de combustíveis }}$ importados por fontes nacionais. Em consequência intensificaram-se projetos hidrelétricos e a ex- 
ploração de petróleo, foram incentivados o uso de carvão vapor e de biomassa, particularmente álcool de cana de açúcar, e lançado o programa nuclear; bem mais tarde, o gás natural foi incluído. (Araujo \& Oliveira: 2003: 645) (grifos nossos)

Foi neste contexto que em 26 de abril de 1973, os ditadores, Presidente do Brasil, Generalde-Exército Emílio Garrastazu Médici e Presidente do Paraguai, General-de-Exército Alfredo

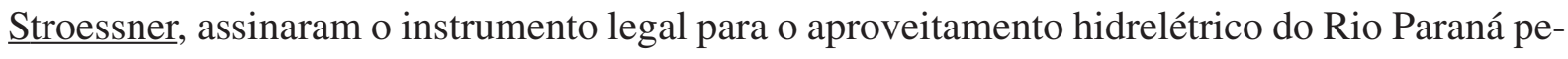
los dois países, o "Tratado de Itaipu”.

A construção da Usina Hidrelétrica de Itaipu, como veremos, além do fato de prover a demanda de energia para o país, apresentou também um papel multifuncional para a geopolítica brasileira. Para demonstrá-los analisaremos algumas partes mais significativas do Tratado de Itaipu e seus Anexos, acrescentando alguns comentários nossos e de outros autores. São eles os principais: a) a reorientação geopolítica dos fluxos paraguaios, magnetizado de vez pelo Brasil; b) A própria Usina Hidrelétrica de Itaipu pode ser caracterizada como um "território de exceção"; e neste tópico se incluem também as questões: b.1) A retirada das populações habitantes da área de interesse de Itaipu e o incremento com outras populações no território maior, em função da movimentação de capital na região da Tríplice Fronteira; b.2) a questão do pagamento de royalties aos municípios lindeiros ao reservatório; b.3) os brasiguaios; c) Os problemas geopolíticos criados com a Argentina.

\section{a) A reorientação geopolítica dos fluxos paraguaios, magnetizado de vez pelo Brasil:}

Considerando que a construção da hidrelétrica foi uma iniciativa dos militares brasileiros, chama atenção a costura geopolítica para manter o Paraguai vinculado e sob as decisões do Brasil na finalização desta "amarração", por meio de tal Tratado. Ele inicia demonstrando essa costura quanto a questão da divisão em partes iguais do Projeto e seu aproveitamento, entre o Brasil e o Paraguai. Vejamos os tópicos a este respeito:

\section{Tratado de Itaipu ${ }^{108}$ :}

Considerando o espírito de cordialidade existente entre os dois países e os laços de fraternal amizade que os unem;

$\underline{\text { O interesse comum em realizar o aproveitamento hidrelétrico dos recursos hídricos do Rio Paraná, }}$

\footnotetext{
108 Obtido em http://www.itaipu.gov.br/institucional/documentos-oficiais. Pesquisado em 15.03.2013. Tratado de Itaipu - Realizado em Brasília, em 26.04.1973. Mario Gibson Barboza - Raúl Sapena Pastor.
} 
pertencentes em Condomínio aos dois Países, desde e inclusive o Salto Grande de Sete Quedas ou Salto de Guaíra até a Foz do Rio Iguaçu;

O disposto na Ata Final firmada em Foz do Iguaçu, em 22 de junho de 1966, quanto à divisão em partes iguais, entre os dois países, da energia elétrica eventualmente produzida pelos desníveis do Rio Paraná no trecho acima referido;

Os estudos da Comissão Mista Técnica Brasileiro-Paraguaia constituída em 12 de fevereiro de 1967; A tradicional identidade de posições dos dois países em relação à livre navegação dos rios internacionais da Bacia do Prata, resolveram celebrar um Tratado e, para este fim, designaram seus Plenipotenciários, a saber:

- O Presidente da República Federativa do Brasil ao Senhor Ministro de Estado das Relações Exteriores, Embaixador Mário Gibson Barboza;

- O Presidente da República do Paraguai ao Senhor Ministro das Relações Exteriores, Doutor Raúl Sapena Pastor;

Os quais, tendo trocado seus Plenos Poderes, achados em boa e devida forma, convieram no seguinte: Artigo I

As Altas Partes Contratantes convêm em realizar, em comum e de acordo com o previsto no presente Tratado e seus Anexos, o aproveitamento hidrelétrico dos recursos hídricos do Rio Paraná, pertencentes em condomínio aos dois países, desde e inclusive o Salto Grande de Sete Quedas ou Salto de Guaíra até a Foz do Rio Iguaçu.

Artigo XIII

A energia produzida pelo aproveitamento hidrelétrico a que se refere o Artigo I será dividida em partes iguais entre os dois países, sendo reconhecido a cada um deles o direito de aquisição, na forma estabelecida no Artigo XIV, da energia que não seja utilizada pelo outro país para seu próprio consumo.

Artigo XIV

A aquisição dos serviços de eletricidade da ITAIPU será realizada pela ELETROBRÁS e pela ANDE, que também poderão fazê-la por intermédio das empresas ou entidades brasileiras ou paraguaias que indicarem.

\section{ATOS QUE APROVARAM E PROMULGARAM O TRATADO:}

1) Decreto Legislativo $n^{\circ} 23$, de 30.5.1973 - Aprova o texto do Tratado de 26.4.1973 celebrado entre a República Federativa do Brasil e a República do Paraguai, bem como as Notas então trocadas entre os Ministros das Relações Exteriores dos dois países. (Publicado no "Diário do Congresso Nacional" de 1.6.1973, pág. 1.659.) 2) Decreto ${ }^{\circ}$ 72.707, de 28.8.1973 - Promulga o Tratado de 26.4.1973, celebrado entre a República Federativa do Brasil e a República do Paraguai, bem como as seis Notas trocadas entre os Ministros das Relações Exteriores dos dois países. (Publicado no "Diário Oficial" de 30.8.1973, págs. 8.642-45.)

3) Lei no 389, de 11.7.1973 (Paraguai) - Aprova e ratifica o Tratado entre a República do Paraguai e a República Federativa do Brasil e as Notas trocadas entre os Ministros das Relações Exteriores dos dois países. 
Artigo XV

O Anexo C contém as bases financeiras e de prestação dos serviços de eletricidade da ITAIPU.

Parágrafo $3^{\circ}$ - A ITAIPU incluirá, outrossim no seu custo de serviço, o montante necessário para remunerar a Alta Parte Contratante que ceder energia à outra.

Parágrafo $4^{\circ}-\mathrm{O}$ valor real da quantidade de dólares dos Estados Unidos da América, destinada ao pagamento dos "royalties", dos rendimentos sobre o capital e da remuneração, estabelecida no Ane-

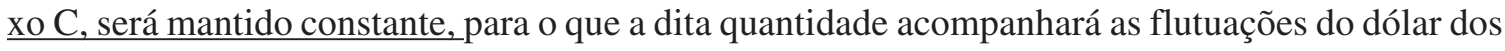
Estados Unidos da América, referido ao seu padrão de peso e título, em ouro, vigente na data da troca dos Instrumentos de Ratificação do presente Tratado.

ANEXO C - AO TRATADO DE ITAIPU - (Brasília, 26.04.1973) Bases Financeiras e de Prestação dos Serviços de Eletricidade da ITAIPU. ${ }^{109}$

II - Condições de Suprimento

II.4 - Cada entidade, tem o direito de utilizar a energia que puder ser produzida pela potência por ela contratada até o limite que será fixado, para cada período de operação, pela ITAIPU. Fica entendido que cada entidade poderá utilizar dita potência por ela contratada, durante o tempo que lhe convier, dentro de cada período de operação, desde que a energia por ela utilizada, em todo esse período, não exceda o limite acima mencionado.

II.5 - Quando uma entidade decide não utilizar parte da potência contratada ou parte da energia a esta correspondente, dentro do limite fixado, poderá autorizar a ITAIPU a ceder às outras entidades a parte que assim se tornar disponível, tanto de potência como de energia, no período referido em II.4, nas condições estabelecidas em IV.3.

III - Custo do Serviço de Eletricidade

III.8 - O montante necessário à remuneração a uma das Altas Partes Contratantes, equivalente a trezentos dólares dos Estados Unidos da América, por gigawatt-hora cedido à outra Alta Parte Contratante. Esta remuneração se realizará mensalmente na moeda disponível pela ITAIPU.

IV - Receita

IV.3 - Quando se verificar a hipótese prevista em II.5 anterior, o faturamento às entidades contratantes será feito em função da potência efetivamente utilizada.

Dessa forma, dado que o Paraguai não veio a utilizar toda a energia disponível, por acordo deste Tratado este país veio a vender a energia sobrante, com exclusividade para o Brasil. O que

\footnotetext{
${ }^{109}$ ANEXO C - AO TRATADO DE ITAIPU - Bases Financeiras e de Prestação dos Serviços de Eletricidade da ITAIPU. (Brasília, 26.04.1973). Publicado no "Diário Oficial” de 30.8.1973, pág. 8.645."VI - Revisão: As disposições do presente Anexo serão revistas, após o decurso de um prazo de cinquenta anos a partir da entrada em vigor do Tratado, tendo em conta, entre outros aspectos, o grau de amortização das dívidas contraídas pela ITAIPU para a construção do aproveitamento e a relação entre as potências contratadas pelas entidades de ambos países." Ou seja, será revisto em 2023.
} 
significaria altas somas ao caixa do Tesouro paraguaio, se não fosse a divida que este país adquiriu para a construção da própria hidrelétrica com o Brasil. Isto tem sido matéria de discussão relativamente recente entre os dois países.

Em matéria jornalística da Folha de São Paulo sobre o caso, artigo denominado "Entenda o Tratado de Itaipu"110, assim é colocado:

A usina hidrelétrica de Itaipu é resultado de acordos entre Paraguai e Brasil, que ganharam impulso na década de 1960, entrando em operação em 1984. A empresa pertence aos dois países em partes iguais. Pelo contrato de 1973, cada um tem direito a 50\% da energia produzida. Caso uma das partes não use toda a cota, vende o excedente ao parceiro a preço de custo. Como o Paraguai utiliza apenas cerca de $5 \%$ dessa energia - o que atende $95 \%$ da demanda do país ${ }^{111}-$, o restante é vendido ao Brasil - no total, $20 \%$ da energia elétrica usada por aqui vem de Itaipu. Pelo acordo, o Brasil paga atualmente US\$45,31 por megawatt ao Paraguai, dos quais porém US\$42,5 são abatidos da dívida que o Paraguai tem pela construção da usina, restando US\$2,81 para uso do país vizinho. Nessa operação, o Paraguai recebe, entre royalties e compensações, uma média de US\$ 375 milhões anuais. Os paraguaios, porém, afirmam que, se vendessem a energia a valores de mercado, obteriam até US \$ 1,8 bilhão. O contrato tem essa forma porque o Brasil bancou sozinho a construção e, depois, a recapacitação da usina. Ao vender energia a preço de custo, o Paraguai está pagando a sua parte de Itaipu. A última "prestação" vencerá em 2023, quando está prevista a renegociação do contrato.

Parece que para o Paraguai, a construção da Itaipu significou o que se chama popularmente de "por o bode na sala”. O Brasil propõe a construção da hidrelétrica ao Paraguai. O Paraguai se endividou com o Brasil com apenas com 50 milhões de dólares (metade do capital social da empresa) que foi financiado pelo Banco do Brasil ${ }^{112}$; o custo total da obra foi de aproximada-

\footnotetext{
$\overline{110}$ Obtido em Folha de São Paulo 2013. Da Folha de São Paulo com Folha Online. http://www1.folha.uol.com.br/ folha/dinheiro/ult91u394644.shtml. Pesquisado em 02.2013.

${ }^{111}$ Não está claro se estas porcentagens estão corretas. Pudemos verificar outras porcentagens em outros meios de comunicação.Por exemplo em http://www.brasil.gov.br/cop/panorama/o-que-o-brasil-esta-fazendo/matrizenergetica. Assim é descrito: O Brasil usa energia hidrelétrica desde o final do século 19, mas as décadas de 1960 e 1970 marcaram a fase de maior investimento na construção de grandes usinas. Devido a essas opções feitas no passado, o País abriga hoje a maior hidrelétrica do mundo em geração de energia. Inaugurada em 1984 depois de um acordo binacional com o Paraguai, a Usina de Itaipu tem hoje potência instalada de 14 mil MW, com 20 unidades geradoras. Essa capacidade é suficiente para suprir cerca de $80 \%$ de toda a energia elétrica consumida no Paraguai e de $20 \%$ da demanda do sistema interligado brasileiro.

112 Stroessner exigiu, por exemplo, que o Paraguai não arcasse com qualquer custo, que tivesse igualdade de direitos e que não oferecesse garantia pelos empréstimos. Até os US\$ 50 milhões da metade paraguaia do capital social da empresa Itaipu Binacional foram emprestados pelo Brasil com prazo de 58 anos, com oito de carência e juros de $6 \%$ ao ano, sendo que o Anexo C do Tratado estipulou a remuneração do capital em 12\%, possibilitando a amortização do empréstimo com os dividendos obtidos do próprio empreendimento. Obtido em http:// interessenacional.uol.com.br/2012/05/a-outra-historia-de-itaipu/. Pesquisado em 17.03.2013.
} 
mente 12 bilhões de dólares pagos somente pelo Brasil por meio de financiamento externo; da metade de energia a que o Paraguai tem direito, usa somente 5\% dela. Os outros 95\% são vendidos ao Brasil. Como o Paraguai tem a divida da construção da obra com o Brasil, a maioria desses recursos volta ás mãos do Brasil, para o pagamento da dívida paraguaia. O Paraguai se endividou de forma significativa para ter energia, a qual não necessitava de tão alta quantidade; por muito menos potencia energética abasteceria todo o país. Se o Paraguai não necessitava de tanta energia, porque se comprometeu com projeto de tão alta escala? Desta forma, até 2023 o Paraguai estará de "mãos amarradas" com o Brasil, por conta desta dívida, nesta data finaliza a última prestação, quando poderão as partes renegociar o contrato. Formula geopolítica ideal para manter o Paraguai submetido ao Brasil.

Por outro lado, não é de se menosprezar os US\$ 375 milhões anuais que recebem, por vender a preço de custo a energia para o Brasil. Mas os paraguaios consideram pouco. Isto porque se não estivessem atrelados ao Brasil pelas condições normativas do Tratado de Itaipu, poderiam alcançar um valor cinco vezes maior nessa venda, ou seja, se vendessem a energia a valores de mercado, obteriam até US\$1,8 bilhão anuais. Dessa forma, poderiam quitar a divida com o Brasil de forma muito mais rápida. Segundo diversos meios de comunicação do Paraguai, o Brasil ao pagar um valor abaixo do mercado, isso configura como uma imposição imperialista por parte do Brasil.

Segundo Leonel I. A. Mello que escreveu a obra "A Geopolítica do Brasil e a Bacia do Prata" ${ }^{113}$, ele concorda com a nossa visão na medida em que afirma:

A completa dependência do Paraguai em relação ao Brasil ficou patenteada no empréstimo que este concedeu aquele para a integralização de sua cota-parte do capital, assim como pela necessidade do aval brasileiro às operações de credito para o financiamento de Itaipu. O Tratado foi na realidade, uma sociedade do pescoço com a guilhotina. Com a elevação dos custos da obra, estimados atualmente em mais de 15 bilhões de dólares, o Paraguai é responsável por 50\% deste montante, o que significa um super endividamento quando comparado ao montante do PIB, avaliado em 5,5 bilhões de dólares. Pelos termos do Tratado, a Itaipu Binacional se obriga a vender a preço de custo (calculado em 0,3 milésimo de dólar por $\mathrm{KW}$ ) a energia elétrica fornecida aos dois países contratantes. A equidade é apenas aparente à medida em que trata igualmente usuários com necessidades de consumo desiguais. O Brasil, cuja cota-parte de 6,3 milhões de quilowatts representa $36 \%^{114}$ do consumo

\footnotetext{
$\overline{113}$ MELLO, Leonel Itaussu Almeida. A Geopolítica do Brasil e a Bacia do Prata. Manaus: EDUA, 1997. 300 p. 114 Já vimos antes que não chega a $20 \%$.
} 
nacional, será altamente beneficiado pelo custo da energia elétrica. Ao contrario, o Paraguai, que consome apenas 300 quilowatts de sua cota-parte de 6,3, só poderá retirar do custo escassos benefícios. A alternativa normal para o Paraguai seria vender a terceiros (à Argentina por ex:) o excedente disponível e auferir com isso um enorme rendimento. Acontece que esta possibilidade não existe, já que o Tratado (Artigo XIII e parágrafo único) estipula que, no caso de consumo parcial da respectiva cota de energia, qualquer das partes se obriga a vender a outra o excedente disponível, a uma remuneração de 300 dólares por gigawatt-hora (1 milhão de KW) que será pago pela Itaipu Binacional em moeda disponível (Anexo C, item III.8). (MELLO: 1997:176)

Para concluir este tópico, ao final os 14.000 MW de potencia de Itaipu foram divididos em partes iguais entre os dois países-sócios, conforme as características negociadas acima relatadas. Segundo Magnoli: A posição brasileira de maior parceiro comercial do Paraguai é reforçada e, com ela, os laços políticos estreitos que ligam o general Stroessner ao Palácio do Planalto (Magnoli: 1988:41). O conceito de "fronteiras vivas de cooperação" entre os dois países passa a ser posto em ação. Estava consolidado assim os objetivos geopolíticos do Brasil em retirar também o Paraguai do domínio geopolítico argentino, o que implicou na perda deste país de sua hegemonia político-econômica na Bacia do Prata, ao mesmo tempo que fortaleceu o Brasil em termos hegemônicos no subcontinente sul-americano. O caráter exclusivo de aproveitamento do rio Paraná entre o Brasil e o Paraguai, significou mais uma vez isolar a Argentina do processo, como veremos a frente.

\section{b) Itaipu Binacional: Território de exceção ou de excepcionalidade}

Tratado de Itaipu

Artigo I

As Altas Partes Contratantes convêm em realizar, em comum e de acordo com o previsto no presente Tratado e seus Anexos, o aproveitamento hidrelétrico dos recursos hídricos do Rio Paraná, pertencentes em condomínio aos dois países, desde e inclusive o Salto Grande de Sete Quedas ou Salto de Guaíra até a Foz do Rio Iguaçu.

"Somos um acordo entre as Altas Partes" - Brasil e Paraguai - é como se reconhecem os representantes da Itaipu Binacional, em particular seu Diretor de Meio Ambiente, Sr. Nelton Friedrich, departamento no qual, trata também da questão indígena; neste contexto este senhor alegou para a autora desse trabalho, sobre a questão indígena, e, como pudemos verificar na ocasião, também por escrito para outros órgãos públicos (em particular para o Ministério do 
Meio Ambiente, quando este cobrava o Licenciamento Ambiental que até aquela altura a Itaipu ainda não havia realizado, fato que prossegue até hoje), alegou que a hidrelétrica por essa razão, não teria a obrigação de seguir as leis indigenistas e socioambientais de seus respectivos países, porque é um acordo somente entre as "Altas Partes”, que rege-se pelo próprio Tratado e Estatuto, sendo então por isso mesmo uma "instituição independente" desses países; como isso era possível pois a hidrelétrica de Itaipu é uma empresa binacional formada por duas empresas públicas? Já desde aí se mostrou ser essa hidrelétrica um "Território de exceção".

Assim vejamos ainda outros artigos do Tratado de Itaipu que podem esclarecer a questão:

Artigo II

Para os efeitos do presente Tratado entender-se-á por:

a) Brasil, a República Federativa do Brasil;

b) Paraguai, a República do Paraguai;

c) Comissão, a Comissão Mista Técnica Brasileiro-Paraguaia, constituída em 12 de fevereiro de 1967;

d) ELETROBRÁS, a Centrais Elétricas Brasileiras S.A. - ELETROBRÁS, do Brasil, ou o ente jurídico que a suceda:

e) ANDE, a Administración Nacional de Eletricidad, do Paraguai, ou o ente jurídico que a suceda;

f) ITAIPU, a entidade binacional criada pelo presente Tratado.

Artigo III

As Altas Partes Contratantes criam, em igualdade de direitos e obrigações, uma entidade binacional denominada ITAIPU, com a finalidade de realizar o aproveitamento hidrelétrico a que se refere o Artigo I.

Parágrafo $1^{\circ}$ - A ITAIPU será constituída pela ELETROBRÁS e pela ANDE, com igual participação no capital, e reger-se-á pelas normas estabelecidas no presente Tratado, no Estatuto que constitui seu Anexo A e nos demais Anexos.

Artigo VI

Formam parte do presente Tratado:

a) o Estatuto da entidade binacional denominada ITAIPU (Anexo A);

b) a descrição geral das instalações destinadas à produção de energia elétrica e das obras auxiliares, com as eventuais modificações que se façam necessárias (Anexo B);

c) as bases financeiras e de prestação dos serviços de eletricidade da ITAIPU (Anexo C). Artigo VIII

Os recursos necessários à integralização do capital da ITAIPU serão supridos, à ELETROBRÁS e à ANDE, respectivamente, pelo Tesouro brasileiro e pelo Tesouro paraguaio ou pelos organismos financiadores, que os Governos indicarem. 
Parágrafo Único - Qualquer das Altas Partes Contratantes poderá, com o consentimento da outra, adiantar-lhe os recursos para a integralização do capital, nas condições estabelecidas de comum acordo.

Artigo IX

Os recursos complementares aos mencionados no Artigo VIII, necessários aos estudos, construção e operação da central elétrica e das obras e instalações auxiliares, serão supridos pelas Altas Partes Contratantes ou obtidos pela ITAIPU mediante operações de crédito.

Se a Itaipu Binacional é constituída pela Eletrobrás e pela Ande, respectivamente empresa pública do Brasil e do Paraguai, e assim constituída com capitais delas, a Itaipu conclui-se que é então uma "empresa pública binacional” pertencente em condomínio aos dois países. Porém, neste Artigo III, é afirmado que ela "reger-se-á pelas normas estabelecidas no presente Tratado, no Estatuto que constitui seu Anexo A e nos demais Anexos", é por isso que ela se coloca como independente das leis do país, o problema é se isso é possível pela normas constitucionais de ambos os países? Novamente demonstra ser essa hidrelétrica um "Território de exceção".

No artigo denominado "Usina Hidrelétrica de Itaipu (BRA) e Hoover Dam (EUA)" 115 , uma comparação feita sobre as duas hidrelétricas, trabalho que, no que tange sobre Itaipu, ao que tudo indica este trabalho é uma compilação do próprio site realizado pela assessoria de imprensa da Itaipu, dado o teor "chapa branca" e "triunfalista", e pelo fato de que é omisso ao esconder as mazelas sociais provocadas pela hidrelétrica; dessa forma, seu discurso é muito semelhante ao da própria Itaipu, a não ser por uma única observação ao longo de todo artigo, a qual seu autor faz, mais com espanto, admirado, do que propriamente um questionamento. Assim ele afirma:

\begin{abstract}
6. Regime Jurídico sem igual:
O Tratado de Itaipu, assinado em 1973, criou uma empresa com regime jurídico único no mundo. É uma empresa binacional, que rege-se pelo próprio Tratado que a originou e seus Anexos (A, B e C), pelos protocolos adicionais e outros atos decorrentes e por seu Regulamento Interno, bem como pelas normas de Direito Público Internacional.
\end{abstract}

Totalmente atípica, não é empresa estatal nem sociedade anônima. Sua moeda de referência é o dólar norte-americano, mas as transações no Brasil são feitas em reais e, no Paraguai, em guaranis.

\footnotetext{
$\overline{115}$ Informação obtida em: http://www.ebah.com.br/content/ABAAABlpYAI/usina-hidreletrica-itaipu-bra-hooverdam-eua?part=5. Pesquisada em 10.03.2013. Titulo: Usina Hidrelétrica de Itaipu (BRA) e Hoover Dam (EUA). Informação envida por Cesar Peixoto Jr ao Curso de Física da Universidade Federal de Goiás. s/d.
} 
Portanto, fica a questão como é possível uma empresa não ser nem estatal e nem sociedade anônima?

O jornalista Juvêncio Mazzarollo presenciou todos os fatos ocorridos a respeito da construção da Itaipu; Sobre este e outros assuntos escreveu o livro denominado "A Taipa da Injustiça: Esbanjamento econômico, drama social e holocausto ecológico em Itaipu"116. Assim relata:

O caráter binacional confere à Itaipu uma autonomia própria de uma republiqueta autônoma, ou quase. Não se trata de empresa brasileira ou paraguaia, estatal ou privada. Mais se parece com um Estado independente formado por um pedaço de território brasileiro e outro paraguaio sobre o qual foi erguida uma usina hidrelétrica. É um ente jurídico inédito no direito internacional. As decisões são irrecorríveis e só podem ser tomadas de comum acordo pelos governos dos dois países ou pela direção da empresa, que tem um diretor-geral em cada margem. Qualquer providencia unilateral representa violação do Tratado de Itaipu, quando não interferência nos assuntos internos de outro país. Segundo seus dirigentes, Itaipu só deve prestar contas à Eletrobrás no Brasil e à Ande no Paraguai.

Em 1980, o então deputado paranaense Nivaldo Kruger, requereu à Câmara Federal a instalação de CPI para investigar as aplicações financeiras em Itaipu, mas a bancada governista rechaçou o pedido. Em seguida, o deputado Mauricio Fruet apresentou a Câmara Federal projeto de lei que obrigava Itaipu a divulgar, pelo Diário Oficial da União, todos os atos desapropriatórios. E na Assembleia legislativa do Paraná, o deputado Gernote Kirinus apresentou projeto semelhante, mas os dois foram frustrados.

Os próprios dirigentes da Itaipu assumiam a tarefa de instruir os parlamentares governistas com este argumento: "Trata-se de uma empresa binacional, e binacional é sinônimo de dualidade de vontades originantes, e ao mesmo tempo espécie do gênero internacional. Por isso, o controle interno é de competência exclusiva do Conselho de Administração da entidade, enquanto o controle externo cabe à Eletrobrás, pelo Brasil e à Ande, pelo Paraguai."

Assim é que Itaipu tem permanecido imune à fiscalização por parte do Congresso Nacional ou do Tribunal de Contas da União - e assim é também que nem brasileiros nem paraguaios podiam saber exatamente o que se passava na republiqueta encravada na fronteira entre os dois países. Sabiam apenas que teriam que pagar a conta da extravagância, do desperdício e da corrupção. (MAZZAROLLO: 2003:27-8).

Essas características de intocabilidade, de não prestar contas, de ser uma empresa sem definição jurídica clara (seu site por exemplo indica ser uma empresa publica “itaipu.gov.br”), de-

\footnotetext{
$\overline{116}$ MAZZAROLLO, Juvêncio. "A Taipa da Injustiça: Esbanjamento econômico, drama social e holocausto ecológico em Itaipu”. Curitiba/São Paulo: Editado conjuntamente por Comissão Pastoral da Terra do Paraná/ CPTPR e Edições Loyola. 2003. 203p
} 
monstra que Itaipu é um território de excepcionalidade, o qual deveria ser investigado; porém, ao que parece todas as forças políticas dominantes junto ao Estado, independentemente do Partido que se encontra no governo, via de regra, estão fechadas para qualquer questionamento, diante do poder de Itaipu.

Outra questão extremamente curiosa é a isenção total da Itaipu a impostos, taxas e empréstimos compulsórios:

\begin{abstract}
Artigo XII
As Altas Partes Contratantes adotarão, quanto à atribuição, as seguintes normas:

a) não aplicarão impostos, taxas e empréstimos compulsórios, de qualquer natureza, à ITAIPU e aos serviços de eletricidade por ela prestados:

b) não aplicarão impostos, taxas e empréstimos compulsórios, de qualquer natureza, sobre os materiais e equipamentos que a ITAIPU adquira em qualquer dos dois países ou importe de um terceiro país, para utilizá-los nos trabalhos de construção da central elétrica, seus acessórios e obras complementares, ou para incorporá-los à central elétrica, seus acessórios e obras complementares. Da mesma forma, não aplicarão impostos, taxas e empréstimos compulsórios, de qualquer natureza, que incidam sobre as operações relativas a esses materiais e equipamentos, nas quais a ITAIPU seja parte;

c) não aplicarão impostos, taxas e empréstimos compulsórios, de qualquer natureza, sobre os lucros da ITAIPU e sobre os pagamentos e remessas por ela efetuados a qualquer pessoa física ou jurídica, sempre que os pagamentos de tais impostos, taxas e empréstimos compulsórios sejam de responsabilidade legal da ITAIPU;

d) não porão nenhum entrave e não aplicarão nenhuma imposição fiscal ao movimento de fundos da ITAIPU que resultar da execução do presente Tratado;
\end{abstract}

e) Não aplicarão restrições de qualquer natureza ao trânsito ou depósito dos materiais e equipamen$\underline{\text { tos aludidos no item b deste Artigo: }}$

Dessa forma, em qualquer modalidade de operação financeira a Itaipu esta isenta de impostos, taxas e empréstimos compulsórios, seja destinada a pessoa física ou jurídica, seja pelos serviços de eletricidade prestados; seja pelos materiais e equipamentos adquiridos (nacionais ou importados); seja pelas operações realizadas para adquiri-los; seja sobre os lucros, pagamentos e remessas; seja pelos não entraves e não imposição fiscal aos fundos; seja pelo transito e deposito de materiais; Assim a Itaipu possui isenção financeira total. Novamente se caracteriza por ser um “Território de exceção". 


\section{Anexo "A" do Tratado de ITAIPU117 - (ESTATUTO)}

\section{CAPÍTULO I}

\section{DENOMINAÇÃO E OBJETO}

ARTIGO $1^{\circ}$ - A ITAIPU é uma entidade binacional criada pelo Artigo III do Tratado assinado pelo Brasil e Paraguai, em 26 de abril de 1973, e tem como partes:

a) a Centrais Elétricas Brasileiras S.A. - ELETROBRÁS, sociedade anônima de economia mista brasileira;

b) a Administración Nacional de Eletricidad - ANDE, entidade autárquica paraguaia.

Seja a ELETROBRÁS, sociedade anônima de economia mista brasileira e a ANDE, entidade autárquica paraguaia, privada ou publica, a hidrelétrica, todas teriam da mesma forma terem que cumprir com as leis constitucionais dos países que fazem parte. É possível que este território de exceção se apresente dessa forma, porque foi constituído num regime político de exceção, a ditadura militar? É provável que sim. Ainda o Tratado de Itaipu revela:

\section{CAPÍTULO II}

CAPITAL

ARTIGO $6^{\circ}-\mathrm{O}$ capital da ITAIPU será equivalente a US\$100.000.000,00 (cem milhões de dólares dos Estados Unidos da América), pertencente à ELETROBRÁS e à ANDE em partes iguais e intransferíveis.

Assim o capital social é pertencente às instituições Eletrobrás e Ande.

CAPÍTULO IV

EXERCÍCIO FINANCEIRO

ARTIGO 24 ${ }^{\circ}$ - O exercício financeiro encerrar-se-á em 31 de dezembro de cada ano.

Parágrafo $2^{\circ}$ - A ITAIPU adotará a moeda dos Estados Unidos da América como referência para a contabilização de suas operações. Esta referência poderá ser substituída por outra, mediante entendimento entre os dois Governos.

A moeda de referencia é o dólar americano. Talvez por conta da alta inflação no período de sua construção. Isso será possível ainda hoje em empresa pública?

Quanto aos custos do Serviço de Eletricidade, assim revela o Tratado de Itaipu:

ANEXO C - AO TRATADO DE ITAIPU (Brasília, 26.04.1973) Bases Financeiras e de Prestação dos Serviços de Eletricidade da ITAIPU.

\footnotetext{
$\overline{117}$ Aprovado em 28 de janeiro de 1986, pela Nota DAM-I/DEM/CAI/01/PAIN LØØEØ5 do Ministro das Relações Exteriores do Brasil, e pela Nota DM/T/N.R. N ${ }^{\circ} 1$ do Ministro de Relações Exteriores do Paraguai, de idêntico teor e mesma data. (Publicado no "Diário Oficial da União" de 20.2.1986, pág. 2.703-06)
} 
III - Custo do Serviço de Eletricidade

O custo do serviço de eletricidade será composto das seguintes parcelas anuais:

III.1 - O montante necessário para o pagamento, às partes que constituem a ITAIPU, de rendimentos de doze por cento ao ano sobre sua participação no capital integralizado, de acordo com o Parágrafo $1^{\circ}$ do artigo III do Tratado e com o Artigo VI do Estatuto (Anexo A).

III. 2 - O montante necessário para o pagamento dos encargos financeiros dos empréstimos recebidos. III.3 - O montante necessário para o pagamento da amortização dos empréstimos recebidos.

III.4 - O montante necessário para o pagamento dos "royalties" às Altas Partes Contratantes, calculado no equivalente de seiscentos e cinquenta dólares dos Estados Unidos da América por gigawatthora, gerado e medido na central elétrica. Esse montante não poderá ser inferior, anualmente, a dezoito milhões de dólares dos Estados Unidos da América, à razão da metade para cada Alta Parte Contratante. O pagamento dos "royalties" se realizará mensalmente, na moeda disponível pela ITAIPU. III.5 - O montante necessário para o pagamento à ELETROBRÁS e à ANDE, em partes iguais, a título de ressarcimento de encargos de administração e supervisão relacionados com a ITAIPU, calculados no equivalente de cinquenta dólares dos Estados Unidos da América por gigawatt-hora gerado e medido na central elétrica.

III.6 - O montante necessário para cobrir as despesas de exploração.

III.7 - O montante do saldo, positivo ou negativo, da conta de exploração do exercício anterior.

III.8 - O montante necessário à remuneração a uma das Altas Partes Contratantes, equivalente a trezentos dólares dos Estados Unidos da América, por gigawatt-hora cedido à outra Alta Parte Contratante. Esta remuneração se realizará mensalmente na moeda disponível pela ITAIPU.

Essas são as taxas que estão embutidas pela Itaipu quando no Brasil o contribuinte paga a energia elétrica. Fora desse calculo está ainda, as taxas que FURNAS cobram para distribuir.

Itaipu é uma Usina Hidrelétrica cheia de superlativos. Para quem desconhece suas características a própria Itaipu ${ }^{118}$ informa:

Com 20 unidades geradoras (700 MW cada) e 14.000 MW de potência instalada, Itaipu fornece $17,3 \%$ da energia consumida no Brasil e abastece 72,5\% do consumo paraguaio. Itaipu produziu em 2012 um total de 98.287.128 megawatts-hora (98,28 milhões de MWh), estabelecendo um novo recorde mundial de produção de energia. Itaipu é a maior usina geradora de energia do planeta. Com apenas uma das 20 unidades geradoras seria possível abastecer uma cidade com 1,5 milhão de habitantes. O Estado do Rio de Janeiro poderia ser suprido com a energia produzida por pouco mais

$\overline{118}$ PERGUNTAS FREQUENTES. Criado em 30/03/2010. http://www.itaipu.gov.br/sala-de-imprensa/perguntas-frequentes. Pesquisado em 07.2010. 
de sete das unidades geradoras de Itaipu. Os Estados do Paraná, Santa Catarina e Rio Grande do Sul poderiam ser abastecidos, ao mesmo tempo, por menos de 13 unidades.

Em maio de 1974 foi criada a empresa Itaipu Binacional, para construir e gerenciar a usina. As primeiras máquinas chegam ao canteiro de obras ainda em 1974. A Itaipu começou a gerar energia em maio de 1984.

O reservatório da Itaipu é apenas o sétimo maior do Brasil, o que mostra o melhor índice de aproveitamento das águas para produzir energia. Na Itaipu, o índice de produção é de 9,3 MW por quilômetro quadrado (ou seja, cada $0,11 \mathrm{~km}^{2}$ de área alagada gera $1 \mathrm{MW}$ ). O lago da Itaipu começou a ser formado em 13 de outubro de 1982. Em 14 dias, estava cheio.

A energia gerada pela Itaipu e destinada ao mercado brasileiro é transmitida por Furnas Centrais Elétricas até o Estado de São Paulo, de onde pode ser distribuída para as cinco regiões brasileiras, inclusive Norte e Nordeste.

O Ativo Imobilizado no Balanço Patrimonial de 2010 totalizando US $\$ 17,4$ bilhões, pode representar o valor da construção da Itaipu. Neste total, porém, estão incorporados os encargos financeiros incorridos durante a construção até a entrada em operação de cada unidade geradora. Ao desconsiderar estes encargos, obtém-se o Investimento Direto, que corresponde a US\$11,8 bilhões, em dezembro de 2010, assim verifica-se que o custo direto do empreendimento seria de aproximadamente US\$ 845 por kW instalado. Os recursos captados para a construção, incluindo as rolagens financeiras, totalizaram US\$26,9 bilhões, além dos US\$100 milhões de Capital Social.

Com a Itaipu, o Brasil desenvolveu uma tecnologia própria de construção de grandes barragens e incorporou ao seu setor elétrico uma usina que hoje responde por quase um quarto de todo o consumo nacional. Já o Paraguai passou a contar com energia suficiente para seu abastecimento durante as próximas décadas sem que precise fazer qualquer outro investimento no setor, além de ter fomentado o desenvolvimento de toda a região de fronteira.

A construção de represas e usinas exige o alagamento de uma área enorme para formar o lago, e muitas vezes alterar o leito do rio. O lago, também chamado de reservatório, é formado pelo represamento das águas do rio, por meio da construção de uma barragem. Essa alteração do meio ambiente atrapalha a vida dos bichos e das plantas da região, além de mudar radicalmente a paisagem, muitas vezes destruindo belezas naturais. Também saem prejudicadas as pessoas que moram nas proximidades e têm que se mudar por causa da inundação.

As vantagens da construção de uma usina hidrelétrica são: - Baixo custo do megawatt; - Forma de energia limpa, sem poluentes; - Geração de empregos; - Desenvolvimento econômico.

As desvantagens da construção de uma usina hidrelétrica são:- Desapropriação de terras produtivas pela inundação; - Impactos ambientais, como as perdas de vegetação e da fauna terrestres; - Impactos sociais, como relocação de moradores e desapropriações; 
- Interferência na migração dos peixes; - Alterações na fauna do rio; - Perdas de heranças históricas e culturais, alterações em atividades econômicas e usos tradicionais da terra.

A Itaipu paga royalties pelo aproveitamento dos recursos hídricos pertencentes aos dois países. Desde 1985 até abril de 2009, a empresa pagou cerca de US\$ 6,6 bilhões em royalties ao Brasil e ao Paraguai. O pagamento está previsto no Anexo C do Tratado de Itaipu. No lado brasileiro, os recursos beneficiam 16 municípios, sendo 15 no Estado do Paraná e um no Mato Grosso do Sul. Os royalties são aplicados na melhoria da qualidade de vida da população, nas áreas de educação, saúde, moradia e saneamento básico.

A transmissão da energia produzida pela Itaipu é feita pela Eletrobrás, por intermédio de Furnas Centrais Elétricas S.A.. Apenas as oito linhas, com extensão entre 8 e 1 quilômetros, que levam a energia da usina até a subestação de Furnas, são de responsabilidade da Itaipu. No Paraguai, a responsabilidade pela transmissão é da Ande (Administração Nacional de Eletricidade), através de 4 linhas em 220 kv, sendo duas com extensão de 4,8 km, até a subestação de Acaray, e outras duas com extensão de 210 km, até a subestação de Carayaó (próxima a Assunção).

\section{b.1) A retirada das populações habitantes da área de interesse de Itaipu e o incremento com outras populações no território maior, em função da movimentação de capital na região da Tríplice Fronteira.}

As partes do Tratado de Itaipu que se referem a declarar de utilidade pública as áreas necessárias à instalação do aproveitamento hidrelétrico, desapropriar terrenos e suas benfeitorias ou a constituir servidão sobre os mesmos, são:

\section{Artigo XVII \\ As Altas Partes Contratantes se obrigam a declarar de utilidade pública as áreas necessárias à instalação do aproveitamento hidrelétrico, obras auxiliares e sua exploração, bem como a pra- ticar, nas áreas de suas respectivas soberanias, todos os atos administrativos ou judiciais ten- dentes a desapropriar terrenos e suas benfeitorias ou a constituir servidão sobre os mesmos. Parágrafo $1^{\circ}$ - A delimitação de tais áreas estará a cargo da ITAIPU, ad referendum das Altas Partes Contratantes. \\ Parágrafo $2^{\circ}$ - Será de responsabilidade da ITAIPU o pagamento das desapropriações das áreas delimitadas.}

\section{Artigo XVIII}

As Altas Partes Contratantes, através de protocolos adicionais ou de atos unilaterais, adotarão todas as medidas necessárias ao cumprimento do presente Tratado, especialmente as que digam respeito a aspectos: 
a) diplomáticos e consulares;

b) administrativos e financeiros;

c) de trabalho e previdência social;

d) fiscais e aduaneiros;

e) de trânsito através da fronteira internacional;

f) urbanos e habitacionais;

g) de polícia e de segurança;

h) de controle do acesso às áreas que se delimitem em conformidade com o Art. XVII.

Artigo XIX

$\underline{\text { O foro da ITAIPU, relativamente às pessoas físicas ou jurídicas domiciliadas ou com sede no Brasil }}$ ou no Paraguai, será, respectivamente, o de Brasília e o de Assunção. Para tanto, cada Alta Parte Contratante aplicará sua própria legislação, tendo em conta as disposições do presente Tratado e de seus Anexos.

Anexo "A" do Tratado de ITAIPU - (ESTATUTO)

CAPÍTULO III - ADMINISTRAÇÃO

ARTIGO $17^{\circ}$ - Os dois Diretores-Gerais são responsáveis, solidariamente, pela coordenação, organização e direção das atividades da ITAIPU e a representarão em juízo ou fora dele, competindo-lhes praticar todos os atos de administração ordinária necessários ao funcionamento da Entidade, com exclusão dos atribuídos ao Conselho de Administração e à Diretoria Executiva. Cabem-lhes, ademais, os atos de admissão e demissão de pessoal em seus respectivos países. ARTIGO $1^{\circ}$ - O Diretor Jurídico Executivo é o responsável pela condução dos assuntos jurídicos da Entidade.

A partir dessas obrigações, Itaipu era responsável por indenizar os ocupantes da área de seu interesse. Mas o processo não ocorreu de forma simples e tranquila conforme é relatado por Itaipu.

Em maio de 1974, foi criada a entidade Itaipu Binacional, para gerenciar a construção da usina. O início efetivo das obras ocorreu em janeiro de 1975. As relações sociais, econômicas, culturais, tanto urbanas, como no campo, passaram a experimentar grandes transformações, por conta da construção da Usina Hidrelétrica de Itaipu. Uma enorme população se dirigiu a região para trabalhar no Grande Projeto. Segundo o próprio site da Itaipu ${ }^{119}$ revela:

Um "formigueiro" humano começou a se formar em meados dos anos 70, ocupando dois dos três territórios do cotovelo internacional que tem as cores paraguaia, brasileira e argentina. A região

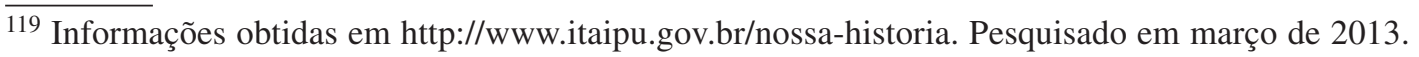


começa a transformar-se num "formigueiro" humano. Entre 1975 e 1978, mais de 9 mil moradias foram construídas nas duas margens para abrigar os homens que atuam na obra. De 1975 a 77, foram construídas 5,1 mil casas - 2.708 na margem esquerda do rio, junto à cidade de Foz do Iguaçu, e 2.392 na margem direita, entre as cidades de Porto Presidente Stroessner ${ }^{120}$, Hernandarias, Porto Presidente Franco e a colônia Porto Presidente Stroessner. Em 1978, foram construídas mais 3.960 habitações, 2.227 na margem esquerda e 1.733 na direita. Até um hospital é construído para atender os trabalhadores. À época, Foz do Iguaçu era uma cidade com apenas duas ruas asfaltadas e cerca de 20 mil habitantes, em dez anos, a população passa para 101.447 habitantes. Entre 1978 e 1981, até 5 mil pessoas eram contratadas por mês. Ao longo da obra, em função do extenso período de construção e da rotatividade da mão-de-obra, somente o consórcio Unicon cadastrou cerca de 100 mil trabalhadores. No pico da construção da barragem, Itaipu mobilizou diretamente cerca de 40 mil trabalhadores no canteiro de obras e nos escritórios de apoio no Brasil e no Paraguai.

Dessa forma, o ecúmeno na região da Tríplice Fronteira, antes quase rarefeito, começou a ser vitalizado com a construção das rodovias Ruta 7 e BR-277, da Ponte da Amizade e em seguida, com a construção de Itaipu, ele é intensificado de forma extremamente célere.

De janeiro de 75 até a inundação do reservatório em 13 de outubro de $1982^{121}$, foi um período de grande sofrimento para as populações habitantes do território de 135 mil hectares que veio a ser inundado. Um contingente populacional grande chegando à região para trabalhar na obra e suas famílias, outros tantos, 60.000 indivíduos sendo obrigados a sair da região por conta da futura inundação, e para organizar isso tudo em função da construção de Itaipu, os Projetos Integrados de Colonização /PIC do INCRA, trataram de dividir as terras que seriam utilizadas para a Hidrelétrica e as sobrantes, de forma extremamente seletiva, para os vários agrupamentos sociais.

O primeiro Diretor-Geral nomeado da Itaipu veio a ser o próprio ex-Ministro do Interior General Jose Costa Cavalcanti, aquele que vimos anteriormente, referido pelo antropólogo Shelton Davis em seu livro Vítimas do Milagre, que foi o Ministro responsável pelo andamento dos projetos de desenvolvimento na década de 70, ao mesmo tempo que responsável também pela política (anti)-indigenista de características integracionistas do governo brasileiro, já que a FUNAI neste período era também subordinada a este Ministério, o do Interior.

\footnotetext{
$\overline{120}$ A cidade de Porto Presidente Stroessner é a atual Ciudad Del Este.

${ }^{121}$ Em 13 de outubro de 1982 fecharam-se as 12 comportas da estrutura do canal de desvio para a formação do lago, cujas águas se espalharam por 135 mil hectares. Em apenas 14 dias formou-se o reservatório. Fonte: http:/ /www.itaipu.gov.br/nossa-historia. Pesquisado em março de 2013.
} 
O tratamento dados aos indígenas e aos animais que viviam na área a ser inundada, foi diferenciado. Quem convive ou conviveu como eu, com os habitantes mais antigos de Foz do Iguaçu, conhece bem a frase, que vários deles relembraram tantas vezes, dizendo a mim, frase a qual se tornou o "lema" repetido por Costa Cavalcanti em função de dar um destino aos animais e aos indígenas: "Os animais para o Refugio os índios para o Paraguai". Somente num contexto de ditadura e autoritarismo, pouco afeito ao cumprimento das leis é que se pode pensar em ouvir tamanha displicência com os direitos dos outros, vindo de uma "autoridade representante do Estado".

\section{"Os índios para o Paraguai”"}

Significativa é a matéria do Jornal O Estado de São Paulo em 1978, quando informou a respeito de como funcionaria as indenizações de Itaipu no lado brasileiro:

A Itaipu Binacional agirá com os índios da mesma forma que com os posseiros das áreas a serem inundadas pela hidrelétrica. Quem tiver documentos de propriedade de terra será indenizado em primeiro lugar; depois, os que possuem somente títulos provisórios, por estarem pagando as terras; e, finalmente, posseiros e ocupantes diversos. Nesta ultima categoria é que estão os índios.

Ou seja, além de diferenciar quem deve receber primeiro a indenização através de uma escala de prioridade regida pelo titulo de propriedade da terra, Itaipu acabou por comparar os indígenas a posseiros, sendo que os primeiros possuem no Brasil uma extensa legislação institucionalizada que cobre em tese seus direitos fundiários e os posseiros pouco (usucapião) ou nada tem, em termos legais que os ampare. Como se vê o preconceito e o regime de exceção durante a ditadura militar, que não considerou direitos constituídos, são claros. Na opinião particular desses que detiveram o poder numa época de exceção, o único título válido era aquele existente no mercado de compra e venda de terras. Transportaram seus próprios conceitos particulares para toda a Nação, desconsiderando outros conhecimentos, opiniões, discussões de há muito estabelecidas e até as próprias leis vigentes.

Ao longo de todo este trabalho vimos como não foi reconhecido os direitos indígenas dos Guarani de Oco'y ao território que ocupavam, em função do alagamento da área territorial para instalação do reservatório de Itaipu. Desnecessário retomar aqui todas as questões vividas pela falta de cumprimento das leis por parte do governo brasileiro, incluindo nelas as ações da Itaipu, do INCRA e da FUNAI, já sobejamente tratadas nesta tese. Cabe somente ressaltar que o agru- 
pamento indígena do Oco’y ainda teve a “sorte” de ser ouvido por defensores da causa indígena. Outros agrupamentos da sociedade Guarani que também foram afetados pela construção da Itaipu, não tiveram a mesma "sorte".

Como vimos no capitulo 4 desta tese, a Itaipu acabou por expulsar das terras indígenas populações Guarani de ambas fronteiras, do Brasil e do Paraguai. São pelo menos ${ }^{122} 8$ (oito) terras indígenas no lado brasileiro, que não foram reconhecidas como tal pela FUNAI e Itaipu, e, sequer algum direito estabelecido constitucionalmente foi considerado neste contexto, incluindo Oco'y. São elas, as aldeias: - Camba’i em Porto Britania e Porto Mendes; - Rio Guavirá; Passo-Kuê; -Takuá-Pindaí; - Mborevy; as quatro aldeias localizadas no antigo município de Alvorada, hoje Santa Teresinha; - o próprio Oco’y-Jacutinga em São Miguel do Iguaçu; - Três Irmãs e - Santa Rosa, as duas no município de Santa Helena, todas no estado do Paraná/Brasil. Muitos dos indivíduos pertencentes a estas aldeias foram compulsoriamente obrigados a se dirigir para o Paraguai. Oco’y teve o tratamento aqui exposto nesta tese e Tekoa Ãnetete, após muita luta dos indígenas foi a única compensação de terras do lado brasileiro, feita por Itaipu. Feita, em termos, como vimos anteriormente, dadas as condições em que a Itaipu vinha submetendo os Guarani.

No lado paraguaio a situação dos indígenas, eram pelo menos ${ }^{123} 5$ (cinco) ou 6 (seis) as terras indígenas que foram inundadas por Itaipu: - Kiritó entre os distritos de Santa Fé e Hernandarias; - Campo Pirã-Pitã no distrito de Santa Fé; - Pikyry entre os distritos de Guaira e Hernandarias; - KM 6 entre os distritos de Guaira e Hernandarias; - Porto Salse no distrito de Guaira; - A aldeia de Aguara Yva no distrito de Hernandarias, os Guarani que informaram, não tinham certeza de qual das hidrelétricas construídas, a impactou; todas estas aldeias estavam localizadas no Departamento de Alto Paraná/Paraguai.

Sobre a questão dos Guarani do lado paraguaio Mazzarollo assim relata:

\footnotetext{
$\overline{122}$ Pelo menos as que pude levantar com dois informantes do Oco’y. O trabalho realizado por nós não tinha exatamente esta finalidade de buscar todas as aldeias que existiam na região brasileira. O levantamento que fizemos se ateve ás aldeias que aqueles dois informantes conheceram e visitaram, e que desapareceram, 32 aldeias. Se fossemos buscar essa informação com outros Guarani que estão mais próximos de Guaira, certamente levantaríamos maior numero de aldeias.

123 Pelo menos as que pude levantar com dois informantes do Oco’y. O trabalho realizado por nós não tinha exatamente esta finalidade de buscar todas as aldeias que existiam na região paraguaia. O levantamento que fizemos se ateve ás aldeias que aqueles dois informantes conheceram e visitaram, e que desapareceram. Se fossemos buscar essa informação com outros Guarani que estão mais próximos de Salto del Guairá, certamente levantaríamos maior numero de aldeias.
} 


\section{A remoção dos índios paraguaios}

A inundação da Itaipu iria varrer para fora de suas terras também 239 famílias de índios Ava-Guarani, do ramo Xiripá, no Paraguai. Seu habitat tradicional era um triangulo limitado a leste do país pelo rio Paraná, ao norte pela cordilheira de Maracaju e ao sul pelos rios Corrientes e Acaray, nos departamentos ("estados") de Alto Paraná, Canindeyu e, parcialmente, nos de Caaguazú e San Pedro.

Essa região, aliás, vinha sendo objeto de intensa ocupação por parte da chamada "invasão brasileira" ${ }^{124}$, que já afetara substancialmente a possibilidade de sobrevivência daquele povo indígena. Com o advento de Itaipu, a ameaça de dispersão e de extinção progressiva ganharia os contornos de fatalidade. Mas aí também foi possível estender-se um braço de socorro à população ameaçada e, embora deixando atrás o rastro da destruição, algumas providencias chegaram a tempo de garantir uma solução melhor aos índios atingidos pela Itaipu no Paraguai.

Em vista da invasão brasileira e da Itaipu, a Associação indigenista Paraguaia (AIP) elaborou o Projeto Guarani, destinado a preservar as terras dos índios e evitar seu aniquilamento. Entretanto, esse processo de legalização e demarcação, que chegou a estabelecer doze colônias indígenas nacionais reconhecidas oficialmente, não atingiu todas as comunidades, ficando de fora justamente as $\underline{\text { atingidas pela Itaipu }}^{125}$. A AIP encaminhou novo expediente à Itaipu, mas não recebeu resposta. Novo estudo foi encaminhado pela Associação de Parcialidades Indígenas (API), em 1981, solicitando "a implementação de projetos de reassentamento, com recursos da entidade binacional".

O engenheiro Enzo Debernardi, diretor-geral paraguaio da Itaipu, respondeu que o propósito da empresa era "respeitar todas as leis e normas legais do país e do tratado binacional". No caso, porém, o respeito às leis significava que a empresa não se sentia obrigada a providenciar o reassentamento de nenhum desapropriado - nem dos índios, portanto. “É oportuno destacar que o tratado não previu a obrigação da entidade binacional com o reassentamento das populações da zona afetada", dizia a resposta de Debernardi, também assinada pelo diretor jurídico Antonio Colmán Rodrigues $^{126}$. A única obrigação da Itaipu, afirmavam as autoridades, era "pagar as indenizações". Novo documento foi encaminhado à Itaipu pela AIP, desta vez com o apoio da Equipe Nacional de Missões, da Conferência Episcopal Paraguaia (CEP) e do Instituto Nacional do Indígena (INDI), propondo a destinação aos indígenas desalojados de uma área de 1300 hectares nas imediações de

\footnotetext{
$\overline{124}$ Mazzarollo se refere aos assim denominados "brasiguaios".

125 No mínimo curioso; pois eram algumas das terras que teriam mais necessidade de serem reconhecidas rapidamente. Porque será que não o foram? De certo houve influencia política impedindo que justamente essas fossem reconhecidas.

${ }^{126}$ Apesar do empreendedor ter causado o dano, a questão não pode estar sujeita à vontade ou não própria dele, do Tratado de Itaipu, e sim às normas legais que exigem como serão feitas as indenizações. Nesta época ainda não havia, no caso do Brasil, as Resoluções CONAMA que normatizaram o assunto. No Paraguai não temos a informação se existem atualmente leis semelhantes.
} 
Arroio Itabó, de outros 1000 hectares nas proximidades do Rio Limoy, 2000 hectares na Colônia Indígena Yuguyry, em Vacaretanguê, e 1012 hectares em Kiritó Pyajú127.

A aquisição das terras compreendidas nos dois primeiros itens deveria ser financiada pela Itaipu, que se obrigaria ainda a pagar 8,9 milhões de guaranis para custear os gastos com a transferência dos indígenas. As terras citadas no terceiro item seriam destinadas pelo Instituto de Bem-Estar Rural (IBR), a um custo estimado em 24 milhoes de guaranis, enquanto a CEP se encarregaria de adquirir a área sugerida no quarto item da proposta, a um custo de mais de 30 milhões de guaranis.

O Paraguai, apesar de ser, como o Brasil, signatário da convenção internacional 107, que dispõe sobre a "Proteção e Integração das Populações Indígenas e outras Populações Tribais ou Semitribais dos Países Independentes" ${ }^{128}$, só em fins de 1981 teve aprovado pelo Congresso Nacional o Estatuto do Indígena, prevendo, "nos casos que resultar imprescindível, o translado de uma ou mais comunidades indígenas ${ }^{129}$, a destinação de terras aptas e pelo menos de igual qualidade das que ocupam ${ }^{130}$, com o pagamento de indenizações pelos danos e prejuízos decorrentes do deslocamento e pelo valor das melhorias" (algo copiado do artigo 20 do Estatuto do Índio do Brasil).

Ao fim de toda a luta travada pelas entidades indigenistas paraguaias e de todas as tentativas da Itaipu de desobrigar-se do reassentamento dessas populações, resultou que as comunidades AváGuarani (Xiripá) foram em parte reassentadas em dois imóveis adquiridos pela binacional e registrados em nome da INDI, um com área de 1000 hectares situados no Reservado 8, distrito de Hernandarias, e outro, de igual tamanho, em Naranjito, também em Hernandarias.

Mesmo assim, já em 1983, a publicação Diálogo Indigenista Misioneiro, manifestava "sua preocupação quanto ao lugar ou aos lugares destinados aos indígenas que viviam na zona inundada pelo lago da represa de Itaipu". A publicação, de responsabilidade da Conferência Episcopal Paraguaia, dava conta de que 112 famílias indígenas não haviam sido reassentadas, e perguntava: "Estarão dispersas pelo Brasil? Dispersas pelos Montes? Ou no lago de Itaipu?" (MAZZAROLLO: 2003:1578-9) (grifos nossos).

\footnotetext{
$\overline{127}$ Mazzarollo não discrimina cada uma das terras afetadas e a correspondente compensação, como seria o correto fazer. Provavelmente reuniram povos de variadas aldeias e os colocaram nessas 4 terras citadas.

1278 A Convenção Internacional de Genebra da OIT n. 107 é de 05.06.1957; ela foi substituída pela Convenção Internacional de Genebra da OIT n. 169 de 07.06.1989; esta ultima abandona o caráter integracionista ou assimilacionista e assim reconhece: "Considerando que a evolução do direito internacional desde 1957 e as mudanças sobrevindas na situação dos povos indígenas e tribais em todas as regiões do mundo fazem com que seja aconselhável adotar novas normas internacionais nesse assunto, a fim de se eliminar a orientação para a assimilação das normas anteriores; Reconhecendo as aspirações desses povos a assumir o controle de suas próprias instituições e formas de vida e seu desenvolvimento econômico, e manter e fortalecer suas identidades, línguas e religiões, dentro do âmbito dos Estados onde moram;" O que mudou na verdade foi o olhar integracionista de quem propõe e faz a lei, olhar dos não índios, dos brancos democratas.

${ }^{128} \mathrm{O}$ que confirma o exposto na penúltima nota.

${ }^{130}$ No Brasil o Estatuto do Índio no Artigo 20 \# $3^{\circ}$ determina: ...destinando-se à comunidade indígena removida área equivalente a anterior, inclusive quanto às condições ecológicas; questão "área equivalente" que não foi prevista pela lei paraguaia.
} 
Ou seja, se no inicio era previsto 239 famílias Avá-Guarani para serem reassentadas e 112 famílias continuaram sem terras, o que representa 46,86 \% do total, enfim quase a metade dessa população continuou sem terra; ou ainda, esses, podem ser os indivíduos que chegaram ao Paraguai expulsos do Brasil.

Pela legislação paraguaia se poderia então reunir povos de diferentes aldeias e colocá-las em terras de dimensões arbitrárias, conforme o "acordo" se se pode chamar assim, e não conforme as terras que possuíam antes.

Interessante observar ainda que Itaipu compensou com mais terras os Guarani do Paraguai que do Brasil. No Brasil somente Tekoa Anetete com 1740 hectares aproximadamente foi compensado e muito mais tarde nos anos 90. Faz sentido a política implementada, dado que ficaram reduzidos a pouquíssimos territórios no Brasil e em sua maioria foram expulsos para o Paraguai. Tinha-se então que estabelecer essas populações de alguma forma em algum território, e isso a Itaipu o fez de forma dirigida, "para o Paraguai".

Os grandes projetos (PNI e Itaipu) “engoliram” subtraindo muitas das terras indígenas no Brasil. Dada a expulsão de indígenas para o Paraguai com a contribuição dos funcionários do INCRA, o que pudemos observar é que o Estado age de forma entrelaçada intra-institucionalmente (Itaipu, FUNAI e INCRA), dificultando a vida dos indígenas que pretendem voltar a se reestabelecer no Brasil. Como vimos antes pudemos ver em algumas ocasiões que quando os Guarani querem voltar ao Brasil, a FUNAI local está instruída por uma ordem superior (que pode ou não ser da sua própria instância superior em Brasília, a sede da FUNAI), tudo indica ser de Itaipu, para não fazer a documentação desses indígenas, o que dificulta sua permanência em solo brasileiro; a fronteira passou a ter portanto, essa função de controle, barrando os "indesejáveis" indígenas. Também a Itaipu limitou o numero de famílias por ano que iriam se instalar em Tekoa Ãnetete e não aceitou nenhum indígena proveniente do Paraguai, os próprios, os filhos ou netos daqueles que foram obrigados a sair do Brasil em direção ao Paraguai, por conta da inundação de Itaipu; intolerantes, com a situação dos indígenas transfronteiriços o poder se recusa em dar a eles cidadania brasileira; quando conseguem algum trabalho esporádico, um dos efeitos dos proventos que recebem serem mais baixos ainda é não possuir documentos; enfim o que se verifica é que no plano individual querem dificultar a vida de cada um dos indígenas, no plano macro o poder vem fazendo uma verdadeira "limpeza étnica" em território brasileiro. O que indica que a intenção por parte do Estado é clara, é como se dissessem: "que se dirijam e permaneçam de vez no Paraguai, lá onde a língua oficial é o Guarani, lá é que é terra de vocês..."; na visão do Estado é como se os Guarani "transbordassem" da fronteira paraguaia; se recusam a 
entender que grande parte dos países da região sul do país era/é de ocupação Guarani; Na verdade esses indígenas são "supranacionais", estavam em todo este território sul da America do Sul, desde antes da própria constituição dos três Estados Nacionais, BR, PY e ARG.

Realmente a geopolítica militar “não quer ver” essas populações indígenas.

Paradoxalmente, aquelas terras onde foram construídas as obras da hidrelétrica, eram tão de posse milenar dos indígenas Guarani, a ponto de seus construtores emprestarem o próprio nome do local dado anteriormente pelos integrantes da língua Tupi-Guarani, "Itaipu”, que significa "a pedra que canta", para batizar a hidrelétrica. Era a denominação de uma rocha que se erguia do leito do rio Paraná e zunia com a força da água, assim denominada pelos Guarani, onde foi construída a Usina.

\section{"Os animais para o Refugio"}

Tratamento diferenciado foi dado aos animais encontrados na área que veio a ser inundada em 13 de outubro de 1982 para a criação do reservatório de Itaipu. Assim por meio do próprio site da Itaipu ${ }^{131}$ podemos observar algumas informações sobre a operação "Mymba-kuera" promovida pela hidrelétrica:

O fechamento das comportas do canal de desvio, para a formação do reservatório da usina, dá início à operação Mymba Kuera (que em tupi-guarani quer dizer "pega-bicho"). A operação salva a vida

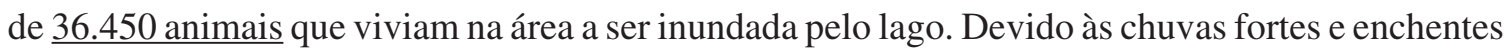
da época, as correntezas do Rio Paraná levaram 14 dias para encher o reservatório. A lâmina de água soma 135 mil hectares.

O site da Itaipu, quando se refere a operação denominada "Mymba-kuera ("pega-bicho” em tupi-guarani)", ao utilizar palavras dessa língua cometeu dois graves enganos, um de transcrição incorreta, outro de interpretação incorreta. A palavra "Mymba" não existe em tupi-guarani. O que existe é Mbia (dívida) + Iya (dano) que corresponde a "aquele que deve". Kuera corresponde a "Sanar". Assim o nome utilizado do Tupi-Guarani deveria ser "Mbia Iya Kuera”, ou seja, "Aquele que tem divida, causou dano, aquele que deve sanar". Convenhamos, trata-se de termo bem mais elegante e apropriado ao caso, próprio aos Guarani, do que "pega-bicho”, utilizado por Itaipu, fácil de falar, porém errado no conceito. Esse registro é bastante simbólico de toda a situação vivida.

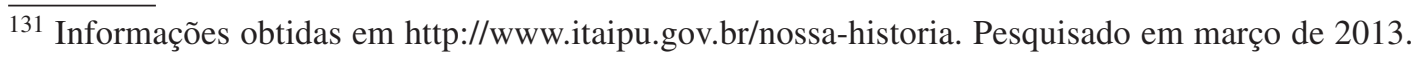


Em função do salvamento dos animais foram criados três Refúgios Biológicos por Itaipu, dois anos mais tarde, em 1984. O Refugio Bela Vista com 1740 hectares e o Refugio Santa Helena de 1421 hectares, ambos no Paraná/Brasil; e o Refugio Maracaju com 1400 hectares ao norte do Rio Pireti'y - afluente do Rio Paraná/Paraguai. Um total de 4.561 hectares para a preservação de fauna e flora.

Em entrevista com alguns funcionários da Itaipu no dia 29.06.2009, em comemoração: "Refúgio Biológico de Itaipu completa 25 anos”, obtido no site da própria hidrelétrica ${ }^{132}$ assim é afirmado:

O Refúgio Biológico Bela Vista, ou Refúgio de Itaipu, era para ser apenas um ponto de recepção dos animais resgatados na operação Mymba-kuera (“caça-bicho” em tupi-guarani). Esta aí até hoje. E, no último sábado, completou 25 anos de existência, o jubileu de prata que celebra a data de um documento interno, de 27 de junho de 1984, sua única certidão oficial de nascimento. Foram 19 dias de operação, 160 funcionários e 13 mil animais resgatados.

Em uma publicação da Itaipu é dito que foram $\underline{36.450 \text { animais resgatados, noutra também }}$ da Itaipu, é dito que foram 13.000 animais? Quase 2/3 a menos?! E continua:

O ponto de partida de um refugio, que atualmente conta com um grande zoológico, um invejável criadouro e um moderno hospital veterinário. Nasceu da necessidade de tirar o bicho da natureza e hoje cuida e reproduz espécies ameaçadas de extinção. (...) Atualmente, o refúgio mantém 388 exemplares de animais, a maior parte de mamíferos (175 exemplares de 26 espécies diferentes). "Nossos bichos reproduzem muito bem, isso é sinal de que o manejo está adequado".

Se eram 36.450 ou 13.000 animais resgatados em 1982, que seja, e se o Refugio Bela Vista apresentava em 2009, somente 388 animais, aonde estão os animais restantes, seja os próprios, seja os seus descendentes que foram reproduzidos? Nos outros dois refúgios, sabemos que não estão. Quais as características reais desse "salvamento"? E continua:

O Refugio Biológico atinge os 25 anos com uma estrutura invejável. São 26 empregados de Itaipu voltados diretamente às atividades do local. Somam-se a eles, cerca de 150 terceirizados das empreiteiras que prestam serviços no Bela Vista. Mas foi meio por acaso que, assim mais na ação do que no planejamento, o refugio completou se jubileu.

\footnotetext{
${ }^{132}$ Informação obtida em: http://www.itaipu.gov.br/sala-de-imprensa/noticia/refugio-biologico-de-itaipu-completa25-anos?page=1. Pesquisado em março de 2013.
} 
"A grande jogada foi abrir o refúgio para a visitação", explica Sebastião Nogueira, responsável pela administração do refúgio. Foi na gestão de Euclides Scalco que Itaipu abraçou definitivamente seu refúgio. Na época, a intenção era destinar a área para a prefeitura de Foz ou à Unioeste, mas os técnicos bateram o pé e convenceram o então diretor-geral brasileiro que seria importante manter o refúgio sob os cuidados de Itaipu. Aberto para as visitas, o local foi institucionalizado na empresa. "Foi assim que asseguramos a permanência do refúgio em Itaipu", orgulha-se Nogueira. (...). $\underline{\text { São }}$ três os tipos de visitas que garantiram a sobrevivência do Bela Vista: as técnicas e científicas, feitas por Itaipu; as turísticas, comandadas pelo Centro de Recepção de Visitantes, e as de educação ambiental, voltadas às escolas e realizadas pelos educadores ambientais de Itaipu.

$\mathrm{Na}$ área de flora, o refúgio tem o programa de plantas medicinais, um banco de germoplasma e a produção de mudas usadas na arborização da usina, nos bosques do Visitante e do Trabalhador. E ainda o viveiro florestal, que produz mudas nativas para ser plantadas no corredor da biodiversidade e na faixa de proteção do lago. Foram 24 milhões de mudas produzidas pelo refúgio para formar os atuais 29,5 mil hectares de faixa de proteção.

Quanto ao Refúgio Biológico de Santa Helena, as informações são desencontradas. No site de Giacobbo ${ }^{133}$ assim ela é referida:

O Refúgio Biológico de Santa Helena situa-se a uma distância de 2 km do centro urbano, oficialmente criado pela Itaipu Binacional em 1984, em uma área de 1.421 Hectares de terra com o obje$\underline{\text { tivo de abrigar a fauna procedentes da Operação Mymba Kuera (pega bicho na língua Tupi Guarani) }}$ por ocasião da formação do Reservatório de Itaipu em 1982 e com isto proteger exemplares repre-

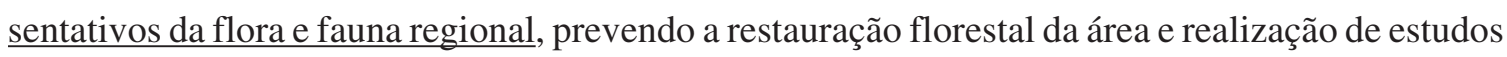
e pesquisas dos seus componentes naturais.

Já no site da prefeitura de Santa Helena ${ }^{134}$ é afirmado que:

Com a formação do lago de Itaipu, Santa Helena foi contemplada com uma unidade de conservação ambiental, denominada Refugio Biológico. Está localizado próximo a nossa cidade, com uma área de 1.421 hectares, contendo no seu interior trilhas interpretativas, $44 \mathrm{~km}$ de estradas para circulação, controle e fiscalização. Essa área antes da formação do lago, era toda mecanizada e produtiva. Com a desapropriação das propriedades, numa atitude exemplar, foi toda ela reflorestada. Atualmente, essa área esta cedida ao município de Santa Helena. Agora, a Administração Municipal,

\footnotetext{
$\overline{133}$ Informação obtida em:http://www.giacobbo.com.br/turismo/cidades.php?c=19. Pesquisado em 04.2013.

${ }^{134}$ Fonte: Assessoria de Imprensa - Pref. de Santa Helena Em 07/10/2010. http://www.guiamedianeira.com.br/ noticia/273/Refugio+Biologico+em+Santa+Helena. Pesquisado em 04.2013.
} 
pretendendo transformar aquele local em área de turismo ambiental, através da Secretaria de Indústria, Comércio e Turismo, fez investimentos em diversas obras. O objetivo é que aquele local seja visitado por professores, estudantes e turistas.

Portanto, como pode o Refúgio Biológico de Santa Helena abrigar a fauna procedentes da Operação Mymba Kuera ("pega bicho” na língua Tupi Guarani) por ocasião da formação do Reservatório de Itaipu em 1982 e com isto proteger exemplares representativos da flora e fauna

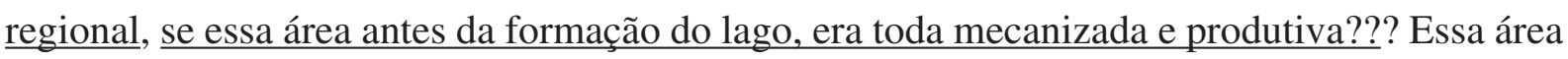
despida de flora não poderia receber fauna silvestre?!

Quanto ao Refugio Biológico de Maracaju ou Mbaracayú, ele pertence aos dois países, dado o conflito anterior pela posse de suas terras pelo Brasil e Paraguai. Quando foi realizada a inundação foi feito este acordo. É área que foi ocupada por gado e da mesma forma não era possível trazer para ela animais silvestres resgatados. Assim descreve o site sobre as reservas paraguaias $^{135}$, a respeito dessa reserva em específico:

Refúgio Biológico Mbaracayú (Maracaju). Desde a sua criação, a Itaipu Binacional desencadeou uma série de ações de recuperação ambiental. Em 1992, iniciou o reflorestamento perimetral na área antes ocupado pela presença de gado bovino. Em 2000, reflorestou outros 323,4 hectares e fez a manutenção em 60 hectares de aceiros como medida preventiva para o controle de incêndios.

Assim ao contrario dos indígenas, fauna e flora podem ser controladas, não reivindicam, não protestam, dão boa visibilidade institucional ao tratamento ambiental oferecido pela Itaipu e podese tornar ainda mercadoria vendável, abrindo o Refugio, caso do Bela Vista, para visitação e pesquisa, promovendo assim, ainda alguma vantagem financeira. Assim, por isso mesmo, é de se supor que na visão do Diretor Geral de Itaipu Costa Cavalcanti, os animais teriam mais direitos de sobreviver no Brasil, do que os indígenas! Porém, como vimos sequer isso aconteceu, dos milhares de animais supostamente "salvos" (36.450 ou 13.000 animais resgatados em 1982 e no Refugio Bela Vista em 2009 havia 388 animais), poucas centenas sobreviveram e se reproduziram.

Ao contrario, quando vemos a descrição de Mazzarollo a respeito da fauna e flora que foram perdidas, é realmente um caso desolador. Muitas páginas são escritas para descrever as Sete Quedas perdidas. O autor descreve que eram na verdade uma sequencia de dezenove cachoeiras e noventa saltos, num desnível de 100 metros, oferecia um espetáculo sem similar

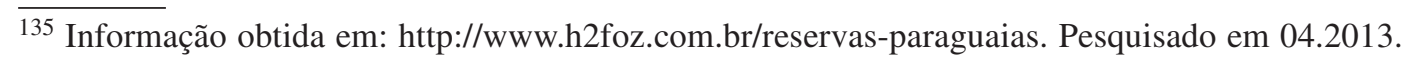


no mundo (MAZZAROLLO: 2003:173-4). Nos atenhamos sobre a descrição de como foram capturados os animais.

Para o resgate dos animais, Itaipu organizou a chamada Operação Mymba Kuera (expressão guarani que significa pega-bicho). Seus trabalhos iniciaram em 1978. Até o fechamento das comportas, a Operação Mymba Kuera capturou cerca de 600 animais. Mas seu grande desafio estava reservado para o exíguo período de enchimento do lago - 14 dias apenas.

Itaipu não tinha solução técnica para tornar mais lento o enchimento do reservatório. Assim 200 homens em 17 lanchas e dois helicópteros não puderam evitar que o grande lago se transformasse num imenso cemitério. Ao final da Operação, inexplicavelmente encerrada poucos dias após o enchimento da represa, as equipes haviam capturados cerca de 11.000 animais na margem brasileira e cerca de

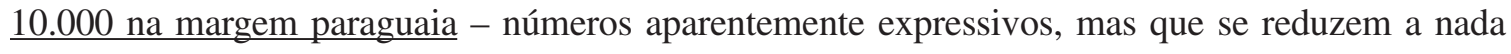
quando se considera que, para cada animal salvo, pelo menos outros 50 foram vitimados pelo dilúvio. Além disso, boa parte dos animais recolhidos acabou morrendo por incompetência e falta de meios de salvamento. (...) O biólogo e antropólogo Claudio Araujo, (...) para acompanhar a panaceia da operação e chorar no funeral da fauna e flora em Itaipu. Em seu regresso, Araujo passou pelos meios de comunicação que encontrava pelo caminho, aos quais relatava o triste espetáculo que assistira:

Aquilo é um lago assassino! Eles não tomaram consciência da loucura que é uma obra colossal como Itaipu.

Araujo denunciou a precariedade das condições humanas e materiais da Operação. "Seria necessário um exercito inteiro para evitar uma mortandade em grau tão elevado" dizia. Em vez disso, assistiu ao trabalho de pessoas voluntariosas, porém sem técnicas e equipamentos adequados à tarefa.

Desse modo, milhares de animais sucumbiram, morreram afogados ou de inanição. Pior do que Itaipu, só mesmo o apocalipse. As equipes de resgate não tem a menor noção da responsabilidade do trabalho que lhes foi atribuído. As lanchas levam quatro peões mais material de captura, que é uma piada. As redes, por exemplo, tem espaços superiores a $10 \mathrm{~cm}$, o que implica na incapacidade de apanhar animais de pequeno porte, e as caixas, sem ventilação, abrigam dezenas de animais ao mesmo tempo. Os perigos são grandes porque eles entram em contato com animais venenosos. $\mathrm{O}$ soro antiofídico, por ex:, seria fundamental, mas nem isso eles têm. (MAZZAROLLO: 2003:181-2)

Por seu turno, os Guarani fazem até os dias de hoje, um artesanato curioso. É uma arvore de caixeta, com vários animais sobre seus galhos, animais esses que não são aves, mamíferos mesmo. Demonstram o que viram: ao subirem as águas os animais nadando, subiam nos galhos das arvores, tentando se salvar, mas depois de um tempo, também as arvores eram encobertas e assim aqueles animais morriam afogados. 
Quanto ao tratamento dado aos que seriam desapropriados, os colonos que viviam na área a ser alagada, o site da Itaipu ${ }^{136}$ informa sobre as indenizações:

Ao longo da faixa de 170 quilômetros submersos entre Foz do Iguaçu e Guaíra, 8.519 propriedades urbanas e rurais são alagadas na margem brasileira, e os donos indenizados. (...) O sucesso deste trabalho de orientação pode ser mensurado: quando da formação do lago, de 8.519 propriedades atingidas (6.913 rurais e 1.606 urbanas), 8.503 foram adquiridas através de acordo e apenas 16 das desapropriações tiveram de ser decididas em juízo. (...) Todos os procedimentos de inventários, avaliações, apoio jurídico de regularizações fundiárias, as negociações, o acompanhamento da saída dos desapropriados foram realizados com a supervisão de cientistas sociais. (...) A desapropriação das terras atingidas pelo lago no Brasil correspondeu financeiramente a cerca de 4,5\% do valor total da usina hidrelétrica. (...) Pesquisas posteriores demonstraram que os desapropriados brasileiros deslocaram-se, acompanhando os fluxos migratórios, para o Paraná (86\%), Mato Grosso (8,89\%) e Santa Catarina (1,16\%). Os outros foram diversos Estados e inclusive para o Paraguai.

As vítimas desse processo, os desapropriados que antes habitavam a área a ser alagada, também são referidos nas obras de Juvêncio Mazzarollo e Guiomar Inez Germani ${ }^{137}$.

Mazzarollo informa que: Foram desapropriadas 8272 propriedades de solo rural e urbano no Brasil e cerca de 1200 no Paraguai. Na margem brasileira foram removidas cerca de 40.000 pessoas e na margem paraguaia, cerca de 20.000. (MAZZAROLLO: 2003:26). Sobre a forma como foram adquiridas as terras por Itaipu o mesmo autor informa no capitulo 3 denominado " $O$ Drama dos Desapropriados":

Patrimônio que não tem preço

$\mathrm{Na}$ área necessária para a imponente hidrelétrica viviam aproximadamente 8.000 famílias (cerca de 40.000 pessoas) na margem brasileira e 4.000 familias (20.000 pessoas) na margem paraguaia. Todas foram forçadas a deixar suas terras, casas e benfeitorias, e lançar-se na luta pela reestruturação de suas vidas, famílias e comunidades. O que tinham propriedade foram indenizados, e entre estes houve os que conseguiam fazer bons negócios e também os que se arruinaram. Mas havia muitos que nada possuíam (posseiros, arrendatários, empregados e bioas-frias) e, estes, salvo exceções, tiveram que abandonar a área de mãos vazias, lançados à própria sorte (MAZZAROLLO: 2003:40) (grifos nossos).

\footnotetext{
$\overline{136}$ Informação obtida em: http://www.itaipu.gov.br/ . Pesquisado em março de 2013.

${ }^{137}$ MAZZAROLLO, Juvêncio. A Taipa da Injustiça: Esbanjamento econômico, drama social e holocausto ecológico em Itaipu. Editado conjuntamente por Comissão Pastoral da Terra do Paraná/ CPT-PR e Edições Loyola. 2003. 203p; e, GERMANI, Guiomar Inez. Expropriados Terra e Água: O conflito de Itaipu. Editora ULBRA/ EDUFBA. 2003. 266 p.
} 
Em seguida Mazzarollo descreve o que o artigo XVII do Tratado de Itaipu estabeleceu, sendo desnecessário fazê-lo, pois já foi descrito acima por nós. Em seguida ele afirma:

Parecia simples. Nem às altas partes contratantes, nem as encarregados de construir a usina, nem à população atingida se desenhou, no anuncio da obra, o drama social que derivaria do cumprimento do disposto naquele artigo do Tratado de Itaipu. O que, segundo esperavam os dirigentes da Itaipu, deveria ser uma rendição conformada e patriótica da população desapropriada acabou se constituindo numa triste vergonha a cercar a construção da grandiosa obra. O conflito que se estabeleceu entre Itaipu e os desapropriados revelou o ponto extremo a que pode chegar a insensibilidade da tecnocracia aos valores humanos (MAZZAROLLO: 2003:40).

(...) Desde o inicio os técnicos manipularam os desapropriados com os mesmos métodos com que manuseavam mapas, dólares e concreto armado. Portavam-se como se para limpar a área bastasse fazer um levantamento e uma avaliação unilateral, sem ouvir a parte interessada, baixar um decreto governamental dando a conta ao proprietário, e este, com santa humildade e brioso patriotismo, iria embora para outro lugar sem criar problemas (MAZZAROLLO: 2003:41) (grifos nossos).

Assim este não parece ser o comportamento de "cientistas sociais" para lidar com a situação, conforme afirmado por Itaipu. O autor continua:

A questão das desapropriações e da transferência dos moradores da área que seria inundada deveria merecer atenção prioritária, tanto na ordem do cronograma quanto na seriedade dos cuidados. As autoridades deveriam discutir com a população afetada a forma mais conveniente de tratar algo tão serio. Talvez um plebiscito fosse conveniente para decidir sobre a execução de uma obra da magnitude de Itaipu. No entanto, seguindo a moda do regime militar, tudo foi decidido e imposto unilateralmente, de cima para baixo.

$\underline{\mathrm{O} \text { descaso com o problema social criado foi tanto que no primeiro orçamento feito para a obra nem }}$ $\underline{\text { sequer constou, entre os gastos previstos, o item das desapropriações e respectivas indenizações, }}$ conforme admitiu o próprio diretor-geral brasileiro na época, o general José Costa Cavalcanti (MAZZAROLLO: 2003:41) (grifos nossos).

O autor faz uma retrospectiva do que aqueles agricultores haviam passado antes para se estabelecer no Oeste do Paraná:

Os agricultores que seriam desalojados já haviam enfrentado de tudo. Migraram de outras regiões do país para o Oeste do Paraná enfrentando grandes dificuldades e correndo sérios perigos. Desbravaram a mata, suportaram doenças, enfrentaram conflitos em que muitos morreram na luta pela 
$\underline{\text { terra, devido à anarquia fundiária que encontraram na região. Em geral, aportaram na região com }}$ parcos recursos. Sofreram a insegurança da instabilidade dos preços de seus produtos. Foram vitimas da monocultura, da mecanização, da introdução de técnicas ditadas pelos interesses de empre$\underline{\text { sas multinacionais e de uma política agrícola eleita para burro-de-carga de um modelo antinacional }}$ e antissocial. Enlearam-se em intrincadas tramas urdidas por bancos de credito. Suportaram o esbulho de confiscos governamentais. Arcaram com o ônus de falências fraudolentas de empresas agropecuárias. Amargaram sucessivas frustrações de safras... e, quase à semelhança da matança de porcos em vista da alegada peste suína africana, poucos anos antes, enfim ouviram este veredicto da Itaipu: "Os agricultores do Oeste do Paraná devem ser sacrificados para o bem e o progresso do Brasil". (MAZZAROLLO: 2003:42) (grifos nossos).

Ao que parece este é o caminho de todos os homens que lidam com a terra: Posseiros migram de outras regiões, desmatam as terras florestadas, entram em conflito com os antigos ocupantes, os indígenas, ou entre eles mesmos devido a desordem fundiária, abrem caminho para uma segunda leva de ocupantes, que adquirem as terras de formas legais e/ou ilegais (grileiros), estes expulsam os primeiros (indígenas e posseiros), estes tem como se estabelecer por conta que conseguem crédito e financiamento nos bancos, diferentemente dos últimos, e por fim todos estes proprietários vão ficar sujeitos ao processo de industrialização da agricultura, enredados com as multinacionais que determinam o que plantar, o preço, em geral para exportar os produtos, sendo um modelo portanto, antinacional e antissocial, pois não se volta para plantar visando o abastecimento da população do país, mas sim atender a demanda externa para abastecer por exemplo o gado existente nos latifúndios. É um ciclo vicioso determinado pelas relações capitalistas de produção. Hoje nesta região do Oeste do Paraná conforme a época do ano, todos os colonos lindeiros ao reservatório de Itaipu plantam somente monoculturas de soja, milho e trigo, a grande maioria para exportação.

Outro problema colocado, no qual se tivesse havido realmente a participação de cientistas sociais no processo de desapropriação, provavelmente não haveria ocorrido, é a desintegração das comunidades. Mazzarollo assim afirma:

"De qualquer maneira, os agricultores sairão daqui magoados, afinal estão deixando não só as suas terras, mas uma historia que escreveram com suor durante 30 anos ou mais no Oeste do Paraná" (Bispo Dom Domingos Wisnieswki/Apucarana). Pessoas forçadas a desintegrar suas comunidades desabafavam: "Aqui a vida era uma beleza. Outro lugar igual a gente não vai encontrar. O povo todo unido, muita amizade, assim se vivia aqui”. (MAZZAROLLO: 2003:44). (...) E mais triste ainda é 
romper laços de união, amizade e cooperação entre familiares, parentes e amigos em toda a diversidade e profundeza de interação consolidada ao longo de anos e anos de convívio. (MAZZAROLLO: 2003:45).

Mazzarollo aprofunda as questões vividas no capitulo 4 denominado "Isolar para Espoliar" (1974-1977). Assim ele relata:

A Constituição... do Brasil determinava que desapropriações feitas em nome do interesse publico deveriam ser pagas a preço justo, sem especificar em que ele consistiria, mas estabelecendo que deveria ser pago em dinheiro. E foi em torno desse eixo que girou todo o conflito social... .

Para as autoridades da Itaipu, o preço pago sempre foi justo, enquanto que para os desapropriados, não foi. (...) "Eu acho que o colono sofre com isso, mas a Itaipu não pode pagar pela terra além do preço que ela vale. Nós queremos construir a hidrelétrica o mais barato possível. Os colonos não conseguem vender a terra a outros pelo preço que a Itaipu paga" - dizia o general José Costa Cavalcanti. "Eles sempre falam de preço justo, mas qual é o preço justo? O que eles estão querem pagar é o preço justo para eles" - contra-argumentavam os desapropriados.

(...) A preocupação dos dirigentes da obra com a economia de gastos nunca apareceu em outros setores com a mesma intensidade com que se evidenciou nas indenizações. A austeridade nas desapropriações perdia todo o mérito quando confrontada com a corrupção, as mordomias e o desperdício de recursos verificados em outros setores do empreendimento.

(...) Eles não foram consultados para nada. Apenas receberam a comunicação de um fato consumado ao qual deveriam se submeter inapelavelmente. A irresponsabilidade e a desconsideração das autoridades foi tamanha que, quando a construção da usina foi iniciada, nem sequer se sabia qual a área necessária para o empreendimento e nem mesmo fora levado em conta, na projeção do orçamento, o custo das indenizações.

(...) Sem conhecer a região e muito menos as características de sua população, lançaram-se à campo com funcionários inteiramente alheios à realidade do Oeste do Paraná. Não tinham (...), a menor ideia do caos fundiário em que a região se arrastava desde que fora iniciada a colonização. Nem sonhavam com o poder de resistência que poderia ser armado pelos desapropriados. Julgavam que nada haveria além da pura e simples submissão ao poder maior e a resignação perante o inevitável. (...) Os afetados ... tiveram que se submeter aos desígnios arbitrários do autoritarismo - tanto assim que as tarefas de avaliar, desapropriar e indenizar as propriedades ficaram a cargo do Departamento jurídico da Itaipu, como se tratasse de mera questão legal, não social e humanitária. O comando da operação foi entregue ao diretor jurídico da Itaipu, o advogado Paulo José Nogueira da Cunha... . (MAZZAROLLO: 2003:47-8) (grifos nossos). 
Vejamos como se deram os trabalhos, segundo o autor:

Entre 1973 e 1974, Itaipu realizou um censo preliminar da área a ser alagada. A primeira etapa consistiu no levantamento e na demarcação das propriedades; a segunda, no esclarecimento à população (já assustada e irritada com o vaivém dos técnicos em suas terras); e a terceira, na formulação das propostas de indenização, a que chamavam de "acordos amigáveis".

"Quando, em 1974, comecei a examinar toda aquela papelada, confesso que fiquei assustado. Era um trabalho gigantesco" - disse Paulo Cunha. Não era para menos: ao longo dos trabalhos foram montados 8.257 processos de desapropriação e indenização: 6.658 na zona rural e 1.599 na zona urbana. Proprietários devidamente documentados detinham 59\% dos estabelecimentos, que perfaziam $75 \%$ da área total, enquanto que $20 \%$ dos estabelecimentos, ou $16 \%$ da área total, estavam sob o domínio de ocupantes, os posseiros, sem titulo de propriedade. Esses dados se referem à margem brasileira. Essas pessoas representavam $11 \%$ da população total dos municípios afetados e $45 \%$ do contingente deslocado era força de trabalho ativa.

As desapropriações correram à solta mesmo sem o necessário decreto da Presidência da Republica declarando de "utilidade publica" a área exigida para a implantação da hidrelétrica. O atraso do decreto desapropriatório, segundo os dirigentes da Itaipu, se deveu à "necessidade de regularização fundiária da região pelo INCRA", que não regularizou coisa alguma. O decreto só seria baixado em 01.03.1979, após a veemente denúncia de atingidos, sindicatos dos trabalhadores rurais e entidades eclesiásticas. As desapropriações efetuadas até a promulgação do decreto foram, então, meras transferências (irregulares) de escrituras à Itaipu Binacional.

Entre 1974 e 1976 foram pagas indenizações na área do canteiro de obras e do complexo administrativo e residencial dos construtores da hidrelétrica. Transcorreram praticamente sem conflitos, porque interessava à empresa expropriante obter rapidamente essas áreas. Os proprietários tomados de surpresa, sem tempo para analisar a questão em profundidade, diante dos preços tentadores, fecharam negocio sem pestanejar. Itaipu começou pagando bem com o objetivo de preparar um ambiente favorável às desapropriações na área do futuro lago.

(...) De acordo com a programação do Departamento Jurídico, as indenizações seriam efetuadas entre 1978 e 1980, porque em 1982 a área deveria estar totalmente desocupada para o represamento do rio. Essa pretensão evidencia outra vez, quanto as autoridades da Itaipu estavam equivocadas com a situação que iriam enfrentar. Em 1980 faltava indenizar ainda cerca de metade das propriedades - atraso causado pela resistência dos proprietários e pela complexidade dos problemas encontrados. (MAZZAROLLO: 2003:49) .

Sobre o tratamento dado aos colonos por Itaipu, segundo Mazzarollo: “O pessoal da Itaipu nos tratou como se fossemos índios, semelhantes àqueles a quem os padres jesuítas levavam 
espelhinhos, presentes e objetos coloridos para atraí-los" ironizavam os desapropriados (MAZZAROLLO: 2003:50). A parte o preconceito dos desapropriados, no caso dos verdadeiros indígenas, como vimos antes, a Itaipu levava somente os mais idosos dos indígenas, aqueles que não sabiam ler, para negociar, segundo depoimento dos Guarani de Oco’y.

Ainda sobre o tratamento dado aos colonos por Itaipu, segundo Mazzarollo:

No começo, as reuniões promovidas pela Itaipu com os desapropriados transcorriam em clima de dialogo e cordialidade, mas isso durou pouco. Logo começaram a surgir reações contra as propostas consideradas inaceitáveis e a partir daí os encarregados das avaliações e indenizações se fecharam e se distanciaram dos interlocutores, impedindo-os inclusive de se manifestar nas reuniões, sob a alegação de que "os colonos não sabem se expressar". Houve momentos em que só eram permitidas perguntas e contestações por escrito.

Itaipu levava consigo interpretes escolhidos entre lideres ligados ao partido do governo. Esses recebiam as perguntas e reclamações por escrito e as "traduziam" para os técnicos. Ainda que fosse verdade que os rudes agricultores tinham dificuldade de expressão em questões técnicas, não era menos verdade que as questões não eram meramente técnicas, além do que, se eles não sabiam se expressar falando (o que não era verdade), muito menos sabiam fazê-lo por escrito, pois grande parte deles não sabia escrever, e os que sabiam raramente se comunicavam por escrita.

(...) O que a Itaipu queria era manter o desapropriado sozinho, desprotegido, para tê-lo como presa fácil das artimanhas muito bem dissimuladas por trás de uma mascara jurídica perfeita. Para isso, realizava acordos individuais em que de um lado estava um humilde e acanhado agricultor e, do outro, técnicos e advogados engravatados. Eles agiam de forma que, pelos acertos feitos aqui e acolá, fosse rompida o quanto antes a solidariedade natural existente entre as comunidades.

Também não faltavam apelos à ilusão: "Com esse dinheiro na caderneta de poupança, você não vai precisar mais trabalhar" - acenavam os enviados da Itaipu. Nem ameaças faltavam: "Vocês não se metam nesse movimento organizado pelas igrejas, senão não vão receber nada". Ou ainda: "Se não aceitarem o que a Itaipu está oferecendo, terão de recorrer à Justiça, e se não saírem da área no prazo $\underline{\text { estabelecido sairão expulsos pela água quando o reservatório for formado" }}$. Outra ameaça consistia em prometer ao desapropriado que, em caso de recusa do acerto proposto, o dinheiro só seria entregue três ou quatro anos depois, mas pelo preço fixado na época da avaliação, inteiramente corroído pela inflação (MAZZAROLLO:2003:50-1) (grifos nossos).

Aí está a razão dos supostos "acordos" e tão poucos ajuizamentos de ação contra Itaipu, os quais ela conta como vantagem no inicio da descrição. Como vimos assim declarou a Itaipu: $\mathrm{O}$ sucesso deste trabalho de orientação pode ser mensurado: quando da formação do lago, de 8.519 
propriedades atingidas (6.913 rurais e 1.606 urbanas), 8.503 foram adquiridas através de acordo $\underline{\text { e apenas } 16 \text { das desapropriações tiveram de ser decididas em juízo. }}$

\section{Continua Mazzarollo:}

De imediato, os desapropriados perceberam que o preço oferecido não era suficiente para se reassentarem em condições satisfatórias e que as possibilidades de permanecerem no Paraná, de preferência no próprio Oeste, como sempre foi o desejo de quase todos, era muito remota. (MAZZAROLLO:2003:51) (grifos nossos).

A Itaipu como vimos afirmou anteriormente que: Pesquisas posteriores demonstraram que os desapropriados brasileiros deslocaram-se, acompanhando os fluxos migratórios, para o Paraná $(86 \%) \ldots$. O que logicamente não foi verdade.

Continua Mazzarollo:

Itaipu classificava as terras em quatro tipos e pagava diferentes preços para cada um. $\underline{\mathrm{O} \text { agricultor. }}$ que não conhecia os critérios de classificação nem era consultado para classificar a terra, havia comprado a propriedade por um preço uniforme, sem discriminação, e pagava impostos iguais por terra branca ou vermelha, plana ou dobrada.

Itaipu sonegava as informações. media, avaliava e formulava as propostas verbalmente, sem deixar nenhum documento (laudo de avaliação) em poder do proprietário (MAZZAROLLO: 2003:51) (grifos nossos).

A questão dos bancos, segundo Mazzarollo:

A maioria dos expropriados tinha financiamento em bancos ou portava as chamadas Notas Promissórias Rurais, as famigeradas NPRs. Tratava-se de documentos assinados pelo produtores nos bancos que financiavam a comercialização dos produtos agropecuários. O produtor recebia o pagamento da produção e assinava a NPR. Caso a empresa compradora não pagasse o banco, este cobrava do produtor. Depois de muitas injustiças e grandes protestos contra o governo federal, as NPRs foram abolidas. As NPRs e os financiamentos eram descontados a vista, com cheques cruzados entre a Itaipu e os bancos, à revelia do desapropriado - operações em que os bancos descontavam o juro correspondente ao tempo de carência que ainda restava ao cliente ali cobrado à vista. O agricultor ficava com as sobras da indenização, sem terras para cultivar, impossibilitado de adquirir nova propriedade, com as maquinas ociosas, e sem o que fazer. (...).

Itaipu media as terras e depois as confrontava com as escrituras em poder dos proprietários. Em muitos casos apareciam diferenças. Se a escritura apresentasse área maior que a encontrada pelos 
técnicos da Itaipu, valia a medição da Itaipu; se apresentasse área menor, valia a do proprietário um curioso critério de encontrar o preço justo (MAZZAROLLO: 2003:52) (grifos nossos).

Outras estratégias utilizadas pela Itaipu na desapropriação, segundo Mazzarollo:

Os preços das terras, principalmente dos lotes urbanos e das chácaras próximas às cidades e vilas, tão logo se anunciaram as desapropriações caíram. Povoados em franco progresso prometiam para um futuro próximo excelente valorização, mas aconteceu o inverso. Os comerciantes iam sofrendo progressiva queda em seus negócios, muitos deles caindo na falência pela perda progressiva de freguesia.

Os municípios atingidos foram condenados ao esvaziamento e à estagnação por longo tempo, com os governos (estadual e municipal) parando de investir em obras de infraestrutura, deixando em péssimas condições estradas, meios de comunicação, escolas hospitais.... .

Itaipu acenava com a "vantagem" de, após o pagamento da indenização, o desapropriado poder continuar cultivando a terra, mas isso se revelou impraticável, pois o agricultor tinha que providenciar um novo estabelecimento e organizá-lo, tornando-se em geral impossível cuidar simultaneamente das duas áreas.

De início o plano da Itaipu era indenizar por áreas, partindo do canteiro de obras e subindo em direção a Guaíra, sem deixar ninguém para trás, mas o plano teve que ser logo abandonado, porque o caos fundiário assim determinou e também porque os dirigentes da empresa constataram que. indenizando aleatoriamente aqui e acolá, dificultavam a união e a mobilização de resistência do povo. Não raro Itaipu indenizou primeiro a infraestrutura (escolas, igrejas, hospitais, clubes, estabelecimentos comerciais), desarmando e esvaziando as comunidades, de modo a inviabilizar a permanência dos moradores e o surgimento de resistências organizadas.

Um agricultor explicou assim as razões da aceitação da proposta feita pela Itaipu:

Fui obrigado a aceitar porque, primeiro, toda a população da vila estava sendo obrigada a sair e eu ficaria sozinho, sem recursos e sem estabelecimento comercial onde comprar ou vender; segundo, os representantes da Itaipu faziam pressão, dizendo que se alguém não aceitasse a proposta, só muito mais tarde seria feita outra, e enquanto isso as terras disponíveis para aquisição subiam de preço. $\underline{\mathrm{O}}$ $\underline{\text { medo de ter que mexer com a Justiça e de não encontrar terra para comprar depois fez muita gente }}$ assinar propostas injustas.

As vilas eram indenizadas antes da zona rural, tirando dos agricultores as fontes de abastecimento de gêneros alimentícios, combustíveis e remédios, escola para os filhos e tudo o mais que só se encontrava em zonas urbanas.

Os posseiros em nada estavam recebendo pelas terras. Só recebiam indenização das benfeitorias introduzidas. Na medição feita por Itaipu eram descontados os rios e as estradas, procedimento 
nunca verificado na comercialização de terra. As redes de eletrificação rural também não eram pagas, embora uma propriedade com energia elétrica instalada tivesse seu valor significativamente aumentado, além de ter representado um custo para o proprietário.

Muitas propriedades não seriam totalmente inundadas, mas Itaipu só pagava pelas áreas remanescentes quando representassem menos de $20 \%$ do total desapropriado, sem considerar que, em muitos casos, a área restante era insuficiente para o agricultor continuar nela.

Não havia preocupação alguma da Itaipu com o reassentamento dos desapropriados. A forma de negociação adotada pela empresa foi a de "comprador para vendedor". Itaipu comprava a terra do colono e este, com o dinheiro recebido, tinha a "liberdade" de escolher um lugar onde se instalar. A única preocupação que a empresa demonstrava consistia em indicar, juntamente com o INCRA, uma relação de colonizadoras cadastradas e com projetos de reassentamento aprovados. As colonizadoras, algumas legalizadas e outras não, e ainda outras "fantasmas", invadiram a região e pareciam como "corvos em carniça" - na expressão de um agricultor.

A lista de problemas era realmente extensa. $\mathrm{O}$ que seria feito dos idosos, impotentes para reiniciar novo projeto de sobrevivência? Como seriam pagos os patrimônios das comunidades (escolas, igrejas, clubes, hospitais etc.), construídos conjuntamente pelos moradores? Por quanto e a quem seriam pagos? A dispersão das comunidades poderia ser evitada? Ou haveria um êxodo desordenado? Para onde ir? Os que ficariam às margens do lago teriam alguma ajuda para enfrentar as mudanças ecológicas e climáticas? Como ficariam as cidades e vilas adjacentes ao lago e mutiladas ou bloqueadas após a formação do lago? Quem custearia novas estradas e pontes necessárias após o alagamento? Porque não se previam diques para represar águas rasas que invadiriam desnecessariamente quilômetros de terra fértil? Quem pagaria as despesas com o transporte da mudança do expropriado? E os desapropriados na margem paraguaia, em situação desesperadora, que tratamento estavam recebendo? E que dizer da demora no pagamento depois de feita a avaliação da propriedade e a celebração do acordo? A inflação corroia os valores antes de serem pagos, sem que Itaipu pagasse juros ou correção monetária, resultando, para o desapropriado, em perda de negócios já tratados ou a consequência de ter de adquirir área menor que a desapropriada.

Em pouco tempo, a confusão criada era total. Itaipu não dava certeza de nada. Limitava-se a alardear que fazia um trabalho de "absoluto rigor técnico" e que pagava o "preço justo", de acordo com o mandamento constitucional. Mas não demorou muito, e os desapropriados se uniram e lutaram, desmascarando por inteiro a falsidade tanto do alegado "rigor técnico" quanto do alardeado "preço justo". (MAZZAROLLO: 2003:52-3-4) (grifos nossos). 
Portanto, a questão das desapropriações não foi em nada tranquila, como a assessoria de imprensa da Itaipu vem afirmando aos quatro ventos. Não havia nenhuma instância publica para mediar o conflito, a luta ficou restrita ao empreendimento Itaipu versus agricultores.

Esse movimento entre Itaipu versus agricultores teve outros inúmeros desdobramentos que infelizmente não cabe mais nesta tese relatar, dado que nos estenderíamos por demais. É importante ressaltar que o movimento dos agricultores atingidos por Itaipu deu origem e/ou contribuiu em muito, a dois movimentos no Paraná: O Movimento dos Atingidos por Barragens/MAB e o Movimento dos Sem Terra/MST.

Dada a inexistência à época da exigência de Licenciamento Ambiental para obras do gênero, muitas injustiças foram cometidas contra a população expropriada, os animais e os ambientes; apesar disso não impede que hoje seja realizado um Termo de Ajuste de Conduta/TAC, visando reparar os impactos; porém, até hoje isto tem sido impossível de se conseguir obter da Itaipu. $\mathrm{Na}$ época dos fatos pesquisados em campo tivemos acesso a um documento do Ministério do Meio Ambiente/MMA, no qual o Ministro exigia que a Itaipu realizasse o Licenciamento Ambiental, mesmo após a conclusão da obra, na qual a resposta da Itaipu foi a de sempre, "somos um empreendimento Binacional das Altas Partes, independente...”. Uma obra deste porte não pode ficar impune, sem a existência de Licenciamento Ambiental até a atualidade. Mais uma vez verifica-se que Itaipu é um território de excepcionalidade, em todos os sentidos.

Vimos até aqui as populações que foram obrigadas a se retirar desta parcela do território. Porém, nesta mesma parcela por conta da construção da Itaipu, e por conseguinte com a grande movimentação de capital, assistiu também a um enorme crescimento populacional, fundamentalmente de caráter urbano, caracterizado pela transformação dos municípios de Ciudad del Leste no Paraguai e Foz do Iguaçu no Brasil.

Vejamos inicialmente a transformação ocorrida em Foz do Iguaçu. O relato foi extraído do site "Usina Hidrelétrica de Itaipu (BRA) e Hoover Dam (EUA)" 138 que como vimos é um "corte cola" do texto do site da própria Itaipu. Descontando o discurso da Itaipu de característica triunfalista e que esconde as mazelas provocadas, assim é relatado no "item 3" denominado "Foz do Iguaçu":

\footnotetext{
${ }^{138}$ PEIXOTO Jr, Cesar. Usina Hidrelétrica de Itaipu (BRA) e Hoover Dam (EUA). Graduação em Física. Universidade Federal de Goiânia. Obtido em http://www.ebah.com.br/content/ABAAABlpYAI/usina-hidreletrica-itaipubra-hoover-dam-eua?part=5. Pesquisado em março de 2013. Texto extraído integralmente do site da Itaipu: http://www.itaipu.gov.br/. Pesquisado em março de 2013.
} 
Em 1974, Foz do Iguaçu, no Oeste do Paraná, era uma cidade quente e poeirenta, com apenas duas ruas asfaltadas e cerca de 20 mil pessoas assustadas com movimento humano que começava a perturbar seu ritmo pacato de viver. O impacto pode ser mensurado pelo crescimento vertiginoso da população urbana no município: em 1970, Foz do Iguaçu tinha 20.147 habitantes; dez anos depois. a população havia quintuplicado: 101.447 pessoas. As notícias da construção da hidrelétrica e o desembarque em massa dos primeiros contratados (...) para trabalhar na linha de frente do projeto, ao mesmo tempo que encantavam, deixavam a cidade em polvorosa.

A reação inicial dos iguaçuenses diante dos forasteiros era de receio e de uma desconfiança que diversas vezes cruzava a fronteira da animosidade. A construção da vilas residenciais em uma área próxima à usina e, portanto, longe do centro da cidade, serviu como arma para os setores mais resistentes à nova realidade, que traçavam a rodovia BR-277 como fronteira entre a "cidade de cá", dos habitantes nativos, e a "cidade de lá", dos forasteiros, que chegavam com bons salários, garantia de moradia e assistência médica para a família, além de outras vantagens, como escola para os filhos, clube social, quadras esportivas e centros comerciais, transporte para o trabalho e para os colégios. O programa de apoio aos trabalhadores foi feito nos mesmos moldes de outras hidrelétricas para atrair os barrageiros e os melhores técnicos e engenheiros para Itaipu. A conquista da "nata" dos profissionais do setor no Brasil foi possível não apenas graças a esses atrativos e à grandeza do desafio, mas também a uma circunstância favorável: as grandes obras do setor elétrico, como Marimbondo, Ilha Solteira e Itumbiara, além de Itaúba, Tucuruí e Salto Santiago, entre outras, estavam em fase de conclusão e a tendência natural para os barrageiros (espécie migratória, que cruza o país atrás de novas obras) era seguir para a fronteira com o Paraguai, no Oeste do Paraná.

$\underline{O}$ choque cultural, natural para quem não tinha proximidade com uma obra daquela envergadura, manifestações de hostilidade, dificuldades de uma ou outra natureza, foram, aos poucos, sendo absorvidos pela integração. $\underline{\text { O perfil da cidade teve que ser alterado: a construção da hidrelétrica }}$ obrigou o governo federal a investir em Foz do Iguaçu recursos que dotassem o município de uma rede melhor de telecomunicações, ampliando o aeroporto (atualmente internacional), abrindo novas

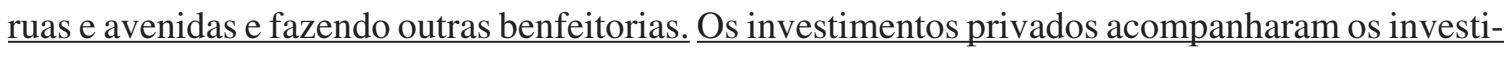
mentos públicos, especialmente na ampliação e modernização do parque hoteleiro e do setor de serviços em geral. Esse processo de melhoramento dos equipamentos urbanos, que aconteceu também do outro lado da fronteira, em Ciudad del Este, e que foi gerado, direta ou indiretamente, pela construção de Itaipu, diminui com o término da obra, mas a economia da cidade não estagnou, como $\underline{\text { costuma acontecer em situações de desaceleração de obras de forte impacto regional. A população }}$ em Foz do Iguaçu, a quinta maior cidade paranaense em 1997, atrás apenas de Curitiba, Londrina, Maringá e Ponta Grossa, era de 231.596 habitantes (IBGE). Um dos maiores pólos turísticos internacionais do Brasil, Foz do Iguaçu cresceu antes, durante e depois de Itaipu. Nesta cidade, a princípio "medrosa" do que pudesse acontecer com a invasão de milhares de forasteiros, a integração humana foi se estabelecendo ao longo dos anos, já que, entre outros motivos, a obra também repre- 
sentou um novo mercado de trabalho para os iguaçuenses. O contato humano entre os que viviam na cidade e os que para lá se dirigiram tornou-se inevitável.

Algumas pessoas de Foz do Iguaçu não entendiam bem todo o fenômeno e a peculiaridade da vida dos barrageiros, que contavam com a infra-estrutura de uma cidade, e prosseguiam reticentes diante da nova realidade. Porém, Wilson de Souza Aguiar, o "Ministrinho", representante do diretor-geral da Itaipu, Costa Cavalcanti, tinha um talento especial e diplomacia para obter junto a autoridades apoio do Estado e União em favor da modernização de Foz do Iguaçu. Desde a organização da estrutura viária da cidade à colocação de uma estátua comemorativa à visita (em 1916) de Santos Dumont ao Parque Nacional do Iguaçu e às suas borbulhantes cataratas. Esta visita resultou, na época, em declaração do governo do Paraná transformando as cataratas em área de utilidade pública, conforme decreto 653, de 28 de julho de 1916.

A partir da instalação, em 17 de maio de 1974, de uma entidade binacional para a construção da maior hidrelétrica do mundo, Itaipu se tornou "a terra prometida" para brasileiros e paraguaios em busca de emprego. Milhares deles, de todos os estados do Brasil e também do Paraguai, vieram tentar a sorte na fronteira e conseguiram se "fichar" nas empreiteiras. "Fichar", na linguagem dos barrageiros, significa ser admitido no emprego. No auge da demanda por mão-de-obra, imensas filas se formavam nos centros de triagem dos consórcios, que chegaram a contratar de 3 mil a 5 mil pessoas por mês. Ao longo da obra, em função do largo período de construção e da rotatividade da mão-de-obra, só o consórcio Unicon "fichou” cerca de 100 mil trabalhadores. No pico da construção da barragem, entre os anos de 1978 e 81, Itaipu mobilizou diretamente cerca de 40 mil trabalhadores no canteiro de obras e nos escritórios de apoio no Brasil e no Paraguai.

Para ilustrar a importância da construção de Itaipu no emprego de mão-de-obra paraguaia, nada mais singular que uma fase do senador Ezequiel González Alsina, líder do governo no Senado à época da aprovação do projeto: “A população economicamente ativa do Paraguai se divide em dois grupos - o dos que trabalham na Itaipu Binacional e o dos que sonham em trabalhar na Itaipu Binacional". Foi de Alsina a costura política no Senado paraguaio para que as bancadas, de situação e oposição, aprovassem o Tratado de Itaipu. Nos momentos que antecederam esta assinatura, Alsina invocou "o patriotismo, o sentido de unidade e a solidariedade, que têm presidido os momentos cruciais de nossa História", para que todos votassem pela aprovação da parceria com o Brasil. A construção da hidrelétrica constituía uma prioridade de governo no Brasil e era importante no conjunto da economia do País, mas muito mais como uma previsão do consumo e da necessidade de suprir a demanda de energia elétrica nas décadas vindouras. No Paraguai, a edificação da hidrelétrica deu novos rumos para a economia do País, com a duplicação da taxa de crescimento anual do Produto Interno Bruto (PIB) de 1975 a 78, passando de 5\% para 10,8\%. A partir de 1976, quando efetivamente começaram as obras civis de Itaipu, o setor industrial paraguaio sustentou um elevado $\underline{\text { ritmo de crescimento. Enquanto em } 1975 \text { o índice de crescimento daquele setor foi de } 1,8 \% \text {, em } 76}$ saltou para $8,1 \%$ e, em 77 , alcançou $21,1 \%$, superando, em muito, o crescimento do setor agrícola 
no mesmo período. No setor de construções, os índices foram ainda mais significativos, com um crescimento de $17,6 \%$ em 1976 e de $31,7 \%$ em 1977.

$\underline{\text { Sim, era um verdadeiro "formigueiro" humano. Os alojamentos e os conjuntos habitacionais para as }}$ famílias dos barrageiros em Foz do Iguaçu, Hernandarias e Porto Stroessner (atual Ciudad del Este) chegaram a somar, em 1981, uma população de 39.9 mil pessoas, total superior ao número de habitantes de Foz do Iguaçu quando do início do empreendimento, em 1974. Em 81, só a população escolar atendida pelos colégios instalados nas vilas chegou a 18.938 estudantes. No mesmo ano, a estrutura especializada no setor na usina realizou 2.226.457 procedimentos médicos e odontológicos e os refeitórios no canteiro de obras serviam uma média de 140 mil refeições a cada dia (a capacidade era para servir 15 mil refeições por hora).

A "invasão" de trabalhadores da hidrelétrica ao centro de Foz do Iguaçu se dava normalmente aos sábados, em especial nas idas que se seguiam aos pagamentos quinzenais dos "peões". Um exército de consumidores ávidos lotava as lojas da avenida Brasil, dando um grande impulso ao comércio e chegando a fazer das Lojas Pernambucanas na cidade uma das três filiais de maior volume de vendas no País, na época. $\underline{\text { A invasão dos forasteiros, }}$, vista nos primeiros tempos com muita desconfiança por alguns, foi o motor do formidável crescimento de Foz do Iguaçu nos anos que se seguiram.

Homem de estilo contido e cortês, o mineiro Rubens Vianna de Andrade era quem dirigia o canteiro de obras de onde saíam os "invasores", uma verdadeira cidade que chegou a ter cerca de 15 mil "peões", sem registrar distúrbios, crimes ou ocorrências mais graves. Era tamanha a presença de Andrade em Itaipu que, em visitas de personalidades, sempre que o diretor-geral brasileiro, o general Costa Cavalcanti, ia apresentá-lo, dizia ao seu interlocutor: "Este aqui é o dono da obra". O "dono da obra" se caracterizou, entre outros fatores, por sua inflexibilidade quando o assunto era economia. Há caminhões de exemplos.

Durante o auge das obras civis, entre os anos de 1978 e 81, Itaipu transformou-se realmente em uma verdadeira cidade, nervosa, frenética, obreira, de sentidos voltados para as metas estabelecidas. Milhares de pessoas, toneladas de matéria-prima, números superlativos, como sempre. Somente o volume de concreto (12,3 milhões de metros cúbicos) utilizado com Itaipu seria suficiente para construir a estrutura de todos os prédios e casas de uma cidade com 4 milhões de habitantes.

O geógrafo Antonio Marcos Roseira, na dissertação de mestrado denominada Foz do Iguaçu Cidade Rede Sul-Americana ${ }^{139}$ demonstra o crescimento populacional de Foz do Iguaçu, onde se pode verificar que no período dos anos 70 a 90, o altíssimo crescimento se dá em função da construção da Itaipu. Ele afirma: A historia do crescimento populacional da cidade se confunde com a historia da construção de Itaipu (ROSEIRA: 2006:68).

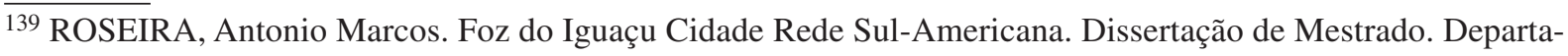
mento de Geografia. FFLCH-USP. São Paulo. 2006. 170p.
} 
Tabela 7.2. Crescimento populacional de Foz do Iguaçu: 1889 a 2003

Gráfico 1

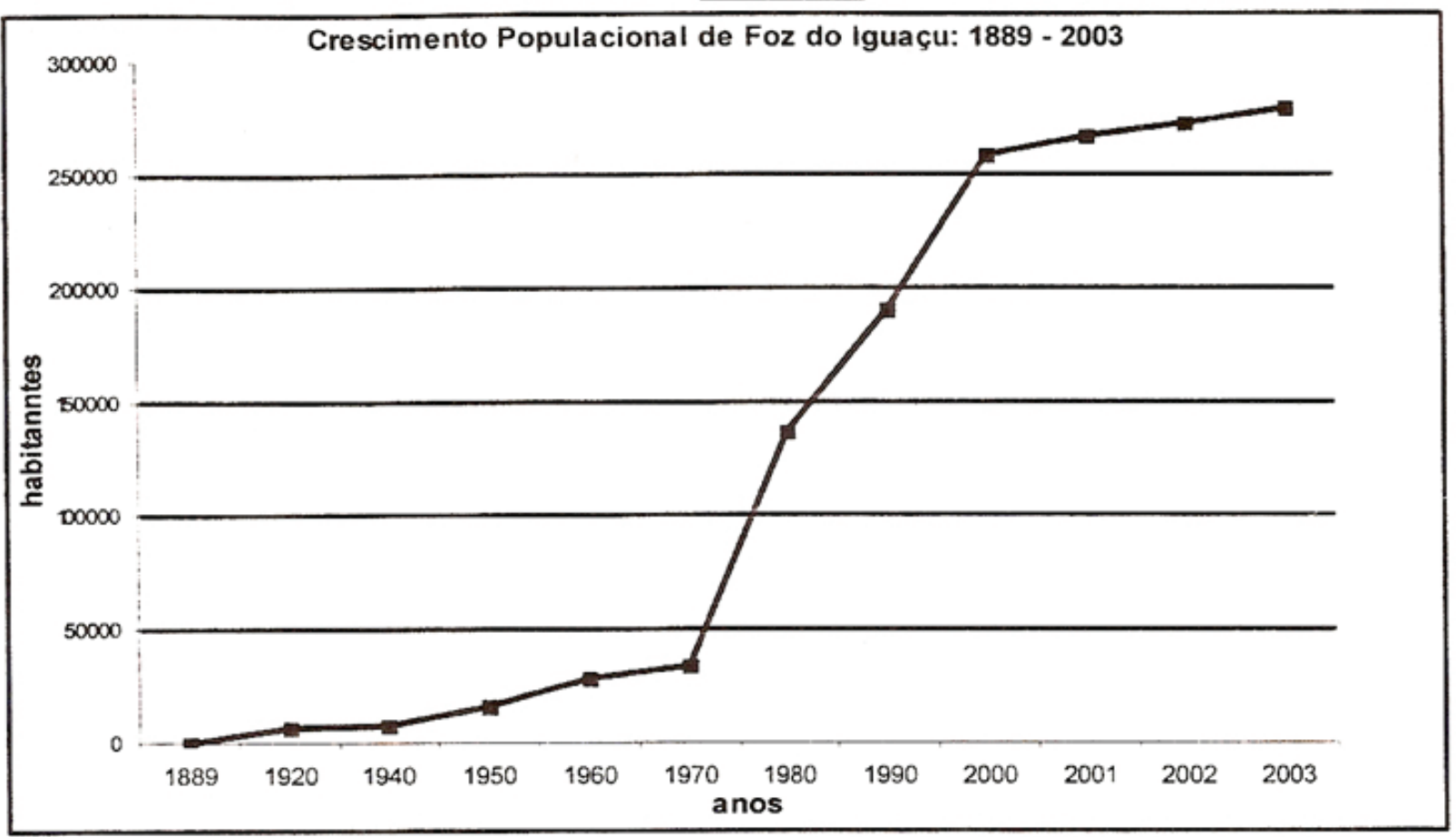

Fonte: IBGE, 2003

Organizador: Antonio Marcos Roseira

Fonte: Antonio Marcos Roseira. Foz do Iguaçu Cidade Rede Sul-Americana. 2006, p. 68.

Roseira afirma que o tipo de trabalho disponível na Itaipu, diferentemente do que a hidrelétrica afirma, se caracterizou em sua maioria absoluta destinado a peões de obra, assim atraiu população com baixo grau de escolarização e parcas condições financeiras, o que exigiu do Estado e do município grandes empreendimentos estruturais para Foz do Iguaçu. Ele completa a afirmação dizendo que as novas estruturas deveriam ser definitivas, pois a maior parte dos imigrantes pelas condições de pobreza vividas nos seus locais de origem se tornariam moradores permanentes.

Outro aspecto levantado por Roseira é que Foz já era confinada pelo rio Paraná e rio Iguaçu e com a construção do reservatório de Itaipu, teria ficado ainda mais confinada, dada a diminuição de seu território pelo reservatório, impossibilitando a expansão de sua área urbana; assim seu crescimento só pode se estender a Oeste, no sentido de uma conurbação com as cidades fronteiriças; no caso ele quer dizer com o Paraguai, fundamentalmente com Ciudad Del Este. É uma das explicações para o fato.

A população cresceu enormemente e a área do município de Foz diminuiu significativamente por conta do alagamento do reservatório, $201,84 \mathrm{~km}^{2}$, perdeu cerca de $1 / 4$ de sua área original. Assim também aconteceu com os outros municípios em parte ou todo inundados pelo reservató- 
rio. Nessa "peneira", estabelecida conforme o poder aquisitivo, para permanecer nas terras readquiridas no oeste do Paraná, como veremos uma população “desejável” pelo poder permaneceu (aquela ligada ao capital) aqueles que foram indenizados primeiro porque tinham títulos de propriedade quitados e uma população "indesejavel” pelo poder, teve que se retirar (indígenas, posseiros etc.).

A questão do turismo deve também ser mencionada, como atrativo para a movimentação de capital na região. Roseira cita as Cataratas e a própria Itaipu como atrativos turísticos: Se a cidade de Foz já era mundialmente conhecida devido à fama de suas belezas naturais, a construção da Usina Hidrelétrica de Itaipu ampliaria os limites de sua projeção (ROSEIRA: 2006:65). Após o período de construção e das mudanças urbanas ocasionadas, a hidrelétrica tendo um forte poder de atração de turistas, passa a contribuir para a confirmação da cidade como um dos mais fortes polos turísticos do Brasil (ROSEIRA: 2006:72).

Quanto ao turismo de Ciudad del Este Roseira afirma:

É nesse contexto que Foz do Iguaçu começa a desenvolver aquela que seria uma de suas características mais marcantes: A partir da década de 80, estabeleceu-se uma relação comercial mais estreita com o Paraguai, entre Foz do Iguaçu e Ciudad del Este. O chamado turismo de compras principalmente entre estas duas cidades, atraiu uma parcela significativa de turistas, que passava a ter na tríplice Fronteira uma tríade central de atrações: Cataratas do Iguaçu, Hidrelétrica de Itaipu e compras em Ciudad del Este (ROSEIRA: 2006:70).

Com o crescimento da área de fronteira, a relação entre as cidades segundo Roseira passa a ser definida tanto pela concorrência quanto pela complementaridade.

O fluxo de comercio entre elas é definido de acordo com o ritmo das políticas econômicas de cada país. As políticas monetárias e as variações cambiais entre os (...) países são fatores preponderantes na definição da direção destes fluxos. (...) A construção da Itaipu fez com que Foz do Iguaçu se tornasse um forte centro especializado em materiais de construção, atraindo compradores argentinos e paraguaios. A deficiência na produção do Paraguai de certos produtos, muitos de primeira necessidade, fez Foz do Iguaçu destacar-se até mesmo como um polo local de exportação. (ROSEIRA: 2006:70-1).

Roseira complementa a este respeito em nota que:

Como o Paraguai não produz bens de consumo duráveis e não duráveis em quantidades e qualidades suficientes para atender sua demanda, o comercio exportador de Foz se beneficiou desse mercado vendendo, àquele país, diversos produtos, principalmente alimentícios, de vestuário, eletrodomésti- 
cos e para a construção civil. Evidentemente, isso determinou um aumento na oferta de empregos e na renda local. Ao mesmo tempo em que as divisas eram retidas na compra de mercadorias no "posto livre" do Paraguai. (ROSEIRA: 2006:71).

Quanto a mão de obra desempregada após o termino da construção de Itaipu, Roseira afirma:

Mas o crescimento do comercio atacadista voltado à exportação não foi suficiente para absorver a mão de obra desempregada após o termino da construção de Itaipu. Estes moradores tiveram na informalidade uma saída para a permanência na cidade. Desta forma, junto ao comercio atacadista, o "turismo de compras" em Ciudad del Este foi o maior responsável por absorver a mão de obra desempregada (ROSEIRA: 2006:71).

É interessante ver como a cidade de Foz do Iguaçu vende a sua imagem, para isso basta ver o site sobre a cidade, existente na Wikipedia ${ }^{140}$ a seguir.

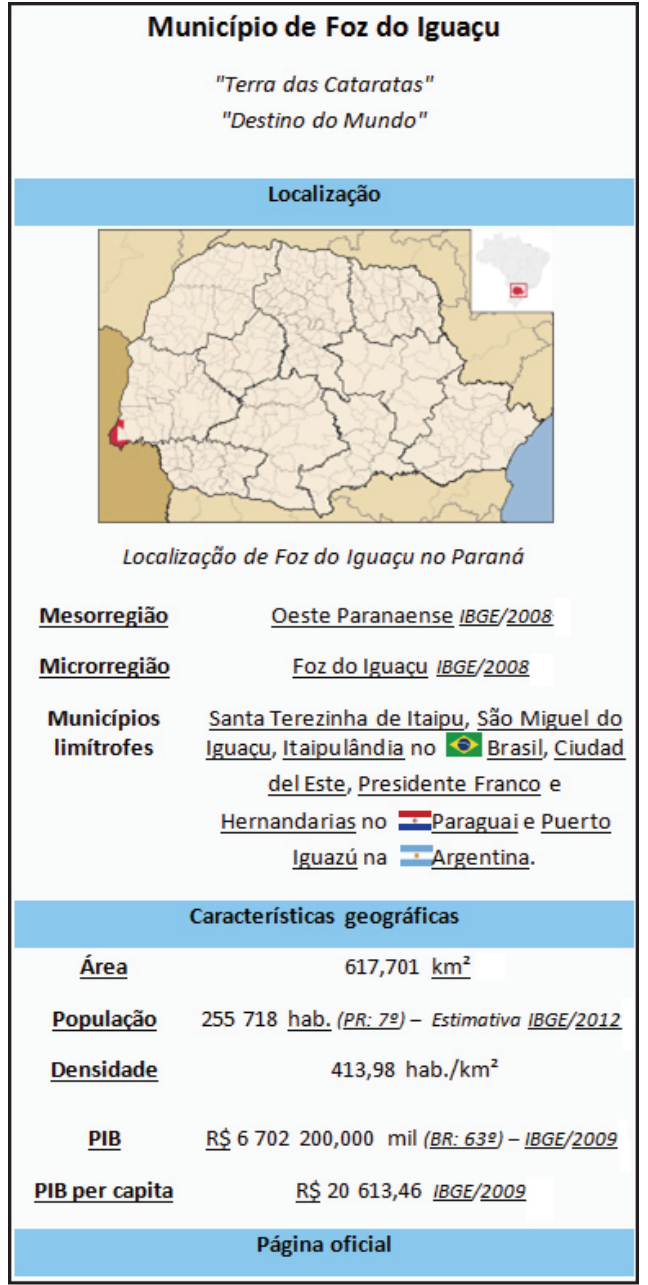

Figura 100. Informações sobre Foz do Iguaçu.
Em 2012 a população praticamente dobrou em comparação aos anos 80. É a $7^{\text {a }}$ cidade do Paraná.

Foz do Iguaçu é um município brasileiro do estado do Paraná, do qual é o sétimo mais populoso, com 255.718 habitantes, conforme estimativa do IBGE. Sua área é de $617,701 \mathrm{~km}^{2}$, dos quais $61,200 \mathrm{~km}^{2}$ estão em perímetro urbano. É o segundo destino de turistas estrangeiros no país e o primeiro da região sul. Conhecida internacionalmente pelas Cataratas do Iguaçu, uma das vencedoras do concurso que escolheu as 7 Maravilhas da Natureza e pela Usina Hidrelétrica de Itaipu, a segunda maior do mundo em tamanho e primeira em geração de energia, que em 1996 foi considerada uma das 7 Maravilhas do Mundo Moderno pela Sociedade Americana de Engenheiros Civis. Integra uma área urbana com mais de 700 mil habitantes, constituída também por Ciudad del Este, no Paraguai e Puerto Iguazú, na Argentina, países com os quais a cidade faz fronteira. Iguaçu é topônimo indígena, podendo ser decomposto, na forma, originalmente, em ig (água) e $a c ̧ u$ (grande), onde, por acréscimo de uma vogal, a atual denominação.

$\overline{140}$ Obtido em http://pt.wikipedia.org/wiki/Foz_do_Iguacu. Pesquisado em abril de 2013. 
Pesquisas arqueológicas realizadas pela Universidade Federal do Paraná no espaço brasileiro do reservatório de Itaipu, antes de sua formação, situaram em 6.000 a.C. os vestígios da mais remota presença humana na região; vários grupos humanos sucederam-se ao longo dos séculos. Os últimos que precederam os europeus (espanhóis e portugueses) foram os índios.

Assim o site de Foz quer fazer crer que os indígenas existiram ali somente antes da colonização (sic). Apesar de premissa falsa, quanto "aos pré-historicos indigenas", isso é uma tonica em todos os meios de comunicação mais fortes da região, da cidade de Foz, do PNI, da hidreletrica de Itaipu.

Em 1881 Foz do Iguaçu recebeu seus dois primeiros habitantes: o brasileiro Pedro Martins da Silva e o espanhol Manuel González.

Novamente os indígenas não são considerados “Habitantes”, talvez sequer sejam considerados "Humanos".

Pouco depois chegaram os irmãos Goycochéa, que iniciaram a exploração da erva-mate. Oito anos após, foi fundada a colônia Militar na fronteira - marco do início da ocupação efetiva do lugar por brasileiros e do que viria a ser o município de Foz do Iguaçu.

A expedição do Engenheiro e Tenente José Joaquim Firmino chegou a Foz do Iguaçu em julho de 1889. Foi levantada a população e identificadas 324 pessoas, em sua maioria paraguaios e argentinos. Mas havia também espanhóis e ingleses já presentes na região, dedicados à extração da ervamate e da madeira, exportadas via rio Paraná.

Novamente os indígenas não são considerados sequer população, muito menos que eram os trabalhadores na extração da erva-mate.

Em 22 de novembro do mesmo ano, o Tenente Antônio Batista da Costa Júnior e o Sargento José Maria de Brito fundaram a Colônia Militar, que tinha competência para distribuir terrenos a colonos interessados.

As terras indígenas que ocupavam extensamente a região.

No ano de 1897 foi criada a Agência Fiscal, chefiada pelo Capitão Lindolfo Siqueira Bastos. Ele Registrou a existência de apenas 13 casas e alguns ranchos de palha. Nos primeiros anos do século XX a população de Foz do Iguaçu chegou a aproximadamente 2.000 pessoas e o vilarejo dispunha de uma hospedaria, quatro mercearias, um rústico quartel militar, mesa de rendas e estação telegráfica, engenhos de açúcar e cachaça e uma agricultura de subsistência. 
Novamente os indígenas não são considerados população.

Em 1910 a Colônia Militar passou à condição de "Vila Iguassu”, distrito do município de Guarapuava. Dois anos depois, o Ministro da Guerra emancipou a Colônia tornando-a um povoamento civil entregue aos cuidados do governo do Paraná, que criou então a Coletoria Estadual da Vila. Em 14 de março de 1914, pela Lei 1383, foi criado o município de Vila Iguaçu, instalado efetivamente no dia 10 de junho do mesmo ano, com a posse do primeiro prefeito - Jorge Schimmelpfeng - e da primeira Câmara de Vereadores. O município passou a denominar-se "Foz do Iguaçu” em 1918. A estrada que liga Foz do Iguaçu a Curitiba tomou sua primeira forma em 1920. Era precária e cheia de obstáculos. Na segunda metade da década de 1950 iniciou-se o asfaltamento da estrada que cortaria o Paraná de leste a oeste, ligando Foz do Iguaçu à Paranaguá, que foi inaugurada em 1969.

\section{Refere-se a BR-277.}

Em 1924 os revoltosos da Coluna Prestes saíram da capital paulista iniciando sua marcha pelo interior do estado na direção sudoeste. Ao ingressar no Paraná, conquistaram muitas cidades fronteiriças ao Paraguai e estabeleceram seu quartel-general em Foz do Iguaçu. Permaneceram até 1925, quando atravessaram o rio Paraná penetrando no Paraguai rumo a Mato Grosso.

Ou seja, apesar de estabelecidos em Foz do Iguaçu "conquistaram cidades fronteiriças ao Paraguai", portanto, no Brasil?! É evidente a tentativa de afastamento de qualquer insinuação ou ideia "comunista" na banda brasileira da região.

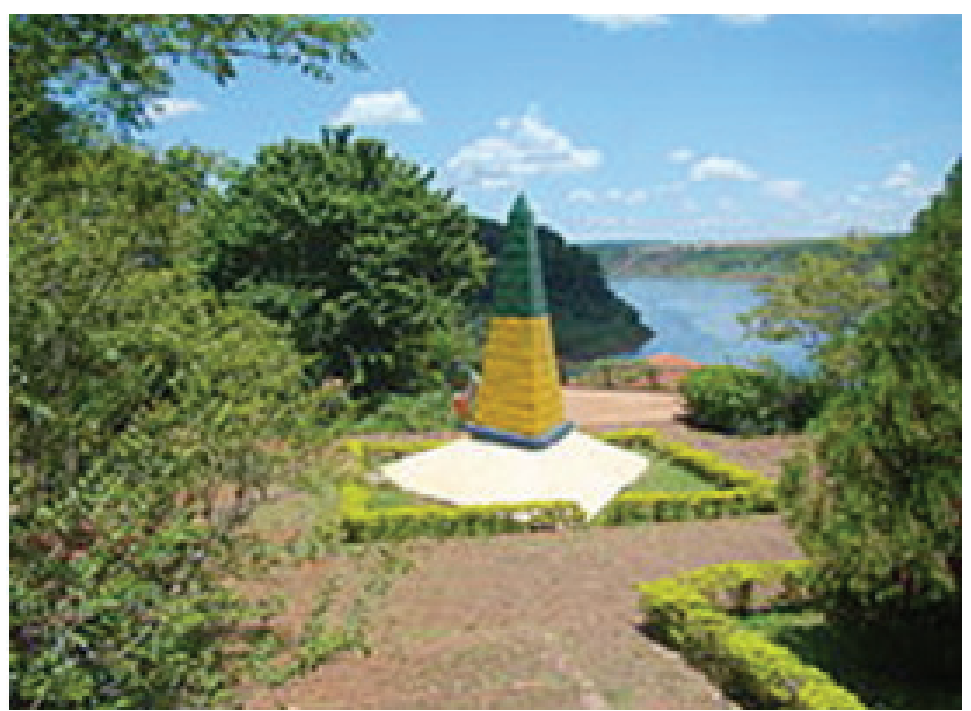

Figura 101. Turismo em Foz. "O Marco das Três Fronteiras recebeu a visita da Coluna Prestes". Fonte: http://pt.wikipedia.org/wiki/Foz_do_Iguacu 
A história do Parque Nacional do Iguaçu começa no ano de 1916, com a passagem por Foz do Iguaçu de Alberto Santos Dumont, o pai da aviação.

Ou seja, lá também os indigenas não são citados como fazendo parte da população integrante da história da região.

A área pertencia ao uruguaio Jesus Val.

Portanto, por este raciocínio, os indígenas "nunca” tiveram a posse dessa área.

Santos Dumont intercedeu junto ao Presidente do Estado do Paraná, Affonso Alves de Camargo, para que fosse desapropriada e tornada patrimônio público. No dia 28 de julho, através do decreto ${ }^{\circ}$ 63, foi declarada de utilidade pública com 1008 hectares e somente em 1939, por decreto do Presidente Getúlio Vargas, a área passou a ter 156.235,77 hectares.

Em 1941 ocorre o primeiro massacre dos Guarani, na Aldeia Guarani no interior de seu próprio territorio, naquela área que veio a ser o Parque Nacional do Iguaçu, descrito nesta tese anteriormente.

Em 1994 os decretos nº 6506 de 17 de maio e de nº 6587 de 14 de junho consolidam e ampliam a área do Parque Nacional dando-lhes os limites propostos pelo chefe da seção de Parques Nacionais; hoje os limites atuais são 185.000 hectares.

Com a inauguração da Ponte Internacional da Amizade (Brasil - Paraguai) em 1965 e inauguração da BR-277, ligando Foz do Iguaçu a Curitiba e ao litoral, em 1969, Foz do Iguaçu teve seu desenvolvimento acelerado, intensificando seu comércio, principalmente com a cidade paraguaia de de Ciudad del Este.

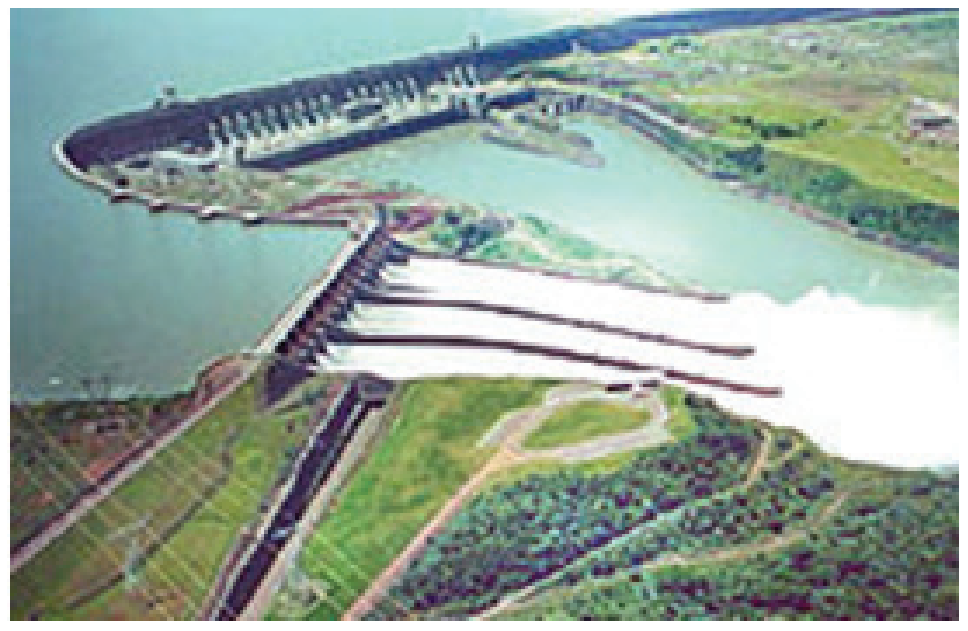

Figura 102. Turismo em Foz. Vista aérea da Usina Hidrelétrica de Itaipu, "a maior do mundo em geração de energia". Fonte: http://pt.wikipedia.org/wiki/Foz_do_Iguacu 
A construção da Usina Hidrelétrica de Itaipu, iniciada na década de 1970, causou fortes impactos em toda a região, aumentando consideravelmente o contingente populacional de Foz do Iguaçu. Em 1960 o município contava com 28.080 habitantes, em 1970 com 33.970 e em 1980, 136.320 habitantes, registrando um crescimento de $385 \%$. O Censo de 2010 indicou uma população de 256.081 habitantes.

Portanto, população maior em 2010 do que em 2012, que o proprio site indica inicialmente. A população decresceu?!

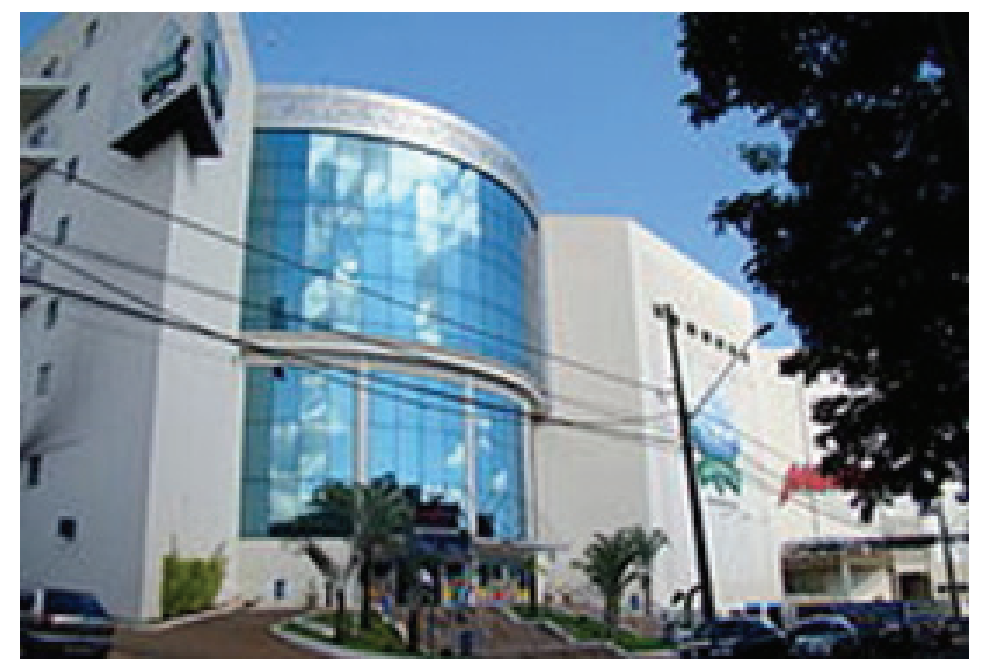

Figura 103. Turismo em Foz. Cataratas JL Shopping, "o maior shopping center do oeste paranaense".

Fonte:

http://pt.wikipedia.org/wiki/Foz_do_Iguacu

As principais fontes de renda de Foz do Iguaçu são o turismo e a geração de energia elétrica.

A base da economia da cidade é o turismo, que alavanca também o comércio e a prestação de serviços na região. É o segundo destino de turistas estrangeiros no país e o primeiro da região sul. Foz do Iguaçu é conhecida internacionalmente por suas atrações, que trazem visitantes do Brasil e do mundo. A mais famosa delas é o conjunto de quedas denominadas Cataratas do Iguaçu, no Parque Nacional do Iguaçu (Patrimônio Mundial Natural da Humanidade tombado pela UNESCO), a Hidrelétrica Binacional de Itaipu (maior hidrelétrica do mundo em produção anual de energia), o Marco das Três Fronteiras, a foz do Rio Iguaçu no Rio Paraná (área onde as fronteiras da Argentina, Brasil e Paraguai se encontram), a Ponte Internacional da Amizade (divisa entre Brasil e Paraguai) e Ponte da Fraternidade (divisa entre Brasil e Argentina), o Parque das Aves (com aproximadamente 900 aves de 150 espécies), entre outras. Além dos tradicionais atrativos da cidade, outro fator de atração de turistas é a possibilidade de compra de produtos com preços reduzidos na vizinha Ciudad del Este. Durante todo o ano é grande o fluxo de sacoleiros (como são conhecidas as pessoas que compram em grande quantidade no Paraguai para revender no Brasil) que atravessam a Ponte da Amizade apenas para comprar, uma vez que normalmente pernoitam em Foz. Outro atrativo oferecido pelas cidades vizinhas é a possibilidade de conhecer o lado argentino das Cataratas; nas proximidades também é possível frequentar os cassinos, atividade não permitida no Brasil. 


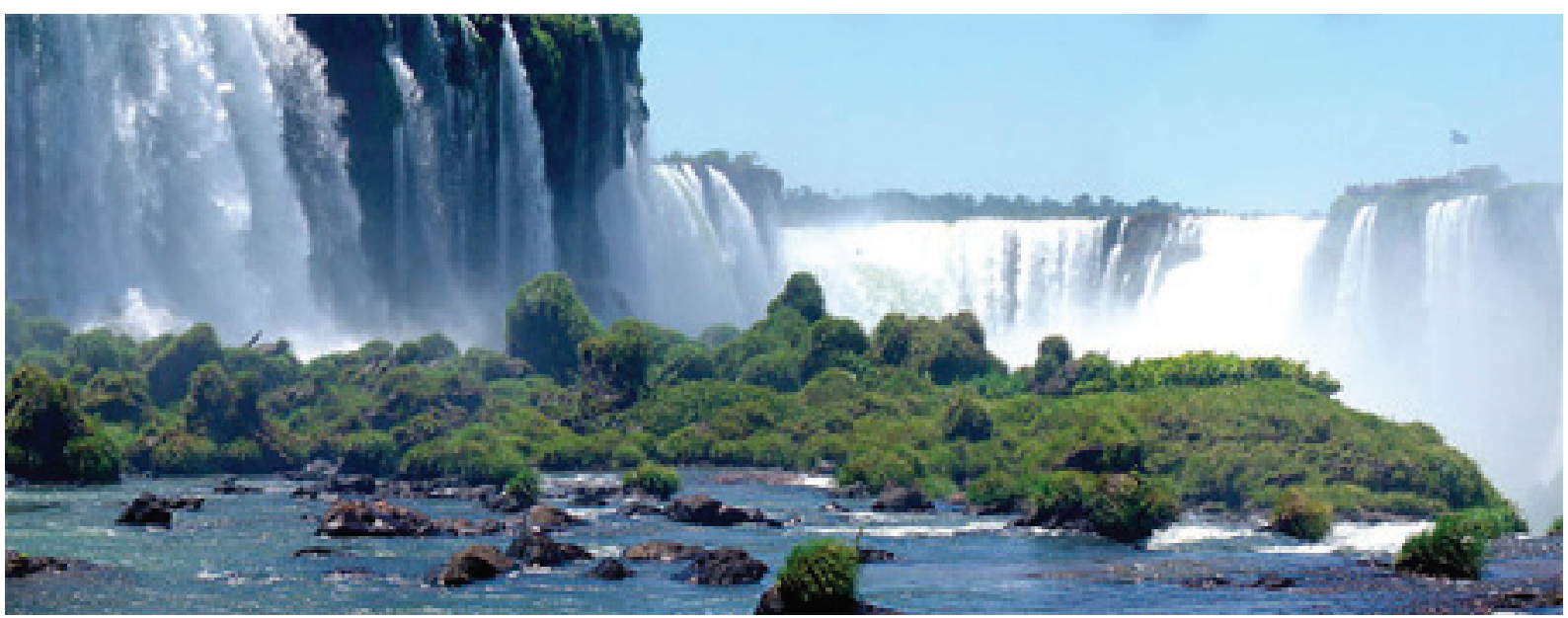

Figura 104. Turismo em Foz. "Panorama do lado brasileiro das Cataratas do Iguaçu. Ao fundo é possível ver a passarela do lado argentino".

Fonte: http://pt.wikipedia.org/wiki/Foz_do_Iguacu

Recentemente foi escolhida para alocar a Universidade Federal da Integração Latino-Americana. A Universidade é uma instituição de ensino superior preocupada com a criação de um ambiente multicultural e interdisciplinar capaz de produzir profissionais e pesquisadores voltados para o desenvolvimento econômico, social, cultural e político da região, num espírito de igualdade entre todos os povos e culturas do continente. "A Universidade Federal da Integração Latino-Americana é um projeto único na história do ensino superior na América Latina. A sua vocação é a de contribuir para o desenvolvimento e a integração latino-americana, com ênfase no Mercosul, por meio do conhecimento humanístico, científico e tecnológico e da cooperação solidária entre as universidades, organismos governamentais e internacionais. Será uma universidade aberta para a América Latina e Caribe: a metade dos 10.000 alunos e dos 500 professores, previstos como meta, serão selecionados e recrutados nos vários países latino-americanos e caribenhos, sendo a outra metade formada por brasileiros." Hélgio Trindade (reitor da UNILA)

Foz do Iguaçu está localizada no extremo oeste do terceiro planalto paranaense, sendo o município

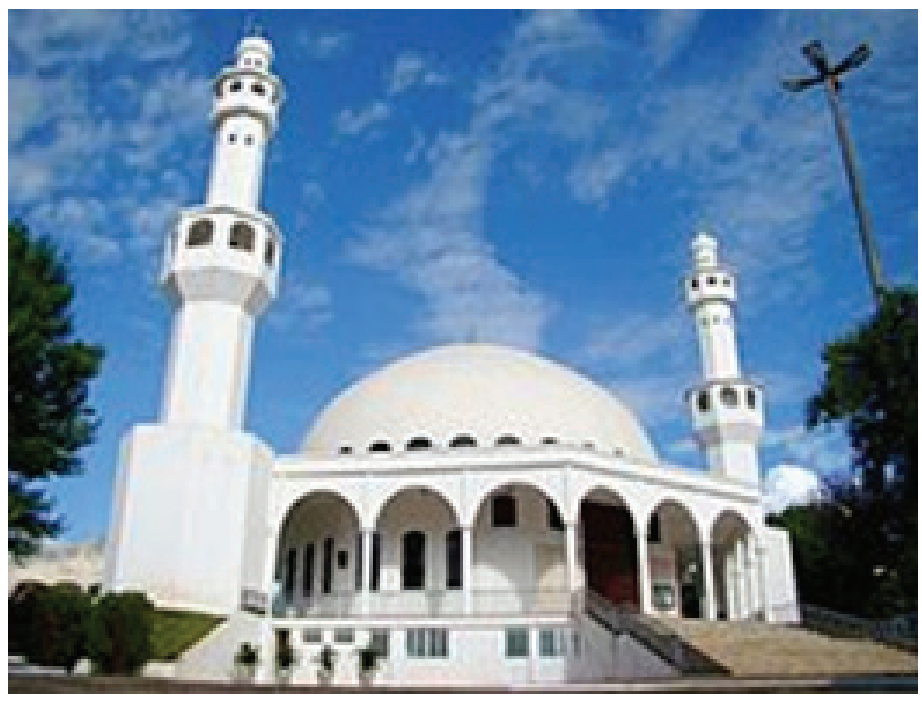
mais a oeste do Paraná. O relevo é suavemente ondulado, o que contribui muito para o desenvolvimento da agricultura. Sua altitude varia em torno dos duzentos metros. A oeste do município corre o rio

Figura 105. Turismo em Foz. Mesquita Omar Ibn Al-Khattab; "a cidade abriga a segunda maior comunidade muçulmana do Brasil". Fonte:

http://pt.wikipedia.org/wiki/Foz_do_Iguacu 
Paraná, ao sul o rio Iguaçu, ao norte fica o Lago de Itaipu e a sudeste o Parque Nacional do Iguaçu, uma das últimas reservas de mata nativa intacta que existem no Paraná. No sudoeste de Foz os Rios Iguaçu e Paraná se unem formando a tríplice fronteira entre Brasil, Argentina e Paraguai.

Foz do Iguaçu é considerada uma das cidades mais multiculturais do Brasil, onde mais de 72 grupos étnicos estão presentes na população, provenientes de diversas partes do mundo. Os principais grupos étnicos de Foz do Iguaçu são italianos, alemães, hispânicos (argentinos e paraguaios), chineses, ucranianos, japoneses, e libaneses, que possuem na cidade, a segunda maior comunidade libanesa do Brasil. Em termos proporcionais, possui a maior comunidade islâmica do Brasil.

Os indígenas Guarani apesar de ter nomeado quase todas as denominações de cidades, vilas, bairros, rios, estado etc., não são mencionados, não fazem parte da cultura da cidade.

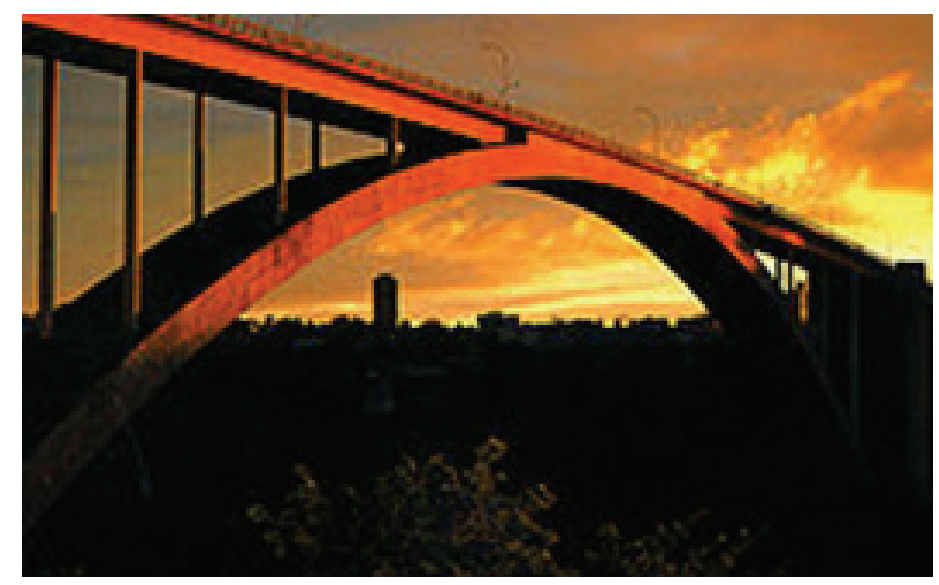

Figura 106. Turismo em Foz. "Ponte Internacional da Amizade". Fonte: http://pt.wikipedia.org/wiki/Foz_do_Iguacu
Devido a sua localização de fronteira com o Paraguai e a Argentina, Foz do Iguaçu apresenta uma grande circulação de mercadorias contrabandeadas, drogas e armas, o que gera diversos problemas sociais, principalmente a violência. Foz do Iguaçu possui uma taxa de homicídios muito alta, levando-se em consideração o tamanho da cidade, e lidera o ranking de homicídios entre adolescentes no país.

Foz do Iguaçu conta com um dos maiores parques hoteleiros do Brasil, além do Aeroporto Internacional Cataratas, servido pelas principais companhias aéreas nacionais e algumas internacionais. Além das conhecidas atrações turísticas, conta com uma grande variedade de restaurantes, churrascarias, bares e casas noturnas e também o maior shopping center do oeste paranaense Cataratas JL Shopping, com mais de 48,500 $\mathrm{m}^{2}$ e 140 lojas. O acesso rodoviário é feito pela BR-277, cujo término se dá na Ponte da Amizade.

\section{Cidades Irmãs}

Jericó - Palestina (24 de abril de 2012)

Puerto Iguazú, Misiones, Argentina

Ciudad del Este, Alto Paraná, Paraguai 


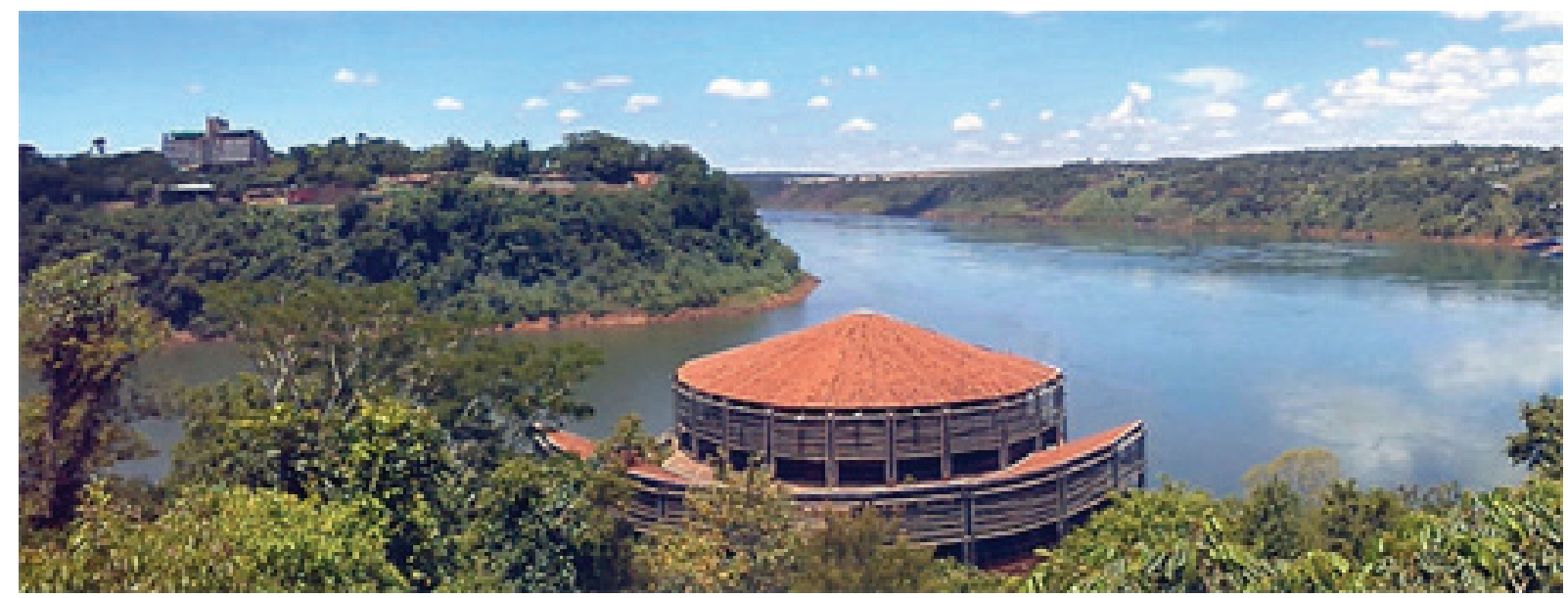

Figura 107. Turismo em Foz. "O Espaço das Américas, localizado junto ao Marco das Três Fronteiras: do lado esquerdo, a fronteira com a Argentina (delimitada pelo Rio Iguaçu) e do direito, com o Paraguai (delimitada pelo Rio Paraná)".

Fonte: http://pt.wikipedia.org/wiki/Foz_do_Iguacu

Foz do Iguaçu é uma das Mercocidades brasileiras. Juntamente da cidade paraguaia de Ciudad del Este e da argentina Puerto Iguazú, formam uma área urbana conhecida na região como Tríplice Fronteira, sendo caracterizadas portanto como Tri-Cidades.

Dessa forma, diante do fato que estamos diante de algumas premissas falsas, é importante caracterizar assim o papel ideológico da midia, com relação, por exemplo, aos indígenas da região; a midia corre em paralelo, em uníssono, ao que as classes dominantes querem fazer crer para a opinião publica. Pois é claro, ela é financiada pela propria classe dominante. O que é veiculado todo o tempo política e ideologicamente é somente tudo aquilo que pode ser transformado em mercadoria, renda, mais lucro para essa mesma classe, portanto, quantas informações úteis, importantes, devem ser diariamente excluídas da mídia.

\section{Ciudad del Este}

Ciudad del Este, localizada no Departamento (estado) de Alto Paraná/Paraguai, como vimos anteriormente havia surgido em função da construção da "Ruta 7" e da "Ponte da Amizade", em 1957. Esta cidade teve seu ecúmeno altamente vitalizado com a construção da Itaipu, dada a movimentação de capital e vinda de grande contingente populacional também deste lado da fronteira, em função de trabalho na grande obra nos anos 70. Assim a geógrafa Torrecilha (2010) comete um pequeno engano quando afirma na primeira frase, a seguir, estando correto todo o restante:

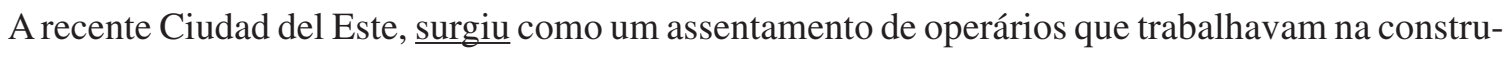
ção da Itaipu, e para estimular o seu crescimento foi declarada zona de livre comercio, atraindo 


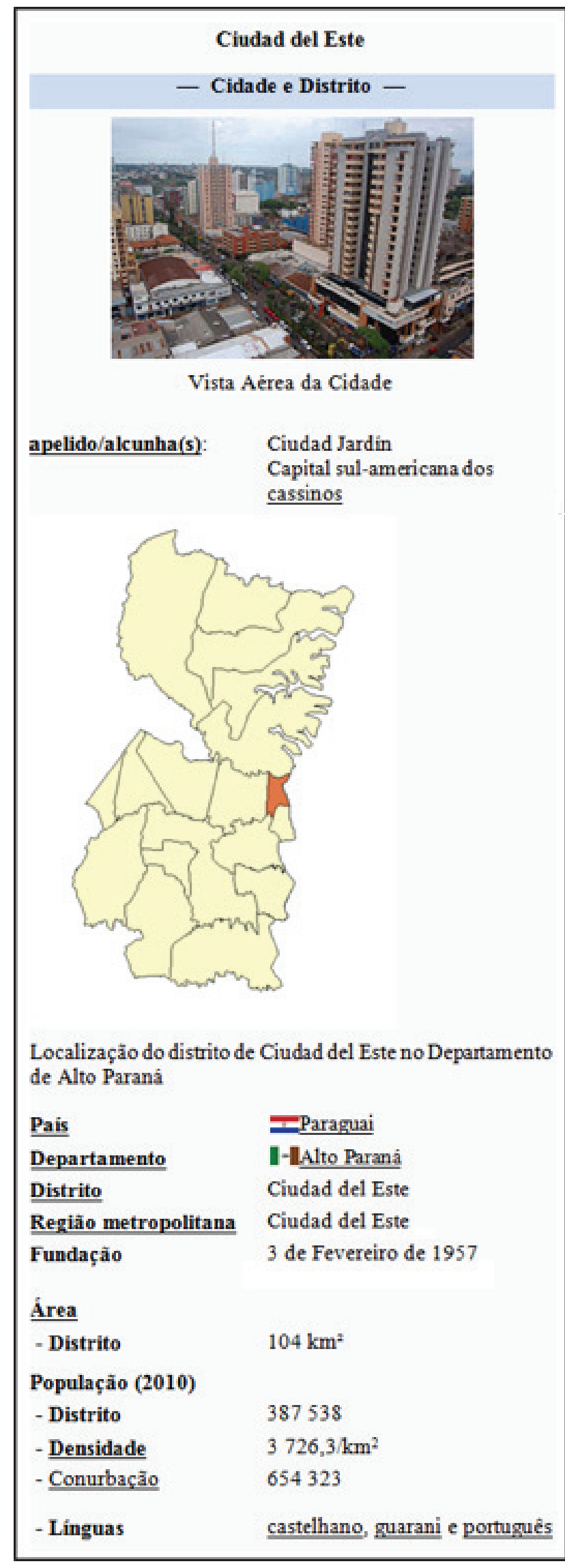

Figura 108. Turismo em Ciudad del Este.

Fonte: http://pt.wikipedia.org/wiki/Cidade_do_Leste imediatamente comerciantes de muitos paí-

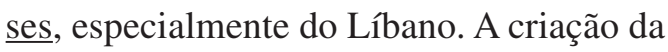
cerca não preocupava só o lado paraguaio. Cerca de 10 mil pessoas que vivem em Foz do Iguaçu cruzam a Ponte da Amizade diariamente para trabalhar em Ciudad del Este, e as autoridades locais temiam, que a redução da atividade comercial de seu vizinho repercutisse imediatamente em seu território (TORRECILHA: 2010:87) (grifo nosso).

Ciudad del Este é um distrito (município) que contém uma região rural e outra metropolitana, onde se concentra toda a zona franca. Vejamos no site da Wikipedia ${ }^{141}$ como ela é descrita:

Ciudad del Este é uma cidade e distrito do Paraguai, situada no extremo leste do país às margens do Rio Paraná. É a capital do departamento de Alto Paraná. Está localizada a 327 km de Assunção. A cidade foi fundada através de decreto em 3 de fevereiro de

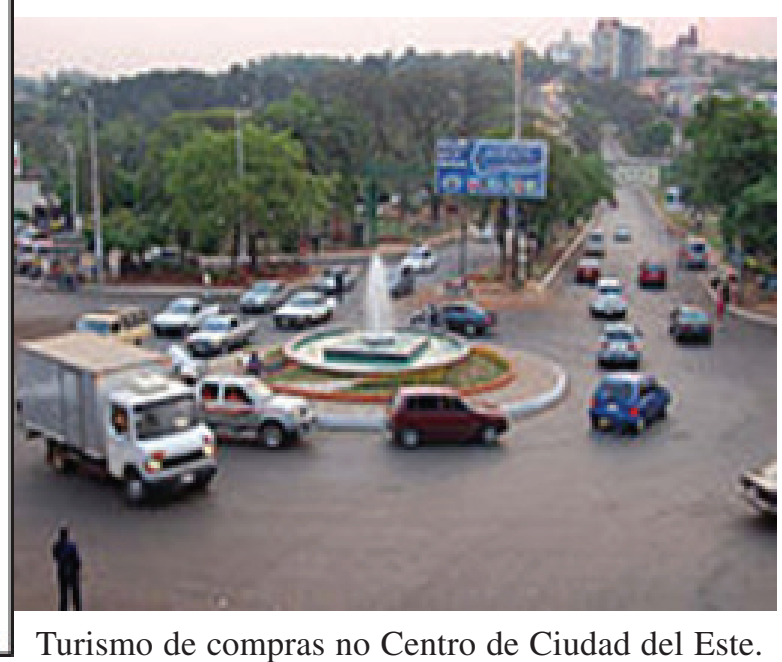

$\overline{141}$ Obtido em: http://pt.wikipedia.org/wiki/Cidade_do _Leste. Pesquisado em abril de 2013. 
1957 com o nome Puerto Flor de Lis. Logo teve seu nome alterado para Ciudad Presidente Stroessner, em homenagem ao ditador Alfredo Stroessner. Após o golpe de estado que depôs o ditador em 3 de fevereiro de 1989, o comando revolucionário utilizou o nome de Ciudad del Este. Nos dias posteriores, através de plebiscito, os cidadãos elegeram e confirmaram o nome de Ciudad del Este.

A cidade faz parte de um triângulo internacional conhecido na região como Tríplice Fronteira, que envolve também Foz do Iguaçu, no estado brasileiro do Paraná, e Puerto Iguazú, na província argentina de Misiones. As três cidades são separadas umas das outras pelo Rio Paraná e pelo Rio Iguaçu.

Com uma aglomeração urbana a 387 mil habitantes (2010), Ciudad del Leste é a segunda cidade mais populosa do Paraguai ficando apenas atras da capital Assunção que tem 742 mil habitantes. Inumeros brasileiros trabalham ilegalmente nessa cidade, quase 50.000 .

Embora a aglomeração urbana seja muito alta, provavelmente esta quantidade de individuos não esta localizada somente na região metropolitana, pode até ser a maioria, mas não toda. Observa-se a intencionalidade dos militares em torná-la uma cidade com alta densidade populacional; para garantir a fixação do ecúmeno e seu crescimento, após a construção da Itaipu, Ciudad del Este foi declarada zona de livre comercio. Se tornou porisso mesmo a segunda maior cidade habitada do Paraguai. Ciudad del Leste em termos comparativos a Foz do Iguaçu é territorialmente cerca de seis vezes menor e possui uma densidade populacional cerca de nove vezes maior que Foz.

$\mathrm{Na}$ exposição acima de dados da cidade é expresso que ali é falada as seguintes línguas: castelhano, guarani e português. Além de notarmos claramente a "invasão brasileira", também é notado que não importa às autoridades governamentais brasileiras ou paraguaias, que há cerca de 50.000 brasileiros trabalhando ali, ilegalmente, sem contar ainda os brasiguaios no campo. Quando é de interesse do Estado, o mesmo não se importa em infringir as leis.

A cidade é responsável por $10 \%$ do PIB paraguaio que é de 150 bilhões de dólares é a terceira maior zona franca de comércio do mundo (após Miami e Hong Kong). Seus clientes são na maioria brasileiros, paraguaios e coreanos atraídos pelos baixos preços dos produtos ali vendidos. Além disso, a cidade é o quartel-general da Itaipu Binacional, juntamente com Foz do Iguaçu no Brasil. A venda de eletricidade da usina hidrelétrica de Itaipu para o Brasil gera mais de trezentos milhões de dólares de renda anual para o país.

Por conta dos dois fatores, zona franca e venda de eletricidade para a própria Itaipu, Cuidad del Leste atingiu um dos maiores PIBs paraguaios, senão for o maior. População, 
recursos financeiros e territorio faz a triade que Raffestin afirmou, de afirmação do Estado naquela específica região.

O turismo de Ciudad del Este é caracterizado pelo 'turismo de compras' porém existe atrativos que diversificam do tradicional objetivo da maioria dos turistas. A $20 \mathrm{~km}$ ao norte, em Hernandarias, se encontra a represa de Itaipú, que pode ser contemplado pelo lado paraguaio. O museu "El Mensú" foi o primeiro espaço destinado para reunir os mais diversos objetos que representam a história, cultura e tradição da cidade, tendo peças da época da fundação da cidade e utensílios de indígenas da região.

Se não é a zona franca com o turismo de compras é a Itaipu com o turismo tecnológico. Novamente a associação de que os indígenas são "coisa do passado", não do presente.

Portanto, os geopolíticos brasileiros realmente pensaram em tudo com o estabelecimento destas grandes obras de engenharia; o ecúmeno se estabeleceu, cresceu e se manteve, se apresentando Foz do Iguaçu juntamente com Ciudad del Leste dois centros urbanos de significativas proporções, tanto para o Paraguai, quanto para o Paraná, se constituindo em uma "barragem" de tamponamento no territorio, e, controle do mesmo, frente a qualquer pretensão expansionista proveniente de Las Misiones argentinas.

\section{b.2) Sobre a questão dos royalties pagos aos municípios lindeiros ao reservatório}

Sobre a questão dos royalties pagos pela Itaipu aos municípios lindeiros ao reservatório, por conta da perda de suas terras em razão da sua utilização para instalação do reservatório e assim gerar potencial hidráulico, assim é previsto pelo Tratado de Itaipu:

Artigo XV

O Anexo C contém as bases financeiras e de prestação dos serviços de eletricidade da ITAIPU.

Parágrafo $1^{\circ}$ - A ITAIPU pagará às Altas Partes Contratantes, em montantes iguais, "royalties" em razão da utilização do potencial hidráulico.

\footnotetext{
ANEXO C - AO TRATADO DE ITAIPU (Brasília, 26.04.1973) Bases Financeiras e de Prestação dos Serviços de Eletricidade da ITAIPU.

III - Custo do Serviço de Eletricidade

III.4 - O montante necessário para o pagamento dos "royalties" às Altas Partes Contratantes, calculado no equivalente de seiscentos e cinquenta dólares dos Estados Unidos da América por gigawatthora, gerado e medido na central elétrica. Esse montante não poderá ser inferior, anualmente, a dezoito milhões de dólares dos Estados Unidos da América, à razão da metade para cada Alta Parte
} 
Contratante. O pagamento dos "royalties" se realizará mensalmente, na moeda disponível pela ITAIPU. V - Outras Disposições

V.2 - O valor dos rendimentos sobre o capital, dos "royalties" do ressarcimento dos encargos e da remuneração mencionados, respectivamente, em III.1, III.4, III.5 e III.8, anteriores, será mantido constante de acordo com o estabelecido no § 4.o do Artigo XV do Tratado.

Peixoto ou a própria Itaipu ${ }^{142}$ explicam como isso se deu historicamente:

Embora seja responsável por quase um terço ${ }^{143}$ da energia elétrica consumida pelo Brasil, Itaipu tem apenas o sétimo maior reservatório de água (com 29 bilhões de metros cúbicos) das hidrelétricas brasileiras. Seu reservatório nasceu precisamente às 5 h45 do dia 13 de outubro de 1982, quando fecharam-se as 12 comportas da estrutura do canal de desvio para a formação do lago, cujas águas se espalharam por 135 mil hectares, com quase quatro vezes o tamanho da Baía da Guanabara. Em apenas 14 dias formou-se o reservatório. O lago abraçou 1.350 quilômetros quadrados, indo molhar as margens de 16 municípios brasileiros (Mundo Novo, no Mato Grosso do Sul, e Guairá, Terra Roxa, Mercedes, Marechal Cândido Rondon, Pato Bragado, Entre Rios do Oeste, São José das Palmeiras, Santa Helena, Diamante D’Oeste, Missal, Itaipulândia, Medianeira, São Miguel do Iguaçu,

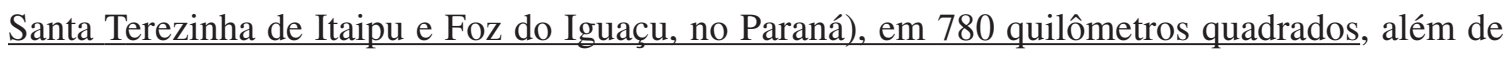
outros oito distritos e dois departamentos (que equivalem aos estados e municípios no Brasil), em

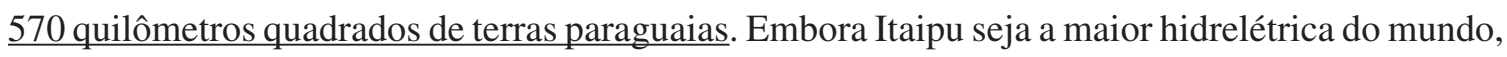
seu reservatório é apenas o sétimo em tamanho, se comparado com outros do Brasil.

Esclarecendo com relação ao Paraguai, na verdade, distrito corresponde a município e departamento corresponde a estado, foram trocadas as designações; assim como não foram citados quais são os distritos e os departamentos que foram atingidos pelo reservatório neste país. Assim o fazemos nós. De sul para o norte são eles: Ciudad del Este, Hernandarias, Santa Fé del Paraná, Mbaracayú e San Alberto, os cinco distritos localizados no Departamento de Alto Paraná; Saltos de Guairá e mais outros dois distritos que, apesar de procurados, não foi possível identificar ${ }^{144}$, os três distritos atingidos estão localizados no Departamento de Canindeyu.

\footnotetext{
$\overline{142}$ PEIXOTO Jr., Cesar. Usina Hidrelétrica de Itaipu (BRA) e Hoover Dam (EUA). Pesquisado em março de 2013.

${ }^{143} \mathrm{Na}$ verdade como já vimos menos de $1 / 4$ (um quarto). É já uma "síndrome" de querer ser sempre superlativo. ${ }^{144}$ O Departamento de Canindeyu possui 11 distritos: Corpus Christi; General Francisco Caballero Álvarez; Itanará; Katueté; La Paloma; Nueva Esperanza; Salto del Guairá ; Curuguaty; Villa Ygatimí; Ypejhú; Yasy Cañy; excluindo Salto de Guairá podem ser os dois distritos que faltam, dois dos 10 citados.
} 
Quanto a forma e a quem é pago, a própria Itaipu ${ }^{145}$ explica como são feitas as transações:

\section{Royalties}

Os governos brasileiro e paraguaio recebem uma compensação financeira, denominada royalties, pela utilização do potencial hidráulico do Rio Paraná para a produção de energia elétrica na Itaipu. Os chamados royalties são devidos mensalmente desde que a Itaipu começou a comercializar energia, em março de 1985, conforme o Anexo C do Tratado de Itaipu, assinado em 26 de abril de 1973. No Paraguai, os recursos dos royalties são repassados integralmente ao Ministério de Hacienda, que já recebeu mais de US\$ 4 bilhões. No Brasil, o Tesouro Nacional recebeu integralmente os royalties devidos desde o início da comercialização de energia da Itaipu. O repasse de royalties é proporcional à extensão de áreas submersas pelo lago. Desde 1985, a Itaipu pagou ao Brasil mais de US\$ 4,3 bilhões em royalties.

\section{Lei dos Royalties}

No Brasil, de acordo com a Lei dos Royalties, a distribuição da compensação financeira é feita da seguinte forma: $45 \%$ aos Estados, $45 \%$ aos municípios e 10\% para órgãos federais (Ministério do Meio Ambiente, Ministério de Minas e Energia e Fundo Nacional de Desenvolvimento Científico e Tecnológico). Do percentual de 45\%, destinados a atender aos municípios, $85 \%$ do valor repassado é distribuído proporcionalmente aos municípios lindeiros, ou seja, os diretamente atingidos pelo reservatório da usina. Os $15 \%$ restantes são distribuídos entre municípios indiretamente atingidos por reservatórios a montante da usina. A legislação dos royalties beneficiou 15 municípios paranaenses e o Governo do Paraná, os principais atingidos pelo alagamento de terras para a formação do reservatório e, também, o município de Mundo Novo no Estado do Mato Grosso do Sul. No Paraná, os municípios que têm direito aos royalties são: Santa Helena, Foz do Iguaçu, Itaipulândia, Diamante D’Oeste, Entre Rios do Oeste, Guaíra, Marechal Cândido Rondon, Medianeira, Mercedes, Missal, Pato Bragado, São José das Palmeiras, São Miguel do Iguaçu, Santa Terezinha de Itaipu e Terra Roxa. Também tem direito a um percentual sobre os royalties de Itaipu, o Ministério do Meio Ambiente, o Ministério de Minas e Energia, o Fundo Nacional de Desenvolvimento Científico e Tecnológico, além dos Estados e municípios indiretamente atingidos, localizados a montante (acima) da Usina de Itaipu. O repasse do valor a ser pago a título de royalties pela Itaipu Binacional, varia conforme a geração de energia destinada a comercialização em cada mês. No último dia 10 de janeiro de 2013, a Itaipu efetuou mais um repasse de royalties ao Tesouro Nacional, no valor de US\$ 9,7 milhões. Ao Governo do Paraná e aos 15 municípios paranaenses que fazem divisa com o reservatório da Itaipu, destinam-se o equivalente a US \$ 7,3 milhões.

\footnotetext{
$\overline{145}$ Obtido em http://www.itaipu.gov.br/responsabilidade/royalties. Publicado em ITAIPU BINACIONAL (http:/ /www.itaipu.gov.br). Início > Responsabilidade Social > Royalties. Criado em 23/03/2010 - 11:43. Pesquisado em 17/01/2012.
} 
Tabela 7.3. Repasse atual e acumulado de royalties de Itaipu aos 16 municipios lindeiros

\begin{tabular}{|c|c|c|}
\hline Município & Repasse atual & Acumulado \\
\hline Foz do Iguaçu & US\$ 715,6 mil & US\$272,4 milhões \\
\hline Santa Terezinha de Itaipu & US\$ 148,6 mil & US\$ 56,5 milhões \\
\hline São Miguel do Iguaçu & US\$ 322,3 mil & US\$ 135,1 milhões \\
\hline Itaipulândia & US\$ 637,2 mil & US\$230,1 milhões \\
\hline Medianeira & US\$ $4,1 \mathrm{mil}$ & US $\$ 1,5$ milhão \\
\hline Missal & US\$ $142,1 \mathrm{mil}$ & US\$ 54 milhões \\
\hline Santa Helena & US\$ 935,2 mil & US\$ 356 milhões \\
\hline Diamante do Oeste & US\$ 19,9 mil & US $\$ 7,5$ milhões \\
\hline São José das Palmeiras & US\$ $6,9 \mathrm{mil}$ & US $\$ 2,6$ milhões \\
\hline Marechal Cândido Rondon & US\$ 198,7 mil & US\$ 82,5 milhões \\
\hline Mercedes & US\$ 68,5 mil & US\$24,7 milhões \\
\hline Pato Bragado & US\$ 166,9 mil & US\$ 60,2 milhões \\
\hline Entre Rios do Oeste & US\$ 116,6 mil & US\$ 42,1 milhões \\
\hline Terra Roxa & US\$ 5,6 mil & US $\$ 2,1$ milhões \\
\hline Guaíra & US\$ 180,9 mil & US\$ 68,8 milhões \\
\hline Mundo Novo (MS) & US\$ 52,2 mil & US\$ 19,7 milhões \\
\hline
\end{tabular}

Fonte: http://www.itaipu.gov.br/responsabilidade/royalties. Janeiro.2012.

A distribuição dos royalties é proporcional à área alagada dos municípios, com percentuais definidos pela Agência Nacional de Energia Elétrica (Aneel).

Tabela 7.4. 16 municipios lindeiros e correspondente área alagada

\begin{tabular}{|l|c|}
\hline Município & Área alagada $\left(\mathbf{K m}^{2}\right)$ \\
\hline Diamante do Oeste & 5,62 \\
\hline Entre Rios do Oeste & 32,90 \\
\hline Foz do Iguaçu & 201,84 \\
\hline Guaíra & 51,01 \\
\hline Itaipulândia & 179,73 \\
\hline Marechal Cândido Rondon & 56,04 \\
\hline Medianeira & 1,16 \\
\hline Mercedes & 19,32 \\
\hline Missal & 40,07 \\
\hline Mundo Novo & 14,71 \\
\hline
\end{tabular}




\begin{tabular}{|l|c|}
\hline Pato Bragado & 47,07 \\
\hline Santa Helena & 263,76 \\
\hline Santa Terezinha de Itaipu & 41,90 \\
\hline São José das Palmeiras & 1,94 \\
\hline São Miguel do Iguaçu & 90,91 \\
\hline Terra Roxa & 1,58 \\
\hline
\end{tabular}

Fonte: http://www.itaipu.gov.br/responsabilidade/royalties. Janeiro.2012.

Os municípios em parte ou todo inundados pelo reservatório. A formação do reservatório da Itaipu implicou no desaparecimento de parte de municípios, assim como municípios inteiros; administrativamente houve por um lado fusão e por outro separação de partes de vários municípios, culminando inclusive na troca de nomes de vários deles, o que gerou ao final por parte dos analistas, grande confusão para se identificar os municípios que existiam e sua localização anterior e o que passou a existir na atualidade. Politicamente deve ter havido também vários efeitos, que devem ser analisados.

Implicou também em grande impacto sobre os moradores da área do futuro reservatório e no deslocamento de um contingente de população rural (a maioria) e urbana, de cerca de 60.000 pessoas nos dois países, de variados extratos sociais.

Implicou ainda em uma reconfiguração territorial, foram diminuídos 135.000 hectares em toda a região do Oeste paranaense, e nesta esteira, implicou também em uma reconfiguração populacional de toda a área, agora tendo que dividir uma área de terras bem menor, às margens do reservatório da Itaipu.

As antigas populações de variados extratos sociais que viviam no interior e nas margens do futuro reservatório, ao se retirar, vieram a ser substituídas por aquelas populações que mantiveram poder aquisitivo para permanecer junto ás margens do reservatório, nas ótimas, valorizadas e, portanto, caríssimas “terras roxas” do Paraná, agora diminuídas em 135.000 hectares e com uma população crescente, de forma muito célere, que chegava ao Paraná, para trabalhar na Itaipu. A oferta de terras diminuiu e a procura aumentou.

Neste rearranjo populacional ocorrido, "peneirados" conforme o poder aquisitivo, restaram estabelecidos na área do entorno do reservatório, assim nas terras readquiridas no Oeste do Paraná, somente "proprietários", aqueles que a Itaipu, na ordem de indenização, afirmou que indenizaria primeiro, os primeiros a escolher as terras e recomprar, a população "desejável” pelo poder de Estado e pelo poder econômico, aquela ligada ao capital da agroindústria, foi a que 
permaneceu; e uma outra população, os indenizados por último, os mal indenizados, os não indenizados, os pequenos agricultores familiares que foram espoliados pelos bancos, os posseiros, a maioria dos indígenas, os "indesejáveis" para o capital, tiveram que se retirar, dada a impossibilidade de adquirir terras com o dinheiro restante ou nenhum, naquela mesma região do Paraná, portanto, acabaram por ser afastados dali. Os primeiros são aqueles agroindustriais que plantam nessa região do Oeste do Paraná, soja, milho e trigo, a maioria para o mercado exportador; é o que se vê quando se viaja às margens do reservatório de norte a sul do Paraná. Pouca mão de obra, no seu lugar mecanização da agricultura. Os últimos são os indígenas Guarani e os denominados "brasiguaios", nos quais a construção da Itaipu contribuiu para engrossar a massa de brasileiros que se dirigiram ao Paraguai, ambos que nesta historia foram obrigados a atravessar a fronteira, assim como outros paranaenses que foram obrigados a se dirigir para outros diversos locais sejam eles urbanos ou rurais, afastados da região em que viviam, próximo ou no interior da área que veio a ser o reservatório.

Assim Itaipu retira da região população de vários extratos sociais; quem pode pagar pela terra valorizada do Paraná, acaba sendo recolocado na região, população capitalizada, uniformizada, passando juntos, Itaipu e proprietários de terras, acordados política e economicamente, a controlar toda a fronteira. Como isso se deu? É o que vamos ver a seguir.

Através de duas medidas: - dos royalties pagos aos municípios lindeiros ao reservatório; - e dos programas destinados somente a estes proprietários, cidadãos destes municípios lindeiros ao $\underline{\text { reservatório, ambos pagos pela Itaipu Binacional. Como diz o velho ditado "Quem paga a banda }}$ escolhe a música".

Itaipu passou a controlar os 15 municípios no Paraná lindeiros ao reservatório, e portanto, passou a controlar geopoliticamente também, toda área de fronteira do Paraná com o Paraguai; e controla também o único município mato grossense, Mundo Novo, também lindeiro ao reservatório, portanto, passou a controlar geopoliticamente uma parte da fronteira do Mato Grosso do Sul com o Paraguai.

Este controle dos municípios vizinhos ao reservatório e, portanto, também controle de toda área de fronteira entre os dois países passou a ser realizado através do pagamento de royalties pela Itaipu, a cada um destes municípios. Ao gerar grandes somas financeiras a cada um destes municípios, logicamente quem escolhe e determina quem serão os governos municipais é a influente Itaipu. É outra forma de se estabelecer uma espécie de "território federal" que necessita de controle na fronteira. 
Portanto, Itaipu veio também para estabelecer maior controle da fronteira, marcando de forma clara a divisa por meio de um largo reservatório de $1350 \mathrm{~km}^{2}$ e controle de todas as margens, os municípios lindeiros; Assim Itaipu marca a permanência do Estado brasileiro na região, como um "totem" que representa o Estado, exercendo o controle - além de sua própria finalidade inicial (geração de energia), com seus “tentáculos” de todos os municípios lindeiros, de forma semelhante aos antigos territórios federais, os quais se remetiam diretamente ao governo central; se antes aqueles exerciam o controle da fronteira através de medidas políticas que representavam quase que apenas um domínio jurídico da região, na atualidade passou a ser um controle mais efetivo, por meio de medidas econômicas, investimentos econômicos, que subordinam à hidrelétrica a política dos municípios, medidas geradas por Itaipu, o totem do Estado, que de forma ambígua "não é" ou "é” propriedade do Estado.

Com relação aos programas destinados somente a estes proprietários, cidadãos destes municípios lindeiros ao reservatório, vejamos:

Peixoto e/ou Itaipu ${ }^{146}$, assim afirmam:

\section{Algumas Razões para a Construção de Itaipu:}

1) O interesse comum em realizar o aproveitamento hidrelétrico dos recursos hídricos do Rio Paraná, pertencentes em Condomínio aos dois Países, desde e inclusive o Salto Grande de Sete Quedas ou Salto de Guaíra até a Foz do Rio Iguaçu;

2) Brasil e Paraguai desenvolveram tecnologias próprias de construção de grandes barragens;

3) O Brasil incorporou, ao seu setor elétrico, uma usina que hoje responde por quase um quarto de todo consumo nacional;

4) Já o Paraguai passou a contar com energia suficiente para o seu abastecimento durante as próximas décadas, sem que este país precise fazer outro investimento neste setor;

5) Além disso, a construção de Itaipu fomentou o desenvolvimento de toda a região de fronteira e municípios lindeiros ao Lago de Itaipu.

"1" é a razão relativa a necessidade de abastecimento de energia para o país (Brasil) e a necessidade geopolítica de controle do Brasil da região do Prata, tendo como meta também magnetizar o Paraguai para si;

“3” é a razão relativa a necessidade de abastecimento de energia elétrica, para o país, Brasil, poder atender ao processo de industrialização e sua demanda crescente;

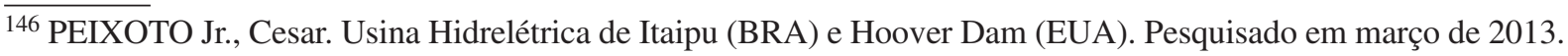


"5" é a razão relativa a necessidade de capturar politicamente os municípios lindeiros ao reservatório por meio da subvenção financeira destinada a eles, aos municípios e aos proprietários da região.

Itaipu afirmava oferecer aos municípios e aos proprietários dos municípios lindeiros uma serie de benesses, que, coincidência ou não, a partir de nossos laudos antropológicos iniciados em 2001, e, finalizados em 2005, sobre a questão indígena aqui relatada, e com as cobranças do MMA quanto à empresa providenciar seu Licenciamento Ambiental, não realizado até hoje, Itaipu, mais do que depressa a partir de 2003, mudou seu discurso, aparentemente diluindo os programas destinados aos municípios e proprietários lindeiros ao reservatório, agora "destinados a toda a comunidade regional e ao meio ambiente".

Peixoto e/ou Itaipu ${ }^{147}$, assim afirmam:

49. Meio Ambiente:

49.1. Programa Cultivando Água Boa

O Programa Cultivando Água Boa é um marco na história da gestão ambiental da Itaipu Binacional, que ampliou o conceito anterior de atendimento aos 16 municípios lindeiros ao reservatório da usina para formar parcerias e trabalhar com os 29 municípios que compõem a Bacia Hidrográfica do Paraná I. As ações do Cultivando Água Boa envolvem parcerias institucionais, não governamentais, com setores dos movimentos sociais, com agricultores, pescadores, catadores, suinocultores, assen-

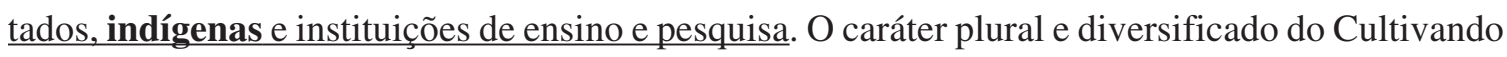
Água Boa garante a gestão compartilhada dos cuidados com o meio ambiente e com o ser humano e aponta para um caminho de esperança na construção coletiva de um lugar ambientalmente correto para se viver (grifos nossos).

50. Flora

A Itaipu Binacional protege e mantém preservada uma floresta de mais 100 mil hectares - área equivalente a mais da metade do Parque Nacional do Iguaçu, que tem 185 mil hectares. Desses 100 mil hectares, 40 mil correspondem a áreas ocupadas por duas reservas e cinco refúgios biológicos localizados ao redor do Lago de Itaipu. Os outros 60 mil hectares correspondem à área ocupada pela Faixa de Proteção, que circunda todo o Lago de Itaipu para reduzir o assoreamento, a erosão e a poluição do reservatório. A faixa tem uma largura média de 217 metros e extensão de 2.900 quilômetros - distância superior à que separa São Paulo de Manaus. Para formar a floresta de 100 mil hectares, Itaipu plantou mais de 2 milhões de mudas de árvores ao longo dos últimos 19 anos, no maior programa de reflorestamento do mundo já feito por uma hidrelétrica.

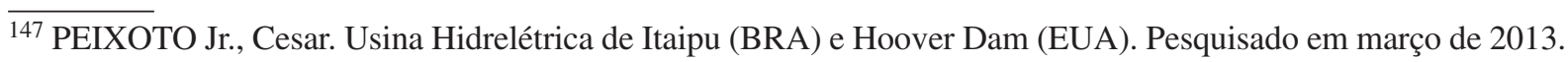




\section{Fauna}

No Refúgio Biológico Bela Vista, ao lado da barragem, a Itaipu desenvolve um programa de reprodução de animais silvestres em cativeiro para repovoar as áreas protegidas. A Itaipu Binacional aderiu à campanha internacional do Programa das Nações Unidas para o Meio Ambiente (PNUMA) de plantar um bilhão de árvores em todo o mundo até o final de 2007. A empresa, juntamente com seus parceiros, contribuiu com o plantio de 500 mil mudas na faixa de proteção do reservatório, nos corredores de biodiversidade (matas que interligam áreas de proteção ambiental) e nas matas ciliares das microbacias da região. "O plantio de árvores em larga escala é uma necessidade urgente frente aos efeitos do desmatamento e do aquecimento global”, afirmou o diretor de Coordenação da Itaipu, Nelton Friedrich.

Roseira (2006), em seu item “5.2. Impactos econômicos do lago de Itaipu no Oeste Paranaense", cita que os reflexos da hidrelétrica de Itaipu reconfigurou toda a mesorregião Oeste do Paraná ... dragou municípios inteiros, centenas de propriedades rurais foram desapropriadas e milhares de moradores foram deslocados para outras áreas. Em seguida Roseira (2006) afirma a respeito do discurso ambiental da Itaipu:

Tendo em vista a grande polêmica sobre os impactos ambientais do represamento, a Itaipu teve uma grande preocupação em criar sinais positivos do empreendimento. A potencialização do turismo na região foi um dos meios pelos quais o Paraná passou a forjar um discurso de modernidade à região. Este discurso foi baseado numa concepção de sustentabilidade, energia limpa, proteção do meio ambiente e até mesmo da formação de um santuário ecológico (ROSEIRA: 2006:76) (grifos nossos).

Roseira aponta também, duas transformações ocorridas no Oeste do Paraná, no período próximo da instalação do reservatório de Itaipu: uma se refere a modernização agrícola e a concentração fundiária e a outra ao desenvolvimento do turismo, duas atividades desenvolvidas pelos proprietários dos municípios, apoiados pela Itaipu na região:

Formado nos anos de modernização agrícola do Oeste Paranaense, o $\underline{\operatorname{lago}}^{148}$ foi um elemento importante na concentração urbana da população (ROSEIRA:2006:73).

Roseira citando em seguida publicação do IPARDES ${ }^{149}$, descreve:

A partir da década de 70 a região integra-se rapidamente aos movimentos mais amplos de expansão da agricultura moderna que se instaura no Paraná, marcado pela introdução maciça, no campo, de

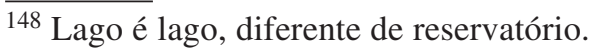

${ }^{149}$ IPARDES. Leituras Regionais: Messoregião Geografica Oeste Paranaense, 2003, p. 69.
} 
avançadas tecnologias de cultivo, de substituição de culturas alimentares pela produção de commodities e de alterações radicais nas relações de trabalho, todos estes elementos altamente poupadores de mão de obra. Desse modo, a região, rapidamente, experimentou um processo intenso de urbanização, estimulados ainda mais pelos efeitos da construção do megaprojeto da Usina Hidrelétrica de Itaipu (ROSEIRA: 2006:73) (grifos nossos).

Voltando ao texto do próprio Roseira:

A modernização agrícola transformaria inteiramente a funcionalidade da região. $\underline{\text { Se as políticas de }}$ colonização caracterizaram o Oeste Paranaense como uma grande área agrícola de produção familiar, a modernização de sua agricultura a partir da década de 70 inscreveu a região no bojo das principais exportações paranaenses. A concomitante concentração agrária criaria um fluxo migratório em direção aos principais centros urbanos (ROSEIRA:2006:73) (grifos nossos).

Roseira citando em seguida novamente publicação do IPARDES ${ }^{150}$, descreve:

Com a intensificação da modernização da produção agrícola apoiada na constituição de um sistema nacional de credito rural, nos anos 60, a região, desde então, vem sofrendo um contínuo processo de $\underline{\text { reordenamento fundiário, }}$ com progressiva redução do numero de estabelecimentos, concentrada naqueles com área inferior a 10 ha, mas que se estende até o estrato de 50 a 100 ha. Entre 1985 a 1995, a redução foi de 13,3 mil estabelecimentos, $19 \%$ do total. Forma produtores que, de modo geral, não conseguiram se adequar às novas exigências tecnológicas - mecanização, insumos quími$\underline{\text { cos e sementes melhoradas -, por incapacidade financeira, ou por não alcançarem a escala mínima }}$ exigida pelo novo padrão (ROSEIRA: 2006:73) (grifos nossos).

Ou seja, na verdade, as formas de produção essencialmente "capitalistas" englobaram as terras e expulsaram parte do campesinato da terra.

Roseira demonstra ser ufanista a este modelo modernizante da agricultura, pouco critico ao contexto, quando afirma:

A concentração fundiária atrelada à modernização trouxe um grande aumento na taxa de produção agrícola dos municípios. De 5000 ha em 1960, o cultivo de soja evoluiu para 172.000 ha em 1969. Forma-se o que é chamado o complexo da soja, por onde atrela grande parte do sistema produtivo da região (ROSEIRA: 2006:76) (grifos nossos).

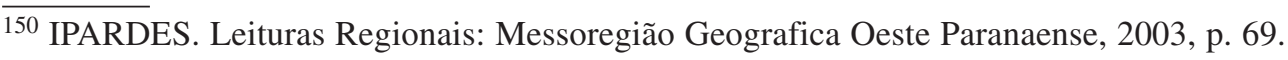


Quanto ao turismo na região do reservatório Roseira afirma:

Mas os impactos da formação do lago de Itaipu, vão muito além da concentração urbana da população, extinção de municípios e o desaparecimento de riquezas naturais. Toda a área as margens do

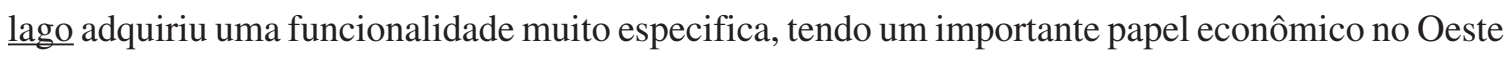
Paranaense. Os principais municípios atingidos pelo Lago de Itaipu foram (...); O turismo passa a ser uma maneira de dinamizar a economia desses municípios às margens da represa, pois considerando a amplitude de toda a região atingida pelo lago, as atividades turísticas tornaram-se a base econômica de uma extensa área do Oeste Paranaense. (...) uma nova regionalidade instituída pelo Lago. Fatores de semelhança econômica, como os Royalties e as atividades agroindustriais, fizeram com que os municípios se articulassem em conjunto tendo em vista fins comuns. Foi tendo em consideração esta nova funcionalidade que a região passou a se organizar, buscando em conjunto ações políticas e econômicas que viessem a desenvolver o seu potencial turístico. A Associação dos Municípios do Oeste do Paraná - AMOP, na busca de potencializar o turismo, agiu no sentido de buscar fomento para esta estruturação e para a divulgação, tendo em vista uma profissionalização das atividades ligadas as suas características históricas, naturais e culturais.

Novamente Roseira encerra com seu ufanismo, se referindo ao novo contexto vivido no Oeste do Paraná:

O turismo adquire um papel fundamental na definição da regionalidade. Junto à modernização agrícola, concentração fundiária e urbanização, o turismo dos municípios às margens do Lago definiu a nova "cara" do Oeste Paranaense. Dentro desta nova conjuntura, a construção da Hidrelétrica de Itaipu teve um papel capital, projetando a região tanto em uma escala nacional quanto internacional (ROSEIRA:2006:76-7) (grifos nossos).

Assim royalties para os municípios do Oeste do Paraná, mecanização da agricultura, insumos químicos com pesticidas que contaminam plantas, terras e águas, sementes transgênicas, pesticida, concentração fundiária e expulsão dos camponeses, urbanização devido a chegada de enorme população para trabalhar na Itaipu somada a migração rural/urbana, e um turismo para as novas elites fundadas, são o verdadeiro resultado atingido.

O que se via antigamente pelas estradas do Oeste do Paraná, eram c amponeses, que plantavam uma diversidade de produtos produzindo alimentos para o país; hoje é uma grande extensão monótona de monocultura para exportação, que se alterna conforme o decorrer do ano entre a soja, o milho e o trigo. Não se vê mais pessoas trabalhando na terra, mas sim, um maquinário aqui 
outro ali. No reservatório de Itaipu se vê uns poucos rapazes com seus possantes Jet skis ou velejando. Tudo que se vê se transformou em mercadoria e para uma nova elite paranaense.

Vejamos o discurso "politicamente correto" da Itaipu ${ }^{151}$ a respeito de sua gestão modernizada, após 2003:

\section{GESTÃO}

A atuação socioambiental é compromisso da Itaipu. A partir da ampliação da missão da empresa, ocorrida em 2003, a Itaipu implementou programas que beneficiam a comunidade, o meio ambiente e o público interno. Em 2005, a empresa investiu US\$ 18 milhões em ações sociais e ambientais no Brasil e no Paraguai, cerca de 50\% para cada país. O mesmo valor destinado a 2006. Os programas desenvolvidos abrangem as áreas de educação, saúde, combate à exploração sexual de crianças e adolescentes, combate à violência, estímulo à geração de renda, incentivo à equidade de gênero e ainda incentivo ao turismo e ao voluntariado. Em relação ao meio ambiente, os temas incluem educação ambiental, pesca, plantas medicinais, agricultura familiar e orgânica, entre outros. A ação da empresa busca melhorar a qualidade de vida dos moradores da região da sua área de atuação. Direta e indiretamente, aproximadamente 1,5 milhão de habitantes são beneficiados pelas ações socialmente responsáveis da Itaipu. No Paraguai, desde a ampliação da missão da empresa, as iniciativas socioambientais estão presentes em todas as regiões do país, não somente na zona de influência da usina. Em 2005, os governos brasileiro e paraguaio firmaram acordo reconhecendo que a responsabilidade social e o cuidado com o meio ambiente são atividades permanentes da empresa. Cartas de igual teor foram trocadas pelos ministérios das Relações Exteriores de Brasil e Paraguai, em 31 de março. Os programas socioambientais da Itaipu integram o Plano Empresarial, que está estruturado por programas e ações. Tudo está vinculado aos objetivos estratégicos e às políticas e diretrizes da empresa. Parte dos projetos conta com parceiros que também investem recursos financeiros, enquanto outros são subsidiados integralmente pela binacional. Também em 2005, foi criada na margem brasileira a Coordenadoria de Responsabilidade Socioambiental e instalado o Comitê Gestor de Responsabilidade Socioambiental, que são responsáveis pelas diretrizes socioambientais da empresa. A Itaipu não concentra a execução de programas na Coordenadoria, mas os mantém distribuídos em todas as diretorias. Desta forma, a empresa busca o envolvimento dos diferentes setores com o tema e privilegia a matricialidade. A Coordenadoria também é responsável pelo acompanhamento e orientação dos projetos realizados, banco de dados, publicação do

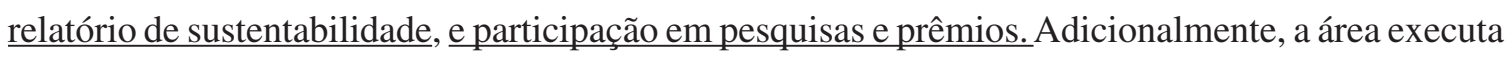
cinco diferentes programas: Força Voluntária, Incentivo à Equidade de Gênero, Rede Cidadã, Pro-

${ }^{151}$ Obtido em http://www.itaipu.gov.br/responsabilidade/gestao. Pesquisado em maio de 2013. 
grama de Proteção à Criança e ao Adolescente e Energia Solidária. Ao Comitê Gestor cabe o acompanhamento dos programas, a definição de políticas e o direcionamento estratégico da responsabilidade socioambiental da empresa. O Comitê é formado por representantes das diretorias brasileiras da binacional, além de representantes dos chamados eixos estruturantes dos programas desenvolvidos: meio ambiente, comunidade, público interno e políticas públicas.

Com toda essa recente infraestrutura, vejamos o tratamento dado aos indígenas Guarani do Brasil, veiculado pelo site da Itaipu. Façamos uma analise de texto primeiramente quanto as "Missões Jesuíticas"152:

\section{MISSÕES JESUÍTICAS}

O que é? Ruínas históricas construídas por religiosos da Ordem dos Jesuítas no Brasil, Argentina, Paraguai e Uruguai.

O que fazer? Conhecer as ruínas e igrejas das Missões Jesuíticas revela parte do esplendor da arte europeia levada para o Cone Sul pelos padres jesuítas. Ocupavam as reduções jesuíticas os índios guaranis, atraídos pela pregação do Evangelho. As missões eram autênticas cidades instaladas na selva, entre os séculos XVII e XVIII. Além da igreja, que era o centro de tudo, havia hospital, asilo, escolas, casa e comida, oficinas e até pequenas indústrias. Foi nas reduções que se começou a industrializar o ferro, a produzir os primeiros tecidos e a criação de gado no continente. $\underline{\text { Só no }}$ Paraguai e na Argentina, mais de 100 mil guaranis teriam sido reduzidos às missões. No final do século XVIII, depois de grandes conflitos, com milhares de mortos, especialmente de índios, Portugal e Espanha expulsaram os jesuítas. Os índios acabaram exterminados, enquanto as reduções perderam parte da riqueza de antigamente ao longo de batalhas.

Quando? Ao longo do ano, agências de turismo organizam pacotes partindo de Foz do Iguaçu. $\underline{\mathrm{O}}$

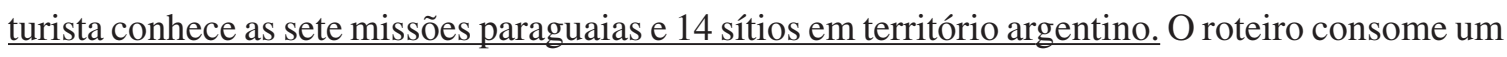
dia inteiro de viagem.

Onde? Das 30 reduções jesuíticas identificadas no Cone Sul, sete estão no Leste do Paraguai e 14 no Norte da Argentina, bem próximas à fronteira com Foz do Iguaçu, dentro de um raio de $300 \mathrm{~km}$.

Assim as ruínas históricas construídas por religiosos da Ordem dos Jesuítas no $\underline{\text { Brasil }}$, apesar de citadas no início, no título, em seguida desaparecem do texto; Não citam os milhares de Guarani que foram reduzidos nas missões do Guairá ou Guaíra no Paraná/Brasil. Não citam sequer a existência de Guaíra hoje como espaço que conteve as Missões no Brasil, o local apesar

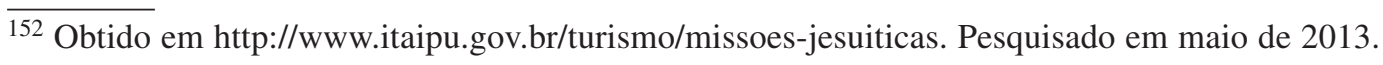


de possuir inúmeros resquícios arquelógicos para tanto, foi o único que não foi recuperado, será porque? Por este site da Itaipu "Os índios acabaram exterminados"; se fosse realmente assim, como explicar a existência dos Guarani da atualidade? Como vimos anteriormente grande parte foi exterminado, outra parte fugiu para as matas do rio Paraná, outros desceram para o Tape no Rio Grande do Sul. Por Itaipu eles foram todos exterminados naquela época passada, fora do território brasileiro, o que faz o desavisado concluir que "inexistiram" povos Guarani no Brasil. Façamos uma analise de texto sobre o "Museu da terra Guarani""153 de Itaipu:

\section{MUSEU DA TERRA GUARANI}

O que é? O Museu da Terra Guarani resgata os 10 mil anos de ocupação e cultura guarani na margem paraguaia da Itaipu.

O que fazer? Conhecer a fundo a milenar cultura guarani, rica em diversidade e ainda viva na margem paraguaia da Itaipu. O Museu da Terra Guarani ilustra os 10 mil anos de história dos povos indígenas da região. Ao longo dos séculos, estas populações mantiveram suas raízes, inclusive o idioma, o guarani, língua oficial do Paraguai. O acervo inclui um interessante arquivo audiovisual em que os indígenas falam de sua visão de mundo. O Museu da Terra Guarani é uma viagem também pela memória do Rio Paraná e sua natureza.

Quando? De terça-feira a sábado, das $8 \mathrm{~h}$ às $11 \mathrm{~h} 30$ e das $14 \mathrm{~h} 30$ às $17 \mathrm{~h}$, aos domingos das $8 \mathrm{~h}$ às 11h30. Às segundas fecha para manutenção.

Quanto? Entrada gratuita.

Onde? Rodovia que liga Ciudad Presidente Franco a Saltos del Guairá, a 11,5 km de Ciudad del Este - Hernandarias (Paraguai).

Ou seja, a cultura Guarani por este site só existiu na margem paraguaia, não no Brasil. Quanto à "Conhecer a fundo a milenar cultura guarani, rica em diversidade e ainda viva na margem paraguaia da Itaipu”, ou seja, a mensagem afirma por negação que os Guarani não existem no Brasil, assim Oco’y, Ãnetete, e outras varias comunidades guarani da região de Guaíra, por Itaipu não “existem” no Brasil. Quanto ao Paraguai, elas segundo Itaipu “ainda vivem”, ou seja, uma reminiscência, um resto por acabar, na visão de Itaipu. A língua é daquele país, então conclui a Itaipu, “os índios só podem ser daquelas terras".

Atenção para as únicas fotos em que aparecem no site dos indivíduos Guarani: fotos 3, 5 e 10, (ver site) os indivíduos são apresentados em branco e preto como se fossem fotos bem

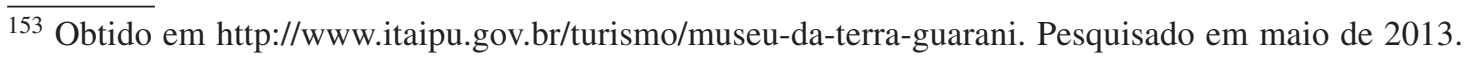


antigas "de um passado", e o restante de todas as fotos, inclusive aquelas próprias 3, 5 e 10, na frente dos indivíduos, aparecem objetos da cultura material feitos pelos Guarani de hoje, cestos, balaios etc que são coloridos, como se Itaipu tivesse "preservado" estes materiais, supostamente também "antigos". O marketing é monstruoso.

Façamos uma analise de texto sobre o "Apoio Integral a Campesinos e Indígenas"154 da Itaipu:

\begin{abstract}
APOIO INTEGRAL A CAMPESINOS E INDÍGENAS
A Itaipu desenvolve um Plano de Apoio Integral a famílias campesinas e indígenas de baixa renda do $\underline{\text { Paraguai, }}$ com o intuito de melhorar a produtividade agropecuária, incentivar a diversificação da produção e garantir a alimentação destas populações. A Itaipu já contribuiu com a preparação de 28 mil hectares de solo para cultivo e adquiriu, em conjunto com municípios dos Departamentos de Caaguazú e San Pedro, 20 tratores agrícolas. O Plano beneficiou ainda 34 mil famílias com a entrega de 202 mil kits de sementes, 850 galinheiros, 138 mil frangos, 600 cabras, 3,2 mil cerdos, 279 mil alevinos, 278 mil quilos de balanceados, além da instalação de 280 estanques, 100 tanquesredes, 950 caixas para apicultura, 3 máquinas para a retirada da polpa de frutas com câmeras frigoríficas e 13 fábricas de amido artesanal.
\end{abstract}

Assim faz parte da política estratégica da empresa incentivar algumas atividades (que de minha parte considero sempre duvidosas, dada a experiência aqui obtida) do lado paraguaio (e não no Brasil), na esperança que todos os Guarani para ali se encaminhem, essa é a lógica da empresa. Tendo visitado há poucos anos atrás o Oco’y, continua ainda de forma mais triste do que encontrei entre 2001 e 2005. Os colonos invadiram ainda mais o território indígena concentrando os Guarani em uma parca terra de dimensões menores ainda entre o reservatório e os próprios colonos. Em termos ambientais, infelizmente é rara a vegetação, eles que são indígenas acostumados a viverem em meio a matas altas, usufruindo da diversidade vegetal. Elas foram substituídas pelos pequenos espaços junto ás casas para o plantio de gêneros alimentícios que não são suficientes para abastecer as famílias. Itaipu fornece aos Guarani apenas cestas básicas. Elas significam uma moeda de troca em que os indígenas são ameaçados, diante de qualquer discórdia, de serem retiradas.

Por todo o acontecido, se estivéssemos num país onde se cumpre a lei, onde se respeita o ser humano, os indígenas Guarani de todas as aldeias que foram expulsos, deveriam na verdade, terem

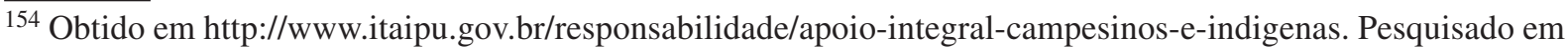
maio de 2013.
} 
repostas as terras que perderam e/ou receberem royalties, pelas terras perdidas e pelos danos advindos de todo este contexto, anos sem terra, interrupção de conhecimentos socioambientais que poderiam ter sido repassados para as novas gerações, inúmeras privações cometidas.

O conjunto destas informações demonstram o quanto Itaipu vêm forjando ideologicamente uma situação, como se não existissem indígenas Guarani no Brasil, sendo de fato o que ela pretende com a política que conduz. Informa ao publico que visita este território informações falsas, desinformando na verdade sobre a realidade existente.

\section{b3) Os brasiguaios}

No contexto do fenômeno denominado "Milagre Brasileiro" havia no Brasil, aliança dos militares com tecnocratas e com o grande latifúndio, onde o lema nos anos 70 passou a ser "exportar é o que importa", visando com as exportações pagar a dívida externa contraída pelo país, para formar a infraestrutura da industrialização.

Luis Carlos Batista, em dissertação de mestrado denominada "Brasiguaios na fronteira: caminhos e lutas pela liberdade" 155 , afirma que nesse período o governo brasileiro criou um novo modelo agrícola, onde se industrializou também o meio rural, aliado a gradativa concentração fundiária das terras nas mãos de poucos, processo que já vinha acontecendo desde os anos 60, por meio muitas vezes da grilagem das terras pura e simples, da mecanização da agricultura que expulsou a mão de obra do campo, criando dessa forma grandes fazendas, fundamentalmente de plantio de soja e trigo para exportação, produção atrelada ao movimento do agronegócio, voltado aos interesses de acumulação capitalista. Uma economia no campo de estilo industrial, dominada pelas multinacionais que promoveram a imposição de modificações nas relações de produção e trabalho. A política dos organismos de planejamento, estruturada pela ditadura militar, serviu para dar o sentido à colonização brasileira voltada aos interesses da constituição efetiva do domínio do modo de produção capitalista no país (BATISTA: 1990:18).

Pequenos proprietários, meeiros, posseiros, milhares de pequenos lavradores brasileiros, desde as décadas de 60 e 70, foram sendo expulsos de suas terras, obrigados a migrar para poder continuar sobrevivendo da lavoura. Famílias que produziam alimentos e não dependiam de outros trabalhos para sobreviver são obrigados a procurar outras terras ou outros meios de sobrevivência fora da lavoura. A presença do camponês como mão de obra ou mesmo como pequeno

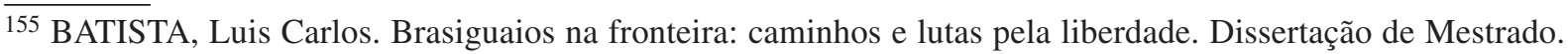
Departamento de Geografia. São Paulo: FFLCH/USP, 1990. 178 p. 
produtor independente foi sendo dispensada. No Brasil não tinham mais condições de trabalho nas terras das quais foram sendo gradativamente expulsos. A terra para o camponês é importante enquanto um modo de vida e, para o capitalista é um modo de produzir/extrair riqueza e lucro (BATISTA: 1990:6). A partir de 1950 a cafeicultura avança nas terras roxas do Paraná até atingir a década de 70, quando a modernização da agricultura e o modelo econômico agroexportador favorecem os empresários que empurram os colonos paranaenses até o Paraguai (BATISTA: 1990:7). Foram muitas vezes utilizados expedientes do tipo: o governo abria projetos de colonização que atraia camponeses para trabalhar na derrubada das matas, preparo das terras, plantações dos cafezais e construção de suas moradias em seus lotes; o governo não garantia os títulos definitivos aos colonos; em seguida o próprio governo renegociava as terras do projeto e despejava os camponeses; autoridades do governo não raro grilavam as terras; jagunços eram postos no encalço dos camponeses, forçando-os a se retirar das terras; nesse processo a terra já estava então "amansada" pelos camponeses para utilização do latifúndio, esse tipo de conduta aconteceu diversas vezes.

Segundo Batista em 1979 o Serviço Federal de Processamento de Dados/SERPRO demonstrou que 52 mil imóveis rurais no Brasil eram de estrangeiros, correspondendo à área em torno de 9,7 milhões de hectares, terras nas quais atingiram inclusive reservas indígenas e em 19 municípios desrespeitou-se o limite de $25 \%$ de ocupação de terras por estrangeiros.

Enquanto no Brasil, investimentos estrangeiros absorvem áreas enormes e as atividades agroindustriais tomam conta da política agrícola nacional, o censo de 1970 registrou que 1.007.167 habitantes, predominantemente camponeses, foram expropriados das terras no Brasil. A maioria dos trabalhadores rurais atravessaram a fronteira para a Argentina, Uruguai, Paraguai, Bolívia e Venezuela na tentativa de conseguir terra para trabalhar. São $15.700 \mathrm{Kms}$ de fronteira do Brasil com a America do Sul a maior parte delas atingidas pelo expansionismo brasileiro (BATISTA: 1990:19).

Os chamados "brasiguaios" representam fluxos migratórios de agricultores que vieram a maioria do Paraná e se instalaram no leste paraguaio, espoliados de suas terras originais por grilagem realizada pelos poderosos da região paranaense, inclusive pelo seu próprio governador Moises Lupion, a partir dos anos 50, o campeão de grilagem de terras naquele estado. Propaganda das grandes colonizadoras anunciavam terras férteis, abundantes e baratas estimulando os pequenos agricultores do Oeste do Paraná a viver no Leste paraguaio, o que significou para a maioria, "solução" que viria a ser um "pesadelo". 
O processo de modernização da agricultura, principalmente no Paraná, acelerou sobremaneira a colonização da fronteira paraguaia por brasiguaios. A população paranaense, principalmente da região norte, diminuiu em 1.268.565 habitantes entre 1970 e 80 . No lugar dos homens entrou a maquina. Em 1970 existiam 18.619 tratores em 1980 registravam 79.682 . Entre 1970 e 75 os pequenos proprietários foram expropriados, obrigando-se a vender suas propriedades ou subordinan-

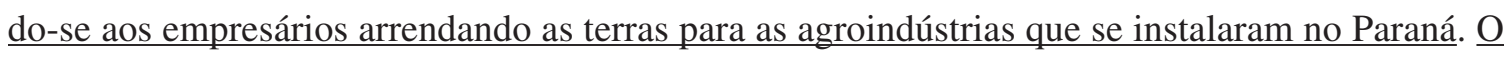
$\underline{\text { IBGE registrou uma diminuição de } 76.515 \text { pequenas propriedades no Paraná, exigindo do governo }}$ uma política que atendesse à ocupação de áreas novas (BATISTA: 1990:25-6).

Batista assim define os brasiguaios:

Os brasiguaios são conhecidos como trabalhadores humildes que, sem terra para trabalhar no Brasil, foram expropriados/expatriados pelo processo de modernização da agricultura e vivem no Paraguai. Constituem $80 \%$ da população paraguaia na fronteira, são posseiros, meeiros, arrendatários, agregados, boias-frias e parceiros que moram nas colônias (...) (BATISTA: 1990:1).

Batista descreve as colônias e mais a frente demonstra em mapa a ocupação dos brasiguaios em 1990 (a tese é desta data). Eles significam a maioria da população em toda a fronteira leste do Paraguai. O caso mais marcante ocorreu nos 1339 kms de fronteira com o Paraguai, onde vivem ao longo de $100 \mathrm{kms}, 500$ mil brasiguaios, representando $15 \%$ dos 3 milhões de habitantes do Paraguai (BATISTA: 1990:20) (grifos nossos).

No Paraguai encontraram matas fechadas por abrir e fazê-las produzir, terras onde viviam a maioria das comunidades Guarani, o que provavelmente gerou conflitos entre os dois grupos sociais. Batista não afirmou nada sobre esse conflito, mas em alguns momentos de sua dissertação, se refere ao leste paraguaio como sendo predominantemente ocupado pelos "índios", e como sabemos ali são terras de ocupação tradicional Guarani. Os camponeses abriram terras, "amansaram as terras como afirmam", desmataram, destocaram, produziram, o que levou anos a fio, passando a serem responsáveis pela maioria da produção agrícola da fronteira leste paraguaia. Abriram estradas, escolas, cadeias públicas, postos fiscais, vilas, povoados ocupando assim as terras. Alguns poucos conseguiram comprar terras do Instituto do Bienestar Rural/IBR, colonizadora oficial do Paraguai.

A miséria e a repressão foram a tônica no Paraguai. Comissários e chefes de Departamento eram/são ao mesmo tempo, Juízes, Delegados, Prefeitos e Administradores, e em nome de serem 


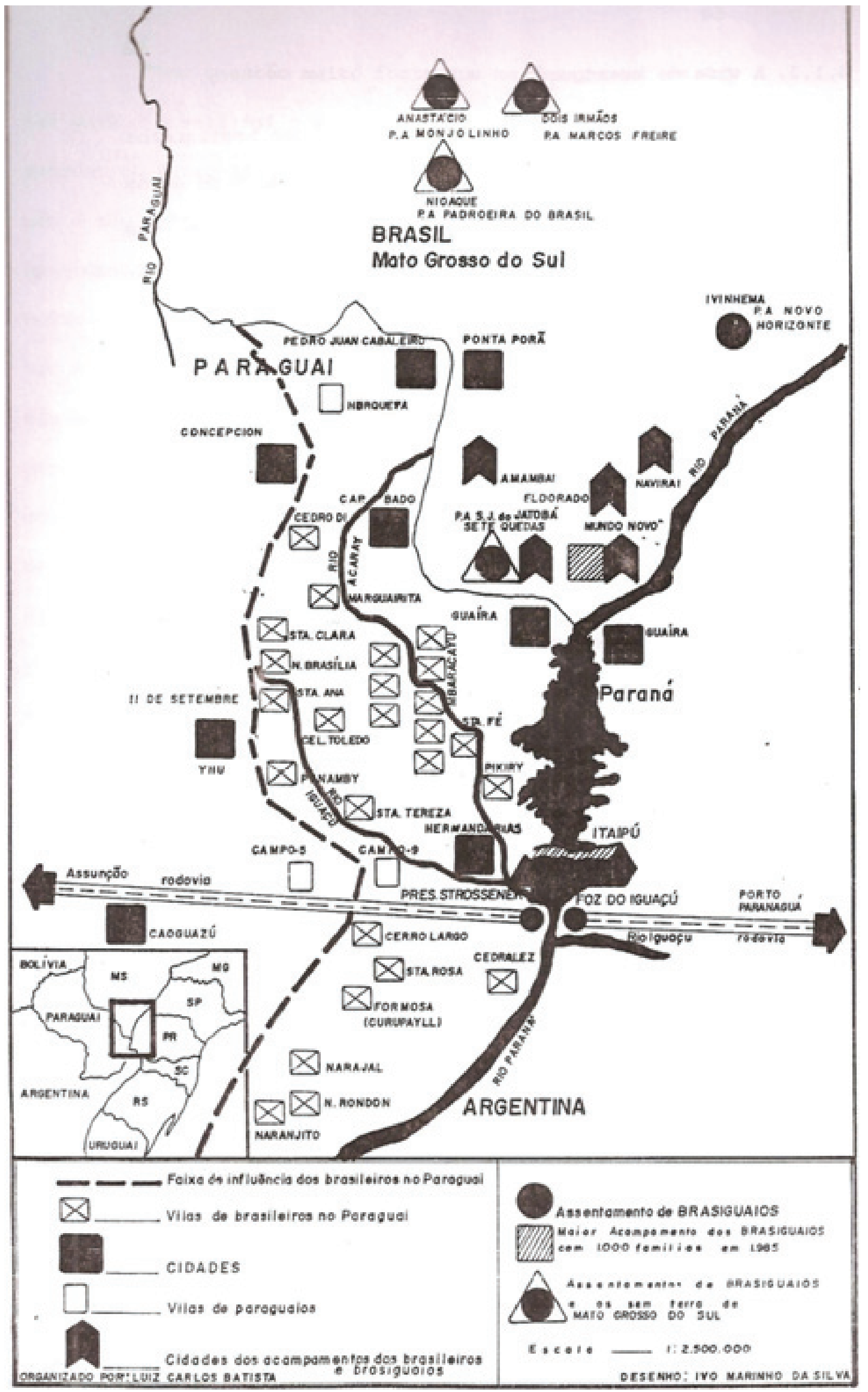

Figura 109. Faixa de influência dos brasileiros no Paraguai.

Fonte: Luis Carlos Batista. Brasiguaios na fronteira: caminhos e lutas pela liberdade. 1990, p 91. 
"autoridades" subtraem arbitrariamente alimentos, bens materiais, recursos financeiros dos lavradores. Os lavradores se encontravam sem incentivo, sem garantia, o custo da produção era alto, além do pouco comercio que alcançava. Eram obrigados a repartir com a polícia que invadia as terras e levavam o que queriam e eram assaltados com "taxas" repetidas ou confisco dos bens. Eram proibidos de se reunir. A maioria era arrendatário, meeiro ou boia-fria, e todos tinham medo, pavor da espoliação seja de alimentos, seja cobrando taxas de "permiso", documento de autorização para permanecer no Paraguai; deviam pagar também a "libreta", imposto para a conservação das estradas, escolas, postos fiscais que foram construídos e conservados por eles próprios. Casos de prisões sem real motivo, sem julgamento, perseguições, espancamentos, torturas e mortes eram comuns. A corrupção era/é generalizada.

Batista comenta a respeito da construção das rodovias que ligam Assunção à Paranaguá e a Ponte da Amizade e sua resultante política: Uma amizade que permitiu a dependência do Paraguai em relação ao Brasil, possibilitando aumentar a presença brasileira naquele país, enquanto os argentinos concediam asilo político aos democratas expulsos do Paraguai (BATISTA: 1990:45).

Batista explora o contexto político da época entre os dois países:

O governo brasileiro preferiu aliar-se aos colorados que, através de um golpe militar liderado por Stroessner, garantiram a influencia brasileira naquele país. O Paraguai mantinha no cárcere 115 prisioneiros políticos, enquanto 500.000 paraguaios viviam principalmente como asilados políticos na Argentina. Além dos opositores que estavam no Paraguai sofrendo torturas e péssimas condições de vida. Utilizando-se taticamente dessa política de aproximação com o Paraguai, o governo brasileiro exercitava uma manobra expansionista inteligente sobre o Paraguai, impondo-se pela dimensão e pressão militar. Utilizando sua presença, facilitada pela Ponte da Amizade que permitia o escoamento da produção paraguaia para exportação via território brasileiro e o povoamento rápido da fronteira por 500.000 brasiguaios que se transformaram no sustentáculo da ditadura. Stroessner substituiu os opositores por seus aliados usando o comercio, turismo, imigração, integração rodoviária e ferroviária, facilitando a dominação brasileira no Paraguai e garantindo a estabilidade para seu governo.

As facilidades para colonizar o Paraguai pelos brasileiros vincularam-se a um Tratado de Amizade e Cooperação Econômica, assinado pelos presidentes Geisel e Stroessner em 12.1975. Este tratado previa a colaboração brasileira no campo tecnológico e da segurança continental. A Itaipu Binacional concretizou as relações diplomáticas entre os dois países, possibilitando a consolidação da ditadura no Paraguai e ajudando na sustentação do governo militar brasileiro.

Para assegurar a segurança continental, impunha-se ocupar uma área de $121.889 \mathrm{~km}^{2}$, ou seja, $33 \%$ do território paraguaio, com uma população de 1.120 .000 habitantes (45\% da população total). 
Nesta região viviam já em 1975, 40.000 brasileiros, numero este que foi aumentando consideravelmente a cada ano com a presença de brasiguaios no Paraguai, servindo estrategicamente como medida de segurança ao projeto hidrelétrico de Itaipu. Enquanto os brasiguaios buscam as terras para a sobrevivência camponesa, o estado os utilizavam como forma de defesa dos interesses imperialistas, quebrando a soberania paraguaia em prejuízo de milhares de campesinos que viviam miseravelmente no país vizinho (BATISTA: 1990:46-7) (grifos nossos).

Com a construção da Itaipu, novas levas de agricultores paranaenses destituídos de suas terras e assim impossibilitados de permanecerem no Paraná, vieram a engrossar o numero de brasiguaios no Paraguai, entre os anos 70 e 80.

Roseira citando o Centro de Estudos Migratórios ${ }^{156}$ assim afirma:

Em apenas dez anos (1970-80), o Estado do Paraná expulsou 1.201.457 migrantes. Desse total, $16,5 \%$ migrou dentro da própria região sul, enquanto 83,4\% (1.106.353) deslocaram-se para fora da região. De um povoamento massivo, o Paraná passou rapidamente para um despovoamento acelerado (ROSEIRA: 2006:80) (grifos nossos).

Fato que mais uma vez comprova que Itaipu forjou os dados também a esse respeito, na medida em que, como vimos anteriormente, a empresa afirmou exatamente o contrario, que a maioria dos desapropriados pela hidrelétrica teriam se reinstalado no próprio estado do Paraná. Assim, como se pode observar em vários momentos, não há seriedade em muitos dos dados que a Itaipu informa.

Camponeses brasiguaios que já estavam no Paraguai, com a construção de Itaipu, também foram desalojados, é o que informa Batista: Com a construção da Itaipu, foram novamente desapropriados recebendo qualquer quantia, porque vivendo em outro país não possuíam nenhum direito legal sobre as terras que ocupavam (BATISTA: 1990:20).

Segundo Batista a intensidade de povoamento da fronteira paraguaia por brasileiros efetivou-se em dois momentos historicamente considerados, um entre os anos 50 e 69 e outro entre 70 e 79 (BATISTA: 1990:21).

Batista descreve a forte influencia do Brasil sobre o Paraguai, por meio do Tratado de Itaipu:

O maior projeto entreguista na fronteira com o Paraguai surgiu na década de 70, através do Tratado de Itaipu. O Brasil passou a ter forte influencia na soberania do Paraguai, que, a partir de 1973,

\footnotetext{
$\overline{156}$ Centro de Estudos Migratórios. Cadernos Migratórios n.4: Brasiguaios, 1989, p9. (Não se sabe assim quem publicou e aonde??)
} 
ficou dependendo do crescimento econômico e do expansionismo brasileiro na busca de seu predomínio sobre a America Latina, beneficiando principalmente as transnacionais imperialistas.

Em torno da Itaipu estão vários empresários instalados na indústria, comercio, bancos, potentes emissoras de radio, propagando valores culturais massificados, o dinheiro brasileiro e reforçando a dominação desta parte do território paraguaio. O povoamento atinge $80 \%$ da população da fronteira paraguaia; são 500.000 brasiguaios, aguardando, inclusive, a possibilidade de o Brasil anexar esta parcela de terra paraguaia. Em entrevistas com brasiguaios, muitos disseram que entraram no Paraguai durante o governo do presidente Figueiredo no Brasil, porque souberam que existia um projeto para a construção de uma estrada que ligaria Porto Stroessner a Pedro Juan Caballero, dividindo o Paraguai na altura de Foz do Iguaçu no Paraná, e Ponta Porã, no Mato Grosso do Sul.

Itaipu só se explica como um projeto geopolítico, já que teoricamente é visível sua irracionalidade. Geopoliticamente no modo de pensar do governo brasileiro, Itaipu é coerente com o Estado autoritário instaurado no país, porque fortalece a liderança de "satélite privilegiado" no cone sul, além de aprisionar um estado-vassalo: O Paraguai. Isso explica porque a Geopolítica é a arma auxiliar do Imperialismo e de que forma é utilizada como elemento de dominação interna. Equalizando forças militares em certos países subdesenvolvidos, mas potencialmente ricos, como o Brasil, ao mesmo tempo que mantém os vizinhos mais pobres (BATISTA: 1990:50-1).

Em seguida no Paraguai, a partir dos anos 80 se repetiu exatamente o mesmo processo de expropriação/espoliação que havia ocorrido antes no Brasil. Não há mais terras para o camponês, a mecanização, o pasto para gado, a soja tomou conta do território, e os trabalhadores brasiguaios, depois de "amansarem as terras para o latifúndio" foram sendo expulsos novamente, agora das terras do Paraguai. A concentração fundiária nas mãos de poucos, através de grilagem e métodos ilegais predominou também no Paraguai. Batista colocou em questão, como ele mesmo afirma, as características gerais da apropriação privada da terra e as formas de sua incorporação à lógica capitalista de dominação e subordinação (BATISTA: 1990:2). Historicamente, a expropriação do camponês, que fica privado de suas terras constitui a base de todo o processo de acumulação de capital, transformando a terra utilizada, propriedade não capitalista, em propriedade capitalista, iniciada com o processo de apropriação privada da terra.

Estes (os camponeses brasiguaios) perderam as terras para colonizadoras que passaram a agir na especulação imobiliária das terras "amansadas" pelos brasiguaios. Foram retirados violentamente de suas terras e as oportunidades só existiam para aqueles que podiam comprar as terras, regularizálas no Cartório de Assunção, e continuar investindo no Paraguai. Os pobres foram transformandose em agregados, parceiros, enquanto varias famílias começaram a pensar no retorno para o Brasil 
(BATISTA: 1990:22). (...) Após o povoamento da região e a valorização das terras preparadas pelos brasiguaios, a maioria destas famílias perdeu suas terras (BATISTA: 1990:25).

Nota-se que é um processo uniforme e repetitivo, a ocupação das fronteiras florestadas pelos indígenas, em seguida camponeses e pequenos proprietários derrubam as matas, preparam as terras e plantam, por fim, firmas colonizadoras abrem os meios para a apropriação privada da terra, a qual expulsam os demais para nova fronteira. Batista assim afirma com relação aos camponeses:

As rearticulações do capitalismo abrem para a America a opção de colonizar as fronteiras promovendo uma ocupação essencialmente camponesa, avançando no território livre, numa investida pela conquista das terras públicas consideradas devolutas, portanto um lugar "aparentemente" comum. A posse dessas terras limita a reprodução do campesinato à sua subsistência. Quando aumenta o povoamento, o excedente da produção é negociado com pequenos centros de comercio e a colonização ${ }^{157}$ é o primeiro instrumento comercial adequado para transformar estas terras em mercadorias, consequentemente o camponês começa a sofrer o processo de expropriação, migrando para a próxima fronteira agrícola (BATISTA:1990:4).

\section{Batista ainda afirma:}

Essa ideologia e os projetos como Itaipu aumentaram o êxodo de brasileiros para o Paraguai e com isso valorizaram as terras no país vizinho. Ao trabalhador paraguaio não tem restado nenhuma oportunidade; o domínio das terras paraguaias pertence a grandes empresas como (descreve empresas estrangeiras: americana, alemã e anglo-argentina), que se encarregaram da expropriação dos camponeses.

As instituições financeiras no Paraguai controlam o credito, favorecendo os grandes empresários estrangeiros. O Banco Real Del Paraguai é a empresa financeira multinacional (filial do Banco Real, um dos três maiores bancos privados do Brasil) que, junto com as Cooperativas, explora a pequena propriedade, vinculando a produção aos financiamentos de produção para exportação. As Cooperativas surgem para atender às exigências das empresas multinacionais, visando uma produção uniforme, onde tudo o que é produzido, é vinculado aos interesses monopolistas (BATISTA: 1990:52).

É observado também através do relato de Batista, que todos aqueles que não tem o titulo de propriedade da terra, não conseguem financiamento nos bancos para bancar a sua produção, o que também é um meio de expulsar o pequeno camponês da terra.

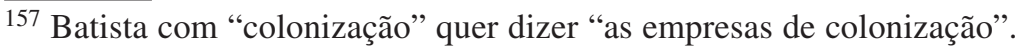


Por fim Batista interpreta da seguinte forma o Tratado de Itaipu:

Em 26 de abril de 1973 consolidou-se, com a assinatura do Tratado de Itaipu, uma aliança "perpetua" 158 entre o Brasil e o Paraguai, "associando o desenvolvimento do povo guarani ao Brasil", segundo afirmações do próprio ditador Stroessner. Assim estava entregue ao Brasil, vitais interesses da soberania e independência do Paraguai, para atender aos monopólios imperialistas instalados no Brasil. Através do Tratado, Stroessner criou impedimentos para a efetiva independência do Paraguai ao firmar o compromisso de uma "aliança perpetua" (BATISTA:1990:53).

O Partido Comunista Paraguaio - PCP defende a anulação dos vínculos entreguistas estabelecidos no Tratado de Itaipu e a renegociação deste em condições democráticas, que não lesem os interesses e direito do povo paraguaio nem de outro país. Os manifestantes comunistas concluem:

“Os operários, camponeses, estudantes, intelectuais, políticos e religiosos, todos os democratas e revolucionários paraguaios saberão encontrar o caminho da coincidência e da unidade para derrotar o regime antinacional e entreguista de Stroessner, formar um governo de democratização e liberar o solo pátrio das ataduras expansionistas e imperialistas". (Voz da Unidade:1988:12). (BATISTA: 1990:53-4)

Em termos geopolíticos, nota-se assim as estratégias de dominação do Brasil em território paraguaio, onde o capitalismo brasileiro e por tras dele o multinacional, acaba por apagar as fronteiras nacionais paraguaias, pela repercussão da presença iniciada com os camponeses brasiguaios. Magnoli já lembrava: Nesse contexto, a expansão recente da agricultura paranaense sobre terras do oriente paraguaio, fundamento do conhecido fenômeno dos "brasiguaios", inclue-se na lógica geral da manobra de hegemonização do Paraguai pelo Brasil. (MAGNOLI: 1986:41)

Nesta fronteira leste do Paraguai, o dinheiro, a língua, os meios de comunicação utilizados são os do Brasil. A soberania paraguaia sobre a parte leste do território está assim ameaçada. Assim como os fazendeiros dos EUA tomaram parte do território mexicano, os empresários brasileiros do agronegócio estão contribuindo para fazer o mesmo no leste paraguaio. O próprio ex-chanceler Mario Gibson Barboza que negociou os termos do Tratado da Itaipu com paraguaios e argentinos, segundo Batista (1990:42), ele também possui 80 mil hectares de terras no leste paraguaio.

O assentamento dos brasiguaios constitui um elemento geopolítico na Bacia Platina. Ao analisar o que denomina desnacionalização das zonas de fronteiras paraguaias em meados da década de 80, Mello afirma que nas áreas limítrofes o dinheiro e a língua paraguaios estão sendo paulatina-

$\overline{158} \mathrm{Na}$ verdade a aliança é por 50 anos de 1974 a 2024, o que não deixa de ser um grande período. 
mente suplantados pela moeda e o idioma português. O autor ainda ressalta que a penetração do radio e televisão, brasileiros, caracteriza-se como fortes elementos de aculturação do paraguaio (ROSEIRA: 2006:81).

Batista observa que as áreas de fronteira, tiveram como tarefa político militar, a adoção de uma consciência nacional do domínio e desenvolvimento do Brasil na America Latina, através da força, e, a serviço do imperialismo e da transnacionalização do capital. (BATISTA: 1990:60).

O projeto de englobamento político-econômico das forças que comandam o Brasil orientou estrategicamente o expansionismo intervencionista do capitalismo nos países vizinhos. Para isso era preciso ter uma fronteira armada e forte para fazer valer a divisão internacional do trabalho, fundamentada na exportação do capital. (BATISTA: 1990:60).

A colonização do Paraguai em sua fronteira com o Brasil é a mais significativa, constituindo-se num avanço dos brasiguaios numa extensão de $100 \mathrm{~km}$, o que corresponde a $15 \%$ da população paraguaia. Do ponto de vista geopolítico, o governo do ditador Stroessner a considerava um fator de desenvolvimento, enquanto que a oposição via a presença de brasiguaios como ameaça a soberania do país. A doutrina geopolítica aplicada é a de "ocupar os espaços vazios" sob orientação do poder central para permitir a captação de influencias e pressões forâneas.

É o caso das Colônias Militares (Alcântara e Foz do Iguaçu) e dos Territórios Federais (Ponta Porã e Iguaçu) implantados na região.

Desta forma os brasiguaios no Paraguai não são poucos diante da pequena população deste país, só em Ciudad del Este são 50.000 brasiguaios atualmente (2013) e no Leste paraguaio como um todo, os dados de Batista, que são de 1990, informava 500.000 brasiguaios. O Paraguai possuía 6,5 (seis e meio) milhões de habitantes, segundo o Censo de 2002. Apesar das datas apresentadas, impedirem de fornecer porcentagens exatas, nota-se que a população de brasiguaios é bastante significativa no país vizinho.

Em matéria do jornalista Igor Ojeda de 2006, denominada "Paraguai: Receita para aniquilar a luta pela terra" 159 encontramos informações que dão conta do quadro político e econômico mais "recente", encontrado neste país, e como o poder age para se manter. Na época, lemos esta matéria, em mente com a seguinte questão: "Paraguai: que país é este para o qual os Guarani

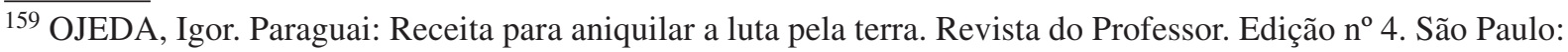
Sindicato dos Professores do ABC (Santo Andre, São Bernardo e São Caetano) / SINPRO. Outubro de 2006. O jornalista Igor Ojeda é colaborador também do jornal "Brasil de Fato".
} 
habitantes do Brasil estão sendo expulsos?”. E assim anotamos as principais informações que o texto de Ojeda nos oferecia, ao mesmo tempo em que o resumia e acrescentava dados sobre os Guarani. Hoje não possuímos mais o original, apenas este, abaixo apresentado, de certa forma "reinterpretado" por nós.

O Paraguai conta com uma área de $406.750 \mathrm{Km} 2$ e população de 6,5 (seis e meio) milhões de habitantes segundo o Censo de 2002. Destes, $79 \%$ (setenta e nove por cento) falam somente a língua guarani; $20 \%$ (vinte por cento) guarani e espanhol e $1 \%$ (um por cento) só espanhol. Neste $1 \%$ concentram-se $99 \%$ (noventa e nove por cento) da elite dominante. A distribuição de terras apresenta enorme concentração: 77 \% (setenta e sete por cento) das terras estão nas mãos de $1 \%$ (um por cento) dos proprietários.

Hoje, no Paraguai, quase não há indústria. A economia caracteriza-se por ser agro-exportadora, baseada em latifúndios de criação de gado e plantio de soja, esta, desde 1990, tornou-se o principal item da economia paraguaia.

O Governo é comandado pelo Partido Colorado, há 60 (sessenta) anos no poder, o mesmo que foi responsável pela ditadura que vigorou no país entre 1954 e 1989. O Partido Colorado é profundamente vinculado aos latifundiários. Os principais jornais e TVs do país são de propriedade das famílias da oligarquia rural. Assim a elite econômica controla a mídia e o poder político de Estado.

Artigo publicado pelo jornalista Igor Ojeda sob o título "Paraguai: Receita para aniquilar a luta pela terra", indica que observadores internacionais constataram haver repressão aos movimentos sociais, combinada com militarização derivada de acordo do Paraguai com os Estados Unidos da América/EUA.

O ex-presidente do Paraguai Nicanor Duarte Frutos, doze dias após sua posse em agosto de 2003, emitiu o Decreto n 167 autorizando as Forças Armadas, em conjunto com a Polícia Nacional, a atuar em ações de "segurança interna". Em 2004 foram criados pelo Ministério do Interior, os "Conselhos de Segurança Cidadã" para combater o "crime". Em maio de 2005 o Presidente assinou um Convênio entre Paraguai e EUA, promulgado como Lei no 2594, prevendo exercícios militares estadunidenses em qualquer parte do território paraguaio; imunidade judicial para os soldados estadunidenses; e capacitação e treinamento das Forças Armadas paraguaias por oficiais estadunidenses para instruí-la no combate ao "terrorismo".

O Governo paraguaio justifica o uso das Forças Armadas em operações policiais pela falta de infraestrutura e de recursos da polícia nacional, que não teria capacidade de combater o crime das supostas "guerrilhas" e "grupos terroristas". As Forças Armadas paraguaias possuem um efetivo entre 8.000 a 12.000 militares. 
Comparativamente, os Conselhos de Segurança Cidadã possuem 22.000 civis financiados e armados oficialmente pelo Governo e extraoficialmente por fazendeiros. Esses latifundiários ainda lançam mão de empresas de segurança privada, como a denominada "Guardas Rurais SA".

Os denominados "brasiguaios", fazendeiros brasileiros que compram grandes extensões de terra para o plantio da soja, agem livremente, já que no Paraguai não há uma lei de segurança fronteiriça. Essas fazendas ocupam terras fronteiriças ao Brasil e à Argentina (leste do Paraguai). É justamente nesta parte do leste paraguaio que se localiza a maior parte das aldeias Guarani. Estas aldeias receberam inúmeras famílias que foram expulsas do Brasil, entre os anos 40 e 80 do século XX. Assim, essas aldeias Guarani no Paraguai, devem se encontrar provavelmente superpovoadas pela imigração indígena proveniente do Brasil. Esta área caracteriza-se por ser uma área de conflito pela posse de terra. Ver mapa apresentado anteriormente de Maria Inês Ladeira, onde demonstra as aldeias Guarani existentes atualmente no leste paraguaio e no oeste paranaense.

Se antes as fazendas de soja ocupavam os campos próximos às fronteiras com o Brasil e a Argentina (leste Paraguaio), o cultivo avança cada vez mais para o interior do país. A área ocupada pela soja - quase toda transgênica, segundo o jornalista em 2006/2007 iria dobrar em relação a 2003/2004. O resultado disso é que conforme a fronteira agrícola avança, extinguem-se a pequena propriedade de produção familiar e os camponeses ou vendem suas terras ou são expulsos dela, no bojo desse contexto os Guarani vivem o mesmo drama, cada vez mais alarmante, já que a disputa pelas terras se tornou maior nos últimos anos, tanto inicialmente pelo lado guarani vindos do Brasil, quanto por fazendeiros. É bom frisar que as populações indígenas no Paraguai são tratadas como camponeses comuns, apesar de existir em tese, leis específicas de proteção aos direitos humanos e fundiários dessa população.

Desde a posse do presidente citado cresceu a militarização tanto na cidade como no campo. Os observadores internacionais descrevem ao percorrer o país, ver militares e policiais armados, um quadro de verdadeiro estado de guerra, o que provoca a eles sensação de opressão.

As ações militares e paramilitares se concentram em áreas do Paraguai onde os camponeses estão mais organizados e onde há maior número de conflitos agrários entre pequenos proprietários e latifundiários. O Departamento de Concepción no nordeste do país é o local onde há atualmente o maior número de violações aos direitos dos camponeses, considerados "guerrilheiros" pela governadora, embora o chefe de policia departamental afirme categoricamente que lá não existem grupos guerrilheiros, apenas delinquentes comuns.

A decisão do governo de criar os "Conselhos de Segurança Cidadã" em 2004, para combater o "crime", tem relação com o surgimento a dois anos de duas frentes de luta social: - a Mesa 
Coordenadora Nacional de Organizações Camponesas / MCNOP ligada à Via Campesina e a Federação Nacional Camponesa/ FNC. O plano de ação dessas organizações se resume à reocupação de terras, protestos pela reforma agrária e contra as privatizações.

Assim a ação repressiva de todos esses grupos: militares estadunidenses, Forças Armadas, Polícia Nacional, Conselhos de Segurança Cidadã e Guardas Rurais SA, tem aparentemente o mesmo objetivo.

Os Guardas Rurais SA contratados por fazendeiros, expulsam os camponeses de suas terras em grande parte não regularizadas, para abrir mais espaço para a soja, tudo sob vista grossa do Estado. Os Conselhos de Segurança Cidadã, são grupos paramilitares que atuam na proteção da propriedade privada do criador de gado e do produtor de soja. Esses Conselhos são autores de repressões, despejos, queima de casas, estupros de mulheres, assassinatos de dirigentes e integrantes de organizações camponesas. Diante da militarização no campo e da truculência dessas forças conjuntas sobre camponeses e movimentos sociais, o resultado disso é a criminalização de organizações sociais e de seus líderes no campo. Nos últimos dois anos foram registrados 49 mortos e vários desaparecidos. Cerca de 2000 camponeses, presos ou livres, respondem a processos na Justiça no Paraguai.

A estratégia do governo é acusar os movimentos sociais de ligações com o "terrorismo" e considerar "atos contra a segurança nacional" ações como marchas, bloqueio de estradas e ocupações de terras ${ }^{160}$.

A partir da assinatura do Convênio com os EUA, verifica-se na prática um aumento da repressão e do "terrorismo de Estado", consequentemente também aumentam as denúncias de violações aos direitos humanos. Os dirigentes camponeses afirmam aos observadores, que as práticas da ditadura voltaram com o atual Governo, que chamam de fascista. O treinamento das Forças Armadas paraguaias pelos soldados estadunidenses, oficialmente objetiva instruir o combate ao "terrorismo", segundo os observadores nada mais é que uma cartilha norte-americana que orienta os passos para a desarticulação e aniquilação dos movimentos sociais. Assim as Forças Armadas orientadas, pressionam e perseguem dirigentes de comunidades e de assentamentos camponeses.

Hoje no Paraguai há de 200.000 a 300.000 famílias sem-terra. Consequentemente há um fluxo migratório para as cidades, aumentando os cinturões de pobreza nas áreas urbanas. Barracões são erguidos às margens do Rio Paraguai, os moradores são denominados de "bañados". Ali

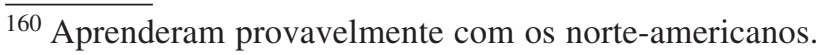


militares e policiais armados reprimem os movimentos organizados dos bañados. Nas ruas da capital, Assunção se vê pobreza e desolação.

A vinculação da imagem dos camponeses com a guerrilha e grupos terroristas, conta com a ampla contribuição da grande imprensa paraguaia, dominada pela oligarquia rural. Recentemente houve tentativa semelhante por parte do Governo, de vincular a imagem do Secretário-Geral da Central Nacional de Organizações Camponesas e Indígenas do Paraguai/ CENOCIP, Tomás Zayas, às Forças Armadas Revolucionárias da Colômbia/FARC, através da fabricação de testemunha falsa. O próprio ex-futuro subornado denunciou antes a falsidade das acusações. Denunciou também os envolvidos nos planos, funcionários do Ministério do Interior e do Ministério da Agricultura e ainda um homem do Partido Colorado.

É curiosa a presença norte-americana em território colombiano e paraguaio. Não é só o latifúndio que pretendem proteger, ao combater as populações camponesas nesses países, afirmam ainda existir nesses países "células terroristas" a combater, representados pelas Forças Armadas Revolucionárias da Colômbia/ FARCs e pelos movimentos camponeses no Paraguai, assim como ventilam também supostas células da Al'Qaeda, diante da presença árabe na fronteira entre Brasil, Paraguai e Argentina. Subjacente a este quadro, na verdade estão localizadas as maiores reservas de água doce destes países e em área vizinha, no Brasil, respectivamente ao norte, a Bacia Amazônica e no sul, o Aquífero Guarani. A história se repete como no Iraque, em nome de "combate aos terroristas" tomou-se as reservas de petróleo e gás daquele país, agora pretendem controlar as maiores reservas de água doce do planeta, aqui localizadas, na América do Sul.

Ainda na mesma época pudemos acessar um documento, "LA INACABABLE TRAGEDIA INDÍGENA Y UNA CONSTITUCIÓN MENTIROSA" $" 161$ que expressava a situação vivida pelos povos Guarani do Paraguai, os quais se consideram indígenas, autóctones, com uma cultura diferenciada, ligada aos seus antepassados, diferenciada dos demais, que também são Guarani, já relativamente assimilados pela cultura dominante. Este texto compara a situação expressa na Constituição do Paraguai, quanto à defesa dos direitos indígenas e a situação vivida na realidade por esses grupos sociais.

Olivera introduz a questão demonstrando quem são as populações indígenas do Paraguai:

Según el último Censo Indígena en Paraguay sobreviven casi 80.000 nativos, lo que equivale aproximadamente al 1,5\% de la población total del país, ya que el Paraguay actualmente tiene casi seis

\footnotetext{
$\overline{161}$ OLIVERA, David Galeano. LA INACABABLE TRAGEDIA INDÍGENA Y UNA CONSTITUCIÓN MENTIROSA. REPÚBLICA DEL PARAGUAY. ATENEO DE LENGUA Y CULTURA GUARANI. "Guarani ñe'ête pyahu myasâihára". Obtido em www.ateneoguarani.edu.py. Pesquisado em 2006.
} 
millones de habitantes. Los 80.000 mencionados pertenecen a su vez a 17 Etnias o Parcialidades Indígenas, entre ellas las que pertenecen a la Familia Linguística Guarani. Lastimosamente, al cuantificar el número de miembros por cada Parcialidad, las cifras se hacen cada vez más reducidas. Así, los Mbya Guarani, los Pâi Tavyterâ, los Ava Guarani y los Nivacle, por ejemplo, son los más numerosos. Cada una de dichas parcialidades posee cerca de 15.000 habitantes respectivamente. Por su parte, los Ache-Guajaki son cerca de 1.000. Existen otras Etnias que están en la "línea de la muerte"; así, los Guana y los Manjui son apenas 500 personas en total; mientras que los Chamakoko apenas alcanzan las 150 personas.

Quanto ao tratamento dado pelos colonizadores:

Tantas excusas tuvo la historia para - cada día - reducirlos más y más. A partir del mentando "descubrimiento de América" -hoy conocido con el nombre menos ofensivo de encuentro de dos mundos- cualquier pretexto sirvió para aniquilar a los hermanos Indígenas. Primero se dijo que eran salvajes, bárbaros o animales monteses y bajo esa denominación fueron cazados de manera inmisericorde. Luego la excusa fue la Colonia y la presencia de los Misioneros (Jesuitas, Franciscanos, Dominicos, Mercedarios, etc.), quienes a "sangre y fuego", y en nombre de Dios y del Rey, mataron a millones y, por otra parte, redujeron a unos cuantos salvajes a la condición de mansos cristianos; es más, en algún momento de la vida colonial fue uno de los reyes de España quien otorgó alma a esa punta de salvajes; por consiguiente, por obra y gracia de aquel rey los indígenas se tornaron gente, ergo seres humanos. No perdamos de vista que miles de mujeres indígenas "se prestaron" forzadamente para saciar los bajos instintos del "héroe conquistador". En aquel tiempo, los indígenas que consiguieron sobrevivir, se convirtieron en parias o esclavos y miles de ellos fueron torturados, humillados y vendidos al mejor postor para que sirvieran como bestias de carga. Los Indígenas fueron sometidos a las más degradantes e inhumanas formas de trato.

Quanto às características da colonização moderna ou atual:

Modernamente la excusa se denomina globalización; también puede denominarse industrialización o desarrollo agroindustrial . Precisamente, esta última denominación es la que en el Paraguay actual arrasa despiadada e inhumanamente las precarias poblaciones indígenas; despojándolas de sus tierras y montes y contaminando sus cursos de aguas; propiciando el tránsito por el último tramo -ojalá se produzca algún milagro- hacia un inevitable y desenfrenado etnocidio.

Sobre a antiguidade dessa população no país:

Y pensar que hasta antes de la llegada de los españoles... ellos fueron los dueños de los montes, de las plantas, de las brillantes mariposas, de los loros, de los ríos, arroyos y peces. Ellos fueron los 
dueños de América y en particular, del actual Paraguay. Y lo fueron por varios miles de años. En efecto, las investigaciones arqueológicas realizadas en el sitio de la Represa de Itaipu revelaron la existencia de vestigios de comunidades humanas de 10.000 años de antiguedad. Es decir, 9.500 años antes de la llegada de los conquistadores, en esa zona vivían miles de nativos, con una cultura muy desarrollada. Basta señalar que los restos fósiles encontrados en dicho sitio se hallaban contenidos en urnas funerarias debidamente ornamentadas, tradición que hasta la actualidad practican quienes aún sobreviven en el Paraguay.

Sobre a reivindicação que fazem frente a INDI e a consideração sobre as leis:

Pero hoy, más que nunca, LOS INDÍGENAS ESTÁN EN PELIGRO DE MUERTE. Hoy ya no viven en los montes, ya no tienen tierras. Por eso, forzados por las circunstancias, vinieron a Asunción, Capital del Paraguay; a reclamar parte de lo que les perteneció. Y lo hacen frente al INDI (Instituto Nacional del Indígena), institución que -según la organización del Estado- debía y debe atender sus necesidades, pero que nunca lo hizo, por 50.000 razones que no viene al caso analizar. Los indígenas vienen a manifestar que la Constitución Nacional y las leyes los ampara. Pero a fuerza de ser sinceros, debemos decir que las letras de la Constitución y las leyes, nacieron muertas, son letras muertas. No sirven para calmar la inacabable tragedia Indígena, porque la Constitución Nacional y las leyes son mentirosas.

Em seguida Olivera faz a comparação entre o que a Constituição paraguaia prevê como direitos aos povos indígenas e o que de fato acontece no país:

La Constitución Nacional del Paraguay, la última, promulgada en 1992, es considerada como una de las más modernas y revolucionarias en su género; sin embargo, por ejemplo, en 15 años (1992-2007) de vigencia NO sirvió para reivindicar a las Comunidades Indígenas que viven en el Paraguay. Analicemos como los 5 artículos que refieren a los Nativos constituyen hasta hoy una mera expresión de deseos.

\section{ART. 62. DE LOS PUEBLOS INDÍGENAS Y GRUPOS ÉTNICOS}

Esta Constitución reconoce la existencia de los pueblos Indígenas, definidos como grupos de cultura anteriores a la formación y organización del Estado Paraguayo.

En referencia a este artículo, cabe decir que este simple reconocimiento que la Constitución hace de los Pueblos Indígenas, es honorífico, es una muestra de lisonjería. No contiene ningún sentimiento, es un reconocimiento vacío. En el fondo, es el signo de la discriminación, de la miseria, de la pobreza o de la desgracia; ya que históricamente la frase Pueblos Indígenas solo significó eso. 


\section{ART. 63. DE LA IDENTIDAD ÉTNICA}

Queda reconocido y garantizado el derecho de los pueblos Indígenas a preservar y a desarrollar su identidad étnica en el respectivo hábital. Tienen derecho, asimismo, a aplicar libremente sus sistemas de organización política, social, económica, cultural y religiosa, al igual que la voluntaria sujeción a las normas consuetudinarias para la regulación de la convivencia interna, siempre que ellas no atenten contra los derechos fundamentales establecidos en esta Constitución. En los conflictos juridiccionales se tendrá en cuenta el derecho consuetudinario Indígena.

Respecto de este artículo, conviene señalar que la identidad étnica cada día que pasa - sin tierra, sin educación, sin asistencia estatal - tiende a desaparecer, haciéndose una verdadera utopía. Los nativos al NO tener sus espacios tradicionales tampoco pueden aplicar sus sistemas de organización política, social, económica, cultural y religiosa, al igual que la voluntaria sujeción a las normas consuetudinarias para la regulación de la convivencia interna.

\section{ART. 64. DE LA PROPIEDAD COMUNITARIA}

Los pueblos Indígenas tienen derecho a la propiedad comunitaria de la tierra, en extensión y calidad suficientes para la conservación y el desarrollo de sus formas peculiares de vida. El Estado les proveerá gratuitamente de estas tierras, las cuales serán inembargables, indivisibles, intransferibles, imprescriptibles, no susceptibles de garantizar obligaciones contractuales ni de ser arrendadas; asimismo, estarán exentas de tributo. Se prohíbe la remoción o traslado de su hábitat sin el expreso consentimiento de los mismos.

En relación a este artículo, cabe manifestar que en la práctica NO se cumple aquello que dice tienen derecho a la propiedad comunitaria de la tierra. Sus tierras hoy pertenecen a poderosos latifundistas paraguayos y extranjeros. Los otrora grandes montes donde ellos convivían, desaparecieron, dando lugar a millones de hectáreas de soja y trigo, regadas periódica y criminalmente con abundante agrotóxicos, que los asfixia y los mata día a día.

\section{ART. 65. DEL DERECHO A LA PARTICIPACIÓN}

Se garantiza a los pueblos Indígenas el derecho a participar en la vida económica, social, política y cultural del país, de acuerdo con sus usos consuetudinarios, esta Constitución y las leyes nacionales .Lo expresado en este artículo también es letra muerta. Jamás, ni el INDI ni otro organismo del Estado, procuró siquiera propiciar la participación de los Pueblos Indígenas en la vida económica, social, política y cultural del país. Ninguno de los proyectos presentados por los Pueblos Indígenas, prosperó. Cuando -por ejemplo- solicitaron desarrollar, ellos mismos, un modelo educativo sustentado en sus lenguas y culturas, el MEC olímpicamente los eludió y jamás atendió esa reivindicación Indígena.

\section{ART. 66. DE LA EDUCACIÓN Y LA ASISTENCIA}

El Estado respetará las peculiaridades culturales de los pueblos Indígenas, especialmente en lo relativo a la educación formal. Se atenderá, además, a su defensa contra la regresión demográfica, 
la depredación de su hábitat, la contaminación ambiental, la explotación económica y la alimentación cultural.

En referencia a lo expresado por este artículo de la Constitución, conviene decir que los nativos NO reciben una educación diferenciada. Ellos nunca pudieron educarse en su propia lengua y cultura pues el MEC los trató y los trata como a cualquiera, por esa "razón" ellos usan los mismos libros (mal hechos y mal impresos) que utilizan todos los demás niños paraguayos, no indígenas. En esos libros no existe mención alguna a su religión tradicional, a su idioma, a sus costumbres, a sus tradiciones, a sus artesanías, a sus héroes. En los libros que ellos leen y “aprenden”, los héroes son los paraguayos o los conquistadores españoles. "Ellos" ni fueron, ni son, ni podrán ser "héroes", mientras sigan leyendo dichos libros.

\section{ART. 67. DE LA EXONERACIÓN}

Los miembros de los Pueblos Indígenas están exonerados de prestar servicios sociales, civiles o militares, así como de las cargas públicas que establezca la ley.

Finalmente, cabe señalar que tampoco se dio cumplimiento debidamente a este mandato Constitucional, ya que hasta hoy son explotados. Por ejemplo, laboralmente reciben una ínfima paga, que las más de las veces NO se materializa en dinero sino en pagos mediante mercadería (sobrefacturadas cuando de ellos se trata). Otra sencilla muestra se da en la época del Rally del Chaco, ante la vista de las autoridades, cuando las mujeres indígenas son abusadas sexualmente a "bajo costo". Asimismo, cuando "caen" en las "fauces" de los militares y se los obliga a cumplir con el servicio militar obligatorio, son maltratados y golpeados salvajemente durante la duración de dicho servicio. La "formación" militar solo generó en ellos la cultura del miedo y la sumisión.

\section{Por fim concluiu:}

Durante mucho tiempo los Indígenas fueron el centro de atención, una especie de atracción fatal, de varios investigadores de la talla de Guido Boggiani, Kurt Unkel, Moisés Bertoni, Friedrich Mayntzhusen, León Cadogan, Branislava Susnik y más recientemente José Perasso, quienes no escatimaban expresiones de elogio para ponderar las virtudes desconocidas de los Pueblos Indígenas. Estos destacadísimos investigadores ponderaron el profundo conocimiento que los Indígenas tenían de la zoología y botánica; también alabaron su concepción de la comunidad, de la solidaridad y de la igualdad; asimismo, destacaron su casi perfecta organización social, política y económica; igualmente, admiraron su concepción religiosa. Por otra parte, hoy, la Lengua Guarani es -sin lugar a dudas- el más preciado "legado" de los Indígenas Guarani del Paraguay. Estos investigadores lograron escribir miles de páginas de monumentales libros, y dedicaron gran parte de sus vidas a promocionar, con profunda convicción, la milenaria, justa, solidaria, democrática y evolucionante Cultura Indígena no solo paraguaya sino americana. 
Sin embargo, los Pueblos Indígenas que habitan actualmente el territorio del Paraguay, sobreviven hoy en miserables e infrahumanas condiciones. Ya no viven en los montes porque ya no hay montes. $\mathrm{Al}$ quedar desposeídos de sus territorios y montes ancestrales, ven desaparecer sus tradiciones, sus costumbres, sus usos y sus creencias. La carencia de alimentos y más que eso, el hambre; han contribuido en su paulatino traslado a los cinturones urbanos, a buscar y vivir de las "sobras", de las migajas y a comer cuando algún asunceno caritativo se lo permiten.

Esta circunstancia - carencia de alimentos- los convirtió en alcohólicos ya que eso les hace pasar la sensación de hambre. Hoy, si no es el alcohol, es la marihuana o la "cola de zapatero". Estos "recursos alternativos" permiten que niños, jóvenes y adultos Indígenas "se olviden" del hambre, por algún tiempo.

Cada candidato a presidente de la república, a senador, diputado, gobernador o intendente, les prometió - en su momento - el oro y el moro. Sin embargo, cada uno de ellos - una vez electos - escudados en la amnesia del poder, olvidó todas las promesas hechas durante la campaña proselitista.

El futuro se torna cada vez más difícil para los Pueblos Indígenas. Las posibilidades de sobrevivencia se acortan. Cada vez están más pobres, más desnutridos, más enfermos, más abandonados, sin derechos humanos, sin asistencia del Estado, sin Constitución ni leyes que los ampare; en síntesis... sin nada. Lo llamativo es que prácticamente ya nadie se inmuta, perturba o escandaliza ante la miseria Indígena. Dejaron de ser importantes, de hecho, nunca lo fueron. La diversidad de "temas más importantes" o "mediáticos" los sustituyeron. De vez en cuando, algún medio (radio, diario o televisión) los desempolva y los pone en situación de emergencia ante la opinión pública. En ese momento son la atracción de algunos, que aprovechan para hacer beneficencia (donándoles ropas usadas o algún objeto que ya no se usa en la casa).

Esta es la situación real de vida de quienes alguna vez fueron los dueños de América y en particular del Paraguay. Esta es la verdadera historia de LA INACABABLE TRAGEDIA INDÍGENA.

Una veza más, el ATENEO DE LENGUA Y CULTURA GUARANI denuncia la situación infrahumana en que sobreviven las comunidades indígenas del Paraguay; y sobre todo, denunciamos la inacción del Gobierno Paraguayo, particularmente del INDI, institución supuestamente creada para precautelar y promocionar a las naciones indígenas que hoy viven en el Paraguay. Nosotros también nos unimos a las justas reivindicaciones de los hermanos indígenas del Paraguay; solicitando trato digno y justo para ellos, respeto a su identidad; lo mismo que, reivindicamos tierra, pan, educación y salud para ellos. 


\section{c) Os problemas criados pelo Brasil com a Argentina}

O Tratado de Itaipu entre as várias considerações feitas, também considerou: o estabelecido na Declaração de Assunção sobre o aproveitamento de rios internacionais, de 3 de junho de 1971.

A construção da Usina Hidrelétrica de Itaipu significou a criação de vários problemas para a Argentina, os quais deram inicio às varias discussões diplomáticas entre o Brasil e este país, que atravessaram os anos de 1967 a 1979. Assim antes e depois da Declaração de Assunção de 1971, houveram problemáticas a serem solucionadas.

A historiadora Camila Belo em artigo denominado "Supremacia Regional no Cone Sul: A Usina de Itaipu como instrumento da luta diplomática entre Brasil e Argentina na década de 70"162 após delinear, como vimos antes, o contexto internacional político e econômico na década de 1960, a guerra fria, em que, em contra partida ao alinhamento cubano ao bloco soviético e à expansão do comunismo na América Latina, o presidente norte-americano Kennedy lançou a Aliança para o Progresso, conjunto de programas econômicos e sociais destinados aos países latino-americanos e financiados pelos Estados Unidos, nos quais investiram maciçamente em intervenções militares nessa região, militares esses que haviam sido preparados pela School of the Americas. A prioridade norte-americana, era impedir a expansão do comunismo, assim se estendeu uma política de interiorização do seu combate nos países sul-americanos. Essa política objetivava o apoio, tanto militar quanto financeiro, a golpes militares de direita. Brasil e Argentina sofreram tais golpes militares e estes buscaram o status de satélite norte-americano no Cone Sul. A intromissão desenfreada da guerra fria no continente levantava ciúmes e suspeitas entre os países, governados por militares que buscavam o tratamento privilegiado dos Estados Unidos em troca de envolvimento político contra a guerrilha. No Cone Sul, essas circunstancias acenderam as rivalidades entre a Argentina e o Brasil, sendo o Brasil o "campeão" do anticomunismo panamericano.

Belo finaliza a questão afirmando:

Portanto, podemos compreender que a busca pela supremacia regional foi pautada pelas políticas norte-americanas. No entanto, não exclusivamente, pois as questões que mais interferiram na pauta diplomática, durante as décadas de 1960 e 1970, das chancelarias brasileira e argentina foram os recursos hídricos da Bacia do Prata. Esses se tornaram a principal causa de problemas e disputas entre os dois países, não deixando de lado um dos principais personagens dessa desavença, o Paraguai, que mantinha como característica diplomática a política pendular de relações, tanto com a Argentina quanto com o Brasil. Tal política podemos observar nos episódios das construções da Usina hidrelé- 
trica Binacional de Itaipu, em parceria com o Brasil, e da Usina de Corpus, desta feita com a Argentina (BELO: s/d:1355) (grifos nossos).

Várias medidas diplomáticas foram criadas de 1967 a 1979, visando equalizar os conflitos decorrentes de questões relativas ao aproveitamento dos recursos hídricos da Bacia do Prata.

I Reunião de Chanceleres da Bacia do Prata - Declaração de Buenos Aires - Buenos Aires/ 1967:

Nela foi elaborada a Declaração de Buenos Aires que explicitava a posição argentina de não inviabilizar projetos de aproveitamento hídrico na Bacia do Prata e que o país portenho procurava garantir a participação de todos os Estados ribeirinhos. Nesse sentido, a atuação da argentina possibilitaria um desenvolvimento harmônico e equilibrado da região platina, em benefício dos interesses comuns de seus países (BELO: s/d:1355).

II Reunião de Chanceleres da Bacia do Prata - Ata de Santa Cruz de La Sierra - Santa Cruz de la Sierra/1968:

Nela assinou-se a Ata de Santa Cruz de La Sierra, sendo delineado os primeiros contornos jurídicos do Sistema da Bacia do Prata e aprovado o estatuto do Comitê Intergovernamental Coordenador CIC, que consistia em um organismo encarregado de examinar e coordenar os projetos multinacionais que visavam a potencialidade econômica da Bacia do Prata (BELO: s/d:1355).

III Reunião dos Chanceles da Bacia do Prata - Tratado da Bacia do Prata ou Tratado de Brasília-Brasília/1969:

Assinado o Tratado da Bacia do Prata ou Tratado de Brasília, completando a institucionalização do chamado Sistema da Bacia do Prata pelos países platinos (BELO: s/d:1355).

O Brasil em parceria com o Paraguai e o isolamento da Argentina nas negociações:

No entanto, os tratados e os atos políticos e diplomáticos não foram suficientes para dar fim aos sucessivos conflitos. Assim, as relações entre a Argentina e o Brasil na década de 1970, continuaram a se caracterizar pelas questões relacionadas ao aproveitamento hídrico da Bacia do Prata, mais

$\overline{162}$ BELO, Camila Nehring. Supremacia Regional no Cone Sul: A Usina de Itaipu como instrumento da luta diplomática entre Brasil e Argentina na década de 70. Pós-graduação em Historia/PPGH. Dourados: Universidade Federal da Grande Dourados/UFGD. Obtido em www.pph.uem.br/cih/anais/trabalhos/373.pdf . Pesquisado em fevereiro de 2013. 
precisamente, a construção da barragem de Itaipu e a consolidação da parceria político-econômica entre o Brasil e o Paraguai, isolando o país portenho das negociações e de futuros empreendimentos que envolvesse a questão. (BELO: s/d:1355).

A criação de problemas para a Argentina na continuidade, a jusante do rio Paraná: - Na Usina de Corpus:

Para além do isolamento político, as medidas tomadas para a construção de Itaipu prejudicavam economicamente a Argentina, como no episódio da usina de Corpus, pois a construção da barragem de Itaipu, em Foz do Iguaçu, inviabilizariam as obras da usina argentina, que seria construída logo abaixo de Itaipu no rio Paraná, reduzindo sua potencialidade e elevando o custo do quilowatt gerado (BELO: s/d:1355-6).

- O risco do rompimento da barragem e o perigo da esquistossomose:

Porém, as objeções portenhas contra a construção de Itaipu não se resumem ao impedimento técnico do ótimo aproveitamento de Corpus, pois a essa questão somam-se o risco do rompimento da barragem e o perigo da esquistossomose, através da infestação dos caramujos pelo represamento das águas (BELO: s/d:1356).

- Controle do curso do rio Paraná sobre as zonas mais ricas e fertéis, La Pampa, da Argentina:

Assim, o episódio de Itaipu se estende por um longo período, e concomitante ao amadurecimento do projeto de Itaipu, o Estado argentino buscava alternativas para inviabilizá-lo, travando verdadeira luta diplomática entre as chancelarias argentina e brasileira, que, acabariam por levar a questão regional para uma esfera extracontinental de atuação, dentro de um jogo realista de busca de equilíbrio pelo poder. Nesse sentido, Itaipu fazia-se presente para a Argentina como um problema de segurança, de acordo com uma linha de pensamento predominante nos setores mais nacionalistas, onde o empreendimento serviria para que o Brasil pudesse controlar o curso dos rios que atravessavam a zona mais rica do país (BELO: s/d:1356).

Os chanceleres partem para outras reuniões. Conferência da Bacia do Prata - Assunção 1971:

Essa linha de pensamento se fez evidente na Conferência da Bacia do Prata, onde o Chanceler argentino Luís Maria de Pablo Pardo propôs a tese da consulta prévia, que consistia em: 
1) nos rios internacionais contíguos, sendo a soberania compartida, qualquer aproveitamento de suas águas deverá ser precedido de acordo bilateral entre os ribeirinhos e;

2) nos rios internacionais de curso sucessivo, não sendo a soberania compartida, cada Estado pode aproveitar as águas na medida de suas necessidades, sempre que não cause prejuízo sensível a outro Estado da Bacia.

Nesse sentido, a estratégia argentina baseava-se em construir, passo a passo, uma base de argumentação para eventualmente levar a questão à Corte de Justiça Internacional. Dessa forma, o presidente argentino Lanusse iniciou uma série de visitas aos países latino-americanos, como parte da estratégia de isolar o Brasil no caso da discussão ser levada a um fórum regional ou mundial (BELO: s/d:1356).

Em artigo denominado "Brasil enfrenta até ofensiva argentina mas obtém acordo na ONU para Itaipu"163, texto formatado a partir das discussões recentes sobre o Tratato de Itaipu e tarifas que o Paraguai pretende revisar, texto esse que acaba por retomar as discussões anteriores entre Brasil e Argentina, a partir das memórias do ex-chanceler brasileiro Mário Gibson Barboza, personalidade ativa pelo Brasil, nas discussões passadas acontecidas nos fóruns internacionais entre Brasil e Argentina.

No contexto de Lanusse estar costurando estratégia de isolar o Brasil no caso da discussão ser levada a um fórum regional ou mundial, através da realização de uma série de visitas aos países latino-americanos, afirma o chanceler e Ministro brasileiro Gibson Barboza:

Nesse contexto foi que veio a frase infeliz (e inoportuna) do presidente americano, Richard Nixon, durante visita do presidente brasileiro: "para onde for o Brasil irá a America Latina". Passei o resto do tempo em que estive no ministério defewndendo-me da frase, lançada de improviso... (s/d:4).

Frase que diz muito à respeito de quem os EUA consideravam como seus reais "aliados", que obtinham o status de "satélite norte-americano" no Cone Sul. Por seu turno, dado esse "apoio", o Brasil viria a se caracterizar como um país "imperialista”, aos olhos do restante dos países latino-americanos.

No contexto da Conferencia da Bacia do Prata, sobre o aproveitamento de rios internacionais, de 3 de junho de 1971, a discussão a portas fechadas entre o chanceler brasileiro Mário Gibson Barboza e o chanceler argentino Ministro das Relações Exteriores Luis Maria de Pablo Pardo assim se deu:

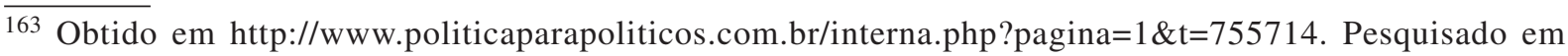
16.03.2013. 
O motivo real

Para Gibson, surgia assim a tese da consulta previa, segundo a qual nós e os paraguaios nada poderíamos fazer sem primeiro consultar os argentinos. E revela que perguntou a Luis Maria de Pablo Pardo o que aconteceria se aceitássemos essa tese e passássemos a consultá-los sobre os passos necessários à construção da usina. Respondeu-me que provavelmente o governo argentino não concordaria com nossas propostas e procuraria adiar a obra ao maximo possível. Espantei-me. Não poderia haver nada mais negativo, e o disse a Pablo Pardo.

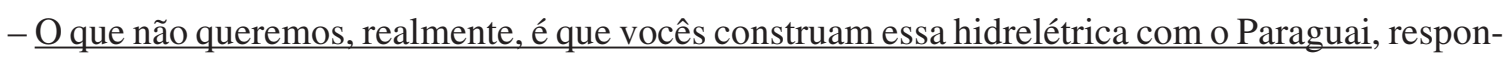
deu-me ele, com desconcertante franqueza.

E prosseguiu explicando que prevalecia na Argentina uma corrente de pensamento geoestratégico segundo o qual, se o Brasil construísse um polo econômico de tal grandeza, na fronteira norte da Argentina, pobre e escassamente habitada, praticamente dominaria aquela região. Explicoume que ele particularmente, ele não compartilhava deste receio, mas que era esta a ideia predominante no seu governo e na oposição, assim como nas classes armadas. Era o impasse (s/d:2)

Assim ao contrario da visão do Embaixador argentino, a visão de seu governo, da oposição e das classes armadas estavam corretas, era exatamente esta a intenção dos militares brasileiros, o Brasil pretendia, com todas as medidas já vistas com relação a Bolívia e ao Paraguai, e especificamente, com a construção de Itaipu, criar as condições para se alçar à supremacia sub-continental sul-americana, perante e justamente colocando em cheque a supremacia decadente da Argentina. E conseguiu ambas.

Durante a Conferencia Pablo Pardo apresentou o projeto de resolução argentino, já acima citado (1) nos rios internacionais contíguos,...; 2) nos rios internacionais de curso sucessivo,...). Sobre isso afirma Gibson Barboza:

Quando vi o projeto não acreditei no que li. Quando a Argentina apresentou a resolução à votação, todos esperavam que o Brasil se manifestasse contra. Pedi a palavra e disse: "Senhor Presidente, não só admiro completamente a esse projeto do meu colega argentino como peço que seja aprovado por aclamação. E proponho que se chame "Declaração de Assunção" " (s/d:2).

Ela foi aprovada em 03.06.1971, e passou daí em diante, aconstituir a mais forte e inviolável proteção do Brasil contra as objeções da Argentina. Por que? Atente-se para os princípios enunciados: No que se referia à Argentina aplicava-se o $2^{\circ}$ parágrafo, o dos rios internacionais de curso sucessivo. Nesse caso cada Estado, em conformidade com a Declaração de Assunção, podia aproveitar as águas do rio na medida de suas necessidades, desde que não causasse prejuízo sensível a outro Estado. 
O equívoco dos argentinos era que, no entender deles, os termos da resolução obrigavam a consultas previas, devendo ser-lhes submetido todos os planos para que se apurasse se lhes causaríamos ou não "prejuízo sensível”. Ora, a posição brasileira era de que a hidreletrica binacional não causaria “prejuízo sensível”. A ela então caberia provar o contrario, pois como se sabe, em Direito o ônus da prova cabe a quem formula a acusação ou objeção.

Nisso finquei pé e jamais admiti a tese argentina da consulta previa. (s/d:3)

Fórum Mundial da Conferência de Estocolmo - 1972, segundo Belo:

Tal fato se concretizou, e a discussão foi levada ao fórum mundial da Conferência de Estocolmo, porém, a tese argentina não obteve êxito, ficando para ser discutida e votada na XXVII Assembleia Geral das Nações Unidas, realizada no mês de agosto daquele mesmo ano, na cidade de Nova York. Assim, em reunião pessoal entre os dois Chanceleres, durante a assembleia, chegou-se a um entendimento: descartava-se o princípio da consulta prévia, sendo assegurando em seu lugar o princípio de não causar danos fronteiriços, ou seja, o princípio da informação prévia. Nesse contexto, o Brasil ficou livre para construir Itaipu, informando à Argentina sobre dados técnicos do projeto, podendo à mesma recorrer a um tribunal internacional, no caso se sentisse lesada ou houvesse algum dano decorrente da obra (BELO: s/d:1356-7).

A assinatura do Tratado de Itaipu entre Brasil e Paraguai - 1973:

O debate sobre a usina prosseguiu e, em 1973, foi assinado o Tratado de Itaipu, que mais uma vez evidenciava o caráter de exclusividade do aproveitamento do Rio Paraná entre o Brasil e o Paraguai. Porém, o tratado não isolava totalmente a Argentina, pois no documento final foi incluído o anexo B, mais conhecido como "clausula peronista", que consistia em uma condição imposta por Stroessner, que havia cedido às pressões do governo argentino. $\underline{\mathrm{O} \text { anexo } \mathrm{B}}$ agrupava o objeto central das discussões portenhas, a inviabilidade da usina de Corpus. Assim, a contenda argentino-brasileira giraria agora em torno da questão da compatibilização dos empreendimentos de Itaipu, já em obras, e de Corpus, hidrelétrica argentino-paraguaio que seria construído a jusante de Itaipu (BELO: s/d:1357) (grifos nossos).

Ao que parece essas considerações não fazem parte atualmente do Anexo B do Tratado de Itaipu.

Magnoli comenta que a preocupação real da Argentina era outra, relativa na verdade, a satelização do Paraguai pelo Brasil.

Uma intensa polemica contrapondo o Brasil à Argentina atravessou a década de 70, desde a assinatura do acordo binacional Paraguai-Brasil, em 1973, dispondo sobre a construção do aproveitamen- 
to de Itaipu. Os principais pontos de atrito localizaram-se aparentemente em questões técnicas relativas à altura e ao potencial da hidrelétrica projetada de Corpus, a jusante das Sete Quedas e dependente das especificações construtivas do lago e da hidrelétrica de Itaipu. Entretanto, a moldura geopolítica da discórdia consiste na preocupação argentina com a satelização do Paraguai pelo Brasil (MAGNOLI: 1988:41) (grifo nosso).

XXVIII Assembleia Geral das Nações Unidas - Resolução 3129/sem data, segundo Belo:

Dentro deste contexto, o Governo argentino procurou retomar as discussões a respeito da consulta prévia, e conseguiu levar a questão para a XXVIII Assembleia Geral d as Nações Unidas, onde foi aprovada a Resolução 3129, que contemplava que "a cooperação entre países interessados na exploração de ditos recursos deve desenvolver-se sobre a base de um sistema de informação e de consultas prévias, no marco das relações normais que existem entre eles". No entanto, a resolução não dispunha de caráter de coerção, sendo que sua força jurídica se daria no plano moral e na boa convivência entre os Estados (BELO: s/d:1357).

Ciclo de negociações tripartites entre Argentina, Brasil e Paraguai: O aproveitamento do Rio Paraná. 1977-1978-1979:

Assim, já no ano de 1977, sinalizando para uma tentativa de diálogo, teve início um ciclo de negociações tripartites entre Argentina, Brasil e Paraguai sobre a questão do aproveitamento do Rio Paraná. Tais reuniões tiveram continuidade nos anos de 1978 e 1979. Nesse ultimo ano, tendo o Brasil um novo Presidente e um novo Embaixador, novos ares foram dados à pauta em questão. Não deixando de lado que o contexto internacional, também, mudou durante os anos do processo da construção da Usina de Itaipu, principalmente, na medida em que as relações econômicas e políticas dos países sul-americanos em relação aos Estados Unidos foram assumindo posições cada vez mais conflitivas. Gerados pelas políticas de direitos humanos e encabeçados pelo presidente Carter (19771981), quepretendia mudar a face do império agressivo e sem escrúpulos, marca registrada do governo Nixon e de seu assessor Henry Kissinger, e, ao mesmo tempo, colocar a URSS numa posição eticamente incomoda. Ainda sobre esse assunto o autor afirma: Como era esperado, os atritos do governo Carter com as ditaduras latino-americanas começaram a estourar. Embaixadores norteamericanos pressionavam os regimes castrenses para que abrandassem os rigores das prisões políticas bem como suprimissem as praticas de tortura. (...) Carter começou a congelar a fornecimento de armamentos a vários países (Guatemala, Nicarágua, Chile e Argentina), sendo que o Brasil terminou por romper o acordo militar com os Estados Unidos, por iniciativa do governo Geisel em 1977. (BELO: s/d:1357-8) (grifos nossos). 
Acordo de Cooperação Técnico-Operativa entre Brasil, Argentina e Paraguai - 19.10.1979, segundo Belo:

Nesse contexto de mudanças, iniciou-se uma tentativa de cooperação e entendimento entre o Brasil e a Argentina e, em 19 de outubro de 1979, foi assinado o Acordo de Cooperação Técnico-Operativa entre Brasil, Argentina e Paraguai, documento que regulamentava a compatibilização de Itaipu e Corpus. Assim, a assinatura do Acordo Tripartite colocou fim ao impasse em torno dos projetos de Itaipu. Não é demais lembrar que a divergência sobre a construção da usina refletia um cenário internacional, que consistia na busca pela supremacia regional (BELO: s/d:1358).

Magnoli acrescenta o papel reservado ao Uruguai:

No esquema geopolítico imaginado pelos estrategistas brasileiros, o Uruguai deveria se transformar de Estado-tampão em país-ponte, fugaz rota de passagem em direção ao eixo oeste-leste transversal ao decadente eixo norte-sul. O superporto de Rio Grande, implantado no ponto mais meridional da Lagoa dos Patos, constitui peça deste sistema. Terminal do corredor de exportação do Rio Grande do Sul, o superporto especializa-se no escoamento de óleos vegetais, grãos, carnes e fumo, ocupando o terceiro lugar entre os portos exportadores brasileiros. A pampa uruguaia passa a ser, potencialmente, esplanada de influência brasileira (MAGNOLI: 1988:42) (grifos nossos).

Talvez não seja por acaso que o porto de Santos seja o primeiro porto brasileiro, que recebe inclusive mercadorias da Bolívia e Peru; que não seja por acaso também, que o porto de Paranaguá seja o segundo porto brasileiro, que recebe inclusive mercadorias do Paraguai; e que não seja por acaso por fim, que o porto do Rio Grande seja o terceiro porto brasileiro, que recebe inclusive mercadorias do Uruguai. Os três maiores portos brasileiros em volume de escoamento, escoam mercadorias também de vários países latino-americanos, portanto, o Brasil, detém esse controle politico-econômico sobre os demais países.

Para finalizar, quem é quem nessa teia de poderes geopolíticos, Magnoli explica:

Entretanto, o conjunto desse movimento estratégico do Brasil na América do Sul insere-se no ordenamento geral dos centros vitais do hemisfério comandado pelos Estados Unidos. A participação da Força Expedicionária Brasileira na Segunda Guerra, ao lado dos aliados, credenciou o país como sócio preferencial da nova superpotência ocidental na parte meridional do continente. $\underline{\text { A postura }}$ ambígua da Argentina no conflito mundial marginalizou-a da teia de alianças cruciais montadas durante a guerra fria. Um resultado sensível da posição ocupada pelo Brasil foi o acordo de consultas bilaterais concluído entre Brasília e o então secretário de Estado norte-americano Henry Kissinger, em 
meados da década de 70. Delegação de poderes, o acordo Brasília-Kissinger confirmava o projeto do "Brasil Grande" dos governos militares brasileiros. (MAGNOLI: 1988:42) (grifos nossos).

O que se pode concluir como resultado geopolítico é que com estas propostas de ação, a estratégia militar brasileira viria a resolver vários problemas. Com os projetos de infraestrutura criados, a ferrovia que liga o porto de Arica/Chile, passando pela Bolívia e terminando no porto de Santos/Brasil, as rodovias (Ruta 7) que ligam Assunção/Paraguai passando pela Ponte da Amizade e pela BR-277 que termina no porto de Paranaguá/Brasil, o aproveitamento hídrico do rio Paraná pela Itaipu no marco da Triplice Fronteira, trouxeram o esperado desenvolvimento econômico à região, pelo capital e força de trabalho, investidos; o ecúmeno da região foi ocupado marcando a presença do Estado na fronteira; a infraestrutura estava dada pelo Brasil, para enlaçar política e economicamente os países vizinhos, Bolivia e Paraguai, subordinando-os a hegemonia brasileira no Cone Sul; em decorrência disto o Brasil desestabilizou a supremacia argentina na mesma região.

As estratégias geopolíticas brasileiras especificamente envolvendo a construção da Itaipu foram cumpridas. O Tratado de Itaipu atrelou o Paraguai ao Brasil pelos 50 anos seguintes (1974 a 2024), período em que o tratado não pode ser revisto e que o Paraguai deve pagar sua parte da obra. Neste sentido o Paraguai está submetido política e economicamente ao Brasil, por meio das normas do Tratado de Itaipu, pela dependência ao porto de Paranaguá para escoamento de seus produtos, com as seguidas dívidas contraídas com o Brasil para construção da rodovia Ruta 7, da Ponte da Amizade e da própria Itaipu, e ainda com a presença dos brasiguaios que movimenta a economia do leste paraguaio. Portanto, o Brasil retirou o Paraguai da submissão vivida anteriormente junto à Argentina, por conta fundamentalmente da dependência do Porto de Buenos Aires, transferindo para si, de forma irremediável, o atrelamento político e econômico de forma submissa do Paraguai.

Quase um quinto (1/5) do abastecimento de energia eletrica do Brasil veio a ser coberto por Itaipu, infraestrutura esta, necessária para cobrir o déficit energético, dado o processo de industrialização vivido, num contexto de altíssimo crescimento econômico que o país atravessava nas décadas de 60 e 70. O Brasil veio a aproveitar a maior parte do potencial de energia produzido pela hidrelétrica, e paga a preço de custo, a parte da cota que utiliza do Paraguai, apesar de esse país ser obrigado a pagar a metade da construção da obra. Uma estratégia extremamente compensadora para o Brasil e nem tanto para o Paraguai. 
Os projetos de infraestrutura, que movimentam capital, que produzem empregos, faz com que aumente a população da região onde se instalam. No caso de Itaipu, como vimos, em nome da construção e operação da grande obra, ampliou de forma a intensificar enormemente, a vitalizar o ecúmeno da região brasileira e paraguaia da Tríplice Fronteira, trazendo um contingente de trabalhadores e suas respectivas famílias para as áreas de fronteira, passando a ocupar os municípios de Ciudad del Este/PY, hoje a $2^{\text {a }}$ cidade mais populosa do Paraguai e Foz do Iguaçu/ $\mathrm{BR}$, atualmente a $7^{\mathrm{a}}$ cidade mais populosa do Paraná.

Outras estratégias foram postas em ação, que envolvem manter o ecúmeno sempre com muito movimento: o desenvolvimento do turismo ambiental para visitar as Cataratas do Iguaçu em Foz do Iguaçu ( $2^{\circ}$ maior fluxo de turismo no Brasil) e Porto Iguassu na Argentina; o desenvolvimento do turismo tecnológico para visitação ás instalações de Itaipu, a obra hoje é a maior hidrelétrica do mundo em termos de potencia instalada e desenvolve vários projetos paralelos, que buscam manter a empresa sempre em evidencia na mídia; e por fim, o desenvolvimento do turismo de compras em Ciudad Del Este que se caracteriza como terceira zona franca mais movimentada do mundo. Todos os espaços do território Guarani por excelência foram se tornando, portanto, mercadorias produtoras de lucro.

Dada a movimentação de capital em todas as regiões onde foram desenvolvidos os projetos estatais, no Brasil, na Bolívia e no Paraguai, projetos esses que provocaram a imigração de populações que continuaram a permanecer nestas regiões, em termos geopolíticos por meio da vitalização do ecúmeno, significou o tamponamento dos territórios em ambos os lados das fronteiras, brasileira/boliviana e brasileira/paraguaia, resultando no primeiro caso no domínio sobre a área de soldadura localizada no Mato Grosso, Paraguai e Bolivia, e no segundo caso no tamponamento e estabelecimento de controle fronteiriço pelo Brasil e Paraguai, frente à La Misiones/Argentina. Com tais ocupações criou-se uma espécie de "barreira" humana de proteção, frente à pretensão econômica expansionista da Argentina, à norte. O conceito de "fronteiras vivas de cooperação" entre o Brasil e a Bolivia e o Brasil e o Paraguai foi posto em ação, por meio dos projetos em parceria.

É o que afirma Raffestin, quando define o Estado: O Estado existe quando uma população instalada num território exerce a própria soberania. Portanto, três sinais são mobilizados para caracterizar o Estado: a população, o território e a autoridade (RAFFESTIN: 1993:22-3).

No meio rural, o Estado, representado por todas as obras construídas de infraestrutura, especialmente com relação à Itaipu, se pode verificar, por meio de um processo seletivo, que foi substituída uma “população indesejável” para o capital - os indígenas, os pequenos camponeses, 
posseiros, arrendatários, meeiros, pequenos proprietários, os quais tiveram o papel de abrir caminho, "amansar" as terras - para ser substituída por outra “população desejável”, comprometida com o capital, que por meio muitas vezes da grilagem de terras se tornaram os "proprietários" da região, são os setores ligados ao agronegócio, que consomem agricultura mecanizada, que contribuem para expulsar os primeiros na medida em que não há mais terras disponíveis e emprego no campo, assim estes substituíram os primeiros no território. Essa elite rural que cultiva monocultura de soja, milho e trigo, fundamentalmente para exportação é apoiada pelo Estado, o qual com as exportações visa criar divisas em moeda estrangeira, inicialmente na historia brasileira para pagar a dívida externa contraída pelo Estado, recursos financeiros esses utilizados para criação de infraestrutura no processo de industrialização do país.

A substituição de uma população “indesejável” por outra “desejável” para o capital, se deu de duas principais formas: por meio da apropriação das terras em posse dos primeiros, através da grilagem $^{164}$ de terras, realizada pelo próprio poder de Estado e colonizadoras privadas; isso se deu também através do controle politico sobre algumas instituições aqui apresentadas, a FUNAI e o INCRA, controle sobre as terras das populações indígenas e das terras das populações de colonos, independentemente das leis existentes que asseguravam terras a estes; vimos também como os bancos sinalizam de forma seletiva o credito para o produtor rural, reservado somente para aqueles que possuem a propriedade da terra, sua garantia, excluindo todos os demais não proprietários, da possibilidade de se manter nas terras, na medida em que não conseguiam receber creditos bancários; essas instituições estavam claramente a serviço dos interesses econômicos dos grupos ligados ao poder de Estado e privado; contribuíram assim para a expulsão dos camponeses da região. A grilagem de terras visou a acumulação de capital pela classe dominante, futuros "proprietários de terras", concentrando maiores extensões de terras, nas mãos de muito menor numero de indivíduos, destinando as terras daquele território, considerado as melhores terras do mundo, a terra roxa, a serviço do capital.

Observando-se a forma como se deu a reorganização territorial dos municípios lindeiros após a criação do reservatório de Itaipu, a hidrelétrica se caracteriza como vimos em todos os sentidos como um “territorio de exceção ou de excepcionalidade", ali, a lei que em tese é para todos, não faz

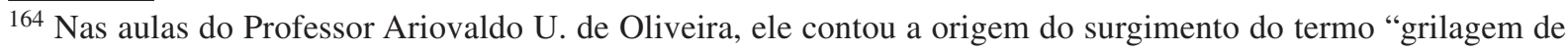
terras"; Após aprontar as escrituras falsas de terra, o pretendente a "proprietário", coloca as falsas escrituras numa gaveta cheia de grilos. Os grilos comem as beiradas das folhas, urinam e excretam fezes nos papéis, que depois de um certo tempo se tornam amarelados e comidos pelas beiradas, enfim com aspecto envelhecido, de "antigos papeis". Prontos esses papéis, são então apresentados ao poder publico, confirmando uma "antiga propriedade". Assim a grilagem é na verdade, roubo de terras por meio de documentos falsos.
} 
muito sentido. Com seus braços “tentáculos” Itaipu controla toda a região do território. No processo de desapropriação de Itaipu foram indenizados primeiro os proprietários, nesta medida estes puderam escolher "primeiro" - com capital no bolso, antes de todos os outros, e, de forma tranquila, antes da especulação que sobreveio - as melhores terras onde se reassentar, próximos dali, nas margens do reservatório, em território paranaense; em seguida foram indenizados aqueles que estavam pagando seus títulos de propriedade, os quais, recebendo apenas a parte que haviam pago, pois os bancos haviam descontado de uma só vez o restante ainda não pago, em negociação direta com Itaipu, portanto, com menor capital de giro, puderam escolher as terras restantes com mais dificuldade, se estabelendo parte no Paraná como parte deles em outras terras, já que estes últimos não conseguiram permanecer nas então, caras terras do Paraná; por fim foram indenizados todos os outros restantes, "os indesejáveis" para o capital, que por exemplo no caso dos posseiros, só receberam os valores referentes às benfeitorias, lavoura etc, o que não foi possível voltarem a se estaberlecer nas terras do Paraná, diante da pouca oferta e da alta procura, foram obrigados assim, a se dirigir para outros estados e países (Paraguai); a maioria dos indígenas foram obrigados a se dirigir para outras regiões, fundamentalmente para o Paraguai; aqueles "indesejáveis", que não conseguem ter credito nos bancos, porque não tem a propriedade para dar em garantia, somaramse à aqueles brasiguaios que já estavam anteriormente no Paraguai, que haviam sido expropriados pelo governo do Paraná e colonizadoras, desde os anos 50, indo também engrossar a colonização do leste paraguaio, "amansar" as terras, para depois novamente serem expropriados e substituídos pelas elites de brasiguaios, como o próprio ex-chanceler brasileiro Gibson Barboza, que nesta região do leste paraguaio, possui a bagatela de 80 mil hectares.

Assim na margem brasileira da Triplice Fronteira permaneceu uma elite de proprietários rurais brasileiros, aqueles que se beneficiam dos royalties pagos pela Itaipu aos 16 municípios lindeiros, elite que tem credito nos bancos, que tem apoio do Estado, região na qual a Itaipu exerce o controle sobre as populações dos municípios também pela escolha dos candidatos a cargos políticos-administrativos da região, e assim, da mesma forma, exerce o controle de fronteira, já que esses municípios às margens do reservatorio são de fronteira; e, na margem paraguaia, após os posseiros "amansarem" as terras, ocupadas também pela população Guarani, por fim, essas terras também foram ocupadas em seguida com as mesmas estratégias, colonizadoras, grilagem, etc e assim os primeiros foram substituídos por uma elite rural brasiguaia, que da mesma forma como no Brasil, passou a desenvolver o agronegócio da soja, nesta banda da fronteira.

Assim são estas, a elite rural brasileira e brasiguaia, que estão hoje nas melhores terras do Oeste do Paraná e do Leste do Paraguai, as terras roxas; instalados no entorno "abraçam" de 
forma a proteger o reservatório de Itaipu, além de proteger a própria fronteira do Brasil com o Paraguai, em troca ganham algumas benesses os royalties no Brasil e projetos no Paraguai.

A expulsão de agricultores brasileiros para o Paraguai, seguida da tomada de terras pela elite dos brasiguaios, fizeram com que ao final, em ambos os lados da fronteira, se criasse uma zona de defesa humana, fundamentalmente de "proprietários" e "brasileiros", sobre o território de domínio exercido pela Itaipu; O Brasil estabeleceu assim, por meio da implantação de relações tipicamente capitalistas, o controle político, econômico e territorial de praticamente toda região, inclusive tomando territorialmente, e ameaçando assim a soberania do Paraguai, em sua fronteira leste.

Bolívia e Paraguai, "prisioneiros geopolíticos” que antes eram dominados econômica e politicamente pela Argentina, com os projetos de infraestrutura desenvolvidos por iniciativa e por capital quase todo proveniente do Brasil, ganharam saídas pelo Atlantico, e assim acabaram por ser satelizados definitivamente para a órbita de poder brasileira, deixando, portanto, a Argentina de "mãos vazias". No contexto de disputa de hegemonia continental com a Argentina, resultou fundamentalmente na finalização da consecução de manobras geopolíticas, visando a supremacia do Brasil no Cone Sul.

Com a construção da Itaipu o Estado brasileiro se fez presente próximo à cunha Argentina, entestando de frente com Las Misiones argentinas, criando espécie de aparador de qualquer pretensão argentina de avanço territorial. Ao mesmo tempo excluíram a Argentina do processo de aproveitamento hidrelétrico por Itaipu, pois dada a localização geográfica, o projeto poderia ser Trinacional, porque não...; ainda o Estado brasileiro veio a prejudicar em termos técnicos a hidrelétrica argentina projetada, Corpus, em condomínio com o Paraguai. O Brasil criou uma espécie de isolamento político da Argentina na região, rejeitando-a no sentido de realização de qualquer obra conjunta.

Portanto, os resultados geopolíticos foram em resumo: desenvolvimento econômico das regiões onde foram instalados os projetos de infraestrutura, vitalização do ecúmeno nas mesmas regiões, exclusão da Argentina de todos os processos relatados e hegemonia geopolítica brasileira no Cone Sul.

Raffestin trata justamente dessa intenção de Itaipu, de estabelecer um poder hierárquico, de criar um sistema de malhas, nós e redes em determinado território:

Isso conduz a sistemas de malhas, de nós e redes que se imprimem no espaço e que constituem, de algum modo, o território. Não somente se realiza uma diferenciação funcional, mas ainda uma diferenciação comandada pelo principio hierárquico, que contribui para ordenar o território segundo a importância dada pelos indivíduos e/ou grupos às suas diversas ações. 
Esses sistemas de malhas, de nós e redes organizadas hierarquicamente permitem assegurar o con$\underline{\text { trole sobre aquilo que pode ser distribuído, alocado e/ou possuído. Permitem ainda impor e manter }}$ uma ou varias ordens. Enfim, permitem realizar a integração e a coesão dos territórios. Esses sistemas constituem o invólucro no qual se originam as relações de poder. Tessituras, nós e redes podem ser muito diferentes de uma sociedade para outra, mas estão sempre presentes. Quer sejam formadas a partir do principio da propriedade privada ou coletiva, nós os encontramos em todas as praticas espaciais. Se insistimos nesse fato é porque estamos em presença, sem duvida nenhuma, de "universais" ou de invariáveis propriamente geográficas. (RAFFESTIN:1993:150-1) (grifos nossos)

Quando o geógrafo é posto diante de um sistema territorial, ele descobre uma produção já elaborada, já realizada. Produção suscetível de mudanças, contudo suficientemente fixa para ser analisada.

Falar de território é fazer uma referencia implícita à noção de limite que, mesmo não sendo traçado, como em geral ocorre, exprime a relação que um grupo mantêm com uma porção do espaço. A ação desse grupo gera, de imediato, a delimitação. Sendo a ação sempre comandada por um objetivo, este é também uma delimitação em relação a outros objetivos possíveis.

Delimitar é, pois, isolar ou subtrair momentaneamente ou, ainda, manifestar um poder numa área precisa. O desenho de uma malha ou um conjunto de malhas é a consequência de uma relação com o espaço e, por conseguinte, a forma mais elementar da produção de território (RAFFESTIN: 1993: 153).

A tessitura territorial podem comportar níveis que são determinados pelas funções que devem se realizar em cada uma dessas malhas. Conforme a importância e a natureza das funções ligadas a cada nível se poderá falar de centralizações e de descentralizações.(...) Uma tessitura em vários níveis pode ter por objetivo assegurar para a população o funcionamento no nível ótimo de um conjunto de atividades, ou pode ter por objetivo assegurar o controle da população em nível ótimo. (...) É preciso distinguir a tessitura desejada da tessitura suportada pelo grupo. A tessitura "desejada" é aquela que tenta otimizar o campo operatório do grupo, enquanto a tessitura "suportada" é aquela que tenta maximizar o controle do grupo. O limite não tem, portanto, de nenhuma forma, o mesmo significado nos dois casos. No entanto, nos dois casos, a tessitura é a projeção de um sistema de limites ou de fronteiras, mais ou menos funcionalizadas. A tessitura é sempre o enquadramento do poder ou de um poder. (...) Finalmente a tessitura exprime a área de exercício dos poderes ou a área de capacidade dos poderes.

Isso nos conduz a considerar os limites não somente do ponto de vista linear, mas também do ponto de vista zonal. A percepção apreendida dos limites conduz, com frequência, a privilegiar a linha em detrimento da zona, e a experiência que temos de fronteiras contribui muito para essa maneira de ver. De fato, muitos limites são zonais na medida em que a área delimitada não é, necessariamente, a sede de uma soberania fixada de forma rígida, mas a sede de uma atividade econômica e cultural que não se 
esgota bruscamente no território, mas de maneira progressiva. É suficiente dizer que as tessituras se superpõe, se cortam e se recortam sem cessar (RAFFESTIN: 1993:153-4) (grifos nossos).

As tessituras de origem política, aquelas criadas pelo Estado, em geral tem uma permanência maior do que as resultantes de uma ação dos atores empregados na realização de um programa. (...) A diferença entre a malha política e a malha econômica esta no fato que a primeira resulta de uma decisão de um poder ratificado, legitimado, enquanto que a segunda resulta de um poder de fato. (...) As tessituras políticas não se apagam tão facilmente (...). Podem-se encontrar porções de fronteiras comunais transformadas em fronteiras nacionais. (RAFFESTIN: 1993:155)

Itaipu pratica as duas formas, estabeleceu a tessitura política e econômica no interior da zona regional. Raffestin elabora ainda sobre a questão dos grupos frente a frente, em determinada rede:

Todo ator se vê e se representa como um centro. O ponto é, de certa forma, a expressão de todo ego; individual ou coletivo. Locais de poderes, mas também locais de referencia, cuja posição se determina de uma forma absoluta ou de uma forma relativa. (...) O que importa saber é onde se situa o Outro, aquele que pode nos prejudicar ou ajudar, aquele que possui ou não tal coisa, aquele que tem acesso ou não a tal recurso etc. Os pontos simbolizam a posição dos atores. Mas esses atores não se opõem; agem e, em consequência, procuram manter relações, assegurar funções, se influenciar, se controlar, se interditar, se permitir, se distanciar ou se aproximar e, assim, criar redes entre eles. Uma rede é um sistema de linhas que desenham tramas. A rede pode assegurar aquilo para o que foi concebida e impedir outras comunicações. (RAFFESTIN: 1993:156)

Toda rede é uma imagem do poder ou, mais exatamente, do poder do ou dos atores dominantes. (RAFFESTIN: 1993:157) (grifos nossos)

$\underline{\text { O sistema (de redes) é tanto um meio como um fim. Como meio denota um território, uma organiza- }}$ ção territorial, mas como um fim, conota uma ideologia da organização. É, portanto, de uma só vez, ou alternadamente, meio e finalidade das estratégias. Toda a combinação territorial cristaliza energia e informação, estruturadas por códigos. Como objetivo, pode ser decifrado a partir das combinações estratégicas feitas pelos atores e, como meio, pode ser decifrado por meio dos ganhos e dos custos que acarreta para os atores. O sistema territorial é, portanto, produto e meio de produção. (RAFFESTIN: 1993:158) (grifos nossos)

Raffestin reflete como a territorialidade expressa a multidimensionalidade do vivido territorial:

De acordo com a nossa perspectiva, a territorialidade adquire um valor bem particular, pois reflete a multidimensionalidade do "vivido" territorial pelos membros de uma coletividade, pelas sociedades em geral. Os homens "vivem", ao mesmo tempo, o processo territorial e o produto territorial por 
intermédio de um sistema de relações existenciais e/ou produtivistas. Quer se trate de relações existenciais ou produtivistas, todas são relações de poder, visto que há interação entre os atores que procuram modificar tanto as relações com a natureza como as relações sociais. Os atores, sem se darem conta disso, se auto-modificam também. O poder é inevitável e, de modo algum, inocente. Enfim, é impossível manter uma relação que não seja marcada por ele. A territorialidade aparece então como constituída de relações mediatizadas, simétricas ou dissimétricas com a exterioridade.A territorialidade se inscreve no quadro da produção, da troca e do consumo das coisas (RAFFESTIN: 1993:158-9) (grifos nossos).

Assim fica claro as relações de poder e discriminação realizadas pelo Estado voltados aos Guarani, na medida em que foram por ele confinados na pequena área territorial do Oco'y, sofrendo as mazelas descritas. Oco'y é o retrato nu e cru do que o Estado pretende para os índios na região. Em todos os capítulos desta tese a cada situação em que os Guarani foram confrontados com o Estado (federal, estadual ou municipal) eles foram "culpabilizados" de alguma forma, sem ter realmente culpa sobre os acontecimentos. A responsabilidade sobre todos os fatos "fora da lei" era de responsabilidade, como vimos, via de regra, do próprio Estado.

Cabe ainda verificar sobre o pensamento de Raffestin, quanto ao que a territorialidade reflete:

Toda a produção do sistema territorial determina ou condiciona uma consumação deste. Tessituras, nodosidades e redes criam vizinhanças, acessos, convergências, mas também disjunções, rupturas e distanciamentos que os indivíduos e os grupos devem assumir. Cada sistema territorial segrega sua própria territorialidade, que os indivíduos e as sociedades vivem. A territorialidade se manifesta em todas as escalas espaciais e sociais; ela é consubstancial a todas as relações e seria possível dizer que, de certa forma, é a face "vivida" da face "agida" do poder.

Eis porque pensamos que a analise da territorialidade só é possível pela apreensão das relações reais recolocadas no seu contexto sócio-histórico e espaço-temporal. (RAFFESTIN: 1993:161-2) (grifos nossos).

Assim o Oco'y é a face vivida, da face "agida" do poder.

A seguir Raffestin tece algumas considerações sobre o "local e o centro", as visões que se pode ter. No caso é completamente real no que se refere ao que acontece entre os indígenas Guarani e a Itaipu, que representa o Estado na região.

(...) a região hoje parece focalizar todo um feixe de protestos endereçados ao Estado que por sua centralização contribuiu para decompor o tecido social. É certo que o Estado persegue uma lógica de unidade e da uniformidade, mas por isso mesmo substitui a diversidade pela generalidade, o que 
significa que a regra se torna um puro instrumento de ordem em vez de ser um instrumento de regulação. Poderia ser de outra forma no modo de produção capitalista, em relação ao qual se pode perguntar se ele não suprime todas as diferenças e, em particular, toda a diferença ligada ao espaço?? Se respondemos pela afirmativa, isso implica que o tempo local e o espaço local serão negados. Mas o que é esse tempo local e esse espaço local? Visto do centro é muito pouca coisa: um agregado de particularidades, de hábitos e costumes que constituem outros tantos obstáculos a uma uniformização. Visto do "local”, é muito, pois é a "territorialidade" cristalizada, ou seja, a significação da vida cotidiana. Destruir essa territorialidade é destruir toda uma simbologia cujo desaparecimento impede a manutenção de um dialogo com o meio espaço-temporal: "Nessa perspectiva, o particular, o $\underline{\text { singular, o concreto, o local se opõe ao universal, ou formal, ao Estado, da mesma forma que o }}$ folclore pode se opor a técnica". É o fim de um dialogo multidimensional: somente o dialogo alto versus baixo é mantido, o diálogo horizontal é anulado. É evidente que isso faz parte da lógica do poder, que se fundamenta na ideia do poder descendente, isto é, do poder que vem do alto e que deve mediatizar tudo. A relação se torna triangular, pois é preciso passar pelo pico para manter para manter uma relação no nível da base: o local só tem significado pelo "todo", abstrato e formalizado (RAFFESTIN: 1993:182) (grifos nossos).

Eis a demonstração de que tal trunfo é fundamentalmente a territorialidade, tal como a definimos. Nesses (...) protestos, o que está em jogo são as relações essenciais e existenciais. Por intermédio deles sente-se a vontade de afirmar a necessidade de relações simétricas com os seres, com os locais, o trabalho e o meio espaço-temporal. Retomar o poder pela base por meio do cotidiano e, sobretudo, recuperar uma malha territorial que possa permitir o exercício desse poder. Em resumo, trata-se de redescobrir, para as coletividades, malhas concretas que se oponham às malhas abstratas propostas pelo Estado. Estamos certamente no limiar de uma era na qual a região, a que é vivida, desempenhará um papel cada vez maior para as diversas comunidades (RAFFESTIN: 1993:185) (grifos nossos).

Ainda é interessante observar o pensamento de Raffestin quanto "as capitais e o poder". Em nosso caso pode-se ler que a capital da região em que tratamos, no Oeste do Paraná e Triplice Fronteira, pode-se ler que é a propria Itaipu.

Em matéria econômica, o comando é quase sempre efetuado a partir da capital, isto é, as decisões são tomadas pelas sedes sociais que ali estão instaladas. $\underline{\text { À aparente dispersão dos estabelecimentos }}$ pode corresponder uma concentração decisória.

Muitas vezes as decisões são tomadas na "capital” econômica... . A dispersão visível corresponde uma concentração, senão invisível, ao menos dificilmente apreensível. Os sistemas de intenções e ações são controlados a partir de uma "capital”" ou centralidade. O quadro espaço-temporal do local de produção não é autônomo, depende do centro de decisão (RAFFESTIN: 1993:194) (grifos nossos). 


\title{
7.4. Ser indígena numa sociedade regida pelo modo capitalista de produção
}

\author{
Antigamente os brancos matavam a gente à bala. Hoje vocês matam a gente aos pouquinhos com \\ caneta e papel. Eu não vou assinar nada. \\ Fala do Cacique Simão ao Juiz Federal Rony Ferreira quando de sua ida a Terra Indigena do Oco’y. \\ Segundo o Cacique o Juiz esperava que ele assinasse um documento em que se comprometia a \\ retirar famílias Guarani provenientes desta aldeia, que haviam reocupado terras florestadas, que \\ foram desses indígenas em passado recente, no Parque Nacional do Iguaçu.
}

Revendo este trabalho podemos verificar algumas projeções que indivíduos provenientes das classes dominantes procuram fazer sobre as sociedades indígenas, por meio de processos socioeconômicos, políticos, ideológicos e territoriais de cunho anti-indígenas. Os indígenas são relacionados a imagens e ações discriminatórias relativas à "entraves ao progresso", "atraso", "arcaísmo", "extinção", "genocídio”, "assimilacionismo”, "integracionismo”, “etnocidio", "aculturação", até afirmam que eles "não existem no território" ou que ainda "existiram apenas num passado remoto". Assim, apesar da Constituição Federal do Brasil reconhecer o direito aos modos de vida e cultura, próprios dos indígenas nas terras que habitam, vem sendo infringido pelas classes dominantes ao longo da historia, em resumo três alternativas a eles que cruamente são expostas a seguir: ou "se expulsa para fora das terras" ou "se mata esses indivíduos e se fica com as terras" ou "fazem com que se entreguem, sendo desta forma integrado, assimilado pela cultura nacional e assim os indígenas perdem as terras".

Todo o material produzido sobre a "História" da região por Itaipu e PNI e seus agregados (inclusive um historiador), como vimos trata a historia real dos índios Guarani de forma inverídica. Tendem a dizer que os Guarani supostamente "viveram há muito tempo atrás, quase na préhistoria da região". Impõe seus códigos, apesar de inverídicos, exercendo certo controle da informação na região. Raffestin também trata dessa materia:

Em matéria sociocultural, a capital domina os sistemas sêmicos e, por intermédio deles, age sobre o meio que dela depende. A língua, a cultura, a informação muitas vezes são determinadas pelos paradigmas que impõe a capital. A capital desempenha, nesse caso, um papel normativo: a língua, (...) pode ser a que se fala na capital. A cultura é aquela ratificada pela capital, (...). a informação chega e parte da capital: $\underline{\text { é o controle sobre o conjunto dos instrumentos de comunicação e sobre o }}$ conteúdo que veiculam.

Portanto, a capital faz uma mais-valia constante sobre o plano espacial, pois suas decisões e suas normas restringem o campo das intenções e das ações das outras regiões. Mas também faz uma mais-valia temporal, no sentido de que seus modelos são progressivamente mais seguidos que os de 
outras regiões. O tempo estritamente regional também se restringe, em proveito do tempo da capital. A capital está pois, com frequência, na origem de uma mais-valia espaço-temporal, uma vez que devora o espaço e o tempo social de outras regiões, impondo seus códigos. Esse controle dos códigos é realizado pelos atores sintagmáticos, que combinam suas estratégias a partir da capital. Maisvalia espacial, pois a capital impõe espaços junto com a ajuda de seus códigos, e mais-valia temporal, pois a capital obriga as outras a trabalharem seus códigos, a utilizá-los por um tempo cada vez maior. Assim, a capital desvaloriza a informação da marginalidade, impondo a da centralidade, isto é, a sua. (RAFFESTIN: 1993:195) (grifos nossos).

Raffestin na Terceira Parte de seu livro em "O Território e o Poder. Capítulo IV - As redes e o poder. I - A circulação e a comunicação" ele completa este raciocínio.

A circulação e a comunicação são as duas faces da mobilidade. Por serem complementares, estão presentes em todas as estratégias que os atores desencadeiam para dominar as superfícies e os pontos por meio da gestão e do controle das distancias. (RAFFESTIN: 1993:200) (grifos nossos). (...) a circulação é visível pelo fluxo de homens e de bens que mobiliza, pelas infra-estruturas que supõe. A circulação é a imagem do poder, mas o poder nem sempre quer se mostrar e, mesmo quando o faz, é sem o desejar. "A circulação é sinal de potencia". (...) O ideal do poder é ver sem ser visto. É o porque de a comunicação ter adquirido uma tal importância na sociedade contemporânea: ela pode se dissimular. Nesse caso, o poder pode controlar, vigiar, interceptar, praticamente sem ser visto. O poder compreendeu que sua eficácia seria tanto maior quanto menos fosse visível. A verdadeira fonte do poder deve, portanto, ser procurada bem mais na comunicação que na circulação. (RAFFESTIN: 1993:202) (grifos nossos)

É relativamente fácil conhecer os fluxos de homens e bens nas redes de transporte. Desta forma liberase às claras os dados sobre a circulação: é a sequencia "liberal" das estratégias do poder. Por outro lado, só se libera muito pouca coisa sobre a comunicação da informação, pois é bem mais fácil dissimulála, escondê-la: é a sequencia "totalitária" da estratégia do poder. A função de mobilidade do poder sóé bem conhecida em matéria de circulação, e pouco ou nada em matéria de comunicação: vulgarização da rede de circulação, privatização da rede de comunicação. Não é por acaso que os atores seguem essa estratégia paradoxal: eles compreenderam que os meios se deslocam cada vez mais em direção à informação, cuja gestão e controle são facilitados pelas técnicas atuais. Essas estratégias paradoxais conduzem a transparência dos fluxos materiais e à opacidade dos fluxos imateriais.

(...) o movimento da informação comanda a mobilidade dos seres e das coisas. O espaço central da comunicação vampiriza o espaço periférico da circulação. A comunicação se alimenta de circulação: o território concreto é transformado em informação e se torna um território abstrato e representado, isto é, deixa-se ver todos os fenômenos particulares e confusos e esconde-se o essencial que se torna organizado (RAFFESTIN: 1993:203) (grifos nossos). 
Daí as informações inverídicas sobre a ocupação tradicional dos Guarani na região do oeste paranaense, veiculadas pela Itaipu, PNI e seguidores: veiculam como se os índios tivessem habitado a região somente a milhares de anos atrás. Folders, revistas e até um livro de historia da região veiculam dessa forma. Continua Raffestin:

$\underline{\text { É conveniente, pois, decifrar as redes por meio de sua historia e do território no qual estão instala- }}$ das, por meio dos modos de produção que permitiram a sua instalação e das técnicas que lhe deram forma. As redes não são somente a exibição do poder, mas são ainda feitas à imagem do poder. (RAFFESTIN: 1993:209)

O espaço não é um dado, mas uma criação. É admitir, que há laços decisivos entre a ocupação do espaço e uma certa orientação da vida social (RAFFESTIN: 1993:210) (grifos nossos).

Quem procura tomar o poder se apropria pouco a pouco das redes de circulação e de comunicação: controle dos eixos rodoviários e ferroviários, controle das redes de alimentação de energia, controle das centrais telefônicas, das estações de radio e televisão. Controlar as redes é controlar os homens e é impor-lhes uma nova ordem que substituirá a antiga. (RAFFESTIN: 1993:213) (grifos nossos).

Nada mais evidente no caso de Itaipu. Na região quase tudo está ligado ao que a Itaipu informa ou permite informar.

Raffestin na “Terceira Parte. O Território e o Poder. Capítulo IV - As redes e o poder. III Os atores e a comunicação", finaliza da seguinte forma:

(...) é comum falar do poder da mídia. É um abuso de termo, visto que as mídias não são um "poder", mas instrumentos de poder combinados em estratégias. É exatamente por isso que os atores políticos ou econômicos se garantem no domínio das redes de comunicação: imprensa, radio, televisão, correio, telegrafo e telefone. Qualquer que sejam as medidas tomadas, a informação acaba sempre por passar, pois se infiltra em toda parte: as barreiras em volta dela não servem para nada. (RAFFESTIN: 1993:220) (grifos nossos)

A toda ação há uma reação. Este trabalho é a maior prova do que foi dito acima.

Em artigo do antropólogo Rinaldo S. V. Arruda, denominado "Imagens do Índio: Signos da Intolerância" 165 ele trata do contexto que apontamos no inicio deste subcapítulo. Vejamos alguns trechos de suas afirmações:

$\overline{165}$ ARRUDA, Rinaldo S. V. Imagens do Índio: Signos da Intolerância. In: Grupioni, L.D.B., VIDAL. L., FISCHMANN, R. (orgs.). Povos Indígenas e Tolerância: construindo praticas de respeito e solidariedade. São Paulo: EDUSP, 2001, p . 43 a 61. 
No Brasil, o desconhecimento ou o desprezo pelo papel da diversidade cultural no estimulo e enriquecimento das dinâmicas sociais e, principalmente, a recusa etnocêntrica da contemporaneidade de sociedades de orientação cultural diversa, tem sedimentado uma visão quase sempre negativa das sociedades indígenas. Na postura ideológica predominante, os índios não contam para o nosso futuro, já que são considerados uma excrescência arcaica, ainda que teimosa, de uma "pré-brasilidade". Segundo essa visão estariam destinados a perder sua cultura própria assimilando-se à onda civilizatória ocidental por meio do processo de aculturação (ARRUDA: 2001:43-4).

As sociedades indígenas tem sido campo fértil para as mais diversas projeções, balizadas ao longo da historia do Brasil por duas visões contraditórias: a do índio como metáfora de liberdade natural e a do índio como imagem do "atraso" a ser superado. Porém, apesar de opostas, essas perspectivas compartilhavam até bem pouco tempo, a convicção sobre a fatalidade de extinção dessas sociedades. (...) Mas embora sejam constantes e recorrentes os processos genocidas e etnocidas que marcam as relações da sociedade brasileira com as sociedades nativas, esse vaticínio parece jamais se completar. (...) As populações indígenas tem apresentado nas últimas décadas um crescimento em taxas maiores do que as da população brasileira. (...) Décadas (às vezes séculos, como foi o caso dos Guarani e muitos outros) de proselitismo religioso e outras pressões de cunho material e ideológico deixam suas marcas, mas parecem não anular a especificidade histórica e sociocultural de povos tidos até então como "deculturados”, vítimas irreversíveis de um etnocídio que se pensava absoluto. (...) entretanto, a constatação de que as sociedades indígenas não estão num estado terminal, de que são povos contemporâneos, companheiros do passado no presente e possivelmente parceiros no futuro, não significa que os processos socioeconômicos e políticos anti-indígenas não continuem predominantes, podendo levar a reversão dessas possibilidades (ARRUDA: 2001:45).

O Estado e os governos que tem representado os povos indígenas relutam em aceitar a realidade pluricultural e multiétnica da sociedade brasileira. As sociedades indígenas tem sido vistas como um problema de segurança nacional e como entraves ao progresso. Até mesmo os avanços da Constituição de 1988 são ainda em grande parte retóricos: das terras indígenas brasileiras só cerca de $40 \%$ estão totalmente regularizadas, ainda que houvesse um prazo constitucional de demarcá-las todas até o ano de 1993 (ARRUDA: 2001:46) (grifos nossos).

O índio é visualizado como um entrave arcaico ao crescimento econômico (...), como uma espécie de "latifundiario" improdutivo, ignorante, indolente e desqualificado, injustificadamente detentor da posse de vastas extensões de terra, que, se abertas ao "trabalho produtivo", supostamente resolveriam a questão da pobreza e do desenvolvimento (ARRUDA: 2001:47).

Dessa forma convém refletir, como se situa as sociedades indígenas em seus territórios, no contexto da lógica de construção do território, sob o modo de produção capitalista. Os indígenas para o capital, não se encaixam nem bem como "proletariado" e nem bem como "proprietários de terras". 
Supostamente poderiam ser considerados, "proletariado", se o projeto dos governos militares autoritários tivesse vingado, "assimilados" e "integrados" à sociedade nacional, seriam considerados reserva de mão-de-obra barata, não especializada, e ainda, despossuídos de suas terras. Quando os indígenas eventualmente trabalham para os não-índios, para as classes dominantes eles representam uma espécie de proletariado que em ocasiões raras e pontuais pode-se usar sua força de trabalho. Em geral, como boias-frias, se caracterizam por uma força de trabalho discriminada, na medida em que realizam trabalhos, nos quais seus empregadores não reconhecem seus direitos trabalhistas. Invariavelmente o empregador paga menos ao indígena do que a qualquer outro trabalhador, e se coloca frente à situação, como se tivesse ajudando o "pobre índio", oferecendo-lhe um emprego temporário e desregulamentado. Raffestin reflete a este respeito:

Há toda uma discriminação no que se refere à energia e informação. A relação de trabalho é particularmente dissimétrica para os grupos raciais ou étnicos submetidos à discriminação. O que isso quer dizer? Que, dessa vez é o tempo dos indivíduos que é discriminado ou, se preferirmos, que o tempo de certos grupos vale menos que os de outros. Entre brancos e negros, as diferenças salariais na África do Sul podem ter, para trabalhos pouco diferentes, uma relação de 1 para 10. Portanto, a mesma quantidade de trabalho fornecida não dá direito a mesma quantidade de energia simbólica, ou seja, de dinheiro. Sem dúvida, as empresas exploram amplamente este fato. Isso, é claro, também se traduz por um acesso diferencial aos recursos, o que do ponto de vista estritamente econômico, corresponde a uma contração do mercado interno artificialmente provocado. Tanto o acesso a energia como o acesso à informação são bloqueados e conhecemos as formas revoltantes que isso pode tomar: escolas, corpos docentes e programas diferentes, conforme o grupo étnico (RAFFESTIN: 1993:135) (grifos nossos).

E nem bem são considerados os indígenas como "proprietários de terras", apesar de legalmente possuírem o uso exclusivo (em tese, dadas as invasões), eles possuem apenas a posse de suas terras, o proprietário na verdade é a União, o Estado; Acresce ao fato que os indígenas não utilizam seus territórios, através de uma visão exclusivamente voltada para a produtividade, como a maioria dos grandes proprietários de terras, o faz. Na posse de suas terras, elas significam um espaço de sobrevivência física e cultural, espaço em que se dá a historia de seus ascendentes e descendentes, espaço modelado pelas formas de viver a sua cultura, território o qual preservam ambientalmente em sua biodiversidade. Originalmente eram completamente auto-suficientes, por meio de uma economia de auto-consumo; ainda hoje a produção indígena é destinada basicamente para a satisfação de suas próprias necessidades de uso, com alguma produção de excedente, 
em pequena escala, para a troca no mercado por produtos de primeira necessidade. Em termos étnicos são povos socioculturalmente diferentes do povo brasileiro e não pretendem, não vislumbram e não querem, não se ajustam ao modo de vida proposto, em uma sociedade capitalista. Os povos indígenas não estão inseridos nas relações de mercado: não arrendam, não empregam, não produzem para o mercado, consomem de forma insipiente os produtos do mercado, não geram renda; não giram, enfim, capital, com a terra que possuem. Assim o território indígena e sua população, quase não participam do mercado capitalista.

Dada à ocupação indígena de fatias consideráveis do país, para o capital e suas forças políticas, essa ocupação indígena do território é uma "excrescência residual do passado", não significam mais do que "um entrave a ser superado", terras que poderiam - consideram, "estar sendo utilizadas na forma capitalista de produção". Na visão do agronegócio as terras são vistas exclusivamente como meio de produção; não se conformam com essa imagem que criaram dos indígenas: de "latifundiários improdutivos" que "não merecem estar nessa grande quantidade de terras", dado que "não produzem em larga escala monoculturas, para venda no mercado". Porque ocupam territórios consideráveis, caros ao capital, que nas mãos destes capitalistas, elas seriam reduzidas a meio de produção, o qual geraria renda e lucro; se os indígenas fossem "integrados" perderiam suas terras e se tornariam mão-de-obra barata; o preconceito se torna então ideologia: imagens do atraso, preguiçosos etc, são a conotação que é imprimida aos indígenas. Uma parte da sociedade dominante desenvolve uma espécie de visão, sempre etnocêntrica, de que supostamente pelo exposto, se percebem como tendo mais direitos às terras do que os primeiros habitantes, os indígenas. Daí o interesse na tomada das terras indígenas pela burguesia, pelos proprietários de terras ou mesmo pelo Estado. É a discriminação espacial que Raffestin se refere. Em seu livro na "Segunda Parte. A população e o poder. Capítulo IV - Raças, etnia e poder. II- As formas de discriminação", assim ele se refere.

Numa sociedade multirracial ou multiétnica há, potencialmente, todo um conjunto de dispositivos possíveis para que um grupo aumente seus trunfos, em detrimento de outros grupos. É a introdução do conceito de discriminação que permite reduzir a competição do grupo ou dos grupos que constituem concorrentes em relação aos trunfos. A discriminação toma formas diversas que evocaremos. Consideremos dois grupos: um majoritário, o grupo A, e outro minoritário, o grupo B.

Uma primeira discriminação pode ser de natureza espacial. O grupo A pode impor ao grupo B uma localização determinada, uma certa região do território (...). A discriminação espacial raramente é a única discriminação pela qual um grupo pode ser atingido; ela em geral é acompanhada de outras medidas, mas é conveniente analisá-la primeiro sozinha. Na pratica, a discriminação espacial tende 
a interditar, aos membros do grupo $\mathrm{B}, \mathrm{o}$ acesso às outras partes do território, de uma forma total ou parcial. (RAFFESTIN: 1993:132) (grifos nossos).

Dialogando com Raffestin: No caso o grupo B foi isolado pelo grupo A numa área muito diminuta, muito menor do que era possível ao grupo sobreviver, somadas as condições ambientais desfavoráveis, pouco espaço para o plantio, água poluída, incidencia de agrotóxicos, etc; o território foi destinado pelo grupo A, a poucas famílias, quando eram na verdade muitas, as famílias, quase todas vieram a se instalar no novo território, acrescido do fato que normalmente essas famílias apresentam crescimento demográfico alto, o que acaba por gerar a superpopulação num território limitado, engessado, interditado para expansão. Raffestin novamente:

Trata-se, portanto, de isolar o grupo B, para melhor controlá-lo e dominá-lo. Melhor dizendo as relações do grupo B com o espaço são determinadas pelo grupo A. Essas relações não são autônomas e as coisas se passam como se fronteiras invisíveis fossem traçadas em torno do grupo B. O raio de ação do grupo B é limitado, o que implica, em geral, que ele é mantido ali desde que se dedique a atividades consideradas possíveis no território em que se instalou e de onde não pode sair ou só dificilmente pode fazê-lo. Trata-se, portanto, de uma relação dissimétrica com o espaço; relação imposta do exterior pelo grupo A, que disso tira todas as espécies de vantagens, uma vez que limita a concorrência do grupo B na maior parte do território. (RAFFESTIN: 1993:133)

Não tendo como sobreviver somente a partir deste território, passaram a ficar reféns das cestas básicas que o grupo A (Itaipu) fornece. A ameaça de retirada das cestas básicas por qualquer motivo que contrarie o grupo A torna o grupo B seus reféns. Com elas, veio também a retirada do Cacique legítimo do grupo B e a colocação do Cacique que foi "preparado" pelo grupo A.

Portanto, a discriminação espacial é um meio de impor, de fato ou formalmente, relações dissimétricas. Quais são as principais consequências dessa discriminação espacial? Em essência, mas não somente, a superpopulação nas zonas discriminadas. Sabe-se que a superpopulação nos guetos negros americanos determina taxas de natalidade e mortalidade muito elevadas. As taxas de doenças e criminalidade também são muito altas. Os guetos negros são verdadeiras bombas depositadas no coração das grandes cidades americanas, apesar dos esforços do governo americano no decorrer desses últimos 20 anos. No fim, as relações dissimétricas impostas pela população branca à população negra acaba por se voltar contra os brancos, que devem despender uma parte de suas finanças para a redução dos efeitos perigosos da discriminação espacial. Os movimentos de revolta que sacudiram as cidades americanas mostraram os perigos que uma minoria oprimida podia esconder. 
Como já dissemos, essa discriminação espacial encobre outras que são consequência da primeira, cujo caráter espetacular e visível não nos deixa esquecer a exploração das diferenças raciais e étnicas. (RAFFESTIN: 1993:134-5)

Vivemos uma época diferente da ditadura militar em que havia um autoritarismo político dedicado à implantação de um modelo econômico tipicamente capitalista. Hoje depois de implantado este modelo há uma aparente democracia, mas permanece um autoritarismo econômico subreptício e seletivo; uma espécie de censura previa a tudo que não colabora com o desenvolvimento do modo capitalista de produção e abertura total somente ao que colabora com tal modo de produção, ou seja, o que pode se tornar de alguma forma, mercadoria. Os povos indígenas como se pode verificar ao longo desta tese, ainda vivem em uma ditadura política ditada pelos interesses econômicos das classes dominantes.

Em artigo do advogado Tarso de Melo denominado "Ser índio em tempos de mercadoria" 166 apesar da ironia caustica com que trata o tema, ele afirma de forma nua e crua, o que vem sendo a realidade indígena Guarani.

A recente divulgação da carta que uma comunidade indígena Guarani-Kaiowá de Dourados (MS) enviou à Justiça Federal pedindo que, uma vez que não lhes é permitido viver da forma que consideram digna, seja logo decretada a morte de toda a comunidade, por cruel que pareça, não deveria causar espanto. Condenados à morte, sejamos sinceros, os índios brasileiros já estão há mais de 500 anos, mas a execução da sentença é lenta, torturante e cínica.

O que espanta, desta vez, é que os próprios Guarani-Kaiowá tenham pedido ao seu inimigo mais ou menos declarado - esta coisa que insistimos em tratar como "civilização" - que seja mais sincero. $\underline{\text { Sim, mais sincero e diga claramente que o índio não interessa, não se encaixa no modo de vida a que }}$ todos, sem privilégios (ouçam o eco iluminista...), estamos condenados.

Aprendemos com Marx que o capital libertou o trabalhador da escravidão à força, típica de formações econômicas pré-capitalistas, para submetê-lo a uma forma diversa de escravidão: o trabalho assalariado, a compra e venda da força de trabalho. (Sim, ainda há trabalho escravo - e ele não é incompatível com o capitalismo. Apenas não pode ser a regra, porque a valorização do capital depende de sua circulação também na forma de salário, o que não impede que um ou outro capitalista faça uso da extração violenta da força de trabalho).

\footnotetext{
$\overline{166}$ Obtido em http://editora.expressaopopular.com.br/noticia/batalha-das-ideias-ser-indio-em-tempos-de-mercadoria. Pesquisado em dezembro de 2012. Tarso de Melo é advogado, mestre e doutor em Direito pela FDUSP, professor da FACAMP e coordenador de pós-graduação da Faculdade de Direito de São Bernardo do Campo. É um dos coordenadores da coleção Direitos e Lutas Sociais (Dobra/Outras Expressões).
} 
O trabalho como mercadoria é - em regra, insisto - o único compatível com uma sociedade em que tudo é mercadoria, em que o acesso aos bens indispensáveis à existência passa inescapavelmente pelo mercado: pagou, tem; não pagou, não tem. Ponto final. É óbvio, neste esquema rigoroso de trocas, que não se tolere qualquer exceção à lógica mercantil. Em outras palavras, o que o capitalismo não tolera é a manutenção, em seu mundo, do que não é mercadoria e, ainda por cima, impede o livre desenvolvimento de suas forças.

O que são, afinal, os índios para a ordem capitalista? Um ônus, um entrave, uma aberração, mas que, por não ser conveniente à "civilização" assim declará-los, recebem da nossa Constituição instrumentos para sua proteção que são constantemente "desmoralizados" (e é inevitável usar aqui esta palavra porque a proteção aos índios assume exatamente uma feição moral na ordem jurídica, ao mostrar como somos gratos e responsáveis com nossas, digamos, “origens”), como na decisão da Justiça Federal que exterminou, por enquanto, a paciência dos índios e sua esperança de viver no espaço que a "civilização" reservou àqueles que a antecederam ${ }^{167}$. E sobreviveram à sua afirmação.

A carta à Justiça Federal não deixa dúvida: os Guarani-Kaiowá cansaram de reivindicar o direito de $\underline{\text { sobreviver como índios e não aceitam viver senão como índios. }}$ Não aceitam migrar para o regime do trabalho precário (prestado, no geral, a quem tomou suas terras) ou da mendicância às margens do exuberante mundo das mercadorias. O "bilhete suicida" que essa comunidade manda para nós, não o tomem como chantagem, "drama" etc. É um "basta", um "chega", mas principalmente uma prova de que os índios, com sua habitual sabedoria, entenderam melhor do capitalismo e de sua "civilização" do que nós, que nele estamos afundados até o pescoço - e um pouco mais.

Não só sua própria existência, mas a forma como os índios insistem em mantê-la é uma grande afronta ao capital e sua lógica. Vejam o que diz a carta: "Nós comunidades cultivamos o solo, produzimos a alimentação aqui mesmo, plantamos mandioca, milho, batata-doce, banana, mamão, feijão e criamos de animais domésticos, como galinhas e patos. Aqui agora não passamos fome mais. As nossas crianças e adolescentes são bem alimentadas e felizes, não estão pensando em prática de suicídio. Assim, há uma década, nesses 12 hectares estamos tentando sobreviver de formas saudáveis e felizes, resgatando o nosso modo de ser e viver Guarani-Kaiowá, toda a noite participando de nosso ritual religioso jeroky e guachire". Como assim alimentadas, saudáveis e felizes? Sem ter pago por isso? Este intercâmbio do homem com seus iguais e com a natureza orientado apenas e tão-somente por suas necessidades - do espírito e do estômago - é inadmissível para o capital. Mais ainda: é sobre sua negação que se constituiu a forma como vivemos nos últimos 3 ou 4 séculos.

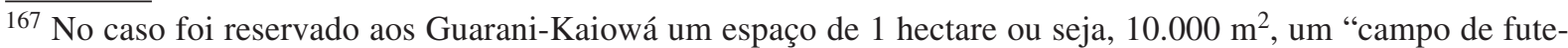
bol”, para 170 famílias.
} 


\section{Os índios, neste contexto, são não apenas supérfluos, mas uma espécie de mau exemplo a ser apagado do horizonte de formas de "ser e viver" à venda - sim, à venda - em nosso tempo. $\underline{\mathrm{O}}$}

que será de uma sociedade "sem alternativas" se tolerar uma forma de vida que se nega à troca, ao dinheiro, à concentração da riqueza, ao desperdício? Desta vez, a pedido dos próprios índios, a "civilização" terá oportunidade de declarar o que pensa a este respeito.

A propósito, a Constituição brasileira afirma que "São reconhecidos aos índios sua organização social, costumes, línguas, crenças e tradições, e os direitos originários sobre as terras que tradicionalmente ocupam, competindo à União demarcá-las, proteger e fazer respeitar todos os seus bens” (art. 231). Se nossas autoridades, que têm sua função justificada por essa mesma Constituição, não se preocuparem em respeitar tais palavras, será muito difícil evitar que se confirmem a tragédia da carta dos índios e o pessimismo das linhas acima. Mas também será cada vez mais difícil - creio e espero manter os grupos oprimidos e suas reivindicações dentro de comportados limites legais.

Outra questão a ser apontada é a manutenção da língua por parte dos povos indígenas em especial pelos Guarani. Esta é uma ação também sociopolítica por parte dos indígenas, na medida em que preserva os próprios códigos, em detrimento das lógicas do dominador. Raffestin reflete a este respeito:

A língua é exemplar porque fornece um modelo de análise para todas as outras propriedades qualitativas da população. A resistência por meio da língua se coloca nos mesmos termos da religião, da etnia ou da raça. Toda tentativa de eliminação das diferenças está repleta de um poder opressor que procura realizar, no espaço e no tempo, um campo de ação para se manifestar. Todo poder que se estabelece unifica, centraliza, concentra, homogeneíza, comprime, esmaga de maneira a só trabalhar com uma massa isotrópica. O poder se nutre de isotropia. A anisotropia oferece resistências. Em toda política de integração e de unificação existe uma vontade de apagar as diferenças. Por quê? Porque as resistências se engancham nessas diferenças, que são outros tantos obstáculos ao desenvolvimento de um poder total. Poder total e diferenças são incompatíveis. Contudo, as diferenças existem e sua supressão não tem nenhum fundamento teórico senão eventualmente um fundamento prático. É a "naturalização” do conceito de unidade. (RAFESTTIN: 1993:118).

Depois de discorrer sobre a evolução dos direitos das minorias no mundo, Raffestin declara:

A Declaração Universal dos Direitos do Homem, que postula relações simétricas, não consegue se impor e é possível desenhar um mapa mundial das liberdades achincalhadas.

A falta de relações simétricas significa que a ação política se faz conforme as estratégias, que combinam códigos procurando homogeneizar os diferentes elementos à disposição. 
O pluralismo e a autonomia que daí decorrem não são valores políticos dominantes. Pode-se duvidar que, no contexto atual, um dia venham a sê-lo. A necessidade do pluralismo racial e étnico só pode ser redescoberta por ocasião de uma crise do sistema ocidental (...).

A eliminação da diferença está relacionada a destruição da informação. É paradoxal que estejamos conscientes desse fenômeno, que é essencial no mundo físico, mas bem menos no mundo humano. Procuramos proteger a "diferença" no mundo vegetal e animal, mas nos esforçamos em destruir a "diferença" no mundo humano. Finalmente, corremos o risco de, a longo prazo, sermos vitimas dessa atitude e desse comportamento (RAFFESTIN: 1993:138-9) (grifos nossos).

Toda atenção que este trabalho teve com relação a expor os fatos ocorridos junto aos Guarani e as leis indigenistas correspondentes, não serviram para que as autoridades estatais mudassem o quadro vivido pelos indígenas, o que demonstra que os interesses econômicos dominantes, assim como os preconceitos dominantes continuam apesar da aparente democracia, a se colocar acima da lei, paradoxalmente lei criada pelo próprio Estado para defender os povos indígenas. Assim de que serve a lei se ela não é cumprida pelo próprio Estado, que a impõe à sociedade? 


\section{CONSIDERAÇÕES FINAIS}

A situação fundiária e portanto, de vida extremamente frágil porque passam os Guarani do Oco'y é resultado de inúmeros esbulhos e ações genocidas promovidas pelos sucessivos governos, demonstrada por meio das ações institucionais envolvidas com esta questão indígena em específico, do Oco'y, pelas instituições estatais IBAMA, Itaipu, INCRA, FUNAI e Justiça Federal de Foz do Iguaçu, ao longo de toda esta tese.

Infelizmente por falta de tempo hábil não foi possível expor o desenlace da situação dos indígenas do Oco'y junto ao governo brasileiro. Tentaremos resumi-las aqui, nestas considerações finais. Em anexo, juntamos os principais documentos a esse respeito.

Nos sete anos de convivência com o Guarani do Oco’y, eles manifestaram várias vezes a vontade de reocupar terras florestadas, que antes, eram imemorialmente ocupadas por eles próprios. Vários artigos de jornais demonstram essa intenção ao longo do tempo (Anexo 1). As terras a serem reocupadas haviam se transformado em Unidade de Conservação, o Parque Nacional do Iguaçu/IBAMA. Os Guarani não pretendiam reaver todos os 185.000 hectares do PNI, muito menos as Cataratas do Iguaçu, embora tivessem sido sua posse (Aldeia Guarani e São João Velho), mas uma parte, que pudessem viver, afastados do turismo, conforme seus costumes tradicionais.

Em 03.09.2005 algumas famílias do Oco’y reocuparam essas únicas terras florestadas na região do Oeste paranaense, dado que a vegetação primária no estado do Paraná, fundamentalmente no Oeste, foi praticamente suprimida, em favor de extensas monoculturas, restando apenas poucas áreas com reservas florestais, conforme se pode verificar na analise da evolução do desmatamento no estado do Paraná 1900-2000. É na mata alta onde se pode realizar o modo de vida específico dos Guarani. 

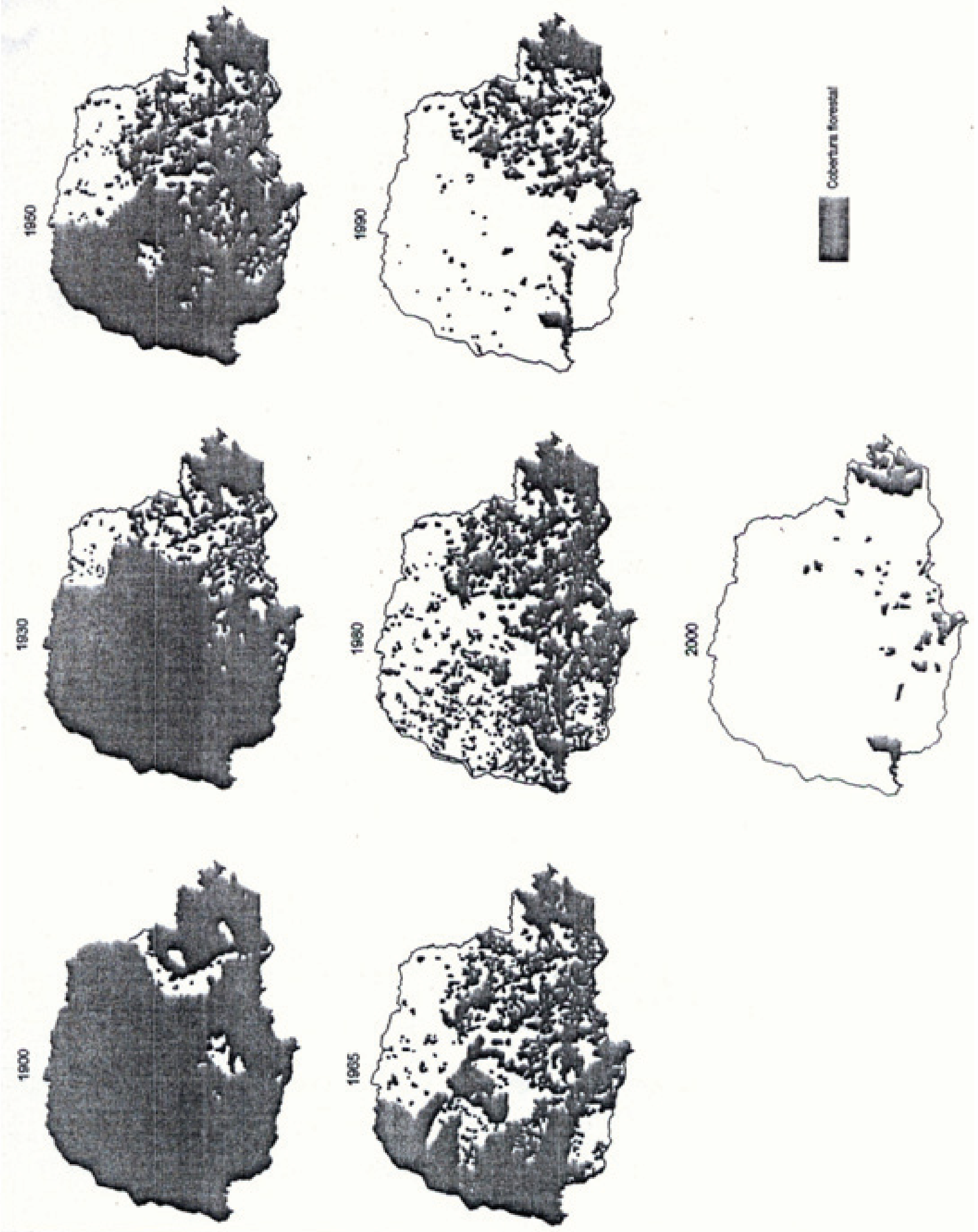

Figura 110. Evolução do desmatamento no estado do Paraná. 1900-2000.

Fonte: Divisão de Cartografia. Secretaria do Meio Ambiente e Recursos Hídricos. Governo do Paraná. 2001 
Enviamos então uma “CARTA CIRCULAR No 01/2005, de 18.09.2005”, aberta às autoridades, explicando a situação (Anexo 2), dado que o Laudo onde comprovava que as terras da atual Unidade de Conservação eram “indígenas” estava em fase de finalização (Laudo II capítulo 5 desta tese).

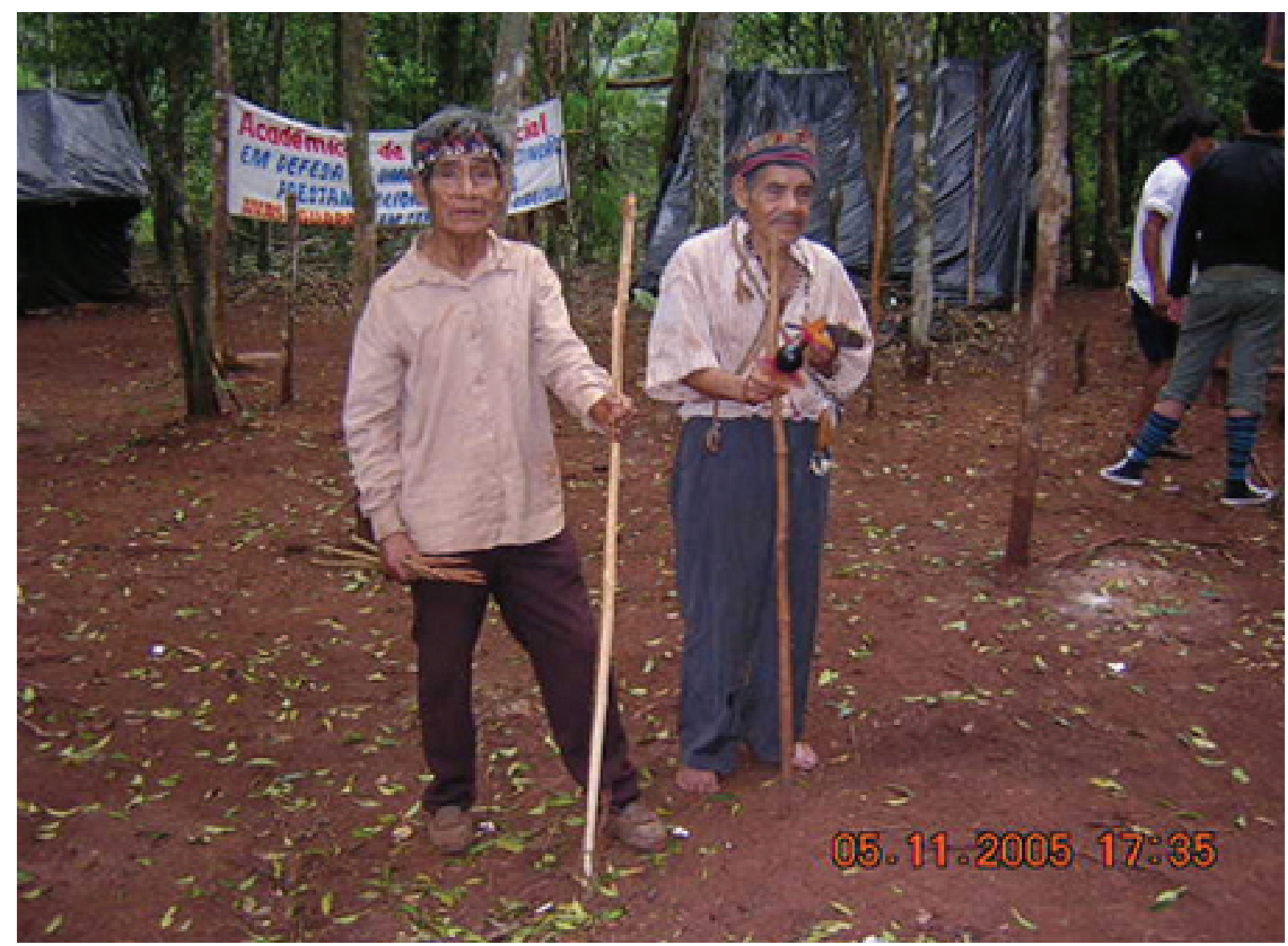

Figura 111. Ocupantes Guarani do PNI. O Sr da direita, pajé Seu Guilherme, com 100 e poucos anos, liderança espiritual, é irmão de Dona Narcisa, ambos quando crianças viveram na Aldeia Guarani, no que hoje é considerado o PNI.

Fonte: Os indígenas Guarani.

O IBAMA solicitou a Justiça Federal a reintegração de posse (Anexo 3 e 4) e os Guarani continuaram com a firme intenção de permanecer nas terras. Em varias reuniões com o Juiz Rony Ferreira/Justiça Federal de Foz do Iguaçu e representantes do IBAMA, as lideranças indígenas não eram ouvidas, segundo depoimento do cacique Simão Villalva e das lideranças. Apesar de solicitada a minha presença pelos Guarani ao Juiz e eu mesma ter solicitado minha ida para as reuniões à FUNAI, não foi requerido pelo Juiz e não foi aprovada pela direção da FUNAI. Em meu lugar o antropólogo Rubem Thomas de Almeida, consultor da Itaipu, foi o "representante" dos índios. Apesar disso enviamos nova carta ao Juiz e a Procuradora da Republica Deborah Duprat (Anexo 5). 


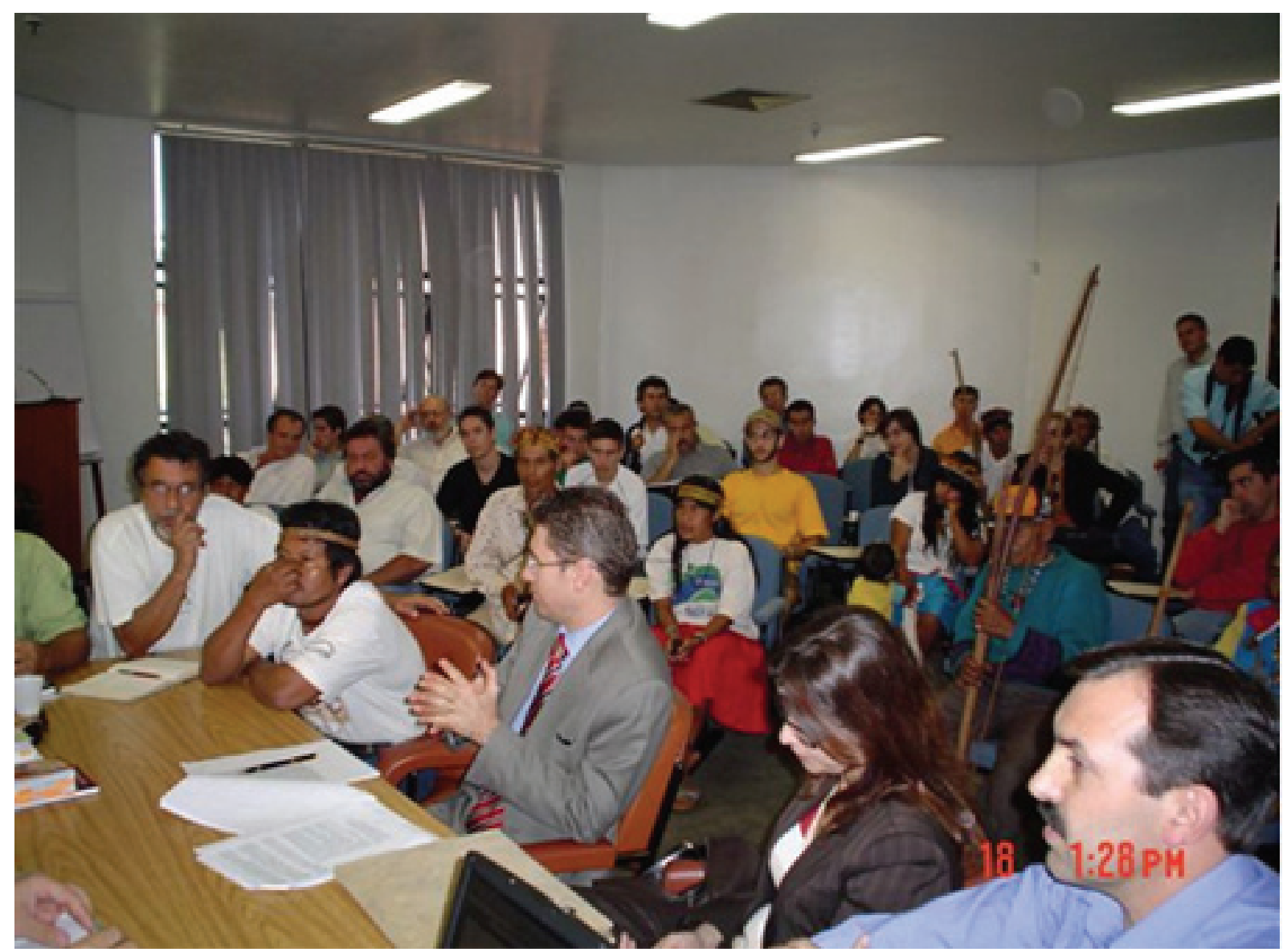

Figura 112. Foto de reunião na Justiça Federal.

Da esquerda para a direita: O antropólogo consultor da Itaipu Rubem Thomas de Almeida; O Cacique Simão Villalba; O Juiz Federal Ronny Ferreira; A Procuradora da Republica (talvez Monica Bora); o Diretor do Parque Nacional do Iguaçu, Jorge Pegoraro.

Fonte: Os indígenas Guarani.

Mais tarde o mesmo juiz se dirige pessoalmente ao Oco'y e determina que o Cacique Simão assine um documento. Foi nesta ocasião que o Cacique respondeu ao Juiz: Antigamente os brancos matavam a gente à bala. Hoje vocês matam aos pouquinhos com caneta e papel. Eu não vou assinar nada. Segundo o Cacique, o Juiz esperava que o Cacique assinasse um documento em que ele se comprometeria em retirar as famílias Guarani provenientes desta aldeia, que haviam reocupado aquelas terras florestadas, as terras que foram desses indígenas em passado recente, no Parque Nacional do Iguaçu. Entre os documentos foi entregue ao Cacique uma intimação (Anexo 6).

O tempo em que os Guarani permaneceram nas terras sofreram muita pressão para que se retirassem. Esses indígenas afirmavam que nossos Laudos comprovavam de que ali eram terras indígenas Guarani e que tinham o direito de ali permanecerem. Essas afirmações constaram de documento feito pelos indígenas, mais tarde em 01.09.06, entregue às autoridades. (Anexo 7). 
A mídia local e nacional se manifestavam de forma a não dizer a verdadeira intenção dos indígenas que se resumia a: eles pretendiam ficar, porque eram terras que no passado foram suas e no Oco’y não tinham mais como sobreviver; nas mídias dizia-se que eles haviam se dirigido para aquelas terras, para apenas protestar com relação às condições de vida e terras no Oco’y

\section{(Anexo 8).}

O Juiz Rony Ferreira aprovou em 03.10.05 a reintegração de posse solicitada pelo IBAMA, conforme noticia veiculada pela internet, esta noticia mais realista com os fatos. (Anexo 9) O IBAMA anunciou negociações com a FUNAI, para a aquisição de terra para os Guarani (Anexo 10).

Os Guarani receberam também o apoio dos professores da UFRJ que anteriormente haviam pesquisado na aldeia a situação referente aos agrotóxicos (Anexo 11).

Desde o inicio desse processo entramos em contato, pessoalmente com o Presidente da FUNAI, na ocasião Mercio Pereira Gomes, por carta com a Dra Débora Duprat/ VI Câmara de Coordenação e Revisão do Ministério Público Federal em Brasília (Anexo 12), ambos já estavam de posse dos Laudos Antropológicos e nós relatávamos as ultimas ocorrências; por fim, nos reunimos com o Consultor-Geral da União da Advocacia Geral da União/AGU, na época o Dr. Manoel Lauro Wolkmer de Castilho, explicando toda a situação, deixando com ele também, copia de todos os Laudos Antropológicos. Após o mandato de reintegração de posse outra carta foi enviada a Dra Débora Duprat/ VI Câmara de Coordenação e Revisão do Ministério Público Federal em Brasília (Anexo 13).

Ao fim de quase 4 meses, em 22.11.05 os Guarani foram cercados pela Policia Federal, a qual determinava a retirada dos indígenas (Anexo 14). O cacique Simão conta que, ao se dirigir ás famílias Guarani, começou a se expressar na língua Guarani, como sempre fazem entre eles. A polícia reagiu proibindo que ele se manifestasse na própria língua. Fale em português! afirmou o policial. Vendo os homens armados, os Guarani então, com muitas crianças e mulheres, acordaram que sairiam desde que a FUNAI resolvesse a questão fundiária, o problema da falta de terras em que viviam.

Assim solicitaram que o ônibus arranjado para o despejo fosse diretamente para a sede da FUNAI em Guarapuava com todas as famílias, para se realizar o tal acordo. A Polícia Federal aparentemente concordou. No caminho ao invés de dobrar na rodovia à direita, sentido Guarapuava, o ônibus dobrou à esquerda em direção ao Oco'y. Iniciou-se então uma discussão que se transformou em confronto, com vários indígenas baleados. 


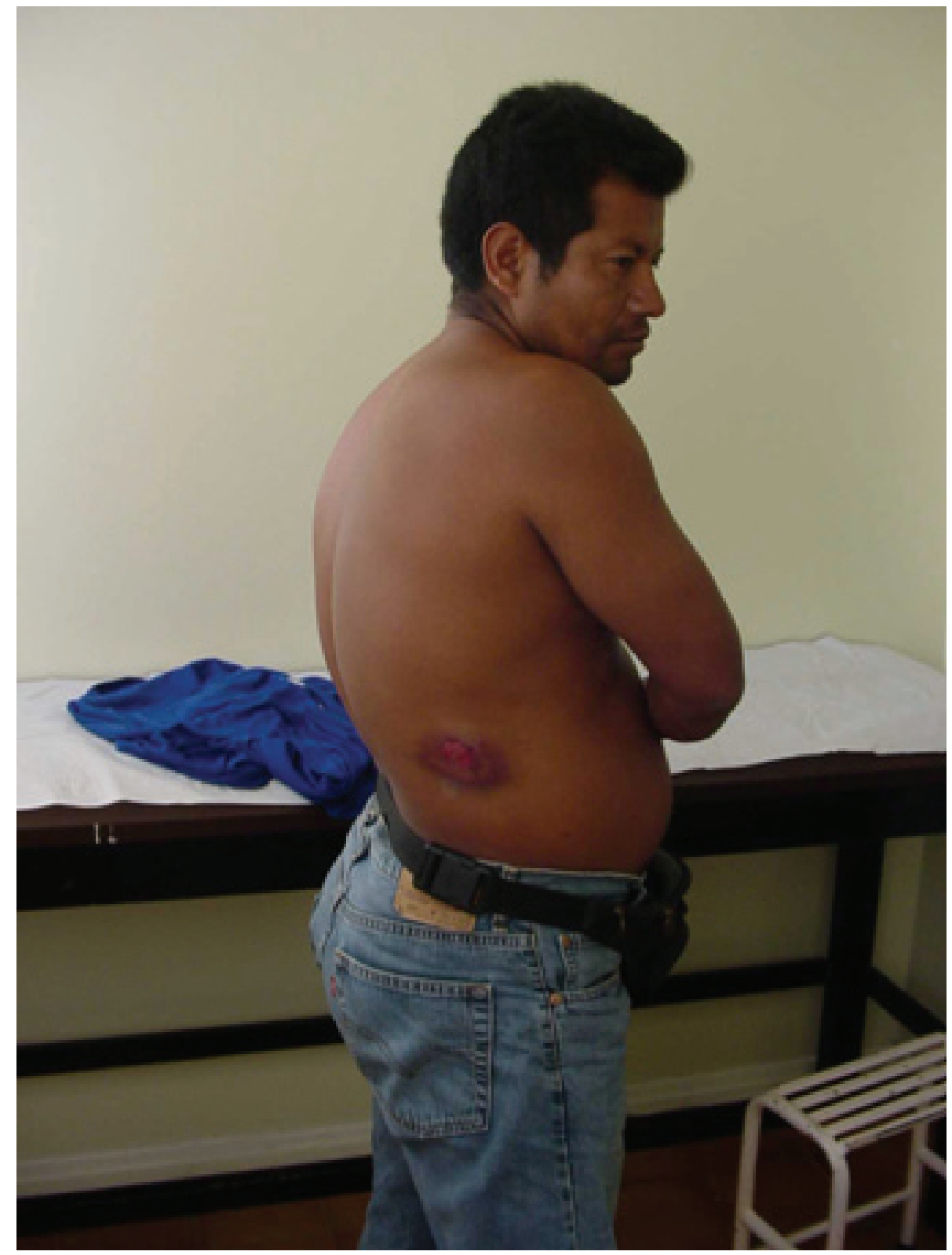

Figura 113. Foto. Cacique Simão Villalva baleado nas costas.

Fonte: Os indígenas Guarani. 


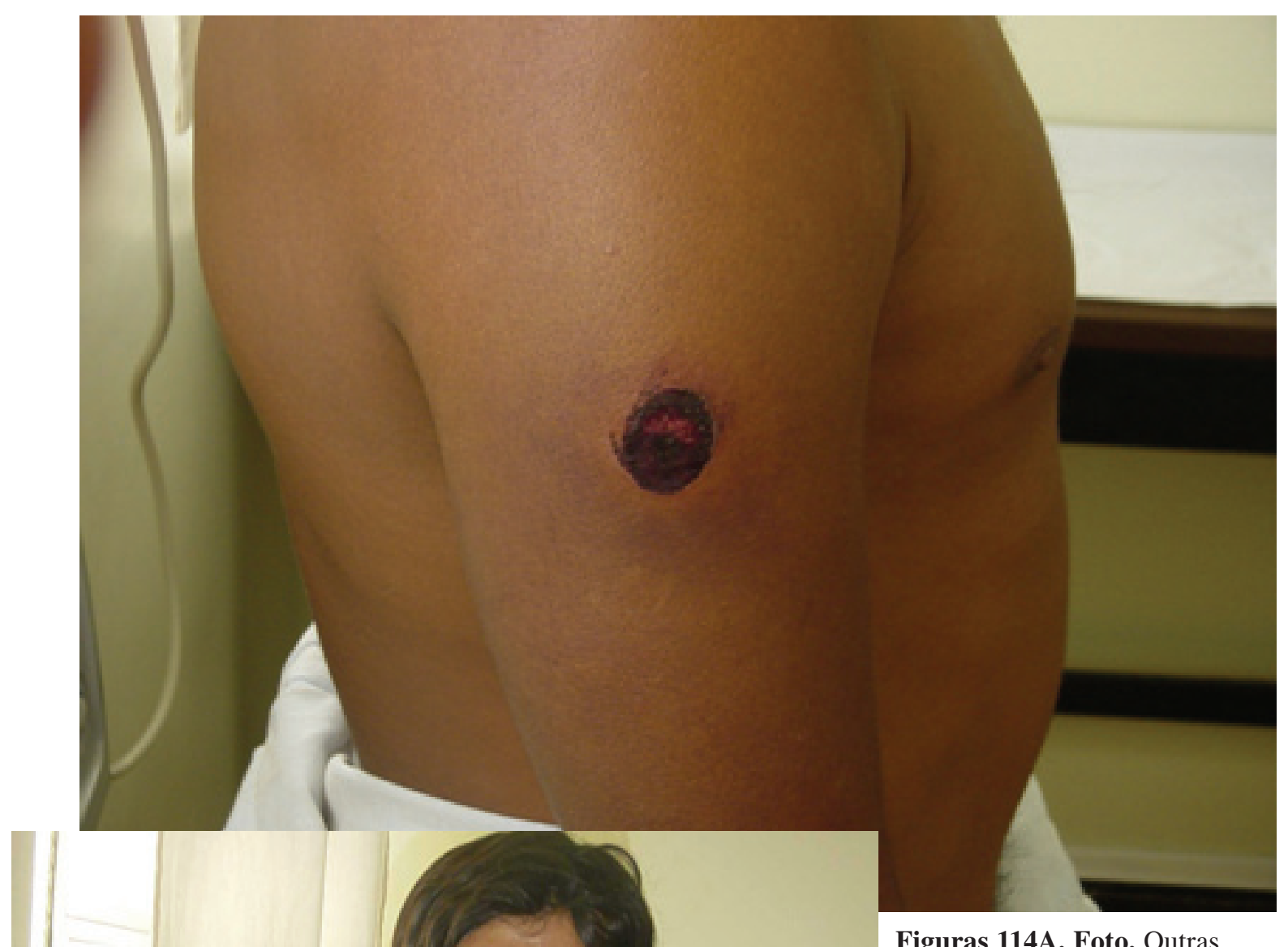

Figuras 114A. Foto. Outras

lideranças indígenas baleadas.

Fonte: Os indígenas Guarani. 


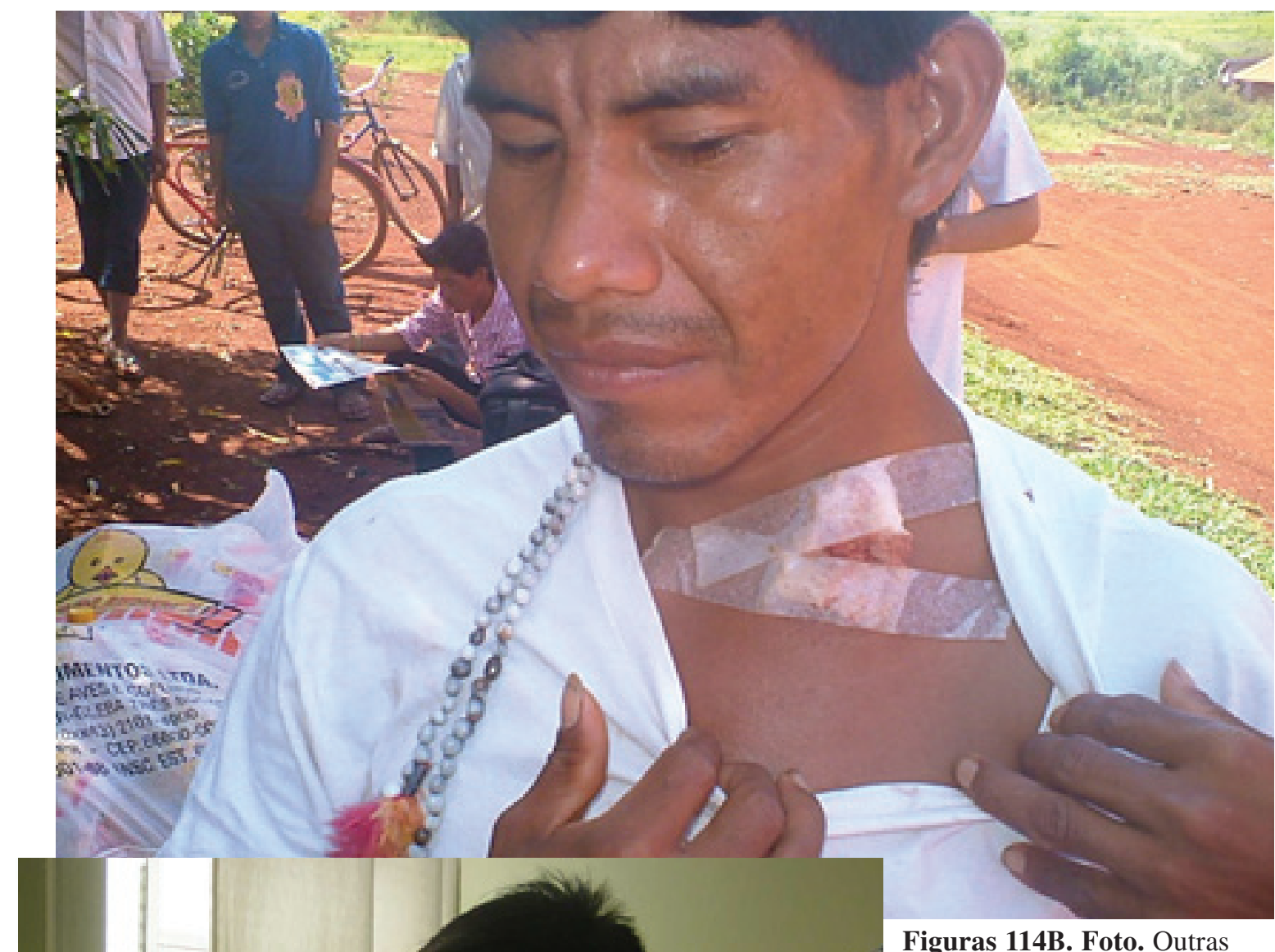

Figuras 114B. Foto. Outras

lideranças indígenas baleadas. Fonte: Os indígenas Guarani.

Figuras 114C. Foto. Outras lideranças indígenas baleadas. Fonte: Os indígenas Guarani. 


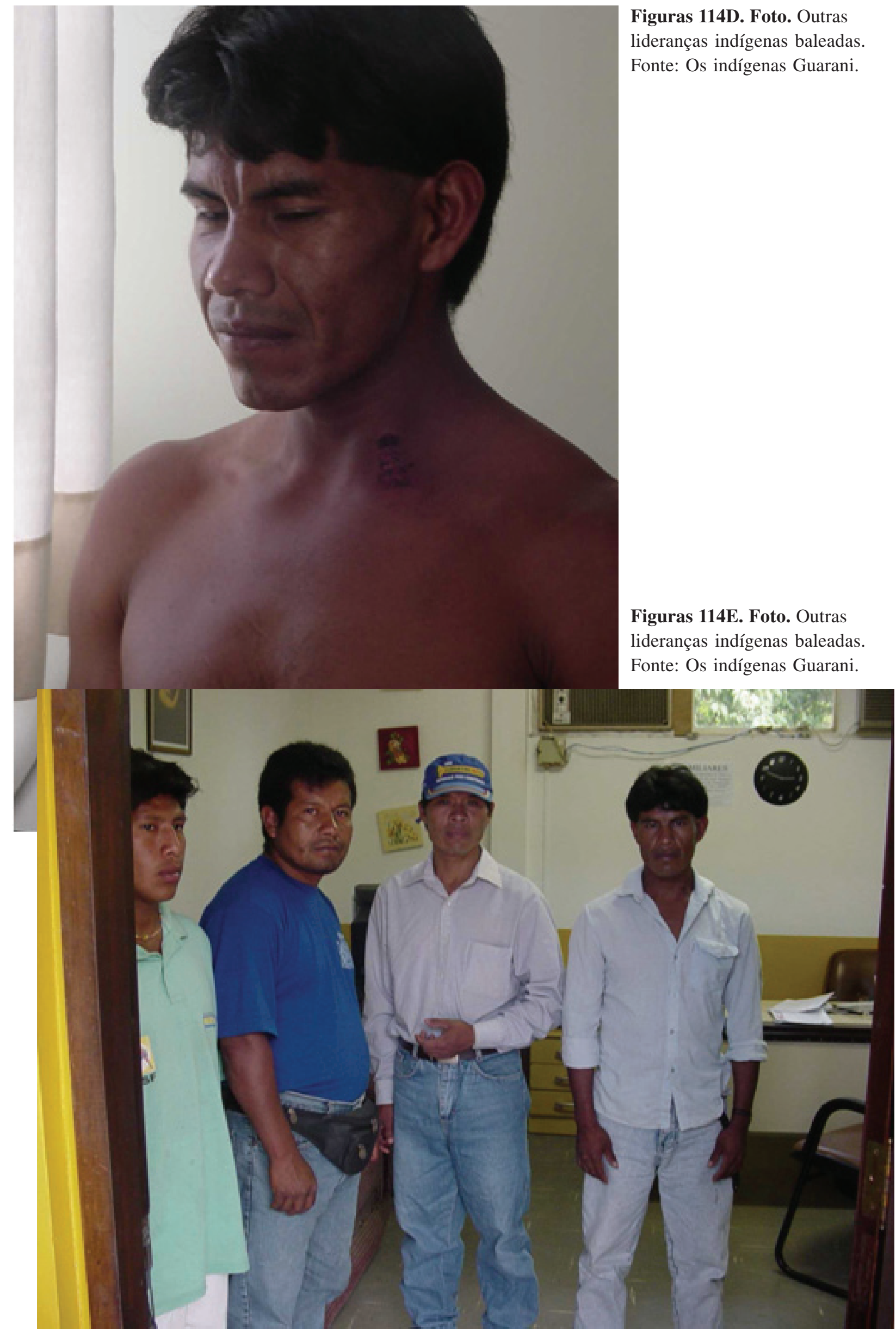




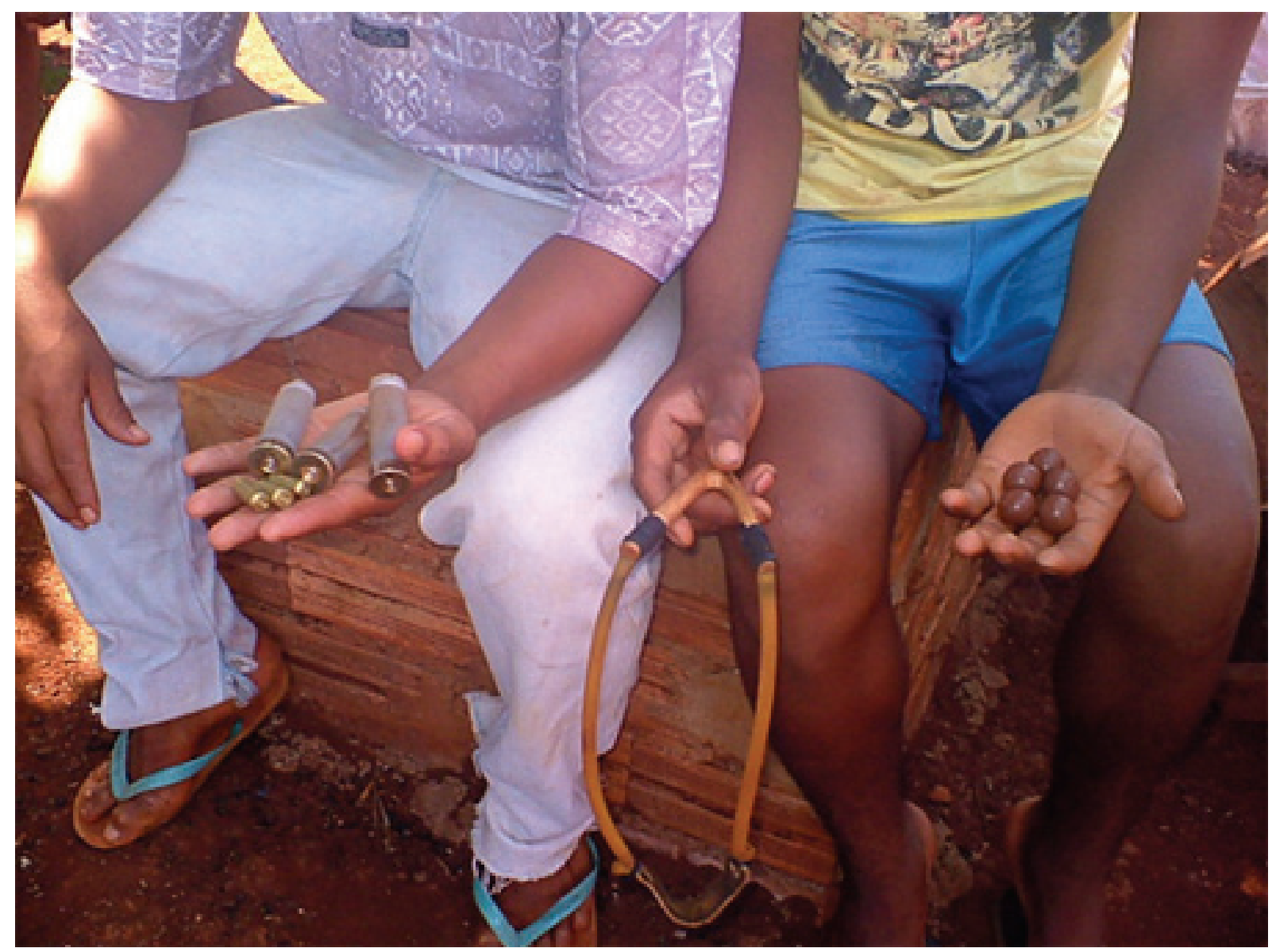

Figura 115. Foto. As armas utilizadas. De um lado armas de fogo e balas de borracha. De outro estilingue com balas de barro.

Assim os Guarani, em pleno governo do Partido dos Trabalhadores, foram autoritariamente despejados no Oco’y, sem que em qualquer momento se desse verdadeira discussão sobre seus direitos.

A maioria das famílias indígenas, que estavam acampadas no Parque acabaram juntando-se ao Movimento dos Sem Terra/MST, à beira da rodovia. Alguns meses depois foram transferidos pela FUNAI de Guarapuava para a Terra Indígena Rio da Areia/ Inacio Martins/Paraná. Enfim, a FUNAI, "solucionou" o caso, por meio da mesma política, recorrente na ditadura, de superlotar aldeias já ocupadas por outra população indígena.

Apesar dos Laudos Antropológicos realizados sobre o assunto pela autora desta tese e entregues às instituições responsáveis, Presidencia da FUNAI, Justiça Federal e Ministério Público Federal de Foz do Iguaçu, VI Camara de Coordenação e Revisão do Ministerio Publico Federal em Brasilia, contudo, a situação desses indígenas permaneceu como antes, durante anos, deixando transparecer que as intenções governamentais recentes (2001 a 2006) permaneceriam com o mesmo perfil dos governos autoritários anteriores. 
Até que um parecer da AGU, 24.02.2006 de autoria também do Dr. Manoel Lauro Wolkmer de Castilho (Anexo 15), indicou a "compra de terras" para essa população, culminando num decreto presidencial do Presidente Luis Inacio Lula da Silva. Questão que até o momento, ainda não se desdobrou em fato concreto, os responsáveis indicados pelo referido parecer, para realizar a compra dessas terras, respectivamente, INCRA e FUNAI, a primeira instituição alegou não ter responsabilidade sobre o fato, escusando-se de qualquer providencia; a segunda, apesar de ter enviado antropólogo a campo em agosto de 2009, em busca de terras, ter localizado as terras enfim, (Anexo 16), ao final, a Diretoria Fundiária da FUNAI alega não ter orçamento para a compra das mesmas (18 milhões de reais). Estamos já em 2013, e nenhuma providencia a partir daí foi tomada, permanecendo os Guarani em condições cada vez mais exaustivas e sub-humanas no Oco’y.

Ou seja, a AGU acabou por colocar sobre os ombros das instituições, digamos "menores", que contam com menor orçamento, a responsabilidade e o ônus que seriam por dever das instituições "maiores”, Parque Nacional do Iguaçu e Itaipu Binacional, em compensá-los, dado que foram as que causaram os impactos sobre os Guarani; ainda, dinheiro para elas não parece ser o problema, respectivamente são, o Parque que produz maior lucro no Brasil e a maior hidrelétrica do mundo, que gera o pagamento de royalties polpudos aos municípios lindeiros, estado e governo federal. Capital a elas não faltam.

O caso é, que diferentemente desta medida - a compra de terras que poria fim a demanda indígena de forma rápida - os Guarani teriam direitos a ser reconhecidos ou por meio da "Identificação de Terras" na região, no início de todo esse processo, e em não acontecendo isso, como de fato não aconteceu, teriam então direito à reparação, por meio de um Termo de Ajuste de Conduta/TAC, que culminaria então, por fim, em serem indenizados em terras, pelo enorme dano causado pelas instituições IBAMA, Itaipu, INCRA e FUNAI, durante os últimos 31 anos, quando foram reassentados indevidamente em 1982 na Terra Indígena Avá-Guarani do Oco’y.

Ao longo desse trabalho que se iniciou em 2001, ficou provado que o Estado brasileiro representado por duas instituições politicamente muito fortes na região, Usina Hidrelétrica de Itaipu e Parque Nacional do Iguaçu, responsáveis pela ocupação das terras Guarani e o seu consequente deslocamento compulsório da região, agiram de forma ilegal, escudadas pelo INCRA e pela própria FUNAI, responsáveis pelo remanejamento ilegal dos indígenas do território, e provado o fato, esperava-se que os responsáveis pela questão indígena na atualidade, cobrassem dessas instituições, os danos causados. A Itaipu e o PNI teriam todas as condições econômicas 
para reassentar essa população indígena de forma a terem um espaço adequado, e não o fazem por quê? Tudo indica ser pelas motivações políticas e econômicas expostas.

A situação vivida atualmente pela comunidade indígena do Oco'y, teve e ainda tem, implicações profundas com o modelo de desenvolvimento imposto pela ditadura militar, caracterizado pelo desenvolvimentismo a qualquer custo, por um capitalismo selvagem, em que era assegurada sua implantação por meio da repressão ao povo (índios, camponeses, estudantes e intelectuais) e especificamente por uma política indigenista que estava vinculada aos planos maiores dessa politica desenvolvimentista.

Parte de todo o material pesquisado e apresentado nesta tese, nos últimos meses esteve a serviço da identificação das terras indígenas existentes no Oeste do Paraná, o denominado GT Guaíra. Não fazemos parte do Grupo de Trabalho/GT justamente para concluir a redação desta tese de doutorado. A situação é tão tensa na região, assim como no Mato Grosso do Sul. Recentemente a Ministra Chefe da Casa Civil do Brasil, a paranaense Gleisi Hoffmann, num ato de afronta a Constituição Federal do país, levantou a possibilidade de suspender os trabalhos de Identificação de Terras na região, ao que tudo indica, dado os interesses aqui apresentados em conflito. As organizações indígenas afirmam que ela esta sendo conivente com os interesses de grupos de proprietários de terras paranaenses, seus financiadores de campanha eleitoral. Ainda, a mesma Chefe da Casa Civil, está propondo alterar todo o procedimento de demarcação de terras indígenas, transferindo a competência do Executivo (FUNAI) para o Legislativo (Camara dos Deputados), quanto a decisão de quais terras irão ou não ser demarcadas e com a participação nos GTs, de claros inimigos das populações indígenas, os setores ligados ao agronegócio, no interior do governo. O que se aprovado enterrará de vez qualquer possibilidade de demarcação de terras indígenas. Em matéria recente publicada em 03 de Junho de 2013, denominada "Planalto e ruralistas promovem "ataque" contra índios, afirma Cimi"1, assim é exposto.

\footnotetext{
$\overline{{ }^{1} \mathrm{http}: / / w w w . t n o n l i n e . c o m . b r / n o t i c i a s / p o l i t i c a / 4,192862,03,06, p l a n a l t o-e-r u r a l i s t a s-p r o m o v e m-a t a q u e-c o n t r a-~}$ indios-afirma-cimi.shtml
} 
Por Felipe Bächtold

PORTO ALEGRE, RS, 3 de junho (Folhapress) - Em meio ao acirramento das ações de índios pelo país, o Cimi (Conselho Indigenista Missionário) divulgou uma carta aberta hoje criticando o governo federal e falando até em uma visão "racista" em medidas tomadas recentemente.

Hoje, houve protestos articulados por índios no Paraná e no Rio Grande do Sul. Em Mato Grosso do Sul, o clima é de tensão após a morte de um índio em confronto com a polícia durante uma ação de reintegração de posse na semana passada.

O Cimi, organização ligada à Igreja Católica, diz na carta que o governo de Dilma Rousseff se submete a pressões de ruralistas para mudar a criação de terras indígenas e que a atual gestão é a que menos demarca áreas desde o regime militar.

"As medidas anunciadas pelo governo com o intuito de superar os conflitos em torno das questões indígenas no Brasil parte do pressuposto equivocado segundo o qual os povos indígenas estariam causando os conflitos e agindo sob o comando de organizações não indígenas, de modo especial o Cimi”, diz o texto.

A carta chama essa concepção de "preconceituosa" e "racista" por considerar os povos seres "inferiores e incapazes de decisões próprias".

A nota do Cimi afirma ainda que Dilma nunca recebeu, como presidente, lideranças indígenas, enquanto costuma abrir espaço na agenda para encontros com ruralistas.

Para a organização que apoia os índios, há um ataque "sincronizado" do governo e uma ação em "legítima defesa" dos povos indígenas. "Mudar o processo de demarcação das terras indígenas não irá resolver o conflito.”

No mês passado, a ministra Gleisi Hoffmann (Casa Civil) disse que o governo busca "equilíbrio" e que a Funai (Fundação Nacional do Índio) se pauta como protetora envolvida com questões indígenas. As demarcações foram suspensas no Paraná e no Rio Grande do Sul.

O plano do governo é incluir mais ministérios nas discussões sobre o assunto, anteriormente restritas à pasta da Justiça. O secretário-executivo do Cimi, Cleber Buzatto, disse considerar os protestos dos índios uma "reação".

Assim finalizamos esta tese em meio novamente ao confronto. Portanto, como vimos ao longo de todo o trabalho, a situação dos indígenas estando em um Estado comandado pela ditadura militar ou comandado por um governo de coalização liderado pelo PT, não difere muito de um para outro sob a perspectiva dos direitos fundiários das comunidades indígenas. O Estado invariavelmente está atado aos interesses das classes dominantes. Só podemos nesse momento nos solidarizar às comunidades indígenas. Esperamos que com esta tese, possamos auxiliar cada vez mais pessoas a entender todo esse processo de injustiça social que os povos indígenas sofrem no país. 


\section{REFERÊNCIAS BIBLIOGRÁFICAS}

ALMEIDA, Rubem Tomás de. Laudo Antropológico sobre a comunidade Guarani-Ñandeva do Oco'y-Jacutinga - Pr. Rio de Janeiro. 1995. 65p.

BARBOSA, Carla G. Antunha. Trazidos por Tupã. A luta pelo território Guarani em São Paulo. 1994. 190f. Dissertação (Mestrado em Geografia Humana) - FFLCH, USP, São Paulo. 1994.

ARAUJO, João Lizardo Rodrigues Hermes de.; OLIVEIRA, Adilson de. Política Energética Brasileira: Mudança de Rumo? In: Colóquio Internacional "Energia, Reformas Institucionales y Desarrollo en America Latina”. Universidad Nacional Autónoma de México - Université PMF de Grenoble, México, DF, 5 a 7 noviembre de 2003, p. 627-657.

ARAUJO, Vitor de Aratanha Maia. Dinâmicas transfronteiriças entre os Guarani na Tríplice Fronteira. 2008. 84f. Monografia (Graduação em Ciências Sociais). Departamento de Antropologia, Universidade de Brasília/UNB, Brasília. 2008.

ARRUDA, Rinaldo S. V. Imagens do Índio: Signos da Intolerância. In: GRUPIONI, L.D.B.; VIDAL. L.; FISCHMANN, R. (Orgs.). Povos Indígenas e Tolerância: construindo praticas de respeito e solidariedade. São Paulo: EDUSP. 2001, p. 43-61.

ASSIS, V. de; GARLET, I. J. Analise sobre as populações Guarani Contemporâneas: Demografia, Espacialidade e Questões Fundiárias. Revista das Índias, Paraná, vol. LXIV, no 230, p. 35 54, 2004. ISSN: 0034-8341

BANDECCHI, Brasil. História Econômica e Administrativa do Brasil. São Paulo: Didática. 1966, 140p.

BANDEIRA, Luiz Alberto Moniz. A CIA e a técnica do golpe de Estado. Revista Espaço Acadêmico, (Local ?), nº 58, ano V, março de 2006, ISSN 1518.6186. Disponível em: <http:// www.espacoacademico.com.br/058/58bandeira.htm>. Pesquisado em 2013.

BATISTA, Luiz Carlos. Brasiguaios na Fronteira: caminhos e lutas pela liberdade. 1990. 178f. Dissertação (Mestrado em Geografia Humana) - FFLCH, USP, São Paulo, 1990.

BATTISTELLI, Edívio. Relatório de Viagem. Curitiba: Processo n. ${ }^{\circ}$ 1053/1976, fls 143/44/45. FUNAI, s/d. 
BELO, Camila Nehring. Supremacia Regional no Cone Sul: A Usina de Itaipu como instrumento da luta diplomática entre Brasil e Argentina na década de 70. 13f. Trabalho de Pós-graduação (Departamento de Historia) - PPGH, Universidade Federal da Grande Dourados/UFGD, Dourados. Disponível em: <www.pph.uem.br/cih/anais/trabalhos/373.pdf.>. Pesquisado em 2013.

BONAVIDES, Paulo. Ciência Política. 1a ed. Rio de Janeiro: Fundação Getulio Vargas, 1967. $339 \mathrm{p}$.

BRASIL. Atlas Geográfico Escolar. Rio de Janeiro: IBGE, 2002. 197p.

A Lei de Crimes Ambientais. Lei Federal nº 9605 de 12.02.1998 e Decreto no 3179 de 21.10.1999. Brasília: IBAMA/MMA, 2000. 38p.

Código Florestal. Lei Federal no 4771 de 15/09/1965. Brasília: Subchefia para Assuntos Jurídicos. Casa Civil. Presidência da República. Disponível em:

http://licenciamento.cetesb.sp.gov.br/legislacao/federal/leis/1965_Lei_Fed_4771.pdf. Pesquisado em: 26.08.2012.

Resolução CONAMA no 013. 06.12.1990. Brasília: Publicada no D.O.U, de 28/12/ 90, Seção I, p. 25.541.

Resolução CONAMA no 237. 19.12.1997. Brasília: CONAMA.

. Constituição Federal: Capítulo VIII - Dos Índios. In: Constituição. República Federativa do Brasil 1988. Brasília: Câmara dos Deputados, Coordenação de Publicações. 1995. p. 108. Série Textos Básicos n. ${ }^{\circ}$.

Cria os territórios federais do Amapá, do Rio Branco, do Guaporé, de Ponta Porã e do Iguassú. Decreto-Lei N. o 5.812, de 13 de setembro 1943. Rio de Janeiro: Subchefia para Assuntos Jurídicos. Casa Civil. Presidência da República.

Decreto Legislativo n. ${ }^{0} 58824$ de 14.07.1966 que ratifica a Convenção Internacional de Genebra n. ${ }^{\circ} 107$ - OIT - 05.06.1957. Brasília: DOU. Diário Oficial da União número: $58824,20.07 .1966$.

Decreto Legislativo n. ${ }^{\circ} 143$ do Senado Federal de 20.06.2002 que ratifica a Convenção Internacional de Genebra n. 169 - OIT. 07.06.1989. Brasília: Publicado no DOU n. ${ }^{\circ} 118$ Seção 1, 21.06.2002.

Dispõe sobre as ações de proteção ambiental, saúde e apoio às atividades produtivas para as comunidades indígenas. Decreto n. ${ }^{\circ} 1141$ de 19.05.94. Brasília: Subchefia para Assuntos Jurídicos. Casa Civil. Presidência da República. 
BRASIL. Dispõe sobre o procedimento administrativo de demarcação de terras indígenas e dá outras providências. Decreto Presidencial no 1775. 08.01.1996. Brasília: DOU, Ano CXXXIV. n. ${ }^{\circ} 6$ de 09.01.1996, p. 265.

Eletrobrás/Plano Diretor de Meio Ambiente do Setor Elétrico. 1990. Brasília: Ministério da Infraestrutura/Secretaria Nacional de Energia. Centrais Elétricas Brasileiras 1991/1993.

Estatuto da Terra. Lei n. ${ }^{\circ} 4504$ de 30.11.1964. Brasília: Legislação Federal. Subchefia para Assuntos Jurídicos. Casa Civil. Presidência da República. 60p.

Legislação Federal. Estatuto do Índio. Lei n. ${ }^{\circ} 6001$ de 19.12.1973. Brasília: Legislação Federal. Subchefia para Assuntos Jurídicos. Casa Civil. Presidência da República. 21p. Mapa etno-histórico do Brasil e regiões adjacentes. Adaptado do mapa de Curt Nimuendajú - 1944. Secretaria de Planejamento e Coordenação da Presidência da República. Brasília: IBGE. 1987.

Mapa. Situação Fundiária Indígena. Brasília: DPT/FUNAI/Ministério da Justiça. Abril 2013.

Terras Indígenas Paraná. Ocupação Territorial dos Povos Indígenas Avá-Guarani. Levantamento Preliminar 2002. Antropóloga responsável Maria Lucia Brant de Carvalho. DAF/FUNAI/Ministério da Justiça.

FUNAI. Normas de levantamento fundiário em terras indígenas e Laudo de Vistoria e Avaliação de Benfeitorias. Ordem de Serviço nº 005 de 1991/FUNAI. Ministério da Justiça. 06.05.1991.

FUNAI. Normas do Manual de Identificação de Terras Indígenas. Ordem de Serviço n. ${ }^{\circ}$ 003/1991/ FUNAI. Ministério da Justiça. 06.05.1991.

Normas de Trabalho de Identificação e Delimitação de Terras Indígenas. Portaria n. ${ }^{\circ}$ 239/1991/FUNAI. Ministério da Justiça. 03.1991.

Orientações básicas para estudos e levantamento cartográficos na identificação e delimitação de terras indígenas. Departamento de Demarcação/FUNAI. Ministério da Justiça. 06.1996.

. Planta demarcação. TI Avá-Guarani do Oco’y/São Miguel do Iguaçu/Pr. DAFI/ FUNAI/MI. 31.07.1982.

Projetos Integrados de Colonização PIC-OCOI I e II. Decreto Federal n. ${ }^{o} 69412$.

INCRA. Paraná. 22.10.1971. 
BRASIL. Regras sobre a elaboração do relatório circunstanciado de identificação e delimitação de Terras Indígenas. Portaria n. ${ }^{\circ} 14$ do Ministério da Justiça. 09.01.1996. Brasília: DO de 10.01.1996. Disponível em: 6ccr.pgr.mpf.gov.br/legislacao/legislacao-docs/ demarcacao/portaria_funai_14.pdf. Pesquisado em 26.08.2012.

Relatório do Grupo de Trabalho FUNAI e Itaipu Binacional. Protocolo de Intenções de 20.05.1994. Processo FUNAI/Bsb n. ${ }^{\circ}$ 0178/94. Foz do Iguaçu em 20.07.1994: p. (ilegível)

Resumo Executivo: Plano de Manejo. Parque Nacional do Iguaçu. Brasília: IBAMA/ Ministério do Meio Ambiente/MMA. 2000. 32p.

Sanções as Condutas Lesivas ao Meio-Ambiente. Decreto Federal n. 3179 de 21.10.1999. Brasília: Subchefia para Assuntos Jurídicos. Casa Civil. Presidência da República.

Sistema Nacional de Unidades de Conservação da Natureza. Lei Federal nº 9985 de 18.07.2000. SNUC/MMA. Brasília: Subchefia para Assuntos Jurídicos. Casa Civil. Presidência da República.

Usina Hidrelétrica de Itaipu. Faixa de Proteção. Decreto Lei no ${ }^{\circ} 83.225$ de 01.03.79.

BURNS, E. Bradford. A Aliança não Escrita: O Barão do Rio Branco e as Relações BrasilEstados Unidos. Rio de Janeiro: EMC, 2003.

CABEZA de VACA, Ãlvar Nuñes. Naufrágios e Comentários. $3^{\text {a }}$ ed. Porto Alegre: L\&PM Pocket, 2002. 257 p.

CAMPOS, Raymundo. Historia do Brasil. São Paulo: Atual, 1983. 254p.

CARDOSO, Jayme Antonio.; WESTPHALEN, Cecília Maria. Atlas Histórico do Paraná. $2^{\text {a }}$ edição. Curitiba: Chain Editora. 1986. 70p.

CARNEIRO da CUNHA, Manuela. Os Direitos do Índio: Ensaios e Documentos. São Paulo: Brasiliense, 1987. 230p.

CARVALHO, Edgard de Assis. Avá-Guarani do Ocoí Jacutinga. Parecer Antropológico. São Paulo: ABA/CIMI/CJP/ANAI. 1981. 14p.

CARVALHO, Maria Lucia Brant de. Saúde de populações indígenas: Tendências após os impactos do contato. 1997. 190fl. Dissertação (Mestrado em Ciências Sociais - Antropologia). São Paulo: Pontifícia Universidade Católica de São Paulo/PUC-SP. 1997.

Introdução: Proposta de Trabalho referente a Laudo Antropológico sobre a Terra Indígena do Oco’y. Laudo Antropológico. Ref: Comunidade Indígena da Terra Indígena Avá-Guarani do Oco’y. Município de São Miguel do Iguaçu. Estado do Paraná. Brasil. São Paulo: AERBAURU/SP/FUNAI/MJ. 2002. 27 p. 
CARVAlHO, Maria Lucia Brant de. 3. ${ }^{\text {a }}$ Parte: O Contexto Atual Vivido Pela População Indígena Avá-Guarani na Terra Indígena do Oco’y/São Miguel do Iguaçu/ Pr. Laudo Antropológico. Ref: Comunidade Indígena da Terra Indígena Avá-Guarani do Oco’y. Município de São Miguel do Iguaçu. Estado do Paraná. Brasil. São Paulo: AERBAURU/SP/ FUNAI/MJ. 2002. 147p.

1. ${ }^{a}$ Parte: Plano Macro-Histórico das Populações Indígenas Avá-Guarani na Região Tradicional de Ocupação: Brasil/Paraguai/Argentina. Laudo Antropológico. Ref: Comunidade Indígena da Terra Indígena Avá-Guarani do Oco’y. Município de São Miguel do Iguaçu. Estado do Paraná. Brasil. São Paulo: AERBAURU/SP/FUNAI/MJ. 2003, 138 p.

População Indígena Tupi-Guarani (Ñandeva). Município Terra Roxa. Estado do Paraná. Brasil. Documentos históricos, geográficos, etnográficos e arqueológicos que comprovam ocupação Tupi-Guarani na região do Guairá/Oeste Paranaense, inclusive sobre localidade denominada outrora Ciudad Real del Guairá, localizada no atual Município de Terra Roxa/Pr. Laudo Antropológico. São Paulo: AERBAURU/SP/FUNAI/ MJ. 04.03.2004. 44 p.

Ref: Comunidade Indígena da Terra Indígena Avá-Guarani do Oco’y. Município de São Miguel do Iguaçu. Relatório de Campo. Estado do Paraná. Brasil. São Paulo: AERBAURU/SP/FUNAI/MJ. 18.03.2004. 37p.

O Relatório Antropológico da FUNAI em resposta a carta colocada à VI ${ }^{\circ}$ Câmara do Ministério Público Federal, pelo antropólogo Rubem Thomaz de Almeida, antropólogo contratado pela Usina Hidrelétrica de Itaipu. População Indígena AváGuarani (Ñandeva). Relatório Antropológico. Terra Indígena do Oco’y. Município de São Miguel do Iguaçu. Paraná. Brasil. São Paulo: AERBAURU/SP/FUNAI/MJ. 2004. 150p.

2. ${ }^{\text {a }}$ Parte: $O$ processo de desterramento da população indígena Avá-Guarani da região do Oco’y-Jacutinga e o reassentamento na Terra Indígena do Oco’y: Aspectos antropológicos e jurídicos. Laudo Antropológico. Vol. I-II-III. Ref: Comunidade Indígena AVÁ-GUARANI. TERRA INDÍGENA OCO'Y. Município de São Miguel do Iguaçu. Estado do Paraná. Brasil. São Paulo: AERBAURU/SP/FUNAI/MJ. 2005. Vol I-174 p.

CASTRO, Eduardo Viveiros de. Índios, Leis e Políticas. In: SANTOS, S. C. (org). O índio perante o direito: ensaios. Florianópolis: UFSC. 1982. p.37-51.

CHMYZ, Igor. Projeto Arqueológico Itaipu. Curitiba - Paraná - Brasil: Convênio Itaipu-IPHAN. 1976. 105p. Volume I. 
CHMYZ, Igor. Projeto Arqueológico Itaipu. Curitiba - Paraná - Brasil: Convênio Itaipu-IPHAN. 1977. 150p. Volume II.

Projeto Arqueológico Itaipu. Curitiba - Paraná - Brasil: Convênio Itaipu-IPHAN. 1978. 141p. Volume III.

Projeto Arqueológico Itaipu. Curitiba - Paraná - Brasil: Convênio Itaipu-IPHAN. 1979. 109p. Volume IV.

. Projeto Arqueológico Itaipu. Curitiba - Paraná - Brasil: Convênio Itaipu-IPHAN. 1980. 102p. Volume V.

Projeto Arqueológico Itaipu. Curitiba - Paraná - Brasil: Convênio Itaipu-IPHAN. 1981. 69p. Volume VI.

Projeto Arqueológico Itaipu. Curitiba - Paraná - Brasil: Convênio Itaipu-IPHAN. 1983. 106p. Volume VIII.

Arqueologia e História da Vila espanhola da Ciudad Real do Guairá. In: Cadernos de Arqueologia, Paranaguá/Paraná: UFPR, n. ${ }^{\circ}$, Ano I, p. 7-103. 1976.

. Pesquisas arqueológicas na área brasileira de Itaipu. In: $2^{\circ}$ Seminário da Itaipu

Binacional sobre Meio-Ambiente/Foz do Iguaçu. Curitiba: CEPA/UFPR, 1987. 4 p.

Relatório Técnico sobre Arqueologia e a Etno-História da Área do Parque Nacional do Iguaçu. Curitiba: CEPA/UFPR, 1999. 81p.

CLASTRES, Hélène. Terra sem Mal. São Paulo: Brasiliense, 1978. 123p.

CLASTRES, Pierre. A Sociedade contra o Estado. Brasil: Francisco Alves, 1978. 152p.

Arqueologia da violência. Ensaios de Antropologia política. São Paulo: Brasiliense, 1982.243p.

COLMÁN, Indalecio. Informe del Cnel. D. Indalecio Colmán, Miembro de la Comisión Mixta Paraguayo Brasileña.

Disponível em: <http://es.wikipedia.org/wiki/Ruta_7_(Paraguay)>. Pesquisado em 15.03.2013. COSTA, Wanderley Messias da. Geografia Política e Geopolítica. Discursos sobre o território e o poder. 1990. 477f. Tese (Doutorado em Geografia Humana) - FFLCH, USP, São Paulo. 1990.

COVRE, Ana Priscila Landivar Ribeiro Victor Rocon. A Matriz Energética Brasileira. 2011. 9 f. Graduação (Engenharia Química). Departamento de Engenharias e Computação, Centro Universitário Norte do Espírito Santo, Universidade Federal do Espírito Santo, Espírito Santo. 2011. 
DALLARI, Dalmo de Abreu. Elementos de Teoria Geral do Estado. 29 ed. São Paulo: Saraiva, 2010. 314p.

DAVIS, Shelton. Vítimas do Milagre: O desenvolvimento e os índios do Brasil. Rio de Janeiro: Zahar, 1978. 208p.

DIEGUES, A. C.; VIANA, V. M. (Orgs) Comunidades tradicionais e manejo dos recursos naturais da Mata Atlântica. São Paulo: NUPAUB e LASTROP-ESALQ/USP, 2000.

DREGUER, R.; TOLEDO, E. História Cotidiano e Mentalidades. Vol. 3. Ed. Atual. 1995.

FAORO, Raymundo. Os Donos do Poder. Formação do Patronato Politico Brasileiro. 13 ${ }^{\text {a }}$ edição. São Paulo: Globo, 1998. 750p. Volume 2.

FARIA, Ivani Ferreira de. Território Indígena: direito imemorial e o devir. 1997. 324f. Dissertação (Mestrado em Geografia Humana) - FFLCH, USP, São Paulo. 1997.

FERREIRA, Aurélio Buarque de Holanda. Novo Dicionário Aurélio. $2^{\mathrm{a}}$ edição. Rio de Janeiro: Nova Fronteira, 1986. 1848p.

FERREIRA, Manoel Rodrigues. A Ferrovia do Diabo. Ed. Melhoramentos: São Paulo. 2005. $123 p$.

FUNAI - ITAIPU BINACIONAL. Relatório do Grupo de Trabalho. Protocolo de Intenções. 20/maio/94. Foz do Iguaçu: Processo Funai/Bsb nº 0178/94. 20.07.1994.

GAIGER, Julio. Direitos Indígenas na Constituição Brasileira de 1988. Brasília: CIMI, 1989. $24 \mathrm{p}$.

GASPARI, Elio. A Ditadura Derrotada. São Paulo: Companhia das Letras, 2003. 538p.

GAULD, Charles. Farquhar, o último titã: um empreendedor americano na América Latina. São Paulo: Editora de Cultura, 2006. 74p.

GERMANI, Guiomar Inez. Expropriados Terra e Água: O Conflito de Itaipu. Salvador: EDUFBA/ULBRA, 2003. 266p.

GOMES, Mercio Pereira. Os índios e o Brasil. Ensaio sobre um holocausto e sobre uma nova possibilidade de convivência. Petrópolis: Vozes, 1988. 237p.

JUNQUEIRA, Carmen. Antropologia Indígena. São Paulo: EDUC,1991. 111p.

IPARDES. Leituras Regionais: Messoregião Geográfica Oeste Paranaense. Curitiba: IPARDES. 2003.

IPARDES. Caderno Estatístico Municipal de Foz do Iguaçu. Curitiba: IPARDES. 2005. 30p ITAIPU BINACIONAL. Questão indígena na área do reservatório da Itaipu Binacional. Documentos e autores vários. Foz do Iguaçu: Itaipu Binacional. s/d. 320p. 
LADEIRA, Maria Inês. O caminhar sob a luz. O território Mbyá a beira do oceano. 1992. 199f. Dissertação (Mestrado em Antropologia) - Departamento de Antropologia, PUC-SP, São Paulo. 1992.

As demarcações Guarani. A caminho da Terra Sem Mal. In: RICARDO, C.A. (Editor)

Povos Indígenas no Brasil. 1996-2000. São Paulo: ISA, 2000. p.782-785.

Espaço geográfico Guarani-Mbya: Significado, Constituição e Uso. 2001. 236f.

Tese (Doutorado em Geografia Humana) - FFLCH, USP, São Paulo. 2001.

LADEIRA, Maria Inês \& outros. Terras Guarani no Litoral. As matas que foram reveladas aos nossos antigos avós. São Paulo: CTI, 2004. 113p.

LADEIRA, M. I.; FELIPIM, A. Apoio à conservação ambiental de terras Guarani e às atividades tradicionais de subsistência. In: DIEGUES A. C. et al (Orgs). Comunidades tradicionais e manejo dos recursos naturais da Mata Atlântica. São Paulo: NUPAUB/USP e ESALQ/ USP, p. 246-263.

LEITE, Jurandyr. Procedimentos para identificação de terras indígenas. Manual do antropólogo-coordenador. Brasília: Documento Interno - FUNAI/ Ministério da Justiça. 1997. LIMA, Mayrá. ESCOLA DAS AMÉRICAS: Brasil ainda manda militares para a Escola de Ditadores. Disponível em: <zequinhabarreto.org.br/?p=587>. Pesquisado em 15.01.2013. LOPES, Sérgio. Raízes do Movimento Pró-Criação do "Estado do Iguaçu. III Seminário do Centro de Ciências Sociais Aplicadas, 18 a 22 de Outubro de 2004, Unioeste, Cascavel, PR. Disponivel em: <http://www.unioeste.br/campi/cascavel/ccsa/IIISeminario/artigos/ Artigo\%2020.pdf >. Pesquisado em 2013.

Luta Indígena. Partida Maio de 1982. Ocoi-Jacutinga. Luta Indígena, Foz do Iguaçu, n.17, p. 16-35. 1982.

MAGNOLI, Demetrio. O que é geopolítica. 2a edição. São Paulo: Brasiliense. 1988. 74 p

MALM, Olaf.; PACHECO-FERREIRA, Heloisa.; et al. Relatório da Visita da Equipe do Núcleo de Estudos de Saúde Coletiva (NESC) e do Instituto de Biofísica (IBCCF), da UFRJ, à aldeia Avá-Guarani situada na região do Oco’y, município de São Miguel do Iguaçu/Pr à convite da Fundação Nacional do Índio/FUNAI do Ministério da Justiça. Rio de Janeiro: NESC, IBCCF/URFJ. 1 a 4 de junho de 2005. 11p. ; et al. Avaliação do contexto de Saúde Humana e Ambiental, com ênfase na contaminação por metais pesados e pesticidas, junto à população indígena da Terra Indígena Avá-Guarani (Oco’y), desterrados de seu imemorial território de ocupa- 
ção tradicional por Grandes Projetos (Parque Nacional do Iguaçu e UHE Itaipu) e circundados por áreas agrícolas de monoculturas. Rio de Janeiro: NESC, IBCCF/URFJ. Projeto sem data. 25p.

MARTINS, José de Souza. O tempo da fronteira: retorno a controvérsia sobre o tempo histórico da frente de expansão e da frente pioneira. Tempo Social. Revista de Sociologia. USP, São Paulo, 8(1), 25-70, maio de 1996.

MARX, Karl, O Capital. Crítica da economia política. O processo de produção do capital. $4^{\mathrm{a}}$ edição. Rio de Janeiro: Civilização Brasileira, 1890. 579p. Livro I. Volume 1.

MAZZAROLLO, Juvêncio. A Taipa da Injustiça: Esbanjamento econômico, drama social e holocausto ecológico em Itaipu. Curitiba: Comissão Pastoral da Terra do Paraná/ CPT-PR e São Paulo:Edições Loyola. 2003. 203p.

MELlAnder, Gustavo A. The United States in Panamanian Politics: The Intriguing Formative Years. Danville, Ill.: Interstate Publishers. OCLC 138568.1971.

MOURA, G. Tio Sam chega ao Brasil, a penetração cultural americana. São Paulo: Brasiliense, 1985. $92 \mathrm{p}$.

MELIA, Bartolomeu. (Editor e Autor) et al. Guarani Retã. Povos Guarani na Fronteira Argentina, Brasil e Paraguai. Argentina, Brasil e Paraguai: AECID, CAFOD, EED, BROT FUR DI WELT, UNICEF. 2008. 24p.

MELO, Tarso de. Ser índio em tempos de mercadoria. Disponivel em: $<$ http://editora.expressaopopular.com.br/noticia/batalha-das-ideias-ser-indio-em-tempos-demercadoria >. Pesquisado em 2013.

MELLO, Leonel Itaussu Almeida. A Geopolítica do Brasil e a Bacia do Prata. Manaus: EDUA. 1997.

MONTEIRO, John Manuel. Os Guarani e a história do Brasil Meridional, séculos XVI e XVII. In: CARNEIRO DA CUNHA, Manuela (Org). História dos índios no Brasil. São Paulo: Companhia das Letras/ Secretaria Municipal de Cultura/ FAPESP. 1992. p 475-498.

Negros da Terra. Índios e Bandeirantes nas Origens de São Paulo. São Paulo: Companhia das Letras. 1994. 312p.

MONTOYA, A. R. de. Conquista Espiritual hecha por los padres de la Campañia de Jesus en las provincias del Paraguay, Paraná, Uruguay e Tape. Bilbao: Imprenta del Corazon de Jesus. 1892. 263p.

MORA MARTÍNEZ, Eliodoro. Campo 9, un polo de desarrollo en la Marcha hacia el Este. Editorial El Lector, Asunción 2008. ISBN 978-99953-1-059-2. 
MORAES, Julio Cesar de. Relatório. Agrotóxicos no entorno da Terra Indígena Avá-Guarani (Oko’y), em São Miguel do Iguaçu-Pr: Sobrevivência física e cultural em risco da população indígena Avá-Guarani. São Paulo: AER BAURU/FUNAI, 07.2004. 69p.

MOREIRA, Regina da Luz. CSN: uma decisão política. Disponivel em: <http://cpdoc.fgv.br/ producao/dossies/FatosImagens/biografias/ernaniamaralpeixoto.>. Pesquisado em 11.04.2013.

MOURA, G. Tio Sam chega ao Brasil, a penetração cultural americana. São Paulo: Brasiliense. 1985. 92p.

NACKE, Aneliese \& WEBER, Cátia. A Hidrelétrica de Itaipu e os Guarani do Ocoí-Jacutinga. In: HELM, Cecília (Coord). A implantação de usinas hidrelétricas e os indígenas no sul do Brasil. Curitiba: GTZ/PIAB/IAP. 1996.

OJEDA, Igor. Paraguai: Receita para aniquilar a luta pela terra. Revista do Professor. São Paulo, Sindicato dos Professores do ABC/ SINPRO, Edição n. ${ }^{\text {4 }}$. Outubro de 2006.

OLIVEIRA, Ariovaldo Umbelino. A Geografia Agrária e as transformações territoriais recentes no campo brasileiro. In: FANI, A.; CARLOS, A. (Orgs). Novos Caminhos da Geografia. São Paulo: Contexto. 1999. p 63-110.

OLIVEIRA, Ariovaldo Umbelino. Espaço e Tempo. Compreensão Materialista Dialética. In: SANTOS, Milton (Org). Novos Rumos da Geografia Brasileira. São Paulo: HUCITEC, 1996. p. 66-110.

OLIVEIRA, Roberto Cardoso de. $O$ índio e o mundo dos brancos. $2^{a}$ edição. São Paulo: Pioneira, 1972.139p.

OLIVERA, David Galeano. LA INACABABLE TRAGEDIA INDÍGENA Y UNA CONSTITUCIÓN MENTIROSA. REPÚBLICA DEL PARAGUAY. ATENEO DE LENGUA Y CULTURA GUARANI. “Guarani ñe'ête pyahu myasâihára”. Disponivel em: <www.ateneoguarani.edu.py.>. Pesquisado em 2011.

PADIS. Pedro Calil. Formação de uma economia periférica: o caso do Paraná. São Paulo: Hucitec, 1981. 235 p.

PADRÓS, Enrique Serra. As Escolas Militares dos Estados Unidos e a Pentagonização das Forças Armadas da America Latina. p. 13-31. Departamento de História e PPG-História/ UFRGS. In: Outros Tempos, ISSN 1808-8031, Vol. 1 esp., 2007.

Disponível em: <www.outrostempos.uema.br.>. Pesquisado em 14.01.2013. 
PALMAR, Aluizio. Relação de militares brasileiros que frequentaram a Escola das Américas (School of the Americas) no período de 1954 - 1996. 28 de janeiro de 2012. Disponível em: < www.documentosrevelados.com.br Torturadores. $>$. Pesquisado em 15.01.2013.

PARANÁ (estado). Resolução no 22/85 -SEIN. (Atual IAP). Superintendência dos Recursos Hídricos e Meio Ambiente. Secretaria de Estado do Interior do Estado do Paraná. DOE 05.07.85. p. 6-7. 1985.

PEIXOTO Jr, Cesar. Usina Hidrelétrica de Itaipu (BRA) e Hoover Dam (EUA). Curso de Física. Universidade Federal de Goiás. s/d. Disponível em: < http://www.ebah.com.br/content/ ABAAABlpYAI/usina-hidreletrica-itaipu-bra-hoover-dam-eua?part=5>. Pesquisado em 10.03.2013.

PEREIRA, Luiz Carlos Bresser. ESTADO e subdesenvolvimento industrializado. Esboço de uma economia política periférica. São Paulo: Brasiliense, 1977. 420 p.

PORTO, Jadison Luis Rebelo. Os Territórios Federais e a sua evolução no Brasil. Universidade Federal do Amapá, Doutorando do Instituto de Economia da UNICAMP. REVISTA DE EDUCAÇÃO, CULTURA E MEIO AMBIENTE- Março, № 15, Vol III, 1999. 11 p. Disponível em: <15jadsonluisrebeloporto_osterritoriosfederaiseasuaevolucao.pdf>.. Pesquisado em 2013.

QUADROS, Jânio \& ARINOS, Affonso. História do Povo Brasileiro. São Paulo: J. Quadros Editores S. A. 1967. 326p. Volume I.

\& __. História do Povo Brasileiro. São Paulo: J. Quadros Editores S. A. 1967. 287p. Volume III.

RAFFESTIN, Claude. Por uma geografia do poder. São Paulo: Editora Ática, 1993. 269p. Volume 29. Serie Temas: Geografia e Política.

RAMOS, Alcida Rita. O antropólogo como ator político. In: ARANTES, Antonio A. et al (Orgs). Desenvolvimento e Direitos Humanos a responsabilidade do antropólogo. Campinas: Editora da Unicamp, 1992. p. 155-162.

Sociedades Indígenas. São Paulo: Ática. 1986. 96p.

Rede Democrática. Escola das Américas - Escola de Assassinos. Disponível em: <http:// www.rededemocratica.org/index.php?option=com k2\&view=item\&id=3281:escola-de-as$\underline{\text { sassino. }}$. Pesquisado em 15.01.2013.

RIBEIRO, Darcy. A Política Indigenista Brasileira. Rio de Janeiro. 1962.

RIBEIRO, Gustavo Lins. Da prefeitura ao Banco Mundial. Para uma metodologia de ação política com relação aos grandes projetos. In: ARANTES, Antonio A. et al (Orgs). Desenvol- 
vimento e Direitos Humanos a responsabilidade do antropólogo. Campinas: Editora da Unicamp. 1992. p. 103-107.

RIBEIRO, Mucio Nobre Costa. Terra Indígena Avá-Guarani do Oco’y. Diagnóstico Preliminar sobre a qualidade das águas. Brasília: DEPIMA/FUNAI/MJ. 07.2002. 70p.

ROCHA, Elaine Pereira. Avá-Guarani ...Presente!!! Xanxerê/SC: CIMI-Sul, 1991. 70p

ROJAS, Blanca G. Pedido de Aquisição do Imóvel Rural “Fazenda Jamaica”. Laudo Antropológico. Terra Indígena Avá-Guarani do Ocoí. Município de São Miguel do Iguaçu/PR. Referencia: Processo Administrativo FUNAI/Bsb n.2960/2008. Brasília: CGID/DAF-FUNAI. 2009. 84p.

ROSEIRA, Antonio Marcos. Foz do Iguaçu. Cidade rede Sul-Americana. 2006. 170f. Dissertação (Mestrado em Geografia Humana) - FFLCH, USP, São Paulo. 2006.

SANTOS, Silvio Coelho dos. O homem índio sobrevivente do sul. Porto Alegre: Garatuja Ltda, 1978. 117p.

Metodologia para o estudo de projetos de desenvolvimento e suas implicações políticas: O caso das hidrelétricas. In: ARANTES, Antonio A. et al (Orgs). Desenvolvimento e Direitos Humanos a responsabilidade do antropólogo. Campinas: Editora da Unicamp, 1992. p. 81-101.

SCHADEN, Egon. Aspectos Fundamentais da Cultura Guarani. $3^{\text {a }}$ edição. São Paulo: EPU; EDUSP. 1974. 190p.

SCHALLENBERGER, Erneldo. A Integração do Prata no sistema colonial: Colonialismo interno e missões jesuíticas do Guairá. Toledo-Paraná: Ed. Toledo, 1997. 247p.

SILVA, Evaldo Mendes da. Folhas ao vento: a micromobilidade de grupos Mbyá e Nhandeva (Guarani) na Tríplice Fronteira. 2007. 214f. Tese (Doutorado em Antropologia Social) Museu Nacional, Universidade Federal do Rio de Janeiro/UFRJ, Rio de Janeiro. 2007.

SILVA, Golbery do Couto e. Geopolítica do Brasil. Rio de Janeiro: José Olympio, 1967. 267p. SILVA, José Afonso da. Terras Tradicionalmente ocupadas pelos índios. In: (Orgs ?). Os Direitos Indígenas e a Constituição. $8^{\mathrm{a}}$ edição. Curso de Direito Constitucional Positivo. São Paulo: Malheiros Editores, 1992. p. 45-50.

SILVA, Luiz Fernando Villares e. (Org). Coletânea da Legislação Indigenista Brasileira. Brasília: CGDTI/FUNAI. Ministério da Justiça. 2008. 817p.

SOUZA FILHO, Carlos Frederico Marés de. O Renascer dos povos indígenas para o direito. Curitiba: Juruá. 1998. 211p. 
STAVENHAGEM, Rodolfo. Etnodesenvolvimento: Uma dimensão ignorada do pensamento desenvolvimentista. In: Anuário Antropológico 84. Rio de Janeiro: Tempo Brasileiro. 1985. p. 11-44.

STECA, L.C. \& FLORES, M.D. Historia do Paraná. Do século XVI à década de 1950. Londrina: UEL. 2002. 205p.

TODOROV, Tzvetan. Nós e os Outros. A reflexão francesa sobre a diversidade humana. Rio de Janeiro: Zahar. 1993. 194p.

TORRECILHA, Maria Lucia. A Gestão compartilhada como espaço de integração na fronteira. Ponta Porã (Brasil) e Pedro Juan Caballero (Paraguai). 2010. 95f. Relatório de Qualificação. (Mestrado em Geografia Humana) - FFLCH, USP, São Paulo. 2010.

TOURINHO NETO, Fernando da Costa. Os direitos originários dos índios sobre as terras que tradicionalmente ocupam e suas consequências jurídicas. In: Os Direitos Indígenas e a Constituição. (Cidade ?).Núcleo de Direitos Indígenas e Sergio Antonio Fabris Editor. 1993. p. 9-43.

TRAVASSOS, Mario. Projeção continental do Brasil. $2^{\circ}$ edição ampliada. São Paulo: Companhia Editora Nacional, 1935. 206 p.

TROTSKY, Leon. Obras de Leon Trotsky. En defensa del marxismo. México: Juan Pablos Editor, 1972. 160p. Tomo 4.

UNKEL, Curt Nimuendaju. As lendas da criação e destruição do mundo como fundamentos da religião dos Apapocúva-Guarani. São Paulo: HUCITEC-EDUSP, 1987. 156p.

WACHOWICZ, Ruy Christovam. Historia do Paraná. $7^{\mathrm{a}}$ edição. Curitiba: Gráfica Vicentina Ltda. 1995. 277p.

WEBER, Catia. ...Aqui outrora retumbaram vozes: Os indios Avá-Guarani e a UH Itaipu Binacional. 1995. 90f. TCC. (Graduação em Ciências Sociais) - Centro de Filosofia e Ciências Humanas, UFSC, Santa Catarina. 1995.

WEINBERG, Albert Katz. Manifest Destiny: A Study of Nationalist Expansionism in American History. Ams Pr Inc; 1st AMS ed edition (June 1976), ISBN 9780404147068.

ZOTZ, Werner. Iguaçu Cataratas/Falls. Brasil. Florianópolis: Aventura Brasileira. 2000. 48p.

Outras fontes

- Apoio integral a campesinos e indígenas na visão de Itaipu. Disponível em: <http://www.itaipu.gov.br/responsabilidade/apoio-integral-campesinos-e-indigenas >. Pesquisado em 05.2013. 
- ATA DE IGUAÇU DE 22.06.1966. BRASIL - PARAGUAI. ATA FINAL . Disponível em: <http://www.itaipu.gov.br/institucional/documentos-oficiais>.. Pesquisado em 1.05.2013>. Também publicado no "Diário Oficial da União" de 08.08.1966, p. 9.061/62.

- Base aérea em Natal. Disponível em: <http://www.revistanavigator.com.br/navig13/art/ N13_art3.html>. Pesquisado em 11.03.2013.

- BR-277. Porto de Paranaguá a Foz do Iguaçu. Brasil. Disponível em: <http://pt.wikipedia.org/ wiki/BR-277>. Pesquisado em 15.03.2013

- Brasil enfrenta até ofensiva argentina mas obtém acordo na ONU para Itaipu. Disponivel em $<$ http://www.politicaparapoliticos.com.br/interna.php?pagina=1\&t=755714>. Pesquisado em 16.03.2013.

- Ciudad Del Este. Disponível em: <http://pt.wikipedia.org/wiki/Cidade_do_Leste>. Pesquisado em 04.2013.

- Criação do reservatório da Itaipu Binacional 1982. Disponível em: <http://www.itaipu.gov.br/ nossa-historia/desafio humano>. Pesquisado em 26.08.2012.

- Doutrina Monroe. Disponível em: <http://pt.wikipedia.org/wiki/Doutrina_Monroe>. Pesquisado em 03.2013.

- Entenda o Tratado de Itaipu. Da Folha de São Paulo com Folha Online. Disponível em: <http://www1.folha.uol.com.br/folha/dinheiro/ult91u394644.shtml>.. Pesquisado em 02.2013.

- Escola das Americas. Disponível em: <http://pt.wikipedia.org/w/index.php?title=Escola_das_ Américas\&oldid=29119323>. Pesquisado em 15.01.2013.

- Foz do Iguaçu. Disponível em <http://pt.wikipedia.org/wiki/Foz_do_Iguacu>. Pesquisado em 04.2013.

- Gestão de Itaipu. Disponível em: <http://www.itaipu.gov.br/responsabilidade/gestao>.. Pesquisado em 05. 2013.

- JK eleito Presidente do Brasil em 1956. Disponível em: <http://educacao.uol.com.br/historiabrasil/ult1689u64.jhtm. Pesquisado em 10.03.2013>.

- JK. Disponível em: <http://www.brasilescola.com/historiab/juscelino-kubitschek.htm>. Pesquisado em 10.03.2013.

- JK. Disponível em: <http://www.suapesquisa.com/historiadobrasil/governo_jk.htm>. Pesquisado em 10.03.2013.

- Missões Jesuíticas na visão de Itaipu. Disponível em: <http://www.itaipu.gov.br/turismo/ missoes-jesuiticas>. Pesquisado em 05.2013. 
- Museu da Terra Guarani na visão de Itaipu. Disponível em: <http://www.itaipu.gov.br/turismo/museu-da-terra-guarani>. Pesquisado em 05.2013.

- Negociações entre Brasil e Paraguai referente a Itaipu. Disponível em: <http:// interessenacional.uol.com.br/2012/05/a-outra-historia-de-itaipu/>. Pesquisado em 17.03.2013

- O Brasil de JK. 50 anos em 5: O Plano de Metas. Disponível em: <http://cpdoc.fgv.br/producao/ dossies/JK/artigos/Economia/PlanodeMetas>. Pesquisado em 10.03.2013.

- Os gastos militares dos EUA são metade do total mundial. 06.01.2011 Disponível em: <http:/ /www.vermelho.org.br/noticia.php?id_secao=9\&id_noticia=144867>. Pesquisado em 25.02.2013.

- Ponte Internacional da Amizade. Disponível em: <http://pt.wikipedia.org/wiki/Ponte_ Internacional_da_Amizade>.Pesquisado em 15.03.2013.

- Porto de Santos. Disponível em: <www.portodesantos.com.br>. Pesquisado em 15.03.2013.

- Porto de Paranaguá. Disponível em: <http://pt.wikipedia.org/wiki/Porto_de_Paranagua>. Pesquisado em 15.03.2013.

- PERGUNTAS FREQUENTES sobre Itaipu. Criado em 30/03/2010. <http://www.itaipu.gov.br/ sala-de-imprensa/perguntas-frequentes $>$. Pesquisado em 07.2010.

- Refúgio Biológico da Itaipu. Disponível em: <http://www.itaipu.gov.br/sala-de-imprensa/noticia/refugio-biologico-de-itaipu-completa-25-anos?page=1>. Pesquisado em 03.2013.

- Refúgio Biológico de Santa Helena. Disponível em:<http://www.giacobbo.com.br/turismo/ cidades.php?c=19>. Pesquisado em 04.2013.

- Refúgio Biológico de Santa Helena. Assessoria de Imprensa - Pref. de Santa Helena Em 07/ 10/2010. Disponível em: <http://www.guiamedianeira.com.br/noticia/273/Refugio+Biologico+ em+Santa+Helena>. Pesquisado em 04.2013.

- Reservas paraguaias da Itaipu. Disponivel em <http://www.h2foz.com.br/reservas-paraguaias>. Pesquisado em 04.2013.

- Royalties. Disponível em: <http://www.itaipu.gov.br/responsabilidade/royalties>. Publicado em ITAIPU BINACIONAL (http://www.itaipu.gov.br). Início >. Responsabilidade Social >. Royalties. Criado em 23/03/2010 - 11:43. Pesquisado em 17.01.2012.

- Tratado de Itaipu-Brasília, em 26.04.1973. Mario Gibson Barboza - Raúl Sapena Pastor. Disponível em: <http://www.itaipu.gov.br/institucional/documentos-oficiais $>$. Pesquisado em 15.03.2013. 


\section{ATOS QUE APROVARAM E PROMULGARAM O TRATADO:}

1) Decreto Legislativo n. ${ }^{\circ} 23$, de 30.5.1973 - Aprova o texto do Tratado de 26.4.1973 celebrado entre a República Federativa do Brasil e a República do Paraguai, bem como as Notas então trocadas entre os Ministros das Relações Exteriores dos dois países. (Publicado no "Diário do Congresso Nacional" de $1^{\circ} .6 .1973$, p. 1.659.)

2) Decreto n. ${ }^{\circ}$ 72.707, de 28.8.1973 - Promulga o Tratado de 26.4.1973, celebrado entre a República Federativa do Brasil e a República do Paraguai, bem como as seis Notas trocadas entre os Ministros das Relações Exteriores dos dois países. (Publicado no "Diário Oficial” de 30.8.1973, págs. 8.642-45.)

3) Lei n. ${ }^{\circ}$ 389, de 11.7.1973 (Paraguai) - Aprova e ratifica o Tratado entre a República do Paraguai e a República Federativa do Brasil e as Notas trocadas entre os Ministros das Relações Exteriores dos dois países.

- Tratamento dado aos desapropriados por Itaipu. Disponível em: <http://www.itaipu.gov.br/>. Pesquisado em 03.2013. 